

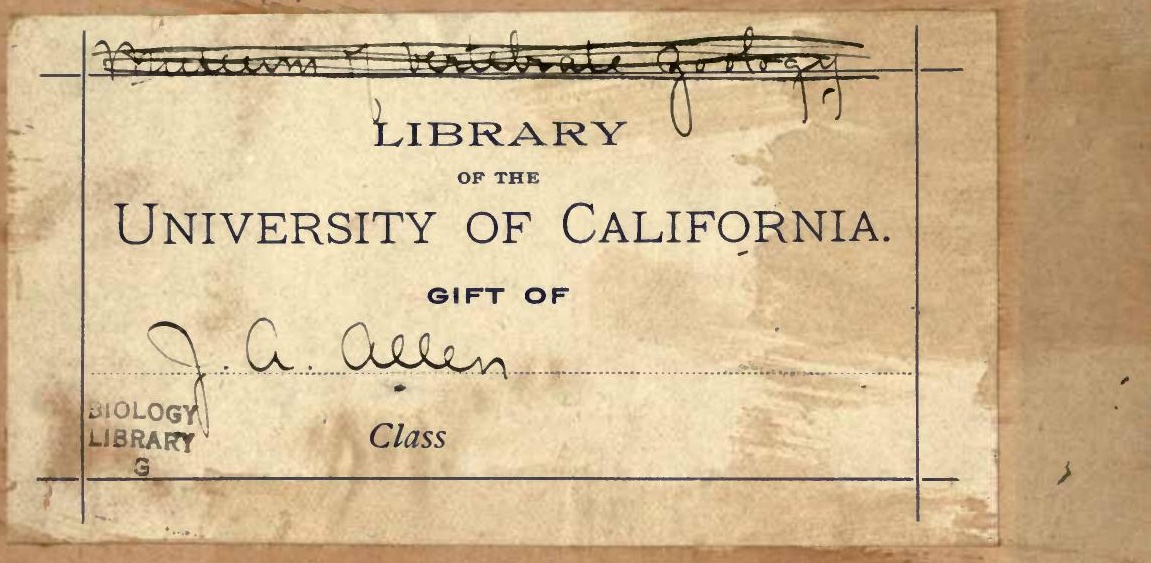








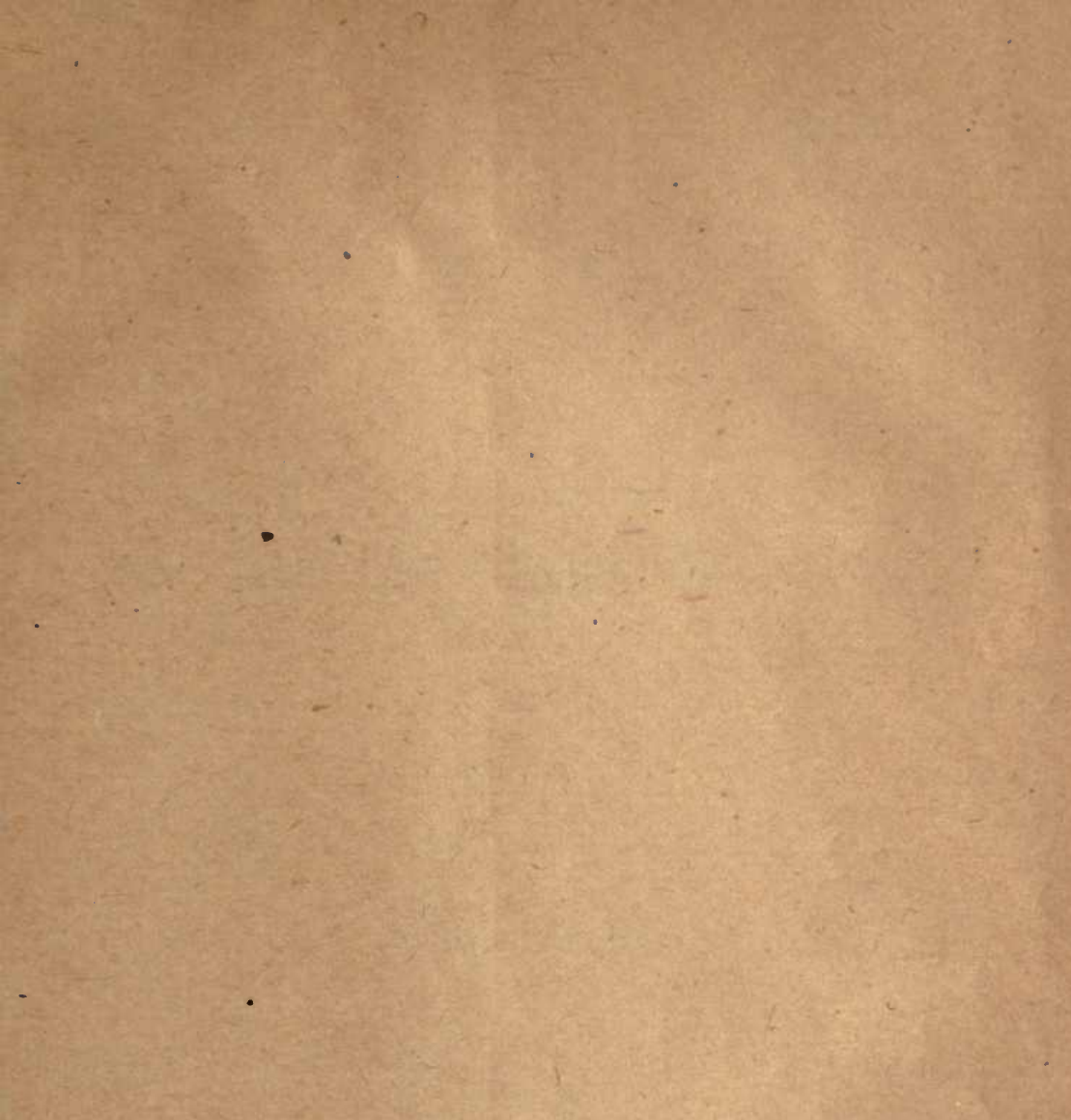



From the P'rucesediugs of the Boston Society of Natural History. Vol. XIII December 15,1869 .

\title{
ON THE MAMMALS OF IOWA.
}

\author{
BY J. A. ALLEN.
}

BOS TON :

PRESS OF A. A. KINGMAN. 1870 . 

1. On the marmals of Iowa.

2. On the classification of the eared seals.

3. Synopsis of the American Leporidae.

4. Geographical variation among North American mamals, especially in respect to size.

5. Sexurl, individurl, and geographical variation in Leucostiote tephrocotis.

6. Geographical distribution-of the mamalia.

7. Symonymatic list of the American Sciuri.

8. On the Coatis (genus Nasua, Storr).

9. On the species of the genus Bassaris.

10. List of mammals collected by Edward Palmer in northeastern Mexico.

11. Preliminary list of works and papers relating to the mammalian orders of Cete and Sirenia.

12. New species and a new subspecies of the grenus Lepus.

13. Collections of mamals made in central and southern Mexico.

14. Two supposed new species of mice from Costa Rica and Texico.

15. New species of big-eared bat, of the genus Histiotus, from southern Cálifornia.

16. Further notes on Maximilian types of South American birds.

17. Mammals from southern Texas and northeastern Mexico.

18. Mammals and birds collected in northeastern Sonora and nor thwestern Chi huahua Mexico on the Iumholtz archaeological expedition, 1890-92.

19. Mammals from the island of Trinidad.

20. Further notes on Costa Rica marmals.

21. Description of a new mouse from Lake county, Calif. 22. New species of Geomys from Costa Rica. 

From the Proceedings of the Boston Society of Natural History, Vol. XIII, Iecember 15, 1869.

\title{
ON THE MAMMALS OF IOWA.
}

\author{
BY J. A. ALLEN.
}

IIBRAR
OF THE

UNIVERSITY

CALIFORNIA

B O T T N :

PRESS OF.A.A. KINGMAN.

1870 . 


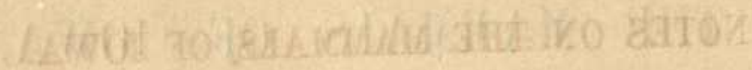

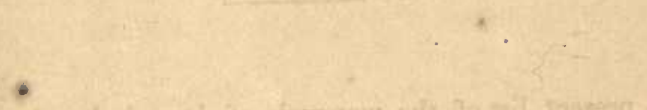

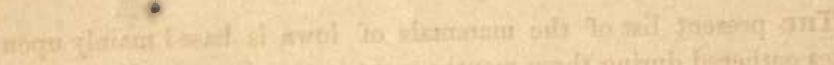

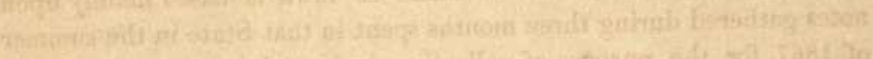

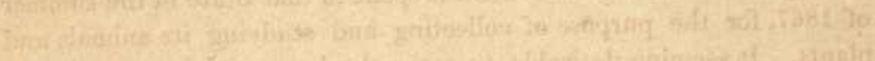

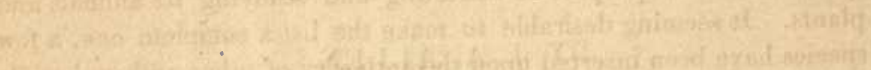

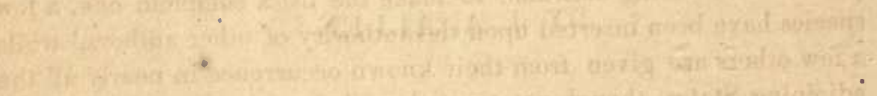

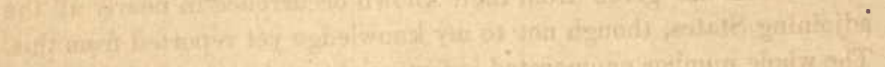

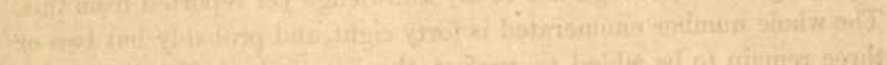

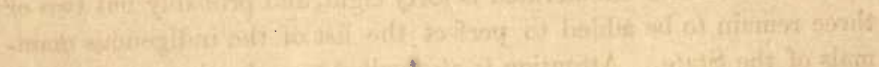

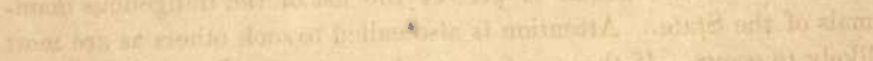

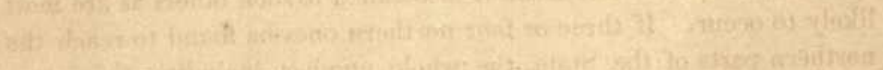

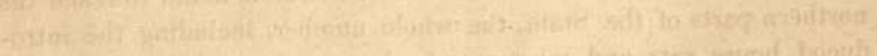

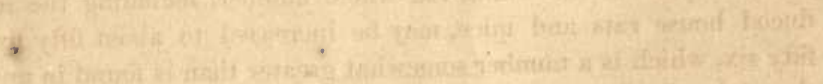

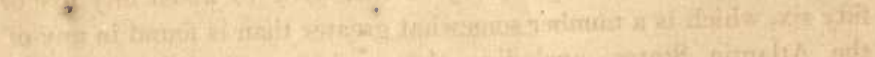

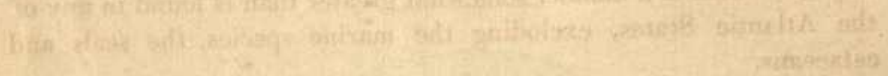

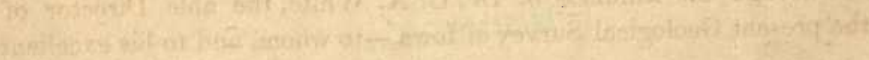

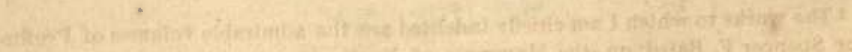

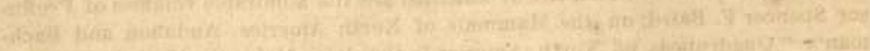

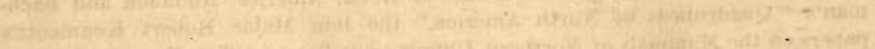
25.

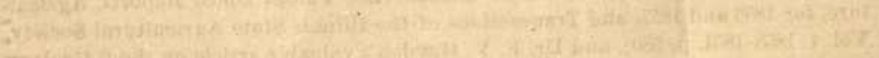
Whathe-

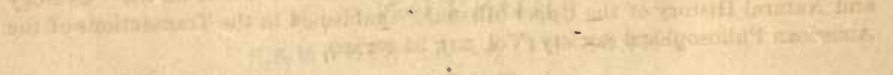

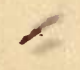




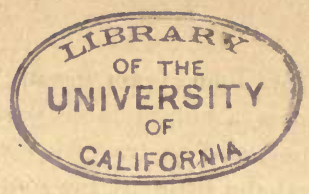

\section{NOTES ON THE MAMMALS OF IOWA.}

THE present list of the mammals of Iowa is based mainly upon notes gathered during three months spent in that State in the summer of 1867 , for the purpose of collecting and studying its animals and plants. It seeming desirable to make the list a complete one, a few species have been inserted upon the authority of other authors, ${ }^{1}$ while a few others are given from their known occurrence in nearly all the adjoining States, though not to my knowledge yet reported from this. The whole number enumerated is forty eight, and probably but two or three remain to be added to perfect the list of the indigenous mammals of the State. Attention is also called to such others as are most likely to occur. If three or four northern ones be found to reach the northern parts of the State, the whole number, including the introdnced house rats and mice, may be increased to about fifty five or fifty six, which is a number somewhat greater than is found in any of the Atlantic States, excluding the marine species, the seals and cetaceans.

Through the kindness of Dr. C. A. White, the able Director of the present Geological Survey of Iowa,-to whom, and to his excellent

\footnotetext{
1 The works to which I am chiefly indebted are the admirable volumes of Professor Spencer F. Baird, on the Mammals of North America, Audubon and Bachman's "Quadrupeds of North America," the late Major Robert Kiennicott's papers on the Mammals of Northern Illinois (See Patent Office Reports, Agriculture, for 1856 and 1857, and Transactions of the Illinois State Agricultural Society, Vol. I 1853-1854, p. 580), and Dr. F. V. Hayden's valuable article on the "Geology and Natural History of the Upper Missouri," published in the Transactions of the American Philosophical Society (Vol. xrI, 2d series).
} 
assistant, Mr. Orestes H. St. John, I am greatly indebted for assistance,-I was enabled to pass a considerable part of this time with one of his exploring parties, and to traverse large portions of nine counties. ${ }^{1}$ These are situated a little to the southwest of the centre of the State, and embrace an area nearly sixty miles square; and to this region most of my special remarks refer. Large portions of this tract were then in a nearly primitive condition, many of its broad prairies being still undisturbed by the plow. Yet the hunter and the "first settler" had passed over it and destroyed or driven away many of the larger mammals. But the recent presence of these animals here was still fiesh in the minds of the older settlers, many of whom had witnessed and assisted in their rapid extirpation.

Iowa being situated in a prairie region, it necessarily differs considerably in the general eharacter of its fauna, and especially in respect to its mammalia, from that of the wooded portion of the United States to the eastward, as all who have given attention to the geographical distribution of animals must be aware. Yet we do not in this State fairly enter upon the so-ealled Middle Province of the continent, which differs so markedly, both in faunal and floral, from the Eastern Province. A great change in the fauna and flora is met with, however, at the point of junction of the wooded and woodless regions of the eastern half of the continent, which in the latitude of Iowa oecurs more than a hundred miles to the eastward of that State. At this point as great and as abrupt a change oceurs as usually takes place between two contiguous faunal districts, one of which lies to the north or to the south of the other, or where the line of division is an isothermal one,separating different climatic and zoölogical zones. A few only, if any, of the species embraced in this list seem to find their eastern limit of distribution in this State; but, with two or three exceptions, they range through southern Wisconsin, Illinois, and even into northwestern Indiana and southern Michigan, or to the eastern limit of the prairies. Also, with very few exceptions, none are restrieted to it in either their northward or southward range. A few of the more northern species, whose southern range is restricted to the southern border of the Alleghanian fauna, may reach the northern counties of Iowa, as a few essentially southern species may approach, or even be found oceasionally within its southern borders. Iowa is hence mainly embraced within the Carolinian fauna, at least so far as its mammals, birds and reptiles are concerned, though generally

1 Dallas, Guthrie, Boone, Greene, Carroll, Crawford, Sac, Calhoun and Audubon. 
heretofore supposed to belong, in great part, at least, to the Alleghanian. Among the strictly prairie mammals represented, are at least four rodents (Spermophilus tridecem-lineatus, S. Franklinii, Geomys bursarius, Hesperomys michiganensis), two carnivores (Canis latrans, Taxidea americana), and at least one insectivore (Scalops argentalus). Only one eastern species, the red squirrel (Sciurus hudsonius), appears to find at the prairie line its western limit, if, as some have supposed, it be true that this animal does not range across the continent. ${ }^{1}$ Hence the difference between the mammalian fauna of the prairies of the Upper Mississippi valley and that of the forest region to the eastward consists in the addition of a number of species peculiar to the prairies.

Since all the larger species of mammalia are everywhere rapidly disappearing before the revolutionizing influences of civilization, and since great and general changes occur in the faunal and floral features of every country when brought under eultivation, it becomes a matter of unusual interest to preserve as correct a record as possible of the primitive conditions of our own country in this respect, for comparison with its subsequent altered status, as well as a history of the change. The natural history of Iowa is of course now far from an unexplored field, yet I find that no adequate record of its animals and plants, nor of those of the country immediately adjoining, has as yet been made. I have hence no hesitancy in presenting the few notes that follow concerning some of the mammals of this State.

FELIDE.

Two species of this family, from their known distribation, undoubtedly occur in portions of the State, but they cannot now be, and probably never were, very numerous. I met, however, with no evidences of their existence, and failed to make special inquiries concerning them. They are the following:

1. Felis concolor Linnæus. ${ }^{2}$ (Panther.)

2. Lynx rufus Rafinesque. (Bay Lynx.)

The $L$. canadensis may also occur in the northern parts of the State.

1 See postea, p. 188.

2 The nomenclature employed in this list is the same as that adopted by me recently in my " Catalogue of the Mammals of Massachusetts," so far as the species are the same. See Bulletin of the Museum of Comparative Zoology, No. VIII, October, 1869. 
The $F$. concolor, however, owing to the open character of the country, can occur only as a straggler from more wooded regions. ${ }^{1}$

\section{CANIDE.}

\section{Canis lupus Linn. (Common Wolf.)}

Although wolves of this species were rather common less than twenty years since, they are now searce, especially in the more settled districts. They are usually termed "mountain" wolves, in distinction from the prairie wolves.

\section{Canis latrans Say. (Prairie Wolf.)}

This species was formerly quite numerous, much more so even than the common wolf ( $C$. lupus), but now, like that species, it is already in some sections nearly extirpated. I was informed that it was still common in the southern part of Guthrie county, where it not unfrequently was destructive to the lambs. It is said to far exceed the common fox in boldness and cunning. In the Proceedings of the Philadelphia Academy of Natural Sciences (Vol. r, p. 188, 1842), it is stated that a specimen of this species, from Illinois, was presented to the Academy by Dr. Blanding. Mr. Kennicott states that it was was once common in northern Illinois.

\section{Vulpes vulgaris Fleming. ${ }^{2}$ (Red Fox.)}

Not apparently numerous in the counties in question, particularly at the southward. About Wall Lake and northwards they were reported to be common. ${ }^{8}$

1 Since writing the above, I have received from Dr. C. A. White, in kind response to recent inquiries of mine conceruing the species of this family found in Iowa, as follows: "The panther has been known within our limits but very rarely. The common wild cat, or bay lynx, is occasionally found, but it is considered rare game. I do not know that the Canada lynx has ever been seen in Iowa."

2 For a recent discussion of the relationship of the so-called $\dot{V}$. fulvus with the $\boldsymbol{V}$. vulgaris of the Old World, see the Bulletin of the Museum of Comparative Zoölogy, No. viII, p. 159.

s I may here add that in Van Buren and Allegan counties in Michigan, four kinds of foxes are recognized by the hunters: the "cross," the "Samson," the "common red," and the "gray." The latter is undoubtedly the southern gray fox ( $V$. virginianus), and the others different varieties of the common red fox. The " cross," so called, is much the rarer, and the red by far the most common. About one third of all taken are of the second variety, which from the very peculiar ap. pearance of their fur are termed "Samson" foxes. They are described as having a coarse, crisp, woolly fur, appearing much as though they had been singed; hence their name of "Samson foxes." Their skins bring much less in market than those of the common red fox, while the animal is represented as less cunning and more eusily trapped: they also have slightly different habits. I regret that I had 


\section{Vulpes velox And. and Bach. (Sivift Fox.)}

Vu'pes cinereo-argentatus Richnrdson, Faun. Bor. Am., I, 98, 1829; nec Caris cinereo-argenteus Erxleben, Syst. Regn. Animalis, 175.

An animal deseribed to me as the "Swift," which oceurs lere more or less frequently, is undoubtedly this species, though I have not known it before reported as occurring east of the Missouri. The character of the country in western Iowa differs little from that of eastern Nebraska, where this species is well known to oceur. It is hence not very unexpected that it should exist in portions of Iowa. Dr. Richardson says it ranges north to the Saskatchewan river, which he gives as its northern limit.

\section{Vulpes virginianus Rich. (Gray Fox.)}

Canis cinereo-argenteus et virginianus Erxleben, Syst. Reg. Anim., $567,1777$.

Frequent, but not especially numerous.

\section{MUSTELIDE.}

\section{Putorius ermineus Linn. ${ }^{1}$ (Weasel.)}

Weasels, probably mostly of this species, were reported to me as common; I saw, however, but one.

9. Putorius vulgaris Linn. (Little Weasel.)

From its known general range, this species must also occur more or less frequently, especially in the northern parts of the State.

\section{Putorius lutreolus Cuvier. (Mink.)}

$P$. vison Gapper, and $P$. nigrescens Aud. and Bach.2

Said to be common. The minks of the prairies are quite different in some respects from the more northern animal, as well as from those of the wooded region to the eastward. They are browner and their fur is much coarser and brings a much lower price in the market.

no opportunity of examining specimens of them myself. Similar foxes, I am informed, occur in Massachusetts, where they are known to fox-hunters by the same singular name. This peculiar condition of the pelage is doubtless unnatural, and probably the result of disease, as $I$ have in several instances seen an apparently similar modification of the pelage in the red squirrel (Sciurus hudsonius), which in one case extended through a whole litter.

1 In the Bulletin of the Museum of Comparative Zoölogy (No. Aun, pp. 168-174, 1869), the writer has given his reasons for believing there are but two species of weasel in the United States east of the Missouri, and that these are identical respectively with the $P$. ermineus and $P$. vulgaris of the Old World.

2 In respect to the supposed distinctness of the American from the Old World minks, see my remarks in Bull. Mus. Comp. Zoöl., No. vıı, p. 175. 
Experienced trappers and fur dealers at the West repeatedly informed me that these differences are so considerable that they ean always readily separate the prairie skins from the forest ones, as those from Illinois, for example, from those taken in Michigan. They also claim that there are two kinds of prairie mink, as of the northern mink, differing in size. This difference probably depends mainly upon sex and age, the males being much larger than the females.

11. Lutra canadensis Sabine. (Otter.)

Said to be common on the Raccoon rivers, and generally more or less so throughout the State.

12. Mephitis mephitica Baird. (Skunk.)

Common, and presents the same varieties in point of color as at the East.

13. Taxidea americana Waterhouse. (American Badger.)

This species is probably nearly as numerous as formerly. Though rarely seen, it being nocturnal, its burrows are frequently met with. Its thick, heavy body and short legs render it a rather elumsy animal, but with stealthy, cat-like habits it combines considerable cunning. In the night unany expert animals becone its prey. It is very powertul, and being armed with strong claws and teeth, is able to offer formidable resistance when attacked by a dog; it is, however, extremely docile to man, allowing itself to be handled, and unless teased, is said to rarely offer to scratch or bite. At Rippey, in Greene county, I saw a half grown one in confinement that had been caught by a boy a few days before, and carried home by him in his arms. When discovered they are said to lie flat and motionless on the ground, and if they think they are not seen will allow a person to pass within a few feet of them without moving. Though generally regarded as a harmless animal by the farmers, the bones and wool of lambs have been found in their burrows. ${ }^{1}$

1 The Mexican Badger (Taxidea Berlandieri Baird, U. S. and Mex. Bound. Sur. Rep., II, Mammals, 21, 1859; Taxidea Berlandieri Baird, Mam. N. Amer., $2(5)$. described as "Similar to the $T$.americana [labradoria], but smaller; above reddislı gray, with a narrow white stripe extending from the muzzle to the root of the tail," from skulls of Mexican specimens and the Mss, notes of Dr. Berlan. dier, seems to be merely the smaller southern race of the common $T$. americana. It differs from it chiefly in being a little smaller, and, according to some reports, lighter in color. The probability seems very great that the slight differences in color pointed out are merely individual differences, although the $T$. Berlandieri may constitute a more or less well-marked climatal race. 
URSID环.

14. Procyon lotor Storr. (Raccoon.)

Common.

15. Ursus aretos Linn. ${ }^{1}$ (Bear.)

The bear is reported to occur here, but I learned nothing of special interest respecting it. From the character of the country it evidently cannot now be common, however numerous it may formerly have been. Localities named after the bear, as Bear creeks, Bear groves, etc., indicate its former greater or less abundance here.

\section{CERVID E.}

\section{Cervus canadensis Erxl. (American Elk.)}

Formerly numerous, but now extinct in most of the region under description. It is but a few years since good antlers of this species were common on the prairies, but through the combined action of two destroying agencies they are now rarely met with, and only in an imperfect condition. In addition to the injury done them by the fires that annually pass over the wild prairies, the two species of Spermophilus and other rodents eat thein, by which animals they are said to be in a short time completely devoured.

An old resident and hunter whom I met at New Jefferson, in Greene county, informed me that but seven years before (now nine years since), the elk were abundant in some parts of that conty. Prior to this date he used to see herds nearly every day, and sometimes several in a day, some of them of very large size. During the early settlement of this part of Iowa they were of great value to the settlers, furnishing them with an abundance of excellent food when there was a scarcity of swine and other meat-yielding domestic animals. But, as has been the case too often in the history of the noblest game animals of this continent, they were frequently most ruthlessly and improvidently destroyed. In the severer weather of winter they were often driven to seek shelter and food in the vicinity of the settlements. At such times the people, not satisfied with kill-

1 In the eighth number of the Bulletin of the Museum of Comparative Zoölogy, the writer has shown that it is impossible to satisfactorily characterize or distin. guish more than a single species of land bear in the colder portion of the Northern Hemisphere, though it must be admitted that between the extremes of variation there are very great differences, more than would be required even to indicate a diversity of species, if the differences were constaut, as they are most notably not, the most distinct forms gradually intergrading. 
ing enough for their present need, mercilessly engaged in an exterminating butchery. Rendered bold by their extremity, the elk were easily dispatched with such implements as axes and corn-knives. For years they were so numerous that the settlers could kill them whenever they desired to, but several severe winters and indiscriminate slaughter soon greatly reduced their numbers, and now only a few linger where formerly thousands lived, and these are rapidly disappearing. Their home here being chiefly the open country, they much sooner fall a prey to the "westward march of civilization," through the most merciless treatment they receive at the hands of the emigrant, than does the deer.

From June to October the elk are said to be always fat and in excellent condition for the table. Their flesh is described as being in texture intermediate between beef and mutton, but superior in flavor to either. In March the bucks shed their horns. As the new ones begin to sprout they leave the herd and keep by themselves, in small parties of about a dozen, till their horns are fully grown and hard, when they begin to "run," as the hunters term it, and again join the herd. About the twentieth of June the females are said to bring forth their young. Towards autumn, when the calves have become large and strong, the elk begin to gather in large herds. The horns appear disproportionately large, especially when "in the velvet," at which time the main branches are as thick as one's arm, and their appearance is far from pleasing.

17. Cervus virginianus Boddært. (Common deer.)

More or less common, but steadily decreasing in numbers. I was informed that in some sections they were on the increase, owing to the fact that they were beginning to have a more favorable range, through the gradual extension of the forests, - due to the protection of the woodlands from the annual fires that formerly swept over the country, and which probably more than any other cause tended to keep the timber-tracts within their former restricted areas. But it does not seem that this increase of the deer can be more than temporary, unless stringent measures are taken to protect them. If exposed to the indiscriminate slaughter to which this animal has generally been subject elsewhere, it must certainly soon disappear, as it has already done over so large a portion of the United States east of the Mississippi.

The white-tailed deer (C. leucurus), according to Dr. Hayden,?

1 Transact. Amer, Phil, Soc, Vol, xIr, 2d series. p. 149. 
should be included among the mammals of Iowa, since he gives its range as extending eastward to the Big Sioux river and Council Bluffs. It does not, however, seem to me to be distinct from the $C$. virginianus.

\section{BOVIDE.}

\section{Bos americanus Gmelin. (American Buffalo.)}

Now nearly exterminated in all parts of the State, though numer. ous in the northwestern counties at a comparatively recent date. Two years since I was informed that a few still remained in that section, and that up to that time one or more had been killed every year as far south as Greene county. Further north they were represented as being more common, but that no herds were met with south of the Sioux river, and rarely east of the Missouri. Those found further east were only stragglers or wanderers from the herds, that in most cases had probably been driven off by the Indians.

\section{VESPERTILIONIDE.}

Bats of at least two species were observed flying about the groves, but I procured no specimens. They were not, however, numerous, and were mainly seen near the timber. A prairie country cannot, evidently, afford such animals favorable haunts; but they will doubtless increase with the further settlement of the country; when more or less open buildings will afford them convenient places of resort. The following species, from their general known distribution, doubtless occur in most parts of the State.

19. Nycticejus crepuscularis H. Allen. (Black-faced Bat.)

20. Lasiurus noveboracensis Tomes. (Red Bat.)

21. Lasiurus cinereus H. Allen. ${ }^{1}$ (Hoary Bat.)

22. Scotophilus fuscus H. Allen. (Brown Bat.)

23. Scotophilus noctivagans H. Allen. (Silvery Bat.)

24. Scotophilus georgianus H. Allen. (Georgia Bat.)

25. Vespertilio subulatus Say. (Little Brown Bat.)

\section{SORECID无.}

During the short time I passed in this State I met with no examples of this family, though several species undoubtedly occur there. Of the long-tailed shrews, or true Sorices, among the species that may be 
looked for are Sorex platyhrinus, S. Richardsonii, S. "Haydeni," and S. "Hoyi." The following, from their ascertained distribution, must be present, specimens of the latter being in fact already known from this State.

26. Sorex Cooperi Bachinan. (Cooper's Shrew.)

27. Blarina brevicauda Baird. (Mole Shrew.)

\section{TALPIDA.}

28. Scalops argentatus Bachman. (Silvery Mole.)

This species is well known to occur in the State, but it does not appear to be very numerous.

28. Condylura cristata Illiger. (Star-nosed Mole.)

This species having been traced westward to the Mississippi, it, doubtless occurs in eastern Iowa, but probably only as a rather rare species. I can find, however, no specimens of it reported from there. It is said to inhabit the prairies of Illinois. ${ }^{1}$

The Brewer's Mole (Scalops Breweri) may also be met with here, though it has not yet been found, so far as I am aware, west of the State of Ohio.

\section{SCIURIDE.}

30. Sciurus carolinensis Gmelin. (Gray Squirrel.)

Said to be more or less numerous in the groves along the water courses. I saw, however, but very few.

31. Sciurus ludovicianus Custis. (Western Fox Squirrel.)

Common in the same situations as the preceding species; I saw it much more frequently. It was, however, far less numerous than I found it to be in Ogle county, Illinois, or in southern Michigan, in both of which localities there was a mueh greater predominance of forest. In these latter localities the preceding ( $S$. carolinensis) was also excessively abundant, both in its black and gray colors, and in every intermediate stage between gray and black. The young, as I have already mentioned in another connection, ${ }^{2}$ more frequently represent the intermediate stage, their fur presenting the annulated appearance mentioned by Prof. Baird as characterizing intermediate color varieties. $^{8}$ This form of $S$. carolinensis was more especially abundant in Illinois, where the greater part of the large number of specimens I

1 Kennicott, Patent Office Rep., Agr., 1857, p. 101.

2 Bulletin Mus. Comp. Zoology, No. vili, p. 222.

3 Yammals of North America, p. 244. 
examined were of the dusky, annulate-haired type; they were also all young.

32. Sciurus hudsonius Pallas. (Chickare. Red Squirrel.)

This species does not appear to occur in the parts of Iowa I visited. I saw not a single specimen, and although I made extended inquiries respecting it, could not learn that it had ever been seen here. I also found it unknown in Ogle county, Illinois (one hundred miles west from Chicago), though said to occur sparingly in some portions of northern Illinois, by Mr. R. Kennicott, ${ }^{1}$ and also in northern Missouri and central Iowa; but in respect to the latter locality I think he may have been mistaken. I never anywhere, however, saw it so numerous as I have found it to be in southern Michigan (Van Buren and Allegan counties). Somewhat to the northward of Iowa, as in the forest region of Minnesota, it is said to be very numerous, and to extend thence far to the westward. Dr. Hayden says it occurs on the eastern side of the Black Hills, in Nebraska. ${ }^{2}$

33. Pteromys volucellà Cuvier. (Flying Squirrel.)

Not common. From its peculiar nocturnal habits this species is one easily overlooked. From its known range it must occur in the State.

34. Tamias striatus Baird. (Striped Squirrel.)

Abundant in and near the thickets and groves.

1 Patent Office Rep. Agriculture, 1856, p. 68.

2 I am far from sure that either of the supposed species called Sciurus Fremonti, $S$. Richardsoni and S. Douglassi are distinct from the common S. hudsonius of the eastern part of the continent. The differences between them are very trivial, and in respect to what these are, authors are by no means unanimous. They are generally slight variations in size, the northern and Rocky Mountain species being generally a little larger than the restricted $S$. hudsonius, but differing only as the representatives of a single species would be expected to under similar differences of habitat. There are no essential differences in color, the variation in this respect being in no case greater than specimens from different localities in New England present, as I have before pointed out (Bull. MIus. Comp. Zoöl., No. vi11, p. 223). Specimens from northern Maine have just as good claims for specific distinctness from those of eastern Massachusetts as either of the above-named supposed species have to be regarded as specifically distinct from the $S$. hudsonius. They diffir in color and in the texture of the fur, the Maine specimens in question being grayer, with thicker, heavier pelage, and larger in size. Those from some localities have also a relatively shorter tail, differences precisely similar to those urged as distinguishing severally these supposed species, and equally great in degree. The habitat of $S$. hudsonius, then, it seems to me, really extends throughout the northern part of the continent, from the Atlantic to the Pacific. Intelligent travellers and iaturallsts perfectly familiar with the S. hudsonius at the East, who have visited the region inhabited by the other supposed species, as Alaska and the Rocky Mountains, report that they saw nothing about the red squirrel they met with there, either in habits or otherwise, that led them to suspect it to be at all different from S. hudsonives. 
35. Spermophilus tridecem-lineatus Aud, and Bach. (Striped Prairie Squirrel. Striped Gopher.)

Abundant, and to the farmers a destructive pest. Seen almost daily, both on the wild prairie and in the cultivated fields. They are active throughout the summer, and quite destructive to the young corn in the spring, the kernel of which they dig up, and thus destroy the crop. It is said, however, to be less frequently noticed during the summer, when the grass is high. than earlier. Their burrows run usually but a few inches below the surface, but sometimes extend horizontally for the distance of ten fect, though usually much less. ${ }^{1}$

36. Spermophilus Franklini Richardson. (Gray Prairie Squirrel. Gray Gopher.)

Abundant, and, in proportion to its numbers, far more destructive than the preeeding ( $S$. tridecem-lineatus). When very numerous they sometimes destroy acres of newly planted corn by eating the seed. During the spring months it is generally numerous, but after about the first of June is rarely observed, and all my efforts to obtain specimens, both in this State and in Illinois, where it is equally common, were ineffectual. The burrows of this species run to the depth of three or four feet, and extend to a considerable distance.

The Prairie Dog (Cynomys ludovicianus), so eharacteristic of the more western prairies, is not met with to the eastward of the Missouri river. Dr. Hayden says the first village he met with in ascending the Missouri was about ten miles below the mouth of the Niobrara. ${ }^{2}$ Mr. Cyrus Thomas erroneously includes this animal in his catalogue of the "Mammals of Illinois," published in Vol. Iv of the Transactions of the Illinois State Agricultural Society.

37. Arctomys monax Gmelin. (Woodchuck. Marmot.)

This animal appears also to be absent from western Iowa. I met with but a single individual who had seen it in the State. He had formerly lived in Davis county, in the southeastern part, where he informs me it occurs, as also in the adjoining counties of Missouri. On this authority it is included in the present list.

\section{Castor fiber Linn. (Beaver.)}

Reported to still exist on the South Raccoon river, but nearly or quite exterminated in most of the eastern and southern portions of the State. A gentleman residing in the southern part of Dallas

1 For a very.complete account of the habits of this species, see the late Robert Kennicott's excellent papers on the Mammals of Illinois, in the Patent Office Reports (Agriculture) for 1856 and 1857 (1856, p. 74).

? Transact. Amer. Phil. Soc., Vol. xIr, 2d series, p. 145. 
county informed me that when he settled there, eighteen years before, he being one of the first settlers of the county, the beaver was then common there. He said it was now quite exterminated in that vicinity, none having been seen for a considerable period. From the frequent occurrence of creeks in Iowa called by the name of this animal, it seems probable that it was once numerous here.

39. Geomys bursarius Richardson. (Pouched or Pocket Gopher.)

Exceedingly numerous everywhere, and a great pest. The farmers regard it as agriculturally the "great curse of the country." In some localities it destroys the fruit trees, the groves planted for shade and the osage-orange hedges, by feeding upon their roots in winter. It seems to be nowhere on the decrease, as from its peculiar habits it is difficult to destroy. As the animal seldom appears above the surface of the ground, and only at night, one may reside for years where they are numerous without seeing one. The moist and the dry portions of the prairie are alike haunted by them; and the farmer too often sees their unwelcome hillocks thrown up night after night in his garden, or within a few feet of his door. As their burrows are always closed, few persons know how to trap them. A few farmers have been successful in poisoning them with strychnine, and now and then one is shot. To shoot them it is necessary to open their burrows and watch with a gun kept in readiness to fire the instant they appear at the opening to close it, as they show their head only, and for merely an instant. The gopher will allow no light to enter its burrow, and when it is broken into it hastens to repair the breach. In trapping them an opening is made into their galleries, through which a small steel trap is inserted as far as it conveniently ean be with the hand, and the opening then partially closed. The animal hastening to close the opening must generally pass over the trap. Occasionally, however, the trap is found pushed up into the opening and firmly wedged there with the impacted earth, in which ease it is usually unsprung. The gopher is hence often credited with a degree of cunning far beyond what it possesses, the safe removal of the trap being purely accidental on the part of the animal. As the burrows are extensive, with many branches, it is impossible to tell on which side of the opening the occupant may be, and hence coming from the side opposite to that where the trap is placed, it often succeds in closing the hole without being captured. ${ }^{1}$

1 For a detailed account of the habits of this interesting species, see Kennicott's papers on the Mammals of Illinois, in the Patent Office Report on Agriculture for 1857, p. 72. 
This aninal is said to be unable to swim, and that it is often drowned in its burrows, when they are inundated by the sudden rise of the prairie streams. ${ }^{1}$ Whether or not large rivers form impassable barriers to it, it seems to be well substantiated that while this animal occurs on the lowa side of the Mississippi and in central Illinois, or throughout that part of the latter State south and east of the Illinois river, it does not exist in that portion situated between the Illinois and the Mississippi. Mr. Kennicott refers to his having heard this reported, but he was unable to vouch for the truthfulness of the account. When in this section of Illinois, however, I was repeatedly informed by competent and trustworthy observers who had resided in this part of the State since its first settlement, and who had traversed it extensively, that the pocket gopher did not exist in that portion of Illinois between these rivers. This fact seems the more strange when we remember that the gopher is common in portions of Wisconsin, being in fact very numerous in Winnebago and Fond du Lac counties, as I have myself ascertained.

The Perognathus fasciatus may well be expected to occur in southwestern Iowa, since it is well known to exist in northeastern Kansas, not many miles from the Iowa border.

\section{MURIDAE.}

\section{Jaculus hudsonius Baird. (Jumping Mouse.)}

Doubtless not uncommon, since it is numerous in neighboring portions of Wisconsin and Illinois.

41. Hesperomys leucopus Wagner. (White-footed Mouse.)

A species I take to be this was not uncommon. From the locality it may be what has been recognized by Professor Baird as the $H$. sonoriensis of Le Conte, ${ }^{2}$ described by the latter gentleman from a specimen from Sonora. Specimens are referred to it by Professor Baird from Fort Union and other localities in northwestern Dacotah, and from various intermediate points southward to Texas and New Mexico; the H. leucopus of Richardson from the Saskatchawan being also referred to it, it is thus recognized as having a considerable range in latitude. The western limit of H. leucopus is given by Professer Baird as the Mississippi. As my specimens are not appreciably different from $H$. leucopus from Massachusetts, one is left to two alternatives; either that of regarding the $H$. leucopus as ranging westward across the State of Iowa to the Missouri, or of considering

1 R. Kennicott. Patent Office Rep., Agriculture, 1857, p. 75.

2 Mam. N. Amer., p. 474.

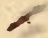


H. eonoriensis as indistinguishable as a species from $H$. leucopus. I am the more inclined to the latter opinion from the almost exact resemblance which authentic specimens of the former that I have examined bear to others unquestionably of $H$. leucopus. Its recognized wide distribution in latitude does not at all accord with its supposed limited range eastward, in a region of so uniform a character as the one now in question. In regard to $H$. sonoriensis, Professor Baird observes : 'This species has the general characters of the white-footed mouse of the eastern States; and it is only after the comparison of extensive series thit I have been able to detect differences which, though slight, are so eonstant and of such a character as to appear something more than a mere local variation. I shall, however, be obliged to indicate the differences rather by comparison than as absolute characters." As I have previously observed, ${ }^{1} I$ believe that a considerable number of merely nominal species of Hesperomys have been recognized as valid, and in a group presenting such a wide range of variation in color and in the proportions of the different parts of the body as different representatives of even the restricted $H$. leucopus do, I fail to see the propriety of basing species on such intangible differences as distinguish $H$. sonoriensis.

42. Hesperomys michiganensis Wagner. (Prairie Whitefooted Mouse.)

Apparently common; several specimens taken. I made my first acquaintance with this species in life, in Ogle county, Illinois, where I found a pair in June in their nest under a flat stone at the edge of a cornfield. A newly born litter of young were attached to the teats of the female. The contrast of color between the dorsal and ventral areas of the body was well marked, and the line of separation along he sides elearly defined. ${ }^{2}$

The Wood Rat (Neotoma floridana) has been found in northwestern Kansas, about a hundred miles from the southwestern corner of Iowa, and judging from what is known of its distribution, it may be expected to occur in portions of the latter State.

43. Arvicola riparius Ord. (Meadow Mouse.)

Apparently common. I obtained several specimens, some of which are scarcely appreciably different from Massachusetts ones; others more resemble some obtainerl by me in Northern Illinois. In the latter

1 Bull. Mus. Comp. Zoöl., No. viri, p. 227.

2 Compare with this the remarks of Mr. Kennicott and Prof. Baird in reference to "Mus Bairdii." Pat. Office Rep., Agr., 1856, p. 92; Mam. N. Amer., p. 477. 
locality I obtained young specimens in the fall that in general characters are referable to $A$. riparius, but which in the character of the fur are quite different from the ordinary type of this species at the same age at the East, the coat being longer and heavier; the longer hairs presented a more bristly appearance, many of which were hoary, thus giving a well-marked grizzly aspect to the pelage. In the long heavy coat it seems to correspond with the prairie variety mentioned by Prof. Baird, and to which he applied the name longipils, in reference to this peculiarity; but they differ from it in color, which may, however, and most probably does, result from a difference in age. The longer and coarser pelage noticeable in the Arvicola of the prairie is sinilar to that previously referred to in this paper as characterizing the prairie minks.

The two following species of Arvicola also doubtless exist, at least in portions of the State, as they are not uncommon in the adjoining State of Illinois.

44. Arvicola austera LeConte. (Prairie Meadow Mouse.)

45. Arvicola pinetorum LeConte. (Pine Mouse.)

46. Fiber zibethicus Cuvier. (Muskrat.)

Common along the streams.

\section{LEPORID A}

\section{Lepus sylvaticus Bachman. (Gray Rabbit.)}

Common about the groves and thickets. In respect to the distribution of this species in Iowa, Dr. White has written me as follows: "It occurs all over the State, but is not common in the northwestern part. Indeed it is most common in the most cultivated districts, especially in southern and southeastern Iowa." He adds that this is the only species of rabbit occurring in the State, to his knowledge.

It is probable that the Prairie Hare ( $L$. campestris Bach.), the western representative of the $L$. americanus of the northern tier of States east of the Mississippi (if there is, in fact, any reason to consider them distinct), may occur in the northern part of the State.

\section{DIDELPHID E.}

48. Didelphys virginiana Shaw. (Opossum.)

From its general known distribution, this species might well be expected to be more or less frequent in the southern part of the State. Dr. White, however, informs me that it is very rare there, but that he saw two specimens some years since in the southeastern part. 


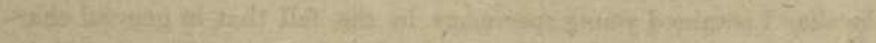

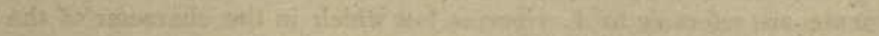

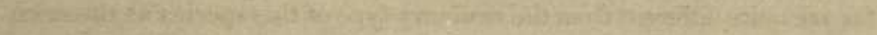

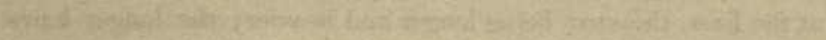

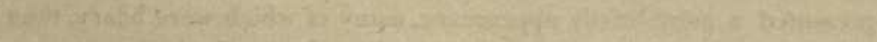

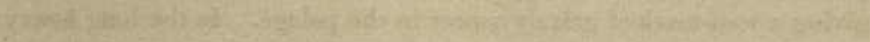

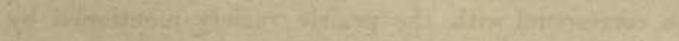

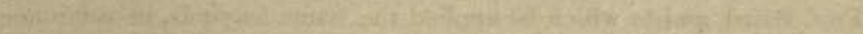

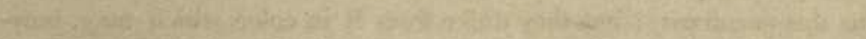
की

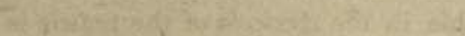

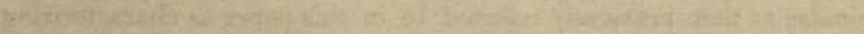

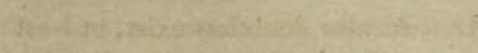

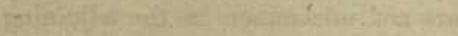

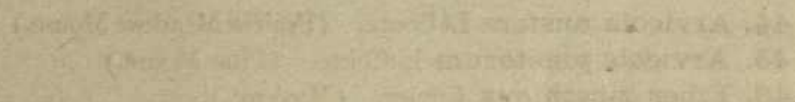

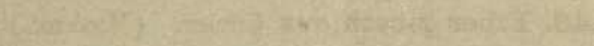

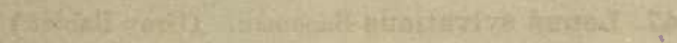

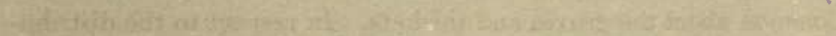

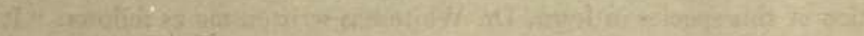

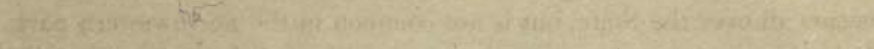

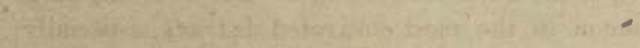

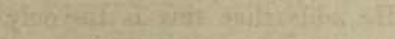

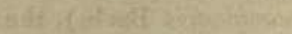

itc to

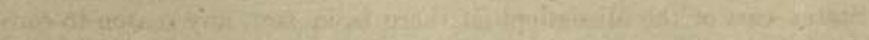
Fint?

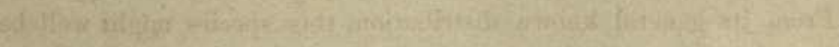

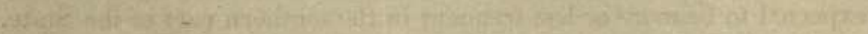

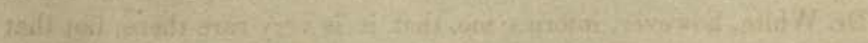

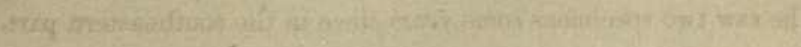



The Classification of tue Eared Seals. - In the review of my paper on the "Eared Seals" * by Dr. Theodore Gill, published in the January number of the Naturalist, $\uparrow$ I was pleased to see that this accomplished zoologist found in it a few things to commend, nor was I surprised to find, knowing his opinions previously, that on a few points we still somewhat differ. I regretted to observe, however, that notwithstanding his accustomed accuracy, Dr. Gill had, in the present article, fallen into several by no means unimportant errors. He quite severely criticises my provisional differentiation of the Otariadce into two subfamily groups, and in so doing has not only questioned the value ascribed by me to the characters alleged to be distinctive of the two groups, but also the existence of such distinctions, at least to anything like the extent claimed for them.

The distinctions given as characteristic of the two groups were differences in the character of the pelage, in size, form, the relative length of the ear and the swimming membranes or toe-flaps. Without discussing here the taxonomic value of these distinctions, I propose to examine briefly whether any of them have been shown by Dr. Gill " to be degraded to absolute nullity."

First, in regard to the pelage. The Oulophocino were characterized as having "thick under fur," and the Trichophocinoe as being "without under fur." As showing that this character is not a trenchant one, Dr. Gill cites the observation of Dr. Peters that the Arctocephalus antarcticus (Otaria pusilla Peters) has very thin under fur, and the remark of Dr. Gray that in Zalophus lobatus ( $Z$. cinereus Gill) the young are "covered with soft fur which falls off when the next coat of fur is developed," both of which. objections I had already noticed. $\ddagger$ 'To go over the ground again, however, I may state that since Dr. Peters wrote, it has been ascertained that both the Arctoceplaalus antarcticus and the $A$. cinereus are richly provided with under fur, so well so, at least, that these animals are pursued for their fur, which forms an article of high commercial value. $\S$ The remark respecting the tem-

* Bulletin of the Museum of Comparative Zoology, Vol. II, pp. 1-108, 1870.

† Vol. IV, pp. 675-684.

$\ddagger$ Bull. Mus. Comp. Zool., Vol. II, p. 41.

$\S A$ nn. and Mag. Nat. Hist., 4th ser., Vol. I, p. 219, March, 1868. Dr. Gray describes the A. cinereus as having the "under fur abundant" (Ann. and Mag. Nat. Hist., 3d ser. Vol. XVIII, p. 236, 1868), which remark is confirmed by a young specimen of this animal in the Museum of Comparative Zoology. 
porary under fur possessed by the young of Zalophus lobatus was made nearly half a century ago, and though often quoted since, has never yet been confirmed, so far at least as I have been able to ascertain. Since such a fact, however, would be contrary to analogy, to say the least, the accuracy of this observation seems to require confirmation. While in the hair seals the homologue of the under fur of the fur seals may be considered to exist in the short, stiff, crisp under hairs, - which are so few as only to be discovered by the most careful search, at least in old males of Eumetopias, and apparently also in Otaria and Zalophus, they do not accord at all in their nature with the fine, soft, abundant, silky under fur of the fur seals. The under fur of the fur seals is known to vary more or less in amount with the season, which variations may have given rise to the observations of Dr. Peters cited by Dr. Gill.

In regard to size, the hair seals were characterized as "large," and the fur seals as "smaller." As the representatives of Otaria and Eumetopias are several times larger, in respect to bulk, than any of the representatives of either Callorhinus or Arctocephalus, and the representatives of Zalophus are considerably larger than any of the fur seals, I fail to see that the difference in size "seems to be more than reduced to a mimimum and to be degraded to absolute nullity."

In regard to form, the fur seals were described by me as being "more slender" than the hair seals. This observation was based upon a comparison of the skeletons of two of the leading genera - Eumetopias and Callorhinus - and the figures and descriptions of the other species. Not only are all the bones smaller in comparison to their length in Callorhinus than in Eumetopias, but the limbs are also slenderer' and longer in proportion to the size of the body. In the comparison Dr. Gill has attempted to make, in his review, of the form of Eumetopias with that of Callorhinus, in order to determine whether there was any difference in form in the two groups, a singularly improper basis was adopted, namely, the "ratio of the skull to the length of the male skin." His rather obscure comparative table serves only to represent the individual variation in the specimens of the same species, as exaggerated in stuffed specimens. Had he computed the ratio the length of the skull bears to that of the whole skeleton, data equally at his command, instead of between the skulls and skins, his table 
would have had some value as showing the variation in respect to this ratio that obtains between specimens of the same species. But the idea of determining the relative slenderness of two animals by the number of times the length of the head is contained in the total length of the body, is, to say the least, a novel one to me, since slenderness and robustness of form usually involve, as is well known, the head as well as the trunk, as a little reflection will doubtless at once convince ny reviewer. That the expression " 'form more slender" of the former [Ouloplocince] implies a greater relative total length for these animals than the head alone would indicate," is an announcement for which I was quite unprepared.

In regard to the length of the ear. in the two groups, it appears that Dr. Gill has also been unfortunate in his generalizations. According to his quoted measurements, the ear in the longest-eared species of the hair seals (Eumetopias) scarcely equals that of the shortest-eared species of the fur seals, but he seems to have forgotten that the bulk of Eumetopias is several times that of the largest of the fur seals, so that while the ear is absolutely but little longer in the fur seals than in the longest-eared hair seals, it is relatively very much longer.

Having said this much in regard to the validity of the characters I gave as distinctive of these two groups, I desire to add a word in respect to the matter of "conservatism."- Dr. Gill says, "In the case of doubtful species - at least of those which have tangible characters, but the value of which may be dubious - some naturalists refer such at once to species which they appear in their judgment to most resemble, while others - probably most - retain them with reserve, awaiting future information. Of the former school, Mr. Allen is an ardent disciple, and finding a certain range of variation in some known form, he concludes that analogous variations are only of like value." In reply to this, I will only say that my practice is to never reduce to a synonyme any species presenting "tangible characters," or even those which appear to have such characters, or where the probability seems to be that it may be distinct, though not as yet properly characterized. When no evidence of the validity of a given species has been advanced, which in the light of present facts can be so considered, I deem it subservient to the interests of science to refer them to the species to which they seem evidently to belong; as in no 
other way will their true character be more likely to be eventually made evident; for those authors who have recognized them as valid will be likely to reinvestigate the subject before submitting to their being dropped from our systems. All zoologists, I think, will admit that the tendency is to a multiplication of nominal species; and all likewise know how difficult it is to eradicate a nominal species from our systems. Probably few naturalists now doubt that many currently received species rest solely on characters of individual variation, and it seems to me unwise to retain such species as are unquestionably of this character in the hope that through some fortunate circumstance they may be some day proved valid. It seems to me impossible, in fact, that any one who has compared a large number of specimens of any well known species with each other, can resist the conviction that, as the number of specimens in our museums increases, the number of species will be greatly reduced, notwithstanding that in the mean time not a few really new ones may be discovered. I have myself found that the more common species of both the birds and mammals of eastern North America-of which I have examined, in many instances, hundreds of specimens of each - vary in size, and even in proportions, in specimens from the same locality and of the same sex, from twelve to twenty per cent. of their average size and form for that locality, and to a corresponding extent in color. Add to this the normal range of the geographical variation each species exhibits, which ordinarily fully equals that of the individual variation, ${ }^{*}$ and it becomes at once evident that with the custom of zoologists to describe species from a single specimen, and often an imperfect one, and their usual want of familiarity with the extent of variation within specific limits in the common species of their own country, the liabilities to an undue multiplication of species have been, and still are, very great. This to many may be a matter of small moment, but to the philosophical zoologist, who desires to carefully investigate the varied phenomena of animal life, it is one of high importance.

Having said thus much in reply to the strictures of Dr. Gill, I now reluctantly turn critic, and pass in review the classification of

* See on this subject a paper in the Bulletin of the Nuseum of Comparative Zoology (Vol. II, pp. 186-250) entitled, "On the Individual and Geographical Variation among Birds, considered in Respect to its Bearing upon the Value of Certain Assumed Specific Characters." 
the eared seals proposed by this author in his above-cited paper. While still agreeing with him in regard to the comparatively wide separation of Zalophus from its nearest allies, and in regard to its being intermediate between the fur and other hair seals in respect to size, but only in this point, I am compelled to still differ with him in respect to its constituting a primary group coördinate with that of all the other eared seals. * Whilst a somewhat aberrant form, it seems to me to be by no means very far removed from Eumetopias and Otaria. - I can, in fact, scarcely comprehend how it has happened that the author in question has overlooked the presence of a well developed sagittal crest in all the genera of the Otariadce except Zalophus, as he seems to have done in the differentiation of his two primary groups of this family. The supposition that he has examined only the skulls of females or young males of the other genera is hardly sufficient to explain this oversight, since figures indicating its presence in the males of the other genera have been long published, to say nothing of the many distinct allusions to it by authors. While familiar with the distinctive characters of Zalophus, he has failed to indicate them in his diagnoses, the comparatively unimportant character furnished by the rostral outline being far less characteristic than its slender elongated muzzle and other features, which had previously been well pointed out by Dr. Gill, as well as by other writers. The sagittal crest reaches, it is true, its maximum development in.Zalophus; but any one who has seen the high sagittal crest possessed by old males of Eumetopias Stelleri, in which as a thin solid plate it attains the height of $38 \mathrm{~mm}$., or an inch and a half; and the relatively scarcely less developed sagittal crest in old males of Callorhinus ursinus; and the figure of old male skulls of Otaria jubata, and some of the species of Arctocephalus, in which a high sagittal crest is represented; cannot but be surprised to find in what is assumed to be an enumeration of "the most obvious and distinctive characters" of the genera Callorhinus, Arctocephalus, Otaria and Eumetopius, a diagnosis contrasting " a sagittal groove from which are reflected the low ridges indicating the limits of the temporal muscles" in these genera, with "a solid, thin, and much elevated sagittal crest" in Zalophus! The females of Callorhinus ursinus and Otaria jubata, and, so far as at present known, of all 
the eared seals, have the "sagittal groove," etc., as above described, as do also the males till they have attained nearly their full size. The sagittal crest in the males of Eumetopias and Callorhinus rises at first as a double ridge on each side of the sagittal suture, beginning at the hinder part of the skull. It develops most rapidly in its posterior part, and gradually extends anteriorly to a point opposite the orbital processes. Gradually the laminæ of this double plate become soldered into one, uniting first posteriorly, while anteriorly the crest remains composed of two elosely applied thin plates, which, in old age, become firmly united the whole length. The sagittal crest in old male skulls of Zalophus hence differs from the corresponding crest in Eumetopias and Callorhinus, only in being relatively somewhat higher, and in being more produced anteriorly. I am not sure, however, that in very aged animals even this slight difference would be constant. In one of the skulls of Zalophus I have seen, the two plates were not entirely soldered at their anterior end, thus indicating their development primarily as a double plate, as in Eumetopias and Callorhinus. The only other character given as separating these two groups - that of the rostral profile-I deem too trivial to require more than the incidental remark already given to it.

In concluding, I may add that the deservedly high standing of my critic as a naturalist seemed to demand from me, in justice to myself, some notice of his sweeping criticisms, especially since not merely the assumed value of the characters given by me as distinguishing what I considered to be two primary groups of the Otariadce were questioned, but also even the existence of such distinctions ; but more especially it was due to the interests of science that his incorrect diagnosis of one of the two groups he considers as the two primary groups of this family, should not pass unnoticed, since on this error was based a new classification of the Otariadce. Having done this, the writer will here let the subject rest.-J. A. A. 


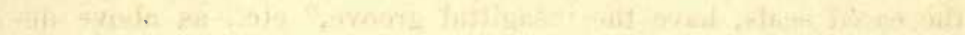

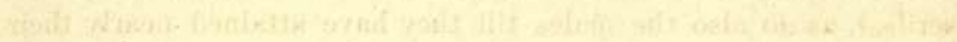

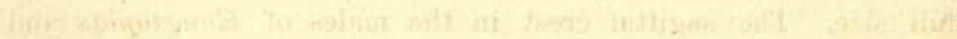

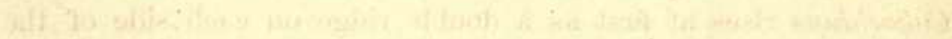

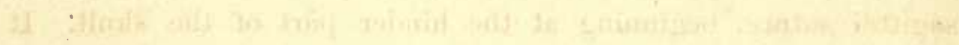

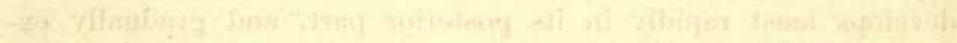

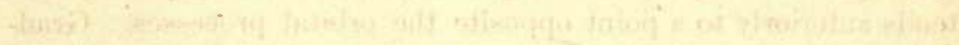

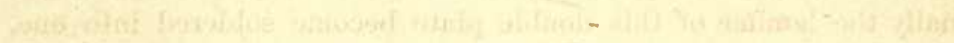

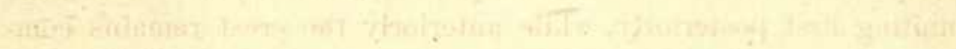

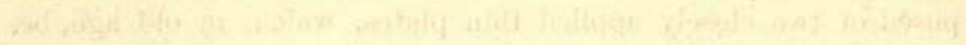

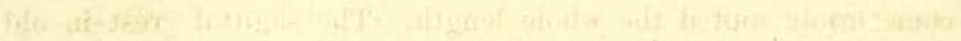
I:

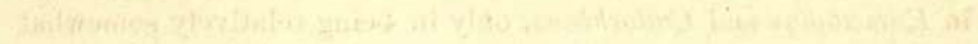

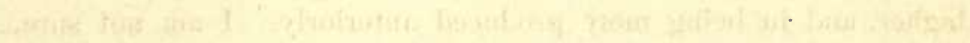

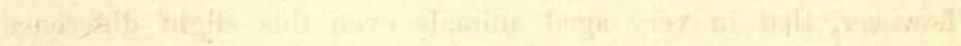

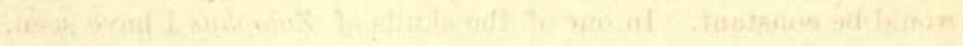

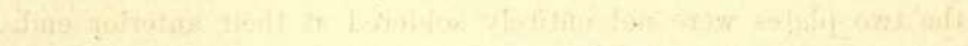

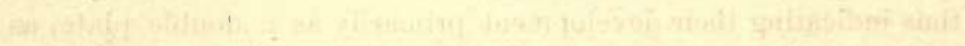
iting

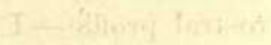

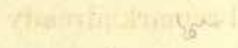

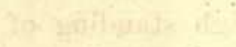

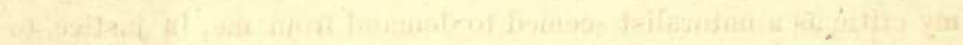

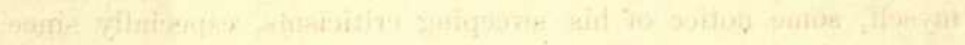

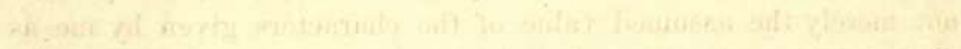

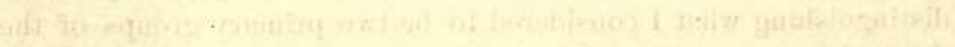

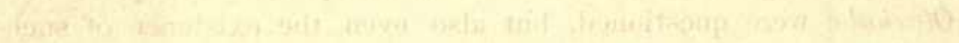

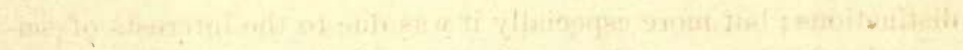

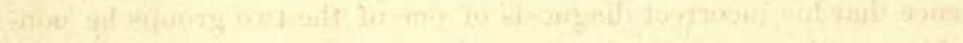

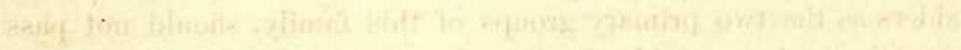

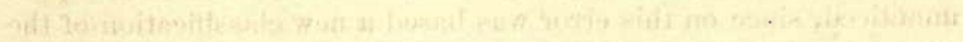

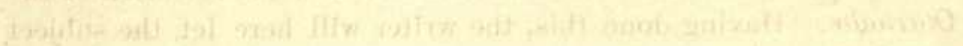

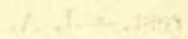





\section{SYNOPSIS}

OF THE

\section{AMERICAN LEPORID E.}

BY J. A. ALLEN.

BOSTON:

1875. 
From the Proceedings of the Boston Society of Natural History, Vol. XVII, February 17, 1875 .

\section{Synopsis of the American Leporide. By J. A. Allen.}

The following synopsis of the species and varieties of American Leporidæ is based mainly on the specimens of this group contained in the museum of the Smithsonian Institution at Washington, but those in the Museum of Comparative Zoology at Cambridge have also been used, as well as all accessible material from other sources. The present paper is an abstract of a monograph, in which the synonomy will be given in full, with extended tables of measurements and detailed descriptions.

\section{Analysis of the Species and Varieties.}

I. Skull much arched above; breadth one half the length; postorbital processes distinct, not soldered with the skull; nasals of medium length, their length equal to about four-fifths of the width of the skull.

A. Hind feet longer than the head. Size large. Postorbital processes divergent, not in contact with the skull posteriorly. Pelage white in winter. 
a. Size large. Nasals about as wide in front as behind.

1. Ears rather shorter than the head. Pelage dusky yellowish gray in summer, pure white to the roots in winter. Tail short, black above in summer. Size very large.

timidus var. arcticus.

2. Ears much longer than the head. Pelage pale yellowish gray in summer, in winter white at the surface and base, and reddish in the middle. Tail long, white on both surfaces. Size smaller . . . . . . campestris.

b. Size medium. Nasals considerably narrower in front than behind.

3. Ears about equal to the length of the head . . americanus.

3a. Pelage in summer pale cinnamon brown; in winter white at the surface and plumbeous at base, with a narrow middle band of reddish brown.

var. americanus.

3b. Pelage in summer cinnamon brown; in winter white at the surface and plumbeous at base, with a broad middle band of reddish brown, which shows through the white of the surface, the white being often a mere surface wash. Fully as large, or rather larger' than var. americanus.

var. virginianus.

3c. Pelage redder in summer and whiter in winter than in the last, and size smaller.

var. Washingtoni.

$3 d$. Size of the last, with the pelage more dusky in summer, and in winter nearly or wholly pure white to the base, the middle reddish band being more or less obsolete. . . . . . . var. Bairdii.

B. Hind feet not longer than the head. Size small. Postorbital processes convergent, frequently (in old specimens) in contact with the skull posteriorly, but only rarely anchylosed with it. Pelage never white.

4. Gray above, varied with black, and more or less tinged with light yellowish brown; under parts white . . syliaticus. 4a. Above yellowish brown, with a tinge of reddish. var. sylvaticus. 
4b. Paler, rather smaller, with slightly larger ears, and rather stouter lower jaw . . . var. Nuttalli.

4c. Color nearly as in var. sylvaticus; rather longer ears, more distinctly black-tipped . . var. Auduboni.

5. Smaller than sylvaticus, with the postorbital process scarcely touching the skull posteriorly. Colors generally more finely blended, and darker. Tail very short, almost rudimentary . . . . . . . . . Trowbridgei.

6. Above gray, varied with black and pale yellow. Size of

Trowbridgei, with the colors and sparsely clothed feet of palustris. Tail very short. . . . . brasiliensis.

II. Skull less convex above; breadth considerably less than half the length; length of nasals more than four-fifths the width of the skull. Ears and hind feet longer than the head. Postorbital processes convergent, touching the cranium behind. Pelage never white. Tail long, black above, this color extending forward on the rump.

A. Lower jaw large, massive.

7. Above pale yellowish gray, varied with black; below white, more or less tinged with fulvous . . . . callotis.

B. Lower jaw disproportionably small, relatively smaller than that of any other American species of Lepus.

8. Somewhat smaller than callotis, and more rufous above.

californicus.

III. Postorbital process anchylosed with the skull. Hind feet short. Pelage never white.

A. Width of the skull half of the length.

9. Size medium. Tail long . . . . . . . palustris.

B. Width of the skull considerably less than half the length.

10. Size large. Tail short . . . . . . aquaticus

\section{Lepus timidus var. articus.}

Lepus variabilis Pallas, Schreber, Gmelin and other early writers.

Lepus timidus Fabricius, Faun. Grœnl., 25, 1780.

Lepus articus Leach, Ross's Voyage, II., App. 151, 1819.

Lepus glacialis Leach, Ibid., 170.

Lepus glacialis Sabine, Richardson, Baird, and subsequent writers generally.

Habitat. Arctic America, southward on the Atlantic coast to Labrador and Newfoundland; in the interior southward to Fort Churchill, the northern shore of Great Slave Lake and the upper Youkon Valley. 
[Allen.

\section{Lepus campestris.}

Lepus variabilis Lewis, Bartram's Med. and Phys. Journ., II, 159, 1806.

Lepus virginianus, var.? Harlan, Faun. Amer., 310, 1825.

Lepus virginianus Richardson, Faun. Bor. Am., I, 224, 1829.

Lepus campestris Bachman, Journ. Acad. Nat. Sci. Phila., VII, 349, 1837. - Baird, Mam. N. Am., 585, 1857.

Lepus Townsendi Bachman, Journ. Acad. Nat. Sci. Phila., VIII, 90, 1839.

Habitat. Plains of the Saskatchewan southward to middle Kansas, and from Fort Riley westward to the Coast Range.

\section{Lepus americanus.}

a. var. americanus.

Lepus americanus Erxleben, Syst. Reg. Anim., 330, 1777. (Based wholly on Hudson's Bay specimens.)

Lepus americanus Baird and most modern authors. (In part only, this name also generally including var. virginianus.)

Lepus hudsonius Pallas, Nov. Sp. Glires, 30, 1778.

Lepus nanus Schreber, Säugt., II, 881, 1792. (In part only.)

Lepus campestris Baird, Ms. (Labels and Record Books, Sm. Inst.) - Hayden, Am. Nat., III, 115, 1869.

Lepus variabilis var. Godman, Am. Nat. Hist., II, 169, 1826. (In part only.)

Lepus borealis Schintz, Synopsis, II, 286, 1845.

Habitat. From the Aretic Barren Grounds southward to Nova Scotia, Lake Superior, and Northern Canada, and in the interior throughout the wooded parts of the Hudson's Bay Territories, and Alaska. Replaced west of the Rocky Mountains by var. Washingtoni.

$b$. var. virginianus.

Lepus virginianus Harlan, Faun. Am., 196, 1825. (Based wholly on Virginia specimens.)

Lepus americanus Bachman, Journ. Acad. Nat. Sci. Phila., VII, 403, 1837. (In part only). - Baird, Mam. N. Amer., 579, 1857. (In part only.)

Hubitat. Nova Scotia to Connecticuten the coast, the Canadas and the northern parts of the northern tier of States westward to Minnesota, and southward in the Alleghanies to Virginia, or throughout the Alleghanian and Canadian Faunæ.

PROCEEDINGS B. S. X. H. - VOL. XVIr. 
c. var. Washingtoni.

Lepus Washingtoni Baird, Proc. Acad. Nat. Sci. Phila., VII, 333, 1855. - Ibid., Mam. N. Am., 583, 1857.

Habilat. West of the Rocky Mountains, (mainly west of the Cascade Range?) from the mouth of the Columbia northward into British Columbia.

d. var. Bairdii.

Lepus Bairdii Hayden, Am. Nat., III, 115, 1869.

Habitat. The higher parts of the Rocky Mountains, southward to New Mexico, northward into British America.

\section{Lepus sylvaticus.}

a. var. sylvaticus.

Lepus nanus Schreber, Säugt., IV, 881, 1792. (In part only.)

Sylvilagus nanus Gray, Ann. and Mag. Nat. Hist., 3d Ser., XX, $221,1867$.

Lepus americanus Desmarest, Mammalogie, II, 354, 1822. - Bachman, Journ. Acad. Nat. Sei. Phila., VII, 326, 1837.

Lepus sylvaticus Bachman, Journ. Acad. Nat. Sci. Phila., VII, 403, 1837. - Ibid., VIII, 78, 1839. - Baird, Mam. N. Am., 579, 1857.

Habilat. United States east of the 97th meridian, excluding those portions embraced in the Canadian Fauna, (Northern New England and the more elevated parts of Appalachian Highlands).

b. var. Nuttalli.

Lepus Nuttalli Bachman, Journ. Acad. Nat. Sci. Ṕhila., VII, 345, 1837. (Based on an immature specimen.)

Lepus Bachmani Waterhouse, Proc. Zool. Soc. Lond., VI, 103, 1838. - Ibid., Nat. Hist. Mam., II, 124, 1848. - Baird, Mam. N. Am. $606,1857$.

Lepus artemisia Bachman, Journ. Acad. Nat. Sci. Phila., VIII, 94, 1839. - Baird, Mam. N. Am., 602, 1857.

Habitat. United States west of the 97th meridian, exclurling a narrow belt along the Pacific coast, and possibly southwestern Arizona and southern California.

c. var. Auduboni.

Lepus Auduboni Baird, Mam. N. Am., 608, 1857.

Habilat. Southwestern Arizona, southern and Lower California.

5. Lepus Trowbridgei.

Lepus trowbridgei Baird, Proc. Acad. Nat. Sci. Phila., VII, 333, 1855.-Ibid., Mam. N. Am., 610, 1857.

Habitat. West of the Sierra Nevada Range, from northern California to Cape St. Lucas. 
[Allen.

\section{Lepus brasiliensis.}

Lepus brasiliensis Linnæus, Syst. Nat., 12th ed., I., 78, 1766. - Also of subsequent authors generally.

Lepus tapeti Pallas, Nov. Sp. Glires, 30, 1778.

Tapeti brasliensis Gray, Ann. and Mag. Nat. Hist., 3d Ser., XX, $22,1867$.

Habitat. Throughout the greater part of South America.

7. Lepus callotis.

Lepus callotis Wagler, Nat. Syst. Amph., 35, 1830.-Baird, Mam. N. Am., 590, 1857.

Lepus nigricaudatus Bennett, Proc. Zool. Soc. Lond., I, 41, 1833.

? "Lepus mexicanus Licht." Richardson, Sixth Rep. British Ass., (1836), 150, 158, 1837.

Lepus [callotis var.] Aavigularis Wagner, Suppl. Schreber's Säught., IV, 107, 1844.

Lepus texianus Waterhouse, Nat. Hist. Mam., II, 136, 1848.-Aud. and Bach., Quad. N. Amer., III, 156, pl. 133, 1853.-Baird, Mam. N. Am., 617, 1857.

Habitat. United States between the 97 th meridian and the Sierra Nevada Mountains, and from Northern Kansas and the Great Salt Lake Basin southward into Mexico.

8. Lepus californicus.

Lepus californicus Gray, Charlesworth's Mag. Nat. Hist., I, 586, 1837.-Baird, Mam. N. Am., 594, 1857.

Lepus Richardsoni Bachman, Journ. Acad. Nat. Sci. Phila., VIII, $88,1839$.

Lepus Bennetti Gray, Zool. Voy. Sulphur, 35, pl. 14, 1844.

Habitat. California, west of the Sierra Nevada Range, south to Cape St. Lucas, Lower Cal.

9. Lepus palustris.

Lepus palustris Bachman. Journ. Acad. Nat. Sci. Phila., VII, 194, 336, pl. 15, 16, 1837. - Baird, Mam. N. Am., 615, 1827.

Lepus Douglassi, var. 2 Gray, Charlesworth's Mag. Nat. Hist., I, $586,1837$.

Hydrolagus palustris Gray, Ann. and Mag. Nat. Hist., 3d Ser., XX, $221,1867$.

Habitat. South Atlantic and Gulf States.

10. Lepus aquaticus.

Lepus aquaticus Bachman, Journ. Acad. Nat. Sci. Phila., VII, 319, pl. 22, fig. 2, 1837. - Baird, Mam. N. Am., 612, 1857. 
Lepus Douglassi, var. 1 Gray, Charlesworth's Mag. Nat. Hist., I, $586,1837$.

Hydrolagus aquaticus Gray, Ann. and Mag. Nat. Hist., 3d Ser., XX, 221, 1867.

Habitat. Gulf States, south through the lowlands of Mexico to Central America, (Orizaba, Mex., Sumichrast, Botteri; Tehuantepec, Mex., Sumichrast; Merida, Yucatan, Schott). 


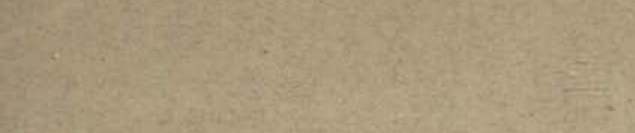

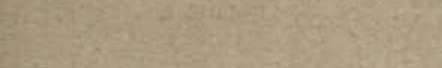

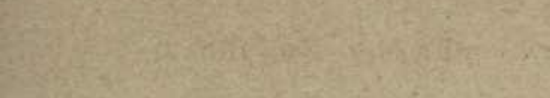

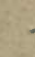

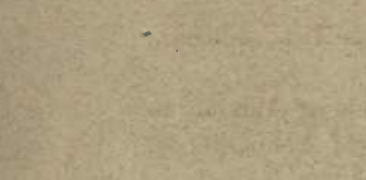

a.

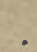





\section{DEPARTMENT OF THE INTERIOR.}

UNITED STATES GEOLOGICAL AND GEOGRAPHICAL SURVEY OF THE TERRITORIES.

F. V. HAYDEN, U. S. Geologist-in-Charge.

I.-SEXUAL, INDIVIDUAL, AND GEOGRAPHICAL VARIATION IN LEUCOSTICTE TEPHROCOTIS.

$$
\text { By J. A. ALLEN. }
$$

II.-GEOGRAPHICAL VARIATION AMONG NORTH AMERICAN MAMMALS, ESPECIALLY IN RESPECT TO SIZE.

$$
\text { By J. A. ALLEN. }
$$

EXTRACTED FROM BULLETIN OF THE GEOLOGICAL AND GEOGRAPHICAL SURVEY OF THE TERRITORIES, VOL. II, NO. 4. 



\title{
GEOGRAPHICAL VARIA'TION AMONG NORTH AMERICAN MAM- MALS, ESPECIALLY IN RESPECT TO SIZE.
}

\author{
By J. A. Allen.
}

\section{FERA (Suborder FISSIPEDIA).}

Having recently bad an opportunity (through the kindness of Professor Baird) of studying with some care the magnificent series of skulls of the North American Mammalia belonging to the National Museum (amounting often to eighty or a hundred specimens of a single species), I have been strongly impressed with the different degrees of variability exhibited by the representatives of the species and genera of eren the same family. The variation in size, for instance, with latitude, in the Wolves and Foxes is surprisingly great, amounting in some species (as will be shown later) to 25 per cent. of the average size of the species, while in other species of the Ferce it is almost nil. Contrary to the general supposition, the variation in size among representatives of the same species is not always a decrease with the decrease of the latitude of the locality, but is in some cases exactly the reverse, in some species there being a very considerable and indisputable increase southroard. This, for instance, is very markedly true of some species of Felis aud in Procyon lotor. Consequently, the very generally-received impression that in North America the species of Mammalia diminish in size southward, or with the decrease in the latitude (and altitude) of the locality, requires modification. While such is generally the case, the reverse of this too often occurs, with occasional instances also of a total absence of variation in size with locality, to be considered as form: ing "the exceptions" necessary to "prove the rule".

That there are such exceptions, both among Birds and Mammals, I have been long aware, and long since noticed that where there is an actual increase in size to the southward it occurs in species that belong to families or genera that are mainly developed within the tropies, there reaching their maximum development, both in respect to the number of their specific representatives, and in respect to the size to which some of the species attain. This fact seems also to hare been observed by others.*

Most of the Mammals of North America belong to families, subfamilies, or genera which have their greatest development in the temperate or colder portions of the northern hemisphere, as the Cervida, the Canida, the Mustelidoe, the Sciuridoe (especially the subfamily Arctomy-

* I find that Mr. Robert Ridgway, some two years since, thus referred to this point. In alluding to the smaller size of Mexican specimens of Catharpes mexicanus as compared with specimens from Colorado, (C. mexicanus var. conspusus) he says: "As we find this peculiarity exactly paralleled in the Thryotharus!ludovicianus of the Atlantic States, may not these facts point out a law to the effect that in genera and species in the temperate zone the increase in size with latitude is toward the region of the highcst development of the group ?"-Baird, Brewer, and Ridgwas's Birds of North America, Vol. III, App., p. 503, 1874. 
ince), the Leporida, the Castorida, the Arvicolina among the Murida, the Saccomyidce, Geomyida, etc. These rarely present an exception to the general law of decrease in size southward, though the variation is less (in fact, occasionally almost $\mathrm{nil}$ ) in some species than in the others. The more marked exceptions, or those in which there is an actual increase in size southward, occur in those families that reach their highest development with the tropics, as the Felidee and Procyonida.

In some species (as I have elsewhere noticed), there probably exists a double decadence in size, the individual reaching its maximum dimen. sions where the conditions of environment are most favorable for the existence of the species, diminishing in size toward the northern (through scarcity of food and sererity of climate) as well as toward the southern (in consequence of the enervating influence of tropical or semitropical conditions) limit of its distribution.

In a general way, the correlation of size with geographical distribution may be formulated in the following propositions :

(1) The maximum physical development of the individual is attained where the conditions of environment are most favorable to the life of the species. Species being primarily limited in their distribution by climatic conditions, their representatives living at or near either of ther respective latitudinal boundaries are more or less unfarorably affected by the influences that finally limit the range of the species. These influences may be the direct effects of too high or too low a temperature, too little or too much humidity, or their indirect effects acting upon the plants or other sources of food. Hence the size of the individual generally correlates with the abundance or scarcity of food. Different species being constitutionally fitted for different climatic conditions, surroundings favorable to one may be very unfavorable to others, eren of the same family or genus. Hence

(2) The largest species of a group (genus, subfamily, or family, as the case may be) are found where the group to which they severaily belong reaches its highest development, or where it has what may be termed its center of distribution. In other words, species of a given group attain their maximum size where the conditions of existence for the group in question are the most farorable, just as the largest representatives of a species are found where the couditions are must favorable for the existence of the species.

(3) The most "typical" or most generalized representatives of a group are found also near its center of distribution, outlying forms being generally more or less "aberrant" or specialized. Thus the Cervidce, though nearly cosmopolitan in their distribution, attain their greatest development, both as respects the size and the number of the species, in the temperate portions of the northern hemisphere. The tropical species of this group are the smallest of its representatives. Those of the teniperate and cold-temperate regions are the largest, where, too, the species are the most nnmerous. Most of the species of this family also have a wide geographical range, and their representatives respectirely present great differences in size with locality, namely, a very marked decrease in size to the south ward. The possession of large, branching, deciduous antlers forms one of the marked features of the family. These appendages attain their greatest derelopment in the uorthern species, the tropical forms having them reduced almost to mere spikes, which in some species never pass beyond a rudimentary state. Beginning at the northward, we hare first, in the subarctic and cold-temperate regions, the Alcine and Sangerine forms, species of the largest size, with heavy, large antlers. Next, in the colder-temperate regions, come the Elaphine species, also of very large size, with nearly the largest antlers of any of the Cervidce. We 
next meet, in the temperate and warmer regions generally, the smaller Capreoline and Rusine forms, decreasing in size south ward, with a rapid reduction also in the size of the antlers. Finally, in the subtropical and tropical portions of the Old World, we meet with antlerless forms, that constitute the smallest species known among the Cervidae and their allies.

The decrease in the size of the antlers south ward among the different genera and species is also well marked among individuals of the same species, especially among the Cariacine deer of North America.

The Canidoe form another family, which, while having a nearly cosmopolitan distribution, is most numerously represented in the temperate regions of the northern hemisphere, where also occur nearly all of the larger species, and where are exclusively found the true Wolves and Foxes. In respect to the latter, the larger species of each occur only at the northward, and the smaller at the soutbward. Thus, in North America, the large Gray Wolf ranges from the arctic regions to Florida and Mexico, while the Coyote is not found much to the northward of the great campestrian region of the interior. The Common Fox ranges also from the subarctic districts southward to the Gulf of Mexico, while the smaller Gray Fox finds its northern limit near the parallel of $42 \circ$, while a third still smaller species is confined within the warmertemperate latitudes. At the extreme northward, we find, however, a smaller arctic form, on the extreme northern confines of the habitat of the family. In the Wolves and Foxes, decrease in size to the south ward is strongly marked, being probably not exceeded in any other group, thongh perhaps nearly equaled in some of the Cariacine Deer.

The Ursidae, while having a wide geographical range, are confined mainly to the north hemisphere, thronghout which they have representatives. Here again the larger species are northern, while all the warmtemperate and subtropical forms are suall. There is also a corresponding decrease in size southward among the representatives of the several species. (See later portions of the paper for a somewhat detailed discussion of the North American species.)

The Mustelida, while mainly confined to the northern bemisphere, have also representatives south of the equator. Of the Mustelince proper, all the larger species are boreal, though some of the smaller extend also to the arctic regions. The Wolverine, the largest of the group, is the most boreal ; the Fisher and the Marten, the next in size, are mainly confined to the subaretic and cold-temperate regions; the Mink, next in size, extends farther southward; the Weasels range also into the middle-temperate latitudes, with a siugle species occurring (only at considerable altitudes) under the tropics. Galictis is its single tropical representative, and is also the most specialized (though not the smallest) type of the group. The Melinoe and Enhydrince, each with a single American representative, and both boreal, are also among the largest representatives of the family. The Mephitince, of medium or rather small size, are strictly a warm-temperate and tropical group, with representatives extending from the northern parts of the United States southward to the southern parts of South America. The Lutrince have a wider range, being found throughout the tropics as well as in the temperate and colder regions, and apparently present not a very great range of geographical variation.

The Felidec, while possessing an almost cosmopolitan range, have their greatest development within the tropics, where thes attain their maximum size and number of species. The single boreal genus found in America is one of the most specialized forms of the family. As will be shown later, the American representatives of this family present a notable exception to the general law of decrease in size toward the No. $4-3$ 
south, and confirm the law of increase in size toward the geographical center of the group to which they beloug.

The Procyonidae are essentially a tropical family, in which regions are found the largest species and the greatest variety of forms. The single North American species presents a marked increase in size southward, as will be fully shown later.

The Glires, or Rodentia, are found throughout the greater part of the world, but are represented by special groups in different regions. Being strictly herbivorous, they are most numerously developed in the tem. perate and warmer latitudes. The largest known species are tropical, but others of large size are more or less boreal. In the northern hem. isphere, the largest species is the Beaver, which formerly ranged throughout the temperate latitudes. Of the Murida, the larger species are southern, the smaller northern; and there is a tendency (among some of the species, at least) to an increase in size southward, as in some of the varieties of Hesperomys leucopus. The Arvicolince, on the other hand, are subarctic and temperate in their distribution, and markedly increase in size to the northward. Here, likewise, the largest species of the group are met with.

The Sciuridce are also a nearly cosmopolitan group, with different genera and subfamilies specially characteristic of different regions. The Sciurince are most numerously represented in the warm-temperate and subtropical latitudes, where also occur the largest species. Yet some of those of the more northern districts show a decided tendency to diminution in size southward, while in others the decrease in this direction is less marked. The Arctomyina are temperate and subarctic, and the largest species occur at the northward. Parry's Marmot is the most boreal and much the largest. Franklin's Spermophile next succeeds, and is one of the largest of the group. Spermophilus grammurus (with its varieties Beecheyi and Douglassi), of about the same dimension, occupies the elevated interior and the Pacific slope, extending, however, quite far southward. The smallest of the group, S. Harrisii, S. spilosoma, and $S$. mexicana, have a more southern range. In all of these species, there is a marked decrease in size to the southward in their respective representatives, as there is among the species themselves. Arctomys and Sciuropterus are boreal genera, with their larger species and varieties occurring at the northward, and a northward increase in size in the representatives of their several forms.

The Leporidae of America are mainly restricted to the northern continent, their center of development as respects the number of species, being the United States. Here occur also nearly all of the larger forms. The Polar Hare, one of the largest, is strictly arctic; three or four others of nearly equal size find their northern limit, with one exception, south of the forty-ninth parallel. The most remarkable trait of the family is the rather small degree of geographical variation its representatives present, both as respects size and coloration. The difference in size between the largest and smallest species is less than is often found in any co-ordinate group having the same number of species, and the species themselves present great constancy of character. There is generally a slight decrease in size southward among individuals of the same species, but sometimes the difference is scarcely perceptible. In the most northerly but one* of the species (Lepus americanus), there is apparently a very slight decrease (certainly no increase) in size northward.

\footnotetext{
* The material at hand is too scanty to afford grounds for any satisfactory generalization respecting the Polar Hare.
} 
With these general remarks, we will pass now to a more special exam. ination of geographical variation in size in several of the more common species of the North American Ferce, based on the abundant material in the National Museum.

\section{CANIS LUPUS.}

The common Gray Wolf of the northern hemisphere presents a range of individual variation in color exceeded by but few known species of Mammals; gray, white, and black individuals, with various intermediate stages of coloration, occurring with greater or less frequency wherever the species abounds, several of these varieties sometimes occurring in the same litter. Black and white wolves seem to occur more frequently at some localities than others, but gray is generally nearly everywhere the prevailing color. Cream-colored and rufous varieties are also said to have a wide prevalence over some parts of the great plains of the interior. To what extent these variations in color are to be considered as geographic is not yet well established.* With such an evident tendency to variability, it is not surprising that geographical variation in size is displayed in this species to a marked degree. The variation in this respect constitutes a pretty uniform decrease in size south ward, as shown (see the subjoined table) by the size of the skall, only fully adult skulls being here taken. The largest are from Fort Simpson and other localities in or near the Mackenzie River district, six of which, out of a series of nine specimens, exceed 10.25 inches in length (one reaching 11.50 !), and the other three average above 9.50, the whole averaging 10.38. The next in size are from the region about Puget Sound, a series of three (the only ones in the collection), areraging nearly 10.50. Of sixteen specimens from Forts Benton, Union, and Randall, on the Upper Missouri, the average is 9.45, the extremes being $\mathbf{1 0 . 5 0}$ and 8.50. Nine specimens from Forts Kearney and Harker (chiefly from Fort Kearney, and all pretty old) average a little larger than the Upper Missouri specimens, the extremes being 10.15 and 9.35. A single specimen from the mountains of New Mexico reaches 10.00, while the three most southern (from the Rio Grande and Sonora, Mexico) average only 8.37 , being the smallest of the whole series, and averaging 2.00 shorter than the series of nine from the Mackenzie River region. This difference is fully 25 per cent. of the average size of a series of upward of eighty specimens; while the difference between the smallest (from Saltillo, Mexico) and the largest (from Fort Simpson) is 3.75 , or nearly 40 per cent. of the average size of the whole series !

* See further on color variation in this species, Bull. Mus. Comp. Zoöl., vol. i, pp. $154-158$. 


\begin{tabular}{|c|c|c|c|}
\hline 密 & 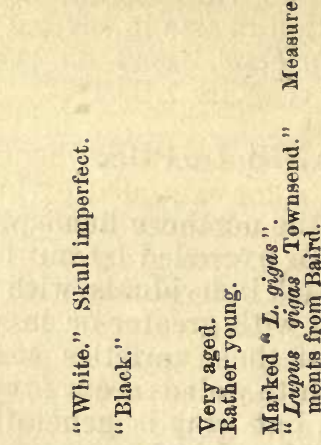 & 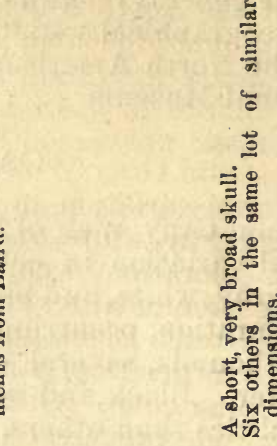 & 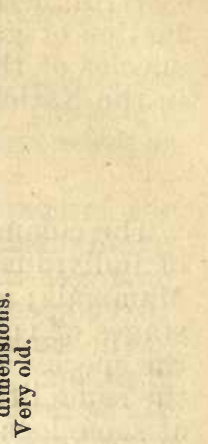 \\
\hline 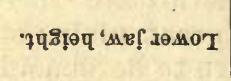 & 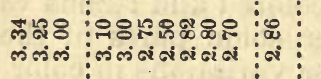 & 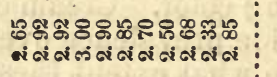 & 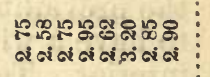 \\
\hline 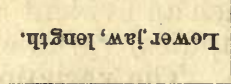 & 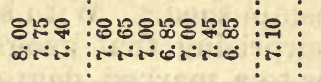 & 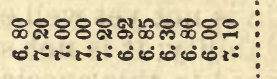 & 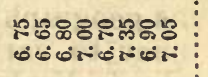 \\
\hline 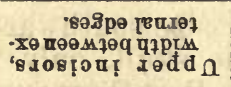 & 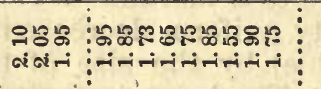 & 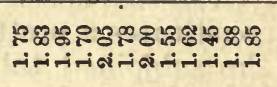 & 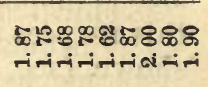 \\
\hline 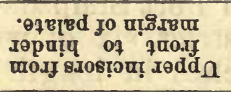 & 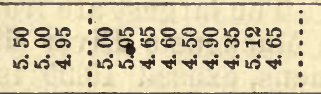 & 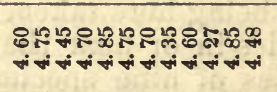 & 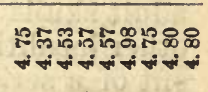 \\
\hline 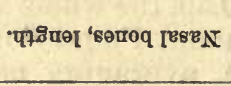 & 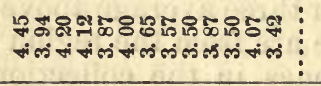 & 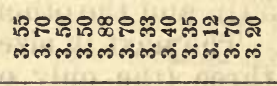 & 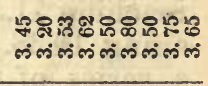 \\
\hline นәөмрәq & 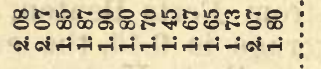 & 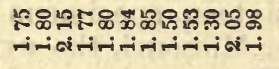 & 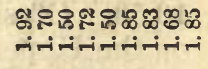 \\
\hline 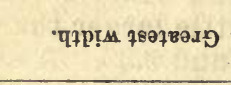 & 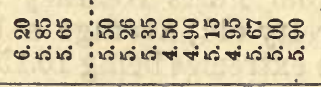 & 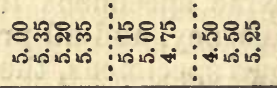 & 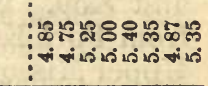 \\
\hline 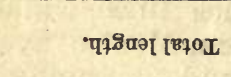 & 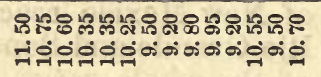 & 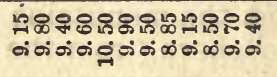 & 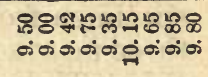 \\
\hline 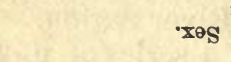 & & & \\
\hline - & 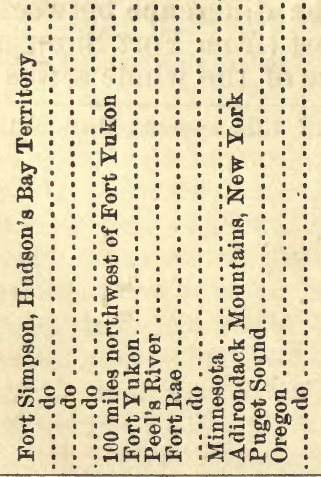 & 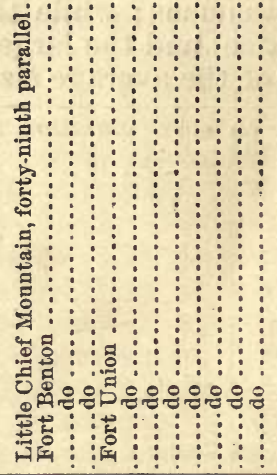 & 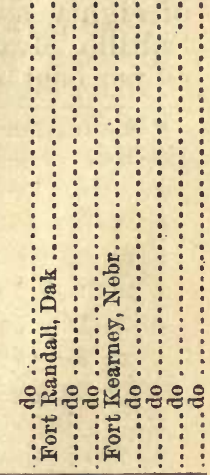 \\
\hline \multicolumn{4}{|l|}{ 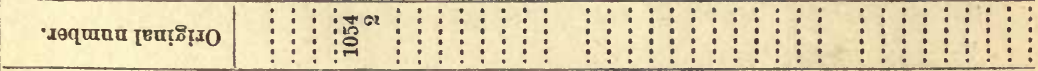 } \\
\hline 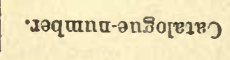 & 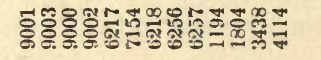 & शి & 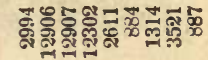 \\
\hline
\end{tabular}




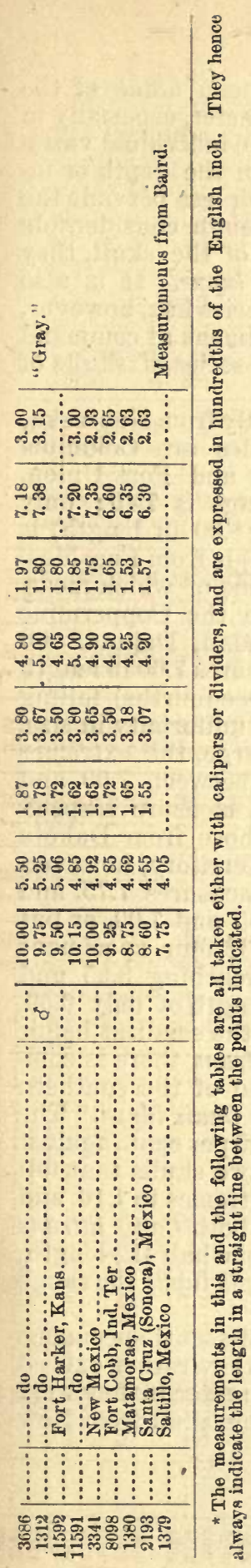




\section{CANIS LATRANS.}

The Coyote, or Prairie Wolf, the nearest American affine of the Gray Wolf, is as remarkable for its constancy of character, especially in respect to color, as the latter is for its variability. The individual variations in the color of Canis latrans consist generally in the depth or intensity of the shadings of black or rufous that more or less pervade the pelage of certain parts of the head and body. Although considerable variations have been noticed in respect to the form of the skull, they are small in proportion to those presented by Canis lupus. It is also much less influenced apparently by locality. The species has, however, a less extended range than Canis lupus, and the specimens at command represent localities less widely separated than do the series of skulls of Canis lupus.

Measurements of forty skulls are given below, mainly from Nebraska, Dakota, and Wyoming. The most distant localities are Columbia River and Fort Tejon, California, Southern Texas, and Fort Union, Montana. Of this series of forty skulls, the average is 7.40 ; only two attain a length of 8.00 , one of which (measuring 8.00 in length) is from Fort Union, and the other ( 8.05 inches in length) is from Fort Massachusetts, New Mexico. Only two fall below 6.95, one of which measures 6.65 and the other 6.50 ; the smaller being from the Coppermine River, New Mexico, and the other from Fort Randall, Dakota. Of thirteen specimens from Fort Randall, the largestmeasures 7.60 in length and the smallest 6.65 , the majority (more than three-fourths) falling between 7.00 and 7.50, thus presenting a remarkable uniformity in size. Ten others from Fort Kearney average fully as large, the extremes being 6.95 and 7.60 , while four-fifths of them fall between 7.00 and 7.50. Three specimens from Fort Tejon, California, measure respectively 7.95, 7.60, and 7.45, or above the average of those from Dakota and Nebraska! Four specimens from Wyoming Territory, however, measure each 7.80. A single San Diego specimen measures 7.75, and two specimens from Southern Texas respectively 6.95 and 7.00 , or but little below the average of northern specimens. Of four specimens from New Mexico, three attain or exceed 7.40, one reaching 8.05 and forming the largest of the series; the other, with a length of only 6.50, forms the smallest of the series, both the largest and the sinallest being from New Mexico. It thus appears that in Canis latrans there is com. paratively little decrease in size southward, instead of the southern averaging fully 25 per cent. smaller, as is the case in Canis lupus. The difference between the extremes is onl 51.55 , or about 20 per cent., against twice that amount in Canis lupus. Throwing out the two skulls that fall below 6.95 would reduce the difference between the extremes to 1.10 , and the variation to only 15 per cent. of the average! In both Canis latrans and Canislupus, the width of the skull averages about one-half the length, ranging in Canis latrans from 0.49 to 0.52 , while in Canis lupus the range in this proportion is from 0.48 to 0.56 .

A glance at the table shows that while the Upper Missouri specimens are rather younger than those from Fort Kearney, they rather exceed them in size, and the difference would be somewhat greater if they were of strictly corresponding ages. The single very large skull from New Mexico is also that of a very old individual. 


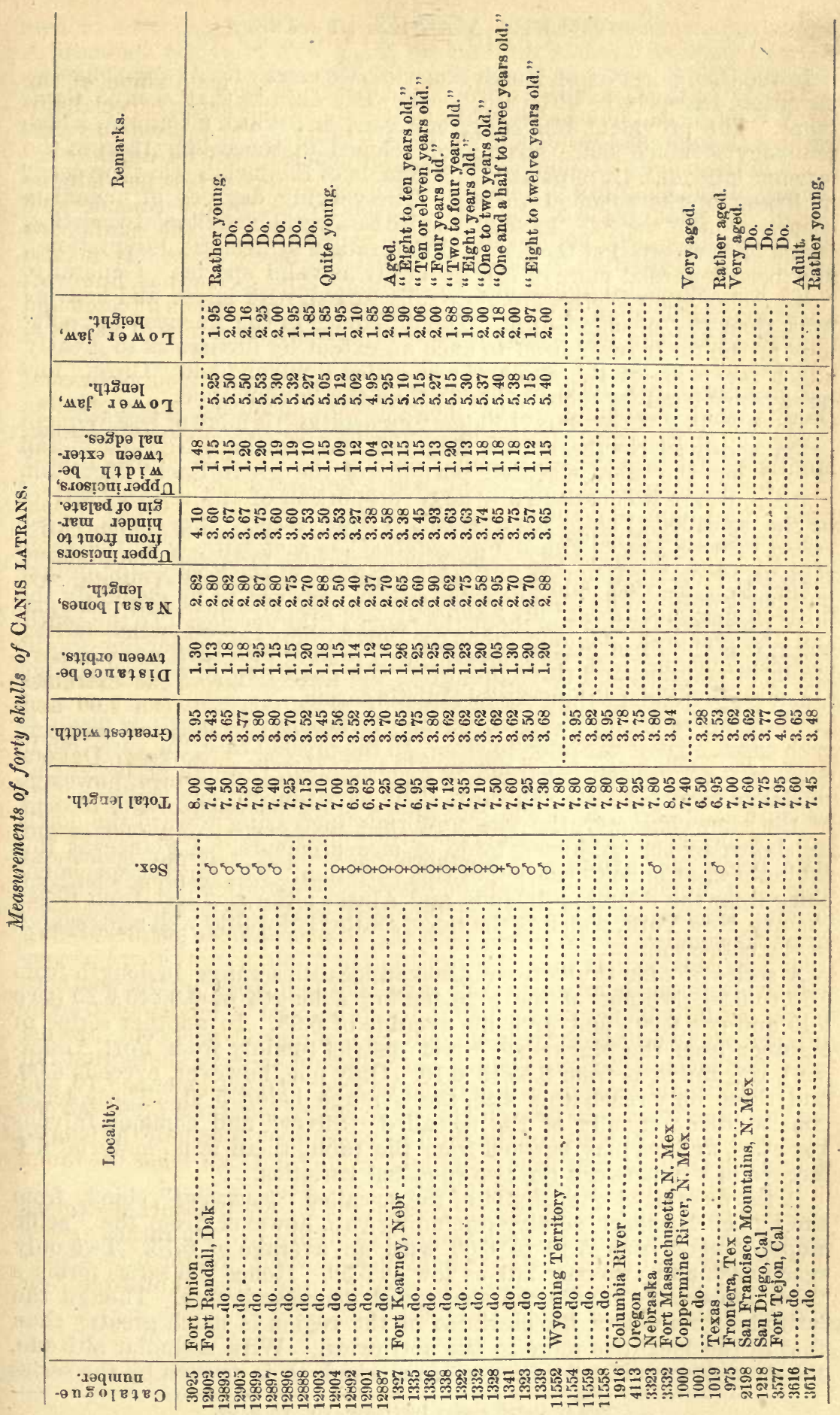




\section{VULPES ALOPEX ET VARS.}

In the Common Fox of North America, we meet with a range of colorvariation, irrespective of locality, somewhat akin to that seen in Canis lupus. The prevalent tendency, however, is toward melanism, which tendency is much more strongly developed in the colder than in the warmer latitudes. Frequently, individuals of the melanistic type occur in litters of the common variety. The varying degrees of melanism occurring in this species have given rise to several commercial varieties, which have received at the hands of naturalists systematic designations, and been regarded more or less generally as valid species. Generally, these melanistic varieties are more fully furred, with larger and heavier tails, than the common form. The difference in the fineness and softness of the fur is recognized to such an extent by furriers as to greatly affect the price of the skins, the so-called "Silver" and "Cross" furs being considered far more valuable than the fulvous type.

The so-called "Cross Fox" (Vulpes "decussatus") is more or less frequent as far south as Northern New England and Northern New York, and throughout the more elevated portions of the great Rocky Mountain plateau, where it constitutes a large proportion of the representatives of the so-called Vulpes "macrurus". More rarely, the Black or socalled "Silver Fox" (Vulpes "argentatus") is met with over the same regions, becoming frequent in the higher parts of the Rocky Mountains* and northward. The fulvous form seems, however, to be generally the more prevalent form throughout the range of the species. To the southward, it is the form exclusively met with; but near timber-line in the RockJ Mountains, and throughout the "fur countries", it seems to be not much more frequent than the melanistic forms.

With this tendency to great rariability in color, we meet, as usual in such cases, a great variation in size. In the present case, the variation in color may be properly regarded as geographical, through an increasing tendency to melanism northward. The variation in size is also chiefly of the same character, the size uniformly increasing toward the north, as shown by the subjoined table of measurements. A glance at this table shows at once the nature of this variation. The largest specimens come from the Aleutian Islands and Alaska; the smallest from Essex County, New York, which is the most southerly locality well represented in the collection.

A series of nine skulls from Alaskan localities range in length from 5.70 to 6.20 , five out of the nine having a length of 6.00 to 6.20 (two 6.15 and two 6.20), and give an average of 5.98. In another series of eighteen from the Mackenzie River district (mainly from Fort Anderson), the range is from 5.55 to 6.10. Ouly one, however, exceeds 6.00, and three only reach this size, the arerage being 5.80. These series consist about equally of the so-called "Silver" and common fulvous rarieties, and, as may be seen from the table, there is no material difference in size between the two so called varieties.

A third series of nine skulls, of the so-called "macrurus", chiefly from the Upper Missouri country (including two, however, from the Pacific slope), ranges from 5.40 to 6.00 , with an average of 5.75 . Two only reach 6.00, and two only fall as low as 5.50. Hence the series forms a third appreciable step in the southward decrease in size. Though the latitude is much less, the elevation of the region is much greater than that of the localities more to the northward. With a similar altitude, the decrease would have been more marked, as is proven by the series

*See Bulletin Essex Institute, vol. vi, p. 54. 
next to be considered. A fourth series of twelve specimens, from the Adirondack region of New York, ranges from 5.20 to 5.68, with an average of 5.40. Only three specimens range above 5.50, while four fall below 5.30. A fifth series of five skulls, from European localities, ranges from 5.50 to 5.70, with an average of 5.58.

In the Alaskan series, the width ranges from 2.90 to 3.32 , averaging 3.20 ; in the Mackenzie River district series, from 2.87 to 3.28 , averaging 3.02 ; in the " macrurus" series, from 2.70 to 3.20 , averaging 2.90 ; in the Adirondack series, the width ranges from 2.70 to 2.95 , averaging 2.80 ; in the European series, from 3.05 to 3.15, averaging 3.08. Hence-

Alaskan series

Mackenzie River District series...................................

"Macrurus" series .............................................

Adirondack series

European serios.

Average width.

\begin{tabular}{|c|c|c|}
\hline 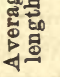 & Average & width. \\
\hline $\begin{array}{l}5.98 \\
5.80 \\
5.75 \\
5.40 \\
5.58\end{array}$ & $\begin{array}{l}3.20 \text {, or } 0.535 \\
3.02 \text {, or } 0.521 \\
2.90 \text {, or } 0.504 \\
2.80 \text {, or } 0.518 \\
3.08 \text {, or } 0.552\end{array}$ & $\begin{array}{l}5 \text { of length. } \\
1 \text { of length. } \\
4 \text { of length. } \\
8 \text { of length. } \\
2 \text { of length. }\end{array}$ \\
\hline
\end{tabular}

It thus appears that in the American specimens there is not only a well-marked southward decrease in size, but also a decrease in the relative breadth of the skull, through the greater elongation of the facial portion; also that the relative breadth is quite appreciably greater in the European form, as noticed long since by Professor Baird.*

While the European Vulpes vulgaris may be considered as subspecifically distinct from the American (Vulpes vulgaris subsp. fulvus), through its wider.skull, less pointed and shorter muzzle, harsher and more reddish fur, etc., the different so-called American "species" or "varieties" ( fulvus, "decussatus", "argentatus", and "macrurus") do not have the same claim to subspecific recognition. The Foxes of the colder regious, it is true, have a fuller and softer pelage, a greater tendency to melanism, shorter muzzles, and are larger, yet these differences are so inconstant, especially the differences of color, and so insensibly intergrade, that any attempt at their subspecific recognition seems impracticable, the most direrse varieties in color occurring at the same localities and eren among individuals of the same litter. $\dagger$

* Mam. N. Amer., pp. 126, 130.

† On this point see Bulletin Mus. Comp. Zoöl., vol. i, pp. 159, 160. 
Measurements of fifty-three skulls of VULPES ALOPEX et vars.

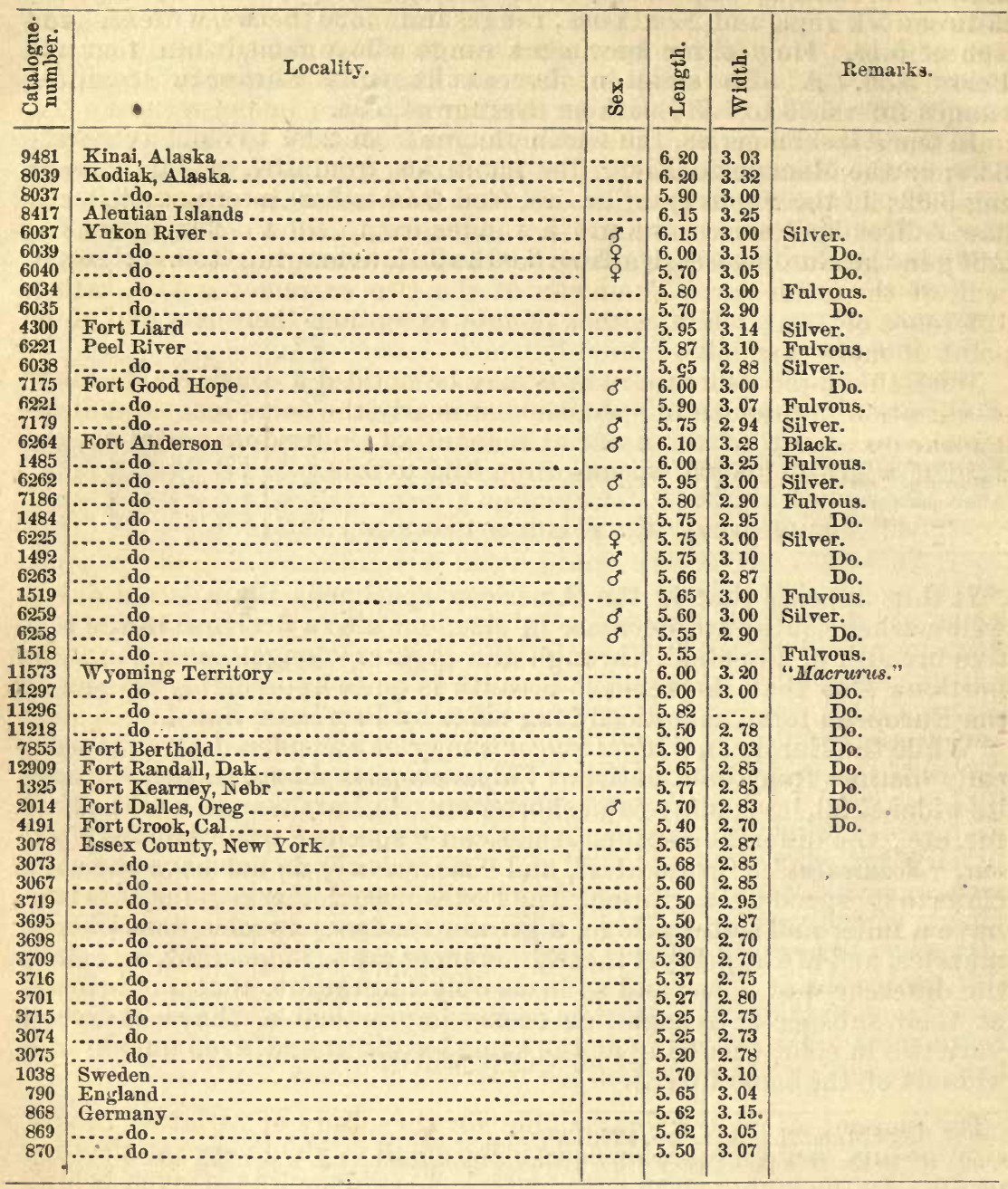

UROCYON VIRGINIANUS.

Measurements of a series of fifteen skulls of this species (all of the available material) form a series grading by slight differences in length from 3.73, the smallest, to 4.77 , the largest. The largest specimens are from Pennsylvania, Washington, and Virginia; all these exceed 4.60 in length. The next in size are from Southern Texas and Southern California, which range in length from 4.63 down to 4.50. Next come three specimens from Tehuantepec, Southern Mexico, which range from 4.40 to 4.15. Between these and the next-a series of three "littoralis" skulls from the islands off Southern California-is an interval of threetenths of an inch, the three "littoralis" skulls ranging from 3.85 to 3.75. The smallest of all, however, is a single well-matured skull from Merida, Yucatan, 3.73 in length, and hence smaller even than the smallest "littoralis" skull, its breadth being only 1.98 against a breadth of 2.05 in the narrowest "littoralis" specimen. The localities represented 
are few and widely separated; there being no specimens from points between Virginia and Southern Texas, and none between Texas and Tehuantepec, Mexico, nor between these two last-named localities and Fort Tejon, Cal. The small insular race known as "littoralis", from the islands off the coast of Southern California, come in between the Tehuantepec specimens and the example from Merida. While there are no rery considerable breaks in the chain, the gradation would be more complete if specimens could be included from other intermediate localities. The specimens at hand are sufficient to show a very great but still very gradual decrease in size southward, amounting to over 25 per cent. of the mean size. The mean of the two extremes is 4.25 , with a difference of 1.04 ; while, with a single exception, there is a gap at no point of more than 0.08 .

With this rapid decrease in size may be noticed a considerable range of variation in breadth in specimens of nearly the same length, indicating the existence of an unusual amount of individual rariation, the ratio of width to length varying from 0.54 to 0.59 .

Measurements of fifteen skulls of UROCyox virgixiaxus.

\begin{tabular}{|c|c|c|c|c|c|}
\hline 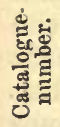 & Locality. & 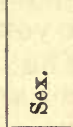 & 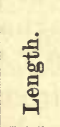 & 递 & Remarks. \\
\hline 4729 & Pennsylvania.... & & 4. 77 & 2. 70 & \\
\hline 968 & Washington, D. C... & $q$ & 4. 70 & 2.56 & \\
\hline 671 & White Sulphur Springs, & $\therefore \ldots$ & 4. 62 & 2.65 & \\
\hline 7491 & 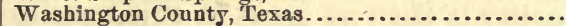 & $\ldots . .$. & 4. 60 & 2. 70 & \\
\hline 1175 & 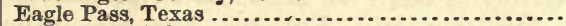 & $\ldots . .$. & 4. 50 & 2.58 & \\
\hline 3543 & Fort Tejon, Cal...$\ldots \ldots \ldots \ldots \ldots \ldots \ldots \ldots$ & $\ldots . .$. & 4. 63 & 2.53 & \\
\hline 3545 & 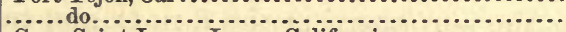 & $\ldots . .$. & 4.55 & 2.65 & \\
\hline 4140 & 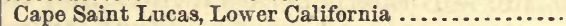 & & 4.50 & 2.43 & \\
\hline 8659 & 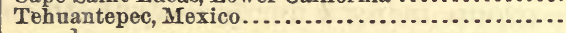 & $\ldots .$. & 4. 40 & 2. 35 & . \\
\hline 8662 & 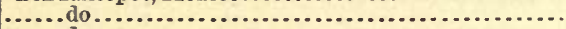 & $\ldots \ldots$ & 4. 27 & 2. 37 & \\
\hline 13851 & ( & $\ldots . .$. & 4. 15 & 2. 25 & \\
\hline 2275 & 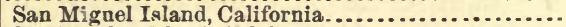 & & 3.85 & 2.23 & Var. littoralis. \\
\hline 2154 & San Nicolas Island, California ................... & ....... & 3. 80 & 2.05 & Do. \\
\hline 6323 & ..... do & $\ldots . .$. & 3.75 & 2.10 & Do. \\
\hline 13477 & 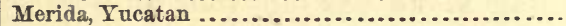 & $\ldots . .$. & 3. 73 & 1.98 & \\
\hline
\end{tabular}

\section{FELIS CONCOLOR.}

The amount of material available for the study of variation in size with locality in the present species is too small to yield very satisfactory results. In the eight specimens of which measurements are given below, it will be noticed that there is a decided increase in size southward. Between the three skulls from northern localities (one each from Northern New York and Washington and Oregon Territories) and the three (mature) skulls from southern localities (Louisiana and the Rio Grande, Texas), the arerage difference is fully an inch, or about one-eighth of the mean size.

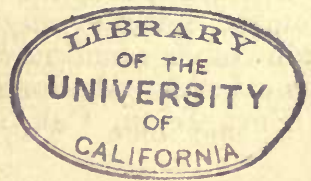


Measurements of eight skulls of FELIS CONCOLOR.

\begin{tabular}{|c|c|c|c|c|c|}
\hline 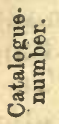 & Loc & $\begin{array}{l}\dot{\mathscr{H}} \\
\ddot{\oplus}\end{array}$ & 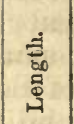 & 营 & Remarks. \\
\hline $\begin{array}{l}3811 \\
8597 \\
3267 \\
1148 \\
1356 \\
1355 \\
1895 \\
1158\end{array}$ & 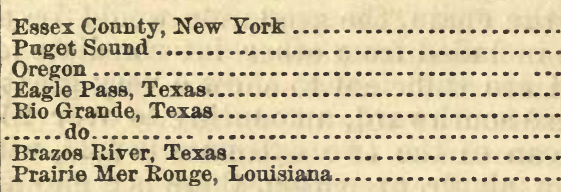 & $\begin{array}{l}\cdots \cdots \\
\cdots \cdots \\
\cdots \cdots \\
\cdots \cdots \\
\cdots \cdots \\
\cdots \cdots\end{array}$ & $\begin{array}{l}7.40 \\
7.50 \\
7.80 \\
7.75 \\
7.50 \\
8.40 \\
8.50 \\
8.75\end{array}$ & $\begin{array}{l}5.25 \\
5.05 \\
5.15 \\
4.95 \\
5.00 \\
5.35 \\
5.60 \\
5.50\end{array}$ & $\begin{array}{l}\text { Old. } \\
\text { Quite immature. } \\
\text { Do. }\end{array}$ \\
\hline
\end{tabular}

FELIS PARDALIS.

Fourteen skulls of Felis pardalis show a most decided southryard increase in size. A series of five skulls from the Lower Rio Grande average about an inch shorter than another series of nine from Southern Mexico and Central America. The largest of the Rio Grande skulls has a length of 5.25, while the smallest of the Mexican and Central American series (excluding one rather young specimen) has a length of 5.20, and the largest a length of 6.20. The three largest (6.00 to 6.25) are from Costa Rica, while one other from Panama and another from Surinam are but little smaller. The smallest of the Rio Grande series (a rather young specimen) is but 4.50 in length; the smallest of the tropical series (a specimen of corresponding age) 5.35 .

The difference in size with locality is thus as great in this species and in Felis concolor as it is in the Wolves and Foxes; but the increase is in the opposite direction,- to the northward in the former and to the southucard in the latter; the one group being a northern type, the other a tropical.

Measurements of fourteen skulls of FELIS PARDALIS.

\begin{tabular}{|c|c|c|c|c|c|}
\hline 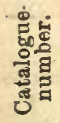 & Locality. & 跑 & 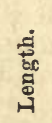 & 要 & Remarks. \\
\hline 1363 & Matamoras, Mexico .. & & 4. 50 & 3. 05 & Mature but not very old. \\
\hline 1362 & ....... do............... & ....... & 4. 90 & 3. 35 & \\
\hline $\begin{array}{l}1361 \\
1359\end{array}$ & 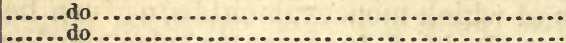 & $\cdots . .$. & 5.05 & 3. 35 & 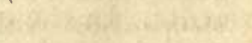 \\
\hline 1358 & 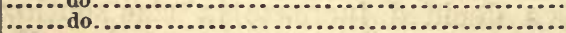 & $\cdots \ldots$ & $\begin{array}{l}5.20 \\
5.25\end{array}$ & $\begin{array}{l}3.00 \\
3.40\end{array}$ & 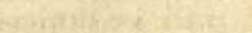 \\
\hline 6023 & Panama..... & & 5. 60 & 3. 75 & \\
\hline 7080 & or, Mexico ..... & & 5. & & \\
\hline 13852 & Tehuantepec, Mexico ... & ....... & 5.50 & 3. 70 & \\
\hline 11743 & Isthmus of Darien ...... & & 5.85 & 3. & \\
\hline 14182 & Costa Rica ................. & . & 6. 00 & 3. 73 & Very old. \\
\hline 14179 & ......do... & & 6.00 & 3. 94 & Do \\
\hline 14180 & ....do... & & 6. 20 & 4. 19 & Do. \\
\hline 14178 & ......do. & & 5. 35 & 3. 60 & Adult but not very ol \\
\hline 13005 & Surinam......... & …. & 5.80 & 3. 83 & Very old. \\
\hline
\end{tabular}

\section{LYNX RUFUS ET LYNX UANADENSIS.}

In the subjoined table are given measurements of thirty-four skulls of North American Lynxes, namely, seven of $L$. fasciatus, ten of $L$. rufus, eight of $L$. maculatus, and nine of $L$. canadensis, representing localities as distant from each other as Alaska and Northern Mexico on the one hand, and New York and Fort Tejon, Cal., on the other. Yet the 
extremes of variation met with at single localities are as great as those from the most widely separated of the above-named localities; in other words, no geographical variation in size is perceptible. The largest northern specimen (canadensis), from Peel River, Arctic America, with a length of 5.30 , a little exceeds in size the largest specimens from any locality south of the latitude of $40^{\circ}$; but it in turn is slightly smaller than a specimen (fasciatus) from Fort Townsend, Wash., which has a length of 5.50, and by another of the same dimensions (rufus) from the Big Sioux River. Eight specimens of the most southern type ( $L$. maculatus), all from Texas and the Mexican side of the Lower Rio Grande, differ in the average from nine specimens of the most northern type $(L$. canadensis), all from Arctic or sub-Arctic America, almost inappreciably, the canadensis series having an average length of 5.01 and the macu. latus series of 5.00 ! The difference in breadth is also only about onetenth of an inch, which the addition of a single specimen to either series might cancel. This is certainly a surprising result when it is remem. bered that one of the chief alleged distinctive characters of $L$. cana. densis has been its supposed larger size!

The average dimensions of these several series are as follows:

\begin{tabular}{|c|c|c|c|}
\hline Species. & $\begin{array}{l}\text { Number of } \\
\text { specimens. }\end{array}$ & Length. & Breadth. \\
\hline 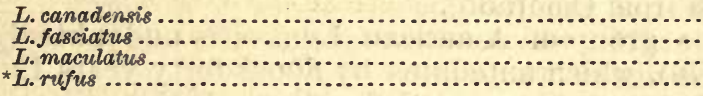 & $\begin{array}{r}9 \\
7 \\
8 \\
10\end{array}$ & $\begin{array}{l}5.01 \\
5.03 \\
5.00 \\
4.91\end{array}$ & $\begin{array}{l}\text { 3. } 52 \\
\text { 3. } 56 \\
3.40 \\
\text { 3. } 41\end{array}$ \\
\hline 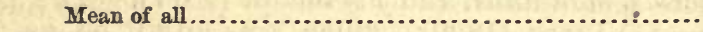 & 34 & 4.98 & 3.47 \\
\hline
\end{tabular}

* The specimens placed under rufus are those that are so marked in the collection, being the speci mens so identified by Professor Baird.

The fasciatus series is the largest, but this series happens to include mare very old specimens than the others, and hence its higher average. Such a constancy of size as is here shown to prevail over an area embracing more than $\mathbf{4 0}$ degrees of latitude is probably without a parallel in any other conspecific group of North American Mammals.

The difference between these heretofore commonly-recognized "species" of the genus Lynx must hence be sought elsewhere than in size. The specific distinctness of $L$. canadensis, the most northern type, has been heretofore scarcely questionéd, in consequence of its supposed larger size, larger limbs, longer, softer pelage, longer ear-tufts, more indistinct markings, and generally lighter or grayer color. The longer eartufts correlate with the longer, softer pelage, that always characterizes the boreal representatives of species having a wide latitudinal range. The difference in coloration is not greater than, or even so great as, that which obtains between fasciatus and rufus, or between fasciatus and maculatus, which forms uaturalists now seem disposed to refer to one and the same species under the name L. rufus. Mnculatus, the most southern form, differs from the "typical" or eastern rufus in its shorter, coarser fur, more reddish tints, and more distinct markings. Its reputed range extends from the Lower Rio Grande westward across the continent to Southern California ; but in the National Museum collection are also specimens marked rufus from many points within this area, including a considerable series from Fort Tejon. The gradation from the "typical" rufus type into maculatus is complete and by almost insensible stages. 
The L. fasciatus or Columbia River race differs from rufus in its moro uniform and darker (chestnut rather than reddish) coloration, by the markings on the dorsal surface and sides of the body being nearly obsolete, and the fuller, softer fur, which is about as heary and soft as in canadensis. We have hence, in this form, only another instance of the duller, darker, and more uniform coloration that characterizes the greater part of the Mammals (and many Birds also) from the humid, heavily-wooded Columbia River region, as compared with their conspecific allies of the other portions of the continent.

L. canadensis differs from these several southern races mainly as the northern representatives of a given species usually differ from its southern representatives, namely, in its softer and longer pelage, more heav. ily-clothed feet, longer ear-tufts, paler or grayer general color, and more indistinct markings, and especially in a tendency to entire obsolescence of the markings on the lower surface of the body and inner side of the legs. The tail has a shorter area of black at the end, and lacks the white on the lower surface at the extreme tip, so constantly seen in the other forms. The tail is but little, if any, shorter, although the greater length and thickness of the fur give it that appearance. There is, however, a tendency to a greater length of tail to the southward. Its supposed greater size and larger limbs are also due almost wholly to the greater fullness and length of the pelage, the fresh carcass (in a specimen from Houlton, Me.) with the skin removed giving the same measurements as in $L$. rufus (a specimen from Colorado).

The prior name for the group of American Lynxes is undoubtedly rufus of Guldenstädt (1776), which antedates by about forty years Rafinesque's names of canadensis, montanus, and floridanus (1817). The $L$. maculatus of Horsfield and Vigors (1829), which was admitted as a valid species by Baird, but regarded as merely a variety of rufus by Audubon and Bachman, is evidently subspecifically indistinguishable

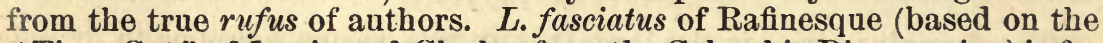
"Tiger Cat" of Lewis and Clarke, from the Columbia River region) is far more tangible, sufficiently so to be properly recognizable as a subspecies (Lynx rufus subsp. fasciatus). The $L$. canadensis of authors seems to have even still stronger claims for nominal recognition, though the differences are still clearly such as characterize geographical races. We hence believe its relationship to the rest of the group is better indicated by a name ( $L$.rufus subsp. canadensis) indicating subspecific rather than. specific rank.

A single adult skull (from Sweden) of the large Lynx of the northern parts of the Old World (Lynx borealis) exceeds in size by an inch the largest specimens of the American Lynxes, and hence seems to indicate an animal fully one-fifth larger than even exceptionally large specimens of $L$. rufus. 
Measurements of thirty-four skulls of LYNX RuFus et vars.

\begin{tabular}{|c|c|c|c|c|c|}
\hline 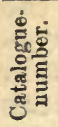 & Locality. & 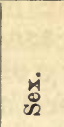 & 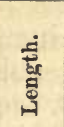 & है & Remarks. \\
\hline 8599 & Puget Sonnd, Wash & & 4. 80 & 3.45 & "fasciatus." \\
\hline 8600 & & & 4. 65 & 3.30 & \\
\hline 3426 & Steilacoom, Wash. . & $q$ & 5. 20 & 3.60 & Do. Very old. \\
\hline 3197 & Fort Umpqua wash & & 5.45 & 3.95 & Do. \\
\hline $\begin{array}{l}3427 \\
3426\end{array}$ & Fort Umpqua, Wash ... & & $\dddot{4} .90$ & $\begin{array}{l}3.32 \\
3.50\end{array}$ & $\begin{array}{l}\text { Do. } \\
\text { Do. }\end{array}$ \\
\hline 2032 & Shoalwater Bay, Wash & & 4. 75 & & Do. \\
\hline 3147 & Fort Townsend, Wash & & 5. 50 & 3.82 & Do. Very old. \\
\hline 2883 & Big Sioux River ....... & $\ddot{q}$ & 5.50 & 3.82 & rufus." Very old. \\
\hline 3775 & Mississippi.. & & 4. 95 & 3. 38 & Do. \\
\hline 7465 & Arizona ...... & ... & 5.10 & 3.55 & Do. \\
\hline 3120 & Florida...... & & 4.85 & 3. 22 & Do. Quite young. \\
\hline 2391 & Louisiana ... & & 4.90 & 3. 27 & Do. \\
\hline 3574 & Fort Tejon, Cal.. & $\ddot{\sigma}$ & 4.80 & 3. 32 & Do. \\
\hline 3542 & $\ldots .$. do $\ldots . . . . .$. & & 4.80 & 3. 50 & Do. \\
\hline 3541 & ....do...... & $\bar{\sigma}$ & 4.93 & 3. 38 & Do. \\
\hline 3570 & .....do... & & 4.65 & 3. 37 & Do. \\
\hline 3576 & .......do & & 4. 65 & 3.37 & Do. \\
\hline 1887 & Fort Belknap, Tex... & $\ldots$ & 5.12 & 3. 72 & "maculatus." \\
\hline 1109 & Eagle Pass, Tex & .... & 5.27 & 3. 51 & Do. \\
\hline 7493 & Washington County, Texas & & 4. 72 & 3.25 & Do. \\
\hline & Matamoras, Mexico........ & $\ldots . .$. & 4.55 & 3,10 & Do. Rather young. \\
\hline & & & 5.10 & 3. 40 & Do. \\
\hline & . & .... & 4. 80 & 3.25 & Do. \\
\hline & ............. & & 5.15 & 3.57 & Do. \\
\hline & Prairie Mer Rouge, Louisiana ....................... & .... & 4. 80 & 3. 28 & \\
\hline & ................... & .... & 4.85 & 3.35 & "canadensis." \\
\hline & Yukon, Alaska & & 4. 95 & 3. 53 & Do. \\
\hline & & ? & 4.75 & 3.35 & Do. \\
\hline & Peel River & & 4.95 & 3.53 & Do. \\
\hline & & & 5. 30 & 3. 70 & Do. \\
\hline & & & 5.15 & 3. 60 & Do \\
\hline & & & 5.00 & 3. & \\
\hline & & & 5.00 & 3. 52 & $\mathrm{D}$ \\
\hline 70 & W yom & & 5.15 & 3.60 & Do. \\
\hline
\end{tabular}

\section{PROCYON LOTOR.}

The present species presents another well-marked case of gradual in. crease in size southward. In a series of fifteen skulls from the Atrantic States (New York, Pennsylvania, and Georgia), only a single specimen exceeds 4.38 in length or 3.00 in width, the largest specimen being from Saiut Simon's Island, Georgia. Three from Essex County, New York, arerage 4.28 ; five from Pennsylvania average 4.29 ; seven from Saint Simon's Island, Georgia, average 4.26 (or 4.29, excluding one very small . one). Six specimens from the interior (Nebraska, Missouri, Indian Territory, and the Lower Rio Grande) average 4.49, two only falling below 4.50; and the largest (Rio Grande) 4.70. Three from California ("hernan(ezi") average 4.63 , the largest reaching 4.78 , with a width of 3.38 . Six from Southern Mexico average 4.58, the largest reaching 4.73 in length, with a width of 3.42 . Three from Costa Rica average 4.69, the largest reaching 4.85 .

In addition to the above, there is a single very aged specimen from Detroit, Mich., which has a length of 4.35 , and two others from Alaska (one middle-aged, the other rather young) which measure, respectively, 4.25 and 4.05 in length, the latter being the smallest of the whole series, although it contains others equally young.

Between the three specimens from Essex County, New York, and the three from Costa Rica, specimens of corresponding ages and constituting the two extremes, the average difference is nearly six-tenths $(0.57)$ of an inch, or about one-seventh of the size of the northern examples.

Besides the difference in size, there is also a considerable range of variation in respect to the general form of the skull in the ratio of width to length, in the shape, degree of concavity of the palate, in specimens 
from the same locality, the ratio of width to length varying from 0.65 to 0.73 .

In addition to the increase in size sonthward, there is a tendency to an increase in the intensity of the colors in the same direction, with a stronger contrast between the light and dark markings. These differences, taken collectively, have given rise to several nominal species, of which the $P$. hernandezi of Wagler and $P$. psora of Gray have become the most prominent. The species normally presents a considerable range of color-variation, tending on the one hand more or less to melanism and on the other to albinism. On these extreme phases of coloration have also been based other nominal species, as the P. obscurus of Wiegmann and the $P$. nivea of Gray. All these names have been already placed by Gray, in his later notices of the group, under the head of $P$. lotor, but separated as being varietally distinct. It seems doubtful, however, whether even the large southern form, usually called hernandezi, is really entitled to subspecific recognition.

Measurements of thirty-six skulls of PROCYON LOTOR.

\begin{tabular}{|c|c|c|c|c|c|}
\hline 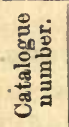 & Locality. & $\begin{array}{l}\dot{\alpha} \\
\text { ळू }\end{array}$ & $\begin{array}{l}\stackrel{0}{0} \\
\text { b0 } \\
0 \\
\stackrel{0}{4}\end{array}$ & 营 & Remarks. \\
\hline 8690 & Alaska... & ...... & 4. 25 & 2. 87 & Middle-aged. \\
\hline $\begin{array}{l}8693 \\
1068\end{array}$ & pe...do do & $\cdots \ldots$ & 4. 05 & 2.92 & Young. \\
\hline 3723 & Essex County, New Yo & ….... & $\begin{array}{l}4.35 \\
\text { 4. } 25\end{array}$ & $\ddot{2.87}$ & $\begin{array}{l}\text { Very old. } \\
\text { Do. }\end{array}$ \\
\hline 3722 & ......do.............. & (n..... & 4. 27 & 2.70 & Middle-aged. \\
\hline 3079 & .....do & $\ldots \ldots$ & 4. 32 & 3.00 & Very old. \\
\hline 898 & Pennsylvania... & $\ldots \ldots$ & 4. 35 & 3.00 & Do. \\
\hline 6025 & ....... do.......... & (...... & 4. 12 & 2.51 & Do. \\
\hline $\begin{array}{r}4817 \\
575\end{array}$ & ......do......... & $\cdots \cdots$ & 4. 38 & 2. 64 & Do. \\
\hline $\begin{array}{l}575 \\
766\end{array}$ & ...... do......... & $\cdots \cdots$ & 4.25 & 2.88 & Do. \\
\hline 2443 & 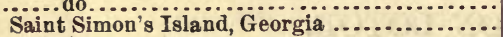 & $\cdots \ldots$. & $\begin{array}{l}4.35 \\
4.25\end{array}$ & $\begin{array}{l}2.93 \\
2.62\end{array}$ & Middle-aged. \\
\hline 2437 & 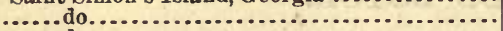 & $\cdots$ & 4. 38 & 3.03 & Very old. \\
\hline 2447 & ..... do........... & ..... & 4. 06 & 2.65 & Do. \\
\hline 2450 & .......do... & $\ldots . .$. & 4. 30 & 2.87 & Do. \\
\hline 2444 & ......do... & $\ldots . .$. & 4. 12 & $\ldots . .$. & Do. \\
\hline 2446 & .......do... & -...... & 4. 12 & 2.90 & Do. \\
\hline $\begin{array}{l}2202 \\
8649\end{array}$ & ¥̈...do...... & (....... & 4. 57 & 3.00 & Do. \\
\hline $\begin{array}{l}8649 \\
8085\end{array}$ & Nebraska $\ldots \ldots \ldots \ldots$ & - $\cdots \cdot$ & 4. 50 & 3.07 & Do. \\
\hline $\begin{array}{l}8085 \\
3325\end{array}$ & bb, Indian Ter.. & ...... & 4.50 & 3.03 & Do. \\
\hline $\begin{array}{l}3325 \\
7739\end{array}$ & Independence, Mo... & |...... & 4. 23 & 2.78 & Young. \\
\hline $\begin{array}{l}7739 \\
1386\end{array}$ & $\begin{array}{l}\text { Long Point, Tex......... } \\
\text { Lower Rio Grande }\end{array}$ & ....... & 4. 32 & $\begin{array}{l}2.98 \\
2.90\end{array}$ & $\begin{array}{l}\text { Old. } \\
\text { Young. }\end{array}$ \\
\hline 1387 & ..... do................ & $|\cdots \cdots \cdot|$ & 4. 70 & 3.15 & old. \\
\hline , 3224 & San Francisco, CaI .. & & 4. 42 & & Very old; "hernandezi." \\
\hline 3933 & Sacramento, Cal. & & 4. 78 & 3. 38 & D้o. \\
\hline 13312 & California. & $\because \cdots$ & 4. 70 & 3.12 & Very old. \\
\hline 7081 & Mirador, Mexico. & & 4. 75 & 3.15 & Middle-aged. \\
\hline 6119 & Colima, Mexico... & $\ldots$ & 4.50 & 3.33 & old. \\
\hline 6481 & .....do.... & & 4. 46 & 3.15 & Middle-aged. \\
\hline 9706 & Tehuantepec, Mexic & . & 4. 50 & 2.83 & Young. \\
\hline 13853 & ........ do.... & & 4. 52 & & Old. \\
\hline 13854 & ........... & 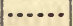 & 4. 73 & 3.42 & Very old. \\
\hline 13300 & $\ldots \ldots \ldots \ldots \ldots \ldots$ & & 4.55 & 3. 03 & Middle-aged. \\
\hline 14190 & . & $\cdots \cdots$ & 4.78 & 3. 32 & Old. \\
\hline 14191 & .....do do & & 4.85 & 3.00 & \\
\hline
\end{tabular}

PUTORIUS VISON.

Eighteen skulls from the northern parts of the continent, mainly from Alaska, average 2.66 in length and 1.58 in width, the extremes being, length, 3.02 and 2.30 ; width, 1.90 and 1.40. Thirteen skulls from the highlands of Northeastern New York average 2.40 in length and 1.34 in width, the extremes being, length, 2.60 and 2.17. Three skulls from Pennsylvania (undoubtedly males) average 2.49 in length and 1.48 in width. In the northern series, the sex of the skull is given by the collector, whence it appears that the twelve males have an average 
length of 2.S1, and the six females an average length of 2.43 , showing a considerable sexual variation in size. Yet the smallest males (2.64 and 2.63 ) fall below the largest female (2.68), if the skulls are all correctly marked. None of the other females, however, exceed 2.55, and only three of the males fall below 2.70. In the New York series, the sex is not indicated; but, judging from the proportion of the small to the large skulls, the sexes are about equally represented in the two series, but in the New York series there is a very gradual decline from the largest to the smallest. The northern series of eighteen is selected from a series of twenty-three; the New York series of thirteen from a series of thirty. In each case only very old skulls were chosen, the immature specimens in each case being thrown out in order to have a fair basis for comparison. The immature and middle-aged specimens greatly predominate in the New York series, owing, doubtless, to the species being more closely hunted there than in the more unsettled districts of the far north.

Taking these two series as a basis for a general comparison, there is indicated a considerable decrease in size from the north south ward, amounting to 0.26 in length and 0.24 in width, or about one-tenth of the average size of the New York series. A single specimen, marked "Brookhaven, Miss.", and another marked "Tuscaloosa, Ala.", however, have a length respectively of 2.60 and 2.80 , the former equaling the largest New York specimens, and the latter nearly equaling the average size of the males of the northern series, while a single male skull from Fort Randall, D. T., 2.90 in leugth, is the second in size of the whole series; one Fort Yukon specimen only being larger! Other specimens from the Upper Missouri region, however, are much smaller, as are other specimens from Prairie Mer Rouge, La., indicating that the specimens above mentioned are much abore the arerage for their respective localities.

No. $4-4$ 
Measurements of thirty-seven skulls of PUTORIUs vison.

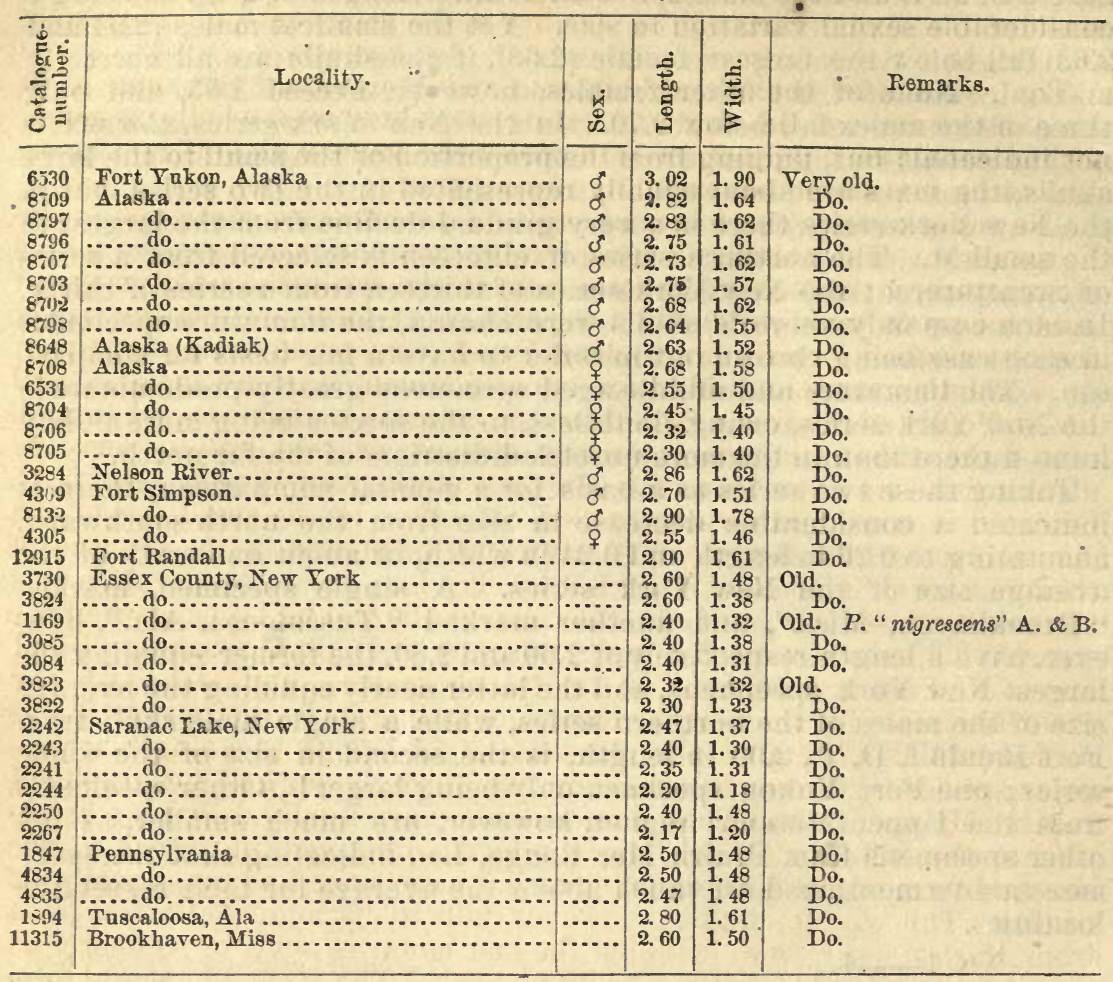

\section{MUSTELA AMERICANA.}

The forty-six male skulls of this species, of which measurements are giren below, are mainly from four or five localities differing widely in latitude. A comparison of the average size of a considerable number from each shows a well-marked decrease in size southward. Four skulls from Peel River, the largest, and also from the most northerly locality, have an average length of 3.39 , and an average width of 2.07 , the extremes being 3.50 and 3.35 in length and 2.12 and 2.02 in width. Nine skulls from. the Yukon (probably mostly from near Fort Yukon) give an average length of 3.34 and an average width of 1.98 , the extremes being 3.55 and 3.00 in length and 2.15 and 1.73 in width. Five skulls from Fort Good Hope give an average length of 3.24 and an average width of 1.95, the extremes in length being 3.37 and 3.15 and in width 2.05 and 1.73. Ten skulls from the northern shore of Lake Superior average 3.14 in length and 1.76 in width, the extremes in length being 2.23 and 3.02 and in width 1.89 and 165. Eight skulls from the vicinity of Umbagog Lake, Maine (Coll. Mus. Comp. Zoöl.), average 2.96 in length and 1.72 in width, the extremes in length being 3.10 and 2.73 , and in width 1.85 and 1.50 . Five skulls from Northeastern Now York average 3.02 in length and 1.61 in width, the extremes being in length 3.10 and 2.92 and in width 1.68 and 1.50. There is thus a gradual descent in the average length from 3.39 to 3.02 , and in width from 2.07 to 1.61. The largest and the smallest of the series are respectively 3.55 and 2.92 in length. Several fall as low as 3.00 , and an equal number attain 3.50. The difference between the 
largest and the smallest, excluding the most extreme examples, is onesixth of the dimensions of the smaller and one-serenth of the size of the larger.

The sexes differ considerably in size, relatively about the same as in Putorius vison; but the above generalizations are based wholly on males, and in each case on those of practically the same age, only specimens indicating mature or advanced age being used.

The series of fully one hundred skulls of this species contained in the National Museum presents a considerable range of variation in details of structure, involving the general form of the skull, the relative size of different parts, and the dentition, especially the form and relative size of the last molar. In a former paper,*. I had occasion to notice somewhat in detail the variations in color our American Martens present, and the difficulty of finding any features of coloration that seemed to indicate more than a single American species, or that would serve to distinguish this even from the Martens of the Old World. Dr. J. E. Gray, it is true, had already called attention to the small size of the last molar in the American Martens as compared with the size of - the same tooth in the Old World Martens; but, as his obserration was apparently based on a single American skull, and as I was at the time strongly impressed with the wide range of individual variation I had found in allied groups, even in dental characters, and also with the great frequency of Dr. Gray's characters failing to be distinctive, I was misled into supposing all the Martens might belong to a single circumpolar species, with several more or less strongly-marked geographical races. My friend Dr. Coues some months since kindly called my attention to the validity of Dr. Gray's alleged difference in respect to the size and form of the last molar, which I have since had opportunity of testing. This character alone, however, fails to distinguish Mustela foina from Mustela americana, in which the last molar is alike, or so nearly so that it fails to furnish distinctive differences. The size and general form of the skull in the two are also the same, the shape of the skull and the form of the last apper molar failing to be diagnostic. The second lower true molar, however, in Mustela foina presents a character (shared by all the Old World Martens) which serves to distinguish it from Mustela americana, namely, the presence of an inner cusp not found in the latter. In Mustela flavigula, the last molar is relatively smaller than even in Mus. tela americana, and of the same form. MLustela martes differs in its more massive dentition and in the heavier structure of the skull, but especially in the large size of the last molar and the very great development of its inner portion. Hence, while the size and shape of the last upper molar serves to distinguish Mustela martes from Mustela americana, it fails as a valid distinction between Mustela americana and Mustela flavigula and Mustela foina. As already remarked, however, Mustela americana lacks the inner cusp of the second lower molar, which is present in the Old World Martens, or at least possesses it only in a very rudimentary condition.

\footnotetext{
* "Mammals of Massachusetts", Bull. Mus. Comp. Zoöl., vol. i, pp. 161-167, Oct., 1869.
} 
Measurements of forty-six skulls of MUSTELA AMERICANA.

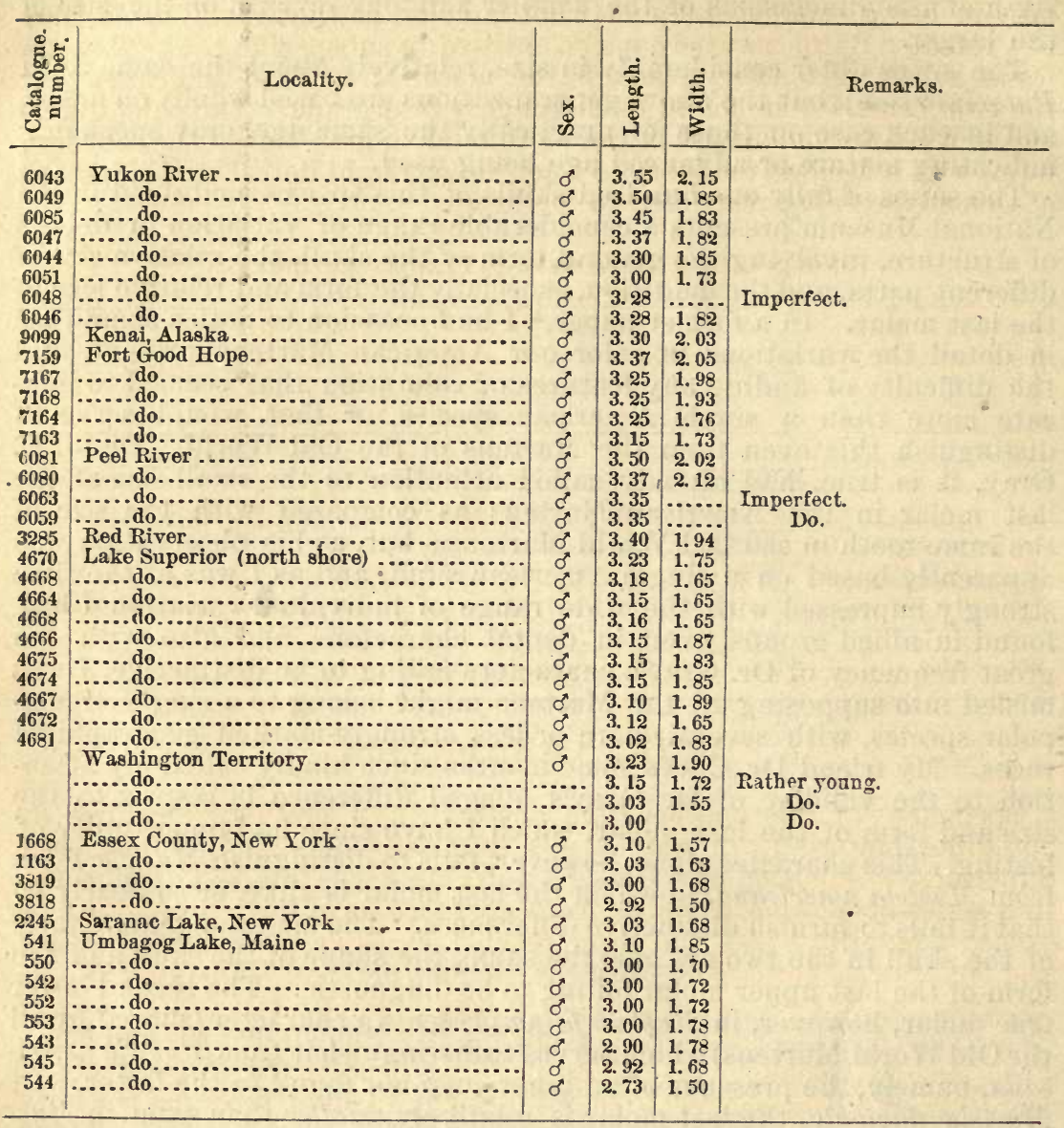

\section{TAXIDEA AMERICANA.}

The sabjoined measurements of eleren skulls of this species (embrac. ing all at present available) show also a well-marked south ward decrease in size. A fuller series would be more satisfactory, but would doubtless only confirm what is here indicated. Six of the specimens are from rather northern localities and five from rather southern localities, the region represented extending from the Upper Missouri southward to the Lower Rio Grande. The specimens composing the two series are of very nearly corresponding ages. The northern series (four from different points on the Upper Missouri, one from Iowa, and one from Oregon) average 5.00 in length and 3.18 in width, the extremes being, in length, 5.22 and 4.92 (4.75 if we include one rather soung example), the width ranging from 3.50 to 2.97. The southern series (including two or three from the vicinity of Matamoras, Mexico, and one each from New Mexico and California) averages 4.62 in length and 2.92 in width, the extremes being, in length, 4.75 and 4.50, and in width, 3.07 and 2.80.

The skulls, and especially the molar teeth, in the American Badgers, vary considerably in different individuals, as long since pointed out by 
Professor Baird.* Southern specimens differ from northern ones not only in being smaller, but somewhat in color, so that the T. berlandieri of Professor Baird may perhaps be entitled to subspecific rank (T.americana subsp. berlandieri), though the material at hand indicates that the two forms will be found to thoroughly intergrade. The chief differences in coloration consist in the more reddish.gray tint of the southern form, with a decided tendency to a continuous light dorsal stripe, instead of this stripe being restricted to the head.

Measurements of eleven skulls of TAXIDEA AMERICANi.

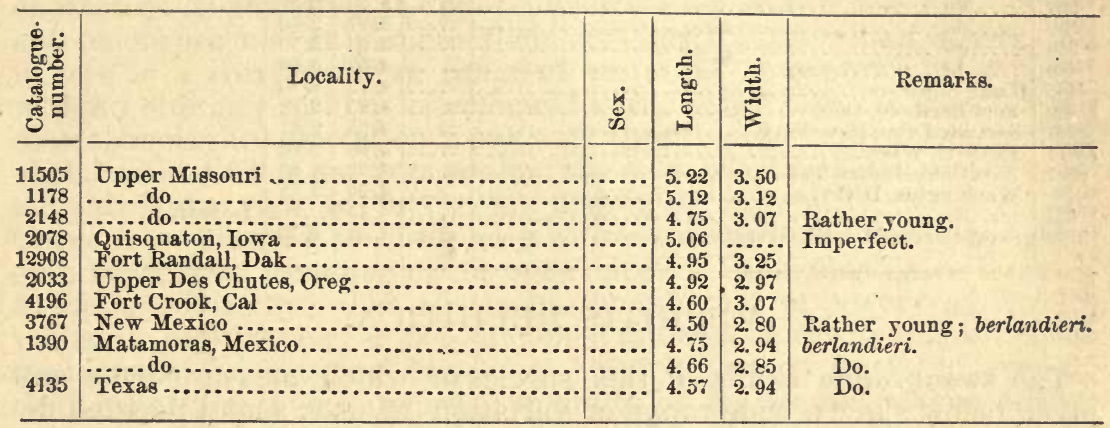

\section{LUTRA CANADENSIS.}

Specimens of this species from northern and southern localities do not differ materially in size; skulls from Newfoundland, Maine, Lake Superior, Washington, and Georgia agreeing very closely in dimensions. In a series of eighteen (mainly from northern localities), nine attain or exceed a length of 4.25 , and three reach 4.50 , while two only fall as low as 4.00. Seven specimens from the vicinity of Lake Umbagog, Maine, (in Mus. Comp. Zoöl.) average 4.28 in length and 2.93 in width; two of these reach 4.50 in length and two fall slightly below 4.00 (3.96 and 3.97). Two specimens from Washington, D. C., have a length respectively of 4.45 and 4.50; one specimen from Saint Simon's Island, Georgia, is nearly as large (1.32), while a Fort Cobb specimen has a length of 4.22. These four are the only ones from very southerly points. Four other specimens, from as many localities, range from 4.05 to 4.15 ; while three specimens from Newfoundland range from 4.03 to 4.25 . While these specimens are too few to warrant positive conclusions as to geographical variations, they seem to point to a great constancy of size throughout a wide range of latitude. 
Measurements of eighteen skulls of LUTRA CANADENSIS.

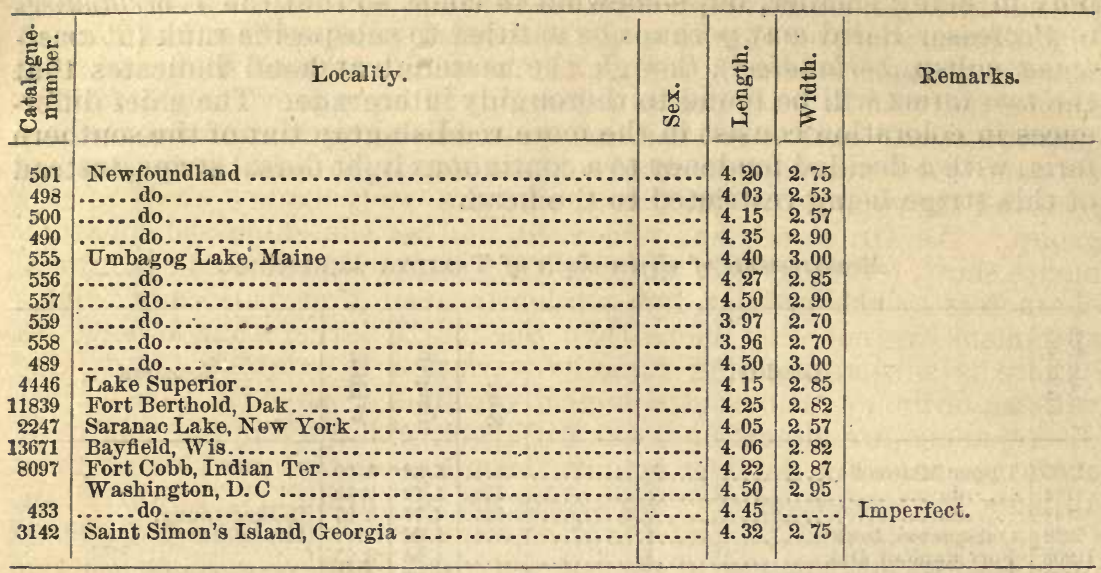

\section{MEPHITIS MEPHITICA.}

The twenty-nine skulls of this species of which measurements are given below show a wide range of variation in size, and a decided decrease southward, The localities embrace such distant points as California and the Atlantic seaboard on the one hand, and Maine and Texas on the other; but, with one or two exceptions, the specimens from any single locality are unsatisfactorily few. The specimens range in length from 2.60 to 3.50 , and in width from 1.60 to 2.25 ! Yet there is not a specimen included in the series that is not so old as to have all the cranial sutures obliterated. A portion of the difference is doubtless sexual, but the specimens, unfortunately, have not the sex indicated. Ten of the specimens may be considered as western, coming mainly from Utah and California; ten others are from Maine and Massachusetts, and one from Northeastern New York; three are from Pennsylvania; and of the remaining five, four are from Texas, and one from Louisiana. The western series of ten average 3.10 in length and 1.95 in width, ranging in length from 2.85 to 3.50 and in width from 1.70 to 2.25 . The New England series of ten average 2.88 in length and 1.72 in width, ranging in length from 2.70 to 3.25 and in width from 1.53 to 1.85 . The single New York specimen scarcely varies from the average of the New England series, while the Pennsylvania specimens fall a little below. The five southern specimens average 2.73 in length, or a little below the New England series, ranging in length from 2.60 to $290 *$ *

It thus appears that the western specimens are decidedly the largest of all, and that the northern are somewhat larger than the southern, the specimens compared being of corresponding ages, though of unknown sex, but doubtless comparable in this respect also.

The difference in size amounts to above one-fourth the size of the largest specimen and above one-third the size of the smallest. Between the western and southern series, the average difference amounts to onethird of the average size of the larger series! The western series includes the so-called Mephitis occidentalis of Baird, based on California specimens, and whose chief difference is merely that of larger size; yet the four specimens from Ugden, Utah (Coll. Mus. Comp. Zoöl.), considerably * The range in width is not fairly indicated, owing to two of the smaller specimens
being imperfect. 
excelled in size the three from California. The southern series represents the so-called M. varians of Gray and Baird.

The unsatisfactory character of the several species of North American Skunks of the mephitica group, and the wide range of color-variation among individuals from the same locality, I have previously had occasion to notice,* and a re-examination of the subject confirms the conclusions then announced, which, I am happy to find, have recently received the support of Dr. Coues, who has lately made a study of this group.t As Dr. Coues has remarked, and as the subjoined measurements show, few species of animals vary so much in size and in cranial characters as the present, independently even of sex and age. Some specimens are not only more than one-fourth larger than others, but "there is a correspouding range of variation in contour. Compared with an ordinary ratio of osteological variability," says Dr. Coues, "the discrepancies are almost on a par with those exhibited by the coloration of the animal when set over against the more constant markings of most animals." In view of this great degree of variability, however, Dr. Coues has ventured to describe a "new species" (M. frontata), based on a fossil skull from one of the bone-cares of Pennsylvania, as it seems to me, unadvisedly. The specimen, though that of a very aged individual, is scarcely larger (see subjoined table) than the average of speci-mens from the Eastern States, its chief difference from the average skull consisting in an abnormal tumidity of the frontal region, arising evidently from disease. It is a feature by no means confined to the present example, but is merely an extreme enlargement of the sinuses of the frontal region often seen in specimens of the existing animal, evi. dently resulting from disease. In No. 917 (Albany, N. Y.), No. 8099 (Fort Cobb, Ind. T.), No. 1878 (Calcasieu Pass, La.), and No. 1620 (Indianola, Tex.), the same tendency is strongly marked, which, in some of these specimens, had they attained equal age, must have resulted in a malformation nearly or quite as great as is seen in the fossil skull in question.

In this connection, I may add that a pretty careful examination of the fossil remains of Carnivora, collected by Professor Baird many years since from the bone-caves of Pennsylvania (of which this fossil skull of the Skunk forms a part), has failed to show any of them to be specifically different from the species now or recently living in the same region. Many of them are remains of individuals of large size, but not exceeding the dimensions of specimens of the recent animal from the same or contiguous regions. These remains include, among others, the following species:-Lynx rufus, Urocyon virginianus, Mustelo pennanti, Mustela americana, Putorius vison, Lutra canadensis, Mephitis mephitica (other specimens than the "frontata" skull), Procyon lotor, Ursus americanus, etc.

* See Bull. Mus. Comp. Zoöl., vol. i, pp. 178-181, Oct., 1869.

+ Bull. U. S. Geol. and Geog. Surv. of the Territories, vol. i, No. 1, pp. 7-15, 18:5, 
Measurements of twenty-nine skulls of MEPHITIS MEPHITICA.

\begin{tabular}{|c|c|c|c|c|c|}
\hline 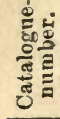 & Locality. & வ & 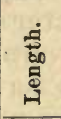 & 률 & Remarks. \\
\hline 2617 & Petaluma, Cal .. & (...... & 3. 30 & 2.07 & \\
\hline 3271 & ̈.... do........ & $\ldots \ldots$ & 3.08 & 2.04 & \\
\hline $\begin{array}{l}2434 \\
4195\end{array}$ & $\begin{array}{l}\text { Port Townsend, Oreg } \ldots \ldots \\
\text { Fort Crook, Cal . }\end{array}$ & $\cdots \ldots$ & 2.93 & 1.70 & \\
\hline $\begin{array}{r}4195 \\
417\end{array}$ & 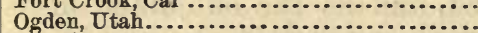 & & $\begin{array}{l}2.80 \\
3.12\end{array}$ & $\because .87$ & \\
\hline 419 & 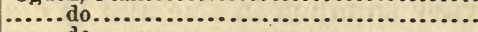 & $\ldots \ldots$ & 3.50 & 2.25 & Very old. \\
\hline 416 & ....... do......... & -..... & 3. 10 & 1.90 & \\
\hline $\begin{array}{r}418 \\
10008\end{array}$ & . $\ldots \ldots \ldots \ldots \ldots \ldots . \cdots$ & ....... & 2.98 & 1.85 & \\
\hline 10008 & Wyoming Territory $\ldots \ldots \ldots \ldots \ldots \ldots \ldots \ldots$ & (....... & 3.15 & 2.05 & \\
\hline $\begin{array}{r}3327 \\
575\end{array}$ & 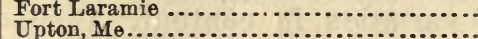 & $\ldots \ldots$ & $\begin{array}{l}2.96 \\
3.25\end{array}$ & 1.78 & Very old. \\
\hline 580 & p. do & $\cdots$ & 3. 00 & 1.85 & \\
\hline 577 & & ....... & 2.87 & 1.75 & \\
\hline 574 & \#...do......... & $\ldots .$. & 2.85 & 1. 73 & \\
\hline 583 & 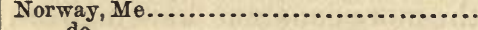 & ....... & 2.90 & 1.75 & \\
\hline 578 & 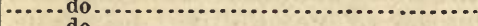 & $\cdots \ldots$ & 2.70 & 1.70 & \\
\hline 569 & \#...do & $\ldots \ldots$ & 2.87 & 1.78 & \\
\hline 567 & 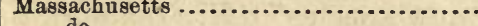 & & 2. 70 & 1.53 & \\
\hline 568 & - & $\cdots \cdots$ & 2.75 & $\because \cdots$ & \\
\hline $\begin{array}{r}576 \\
3816\end{array}$ & 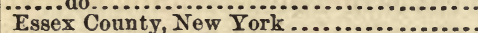 & $\cdots \ldots$ & $\begin{array}{l}2.72 \\
2.88\end{array}$ & $\begin{array}{l}1.70 \\
1.78\end{array}$ & \\
\hline 2232 & 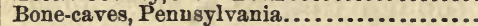 & & 2.90 & ....... & Fossil; M. frontata Coues. \\
\hline 610 & Carlisle, $\mathbf{P a}$. & $\ldots$ & 2.87 & $\ldots \ldots$ & Imperfect. \\
\hline 4833 & Chester County, Pennsylvania............... & .... & 2. 60 & 1.65 & \\
\hline 1620 & Indianola, Tex $\ldots \ldots \ldots \ldots \ldots \ldots \ldots \ldots \ldots$ & & 2.80 & 1.78 & \\
\hline 1004 & Eagle Pass, Tex.... & & 2.60 & & Imperfect. \\
\hline 1113 & ....do............. & & 2.68 & 1.60 & \\
\hline 1395 & $\cdots \ldots, \ldots, \ldots, \ldots, \ldots$ & $\ldots$ & 2.90 & 1.90 & \\
\hline 18.5 & Calcasieu, La. & & 2.68 & $\cdots \ldots$ & Impertect. \\
\hline
\end{tabular}

URSUS ARCTOS, ET VARS.

In a series of serenteen rather aged skulls of Ursus arctos and its varieties (all but one of the specimens, being American), the largest specimens are from California, the great metropolis of the "Grizzlies". Of the eight skulls from this State, five attain a length of 14.50 or more, three exceeding 15.00 , and one reaching 15.60 , while the smallest falls as low as 13.25. Of five specimens from different localities in the Rocky Mountains, three reach or exceed 14.40 , the extremes being 14.75 and 13.25. Of three specimens from the Arctic coast, one has a length of 13.40, and the others respectively 12.40 and 12.35. A single specimen from Russia has a length of 13.75 . These I regard as being all unquestionably conspecific, though perhaps referable to two or three subspe. cies. Whether strictly so or not, we have the fact of the culmination in size in the region where the Grizzlies are most abundant, namely, in California; these two facts, greatest abundance and largest size, seeming to indicate this region as presenting the most favorable conditions for the existence of these animals. The Rocky Mountain specimens average considerably smaller than the Californian; and though the species is pretty frequent here it is far less abundant than on the Pacific slope, especially in California and Oregon. The Franklin Bay specimens, representing the so-called "Barren Ground Bear", and indistin. guishable from the true arctos of the Old World, are smaller even than the specimens from the Rocky Mountains. 
Measurements of seventeen skulls of URSUS ARCTOS (chiefly subsp. HORRIBILIS).

\begin{tabular}{|c|c|c|c|c|c|}
\hline 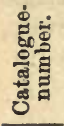 & Locality. & ஜू & 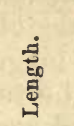 & 萢 & Remarks. \\
\hline 3837 & Sacramento, Cal . & & 15.60 & 9.05 & Very old. \\
\hline 1218 & Monterey, Cal.... & ....... & 15.75 & & Do. \\
\hline $\begin{array}{l}7401 \\
3630\end{array}$ & 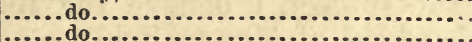 & $\ldots . .$. & $\begin{array}{l}14.05 \\
16.00\end{array}$ & $\begin{array}{l}7.75 \\
8.50\end{array}$ & Dercola \\
\hline $\begin{array}{l}3630 \\
6905\end{array}$ & …....do do............. & o & $\begin{array}{l}16.00 \\
15.40\end{array}$ & $\begin{array}{l}8.50 \\
8.10\end{array}$ & $\begin{array}{l}\text { Very old. } \\
\text { Do. }\end{array}$ \\
\hline 3538 & Fort Tejon, Cal ... & 0 & 13. 25 & 7.45 & \\
\hline 3537 & .......do .............. & $0^{*}$ & 14. 75 & 8.90 & \\
\hline 3536 & $\ldots \ldots$ do $\ldots \ldots \ldots \ldots . . . . .$. & $\%$ & 14.50 & 9.20 & \\
\hline 2086 & Los Nogales, Sonora... & & 14.40 & 8.00 & Var. "horriaeus" Baird. \\
\hline 990 & 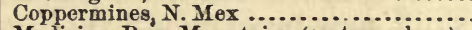 & $\sigma^{*}$ & 14.50 & 8.25 & Do. \\
\hline 3818 & Medicine Bow Mountains (eastern slope). & & 14.75 & 8.50 & \\
\hline 13245 & Big Porenpine Creek, Mont ................... & $\ddot{q}$ & 13.25 & 7.40 & \\
\hline 14785 & Nebraska $\ldots . . . . . . . . .$. & $f$ & 33. 45 & 6. 90 & \\
\hline & Franklin Bay, Arctic Sea............. & $\ddot{\sigma}$ & 12.35 & 7. 30 & "Barren Ground Bear." \\
\hline & 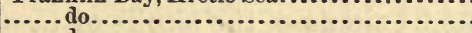 & & 13.40 & 8.65 & Do. \\
\hline 6548 & 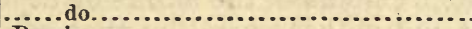 & ...... & 12.45 & 7.25 & Do. \\
\hline .4441 & Russia.......... & .... & 13. 75 & 7.53 & \\
\hline
\end{tabular}

The question of the relationship of the large Bears of North America to those of the Old World has long been a rexed one, and is, of course, one not easily settled. In the present collection are thirty-three skulls, representing various ages, but the greater part are adult. These include two only from the Old World, six from the Arctic coast, eleven from California, and fourteen from various localities in the Rocky Mountains, from Idaho Territory to Arizona.

Among the American specimens are two rather easily distinguishable forms, one of which is the large Grizzly, or $U$.horribilis of authors, from the western parts of the United States ; the other, the smaller so-called Barren Ground Bear of Arctic America; both being undoubtedly specifically distinct from the Ursus americanus. The Barren Ground form* differs from the more southern Grizzly not only in its smaller size, but in its strong tendency to a depression of the frontal region of the skull, where the simple flattening of this region in the Grizzly is here often carried so far as to form a well-marked concavity as in the true arctos of the Old World. Sometimes, however, U. horribilis also presents a con. siderable depression between the postorbital processes, as great even as in arerage specimens of $U$. arctos, as is the case in No. 7401 from Monterey, Cal. The Barren Ground Bear's skull generally presents a more dog.like aspect, in consequence of the thickening superiorly of the postorbital border of the frontals, than is seen in U. horribilis, it approaching in this respect to the form seen in Ursus spelceus, where this feature attains its highest development, resulting in the very strong frontal depression so characteristic of the skulls of that species.

The dentition of $U$.arctos, $U$. richardsoni, $\dagger$ and $U$. horribilis presents no important differences, the chief difference being the relatively rather smaller size of the teeth in the latter. The form of the last upper molar is almost precisely the same in the two first named, and the differences presented by $U$. horribilis are both slight and inconstant. In U. richardsoni, this tooth narrows gradually, and about equally, on each side posteriorly, almost exactly as in $U$. arctos, it being widest at or near its extreme anterior border. While this is sometimes the case in $U$. horribilis, its greatest breadth is generally one-fifth the length of the tooth behind the anterior border, and the tooth is relatively broader posteriorly

* Named by Captain Mayne Reid, in one of his stories, "Ursus Richardsoni" !

+ The Barren Ground Bear skulls in the collection are labeled with this name. 
than in the others. Specimens of $U$. horribilis, from the same locality, however, differ more among themselves in this respect than the average difference between $U$. horribilis and $U$. arctos. The teeth, howerer, in $U$.arctos are relatively larger than in $U$.horribilis, the difference being quite appreciable. The teeth of the Franklin Bay specimens ( $U$. richardsoni), on the other hand, are of the same relative size as in the Old World examples of $U$. arctos.

After a careful consideration of the subject, I believe the Barren Ground Bear of Richardson ( $U$. richardsoni of Mayne Reid) to be not even subspecifically distinct from the true $U$. arctos of the Old World. The Grizzly, from its larger size, widely different geographical distribution, apparently larger claws, slight differences in the dentition and in the form of the frontal region of the skull, may be so regarded (U.arctos subsp. horribilis), as it can hardly be doubted that it gradually passes into the Barren Ground form.

The subjoined table of detailed measurements of the skulls of $U$. arctos horribilis indicates the wide range of individual variation that may be looked for among skulls from the same locality. These variations not only affect the ratio of width to length, through the greater or less elongation of the facial portions of the skull as compared to the rest, but also all the other proportions are more or less variable, including even the teeth themselves. Thus, two specimens from California, of practically the same length (15.60 and 15.40$)$, vary in breadth from 8.10 to 9.05 , while two others vary still more, one, with a breadth of 9.20 , having a length of only 14.50 , while another, with a breadth of 8.50 , has a length of 16.00 ! In these last, the ratio of width to length varies from 0.53 to 0.63 . In two California specimens of practically the same length (15.60 and 15.75), the length of the last molar varies from 1.43 to 1.58. In the series of California specimens alone, the length of the last molar varies from 1.35 to 1.66 , and the width of the same from 0.67 to 0.80 , the widest tooth being, furthermore, not the longest. As already stated, the last upper molar attains its greatest width near the anterior border, but in several specimens the width of the anterior third is nowhere greater than the width of the tooth at its middle; and the same is also some. times true in $U$. richardsoni. 


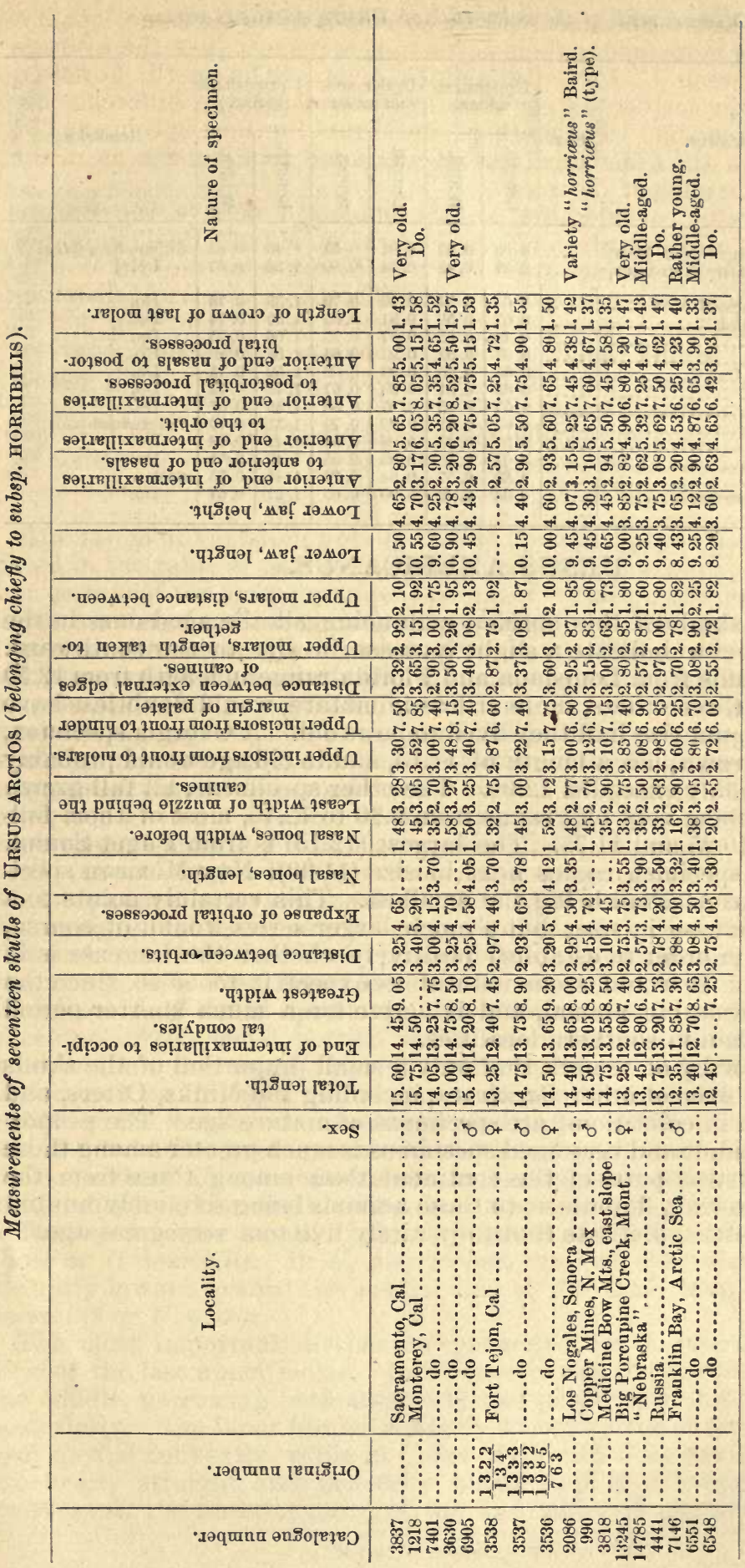


Measurements of the molar teeth of URSUS ARCTOS et var.

\begin{tabular}{|c|c|c|c|c|c|c|c|c|c|}
\hline \multirow{2}{*}{ 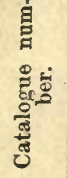 } & \multirow{2}{*}{ Locality. } & \multirow{2}{*}{ Sex. } & \multicolumn{2}{|c|}{$\begin{array}{l}\text { Upper first } \\
\text { molar. }\end{array}$} & \multicolumn{2}{|c|}{$\begin{array}{l}\text { Upper sec- } \\
\text { ond molar. }\end{array}$} & \multicolumn{2}{|c|}{$\begin{array}{l}\text { Upper third } \\
\text { molar. }\end{array}$} & \multirow{2}{*}{ Remarks. } \\
\hline & & & 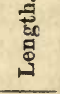 & 总 & 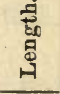 & 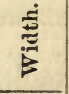 & 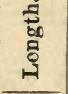 & 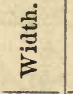 & \\
\hline $\begin{array}{r}13245 \\
3318\end{array}$ & $\begin{array}{l}\text { Big Porcupine Creek, Mont. } \\
\text { Medicine Bow Mountains, } \\
\text { Wash. }\end{array}$ & -.. & $\begin{array}{l}0.60 \\
0.57\end{array}$ & $\begin{array}{l}0.52 \\
0.48\end{array}$ & $\begin{array}{l}0.91 \\
0.74\end{array}$ & $\begin{array}{l}0.63 \\
0.60\end{array}$ & $\begin{array}{l}1.40 \\
1.36\end{array}$ & $\begin{array}{l}0.65 \\
0.67\end{array}$ & $\begin{array}{l}\text { Subsp. horribilis. } \\
\text { Do. }\end{array}$ \\
\hline $\begin{array}{r}990 \\
7401 \\
3630 \\
6905 \\
3537 \\
3536 \\
3538 \\
6557 \\
6548 \\
7146 \\
4441 \\
1033\end{array}$ & 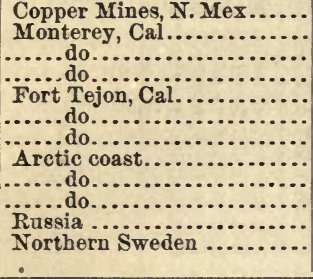 & 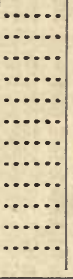 & $\begin{array}{l}0.60 \\
0.67 \\
0.72 \\
0.67 \\
0.65 \\
0.65 \\
0.55 \\
0.66 \\
0.57 \\
0.62 \\
0.68 \\
0.63\end{array}$ & $\begin{array}{l}0.54 \\
0.52 \\
0.65 \\
0.53 \\
0.50 \\
0.51 \\
0.45 \\
0.51 \\
0.45 \\
0.48 \\
0.57 \\
0.40\end{array}$ & $\begin{array}{l}0.92 \\
0.91 \\
0.97 \\
0.93 \\
0.93 \\
0.93 \\
0.87 \\
0.95 \\
0.88 \\
0.92 \\
0.94 \\
0.90\end{array}$ & $\begin{array}{l}0.70 \\
0.65 \\
0.75 \\
0.64 \\
0.69 \\
0.67 \\
0.66 \\
0.70 \\
0.64 \\
0.65 \\
0.72 \\
0.65\end{array}$ & $\begin{array}{l}1.35 \\
1.50 \\
1.66 \\
1.56 \\
1.52 \\
1.43 \\
1.35 \\
1.37 \\
1.41 \\
1.40 \\
1.40 \\
1.27\end{array}$ & $\begin{array}{l}0.70 \\
0.74 \\
0.75 \\
0.80 \\
0.75 \\
0.72 \\
0.67 \\
0.70 \\
0.68 \\
0.71 \\
0.75 \\
0.67\end{array}$ & $\begin{array}{l}\text { Do. } \\
\text { Do. } \\
\text { Do. } \\
\text { Do. } \\
\text { Do. } \\
\text { Do. } \\
\text { Do. } \\
\text { "richardsoni." } \\
\text { Do. } \\
\text { Do. } \\
\text { arctos. } \\
\text { Do. }\end{array}$ \\
\hline
\end{tabular}

\section{URSUS AMERICANUS.}

Seventeen skulls of this species, embracing all the aged ones in the collection, seem to indicate a slight increase in size to the southward. Four aged skulls from Louisiana and Florida range in length from $\mathbf{1 2 . 5 0}$ to 13.10 , and three others, more or less immature, would doubtless have attained an equal size had they lived to be as old. A Georgia specimen, also not full-grown, has a length of 11.15 , and in old age would probably have considerably exceeded 12.00. The other specimens, all full-grown and some of them very old, range from 9.90 to 12.15, most of them falling between 10.25 and 11.75. The largest (12.15) is from Puget Sound. A New York specimen comes next in size (11.90); New Mexican specimens next, the Alaskan being the smallest. This certainly points to a southward increase in size; but a much larger series would, of course, be necessary in order to establish positively whether the increase is in this direction. It would seem natural to expect it to be so, since the Bear is a hibernating animal, and is active for a much shorter period in northern than in southern localities.

It seems worthy of remark that only a small proportion of the skulls of Bears, and even of other Carnivora, including the Minks, Otters, and Martens, seen in collections, are specimens of mature age. The proportion of fully adult and very aged specimens is much greater among those from the unsettled parts of the continent than among those from the older States, owing; doubtless, to these animals being so closely hunted in the more settled districts that they rarely live to a very great age. 
Measurements of seventeen skulls of URSUS AMERICANUS.

\begin{tabular}{|c|c|c|c|c|c|}
\hline 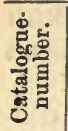 & Locality. & $\begin{array}{l}\dot{4} \\
\dot{0}\end{array}$ & 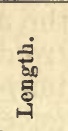 & 苞 & Remarks. \\
\hline 3834 & Key Biscayne, Fla.... & $\cdots$ & 13. 10 & & Very old. \\
\hline 1155 & Prairie Mer Rouge, La . & .... & 12. 90 & 7. 40 & Do. \\
\hline 1156 & ......do & $\cdots$ & 12. 70 & 7.45 & Do. \\
\hline $\begin{array}{r}987 \\
1154\end{array}$ & 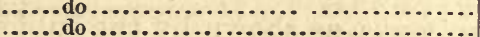 & $\cdots$ & 12.50 & 7.35 & $\begin{array}{l}\text { Do. } \\
\text { Middle-aged. }\end{array}$ \\
\hline 988 & 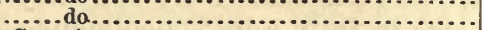 & $\therefore$. & $\begin{array}{l}11.10 \\
10.60\end{array}$ & $\begin{array}{l}6.10 \\
5.95\end{array}$ & $\begin{array}{l}\text { Middle-aged. } \\
\text { Rather young. }\end{array}$ \\
\hline 3894 & Georgia ......... & & 11.15 & 6.10 & Middle-aged. \\
\hline $3798^{\circ}$ & .................... & .... & 11. 80 & 7.35 & \\
\hline 2250 & & & 11.00 & 7.55 & \\
\hline 994 & Copper Mines, N. Mex..................... & ... & 9.90 & 6.07 & Very old; brown. \\
\hline $\begin{array}{l}992 \\
991\end{array}$ & 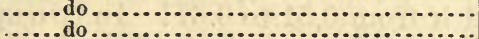 & $\cdots$ & $\begin{array}{l}11.35 \\
11.75\end{array}$ & $\begin{array}{l}7.05 \\
6.85\end{array}$ & Do. \\
\hline 12398 & 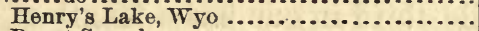 & 8 & 11. 40 & 7.40 & \\
\hline 3650 & 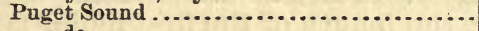 & ... & 12.15 & 7.40 & \\
\hline 6949 & .....do................. & & 10.20 & 6.00 & \\
\hline 8695 & 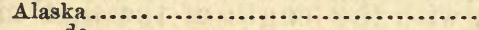 & $\cdots$ & 10.25 & 6.30 & \\
\hline 9477 & ......do.... & & 10.07 & 5.15 & \\
\hline
\end{tabular}

The range of variation not dependent upon locality is more fully indi. cated in the table of detailed measurements of these skulls giren below, but certain of the most prominent points of variation are not well shown by any series of measurements. Especially is this the case in respect to the amount of convexity different specimens present, in which individual rariation is strongly marked. One of the most prominent distinctions of $U$. americanus as compared with $U$. arctos and its varieties is the great convexity of the upper outline of the skull, both antero-posteriorly and transversely. Another feature is the constriction of the facial portion, giving a concare outline to the nasals when viewed in profile. But there are exceptions, even to the first of these distinctions, one or two specimens occurring (especially No. 2250 from New York) in which the flattening of the frontal region is as marked as in average skulls of $U$. horribilis. This flattening is also well marked in Nos. 1155 and 1156, from Louisiana. The greatest convexity is reached in No. 3484, from Key Biscayne, Fla. ; this and No. 2250 (New York) presenting the two extremes in respect to convexity. No. 3 $\{94$, from Georgia, has about the same degree of convexity as the Flcridia specimen. No. 2200 is also remarkable for the shortness of the facial portion of the skull, thereby imparting to it a greater than the usual ratio of width to length. In this specimen (mentioned by Professor Baird as remarkable for its tidth*), the width is 0.69 of the length. In another, from Louisiana (No. 115ॅ), it falls as low as 0.54 ! The average ratio of width to length is about 0.56 to 0.60 .

The teeth of $U$. americanus seem, in looking at them, to be relatively much smaller than in $U$. arctos, but, upon careful measurement, the difference is quite small, while they are of the same relative size as those of $U$. horribilis. In $U$. americanus, the temporal ridges pass more abruptly inward toward the medial line of the skull than in either $U$. horribilis or $U$. arctos.

The most important distinction presented by $U$. americanus is the form of the last upper molar. In $U$. americanus, the crown is widest at the middle, narrowing both anteriorly and posteriorly, but most rapidly posteriorly. The inner border is nearly straight; the outer has a prominent medial convexity, while in $U$. horribilis and $U$. arctos both outlines are nearly straight and generally about equally convergent. In $U$. americanus, the anterior third of the last molar is generally narrower 
than the middle third, though sometimes equaling it; but it is never wider, as it almost invariably is in $U$. horribilis and $U$. arctos. The $\mathrm{Pu}$ get Sound specimens have the anterior third the narrowest; in Alaskan specimens, it reaches its extreme width, while New York and Louisiana examples present the medium phase.

The skulls of $U$. cinnamomeus do not seem to be in any way distinguishable from average skulls of $U$. americanus, the distinction between them being one of color only and inconstant as characterizing any particular locality or region.

The upper molar teeth of $U$. americanus, as shown by the subjoined measurements, differ considerably in size in fully adult specimens. The first molars range in length of crown from 0.40 to 0.52 , and in the width of the same from 0.27 to 0.42 . The second ranges in length from 0.67 to 0.78 ; the third from 0.94 to 1.22 , and in width from 0.51 to 0.67 ! In two specimens, with the first 0.44 in length, the third in one has a length of only 0.94 and the other 1.07! In another, the length of the first molar is 0.41 and the third 1.11. In still another, with the length of the first molar 0.43 , the length of the third is $\mathbf{0 . 9 6}$. In two others, while the length of the first molar is 0.50 in each, the third molar in one has a length of 1.22 and in the other 1.15 .

The largest skulls of $U$. americanus nearly equal in size the smaller skulls of U. arctos horribilis, and actually overlap the series from Franklin Bay and the measurements given by authors of the true arctos of the Old World. In view of this fact, and of the great range of individual variation in size, cranial and dental characters, and the unreliability of color as a specific character, I too hastily, in former papers, ${ }^{*}$ referred all the American land-bears, including the $U$. americanus, to the $U$. arctos, which I am now convinced was a mistake; $U$. americanus being, I now believe, unquestionably specifically distinct, and the Grizzly subspecifically separable from the $U$. arctos of the Old World.

* Bulletin Mus. Comp. Zoöl., vol. i, pp. 184-192, Oct., 1869; Bulletin Essex Institute, vol. vi, pp. $46,54,59,63,1874$. 


\begin{tabular}{|c|c|}
\hline 离 & 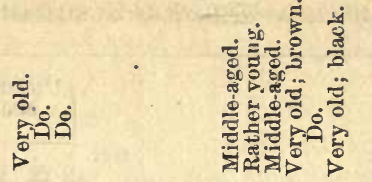 \\
\hline 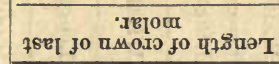 & 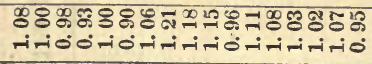 \\
\hline 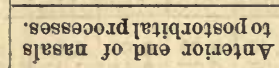 & 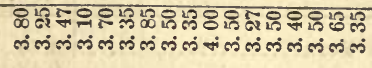 \\
\hline 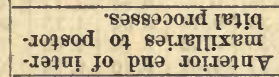 & 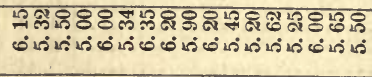 \\
\hline 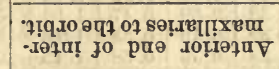 & 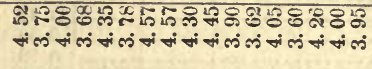 \\
\hline 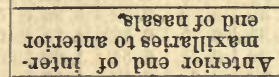 & 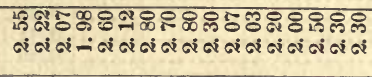 \\
\hline 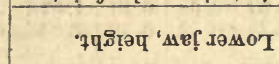 & 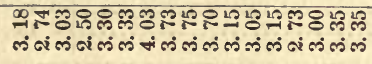 \\
\hline 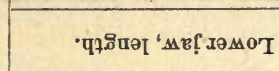 & 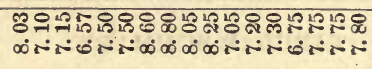 \\
\hline 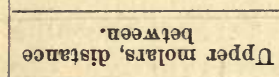 & 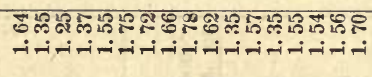 \\
\hline 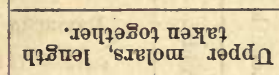 & 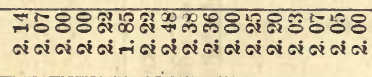 \\
\hline 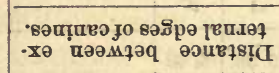 & 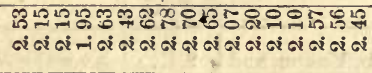 \\
\hline 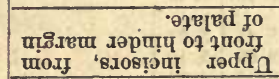 & 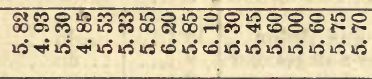 \\
\hline 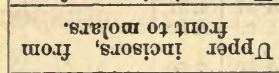 & 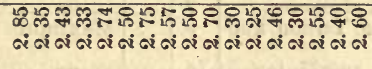 \\
\hline 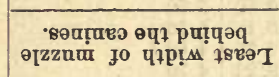 & 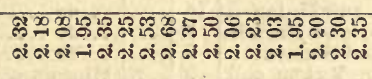 \\
\hline 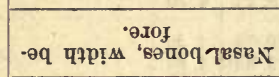 & 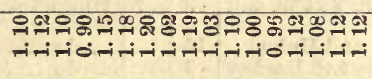 \\
\hline 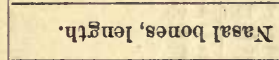 & 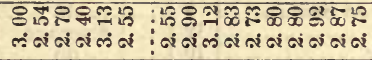 \\
\hline 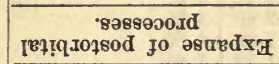 & 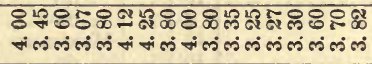 \\
\hline - & 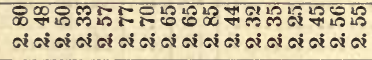 \\
\hline 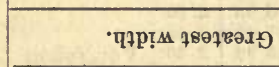 & 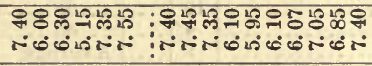 \\
\hline 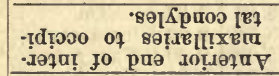 & 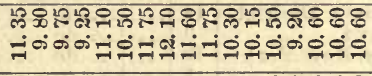 \\
\hline 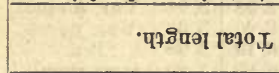 & 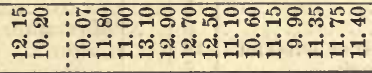 \\
\hline 'xəS & $\vdots \vdots \vdots \vdots \vdots \vdots \vdots \vdots \vdots \vdots \vdots \vdots \vdots \vdots \vdots \vdots 0$ \\
\hline . & 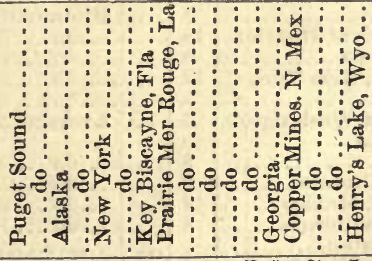 \\
\hline 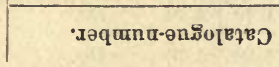 & 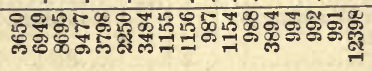 \\
\hline
\end{tabular}


Measurements of the molar teeth of URSUS AMERICANUS.

\begin{tabular}{|c|c|c|c|c|c|c|c|c|}
\hline \multirow{2}{*}{ 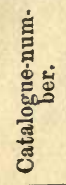 } & \multirow[b]{2}{*}{ Locality. } & \multirow[b]{2}{*}{ Sex. } & \multicolumn{2}{|c|}{$\begin{array}{l}\text { Upper first } \\
\text { molar. }\end{array}$} & \multicolumn{2}{|c|}{$\begin{array}{l}\text { Upper sec- } \\
\text { ond molar. }\end{array}$} & \multicolumn{2}{|c|}{$\begin{array}{l}\text { Upper third } \\
\text { molar. }\end{array}$} \\
\hline & & & 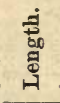 & $\underset{⿱ 乛 龰}{\stackrel{D}{ \pm}}$ & 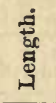 & 害 & 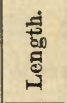 & 焉 \\
\hline 897 & Saint Lawrence Count & & 0. & 0 & 0. & 0.60 & 1. 22 & 0.64 \\
\hline 3857 & & & 0 . & & 0. & 0.54 & 1.17 & 0.60 \\
\hline 8161 & Nulato, Alas & & 0. & 0. & 0. & 0.54 & 1.15 & 0. \\
\hline 9477 & Alaska. & & 0.45 & 0. & 0. & 0. & 1.00 & 0. \\
\hline 8695 & do. & & 0.44 & & & & 0.94 & 0. \\
\hline 1155 & Prairie Mer $\mathrm{R}$ & & 0.42 & 0. & 0. & 0. & 1. & 0 . \\
\hline 1156 & .......do . & . & 0.50 & 0. & 0.76 & 0.55 & 1.18 & 0. \\
\hline 987 & & & 0.50 & 0. & 0. & & 1. & 0. \\
\hline 1154 & do ... & & 0.43 & 0. & 0.50 & 0.52 & 0.96 & 0.5 \\
\hline 988 & & & 0.41 & & 0.75 & 0. & 1. & 0. \\
\hline 3894 & Geo & & 0.40 & & 0.71 & & 1. & 0.57 \\
\hline 991 & N.Mex.. & & 0. & & 0. & 0.50 & 1. & 0.57 \\
\hline 994 & 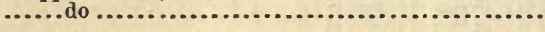 & & 0.43 & 0.32 & 0.70 & 0.50 & 1.03 & 0.54 \\
\hline
\end{tabular}

TABULAR SUMMARY.

\begin{tabular}{|c|c|c|c|c|c|c|c|}
\hline Species. & Locality. & 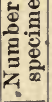 & $\stackrel{\leftrightarrow}{0}$ & & 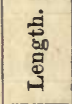 & 胥 & Remarks. \\
\hline Canis I & $\begin{array}{l}\text { Forts Simpson, Yukon, and } \\
\text { Rae. }\end{array}$ & 9 & .... & Average... & 10.38 & 5.40 & \\
\hline Do & Forts Benton and Union... & 16 & & ....do & 9.45 & 5.07 & \\
\hline $\begin{array}{l}\text { Do... } \\
\text { Do... }\end{array}$ & Forts Kearney and Harker. & 9 & $\cdots$ & $\ldots . . d$ & $\begin{array}{l}9.69 \\
8.37\end{array}$ & 5.18 & \\
\hline $\begin{array}{l}\text { Do.. } \\
\text { Do.. }\end{array}$ & $\begin{array}{l}\text { Rio Grande and Sonora.... } \\
\text { Forts Simpson, Yukon, and }\end{array}$ & $\begin{array}{l}3 \\
9\end{array}$ & $\cdots$ & Maximum. & $\begin{array}{r}8.37 \\
11.50\end{array}$ & $\begin{array}{l}4.31 \\
6.20\end{array}$ & \\
\hline Do. & $\begin{array}{l}\text { Rae. } \\
\text { Forts Benton and Union... }\end{array}$ & 16 & & ..... & 10.50 & 5.50 & \\
\hline $\begin{array}{l}\text { Do. } \\
\text { Do }\end{array}$ & Forts Kearney and Harker. & 9 & ... & ....do & 10.15 & 5. 50 & \\
\hline $\begin{array}{l}\mathrm{Dc} \\
\mathrm{D}\end{array}$ & Rio Grande and Sonora.... & 3 & .... & $\because$ do & 8. 75 & 4. 62 & \\
\hline $\mathbf{D}$ & $\begin{array}{l}\text { Forts Simpson, Yukon, and } \\
\text { Rae. }\end{array}$ & 9 & $\cdots$ & Minimum . & 9.20 & 4.50 & \\
\hline $\begin{array}{l}\text { Do } \\
\text { Do. }\end{array}$ & Forts Benton and Union... & 16 & & $\ldots d$ & 8.75 & 4. 50 & \\
\hline $\begin{array}{l}\text { Do. } \\
\text { Do. }\end{array}$ & Forts Kea & 3 & ... & & 9.35 & 4.85 & \\
\hline $\begin{array}{l}\text { Do. } \\
\text { Canis la }\end{array}$ & Rio Grand & 9 & .... & ....do ..... & 7.75 & 4. 05 & \\
\hline $\begin{array}{c}\text { Canis la } \\
\text { Do. }\end{array}$ & 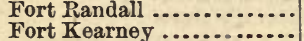 & 12 & $\cdots$ & Average... & 7.23 & 3.61 & \\
\hline & 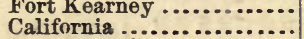 & $\begin{array}{r}10 \\
4\end{array}$ & $\cdots \cdot$ & ....do & $\begin{array}{l}7.25 \\
7.69\end{array}$ & $\begin{array}{l}3.65 \\
3.75\end{array}$ & \\
\hline & Fort Randall $\ldots \ldots \ldots \ldots$ & 12 & $\cdots$ & Maximum. & 7.60 & 3.80 & \\
\hline $\begin{array}{l}\mathbf{D} \\
\mathbf{D}\end{array}$ & Fort Kearney ............... & 10 & $\cdots$ & ....do ..... & 7.95 & 4.00 & \\
\hline & California $\ldots . . . \cdots \ldots \ldots \ldots$ & 4 & $\ldots$ & $\ldots$ do & 7.60 & 3. 80 & \\
\hline I & Fort Randall ................ & 12 & .... & Minimum . & 6.65 & 3.38 & \\
\hline & Fort Kearney .............. & 10 & $\cdots$ & .... do .. & 6.95 & 3.50 & \\
\hline Do. & $\begin{array}{l}\text { California } \ldots \ldots \ldots \\
\text { Alaska } . . .6 \ldots \ldots\end{array}$ & $\begin{array}{l}4 \\
9\end{array}$ & $\cdots \cdot$ & $\ddot{\mathrm{A}}$ & $\begin{array}{l}7.45 \\
5.98\end{array}$ & $\begin{array}{l}\text { 3. } 48 \\
\text { 3. } 20\end{array}$ & Var. fulvu \\
\hline Do.... & Mackenzie River District. & 18 & $\cdots$ & a... do..... & 5.80 & 3.02 & Do. \\
\hline & Upper Missouri ............ & 9 & $\cdots$ & ... do ... & 5. 78 & 2.90 & "macrurus." \\
\hline I & Essex County, New York.. & 12 & $\cdots$ & ....do do & 5.40 & 2.80 & Var. fulvus. \\
\hline & Europe...$\ldots \ldots \ldots \ldots \ldots$ & 5 & $\ldots$ & $\because$ & 5.58 & 3. 08 & Var. alopex. \\
\hline I & 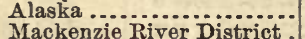 & 9 & .... & Maximum. & 6.20 & 3. 32 & Var. fulvus. \\
\hline & $\begin{array}{l}\text { Mackenzie River District . } \\
\text { Upper Missouri ........... }\end{array}$ & 18 & $\cdots$ & ... do ...... & 6.10 & 3.28 & Do. \\
\hline & & 9 & & & 6.00 & 3.20 & "macrurus." \\
\hline & $\begin{array}{l}\text { Jounty, New York... } \\
\theta \ldots . . . . . . . . . . . . . . . . .\end{array}$ & $\begin{array}{r}12 \\
5\end{array}$ & $\cdots$ & ....do $\ldots$ & $\begin{array}{l}5.68 \\
5.70\end{array}$ & $\begin{array}{l}2.95 \\
3.15\end{array}$ & Var. fulvus. \\
\hline & 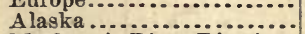 & 9 & $\cdots$ & Minimnm. & 5.70 & 2.90 & Var.fulvus. \\
\hline & Mackenzie Riv & 18 & $\ldots$ & ....do ... & 5.55 & 2.87 & Do. \\
\hline & Upper Missouri ... & 9 & & .... do .. & 5. 40 & 2.78 & "macrurus." \\
\hline & Esex County, New York .. & 12 & ... & $\ldots .$. & 5.20 & 2. 70 & Var. fulvus. \\
\hline Urocs & Europe & 5 & & & 5.50 & 3.04 & Var. alopex. \\
\hline Urocy & $\begin{array}{l}\text { Pennsylvania, Washington, } \\
\text { and Virginia. }\end{array}$ & 3 & & Average & 4.97 & 2.64 & Var. virgin \\
\hline & Texas ............... & 2 & & ... & 4. & 2. 64 & D \\
\hline & Sout & 3 & & & 4.56 & 2.54 & Dc \\
\hline & ntepec, Mexico.. & 3 & $\cdots$ & ....do & 4. 20 & 2.32 & Do: \\
\hline & Islands off California. & 3 & $\ldots$ & .... do & 3.80 & 2.03 & Var. littoralis. \\
\hline & Merida, Yucatan. & 1 & $\cdots$ & & 3. 75 & 1.93 & Var. virginianu \\
\hline & Pennsylvania, Washington, & 3 & & Maximum. & 4. 70 & 2.70 & \\
\hline & Texas... & 2 & & & 4. 60 & 2. 70 & Do. \\
\hline
\end{tabular}


TABULAR SUMMARY-Continued.

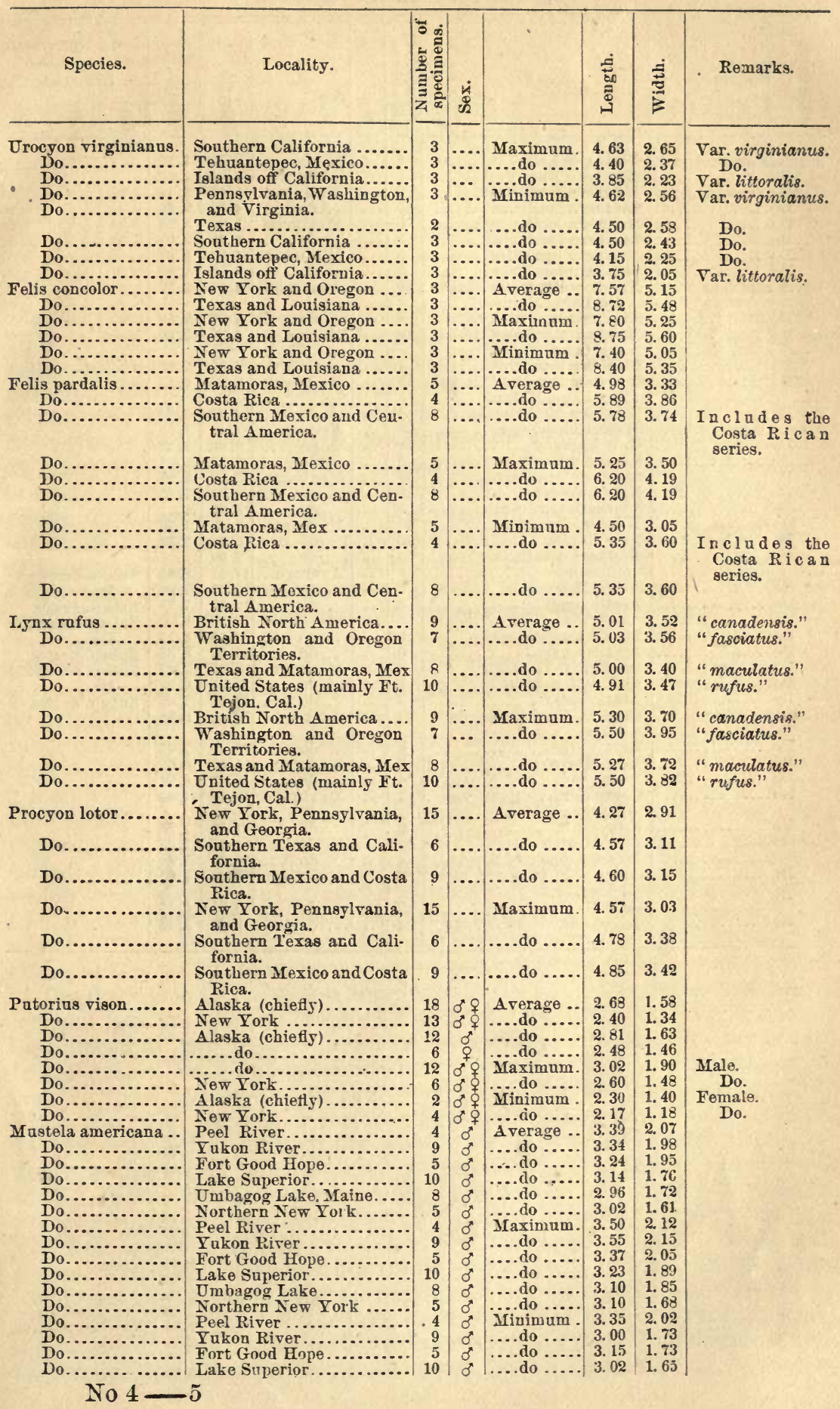


TABULAR SUMMARY-Contiuued.

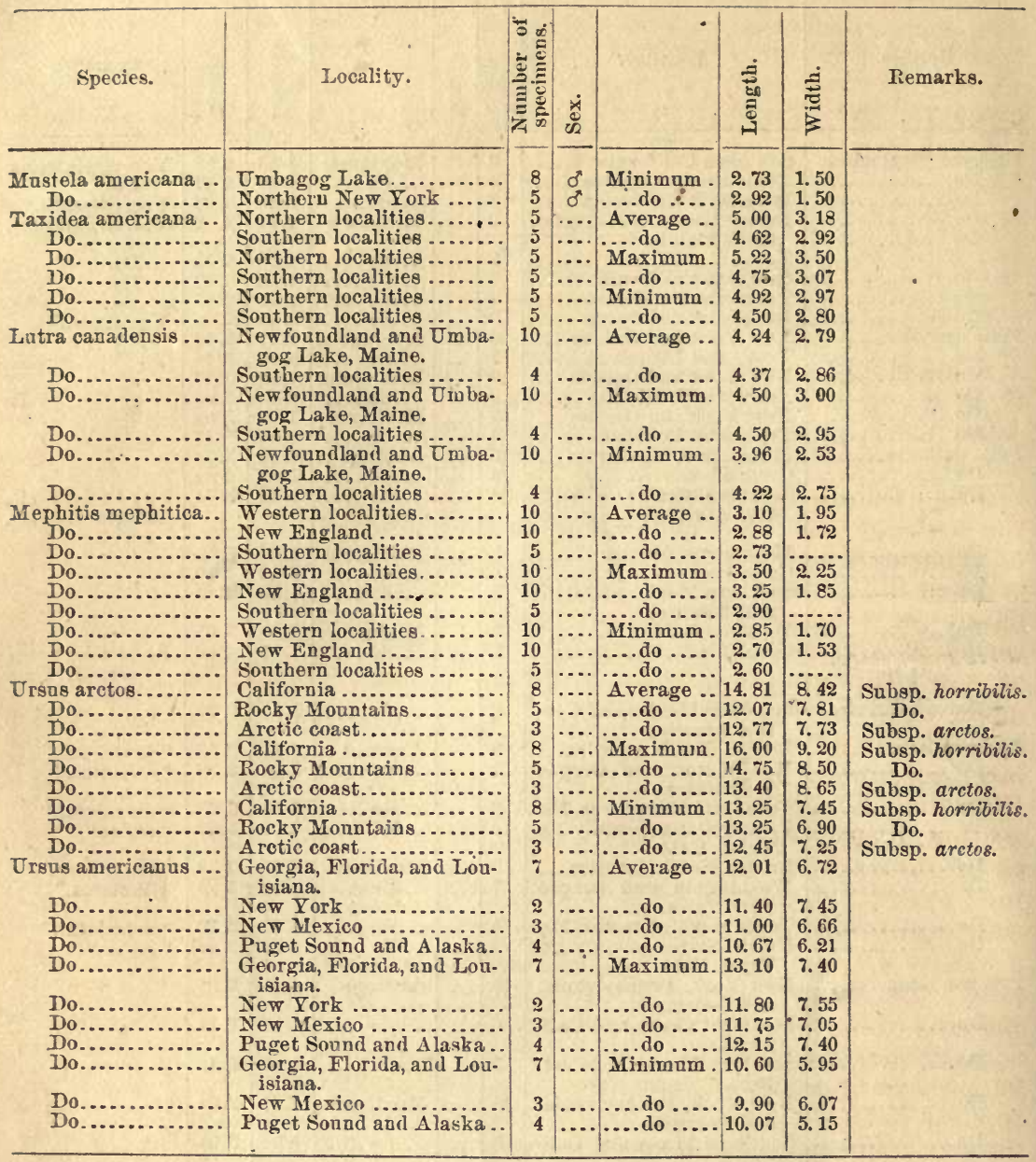


SEXUAL, INDIVIDUAL, AND GEOGRAPHICAL VARIATION IN LEUCOSTICTE TEPHROCOTIS.

-

BY J. A. AlLEN.

Some months since, my attention was called by Capt. Charles Bendire, U.S. A., to the fact of the existence of a well-marked difference in color between the sexes of two varieties of Leucosticte tephrocotis, namely, littoralis and tephrocotis. Under date of January 28, 1876, Captain Bendire wrote me, "There is a good deal of difference between the sexes of both varieties; so much that they can in almost every case be separated before dissection. The brown on the breasts of the females is much duller than that of the males." This statement, he added, was based on a series of serenty specimens of variety littoralis and on a series of about a dozen specimens of variety tephrocotis. Under date of April 18, Captain Bendire wrote me further on the subject, he in the mean time having sent me two lots of specimens, about two dozen examples in all, which seemed to fully confirm his statements. In the later account, in speaking of a series of eighty-five specimens of variety littoralis, of which the sex of each had been determined by careful dissection, he says there was not a single fernale in the whole lot that was as bright as the palest-tinted males. He says further, "I have examined over two hundred skins of variety littoralis and about thirty of rariety tephrocotis. I find a constant difference, and have never yet obtained a female which I could not readily distinguish from a male before skin. ning; but, nevertheless, everyospecimen was dissected, and the sex not guessed at." With this letter was forwarded to me by Captain Bendire a series of thirteen skins of variety littoralis and three of variety tephrocotis, which were selected impartially by himself and Lieut. George R. Bacon, to show the extreme ranges of variation in color in the two sexes of each variety. The series of variety littoralis was taken from a lot of eighty-two skins, and is stated to embrace two of the brightest females and several of the dullest males of the whole lot. Separating the series by color, without reference to the labels, I found, on looking at the labels, that I had placed all the females in one series and all the males in the other. In the case of only one specimen was there any reason for hesitancy in making the separation; but this eren, I found on reference to the label, I had placed in its proper series. The general aspect of the two series I found was quite different, noticeably so at a considerable distance, through the much paler tints of the females. "Several of the skins", adds Captain Bendire, "are poorly prepared; but they will answer every purpose for description, and I repeat my statement that they rep. resent the brightest females and dullest males of the whole lot." Lieutenant Bacon, who assisted in making the selection, says (writing at the same time) that the series sent to me was made up with great care, so as to show the dullest and brightest of each sex. "I have prepared", Lieutenant Bacon adds, "some eighty skins of variety littoralis, and have found no difficulty in distinguishing the sexes before skinning. I hare not 
found one female as bright as the dullest male. It is my opinion that the same remarks apply to variety tephrocotis."

The abore statements of Captain Bendire and Lieutenant Bacon are made in reference to some very positive remarks by Mr. Robert Ridgwas, in his recent very elaborate monograph of the genus Leucosticte, in respect to sexual variation among the different forms of this group. Mr. Ridgway says, "The American species of this genus fall into two dis. tinct groups, according as the sexes do or do not differ in appearance. In $L$. tephrocotis, in all its forms, there is not the slightest sexual difference; but, in $L$. atrata and $L$. australis, the distinction is very marked." * Under the head of $L$. tephrocotis var. littoralis, Mr. Iidgway further sars, "In regard to the two sexes, as compared to one another, there is the same absolute similarity in appearance and sizet that exists in griseinucha and tephrocotis, many females † being more brightly colored and some larger than some males. : The apparently larger arerage of the dimensions of the [seven] female[s] indicated in the abore measurements is no doubt due to the small number of specimens of the sex examined." $\ddagger$

Mr. Ridgway's tables seem to indicate that the sex was known in only a small proportion of his specimens, namely, in fourteen (seven males and seren females) out of forty-eight in rariety littoralis, and in about onethird in rariety tephrocotis. As already stated, Captain Bendire's specimens, in which the sex was carefully determined by dissection, show a very considerable constant sexual difference in coloration, and, as will be presently shown, also in size.

Through some unfortunate inadvertence, an important error has crept into Mr. Ridgway's table of comparative measurements given on page $60\left(l_{\text {. c. }}\right.$ ); the measurements of the two sexes of $L$. tephrocotis being given as, male, wing, 4.21 ; tail, 3.12 ; female, wing, 4.16 ; tail, 3.12 ; thus apparently sustaining Mr. Ridgway's generalization in respect to the absence of difierence in size in the two sexes of this form. In examining Captain Bendire's specimens, however, I was struck with the apparently smaller size of the females; and, on referring to the measurements recorded on his labels, this apparent difference proved to be real. I then turned to Mr. Ridgwar's table of the measurements of $L$. tephrocotis, and, carefully computing the averages giren by Mr. Ridgway, I met with quite different results, the thirty-four females giving an arerage length of wing of 4.05 , and of tail of 2.97 , against the 4.16 and 3.12 given by Mr. Ridgwas, and of course giving a considerably smaller arerage than for the males, namely, 4.05 against 4.21 for the wing, and 2.97 against 3.12 for the tail.

The averages given in the same connection by Mr. Ridgway for the two sexes of $L$. littoralis (seven males and seren females) are borne out by the table of measurements on which they are based, and seem to indicate that there is no sexual rariation in size in this form. Through the kindness of Captain Bendire, I have before me measurements (sent to me by my special request) of forty-two males and twenty-six females of $I$. littoralis, in which the wing averages respectively 4.23 for the males and 4.05 for the females. In addition to these, seren males and six females, which he had previously sent me, gare 4.19 for the length of the wing in the male and 4.02 for the same in the female; thus showing that not only in coloration but also in size there is a well. marked sexual rariation in this form as well as in teplirocotis, about the

* "Monograph of the genus Leucosticte," etc., Bull. U. S. Geo'og. and Geograph. Survey of the Territories. No. 2, second series, p. 60, May, 1375.

+Not italicized in the origina!.

$1 \mp$ Loc. cit., p. 75 . 
same, in fact, as occurs in $L$. australis, in which and in L. atrata Mr. Ridgway admits it to be well marked.

L. griseinucha is the only other American form of Lencosticte alleged by Mr. Ridgway to show no sexual difference in size or color.

In respect to individual variation, Mr. Ridgway remarks as follows: "There is no noticeable range of individual variation amnng typical examples of any form, and it is only the transitional specimens connecting two races of one species that vary at all from the normal standard","* etc. $(l . c .$, p. 60). "Regarding the subject of individual variation, we shall say little, since the immense series at our command shows that this is really insignificant" (l. c., p. 58). These remarks are made in reference to statements of mine quoted by Mr. Ridgway, in which I say that "it seems probable that some of the differences whereon certain species $\dagger$ of Leucosticte have been founded may be only individual variations". This remark had reference to a series of mounted specimens in the Museum of the Boston Society of Natural History, collected at Central City, Colo., by Mr. F. E. Everett. My remarks respecting these Mr. Ridgway also quotes ( $l_{\text {. }} .$, p. $\left.5 \tilde{3}\right)$, and, without having seen them, in commenting on them in foot-notes, assigns them, with great positiveness, to his different species and varieties of Leucosticte. In point of fact, there is a considerable range of color-variation in birds of the same sex from the same localities, referable, unquestionably, to the same varieties. These affect not only the inteusity of the general tints, but the areas of dusky and ashy markingsabout the head, as Mr. Ridgway's own comments under L. littoralis sufficiently show. Whether or not such specimens form the intergrading hinks between varieties is immaterial to the point at issue.

In respect to individual variation in size, it is sufficient to say that the length of the wing varies in males of variety littoralis from 3.90 to 4.50 , and in the females from 3.88 to 4.25 ; in variety tephrocotis (see Mr. Ridgway's tables), from 4.00 to 4.40 in the males, and from 3.90 to 4.30 in the females ; in variety griseinucha, from 4.25 to 4.75 in the males, and from 3.90 to 4.80 in the females! It seems a priori improbable that such a wide range of individual variation in size should obtain without there being also considerable variability in color. Such a state of things would certainly be an exceptional and noteworthy fact in our present knowledge of individual variation among birds.

As the present forms a convenient opportunity for noticing some other strictures by Mr. Ridgway on some general remarks of mine respecting this group, I will add a few words respecting geographical variation among the different forms of Leucosticte. Mr. Ridgway, in commenting on my attempt "to show a correlation between the distinguishing characters of the different forms of this genus and the recognized general laws of geographical variation", in which I claim the northern forms to be larger, with more ash on the head, etc., says that, respecting these statements, "there is need of correction. There is no such variation from the north southward as that stated in the passage quoted, for the northern forms are quite as brightly colored as the most southern ones, $\ddagger$ while in the gray-headed races of $I$. tephrocotis it is the more southern one (var. littoralis) which has the most gray. Thus, in this latter race the throat is more or less gras, frequently entirely gray; while, in var. griseinucha, the whole throat is black. Var. griseinucha is also much

* Not italicized in the original.

† Referring, among others, to L. campestris, a form Mr. Ridgway himself does not regard as even varietally distinguishable.

$\ddagger$ Not italicized in the original. 
brighter-colored than its southern ally, the red being not only deeper and more extended, but the brown of the body is darker and richer! ...... The fact that littoralis has more gray on the head than tephrocotis cannot be explained by stating that the former is more northern in its distribution, for such is not the ease, since the breeding grounds of var. tephrocotis are quite as far northward in the interior as those of var. littoralis is on the coast. We must, therefore, look to some other explanations of these variations than the laws of elimatic modifications which are now recognized. The single instance of apparent correspondence to a general rule of geographical variation is seen in $L$. griseinucha of the Alaskan coast, which is more nortbern in its habitat than $L$. littoralis of the more southern North-Pacific coast, and is also larger in size."(Loc. cit., pp. 58, 59.)

From much of the above I must beg leave to dissent, as matters of fact. In the first place, $L$. australis was one of the forms to which I especially referred, and which, because it has since been considered by him as a species rather than a variety, Mr. Ridgway leaves wholly out of consideration in this connection. It is, however, one of the "forms of Leucosticte" to be considered, and is also the most southern, the smallest, and by far the brightest-colored.* Climatologically considered, $I$. tephrocotis is the next most southern, $\dagger$ is the next in size (at least is not larger than variety littoralis), and has the least ash on the head. The breeding-range of $L$. littoralis is not known, and this form has not yet been taken on the "southern part of the North-Pacific coast", unless Alàska can be so considered. In size, it does not appreciably differ from $L$. tephrocotis. It probably passes the summer in the interior, to the westward of the breeding-range of $L$. tephrocotis, and hence under rather more northern elimatic conditions. L. griseinucha is the most northern and much the largest. Its darker colors are easily explainable on climatic grounds, or by "the laws of climatic modification which are now recog. nized". Its darker colors simply correlate with those of the generality of the varietal forms of Birds and Mammals inhabiting the same region, remarkable for its immense annual rain-fall and great humidity of

*L. "atrata" I have purposely omitted in this consideration. If, however, it is anything more than a melanotic phase of variety tephrocotis, it finds in that form a very near ally, and if entitled to specific, or even varietal, recoguition, gives further proof of the generalization here proposed, it being much darker and smaller than tephrocotis. Mr. Ridgway says of atrata, "the pattern of coloration is precisely similar to that of $L$. tephrocotis, but the totally different tints (black or dusky-slate, instead of chocolatebrown), and the very marked difference between the sexes, ${ }^{*}$ separate it at once as a distinct species. It may be suggested that it is a melanism of tephrocotis; but, if this were so, there would be no such entire uniformity of characters as is exhibited throughout the series of five specimens, while in tephrocotis there is not the slightest sexual difference in colors."* It will be noticed from the above that one of the strong points relied upon by Mr. Ridgway as distinguishing atrata from tephrocotis is the supposed absence of sexual variation in tephrocotis, and its presence in atrata, a distinction founded on error.

tIn this view I find I am sustained by Mr. C. E. Aiken, who says, "From these facts, and information derived from other sources, I infer that the gray-cheeked variety (littoralis) is the most northern race, and that many of them do not find their way so far south [as Cañon City, Colo.] except in severe winters. In this belief I am strengthened by the fact that, of sixty birds killed in Wyoming in 1870, all but one or two were typical tephrocotis; that tephrocotis occupies, during the breeding season a more southern locality than the preceding [littoratis], and winters, regularly, in the Rocky Mount ains of Colorado, and even farther south; that australis inhabits the next lower section, breeding in Colorado, and probably extending into the British possessions, but wintering, for the most part-especially in severe winters-south of this Territory; that atrata, if anywhere common, must occupy a more southern locality."-(Quoted from Mr. Ridgway's Mon., $l$. c., pp. 62,63.) 
climate;* a fact that Mr. Ridgwas şeems for the moment to have forgotten.

As a further contribution to the history of Leucosticte tephrocotis, I append the measurements of seventy-seven specimens of varieties littoralis and tephrocotis, kindly sent me by Captain Bendire. As the measurements were made by the collector from fresh specimens, and as the sex of each specimen was determined by actual dissection, they are of special interest in the present connection.

Measurements of LEUCOSTICTE TEPHROCOTIS var. LITTOR.LIS.

\begin{tabular}{|c|c|c|c|c|c|c|}
\hline Locality. & Date. & $\begin{array}{l}\dot{x} \\
\stackrel{0}{0} \\
\ddot{\Sigma}\end{array}$ & 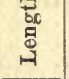 & 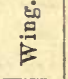 & & Collected by- \\
\hline 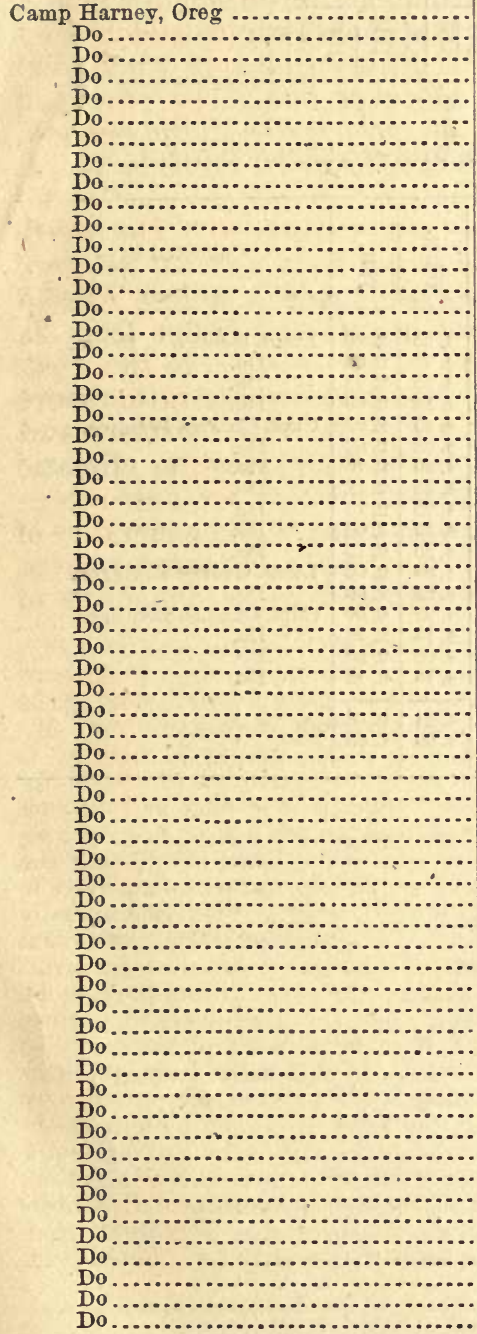 & $\begin{array}{l}\text { Mar. } 1 \\
\text { Feb. } 26 \\
\text { Feb. } 26 \\
\text { Jan. } 26 \\
\text { Jan. } 6 \\
\text { Jan. } 20 \\
\text { Jan. } 6 \\
\ldots . . . . . . . . .\end{array}$ & $\begin{array}{l}0 \\
0 \\
0 \\
0 \\
0 \\
0 \\
0 \\
0 \\
0 \\
0 \\
0 \\
0 \\
0 \\
0 \\
0 \\
0 \\
0 \\
0 \\
0 \\
0 \\
0 \\
0 \\
0 \\
0 \\
0 \\
0 \\
0 \\
0 \\
0 \\
0 \\
0 \\
0 \\
0 \\
0 \\
0 \\
0 \\
0 \\
0 \\
0 \\
0 \\
0 \\
0 \\
0 \\
0 \\
0 \\
0 \\
0 \\
0 \\
0 \\
0 \\
0 \\
0 \\
0 \\
0 \\
0 \\
0 \\
0 \\
0 \\
0 \\
0 \\
0 \\
0 \\
0 \\
0 \\
0 \\
0 \\
0 \\
0 \\
0 \\
0 \\
0 \\
0 \\
0 \\
0 \\
0 \\
0 \\
0 \\
0 \\
0 \\
0 \\
0 \\
0 \\
0 \\
0 \\
0 \\
0 \\
0 \\
0 \\
0 \\
0 \\
0 \\
0\end{array}$ & $\begin{array}{l}6.75 \\
7.00 \\
6.65 \\
7.00 \\
7.00 \\
6.90 \\
7.00 \\
7.00 \\
7.00 \\
7.00 \\
7.00 \\
6.95 \\
6.60 \\
6.75 \\
6.65 \\
6.50 \\
6.90 \\
6.50 \\
7.00 \\
7.12 \\
7.00 \\
6.94 \\
6.60 \\
6.80 \\
7.25 \\
6.87 \\
6.75 \\
7.00 \\
6.93 \\
7.00 \\
7.00 \\
7.00 \\
7.00 \\
6.45 \\
6.80 \\
7.00 \\
6.80 \\
7.03 \\
6.95 \\
6.30 \\
6.75 \\
6.98 \\
6.94 \\
7.05 \\
6.75 \\
7.05 \\
6.75 \\
6.75 \\
7.00 \\
6.75 \\
6.50 \\
6.60 \\
6.75 \\
6.50 \\
6.70 \\
6.68 \\
6.70 \\
6.60 \\
6.68 \\
6.95 \\
6.65 \\
6.75 \\
6.75\end{array}$ & $\begin{array}{l}4.00 \\
4.32 \\
4.00 \\
4.21 \\
4.25 \\
4.25 \\
4.30 \\
4.37 \\
4.00 \\
4.25 \\
4.25 \\
4.20 \\
4.15 \\
4.00 \\
4.00 \\
4.00 \\
4.25 \\
3.90 \\
4.40 \\
4.25 \\
4.37 \\
4.23 \\
4.00 \\
4.00 \\
4.25 \\
4.25 \\
4.20 \\
4.30 \\
4.32 \\
4.45 \\
4.32 \\
4.42 \\
4.25 \\
4.50 \\
4.25 \\
4.13 \\
4.35 \\
4.31 \\
4.32 \\
4.05 \\
4.27 \\
4.35 \\
4.18 \\
4.37 \\
4.32 \\
4.32 \\
4.25 \\
4.25 \\
4.13 \\
4.00 \\
4.12 \\
4.00 \\
4.00 \\
4.00 \\
4.00 \\
4.00 \\
4.00 \\
3.95 \\
3.88 \\
4.12 \\
4.00 \\
4.13 \\
4.02\end{array}$ & $\begin{array}{l}2.70 \\
3.00 \\
2.70 \\
2.90 \\
2.75 \\
3.00 \\
3.00 \\
3.05 \\
3.00 \\
2.90 \\
3.00 \\
2.88 \\
2.90 \\
2.90 \\
2.95 \\
2.75 \\
3.00 \\
2.75 \\
2.90 \\
3.12 \\
2.94 \\
2.87 \\
2.75 \\
2.65 \\
3.00 \\
3.00 \\
2.75 \\
2.80 \\
2.96 \\
2.94 \\
2.98 \\
2.90 \\
2.90 \\
2.95 \\
2.75 \\
2.94 \\
2.95 \\
2.93 \\
3.00 \\
2.68 \\
2.70 \\
2.95 \\
2.75 \\
2.87 \\
2.75 \\
2.96 \\
2.90 \\
2.95 \\
2.80 \\
2.65 \\
2.90 \\
2.50 \\
2.75 \\
2.75 \\
2.75 \\
2.80 \\
2.90 \\
2.75 \\
2.78 \\
3.00 \\
2.75 \\
2.75 \\
2.65\end{array}$ & $\begin{array}{l}\text { Capt. Charles Bendire. } \\
\text { Do. } \\
\text { Do. } \\
\text { Do. } \\
\text { Do. } \\
\text { Do. } \\
\text { Do. } \\
\text { Do. } \\
\text { Do. } \\
\text { Do. } \\
\text { Do. } \\
\text { Do. } \\
\text { Do. } \\
\text { Do. } \\
\text { Do. } \\
\text { Do. } \\
\text { Do. } \\
\text { Do. } \\
\text { Do. } \\
\text { Do. } \\
\text { Do. } \\
\text { Do. } \\
\text { Lieut. George R. Bacon. } \\
\text { Do. } \\
\text { Do. } \\
\text { Capt. Charles Bendire. } \\
\text { Do. } \\
\text { Do. } \\
\text { Lieut. George R. Bacon. } \\
\text { Do. } \\
\text { Do. } \\
\text { Do. } \\
\text { Do. } \\
\text { Do. } \\
\text { Do. } \\
\text { Do. } \\
\text { Do. } \\
\text { Do. } \\
\text { Do. } \\
\text { Do. } \\
\text { Do. } \\
\text { Do. } \\
\text { Do. } \\
\text { Do. } \\
\text { Do. } \\
\text { Do. } \\
\text { Do. } \\
\text { Do. } \\
\text { Do. } \\
\text { Capt. Charles Bendire. } \\
\text { Do. } \\
\text { Do. } \\
\text { Do. } \\
\text { Do. } \\
\text { Do. } \\
\text { Do. } \\
\text { Do. } \\
\text { Do. } \\
\text { Do. } \\
\text { Do. } \\
\text { Dorge R. Bacon. } \\
\text { Dendire. } \\
\text { Dte. } \\
\text { Do }\end{array}$ \\
\hline
\end{tabular}

* See Bull. Mus. Comp. Zoölogy, vol. ii, pp. 237, 239, A pril, 1871; Proc. Bost. Soc. Nat. Hist., vol. xvi, pp. 279-284, June, 1874. 
Measurements of LEUCOSTICTE TEPHROCOTIS var LITTORALIS-Continued.

\begin{tabular}{|c|c|c|c|c|c|c|}
\hline Locality. & Date. & ஜू் & 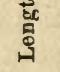 & $\stackrel{80}{E}$ & ᄅं & Collected by- \\
\hline 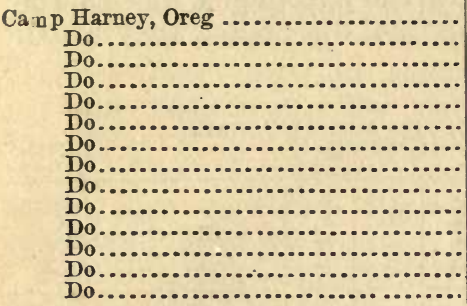 & 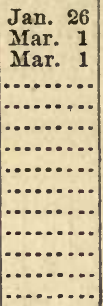 & 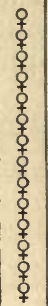 & $\begin{array}{l}6.70 \\
6.75 \\
6.50 \\
6.65 \\
6.50 \\
6.60 \\
6.75 \\
6.50 \\
6.70 \\
6.68 \\
6.70 \\
6.60 \\
6.68 \\
6.95\end{array}$ & $\begin{array}{l}4.00 \\
4.05 \\
3.92 \\
4.00 \\
4.12 \\
4.00 \\
4.00 \\
4.00 \\
4.00 \\
4.00 \\
4.00 \\
3.95 \\
3.88 \\
4.12\end{array}$ & $\begin{array}{l}2.85 \\
2.88 \\
2.50 \\
2.65 \\
2.90 \\
2.50 \\
2.75 \\
2.75 \\
2.75 \\
2.80 \\
2.90 \\
2.75 \\
2.78 \\
3.00\end{array}$ & $\begin{array}{l}\text { Lieut. George R. Bacon. } \\
\text { Do. } \\
\text { Capt. Charles Bendire. } \\
\text { Lieut. George R. Bacon. } \\
\text { Do. } \\
\text { Do. } \\
\text { Do. } \\
\text { Do. } \\
\text { Do. } \\
\text { Do. } \\
\text { Do. } \\
\text { Do. } \\
\text { Do. } \\
\text { Do. }\end{array}$ \\
\hline $\begin{array}{l}\text { Average of } 49 \text { males.............. } \\
\text { Average of } 28 \text { females........... }\end{array}$ & $\ldots$ & $\ldots$ & $\begin{array}{l}6.82 \\
6.67\end{array}$ & $\begin{array}{l}4.22 \\
4.01\end{array}$ & $\begin{array}{l}\text { 2. } 89 \\
2.76\end{array}$ & \\
\hline
\end{tabular}

Measurements of LEUCOSTICTE TEPHROCOTIS var. TEPHROCOTIS.

\begin{tabular}{|c|c|c|c|c|c|}
\hline Locality. & $\begin{array}{l}\dot{x} \\
\ddot{D}\end{array}$ & 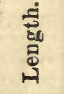 & $\stackrel{घ}{\vec{k}}$ & Еี & Collected by- \\
\hline 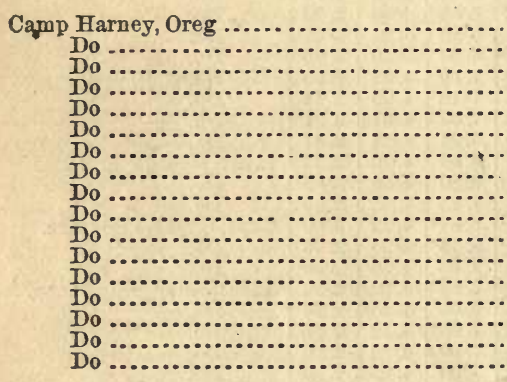 & $\begin{array}{l}0 \\
0 \\
0 \\
0 " \\
0 \\
0 \\
0 \\
0 \\
0 \\
0 \\
0 \\
0 \\
0 \\
0 \\
0 \\
0 \\
0 \\
0 \\
0 \\
0 \\
0 \\
0 \\
0 \\
0 \\
0 \\
+\end{array}$ & $\begin{array}{l}6.85 \\
6.85 \\
6.50 \\
6.75 \\
6.85 \\
6.80 \\
6.75 \\
6.80 \\
6.50 \\
7.18 \\
6.80 \\
6.75 \\
6.85 \\
6.50 \\
6.60 \\
6.25 \\
6.70\end{array}$ & $\begin{array}{l}4.25 \\
4.25 \\
4.12 \\
4.12 \\
4.45 \\
4.08 \\
4.20 \\
4.25 \\
4.25 \\
4.39 \\
4.30 \\
4.00 \\
4.25 \\
4.00 \\
4.15 \\
4.00 \\
4.16\end{array}$ & $\begin{array}{l}2.85 \\
2.85 \\
2.75 \\
2.60 \\
2.95 \\
2.62 \\
2.70 \\
2.78 \\
2.75 \\
3.00 \\
2.75 \\
2.62 \\
2.90 \\
2.50 \\
2.70 \\
2.50 \\
2.75\end{array}$ & $\begin{array}{l}\text { Lieut. George R. Bacon. } \\
\text { Do. } \\
\text { Do. } \\
\text { Do. } \\
\text { Capt. Charles Bendire. } \\
\text { Do. } \\
\text { Do. } \\
\text { Do. } \\
\text { Do. } \\
\text { Do. } \\
\text { Do. } \\
\text { Lieut. George R. Bacon. } \\
\text { Do. } \\
\text { Capt. Charles Bendire. } \\
\text { Do. } \\
\text { Do. } \\
\text { Do. }\end{array}$ \\
\hline $\begin{array}{l}\text { Average of } 11 \text { male } \\
\text { Average of } 6 \text { female }\end{array}$ & $\cdots \ldots$ & $\begin{array}{l}6.79 \\
6.61\end{array}$ & $\begin{array}{l}4.24 \\
4.09\end{array}$ & $\begin{array}{l}2.78 \\
2.66\end{array}$ & \\
\hline
\end{tabular}


DEPARTMENT OF THE INTERIOR. UNITED STATES GEOLOGICAL AND GEOGRAPHICAL SURVEY.

F. V. HAYDEN, U. S. Geologist-in-Charge.

\section{THE GEOGRAPHICAL DISTRIBUTION} OF THE

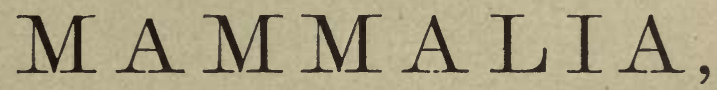

CONGIDERED IN RELATION TO THE PRINCIPAL

\section{ONTOLOGICAL REGIONS OF THE EARTH,} AND THE LAWS THAT GOVERN THE

DISTRIBUTION OF ANIMAL LIFE.

BY

JOEL ASAPH ALLEN.

FXTRACTED FROM THE BULLETIN OF THE SURVEY, VOL. IV, NO. 2. 

ART. XV. -THE GEOGRAPHICAL DISTRIBUTION OF THE MAMMALIA, CONSIDERED IN RELATION TO THE PRINCIPAL ONTOLOGICAL REGIONS OF THE EARTH, AND THE LAWS THAT GOVERN THE DISTRIBUTION OF ANIMAL LIFE.

\author{
By Joml Asaph Allen.
}

\title{
I.-DISTRIBUTION OF MAMMALIAN LIFE IN THE NURTH. ERN HEMISPHERE, CONSIDERED IN RELATION TO LAWS OF GEOGRAPHICAL DISTRIBUTION.
}

When, in 1871, I published* a few preliminary remarks concerning the general subject of geographical zoölogy, it was my intention soon to present more fully the facts whereon were based the few general principles then stated. In this paper I claimed, in accordance with the riews of Humboldt, Wagner, Dana, Agassiz, De Candolle, and others, that life is distributed in circumpolar zones, which conform with the climatic zones, though not always with the parallels of the geographer. Subsequent study of the subject has confirmed the convictions then expressed. These are directly antagonistic to the scheme of division of the earth's surface into the life-regions proposed by Dr. Sclater in 1857 , based on the distribution of birds, and since so generally adopted. Their wide acceptation, it seems to me, has resulted simply from the fact that so few have taken the trouble to sift the facts bearing upon the subject, or to carefully examine the basis on which Ur. Sclater's divisions are founded. The recent appearance of Mr. Wallace's laborious and in many respects excellent and praiseworthy workt has now rendered a critical presentation of the subject more necessary than before, since, instead of seeking in the facts of geographical zoölogy a basis for a natural scheme of division, he has unhesitatingly accepted Dr. Sclater's ontological regions and marshalled his facts and arranged his work wholly in conformity with this, as I shall presently attempt to show, grossly misleading scheme. The source of error, as I hope to make evident, lies in method of treatment. Assuming apparently that the larger or continental land-areas are necessarily coincident with natural ontological regions, divisions of the earth's surface wholly incompara-

* On the Geographical Distribution of the Birds of Eastern North America, with special reference to the Number and Circumscription of the Ornithological Faunæ. <Bull. Mus. Comp. Zoöl., vol. ii, No. 3, pp. 375-450. April, 1871.

†The Geographical Distribution of Animals. With a Study of Living and Extinct Fannas as Elucidating the Past Changes of the Earth's Surface. By Alfred Russel Wallace. Two vols. $8^{\circ}$. With maps and illustrations. London, 1876.

Bull. iv. No. $2-1$ 
ble have been contrasted, and erroneous deductions have been the result. In the division of the northern hemisphere into two primary regions, the so-called "Nearctic" and "Palæarctic", no account has been taken of the almost homngeneous character of life throughout the Arctic and Sub-Arctic regions, and the equally important principle of temperature as a powerful limiting agent, nor of the facts of the rapid increase of organic forms and the consequent differentiation of life from the Arctic regions toward the Equatorial in an ever increasing ratio in proportion to the extent and divergence of the principal land-areas. At the northward, this method of division separates, into primary liferegions, areas of the closest ontological resemblances, while at the southward these divisions each embrace faunæ so unlike those of their northern portions respectively that the two extremes of either region have little in common, scarcely more than have the southern portions of these two regions as compared with each other. It is the neglect of the above-stated fundamental facts and principles that forms the fatal weakness of the scheme of life-regions proposed by Dr. Sclater, and so widely and thoughtlessly accepted. That the facts and principles above alluded to are fundamental, -in other words, that life is distributed in circumpolar zones under the controlling influence of climate and mainly of temperature,-I propose to show by a tabular presentation of the facts of distribution of mammalian life in the northern hemisphere.

One of the reasons given by Mr. Wallace for adopting Dr. Sclater's regions is that "it is a positive, and by no means an unimportant advantage to have our named regions approximately equal in sizo, and with easily defined, and therefore easily remembered, boundaries", providing that "we do not violate any clear affinities or produce any glaring irregularities". It is further claimed that "all elaborate definitions of interpenetrating frontiers, as well as regions extending over three fourths of the land surface of the globe, and including places which are the antipodes of each other, would be most inconvenient, even if there. were not such difference of opinion about them".*

These arguments can be scarcely characterized as otherwise than trivial, since they imply that truth, at least to a certain degree, should be regarded as secondary to convenience. They further show that the author of these propositions has not worked out in detail the distribution of life, species by species, over a diversified area of considerable extent, like, for instance, that of Eastern North America, where an interdigitation of the lesser faunal areas is one of the marked features of the region, as it is elsewhere wherever there is a varied topngraphy and consequent inequality of climate under the same parallels of latitude. Again, Mr. Wallace says,- "On two main points evers system yet proposed, or that probably can be proposed, is open to objection; they are,-1stly, that the several regions are not of equal rank;-2ndly, that they are not equally applicable to all classes of animals. As to the first objection, it will be found impossible to form any three 
or more regions, each of which differs from the rest in an equal degree or in the same manner. One will surpass all others in the possession of peculiar families; another will have many characteristic genera; while a third will be mainly distinguished by negative characters. There will also be found many intermediate districts, which possess some of the.characteristics of two well-marked regions, and a few special features of their own, or perhaps with none; and it will be a difficult question to decide.in all cases which region should possess the doubtful territory, or whether it should be formed into a primary region by itself." *

In geographical zoölogJ, as in the genetic relation of animals, we find, as a rule, no strongly marked boundary-lines, and in the liferegions, especially those of lesser rank, the boundaries can be given only approximately, owing to the intergradation of contiguous faunæ and floræ, contingent upon the gradual modification of climatic conditions; yet it is not hard to find boundary-lines that shall be, if not sharply definable, at least easy of recognition. This at least proves to be the case wherever the distribution of specific forms is thoroughly known. The first objection, "that the several regions are not of equal rank," forms to my mind no objection at all, since it matters little whether they are equal or unequal if they correctly indicate the distribution of life.

The second objection Mr. Wallace has himself satisfactorily answered, in discussing the question "Which class of animals is of most importance in determining Zoölogical Regions." As Mr. Wallace here points out, and as must become apparent to every careful investigator of this question, the mammalia are pre-eminently of the greatest importance in deter. mining zoölogical regions. To summarize Mr. Wallace's argument on this point, their dispersal is less dependent on fortuitous circumstances than that of the representatives of other classes; from their high organization they are less dependent upon "other groups of animals", and have so much power of adaptation that they are "able to exist in one form or another over the whole globe", as is certainly not the case with two of the lower classes of vertebrates, the reptilia and amphibia. Their distribution and dispersal are dependent on the distribution of the land-areas, and are modified by such physical conditions as mountain barriers, areas of forest, and grassy or desert plateaus. Furthermore, their geological history, as well as their geographical range, is better known than that of most other classes, and there is also a greater unanimity of opinion respecting their natural affinities and the limitation of families and genera in this class than in most others. "We should therefore", says Mr. Wallace (and I heartily agree with the remark), "construct our typical or standard Zoölogical Regions in the first place, from a consideration of the distribution of mammalia, only bringing to our aid the distribution of other groups to determine doubtful points. Regions so established will be most closely in accordance with 
those long-enduring features of physical geography, on which the distribution of all forms of life fundamentally depends; * and all discrepancies in the distribution of other classes of animals must be capable of being explained, either by their exceptional means of dispersion or by special conditions affecting their perpetuation and increase in each locality." "If these considerations are well founded," he continues, " the objections of those who study insects or molluscs, for example,-that our regions are not true for their departments of nature-cannot be maintained. For they will find, that a careful consideration of the exceptional means of dispersal and conditions of existence of each group, will explain most of the divergences from the normal distribution of higher animals." +

In the present paper I shall consequently, in my discussion of the zoölogical regions of the northern hemisphere, confine myself primarily to mammals. Throwing aside, for the moment, all theoretical considerations, I shall endeavor first to present the facts of the case, and then consider what generalizations may be legitimately drawn from them.

A word, however, first in respect to the conformation and distribution of the land-areas. In reference to this part of the subject I can hardly do better than to again quote the words of Mr. Wallace, who has thus forcibly presented the subject :- "One great peculiarity of the distribution of land lies in its freedom from complete isolation . . . The continents, indeed, resembling as they do a huge creeping plant, with roots at the North Pole, and the matted stems and branches of which cover a large part of the northern hemisphere and send three great offshoots toward the South Pole, offer great facilities for the transmission of varied forms of animal life. There is evidence to prove that during the greater part of the Tertiary period the relative positions of our conti-

\footnotetext{
* The italicizing is my own.
}

t The question, Which class of animals is best fitted to form the basis of a division of the earth's surface into life-regions? has a wider bearing than might be at first supposed, since the same power of adaptation to diverse climatic conditions that results in a wide distribution in some cases and a limited rango in others would also impart different degrees of ability to resist the influence of geological changes, and is hence related to the question, Which class forms the best index for marking geological time ? The relative importance of different groups as geological indices is necessarily connected with their power to resist unfavorable influences, and hence groups that succumb most readily would give the best clue to such changes in the past. Among vertebrates the mammalia are undoubtedly, as a class, the best able to survive a wide range of climatic conditions. Birds are to so great a degree migratory that they are in great measure able to avoid seasonal extremes of climate by a change of habitat. Extremes that mammals readily survive prove quickly fatal to reptiles and amphibians.

Climate, though in itself a powerful geological agent, is, of course, subject to profound modification due to geological causes. Any great amount of upheaval or subsidence of the earth's crust, or the gradual uplifting of mountain chains, must necessarily induce changes in the climate of the regions where such disturbances occur, the effect of which must extend over an area far greater than that of the disturbed district. A comparatively slight change of climate, either in respect to temperature or humidity, has a most marked influence upon vegetation, and especially upon the distribution of forests. The presence or absence of particular species of plants is well known to determine the presence or absence of many species of insects, while the distribution of whole families of the latter is determined wholly by the character of the vegetation; 
nents and oceans did not greatly differ from their present form, and the former, back to the time of the Devonian formation, were never so completely submerged as to be replaced by oceans comparable in depth with our Atlantic and Pacific."* "This curious fact," he says again, "of the almost perfect continuity of all the great masses of land, notwithstanding their extremely irregular shape and distribution, is no doubt dependent on the [geological] circumstances just alluded to; that the great depth of the oceans and the slowness of the process of uphearal, has almost always produced the new lands close to, or actually connected with, pre-existing lands; and this has necessarily led to a much greater uniformity in the distribution of organic forms, than would have prerailed had the continents been more completely isolated from each other. - . the whole land is almost coutinuous. It consists essentially of only three masses : the American, the Asia-African, and the Australian. The two former are only separated by thirty-six miles of shallow sea at Behring's Straits, so that it is possible to go from Cape Horn to Singapore or the Cape of Good Hope without erer being out of sight of land; and owing to the intervention of the numerous islands of the Malay Archipelago the journey might be continued under the same conditions as far as Melbourne and Hobart Town." $\dagger$ The close proximity of the great land-masses in the Arctic regions is a fact to be kept in mind in any discussion of the distribution of life in the northern hemisphere, and also the fact that in Tertiary times the connection was almost indisputably more intimate than it is now.

and even mammals and birds are greatly affected, and even some are mainly controlled, in their range by the presence or absence of forests, the distribution of which is so intimately connected with climate. The reptiles, unlike mammals and birds, are quickly influenced by changes of temperature, and are unable to exist in the colder parts of the earth. Amphibians also require a moderately warm, or at least temperate, climate, and though ranging beyond the true reptiles become reduced to a few types in the coldtemperate latitudes, beyond which they wholly disappear. Fluviatile and terrestrial mollusks are also exceedingly susceptible to changes in the conditions of life that affect but slightly either insects or vertebrates, especially the two higher classes of the latter, even the geological character of a country having a powerful influence upon their distribution, as well as affecting their size and the thickness of their calcareons covering. While the mammalia are able to survive changes that would exterminate reptiles and amphibians, and are somewhat independent of the influences that govern the existence of many insects and mollusks, their fossil remains must give, for this reason, a less minute record of past geological and climatic changes than either the lower classes of vertebrates, the mollusea, or the insects, and afford a far less detailed record than plants. Among mammals sometimes the same species, and often the same genus, has a range extending from the Arctic regions to the warm-temperate or subtropical latitudes, thus showing an adaptability to varied conditions of existence not exhibited by the lower vertebrates, or by mollusks or plants. While their lack of exceptional means of dispersal and their superiority to forces of restriction that limit many groups of animals render them bighly useful as a standard of reference in respect to present life-regions, the latter necessarily detracts from their importance as a medium of geological record, so far at least as regards the minuter details.

* Report of a Lecture before the Royal Geographical Society; in Geogr. Mag., vol. iv, August, 1877, p. 221.

† Geogr. Dist. Anim., vol. i, p. 37. 
As is well known, and almost universally admitted, the animal and plant life of the Arctic lands is nearly everywhere the same, many of the species having a circumpolar range, while the genera are mainly, and the families almost entirely, the same throughout. Especially is this the case with mammals. To show how gradual is the change from almost absolute uniformity in the Aretic regions to the ultimate diversity met with in the intertropical latitudes it is only necessary to divide latitudinally the so-called "Nearctic" and "Palæarctic" regions into several minor areas, and to tabulate and compare the genera found in each. Adopting as our first division the region approximately bounded southward by the isotherm of $36^{\circ} \mathrm{F}$., and hence embracing the Arctic, SubAretic, and Cold Temperate lands of the northern hemisphere, we find that of the fifty-four commonly recognized genera of non-pelagic mammals occurring north of this boundary, five are subcosmopolitan; twenty. seven, or more than one half, are strictly circumpolar, being represented throughout the greater part of the region north of this boundary; that five more are found on both shores of the Atlantic, and that five others are common to both shores of the Pacific. This leares only twelveless than one-fourth-that are peculiar to either the northern portion of North America or to the corresponding portion of the Old World, of which eight are restricted to $\Lambda$ merica and four to the Europæo-Asiatic continent. These genera and their distribution are approximately shown in the subjoined table.

Genera of mammals of the Arctic and Cold Temperate portions of the northern hemisphere (the region north of the mean anuual of $35^{\circ} F$.).

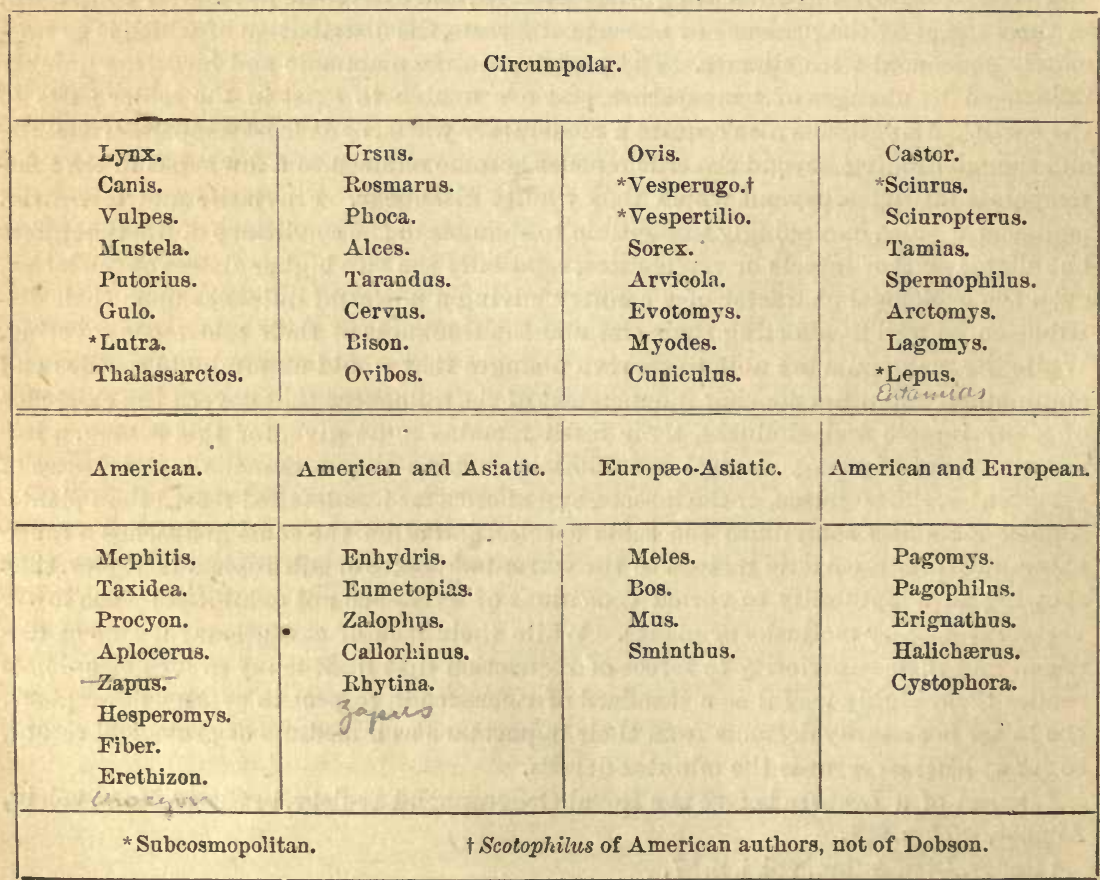


Summary.

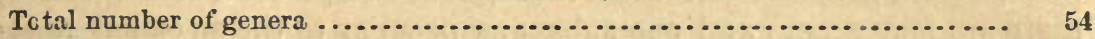

Subcosnopolitan .............................................. 5

Circumpolar .................................................... $2 \gamma$

Shores of North America and Asia .................................. 5

Shores of North America and Enrope ............................... 5

Exclusively either American or Europæo-Asiatic . . . . . . . . . . . . . . . . . . . . . 12

Peculiar to America $\ldots . \ldots \ldots \ldots \ldots \ldots \ldots \ldots \ldots \ldots \ldots \ldots \ldots \ldots \ldots \ldots \ldots \ldots \ldots \ldots \ldots \ldots \ldots . . \ldots$

-Peculiar to the Europæo-Asiatic continent............................. 4

The above-given statistics show most clearly that the mammals of the northern third of the northern hemisphere present few generic or subgeneric forms that are peculiar to either North America or to the Europæo-Asiatic continent. In many cases, these are closely representative forms; in other cases, the peculiar genera extend but a short distance into the region, being temperate forms rather than hyperboreal.

The close relationship of the mammalian life of the northern lands, as compared with the diversity met with.between that of the northern and southern portions of the two northern continents, is further shown by a tabulation of the genera met with in the region intervening between the cold-temperate and sub-tropical zones of life, the northern and southern boundaries of which may be considered respectively as the isotherms of $36^{\circ}$ and $68^{\circ}$ to $70^{\circ} \mathrm{F}$. Rather more than one-half of the above-enumerated genera extend also over a large portion of this more southern belt, and impart thereby a general similarity to the facies of the mammalian faunæ of the two regious. In addition to these, however, we find in North America thirty-one genera and seven subgenera that are not found much, if any, to the northward of the isotherm of $36^{\circ} \mathrm{F}$., and about the same proportion of new generic and subgeneric types make their appearance in the corresponding region of the Old World. Turning first to North America, we find that of these added forms one has so wide a distribution that it may be properly considered as subcosmopolitan, being found in the corresponding region of the EuropæoA siatic continent as well as far to the southward of the region under notice. One other occurs also in Eastern Asia and six more belong rather to Tropical America than to Temperate North America. Excluding these, leaves about thirty as strictly American and twenty-two that are almost wholly restricted to Temperate North America; there is, hence, twice as great a difference between the mammalian faunæ of the middle temperate region of North America and the colder portion of the same continent as there is between those of the colder parts of the two northern continents, or the northern portions of the so-called "Nearctic" and "Palæarctic Regions". But we get in Temperate North America not only twenty-two generic and subgeneric forms peculiar to this region, but a differentiation of this region into three well-marked faunal areas, differing more from each other than do the boreal parts of the New World ("Nearctic Region") from the boreal parts of the Old World ("Palæarctic Region"). While thirteen of the genera, or about one- 
third, have a general distribution throughout Temperate North America, there are four genera and one subgenus peculiar to the so-called Eastern Province, five genera and one subgenus mainly restricted to the Middle Province, and five genera and two subgenera almost wholly lim. ited to the geographically much smaller Western Province. In addition to this, there are five other gevera and one subgenus common to the greater part of the Middle and Western Provinces that are not found in the Eastern.* The genera that may be regarded as characterizing the middle temperate region of North America and their relative distribution is shown in the subjoined table.

Terrestrial genera and subgenera of Middle North America (between the mean annuals of $36^{\circ}$ and $68^{\circ} \mathrm{F}$.), not found in the Arctic and Cold Temperate latitudes.

[NoTE.-Subgenera are enclosed in parentheses.]

\begin{tabular}{|c|c|c|c|c|c|}
\hline \multicolumn{2}{|c|}{ Of general distribution. } & $\begin{array}{l}\text { Limited to the } \\
\text { Eastern }\end{array}$ & $\begin{array}{l}\text { Limited to the } \\
\text { Middle Prov- }\end{array}$ & $\begin{array}{l}\text { Limited tothe } \\
\text { Western }\end{array}$ & $\begin{array}{l}\text { Common to the Mid- } \\
\text { dle and Western }\end{array}$ \\
\hline $\begin{array}{l}\text { Felis. } \\
\text { Urocyon. } \\
\text { Cariacus. } \\
\text { Lasiurus. } \\
\text { Scapanus. } \\
\text { Scalops. } \\
\text { Neosorex. } \\
\text { Neotoma. }\end{array}$ & $\begin{array}{l}\text { * Sigmodon. } \\
\text { Ochetodon. } \\
\text { (Pitymys.) } \\
\text { Geomys. } \\
\text { Didelphys. }\end{array}$ & $\begin{array}{l}\text { Nycticejus. } \\
\text { *Synotus. } \\
\text { Condylura. } \\
\text { Blarina. } \\
\text { (Oryzomys.) }\end{array}$ & $\begin{array}{l}\text { *Bassaris. } \\
\text { Antilocapra. } \\
\text { *Dicotyles. } \\
\text { *(Notiosorex.) } \\
\text { Synaptomys. } \\
\text { Cyncmys. }\end{array}$ & $\begin{array}{l}\text { *Macrotus. } \\
\text { Antrozous. } \\
\text { *Nyctinomus. } \\
\text { † Urotrichus. } \\
\text { (Onychomys.) } \\
\text { (Chilotus.) } \\
\text { Haplodon. }\end{array}$ & $\begin{array}{l}\text { (Otospermophilus.) } \\
\text { (Pedomys.) } \\
\text { Perognathns. } \\
\text { Cricetodipus. } \\
\text { Dipodomys. } \\
\text { Thomomys. }\end{array}$ \\
\hline
\end{tabular}

Summary.

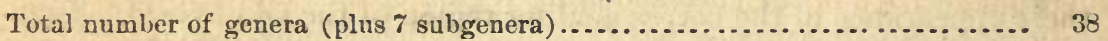

Of general distribution. ............................................. 13

Peculiar to the Eastern Province....................................... 5

Peculiar to the Middle Province....................................... 6

Peculiar to the Western Province .................................... 7

Common to the Western and Middle Provinces, but not found in the Eastern.... 6

Mainly tropical or subtropical ................................... 8

* Mr. Wallace, in his late work (Geogr. Dist. Anim., vol. i,p. 6), refers to the Rocky Mountains as forming a barrier to species, "almost all the mammals, birds, and insects" belonging to different species on the two sides of the Rocky Mountains. Nothing, so far as mammals and birds are concerned (and I am informed by good authorities that the same is true of insects), could well be further from the truth. Only in rare instances do the Rocky Mountains form such a barrier, the division between the Eastern and Middle Provinces lieing more than six hundred miles to the eastward of this range, while the boundary between the Middle and Western Provinces is formed by the Sierra Nevada chain. The same species, as a rule, range over the greater part of the great elevated interior plateau, of which the Rocky Mountains constitute the axis. So far as the distribution of both birds and mammals is concerned, the presence or absence of forests, and the accompanying diverse climatic conditions, have far more to do with the limitation of habitat than the commonly so-called "Rocky Mountain barrier". This is obviously due to the longitudinal direction of this sapposed barrier, which, if trending in a latitudinal direction, would certainly form an impassable obstacle to very many species. 
Between the warm-temperate belt we have been considering and the zone next to the southward-the subtropical-the faunal differences are far greater than between the warm-temperate and colder zones. Aside from the few subcosmopolitan genera still present, and the few essentially tropical genera that range northward into the warmer temperate zone, there is little in common to the mammalian faunæ of these two regions. At or near this boundary (the isotherm of about $68^{\circ} \mathrm{F}$.- say $68^{\circ}$ to $70^{\circ} \mathrm{F}$.) several strictly tropical families first make their appearance, and tropical genera begin largely to replace those of the colder region to the northward.

In respect to the Europæo-Asiatic continent, we have already seen how small a proportion of the genera of mammals met with north of the thirty-sixth isotherm are really peculiar to this region, the number being less than twelve per cent., the remainder being circumpolar. Passing, however, to the warm-temperate division of this Europæo-Asiatic continent, or that portion between the isotherms of $36^{\circ}$ and $68^{\circ}$ to $70^{\circ}$ F., and we meet with many genera not found to the northward. While many circumpolar genera still prevail, at least three-fourths of the whole number are here first met with. A considerable proportion (about one-fifth) are properly southern or subtropical, and extend far to the sonthward of the warm-temperate zone. About one-half, however, are peculiar to this zone, and belong to groups (families of subfamilies) especially characteristic of the North Temperate Realm. In adopting the isotherm of $70^{\circ} \mathrm{F}$. as its southern boundary, we include not only the Mediterranean Province (and hence Northern Africa), but all of Asia north of the great Himalayan chain, together with Northern China and the Persian-Peninsula. Hence quite a number of such southern forms occur as Macacus, Herpestes, Genetta, Hycena, Hystrix, etc., that are more properly members of the intertropical fauna. Owing to the great extent of this region, we meet with many genera peculiar to special districts, giving a higher proportion of peculiar forms than is met with in the corresponding portion (but far more limited in area) of North America. Of about fifty genera met with here that do not occur to the northward, about one-fourth may be thrown out as more properly tropical, since they in most cases barely enter the southern border.

Of the remainder, fully one-half are restricted in their range wholly or almost wholly to this region, the rest extending far into or throughout the Old World tropics. There is thus more than thrice as great a difference between the mammalian fauna of the boreal parts of the Europæo-A siatic continent and that of the warmer parts of the same continent as between the fauna of the boreal parts of the Europæo-Asiatic continent and the corresponding region of North America. The differentiation is here again, as in North America, from the north southward, not through the rapid increase of land-area and diversity of physical structure, but purely from climatic conditions, - through the multiplication of life in consequence of increase of temperature and means of 
subsistence. This is still more strikingly shown by a comparison of the fauna of the middle portion of the so-called "Palæarctic Region" with that of its southern border, at which point the truly tropical forms begin to appear. The genera of a zone, say two degrees in width, at these two points would be not ouly in large part different, but those of the southern belt would be far more numerous.

Genera of mammals of the warm-temperate portions of the eastern hemisphere (between the isotherms of $36^{\circ}$ and $68^{\circ}$ to $70^{\circ} \mathrm{F}$.), not occurring to the northward of the 36 th isotherm.

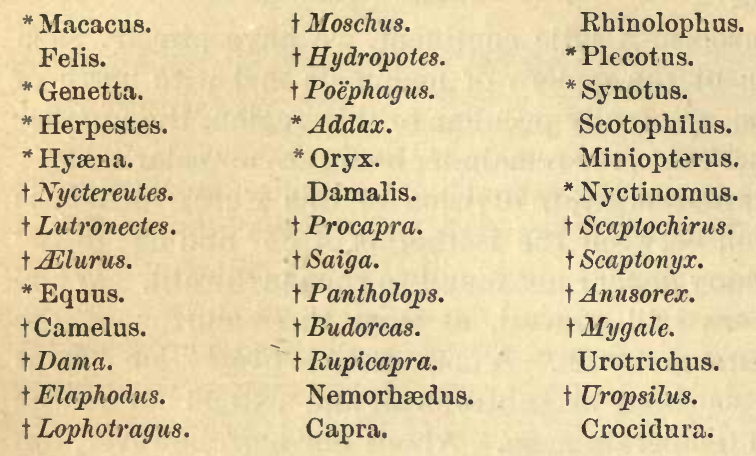

t Nectogale. Spalax. Rhizomys.

†Siphneus.

Meriones.

+ Cricetulus.

+ Alactaga.

* Gerbillus.

* Dipus.

Muscardinus.

Eliomys.

* Hystrix.

Summary.

Total number

Occurring in southern portions only.

Peculiar to the region, and generally restricted to a limited range............ 24

. Of rather wide range southward ..................................... 14

A comparison of the families represented in different portions of the northern hemisphere north of the isotherm of $70^{\circ} \mathrm{F}$. brings into prominence some of the points already stated, without the confusion of detail incident to a comparison on the basis of genera, and gives also a more convenient standard for the next stage of comparison, namely, a comparison of the faunæ of the temperate zones with those of the tropical, as well as with the faunæ of the two great land-areas of the northern hemisphere. Of thirty-three families of non-pelagic mammals found north of about the isotherm of $70^{\circ} \mathrm{F}$. $\left(68^{\circ}\right.$ to $\left.70^{\circ}\right)$, thirteen have a nearly cos. mopolitan distribution, and six others are common to both the OId World and the New, leaving fourteen, or about one-third, peculiar to either North America or to Europe and Asia. Three of these are essentially subtropicopolitan or tropicopolitan, having merely straggling representatives north of the 68 th isotherm, and five others are represented each by only a single species. Seven of these fourteen families (four only

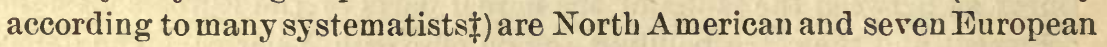

* Occurring in southern portions only; chiefly tropical.

+ Peculiar to the region and mostly of restricted range.

$\ddagger$ I here admit to family rank Antilocaprida, Zapodida, and Geomyida, the two former of which are treated by Mr. Wallace as subfamilies of subcosmopolitan families, while the other is not commonly recognized as distinct from Saccomyidae. On the other hand, I refer the Cercolabida to the Hystricida. 
and Asiatic. One or two others barely touch, or possibly overlap slightly, the above-given boundary. North of the isotherm of $36^{\circ} \mathrm{F}$. not more than two or three families are met with that are not cosmopolitan, and two of these have each but a single species north of this line.

The following is a list of the families referred to above, with approximate indications of their distribution.

Families of non-pelagic mammals occurring north of the mean annual of $70^{\circ} \mathrm{F}$.

\begin{tabular}{|c|c|c|c|c|}
\hline \multicolumn{2}{|c|}{ Subcosmopolitan: } & Circumpolar. & North American. & Europæo-Asiatic. \\
\hline $\begin{array}{l}\text { Felidæ. } \\
\text { Canidæ. } \\
\text { Mnstelidæ. } \\
\text { Ursidæ. } \\
\text { Otariidæ. } \\
\text { Phocidæ. } \\
\text { Cervidæ. }\end{array}$ & $\begin{array}{l}\text { Bovidæ. } \\
\text { Vespertilionidæ. } \\
\text { Muridæ. } \\
\text { Sciaridæ. } \\
\text { Hystricidæ. } \\
\text { Leporidæ. }\end{array}$ & $\begin{array}{l}\text { Rosmaridæ. } \\
\text { •Rhytinidæ. } \\
\text { Talpidæ. } \\
\text { Soricidæ. } \\
\text { Castoridæ. } \\
\text { Lag'omyidæ. }\end{array}$ & $\begin{array}{l}\text { †Procyonidæ. } \\
\text { †Antilocapridæ. } \\
\text { †Zapodidæ. } \\
\text { Geomyidæ. } \\
\text { Saccomyidæ. } \\
\text { † Haplodontidæ. } \\
\text { † Didelphyidæ. }\end{array}$ & $\begin{array}{l}\text { Erinaceidx. } \\
\text { +Suidæ. } \\
\text { Equidæ. } \\
\text { Myoxidæ. } \\
\text { Spalacidæ. } \\
\text { Dipodidæ. } \\
\text { Rhinolophidæ. }\end{array}$ \\
\hline
\end{tabular}

* Formerly occurring on the shores of the North Prcific only, bat now extinct.

tTropical; one species only found north of 70th isotherm.

$\ddagger$ Represented by a single species.

\section{Summary.}

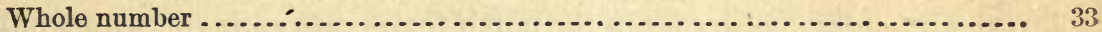

Subcosmopolitan ................................................ 13

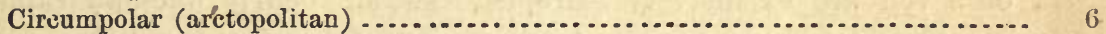

American (exclusively)* ........................................ 7

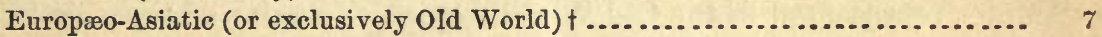

In regard to the southern extension of these thirty-three families, thirteen range far into, and most of them over, the greater part of Intertropical America, and eighteen far into, and most of them over, the greater part of the intertropical portion of the Old World.

In Intertropical America, only thirty families are represented. Of these, thirteen occur over much of Temperate North America, while eleren are subcosmopolitan, and the same number are peculiar to the region, while one-half of the whole do not range much beyond the northern tropic. Seven are semitropicopolitan, or occur also in the warmer parts of the Old World; but of these, three are Chiroptera and another is marine. The approximate range of the families represented in Intertropical America is indicated in the annexed table.

*Five only are exclusively North American.

†Two only are exclusively "Palæarctic". 
Families of non-pelagic mammals occurring in Intertropical, America (between the northern and southern isotherms of $70^{\circ}$ F.).

[NotE.-The names of families peculiar to the region are printed in italics.]

$\begin{array}{llll}\text { Cebida. } & \text { Otariidæ. } & \text { Soricidæ. } & \text { Hystricidæ. } \\ \text { Midida. } & \text { Cervidæ. } & \text { * Centetidæ. } & \text { Leporidæ. } \\ \text { Felidæ. } & \text { * Trichechidæ. } & \text { Sciuridæ. } & \text { Brachypodida. } \\ \text { Canida. } & \text { *Tapiridæ. } & \text { Muridæ. } & \text { Dasypodida. } \\ \text { Mustelidæ. } & \text { Dicotylida. } & \text { *Octodontidæ. } & \text { Myrmecophagida. } \\ \text { †Procyonidæ. } & \text { Phyllostomidæ. } & \text { Dinomyida. } & + \text { Didelphyida. } \\ \text { Bassaridida. } & \text { Emballonuridæ. } & \text { Caviida. } & \\ \text { Cercoleptida. } & \text { Vespertilionidæ. } & \text { Dasyproctida. } & \end{array}$

\section{Summary.}

Total number

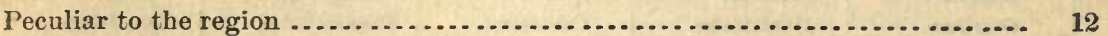

Not found in temperate parts of North America ........................ 16

Subcosmopolitan ............................................... 11

Occurring in the warmer parts (only) of the Old World .................. 5

Occurring in North America (at large).............................. 13

Fifty families are represented in the intertropical portions of Asia and Africa. Of these nearly thirty do not range much beyond the Northern Tropic, of which about twenty-three are limited to this region. Of the thirty-two families occurring in the north-temperate zone (of which only six or seven are exclusively Europæo-Asiatic), nearly, one-half range over most of the Indo-African tropics. The following is a list of the families represented in the Old World tropics, exclusive of those limited to Madagascar and the Australian Realm.

Families of non-pelagic mammals occurring in the Indo-African Tropics (between the northern and southern isotherms of $70^{\circ} \mathrm{F}$.)

[XOTE.-The names of families not occurring northward of the region are printed in italics.]

Simiida.

Cynopithecida.

Lemurida.

Tarsiida.

Felidar.

Protelida.

Hycenida.

Viverrida.

Canidæ.

Mustelidæ.

Ursidæ.

Eluridæ.

Camelidæ.
Giraffidae.

Bovidæ.

Cervidæ.

Tragulidæ.

Hippopotamidee.

Phacochorida.

Suidæ.

Equidae.

Rhinocerotida.

$\S$ Tapirida.

Hyracida.

Elephantida.

Halicorida.
$\S T$ richechida.

Pteropida.

Rhinolophidæe.

Nycterida.

Vespertilionidæ.

§Emballonurida.

Galeopithecidae.

Talpidæ.

Soricidæ.

Erinaceidæ.

Potamogalida.

Macroscelida.
Tupayida.

Lophiomyida.

Dipodidæ.

Muridæ.

Myoxidæ.

Sciuridæ.

Anomalurida.

Hystricida.

§otodontidae.

Leporidæ.

Manidida.

Orycteropodida. 


\section{Summary.}

Total number

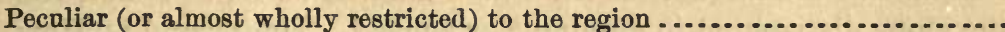

Subcosmopolitan

Represented in the American tropics (only).

Tropical

It thus appears that only about three-fifths as many families of mam. mals occur in the intertropical parts of the New World as in the corresponding parts of the Old World. The disproportion in the same direction in respect to genera and species is still greater. This is obviously due to the difference in size and configuration of the two areas. The Old World intertropical land-surface is not only several times greater than the American (embracing thrice as great a breadth longitudinally), but is differentiated into one continental (Africa), two large peninsular (India and China) areas, and a group of large, highly differentiated islands (Malay Archipelago), while the intertropical region of America forms a single unindented region, with a single narrow isthmic prolongation. In the one case (America) we have a striking uniformity of mammalian life throughout, corresponding with the general uniformity of the climatic conditions characteristic of this area, contrasting with well-marked subdivisions in the other, and a much greater diversity of énvironing circumstances, originating geologically far back in the history of these several land-masses. As Mr. Wallace has remarked,- "To those who accept the theory of development as worked out by Mr. Darwin, and the views as to the general permanence and immense antiquity of the great continents and oceans so ably developed by Sir Charles Lyell, it ceases to be a matter of surprise that the tropics of Africa, Asia, and America should differ in their productions, but rather that they should have anything in common. Their similarity, not their diversity, is the fact that most frequently puzzlee us." "*

In the foregoing remarks, no reference has been made to Madagascar or to Australia, for the reason that they belong to distinct primary liferegions having little in common with the great Europæo-Asiatic landarea (of which Africa, on the other hand, is an inseparable appendage), which, with America, form the regions to which the discussion has thus far been intentionally limited. As will be more fully considered later, the intertropical old World area is divisible into secondary regions, which for the present need not enter into the questions immediately at issue. These are, first, Does that portion of the northern hemisphere north of the northern subtropical zone admit of division into two primary life-regions, conforming in their boundaries to the configuration of the two great northern land-areas? And, secondly, Iu accordance with what principle does the life of the northern hemisphere become differentiated from the homogeneity characteristic of the northern regious

${ }^{*}$ Geogr. Dist. Anim., vol. i, p. 51. 
to the great diversity met with under tropical latitudes? The fundamental question which underlies the whole subject is, Is, or is not, the life of the globe distributed in circumpolar zones? The second is, How and under what influences does it become differentiated?

To the first of these questions, I rentured some six years since, ${ }^{*}$ to give an affirmative answer, in accordance not only with the views of numerous high anthorities on the subject of the geographical distribution of life, but with what seemed to me to be incontrovertibly the facts in the case. While this view has since received the support of other high authorities, it has been altogether ignored by the advocates of Dr. Sclater's division of the earth's surface. Mr. Wallace, who faithfully reflects the views of the Sclaterian school, in referring to this subject says :- "Mr. Allen's system of 'realms' founded on climatic zones . . . calls for a few remarks. The author continually refers to the 'law of the distribution of life in circumpolar zones', as if it were one generally accepted and that admits of no dispute. But this supposed 'law' only applies to the smallest details of distribution-to the range and increasing or decreasing numbers of species as we pass from north to south, or the reverse ; while it has little bearing on the great features of zoölogical geography-the limitation of groups of genera and families to certain areas. It is analogous to the 'law of adaptation' in the organization of animals, by which members of various groups are suited for an aerial, an aquatic, a desert, or an arboreal life; are herbivorous, carnivorous, or insectivorous ; are fitted to live underground, or in fresh waters, or on polar ice. It was once thought that these adaptive peculiarities were suitable foundations for a classification,- that whales were fishes, and bats birds; and even to this day there are naturalists who cannot recognize the essential diversity of structure in such groups as swifts and swallows, sun-birds and humming-birds, under the superficial disguise caused by adaptation to a similar mode of life. The application of Mr. Allen's principle leads to equally erroneous results, as may be well seen by considering his separation of 'the southern third of Australia' to unite it with,New Zealand as one of his secondary zoölogical divisions."†

Leaving Mr. Wallace's last-quoted objection for notice in another connection (see a foot-note beyond, under the sub-heading "Australian Realm"), I unblushingly claim, in answer to the main point, that the geographical distribution of life is by necessity in accordance with $a$ "law of adaptation", namely, of climatic adaptation; that such a law is legitimate in this connection, and that the reference to the "superficial disguise" adapting essentially widely different organisms to similar modes of life is wholly irrelevant to the point at issue, - a comparison of things that are in any true sense incomparable; furthermore, that the "law of distribution of life in circumpolar zones" does apply as well in a general sense as to details_- to groups of genera and families" as well as

*Bull. Mus. Comp. Zoöl., vol. ii, p. 376, 1871.

t Geogr. Dist. Anim., vol. i, p. 67. 
to species. In the foregoing remarks I have had little to say respecting the range of species, and have tabulated merely genera and families. These tables clearly show that a large proportion of the mammalian genera and families of the northern hemisphere have a circumpolar range, the same genera and families occupying the Arctic and Sub-Arctic lands in both the Old World and the New, and that only a small per cent. of the whole number found here are peculiar to either of the northern land-areas; that a large part of the genera and families met with in the temperate and warmer latitudes occur on the eastern continent as well as on the western; that again a considerable proportion of the genera and families met with in the warmer parts of the earth occur also both in the Old World and the New, while many others are well known to have been common to the two during the Tertiary period. It has been further shown that there is a greater diversity of life between contiguous climatic belts of the same continent than between corre. sponding belts of the two continents, especially north of the forty-fifth parallel of latitude, and that any marked faunal differentiation of the two continents begins only in the warm-temperate and subtropical latitudes. On each continent, the arctic, temperate, and tropical zones are each marked in their general facies respectively by corresponding phases of life. So obvious is this that we have in current use the expressions "arctic life", "temperate life", and "tropical life", in recognition of certain common features of resemblance by which each of these regions is distinguished as a region from the others. This is in accordance with a law I have termed the law "of differentiation from the north southward",* or in accordance with increase of temperature and the conditions resulting therefrom favorable to increased abundance of life.

In this connection it may be well to recall certain general facts previously referred to respecting the geographical relations of the lands of the northern hemisphere and their past history. Of first importance is their present close connection about the northern pole and their former still closer union at a comparatively recentdate in their geological history; furthermore, that at this time of former, more intimate relationship, the climatic conditions of the globe were far more uniform than at present, a mild or warm-temperate climate prevailing where now are regions of perpetual ice, and that many groups of animals whose existing representatives are found now only in tropical or semitropical regions lived formerly along our present Arctic coasts. We have, hence, an easy explanation of the present distribution of such groups as Tapirs, Manatees, many genera of Bats, etc., in the tropics of the two hemispheres, on the wholly tenable assumption of a southward migration from a common wide-spread northern habitat, to say nothing of the numerous existing arctopolitan and semi-cosmopolitan genera. The former greater community of life in the northern hemisphere in preglacial times is further evinced by the wide spread occurrence there of the remains of Camels,

*Bull. Mus. Comp. Zoöl., vol. ii, p. 379. 
Elephants, Mastodons, Rhinoceroses, and Horses, which, though extinct in America, have living representatives in the tropies of the so-called "Old World", to say nothing of the evidence afforded by the remains of still earlier types of arctopolitan range. The succeeding epochs of cold caused extensive migrations of some groups and the extinction of others; with the diverse climatic conditions subsequently characterizing high and low latitudes came the more pronounced differentiation of faunæ, and the development, doubtless, of many new types adapted to the changed conditions of life-the development of boreal types from a warmtemperate or semi-tropical stock. The accepted theories respecting the modification of type with change in conditions of environment-changes necessarily due mainly to climatic influences-render it certain that if animals are so far under the control of circumstances dependent upon climate, and emphatically upon temperature, as to be either exterminated or greatly modified by them, the same influences must govern their geographical distribution.

Recent discoveries respecting the mammalia inhabiting North America during the Tertiary period have shown that many of the leading types of mammals-including not only those above named, but also many others-now found only in the eastern hemisphere, originated in North A merica, and migrated thence to Asia, Europe, and even Africa, either as somewhat generalized types, or after they had nearly reached their present degree of differentiation; in short, so far as mammalian life is concerned, that America is the "Old World" from which the so-called "Old World" has been mainly peopled. The present genetic convergence of life about the northern pole seems to show that not only has there been here a comparatively free intercommunication, but that the mammalian life now existing there has lived there for a long period under similar conditions of euvironment; and that these conditions are unfavorable, in consequence of a comparatively low temperature, to rapid change of form or structure.

This is shown not only by the great diversity of life met with in the intertropical regions, as compared with the uniformity met with in the semi-frigid regions (equal areas being, of course, compared), but by the coincident occurrence of a simple, homogeneous arctic marine fauna, with the low temperature over the sea-floor far to the south ward of where such forms occur in the warmer surface and shore-waters. The intimate relation between temperature and the distribution of life is most forcibly shown by the existence under the same parallel of latitude of diverse faunæ not only at different elevations above the sea on mountain-slopes, but at different depths beneath the surface of the ocean, where the several faunæ are characterized not only by the presence of different species, but by the prevalence of different genera, and even families. In fact, it is to me a matter of surprise that, with our present knowledge of the subject, any naturalist of note should assume that temperature has nothing to do with the circumscription of faunæ, or that any law 
based on it can have "little bearing on the great features of zoölogical geographs-the limitation of groups of genera and families to certain areas".

\section{II.-MAMMALIAN REGIONS OF THE GLOBE.}

The influence of temperature as a limiting agent in the distribution of life, as well the "law of the distribution of life in circumpolar zones", was fully recognized by Humboldt nearly three-fourths of a century ago, and later, practically if not explicitly, by Ritter, De Candolle, Agassiz, Wagner, Forbes, Dana, Günther, Meyen, Middendorff, and many other leading zoölogists and botanists. While this law must incontrovertibly underlie erery philosophic scheme of lief-regions, the number of zones to be recognized, as well as their bonndaries, must in a measure be open to diversity of opinion. Prof essor Dana, in 1852, recognized five primary zones for marine animals, namely, a torrid, a north and a south temperate, and a north and a south frigid. The torrid and temperate were subdivided, the first into three, the others each into five sub.zones, the two frigid being left undivided. Mr. A. Agassiz, in treating of the distribution of the Echini, ${ }^{*}$ recognizes also five zones, a torrid, two temperate, and two frigid. These five primary zones prove to be applicable also to the mammalia, and even their subdivisions may be readily traced, but are rather too detailed for practical use. Owing to the irregular surface of the land-areas, occasioned by elevated plateans and mountain-chains, these zones of distribution hare of course a less regular breadth and trend than they preserve orer the oceans. Their boundaries, however, approximate to the courses of the isotherms, by certain of which they may be considered as in a general way limited.

In recognition of these zones, and also of the law of differentiation of life with the relative isolation of the principal land-areas, I proposed in a former paper $(l . c ., p .380)$ a division of the land-areas into eight "Realms", namely: I, Arctic; II, North Temperate; III, American Tropical; IV, Indo-African; V, South American Temperate; VI, African Temperate; VII, Antarctic; VIII, Australian. A subdivision of most of these primary regions was provisionally suggested, but only the North American was treated with any degree of detail, and this mainly with reference to the birds, and more especially those of its eastern portion. Subsequent study of the distribution of mammalian life over the globe has led me to modify some of the views then expressed, especially in relation to the divisions of the Australian Realm, and to unite the South African Temperate with the Indo-African, as a division of the latter, and also to recognize Madagascar and the Mascarene Islands as forming together an independent primary region, in accordance with the views of Sclater, Wallace, and others. Whether or not the Arctic and Antarctic Regions should staud as primary divisions seems also open to question. While perhaps tenable on general

* Iliustr. Cat. Mus. Comp. Zoöl., No. vii, 1872, pls. A-F.

Bull. iv. No. $2-2$ 
grounds, they are hardly required for the elucidation of the distribution of the mammalia, since they must be mainly characterized negatively.

Beginning with the Arctic Region, we meet, as already shown, and as is almost universally admitted, a continuous homogeneous fauna, of considerable geographical area, but mainly characterized by what it lacks. Its southern boundary may be considered as the northern limit of forest regetation. Continuing sonthward, few other than aretopoli. tan genera of mammals are met with north of the mean annual of $36^{\circ}$ F. This considerable belt hence includes what may be termed the cold. temperate zone. The American and Europæo-Asiatic portions of this zone are only to a slight degree differentiated, while each is essentially homogeneous.

Below this, non-arctopolitan genera, or those restricted to more or less limited areas, become more frequent, and, indeed, form a considerable proportion of the genera represented. This belt occupies the remainder of the north-temperate zone, extending to about the mean isotherm of $70^{\circ} \mathrm{F}$, and may be termed the warm-temperate zone. Unlike the cold-temperate zone, it is divisible on each continent into sereral well-marked minor regions, which are, however, more strongly differentiated, inter se, in the Old World than in the New.

The tropical zone embraces, of course, in its fullest extension, a much greater latitudinal breadth than the temperate, but its southern landborder is very irregular, its only considerable development south of the equator being in South America and Africa. It is also so much diversified in many parts by mountain-chains that subdivision into secondary zones seems less feasible than in the case with the north-temperate zone. A central torrid and a north and a south sub-torrid zones might, however, be readily made, but such a division has not been attempted in the present connection. A northern sub-torrid division may indeed be very conveniently recognized, extending from about the annual isotherm of $67 \circ$ to that of about $74^{\circ} \mathrm{F}$., and including a transitional region consisting of the extreme southern border of what has been abore defined as the warm-temperate zone and the northern border of the tropical.

In like manner, the distribution of life seems to warrant the recognition, in Africa and South America, of a corresponding transitional belt between the two torrid and the southern warm-temperate zones. Aside from these divisions, the Torrid Zone admits of others of a more practical or useful character. These become at once obvious, since they result from the position and configuration of its component land elements. The first is a primary separation into two "realms", an American and an Indo-African. Each of these is again divisible into several minor portions or "provinces"; but the Indo.African admits also of division into two "regions", an $\Delta$ frican and an Indian, which are divisions of secondary rank, each having several "provinces".

The South Temperate Zone has a very limited land-surface, consisting 
of the southern third of South America, a small portion of Southern Africa, and the greater portion of Australia. Extra-tropical South Africa is all comprised within the Warm Temperate Zone, aud is so small in area and so intimately related, both geographically and faunally, with Tropical Africa, that its formal separation, while, perhaps, warranted in the abstract, is hardly practically necessary. Temperate South America is exceedingly irregular in its northern outline, owing to peculiarities of configuration, resulting from the presence of the great Andean Platean, by means of which it extends along the western border of South America far northward of the southern tropic. Temperate Australia is clearly separable from the tropical portion of the Australian Realm. The South Temperate Zone hence consists of three comparatively small land-areas, widely separated from each other, and consequently, as would be supposed; have little in common.

The Antarctic Region has a very limited amount of land-surface, and the few species that compose its fauna are almost wholly either marine or pelagic. As previously stated, as a mammalian region it has little significance.

This hasty sketch shows that the differentiation of the land-surface of the earth into realms, regions, and minor divisions has relation not only to climate, but to the divergence and isolation of the different principal land-areas; that at the northward, where the lands converge, there is no partitioning in conformity with continental areas, the temperate and colder portions of the northern hemisphere all falling into a single primary division, and that only the southern half is susceptible of divisions of the second rank. Within the tropics, on the other hand, the lands of the eastern and western hemispheres fall at once into different primary regions, and one of these is again divisible into regions of second rank. Beyond the tropics, the land-surfaces are of small extent, widely separated, and faunally have almost nothing in common.

With these preliminary remarks, we may now pass to a detailed consideration of the several primary regions and their subdivisions.

\section{I.-ARCTIC REALM.}

Whether or not an Arctic Region should be recognized as a division of the first rank is a question not easy to satisfactorily answer. Naturalists who have made the distribution of animal life in the boreal regions a subject of special study very generally agree in the recognition of a hyperboreal or circumpolar fauna, extending in some cases far southward over the Temperate Zone. The Arctic portion of this hyperborean region has been frequently set off as a secondary division, or subregion,* and generalls recognized as possessing many features not

*It forms Mr. Blyth's "Arctic Subregion" (Nature, vol. iii, p. 427, March 30, 1871), Mr. Brown's "Circumpolar" division (Proc. Zool. Soc., Lond., 18c8, p. 337), and Dr. von Middendorff"s "Zirkumpolar-Fauna" (Sibirische Reise, Bd. iv, p. 910, 1867). It also accords very nearly with Agassiz's “Arctic Realm" (Nott and Gliddon's Trpes of Mankind, 1854, p. Ix and map). 
shared by the contiguous region to the southward. For the present I prefer to still retain it as a division of the first rank. It is characterized mainly by the paucity of its life, as compared with every region except the Antarctic, and by what it has not rather tban by the possession of pecaliar species or groups. It wholly lacks both Amphibian and Reptilian life, is almost exclusively the summer home of many birds, and forms the habitat of the Esquimaux, the Arctic Fox, the Polar Bear, the Musk Ox, the Polar Hare, the Lemmings, the Walruses, the Narwhal, and the White Whale, which are confined within it. It has no Chiroptera nor Insectivora, two or three species of Shrews, howerer, barely reaching its southern border. It shares with the cold-temperate belt the presence of the Moose and the Reindeer, several Pinnipeds, a number of boreal species of Glires, several fur-bearing Carnivora, and a considerable number of birds. Its southern boundary may be considered as coinciding very nearly with the northern limit of arboreal regetation, and hence approximately with the isotherm of $32 \circ \mathrm{F}$. Its more characteristic terrestrial forms range throughout its extent, none being restricted to either the North American or Europæo-Asiatic continent. Hence it is indivisible into regions of the second and third grades (regions and provinces), and may be considered as embracing a single hyperborean assemblage of life.

\section{II.-NORTH-TEMPERATE REALM.}

Very few writers on zoölogical geography have failed to recognize the striking resemblance the fauna of Temperate North America bears to that of the corresponding portion of the Old World. The resem. blance is less in the Avian class than among mammals, but is generally acknowledged as obtaining even there. Dr. Sclater, while admitting a strong resemblance between these areas, considered them as separable into two primary regions, in which view of the case he has been followed, among prominent writers on the subject, by Dr. Günther, Mr. Wallace, Mr. Murray, and Professor Ccpe. Dr. Günther, while provisionally accepting Dr. Sclater's "Nearctic" and "Palæarctic" regions, refers pointedly to the disagreement of the distribution of Batrachians with these divisions; for in discussing the distribution of this class he says,"Dissimilarity and similarity of the Batracho-fauna depend upon zones. Palæarctic and Nearctic regions resemble each other more than any other third; the same is the case with Australia and South America; the Ethiopian region exhibits similarity with South America, as well as with the Last Indies, but more especially with the latter."* Mr. Murray admits that "the boreal extremity of North America is tinged with a Europeo-A siatic admixture", which he regards as "an extraneous element grafted upon the genuine stock, and easily eliminated from it". $\dagger$ But in his map of "Great Mammalian Regions" the boreal parts of

\footnotetext{
* Proc. Zoöl. Soc. Lond., 1858, p. 390.

+ Geogr. Dist. Mam., p. 312.
} 
both continents are similarly colored, the same color, however, extending only to about the forty-ninth degree of north latitucle in North America, while in Africa it descends to north latitude 150, and in Asia ranges from north latitude $30^{\circ}$ to $25^{\circ}$ ! His divisions as recoguized in the text are still more arbitrary and unphilosophic.

Mr. Wallace, in his discussion of zoölogical regions, says,-_"The distinction between the characteristic forms of life in tropical and cold countries is, on the whole, very strongly marked in the northern hemisphere; and to refuse to recognize this in a subdirision of the earth which is established for the very purpose of expressing such contrasts more clearly and concisely than by ordinary geographical terminology, would be both illogical and inconvenient. The one question then remains, whether the Nearctic region should be kept separate or whether it should form part of the Palæarctic or of the Neotropical. Professor Huxley and Mr. Blyth adrocate the former course; Mr. Andrew Murray (for mammalia) and Professor Newton (for birds) think the latter would be more natural. No doubt," Mr. Wallace adds, "much is to be said for both views," but decides in favor of the separation of the two regions in accordance with Dr. Sclater's scheme.*

While Mr. Blyth includes North America in his "Boreal Region" (as "2. Neo-septentrional Sub-region"), he adds also Central America and the Antilles (as "3. Neo-meridional Sub-region"), and, still more strangely, the Andean Region, with Chili, Patagonia, and the Fuegian and Falkland Archipelagos (as "4. Andesian Sub-region").t

Professor Huxley, in writing of the primary ontological regions of the globe, thus observes:- "In a well-known and very valuable essay on the Geographical Distribution of Birds, Dr. Sclater divides the surface of the globe primarily into an eastern and a western area, which he terms respectively Palcogcea and Neogca. However, if we take into consideration not merely the minor differences on which the species and genera of birds and mammals are often based, but weigh the morphological value of groups, I think it becomes clear that the Nearctic province is really far more closely allied with the Palrearctic than with the Neotropical region, and that the inhabitants of the Indian and Ethiopian regions are much more nearly connected with one another and with those of the Palæarctic region than they are with those of Australia. And if the frontier line is latitudinal rather than longitudinal, and divides a north world from a south world, we must speak of Arctogaca and Notogcea rather than of Neogæa and Palæogæa as the primary distributional areæ. The secondary divisions, or geographical provinces, proposed by Dr. Sclater, answer, in great measure, to those which are suggested by the distribution of the Alectoromorphce-except that, in common with many other naturalists, I think it would be convenient to recognize a circumpolar province, as distinct from the Nearctic and

* Geogr. Dist. Anim., vol. i, pp. 65, 66.

+ Nature, vol. iii, p. 427, March 30, 1871. 
Palæarctic regions."* Professor Huxley thus emphatically recognizes a region equivalent to my North Temperate Realm.

Mr. Robert Brown, in writing of the distribution of the mammals of Greenland, also recognizes a North Temperate Region, which he divides into a European Temperate Province and a North American Temperate Province, from which he separates a Circumpolar Region, equivalent to the Arctic Realm above characterized. $t$

Dr. Gill, in regard to fishes, recognizes an "Arctogæan" region, "embracing Europe, Northern Asia, and Northern America", as distinct on the one hand from the American Tropical and Transtropical Region, and on the other from Tropical Asia and Africa. $\neq$

Dr. Packard, in discussing the distribution of the Phalænid Moths, recognizes both an Arctic Realm and a North Temperate Realm, as here characterized. Referring to a previously given table of subalpine and circumpolar species, he says, - "This table indicates how wide are the limits of distribution of these species, and it will be seen how import. ant it is to follow circumpolar and north-temperate insect-faunæ around the globe, from continent to continent. It will be then seen how inadequate must be our views regarding the geographical distribution of the animals and plants of our own continent, without specimens from similar regions in the same zones in the Old World. It will be found that for the study of the insect-fauna of the Rocky Mountains and Pacific coast we must have ample collections from the Ural and Altai Mountains and surrounding plateaus," etc.

Dr. August von Pelzeln also recognized a circumboreal region (" arktische Region"), and considers the "Nearctic" and "Palæarctic" as form. ing inseparable parts of a single region. He says :- "Die paläarktische Region scheint mir von der nearktischen nicht trennbar zu sein, son. dern beide dürften ein Ganzes bilden, welches man als arktische Region bezeichnen könnte. Ihre Zusammengehörigkeit tritt mit voller Evidenz in den hochnordischen Ländern des alten und neuen Continentes hervor und erst in niedereren Breiten macht sich die Differenzirung geltend.

* Proc. Zoöl. Soc. Lond., 1868, pp. 314, 315.

† Proc. Zoöl. Soc. Lond., 1868, pp. 337, 338.

‡ Says Dr. Gill :- "In fine, dividing the earth into regions distinguished by general ichthyological peculiarities, several primary combinations may be recognized, viz. :-1, an Arctogcean, embracing Europe, Northern Asia, and Northern America; 2, an Asiatic, embracing the tropical portions of the continent; 3 , African, limited to the region south and east of the Desert; 4, an American (embracing the America par excellence dedicated to Amerigo Vespneci), including the tropical and transtropical portions; and, 5, an Australasian. Further, of these (a) the first two [Arctogæan and Asiatic] have intimate relations to each other, and $(b)$ the last three others among themselves; and some weighty arguments may be adduced to support a division of the faunas of the globe into two primary regions coinciding with the two combinations alluded to- $(a)$ a $C a-$ nogcea and (b) an Eogcea, which might represent areas of derivation or gain from more or less distant geological epochs." $-A n n$. and Mag. Nat. Hist., 4th ser., vol. $\mathrm{xv}, 1875$, pp. 254, 255.

$\$$ Monograph of Geometrid Moths, or Phalænidæ, of the United States, pp. 567, 586, 1876. 
Die Vergleichung der Thierwèlt beider Continente zeigt nämlich, dass die circumpolare Fauna in beiden dieselbe ist, dass in der Hochgebirgsfauna noch bedeutende Uebereinstimmung herrscht, dass in der iibrigen paläo- und neoborealen Thierbevölkerung sowohl identische $\Delta$ rten als gemeinsam eigenthümliche Gattungen sich finden, endlich dass selbst jene Typen, welche jedem Continente eigenthümlich sind, doch eine gewisse Uebereinstimmung hinsichtlich des Charakters der Fauna an sich tragen, so dass sie einander näher stehen als Angehörigen anderer Regionen. In der neuen Welt ist eine Modification der Fauna auch durch das Eindringen neotropischer Formen gegeben."* He further also calls attention to the similarity of life which prevailed throughout this circumpolar region during the Quaternary period.

It is unnecessary to cite further, from the abundant material at hand, the opinions of specialists in reference to the propriety of recognizing a North Temperate Realm, as distinguished from the tropical regions of the globe, and in contradistinction from a north and south line of division of the North Temperate Zone into two primary ("Palæarctic" and "Nearctic") regions.

The chief differences between Dr. Sclater's division of the northern hemisphere and the present consist in setting off at the northward an Arctic Realm, the union of the so-called Nearctic and Palæarctic Regions into one circumpolar belt, and in the adoption for the same of a more northern limit than that proposed as the boundary of the two above. named Sclaterian regions. As will be shown later, the subdivisions of the North Temperate Realm or ("Arctogcea") as here defined agree in the main with the "subregions" of Sclater and Wallace. The more northward location of the southern boundary of the North Temperate Realm in North America results in the elimination of several characteristic tropical types, which extend a short way only into Dr. Sclater's Nearctic and Palæarctic Regions, and which, when considered as members of these regions, give false or misleading results when the two regions are contrasted on a numerical basis, grounded on the proportion of peculiar types,-numerous forms being thus reckoned as components of the Nearctic and Palæarctic regions which are properly tropical.

In North America, the division between characteristic temperate and tropical forms of life approximately coincides with the isotherm of $68^{\circ}$ $\mathrm{F}$, or somewhere between $68^{\circ}$ and $70^{\circ} \mathrm{F}$. This line begins on the Atlantic coast a little below the northern boundary of Florida, and runs thence westward along the Gulf coast to Southern Texas, and thence farther westward to the Pacific, not far from the international boundary between the United States and Mexico, swerving more or less northward or southward in accordance with the configuration and elevation of the land-surface. It thus leaves the greater part of the peninsula of Florida within the American Tropical Realm, to which the fauna of its

* Verhandl. der K. K. Zool.-Bot. Gesell. in Wien, Bd. xxv, 1876, pp. 50, 51; see also p. 62 . 
southern half is certainly closely allied. A portion of the Mexican highlands are undoubtedly to be included in the North Temperate Realm, but their fauna is too little known to admit of the boundary being at present definitely drawn.

On the other hand, the lower portion of the Great Colorado Valley and the coast region of Southern California are, perhaps, better referable to the American Tropical Realm than to the North Temperate. At the junction of the two realms, there must be a belt of debatable or doubtful ground. The approximate boundary I would place near the northern limit of distribution of such mammalian forms as Nasua, Dicotyles, Manatus, Dasypus, and the tropical species of Felis (as, F. onca, F. pardalis, F. eyra, and $F$. yaguarundi). This boundary also coincides quite nearly with the southern limit of distribution of the Lynxes, the Gray and Prairie Wolves, the Common Fox, the Mink, the Black and Grizzly Bears, the Wapati and Virginian Deer, the Bison, the Pronghorn, the Bearer, Prairie Dogs, Muskrat, the Arvicola, and the Moles (Scalops and Condylura). Bassaris is properly tropical, although straggling considerably farther northward than the other above-mentioned forms. Florida, for conrenience, might be allowed to stand as a portion of the North Temperate Realm, although, as I have previously shown, it forms a distinct fauna, with strongly tropical affunities, * it having not less thau iwelve characteristically tropical genera of birds, sereral tropical genera of mammals (notably the Manatee and several Bats), and also several tropical genera of Reptiles and Batrachians, none of which range much, if any, to the north ward of its southern balf.

The southern boundary of the North Temperate Realm in the Old World may be doubtless approximately drann near the same isotherm (about the mean annuals of 680 to $700 \mathrm{~F}$.). This coincides closely with the southern boundary of the so.called Palæarctic Region. There is, however, here a broader belt of debatable or transitional ground than in the New World, into which so many tropical forms extend that it becomes almost a question whether the boundary between Tropical and Temperate life should not be carried considerably more to the north ward, so as to leare Mr. Wallace's "sub-regions" 2 and 4 (Mediterranean and Manchurian) in the Tropical Realm rather than in the North Temperate. Despite, howerer, the presence of a considerable number of tropical genera in these regions, the North Temperate forms still greatly predominate. In the Western or "Mediterranean" district, for instance, we hare species of Macacus, one of which even reaches the Spanish Peninsula. Herpestes has a similar northward extension. Hycena and Hystrix range not only over most of this district, but also orer the greater part of the Manchurian, where we again find a species of Macacus, and meet with Semnopithecus, while Hyrax just enters the Mediterranean from the southward. On the western border of the Manchurian we get also Pterupine Bats, and species of Equida, straggling remnants of the more

* Bull. Mns. Zoöl., vol. ii, pp. 391, 392. 
northward extension of tropical life which inhabited this region during the middle and later portions of the Tertiary Period and in the Quaternary.

Divisions of the North Temperate Realm.-The North Temperate Realm is primarily divisible in two directions, giving in each two regions, namely, (1) by a longitudinal division into (a) a North American Region and (b) a Europco-Asiatic Region; and (2) latitudinally, into (a) a Cold Temperate and (b) a Warm Temperate Region. The Cold Temperate, if limited on both continents by the isotherm of $360 \mathrm{~F}$., presents a nearly uniform fauna throughout, its southern limit in both corresponding with the natural (that is, before modified by human ageney) southern limit of distribution of Tarandus and Alces. While there is at this point in North America a well-marked transition in the fauna, the change in Europe and Asia appears to be less marked, the first important transition in the Old World being much farther southward, even as low almost as the isotherm of $60^{\circ} \mathrm{F}$. Hence the divisions of the Temperate Realm in the Old World partake of the nature of temperate and subtropical rather than cold-temperate and warm-temperate. Here, in consequence of the great elevation and extent of the Himalayan Plateau, the northern or temperate division is greatly narrowed in Central Asia, where it becomes, according to Mr. Wallace, almost wholly separated into two quite widely detached regious, namely, the "Mediterranean" and "Manchurian Subregions".

As thus divided, the temperate and subtropical divisions of the Old World are very strongly marked. The latter consists mainly of North. ern Africa, Asia Minor, Persia, Afghanistan and Beloochistan, Northern China, and Manchuria, with barely a narrow belt along the Mediterranean coast of Europe and the Spanish Peninsula. As already stated, it is strongly tinged with tropical forms. While there is a general prevalence of temperate types, we meet also with the large and essentially tropical forms of Felis, several Monkeys, several species of Viverridœ, Hyœna, Hystrix, Equus, and other distinctively tropical or subtropical types. The northern or temperate division of the EuropæoAsiatic Region seems to constitute two well-marked provinces, the one Eastern or European, the other Western or Asiatic. 'The former corresponds with Mr. Wallace's "European Subregion", exclusice of its northern third; the latter with his "Siberian Subregion", exclusive likewise of its boreal portion. For the southern or subtropical division I adopt the subdirisions proposed by Mr. Wallace, with, for the present, the boundaries he has assigned them,-namely, a Western or Mediterranean Province and an Eastern or Manchurian Province. These two provinces, as already noted, are quite widely separated, in consequence of the southward extension of the cold-temperate fauna over the Thibetan plateau to the Himalayas. The fauna of the Thibetan plateau is said by Mr. Blandford to be "essentially Boreal, Alpine and even Arctic types prevailing, the country having in many parts a cli- 
mate scarcely equalled elsewhere for intensity of cold out of the Arctic Regions. This high barren tableland extends from Afghanistan to Yunan ; it comprises the drainage-areas of the Upper Indus and the Sanpú, and is bounded on the north in its western portion by the Kuenluen range, but it is less defined and its boundaries less accurately known to the eastward, although much light has been thrown upon the subject by Prejewalski's explorations".* In the "List of Mammalia known to inhabit the Thibetau Plateau", given by Mr. Blandford, the only distinct. ively southern genus is Equus. The only peculiar genus is Poëphagus, but the list is evidently quite incomplete, the only Bat given being a species of Plecotus, and the only Insectivore a species of "Crocidura". Budorcas, usually attributed to Thibet, is excluded, and several other genera, as Nectogale, Uropsilus, and AEluropus, currently given as pecu. liar to the Thibet plateau, are not mentioned. While the Thibetan plains belong certainly to the colder division, so many types mainly restricted to this region occur that the question arises whether it may not be proper to recognize the region as a Thibetian Province of the Temperate Subregion.

North American Region.-The North American Region has been divided by Professor Baird into three "provinces", termed respectively "Eastern", "Middle", and "Western". Though not co-ordinate in point of differentiation with the dirisions of the Europæo-Asiatic Region above recognized as provinces, they nevertheless possess distinctive features and form natural regions. They are of course far smaller in area, and possess a much smaller number of genera, but hare about the same proportion of peculiar generic and subgeneric types.

In the subjoiued tables an attempt is made to give lists of the genera of the two primary divisions of the North Temperate Realm, with approximate indications of their distribution in the various subdivisions of the two regions.t

* Proc. Zoöl. Soc. Lond., 1876, pp. 632, 633.

tIn these lists, as elsewhere in the tabulated lists given in this paper, it is not assumed that the groups adopted as "genera" are always of co-ordinate value. The equation attempted is doubtless open in many cases to criticism. While the attempt is made to assume an intermediate position between undue conservatism and excessive multiplication in respect to groups assumed by different writers as "generic", the lists can of course be considered only as provisional. Again, it is occasionally difficalt to decide whether certain genera should be assigned, even in a general way, to one of the faunal divisions rather than to another. However defective the result, the intent has of course been to give a fair presentation of the facts of distribution. 
Genera of the North American Region.

[Xrors.-The namea of circumpolar genera are in italics; those of genera peculiar to the region, in [ SMALL CAPITALS.]

\begin{tabular}{|c|c|c|c|c|c|}
\hline \multirow[b]{2}{*}{ Genera. } & \multicolumn{2}{|c|}{ Subregiòns. } & \multicolumn{3}{|c|}{ Provincee. } \\
\hline & 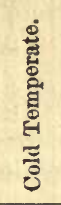 & 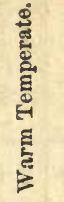 & 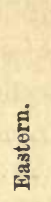 & $\underset{\Xi}{\Xi}$ & 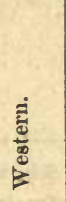 \\
\hline Felis ...... & - & + & + & + & + \\
\hline Lynx ........... & + & + & + & + & + \\
\hline Canis ........... & + & + & + & + & + \\
\hline Vulpes ..................... & + & + & + & + & + \\
\hline UROCYON ................... & - & + & + & + & + \\
\hline Gulo ...................... & + & - & + & - & - \\
\hline 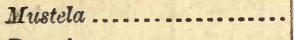 & + & $?$ & + & + & + \\
\hline Putorius .................... & + & + & + & + & + \\
\hline MEPHITIS ........................ & + & + & + & + & + \\
\hline SPILOGALE ................. & - & + & + & + & + \\
\hline TAXIDEA....................... & + & + & + & + & $+\bullet$ \\
\hline Lutra .......................... & + & + & + & + & + \\
\hline 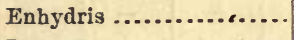 & + & - & - & - & + \\
\hline Procyon ........ & + & + & + & + & + \\
\hline Ursus........... & + & + & + & + & + \\
\hline Phoca.......... & + & - & + & - & + \\
\hline Pagomys ....... & + & - & + & - & - \\
\hline Fagophilus.... & + & - & + & - & - \\
\hline Erignathus.... & + & - & + & - & - \\
\hline Halichoerus ... & + & - & + & - & - \\
\hline Cystophora..... & + & - & + & - & - \\
\hline Eumetopias.... & + & $+?$ & - & - & + \\
\hline Zalophus ...... & + & $+?$ & - & - & + \\
\hline Callorhinus.... & + & +2 & - & - & + \\
\hline Alces............................ & + & - & + & - & - \\
\hline Rangifer ........................ & + & - & + & - & - \\
\hline Cervus ..................... & + & + & + & + & + \\
\hline CaRIaCUs .................. & - & + & + & + & + \\
\hline Mazama .................. & + & - & - & + & + \\
\hline Ovis ........................... & + & - & - & + & + \\
\hline Bison ....................... & + & + & + & + & - \\
\hline ANTILOCAPRA ............. & - & + & - & + & - \\
\hline Nyctinomus............... & - & + & $?$ & + & +3 \\
\hline Nycticejas............. & - & + & + & $?$ & - \\
\hline Lasiurus.................. & + & + & + & + & + \\
\hline Tesperugo.................. & + & + & + & + & + \\
\hline Vespertilio ................ & + & + & + & + & + \\
\hline Synotur.............. & - & + & + & + & $-?$ \\
\hline Antrozous ..................... & - & + & - & + & + \\
\hline SCALOPS .................. & - & + & + & + & + \\
\hline SCAPANUS ............... & - & + & + & + & + \\
\hline Urotrichus........... & - & + & - & - & + \\
\hline NEOSOREX ............ & - & + & + & + & + \\
\hline sorex ........................ & + & + & + & + & + \\
\hline BLARINA ................. & - & + & + & $+?$ & - \\
\hline Sciuropterus ................ & + & + & + & + & + \\
\hline
\end{tabular}


Genera of the North American Region-Continued.

\begin{tabular}{|c|c|c|c|c|c|}
\hline \multirow[b]{2}{*}{ Genera. } & \multicolumn{2}{|c|}{ Subregions. } & \multicolumn{3}{|c|}{ Provinces. } \\
\hline & 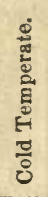 & 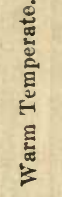 & 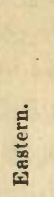 & 䒕 & 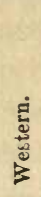 \\
\hline Sciurus ....... & + & + & + & + & + \\
\hline Tamias ................. & + & + & + & + & + \\
\hline spermophilus ......... & + & + & - & + & + \\
\hline Crnomys......... & - & + & - & + & + \\
\hline Arctomys ....... & + & + & + & + & + \\
\hline HAPLODON ...... & + & - & - & - & + \\
\hline Neotoma......... & - & + & + & + & + \\
\hline Sigmodon........ & - & + & + & - & - \\
\hline OCHETODON.............. & - & + & + & + & + \\
\hline Hesperomys ............... & + & + & + & + & + \\
\hline Arvicola .................... & + & + & + & + & + \\
\hline Evotomys............ & + & - & + & - & - \\
\hline SYKAPTOMYS .............. & + & + & + & + & + \\
\hline FIBER...................... & + & + & + & + & + \\
\hline 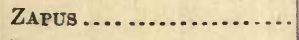 & + & - & + & - & - \\
\hline Perognathus ............. & - & + & - & + & + \\
\hline Cricetodipus ............. & - & + & - & + & + \\
\hline DIPODOMYs............... & - & + & - & + & + \\
\hline GEOMrS...................... & - & + & + & + & - \\
\hline тномомүя................. & - & + & - & + & + \\
\hline Castor ....................... & + & + & + & + & + \\
\hline ERETHIzon........... & + & $-?$ & + & + & + \\
\hline Lepus............... & + & + & + & + & + \\
\hline Lagomys............ & + & - & $-i$ & + & + \\
\hline Didelphys ............ & - & + & + & + & + \\
\hline
\end{tabular}

\section{Summary.}

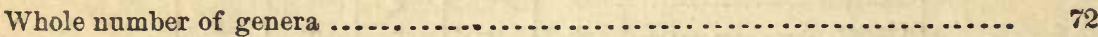

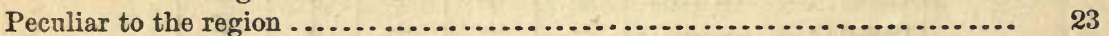

Circumpolar ....................................................... $\quad 32$

Of general distribution thronghout the region ......................... $\quad 26$

Occurring in the Cold Temperate Subregion......................... 47

Occurring in the Warm Temperate Subregion........................ 53-56

Land genera represented in the Eastern Province........................ 47

Genera represented in the Middle Province........................... 51

Land genera represented in the Western Province ....................... 48

Land genera restricted to the Eastern Province........................... ${ }^{*} 6$

Genera common to the Middle and Western Provinces not represented in the

Eastern Province.................................................... 8

Genera restricted to the Middle Province............................... 2

Land genera restricted to the Western Province........................... t3

Maritime genera restricted to the Eastern Province ....................... 5

Maritime genera restricted to the Western Province ..................... 5

Maritime genera occurring in both Eastern and Western Provinces ........... 1 
Europce-Asiatic Region.-The Europæo-Asiatic Region embraces a far greater (about four times greater) area than the North American, and is physically much more highly diversified. It is similarly divisible into a Cold Temperate Subregion and a Warm Temperate Subregion, and is further differentiated into a number of well-marked provinces, two of which belong to the Cold Temperate Subregion, and three or more to the Warm Temperate Subregion.*

\section{Genera of the Europoso-Asiatic Region.}

[Note.-A few almost exclusively tropical genera, which barely reach or doubtfully extend a short distance over the southern boundary of the region, are omitted as being not properly faunal elements of the region.

The names of circumpolar genera are in italics; those of gerera pecnliar to the region in SMALL CAPK TALS.]

\begin{tabular}{|c|c|c|c|c|c|c|}
\hline \multirow[b]{2}{*}{ Genera. } & \multicolumn{2}{|c|}{ Subregions. } & \multicolumn{4}{|c|}{ Provinces. } \\
\hline & 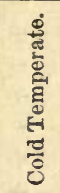 & 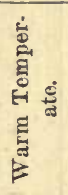 & 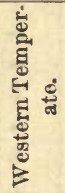 & 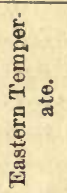 & 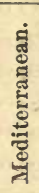 & 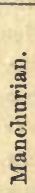 \\
\hline Macacus ... & - & + & - & - & + & + \\
\hline Felis........ & - & + & - & - & + & + \\
\hline $\operatorname{Lynx} \ldots . .$. & + & + & + & + & + & + \\
\hline Cynælurus.... & - & + & - & + & + & + \\
\hline Genctta....... & - & + & - & - & + & - \\
\hline Herpestes... & - & + & - & - & + & + \\
\hline Hyæna ..... & - & + & - & - & + & + \\
\hline Canis...... & + & + & + & + & + & + \\
\hline Cnon ....... & + & + & - & + & - & + \\
\hline Vu'pes ..... & + & + & + & + & $+t$ & + \\
\hline Arctonyx... & - & + & - & + & - & + \\
\hline NrCterEUTES. & - & + & - & - & - & + \\
\hline Gulo.......... & + & - & + & + & - & - \\
\hline Mustela...... & + & - & + & + & - & - \\
\hline Putorius..... & + & + & + & + & + & + \\
\hline Lutra ....... & + & + & + & + & + & + \\
\hline LUTRONECTES . & - & + & - & - & - & + \\
\hline Enhydris .... & + & - & - & + & - & - \\
\hline Mellivoca ..... & - & + & - & + & - & + \\
\hline Meles ....... & + & - & + & + & - & - \\
\hline Elarus ..... & - & + & - & - & - & + \\
\hline ELUROPUs... & - & + & - & - & - & + \\
\hline
\end{tabular}

"I am far from sure that what is here recognized as the "Mediterranean Province" should not be subdivided, and the Eastern or Persian division recognized as a "Persian Province". If the Eastern, Middle, and Western divisions of the North American Re. gion are to be accorded the rank of "Provinces", it may be necessary to admit, on similar grounds, a "Japanese Province"; but I am not at present prepared to adopt these divisions as "Provinces". To make the Provinces of the North American and Europæo-Asiatic Regions more nearly co-ordinate, I should prefer to unite the Middle and Western Provinces of the North American Region as forming a single Province. In fact, it seems donbtful whether the North American Region is differentiated into primary divisions that shonld be regarded as having co-ordinate rank with the Mediterranean and Manchnrian divisions of the Europæo-Asiatic Region. 
Genera of the Europceo-Asiatic Region-Continued.

\begin{tabular}{|c|c|c|c|c|c|c|}
\hline \multirow[b]{2}{*}{ Genera. } & \multicolumn{2}{|c|}{ Subregions. } & \multicolumn{4}{|c|}{ Provinces. } \\
\hline & 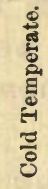 & 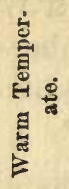 & 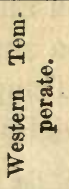 & 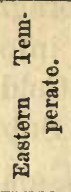 & 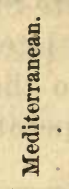 & 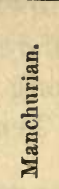 \\
\hline Crsus....... & + & + & ti & + & + & t. \\
\hline Callorbinus... & + & - & - & + & - & - \\
\hline Zalophus............. & + & + & - & + & + & + \\
\hline Eumetopias.. & + & + & - & + & + & + \\
\hline Phoca ........ & + & - & + & + & - & - \\
\hline Pagomys..... & + & - & + & + & - & - \\
\hline Pagophilus.... & + & - & + & + & $-\bullet$ & - \\
\hline Halichoerus ............... & + & - & + & - & - & - \\
\hline Erignathus....... & + & - & + & - & $1+$ & - \\
\hline Pelagivs ..... & - & + & - & - & + & - \\
\hline Cystophora... & + & - & + & - & - & - \\
\hline CAMELUS....... & - & + & - & - & + & + \\
\hline Alces........... & + & - & + & + & - & - \\
\hline Rangifer....... & + & - & + & + & - & - \\
\hline Cerous .......... & + & + & + & + & + & + \\
\hline DAMa.......... & - & + & - & - & + & - \\
\hline ElaPHODUS... & - & + & - & - & - & + \\
\hline LOPHOTRAGUS. & - & + & - & - & - & + \\
\hline CAPREULUS .... & + & + & + & - & + & + \\
\hline Moschus ..... & - & + & - & - & $+?$ & + \\
\hline HYDROPOTES. & - & $\dot{+}$ & - & - & - & + \\
\hline Bison ............ & + & - & + & - & - & - \\
\hline Poteriagus .. & - & + & - & - & - & + \\
\hline ADDAX $\ldots . .$. & - & + & - & - & + & - \\
\hline Oryx.......... & - & + & - & - & + & - \\
\hline Gazella ...... & - & + & - & - & + & $-?$ \\
\hline Procapra ... & - & + & - & + & + & + \\
\hline SAIGA......... & - & + & - & - & +8 & $+?$ \\
\hline Panthalors ... & - & + & - & + & - & - \\
\hline BuDORCAS ...... & - & + & - & + & - & + \\
\hline RUPICAPRA...... & - & + & - & - & +1 & $+?$ \\
\hline Nemorhædus .... & - & + & - & - & - & + \\
\hline Capra............ & - & + & - & - & + & -9 \\
\hline Ovis.............. & + & + & - & + & + & + \\
\hline Ammotragus ... & - & + & + & - & + & - \\
\hline Sus ............. & + & + & + & + & + & + \\
\hline Asinus.......... & - & + & - & - & + & + \\
\hline Rhinolophus .............. & - & + & - & - & + & + \\
\hline Plecotus................. & - & + & - & - & + & - \\
\hline Synotus...................... & - & + & - & - & + & + \\
\hline Vesperugo................... & + & + & + & + & + & + \\
\hline Vespertilio ................. & + & + & + & + & + & + \\
\hline Miniopterus .............. & - & + & - & - & + & + \\
\hline Taphozors................. & - & + & - & - & + & + \\
\hline Rhinopoma .............. & - & + & - & - & + & +8 \\
\hline Nyctinomus .............. & - & + & - & - & + & + \\
\hline Erinaceus ................. & + & + & + & + & + & + \\
\hline Talpa ................... & + & + & + & + & + & + \\
\hline
\end{tabular}


ALLEN ON GEOGRAPHICAL DISTRIBUTION OF MAMMALS. 343

Genera of the Europao-Asiatic Region-Continued.

\begin{tabular}{|c|c|c|c|c|c|c|}
\hline & Subr & gions. & & Pro & inces. & \\
\hline Genesa. & 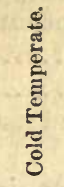 & 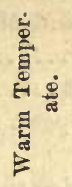 & 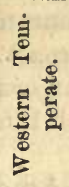 & 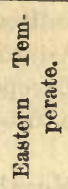 & 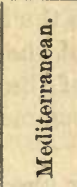 & 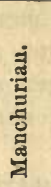 \\
\hline ScaPtochIRUS & - & + & - & - & - & + \\
\hline AXUROSOREX. & - & + & - & - & - & + \\
\hline MYOGALE.... & - & + & $+?$ & - & + & - \\
\hline Nectogale. & + & - & - & + & - & - \\
\hline Urotrichus... & - & + & - & - & - & + \\
\hline UROPSILUs ... & $+?$ & + ? & - & $+?$ & - & $+?$ \\
\hline Sorex .......... & + & + & + & + & $1+$ & + \\
\hline CRO:EOPUS... & + & - & + & - & - & - \\
\hline Crocidura.... & - & + & - & - & $+?$ & + ? \\
\hline Mus ........... & + & + & + & + & + & + \\
\hline Cricetus ... & + & + & + & + & + & + \\
\hline CrickTUlus. & - & + & - & - & - & + \\
\hline Meriones .... & - & + & - & - & + & + ? \\
\hline RHombonys. & - & + & - & - & + & + ? \\
\hline Psammomys.. & - & + & - & - & + & - \\
\hline Smixthus .... &,+ & - & + & + & - & - \\
\hline Arvicola ..... & + & + & + & + & + & + \\
\hline Evotomys .... & + & - & + & + & - & - \\
\hline MrospalaX.. & - & + & - & - & - & + \\
\hline Ellobius .... & + & - & + & $+?$ & - & - \\
\hline SIPHNEUS :.... & + & - & + & - & - & - \\
\hline Spalax ...... & + & + & + & + & - & - \\
\hline Dipus......... & - & + & - & - & + & + \\
\hline ALACTAGA ... & + & + & + & + & + & - \\
\hline Mroxus ......... & + & + & + & - & + & - \\
\hline Mascardinus.... & + & + & + & + & + & + \\
\hline Eliomys ........ & - & + & + & - & + & - \\
\hline Castor ....... & + & - & + & + & - & - \\
\hline Sciurus ....... & + & + & + & + & + & + \\
\hline Tamias ............ & + & - & + & + & - & - \\
\hline sciuropterus ......... & + & + & + & + & + & + \\
\hline Pteromys..... & - & + & - & - & - & + \\
\hline spermophilus..... & + & - & + & + & - & + \\
\hline 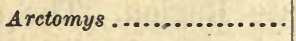 & + & - & + & + & - & - \\
\hline Hystrix.............. & - & + & - & - & + & - \\
\hline Lagomys..... & + & - & + & + & - & - \\
\hline Lepus......... & + & + & + & + & + & + \\
\hline
\end{tabular}

\section{Summary.}

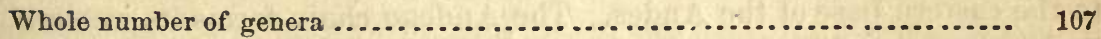

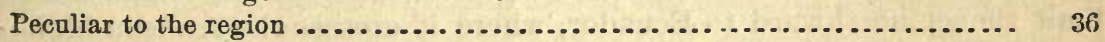

Circumpolar ..................................................... 22

Of general distribution throughont the region $\ldots . \ldots \ldots \ldots \ldots \ldots \ldots \ldots \ldots \ldots \ldots \ldots . . . . \ldots$

Occurring in the Cold Temperate Subregion .......................... 54

Occurring in the Warm Temperate Subregion......................... 80

Genera occurring in the Western Temperate (European) Province........... 48 
Genera occurring in the Eastern Temperate (Asiatic) Province................ Genera of the Mediterranean Province .............................

Genera of the Manchurian Province....................................

Genera common to the Eastern and Western Temperate Province.............

Genera common to the Mediterranean and Manchurian Province ..............

Maritime genera of the Asiatic coast................................

Maritime genera of the European coast ...............................

Maritime genera common to both European and Asiatic coasts ...............

In comparing the North American Region with the Europæo-Asiatic Region, the following resemblances and differences become apparent:-1. The number of genera in the Europæo-Asiatic Region is rather more than one-fourth greater than in the North American Region, with consequently a smaller proportion of circumpolar genera. 2. But this difference results almost wholly from the greater preponderance of peculiar types in the Southern Subregion, due evidently to the immensely greater extent and greater physical diversity of this portion of the Europæo. Asiatic Region as compared with the corresponding portion of the North American Region. 3. While the colder portions of the two regions have each about the same number of genera, which are in great part (nearly two-thirds) common to the two regions, the Warm Temperate (really Subtropical) Subregion of the Europæo-Asiatic Region has a far greater number of genera that do not extend to the northward of it than has the Warm Temperate Subregion of the North American Region, while a small proportion only (chiefly arctopolitan and subtropicopoli$\tan$ ) are common to the two subregions. Hence, 4 . The two regions (Europæo-Asiatic and North American) are mainly differentiated (as already noticed) through the presence of genera limited to their southern subregions.

\section{III.- $A M E R I C A N$ TROPICAL REALM.}

The American Tropical Realm is approximately bounded by the northern and southern mean annuals of $70^{\circ} \mathrm{F}$. Its northern bound. ary has been already indicated in defining the southern limit of the North Temperate Realm, it being concurrent with the southern boundary of the North American Temperate Region. The southern boundary of the American Tropical Realm leaves the Atlantic coast near the thirtieth degree of south latitude, or near the southern extremity of Brazil, but in passing from the coast sweeps rapidly northward till it nearly or quite reaches the Tropic of Capricorn in Northeastern Buenos Ayres; it then bends to the south ward and continues westward to the eastern base of the Andes. The Andean chain forms its western limit thence northward to Ecuador, where it crosses the Andean highlands and is again deflected southward, thus including a narrow belt of the coast region west of the Andes in Northwestern Peru.

As thus defined, the southern border of the American Tropical Realm is nearly coincident with the sonthern boundary of the "Brazilian 
Region" as mapped by Mr. Wallace,* Brazil, nearly all of Paraguay, and Bolivia east of the Andes being included within this realm.

Its characteristic genera include all of the American Quadrumanes (families Cebidce and Mididce,=Hapalida of most authors), all the American Edentates, and nine-tenths of the American Marsupials. It is also the home of nearly all the American Felidce, except the Lynxes. It also has many peculiar genera of Glires and Chiroptera, while it almost alto. gether lacks the characteristic forms of mammalian life found in the northern temperate regions. Among the characteristic North American types unrepresented in the American Tropical Realm are, among Car. nivores, not only the Lynxes, but the true Wolves and Foxes, the Mar tens, Wolrerenes, Badgers, and Bears; among Ungulates, the Prong* horn, the Bison, Mountain Sheep, and Mountain Goat, and several important genera of the Cervidac; among Rodents, the Spermophiles, Marmots, Muskrat, Beaver, Pouched Rats, "Gophers" (Geomys and Thomomys), the numerous species of Arvicola, etc.,-in short almost all of the prominent and characteristic genera of the order except the almost cosmopolitan genera Lepus and Sciurus; among Insectivores, all the Moles and Shrews, except a few forms of the latter, which extend over most of the Central American Region.

The American Tropical Realm is divisible into three regions, - the Antillean, the Central American, and the Brazilian. The Antillean Region includes only the West Indies and the southern extremity of Florida. The Central American Region embraces Mexico (exclusive of the elevated tablelands), the whole of Central America, and the extreme northern parts of South America (Venezuela north of the Orinoco Basin, Northern and Western New Granada, and most or all of that portion of Ecuador west of the Andes). The Brazilian Region comprises all the intertropical parts of South America not embraced in the Central American Region, including the whole area east of the Andes southward to the boundary already given.

Central American Region.-Of the genera occurring in the Central American Region (see subjoined table), only about one-ninth can be considered as peculiar to the region; about one-sixth are either subcosmopolitan or tropicopolitan; about three-fifths range also over the Brazilian Region, and a few over nearly all of South America ; about onehalf extend far into North America, among which are several that are also common to the greater part of the North Temperate Realm, while about one-eleventh are also found over most of both North America and Soith America. Aside from the few peculiar genera, the fauna is composed largely of genera cummon also to the Brazilian Region, which find their northern limit of distribution within the Central American Region, plus a very large proportion that extend southward from the North American Temperate Region, and which find their southern limit of distribution within the region under consideration. . Its distinctive

* Geogr. Dist. Anim., vol. ii, map facing page 3.

Bull. iv. No. 2 
feature is hence an approximately equal blending of temperate and tropical forms, whose respective habitats here overlap. Many of the worthern forms do not quite reach the southern limit of the region, just as many of the southern forms do not quite reach its northern limit. It is distinguished from the North American Temperate Region by the preponderance of tropical life, and from the Brazilian Region by the copious intermingling therewith of northern forms, an element wholly lacking in the Brazilian Region.

Genera of the Central American Region.

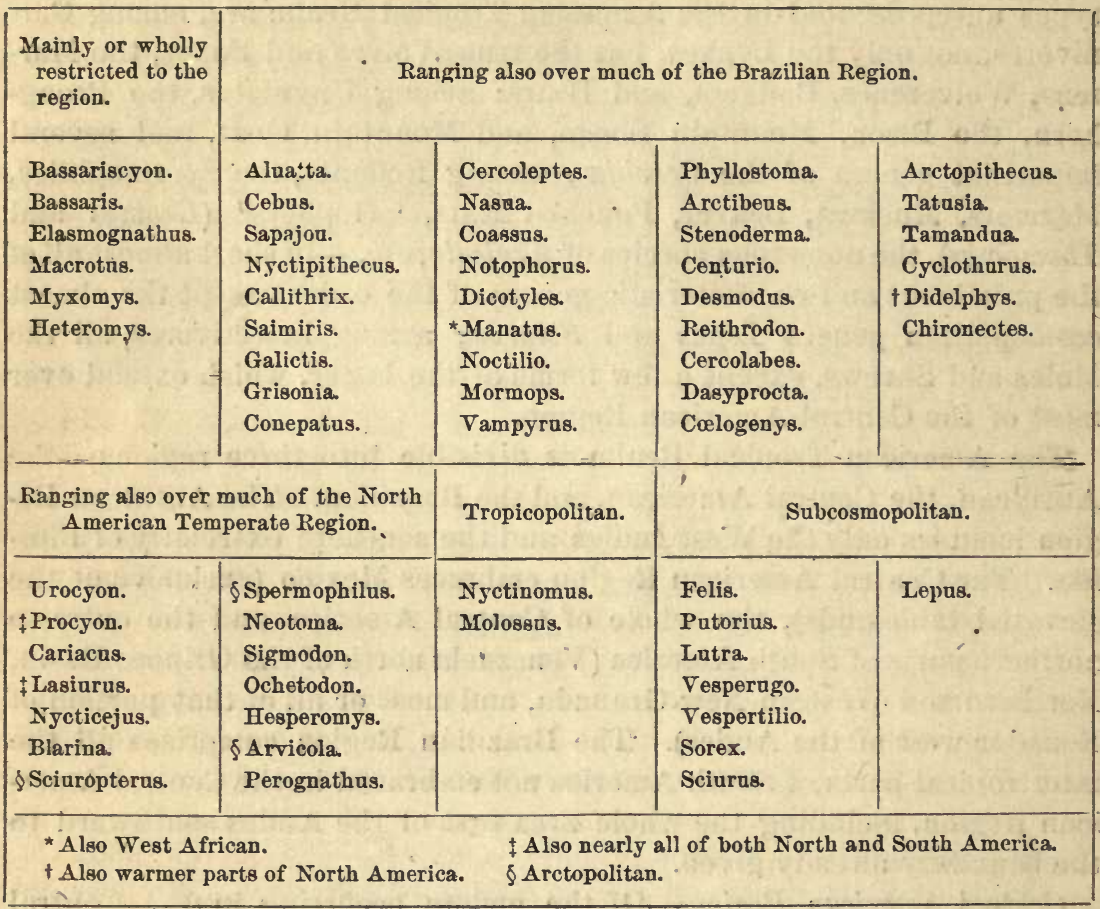

\section{Summary.}

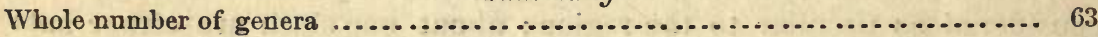

Peculiar or mainly limited to the region $\ldots \ldots \ldots \ldots \ldots \ldots \ldots \ldots \ldots \ldots \ldots \ldots \ldots . . .6$

Occurring also over most of the Brazilian Region ....................... 40

Occurring also over much of the North American Region.................. 24

Occurring also over most of both North and South America, but not in the Old

World ...................................................... 5

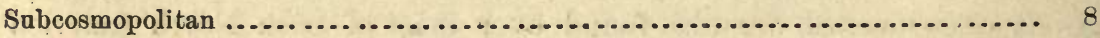

Tropicopolitan ................................................. 2

Antillean Region.-The Antillean Region differs from both the Central American and Brazilian most strongly in negative charactersthrough what it lacks rather than in what it has-although it possesses a number of peculiar genera. The Chiroptera form two-thirds of the genera and not less than five-sixths of the species. Of the eight peculiar genera, five are Bats, the others being Solenodon (the only Insectirore), Capromys, and the closely allied Plagiodonta, which together 
constitute a family peculiar to the region. Two orders-Primates and Bruta-highly characteristic of the Central American and Brazilian regions, are wholly absent. There are also no Ungulates, very few Carnivores, and rery fow Rodents; the latter, however, are of mostly peculiar species, as are many of the Bats. The single Insectivore is of a remarkable type, which finds its nearest ally in the remote island of Madagascar, the ordinary Insectivores of the neighboring Central American and North American Regions being wholly unrepresented.

Genera of the Antillean Region.

\begin{tabular}{|l|l|l|l|}
\hline Peculiar to the region. & \multicolumn{2}{|c|}{ Tropical American. } & Wide-ranging. \\
\hline Nycticellus. & Nasua. & Mormops. & Lutra. \\
Lonchorhina. & Cercoleptes. & Macrotus. & Procyou. \\
Phyllodia. & Manatus. & Vampyrus. & Lasiurus. \\
Brachyphylla. & Natalus. & Arctibeus. & Vesperugo. \\
Phyllonicteris. & Thyroptera. & Stenoderma. & Vespertil:o. \\
Solenodon. & Noctilio. & Heteromys. & Hesperomss \\
Capromys. & Molossus. & Dasyprocta. & \\
Plagiodouta. & Nyctinomus. & Dldelphys. & \\
& Chilomscteris. & & \\
\hline
\end{tabular}

Brazilian Region.-Of about ninety commonly recognized genera, a little less than one-third may be considered as either wholly or mainly restricted to the region; a little less than another third range to the northward over much of the Central American Region, and may be considered as characteristic of the American Tropical Realm at large rather than of the Brazilian Region. Abont one-tenth of the remaining genera occur also orer a large part of the Central American Region, while the remainder are divided abont equally between tropicopolitan and cosmopolitan genera, and those that range southward orer the South American Temperate Bealm. One genus is also East Indian and another African, while quite a number rauge throughout the temperate and tropical parts of both Americas, and a few others over Temperate South America.

It is eminently characterized by its dozen genera of Monkeys, which, excepting $\cdot a$ few that range into the Central American Region, are restricted wholly to this region; also by twelve to fifteen genera of Bats, which are scarcely found beyond its borders; nearly as many genera of Rodents, and quite a number of peculiar genera of other groups. Negatively it is characterized by the absence of Insectivores, the great bulk of the northern types of Carnivores, Ungulates, and Rodents. Its sole affinity with the life of the North Temperate Realm consists in the presence of a few such wide-ranging (cosmopolitan) genera as Felis, Sciurus, Lepus, Vespertilio, etc., and two other genera (Procyon and Didelphys) that range far into North America.

It is susceptible of division into several provinces, upon the detailed

* Dr. Coues gives Hesperomys (Oryzomys) palustris as Jamaican.-Mon. N. Am. Rod., 116 , foot-note. 
consideration of which it is not proposed at present to enter. These are the Upper Amazonian Province, embracing the region drained by the Upper Amazon and its principal tributaries (Western Brazil and those portions of Peru and Bolivia east of the Afndes); the Lower Amazonian Province, embracing the Lower Amazonian and Orinoco Basins; and the Southeast Brazilian Province, embracing Southeastern Brazil and Paraguay. They are characterized by the occurrence of numerous peculiar species rather than by peculiar genera. The geuus Lagothrix appears to be confined, however, to the Upper Amazonian Province, Chrysothrix to the Lower Amazonian, and Brachyteles to the Southeast Brazilian, where occur also Icticyon, Thous, Lycolepex, etc., not found in the other regions, but ranging thence southward to Patagonia.

Genera of the Brazilian Region.

\begin{tabular}{|c|c|c|c|}
\hline & Mainly confine & Brazilian Region. & \\
\hline $\begin{array}{l}\text { Lagothrix. } \\
\text { Eriodes. } \\
\text { Pithecia. } \\
\text { Brachyurus. } \\
\text { Nyctipithecns. } \\
\text { Cheropotes. } \\
\text { Midas. } \\
\text { Icticyon. }\end{array}$ & $\begin{array}{l}\text { Pteronura. } \\
\text { *Tapiras. } \\
\text { Macrophyllum. } \\
\text { Vampyrus. } \\
\text { Saccopteryx. } \\
\text { Diphylla. } \\
\text { Habrothrix. } \\
\text { Holochilus. }\end{array}$ & $\begin{array}{l}\text { Oxymicterus. } \\
\text { Dactylomys. } \\
\text { Cercomys. } \\
\text { Mesomys. } \\
\text { Echimys. } \\
\text { Loncheres. } \\
\text { Chætomys. } \\
\text { Hydrochœrus. }\end{array}$ & $\begin{array}{l}\text { Bradypus. } \\
\text { Prionodontes. } \\
\text { Xenurus. } \\
\text { Tolypeutes. } \\
\text { Myrmecophaga. } \\
\text { Hyracodon. } \\
\text { Chironectes. }\end{array}$ \\
\hline
\end{tabular}

Tropical America generally.

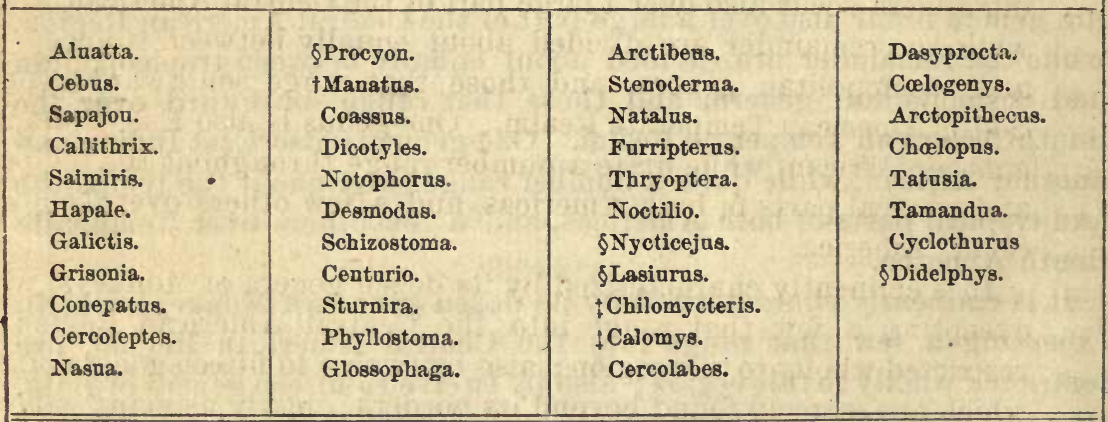

Extending also over Temperate South America.

Chrysocyon.

Lycalopex.

Pseudalopex.

Blastocerns.

Ctenomys.

\section{Cavia.}

Kerodon.

Myopotamus.

Dasypus.

Subcosmopolitan and tropicopolitan.

Felis.

Lutra.

Nyctinomus.

Molossus.

Dysopes.
Vesperugo.

Vespertilio.

Sciurus.

Lepus.
* Also East Indian.

† Also West African. $\ddagger$ Also Temperate South America.

Also North American. 


\section{Summary.}

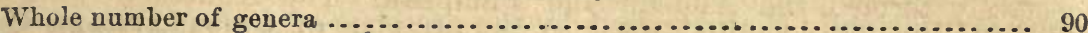

Mainly restricted to the region $\ldots \ldots \ldots \ldots \ldots \ldots \ldots \ldots \ldots \ldots \ldots \ldots \ldots \ldots \ldots \ldots \ldots \ldots \ldots \ldots, 31$

Of general distribution throughout the American Tropical Realm .............. 41

Occurring also over much of the South American Temperate Realm............ 9

Oecurring also in the warmer parts of the North Temperate Region............ 6

Tropicopolitan ................................................... 3

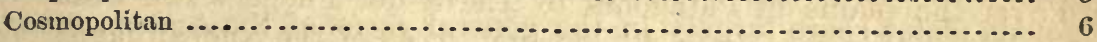

\section{IV.-SOUTH AMERICAN TEMPERATE REALM.}

What is here termed the South American Temperate Realın embraces all that portion of the South American continent and adjacent islands not included in the American Tropical Realm as already defined. It coincides very nearly with Mr. Wallace's "South Temperate America or Chilian Subregion".* Its northern limit on the Atlantic coast is near the thirtieth parallel. On leaving the Atlantic coast, the northern boundary passes obliquely northwestward, rising in the region of the Chaco Desert, to, or possibly a little beyond, the Tropic of Capricorn. Again descending to about the twenty-fifth parallel, it turns abruptly northward and eastward, along the eastern border of the Andean chain, nearly to the fifth degree of south latitude, near which point it strikes the Pacific coast. It thus embraces a large part of the great Andean plateau, with the neighboring coast region to the westward, nearly all the La Plata plains, and the region thence southward to Tierra del Fuego, which belongs also to this region.

As contrasted with the Tropical Realm to the northward, it is characterized, in respect to mammals, by the absence of all Quadrumana and the paucity of Edentates and Marsupials, there being neither Sloths nor Anteaters, while only two or three species of Opossums barely extend over its borders; the absence of all genera of Leaf-nosed Bats, and of not less than a dozen important genera of Rodents, the Coatis, the Kinkajou, the Tapirs, and many other genera characteristic of the American tropics. $t$ As noted by Mr. Wallace, it is further characterized by the possession of the entire family of the Chinchillida, the genera Auchenia, Habrocomus, Spalacopus, Actodon, Ctenomys, Dolichotis, Myopotamus, Chlamadophorus, to which may be added the marine genera Otaria, Arctocephalus, Morunga, Lobodon, and Stenorhynchus, very few of which range beyond the northern border of this region. The Spectacled Bear is also confined to it, and here are also most largely dereloped the Murine genera Calomys, Acodon, and Reithrodon.

Although one of the smallest of the primary regions, it is apparently divisible into two more or less well-marked provinces, which may be

\footnotetext{
*Geog. Distr. Animals, vol. ii, p. 36, and map of the "Neotropical Region".
}

tAmong the genera of the Brazilian Region here unrepresented are, aside from the Quadrumana, Cercoleptes, Nasua, Tapirus, Bradypus, Choclopus, Myrmecophaga, Tamandua, Cyclothurus, Phyllostoma, Glossophaga, Arctibeus, Dysopes (and other genera of Chi. roptera), Hydrochœrus, Cercomys, Dactylomys, Loncheres, Echimys, Cologenys, Dasyprocta. Chatomys, Cercolabes, Lepus, Sciurus, Habrothrix, Oxymycterus, Holochilus, etc., $=27+$. 
respectively termed the Andean and Pampean. The Andean Province is principally characterized by the presence of Ursus (Tremarctus) ornatus, the genera Pudu, Furcifer, Tolypeutes, Chlamydophorus, Chinchilla, Lagidium, Spalacopus, Habrocomus, and Octodon. Auchenia and several genera of Rodents range from the Andean Province southward over the plains of Patagonia to Tierra del Fuego. The Patagonian plains share largely in the general facies of the Andean fauna. A few genera only are restricted to the Pampean Province, these being mainly Ctenomys, Lagostomus, and Dolichotis. The differences between these two provinces relate mainly to species rather than to genera. The Pampean Province is much the smaller, embracing only the comparatively level pampa district bordering the La Plata and Lower Parana Rivers. So little is definitely known respecting the range of the mam. mals of this general region that it is scarcely practicable to attempt at present a definition of the boundaries between the Pampean and Andean divisions.

The relation of the South Temperate American to the Tropical American Realm is of course far closer than to any other, there being as usual a gradual transition betreen the two along their line of junction, through the extension of a few forms characteristic of the one for a short distance into the other, just as has been obserred to be the case between the North Temperate and Tropical American Realms. It has, however, nothing in common with the North Temperate American Realm bejond the presence of a few cosmopolite types that extend across the intermediate Tropical Realm. So far as land mammals are concerued, it has no genera common to the South Temperate portions of the Old World, except a few that are almost cosmopolite. The case is different, however, with the marine species. Of the half dozen or more genera of Pinnipeds (the only marine forms we are here called upon to consider), none are peculiar to the shores of Temperate South America but are common to South Temperate and Antarctic shores generally. None of them, howerer, occur north of the tropics, ${ }^{*}$ and it is hence only through theso that there is any closer affinity between the mammalian life of this region and the South Temperate Zone generally than between it and that of north temperate latitudes.

Of the thirty-four land genera below eninmerated as occurring in the South American Temperate Realı, rather more than one-half (eighteen) are nearly or wholly confined to it. Most of the remainder extend far to the northward into Tropical America, and others reach North America, while five are almost cosmopolitan.

* Otaria alone reaches the Galapagos, which, although situated under the equator, are still within the influence of the cold Peruvian current, and appear to constitute an outlying element of the South American Temperate Realm. 
ALLEN ON GEOGRAPHICAL DISTRIBUTION OF MAMMALS. 351

Genera of the South American Temperate Realm.

\begin{tabular}{|c|c|c|c|c|}
\hline \multicolumn{2}{|c|}{ Mainly or wholly limited to the reglon. } & $\begin{array}{c}\begin{array}{c}\text { Marine, and } \\
\text { mainly Antarctic. }\end{array} \\
\text { Otaria. }\end{array}$ & \multicolumn{2}{|c|}{ Wide-ranging. } \\
\hline $\begin{array}{l}\text { Tremarctus. } \\
\text { Furcifer. } \\
\text { Pudu. } \\
\text { Auchenia. } \\
\text { Lophostoma. } \\
\text { Octodon. } \\
\text { Spalacopus. } \\
\text { Habrocoma. } \\
\text { Reithrodon. } \\
\text { Acodon. }\end{array}$ & $\begin{array}{l}\text { Ctenomys. } \\
\text { Drymomys, } \\
\text { Dinomys. } \\
\text { Chinchilla. } \\
\text { Lagidinm. } \\
\text { Lagostomus. } \\
\text { Dolichotis. } \\
\text { Chlamydophorus. }\end{array}$ & $\begin{array}{l}\text { Otaria. } \\
\text { Arctocephalus. } \\
\text { Lobodon. } \\
\text { Stenorh snchus. } \\
\text { Morunga. }\end{array}$ & $\begin{array}{l}\text { Feliz. } \\
\text { Psendalopex. } \\
\text { Lycolopex. } \\
\text { Chrysocyon. } \\
\text { Putorius. } \\
\text { Lutra. } \\
\text { Conepatus. } \\
\text { Vespertili . } \\
\text { Vesperugo. } \\
\text { Kerodon. }\end{array}$ & $\begin{array}{l}\text { Cavia. } \\
\text { Myopotamns. } \\
\text { Calomys. } \\
\text { Habothrix. } \\
\text { Tatusia. } \\
\text { Didelphys. } \\
\end{array}$ \\
\hline
\end{tabular}

\section{V.-TUE INDO-AFRICAN REALM.}

The Indo-African Realm consists maiuly of Intertropical Africa and Intertropical Asia, to which it seems proper to add Extratropical South Africa. The small portion of Africa south of the Southern Tropic lies wholly within the warm-temperate zone. Its small extent and broad connection with Tropical Africa render its separation as a distinct realm (as I at one time rather hastily considered it) almost inadmissible, since it is especially open to the influence of the great intertropical African fauna, as is shown by the extension of many tropical forms down to within a few degrees of its southern extremity. The area really possessing a temperate climate is restricted to its extreme southern border, where alone appear the few generic and family types that do not have a rery general range over the tropical portions of the continent. This area is many times smaller than the temperate portion of South America, but, though so small, has quite a number of peculiar genera, which impart to it quite distinctive features. It jet seems better to regard it as an appendage of the great Indo-African Realm rather than as a distinct primary region. Madagascar, with the Mascarene Islands, on the other haud, while perhaps possessing a closer affinity with Africa than with any other continental region, has jet a fauna made up so largely of peculiar types that it seems more in accordance with the facts of distribution to regard it as a separate primary region.

The Indo-African Realm, as thus restricted, forms a highly natural division. Although its two principal areas are quite widely separated, being in fact geographically almost wholly disassociated, they possess a wonderful degree of similarity. Of the fifty commonly recognized families of mammalia occurring within its limits, three-fifths are distributed throughout almost its whole extent. Of the remainder, onehalf are confined to Africa, and one is African and American, leaving only nine in India that are unrepresented in Africa; three only of these latter are, however, peculiar to the Indian Region; all extend bejond it to the northward, fire of them eren occurring over the greater part of 
the northern hemisphere. Thus the African Region is the more specialized division, only a small portion of the tropical element in the Indian Region, through which it is differentiated from the great EuropæoA siatic Temperate Region, being unrepresented in the African, while the African bas three times as many peculiar families as the Indian.* As shown by the subjoined table, thirty of the fifty Indo-African families have a wide extralimital distribution, not less than one-fourth being emphatically cosmopolitan.

Families of Mammals represented in the Indo-African Realm, arranged to show (approximately) their distribution.

\begin{tabular}{|c|c|c|c|c|}
\hline $\begin{array}{l}\text { Occurring in the } \\
\text { Indian Region, } \\
\text { but not in the } \\
\text { African. }\end{array}$ & $\begin{array}{l}\text { Peculiar to the } \\
\text { African Region. }\end{array}$ & \multicolumn{2}{|c|}{ Common to both regions. } & $\begin{array}{l}\text { Common to both } \\
\text { Regions, and also } \\
\text { of wide extra. } \\
\text { limital range. }\end{array}$ \\
\hline $\begin{array}{l}\text { * TARSIDA. } \\
\text { † Eluridǽ. } \\
\text { † Ursidæ. } \\
\text { † Cervidæ. } \\
\text { † Camelidæ. } \\
\text { § Tapiridæ. } \\
\text { * GALEOPITHECID E. } \\
\text { † Talpidæ. } \\
\text { * TUPAYIDA. }\end{array}$ & $\begin{array}{l}\text { Protelidæ. } \\
\text { Hippopotamidæ. } \\
\text { Phacochœridæ. } \\
\text { Giraffidæ. } \\
\text { Hyracidæ. } \\
\text { Chrysochloridæ. } \\
\text { Macroscelidæ. } \\
\text { Potamogalidæ. } \\
\text { Lophyiomyidæ. } \\
\text { Orycteropodidæ. }\end{array}$ & $\begin{array}{l}\text { Simiidæ. } \\
\text { Semnopithecidæ. } \\
\text { Cynopithecidæ. } \\
\text { Lemuridæ. } \\
\text { Viverridæ. } \\
\text { Hyænidæ. } \\
\text { Tragulidæ. } \\
\text { Equidæ. } \\
\text { Snidæ. } \\
\text { Rhinocerotidæ. } \\
\text { Elephantidæ. } \\
\text { Halicoridæ. }\end{array}$ & $\begin{array}{l}\text { li Nycteridæ. } \\
\text { Erinaceidæ. } \\
\text { Myoxidæ. } \\
\text { Spalacidæ. } \\
\text { Dipodidæ. } \\
\text { Manididæ. }\end{array}$ & $\begin{array}{l}\text { Felidæ. } \\
\text { Canidæ. } \\
\text { Mustelidæ. } \\
\text { Bovidæ. } \\
\text { Pteropodidæ. } \\
\text { Rhinolophidæ. } \\
\text { Vespertilionidæ. } \\
\text { Soricidæ. } \\
\text { Octodontidæ. } \\
\text { Sciuridæ. } \\
\text { Hystricidæ. } \\
\text { Leporidæ. }\end{array}$ \\
\hline
\end{tabular}

I The Trichechida (= Manatidae) occur in Africa but not in India, but ard found also in the warmer parts of America.

* Wholly restricted to the Indian Region. t Mainly restricted to the Indian Region.
‡ Of wide extralimital range.

$\S$ Found also in Intertropical A merica.

\| Chiefly African.

\section{Summary.}

Wholo number

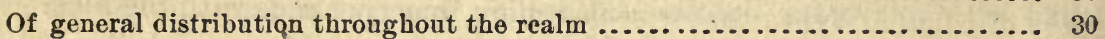

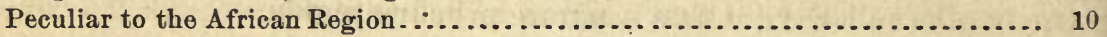

Peculiar to the Indian Region........................................ 3

Occurring in the Indian Region, but not in the African ..................... 6

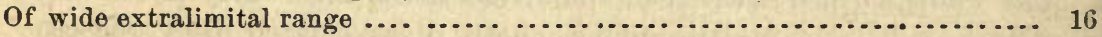

African Region.-The African Region, as here recognized, is nearly equivalent to Mr. Wallace's "Ethiopian Region", with the exclusion

* Mr. Wallace has arrived at rather different conclusions respecting the specialization of the African Region, since he considers its specialization due wholly to the peculiar forms developed in Madagascar. Deducting these-for he considers Madagascar and its neighboring islands as forming a "subregion"merely of the "Palæotropical" he believes would leave, in respect to specialization, the African and Indian Regions "nearly equal". In this comparison, however, I wholly exclude the Madagascan or "Lemurian" fauna, and still find Africa a considerably more specialized region. 
of his "Lemurian Subregion". Its northern boundary will be pro. visionally considered as the northern mean annual of $70^{\circ} \mathrm{F}$.

As thus limited, the greater part of the Arabian Peninsula and the southern portion of the Great Saliara belong to it. But just how much of the latter belongs here, and how much to the Mediterranean Region, cannot at present be readily determined. As already noticed, it consists largely of transitional ground, and is as yet quite imperfectly known. It is to some extent, doubtless, also a barrier region; but that it is by no means an impassable obstacle is sufficiently shown by the large number of generic ty pes of mammals that extend from the Indian Region as far southward eren as the Cape of Good Hope. Even if it were an insurmountable barrier, the comparatively hụmid and fertile eastern coast border would afford a sufficient highway of intercommunication betreen Trop. ical Asia and Tropical Africa, and the community of life of the two regions shows that for long ages there has been this open way of interchange.

The African Region, considering its great extent and its tropical climate, is to a great degree zoölogically a unit, yet it is by no means homogeneous. At least, three subdivisions may be recognized, each of which is characterized by many peculiar genera. These subregions have already been characterized by Mr. Wallace under the names of Eastern, Western, and Scuthern. The Western (West African Province) consists of the humid, hearily wooded region of the west coast, extending to a considerable, but at present not definitely determinable, distance into the interior, but probably with boundaries nearly as drawn by Mr. Wallace.* The Eastern (East African Province) includes the remainder of Intertropical Africa, while to the Southern (South African Province) belongs the southern extratropical portion of the continent.

Of these divisions, the Eastern contains the greatest number of genera, as it likerise contains by far the greatest area; but it is the least specialized, only two-fifteenths of its genera being peculiar to it, while of the genera of each of the other regions about one-fourth are peculiar. Nearly one-half (about forty-four per cent.) of the genera of the Eastern Province have a more or less general distribution over the whole African Region, while only a little more than a third (thirty-three to thirty-eight per cent.) of the genera of the other province have a similarly wide range.

A much larger proportion of Indian genera are represented in the Eastern and Southern Provinces than in the Western. This difference is due to obvious conditions, the fertile belt of the Nile district and adjoining coast forming an easy way of intercommunication between the

* The conclusions and details here presented were worked out independently and de novo by the present writer. That they agree so closely with the views and results attained by Mr. Wallace, so far as Africa south of the Great Desert is concerned, is to me a source of gratification. In order to avoid unconscious bias I purposely avoided a detailed study of Mr. Wallace's writings on this subject till my own results were written ont, and on then comparing my own conclusions with those r£ached by Mr. Wallace, became for the first time aware of their close agreement. 
two former not equally open to the Western Province. The Eastern and Southern Provinces further resemble each other in consisting largely of grassy plains, and in being, par excellence, the land of Antelopes. On the other hand, the Western Province, in consequence of its moist climate and dense forests, is the metropolis of the African Quadrumanes, to which region no less than six genera are restricted, and where all but one are represented, while only four occur in the Eastern, and merely a few outlying 'species reach the Southern. Hence the Eastern and Southern Provinces are far more closely allied than is either with the Western.

Eastern Province.-The East African Province or "Subregion" includes, as claimed by Mr. Wallace, not only East Africa proper, but also a considerable portion of the Great Sahara and the whole of the northern portion of Tropical South Africa, thus bounding the Western Province on three sides. In other words, it not only includes East $\Delta$ frica and Southern Arabia, but all of Tropical Africa, except the western portion, situated (speaking generally) between latitude $15^{\circ}$ north and latitude about $22^{\circ}$ south. As is well known, it consists mainly of a moderately elerated plateau, rising, in Abyssinia, into lofty mountains. It is generally an open region, "covered with a vegetation of high grasses or thorny shrubs, with scattered trees and isolated patches of forest in favorable situations. The only parts where extensive continuous forests occur are on the eastern and western slopes of the great Abys. sinian plateau, and on the Mozambique coast from Zanzibar to Sofala."* It is worthy of note that the species peculiar to the province occur almost exclusively in Mozambique, or in Abyssinia and adjoining portions of Northeast Africa, a few extending into the Arabian Peninsula.

Of the ninety genera occurring in this province, ten, which are almost cosmopolite, may be considered as baving too wide a range to possess any special significance. Of the remaining eighty, about one-fourth are found also in the Indian Region, leaving three-fourths (thirty-nine) as peculiarly African. Of these, twelve only are restricted to the Eastern Province, sixteen being common to the Southern Province, and ten to the Western. The subjoined tabular list indicates approximately the distribution of the genera of the Eastern Province.

*Wallaee, Geogr. Dist. Anim., vol. i, p. 259. 
Genera of the East African Province.

\begin{tabular}{|c|c|c|c|}
\hline $\begin{array}{l}\text { Restricted to the } \\
\text { province. }\end{array}$ & \multicolumn{3}{|c|}{ Exclusively African, but occurring also in the oiher provinces. } \\
\hline $\begin{array}{l}\text { *Theropithecus. } \\
\text { *Galerella. } \\
\text { Rhinogale. } \\
\text { *Neotragus. } \\
\text { Nesotragus: } \\
\text { † Petrodromus. } \\
\text { † Rbynchocyon. } \\
\text { i Saccostomus. } \\
\text { † Peleomys. } \\
\text { *Lophiomss. } \\
\text { †Heliophobius. } \\
\text { Pectinator. }\end{array}$ & $\begin{array}{l}\text { Colobus. } \\
\text { Gnerza. } \\
\text { Cercopithecus. } \\
\text { Cynocephalus. } \\
\text { Galago. } \\
\text { Athylax. } \\
\text { Ichneumea. } \\
\text { Bdeogale. } \\
\text { Helogale. } \\
\text { Mungos. } \\
\text { Crossarchus. } \\
\text { Lycaon. } \\
\text { Zorilla. }\end{array}$ & $\begin{array}{l}\text { Giraffa. } \\
\text { Oreas. } \\
\text { Tragelaphus. } \\
\text { Oreotragns. } \\
\text { Epyceros. } \\
\text { Kobus. } \\
\text { Nanotragus. } \\
\text { Cephalophus. } \\
\text { Egocerus. } \\
\text { Alcelaphus. } \\
\text { Connochetes. } \\
\text { Hippopotamus. } \\
\text { Potamochœrus. }\end{array}$ & $\begin{array}{l}\text { Phaccchorus. } \\
\text { Rhinaster. } \\
\text { Hyrax. } \\
\text { Dendrohyrax. } \\
\text { Epomophorus. } \\
\text { Macroscelides. } \\
\text { Cricetomys. } \\
\text { Steatomys. } \\
\text { Otomys. } \\
\text { Georychus. } \\
\text { Xerus. } \\
\text { Anlacodus. } \\
\text { Orycteropus. }\end{array}$ \\
\hline \multicolumn{3}{|c|}{,Occurring also in the Indian Region. } & Wide-rarging. \\
\hline $\begin{array}{l}\text { Viverra. } \\
\text { Genetta. } \\
\text { Herpestes. } \\
\text { Calogale. } \\
\text { Mellivora. } \\
\text { Aonyx. } \\
\text { Hyæna. } \\
\text { Bubalus. } \\
\text { Oryx. } \\
\text { Gazella. }\end{array}$ & $\begin{array}{l}\text { Elepbas. } \\
\text { †Sus. } \\
\text { Asinus. } \\
\text { Halicoro. } \\
\text { Cynonycteris. } \\
\text { Cynopterus. } \\
\text { Rhinolophus. } \\
\text { Phillorhina. } \\
\text { Mfgaderma. } \\
\text { Nycteris }\end{array}$ & $\begin{array}{l}\text { Scotophilus. } \\
\text { Miniopterus. } \\
\text { Taphozous. } \\
\text { Rhinopoma. } \\
\text { Nyctinomus. } \\
\text { Crocidura. } \\
\text { Acanthom 5s. } \\
\text { Rhizomys. } \\
\text { Hystrix. } \\
\text { Manis. }\end{array}$ & $\begin{array}{l}\text { Felis. } \\
\text { Canis. } \\
\text { Vespertilio. } \\
\text { Vesperugo. } \\
\text { Erinaceus. } \\
\text { Mus. } \\
\text { Dipus. } \\
\text { Meriones. } \\
\text { Sciurus. } \\
\text { Lepus. }\end{array}$ \\
\hline
\end{tabular}

The Southern Province.-The South African Prorince consists of only that small portion of the continent lying south of the Southern Tropic, and is bence situated wholly within the southern warm-temperate zone. In consequence of its configuration, its limited extension, and its geographical position in relation to Intertropical Africa, it could scarcely be expected to form more than an appendage of the intertropical zone, and such it proves really to be. Its area is equal to only about one-tenth of that of the Eastern Province, yet it has eight-ninths as many genera, fully two-thirds of which are common to the two. It hence presents to only a limited degree the features of a strictly temperate fauna, and these become prominent only over the narrow belt of country south of the mountain ranges forming the northern boundary of Cape Colony and Caffraria; but here even there is a strong invasion of essentially tropical forms.

In general facies it differs little zoölogically from the Eastern Province, of which it is merely a somewhat modified continuation. From its semi-temperate character it is less rich in Quadrumanes, but many other properly tropical types range nearly or quite to its southern bor- 
der. It has, however, about one-fourth more peculiar genera, divided about equally, and mainly between Carnivores and Rodents, four only being Antelopes, and one only (Chrysochloris) an Insectirore. Of the twenty-four genera common also to the Indian Region, one-third are Chiropters. The remaining genera are, with very few exceptions, such as occur also in the Eastern Province, only three or four being common to the Southern and Western Provinces that do not also occur in the Eastern.

Of the eighty-two genera below enumerated as occurring in the Southern Province, a considerable portion are restricted to its southern half, while many others extend only over its northern portions. A few others, while mainly restricted to this region, and eminently characteristic of it, also extend somewhat into the Eastern Province.

Genera of the South African Province.

\begin{tabular}{|c|c|c|c|c|}
\hline $\begin{array}{l}\text { Restricted to the } \\
\text { province. }\end{array}$ & \multicolumn{2}{|c|}{ Ranging into Tropical Africa. } & \multicolumn{2}{|c|}{ Occurring also in the Indian Region. } \\
\hline $\begin{array}{l}\text { Ariela. } \\
\text { Cynictis. } \\
\text { Suricata. } \\
\text { Proteles. } \\
\text { Megalotis. } \\
\text { Hydrogale. } \\
\text { Strepsiceros. } \\
\text { Antidorcas. } \\
\text { Scopophorus. } \\
\text { Pelea. } \\
\text { Chrysochloris. } \\
\text { Dendromys. } \\
\text { Malacothrix. } \\
\text { Mystromys. } \\
\text { Bathyergns. } \\
\text { Pedetes. } \\
\text { Petromys. }\end{array}$ & $\begin{array}{l}\text { Galago. } \\
\text { Athylax. } \\
\text { Ichnenmia. } \\
\text { Helogale. } \\
\text { Mungos. } \\
\text { Lycaon. } \\
\text { Zorilla. } \\
\text { Phacochœrus. } \\
\text { Giraffa. } \\
\text { Oreas. } \\
\text { Tragelaphus. } \\
\text { Damalis. } \\
\text { Alcelaphns. } \\
\text { Connochetes. } \\
\text { Kobus. } \\
\text { Żpyceros. } \\
\text { Calotragns. }\end{array}$ & $\begin{array}{l}\text { Cephalophus. } \\
\text { Eleotragus. } \\
\text { ZEgocerus. } \\
\text { Rhinaster. } \\
\text { Hyrax. } \\
\text { Dendrohyrax. } \\
\text { Macroscelides. } \\
\text { Steatomys. } \\
\text { Otomys. } \\
\text { Georychus. } \\
\text { Graphiurus. } \\
\text { Xerus. } \\
\text { Aulacodus. } \\
\text { Orycteropus. }\end{array}$ & $\begin{array}{l}\text { Cyanælurus. } \\
\text { Genetta. } \\
\text { Herpestes. } \\
\text { Calogale. } \\
\text { Mellivora. } \\
\text { Aonyx. } \\
\text { Hyæna. } \\
\text { Oryx. } \\
\text { Bubalus. } \\
\text { Gazella. } \\
\text { Asinus. } \\
\text { Elephas. } \\
\text { Cynonycteris. } \\
\text { Cynopterus. } \\
\text { Rhinolophus. } \\
\text { Phillorhina. } \\
\text { Nycteris. }\end{array}$ & $\begin{array}{l}\text { Miniopteris. } \\
\text { Scotophilus. } \\
\text { Taphozous. } \\
\text { Rhinopoma. } \\
\text { Crocidura. } \\
\text { Hystrix. } \\
\text { Manis. }\end{array}$ \\
\hline \multicolumn{5}{|c|}{ Wide-ranging. } \\
\hline $\begin{array}{l}\text { Felis. } \\
\text { Canis. }\end{array}$ & $\begin{array}{l}\text { Vespertilio. } \\
\text { Vesperugo. }\end{array}$ & $\begin{array}{l}\text { Erinaceus. } \\
\text { Mus. }\end{array}$ & $\begin{array}{l}\text { Meriones. } \\
\text { Dipus. }\end{array}$ & $\begin{array}{l}\text { Sciurus. } \\
\text { Lepus. }\end{array}$ \\
\hline
\end{tabular}

The Western Province.-As already stated, the Western Province differs greatly in respect to its physical characteristics from either of the other provinces of the African Region, and has, in consequence, a correspondingly specialized mammalian fanna. It resembles the Indian Region in its hot, damp climate and dense forests. And its fauna, though distinguished by many peculier genera, is also, in respect to its general facies, more like that of the Indian Region than is the fauna of any other portion of the African Region. It is similarly rich in the higher Quadrumanes and poor in Antelopes, while it shares with the 
Indian Region the possession of the Tragulidw. Its peculiar genera consist largely of Anthropoid Apes, found elsewhere only in India, but also includes several each of Carnivores Bats, and Rodents. It is preeminently the tropical province of the African Region. While it contains a smaller number of genera than either of the others, it has relatively a much larger number restricted to it, having eighteen peculiar genera out of a total number of seventy-five, while the Eastern Province, with ninety-one genera, has only twelve that are peculiar, and the Southern serenteen out of eighty-two.

Genera of the West African Province.

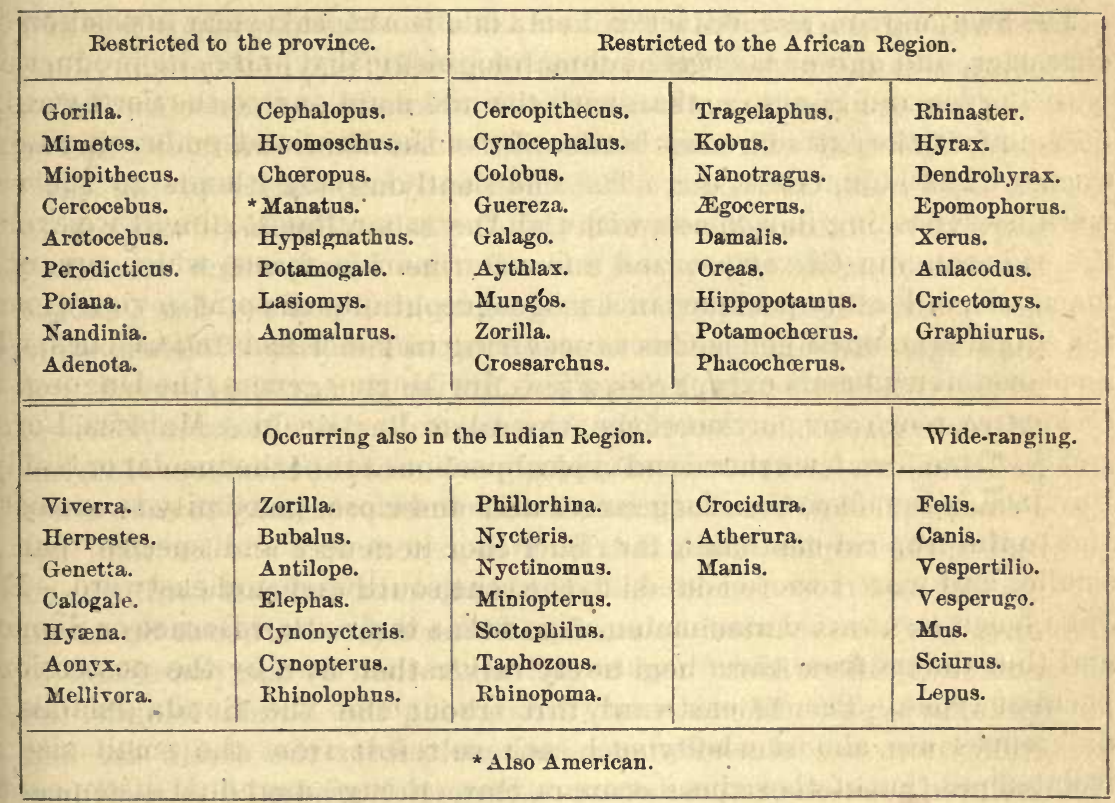

General Summary.

The number of genera represented in the African Region, and their range, is approximately as follows :-

\begin{tabular}{|c|c|c|c|}
\hline & $\begin{array}{c}\text { Eastern } \\
\text { Prorince. }\end{array}$ & $\begin{array}{l}\text { Southern } \\
\text { Province. }\end{array}$ & $\begin{array}{l}\text { Western } \\
\text { Province. }\end{array}$ \\
\hline Peculiar genera ............................................ & 12 & 17 & 18 \\
\hline $\begin{array}{l}\text { Restricted to the African Region, but occurring more or less } \\
\text { generally over two or more of the provinces ................. }\end{array}$ & 39 & 31 & 26 \\
\hline Occurring also in the Indian Region ....................... & 30 & 24 & 24 \\
\hline Wide-ranging ........................ & 10 & 10 & 7 \\
\hline Whole number .................................... & 91 & 82 & 75 \\
\hline
\end{tabular}

Indian Region.-The Indian Region may be defined, in general terms, as consisting of Intertropical Asia. It hence embraces Continental India 
from the Lower Indus to the Formosa Straits, the islands of the Indian Archipelago, as well as Formosa, the Philippines, Celebes, and all of the Sunda Islands. As far as the mammalia are concerned, only two primary subdivisions, or provinces, seem to be recognizable, the one a Northern, or Continental, the other a Southern, or Insular ("Malayan"). The former, or Continental, inclndes nearly all of the Hindostan and Indo. Chinese Peninsulas, excepting the extreme southern border of the latter and Malacca. These areas belong to the Insular Province, which comprises not only Borneo, Sumatra, and Java, but all of the above-named smaller islands to the eastward, except Formosa, which pertains to the Continental Province.

The long, narrow Malaccan Peninsula is almost insular in position and character, and agrees far better, climatologically, and in its productions, with Borneo and Sumatra, than with the mainland to the northward, as does, in fact, the extreme coast border of the mainland, embracing Lower Cochin China, Cambodia, etc. The small outlying islands to the eastward have nothing in common with the Australian Realm (if we exclude the wide-ranging Chiroptera and a few marine forms, which are, of all mammals, of least importance in a zoögeographical point of view), except the single Marsupial genus Cuscus occurring in Timor and Celebes, while no placental mammals except Sus, a few Muri :e genera, the Dugong, and Chiroptera, reach any portion of the Australian Realm. Malacca, Borneo, and Sumatra form the central and typical portion of the Insular or Malayan Province, being, from their larger area and closer proximity to each other and to the tropical mainland, far richer in genera and species than the smaller and more remote islauds to the south ward and eastward. Even Java has a less varied mammalian fauna than either Borneo or Sumatra, and thus differs from them negatively rather than by the possession of peculiar types. Thence eastward, throughout the Sunda Islands, the differences are almost wholly such as result from the small size and isolated position of these insular areas, through a gradual disappearance of many types present in the larger islands. The Philippines, for similar reasons, lack a large proportion of the genera found in the central portion of the province, while those they do possess, with few excep. tions, are such as are common to the larger areas. The few that are peculiar are Indian, rather than Australian, in their affinities.

Celebes and Timor contain one strictly Australian genus (Cuscus, represented by several species), but the few other mammals found there are either Indian or possess strictly Indian or Indo-African affinities. Hence I fail to see any good reason for assigning Celebes and all the smaller Sunda Islands to the Papuan Province, as Mr. Wallace and others hare done, but abundant evidence that such is not their real affinity. Even Mr. Wallace's own tables of distribution show at a glance the wide disassociation of these islands from the Papuan fauna, and their much nearer relation to the Indian, there being but one typically Australian or Papuan form represented in any of them, while none of the placental 
land mammals (excepting several subtropicopolitan genera of Bats and a few Muriform Rodents) are common to these islands and the Papuan. Australian division. The genera peculiar to the Philippines and Celebes (except Cuscus in the latter) have little if any more significance than the occurrence in Borneo and Sumatra of a few genera wholly restricted to one or the other of these last-named islands.

Ceylon and the adjoining low-coast portions of the Hindostan Penin. sula are more tropical in character than the plateau region to the northward. While a few genera are restricted to this suall area, and many more species occur here that are not found to the northward, the differentiation seems hardly great enough to warrant the separation of these areas as a region of co-ordinate rank with the "Malayan". It hence seems to me that Mr. Wallace has too emphatically recognized this comparatively unimportant difference in making it the basis of a distinct subregion (termed by him the "Ceylonese Subregion"). The only mam. malian genera peculiar to this division are a genus of Lemurs (Loris), three geuera (or subgenera) of Herpesince (Calictis, Taniogale, Onychogale), and a genus of Mice (Platacanthomys), each represented by a single species, and, so far as known, of limited distribution.

Continental Province.-As already intimated, the Continental Prov. ince includes nearly all of Hindostan and Indo-China, or the whole of the tropical portion of the Asiatic continent escepting. Malacea and the southern portions of Tenasserim, Siam, Cambodia, and Cochin China. It also extends into Southern China somewhat beyond the tropic (prob. ably to the divide between the Li-kiang and Yang-tse-kiang Rirers), and also to the southern slope of the Himalayas.*

The plains of the Upper Indus appear, however, to belong to the Temperate Region to the north ward, as does probably most of the country northwest of Delhi. The greater part of the interior of the Mindostan Peuinsula has a less tropical character and a less varied fauna than Bengal, Assam, and Burmah, situated under the same parallels. I cannot agree, however, with Messrs. Blyth, Blandford, and von Pelzeln, $\uparrow$

* "On the southern slope of the Himalayas there is everywhere, until it has been cleared, luxuriant forest up to at least 12,000 feet above the sea, inhabited by a fauna which extends, without any great change of generic forms, throughout the Malay Peninsula and into the hill tracts of some at least of the Malay Islands."-BLANDFord, Proc. Zoöl. Soc. Lond., 1876, p. 632.

† Mr. Blyth makes "Hindostân proper, or the plains of Upper Iudia east and south of the North West desert; Dukhun, or tableland of the Peninsula of India, and the intervening territory, inclusive of the Vindhaian ghatts; Coromandel Coast and low northeru half of Ceylon". a subregion of his "Ethiopian Region" (Natare, vol. iii, p. 428). Mr. Blandford holds that the "hills of Southern India with the Malabar Coast and Southern Ceylon form a province of the Malay region, whilst the greater portion of the Indian peninsula is African in its affinities" (Proc. Zoöl. Soc. Lond., 1876, p. 632). Von Pelzeln considers India proper, from the Lower Brahmaputra River westward, a distinct primary region, which he calls the "hindostanische Region". His "malayische Region" hence consists of Warm-temperate and Tropical Asia, minus the Hindostan Peninsula, to which he adds the Philippines, Borneo, Bali, Java, and Sumatra. It includes China as far as the Yang-tse-kiang River, and the Himalayan plateau from 
that the larger part of Hindostan should be joined to the African Region rather than the Indian; since only a very few African genera occur here that do not also range far to the eastward, or almost throughout the Indian Region. According to von Pelzeln,* about one-third of the genera of the "hindostanischen Fauna" are peculiar to it, while it shares almost another third with Indo.China. The remaining third (fourteen genera) are common to the African Region, but all except four of them occur also more or less generally over the Indian Region. Of these, two (Hyona and "Ratelus" = Mellivora) scarcely reach the limits of the Indian Region as here defined. Among the genera given by him as peculiar are, however, several that range beyond the Indian Peninsula.

There is more reason for Mr. Wallace's separation of the Hindostan Peninsula from the Indo-Chinese portion of the Indian Region, and its subdivision into two "subregions"-a northern "Hindostan Subregion" and a southern "Ceylonese Subregion". As already shown, the latter has a number of peculiar forms, while three or four genera are also peculiar to the Hindostan Peninsula at large. But the scale of division that would make the Hindostan Peninsula separable into two subregions would also require a somewhat similar subdirision of Indo-China, making four divisions of what I here term the Continental Province. While these divisions would have some natural basis, they are too detailed to come into the category of divisions for which I adopt the term "pror. ince".

Continental Province.-The Continental Province, with the limitations here assumed, is nearly equivalent to Mr. Wallace's three "subregions", termed respectively "Hindostan", "Ceylonese", and "Indo-Chinese". Of about ninety-four genera represented in it, about two-thirds have a pretty general range throughout the province, while only about oneeighth are limited to the Hindostanese portion, including those already named as almost peculiar to Ceylon and the low coast region east of the Eastern Ghâts. Excluding about a dozen that range over at least half the surface of the globe, one-third of the remainder (more than onefourth of the whole) are common to the African Region; more than onehalf (almost one-half of the whole) are restricted to the Indian Region and a little more than one-fifth (about one-eighth of all) are peculiar to the province. This shows, as already noted in discussing the fauna

Burmah, Assam, and Bengal to the Kuenluen Mountains, thus embracing Nepal, Butan, and Thibet. It is divided into five subregions, the two northernmost of which belong mainly to the North Temperate Realm. (Festschrift z. Feier des fünfundzwanzigjührigen Bestehens d. K.-K. Zool.-Bot. Gesells. in Wien, 1876, pp. 53-74 u. Karte.) The fauna of the Thibetan plateau, as claimed by Mr. Blandford, being boreal and alpine, aud having almost nothing in common with the tropical region to the southward, the artificial character of von Pelzeln's "subregions" is shown by his assuming the Yangtse-kiang River to be a uatural bonndary between two primary regions, and his separation of Malacca from Sumatra and Borneo to form a part of his "hinter-indische Unterabtheilung", which thus consists of the whole of the Indo-Chinese Peninsala down to the very southern extremity of Malacca!

* Verhandl. d. K.-K. Zool.-Bot. Gesells. in Wien, xхr. Bd., p. 57, 1875. 
of the Indo-African Realm, how strong an affinity exists between the African and Indian Regions, two-fifths of all the genera of the Indian Region which have an extralimital range occurring also in the African Region. The close affinity of the two provinces of the Indian Region is shown by the fact that two-thirds of the peculiar Indian genera found in the Northern or Continental division range also into the Southern or Insular. As will be shown later, the Insular Province is the more highly specialized of the two divistons.

Genera of the Continental Province.

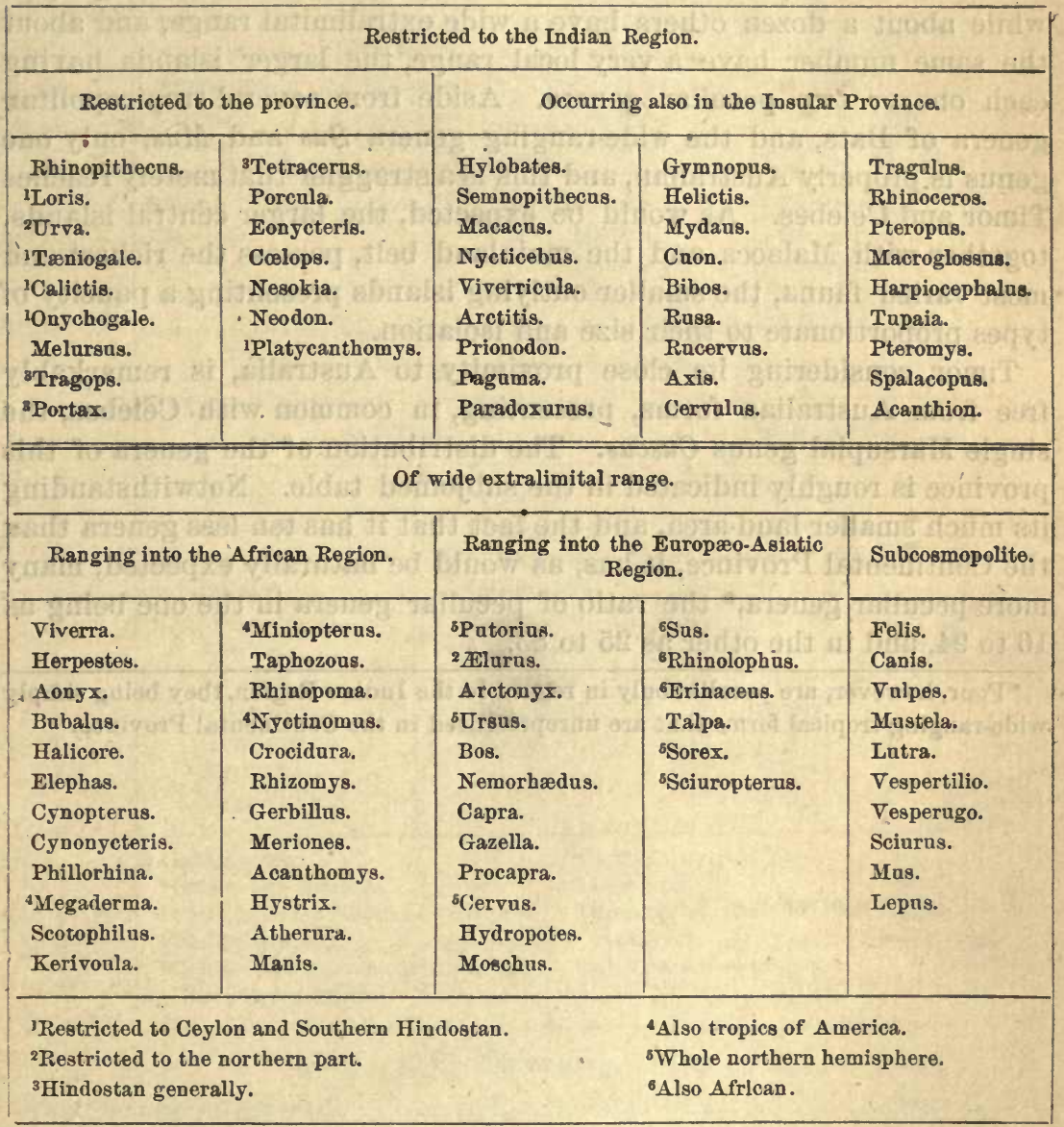

Summary.

Restricted to the Indian Region.................................. 43

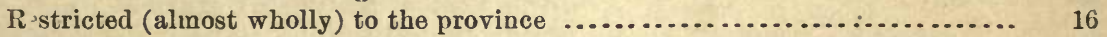

Other genera ranging over most of the Indian Region and restricted to it ...... 27

Common to the African Region .................................. 28

Common to portions of the Europæo-Asiatic Region ................... 34

Ranging over most of the northern hemisphere $\ldots . . \ldots \ldots \ldots \ldots \ldots \ldots \ldots \ldots . . .17$

Nearly cosmopolite .............................................. 10

Restricted to Southern Hindostan and Ceylon........................... 5

Bull. iv. No. $2-4$ 
Insular or "Malayan" Province.-The northern boundary of the Insular Province is not at present easily determinable, but it is quite evident that, as already stated, the southern maritime portions of Indo-China belong here rather than with the northern division of the Indian Region. To the southward and eastward it embraces, as already explained, the Sunda Islands, the Philippines, and Celebes. Of the eighty-three genera occurring in it, twenty-five, or nearly one-fourth, are peculiar, while tweuty-seven others do not range beyond the Iudian Province. Twenty of the remuinder are properly Indo-African genera, while about a dozen others have a wide extralimital range, and about the same number have a very local range, the larger islands having each one or two peculiar genera. Aside trom several tropicopolitan genera of Bats, and the wide-ranging genera Sus and Mus, only one genus is properly Australian, and this is a straggler that merely reaches Timor and Celebes. As would be expected, the larger central islands, together with Malacca and the mainland belt, possess the richest and most varied fauna, the smaller outlying islands presenting a paucity of types proportionate to their size and isolation.

Timor, considering its close proximity to Australia, is remarkably free from Australian forms, presenting, in common with Celebes, the single Marsupial genus Cuscus. The distribution of the genera of this province is roughly indicated in the subjoined table. Notwithstanding its much smaller land-area, and the fact that it has ten less genera than the Continental Province, it has, as would be naturally expected, many more peculiar genera,* the ratio of peculiar genera in the one being as 16 to 94 , and in the other as 25 to 83 .

* Four, however, are peculiar only in regard to the Indian Region, they being simply wide-ranging tropical forms that are unrepresented in the Continental Province. 
Genera of the Insular Province.

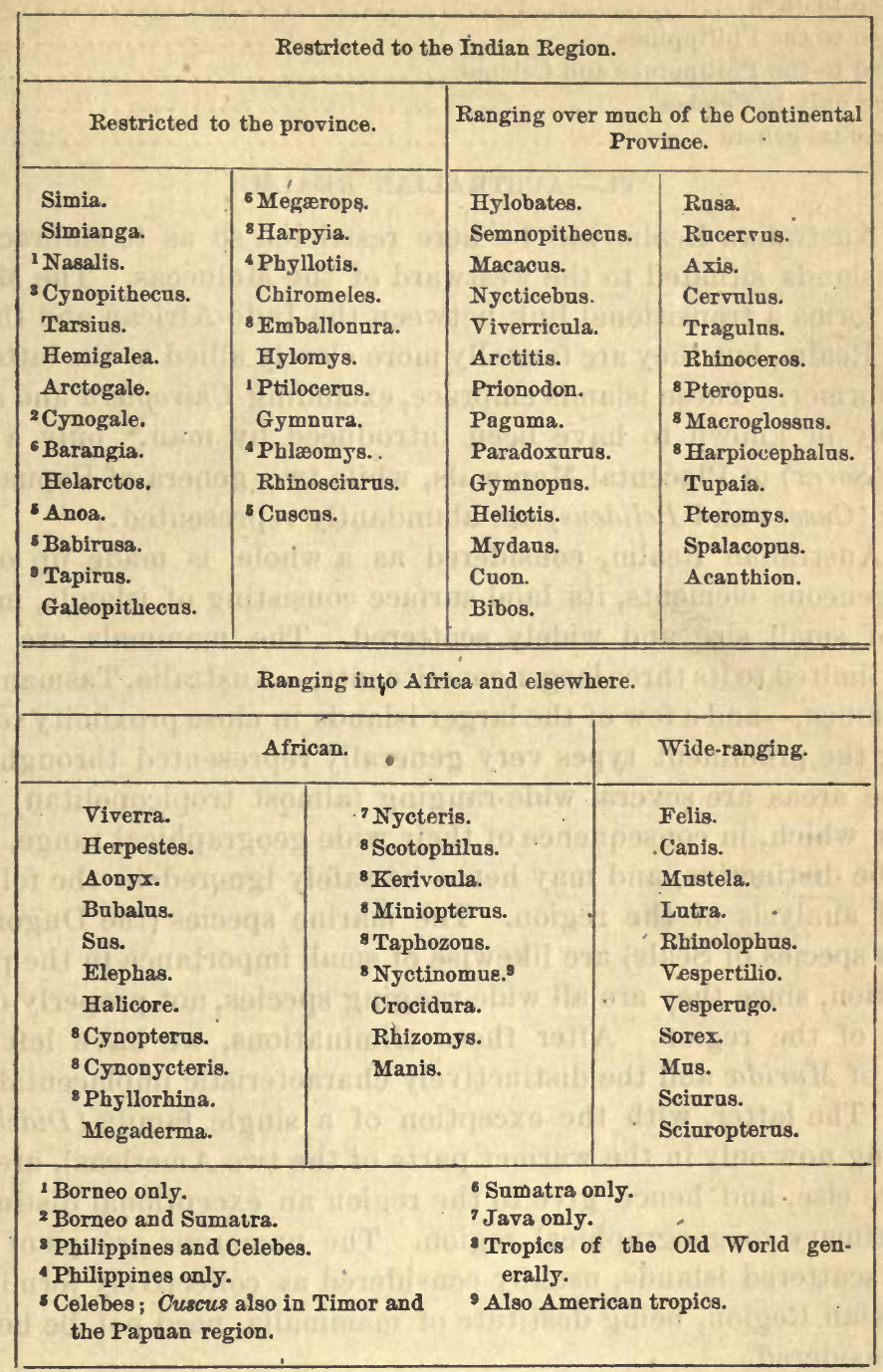

Summary.

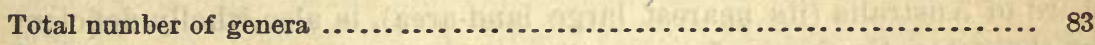

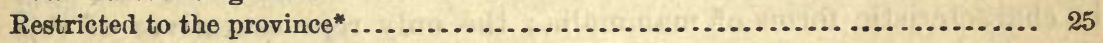

Restricted to the Indian Region .................................. 52

Found outside of the Indian Region in the African only .................. 20

Common to the African and Indian Regions ........................... 29

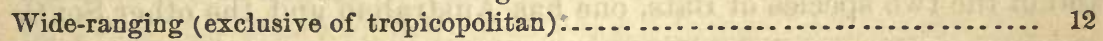

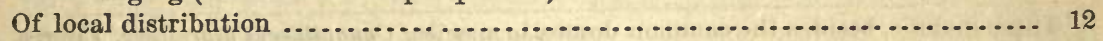

Restricted to Borneo ............................................ 2

Restricted to Borneo and Sumatra.................................... 1

* Exclusive of several tropicopolitan genera not occurring elsewhere in the Indian Region. 
Restricted to Sumatra ........................................ 2

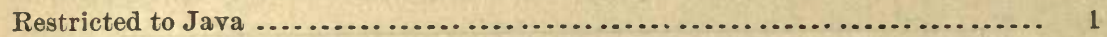

Restricted to the Philippines ........................................ 2

Restricted to the Philippines and Celebes ............................ 1

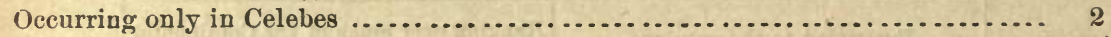

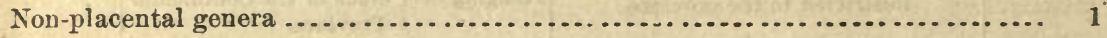

\section{VI.-AUSTRALIAN REALM.}

The Australian Realm will be here restricted so as to embrace none of the islands situated to the westward of the Moluccas. The Molucca Group forms a transitional link between the Indo-African and the Australian Realm, but they are faunally more closely allied to the latter than to the former. These islands embrace, excluding Chiroptera and species probably or known to have been introduced by man,* only a single genus (Sorex) of Placental Mammals, while two genera of Papuan Marsupials (Cuscus and Belideus) are abundantly represented.

The Australian Realm, considered as a whole, is made up of very heterogeneous elements, its land-surface consisting of islands, many of them of small size and widely scattered. The mammals are almost wholly limited to its three larger constituents,-Australia, Tasmania, and New Guinea,-and a few of the larger islands in close proximity to them. Among the prominent types very generally represented throughout all of these areas are several wide-ranging (almost tropicopolitan) genera of Bats, which, in consequence of their wide geographical range, wholly fail to be distinctive, and may hence be safely ignored in the following general analysis of the region. The marine species (the Dugong and various species of Seals) are likewise of small importance in the present connection, since they are all wide-ranging species, not properly charac. teristic of the region. After these eliminations, we have left a few genera of Muridoe and the distinctively characteristic implacental mam. malia. The latter, with the exception of a single family (Didelphida, occurring now only in the warmer parts of the two Americas), are found nowhere else, and hence give to the region an exceptional distinctness as a primary zoögeographical region. The numerous groups of small, widely scattered islands, usually considered as collectively forming the Polynesian Region, being destitute of mammalia, need not be here further considered.

New Zealand, situated more than a thousand miles to the southeast. ward of Australia (its nearest large land-area), is also wholly deficient in characteristic forms of mammalia; the only representatives of this class, aside from Seals and Bats, being a Rodent, supposed, rather than certainly known, to be found there. The Seals are wide-ranging species, and of the two species of Bats, one has Australian and the other South

\footnotetext{
" These include, besides the common domestic species, Cynopithecus nigrescens, Viverra tangalunga, Babirusa alfurus, and Cervus hippelaphus var. moluccensis, considered by Mr. Wallace as "probably" or "almost certainly" introduced by man, since they are species "habitually domesticated and kept in confinement by the Malays"-Geogr. Dist. Anim., vol. i, p. 417.
} 
American affinities. Judged by other classes of animals, the fauna of New Zealand is Australian (or Australian and Polynesian), but is yet so specialized that the New Zealand islands must be recognized as forming a distinct and highly differentiated region (New Zealand Region) of the Australian Realm.

As regards mammalia (and the same is true of the fauna and flora considered collectively), Tasmania, Australia, and New Guinea have many features in common, fülly one-half of the genera (seven out of fourteen) of mammals occurring in Tasmania being represented not only throughout the greater part of Australia, but also in New Guinea.

Tasmania and New Guinea are less rich in mammalia than Australia, but this is obviously due to their insular character and small area. Tas. mania is scarcely more closely related to Southern Australia than New Guinea is to Northern Australia. Formerly, New Guinea was thought to be very distinct from Australia, but the recent exploration of the interior of New Guinea by MM. Beccari, d'Albertis, and Laglaize, has brought to light the existence there of many forms before supposed to be restricted to Australia and Tașmania. M. Alphonse Milne-Edwards, in a recent communication to the French Academy respecting some new species of mammalia discovered in New Guinea by M. Laglaize, in referring to the close relationship existing between the faunæ of New Guinea and Australia, thus observes:- "Plus on étudie la faune de la NourelleGuinée, plus on lui trouve de ressemblance avec celle de l'Australie, et les indications fournies par la répartition des espèces animales permet d'affir. mer qu'autrefois ces terres ne formaient qu'un seul grand continent. Déjà les résultats des voyages de circumnavigation entrepris dans la première moitié de ce siècle . . . avaient permis de soupçonner cette conformité d'origine; mais elle a été principalement mise en lumière à la suite des explorations de M. Wallace, de M. Beccari et de M. d'Albertis. Enfin les collections qui M. Laglaize a formées dans ces régions, ainsi que celles qui lui ont été remises par M. Bruijn et qui viennent d'arriver en France, fournissent des faits nouveaux qui accentuent encore les ressemblances entrevues."**

Formerly the Monotremes were supposed to be restricted to the sonthern half of Australia and Tasmania, but within the last tro or three years the existence of Tachyglossus in North Australia (latitude 210) has been established, and an allied species bas been discovererl in the mountains of New Guinea. M. A. Milne-Edwards has also just described a species of Dromicia from New Guinea, and also a species of Hapalotis, and Dr. Peters has recently added species of Phalangista, Choetocercus, and Hydromys, makiug six genera recently discorered in New Guinea that were previously known only from Australia and Tasmania.

So far as at present known, only three or four genera (Uromys, Den. drolagus, Dorcopis, and Myoctis) of mammals are peculiar to New Grinea and the small islands situated between New Guinea and Australia, and

* Compte-rendu, tom. $1 \times x \times v, 1079$, déc. $3,18 \%$. 
probably some of these will yet be found in Australia. One of these (Myoctis) has been thus far reported only from the Aru Islands. As Tasmania has two peculiar genera (Thylacinus and Sarcophilus), New Guinea, in view of its four or five times greater area, is in reality scarcely more specialized than is Tasmania, and is hence faunally as much a part of Australia as is the latter. As will be shown later, nearly as many of the genera occurring in Southern Australia have been found in New Guinea as in Tasmania. Scarcely two years ago Mr. Wallace stated that "as yet no other [referring to the genus Sus] nonmarsupial terrestrial mammal has been discovered [in "Papua, or the New Guinea Group"] except a Rat, described by Dr. Gray as Uromys aruensis, but about the locality of which there seems some doubt."* This genus has not only. now been established as occurring there, but four additional species of it have been described by Dr. Peters, who has also added a species of Hydromys, and Mr. Alston has added a species of Mus and M. A. Milne-Edwards a species of Hapalotis, in all seven species, belonging either to Australian genera or having decided Australian affinities.

Regions of the Australian Realm.-Accepting the Polynesian Islands as forming one region (the Polynesian), and New Zealand as constituting another (the New Zealand), we have left for detailed consideration only the larger land-masses, consisting of Tasmania, Australia, and New Guinea with its associated islands, forming the third or Australian. The close zoölogical affinity of Tasmania and Australia no one questions, and it has been already shown that New Guinea and Australia are almost equally inseparable. Although many genera range from Tasmania across Australia into New Guinea, this large area, embracing as it does nearly fifty degrees of latitude, falls naturally into.two well-marked subdivisions, the oue tropical the other temperate.t These

* Geogr. Distr. Anim., vol. i, pp. 409, 410.

t In 1871, in referring to the Australian Realm (Bull. Mns. Comp. Zoöl, vol. ii, p. 381), I said :- "It is divisible into a Temperate and a Tropical Region, the former embracing New Zealand and Australia." The latter portion of this statement was of course made without due consideration. As already stated, New Zealand has no intimate relationship with Australia, and should be treated as a separate and independent region of the Australian Realm. Mr. Wallace, in stating his "Objections to the System of Circumpolar Zones" (Geogr. Distr. Anim., vol. i, p. 67), has very naturally taken notice of this unfortunate slip, and cites it as evidence of the "erroneous results" that follow from the aduption of the principle of the "distribution of life in circumpolar zones". My "separation of New Zealand to unite it with the southern third of Australia" was certainly most thoroughly erroneous; but while, as Mr. Wallace says, the fauna of Australia, taken as a whole, is exceptionally homogeneous, I cannot agree with him that New Guinea, so far at least as its mammalian fauna is concerned, is "as sharply differentiated from Australia as any adjacent parts of the same primary zoölogical region can possibly be"-in other words, that it can be only arbitrarily joined with the uorthern portion of Australia. I freely admit that I was not only in error as regards New Zealaud, but also in respect to my division of the Australian continent, and I accept this portion of Mr. Wallace's criticism as fairly made. That the error was not one of "principle", but merely a wrong application of a principle, I think the text 
I consider, so closely are they related, rather as provinces than regious, and may be termed respectively the Papuan Province and the Australian Province. The former is situated almost wholly between the equator and the twentieth deg ree of south latitude. The latter embraces that portion of Australia south of this line, together with Tasmania. The boundary between the two regions can of course be drawn only approximately, but may be provisionally assumed as the vicinity of the isotherm of $70^{\circ} \mathrm{F}$.* The reason for uniting the northern portion of Australia with New Guinea as a part of the Papuan Province lies in the fact that not only so many of the mammalian genera are common to the two, but that these genera are absent from the more southern portions of Australia, where they are replaced by others wholly restricted to South Australia and Tasmania. Three-fourths of all the genera of Marsupials (excluding, of course, the American family Didelphidoe) are, so far as at present known, restricted to the Australian Province, as are sereral gen. era of Muridoe and the Ornithorhynchus. Of the remaining Marsupial genera, six only are limited to the Papuan Province.

The Papuan Province.-The Papuan Province embraces not only New Guinea, but the Molucca and Aru' Islands on the west and the Solomon

here following sufficiently shows. The principle I still hold as applying to Australia with the same force as elsewhere, only I make the division more to the northward, as a little more care would have led me to do originally. The York Peninsula, and most probably the whole northern coast region north of $20^{\circ} \mathrm{S}$. lat. (except the high arid interior), has certainly closer affinities, as regards mammals, with New Guinea than it has with any portion of South Australia. Of the strictly Papuan genera, only two out of nine are restricted to New Guinea, the rest being common to both North Australia and Papua. Of the other North Australian genera, about one-half occur generally througbout the continent, but the remainder are essentially South Australian, represented by only stragglers in Northern Australia. On the other hand, more than twenty genera occurring in Sonthern Anstralia and Tasmania, are wholly unrepresented in the portion of Australia I here assign to the Papuan Region. In other words, we get the same wide fannal differences between the tropical and temperate portions of the Australian Realm that we get elsewhere under similar climatic conditions.

In the same connection, Mr. Wallace cites my separation of Temperate South Africa as a primary region as another instance of the misleading nature of the principle of the distribution of life in zones. This I have also seen fit to abandon (see anteà, p. 351) on a detailed re-examination of the subject, not because the principle is erroneous, but in consequence of certain peculiar geographical conditions, namely, the comparatively small area subject to a temperate climate and to its liraited extension into the temperate region. It is, in fact, wholly within the warm-temperate belt, and widens rapidly northward to abut very broadly against the tropical zone. Only a very small portion really comes under the influence of temperate contitions. Here we get, as usual, a temperate aspect in the fanna, and I still maintain my separation of South Africa as a faunal division, simply lowering its grade from a primary region to a "province" of the great IndoAfrican Realm, simply from the fact that the smallness of its area and warm-temperate, rather than temperate, conditions have prevented, as would he naturally expected, any great amount of differentiation.

* Mr. E. Blyth, in a paper (Nature, vol. iii, p. 428, issue of March 30,1871) published almost simultaneously with my own cited in the last foot-note, included-a portion of Northern Australia in his "Papuan Sub-region", namels, "York Peninsula and eastern half of Queeusland (as far as the dividing range), on the main land of Austaalia". 
Group on the east, as well as the most northerly portion of Australia, including the York Peninsula, and probably the whole northern coast region, or that portion of Australia north of the Southern Tropic, except the elevated arid interior. Of the twenty-seven genera (exclusive of Chiroptera and marine species) represented in the Papuan Province, ten are not found elsewhere in the Australian Realm. Three of these (Sus, Sorex, found only in the Moluccas, and Mus) have a wide Indo-African range; four (Uromys, Dendrolagus, Dorcopsis, and Myoctis) are found only in New Guinea and the Aru Islands; and one (Dactylospila) in the Aru Islands and the York Peninsula.

The serenteen remaining genera belong more properly to the Australian Province, or perhaps to Australia at large. Many of them, while numerous in species, have here (like Halmaturus, Antechinus, Podabrus, Mus, Hapalotis, etc.) only straggling representatives, but are numerously represented in the temperate region to the southward. The distribution of the genera is approximately indicated in the subjoined table.

\section{Genera of the Papuan Province.}

[Notk.-The New Guinea representatives of the genera Hapalotis, Phalangista, and Tachyglossus have recently been separated from their Australian affines as distinct subgenera. Babirusa is also re. ported from Bouru, but as probably introdnced from Celebes.]

\begin{tabular}{|c|c|c|c|c|}
\hline $\begin{array}{l}\text { Restricted to New } \\
\text { Guinea and } \\
\text { neighboring } \\
\text { islands. }\end{array}$ & $\begin{array}{l}\text { Restricted to New } \\
\text { Guinea and } \\
\text { North Anstralia. }\end{array}$ & \multicolumn{3}{|c|}{ Also ranging over most of the Australian Rogion. } \\
\hline $\begin{array}{l}\text { Sus. }{ }^{1} \\
\text { Sorex. }{ }^{2} \\
\text { Uromys. } \\
\text { Dendrolagus. } \\
\text { Dorcopsis. } \\
\text { Myœctis. }\end{array}$ & $\begin{array}{l}\text { Acanthomys. }{ }^{3} \\
\text { Phascogale. } \\
\text { Cuscus. } \\
\text { Dactylopsila. }^{5}\end{array}$ & $\begin{array}{l}\text { * Mus. } \\
\text { * Hapalotis. }{ }^{6} \\
\text { * Hydromys. }{ }^{6} \\
\text { Dasyurns. }{ }^{6} \\
\text { * Antechinus. }{ }^{6} \\
\text { * Chætocercus. }\end{array}$ & $\begin{array}{l}\text { Halmaturus. }{ }^{6} \text {. } \\
\text { * Perameles. }{ }^{6} \\
\text { Macropus. }{ }^{6} \\
\text { Osphranter. } \\
\text { Onychogalea. } \\
\text { Largorchestes. }\end{array}$ & $\begin{array}{l}\text { Petrogale. } \\
\text { *Phalangista. } \\
\text { * Belidens. } \\
\text { * Dromicia. } \\
\text { * Tachyglossus. }\end{array}$ \\
\hline $\begin{array}{l}\text { 'New Guinea onl } \\
{ }^{2} \text { Moluccas only. } \\
{ }^{3} \text { North Australia } \\
{ }^{4} \text { Also Celebes, Ti }\end{array}$ & $\begin{array}{l}\text { only. } \\
\text { mor, and Molnceas. }\end{array}$ & ming in New & $\begin{array}{l}\text { nds, New Gi } \\
\text { ula }(\text { Krefft }) \text {. } \\
\text { arge South } \\
\text { epresented i } \\
\text { uinea. }\end{array}$ & $\begin{array}{l}\text { Peters), and } \\
\text { lian genera, } \\
\text { th Australia }\end{array}$ \\
\hline
\end{tabular}

\section{Summary.}

Total number of genera .......................................... 27

Restricted to the region (including, however, two Indo-African genera) ........ 10

Represented in New Guinea....................................... 18

Ranging also over the Australian Region ............................ 16

Restricted to New Guinea and neighboring islands (exclusive of two Indo-African

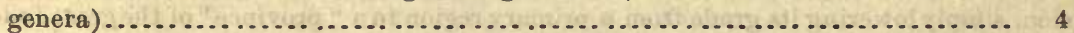

Common to unly New Guinea and North Australia ......................... 4

Genera properly belonging to the Australian Region, but sparingly represented in the Papuan Region ................................................ 10

Distinctively characteristic of the Papuan Region, about.................. 15

Australian Province.-The Australian Province, embracing Tasmania and all of Australia south of about the southern isotherın of $70^{\circ} \mathrm{F}$., 
contains not less than fifteen to eighteen genera, out of a total number of thirty-four that are restricted to this region, while of the remainder much more than one-half have their chief development here. One-third of the whole are represented in Tasmania, and nearly onefourth range into New Guinea. Two only are peculiar to Tasmania. The distribution of the genera is shown somewhat in detail in the subjoined table.

In this connection it may be added that the close affinity of the Papuan fauna with that of Australia is sufficiently evinced by the fact that of the thirty-four genera represented in South Australia nine range into New Guinea-nearly as many as occur in Tasmania!

Genera of the Austratian Province.

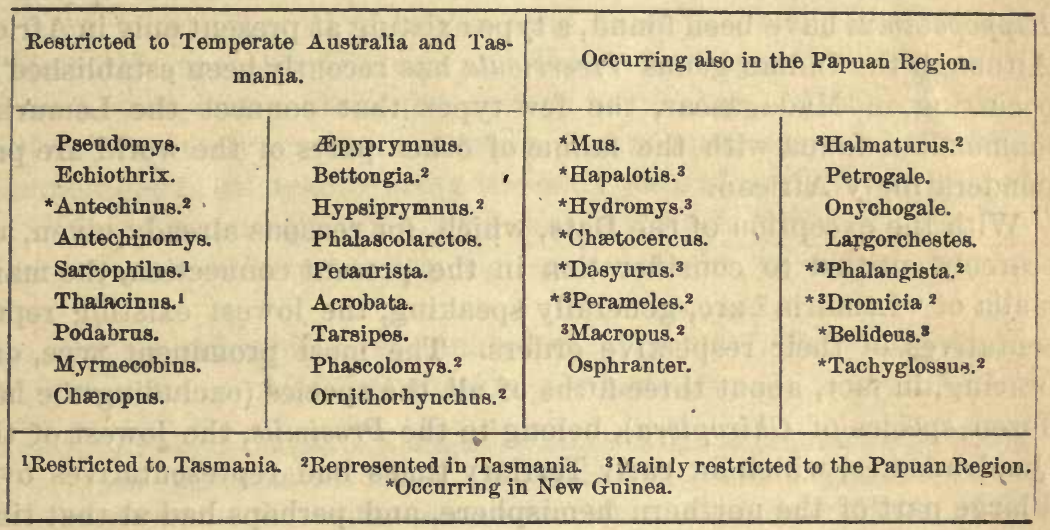

Summary.

Total number of genera .......................................... 34

Restricted to the Australian Region ................................. 18

Occurring also in the Papuau Region ................................. 16

Represented in Tasmania ........................................... 12

Represented in New Guinea ....................................... 10

Restricted to Tasmania......................................... 2

\section{VII.-LEMURIAN REALM.}

As was long since claimed by Dr. Sclater,* Madagascar is faunally so distinct from every other ontological division of the globe as to be entitled to the rank of a primary zoögeographical region. With it, as is generally admitted, should be, associated the Mascarene Islands. The very few maminals indigenous to these islands are decidedly Madagascarene in their affinities, as are the birds and other land animals. While the Lemurian fauna shows decided African affinities, it is second only to the Australian in its degree of specialization. It departs most strikingly from all other regious in what it lacks, through the absence of all Carnivores save one peculiar family (Cryptoproctida),

\footnotetext{
* Quarterly Journ. Sci., vol. i, April, 1864, pp. 213-219.
} 
represented by a single species, and four peculiar genera of the family Viverrida; of all Ruminants and Proboscidians; all Pachyderms except a single African genus of Suida; and all Rodents except a few species of Muridoe. The Insectivores are almost wholly represented by one or two species of Crocidura, and a family, embracing several genera, not found elsewhere, save a single genus in the West Indies. Four families of Bats occur, but are represented, with one exception, each by a single species. They belong to groups of semi-cosmopolitan range, and owing also to the exceptional means of dispersal possessed by the Chirnptera, have little weight in determining the affinities of the fauna. The Quadrumanes are represented only by the Prosimia, of which three-fourths of all the species occur here, while about four-fitths of the remainder are African. The remains of an extinct species of Hippopotamus Lare been found, a type existing at present only in Africa. Although the Indian genus Viverricula has recently been established as occurring in Madagascar, the few types that connect the Lemurian mammalian fauna with the faunæ of other parts of the world are prepouderatingly African.

With the exceptiqn of the Bats, which, for reasons already given, are scarcely entitled to consideration in the present connection, the mammalia of "Lemuria" are, generally speaking, the lowest existing representatives of their respective orders. The most prominent type, einbracing, in fact, about three-fifths of all the species (excluding the half dozen species of Chiroptera), belong to the Prosimioe, the lowest of the Quadrumanes, which in early Tertiary times bad representatives over a large part of the northern hemisphere, and perhaps had at that time a nearly cosmopolitan distribution. The Carnivores are likewise allied to early types of the Viverridoe, which formerly had a much wider range than at present; and the Insectivores are also of low forms, and allied to early types. These facts seem, at first sight, to lend support to the hypothesis, first advanced by Dr. Sclater, that Madagascar and the Mascarene Islands are but remnants of a former extensive land-area that possibly had connection with America as well as India, and embraced portions of Africa. The supposed former relationship with America is indicated perhaps not so much by the presence of Solenodon in the West Indies, and of American forms of Serpents, Lizards, and Insects in Madagascar, as by the abundant occurrence of Lemuroid remains in the North American Eocene. Since, however, these early Lemuroid forms appear not to bave been true Lemurs, but a more generalized type, having affinities also with the Carnivores and Insectivores, and since they occurred also in Europe, aud probably in Asia (for recent palæontological discoveries in our American Tertiaries show that much may be expected from future explorations elsewhere), it is possible that the explanation of the present distribution of the Prosimice needs not the supposition of the existence of any very extensive land-area that has since disappeared: in other words, that the African and Madagascarene Lemuridoe may. 
have reached their present homes by migration from the northward (leaving a remnant in India), at a time when North America and Asia formed a continuous land-area, just as there is good reason for believing that the greater part of the present faunæ of India, Southern Europe, and Africa are a comparatively recent immigration from the north ward; that Madagascar derived, at a comparatively early period, its existing fauna from Africa, as Mr. Wallace believes to have been the fact; and, finally, that at a time antedating the appearance of the present African fauna, Madagascar was actually united to the African continent.* America is now not only currently considered to be the "Old World" geologically, but it seems probable, as has recently been suggested, $\uparrow$ that the Equine, Tapiroid, Rhinoceroid, Cameloid, Suilline, and Cervine forms, the Prosimice, and possibly the Proboscidians, Marsupials, and Edentates, were either first developed in America, or had their origin there in early generalized forms, and have since spread to the more recently formed continents of the eastern hemisphere. Many of them, as well as other early, generalized types, are known to have had a nearly contemporaneons existence during the early part of the Tertiary period both in America and Europe. This certainly lends probability to Mr. Wallace's hypothesis respecting the origin of the present Lemurian fauna.

The families and genera represented in "Lemuria", their faunal alliances, and areas of chief distribution, are as follows :-

LenurID \&.-Chiefly developed in Madagascar, but occurring in Tropical Africa, Southern-India, and the Malay Archipelago. Represented by about twelve genera and about fifty species, three-fifths of which are peculiar to Madagascar, and three-fourths of the remainder to Africa. Genera:-Indris, Propithecus, Lemur, Hapalemur, Microcebus, Lepilemur, Chirogaleus.

Daubentonuda.-Peculiar to Madagascar and represented hy a singlo species-Dau. bentonia (=Chiromys) madagascariensis.

CRYPTOPROCTIDE.-One species (Cryptoprocta ferox), found only in Madagascar.

VIVERRIDAs.-Warmer parts of As:a, the Malayan Islands, and Africa. Represented in Madagascar by several peculiar genera and the Indian genus Viverricula. Genera:-Fossa, Galidia, Galidictis, Viverricula. Species of the African genus Herpestes also reported.

EUPLERID A.-Peculiar to Madagascar, and embracing the single genus Eupleres.

SuID s.--Eastern henisphere generally. Represented in Madagascar by species of the African genus Potamochorus.

HipPopotamide.-African. Represented in Madagascar by the remains of a species believed to have but recently become extinct.

PTERopIDs.-The tropics everywhere, except Tropical America. Represented in Madagascar and the Mascarene Islands by two species of the Indian and Australian genns Pteropus.

RHINOLOPHIDE.-Warmer parts of the eastern hemisphere. Represented in "Lemuria" by species of Rhinolophus.

* Geogr. Distr. Anim., vol. i, p. 273; Nature, vol. xvi (Oct. 25, 1877), p. 548.

t See especially Prof. O. C. Marsh's address, on "the Introduction and Succession of Vertebrate Life in America", delivered before the Nashville meeting of the American Association for the Advancement of Science, Aug. 30, 1877. 
VESPERTHIONIDA.-Cosmopolitan. Represented by the cosmopolite genus Vespertilio. LMBaLlonukIDA.-Warmer parts of the world. Represented by the genus Taphozous. Centetide.-Confined to Madagascar except one genus (Solenodon) in the West Indies. Represented in Madagascar by nearly a dozen species. Genera:-Centetes, Hemicentetes, Ericulus, Oryzorictes, Echinops.

SORICIDE.-The whole world, except South America and Australia. Represented in Madagascar by one or two species of Crocidura, a genus found in Africa, and the warmer parts of the eastern hemispbere generally.

MURIDs.-Cosmopolitan. Represented by several geuera of African affinities, namely, Nesomys, Brachytarsomys, Hypogeomys.

\section{VIII.-ANTAROTIO REALM.}

The Antarctic Realm is geographically almost wholly oceanic, and its fauna hence consists almost exclusively of marine or pelagic species. It necessarily embraces not only the Antarctic Zone, but a large part of the cold south-temperate, since very few of its characteristic species are wholly restricted to the Antarctic waters. It will hence include not only the few small groups of Antarctic Islands, but also Tierra del Fuego and the Falkland Islands, and perhaps also the extreme southern shores of South America, while some of its characteristic forms also extend to New Zealand, and even Australia and the Cape of Good Hope. The only mammals that can be considered as strictly characteristic of this region are Pinnipeds and Cetaceans, of which several genera of each are almost wholly restricted to it. A "South Frigid", "Antarctic", or "South Cireumpolar" "Zone", "Region", or "Realm", has been recognized by various writers for the marine invertebrates, and, by von Pelzeln for birds, with limitations much as here assigned. While the number of species peculiar to it is small, it is large relatively to the whole number represented, especially in the colder latitudes. There is, of course, a broad belt along its northern border of a transitional character, where Antarctic types overlap the range of groups characteristic of south-temperate latitudes.

One of the most important features of the South Circumpolar or Antarctic Realm is the resemblance of its life to the marine life of the Arctic or North Circumpolar Realm. While perhaps in no case are the species identical, the genera are frequently the same, not only among the mammalia, but among invertebrates. This is especially significant as regards the mammalia, since the terrestrial mammals of the extreme north and extreme south present no such parallelism, but the utmost divergence. Among Pinnipeds, most of the genera are peculiar to either the northern or southern waters, but in several instances the genera of the two regions are strictly representative. Thus, Otaria and Arctocephalus of the Southern Seas are represented in the Northern by Eumetopias and Callorhinus. Zalophus and Macrorhinus are both Northern and Southern. Stenorhynchus, Lobodon, Leptonyx, and Ommatophoca are etrictly Southern, while Phoca, Halichcerus, Erignathus, Cystophora, Monachus, and one or two others, are strictly Northeru, as are also the Walruses. The Mysticete, or Baleen Whales, among Cetaceans, have 
a somewhat similar distribution. While a few genera are restricted respectively to the Northern and Southern waters, the larger unmber are common to both, though represented by different species in the two regions, while they are (in some cases at least) absent from the interrening tropical seas. A large proportion of the Denticete, or Toothed Whales (Dolphins, Porpoises, Rorquals, etc)., are either limited to the warmer seas or have there their chief development, quite a number of genera being peculiar to the tropics. Others, however, like Monodon, are eminently boreal, while others, like Beluga, are common to the colder waters both north and south of the tropics. In most cases, howerer, we know as yet too little respecting the range of the difierent species and genera of Cetacea to be able to make much use of them in determining questions in geographical zoölogy.

This similarity between the marine life of the Arctic and Antaretic Regions evidently indicates that the forms commou to the two had a common origin, and, at some former period, a continuous, probably circumtropical, distribution, and that on the increase of temperature in the intertropical regions, through well-known geological causes, they sought the more compatible cooler waters toward the poles. The similarity of the Arctic and Antarctic marine life is also a feature that sharply differentiates the fauna of the South Circumpolar Realm from that of the South Temperate and Tropical Zones.

\section{III.-GENERAL SUMMARY.}

As. stated at the beginning of the present paper, one of the chief topics here proposed for discussion was the influences and laws which govern the distribution of life,-whether it is or is not co-ordinated with climatic zones, and governed in a large degree by climatic conditions, and especially by temperature. In fact, so generally is temperature recognized by the leading writers on the distribution of marine life that it seems superfluous to reiterate or emphasize this principle. That the zones of life should be perhaps a little less obvious over the land-areas,-in consequence of the diversity of contour resulting from differences of elevation, and the interruptions and exceptional conditions due to mountain chains and high plateaus,-than over the oceanic expanses, is naturally to be expected. That there is, however, a similar correspondence between climatic belts and the zones of life seems to me abundantly evident. As has been already shown, the broader or primary zones are, first, an Aretic or North Circumpolar Zone, embracing the aretic, subarctic, and colder temperate latitudes of the northern hemisphere, throughout the whole of which area there is a marked homogeneity of mammalian life, as well as of animal and vegetable life in general; secondly, that below this there is a broad belt of life, which, in its general facies, is distinctive of the temperate and warm-temperate latitudes, and that these two zones of life are far more closely related inter se than with the life of the intertropical regions, with which regions they may be collectively con. trasted, and together receive the appropriate name of "Arctogcea"; 
thirdly, it has been shown, so far as the northern hemisphere is concerned, that the life of the tropical and temperate regions of the same continent is more widely different than is the life of corresponding portions of the temperate and colder parts of the (so-called) Old World and the New; fourthly, that the life of Tropical America has very little in common with that of the tropical portions of Asia and Africa; fifthly, that the life of the South Temperate Zone presents a facies distinct from that of the tropies, and bas still less in common with that of the North Temperate Zone; sixthly, that Australasia is so highly differentiated as to form a distinct primary region, having little in common with other lands, even with those of contiguous regions, or those having a similar geographical position; seventhly, that Madagascar and its contiguous islands, while to some extent African in affinity, form also a highly specialized region; lastly, that the antarctic and cold south-temperate oceanic regions are recognizable as a primary region, characterized by a peculiar general facies of life that more strongly recalls that of the. corresponding portions of the northern bemisphere than of any other portion of the earth. It has been further shown that the Australian Realm is divisible into temperate and tropical portions, and also that the land surface is separable into zones of even still narrower limits, corresponding in a general way with those recognized by Dana for marine life.

The almost total absence of identical genera, or even of families, excepting such as are essentially cosmopolitan, in the American and Old World tropics, as well as the distinctness of the Lemurian Realm, and the almost total isolation of the Australian Realm, evidently require for their explanation other causes than merely the existing climates. The geological history of these land-areas and their faunæ must be of course considered in order to understand their present relationships. As the northern hemisphere at present most clearly shows, nearly continuous land surface and similarity of climatic conditions implies identity of fauna, while isolation, especially when joined with diverse climatic conditions, implies diversity of life, and a differentiation proportionate to the degree of isolation, and the length of time such isolation has existed; in other words, that the present want of affinity between the life of the Lemurian and Australian Realms and that of the rest of the world is due rather to their long geographical isolation than to present climatic conditions, and that we here find, for reasons perhaps not wholly apparent, the remnants of a somewhat primitire or early fauna that was formerly shared more largely by other areas than at present,-that these regions became isolated before the development of many of the bigher and now prevalent types of the larger and more diversified land-areas, and that here difterentiation has proceeded less rapidly and along fewer and narrower lines' than elsewhere; furthermore, that the present highly diversified fauna of the chief tropical areas, in comparison with the fauna of the north-circumpolar lands, is due in part to the southward migration, near the close of the Tertiary 
period, of forms adapted to a high temperature, and in part to the high rate of differentiation favored by tropical conditions of climate. Hence, given: 1. Arctic and cold-temperate conditions of climate, and we have a fauna only slightly or moderately diversified; 2. A moderate increase of temperature, giving warm-temperate conditions of climate, and we have the addition of many new types of life; 3 . A high increase of temperature, giving tropical conditions of climate, and we have a rapid multiplication of new forms and a maximum of differentiation. Again, given: 1. A long-continued continuity of land surface, and we have an essential identity of fauna; 2 . A divergence and partial isolation of land-areas, and we find a moderate but decided differentiation of faunæ; 3. A total isolation of land-areas, and we have a thorough and radical differentiation of faunæ, proportioned to the length of time the isolation has continued. Hence, the present diversity of life is correlated with two fundamental conditions: 1 . Continuity or isolation, past as well as present; of land surface; and, 2. Climatic conditions, as deter. mined mainly by temperature.*

In accordance with these principles, which rest on incontrovertible facts of distribution, it follows that the nearly united lands of the North . present a continnous, almost homogeneous, arctopolitan fauna; that farther southward, in the warmer temperate latitudes, we begin to find a marked differentiation on the two continents; that this differentiation is still further developed in the tropical continuations of these same land-areas, till an almost total want of resemblance is reached, except that there is what may be termed, in contrast with the more northern regions, a "tropical facies" common to the two. The small amount of land surface belonging to these primary land regions south of the tropics have no more in common (a few marine species excepted) than have these two tropical areas, but it is hardly possible for them to have much less. The Antarctic (mainly oceanic) region has a fauna strongly recalling the marine fauna of the Arctic, but has no resemblance to that of the intervening area.

The northern circumpolar lands may be looked upon as the base or centre from which have spread all the more recently developed forms of mammalian life, as it is still the bond that unites the whole. Of the few cosmopolitan types that in a manner bind together and connect the whole mammalian fauna of the globe (the Lemurian and Australian Realms in part excepted), nearly all have either their true home or be. long to groups that are mainly developed in the northern lands. A fer

* In illustration of the above, it may be added that the circumpolar lands north of the mean annual of $36^{\circ} \mathrm{F}$., or, in general terms, north of the fiftieth parallel, with approximately an area of about $12,500,000$ square miles, have representatives of about fifty-four genera of mammals ; Tropical America, with an approximate area of about $5,000,000$.square miles, has abont ninety genera; the Indo-African Realm, with an approximate area of about $15,000,000$ square miles, has aboụt two. hundred and fifty genera. Hence the tropical lands are four to five times richer in genera, in proportion to area, than those of the Cold-temperate and Arctic regions. 
have been pressed a little to the southward by the extreme rigor of an Arctic climate, but are still characteristic elements of all boreal faunas. The very few truly tropicopolitan mammalia are either Chiroptera, or marine, or at least aquatic, and have thus exceptional means of dispersal.

The primary regions and their subdivisions, recognized in the preceding pages, are enumerated in the subjoined schedule.

$$
\text { 1.-Primary divisions, or "Realms". }
$$

I. An 'Arctic, or North Cirdumpolar.

1I. A North Temperate, divided into two regions and eight provinces.

III. An American Tropionl, with three regions. (Provinces not characterized.)

IV. An INDO-AFRICAN, with two regions and five provinces.

V. A South American Temperate, with two provinces.

VI. An AUSTRALIAN, with three regions and two provinces.

VII. A Lemurian.

VIII. An ANTarctic or South Circumpolar.

\section{2.-Secondary divisions, or "Regions".}

II. North Temperate Realm : 1, American ; 2, Europæo-Asiatic.

III. American Tropical Realm: 1, Antillean; 2, Central American; 3 , Brazilian.

IV. Indo-African Realm : 1, African; 2, Indian.

VI. Australian Realm : 1, Australian (Australia, Tasmania, and New Guinea); 2, Polynesian; 3, New Zealand.

\section{3.-Divisions of third rank, or "Provinces".}

II, 1. American Region: $a$, Boreal*; $b$, Eastern; $c$, Middle; $d$, Western. II, 2. Europæo-Asiatic Region: $a$, European; $b$, Siberian; $c$, Mediterranean ; $d$, Manchurian.

IV, 1. African Region : $a$, Eastern; $b$, Western; $c$, Southern.

IV, 2. Indian Region : $a$, Continental ; $b$, Insular.

$\nabla$. South American Temperate Realm : $a$, Andean; $b$, Pampean.

VI, 1. Australian Region: $a$, Australian; $b$, Papuan.

*A "Boreal" province has not been distinctly recognized in the preceding pages as a division belonging to the same category as the other so-called or commonly recognized provinces, and is not at all recognized in the table of distribution given at $p$. 339. It is nearly equivalent to what is there implied by "Cold Temperate". I hope soon to be able, in a paper to be devoted especially to a consideration of the geographical distribution of North American mammals, to define and characterize it more definitely. 
ALLEN ON GEOGRAPHICAL DISTRIBUTION OF MAMMALS. 377

The relation of the different primary regions and their subdivions may be approximately indicated diagrammatically as follows:-

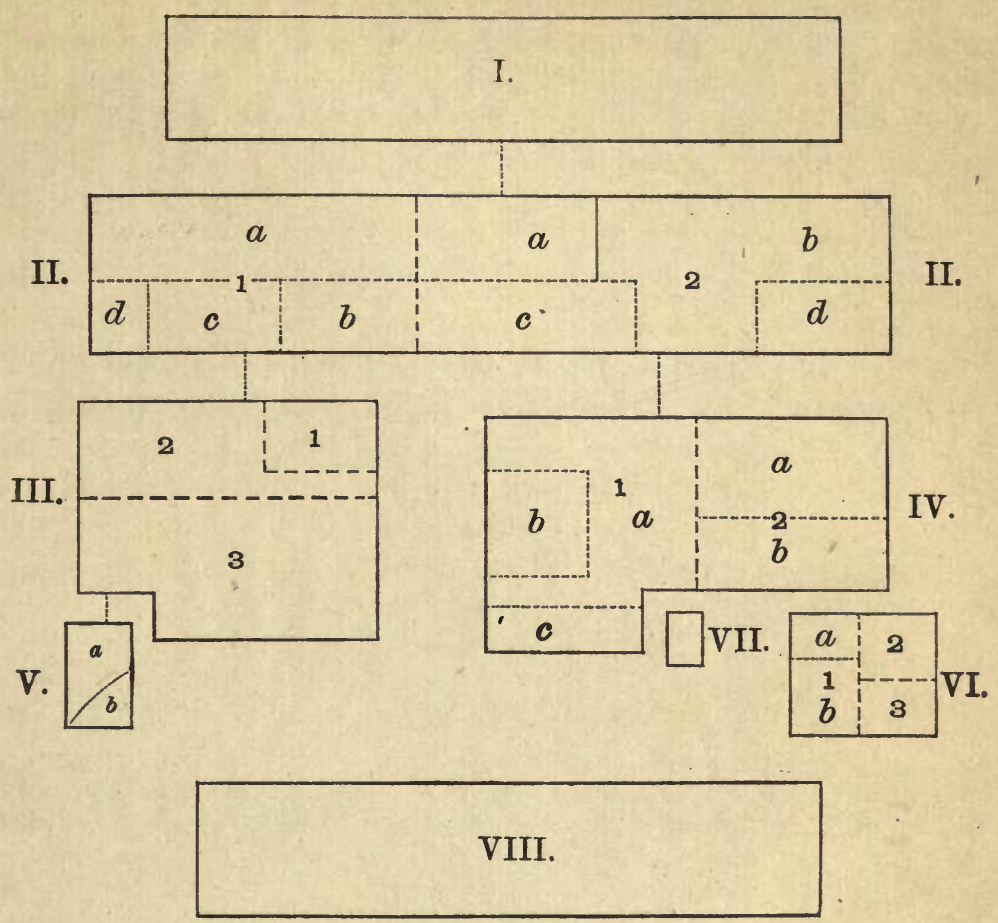

Bull. iv. No. $2 \longrightarrow 5$ 

DEPARTMENT OF THE INTERIOR. UNITED STATES GEOLOGICAL AND GEOGRAPHICAL SURVEY.

- F. V. HAYDEN, U. S. Geologist-in-Charge.

\section{SYNONYMATIC LIST}

OF THE

\section{AMERICAN SCIURI,}

OR

ARBOREAL SQUIRRELS.

BY

J. A. ALLEN.

EXTRACTED FROM THE BULLETIN OF THE SURVEY, VOL. IV, NO. 4. 
[From Bulletin U. S. Geol. and Geogr. Survey, Vol. IV, No. 4, p. 905, foot-note.]

*P.S. - Sciurus rufoniger, Pucheran. - Since the paper on Sciuri passed out of my hands I have received, through the kindness of Mr. E. R. Alston, one of the types of his Sciurus rufoniger, indorsed on the label, "Compared with Pucheran's type in Paris Museum. E. R. A. April, 1878." This specimen, as shown by the sexual organs, is a fully adult male, though scarcely five and a half inches long, and hence cannot be regarded as an immature example of $S$. deppei, the possibility of which is above suggested. In coloration it differs little from frequent examples of $S$. hoffmanni. The tail, however, is relatively much shorter, the size nearly one half less, and it has two upper premolars (Alston) instead of one. In this last feature, as well as in size, proportions, and coloration, it finds a near affine in $S$. pusillus. - J. A. A. November, 23, 1878.

[* Note. - The above was received too late for insertion in its proper place, the Bulletin having been worked to p. 887. - ED.] 


\section{ART. XXXVII.-SYNONYMATIC LIST OF THE AMERICAN SCIURI, OR ARBOREAL SQUIRRELS.}

By J. A. Allen.

Since the publication last year of my revision of the American Sciuri,* the "Neotropical" species of the group have been ably reviewed by Mr. E. R. Alston, $\nmid$ under unusually favorable circumstances. With his accustomed thoroughness, he has taken the trouble to seek out the types, so far as they are extant or accessible in sereral of the principal museums of Europe, of most of the species of former authors, and has thus been able to determine the character of many species so inadequately described, that in no other way could their proper allocation be satisfactorily determined. His careful elucidation of this obscure and perplexing group has not only placed his fellow-workers in the same field under lasting obligations to him, but must mark an era in the history of the subject. Of the fifty-nine nominal species of this group described by different authors, he informs us that he has examined the types of no less than forty-one! With the rich material of the British Museum at his command, be has been able to tell us exactly what the late Dr. Gray had for the basis of his nineteen "new species", described in a single paper in 1867 , some of them so vaguely or inaccurately that the descriptions are sometimes misleading, and often inadequate indices of what he actually had before him. Mr. Alston has also been able to allocate the species described previously by the same author, and by Richardson, Bennett, Ogilby, and other British writers. In the Paris Museum, he found still extant the types of most of the species described many jears since by Is. Geoffroy, Lesson, F. Cuvier, and Pucheran, and in the Berlin Museum types of the species described by Dr. Peters; so that the only important ones not seen by him are those of Brandt, Wagner, and Natterer. To assist him in collating my own work, I had the pleasure of sending him examples of the greater part of the species recognized by me in $\mathrm{my}$ recent monograph of the American Sciurida. As I had not access to the types of the species described by foreign authors, I made, in some instances, my allocations of synonymy with doubt, and, in other cases, only provisionally, feeling conscious of the uncertainty with which refer-

\footnotetext{
*Coues and Allen's “Monographs of North American Rodentia”, pp. 666-797, August, 1877.

†"On the Squirrels of the Neotropical Region", Proc. Zoöl. Soc. Lond. 1878, pp. 656-670, pl. xli. This highly important memoir gives excellent diagnoses of the species, with their synonymy in full, and a critical commentary on the species of previous authors.
} 
ences to many of the species must necessarily, under the circumstances, be made. Although Mr. Alston has shown the incorrectness of some of my identifications, and the necessity of substituting, in two instances, names other than those I was led to adopt, I feel, on the whole, no small degree of satisfaction in the confirmation of so large a portion of my synonymic work by the trying ordeal to which it has been submitted; especially as Mr. Alston bas done me the kindness to state, in several instances, that I was led into mistakes by descriptions that did not properly represent the objects described. The purpose of the present paper is to correct these errors, so far as they have been satisfactorily shown, and to present a nomenclature that fairly reflects the present state of the subject.

In my former revision of the Sciuri of Tropical America, I felt author. ized in reducing fully four-fifths of the previously described species to synonyms, and stated it as my belief that I had still recognized too many rather than too few. Mr. Alston, with far more-and mainly historic-material at his command, has, in one or two instances, carried the reduction still further, but, on the other hand, has added one or two species unrepresented in the material I had before me. While I recognized ten species and two subspecies, he has raised the number of the former to twelve. The changes, so far as species are concerned, consist in his elerating one of my subspecies to full specific rank; in treating as a species a form I regarded as the joung of another species; in uniting, in two instances, two of my species into one; and in restoring two species I treated as nominal. These changes, as well as those of nomenclature and synonymy, will be fully noted in the following pages.

For the purpose mainly of presenting a connected view of the American Sciuri, but partly to correct one or two errors of synonymy, I include the North American species in the subjoinea enumeration, although $I$ have no changes to make in the nomenclature adopted in "Monographs of North American Rodentia". In order to distinguish readily those that are represented in the North American fauna, I divide the species, as before, into two geographical series. Gray's species are assigned in accordance with Mr. Alston's determinations, based on an examination of the types, as are also those of Peters, Pucheran, Cuvier, Geoffroy, Bennett, and Richardson. Consequently the synonymatic tables bere presented are substantially the same as Mr. Alston's.

\section{A.-NORTH AMERICAN SPECIES.}

I.-Sciurus hudsonius, Pallas.

\section{1.-Var. hudsonius.}

Sciurus vulgaris, Fonster, Phil. Trans. 1xii, 1772, 378.

Sciurus vulgaris, $\varepsilon$, hudsonicus, ERxLEBEN, Syst. Anim. 1777, 416.

Sciurus hudsonius, Paldas, Nov. Spec. Glires, 1778, 376.

Sciurus carolinus, ORD, "Guthrie's Geogr. (2d Am. ed.) ii, 1815, 292."

Sciurus rubrolineatus, Desmarest, Mam. ii, 1822, 333. 
2.-Var. richardsoni.

Sciurus richard8oni, Bachman, Proc. Zoöl. Soc. Lond. vi, 1838, 100.

\section{3.-Var. douglassi.}

Sciurus hudsonius, var. $\beta$, Richardson, Faun. Bor.-Am. i, 1829, 190.

Sciurus douglassi, Gray, Proc. Zoöl. Soc. Lond. 1836, 88 (no description).-Bachman, Proc. Zoöl. Soc. Lond. 1838, 99.

Sciurus townsendi, Bachman, Journ. Acad. Nat. Sci. Phila. viii, 1839, 63 (MS. name).

Sciurus lanuginosus, Bachman, Proc. Zoöl. Soc. Lond. 1838, 101.

Sciurus mollipilosus, Audubon \& Bachman, Proc. Acad. Nat. Sci. Phila. i, 1842, 102.

Sciurus belcheri, GRAY, Ann. and Mag. Nat. Hist. x, 1842, 263.

Sciurus suckleyi, BaIrd, Proc. Acad. Nat Sci. Phila. vii, 1855, 333.

\section{4.- -Var. fremonti.}

Sciurus fremonti, Audubon \& BaChmax, Quad. N. Amer. iii, 1853, 237, pl. cvlix, fig. 1.

\section{II.-Sciurus Carolinensis, Gmelin.}

1.-Var. leucotis.

Sciurus cinereus, Schrebier, Säuget. iv, 1792, 706, pl. cexii (nec Liuné, 1758).

Sc urus pennsylvanicu8, ORD, "Guthrie's Geog. (2d Am. ed.) ii, 1815, 292" (melanistic).

Sciurus niger, Godman, Am. Nat. Hist. ii, 1826, 133 (melanistic; nec Linné, 1758).

Sciurus carolinensis, Godman, Am. Nat. Hist. ii, 1826, 131.

Sciurus leucotis, GAPPER, Zoöl. Journ. $\nabla, 1830$, 206, pl. xi.

Sciurus vulpinus, DeKaY, N. Y. Zoöl. i, 1842, 59.

Sciurus migratorius, AUdUBon \& BaChMaN, Quad. N. Amer. i, 1849, 265, pl. xxxv.

\section{2.-Var. carolinensis.}

Sciurus carolinensis, GMELIN, Syst. Nat. i, 1788, 148.

Sci «rus fuliginosus, Bachman, Proc. Zoöl. Soc. Lond. 1838, 96.

\section{3.- Var. yucatanensis.}

Soiurus carolinensis var. yucatanensis, ALLEN, Mon. N. Am. Rod. 18i7, 705.

NOTE.-In "Monographs of the North American Rodentia", p. 701, exclude from synonyms of var. leucotis, "? Macroxus melania, Gray", and from synonyms of var. carolinensis exclude "? Sciurus deppei", respecting which see infrà, pp. 881, 885. Variety yucatanensis seens to be a rare form in collections, $\mathrm{Mr}$. Alston stating that the only specimen he has seen being the one I sent him.

\section{III.-SCIURUS NIGER, Linné.}

1.-Var. niger.

Sciurus niger, Linn6, Syst. Nat. i, 1758, 64.

Sciurus variegatus, ERXLEBEN, Syst. Anim. 1777, 421 (in part).

Sciurus v'ulpinus, Gmelis, Syst. Nat. i, 1788, 147.

Sciurus capistratus, Bosc, Aun. du Mus. i, 1802, 281.

Sciurus rufiventris, M'M URTRIE, Cuvier's An. King. (Am. ed.) i, 1831, 433.

Sciurus texianu8, BACHMaN, Proc. Zoöl. Soc. Loud. 1838, 86.

\section{2.-Var. cinereus.}

Sciurus cinereus, Lixvé, Syst. Nat. i, 1758, 64.

Sciurus vulpinus, ScHrebER, Säuget. iv, 1792, i72, pl. cexr, B. 
- Sciurus hyemalis, OnD, "Guthrie's Geog. (2d Am. ed.) ii, 1815, 293, 304."

9. Macroxus neglectus, Gray, Ann. and Mag. Nat. Hist. 3d ser. xx, 1867, 425 (locality unknown).

\section{3.-Var. ludovicianus.}

Sciurus ludovicianus, Custis, Barton's Med. and Phys. Journ. ii, 1806, 43.

Sciurus ludovicianus var. atroventris, ENGelmans, Trans. Acad. Sci. St. Louis, i, 1859, 329.

Sciurus macroura, SAY, Long's Exp. R. Mts. i, 1823, 115.

Sciurus macroureus, Godman, Am. Nat. Hist. ii, 18:26, 134.

Sciurus magnicaudatus, HARLAN, Faun. Am. 1825, 178.

Sciurus subauratu8, Bachman, Proc. Zoöl. Soc. Lond. 1838, 87.

Sciurus auduboni, Bachman, Proc. Zoöl. Soc. Lond. 1838, 97.

Sciurus occidentalis, Acdubon \& Bachman, Journ. Acad. Nat. Sci. Phila. viii, 1842, 317. Sciurus rubicaudatus, AUdubon \& BaCHMan, Quad. N. Am. ii, 1851, 30, pl. Iv.

Sciurus sayi, Audubon \& Bachman, Quad. N. Am. ii, 1851, 274, pl. Ixxxix.

Sciurus limitis, BaIrd, Proc. Acad. Nat. Sci. Phila. vii, 1855, 331.

Note.-Under Var. ludovicianus, Mon. N. Am. Rod. p. 718, exclude "? T(,MEs, Proc. Zoöl. Soc. Lond. 1861,281 (Costa Rica [lege Guatemala])".

\section{IV.-Sciurus fossor, Peale.}

Sciurus fossor, PEAle, Mam. and Birds U. S. Expl. Exp. 1848, 55.

Sciurus heermanni, LeConte, Proc. Acad. Nat. Sci. Phila. vi, 1852, 149.

\section{V.-SCIURUS $\triangle$ BERTI, Woodh.}

Sciurus dorsalis, Woodhouse, Proc. Acad. Nat. Sci. Phila. vi, 1852, 110 (nec Gray, 1848). Sciurus aberti, Woodhouse, Proc. Acad. Nat. Sci. Phila. vi, 1852, 220.

Sciurus castanotus, BAIRD, Proc. Acad. Nat. Sci. Phila. vii, 1855, 332 (typ. error for castanonotus).

\section{VI.-SCIURUs ARIZONENsis, Coues.}

Sciurus arizonensis, Coues, Amer. Nat. i, 1867, 357.

Sciurus colliøi, Allen, Mon. N. Am. Rod. 1877, 738 (exclusive of synonyms, which all belong to the next species, except "q S. leporinus, AUD. \& BACH.", which is indeterminable).

NOTE.- "Misled by imperfect descriptions and a bad figure of Richardson's type, Mr. Allen has referred the Arizona Squirrel of Dr. Coues to Richardsou's S. collicei. He has since kindly intrusted me with a typical example of S.arizonensis; and I find that it is quite distinct from S. collicei (which is Mr. Allen's S. boothice), being much more nearly allied to S. carolinensis, from which, howerer, both Dr. Coues and Mr. Allen consider that it is "thoroughly distinct'."-ALSTON, l.c.p. 659.

\section{B.-SPECIES OF MEXICO AND CENTRAL AND SOUTH} AMERICA.

\section{VII.-Sciurus Griseoflavus, (Gray) Alston.}

Macroxus griseoflavus, Gray, Ann. and Mag. Nat. Hist. 3d ser. xx, 1877, 427.

Sciurus griseoflavus, Alston, Proc. Zoül. Soc. Lond. 1878, 660.

I Sciurus ludovicianus, Tomes, Proc. Zoöl. Soc. Lond. 1861, 281 (according to Alston, l.c. p. 660 ).

NotE.-Referred by me to my S. leucops. Considered by Mr. Alston to be "closely allied" to S. arizonensis, of which be suspects "it will 
eventually prove to be a southern race. More specimens, howerer, are required before they can be united ; and provisionally I therefore accept S. griseoflavus as a distinct species." My own inclination, in view of Mr. Alston's diagnosis of S. griseoflavus, is to unite them, but I refrain from doing so at present.

Mr. Alston further remarks :- " Mr. Allen considers Gray's M. griseoflavus to be specifically identical with his [Allen's] M. leucops; and the original diagnosis certainly seems to give countenance to such a view. The typical specimens (five in number), however, are very different. - . . In consequence of my referring Gray's Macroxus griseoflavus to my $S$. leucops, he quotes the latter as a synonym of S. griseoflavis, Alston, but the specimens I referred to my S. leucops represent his S. variegatus var. leucops.

\section{VIII.-SCIURUS HYPOPYRRHUS, Wagler.}

I Sciurus variegatus, Erxleben, Syst. Anim. 1777, 421 (in part).

Sciurus hypopyrrth us, WAGLER, Isis, 1831, 610.

Sciurus nigrescens, BennetT, Proc. Zoöl. Soc. Lond. 1833, 41 (melanistic).

Sciurus collioci, Richardson, Zoöl. Voy. Blośsom, 1839, 8, pl. i.

Sciurus variegatoides, OGIL.BY, Proc. Zoöl. Soc. Lond. 1839, 117.

Sciurus richardsoni, GraY, Ann. and Mag. Nat. Hist. x, 1842, 264 (nec Bachman, 1838).

Sciurus boothice, Gray, List Mam. Brit. Mus. 1843, 139 (=S. richardsoni, Gray).

Sciurus griseocaudatus, Glis, Zoöl. Voy. Sulphur, 1844, 34, pl. xiii, fig. 2 (animal), pl. xviii, figs. 7-12 (skull and teeth).

Sciurus fuscovariegatus, Schinz, Synop. Mam. 1845, 15 (= S. richardsoni, Gray).

Sciurus adolphei, Lesson, Descrip. de Mam. et d'Ois. 1847, 141.

Sciurus pyladei, Lesson, Descrip. de Mam. et d'Ois. 1847, 142.

Sciurus dorsalis, Gray, Proc. Zoöl. Soc. Lond. 1848, 138, pl. vii.

Sciurus rigidus, Peters, Monatsb. Köngl. Preuss. Akad. Wissensch. zu Berlin, 1863, (1864), 652.

Sciurus oculatus, Peters, Monatsb. Köngl. Preuss. Akad. Wissensch. zu Berlin, 186:3, (1864), 653 (formerly referred by me to my " $S$. colliaei" =S.arizonensis, Coues).

Sciurus intermedius, "Verreaux", Gray, Ann. and Mag. Nat. Hist. 3d ser. x⿺ 1867, 421. Sciurus nicoyana, GrAY, Aun. and Mag. Nat. Hist. 3d ser. Xx, 1867, 423.

Sciurus melania, Gray, Ann. and Mag. Nat. Hist. 3d ser. xx, 1867, 425 (formerly referred by me, with a query, to $S$. carolinensis).

Sciurus colliai, Allen, Mon. N. Am. Rod. 1877, 738 (the synonyms, except S. arizonensis, Coues, but not the specimens, nor the descriptive text).

Sciurus boothia, Allen, Mon. N. Amer. Rod. 1877, 741 (synonyms, text, and specimens). Sciurus hypopyrrhus, AldLeN, Mon. N. Amer. Rod. 1877,746 (synonyms,-except Macroxus maurus, Gray,-text, and specimens, except the series from Guayaquil and the text relating to them).

Note.-This species, as at present defined, includes both my S. boothia and S. hypopyrrhus, except certain specimens from Guayaquil described by me under the latter name, which represent, according to Mr. Alston's determination of them, $S$. stramineus. In uniting my $S$. boothice and S. hypopyrrhus, Mr. Alston confirms a suspicion I had already expressed of their possibly proving identical. I kept them apart mainly from the impression made upon me by the Guayaquil specimens, which I felt pretty sure were specifically different from those I referred to $S$. 
boothice, and which were really the basis of what I recognized as S. hypopyrrhus. I associated with them, however, specimens representing the S. dorsalis of Gray, from their apparently slenderer form and relatively longer ears and tail. Although Mr. Alston has not seen the types of either Wagler's S. hypopyrrhus or of S. stramineus, I defer for the present to his judgment in adopting hypopyrrhus as the name of this highly polymorphic group.

Under S. hypopyrrhus, Mr. Alston recognizes five "types", namely :1. "The hypopyrrhus type", to which he refers $S$. nigrescens, Bennett, and Macroxus boothice, Gray, 1867. 2. "The rigidus type", to which he refers S. rigidus, Peters, S. intermedius, Verreanx, and S. nicoyanus, Gray. 3. "Thedorsalis type." 4. "The collicitype", to which he refers S.colliai, Richardson, S. adolphei and S. pyladei, Lesson, S. variegatoides, Ogilby, S. oculatus, Peters, and S. griseocaudatus, Gray. 5. "The melania type"

"With regard to the synonymy," Mr. Alston writes, "I may ob. serve that I have been able to examine the types of all the 'species' here united, excepting that of S. hypopyrrhus, which, however, has been well described by Wagler and Wagner; it appears to be a dark variety without the usual wash of white on the tail. ..."

"Of the geographical distribution of the races," he says, "we can only judge from the comparatively fow specimens of which the exact localities have been noted. The hypopyrrhus phase appears to be the most northern, the collicei to obtain principally along the Pacifie slopes, and the dorsalis to be the most southern. Each, however, appears to be found along with the others in some parts. Thus, I have seen specimens of the hypopyrrhus type from Mexico, Honduras, and Guatemala, of rigidus from Guatemala, Nicaragua, and Costa Rica, of dorsalis from Nicaragui, Costa Rica, Veragua, and Panama, and of collicei from the west coast of Mexico and Guatemala, Nicaragua, and Costa Rica. The only localities which I know for S. melania are Nicaragua and Veragua."* In all probability, these five types will prove to be entitled to varietal rank.

\section{IX.-SCluRUS AUReigaster, F. Cuvier.}

Sciurus aureogaster, F. Cuvier, Hist. des Mam. iii, livr. lix, 1829.

Sciurus leucogaster, F. Cuvier, Suppl. de Buff. i, Mam. 1831, 300.

Sciurus albipes, WAGNER, $\Lambda$ bh. Bayer. Ak. ii, 1837, 501 (according to Alston; formerly referred by me, vith a ?, to the preceding species).

Sciurus socialis, WAGNER, Abh. Bayer. Ak. ii, 1837, 504, pl. v (according to Alston).

Siciurus ferruginiventris, Audubon \& Bachman, Proc. Acad. Nat. Sci. Phila. 1841, 101; Quad. N. Am. pl. xxxviii.

Sciurus varius, WAGNer, Suppl. Schreber's Säuget. iii, 1843, 168, pl. cccxiii D ("S. albipes" on plate $;=S$. albipes, Wagner, 1837 ).

Macroxus morio, Gray, Ann. and Mag. Nat. Hist. 3d ser. xx, 1867, 424.

Macroxus maurus, Gray, Ann. and Mag. Nat. Hist. 3d ser. xx, 1867, 425 (formerly referred by me to the preceding species).

Yacroxus leucops, Gray, Ann. and Mag. Nat. Hist. 3d ser. $x x, 1867,427$.

Sciurus aureigaster and S. leucops, AlLex, Mon. N. Am. Rod. 1877, 750, 753.

Sciurus variegatus, Alston, Proc. Zoöl. Soc. Lond. 1878, 660 (ex Erxleben). 
NotE.-"Under this name I feel myself obliged to bring together two Mexican Squirrels of which typical specimens are very different in appearance. Mr. Allen has kept them separate under the names of $S$. aureigaster and $S$. leucops, remarking that the difference in coloration leaves little doubt of their distinctness, but adding that ' more abundant material may show that they are not. specifically separable' (op. cit. p. 755). The color-variation is not nearly so great as we shall find it to be in the next species [i.e.S.hypopyrrhus]; and after a careful examination of a great number of specimens, especially of the fine series in the Puris Museum, I have been unable to find a single distinctive character which is constant."-Alston, l. c. p. 661.

Of this species Mr. Alston recognizes two forms, denominated respectively " 1 , the aureogaster type", and "2, the leucops type".

Unfortunately, as it seems to me, Mr. Aiston has selected for this species Erxleben's name variegatus, remarking that it is "primarily founded" on the "Coztiocotequallin" of Hernandez, and that Buffon's "Coquallin" is quoted only as a synonym; and adds, "Erxleben's diaguosis and clescription appear to me to be quite characteristic of the leucops form of the present species. By retaining this appropriate name," he contiuues, "we are enabled to escape from F. Cuvier's barbarous term aureogaster, under which this beautiful species has labored in so many works" (l. c. pp. 661, 662). However pleasant it might be to escape Cuvier's barbarous name, this to me is not so clearly the way to do it. Erxleben's species is admittedly a composite one, and neither his diag. nosis nor Hernandez's account of the "Coztiocotequallin" belps the matter, since the best that can be made out is that Erxleben's species was black above, varied with white and brown, and yellow below, twice the size of the European Squirrel, and with the ears not tufted; a characterization broad enough to apply to the dusky phase of any of the larger Mexican Squirrels. F. Cuvier's excellent figure and detailed description, on the other hand, leave nothing to be guessed at in respect to just what his aureogaster was, the types of which, it appears also, are still preserred.

\section{X.-Sciurus stramineus, Eyd. \& Soul.}

Sciurus stramineus, Eydoux \& Souleyet, Voy. de la Bonite, Zool. i, 1844, 3\%, pl. ix.

Sciurus nebouxii, Is. Geoffrov, Voy. de La Vénus, Zool. 1855, 163, pl. xii.

Macroxus fraseri, Gray, Ann. and Mag. Nat. Hist. 3d ser. xx, 1867, 430.

Sciurus hypopyrrhus, Alles, Mon. N. Am. Rod. 1877, 747 (in part).

NotE.-As already stated, this species was embraced under my $\mathbf{S}$. hypopyrrhus. The s. stramineus I included among the synonyms of $S$. variabilis. The S. nebouxii I was unable to identify, and gave it among my undetermined species. The Macroxus fraseri I referred doubtfully to S. tephrogaster.* Mr. Alston has examined the types of $S$. nebouxii and

* "It is only fair to Mr. Allen to add, that Gray's description of M. fraseri is so imperfect that it is not surprising that the American zoölogist should have doubtfully referred it to S. tephrogaster."-AxsToN, l. c. p. 665. 
S. fraseri, and their allocation here is on his authority. It turns out that the Guyaquil specimens of my S. hypopyrrhus series (one of which Mr. Alston has seen) represent this species. Mr. Alston states that this species is rare in collections, and appears to be the only representative of the genus in Western Peru. He further says :- "A remarkable peculiarity of this species is its tendency to the development of irregular tufts of pure white hairs, rather longer than the rest of the fur, and sometimes uniting in large patches. These asymmetrical markings are present in the majority of the individuals examined." This peculiarity in the texture and color of the pelage I looked upon as abuormal and as indicating a tendency to albinism, and am surprised that it should prove of such general occurrence.

\section{XI.-Sciurus variabilis, Is. Geoffroy.}

Sciurus variabilis, Is. Geofwroy, Mag. de Zool. 1832, i, pl. iv.

Sciurus langsdorffi, Brandt, Mém. Acad. de St. Pétersb. $6^{e}$ sér. Math. Phys. et Nat. iii, $2^{\mathrm{e}} \mathrm{pt}$. $1835,425, \mathrm{pl}$. xi.

Sciurus igniventris, "NATTERER", WAGNER, Wiegm. Arch. 1ür Naturg. 1\&42, i, 360. Sciurus pyrrhonotus, "NATteren", Wagner, Wiegm. Arch. für Naturg. 1842, i, 360. Sciurus tricolor, "PÖPPIG", Tschud, Faun. Peruan. 1844-46, 156, pl. xi.

Sciurus morio, WAGNeR, Abh. Bayer. Ak. v, 1 50, 275.

Macroxus gerrardi, GraY, Proc. Zoöl. Soc. Lond. 1861, 92, pl. xvi.

Sciurus brunneo.niger, "CAstuena U", Gray, Ann. and Mag. Nat. Hist. 3d ser. xx, 1867, 429. Sciurus fumigatus, Gray, Ann. and Mag. Nat. Hist. 3d ser. xx, 1867, 428.

Sciurus variabilis and S. gerrardi, ALIEN, Mon. N. Am. Rod. 1877, 768, 766.

NotE.-Mr. Alston exteuds this species to cover my S. gerrardi, which I separated mainly on the ground of smaller size. He says:- "Here, again, the greater amount of material compels me to go beyond Mr. Allen in the identification of nominal species. Most of the above synonyms were brought together by him under the name of S. variabilis ; but S. gerrardi and S. rufo-niger [lege brunneo-niger] were kept separate under the former title. The principal points on which he rested were the smaller size and shorter ears of S. gerrardi; but on examination of a sufficient series, I have not been able to find auy constancy in the pro. portious of the ears, while the difference in size totally disappears. . . The smaller specimens (S. variabilis, S. gerrardi, etc.) appear to prevail towards the north; but this is not constant. . . . Nor is it constantly connected with any of the numerous varieties of colorationrufous, grizzled, and melanistic specimens occurring of all sizes." These color-variations, he says, seem to resolve themselves into three primary groups, namely:- " 1 , the morio type", melanistic; " 2 , the variabilis type", red, varied with black; "3, the langsdorff type", reddish- or yellowish.grizzled. Each of these types seems to prevail in certain localities, but there is no regularity in their distribution, the red and grizzled often occurring together.

Our synonymy of this rariable group agrees, except that I included S. stramineus under variabilis, and Gray's Macroxus xanthotus under S. gerrardi, which latter Mr. Alston refers to S. griseogenys (= Sciurus 
cestuans var. rufo-niger, Allen), with the remark, "By some curious error Gray's account of this last (Macroxus xanthotus) has been printed after that of $\boldsymbol{M}$. brunneo-niger, instead of after $\boldsymbol{M}$. griseogena; so that the remark, 'very like the former', etc., naturally led Mr. Allen to refer the synonym to S. gerrardi" (l. c. p. 667).

\section{XII.-Sciurus DEPPEI, Peters.}

Sciurus deppei, Peters, Monatsb. K.-P. Al. Wissen. Berlin, 1863, (1864), 654 (formerly referred by me, with a :, to S. carolinensis).

Macroxus tephrogaster, GRAY, Ann. and Mag. Nat. Hist. 3d ser. xx, 1867, 408.

Macroxus middellinensis, GRAY, Ann. and Mag. Nat. Hist. 3d ser. xx, 1867, 408.

Macroxus toniurus, GraY, Ann. and Mag. Nat. Hist. 3d ser. Xx, 1867, 431.

Sciurus tephrogaster, ALLEN, Mon. N. Am. Rod. 1877, 763 (excluding "\&Macroxus fraseri, Gray").

NotE.-The examination of the type of S. deppei, Peters, by Mr. Alston, shows it to be identical with Gray's M. tephrogaster, over which it has three years" priority. "As already observed," says Mr. Alston, "M. fraseri, Gray, was so insufficiently, described that Mr. Allen was led to identify it with the present species, which is about half its size and totally different in coloration" (l. c. p. 669).

\section{XIII.-Sciurus astuans, Linné.}

Sciurus astuans, LiNNe, Syst. Nat. i, 1766, 88.

Sciurus astuans var. guanensis Peters, Monatsb. K.-P. Akad. Wissens. Berlin, 1863, (1864), 655.

Myoxus guerlingus, SHaw, Gen. Zoöl. ii, 1801, 171, pl. clvi.

Sciurus gilvigularis, "NATTERER", WAGNeR, Wiegm. Arch. für Naturg. 1843, ii, 43 ; ib. 1845, i, 148.

Macroxus leucogaster, GRAY, Ann. and Mag. Nat. Hist. 3d ser. xx, 1867, 430.

Macroxus irroratus, Gray, Ann. and Mag. Nat. Hist. 3d ser. xx, 1867, 431.

Macroxus flaviventer, "CastelNaU", Gray, Ann. and Mag. Nat. Hist. 3d ser. xx, 1867, 432. Sciurus astuans var. astuans, Allen, Mon. N. Am. Rod. 1877, 756 (exclusive of "I $S$. pusillus, Geoffroy", and "M. kuhli, Gray", and inclusive of "M. irroratus, Gray", referred to var. rufoniger).

NOTE.- "M. irroratus must also be placed here, although the original description is such that Mr. Allen unhesitatingly referred it to the last species [S. griseogenys]."-ALsToN, l. c. p. 668.

\section{XIV.-Sciurus hoffmanni, Peters.}

Sciurus cestuans var. hoffmanni, Peters, Monatsb. K.-P. Ak. Wiss. Berlin, 1863, (1864), 654. Sciurus hyporrhodus, GRAY, Ann. and Mag. Nat. Hist. 3d ser. xx, 1867, 419.

Macroxus xanthotus, GRAX, Ann. and Mag. Nat. Hist. 3d ser. xx, 1867, 429.

Macroxus griseogena, Gray, Ann. and Mag. Nat. Hist. 3d ser. xx, 1867, 429.

Sciurus griseogenys, ALsToN, Proc. Zoöl. Soc. Lond. 1878, 667.

Sciurus cestuans var. rufoniger, ALLEN, Mon. N. Am. Rod. 1877, 757 (excluding S. rufoniger and S. chrysosurus, Pucheran, and adding $M$. xanthotus, Gray, formerly referred to $S$. gerrardi).

Note. - Mr. Allen, in his monograph, regards this Squirrel as a 'variety' or geographical race of the next species [i.e. S. cestuans], 
differing in its uniformly larger size and strikingly in the coloration of its tail. In a subsequent letter to me he says :- 'It wonld perhaps be just as well to recognize it as entitled to specific rank, although I still feel sure of their intergradation.' That such connecting links may jet be found seems very probable; but $I$ have not been able to find such in the vers large series which I have examined, and am consequently compelled to keep them provisionally distinct. Unfortunately Mr. Allen has identified this species with Pucheran's S. rufo niger, which, as will be seen presently, is a much smaller and quite distinct species. Dr. Peters described it only as a variety of S. cestuans; and though specimens in the Berlin Museum are labelled 'Sciurus hoffmanni', the name remains a manuscript one. Of Gray's three titles I have adopted griseogena (more correctly griseogenys) as being simultaneous in date with the others, and as indicating the typical form."-ALSTON, l. c. p. 667.

Accepting provisionally this Squirrel as specifically distinct from $S$. westuans, I dissent from the foregoing only respecting its proper title. Although the name hoffmanni may remain a manuscript one as applied in a specific sense, its publication as a varietal name for this form, three sears prior to the publication of Gray's names, appears to me to warrant its use as a specific designation for the same form. Such a procedure bas certainly the sanction of numerous precedents.

\section{XV.-Sciurus RUfoniger, Pucheran.}

Sciurus rufoniger, Pucheran, Rev. de Zoöl. 1845, 336.-Alston, Proc. Zoöl. Soc. Lond. $1868,669$.

Sciurus chrysurus, Pucheran, Rev. de Zool. 1845, 337.

"Macroxus tephrogaster minor, GRAY, MSS." apud Alston.

NoTE. -This species I introduce entirely on the authority of Mr. Alston, who has examined the types. I referred both of Pucheran's species unhesitatingly to the preceding species, but the presence of two upper premolars in S. rufoniger would seem to render it unquestionably distinct from S. hoffmanni, and to ally it with $S$. deppei (as perhaps the soung of that species).

Respecting this species, Mr. Alston remarks as follows :- "On examining the type of Pucheran's S. rufo-niger in the Paris Museum, I found that it was not identical with $S$. griseogenys [S. cestuans var. rufoniger, Allen, Mon. N. Am. Rod.]; as Mr. Allen supposed, but rather allied to S. deppei [S. tephrogaster, Allen, l. c.]; and I soon recognized in it a small Squirrel from Panama, and which I had begun to fear would require a new name. These examples prove to agree further with $S$. deppei in having two upper premolars, but differ in being more than one third smaller, in the color of the lower parts (which are only paler than the upper, save on the breast), and in the tail being nearly uniform in color with the back (the hairs having only very minute white or yellow tips). Specimens in the British Museum are labelled $M$. tephrogaster minor; but I cannot doubt the distinctness of the form. The type of S. rufo. 
niger has the middle of the back nearly black; while that of $M$ chryso. surus appears to be a variety, merely differing in the tail being more rufous" (l. c. p. 669). There is nothing in Pucheran's description of the last-named species to indicate it is not the young of S. hoffmanni.

Judging from what I hare seen in other species, the darker color of the lower surface in Alston's S. rufoniger as compared with S. deppei might result from immaturits; but in deference to Mr. Alston's opinion, grounded on excellent opportunities for deciding, I give the species provisional recognition.

\section{XVI.-Sciurus PUsillus, Geoffroj.}

Sciurus pusillus, “Is. Geoffroy", Desmarest, Dict. d'Hist. Nat. x, 1817, 109 ; Mam. 1822, 337, pl. Ixxvii, fig. 2.-Alston, Proc. Zoül. Soc. Lond. 1878, 670 pl. xli.

Macroxus kuhli, Grax, Aun. and Mag. Nat. Hist. 3d ser. xx, 1867, 433.

NoTE.-These names-the first with a query, the second unhesitatingly-I referred in my monograph to $S$. cestuans, influeuced mainly by the strong aspect of immaturity presented by a specimen in the Museum of Comparative Zoölogy, which undonbtedly represents this species, notwithstancling the statement by Buffou, quoted by me, that the type of the species was shown by the sexual organs to be adult. Although Vir. Alston was unable to find the type of Geoffroy's s. pusillus, he seems to have established its distinctness from S. cestuans by finding two upper premolars in the British Museum specimens bearing that name. He considers Gray's M. kuhli (which I treated also as the young of S. cestuans) as unquestionably identical with S. pusillus. This is apparently a very rare species, as I have met with references to not more than half a dozen specimens in all. It is by far the smallest American species of Sciurus.

The subjoined summary indicates the changes in nomenclature here made from that adopted in "Monographs of North American Rodents", and also that employed by Mr. Alston in his recent paper "On the Squirrels of the Neotropical Region":-

\begin{tabular}{|c|c|c|}
\hline Allen, November, 1878. & Alston, October, 1878. & Allen; Angnet, lez7. \\
\hline 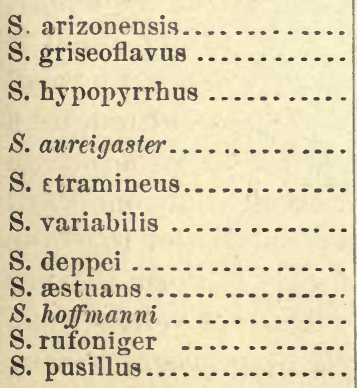 & 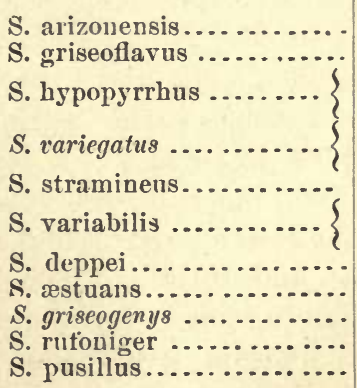 & $\begin{array}{l}\text { S. colliæi. } \\
\text { S. hypopyrrhus. } \\
\text { S. boothiæ. } \\
\text { S. aureigaster. } \\
\text { S. leucops. } \\
\text { S. hypopvrrhus. } \\
\text { S. variabilis. } \\
\text { S. gerrardi. } \\
\text { S. tephrogaster. } \\
\text { S. æstuans var. æstuans. } \\
\text { S. æestuans var. rufoniger. } \\
\text { S. æstuans. }\end{array}$ \\
\hline
\end{tabular}


Q6.

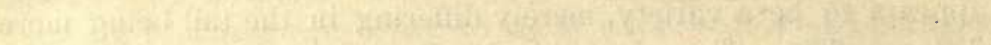

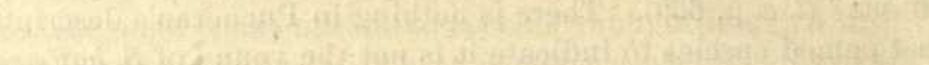

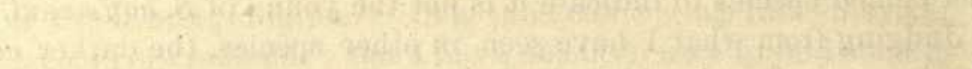

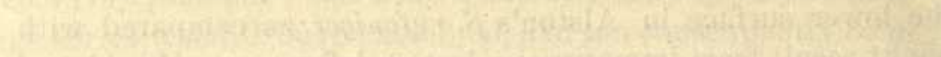

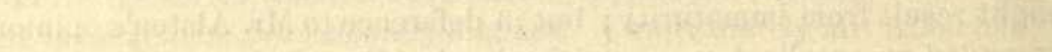

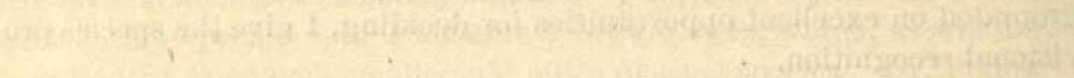

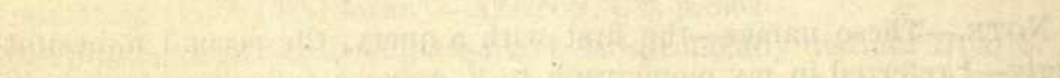

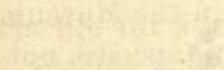




DEPARTMENT OF THE INTERIOR. UNITED STATES GEOLOGICAL AND GEOGRAPHICAL SURVEY.

F. V. HAYDEN, U. S. Geologist-in-Charge.

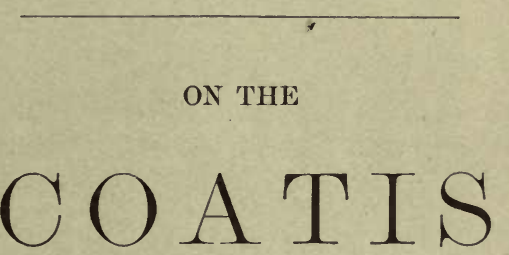

( GENUS NASUA, STORR).

BY

J. A. ALLEN.

EXTRACTED FROM THE BULLETIN OF THE SURVEY, VOL. V, NO. 2. 



\section{B U L L E T I N}

OF THE

\section{UNITED STATES GEOLOGICAL AND GEOGRAPHICAL SURVEY OF THE TERRITORIES.}

\section{Art. $\mathbf{X}$. - On the Coatis (Genus Nasua, Storr).}

\section{By J. A. Allen.}

Few of the terrestrial Ferce present a greater range of color-variation, wholly independent of sex and age, than do the species of Coati. Neither does the history of many groups afford so remarkable a record of malidentifications and consequent confusion and complication of synonymy. Before entering further upon the general subject, it may be stated that the number of species recognized by even comparatively recent authors varies from one to five, while the aggregate number of synonyms falls little short of thirty. The two valid species of the group were very early and simultaneously recognized, but later one of them xas almost wholly lost sight of for nearly half a century, so that the names given to them by the early systematic writers were variously combined and almost indiscriminately referred by later authors to the various nominal species they respectively recognized. As preliminary to any attempt to discriminate the species, and for the purpose of elucidating the tables of synonymy given below, a somewhat extended historical summary of the literature of the subject may not be out of place.*

Brisson, in his "Règne Animal," in 1756, described two species of Coati under the names "Le Coati-Mondi" and "Le Coati-Mondi à quene annelee," which afterward became the basis respectively of Linné's $Y i$ verra narica and Viverra nasua. Brisson also described "Le Blaireau de Surinam-Meles surinamensis," which is also a Coati, referable to the

* The present revision of the group is based mainly upon the rich material contained in the National Museum, the whole of which has been unreservedly placed at my clisposal by the Director, Professor Spencer F. Baird. I am also greatly indeloted to Mr. Alexander Agassiz for the use of the material contained in the Museum of Comparative Zoülogy at Cambridge, Mass., which happily supplies important data that would have beten otherwise inaccessible to me.

Bull. $v, 2-1$ 
species with an annulated tail. This later became in part the basis of Erxleben's Viverra vulpecula.* Only the first two of Brisson's three species above cited have special importance in the present connection. His diagnoses are so explicit as to leave no doubt respecting the particular species characterized, and they thus render Limnés Viverra narica and $V$. nusua perfectly determinable. Buffon also described and figured both species from specimens he was able to study in life, under the names "Le Coati brun" and "Le Coati noirâtre," corresponding respectively with Linnés Viverra narica and V.nasua. Schreber copied Buffon's plates and adopted Linné's names. He seems, however, to have had personal knowledge of both species, and takes pains to clearly point out their specific differences, alluding to the fact that both Buffon and Pennant considered Viverra narica as merely a "variety" ("blosse Spielarten") of V.nasua. Erxleben and Gmelin also adopted Linné's names, and correctly referred to them Brisson's and Buffon's species. G. Cuvier, in 1798, employed Buffon's vernacular names, but referred the species to the genus Ursus, retaining, however, the specific names given by Linné. Shaw, in 1800, gave Viverra narica as a "var.?", remarking that it had usually been considered as a variety of Viverra nasua, but adds: "It is, however, rather larger than the former [ $V$. nasua], of a browner color, and without any annuli, or, at least, without any distinct variegations on the tail," thereby showing that he appreciated correctly some of the more obvious external characters of the two species. Up to this time the two species had not been confounded by systematic writers, and the references to Brisson and Buffon prove to have been correctly allocated.

Desmarest, in 1817, apparently intended to adopt for the group Storr's generic name Nasua, of which he recognized three species, as follows: 1. "Le Coati, Nasua quasje, Geoffroy," to which he referred "Viverra quasje, Linn." (i. e., Gmelin†), and Buffon's "le Coati noirâtre." 2. "Le

* The Viverra vulpecula of Erxleben is one of those eurious compositions so frequently met with in the works of the earlier systematists, particularly those of Linné, Erxleben, and Gmelin, based on the descriptions and figures of still earlier writers, especially those of Hernandez, Seba, Jonston, Brisson, Buffon, and Schreber. These compositions frequently embraced what, in the light of the present day, can be recognized as several widely diverse species, belonging not unfrequently to distinct families of animals. While some of the citations are still indeterminable with certainty, others may be readily identified. Erxleben's first citation under his vulpecula is "Yzquiepatl seu Vulpecula, quae Maitzinm torrefactum aemulator colore Hernand. Mex. p. 332 cum fig. mediocr.", which is apparently the "Ichneumon de Yzquiepatl, seu Vulpecula Americana, quæ eolore Maizium torrefactum æmulator" of Seba (Thesau. i, 1634,68 , pl. xlii, fig. 1), said to be "in America Quasjo vocatur" and "vivum ad Surinam." The description and figure indicate an animal having some resemblance to a Coati, but is as likely to have been a Raccoon, and is certainly indeterminable with certainty. With it are combined Brisson's "Le Blairean de Surinam," which is unquestionably a Nasua, and Buffon's "Le Coase" (Hist. Nat., xiii, pp. 288, 299, pl. xxxviịi), which is beyond doubt the Pekan or Fisher of "Virginie," the Mustela pennanti of moderu systematists, and (primarily) the Viverra vulpecula of Schreber, whieh Erxlebeu also quotes.

† Although varions writers eite a "Viverra quasje, Linn.", the name originated with Gmelin (Syst. Nat., i, 8i), whose first reference is: "V. castanea subtus flaveseens, naso 
Coati brun, Viverra narica, Linn.", to which he referred Buffon's "pl. 48" (the same plate is also referred to the preceding species!). 3. "Le Coati roux, Viverra nasua, Linn.", to which is referred Schreber's "pl. 118." In 1820 he made a still more thorough eonfusion of the species, of which he nominally. recognized two, under the names Nasua rufa and Nasua fusca. His N. rufa is F. Cuvier's "Coati roux" (Hist. des Mam., livr. i), which is merely a red phase of the common $V$. nasua of Linne, while his $N$. fusca is a composition of Linné's $V$. narica with Maregrave's "Coatimondi" (referred by Linné to his $V$. nasua), the Coati and Coati noirâtre of Buffon, and F. Cuvier's "Coati brun," which last is also referable to Linné's $V$. nasua.

F. Cuvier,* in 1817, nominally recognized two species, but really described only one, but confounded the synonyms of both. These are: 1 . "Coati roux; Viverra nasua Linn." In his description of this he correctly says: "le queue est annelée de noir et de fauve." 2. "Coati brun; Viverra narica, Buff., pll. 47-48." In his description of this he says: "le queue est annelée de noir et de jaune sale," and therefore it is not the Viverra narica of Linné. Furthermore, in eiting here both of Buffon's plates lxvii and lxviii, he confounds both of the Linnæan species under the name "Viverra narica," and fails altogether to recognize the true narica.

Desmoulins, in 1823, followed F. Cuvier in making two species, and while he adopted Linné's names he wrongly referred Schreber's plate exviii to Viverra nasua, and cites both of Buffon's plates Ixvii and lxviii under V. narica. Lesson, in 1827, simply followed Desmarest's nomenclature and determinations of 1820 .

F. Cuvier, in the first livraison of his "Histoire des Mammifères," published in 1818, figured the red phase of the Viverra nasua of Linne under the name "Le Coati roux," and in the fourth livraison (1819) of the same work figured a pale fulvous rariety and a pale brown rariety under the titles, respectively, of "Coati brun femelle, variéte fauve," and "Coati brun, femelle," and in the forty-eighth livraison (1825) figured still another variety under the name "Coati brun-foncé"; all of which are unquestionably referable to the Linnæan Viverra nasua.

In 1826, Prinz Maximilian published his "Beiträge zur Naturgeschichte von Brasilien," in which work he bestowed on Linne's Viverra nasua the name Nasua socialis, and added a* second species as "? 2. N. Solitaria," and further indicated 3. "? Nasua nocturna." He calls attention to the great variability in color that the Coatis present, referring to the fact that in the common Coati, known in systematic works as

producto, cauda annulata. Syst. Nat. X, p. 44." His second citation is: "Meles ex - saturate spadiceo nigricans, cau da fusca annulis flavicantibus quasi cincta. Briss.quadr. p. 185." Whether the first reference relates to Nasua or to Procyon is hard to determine, but the second is simply Brisson's "Blaireau de Surinam." "Quasje" is well known to be one of the native names applied to the Coatis in Surinam and some other parts of South America.

* Dict. des Sci. Nat., tome ix, 1817, p. 464. 
"Nasua rufa," or "Viverra nasua," he had found red, gray, and brownish indiriduals in the same family. He therefore held all these animals for a single species till he learned from hunters that there were two, of which one was small and slender, and associated in numerous companies, while the other was larger, less slender, and lived singly or in families; the first being termed by the natives "Cuati de Bando"; the second, "Cuati Mundéo." Of the last, he says he had seen only a single example, jet he believed in its existence in consequence of the reports of the Brazilian hunters. He also says he regards it as unwise to name the species in reference to their color, as, for example, "Nasua rufa and subfusca," but deems it better to bestow names in reference to their modes of life. He accordingly gires the name Nasua socialis to the "Cuati de Bando" of the natives, of which he met with many specimens, and of which he gives a detailed description. He says this is the common variety, which has been named Nasua rufa, and which is sometimes of a purer, sometimes of a more brownish red. His $N$. solitaria is the "Cuati Mundéo" of the Brazilians of the eastern coast, but he expresses doubt respecting its specific distinctness from his $N$. socialis. He describes the body as entirely yellowish ash-gray, darker on the back, pale yellowish-red below and yellowish-brown on the sides; tail very pale grayishred, annulated with blackish-brown. The single example seen by him, and which he describes, was an old male. Its larger size and stouter form, as compared with his $N$. socialis, described from female examples, as well as its different habits, have since been shown to be merely sexual or due to age. According to the Indians, this larger Coati (N. solitaria) agrees in habits with the other species, except that it lives singly or in families and is less social.

In commenting upon the general subject, he says it is certainly wrong to recognize three species of Coati, namely, "Nasua rufa, obfusca,* und nirica," as Eschwege has done, or four, by adding Geoffroy's Nasua

* Illiger is credited by Maximilian, Fischer, Gray, and others, with the names Nasua monde and Nasua obfusca, but neither of them gives references to the places of their oceurrence. Gray, however, incorrectly adds, "Prodromus," but neither of these names occurs in Illiger's "Prodromus," where he merely recognized two species under the Linnæan names of nasua and narica. In his "Verzeichniss der in Süd-Amerika vorkommenden. Gattungen und Arten," in his "Ueberblick der Säugthiere nach ihrer Vertheilung iiber die Welttheile".(Abhandl. Berlin. Akad. 1804-11), he enumerates eight "species" of Nasua as folloris: "Nasua Monde, minor, spadicea, Narica, Quasje?, Squash?, ? Cuja, ? canina," but gives only the following means of identifying the new names. In reference to them he says: "Die Arten [der Nasua], von ähnlicher Farbe und Bildung, sind bei den Schriftstellern sehr verwirrt. Ob Vulpecula, Quasje und Squash, wirklich selbständige Arten, oder nur junge Thiere andrer Arten sind, kann man nicht mit Sicherheit bestimmen. Ich rechne noch Mustela Cuja Molina und Gmelin, und Zimmermann's Koupara, den Canis sylvestris Scba Thesaur. I. Tab. 30. Fig. 1, zu dieser Gattung." The memoir in question abounds in similar instances of the multiplication of names without formal characterization, five South American "species" of Gulo, for example, being enumerated in the same connection. 
pusilla, * which he says is apparently a young animal. He adds: "Höchstens zwei Arten des eigentlichen Cuati kann man als in den von mir bereis'ten Gegenden einheimisch annehmen, wenn sie nicht auf eine reducirt werden miissen, die Farbe aber kann, meinen Becbachtungen zufolge, keine Species derselben bestimmen" (l. c., ii, p. 297). Finally, he concludes his article on the Coatis with an "Anmerkung;" in which he says he has imperfectly learned of another-animal which appears to belong to the group of Coatis, but which differs a little in its habits from the two species he has described. This is his "? Nasua nocturna, das Jupará oder nächtliche Cuati." The only skin he saw of this reputed animal, said to inhabit the great forests of the eastern coast of Brazil, was so imperfect that he was unable to determine certainly about the genus. It differed from the other described Coatis somewhat in color in being pale grayish-yellow above and pale yellowish-red below, and through the absence of color-rings on the tail, which was colored uniformly with the back. According to the Brazilian hunters, it lives during the day in holes in trees, and goes abroad only in the night, the hunters never seeing it in the daytime. It differs, he says, from the other Coatis, if indeed it really belongs with them, not only in its nocturnal habits, but in its soft, fine hair and uniformly colored ("ungefleckten") tail.

Wagner, $\uparrow$ in 1841 , united all the Coatis into one species, under the name Nasua socialis, but grouped his bibliographical references under the heads of two varieties, called respectively "var. rufa aut fulva," and "var. brunea." His view of the case may be best presented in his own words: "Die beiden Arten, welche aus dem gemeinen Cuati errichtet worden, sind weiter nichts als Farbenabänderungen, die sich, wie diess der Prinz von Neuwied und Rengger gezeigt haben, in einer und derselben Familie und in demselben Wurfe beisammen vorfinden, und weder vom Geschlecht, noch rom Alter, noch rom Klima bedingt sind."

Von Tschudi, a little later (1844-46), recognized five species in his "Fauna Peruana" (pp. 98-103), namely, the Nasua socialis and N. sotitaria of Maximilian, and three new ones. The latter are $N$. leucorhynchus, $N$. vittata, and $N$. montana. He gives only two as found in Peru-N. socialis, the usual or common species, and $N$. montana, known from a single specimen collected in the Peruvian Andes at an altitude of 8,000 feet above the sea. The $N$. leucorhynchus, von Tschudi states, is often brought by travellers from the interior of Brazil, but there is apparently good reason for questioning the correctness of the locality here assigned. Under this name is given a good description of Linné's Viverranaricathe first recognition of the species for nearly half a century, and the first

*A "Nasua Quasje, Geoffr. Collect. du Mus.", is eited also by Fischer, and Gray gives "Nasua quasie, Geoff. Mus. Paris"; but I cannot find that the name was ever published by Geoffroy.

† Schreber's Säugt., Suppl., ii, 1841, p. 165.

$\ddagger$ As synonyms of $N$. socialis he cites Fiverra "nasuta" and $\Gamma$. narica of Linne, and Nasua rufa and N. "rufina" of Desmarest. 
detailed description. The $N$. vittata was based on a melanistic specimen collected by the traveller Schomburgk in the interior of Guiana, to which is referred the black variety of Coati mentioned by his brother in the "Annals of Natural History" (vol.iv, p. 431). The N. montana is also a melanistic type, without the usual white spots about the eyes. Four of von Tschudi's species are thus referable to the Limnæan V.nasua, and one to the $V$. narica.

Gray, ${ }^{*}$ in 1843 , revived the Linnæan name narica, but, although he cites as the first synonym "Viverra narica, Limn.," all his other citations, and doubtless all his specimens, are referable to Linné's $V$. nasua. He recognized two species, the other being "Nasua rufa, Desm.," by which he evidently intended the Viverra nasua of Linné. In 1864, $\uparrow$ he formally reviewed the group of Coatis, recognizing three species, adding as new a "Nasua olivacea." He perpetuates the confusions of nomenclature and synonymy of his earlier notice, and, so far as ean be determined by his descriptions, his material is all referable to the single Linnæan species Viverra nasua. In 1866 $\ddagger$ he added still another nominal species under the name Nasua dorsalis. In 1869, in his "Catalogue of Car nivorous, Pachydermatous, and Edentate Mammalia in the British Museum" (pp. 238-241), he gives the four species he had previously recognized as follows: 1. Nasua rufa; 2. Nasua narica; 3. Nasua dorsalis; 4. Nasua olivacea. The references under $N$. rufa are all pertinent to the Viverra nasua of Linné; those under Nasua narica, except the first three ("Viverra Narica, Linn. S. N. i. p. 64; Schreb. Säugeth. t. 119 ; Ursus narica, Tab. Elém. p. 113, 1798"), and the "Nasua leucorypha [lege leucorhynchus] Tschudi, Arch. für Naturg.", are also all referable to the same species, as are his own $N$. dorsalis and $N$. olivacea. To judge by his descriptions, as well as by the localities given, his material is also all referable to Linné's Viverra nasua, as all his species are described as having annulated tails. It would be unsafe, however, to assume, that the Viverra narica was unrepresented in the material at his command. Respecting his $N$. rufa and $N$. narica he says: "I have examined with care a series of skulls which are said to have belonged to these two species, but have been unable to discover any characters by which the skulls belonging to one species ean be distinguished from those belonging to the other. ... If I had only two or three skulls, I might have perhaps seen differences which I might have regarded as distinctions ; but when a series of some twenty or more are examined, it is impossible to define any distinction." These suggestive remarks confirm me in the conclusion above expressed, that Gray had before him only skulls of Viverra nasuc, for he certainly could not have failed to distinguish the skulls, or eren the skins, of the true $V$.narica (Nasua leucorhynchus, von Tschudi) if he had had them.

Giebelફ in 1855, recognized two species, mamely, Nasua socialis and

* Cat. Mam. Brit. Mus., 1843, p. 74.

† Proc. Zoöl. Soc. London, 1864, pp. 701-792.

¥ Proc. Zoöl. Soc. Lond., 1866, p. 169, pl. xvii.

§ Säugethiere, pp. 749-751. 
Nasua solitaria. To the first he virtually referred all the species of previous authors except $N$. solitaria of Maximilian, which alone constitutes his second species. This, however, as Hensel has shown, unquestionably relates only to old males of the common species.

In 1860, Weinland described and figured* a species of Coati from Vera Cruz, Mexico, under the name Nasua solitaria var. mexicana. The specimen was taken when two months old, and transmitted alive to the Frankfort Zoölogical Garden, and when described and figured was already nearly five years old. Weinland's detailed description of its external characters and hisexcellent figure, drawn and colored from the living animal, form the first definite information recorded in reference to the Mexican Coati. The species, however, is wrongly referred to Prinz Maximilian's Nasua solitaria, and although the author in his general history of the subject refers to von Tschudi's Nasua leucorhynchus, he failed to perceive that the example he here describes represented that species as well as the old Linnæan Viverra narica.

De Saussure, in 1862, $\dagger$ recognized twó species from Mexico under the names Nasua socialis and Nasua solitaria, which, he suys, bear respectively the native names "Tejon de manada" and "Tejon solo." Both are referable to the Nasua leucorhynchus of von Tschudi (=Viverra narica, Linné). He seems to have made here the same mistake respecting the Coatis of Mexico that Prinz Maximilian made in reference to those of Brazil, namely, that of describing the old males as a distinct species, adopting for it Maximilian's name solitaria, and retaining the same author's name socialis for the younger males and females; but the two supposed species to which De Saussure gave these names are not the two so named by Maximilian.

V on Frantzius, in 1869, stated $\ddagger$ that the specimens collected by him in Costa Rica had been determined by Professor Peters to be the Nasua leucorhynchus of von Tschudi. He says that two species are recognized in Costa Rica under the names "Pisote solo" and "Pisote de manada," which are respectively the "einsame Rüsselbär" (Nasua solitaria, anct.) and the "gesellige Rüsselbär (N. socialis, auct.). But he says that all of the Costa Rican specimens that he had examined belonged to Nasua leucorhynchus, and he thinks it therefore probable that only this species occurs there, and that the so-called "geselligen Rüsselbären" are only the young and females of $N$. leucorhynchus, and not the $N$. socialis. Consequently he believes that $N$. leucorhynchus may be considered as the only representative of the genus in the Northern Tropies, and that $N$. socialis is restricted to the Southern Tropics. He further notes that the coloration of the Costa Rican species is very variable, the young being browner and the old animals more varied with blackish and white.

Hensel, in 1869, in his "Beiträge zur Kenntniss der Thierwelt Bra-

* Zoologische Garten, Jahrg. i, 1860, p. 189.

† Zoologische Garten, Jahrg. iii, 1862, pp. 53, 56.

$\ddagger$ Arch. für Naturg., 1869, i, pp. 292-294. 
siliens,"* in his account of the Brazilian Coati, claimed that Maximilian's Nasua solitaria (the "Coati mondeo" of the Brazilians) was based merely on old males of the common species. He refers to the great sexual differences these animals present in respect to habits, as being the basis of a grave error committed by zoölogists, and to certain climatic differences in color. He even goes so far as to say: "Ich glaube, dass es nur eine einzige Art, die Nasua socialis gibt, wenigstens enthalten die Beschreibungen anderer nichts, was sich nicht auch bei der genaunten Art vorfände."

In $1873, \dagger$ however, he recognized two spocies, namely, Nasua socialis and Nasua lencorhynchus. The first he had found so abundant in Southern Brazil that he collected of it not less than two hundred skulls, as well as many skeletons. He states that from the comparison of these skulls, as from observation of the animal in a state of nature, it appears that the old males live solitary, and have been accounted a different species under the name Nasua solitaria. The Brazilian hunters, he says, also distinguish it as "Coati monde" from the common "Coati de vara," but at the same time recognize very well their relationship. Among his aborementioned skulls were a considerable number of those of old hermits, or solitaires ("Einsiedlern"). At a particular time of life-that is to say, when the long canines begin to become worn-the old males leave the troops, of which, in company with the old and young females, they had hitherto formed a part, and afterward only run with them during the pairing season. One can tell, he says, with considerable certainty, by the skull, whether or not the animal had already left the troop. The males that run with the troops are, as shown by an examination of their skulls, not fully grown, so that size becomes a distinctive character of the old solitary males. It is difficult, he says, to find any difference in color between the two assumed species; and although he examined every example carefully, and with the object of finding two species, he was never able to find any color-differences. He further states that solitary females are never met with, unless, perhaps, they have been driven from the herd in hunting them.

He later refers to the fact that a considerable number of species hare been recognized, but adds that, with one exception, he has no judgment to render respecting them. In Rio de Janeiro he saw an example in confinement, which he thonght probably came from Bahia or Pernambuco, that was distinguishable by its reddish color. He thought it perhaps represented Desmarest's Nasua rufa, but to him it appeared to differ from the Southern Nasua only in its color, through the yellow being of a reddish tone. $\ddagger$

\footnotetext{
* Ibid., Jahrg. x, 1869, pp. 289-293.

+ "Beiträge zur Kenntniss der Süugethiere Süd-Brasiliens," Abhandl. Königl. Akad. Wissensch. zu Berlin, 1872, (1873), pp. 63-67.

$\ddagger$ In his former paper, in alluding to this subject, he says: "In Rio de Janeiro, in Bahia und Pernambuco sah ich gezähmte Coatis, an denen das Gell der Haare dunkler war und einen röthlichen Tou hatte, so dass der Farbenton des ganzen Thieres auch
} 
The second species he here admits is the Nasua leucorhynchus from Costa Rica, which, from a comparison of skulls sent him by Dr. von Frantzius, he found to be smaller* than $N$. socialis, the skull rounder, with the crests and ridges less developed, and the molar teeth thicker.

From the foregoing it will be seen that the two species of Coati owe their first introduction into systematic literature to Linné, who in turn derived them from Brisson and Buffon, by each of whom both were described at nearly the same date. It further appears that these species were properly defined (as far as they were then known) and clearly recognized by all the leading systematists, down to the early. part of the present century, and that confusion and obscurity originated with the French encyclopædists, the two species being similarly more or less involved at the hands of both Desmarest and F. Cuvier in the jear 1817, and that malidentification and confusion of synonymy have since been the rule. It furthermore appears that the Limnæan name narica, when used at all. has, since that date, covered only color-variations of the Linnæan nasua, and that the true narica of Linne finally became again specifically distinguished in the leucorhynchus of ron Tschudi, and is at last currently recognized under that name as the second and only other valid species of the genus Nasua.

These two species may be briefly diagnosed as follows:

Common Characters. - Nose produced, terminating in a bald, cartilaginous snout; tail nearly as long as the body. Skull narrow, long, the frontal region elevated; palate prolonged backward; postorbital processes rudimentary in youth, well developed in old age; sagittal and occipital crests strongly developed in the males in old age, but the former permanently obsolete in the females. Incisors $\frac{3-3}{3-3}$, of moderate size, the outer upper separated from the others, and placed more posteriorly; canines $\frac{1-1}{1-1}$, all curved outward, greatly developed in the males, of moderate size in the females; the upper laterally compressed with cutting edges; the lower rather larger and subtriangular, with a deep longitudinal groove on the inner anterior border; premolars $\frac{3-3}{3-3} ;$ molars $\frac{3-3}{3-3}$. A small white spot abovo, another below the eye, and a third on the cheek ........... Genus Nasua Storr.

Differential Characters.-1. Nose and edge of upper lip white, in strong contrast with the dark brown of the cheeks and facial region; tail concolor with the back, or with obsolete half-rings on the lower surface of the basal half. Pelage long, soft, the long hairs of the dorsal surface tipped with rufous, fulvous, or whitish. Hinder portion of the palate angularly depressed medially...narica.

2. Nose and upper lip gray, uniform in color with the cheeks and facial region; tail conspicuously annulated with about 7 to 9 rather broad fulvous or rufous rings, alternating with dusky or black ones. Pelage generally short, harsh, shining, the long hairs of the dorsal surface usually black-tipped. Size smaller and nasal region of the skull narrower than in the preceding; palatal region also narrower, with its posterior portion flat-not sharply depressed in the middle, as in the preceding. Ears also rather longer and more pointed ......rufa.

etwas röthlich war; allein im Uebrigen glichen sie ganz den Coatis des Südens und könnten höchstens als klimatische Farbenvarietät betrachtet werden."-Loc. cit., p. 291.

* His Costa Rican specimens, as shown by his descriptions and measurements of them, were not fully grown, which accounts for his statement that the Costa Rican species is smaller, it being in reality larger. 


\section{NASUA NARICA, (Limné) Illiger.}

\section{Mexican CoAti.}

Le Coati-Mondi, Brisson, Reg. Anim., 1756, 262.

Coati brun, Buffos, Hist. Nat., viii, 1760, pl. xlviii.

Viverra narica, Lixvé, Syst. Nat., i, 1765, 64. Based entirely on Buffon, as above.SCHreber, Sängth., iii [17\%6?], p. 438, pl. cxix (fig. from Buffon).-EnxlebeN, Syst. Reg. Anim., 1777, 486.-Zimmermaxy, Geogr. Gesch., ii, 1780, 291.Gmelin, Syst. Nat., i, 1788, 85.-Shaw, Gen. Zoöl., i, 1800, 385 (given as a "var.?").-Desmarest, Nouv. Dict. d'Hist. Nat., vii, 1817, 219.

Crsus narica, G. Cuvier, Tabl. Élém. d'Hist. Nat., 1798, 113.

?: Nasua nocturna, Maximiliax, Beitr. Naturges. Bras., ii, 1826, 298.

Nasua leucorhynchus, vox TschUdi, Fauna Peruana, 1844-46, 100.-Fraxtzius, Arch.

für Naturg., 1869, 292.-Dugés, La Naturaleza, i, 1869, 137.-Hrissel, Ab.

handl. Königl. Akad. Wissens. Berlin, 1872, (1873), 65.

Nasua socialis var. fusca, Fischer, Synop. Mam., 1829, 149.

Nasua socialis var. brunea, WAGNER, Suppl. Schreber's Säugth., ii, 1841, 165.

Nasua socialis, De SAussure, Zoologische Gartén, Jahrg. iii, 1862, 53.

Nasua solitaria var. mexicana, Wenvlaxd, Zoologische Garten, Jahrg. i, No.11, Aug. 1860, 191, with a colored plate from life.-DE SAUssure, Zoologische Garten, Jahrg. iii, No. 2, Feb. 1862, 27 (habits), 54 (external characters).

Nasua solitaria, De SAussure, Zoologische Garten, Jahrg. iii, 1862, 54.

Bassaricyon gabbii, Allen, Proc. Acad. Nat. Sci. Pliila., 187\%, 267, pl. ii, animal (not Bassaricyon gabbii, Allen, ibid., 1876, 20, pl. i, skull).

External Characters.-Nose, edge of upper lip, a spot below the eye, another above the eye, and a small spot on the cheek, white; a white line, more or less distinct, usually connects the white spot above the eye with the white nasal area; rest of the facial portion of the head blackish-brown; forehead, sides and top of the head, hind neck, and a triangular area over the shoulders, lighter brown, varying in different specimens, however, from dark brown to yellowish-brown, or even deep golden. In many specimens this more or less fulvous area has well-defined outlines, and terminates posteriorly in a triangular extension reaching nearly to the middle of the back; in others, it is less well defined, and has a more restricted extension posteriorly. The ears are broadly margined with whitish, with long brown hair externally at the base, which in winter pelage forms overhanging tufts that nearly cover the ears. The general color of the rest of the dorsal surface is dark brown, becoming darker posteriorly, and varying in different specimens from fulvous to blackishbrown, with the tips of the long hairs lighter and lustrous, varying in different specimens from nut-brown through fulvous to pale yellowish-white or silvery. The color of the tail is nearly uniform with that of the hind portion of the back, with the distal third darker or blackish. Faint annulations are often observable, on close inspection, particularly on the basal two. thirds of the lower surface, but they are apparently never conspicnous in the adults, and frequently specimens occur in which no traces of annulations can be detected. They appear to be more prominent in very young specimens than in those that are full grown, and to become obsolete in old age. They are, however, sometimes entirely absent in the young. Sirles of the 
neck whitish, varying from fulvons-white to silvery, this color usually extending over the fore-limbs as far as the elbow, and posteriorly along the sides of the borly; on the sides of the neck it often forms a welldefined patch extending upward to the ear. The thighs are also more or less whitish. Distal portions of the limbs dark brown, passing into blackish on the feet. Chin, to beyond the symphysis of the jaw, pure white; throat, breast, and anterior half of the ventral surface, whitish or grayish-white, more or less obscured by the brown of the basal portions of the hairs. The pure white of the chin is usually separated from the grayish-white of the throat by a dusky band, formed by the extension and confluence of the dark brown of the cheeks; this, however, is an extremely variable feature, being sometimes wholly absent, often indistinct, but sometimes very broad and prominent. The color of the ventral surface is variable, being sometimes wholly silvery, or grayish-white, or entirely dusky, with no whitish anywhere gn the lower surface except on the chin and a patch of dingy or yellowish-white on the throat and breast. Usually the anterior half of the ventral surface is more or less whitish, through which the fuscous bases of the hairs show, the whitish surfacecolor being formed by the white tips of the hairs. A similar whitish or yellowish-white tint is seen over the inguinal region. On the chin, the hairs are short and white to the base; on the rest of the lower surface they are dusky at base and whitish at the tips, resulting usually in the production of a dingy gray.

The pelage is full, long, and soft, and the tail full and bushy. The hairs composing the whitish patches on the sides of the neck are usually longer than those of the adjoining parts.

Judging by the specimens in hand, there are no sexual differences in color, one of the darkest specimens of the series being a female.

In very young specimens, the pelage is softer and more woolly, with the look of immaturity usually characteristic of young animals. They show, however, the same facial markings as the adults. The annulations of the tail appear to be generully more strongly marked in the young, being, in some cases, quite conspicuous, but are sometimes entirely absent.

A series of fourteen skins from various parts of Mexico and Central America presents a wide range of individual variation in color, but not greater than most mammals present, and not nearly so great as is seen in Nasua fusca. There seems, also, to be a recognizable amount of geographical variation, the Mexican specimens being much lighter-colored than those from Guatemala and Costa Rica. The lightest-colored specimen of all comes from the Texan side of the Rio Grande, near Fort Brown. In this example (Nat. Mus., No. 12757, Dr. J. C. Merrill), the general aspect of the dorsal surface is yellowish-gray, with a large, whitish area on the sides of the neck, and much white along the sides of the body; below, strongly whitish throughout. The white eye-markings do not quite form a continuous ring, but the spot above the eye has a whitish band connecting it with the white nasal area. The pelage is 
very long' and 'full, and the fulvous under-color of the dorsal surface shows strongly through the light tips of the long hairs.

A Mazatlan specimen (Nat. Mus., No. 9068, T. Bischoff) lias the top of the head, back of the neck, and a long, triangular area over the shoulders, deep yellowish-brown or golden, and the whole upper surface is strongly fulvous, through the long hairs being tipped with this color. The white area on the nose is very broad; the two white eye-spots form a very broad, continuous ring around the eye, which is connected with the white nose-patch by a prominent stripe of the same color. The breadth of the white eye-ring above the eye is $15 \mathrm{~mm}$. The white of the chin, throat, and breast forms a continuous area, and is of unusual purity. In rery farorable lights, about four or five indistinct rings ean be traced in the basal two-thirds of the tail; but on casual inspection the tail would be pronounced unicolor with the back, except that it has a blackish tip. A Colima (Mexico) specimen (Nat. Mus., No. 7228, John Xantus) presents the same general appearance as the Mazatlan specimen, except that the golden on the hind-head, nape, and shoulders has a more restricted area. The white on the nose is also much reduced, and the white about the eye only forms two small, wholly separated spots, the upper of which is connected with the white of the nasal region by a narrow, half-obliterated line. A specimen from Pacuare, Costa Rica (Nat. Mus., No. 12878, Jose C. Zeledon), has the face-markings nearly as in the Mazatlan specimen, but the ocular ring is interrupted at the posterior eanthus of the eye. The yellow area of the nape and neighboring parts is less well defined than in either of the preceding, and has a redder east. The dorsal surface, particularly posteriorly, is much darker, and the light tippings of the hairs are silvery on the sides, and rufous or reddish-brown over the shoulders and middle of the back. In other words, the specimen is much darker. The tail has obsolete rings and a dark tip, as in the others.

A specimen from Central Guatemala (Nat. Mus., No. 8622, Henry Hagne), in general features greatly resembles the last, but the brown of the face is darker and the white markings more restricted, the eye-spots being small, widely separated, and wholly cut off from the white area on the nose. The posterior lialf of the dorsal surface and the tail are much darker (blackish-brown), but the sides of the body, from the head to the middle of the body, have the long hairs tipped for nearly half their length with silvery white, tinged more or less with yellow. A specimen from Talamanca, Costa Rica (Nat. Mus., No. 12197, José Zele(lon), in much worn pelage, is very dark throughout, and, apparently owing to the wearing-off of the ends of the long hairs, shows none of the usual light tippings. This specimen is the darkest of the series: it shows trace of annulation in the tail. A specimen from Mexico (Nat. Mus., No. 7230, labelled "Nasua leucorhynchus, Tsehudi, Mexique, Maison Verreatix") is deep blackish-brown throughout, the long hairs slightly tipped with light-yellowish over the shoulders, passing into silvery on the sides of the shoulders. Sides of the neck with a small area of white, 
over which the hairs are conspicnously lengthened; throat and fore limbs externally whitish; hind limbs nearly black, the loug hairs lustrous black. The white face-markings are greatly restricted, the eyespots being very small, and the white nasal area greatly reduced. The whole lower surface of the head posterior to the mandibular symphysis is deep blackish-brown, within which, just behind the oral angle, is a small white spot, enclosing the mandibular tuft of whiskers. This example (in full winter pelage) is a female that had apparently suckled young the previous year. In general appearance, the coloration in this example is similar to that of a melanistic Woodchuck (Arctomys monax). There is no white anywhere on the ventral surface, except on the chin, and a sprinkling of yellowish-white hairs on the throat. Another specimen from Las Cruces de Candelaria, Costa Rica (Nat. Mus., No. 9069, José Zeledon), collected during Dr. von Frantzius's explorations in Costa Rica, also in full winter pelage, is quite similar to the last, but has rather more white on the face, and less white on the sides of the neck and fore limbs, and the white on the lower surface is continuous from the point of the chin to the middle of the body, with no cross-band of brown across the posterior part of the lower jaw. There is no trace of annulations in the tail.

Another specimen from Costa Rica (Nat. Mus., No. 11405, J. Carmiol) differs remarkably from all the others. It is little more than half-grown, but the long hairs are worn off from the sides of the borly posteriorly, and the pelage generally has a much worn aspect. In this specimen, the whole head is pale fulvous, including the parts usually white, but the usual face-marking can be dimly traced. The general color of the body is dark fulvous, lighter on the more worn parts. Orer the shoulders and along the middle of the back, where the long hairs are intact, the color is darker, approaching chestnut, with short rusty tips to the long hairs. This example seems to represent in this species the red phase of Nasua rufa.

There are also in the collection two young specimens, apparently not more than two to three months old. One is from Tehuantepec (Nat. Mus., No. 9375, Prof. F. Sumichrast); the other from Belize (M. C. Z., No. $5 \tilde{5} 42$, Dr. H. Berendt). They present a general aspect of immaturity in the texture of the pelage and in the rather darker tone of the under color; but they have the same general markings as the adults, the facial pictura being the same, and the long hairs of the pelage being similarly tipped with yellowish. The tail is, howerer, more distinctly annulated, the annulations in the 'Tehuantepec specimen being very prominent. The hair on the tail is also rather short and woolly.

A still younger specimen from Jalapa, Mexico (M. C. Z., No. 2630, -Montes-de-Oca), less than nine inches long (head and body), and probably not more than two or three weeks old, differs from those last described in having the whole dorsal surface nearly uniform brownish- 
black; in the pelage being wholly soft and woolly, the long lightertipped hairs having not yet appeared. The sides of the neck and the whole lower surface are uniform grayish-white, with no separating band cutting off the white of the chin from that of the throat. Lower surface of the tail for two inches at the base yellowish-white, crossed distally by two dark bars. In other respects, the tail is colored uniformly with the back, and shows no other trace of annulations. It consequently appears that in very young individuals the tail may be either entirely without annulations or have them quite conspicuous. The face presents the maximum extension of white, and agrees exactly with the very whitefaced adult example from Mazatlan already described.

In the series of specimens above described there is a complete intergradation from the light grayish fulvous example from the Lower Rio Grande to the blackish-brown specimens from Central America, though simply an increased intensity southward in the coloration. At the same time, there is a wide range of purely individual variation in the size of the white face-marks, and especially in the coloration of the lower surface of the anterior half of the body. As previously stated, there appear to be no well-marked sexual differences of color.

SKuLL.-A series of six adult skulls of this species (four males and two females), and three others from half-grown examples, shows that the skull varies greatly with age and sex. None of the male skulls are very old, the molar teeth being unworn, while one of the female skulls has the tubercles of the molars wholly worn away. Yet in this last the sagittal crest is wholly undeveloped, while the middle-aged males have welldeveloped crests, varying from 5 to $11 \mathrm{~mm}$. in height. The male skulls are also larger, with much larger canines and more heavily developed and more widely spreading zygomata. The male skulls vary considerably in size, the smallest having a length (from front edge of intermaxillæ to posterior border of occipital condyles) of $119 \mathrm{~mm}$. and a breadth (at the point of greatest expansion of zygomata) of $77 \mathrm{~mm}$., against, respectively, $138 \mathrm{~mm}$. and $81 \mathrm{~mm}$. in the largest. The largest (but not the oldest) female skull has a length of $123 \mathrm{~mm}$. and a width of $65 \mathrm{~mm}$., showing that as regards the length of the skull some of the fernales exceed in size somę of the males. The average of four male skulls, however, gives a length of $129 \mathrm{~mm}$. and a width of $79 \mathrm{~mm}$., against, respectively, $122 \mathrm{~mm}$. and $63 \mathrm{~mm}$. for the two female skulls. In the females, in addition to the very much smaller size of the canines and the entire absence of a sagittal crest, the zygomatic arches are much weaker and much less widely divergent.

General History and Srnonyry.-As already stated in the general history of the subject, the present species was described by Brisson in $\mathbf{1 7 5 6}$ under the name "Le Coati-Mondi," and was redescribed and figured by Buffon in 1760 as "Le Coati brun." On the latter was exclusirely based Linnés Viverra narica. Although the habitat of the specimens described is not stated by either of these anthors, and was 
probably unknown to them,* Buffon's figure, as well as his and Brisson's descriptions, leare no reasonable doubt that the name narica was based on the Mexican Coati.t By writers of the first quarter of the present century, the present species was virtually lost sight of, for, although the name narica was more or less generally retained, it was applied to a nominal species referable to the Linnxean Viverra nasua. Fischer, while referring all the Coatis to one species, for which he adopted Maximilian's name Nasua socialis, wisely separated the references to the two valid species under the varietal names rufa and fusca, and under these heads made a judicious allocation of the synonyms of the group. The first possible synonym is the "? Nasua nocturna" of Maximilian (1826), based on an imperfect skin and the reports of the native hunters. He says the tail shows no color-rings, but has the same mingling of tints as the upper part of the body. $\neq$ It has, however, the matter of locality against it, as well as the "fahl gelbröthliche Farbe" of the lower parts. He refers especially to its soft thick pelage, which corresponds well enough with that of the present species, but it may not be a Nasua at all, as he was himself in doubt as to whether it was really this genus, and as no subsequent explorer appears to have met with a Nasua in Eastern Brazil having the tail colored uniformly with the back.

Von Tschudi, however, in 1844-46, described a Nasua lencorhynchus which good authorities have since identified with the Mexican Coati. His diagnosis ("N. rostro albo, cauda corporis longitudine, concolore in adultis"), as well as his whole description, relates unquestionably to this form, which alone can be described as having a white nose and unicolored tail. He appears to have based his excellent description of the species upon an examination of quite a number of examples, as he alludes distinctly to young as well as adult specimens, and refers to various features of individual variation, and evinces a thorough knowledge of the species. He gives its habitat as the interior of Brazil, remark-

*Brisson says of his specimen, "Je l'ai vâ chez M. Lievre Distillateur," without offering even a conjecture as to the country whence it eame. Buffon simply tells us that the original of his Coati, figured in pl. xlvii, and of which is given a detailed account of the anatomy as well as a figure of the skeleton (in pl. xlix), is a speeimen he had had alive, and that he had seen another Coati, of which he also gives a description and figures (pl. xlviii) as "Le Coati brun," without informing us whence either was obtained. The last is unquestionably the Mexican Coati.

†This species appears to have been thoronghly well known to Schreber, as his whole account most emphatically shows, in evidence of which, but especially from its historic interest, I transcribe the following from his account of $V$. narica: "Die Schnauze, Lippen und Kehle weislich. . . . Der Kopf, Hals und Leib graubraun; so anch der Schwanz, der, besonders unterwarts, undeutliche dunklere Ringe hat; die untere Seite des Halses, die Schultern, Brust und der Bauch weislich; der Ranm zwischen den Hinterschenkeln fast gelb. Jedes Haar ist in der Mitte schwarz, an der Spitze gelbbraun. . . . Das Vaterland ist südliche Amerika. . . . Nach Europa lï̈mnt es weit seltener, als das rothe [ ${ }^{\text {. nasua }] . "-S a ̈ u g t ., ~ T h . ~ i i i, ~ p . ~} 433$.

$\ddagger$ "Der Schwanz zeigt keine farblichen Ringe, sondern ist von derselben Mischung wie die oberen Theile des Körpers." 
ing: "Das Innere von Brasilien nährt diese dritte Species von Nasua, von wo sie von mehreren Reisenden nach Europa zuriick gebracht worden ist." He thus evidently knew the species only through museum specimens or living examples seen by him in European eities, and as no writer appears to have yet given any other authority for its occurrence in Brazil, from which country it is still otherwise .unknown,* the locality here assigned for the species may be fairly considered as open to question. $\dagger$

Weinland, in 1860, was the first recent writer to describe and figure the Mexican Coati, but he regarded it as specifically identical with the South American species, of which he made it a variety, ealling it Nasua solitaria var. mexicana. De Saussure, two years later, distinguished two species of Mexican Coati, adopting for them Maximilian's names Nasua solitaria and Naisua socialis, neither of which names have any relation to the Mexican animal. His detailed descriptions and comparison of two specimens, one in winter pelage and the other presumed by him to be in summer pelage, show that his two species were based merely on characters of individual variation, the one referring to the light phase and the other to the dark phase of the species.t Later Dr. von Frant-

\footnotetext{
* Schreber, however, should perhaps be excepted, as he says the habitat of $T$. narica is "südliche Amerika," but which may or may not mean South America.

†Dr. Günther, in the "Zoölogical Record" for 1869 (p. 17), appears to accredit tho species to Peru, as he says "Nasua leucorhynchus from Peru occurs also in Costa Rica," etc., but $I$ have yet to meet with any authority for its occurrence in Peru.

$\ddagger$ I append herewith a translation of De Saussure's remarks respecting the question of whether one or two species exist in Mexico.

"In Mexico," he says, "the same view prevails among the natives respecting the question of the existence of two species of Coati as in South America. They are distinguished by the names solituria and socialis (Tejo solo and Tejo de mannada) given by Prinz von Neuwied in his Fauna of Brazil.
}

"Whether this discrimination is arbitrary and rests upon error, as the majority of authors appear to accept, or is well founded, will be here more closely examined.

"I will first mention that the Coatis of Mexico appear to me to be entirely identical with those of Brazil, and in order to compare the two types I suljoin detailed descriptions.

"Nasua solitaria is larger, of a darker color, than socialis, but still pretty similar to it, and for this reason they are united, being regarded as merely variations of age, the species solitaria as old males, which seclude themselves from the small troops in which N. socialis live, as do the old deer, wild boars, and elephants. I myself long shared this opinion, but a thorough investigation of the matter induced me to entirely change iny view.

"The principal reasons which to me appear to indicate the propriety of separating the two species are the following:

"First of all, Nasua solitaria is by no means searce, though difficult to obtain, as are usually the old male swine. They are as often killed as socialis, which cirenmstance entirely removes the suspicion that solitaria is nothing but old males, which become solitaria when they leave the younger animals, or at least from their second or third year. Finally, I have seen in Mexico the self-same Nasua which has been described and figured from life. This individual belonged to Dr. Müller, whom I fortunately happened to meet in Mexico, and whose Coati I directly conpared with those which I had living in my possession. Although all these Coatis at that time were young, and therefore far from 
zius (in 1869, on the identification of Dr. Peters) and Hensel (1873) recognized the Mexican Coati as specifically distinct from the common South American species, adopting for it Maximilian's name leucorhynchus. This name, however, is antedated by the Linnzan naine narica, which must take precedence for the species.

In addition to the above complication of synonymy, I had the mortifying misfortune, in 1877, to add another, by describing and figuring a skin under the name Bassaricyon gabbii,* supposing it at the time to be the skin belonging to the skull previously figured and described by met under that name. Without going into details respecting the attenuating circumstance of the case, or how I was led into such an egregious blunder, I will merely state that the skin described and figured as that of Bassclricyon gabbii, as above cited, has nothing whatever to do with that species, but is simply the Mexican Coati, Nasua narica, and that the external characters of the true Bassaricyon gabbii remain still wholly unknown.

Geographical Distribution.-The first recent mention of the Coati as an inhabitant of Mexico appears, as previously noted, to have been made by Dr. Weinland in 1860, who states, on the authority of Dr. Muiller, that it is common over the whole of the eastern slope of the high tablelands, or "Terra templada," but does not occur in the "Terra calienta" of the coast region. He adds that, notwithstanding this, he finds no previons mention of its occurrence. De Saussure, in 1862, endorses Dr. Weinland's statement that previous writers had made no mention of the occurrence of the Coati in Mexico, although, he says, it is one of the commonest mammals of that country. Tomes, in 1861, gives Nasua fusca in the list of mammals collected in Guatemala by Mr. Salvin, but without comment. Dr. von Frantzius, in 1869, refers to Nasua leucorhynchus as of common occurrence in Costa Rica. These are the only references to its distribution $\mathrm{I}$ have met with that I consider as of unquestionable authenticity. As already stated, owing to the absence of all reference to the occurrence, in South America, of a species of Coati with a white nose and unicolored tail, except von Tschudi's statement that his $N$. leucorhynchus

being fully developed, we found them still very different. 'Dr. Müller's (now in the Zoölogical Garden of Frankfort) had already all of the characters of $N$. solitaria, while mine, on the contrary, belonged to the type of $N$. socialis, which sufficiently showed that the differences are not merely those of age.

"To show what they are the following descriptions of both types are given, based on many individuals, either stuffed or in skins, which I brought from Mexico."-Zoologische Garten, Jahrgang iii, 1862, pp. 52-53.

Very detailed descriptions of both species then follow, from which it appears that his "N. socialis" is merely the lighter-colored and his "N. solitaria" the darker phase of the common $N$. narica; and, furthermore, that M. De Sanssure could not have been very familiar with the characters of the Brazilian species. I will here observe that in all probability the "Tejo solo" of the Mexicans, like the "Pisote solo" of the Costa Ricans, and the "Coati mondeo" of the Brazilians, as shown by von Frantzius and Hensel, was given to the old solitary males.

* Proc. Acall. Nat. Sci. Phila., 1877, p. 267, pl. ii.

tProc. Acarl. Nat. Sci. Phila., 1876. p. 20, pl. i.

Bull. v, 2-2 
inhabits the interior of Brazil, I deem it probable that the assigned locality of the latter is erromeous, and that his specimens really came from Mexico or Central America.

My own material indicates that the range of this species extends from the Isthmus of Panama northward throughout Central America and the greater part of Mexico, as far northward on the eastern coast as the Texas side of the Lower Rio Grande, and on the western coast probably north ward nearly to California. I have specimens, however, from that coast only from as far north as Colima and Mazatlan.

Nasua narica appears hence to prevail from the Isthmus of Panama northward throughout Central America and the warmer parts of Mexico, where it also seems to be the sole representative of the genus.

\section{NASUA RUFA, Desmarest.}

\section{Brazilian Coati.}

Coati, MarcGrave, Hist. Nat. Brasil., 1648, 228.

Coati, Vamont de Bomarre, Dict. Rais. Univ. d'Hist. Nat., ii, 1775, 596.

Le Blaireau de Surinam,-Meles surinamensis, Brisson, Reg. Anim., 1756, 255.

Quasje, Schreber, Säugt., iii [1766 ?], 441 (=Meles surinamensis, Brisson).

Le Coati-Mondi à queue annelée, Brissox, Reg. Anim., 1756, 263.

Coati noirâtre, BuFfos, Hist. Nat., viii, 1760, 358, pl. xlvii.

Viverra nasua, LrNve, Syst. Nat., i, 1766, 64. Based entirely on Maregrave's "Coati" and Brisson's "Coati-Mondi à queue annelee."-SCHrEBer, Sïugth., iii [1776 ?], 435, pl. cxviii (fig. from Buffou).-Erxleben, Syst. Reg. Anim., 1777, 485.Zimmermann, Geogr. Gesch., ii, 1780, 290.-Gmelin, Syst. Nat., i, 1788, 86.Shaw, Gen. Zö̈l., i, 1800, 386.-F. Cuvier, Dict. des Sci. Nat., ix, 1817, 464.Desmarest, Nouv. Dict. d'Hist. Nat., vii, 1817, 219.-Desmounaxs, Dict. Class. d'Hist. Nat., iv, 1823, 146.

Crsus nasua, G. Cuvier, Tabl. Elém. d'Hist. Nat., 1798, 113.

Fiverra vulpecula, ERxLEBEx, Syst. Anim., 1777, 490 (in part, as it includes "Lo Blaireau de Surinam, Meles surinamensis," Brisson; not Viverra vulpecula, Schreber, which is primarily Buffon's "Le Coase"=Mustela pennanti).

Viverra quasje, GMelis, Syst. Nat., i, 1788, 87 (in part).

Nasua quasje, Desmarest, Nouv. Dict. d'Hist. Nat., vii, 1817, 217 (certainly in part, as it includes Buffon's "Coati noirâtre").

Viverra narica, F. Cuvier, Dict. des Sci. Nat., ix, 1817, 464 (not of Linne).-DesmouLINs, Dict. Class. des Sci. Nat., iv, 1823, 246.(mainly).

Nasua narica, GraY, Cat. Mam. Brit. Mus., 1843, 74 (in part); Proc. Zoöl. Soc. London, 1864, 702 (in part only); Cat. Carn., Pachy., and Edent. Mam. Brit. Mus., 1869, 239 (excluding part of the synonyms). Not Viverra narica, Linn6.

Quachi, Valmont dE Bomarre, Dict. Rais. Univ. d'Hist. Nat., iv, 1775, 577.

Coati roux, F. Cuvier, Hist. Nat. des Mam., livr. i, 1818.

Nasua rufa, Desmarest, Mam., 1820, 170 (based on the "Quachi" of Bomarre and "Couti roux" of F. Cuvier as above, but mainly on the latter).-LEssos, Man. de Mam., 1827, 139.-GraY, Cat. Mam, Brit. Mus., 1843, 74 (in part only); Proc. Zoül. Soc. Lond., 1864, 701 (in part only); Cat. Carn., Pachy., and Edent. Mam. Brit. Mus., 1869, 239.

Nasua fusca,Desmarest, Mam., 1820, 170.-Lesson, Man. de Mam., 1827, 139 (mainly).Schomburgk, Ann. Nat. Hist., iv, 1839, 431 (habits).

Tamandua, Buffov, Hist. Nat., Suppl., iii, 1776, 284, pl. lvi (based on a Coati said by Cuvier to have been artificially colored). 
Myrmecophaga striata, SirAw, Gen. Zoöl., i, 1800, 51 (=Buffon's "Tamandua" as abore). "Myrmecophaga, Krusenstern, Voy. autour du Monde."

Myrmecophaga annulata, Desmarest, Mam., 1822, 374 (=Myrmecophaga, Krusenstern, as above).

Tamandua, annulated var.?-Myrmecophaga tetradactyla, L. ?, Grifrith's Cuvier's Anim. Kingd., iii, 1827, 305, pl. (original figure from a stuffed specimen*).

Nasua socialis, Maximiliax, Beitr. Naturg. Bras., ii, 1826, 283.-Schinz, Nat. u. Abbild. d. Süugt., 1826, 110, pl. xxxiii (from nature).-VoN Tschudr, Fauna Peruaua, 1844-46, 98.-Burmeister, Syst. Uebers. der Thiere Brasil., 1854, i, 120 (excluding from synonymy Viverra narica, Linn.).-GIEBEL, Sängeth., 1855, 750 (in part only; includes Viverra nasua, V. norica, Linn., V. quasje, Gmel., Nasua rufa and fusca, Desm., $N$. leucorhynchus, von Tschudi, etc.).-Werndand, Zoologisohe Garten, 1860, 61.-Hexsex, Zoologische Garten, 1869, 290 (habits, the chase, individual and climatic variations, etc.); Abhandl. König. Akad. Wissens. Berlin, 1872, (1873), 63.

Nasua socialis var. rufa, Frscher, Synop. Mam., 1329, 148.

Nasua socialis var. rufa aut fulva, WAGNer, Suppl. Schreber's Sïugth., ii, 1841, 165.

Nasua solitaria, Maximliax, Beitr. Naturg. Bras., ii, 1826, 292 (old males).-Fischer, Synop. Mam., 1829, 149.-VoN Tschudr, Fauna Peruana, 1844-46, 99.-BurMErster, System. Uebers. der Thiere Bras., 1854, i, 121.-Grebex, Säugeth., 1855, 751. (These notices are all of them compiled, and are based on Maximilian's description of the single original specimen, namely, an old male of the common Coati.)-Schmid, Zoologische Garten, Jahrg. iii, No. 2, Feb. $1862,32$.

Nasua vittata, voN Tschudr, Fauna Peruana, 1844-46, 101.

Nasua montana, von Tschudr, Fauna Peruana, 1844-46, 102, pl. v.

Nasua olivacea, Gray, Proc. Zoöl. Soc. Lond., 1864, 703; Cat. Carn., Pachy., and Edent. Mam. Brit. Mus., 1869, 241.

Nasua dorsalis, Gray, Proc. Zoöl. Soc. Lond., 1866, 169, pl. xvii ; Cat. Carn., Pachy., and Edent. Mam. Brit. Mus., 1869, 240.

"Le Coati Mondi, Perrault, Anim., ii [about 1668], 15, pl. xxxvi." See "Mém. Acad. Roy. des Sci., dep. 1666-1699," probably tome ii.

Brazilian Weesel, Pennant, Syn. Quad., 1771, 229; Hist. Quad., ii, 1793, 61 (in part only).

Cuati, AzAra, Hist. Nat. Quad. Paraguay, i, 1802, 293.

Coati roux, mâle, F. Cuvier, Hist. Nat. des Mam., livr. i, 1818.

Coati brun, femelle, F. Cuvier, Hist. Nat. des Mam., livr. iv, 1819.

* Dr. Gray says (Proc. Zoöl. Soc. Lond., 1864, p. 701), "Mr.Turner (P. Z. S., 1851, p. 218) professes to have rediscovered the fact (though it is stated in the 'Catalogue of the Mammalia in the British Mnsium,' p. 74, 1843), that Krnsenstern's M. annulata is only a Coati-Mondi; but he is puzzled to explain the figure in Griffith's 'Animal Kingdom.' This figure is engraved from a drawing of Major Hamilton Smith's, no doubt copied from Krusenstern's figure, but altered and improved, as was his habit when making his very large collection of drawings-a bad habit, that has rendered them of comparatively small value for scientific purposes, as it is impossible to determine whether they are from a figure or a specimen."

In reference to the line I have italicised in the above passage, I quote the following from the text (1. c., pp. 305, 306) accompanying Hamilton Smith's figure: "The figure we have engraved, under the title of the Tamandua annulated variety? seems likely to be the same as that indicated by the circumnavigator [Krusensteru], differing principally in the absence of the dark spot round the eye. This was also drawn [like the plate preceding the one in question] from a stuffed specimen, and is subject to the same observations as to the position of all the feet as that last mentioned ["Ursine Anteater"]." 
Coati brun, femelle, variéte, F. Cuvrer, Hist. Nat. des Mam., livr. iv, 1819.

Coati brun-foncé, F. Cuvier, Hist. Nat. des Mam., livr. xlviii, 1825.

Coati de Bando of the Brazilians.

Coati mundeo (old males), ibid.

Gescllschaftliches Cuati, Maximulax, l. e.

Einsames oder grösstes Cuati (old males), ibiđ̄.

Nasenthier, Nasenbär, Schnauzenbär, Rü̈selbär, Frettbür, and Rüsseltrüger of German writers.

Coati and Coati-Mundi of English and French writers, etc.

Cuati of the Spanish writers.

Quasie of the Northern Indian tribes of South America.

Externat Characters.-Eye and cheek-spots nearly as in the preceding, but of a soiled white (brownish-white or yellowish-white) color; sometimes obsolete, and usually less strongly contrasted with the surrounding tints, and with no white on the nose, which is colored uniformly with the sides of the head and frontal region. Head (excepting the whitish spots already noted), including facial region, gray, varied with blackish, particularly on the sides of the nose. General color of the dorsal surface, and of the limbs externally, gray, the former more or less strongly varied with black and fulvous, or rust-yellow. Whole lower surface, and the limbs internally, yellowish-white, varying to strong fuilvons, or even gamboge yellow. The hairs of the back are usually black at the surface, with a broad subterminal bar of fulvous, varying often to rufous, and brown at the base, like the softer under-fur. Tail black, with about eight (seven to nine) rather narrow fulvous rings.

The color varies greatly in different individuals, through the greater or less amount of black tipping the hairs of the dorsal surface present, and in the amount and tone of the under-color. A specimen from Brazil (M. C. Z., No. 2820, Thayer Exped.) has the prevailing color above shining black, varied with grayish-fulvous. Another (M. C. Z., No. 1839, Manaos, Brazil, Thayer Exped.) has the dorsal surface shining black, varied with deep yellowish-rufous. Still another (M. C. Z., No. 1440, Manaos, Brazil, Thayer Exped.), abont half-grown, has the middle of the back strongly blackish, and the sides dingy yellowish-brown varied with blackish. In these the pelage is short, crisp, and shining. Two other specimens (Nat. Mus., No. 4657 and No. 2978), one certainly and the other probably, from Paraguay (Corrientes, Captain Page), has the pelage long, soft, and full, and the surface tint pale yellowish-gray, with a narrow subterminal zone of black, and the basal portion pale yellowish-brown. Another specimen (Nat. Mus., No. 3996, locality not given) has the dorsal surface dark red or intense chestnut, darkest along the middle of the back, especially posteriorly, and lighter on the sides, passing into fulvous on the lower surface. The tail is dark reddish chestnut, with narrow rings of blackish. The usual face-markings are faintly distinguishable. This specimen seems to represent the Coati roux of F. Cuvier.

Occasionally specimens occur in which the face is marked more or less 
distinctly with broad indistinctly defined longitudinal bands of whitish and dusky or eren black, with an indistinct transverse blackish band through the eye. In one example thus marked the usual whitish facemarkings are obsolete.

As already noted, writers who have observed the animal in a state of nature refer to great variability of color in even individuals of the same litter. In some specimens, the white facial markings are obsolete, as in von Tschudi's Nasua montana. Nielanistic examples appear to be not unfrequent, and there is also a strong tendency to erythrism, in which the whole pelage is more or less reddish, even to the base of the hair, and unvaried by other tints save the blackish rings on the tail; at other times, the middle of the back posteriorly is blackish, as are also the sides of the nose.

SKuLL.-A series of eight skulls of this species, mostly from Santa Rita, Southern Brazil, indicates a considerable amount of both sexual and individual variation. The females are smaller than the males, with relatively very much smaller canines. Two male skulls from Santa Rita (M. C. Z., Nos. 1000 and 1001, Thayer Exped.) measure respectively as follows, the smaller being much the older: length (from front edge of intermaxillæ to posterior border of oecipital condyles) respectively 127 $\mathrm{mm}$. and $115 \mathrm{~mm}$.; breadth (at point of greatest expansion of zygomata) respectively $73 \mathrm{~mm}$. and $74 \mathrm{~mm}$. An adult female skull (M. C. Z., No. 999, Santa Rita, Brazil, Thayer Exped.) measures $110 \mathrm{~mm}$. by $61 \mathrm{~mm}$. Dr. Hensel states that the maximum length (measured as above) of a series of thirty-four old male skulls is $126 \mathrm{~mm}$., and the minimum 112 $\mathrm{mm}$; ; and of the "normal skull" $118 \mathrm{~mm}$. He gives the maximum length of a series of forty-nine old female skulls as $114 \mathrm{~mm}$; minimum, $103 \mathrm{~mm}$. ; "normal," $107 \mathrm{~mm}$.

General History AND SyNoNymy.-A more complicated case of synonymy than that presented by the present species is rarely to be encountered. The introduction of the species into literature can be traced back to Maregrave (1648), and even Theret (1558), but the first important reference is that by the former, which became, in conjunction with Brisson's "Coati-Mondi à queue annelée" (1756), the basis of the Linnæan Viverra nasua. The "Coati noirâtre" of Buffon $(1760)$ is unquestionably the same animal on which was based the first figure of the species under that name, published by Schreber in 1776. "Under this title, and unmixed with any other species, the present species was currently known until about 1817, when F. Cuvier and Desmarest introduced confusion by losing sight entirely of Linné's Viverra narica, their Viverra narica being merely a color-variety of the present species. The last-named author also introduced a third nominal species referable to the present one uncker the name Viverra quasje. For the next fifty years the narica of those authors who used the name is referable to the nasua of Linné. In 1820, Desmarest abandoned both of the Linnæan names nasua and narica,the first in consequence of Storr's adopting the name Nasua (in 1780) as 
the generic name of the Coatis,-and introduced the names rufa and fusca, both of which, as already shown, are referable to the $V$. nasuca of Linné. Maximilian, in 1826, deliberately ignored all the prior specific names, and introduced in their place socialis and solitaria, both based on the present species, although by some subsequent writers the latter was adopted for the Linnæan narica. Von Tschudi, in recognizing fire species of the genus Nasua, added two new synonyms to those of the present species.

The changes that have been rung on the various names above entmerated, especially socialis and solitaria, are sufficiently indicated in the above table of synonymy, and in the general history of the literature relating to the group already given (antèa,pp. 153-162). Other synonyms of less prominence, although of earlier origin, are the Viverra vulpecula of Erxleben, already mentioned as a curious compound of several widely diverse species, including one unquestionably referable here. It is apparently primarily based on Brisson's "Blaireau de Surinam," which is unquestionably the present species, but also included Buffon's "Coase," which is the Fisher or Mustela pennanti of recent authors. Gmelin's Viverra quasje had in part the same origin, since it also included Brisson's "Blaireau de Surinam." Other less important or less prominent synonyms are Desmarest's Myrmecophaga annulata and the "Myrmecophaga tetradactyla, L.?," of Griffith's Animal Kingdom. Among later synonyms are Gray's Nasua olivacea and $N$. dorsalis, which relate only to particular phases of coloration.

The Linnæan specific name nasua having become untenable through its adoption in a generic sense, the first name strictly eligible, thongh by no means eminently appropriate, as it had originally reference to only a prominent color-variety of the species, is that of rufa of Desmarest. Socialis, applied later to the species in a broader sense, is otherwise not especially distinctive, and is antedated by both rufa and fusca of Desmarest, as well as by the barbarous term quasje.

GEOGRAPHICAL Distribution.-The present species appears to range over the greater part of the continent of South America-certainly from Surinam to Paraguay, and from the Atlantic coast to the Andes, - over which extensive region it is one of the most abundant of the carnivorous mammals, and apparently the sole representative of its genus. The first suggestion as to the correct limits of the habitat of the present species seems to have been made by Dr. von Frantzius in 1869, as already cited, he claiming that in all probability the present species did not occur in Costa Rica, and was therefore limited to the Southern Tropics, as the Costa Rican species doubtless was to the Northern Tropics. The exact boundaries of the habitat of either species still remain to be determined, as well as also orbether the two species anywhere occur together. 
AUTHOR'S HDITION.

DEPARTMENT OF THE INTERIOR. UNITED STATES GEOLOGICAL AND GEOGRAPHICAL SURVEY.

F. V. HAYDEN, U. S. Geologist-in-Charge.

\section{ON THE SPECIES}

OF THE

\section{GENUS BASSARIS.}

BY

\section{J. A. ALLEN.}

EXTRACTED FROM THE BULLETIN OF THE SURVEY, VOL. V, NO. 3. 



\section{BULLETIN}

OF THE

\section{UNITED STATES GEOLOGICAL AND GEOGRAPHICAL SURVEY OF THE TERRITORIES.}

\begin{tabular}{lll}
\hline VOLUME V. & 1879. & NUMBER 3.
\end{tabular}

\section{Art. XVHII.-On the Species of the Genus Bassaris.*}

\section{By J. A. Allen.}

The mammals of the genus Bassaris were for a long time a puzzle to the systematists, who, however, generally referred them to the Viverrida, as constituting the only American representatives of the family. Some authors, as Gervais, while believing that they were Viverrine, have seen in them some affinities with the Mustelida, while others, as Waterhouse and Turner, have hinted at an Ursine alliance, especially to such forms as Procyon and Nasua. Professor Flower, $\nmid$ who has especially investigated the affinities of Bassaris, concludes: "On the whole I think there can be little question that evidence has been adduced to prove that Bassaris is a member of the Aretoid sub-division of the Carnivora, and among these approaches most nearly to Procyon and Nasua" (1. c., p. 34). Dr. Gill, in 1872, $\ddagger$ assigned it the rank of a family (Bassaridida) of the Arctoidea, and a position at the end of the group, following Procyonida.

\section{GENERAL IIISTORY.}

Although the Bassarids are of common occurrence throughout Mexico, and range also far both to the southward and northward of that country, and were known to Hernandez as early as the middle of the serenteenth century, they escaped the notice of systematic writers till within the last half century. The first modern account of them was pub-

* The material on which the present paper is based is almost exclusively that of the National Museum, for the free use of which I am indebted to its able director, Prof. Spencer F. Baird.

tOn the Value of the Characters of the Base of the Cranium in the Classification of the Order Carnivora, and on the Systematic Position of Bassaris and other disputed forms. By William Henry Flower, F. R. S., F. Z. S., etc., Conservator of the Museum of the Royal College of Surgeons. Proc. Zoöl. Soc. Lond., 1869, pp. 4-37.-Bassaris is treated at pp. 31-34, which see for a fuller history of the views of systematists respecting its affinities.

$\ddagger$ Arrangement of the Families of Mammals, p. 67 . 
lished by Lichtenstein in 1830, based on specimens sent from Mexico by Herr Deppe, in 1826 and subsequent years, of what proves to have been the northern form of the genus. This Lichtenstein, in his commentary on the mammals noticed by Hernandez, ${ }^{*}$ named and briefly described Bassaris astuta, he recognizing in it the Cacamiztli, or Caca-mixtli, of Hernandez, which the latter also mentioned under the name Tepe-maxtla. These are still the common natire names of the species, and mean respectively "Rush Cat" and "Bush Cat." Shortly after B. astuta was more fully deseribed by Lichtenstein, and also figured. $\uparrow$

During the next thirty years, the habits of Bassaris astuta were referred to by different writers, and the species repeatedly described and figured, the illustrations including colored figures of the animal and representations of the skull, skeleton, and dentition.t The notices of Bassaris published prior to 1860 all relate, singularly enough, exclusively to $B$. astuta, at which date the second or southern species ( $B$. sumichrasti) was first described.

Professor Baird, writing in 1858 (Mam. N. Amer., p. 147), says: "It is as yet uncertain whether America possesses one or two species of Bassaris, further investigation being necessary to determine the character of the California species. They are found as far north as Red River, Arkansas, on the eastern slope of the continent; on the western to the latitude of San Francisco; south ward they extend throughout temperate Mexico. They bear in the United States the name of civet, Mexican, or ring-tailed cats, and are frequently tamed in Mexico and California; in the latter country they are great pets of the miners." He adds: "Only one authenticated skin, (No. 2343,) has been received from California; this is a hunter's skin, not sufficiently perfect to furnish a description." The following year Professor Baird described (Rep. U. S. and Mex. Bound. Surv., Marn., pp. 18, 19), under the name Bassaris astuta, two specimens from Texas and another from an unknown locality, supposed to have come from California, naming the latter provisionally Bassuris raptor. His detailed account of the external features of the Texas specimens indicate very fairly the northeastern phase of Bassaris astuta. Respecting the specimen to which the name $B$. raptor was provisionally given, he says: "In the spring of 1852 (April 23), a specimen of

* Erlïuterungen der Nachrichten des Fran. Hernandez von den vierfiissigen Thieren

Neuspaniens. Abhandlungen d. Berlin. Akad. 1827 (1830), pp. 89-128.-Bassaris astuta is described and named at p. 119 . The paper was read before the academy in 1827 , but not published till 1830 .

The genus Bassaris and the species $B$. astuta were also described by Wagler in the "Isis" for 1831 (p. 511), one year subsequent to the publication of Lichtenstein's above-cited paper, both being accredited by him to Lichsenstein; yet various writers have attributed the earliest notice of $B$. astuta to Wagler.

†Darstellung neuer oder weniger beliannter Sïngethiere in Abbildungen und Beschreibungen von fünfundsechzig Arten, 1827-1834, pl. xliii.

† See posteà, table of reference under $B$. astuta. The skeleton has been figured by Gervais and De Blainville, the dentition by Blainville and Giebel, the skull by Lichtenstein, Baird, and Flower, and the animal by Lichtenstein, Wagner, Audubon and Bachman, Wolf and Sclater, and Cordero. 
Bassaris was killed in a hen-roost, near Washington, after it had committed great derastation among the poultry of the neighborhood. It had evidently escaped from confinement, as shown by the marks of a collar around the neck. There was, of course, no indication whence it came originally, but it was supposed to have been brought from California. This specimen is somewhat different from those obtained in Mexico and Texas, although perhaps not specifically distinct. The tail is strikingly different in having the black rings fewer in number and of much greater extent compared with the white portion. Of these black rings there are only five distinctly marked ones besides the tip, and the last or subterminal one is more than two inches long instead of about one. Below the black ring is nearly complete, separated only for the thickness of the vertebre by the white of the under surface. There is no appreciable difference in the colors of the remaining portions of the body. The ears are decidedly smaller, Very considerable differences are discernible between the skull of this specimen and the others; the cranium is broader, but more constricted behind the orbital processes of the frontal bone; the distance between the zygomata is considerably greater, and the temporal crests of opposite sides much closer together. The pterygoid bones, also, are further apart. The proportion of greatest breadth of skull to length is as 63 to 100 instead of 59, as in No. 4 [female], from Texas. Should the examination of further specimens show these distinctions to be such as to indicate a different species, it might be called Bassaris raptor." In passing, I may add that the examination of more material shows that the cranial differences here indicated are not important, and show mainly only the usual variations accompanying differences of age in Bassaris astuta. The color of the tail very nearly coincides with that of a specimen before me from Oregon, with which it so much more nearly agrees than with Texas examples that I have little doubt that the supposed Californian origin of Bassaris raptor is its correct locality. The wide separation of the pterygoid bones is certainly exceptional, but is probably strictly individual, as I find a perfectly parallel variation in this highly variable feature in the skulls of B. sumichrasti. Consequently in Bassaris raptor we have the earliest synonym of $B$. astuta.

In 1860, M. De Saussure described and figured (Rer. et Mag. de Zool., $2^{\ominus}$ sér., xii, Jan., 1860, p. 7 , pl. i, animal, fig. uncolored), a second species, under the name Bassaris sumichrasti, based on a single very old individual collected by himself in Mexico. Although De Saussure's description is explicit and detailed, and notwithstanding that in his careful comparison of the new species with $B$. astuta (of which he had a large suite representing all ages), he clearly set forth all the leading points of difference, Dr. Peters, in 1874 (Monatsb. der k. Akad. der Wissensch. zu Berlin, 1874, p. 704, pll. i, ii, meeting of Nov. 16, 1874), referred B. sumichrasti of De Saussure doubtfully to B. raptor, Baird, at the same time redescribing $B$. sumichrasti under the name Bassaris variabilis. At all events, he says: "Es war bis jetzt mit Sicherheit nur 
eine Art dieser Gattung, Bassaris astuta, ans Mexico bekannt, der ich eine zweite aus Centralamerica hinzufiigen kann." Yet he notes among the distinctive characters of $B$. variabilis most of those especially mentioned by De Saussure as characterizing B. sumichrasti, omitting, however, some, and adding others not mentioned by De Saussure. Peters's B. variabilis was based on a skin and skull of a very old male, and on a second skin supposed to be that of a female, all of which he figured.

Almost simultaneously with the publication of Dr. Peters's paper, Señor Cordero again described (La Naturaleza, iii, p. 270, with a plate; the paper is dated Dec. 1, 1874, and was published May 31, 1875) B. sumichrasti, under the name Bassaris monticola. His description is very detailed, and in his comparison of B. monticola with B. astuta he brings into strong relief the distinctive characters of the two species, they embracing all those previously mentioned by De Saussure and Peters as eharacterizing respectively $B$. sumichrasti and $B$. variabilis. He gives also excellent comparative (colored) figures of the external characters of the two species, and illustrates the cranial characters and dentition of B. monticola. Although he shows himself to have been perfectly conversant with the two species of Bassaris, he appears not to have been aware that his $B$. monticola had been previously described and named by De Saussure.

Dr. Gray in 1864 (Proc. Zoöl. Soc. Lond., 1864, 512) and in 1869 (Cat. Carn. Pachyd. and Edent. Mam., 1869, 246) gave a "var. fulvescens," adding, "Fur more fulvous, perhaps of a different season." To his "Bassaris astuta var. fulvescens" he referred unqualifiedly De Saussure's B. sumichrasti. His description of the cranial characters seems to indicate that he had before him only skulls of $B$. astuta.

From the foregoing it will be seen that the large southern species of Bassaris has been thrice described as new; that the skull has been figured twice; and that one plain and three colored (Dr. Peters gives two) figures of the animal have been given.

\section{DIFFERENTIAL CHARACTERS OF THE SPECIES.}

The external and eranial characters of the Bassarids are so well known that it is unnecessary in the present connection to give them in detail further than is necessary to the elucidation of the distinctive features of the two species, which, so far as at present known, constitute the genus Bassaris. They are, as is well known, in general appearance sinall foxlike animals, with soft, loose pelage, pointed nose and ears, and a ringed tail as long as the body, giving a tout ensemble intermediate, on the one hand, between the Coatis and Raccoons, and the Foxes on the other, but of smaller size than either. The distinctive characters of the species are indicated in the subjoined diagnoses.

Synopsis of the Species.

Commox Characters:-Tail with the hairs about equal to or a little longer than the head and body. Color abore gray, more or less suffised with yellowish-brown, 
with a wash of black of variable amount, produced by the black tips or the longer hairs, usually strongest along the middle of the back; below whitish, tinged more or less strongly with pale yellow. Eyes narrowly encircled with brownish-black. Behind and above each eye a large, sometimes rather indistinct, spot of yellowishgray, and a smaller spot of the same color below each eye. Tail with alternating rings of white or gravish-white and black, and black at the tip. The usual number of rings of either color varies from 7 to 9 . The females are considerably smaller than the males.

\section{B. astuta.}

Ears rather narrow and pointed. Soles and palms with short soft hair on the edgas and at the base of the toes between the naked pads.

Upper surface of the feet slightly or not at all blackish.

Light rings of the tail broad, pure white, or sometimes slightly grayish-or yellowishwhite, nearly as broad as the intervening black ones. The black rings are divided below by a more or less broad mesial band of white, running nearly the whole length of the tail, the lower surface of which is white, broadly scalloped on the edges with black.

Anterior surface of upper incisors smooth, the cutting-edge even.

First upper molar with both limbs longer and narrower than in B. sumichrasti, the inner with two distinct cusps, and another on the posterior outer edge of the tooth.

Second upper molar with the transverse diameter, compared with the antero-posterior, relatively greater than in $B$. sumichrasti.

Last lower premolar with a small accessory cusp on the posterior border.

Canines and whole dental armature relatively weaker, the molars narrower, and their cusps sharper and more numerous than in B. sumichrasti, in specimens of corresponding ages and degree of attrition of the teeth.

Auditory bullæ strongly inflated, spherical, the meatus auditorius very large.

Size less than in B. sumichrasti. Length of head and body $14 \mathrm{in.} \mathrm{(q)} \mathrm{to} 17 \mathrm{in.} \mathrm{(} \vec{\delta}$ ); tail-vertebræ about 12 to 15 ; tail to end of hairs about equal to length of head and body. Skull, length 3.00 to 3.25 ; width i. 85 to 2.05 .

\section{B. sumichrasti.}

Ears broader and shorter, absolutely as well as relatively, and less pointed. Soles and palms wholly naked.

Upper surface of the feet black or blackish, and general color of dorsal surface usually darker than in $B$. astuta.

Light, rings of the tail narrow, gray, sometimes tinged with brownish. The black rings are much broader than the alternating white ones, unbroken, completely encircling the tail, the lower surface of the tail scarcely differing in color from the upper.

Anterior surface of the upper incisors with two slight longitudina: grooves dcepening apically, producing a distinctly crenulated cutting-edge.

First upper molar shorter and thicker than in $B$. astuta, with no accessory cusp on the posterior outer corner, and lacking that seen on inner anterior angle of the tooth in B. astuta.

Second upper molar heavier than in $B$. astuta, with a relatively shorter transverse diameter.

Last lower premolar with no accessory cusp on the posterior border.

Auditory bullæ less. swollen, flatteued on the posterior inner face, with a much smaller meatus auditorius.

Size larger. Length of head and body $15 \frac{1}{2}$ in. ( $q$ ) to $19 \frac{1}{2}$ in. ( $\delta$ ); tail-vertebræ 16 to 20 ; tail to end of hairs 18 to 22 . Skull, length 3.25 to 3.60 ; width 2.25 to 2.50. 


\section{BASSARIS ASTUTA, Lichtenstein.}

\section{Northern Civet Cat.}

Bassaris astuta, Lichtensten, Abhandl. d. Berlin. Acad. 1827, (1830), 119; Darstellung Säugeth., 1827-1834, pl. xliii (skull and animal).-W AGLER, Isis, 1831, 511.Gervais, Voy. de la Bonite, Zoöl., i, 1841, 18, pl. iv (skeleton and visceral anatomy).-Charlesworth, Proc. Zoöl. Soc. Lond., 1841, 60 (habits).-De Blainvinte, Ostéog., Des Mustelas, 1842, pl. v bis (skeleton), pl. xiii (dentition).-W AGNER, Schreber's Sängeth.,Suppl.,ii, 1841, 278, pl. exxv C (animal).Thomson, Proc. Zoöl. Soc. Lond., 1842, 10 (habits).-Audubon \& Bacmuan, Quad. N. Am., ii, 1851, 314, pl. xeviii (animal).-GIEBEL, 'Odontog., 1855, 31, pl. xi, fig. 10 (dentition); Säugeth., 1855, 803.-BAIrD, Mam. N. Am., 1858, 147 ; Rep. U. S. and Mex. Bound Surv., ii, 1859, Mam., 18, pl. xiv, fig. 2 (skull).Wolf \& Sclater, Zoölog. Sketches, i, 1861, pl. xiv (animal, from life).-Gray, Proc. Zoöl. Soc. Lond., 1864, 512 ; Cat. Carn. Pachy. and Edent. Mam., 1869, 246.-Coues, Am. Nat., i, 1867, 351 (Arizona).-Flower, Proc. Zoöl. Soc. Lond., 1869, 31, fig. $3 a$, skull (systematic position).-Villada, La Naturaleza, i, 1870, 297.-Sullivant, Am. Nat., vi, 1872,363(Ohio).-Coues, Am. Nat., vi, 1872, 264 (distribution).-AlleN, Bull. Essex Institute, vi, 1874, 45 (Kansas).- "KIRKPatrick, Proc. Cleveland Acad. Nat. Sci., 1874, 377 (Ohio)."-Cordero, La Naturaleza, 1875, iii, 273, plate (animal).-Couns, Amer. Nat., xii, 1878, 253 (Rogue River, Southwestern Oregon).

Bassaris astuta var. fulvescens, GraY, Proc. Zoöl. Soc. Lond., 1864, 512; Cat. Carn. Pachy. and Edent. Mam., 1869, 246.

Bassaris raptor, BaIRD, Rep. U. S. and Mex. Bound Surv., ii, 1859, Mam., 19.

Caca-miztle, Caco-Mixtle, and Tepe-Maxtlaton, Hernandez.

Cacomistle, Cacamiztli, and Cuapiote, of the Mexicans.

Katzenfrett, German authors.

Civet Cat, Ring-tailed Civet Cat, Texas Civet Cat, Mexican Civet Cat, Cat Squirrel, Mountain Cat, Raccoon Fox, etc., of English writers, and locally in the United States.

The comparative diagnoses abore given indicate the arerage characters of the species, but a series of eight specim ns shows a consiclerable range of variation in color and other details. Aside from the smaller size of the female, $I$ have noted no other important sexual differences. The number of white rings on the tail in B. astuta varies from six to nine, the usual number being either seren or eight. They vary in width, being usually narrower than the black ones, sometimes equalling them, while in rare instances the white rings are the wider. The general color above is gray or brownish-gray, varying in some examples to yellowish-brown, the anterior half of the body being usually purer gray (less suffused with brownish-yellow) than the posterior half. The black terminating the longer hairs varies greatly in amount, but always gives a conspicuous blackish cast to the dorsal surface, while in some the prevailing color, especially along the midile of the back, is black. In such specimens, the upper surface of the feet is more or less blackish or brownish-black; the black rings in the tail are broader and the black terminal portion of the tail more extended. A single skin from Oregon* is dark throughout, being as black as the darkest examples of $B$. sumichrasti, and contrasts strongly with the light.colored specimens from Texas and Northeastern

*This is the specimen mentioned by Dr. Coues in Amer. Nat., xii, 1878, p. 253. 
Mexico. The next darkest specimen is from Orizaba, Mexico. The lower surface is sometimes nearly pure white, but is usually strongly tinged with pale yellow, varying in some specimens to pale brownish-yellow, especially on the chin and throat. The relative amount of black and white on the tail is also variable. In the lighter specimens, the greater portions of the lower surface of the tail is pure white; in others, the black rings are only broken below by a narrow band of white. In the Oregon specimen, they are almost continuous below (the last two apical ones wholly so), though much narrower than above. The rings usually increase in width from the base of the tail apically, especially in case of the black ones.

The extremes of variation in color are in specimens No. 11849, from Camp Grant, Arizona (E. Palmer), and No. 12849, from Oregon (A. H. Wood). The Arizona specimen is pale brownish-gray above, varied with blackish, principally along the median line, caused by the black tips of the long hairs. Below it is pale yellowish-white. The tail is mostly white below, but above is crossed by alternate rings of black and white of nearly equal breadth. The Oregon specimen has the prevailing tint of the dorsal region intense black, quite obscuring the brownishgray ground-color. Below, it is strongly brownish-yellow, deepest on the throat and chin. The tail is mostly black above, the white being mostly half-rings confined to the lower surface. These two specimens accord with the peculiar phases of geographical color-variation commonly characterizing the mammals and birds of the two regions in question. Should the Oregon specimen here described prove to indicate the average condition of the species along the Pacific coast to the northward, as seems probable, the form there prevailing may require to be varietally distinguished under the name raptor, Baird, this name doubtless referring to the Pacific coast form, as already explained. Five specimens from near the southern border of Texas agree in being rather darker than the Arizona specimen, and present only a moderate range of color-variation. A specimen from Orizaba (No. 8567, $\vec{z}$, Botteri) is rather darker, the lower surface more strongly yellow, and the white on the tail is slightly tinged with yellow.

In a young specimen about one-fourth grown, and still retaining the milk dentition, the pelage is soft, long, and woolly; the color above pale yellowish-brown varied with darker brown, but with no black; below grayish-white, faintly tinged with yellow anteriorly. The tail has seven white rings, and the light spots below and behind the eyes are nearly pure white.

In old female skulls, in which the teeth show a considerable degree of attrition, there is no trace of a crest. Probably in old males this will be found to be present, but the only male specimens before me are only of middle age and do not show it. The most notable variation in the skulls of $B$. astuta is the unusually wide separation of the pterygoid bones, and the consequent unusual breadth of the posterior nares in 
the original skull of Baird's B. raptor. As this is a feature in which variation is apt to occur, and as my series of skulis of $B$. sumichrasti presents an example equally aberrant from the usual condition in the last-named species, I cannot look upon it as other than an individual variation of more or less frequent occurrence in other mammals.

GEOGRAPHICAL DistribUtion.-The Northern Civet Cat appears to range throughout the temperate portions of Mexico, and thence northward far into the United States. The most southern localities represented by the specimens before me are Orizaba in the State of Vera Cruz, San Luis Potosi in the interior, and the Sierra Santiago near the Pacific coast. It is said to be a well-known inhabitant of California, and ranges thence northward into Southwestern Oregon, where, however, it is supposed to be of rare occurrence.* More to the eastward it has been found in Arizona, and has long been known to occur throughout most parts of Texas. I found it to be a well-known animal in Middle Kansas, and a number of specimens have been taken at different times as far northward and eastward as Ohio. Though nowhere apparently abundant, it appears to be rather common in Northern Mexico and in Texas, but further northward and eastward is evidently rare.

\section{BASSARIS SUMICHRASTI, De Saussure.}

\section{Southern Civet Cat.}

Bassaris sumichrasti, De SAUSsure, Rev. et Mag. de Zoologie, $2^{2}$ sér., xii, 1860, 7, pl.i (animal).

Bassaris variabilis, Peters, Monatsb. d. K. P. Akad. Wissensch. zu Berlin, 1874, 704, pl. i (animal), pl. ii (skull).

Bassaris monticola, Condero, La Naturaleza, iii, 1875, 270, plate (animal and skull). Tepechichi del Cofre de Perote, Cacomistle de monte, Cordero, l. c., p. 270.

Bassaris sumichrasti presents variations in general color strictly parallel with those already noted as occurring in B. astuta. The groundcolor above varies from nearly pure gray to yellowish-brown, and even golden, and the wash of black is sometimes sufficient to render this the prevalent tint of the dorsal surface. The yellowish-brown suffusion is always much stronger on the posterior half of the body than it is anteriorly. The color of the ventral surface varies from nearly pure white to pale gamboge-rellow. The dorsal surface of the feet is generally black, always decidedly .blackish in all the specimens examined. The terminal fourth or more of the tail is usually deep black, with sometimes faint indications of one or two gray rings on the lower surface. The light rings are much narrower than the intermediate black ones, and vary in different specimens from pure gray to whitish-gray and yellowish gray. They are usually broader on the lower side of the tail than on the upper. The number of light rings more or less distinctly traceable varies from seven to ten, but is usually either eight or nine. These remarks are based on an examination of seven skins from Southern Mexico and Costa Rica. 
Of two specimens taken at Tehuantepec, January 15, 1869, and labelled by the collector (Prof. F. Sumichrast) as found in coitu, the male is much the larger, grayish-brown above, varied with black, and strongly suffused with fulvous posteriorly ; below, pale yellow; terminal third of the tail wholly black; the light rings are gray; length of head and body $19 \frac{1}{2} \mathrm{in}$; tail-vertebræ $20 \mathrm{in}$; t tail to end of hairs $22 \mathrm{in.}$ The female is much purer gray above, with only a slight suffusion of brownish-fulvous posteriorly; below, pale yellow; the light rings of the tail whitish-gray; length of head and body $15 \frac{1}{2}$ in.; tail-vertebræ 18 in.; tail to end of hairs 20 in. Another male from the same locality, collected in March, 1872, agrees very nearly in color with the male already described, but is rather less strongly suffused with brownish-fulvous; the light tail-rings are grayish-white, and only the terminal fifth of the tail is wholly black. Another example (sex unknown) from Mirador (Dr. Sartorius) is much darker dorsally throughout, where the prevailing tint is decidedly black, the light tail-rings are narrower and more indistinct, and the terminal third of the tail is wholly black. The black prevails on the tail to such an extent that above the light rings are well defined only toward the base of the tail. Two specimens from La Palma, Costa Rica, collected in December, 1876 (J. C. Zeledon), differ very little from the last, except that the light rings of the tail are more distinct and whitish-gray.

It will thus be seen that $B$. sumichrasti is considerably larger than $B$. astuta, darker or more blackish in color, with a relatively longer tail, on which the light annulations are narrower, rather more numerous, and unbroken below, where they are merely a little narrower than they are on the upper surface. The ears are broader, less pointed, and about one-fifth shorter than in B. astuta, notwithstanding the smaller size of the last-named species.

Dr. Dugés, in some remarks appended to Cordero's description of his $B$. monticola, rather questions the importance of some of the characters given by Cordero as distinguishing B. monticola from B. astuta, especially the grooving of the incisors, stating that they are to be found also in young examples of $B$. astuta, and that they are features that probably disappear with age. Dr. Dugés's remarks respecting other characters, as well as this, show that he has evidently confounded the two species. In respect to the trilobed border of the incisors, which Cordero refers to as having "la figura de una flor de lis," I may say that I have been unable to find any traces of this character in wholly unworn teeth of $B$. astuta, while in B. sumichrasti it persists in the very oldest specimens, and is even present in one example in which the teeth are all very much worn and some of the incisors are broken off, the two or three remaining incisors still showing the grooves and the resulting lobed cutting-edge.

Geographical Distribution.-Neither De Saussure, Peters, nor Cordero state definitely the localities whence their specimens of this animal were received. De Saussure gives mereıy "Mexique, and Peters 
says "aus Centralamerica." Cordero's introductory remarks seem to imply that his specimens were obtained in the vicinity of Jalapa. It is not mentioned by Tomes as included in the collection of mammals made by Mr. Salvin at Dueñas, Guatemala,* nor by Dr. von Frantzius in his list of the mammals of Costa Rica.t Consequently the only information I can give is limited to the material I have had opportunity of examining. The localities reprsented are Jalapa, Mirador, and Tehuantepec, Mexico, and La Palma, Costa Rica. As Cordero refers to his having examined eight or ten specimens, it is doubtless not uncommon about Jalapa, and probably ranges thronghout Southern Mexico, Guatemala, and Costa Rica. To what extent the habitats of the two species of Bassaris overlap still remains to be determined. The abore-mentioned Orizaba specimen of $B$. astuta shows that the two species occur together in the State of Vera Cruz, and B. astuta may be inferred to be the prevailing form about the city of Mexico.

* Report on a Collection of Mammals made by Osbert Salvin, Esq., F. Z. S., at Dueñas, Guatemala, with notes on some of the species by Mr. Fraser. By Robert F. Tomes, Corr. Mem. Z. S. <Proc. Zoöl. Soc. Lond., 1861, pp. 278-288.

†Die Säugethiere Costaricas, ein Beitrag zur Kenntniss der geographischen Verbreitung der Säugethiere Amerikas. Von Dr. A. von Frantzius. <Archiv fïr Naturgeschichte, 1869, i, pp. 247-325. 


\title{
Bulletin of the Museum of Comparative Zoölogy,
}

AT HARVARD COLLEGE.

Vol. VIII. No. 9.

LIST OF MAMMALS COLLECTED BY DR. EDWARD PALMER IN NORTH-EASTERN MEXICO, WITH' FIELD-NOTES BY THE COLLECTOR.

\author{
By J. A. Allew.
}

CAMB RIDGE :

PRINTED FOR THE MUSEUM.

MARCH, 1881. 

No. 9. - List of Mammals collected by Dr. Edward Palmer in Northeastern Mexico, with Field-Notes by the Collector. By J. A. ALLEN.

THE region traversed by Dr. Palmer includes the eastern portion of the State of Coahuila, the southern parts of Nuevo Leon and Tamaulipas, and a large part of the State of San Luis Potosi. The specimens were collected chiefly in the vicinity of the city of San Luis Potosi, but include a number from Monclova, Parras, Saltillo, Rio Verde, and the neighborhood of Tampico. The remarks respecting the distribution and abundance of the species, when of a general character, may be taken as relating to the general region traversed. The collection throws much light on the range of Mexican mammals, and in a few cases extends their range much beyond their previously known limits. The detection of a species of Heteromys so far northward is perhaps the most important single fact of the list. The notes on the relative abundance and distribution of the species, written from Dr. Palmer's dictation, are distinguished by being enclosed in marks of quotation.

\section{Canis latrans, Say. Pratrie Wolf; Coyote.}

"Generally dispersed but not common, having been to a large extent destroyed by poisoning and shooting." Dr. Palmer reports their occurrence in small numbers in all the parts of Eastern Mexico visited by him. One specimen was sent from San Luis Potosi.

2. Urocyon cinereo-argentatus (Schreb.), Coues. Grax Fox.

"Generally dispersed and very common. Often domesticated."

\section{Putorius brasiliensis frenatus (Licht.), Coues. Bridied Weaset.}

Mountains near Saltillo, August 11, 1880. The species is represented in the collection by a skin and skull. "Apparently not common."

\section{Taxidea americana berlandieri (Baird), Allen. Mexicax Badger.}

The localities represented are San Luis Potosi, San Pedro (Chihuahua), and Saltillo. Not common.

\section{Bassaris astuta, Licht. Civet Cat.}

One specimen, San Luis Potosi, March 29, 1879, "Not very common, but occurs in small numbers nearly everywhere. Often tamed as pets."

vor. virI. - No. 9. 


\section{[Bison americanus (Gmelin), Smith. American Bison.}

Of this species no specimens were of course observed, but it is here introduced for the purpose of recording some traditional evidence of its former presence at points outside of its hitherto definitely recorded range. "According to the testimony of old people," says Dr. Palmer, "the Bison was very abundant about Monclova and Parras when the first settlers reached these points, probably half a century after the conquest. For some years they killed large numbers for food, but soon they ceased to appear. There seems to be no reason why, so far as the nature of the country is concerned, the Bison may not have ranged also to Saltillo. Careful observation failed to detect any of their remains, nor could I learn that such have been met with. Little attention, however, is paid to such things by the inhabitants, which might easily pass unnoticed, even if existing."]

\section{Cariacus virginianus mexicanus (Gmelin), Allen. Common Deer.}

The collection contains the head of a male, obtained at Savinito, Tierre Caliente. "Common everywhere in the wooded mountains, to which they are restrictel. Very common about Tampico, and are frequently exposed for sale in the markets of the town."

[Dr. Palmer informs me that he found no indication of the presence of the Prong-horn (Antilocapra americana) in any portion of the region he traversed. This is an important negative fact, as tending to fix the southern limit of this species, as it is known to occur further westward in the northern parts of the States of Chihuahua and Sonora.] Berlandier is cited (Alston, Biol. Cent. Amer., Mam., p. 113) as authority for the statement that its range extends "southwards at least throughout the State of Tamaulipas."

7. Nyctinomus brasiliensis, Is. Geoffroy.

Four specimens, San Luis Potosi. "Common, infesting the houses. This is the common Bat of this region."

\section{Plecotus auritus, LeConte. Big-eared Bat.}

One specimen, San Luis Potosi. This appears to be the first record of this species from any part of Mexico.

\section{Spermophilus grammurus (Say), Bachman. Lined-tailed SPER- MOPHILE.}

One specimen, taken at Angostura, Rio Verde, one hundred and sixty miles south of San Luis Potosi. "Occurs here and elsewhere abundantly about old walls and rocky places. Very destructive to the crops, and a great pest. From the nature of their haunts they are hard to capture."

10. Spermophilus mexicanus (Licht.), Wagner. Mexican Spermophile.

One specimen, Monclova. "Widely distributed at favorable localities, but not nearly so abundant as the smaller species" (S. spilosomus). 


\section{Spermophilus spilosomus, Bennett. Sonoran Spermophile.}

Eleven specimens, representing both the young and the adult, are in the collection from San Luis Potosi, and one each from San Pedro (Coahuila) and Parras. There is very little variation in color with age or individually.

"Abundant. Lives on the open plains and about the edges of fields, where it is a troublesome pest. Hibernates. Many are tamed."

\section{Cynomys ludovicianus (Ord), Baird. Eastern Prairie Dog.}

Five specimens, from the vicinity of Saltillo. "Only a single small colony was met with, in a little valley surrounded by mountains, not far from Saltillo, confined to an area of some thirty or forty acres." ,

This discovery extends the range of the species considerably to the southward and eastward of any point from which it has hitherto been reported. In "Monographs of North American Rodentia," p. 896, I inferentially gave its southern limit as the Staked Plains of Western Texas, overlooking the fact that it had been recorded by Dr. Kennerly (Rep U. S. Mex. Bound. Surv., II. Mamm., p. 40) and by Dugés (La Naturaleza, I. p. 137) from the State of Chihuahua, the former observing it as far westward as the Sierra Madre.

\section{Mus decumanus, Pallas. Brown Rat.}

"Abundant in the cities of the interior, as well as in those of the coast. It was common at San Luis, and extends as far north at least as Zacatecas."

\section{Mus alexandrinus, tet. Geoffroy.}

Four specimens, from San Luis, where it is "common in the houses." In addition to these are two specimens which seem to be unquestionably hybrids between this species and $M$. rattus, with which it has been repeatedly stated to interbreed.

\section{Mus rattus, Linné. Black Rat.}

Two specimens, San Luis Potosi. "Lives in the houses and also in fields."

16. Mus musculus, Linné. House Mouse.

"A numerous pest everywhere in the houses."

\section{Hesperomys melanophrys, Coues.}

One specimen, a full-grown male, San Luis Potosi, September 1, 1879. "Rather common in the fields."

As admitted by both Coues (North Amer. Rodent., p. 102) and Alston (Biol. Cent. Amer., Mam., p. 147), there is strong probability that H. melanophrys, Coues, and $H$. mexicanus, De Sauss., are identical. The specimen collected by Dr. Palmer agrees in size with Dr. Coues's largest examples from Tehuantepec ; the black eye-ring is also quite conspicuous, but the back posteriorly is apparently more strongly ferrugineous. I therefore provisionally adopt Coues's name in preference to De Saussure's. 


\section{Neotoma floridana mexicana (Baird), Allen. Mexicax Busu Rat ; "RATA del CAMPo."}

Neotoma mexicana, BaIrd, Proc. Acad. Nat. Sci. Phila., VII., April, 1855, 333 ; Mam. N. Am., 1857, 490 ; U. S. \& Mex. Bound. Surv., II. Pt. 2, 1859, Mam., p. 54, Pl. XXIV. fig. 1, skull.

Neotoma micropus, Baird, Proc. Acad. Nat. Sci. Phila., VII., April, 1855, 333 ; Mam. N. Am., 1857, 492 ; U. S. \& Mex. Bound. Surv., II. Pt. 2, 1859, Mam., p. 44.

Neotoma floridana, Geoffroy, Zoöl. Voy. Venus, 1855, 154, Pl. XIII. - Coues, Mon. N. Am. Roden., 1877, 14 (partim). - Dugés, La Fraternidad, I., 1874, 82, Pl. (animal, details of external parts, skull, and dentition).

A series of eight specimens, two collected in October and the remainder in March, at San Luis Potosi, contrast so strongly in color and size with Florida examples of Neotoma that the Mexican form seems eminently worthy of varietal recognition. The Mexican specimens are fully one fourth smaller, the tails are much more thickly clothed, and the color is widely different, agreeing, however, in every respect with $N$. mexicana, Baird. The tail is sharply bicolor, and the feet and the lower surface of the body are snowy white, separated from the mouse-brown of the back by a well-marked band of yellowish-rufous or golden-rust, varying in intensity in different individuals. Two specimens have the dorsal surface strongly ferrugineous throughout, varied of course with black medially, passing into strong reddish brown on the sides, thus in general tint strongly resembling $N$. ferruginea, for which they were at first mistaken. One is a male, the other a female, and they were taken, respectively, March 10 and March 24. Another specimen, a female, taken March 20, presents the opposite extreme of paleness, being gray above, varied with black and faintly tinged on the sides with a pinkish hue. These examples indicate an exceedingly wide range of individual variation in color ; the other specimens, however, are variously intermediate, and form altogether a closely intergrading series.

"These rats are sold in the markets as food for invalids whose stomachs are unable to retain other food; as a cure for chronic diarrhœa and dysentery is believed to have few equals. The aninials are split open and applied as a poultice to parts affected with pain. The market of San Luis Potosi is never without these rats. They are said to be good eating aside from their ascribed medicinal virtue. They are very abundant, inhabiting the localities of the magueys or agaves, about the roots of which they live, probably because the thorny nature of the plant prevents rapacious animals from burrowing after the rats, or possibly in order to feast upon the roots. They live in the ground, and the daily supply seen in the market of San Luis Potosi is obtained by digging them out of their burrows. They are known under the name Rata del Campo."

Dr. Palmer has kindly called my attention to two papers on this species in "La Fraternidad" * by Don Alfredo Dugés and Dr. Gregorio Barrocta, the

* La Fraternidad - Periódico de la Sociedad Medica de San Luis Potosi, Tom. I., Entr. No. 6, Junio de 1874, pp. 82-87 y pl. 
first accompanied by a plate giving a life-size figure of the animal, with numerous details, including the skull and dentition. Dr. Barrocta alludes especially to its supposed medicinal qualities, to the use of its flesh as food by the poorer classes, and to the daily sale of the animals in the market. Dugés states that they are readily domesticated and form agreeable pets.

\section{Dipodomys phillipsi, Gray. Kangaroo-Rat.}

Nine specimens, San Luis Potosi, September, October, March, and May, including adults of both sexes and half-grown young. In point of coloration they present great uniformity, the young exactly agreeing in this respect with the adult.

"Everywhere common. Very troublesome in the cornfields. Nocturnal. Obtained with difficulty and only by digging them out of their burrows."

\section{Heteromys longicaudatus? Gray. Mexican Hispid Mouse.}

\section{Heteromys alleni, Coues, MS.}

Dr. Palmer's collection contains a single specimen of Heteromys, an adult male, taken at the Hacienda Angostura, Rio Verde, February 26, 1878. Dr. Palmer states that it was discovered in a mound in digging for antiquities. Two were seen, but one of them escaped. He believes it to be rare, as it was not recognized by the natives. Appreciating its importance he offered a reward of a dollar apiece for other specimens, but was unable to obtain any more.

The genus Heteromys has hitherto been known only from Southern Mexico (Oaxaca) and thence southward to Northern South America. Numerous species have been described, but only four are recognized by Mr. Alston (Biol. Cent. Amer., Mam., pp. 166-168) as valid, and of these two only ( $H$. desmarestianus and $H$. longicaudatus) are found north of the Isthmus of Panama. The present example differs apparently in important features from either of these, and a detailed description of it is therefore appended.

"In size and general appearance it greatly resembles Perognathus fasciatus, but is a typical Heteromys; the upper incisors being smooth while the pelage is mixed with flat grooved spines. Tail vertebræ as long as head and body; with hairs, half an inch longer. Tail tufted at the end, the lengthened hairs forming a crest, as in Perognathus pencillatus. Soles hairy from the heel nearly to the bases of the toes; but a slight strip along the heel is naked. A very prominent black tubercle at the base of the inner toe. Under surfaces of the toes naked and scaly. Palms naked from the wrist. Upper surfaces of hands and feet densely hairy. Ears large, orbicular, projecting beyond the fur ; notch bounded behind by a very large flap-like lobe, in front by a slight fold (much as in Perognathus pencillatus).

"Coloration not unlike that of Perognathus fasciatus, but darker. Under parts pure white. A conspicuous stripe of fawn-color extends the whole length of the head and body, separating the white under parts from the dark upper parts. Nearly the whole fore leg is colored like the upper parts; this dark color also descending the hind leg and advancing a short distance on the tarsus. The 
dark color of the fore leg is separated from that of the upper parts by the fawncolored stripe ; that of the hind leg is continuous. Ears conspicuously bordered with white. The general color of the upper parts is blackish intimately grizzled with gray and sandy ; the dark colors predominate and give the general effect on the back, the admixture of sandy increasing on the sides in approaching the fawn-colored stripe. The spines are colorless in all their grooved portion, the smooth sharp lips being blackish ; these comprise one fifth to one fourth of the whole length. The very slender hairs intermixed with the spines are similarly colored. The spines are restricted to the upper parts; elsewhere the fur is soft, but coarse, and there appears to be no under fur. The hairs of the white under parts, and of the fawn-colored stripe, are uniformly colored from root to tip. The tail sharply bicolor, blackish above and white below, fully haired, the hair completely hiding the scales; the pencil at the end is entirely dark-colored and occupies the terminal inch of the vertebræ. Whiskers partly blackish and partly colorless. Claws nearly colorless. Incisors yellow.

"The length of the well-prepared skin (No. 5889, M. C. Z.) is 4.30 inches. Tail vertebræ the same. Tail with hairs, 4.75. Hind foot, 1.15. Ear, .55 above notch.

"As above stated, this example is of the size of Perognathus fasciatus, which it much resembles in general appearance, especially in the conspicuous fawncolored stripe along the sides; in its long tufted tail it resembles $P$. pencillatus, but is of course generically different from either. The white rim of the ears is also a strong mark." - Coues, MS.

In 1868, Dr. J. E. Gray (Proc. Zoöl. Soc., 1868, pp. 204, 205) described three species of Heteromys from Mexico (H. longicaudatus, irroratus, and albolimbatuis) and one from Honduras ( $H$. melanoleucus), all of which Mr. Alston has referred to a single species, together with another $(H$. adspersus) from Panama described by Dr. Peters, in each case from an exanination of the types. For this species he adopts the name longicaudatus as "the only one of Gray's names which is not absolutely misleading." In view of this large number of synonyms it seems presumptuous to take the risk of adding another, although the present example does not agree with the characters given by Mr. Alston for $H$. longicaudatus, nor with those of any of the species described by Gray, although recalling certain features of two of them. It has, for instance, the white-rimmed ears of $H$. albolimbatus, and "the yellow streak on the side," or "widish interrupted yellow line," of $H$. irroratus (which, however, Mr. Alston says, is merely "a slight tinge of pale fawn along the edge of the darker coloring "), except that in the present example it is not interrupted and forms a conspicuous feature of the coloration. There is no allusion in any of the descriptions, nor in Mr. Alston's diagnosis and remarks, to the conspicuous crest of long (.50 to .65 of an inch in length) blackish hairs along the terminal fifth of the tail-vertebræ, unless it be that the phrase, "short black hairs, which are more abundant on the upper part near and at the tip, forming a kind of pencil," in the description of $H$. albolimbatus, can be so construed. From Mr. 
Alston's determinations it is evident that specimens he refers to $H$. longicaudatus present considerable variations in color, in the length and hairiness of the tail, etc., and may or may not have white-edged ears. In view of this fact a conservative course seems the only advisable one in the present instance.

I may here add that some months since (before the appearance of Mr. Alston's revision of the group) I submitted the specimen to Dr. Coues, who considered it as undescribed (an opinion I then fully shared), and returned it with the above-given description and MS. name.

\section{Thomomys talpoides umbrinus (Rich.), Coues. Southern Pocket} GOPHER.

Two specimens, San Luis Potosi. "Abundant. Very troublesome in the sugar fields."

The specimens collected by Dr. Palmer extend the known range of the species much to the southward (some $10^{\circ}$ of latitude) and eastward of previously recorded localities (Espia and Santa Cruz, State of Sonora).

\section{Lepus sylvaticus, Bachm. Wood Hare; "Gray Rabbit."}

Six specimens, from the vicinity of San Luis Potosi. The series includes both young and adult.

"Everywhere abundant. Brought into the towns by the mule-load."

\section{Lepus callotis, Wagler. Mexican Hare ; "Jackass Rabitt."}

Eleven specimens, including a series of young examples, from San Luis Potosi.

"Abundant everywhere; more common even than the smaller species $[L$. sylvaticus] and forms an important source of food."

\section{Tatusia novemcincta (Linné). Armadillo.}

There is a single carapace in the collection from the Tierra Calienta of the State of San Luis Potosi, where, according to Dr. Palmer, the animal is not uncommon.

\section{Didelphys}

Parras, two specimens (skins and skulls in spirits), apparently about halfgrown, of a species not yet determined. The ears are entirely white ; there are three prominent black stripes on the face, and the long hairs of the dorsal surface are black, imparting this color to the whole dorsal aspect.

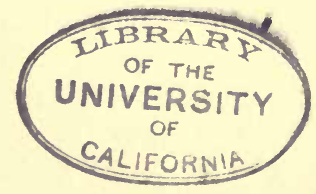





DEPARTMENT OF THE INTERIOR. UNITED STATES GEOLOGICAL AND GEOGRAPHICAL SURVEY.

F, V. HAYDEN, U, S. Geologist-in-Charge.

\section{PRELIMINARY LIST}

OF

\section{WORKS AND PAPERS}

RELATING TO THE

\section{MAMUALIAN ORDERS OF CETE AND SIRENIA. \\ $\mathbf{B X}$}

JOEL ASAPH ALLEN.

EXTRAOTED FROM THE BULLETIN OF THE SURVEX, VOL. $\nabla I$, No. 3. 


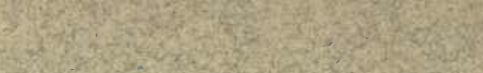

W.

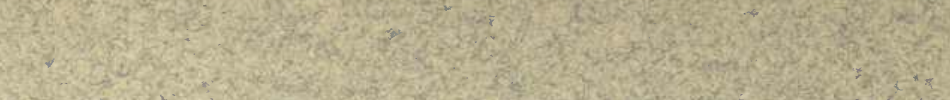

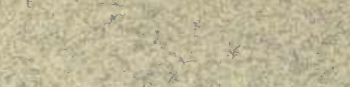

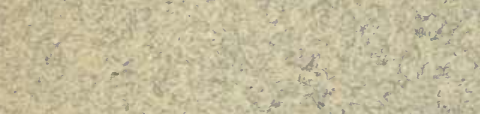

W.

(1)

(1)

(20) $43^{2}$ P. $x+4$ 


\section{Art. IVIII.-Prelimimary List of Works and Pa- pers Relating to the Mammalian Drders Cete and Sirenia.}

\section{By Joel Asaph Allen.}

OwING to the illness of the author, which prevented his revision of the proofsheets, it was necessary to stop the printing of the "List" at the end of the year I840. The present instalment comprises only a little more than one-third of the article; the remainder will be published as soon as the author's health renders it practicable.

Cambridge, Sept., 1882.

J. A. ALLEN.

reached in the collection of titles nere preserrteu. uno uopewnenent of the subject of the Whale-fishery, for example, has been intentionally wholly neglected, namely, legislation for its promotion and regulation by different governments. This alone would furnish hundreds of titles, which, while having only a remote bearing on the natural history of Whales, would still have some importance in regard to the history of Whaling.

The titles here given have been taken by the writer, when not otherwise stated, from the works and papers mentioned, and the comments, unless otherwise indicated, are based on personal examination of the same. Many titles relating to the Whale-fishery have been copied from D. Mulder Bosgoed's invaluable "Bibliotheca Ichthyologia et Pis- 



\section{Art. XVIII.-Preliminary List of Works and Pa- pers Relating to the Mammalian Orders Cete and Sirenia.}

\section{By Joel Asaph Allen.}

Preparatory to undertaking the preparation of a history of the species of the North American Cete and Sirenia, I began, some time since, a systematic examination of the literature of the subject, taking titles and making notes for future reference. It soon occurred to me that the annotated list begun for my own use might be of service to other investigators in Cetology and Sirenology, and with this point in view I set about the preparation of a bibliography of these subjects. The titles thus far gathered are believed to cover nearly everything of importance bearing upon their technical aspects, besides the more important of those relating to their economical and commercial phases. The deficiencies relate mainly to the latter, and consist in great degree of casual notices of animals of the above-named orders in narratives of travel and exploration, and in periodicals of an ephemeral or non-scientific character, relating generally to the capture or stranding of Whales at different localities, and notices of Whaling. To make a bibliography which should be exhaustive in these respects would be, it is needless to say, the work of a lifetime, and would scarcely repay the labor expended beyond a certain point of completeness, believed to have been nearly reached in the collection of titles here presented. One department of the subject of the Whale-fishery, for example, has been intentionally wholly neglected, namely, legislation for its promotion and regulation by different governments. This alone would furnish hundreds of titles, which, while having only a remote bearing on the natural history of Whales, would still have some importance in regard to the history of Whaling.

The titles here given have been taken by the writer, when not otherwise stated, from the works and papers mentioned, and the comments, unless otherwise indicated, are based on personal examination of the same. Many titles relating to the Whale-fishery have been copied from D. Mulder Bosgoed's invaluable "Bibliotheca Ichthyologia et Pis- 
catoria" ( $8 \circ$, Haarlem, 1873), especially many of those published in the Dutch language. The titles have, in many eases, been taken by preference from this author, for two reasons: first, they are generally more fully given by him, and with greater regard to literal transcription, than in many other works; and, secondly, they are usually accompanied with references to the particular portion of works, when of a general character, relating to the special subject here in hand. The titles unaccredited may be considered as representing the literary resources in this field of research afforded by the principal libraries of Cambridge and Boston, circumstances having thus far prevented me from consulting those of other cities. In some cases the sets of periodical publications have proved incomplete, and in a few eases wholly wanting. To cover these deficiencies, titles of works or papers known to me throngh citation by authors have been taken from the Royal Society's "Catalogue of Scientific Papers," or from other bibliographical sources. In this way it is believed that few papers of actual scientific value have escaped record. I have, however, proof of the incompleteness of this "Preliminary List" in the considerable number of "catch references" still in hand, which are too incomplete for insertion, but which an effort will be made to perfect as opportunity may favor, to be giren later, with such others as mav be met with, in a contemplated reprint of the present "List." In view of a probable later edition, the author earnestly solicits the correction of errors that may be discovered in the present, and would be glad to have his attention directed to any omissions.

In regard to the plan of the present undertaking, it may be stated that the titles are arranged chronologically, with an alphabetical disposition of authors under each year. The index to the "List" (the titles being consecutively numbered) will facilitate reference to any particular author or paper desired. In the case of minor papers, the annotations are intended as simply an amplification of the titlein other words, an explanation of the scope and nature of the article cited. In works of a general character, containing brief references to the matter here in hand, the particular portion of the work relating to the subject is stated, with an indication of its extent and importance. In the case of monographs, anatomical memoirs, or special works, the contents are indicated by the transcription of sub-titles, when such occur, and by further amplification when deemed desirable; in other cases by supplied sub-headings. Each species formally mentioned or figured is enumerated, with page-references, and in case of figures an indication is given of their nature or bearing. As a matter of convenience, the species are generally numbered with Arabic numerals in heavy type, these showing at a glance the number of species formally treated or recognized in the work or memoir. In the case of old works, or where vernacular names are alone used, the modern current systematic equivalent is frequently indicated. In every instance where such occur, new species and new genera are especially distinguished. 
Great care has been taken to make the transcription of titles strictly literal, interpolations or emendations being inclosed in brackets. Errors of transcription can, nevertheless, scarcely be otherwise than frequent, as every bibliographer must be well aware. The orthography and capitalization of scientific names are intended to be literal, or in accordance with the usage of the particular work under notice, from which, however, there are doubtless occasional lapses. The attempt has been made to bring the "List" down to the end of the year 1880, but a few later titles have been added, and there are doubtless many deficiencies for the last year of the record.

MUSEUM OF Comparative Zoology, Cambridge, Mass., September, 1581.

1495. Albertus Magnus. Dini Alberti Magni de Animalibus | libri vigintisex Novissime Impressi. [First page.] fol. 11. 6, ff. 1-254.

Impressum Uenetijs per Joaunem \& Gregorium / de Gregorijs fratres. Anno incarnationis dominice | Millesimo quadringentesimo nonagesimo quinto | die, xxi. Maij. Regnante dño Augustino Barbadi co | inclito Duce Uenetia 2 [f. 254].

Cetus, f. 240; Delphinus, f. 211; Monoceros, f. 244. The interest attaching to the cetological matter is purely historic.

1510. ANDREW, LAOR. "The wonderfnl shape and nature of man, beastes, serpentes, fowles, fishes, and monsters, translated out of divers autliors by L. Andrew of Calis, and printed at Antuerpe, by John Doesborow. (Doesborch, 1510.) fol. With pictures."

Not seen; title from Bosgoed, op. cit., p. 2, no. 10.

1526. Oviedo, G. F. DE. Oniedo dela natural hy / storia delas Indias. / Con preuilegio dela | S. C. C. M. | [Por Gonzalo Fernandez de Oviedo y Valdés. Toledo. 1526.] $4^{\circ}$. ff. i-lij+3 pp.

Delos manaties, f. xlviij (30 lines). The account of the Manatee here given is brief in comparison with that in the Hist. gen. Ind., 1535, q.v.

1533. Martyr, P. Petri Martyris | ab Angleria mediolanen. Oratoris | clarissimi, Fernandi \& Helisabeth Hispaniarum quondan regum | à consilijs, de rebus Oceanis \& Orbe nouo decades tres: quibus | quicquid de inuentis nuper terris traditum, nouarum rerum cupi- | dum lectorem retinere possit, copiose, fideliter, eruditíß tres: vbi praeter oratorii mvneris | pulcherrimum exemplum, etiam quicquid in uariarum gentium mori- | bus \& institutis insigniter preclarum nidit queq́ terra mariø̧ acciderunt, | omnia lectu mirè incunda, genere dicendi politissimo traduntur. | [Design.] Basileae, |-| M. D. XXXIII. | fol. 11. 12, ff. 1-92.

Manati, f. 60, C, D.

1535. Oviedo, G. F. DE. La historia general | delas Indias. | [Por Gonzalo Fernandez de Oviedo y Valdés.] Con priuilegio imperial. [Sevilla, 1535.] I $4^{\mathrm{C}}$. 11. 4, ff. i-cxciij.

Capitulo x. Del Manati y de sn grandeza \& forma: \& de la manera que algunas vezes los indios tomanan este grāde animal conel pexe renerso : \& otras particularidades. ff. evj-cvijj, fig.

The account occupics $5 \mathrm{pp}$., and is important as the source whence many later compilers drew their materials for the history of the Manatee, and is still historically of the highest in. terest. There is a small, very rude cut, bearing some likeness to the general form of tho Manatee-the earliest figure of the animal published. In the edition of 1547 the text (ff. $\mathrm{cvj}-$ crijj) is the same as in the present, but the figure is slightly different, showing an attempt at artistic improvement. 
1551. Bélon, Prerre. "L'histoire Naturelle des Estranges Poissons Marins, avec la vraie Peincture et Description du Dauphin et de plusieurs autres de son espece, Observée par Pierre Bélon du Mans. A Paris, 1551. 4. pp. 115."

Not seen; title from Dr. Darid Cragie in Edinb. Phil. Journ., xi, 1831, p. 43, where he gives a critical rísumé (op. cit., pp. 43-48) of Bélon's account of the anatomy of the Porpoise.

1552. Aristoteles. Aristotelis et / Theophrasti | Historiæ, Cùm de natura Animalium, tum de Plantis | \& earum Causis, cuncta ferè, quæ Deus opt. | max. homini contemplanda exhibuit, ad | amussim complectentes: nunc iam sno resti- | tutæ nitori, \& mendis omnibus, quoad fieri | potuit, repurgatæ. | Crm Indice Copio- | sissimo: | Ex quo superfluum quod erat, decerpsimus: quod nerò | necessarium nobis uisum est, superaddidimus. | Estote Prvdentes, | [Vignette] | sicvt serpentes. | Lvgdvni, | Apud Gulielmum Gazeium, | M.D.LII. | Cum Prinilegio Regis. | 80. 11. 40, pp. 1-495, 11. 8 (animal.), 11. 28, pp. 1-399, 11. 7 (plant.).

De partu, \& pullorum numero piscium uiviparum, delphino, balæna, vitalo marino, \& reliquis, quæ cete appellantur. Liber vi, caput xiii, pp. 141-143.

Several earlier and numerous later editions and commentaries of this work are intentionally omitted.

1553. Betron, P. [or Belon, P.] Petri Bellonii Cenomani | De aquatilibus, Libri duo $\mid$ Cum econibus ad vinam ipsornm effigiem, quoad | eius fieri potnit, expressis. | Ad amplissimum Cardinalem Castillionæum. | Parisiis. | Apud Carolum Stephanum, Typographum Regium. | M. D. LIII. | Cum privilegio Regis. obl. $8^{\circ}$. 11. 16, pp. 1-448.

De cetaceis, ossibus præditis ac riuiparis, pp. 4-18.-Balena, pp. 4,5; Delphinus, pp. 7, 8, fig., p.6 (apparently of Phocana communis); fig., p. 9 (apparently of Delphinus delphis); Non esse Delphinvm incrrvvm, p. 9; fig., p. 10 (apparently of Delphinus delphis); Duo Delphini incurui, dorso repando, ex antiquissimo numismate æreo, figs., p. 11; Quid Delphinus a Trrsione distet, p. 12 ; Matricis Delphini cnm foetu effornatio, fig., p. 13 ; Delphini caluaria, text and fig., p. 14; Trrsio, p. 15, fig., p. 16; Orca, pp. 16, 17, fig., p. 18. Dolphin-like fignre with footus attached by foetal envelopes.

The figures were all reproduced by Gesner, and were also copied by varions later au. thors.

1554. Gomara, F. L. DE. La Historia / general delas Indias, | con todos los descubrimientos, y cosas nota | bles que han acaescido enellas, dende | que se ganeron hasta agora, escri- | ta por Francisco Lopez | de Gomara, clerigo. | Añadiose de nueno la descripcion y traça delas Indias, | con una Tabla alphabetica delas Prouincias, Islas, | Pucreos, Ciudades, y nombres de conquistadores | v varones principales que alla han passado. | [Cygnet.] En Anvers. | En casa de Iuan Steelsio. | Año M. D. LIIII. | sm. 80. 11. 16+ff. 1-287.

Dela Pez que llaman enla Española Manati, cap. xxxi, ff. 37, 38.

1554. Rondelet, G. Gvlielmi | Rondeletii | Doctoris medici | et medicinae in schola | Monspeliensi Pro- | fessoris Re- | gii. | Libri de Piscibus Marinis, in quibus | veræ Piscium effigies expressæ sunt. | Quæ in tota Piscium historia contineantur, indicat | Elenchus pagina nona et decima. | Postremò accesserunt Indices necessarij. | [Design.] Lrgdvni / Apud Matthiam Bonhomme. | - | M. D. LIII. | Cum Priuilgio Regis ad duodecim annos. 2०. 11. 8, pp. 1-583, 11. 12.

De Delphino, lib. xvi, cap. viii, pp. 459-473, fig., p. 459 (a Dolphin with young in foetal envelopes). De Phocæna, lib. xvi, cap. ix, pp. 437, 474. De Tursione, lib. xri, cap. x, pp. 474, 475, fig. De Balæna valgd licta sine de Mascule, lib. xvi, cap. xi, pp. 475-482, fig., p. 475 (view from above of some pisciform creature having more resemblance to a fish than a Whale. Also fig. of a harpoon on same page). De Balena vera, lib. xvi, cap. xii, pp. 482, 483, fig. (anim. fict.). De Orea, lib. xvi, cap. xiii, pp. 483-485, fig., p. 483. De Physetere, lib. xvi, cap. xiiii, pp. 485-487, fig., p. 485. De Manato, lib. xvi, cap. xviii, p. 490.

The figure "De Delphino" greatly resembles Bellon's figure of his "Orca, Oudre, ou grand Marsouin," but differs in details, and is not the same.

[10.]

1555. "Belon, P. La nature et diversité des poissons. Avec leurs pourtraicts representez au plus prìs naturel. Paris, Cl. Estienne, 1555. obl, $8^{\circ} .448$ 1l."

Not seen; title from Bosgoed, op. cit., p. 3, no. 24. 
1555. "Olaus Magnus. Historia do gentibus septentrionalibus earumque diversis statibus, conditionibus, moribus, ritibus, superstitionibus. Romae, de Viottis, 1555. 4०. [fol. ?] Met houtgr."

"Lib. xxi. De piscibus monstrosis; de modo riscandi Cetos et Balenas; de Spermate ceti. etc., ete."

Not seen; title and reference from Bosgoel, op. cit., p. 109, no. 1732.

This is said by Bosgoed to be the first and best edition of the work. Other editions appeared later: Antwerp, 1558 (Latiu) and 1561 (French); Venice, 1565; Basel, 1567; Amsterdam, 1599; Frankfort, 1025; Lesden, 1645; Amsterdam, 16.52; the form varying from $8^{\circ}$ to fol., and the text modified by abridgment, or amplified by the addition of extraneous matter. I give infra, from Bosgoed, a collation of the Dutch edition of 1599, $q . v$.

[12.]

1558. "Boussuetr, Fr. De natura aquatilium carmen, in universam G. Roudeletii, quam de piscibus mariuis seripsit historiam. Cum vivis eorum imaginibus. Lugduni, apud M. Bonhomme, 1558. 2 pt. 4 ०."

Not seen; title from Boszoed, op. cit., p. 4. no. 35 .

1558. Gesner, Conrad. Conradi Gesneri | medici Tigurini Historiæ Animalinm | Liber IIII. qui est de Piscium \& | Aquatilium animantium | natura. | Crm Iconibvs singvlorvm ad | riva!n expressis fere omnib. DCCVI. | Continentur in hoc Volumine, Gvlielmi Rondeletii quoc, | medicinæ professoris Regij in Schola Monspeliensi, \& Petri Bel- | lonii Cenomani, medici hoc tempore Lutetiæ eximij, de | Aquatilium singulis scripta. I Ad invictissimvm, principem divvm Ferdinan- | dum Imperatorem semper Augustum, \&c. | . . . [motto in Greek, 1 line.] | [Vignctte.] Cvm Priuilegijs S. Cæsareæ Maiestatis ad octennium, \& poten- | tissimi Regis Galliarum ad decennium. I Tigvri apvd Christoph. Froschovervm, | Auno M. D. LVIII. | gr. 20. 11. 6, pp. 1-1:297. (Figg. in text.)

De Balaena vrlgo dicta, sire de Mgsticeto Aristotelis, Mrserlo Plinii, pp. 132-141 (fig. p, 132). De Cetis vel Cetaceis piscibus, et Bellvis marinis in genere, pp. 229-237. De Cetis diversis, pp. 237-256, fig., p. 255 (de . . Cetis Oceani Germanici). Do Delphịno, pp. 380-410. De Phoeaena sev Trrsione, pp. 837-839. De (Physalo Bellva, sev) Physetere, pp. 851-859.

Includes, in substance, the text of Belon and Rondelet, with much additional watter, mainly from still earlier authors. The above-cited figures are, with possibly one exception, fron either Belon or Rondelet. At pp. 246-251 are descriptions and figures, mostly from Olaus Magnus, of various fabulous marine monsters.

For editions of 1560 and 1563, see infrà; later ones (not seen by me) are: Frankfort, gr. fol., $1604,1620$.

1558. Rondelet, G. Le Premiere Partie | de | l'Histoire | entiere des | Poissons, | Composée premierement en Latin par maistre | Guilaume Rondelet Docteur regent en Me- / decine en l'université de Mompelier. | Maintenant Traduite en François sans auoir | rieu ... [ [ rord torn ont] necessaire à l'intelligence d'icelle. | ... [word torn out] portraits au naif. | [Vignette.] À Lion, | par Mace Bonhome | a la Masse d'Or. | - | M. D. LVIII. | Avec privilego dv Roy povr dorze ans. $4^{\circ}$. 11. 6, pp. 1-418, 11. 7. [Partie Seconde.] pp. 1-181, 11. 5. [Numerous ents in the text.]

Le Seiziéme Lirre des Poissons; Des Poissons Cétacées é grandes bestes marines. éspec!alement des Tortnes, pp. 336-364.-Du Dauphin, pp. 344-350, cut; Du Marsouin, p. 350, cnt; De la Balene vulgaire, pp. 351.3:3, cut; De la vraie Balene, pp. 353, 354, cut; De l'Espaular, pp. 354, 355, cut; Du Malar ou Sendette, pp. 355, 356, cut; De la Vinelle, pp. 356, 357, cut; De la Scolopendre cetacée, pp. 357, 358, cut; Du Tibnron, pp. 358, 359; Du Maraxe, p. 359; Du Manat, pp. 359, 360.

Le Seiziéme Livre includes not only the species above named, but also the Sea-Tortoises, and varions anthropomorphous marine monsters. The first four books treat of the general economy of "Fishes," including their external and internal anatomy, their habits, faculties, etc., and of modes of eapturing them, including the Cetacea parsim. The figures are the same as those of the Latin ed. (1554), q. v. The second division of the work contains the marine Invertebrates, the fluviatile Fishes, $\Delta$ mphibians, Reptiles, and Turtles, and also the Beaver, "le Bieure."

1558. Thevet, F. A. Les | Singvlari- | tez de la France an- | taretiqve, avtrement nom- | mée Amerique, \& de plusieurs Ter- | res \& Isles deconuertes do no- | stre temps: | Par F. Andre Theret, na- | tif d'Angovlesme. | [Seal.] A An- 
1558. Thevet, F. A.-Continued.

vers, | De l'imprimerie de Cliristophle Plantin | a la Licorne d'or. | 1558. | Avec Privilege dv Roy. I sm. 80. 11. 8, 1-163+1. (Cuts in text.)

Description du manati, poisson estrange, p. 138.

1560. Gesver, Conrad. Nomenclator / aqvatilivm animantivm. | Icones Animalivm a- | quatilium in mari \& dulcibus aquis de- / gentinm, plus quàm Dcc. cum nomen- | claturis singulorum Latinis, Grecis, Itali- | cis, Hispanicis, Gallicis, Germanicis, | Anglicis, alij'sq; interdum, per cer- | tos ordines digestæ. | Explicantvr autem singulorum nomina ac nominū rationes, præ- | certim in Latina et Græca lingna vberrime: et nominum confirmandorum cansa : descriptiones quorundam, et alia quædam, prosertim in magno nostro Do aqnatili- | bus volumine non tradita, adduntur: deł̧ singulis Rondeletij, Bellonij, Saluiani et | nostræ sententiæ explicantur breuissimé. | Per Conradrm Gesnervm Tigvrinvm. | Le Figure de pesci e d' altri animali, li quali niuono ne l' acque | salse e dolci, piu che DCC. / ... [The same repeated in French, 2 lines, and in German, 2 lines.] / Crm Privilegijs S. Cæsaræ Maiestatis, ad annos octo, \& poten- | tissimi Regis Galliarum ad decenninm. | Tiguri excvdebat Christoph. Froscho- / vervs. Anno M.D.LX. | $2^{\circ}$. 1l. 14, pp. 1-374, 1. 1. (Figg. in text.)

Ordo XII: De Cetis proprie dictis, pp. 160-185. Figg. Delphinus fœemina cum fœetu masculoso, ut Rondeletins exhibuit $[=$ Phoccena communis $]$, p. 161; Alia Delphini pictnra, quam a Corn. Sittardo habni [ = Delphinus delphis], p. 161; Delphini caluaria è libro Bellonij [ =D. delphis], p. 162; Ex codem, Delphini matricis cum fœetu efformatio: quæ Phocæna ctiom conuenit, p. 162; Ex eodem, Antiquissimi numismatis ærei pictura: quod Dolphinos dnos dorso repando curuos ostendit, non qudd eiusmodi uerè sint:... p. 162; Tursio, p. 163; I:alænæ, fig. et descrip., pp. 166-169 (3 figg.): Pristris aut Physeter, horribilo genus cetorum, \& ingens ex capite multum aquæ in naues effat, \& aliquando submergit, Olaus Magnus in Tabulæ suæ explicatione: ... p. 170; Balæna, Adden., pp. 366-308, fig., p. 367 [= Physeter macrocephalus]. Rostrum uel os à capite prominens, satis conmodè exprimi uidetar: roliguum uerò corpus ad coniecturam à Rondeletio effictum, p. 171.

The article "De Cetis" includes not only the true Cete but also Pinnipedia, and the pelagio Turtles, as well as the many fabulons monsters of the sea depictel by Olaus Magnus, etc.

In this work, usually cited as Icon. Anim. Aquat., the text is much reduced from that of the Hist. Animal., 1558, q.v. (from about 80 pp. to $24 \mathrm{pp}$.), but the cnts are nearly all reproduced (three or four only are omitted), and otbers are added, including a larger and much improved one of the skull of the Dolphin in place of the former one. In the "Adldenda" is a description and figure of a Sperm Whale stranded June, 1755, on the coast of the Afriatic Sea. This is one of the earliest figures of this species, and a better one than some publisbed two centuries later.

[17.]

1560. Grovio, Paolo. Libro di / mons. Paolo Giovio / de' pesci Romani. / tradotto in Volgare da | Carlo Zancarnolo. | Con privilegio. | [Vignette with motto.] In Venetia, appresso il Gualtieri, 1560. 4०. pp. 1-198.

Del Capidoglio (=Orca), cap. 2, pp. 22-27.

1563. GFsner, Conrad. "Fishbuch Das ist ein kurtze, doch vollkō̄ne beschreybung aller Fischen so in dem Meer unnd suissen wasseren, Seen, Flïssen oder anderen Bächen jr wonung habend, sampt jrer waaren conterfactur: zü nutz u. güten allen Artzeten etc. gestelt: insonders aber denen so ein lust habend zï erfaren und betrachten Gottes wunderbare werck in scinen geschöpfften. Erstlich in Latein durch Cünradt Gässner beschriben; yetz neïwlich aber durch Cünradt Forer etc. in das Teütsch gebracht. (Mit eingedr. Holzschnitten:) In Fol. Zürych, (1563 u.) 1575. Froschorcr. (9 u. 404 S.)"

Not seen; title from Carus and Engelmann, Bibl. Hist. Nat., i, p. 433. For acconnt of Cetological matter see the ed. prin., 1560.

1565. Bexzoni, G. La Historia del | Mondo Nrovo | Di M. Girolamo Benzoni | Milanese. | Laqval Tratta dell'Isole, | \& Mari nuouamente ritrouati, \& dello nuoue | Città da lui proprio vedute, per acqua | \& per terra in quattordeci anni. | [Portrait.] Con Priuilegio della Illnstrissima Signoria | di Venetia, Per anni $x x[=1565]$. sm, $8^{\circ}$ by sig., $24^{\circ}$ size. . ll. 4, ff. 1-175. Reverse of $f$. 175: In Venetia, | appresso Francesco | Rampazetto. | MDLXV. 
1565. Ramusio, G. B. Terzo Volvme / delle Navigatione et Viaggi / raccolto gia da M. Gio. Battista Ramusio | nel quale si contengono | ... [ $=13$ lines descriptive of contents]. Si come si legge nelle diuerse Relationi, tradotte dal Ramusio di Lingua | Spagnuola \& Francese nella nostra, \& raccolte in questo volume. | ... [ = 3 lines]. | [Design.] In Venetia vella stamperia de' Givnti. | L'Anno M. D. LXV. fol. 11. 6, ff. 1-34, 1-456. Maps and cuts.

Manati, ff. 40, 71, 72, 159-161; cut, f. 159. The figure is a copy of Oriedo's, apprecisbly altered. The account given is also a translation from Oviedo.

1577 (circa). ANov. "Ware und eigentlicher Contrafactur eines Wallfisehes, gefangen in der Scheldt, nicht weit von Antorff, Am 5 Julij Anno 1577. (Als bovensehrift van de prent. Van onderen een 16 regelig Hoogduitsch vers.) br. folio."

Not seen; title from Bosgoed, op cit., p. 176, no. 2771, who says: "Zie: Jfuller, Beschrijving van Ned. historieprenten, no. 738."

1578. Benzovi, Girolamo. Novae Novi | orbis Historiæ, I Id est, / Rerum ab Hispanis in Indła Occidentali ha- | etenus gestarum, \& acerbo illorum | in eas gentes dominatu, | Libri tres, | Vrbani Calvetonis | opera industriáque ex Italicis Hieronymi Benzo- | nis Mediolaneusis, qui eas terras xiiii. anno- | rum peregrinatione obijt, commentarijs descripti; Latini facti, ac perpetuis notis, argumentis \& locu | pleti memorabilinm rerum ąccessione, illustrati. | His ab eodem adiuncta est, I De Gallorum in Floridam expeditione, \& insigni Hispanorum / in eos feuitiæe exemplo, Breuis Historia. | Anchora [Design] Sacra. | [Genevæ.] | Apvd Evstathivm Vignon. | - M.D.LXXVIII. 8․ 11. 16, pp. 1-480, 11. 6.

Manati pisces, cap. xiii, pp. 213,214, 216, 217. There is first in the text (pp. 213, 214) a short account of the Manati of Nicaragua, and at the end of the chapter (pp. 216, 217) a further account, based on that given by Peter Martyr (1533), q.v. The last is additional to that of the original edition, $1565, q . v$.

1590. Acosta, J. DE. Historia | Natvral | y | moral delas | Indias, | en que se Tratan las Cosas | notahles del cielo, y elementos, metales, plantas, $y$ ani- | males dellas: y los ritos, y ceremonias, leyes, y / gonierno, y guerras de los Indios. I Compuesta por el Padre Ioseph de Acosta Religioso | de la Compañia de Iesus. | Dirigida ala serenissima | Infanta Doña Isabella Clara Engenia de Austria. | [Design.] Con Privilegio. | Impresso en Seuilla en casa de Iuau de Leon. | - | Año de 1590. $4^{\circ}$. pp. 1-535, 11. 15.

De diuersos pescados, y modos de pescar de los Indios. Lib. iii. cap. "17" (i. e. xV), pp. 158-162.

Manati, p. 158; Vallena, pp. 160, 161.

There are only a few lines about the Manati, and these are not important. The account of the capture of Whales by the Indians of Florida, as related to him by " some expert men," is of special interest, as being doubtless the origin of the relation, so often told later, of how the Indians of Florida capture the Whale by getting astride his neck and plugging his nostrils with wooden stakes, to which thoy afterwards attach corls and by them tow the Whale, thus killed, to the shore. It is doubtless on this description that the illustration of this manner of killing Whales is based in De Bry. (See Be Bry, 1602.)

Of the numerous subsequent editions and versions of Acosta's work a number are giren below, including an Italian (1596), a French (1598), and an English (1604). (See Acosta, J. $\mathrm{DE}$, under these dates.) There is a Latin translation in De Bry, fol., 1602 (part ix of the "Greater Voyages.")

1593. Prinrus Secundus, C. C. Plinij Secundi / Historiæ Mvndi / Libri xxxvii. | A Sigismvndo Gelenio | summa fide castigati, veterúmque tum excu- | sorum tum manuscriptorum codicum atten- | tissima collatione restituti. | Accessere ad marginem variæ lectiones, ex | Pintiani, Tvrnebi, LipsiI, | aliorímque doctissimorum qui pagina quarta | indicantur scriptis fideliter exceptæ. | Opus tributum in tomos tres cum Indice | rerum onnium copiosissimo. | Tomus

- Primus [-Tertius]. | [Vignette.] | Apvd Iacobvm Stoer. |-| M. D. XCIII. The title changes in the second and third volumes to the following:

C. Plinii | Secvndi Histo- | rix Mrrdi | Tomus Secundus[-Tertius], A Sigismvudo Gelenio diligenter | castigatus, veterúmque codicum colla- | tione 


\section{Plinius Secundus, C.-Continued.}

restitutus. | Additæ ad marginem variæ lectiones ex | doctorum virorum scrip. tis fideli- | ter exceptr. | Quro hoc Tomo continentur sequens | pagina indicat. | [Vignette.] Apvd Iacolvvm Stoer | - | M. D. XCIII. 3 vols. sm. $8^{\circ}$ by sig., $16^{\circ}$ size.

De balænis, \& orcis, tom. i, liber ix, cap. ri, pp. 415, 416. De Delphinis, cap. viii, pp.417-421. De tursionibus, cap. ix, p. 421.

There are earlier and numerous later editions and commentaries of the work, but they are intentionally omitted.

1594. Pomet, Pierre. Histoire | generale | des | Drogues, | traitant | Des Plantes, des Animaux, | \& des Mineraux; Ouvrage enrichy de plus de | quatre cent Figures en Taille-douce tirées d'aprés | Nature; avec un discours qui explique leurs | differens Noms, les Pays d'où elles viennent, la | maniere de connoitro les Veritables d'avec les | Falsisiées, \& leur proprietez, où l'on découvre | l'erreur des Anciens \& des Modernes; Le tout tres | utile an Public. | Par lo Sieur Pierre Pomet, Marchand Epicier \& Droguiste. I [Design.] A Paris, I ('hez Jean-Baptiste Loyson, \& Angustin Pillon, sur le Pont au Change, I a la Prudence. | Et au Palais, | Chez Estienne Ducastin, dans la Gallerie des Prisonniers, au bon Pasteur. | - | Avec Approbation \& Privilege du Roy. | M. DC. XCIV. fol. 1l. 6, pp. 1-16; pt. i, 1-304; pt. ii, 1-108; pt. iii, 1-116, 11. 19.

Sur l'Ambre gris, p. 3 (de sér. prem. de pag.); part ii, chap. xxvi, pp. 57-60. De la Baleine, part ii, chap. xxxi, pp. 73-75, 2 tigs. (Cachalot, ou Baleine Masle et Baleine Femelle). Du Narwal, part ii, chap. xxxiii, pp. 78-80, 2 figs. (Licorne de Mer et Narwal). Du Lamantin, part ii, chap. $x \times x v$, pp. 82-84, fig.

The figures are very curious, as is also the text. The figures of the Cachalot represent the process of flensing. The figure of the Manatee is apparentls copied from an earlier design.

[26.]

1595 Goltzius, H. "Walvisch of Tonyn, gestrand te Zandvoort, 1595. Met adres van (en door) $H$. Goltzius, en 14 regelig hollandsch vers. br. $40 . "$

Not seen; title from Bosgoed, op. cit., p. 176, no. 2772, who says: "Zie: Muller, Historieprenten, no. 1033."

1596. Acosta, J. DE. Historia | Natvrale, e Morale | delle Indie; | scritta | Dal R. P. Gioseffo di Acosta | Della Compagnia del Giesù ; | Nellaquale si trattano le cose notabili del Cielo, \& de gli | Elementi, Metalli, Piante, \& Animali di quelle: | i suoiriti, \& ceremonie: Leggi, \& gouerni, | \& gnerre degli Indiani. | Nouamente tradotta della lingua Spagnuola nella Italiana | Da Gio. Paolo Galveci Salodiano | Academico Veneto. | Con Privilegii. | [Design.] In Venetia, |-| Presso Bernardo Basa, All' insegna del Sole.| M. D. XCVI. 4०. ff. 24, 1-173.

Di dinerse pesci, \& modi di pescare delli Indini, lib. iii, cap. xv, ff. 48-50.

For comment, see the editio princeps, 1590.

1598. Acost A, J. DE. Histoire | Natvrelle | et Moralle | des Indes, tant Orientalles | qu'Occidentalles. | Où il est traictó des choses remarquables du Ciel, | des Elemens, Metaux, Plantes \&. Animaux | qui sont propres de ces païs. Ensemble des | mœurs, ceremonies, loix, gouuernemens \& $\mid$ guerres des mesmes Indiens. | Composée en Castillan par Joseph Acosta, \& | traduite en François par Robert | Regnault Cauxois. | Dedió av Roy. | [Vignette.] A Paris, I Chez Marc Orry, rü̈ S. Jaques, | au Lyon Rampant. | - | M. D. XCVIIL. sm. $8^{\circ}$. 11. 8 , ff. $1-375+17$.

De diuers poissons, \& de la maniere de pescher des Indiens, liv. iii, chap. $x \mathrm{v}, \mathrm{ff} .102-105$. Manati, f. 102; Pesche de la Balaine en Florida, f. 103.

For comment, see the original ed. of 1590.

1593 (circa). Axon.? "Description du grand poisson baleine, qui s'est venue rendre à Berkhey en l'an MDXCVIII le III Febvrier, etc. (Znd. pl. of jaar.)"

"Vertaling van het roorgaande, met dezelfde af beelding op den titel.

"Eene Engelsche vertaling verscheen te London, 1569. 4०."

Not seen ; title and comment from Bosgoed, op. cit., p. 175, no. 2760. 
1598 (circa). Axon.? "Eeno beschrijvinghe des grooten Vischs, die tot Berkhey ghestrandet is $A^{\circ}$. 1598 den 2 Febr., met eeno verclaringhe der dinghen die daernaer ghevolght zijn. Met noch een cort verhael, enz. (Znd. pl. of jaar.)"

"Met eene af beelding van den walvisch op den titel.

"Zie: Tiele, Bibl. van pamfletten, no. 431-Bor, Ned. Oorl., (1697), iv, f. 434; (1621), 35" boek, f. 11."

Not seen; title and comment from Bosgocd, l. c., p. 175, no. 2759.

1598 (circa). Mathaм, J. "Walvisch, gestrand tusschen Schcveningen en Katwijk in 1598. Door J. Matham, met 12 regelig hollandsch vers. - Van deze prent bestaan verschillende kopyen, o. a. door G. van der Gouwen. br. fol."

Not seen; t:tlo from Bosgoed, op.cit., p. 176, no. 27i3, who sajs: Zie: Ifuller, Historieprenten, no. 1081-1084."

(Muller's Beschrijv. van Ned. historieprenten, hero and elsewhere cited from Bosgoed, I have been unable to see.)

1599. "Olaus Magrus. Do wonderlycke historie der Noordersche Landen, beschreven door Olaus do Groote. Ook aiter aen by ghevoecht verscheyden waerachtige Nauigatien tegent Noorden ghedaen by onsen tyt, als op NovaZembla, Groenlant en door de Strate van Nassouwen anders Weygats ghenaemt. Amsterdam, Cornelis Clacsz." (1599.) $4^{\circ}$.

"Zie aldaar, 21 e en $22 \mathrm{e}$ boek: Van de visschen; van do vreemde en gedrochtelijke visschen, en walvisehvangst. De appendix bevat do reizen naar het Noorden van St. Burrongh, Fro. bisher, Pet and Jackman, en de drie eersten reizen der Hollanders. De 2e druk, 1652, $8^{\circ}$, bevat tevens 'Een korte en klare beschrijving van Ijslandt en Groenlandt,' door Dithmarius Blefkenius."

Not seen; title and comment from Bosgoed, op. cit., p. 244, no. 3526. See, also, Latin ed. of 1555 .

1599. - The request of an honest merchant to a friend of his, to be aduised and directed in the course of killing the Whale, as followeth. An. 1575. <Hakluyt's Narig. and Voyag., i, 1599, pp. 413, 414.

A series of questions respecting the provisioning and furnishing of a ship for a whaling voyage, with detailed answers, " which may serue as directions for all such as shall intend the same voyago, or the like, for the Whale."

[34.]

1601. Saexredax, J. "Walvisch, gestrand onder Beverwyk, bezichtigd door Graaf Ernst Casimir, 1601. Door J. Saenredam. (Met 32 regelig latijnsch vers door T. Screvelius.)" gr. br. fol.

"Dezelfde prent met het adres van J. Janssonius, 1618. gr. br. fol."

Not seen; title and comment from Bosgoed, op. cit., p. 176, no. 2774, who refers to "MI uller, Historieprenten, no. 1160."

1602. [Acosta, J. DE.] De Novi Orbis Natvra et Ratione. <De Bry, America nona \& postrema Pars, 1802, pp. 1-362.

De diuersis generibus \& formis piscium, in India nascentium, lib. iii, cap. xv, pp. 10j-109.

For comment seo orig. ed., 1590, and next title.

1602. DE BRY, Thikodonus, J. T., et J. I. Idaa / vera et genvina, | Præcipvarvm Historia- | rvm omnivm, vt et variorvm / Ritvvm, Ceremoniarvm, consvetvdi- | numq́ue gentis Indicæ: Sicut \& primarium ciuitatum, Insularum- | que \& areium seu propugnaculorum: de quibus in hac | uona Americæ seu Indis Occidentalis histo- | riarum parte pertractatur. | Cvilibet Historica designationi, | facilioris intellectus, maioris $̧ \mathbf{p}$ oblectationis causa, Icones ali- | quammultæ, artificiosissimè in æes incisæ, annexæ | appositæó sunt, | Sumptibus, Studio \& industria | Theodori de Bry, p. m. relictæ vidnæ, \& Ioann. Theodo- | ri ac Ioann. Israel. filiorum. | [Design.] Francofvrti, | Exevdebat Matthærs Becker. | $\mid$ M.DCII. fol. Tab. i-xxvi, cum texte.

Tab. i. De Indorvm mira piseationis ratione. Plate and 15 lines of text, illustrating the way in which the Indians capturo whales, viz, by rowing up to them in their canoes and get. ting astride the neck and then driving wooden stakes into their blow-holes, which speedily causes their death by suffocation. They then attach lines to the stakes and tow the dead whale ashore. In the background is seen a dead whale being thus towed by an Indian in a canoe, and more in the foreground is an Indian astride a whale driving in the stakes, his canoe. resting on the whale's back! Tho blow-holes are represented, as in other cuts of this date, 


\section{De BRY, Theodorus, J. T., et J. I.-Continued.}

as tubular projections on the sides of the head! This absurdity is apparently based on Acosta's account of the capture of whales by the Indians of Florida. (See A CosTA, J. DE, 1590.)

The fasciculus having the above-given titlo forms part of De Bry's celebrated Collection of Voyages. In the cony examined it is bound as the second fasciculus of "Nona pars Ame. ricæ," containing the voyages of Sebalt do Weert.

1604. Acosta, J. DE. The / Natvrall | and Morall Historie of the | East and West | Indies. | Intreating of the remarkeable things of Heaven, of the | Elements, Mettalls, Plants and Beasts which are pro- I per to that Country: Together with the Mauners, | Ceremonies, Laws, Governements, and Warres of | the Indians. | Written in Spanish by Ioseph Acosta, and translated / into English by E. G. [Edward Grimeston]. [Design.] London / Printed by Val: Sims for Edward Blount and William | Aspley. 1604. 80. 11. 10, pp. 1-590.

Of Sundry Fishors, and their maner of fishing at the Indies, lib. 3, chap. 15, pp. 163-169.Manati, p. 164. Manner of capturing whales by the Florida Indians, pp. 166-168.

For comment see the orig. ed, 1590.

1605. Clusius, C. Caroli Clvsii Atrebatis, | Aulæ Cesareæ quondam Familiaris, | Exoticorvm | Libri Decem: | Quibus Animalium, Plantarum, Aromatum, | aliorumq́ue peregrinorum Fructuum | historix describuntur: | Item | Petri Belonii Observationes, | eodem Carolo Clusio interprete. | Scries totius operis post Præfationem indicabitur. $|-|$ Ex Officinâ Plantinianâ Raphelengii, 1605. [Title-page with engraved border.] $2^{\circ}$. 11. 8, pp. 1-378, 11. 5.

Cete admirablis formæ, p. 180, cum fig.; Aliud Cete admirabile, p. 131, cum fig.; Manati Phocæ genus, pp. 132-135, eum fig.

The "Ceto admirabilis formø" is a Cetoid monster; the mouth is open, dieplaying a continuous row of sharp-pointed teeth in the lower jaw; there are ncither pectoral nor dorsa! fins; the head is upturned, projects much beyond the lower jaw, and its termination may be likened to a cap formed of a gigantic squid, of which the tentacles constitute a fringe around the neck. The "Aliud Cete admirabile" is a Cachalot (Physeter macrocephalus), or "Potwalvisch" (as the text states it to have been called by the Hollanders), deseribed and figured from a specimen stranded on the west coast of Holland in 1598. The figure is a half-sido riew, displaying the ventral surface, with the mouth open and the penis exserted. This is noteworthy as being apparently one of the earliest figures extant of the Sperm Whale. A specimen stranded three years later is also briefly described. Of the "Manati Phocre genus" there is a quite characteristic, although rude, figure from a stuffed specimen brought to Amsterdam in the year 1600 by a Dutch navigator "ex Occidentali Occano." In respect 10 the carly history of the Manatee, Clusius justly holds the first place, his description and fig. ure being the first based on an original examination of specimens.

There appcars to have been an earlier edition, the work being cited at 1601 by Bosgoed (Bibl. Ichth. et Piscat.,p. 168).

1606. Gomara, F. L. DE. Histoire / generalle | des Indes occiden- | tales, et terres | neunes, qui iusques à present | out est6́ descounertes. | Augmentee en ceste cinquiesme edition de la description de | la nouvelle Espagne, \& de la grancle ville de Me- / xicque, autrement nommee, | Tenuctilan. | Composee en Espagnol par François Lopez de Go- / mara, \& traduite en François par le / S. de Genille | Marr. Fumée. | [Design.] A Paris. | Chez Michel Sonnius, ruë sainct Iaquez à l'enseigne | de l'escu de Basle. | - | 1606. | Avec privilige dv Roy. sm. $8^{\circ}$. ff. $4,1-485+19$.

Des poissons qu'on appelle en l'Isle Espagnole Manati, chap. 31, f. 41 (2 pages).

1608. Axos. "Ware Verthooning ende afbeeldinghe van een dooden. . . Vis, door die Zee aen der Strande opgheworpen den 20 Sept. 1608, tusschen Catwijck ende Schevelingen. Middelburg, 1608. 4\%. 20 bladz. tekst met af beelding."

Not seen; titlo from Bosgoed, op. cit., p. 175, no. 2761.

1612. [Hudson, Henry.] "Beschryvinghe van der Samoyden Landt in Tartarieu. Nieulycks onder't ghebiedt der Moscoviten ghebracht. Wt de Russche tale overgheset, Anno 1609. Met een verhael van de opsoecking ende ontdeckinge van de nieuwe deurgang ofte straet int Noordwesten na de Rijcken van China ende Cathay. Ende een Memoriael gepresenteert acnden Coningh ván Spaen- 
1612. [Hudson, Hexry]-Continued.

gien, belanghende de ontcleckinghe ende gelegenheyt van 't Land ghenaemt Australia Incognita. 't Amsterdam, by Hessel Gerritsz. A A ${ }^{\circ}$ 1612. $4^{\circ}$. Met 3 kaarten."

Not seen; title transcribed from Bosgoed, op. cit., p. 233, no. 3427. The title as given by Fr. Muller (Cat. Am. Books, 1877, p. 80) is abbreviated by the omission of the second and third sentences, and also otherwise. As the two titles othorwise differ, it is doubtful whether either is literally given, Bosgoed's appearing to be partly modernized in orthography. Muller's English rendering of his is as follows: "Description of the country of tho Samovedes in Tartary, With an account of the research and of the discovery of the new passage or strait in the North-West to the empires of Cbina and Cathav (by Henry Hudson). And a memorial offered to the King of Spain (by P. F. de Quir) concerning the discovery and the situation of the Land called A ustralia Incognita." (For the title of the Latin translation, published the following year, see 1613. Hudsox, H.)

Respecting the present Dutch edition, Mullcr says: "Of this original Dutch edition of tho famous Detectio freti . . hardly 4 or 5 copies aro known in all the European libraries. . . This original book is the foundation-stone for the history of Hudson's and other arctic expeditions, etc. The collection formed by Ilessel Gerritsz consists of four tracts. by Is. Massis, F. de Quir, and the editor, Hessel Gerritsz himself."-F. Mullek, Cat. Amer. Books, 1877, p. 80 , no. 1425 .

1013. "Gerritz. vax Assum, Hessel. Histoiro du pays nomme Spitsberghe. Monstrant comment qu'il est trouvée, son naturel et ses animauls, avecques la tristo racompte des maux, que nos pecheurs tant Basques que Flamens, ont en is souffrir des Anglois, en l'esté passée l'An de grace, 1613. Escrit par H[essel]. G[erretsz]. [de] A[ssum ]. Et en apres une protestation contre les Angloys, et annullation de touts leurs frivoles argumens, parquoy ils pensent avoir droict, pour se faire Maistre tout seul, dudict pays. En Amsterdam, a l'euseigne de la carte nautiq. MDCXII [sic] Chez Hessel Gerritsz. 4०. Met 2 kaarten en eene plaat."

Not seen; title from Bosgoed, op. cit., p. 236, no. 3462. Muller's collation gives the date as 1613, and " 2 maps and 2 pl."-(Cat. Am. Books, etc., 1877, p. 80, no. 1423.)

The original edition is "of the utmost rarity." A fac-simile reprint (of 50 copies onls) was issued in 1872 by Fr. Muller (Amsterdan), "with the real old types" of the 17th century, on old paper.

1613. Hudso:-, H. Descriptio ac delineatio Geographica | Detectio- | nis Freti, | Sivo Transitus ad Oceasum supra / terras Americanas, in Chinam / atos Iaponem ducturi. | Recens investigati ab M. Henrico Hudsono Anglo. | Item, | Exegesis Regi Hispanise facta super | tractu recens detecto, in quintâ Orbis parte, cui nomen, | Avstralis Incognita. | Cum descriptione / Terrarum Samoiedarum, \& Tingoesiorum, in | Tartariâ ad Ortum Freti V Vaygats sitarum, nuperç | sceptro Moscovitarnm adseitarum. | Amsterodami | - | Ex Officina Hesselij Gerardi. Anno 1513. sm. 4\%. 11. 25, unpaged, 4 folded maps and 3 cuts.

Contains "Veram Effigiem Balenarum" (a half-page cut), aud 8 lines of descriptive text. It occupies a separato leaf at the end of the book in two copies examined (in Harvard College Library), occurring after the word "Finis," which closes tho preceding page. It almost has the appearance of not belonging to the book. Neither of these copics contain Hessel Gerrard's remarkable picture of the Walrus, said to occur in some copies of this work. (Cf. A Llen, Hist. N. Amer.Pinnipeds, 1880, pp. 96, 97.)

"On this small but high!y important work, see at large: Tiele, pp. 179 to 190, and my: Essai d'une Bibliograplie Néerl. Russe, 1859, pp. 71, 103-106, especially on the unknown anthor,

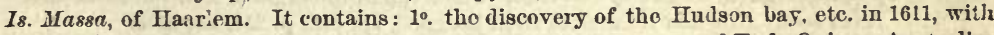
map, with additions to the former edition of $1612 ; 2^{\circ}$. the account of F. de Quir on Anstralia; $3^{\circ}$. and $4^{\circ}$. the description of tho Samojedes, their country, etc., etc., by Id. Massa, of Haarlem."-F. Muller, Cat. Amer. Books, 18i7, p. 85, no. 1493.

A facsimile reprint, "with the real old types" of the 17 th century, on old peper, has been recently published at Amsterdam by Frederik Muller \& Co.

1615 (circa?) VELDE, Es. VAN DEN. "Pot-Walvisch, gestrandt by Noortwyck op Zee, den 28 Dec. 1614. Door Es. van den Velde. kl. br. fol."

"Eene andere druk met adres van C. J. Visseher.-Van deze prent bestat ook eene teekening in sepia door J. van do Velde."

Not seen; titlo from Bosgoed, op. cit., p. 176, no. 2775, who refers to Muller's "Historieprenten, no. 1292-1293." 
1617. Purchas, S. Of King Iames his Newland, alias, Greenland : And Of The Whale And Whale-Fishing. <Purchas his Pilgrimage, or Relations of the World \& the Religions observed in al Ages \& Places, etc., 3d ed., 1617, pp. 920-924.

Of special interest as containing the earliest English, and the first distinct, deseription of the Greenland Whale (Baloena mysticetus)-detailed, exceedingly quaint, and in the main quite correct. It was derired from information furnished by Master Thomas Sherwin, based on his experiences in whaling in the year 1611.

1622. Whitbourne, R. A | Discovrse | and Discovery : of Nevv-forndland, with | many reasons to prooue how worthy and bene- | ficiall a Plantation may there be made, after a far | better manner than now it is. | Together with the laving | open of certaine enormities | and abuses committed by some that trade to that | Countrey, and the meanes laide downe for | reformation thereof. | Written by Captaine Riehard Whitbourue of | Exmouth, in the County of Deuon, and pub- | lished by Anthority. I As also, an Inuitation: and likewise certaine Letters sent / from that Countrey; which are printed in the / latter part of this Booke. [Design.] I Imprinted at London by Felix Kingston.

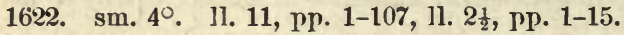

Reference to cod-1shing and whale-fishing (pp. 11-13) as carried on at the Grand Banks by the Biscayners in 1615.

The work was first published in 1620, without the appendix of the present edition; there is also a later (1623) edition, neither of which have I seen. The 1622 ed. seems to be the same as the ed. of 1620 , so far as the bociy of the work is concerned, to which there is added, besides the above-mentioned appendix, 2 preliminary leaves, containing also new matter.

1622-35. "WAssenaer, Clafs. Historiseh verhael alder'ghedenck-weerdichste Geschiedenissë, die hier en daer in Europa, als in Duitsch-lant, Vranckrijk . . . en Neder-laut, Asia, America en $\Lambda$ frica, van den beginne des jaers 16:1 tot Octobri des jaers 1632 voorgevallen sijn. (Met platen, kaarten en portretten.) Tot Amstelredam, by Jan Evertsz. Kloppenburgh, 162:2-1624, J. Hondius, 1624, en Jan Jansz, 1625-35. 21 dln., 7 bdn. $4^{\circ}$.

"Zie aldaar: Welvaert van de Noortsche Compagnie (gelukkige walvischvangst). De inwoonders van Spitsberghen. Het verloop van de walvisschen, v, 16:3, Septemb., bl. 157158. Van het eylandt Spitsbergen, alwaer de genereuse Willem Tas, capiteyn, zijn couragio toont. Ook van de walvisschen, haer baerden en rinnon, baleynen genaemt, die Jan Osborn, seer konstigh verwerckt. Handelingh van de Noordersche Compagnie. Verslag ran de reis van Willem Vermuyden, 1612. Wat recht de Engelschen pretendeeren op de walvischrangst bij Spitsbergen, met de wederlegging van Petr. Plancius. Overeenkomst tusschen $\Delta$ nt. Monier en Benj. Joseph, aangaando de verdeeling van dẹn vischgrond bij Spitsbergen en verdere bijzonderheden betrokkelijk do walvischrangst, viii,-1624, Decemb., bl. 86-96. Ontdeckingen van Goenlant en Nieu-Nederlant, ix, 1625, A pril, bl. 43, 44. Placcaet der H. H. Staten op den haringhvanghst, 'teghens d' inghesetenen van Schotlandt haer wel to draeghen, ix, 1625, Mai, bl. 56, 57. Vervolgh van het ontdecken van de doorvaert in 't Noorden. Toerustinghe van een nieuwe ontdeckinghe, door Waygatz, tusschen Nova-Zembla en 't vaste lanit Russien, ix, 1625, Julins. Vau do Spitsberch-vaerders, met het succes van de walvischvanghers, $x, 1625$, Decemb., bl. 106, 107. Verhael vun de reyse op Wargatz, na de Tartarische zee gedaen, alsmede van de reyse door het Fretum Davis, om daerdoor nae China te gaen. Nieuwe walrus-rangers, xi, 1626, May, bl. 57.

"Walvischvaugst ghemist. De buysen rerstoort. Walrnsvanghen en 't seylen door Way. gats ghemist, xi, 1626, Sept., bl. 131-133. Wederom-comst van do walvischvanghers, alsmede de Spitsbergh-vaerders, onder do Noortsche Compagnie, xii, 1626, Octol., bl. 8, 9. Visscherije op Spitsberghen, xvi, 1628, Novemb. Staet ran Spitsberghen, xvi, 1628, Decemb."

Not seen; title and references from Bosgoed, op. cit., p. 251, no. 3603.

1624. "Baudartius, W. Memoryen ofte Cort Verhael der Gedenck-weerdiehste, Gheschiedenissen van Nederland, Vranckrijck, Iloogh-Duytschland, Groot Brittannyen enz. Van den jaere 1ó03-1624. Tweedo editie grootelicx vermeerdert. Met portretten. Arnbem, Jan Jansz. 1614. 2 din. folio.

"Zie aldaar: Enghelsche verhinderen de Hollanders in den walvisch-vanck. Boek $\mathbf{}$, bl. 43. Jacobus VI vernieuwt de questio ran den harinck-vanck. xii, bl. 16. Nederlanders ende Enghelsche int gevecht om de visvangh. Misverstant tussche de Enghelsche ende Nederlanders om den walviseh-vanck. ix, bl. 97. Vier walvisschen bij den Hage (Scheveningen) gevangen. ix, bl. 97, 202."

Not seen; title and comment from Bosgoed, op. cit., p. 232, no. 3424. 
1624. "Lrsschotex, Jax Huygev van. Voyasie, ofte schipvaert van Jan Hugghen van Linsehoten, van bij Noorden om langes Noorwegen de Noordt Caep, Lilplandt, Vinlandt, Ruslandt, de Wittee Zee, de Kusten van Kardenoes, Swetenoes, Pitzora, etc. door de Strate ofte Enghte van Nassouw tot voorby de Reviere Oby. Waer inne seer distinetelycken Verhaels-gewyse beschreven ende aen gewesen wordt, alle hetgene dat hem op deselve. rejse van dach tot dach bejegent ende voorgekomen is. Met alle de afbeeldtsels van alle de Kusten. . . . Ghelyck als hij 't alles selfs sichtelycken ende waerachtelycken nae 't leven uyt-geworpen ē̄ geannoteert heeft, etc. Anno 1594 ende 1595. T'Amsterdam, by Jan Evertszen Cloppenberg. A A 1624 . folio."

"Tweede druk met gefigur. titel en 15 platen, gegraveerd door J. en B. ran Doetecom. De eerste diuk verscheen te Franeker bij Gerard Ketel. $A^{\circ} 1601$. folio. Eeno verkorte nitgare zag in 1663 te Amsterdam, by Saeghman, het licht. 4०. Deze twee reizen van Linschoten zijn vertaald opgenomen in: Recueil do royages an Nord. Amsterdam, J. F. Bernard, 1731. dl. iii, bl. 1-304. Zie verder: Tiele, Mémoire bibliogr., bl. 190-195.

"Zie betrekkelijk de walvisschen in dezen $2 \mathrm{n}$ druk: Walvissehë in de haven van Toxar. Vangen een walvisch duer so 20 tonnë specks af krijghen. Wonderlycke liefle der walvisschë met den anderë. Eene teelt van walvisschë in de haven van Toxar-"ende is te ghelooven, dat soomender op toeleyde, ende op versien quam, men soude daer sonder tryffel een goede visscherye afdoen." bl. 7. Sien reel walvisschë in de Tartarische zee. bl. 17. Vervolgens bl. $22^{\mathrm{b}}, 26,31^{\mathrm{b}}$."

Not seen; title and comment from Bosgoed, op. cit., p. 241, no. 3503.

1625. Baffix, William. A Iournall of the Voyage made to Greenland with sixe English ships and a Pinnasse, in the yeere 1613. Written by Master William Baffin. $<$ Purchas his Pilgrimes, iii, 1625, pp. 716-720.

Short history of the adventures and achievements of the English whaling-fleet during the year 1613.

1625. Baffin, William. [Letter] To the Right Worshipfull Master Iohn Wostenholme Esquire, one of the chiefe Aduenturers for the disconerie of a passage to the North-west. [Signed, William Baffin.] <Purchas his Pilgrimes, iii, 1625, pp. 843,844 .

Reference to the "Grand Baye Whales" of Newfoundland, "of the same kinde which are killed at Greenland "; also to the "Sea Unicorne."

1625. [Baffin, William.] A briefe and true Relation or Ioturnall, contayning sueh accidents as happened in the fift voyage, for the disconerie of a passage to the North-west, set forth at- the charges of the right Worshipfull Sir Tho. Smith Knight, Sir Dudly Digges Knight, Master Iohn Wostenholme Esquire, Master Alderman Iones, with others, in the good ship called the Discouerie of London; Robert Bileth Master, and my self Pilot, performed in the yeere of our Lord 1616. <Purchas his Pilgrimes, iii, 1625, p1. 844-848.

Whale Sound ( $\left(77^{\circ} 30^{\prime}\right.$ N. Lat.), named from the great number of wholes seen in it, p. 846; many "Sea Vnicornes" seen during the voyage. The context following shows the "lielation" to have been written by William Baftin.

1625. Fdge, Thomas. A briefe Diseonerie of the Northerne Discoueries of Seas, Coasts, and Countries, deliuered in orler as they were hopefully begunne, and haue euer since happily beene continued by the singular industrie and charge of the Worshipful Society of Musconia Merchants of London, with the ten seuerall Voyages of Captaine Thomas EDGe the Authour. <Purchas his Pilgrimes, iii, 1625 , pp. 462-473.

First Whale-killing (year 1611), pp. 465, 466. Whaling voyages of 1612-1622, pp. 466-470. "The Description of the seuerall sorts of Whales, with the manner of killing them," pp. 470472. "Eight seuerall kinds of Whales" are briefly described, as follows: 1. Grand-bay, taking hls name from Grand-bay in Newfoundland"=Baloena mysticetus. 2. Sarda=Balona biscayensis. 3. Trumpa = Physeter macrocephalus. 4. Otta Sotta-a whalebone Whale, gray in color, and "hauing finnes in his mouth all whito but not abouo half a yard long"-probably Agaphelus gibbosus, Cope. 5. Gibarta = some kind of Finner Whalo. 6. Sedena, "of a whitly colour, and bigger than any of the former, the finnes not aboue one foot long, and he 
1625. Edge, Thomas-Continued.

yeelds little or no Oyle." 7. Sedena Negro ... "with a bumpe on h's backe" =1 Megcptcra longimana. 8. Sewria, "of colour as white as snow," etc. = Beluga catodon.

A map (pp. 472, 473's ) of Greenland (i.e., Spitzbergen) accompanies Captain Id ge's memoir. with border at sides and bottom consisting of views illustrative of the Whale and "Seamorce" fisberies. At the upper left corner is a picture of a Whale lying on its side, with the legeud "A Whale is ordiuarily about 60 footelonge." Immediately below this is a scene illustrating the capture of a Whale, with 4 lines of deseriptive text. Below this are two others illustrating respectively the eutting in of the Whale and the trying ont of the blubber, cach with a descriptive legend 4 to 6 lines in length. On the right-hand border four of the five scencs depict respectively the towing of the Whale to the ships, the towing of the blubber to sbore, the preparation of the fins (the legend reads: "Thus they make cleane and scrape $\mathrm{y}^{\mathrm{*}}$ whale fins"), and "A teut and Coopers at workc."

1625. Fotherbye, R. A Voyage of Disconerie to Greenland, \&c. Anno 1614. Written by Ro. Fotherbye. <Purchas his Pilgrines, iii, 1625, pp. 720-728.

Gives an account of the capture of Whales during the voyage.

1625. Helwy, W., and others. Diuers other Voyages to Greenland, with Letters of those which were there employerl, communicated to mee by Master William Heley. <Purchas his Pilgrimes, iii, 1625, pp. 732-738.

Eleven letters, writteu by various persons, relating briefly to the history of Whaling by the Englisl: duriug the years 1617 to 1623 inclusive.

1625. "Late, J. DE. Nienwe Wereldt | ofto | Beschrijvinghe | van / West-Indien, | wt veelerhaude Schriften ende Aen-teckeningren | van verscheyden Natien by een versamelt | Door | Ioanues de Laet, | Ende met Noodighe kaerten en Tafels voorsien. Tot Leyden, | In de Druckerye van Isaack Elzevier. | Anno 1625. | Met Privilegie der Ho. Mo. Heeren Staten Generael, voor 12 Jaren. | fol. pp. (2), xxii, 5:26. Maps.

"See AsHER's 'Essay,' no. 1. This invaluable work was much improved in the subsequent editions and translatious by the autbor, but the maps were unchanged."

Editio princeps. Not seen; title and comment from Sabin, Bibl. Am., x, 1878, p. 15. For notice of the account of the Manatee in Laet's work, see infrà the Latin ed., 1633.

1625. [Muscovy Merchants.] A Commission for Thomas Edge our seruant, appointed to goe as our Factor in the Ship called the Mary Margaret, of the burthen of one hundred and fiftie Tunnes, for the killing of the Whale and Morses vpon the coast of Greenland, or any other place in the North Ocean: Giuen the 31. of March, 1611. LPurchas his Pilgrimes, iii, 1625, pp. 709, 710.

This is a letter of instruction issued by the "right Worshipfull Company of New Trades," or "Muscouie Merchants," as above. Among other things it directs the "procuring of sixo men of Saint Iohn de Luz" to act as whale-men; describes the different kinds of Whales to be sought, and their products, etc., this information being evidently based on Thomas Edge's "Deseription of the seuerull sorts of Whalcs, with the manner of killing them," as given in Purchas, iii, pp. 471, 472.

1625. Poole, Jonas. A briefo Declaration of this my Voyage of discouery to Greenland, and towards the West of it, as followeth : being set forth by the right Worshipfull Sir Thomas Snith, Gouernour of the right Worshipfull Company of new Trades, \& c., written by Jonas Poole. <Purchas his Pilgrimes, iii, 1625, pp. 711-i13.

Short history of the first English whaling royage to "Greenland" (i. e.. Spitzbergen), made in the year 1611.

1625. Poole, Jonas. A relation written by Jonas Poole of a Voyage to Greenland, in the yeere 1612. with two ships, the one called the Whale; the other the Sea-horse, set out by the Right Worshipful the Muscouie Merchants. <Purehas his Pilgrimes, iii, 1625, pp. 713-715.

1625. [Purchas, Samuel.] Extracts of Gonzalo Ferdinando De Oviedo his Summarie and Generall Historio of the Indies. <Purchas his Pilgrimes, iii, 1625, pp. $970-1000$.

Description of the "Manati" at pp. 987, 989. 
1628. "Hernandez, [F.] Rerum Medicarum Novæ Hispaniæ Thesaurus, seu Plantarum Animalium Mineralium Mexicanorum historia ex Francisci Hernandi Noui orbis medici Primarij relationibus in ipsa Mexicana vrbe conseriptis a Nardo Antonio Reccho ... Collecta ac in ordinem digesta à Joanne Terrentio Lynceo notis illustrata; cum Indice, et Histuriæ Animalium et Kineralium libro. Nune primum in naturaliū rerū studiosor gratiā et utilitatē studio et impensis Lyuceorum Publici iuris facta Philippo magno dicata. I'oma. M. DCXXVIIII. Ex Typographeio Jacobi Mascardi. fol. Engiaved title, pp. 950, 17 1. 'Historiæ Anima lium,' pp. 90 (6).

"This edition was abridged and edited from the anthor's MS. lyy Dr. Reccho, of Naples; pp. 345-455 are additions by Terrentius de Constance; pp. 460-840 by John Faber; pp. 841-899 are annotations by Fabio Colonno; the tables by Prince Cesi. Leclerc, no. 457, describes: Fabri (Joannis lyncei). Animalia Mexicana Descriptiouibus, scholijø. exposita. Romæ, 1628, folio, which is merely an extract, pp. $460-840$, from the foregoing.'

Not seen; title and comment from Sabin, Bibl. Amer., vol. viii, p. 239. See infra edition of 1651, for notice of cetological matter, etc. Sabin also gircs (as do Carus and Engelmunn) a Spanish edition, Mexico, $1615, \mathrm{sm} .4^{\circ}$, translated and enlarged by Fr. Francisco Ximcnez. Stevens (Bibl. IIist., p. 76, no. 891) eites an edition of date 1 ģc4.

See furthrr on Heruandez and his work, Sabin, op. cit., pp. 239-241. Sce, also, Coues, Bds. Col. Vall., p. 575.

1629. Kittrensteyn, C. "Walvisch, gestrand by Noortwyk, 1629. Naer P. Mosiju, door C. Kittensteyn, br. fol."

From Bosgoed, op. cit., p. 176, no. 2776.

1632. SaGard-Theodat, G. Le Grand Voyage / Dv pajs des Ifrrons, / situé en l'Amerique vers la Mer | douce, és derniers confins | de la nouuelle France, | dite Canada. | Où il est amplement traité de tout ce qui est du pays, des | mœurs \& du naturel des Sanuages, de leur gonuernement | \& façons de faire, tant dedans leurs pays, qu'allans en voya- $\mid$ ges: De leur foy \& crosance; De leurs conseils \& guerres, \& / de quel genre de tourmens ils font mourir leurs prisonniers. | Comme ils se marient, \& esleuent leurs enfans: De leurs Me- | decins, \& des remedes dont ils vsent à leurs maladies: De | leurs dances \& chansons: De la chasse, de la pesche \& des | oyseaux \& animaux terrestres $\&$ aquatiques qu'ils ont. Des | richesses du pays: Comme ils cultiuent les terres \& accom- | modent leur Menestre. De leur deuil, pleurs \& lamenta- | tions, \& comme ils ensenelissent \& enterrent leurs morts. I Auec vn Dictionnaire de la langue Huronne, pour la commodi- I té d e ceux qui ont à voyager dans le pays, \& n'ont | l'intelligence d'icelle langue. | Par F. Gabriel Sagard Theodat, Recollet de | S. François, de la Prouince de S. Denys en France. | - | A Paris, | Chez Denys Moreav, ruë S. Iacques, à | la Salamandre d'Argent. | - | M. DC. XXXII. | Auec Priuilege du Roy. 1 vol. 16॰. 11. 12 (=eng. title, 1 l.; plain title, $1 \mathrm{l}$.; invocation to Jesus Christ, 2 11.; to Henry de Lorraine, 2 ll.; to reader, 3 ll.; contents and royal privilege, \&c., 3.11 ), pp. 1-380. Dictionaire de la Langve Hronne, 11. 80.

Des Baleines, pp. 24-27; Marsoins bl incs (=Beluga catodon), pp. 51, 52.

There is a late textual reprint of this rare work, published in 1865 , "giving fac-simile of the original title-pages, indication of the original pagination, etc."

1633. LAET, J. DE. Novvs Orbis | seu | Descriptionis / Indiæ Occilentalis | Libri XVIII. | Authore | Joanne de Laet Antwerp. | Novis Tabulis Geographicis et variis | Animantivm, Plantarum Fructunmque | Iconibus illustrati. | Cum Privilegio. | Lvgd. Batav. apnd Elzevirios. A ${ }^{0}$. 1633. fol. 11.15 (incl. engr. title-page), pp. 1-104, 205-690, 11. 9. Maps and cuts.

Manati, p. 6, fig. The account occupies nearly a page; the figure is a copy from Clusius. [65.]

[1634?] Segersz VAN Der BrugGe, JACOB. "Journael, of Dagh-Register, gehourlen by Seveu Matroosen, in haer Overwinteren op Spitsbergen in Maurits-Bay, Gelegen in Groenlandt, t' zedert het vertreck van de Visschery-schepen der Geoctroyeerde Noordtsche Compagnie, in Nederlandt, zijude den 30 Augusty, 1633 tot de wederkomst der voorsz. schepen, den 27 May, Anno 1634. Beschre- 


\section{[1634?] SEgersz VAN DER BrUGGe, JACOB-Continued.}

ven door den Bevelhebber Jacob Segersz van der Brugge. t'Amsterdam, Gedruckt By Gillis Joosten Saeghman. (z. j.) $4^{\circ}$. [Circa 16:34.]

"Het verhaal van de Orerwinteringen in 1633 en 1634 vindt men verkort in: (Is. de la Peyrère), Nauwkeurige Beschrijvingh van Groenland. Amsterdam, 1678. 40. bl. 114-122. Tevens wordt $\operatorname{van}$ het bovengenoemde jonrnael van Segersz een uittreksal gevonden in: De Walvischvangst, ii, bl. 26-36."

Not scen; titlo and remarks from Bosgoed, op. cit., p. 239, 340, no. 3491.

1035. Nifremberg, J. E. Ioannis Evsebii Nierembergii | Madritensis ex Sociatate Iesv | in Academia Regia Madritensi | Physiologiæ Professoris | Historia | Naturæ, | Maxime peregrine, | Libris xvi. Distincta. | In quibus rarissima Naturis arcana, etiam astronomica, \& I ignota Indiarum animalia, quadruperles, aues, pisces, | reptilia, insecta, zoophyta, plantæo, metalla, lapides, \& | alia mineralia, flnuiorumque \& elementorum condi- | tiones, etiaun cum proprietatibus medicinalibus, descri- | buntur; nous \& curiosissinæ quæstiones disputantur, ac | plura sacræ Scripturæ loca eruditè enodantur. | Accedunt de miris \& miraculosis Naturis in Europâ Libri dno: | item de iisdem in Terrâ Hebræis promisâ Liber unus. | [Vignette.] Antverpiæ, | ex Officina Plantiniana Balthasaris Moreti. | M. DC. XXXV. 2०. 11. 4, pp. 1-502, 11.50. Figs. num. in text.

Caput lix. De balænis pugnacibus, p. 261; caput lx (pp. 262-263), De piscatione balænarum. Contains a figure of a male Cachalot lying on the side and showing ventral surfacefrom Clusius, many times copied by later compilers; also, a figure of a fabulous creature, from Clusius, suggestive in some respects of the Cachalot, the two figures bearing the legend Cete admiribilis forma.

1636. Sagard Theodat, G. Histoire | du Canada | et | Voyages que les freres | Mineurs Recollects y ont faicts pour | la conuersion des infidelles | divisez en quatre livres | Où est amplement traicté des choses principales ar- | rinées dans le pays depuis l'an 1615 iusques à la pri- | se qui en a esté faicte par les Anglois. Des biens \& / commoditez qu'on en peut esperer. Des inoeurs, | ceremonies, creance, loix, \& constumes merueil- | leuses de ses inhabitans. De la connersion \& baptes- | me de plusieurs, \& des moyés necessaires pour les amener | it la cognoissance de Dien. | L'entretien or- | dinaire de nos Mariniers, \& autres particularitez | que se remarquent en la suite de l'histoire. I Fait \& composó par le | F. Gabriel Sagard, | Theodat, Mineur Recollect de la Prouince de Paris. | - | A Paris, | Chez Clande Sonnius, ruë S. Jacques, à l'Escu de | Basle, \& au Compas d'or. | - | M. DC. XXXVI | Auec Prinilege \& Approbation. sm. 8. pp. 1-1005, 11. 22.

Marsoins, pp. 118, 124, 135. Des Baleines, pp. 130-133. Marsoin blanc, p. 1577.

A textual reprint of this rare work, in 4 rols., $12^{\circ}$, Paris, appeared in 1866.

1640. LAET, J. DF. L'Histoire / dv / Nonvean Monde / ou | Description | des Indes | occidentales, | Contenant dix-hnict Liures, | Par le Sieur Jean de Laet, d'Anuers; | Enrichi de nouuelles Tables Geographiques \& Figures des | Animaux. Plantes \& Fruicts. | [Vignette.] A Leyde, | Chez Bonauenture \& Abraham Elseuiers, Imprimeurs | ordinaires de l'Vninersité. | - | CID I $I_{D} \mathrm{C}$ X. fol. 11. 18, pp. 1-632, 11. 6 .

Le Manati, p. 6, fig.

1616. Albertz. van Raven, Dirk. "Jonrnael ofte Beschrijrinģe vau de reyse ghedaen bij den Commandeur Dirk Albertsz. Raven, nae Spitsberghen, in den jare 1639, ten dienste vande E. Heeren Bewindt-hebbers van de Groenlandtsche Compagnie tot Hoorn. Waer in verhaelt wordt sijn droevighe Schipbreucke, syn ellende op 't wrack, en syn blijde verlossinge. Met noch eenighe ghedenckweerdige Historien. Alles waerdigh om te lesen. Tot Hoorn. Gedruckt by Isaac Willemsz. Voor Ian Iansz. Deutel. Ao. 1646. $4^{\circ}$. Met eene plaat.

"Hierbij zijn geveogd nog drio Reisjournalen naar het Noorden, en wel van: Andrir-s Jansz. van Middelburgh in 1634; van Raven in 1633; van Pieter Jansz. Pickman in 1616. Het 
1646. Albertz. van Raven, Dirk-Continued.

journaal van Raren vindt men gewoonlijk als appendix achter het Iournael van de Oost Indische Reyse van Willem IJsbrantsz. Bontekoe. Hoorn. $4^{\circ}$. Het is ook opgenomen in: Hulsius Sammlung von 26.Schiffahrten. Neurnberg, 1598-1640."

Not seen; titlo and comment from Bosgoed, op. cit., p. 240, no. 3492.

1647. La PeYrìne, IsAac de. Relation | dv | Groenland. | [Par Isaac de La Peyrère.] [Vignette.] A Paris, / Chez Avgvitin Covrbe, dans la / petite Salle dv Palais, à la Palme. | - | M. DC. XLVII. | Auec Priuilege dv Roy. sm. 80. 11. 8, pp. 1-278, 11. 2. Map and pll.

For notice of cetological matter see infra, ed. of 1663.

1648. Axon. "Kort verhael nyt het journael van de personen die op Spitsbergen in 't overwinteren, gestorven zijn. Anno 1634. Gedrukt te Hoom, 1648.

"Behoort bij het Journaal van D. Alb. Raven."

Not secn; title from Bosgoed, op. cit., p. 249, no. 3576. See 1646. Raven, D. A.

1648. "Guicciardini, L. Belgium, dat is: Nederlandt, ofte Beschryvinge derselviger provincien encle steden. Met veel bijvoegselen, landcaerten en de af beeldinge der steden. Amsteld., J. Jansonius, 1648. $2 \circ$.

"Walvisschen, p. 302a."

Not seen; title from Bosgocd, op.cit., p. 70, no. 1100.

1650. Josston, J. Historiæ Naturalis | De Piscibus et Cetis | Libri V. | Cum æneis figuris | Iohannes Ionstonus Med. Doctor | concin̄auit. | Francofvrti ad Moenum / Impensà | Matth[æi] Meriani. [Seal.] [No date. Engraved titlepage.] $2^{\circ}$. pp. 1-228, pll. i-xlvii.

Historiæ Naturalis | De | Exangvibus | Aqvaticis | Libri IV. | Cum figuris æneis | Joannes Jonstonus | Med. D. concinnavit. | [Seal.] Francofrrti | ad | Moenvm, | Impendio | Matthæi Meriani. | - | M DC L. pp. 1-78, pll. i-xx.

The work is in two parts, with separate pagination and notation of plates, and the two titlepages above transeribed. The index to the two series of plates is on one page, and the general index to the two parts is partly on the same leaf. The first title-page is without date; the second is dated M. DC. L., ostensibly the date of publication of the whole work.

Liber v. De Cetis (=Cetacea + Sirenia et Pinnipedia), pp. 213-224, pll. xli-xliv. Capvt i, De Cetis in genere, pp. 213, 214. Capvt ii, De Cetis in specie. Articulus i, De Balæna, pp. 215, 216, pll. xli, xlii; Articulus ii, De Balæna vulgi, \& Phjsetere, pp. 216, 217; Articulus iii, De Puste \& Orea, pp. 217,218, pl. xliii ; Articulus iv, De Delphino, pp. 218-220, pl. xliv ; Articulus $\checkmark$, De Phocæna \& Scolopendra Cetacea, pp. 220, 221, pl. xli ; Articulusvi, De Phoca, scu Vitulo marino, pp. 221-223, pl. xli; $\Delta$ rticulus vii, De Manati Iudorum, pp. 223, 224, pl. xliii.

PL. xli, 5 figg.: upper, "Balæna-Wallfisch"=Physeter macrocephalus ; second fig., "Balæna-Wallfisch"= Physeter macrocepha? us, from Clusius ; middle fig., "Balæna Monstrosa" (teeth in lower jaw, and some other features of Physeter, of which it may be a gross caricature); fourth fig., "Balæna-Ein ander art Wallfisch," apparently based on tho Orea, but the pectoral limbs terminate in eurved claws; last fig., "Phocæna-Meer Schwein, Braunfisch" =Phocoena. Pl.xlii: "Balæna. Ein Grosser Wallfisch von 60 Schuch lang vnd 41 Schnch hoch," a full-page figure, with scenery, of an unmist akable Physeter macrocephalus, lyiug on its side. Pl. xliii, 7 figg. : upper fig., "Vtilis Piscis sersam ad instar Pristis habens"- a fabulous creature, with the sword of a saw-fish (Pristis) protruding from the top of the head; second fig., "Delphinus prior, Delphin" (not determinable); third fig., "Delphinus alter, Delphin" (probably an Orca); fourth and fifth figg., "Antiq. Metal.," obverse and reverse of an ancient coin or medal, on one rude effigies of two Dolphins; sixth fig., "Delphinus fomina, Delphin Weiblein" = Phoccena, with a young one attached by the fœtal envelopes; scventh fig., "Delphinus alius, Ein ander art Delphin"=Common Dolphin. Pl. xliv, 8 figg.: upper fig., "Caput Delphini, Delphins Kopf" = Phocoena ; second fig., "Gladius piscis Serixe, Der Kopf des Schwertfisch," skull of Pristis ; third fig., "Scolopendra cetacea," a fabulous creature with some features of a Cetacean; fourth fig., "Phoca siue Vitulus marinns, Seehund," Seal ; fifth fig., "Vitulus, Seehundt," Seal; sixth fig., "Rosmarus, Wallross"; seventh fig., "Rosmarus Vetus, Ein Alt Meer Ros"; and eighth fig., "Rosmarus juueucus, Ein Iung Meer Ros," from the well-known figure published by Gerard. In the article "De Manati Indorum" there is a reference to "Tab. xliii," but there is no corresponding figure on the plate.

Nono of the figures are original, most of them being copies from Belon, Rondelet, Olans Magnns, Gesner, ctc. 
1651. Albertus Magnus. Beati | Alberti | Magni, | Ratisbonensis Episcopi, | ordinis prædicatorvm, | de Animalibrs Lib. XXVI. | Recogniti per R. A.P. F. Petrvm Iammy, sacræ Theologiæ Doctorem, Conuentus | Gratianopolitani, eiusden Ordinis. | Nvne primvm in lvcem prodevnt. | Operum Tomus Sextus. | [Vignette.] Lvgdvni, I

Sumptibus $\left\{\begin{array}{l}\text { Clavdii Prost. } \\ \text { Petri \& Clavdii Rigavd, Frat. } \\ \text { Hieronymi Delagarde. } \\ \text { Ioan. Ant. Hvgvetan. }\end{array}\right\}$ Via Mercatoria. I

M. DC. LI. | Crm privilegio Regis. fol. 11. 8, pp. 1-684.

Liber xxiv. De natura natatilium primo in communi, \& consequenter in speciali, pp. 645661. De cetu, pp. 650, 651. De delphino, pp. 653,654. De gladio, p. 655. De monocerote, pp. 657.

[75.]

1651. Herxaxdez, F. Nova | Plantarvm, Animalivm | et Mineralivm Mexicanorvm | Historia | a Francisco Hernandez Medico | In Indijs præstantissimo primum compilata, | dein a Nardo Antonio Reccho in volvmen digesta, | a Io. Terentio, Io. Fabro, et Fabio Colvmna Lynceis | Notis, \& additionibus longe doctissimis illustrata. | Cui demum accessere | aliqvot ex principis Federici Cæsii Frontispieiis | Theatri Naturalis Phylosophicæ Tabulæ | Vua curn quamplurimis Iconibus, ad octingentas, quibns singula | contemplanda graphice exhibentur. | [Vignette.] | Romae MDCLI. | Sumptibus Blasij Denersini, \& Zanobij Masotti Bibliopolarum. | Typis Vitalis Mascardi. Superiorum permissu.

[Or, ] Rervin Medicarvm | Novæ Hispaniæ | Thesavrvs | sev | Plantarvm Animalivm | Mineralivm Mexicanorvm | Historia ! ex Francisci Heruandez | Noui Orbis Medici Primarij relationibus | in ipsa Mexicana Vrbe conscriptis | a Nardo Antonio Reccho | Monte Coruinate Cath. Maiest. Medico | Et Neap. Regni Archiatro Generali | Iussu Philippi II. Hisp. Ind. ecc. Regis | Collecta ac in ordinem digesta | À Ioanne Terrentio Lynceo | Constantiense Germº. Phō. ac Medico | Notis Illustrata | Nunc primũ in Naturaliũ rer. Studiosor. gratiã | lucubrationibus Lynceorũ publici iuris facta. | Quibus Jam excussis accessero demum alia / quor. omniumu Synopsis sequenti pagina ponitur / Opus duobus voluminibus dinisum | Philippo IIII. Regi Catlolico Magno | Hispaniar. vtriusß̧ Siciliæ et Indiarũ etc Monarchæ | dicatum. | Cum Priuilegijs. Romæ Superior. permissu. Ex Typographeio Vitalis Mascardi. M. DC. XXXXXI. fol. 11. 9 [= ill. title (the one first given above), engr. title (the second given above), ledic. to the reader, index ], pp. 1-950, 1.1, pp. 1-90, 11. 3 [= index and errata], 11. 10 [gen. index, index of authors, errata, and corregenda]. The leaves containing the general index, etc., here placed at the end of the volume, are in some copies bound in at the front of the general text. The "Historiæ Animalivın et Mineralivm Novae Hispaniae ... Francisco Fernandez Philippi Secundi primario medico avthore" (pp. 1-90+11. 3) is also similarly transposed in binding.

There are carlier editions, none of which I have been able to see: the collation of that of 1628 ( $q . v$. ) has been already given, copied from Sabin. On Hernandez and his wurks see Rich; Books relating to America, 1493-1700, pp. i2-74.

The matter of special interest in the present connection is: De Manati, Nardi Ant. Recchi, ix, cap. xiii, pp. 323, 324, 2 figg.

About $\frac{2}{3} \mathrm{p}$. of text, and 2 cuts, one in profile, the other from above, scarcely recognizable as having any relation to the Manati : body clliptical, tail broad and rounded, with a ring at base; head in profile, sui generis; from above, somowhat calf-like; fore-limbs quite long, feet hoofed, and of a bovine form, especially as secn in the profile figure. The characters given by the artist do not conform to those in the text, which is, compared with other early accounts, not remarkable for accuracy.

Ambra grisea seu ollorata, Io. Fabri Lyncei Expos., pp. 564-579. A long disquisinon about Ambra grisca, its nature, origin, and medicinal properties, etc., with reierences passim to Balænæ. 
1652. ANon. "De Vrye Zee, aengaede haere vryheyt in 't varen en visschen voor de Veeren Nederlanden, verdedigt tegen alle bestryders der Gerechticheyt, insonderheyt teghen die hedendaechsche Regeringe in Engeland. [No place.] 1652. $4^{\circ}$."

"Pp. 55-62 treat of the Herring-and Whale-fishery and the pretensions of the English on Greenland and Spitzbergen."

Not seen; title and comment from.Fr. Muller, Cat. A mer. Books, 1877, p. 200, no. 3424.

1655. "N. N." America : | or | An Exact Description | of the | West Indies: | More especially of those | Provinces which are under | the Dominion of the | King of Spain. | - | Faithfully represented by N. N. Gent. | - | London, printed by Ric. Hodgkinsonne for Edw. Dod, I and are to be sold at the Gun in Ivy-lane, 1655. sm. $8^{\circ}$ by sig. 11. 7, pp. 1-484, 1. 1, map.

The Manati or Oxe-fish, pp. 154, 155. Account based mainly on Hernandez and Laet.

1655. Worm, Olaus. Museum Wormianum. | Seu | Historia | Rerum Rariorum, Tam Naturalium, quam Artificialium, tam Domesticarum, | quam Exoticarum, quæ Hafniæ Danorum in | ædibus Authoris servantur. | Adornata ab | Olao Worm, med. doct. | \&, in Regiâ Hafniensi Academiâ, olim | Professore publico. | Variis \& accuratis Iconibus illustrata. | [Vignette.] Lugduni Batavorum, | Apud Johannem Elsevirivm, Acad. Typograph. | - | CI D I DC LV. 2०. 11. 9, pp. 1-390, 1. 1. Cuts in text.

Cap. xiii, De Cetis, pp. 279, 280; cap. xiv, De Ceto dentato, Balena, Monocerote, pp. 280 287; cap. $x v, D \ominus$ Delphino, Pristi, Phoca, Rosmaro, pp. 288-290. Skull of Narwhal figured, three views, and a view of the tusk separate, pp. 283-285; also a grotesque figure of the animal, p. 282.

Cap. xiii, De Cetis, consists mainly of a briefiy descriptive list of Whales from the celebrated Icelandic mannscript "Specvlnm regale," numbering 22 species. (Cf. Eschricht and Reinhardt, "Om Nordhvalen," 1861, p. 39, and the English translation, "Memoirs on Ceta. cea," Ray Society, 1866, p. 32.) The account and figures of the Narwhal are from the MSS. of D. Thorlacus Sculonius.

1657. "Bartholinus, TH. Cetorum genera."

"Zie: Th. Bartholinus, Historia Anatom., cent. 1v, 1657, pp. 272-285."

Not seen; from Bosgoed, Bibl. Ichthyol. et Piscat., p. 157, no. 2477.

1657. Jonston, John. An | History | of the | Wonderful Things of Nature: I Set forth in Ten severall Classes. | Wherein are contained |

I. The Wonders of the Heav-) (VI. Of Birds. ens.

II. Of the Elements.

III. Of Meteors.

IV. Of Minerals.

V. Of Plants.

VII. Of Four-footed Beasts.

VIII. Of Insects, and things wanting blood.

IX. Of Fishes.

| - | Written by Johannes Jonstonus. I And now Rendred into | English, | by | A Person of Quality [John Rowland]. | - | London, | Printed by John Streater, living in Well-Yard near the Hospitall of | St. Bartholomew's the Lesse, and are to be sold by the Book- I Sellers of London, 1657. 80. 811 ., pp. 1-344.

Classis ix, chap. iii, of the Whale and Barbel, pp. 290, 291. Chap. xi, of Manaty, and the Whiting, pp. 296, 297. Chap. xii, of Mirus, Mola, and Monoceros, pp. 297-298.

1658. "Rochefort, C. DE. Histoire | Naturelle et morale / des | Iles antilles | de l'Amerique. | Enrichie de plusieurs belles figures des Raretez les plus | considerables qui y sont décrites. | Vvec vn Vocabulairo Caraỉbe. | [Dessin.] | A Roterdam, | Chez Arnould Leers, | - | M. DC. LVIII. 1 vol. $8^{\circ}$ (or sm. $4^{\circ}$ ). Engr. title, 8 prel. pp. incl. regular title, pp. 1-527, 6 1l. (contents).

This is the original ed. Not seen; title from Cones, Bull. U. S. Geol. and Geogr. Surv. Terr., v, no. 2, Sept. 6, 1879, p. 240. For Cetacean matter, etc., see second ed., 1665. Also, the Dutch version, 1662. 
1660. Hrrrara, A. DE. Histoire | generale | des Voyages | et Conqvestes | des Castillans, dans les Isles \& Terre-fermo / des Indes Occidentales. | Traduite de l'Espagnol d'Antonio d'Herrara, Historiographe de sa | Maiesté Catholique, tant des Indes, que des Royaumes de Castille. | Par N[icolas]. de la Coste. | Premiere Decade, contenant les Pre- 1 ... [ [ etc., 7 lines $]$. | A Paris, | Chez Nicolas \& Iean de la Coste, au Mont Saint Hilaire, à | l'Eseu de Bretagne; et en leur boutique, à la petite porte | du Palais, qui regarde le Qay des Angustins. $|-|$ M. DC. LX. Avec Privilege dv. Roy. 3 vols. 4․ 1660-61.

Du poisson apellé Manati [sic], tome i, pp. 378, 379.

1660. Jo[N]śtox, J. Naeukeúrige beschryving van de natuur der viervoetige dieren, der vissen en bloedloze waterdieren, der vogelen, der gekerfde of kronkeldieren, slangen en draken, neffens haar beeldnissen. Uit het Latyn vertaeld door M. Grausius. Amsterdam, Schipper, 1660. fol. Met 249 koperen platen."

Not seen; title from Bosgoed, op. cit., p. 10, no. 108.

1662. Rocherort, C. DE. Natuurlyke on zedelyke | Historie / van | d'Er rlanden | de Voor-Eylanden | van Amerika. | Verrijkt met vele schoone Platen, die uytbeelden d' aller-aan- | merkelijkste seldsaambeden die'er in besehreven zijn. | Met eenen Caraïbaansehen Woorden-schat. | Door D. Charles de Rochefort voor desen Bedienaar | des H. Euangeliums in d' Eylanden van Amerika, en tegenwoor- | digh Herder van de Kerke der Françoysehe Tale tot Rotterdam. | Vertaalt in Nederduytsch door H[eiman]. Dullaert. I Alles na een Voorselurift door de Sclirijver oversien | en veel vermenighvuldight. | [Vignette.] Tot Rotterdam, | By Arnout Leers, Boekverkooper. | M. DC. LXII. sm. 40.

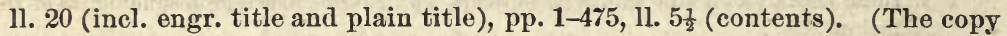
examined lacks the folding plates of the Freneh ed. of 1665 , but appears to have all the others.)

XVII. Hooft-stuk: Van de Zee-gedrochten die in dese gewesten gevonden worden, pp. 151-159. Van de Marsoüins, of Zee-verkens, p. 152. Van den Lamantin, pp. 155, 1506. Van de Walvisschen, en andere Zee-gedrochten, p. 156. XVIII. Hooft-stuk: Bysondere beschrijving van eenen Zee-Een-hoorn, die strande op de Kheede van het Eryland van de Schild-padde in het jaar 1644, etc., pp. 159-177. XX. Hooft-stuk: Van den Ambergrijs; Van sijnen oorspronk, en van de teykenen des genen die goed is, en sonder vermengeling, pp. 190-194.

For comment on the cetological matter, etc., see the French ed. of 1665.

1663. La Peyrère, IsAaC DE. Relation | dv | Groenland. | [Par Isaac do La Peyrère.] [Vignette.] A Paris, | Chez Lovis Billaine, au seeond | pillier de la grand' Salle du Palais, à la | Palme, \& au grand Cesar. | - | M. DC. LXIII. | Aree Privilege dv Roy. 11. 9, pp. 1-278, 11. 2. Map and pll.

References to the Narwhal (le Licorne) and to Whales passim, but especially to the former at pp. 192, 193, and to the latter at pp. 220-223. The plate facing p. 145 gives a figure of the Narwhal (animal) and three views of the sknll, evidently after Worm.

This appears to be a reissue, with a different imprint, of the edition of 1617 (ed. prin., q.v.). There is a Dutch translation (Hoorn, 1678), and a German (Nürnberg, 1679). It is alao given in English by Churchill (Coll. Voy.), and by the Haklnyt Society (Coll. Doc. on Spitz. and Greenl., pp. 175-249). T he cetological matter is unimportant.

1664. Boucher, P. Histoire | veritable | et | Natvrelle | des | Moevrs et Prodvetions | dv Pays | de la | Novvelle France. | Vvlgairement dite | le | Canada. | [Par Pierre Bouchet.] [Ornament.] A Paris, | Chez Florentin Lambert, ruë| Saint Iaques, vis à vis Saint Yues, | à l'Image Saint Paul. | - | M. DC. LXIV. | Auec Permission. 12०. 11. 12, pp. 1-168.

Noms des Poissons qui se trouuent dans le grand Fleuue S. Laurens, \& dans les lacs \& riuieres qui descendent, dont nous auons connoissance. Chap. vii, pp. 74-87. Marsoin blanc [= Beluga catodon], pp. 74, 75. "On en void des quantitez admirables, depuis Tadon ₹sac jusques à Quebec, qui bondissent sur la riuiere" (p. 75).

1664. Zesen, Fulips von. "Besehreibung der stadt Amsterdam, darinnen von derselben ersten ursprunge bis auf gegenwärtigen Zustand, ihr unterschiedlicher anwachs, herliche vorrechte, und in mehr als $70 \mathrm{Kupferstïkken} \mathrm{entworfene}$ führnemhste Gebeue, zusamt ihrem Stahtswesen, Kauf-handel und ansehnlicher macht zur See, wie anch was sich in und mit Derselben märkwürdiges 


\section{Zesen, Filips voN-Continued.}

zugetragen vor augen gestellet werden. $\mathrm{Zu}$ Amsterdam, Gedrukt und verlegt durch Joachim Noschen. Im Jahr 1664. 4०."

"Zie aldaar: Fischmärkte, bl. 226, 227-231, benevens eenige bijzonderheden omtrent den verkoop ran visch. Grühnländische Geselschaft, was vor freiheit sie habe, bl. 359. Grühnländische Pakheuser, bl. 358. Walfische, wie sie gefangen und der trahn daraus gesotten wird, bl. 359. Härings-Pakkerei und Pakker-turn, bl. 76, 103, 172.

Not seen; title and references from Bosgoed, op. cit., p. 253, no. 3613.

1665. Anow. Of the New American Whale-fishing about the Bermudas. <Philos. Trans. Lond., i, no. 1 [1665], pp. 11-13.

1665. [Rochefort, C. DE.] Histoire / naturelle et morale / des / Iles Antilles | de l'Amerique. | Enrichie d'un grand nombre de belles Figures en taille douce, | des Places \& des Raritez les plus considerables, I qui y sont décrites. | Avec un Vocabulaire Caraïbe. | Seconde edition. | Reveü̈ \& augmentée de plpsieurs Descriptions, \& de quelques | éclaircissemens, qu'on desiroit en la precedento. | [Par César de Rochefort.] [Dessin.] | A Roterdan, | Chez Arnout Leers, | - | M. DCC. LXV. sm. 4․ 18 1l. (incl. eng. title and plain title), pp. 1-583, 1l. $6 \frac{1}{2}$ (contents), 3 fold. pll., and numerous euts of plants and animals.

Chapitre xvii. Des Monstres Marins qui. se trouvent en ces quartiers, pp. 190-200. [Contenant entre autres], Des Marsoüins, p. 191; Du Lamantin, pp. 194, 195, fig., p. 199; Des Baleines \& antres Monstres de Mer, p. 195.

Chap. xviii. Description particuliere d'une Licorne de Mer, qui s'echona à la rade de l'lle de la Tortuë en l'an 1644. Avec un recit curieus, par forme de comparaison \& de digression agreable, touchant plusieurs belles \& rares cornes qu'on a apportées depuis peu dn détroit de Davis; \& de la qualité de la terre, \& des meurs des Peuples qui y habitent, pp. 200-220, 2 figs., p. 204 .

Chap. xx. De l'Ambre gris; De son Origine \& des marques de celuy qui est bon, \& sans mélange, pp. 236-241.

The remarks about Marsouins and Baleines are brief and of no importance. The account of the Lamantin (1 page and 3 lines in length) is explicit and interesting, describing correctly the general appearance and habits of the animal, inclading its reproduction, and the use of its flesh as food by the natives. The cut (p. 199) is a very good figure (its date, of course, considered) of the animal - an old Lamantin folding its young one in its arms. The account of the Licorne de Mer (pp. 200-202), said to have been stranded "au rivage de l'Ile de la Tortuë, voisine de l'Mle Hispaniola, on Saint Domingue," is given in the words of M. du Montel, who saw it. It was about 18 feet long, its body of the size of a barrel. It had 6 large fins-2 placed "an defant des ouyës," the other 4 on the sides of the belly at equal distances. The body was covered with large scales; therefore, whatever it may have been, it was not a Cetacean. 'The horn projecting from the front of the horse-like head was $9 \frac{1}{2}$ feet long. The horn was preserved for two years, and finally carefully boxed and shipped by the governor of the island, as a present, to "Monsieur des Traucarts, Gentilhomme de Saintonge," but, alas, the ressel was wrecked on the passage, and this precious relic was lost, as well as all the merchandise. Following this relation is a short account of the Narwhal with (on page 204) "les figures de la Licorno laquelle s'echoüa en l'Mle de la Tortuë, \& d'une de celles du Nord," to show how great is the difference between the two species.

In the chapter on Ambergris, after stating the fact that it was unknown to the ancients, and the various theories respecting its origin, the author observes: "Mais c'est plns vrai-semblablement une sorte de Bitume, qui s'engendre au fond de la mer," etc., and procecds to give his view of how it may be detached, etc. The whole account is one of special interest in relation to the early history of Ambergris.

For the original edition of this work, see Rocheront, at 1658. There is also a later ("derniere") edition (Rotterdam, 1681), of which Dr. Cones has recently giren the collation (Bds. Col. Vall., p. 241). An English translation was published in London in 1666 (not seen lo, me), and a Dutch in 1662, q. v.

1666. Axon. A Further Relation of the Whale-fishing abont the Bermudas, and on the Coast of New-England and New-Netherland. <Philos. Thans. Lond., i, no. 8 [1666], pp. 132, 133 .

1667. "MerretT, C. Pinax | Rerum Naturalium | Britannicarum, | continens | Vegetabilia, Animalia, | et | Fossilia, | In hac Insula reperta inchoatus. | - | Authore | Christophoro Merrett, | Medicinæ Doctore utriusqne Societatis |

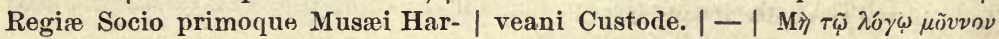

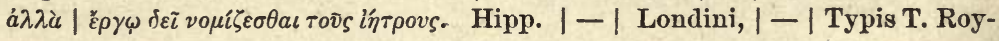


166\%. "Merretr, C.-Continued.

croft, Impensis Cave Pulleyn. | MDCLXVII. Vol. unic. 16mo. Tit. 1 f. Epist. dedic., 5 f. Epist. ad Lect., 10 f. pp. 1-22:3+1."

"Edit. altera. Ed. princeps 1666. Ed. nova 1704."

Not seen; title from Coues, Proc. U. S. Nat. Mus., ii, 1880, p. 361. The work is also cited by Bosgoed, op. cit., p. 102, no. 1619.

1667. Norwood, R. An Extract Of a Letter, written from the Bermudas, giving an account of the Course of the Tides there, of Wells both Salt and Sweet, digg'd near the Sea; of the Whale-fishing there practised anew, and of such Whalcs, as have Sperma Ceti in them. <Philos. Trans. Lond., no. 29 [1667]; pp. 565-567.

1667. Tertre, [J. B.] DU. Histoire | generale | des | Antilles | habitées par les François. | Tome ii. | Contenant I Histoire | natverelle, | Enrichy de Cartes \& de Figures. | Par lo R. P. [Jean Baptiste] dv Tertre, de l'Ordre FF. Prescheurs, | de la Congregation de S. Louis, Missionnaire Apostolique | dans les Antilles. | [Arms.] A Paris, | Chez Thomas Iolly, au Palais, en le Salle des Merciers | à la Palme, | \& aux Armes d'Hollande. | - | M. DC. LXVII. | Avec Privilege. 4\%. [3 vols., 4º. Vol. i, vol. ii, 1567; vol. iii, 1671.]

Vol. ii, Traite iv. Des Poissons. Chap.i. Des Poissons do la mer, pp. 195-233.- i. Des Baleines, pp. 196-198. §ii. Des Sonfflears, pp. 198, 199. §iii. Du Lamantin ou Manaty, pp. 199-209, fig. (pl. fac. p. 195). The remarks about the "Baleines" and "Souffleurs" aro very general and of little importance. The account of the Manateo is more detailed, treating of its external characters, habits, products, and capture. The figure is like Laet's, which is a copy from that of Clusins, $q \cdot v$.

[94.]

1668. Stafford, R. Of a Letter, written to the Publisher from the Bermudas by Mr. Richard Stafford; concerning the Tydes there, as also Whales, Sperma Ceti ... <Philos. Trans. Lond., iii, no. 40 [1668], pp. 792-795.

1669. "Montanus, ARs. Gedenkwaerdige Gezantschappen der Oost-Indische maatschappy, aen de Kaisaren van Japan. Vervaetende wonderlijke voorvallen op de togt der Nederlandsche gezanten. Beschryving van dieren, gewassen enz. t' Amsterdam, by Jacob van Meurs, 1669. fol. Met gegrav. platen en kaarten."

"Zio aldaar: Besehryving der walvisschen en der walvischvangst, bl. 448,449. Japansche visschers, haer manieren van visschen. Met afbeelding, bl. 55 en 279."

Not seen; title and comment from Bosgoed, op. cit., p. 169, no. 2675.

1670. Bartholinus, Thomas. De Sirene Danica. <Ephem. Med.-phys. Germ. Acad. Nat. Curios., i, 1670, pp. 85-89; edit. secund., 1684, pp. 73-79.

1670. "Nieunof, JoAN. Het Gezantschap der Nêerlandsche Oost-Indische Compagnie, aen den grooten Tartarischen Cham, den tegenwoordigen Keizer van China. Waerin de gedenkwaerdighste geschiedenissen. Benefiens beschryving der dieren, gewassen, enz. Verçiert met over de 150 af bceltsels. t' Amsterdam, by Jacob van Meurs, $A^{\circ} .1670$. fol."

"Zio aldaar, Visschen: De walvisch, haar gestalte en teelt; hoe zy gevangen worden, bl. $157 a-160 a$. Vliegende visschen. Met af beelding, bl. 203, 204."

Not seen; title and comment from Bosgoed, op. cit., p. 170, no. 2682.

1670. Scilla Agostino. La | Vana Specvlazione | disingannata | dal Senso. | Lettera risponsiva | Circa-i Corpi Mariné, che Petrificati fi trouano | in varij loughi terrestri. | Di Agostino Scilla Pittore | Accademico della Freina, | detto lo Scolorito. | Dedicata | all' illvstrissimo Signore, | il Signor | D. Carlo Gregori | Marchese di Poggio Gregorio, | cavaliero della Stella | - | In Napoli, | Appresso Andrea Colicchia. M. DC. LXX. I Con licenz a de' Superiori. $4^{\circ}$. 11. 5, pp. 1-168, pll. i-xxviii+frontisp.

At page 123 is a description of a fragment of a lower jaw containing threo toeth; the fragment is figured, pl. xii, fig. 1. The teeth are recognizable as those of Squalodon. (Cf. VAN BENEDEN, "Recherches sur les Squalodonts," in Mém. de l'Acad. roy. de Belgique, vol. xxxv, 1865.)

The work thus has the importance of containing the first unquestionable description and figure of remains of Squalodonts. 
1671. “Martinì̀re, P. M. DE LA. Voyage des pays septentrionaux. Dans lequel se voit les moeurs, manière de vivre et superstitions des Norwóguiens, Lappons, Sybériens, Samojèdes, Zembliens, Islandois. Paris, 1671. kl. 8०. Met fig."

"Herdrukken verschenen to Parjis, 1676. $8^{\circ}$, en to Amsterdam, 1708 (zonder naam van den schrijver). Eeene engelsche vertaling: London, 1074; ecne hoogduitsche: Hamburg, 1675, en Leipzig, 1711; eene italiaansche in 1683. Zie voor de Hollandsche uitgave: De Noordsche Weereld ... [Zio 1685. Martrnière en MarTexs.] Adelung geeft in zijn: 'Geschichte der Schiffahrten,' bl. 298-319, een nitvoerig uittreksel van dezo rcis."

Not seen; title and note from Bosgoed, op. cit., p. 243, no. 3512.

1671. RAY, J. An Account of the Dissection of a Porpess, promised Numb. 74; made, and communicated in a Letter of Sept. 12,1671, by the Learned Mr. John Ray, having therein observ'd some things omitted by Rondeletius. <Philos. Trans. Lond., vi, no. 74 [1671], p. 2220; no. 76 [1671], pp. 2274-2279.

[101:]

1672. ANoN. "A proportional view of the large Spermaceti whale run aground on Blyth Sand, and there killed himself. 30 Jan. 167\%. [Pl. $8 \times 14$ inches.] Sold by W. Tringham."

Not seen; title from Bosgoed, op. cit., p. 171, no. 2697.

1672. Josselyn, J. New-Englands | Rarities | Discovéred: | In | Birds, Beasts, Fishes, Serpents, | and Plants of that Country. | Together with | The Physical and Chyrurgical Remedies | wherewith the Natives constantly use to | Cure their Distempers, Wounds, | and Sores. | Also | A perfect Description of an Indian Squa, | in all her Bravery; with a Poem not | improperly conferr'd upon her. | Lastly | A Chronological Table | of the most remarkable Passages in that | Country amongst the English. | - | Illustrated with Cuts. | - | By John Josselyn, Gent. | - | London, Printed for G. Widdowes at the / Green Dragon in St. Pauls Church yard, 1672. sm. 80 by sig., $24^{\circ}$ size. 11. 2, pp. 1-114, cuts.

Reprinted in Archaevlogia Americana or Trans. and Coll. Amer. Antiq. Soc., iv, pp. 133-238.

The Sperma Ceti Whale; What Sperma Ceti is ; What Ambergreece is, pp. 35, 36. "Now you must understand this Whale feeds upon Ambergreece, as is apparent, finding it in the Whales Maw in great quantity, but altered and excrementitious: I conceive that $A$ mber. greece is no other than a kind of Mushroom growing at the bottom of some Seas..." (p. 30).

[103.]

1672. Tulpius, N. Nicolai Tulpii | Amstelredamensis | Observationes Medicæ. | Editio Nova. | Libro quartior anctior, \& Sparsim multis | in locis emendatior. | [Vignctte.] Amstelredami, | Apud Danielem Elsevirium, | CI $I_{\supset}$ C LXXII. sm. 80. 1l. 7, pp. 1-392, pll. i-xviii.

Unicornu marinam, lib. iv, cap. lix, pp. 374-379, tab. xviii. The three very rude figures represent the animal in profile and the skull from above and below. They are the same as those given by Worm, by whom they were copied from Tulpius.

The editio princcps I have not seen; the dedication "Ad Petrum Tulpium filium" is dated 1641 , which is probably tho date of the first edition. There are numerous later editions, of which editio quinta is the only one I have seen $(q . v .-1716$. TulpIUs, N.).

[104.]

1673. BoYLe, R. A Letter of the Honorable Robert Boyle of Sept. 13, 1673, to the Publisher, concerning Amber Greece, and its being a Vegetable Production. <Philos. Trans. Lond., vii, no. 97, 1673, pp. 6113-6115.

Stated, on the authority of a factor of the Dutch East India Company, to issue from the root of a tree.

[105.]

1675. Josselyn, J. An | Account | of two | Voyages | to New-England. | Wherein you have the setting out of a Ship, / With the charges; The prices of all necessaries for | furnishing a Planter \& his Family at his first com- | ing ; A Description of the Country, Natives and | Creatures; The Government of the Countrey as | it is now possessed by the English, \&c. A large | Chronological Table of the most remarkable / passages from the first discovering of the Conti- | nent of America, to the year 1673. | - | By Jnhn Josselyn Gent. | - I The Second Addition. | - | [Quotation, 6 lines.] | London Printed for G. Widdowes at the Green Dragon in St. | Pauls Church-yard, 1675. sm. 8०. 11.4, pp. $2-279+3$. 


\section{Josselyn, J.-Continued.}

Orig. ed. 1664 ; the present is textually the same, except the title-page. Reprinted in the Coll. Mas8. Hist. Soc., 3d ser., iii, 1833, pp. 211-296, "and was again reprinted in 1865 by William Veazie, following the Harvard College copy" of the 1675 ed., from which copy the above collation is taken.

The Ambergreese. Whale, pp.104,105." "Anno Dom. 1668 the 17 of July there was one of them thrown up on the shore between Winter-harbour and Cape-porpus [near Boston], abont eight mile from the place where I lived, that was five and fifty foot long" (p. 104). Nothing else of importance relating to Cetacea.

1675. Martens, F. Friderich Martens / vom Hamburg | Spitzbergische oder Groenlandische | Reise-Beschreibung | gethan im Jahr 1671. | Aus eigner Erfahrunge beschrieben, die dazu erforderte | Figuren nach dem Leben selbst abgerissen, (so hierbey in | Kupfer zu sehen) und jetzo durch den | Druck mitgetheilet. | [Vignette.] Hamburg, | Auff Gottfried Schultzens Kosten gedruckt, | Im Jahr 1675. sm. $4^{\circ}$. Il. 4, pp. 1-132, 1l. 2, pll. $A-Q=16$.

Cetacea, pp. 92-127. Meerschwein oder Tunin, pp. 92, 93. Butskopf, pp. 93, 94. Weisfische [=Beluga catodon], p. 94. Vom Einhorn [= Monodon monoceros], pp. 94, 95. Ságenfisch ins gemein genannt Schwerdtfisch [= Orca], pp. 95, 96. Vom Wallfisch, pp. 98-109, pll. A and Q (figs. $a, b$, Baloena mysticetus). Vom Wallfischfang, pp. 110-118. Wie sie mit den todten Walfisch ümbgehen, pp. 118-123. Von des Fetts, oder Trahns Brennerey, pp. 123-125. Von Finfisch [=Balonoptera sp.], pp. 125-127, pl. Q, fig.e.

Martens's work in relation to Cetology is one of great interest and importance, not only from its early date, but for the good account it gives of the Greenland Right Whale and the Whale-fishery, and also especially for its very good figures of the Greenland Whale and of the Finfish. They may be fairly considered as the first passable figures of these species, and those of the first were the standard figures down to the time of Scoresby $(1820)$, and as such were many times copied. His references to the other northern Cetacea are intelligent, and of great historic interest. The only separate translations of the work I have seen cited are an Italian (Venice, 1680, 12) and a Dutch (Amsterdam, 1710, $4^{\circ}, q . v$. ), but various rersions, generally more or less abridged, have appeared in collections of voyages, etc., as Vries's (Amsterdam, 1685), Narborough's (London, 1694), Harris's (London, 1705), Bernard's (French, Amsterdam, 1731), Adelung's (German, Halle, 1768), etc. Also, White's (1855, Hakluyt Soc.), q.v.

[107.]

1676. Debes, L. J. Færoœ, \& Fœroa Reserata: | That is / A Description | of the | Islands \& Inhabitants | of | Fœrœ: | Being | Seventeen Islands subject to the | King of Denmark, lying under 62 | deg: 10 min. of North Latitude. | Wherein several Secrets of Nature | are brought to Light, and some Anti- | quities hitherto kept in darkness | discovered. | Written in Danish by Lucas Jacobson | Debes, M. A. and Provost of the / Churches there. | - Englished By J[ohn]. S[terpin]. Doctor of Physick. | - | Illustrated with Maps. | - | Printed by $F$. L. for William Iles, at the Flow- | er-de-Luce in Little Brittain, over against | St. Bartholomews Gate. 1676. 120. 11. 12, pp. 1-408. ['The copy examined (Harv. Coll. Libr.) lacks the maps.]

Chap. iii. Of the Waters Fertility, pp. 163-189.-Grind-Whales [= Globiocephalus mclas], pp. 171-179. Doglings [= Hyperordon sp.], pp. 179-184. Roar and Witch-Whale, pp. 184-188.

The chapter "Of the Waters Fertility" is full of quaint and curious information about the myths and superstitions prevalent among the Foero islanders in the 17th century respecting the marine mammalia found about these islands, as well as replete with interesting matter relating to the natural history of the Seals and Cetaceans. The account of the Grind-Whale (Globiocephalus melas) is especially important.

"The Fishes wherewith this people maintain themselves are of three sorts; first, small Fishes, secondly Seals, and in the third place Whales" (p. 164).

The date of the original Danish edition I am unable to give. A German version ( $8^{\circ}$, Kopenhagen und Leipzig) was published in $1757, q: v$.

[108.]

1670. "Sachs, Paul Ludw. Monocerologia seu de genuinis Unicornibus. Dissert. Raceburgi, 1676. 80. pp. 182, pl. 1."

Not seen; title from Carus and Engelmann.

16\%. Avon. "Strange news from the deep, being a full account of a large prodigions whale lately taken in the river Wioner, within six miles from ? Colchester. (z. pl.) 1677. $4^{\circ}$."

Not scen; title from Bosgoed, op. cit., p. 171, no. 2695. 
1677. Charltox, W. Gualteri Charltoni | Exercitationes | de | Differentiis \& Nominibus Animalium. | Quibus accedunt | Mantissa Anatomica, | Et quædam | Do variis Fossilium generibus, | Deque differentiis \& nominibus Colorum. | Editio secunda, duplo fere auctior priori, novisque iconibus ornata. | [Vignette.] Oxoniæ, | E Theatro Sheldoniano, An. Dom. 1677. 40. 11. 10. Animalia Quadrupeda, Serpentia, Insecta, Aves, pp. 1-119; Pisces, etc., pp. 1-106; Fossilia, etc., 1. 1, pp. 1-78, 11. 10, Indices. (With figures in the text.)

Piscium Cetaceorum Classis [pars ii], pp. 46-50. I. Balcena. 1. Balsna vulgaris, the common Whale, p. 46; 2. Physeter, \& Physatus, the puffing aut spouting Whale, p. 47; 3. Cetus Dentatus, à Carolo Clusio, the Sperma-Ceti Whale, p. 47; 4. Pustes, the Swift Whale, p. 47; 5. Orca, the Ork, p. 47; 6. Monoceros, Unicornu Marinum, the Unicorn Whale, p. 47. II. Pristis, p. 47. III. Delphinus, the' Dolphin aut Grampus, p. 47. IV. Phocaena, the Porpus aut Porpes, p. 48. V. Scolopendra Cetacea, p. 48. VI. Phoca, p. 48. VII. Walrus, aliis Mors, p. 49. VIII. Manati, p. 49. IX. Hippopotamus, p. 50. The Editio princeps, 1672, I have not seen.

[111.]

1678. "BARtholives, Tri. De Unicornu observationes novae, secunda editione auctiores et emendatiores, editae à filio Casp. Bartholino. Anstelodami, Wetstenius, 1678. kl. $12^{\circ}$. Met 2 platen en af beeldingen in den tekst."

Not seen; from Bosgoed, op. cit., p. 157, no. 2478.

1678. Capel, RudolfF. Norden, | Oder | Zu Wasser und Lande im Eise | und Snee, mit Verlust Blutes und Gutes | zu Wege gebrachte, und fleisig | beschriebene | Erfahrung und Vorstellung | des Norden, | Auss | Denen, welche | zu unterschiede- | nen Zeiten gelebet, viel im Norden versu- | ehet, viel auch umbsonst angefangen und ange- | wandthaben: | Auff guter Freunde Begehren zusammen gebracht | dargereichet, und ferner zu betrachten und | zuvermehren, | von | Rudolff Capel, der H. Schrifft D. | und Historiarum P. P. | aussgefürtiget. | - | Hamburg, | Bey Johann Nanmann. | und Stockholm | Bey Gottfried Liebezeit, In 1678sten Jahre der Christer. $4^{\circ}$. 11. 4, pp. 1-236, .11. 12.

Das 5 Capittel. Georg Niclaus Schurtzen bericht, von der Natur und Eigenschaft, auch Nachstellung und Fang des Walfisches, im Jahr nach C. G. 1672. aussgefertigtet, pp. 197212. There are also references to Whales at pp. 55 and 67 . Chapter $r$ gives a quite detailed account of the external characters, habits, products, and eapture of the Greenland Right Whale. The female is said to be the larger, etc. There are also other passing allnsions to Whalefishing (Walfischfangst), as at pp. $141,158,159$, etc. There is also a large plate $\left(13 \frac{1}{2} \times 11\right.$ inches), bound (in the copy examined) to face p. 156, which is a faithful reproduction of Martens's plate of the common Balcena mysticetus (two figures), and a Finner Whale, with the accessories of whale-louse, harpoon, and lance.

[113.]

1578. "Exquemelin, Alexandre Olivier. De | Americaensche | Zee Roovers. I Behelsende een pertinente en waerachtige Beschrijving van alle de / voornaemste Roveryen, en onmenschlijcke wreedheden, | die de Engelse en Franse Rovers, tegens de Spanjaerden | in America, gepleeght hebluen. | Verdeelt in drie deelen: | Het Eerste Deel verhandelt hoe de Fransen op Hispanjola gekomen zijn, de / aerdt van't Landt, Inwoonders, en hun manier van leven aldaer. I Het Tweede Deel, de opkomst van de Rovers, hun regel en leven onder mal- | kander, nevens verscheyde Roveryen aen de Spanjaerden gepleeght. Het Derde 't verbranden van der Stadt Panama, door d' Engelsche en Franse | Rovers gedaen, neveus het geen de Schrijver op sijn Reys voorgevallen is. I Hier achter is bygevoeght, | Een korte verhandeling van de Macht en Rijkdommen die de Koninck van | Spanje, Karel de Tweede, in America heeft, nevens des selfs | Inkomsten en Regering aldaer. | Als mede een kort begrijp van alle de voornaemste Plaetsen in het selve Gewest, | onder Christen Potentaten behoorende. | Beschreven door A. O. Exquemelin. | Die self alle dese Roveryen, door noodt, bygewoont heeft. | Met schoone Figuren, Kaerten, eu Conterfeytsels, alle na 't leven geteeckent, versien. I t' Amsterdam, By Jan ten Hoorn, Boeckverkoper, over 't Oude | Heeren Logement. 


\section{8. "EXquemelin, AleXandre Olivier.-Continued.}

Anno 1678. | 40. 2 titles, 1 of which is engraved, 21 ., pp. 186, 4 portraits, 6 copper-plates, and 2 maps."

"First edition, of extreme rarity. Perhaps no book in any language was ever the parent of so many imitations, and the source of so many fictions, as this, the original of the buccraeers of America. . . There is certainls no other book of that time which experienced a popularity similar to that of the "Buccaniers of America," which was, in the ten years following its publication, translated into most of the European languages; and there is a fact most curious in the literary history of all times, that the original was certainly unknown to all translators but one. They were all inclined to take the Spanish edition for the original; naj, even the learned editors of Mr. Grenville's catalogue seem doubtful whether the Dutch edition existed in print, or in MS. only.' "

Not seen; title and comment from Sabin, Bibl. Amer., vi, pp. 309, 310, no. 23468. There is a later "very much altered" Dutch edition, 4, Amsterdam, 1700; a German, $12^{\circ}$, Nürnberg, 1679; a Spanish, 40, 1681, "translated from the [first] Dutch"; also, later Spanish editions. The first French edition, "of extreme rarity," was published in 2 vols., $12^{\circ}$, Paris, 1686, "a translation from the English"; a second French, by the same publishers, in 1688; the collation of two later French editions $(1744$ and 1774, q. v.) is given infra. Three English versions (one said to be an abridgment), translated from the Spanish, appeared in $1684(q . v$.$) , with$ several later editions, and possibly other translations into English. (Seo Sabin, Bibl. Amer., vi, pp. 309-318, 328, nos. 23468-23494.)

I have examined the following editions, the collation of which is given by Sabin (op. cit.): $4^{\circ}$, Spanish (translated from the English), 1631 (no. 23471 of Sabin), in which the account of

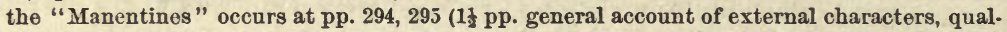
ity of flesh, habits, and mode of capture, with no figure); $12^{\circ}$, Spanish, "Impression Segunda," 1682 (no. 23473 of Sabin); account of the "Manentines" at pp. 438-440, and the same as that of the $4^{\circ}$ edition of 1681 ; no figure. Dutch, $4^{\circ}, 1700$ (no. 23469 of Sabin); account of the "Zee-Koe" at pp. 131, 132 of Deel 1, substantially the same as the Spanish; no figure. English, "The Third Edition," 1704 (no. 23485 of Sabin); account of the "Sea-Cows" at pp. 160-162 (8 lines less than one page in length, and substantially the same as the Spanish). English, "The Fifth Edition," 1771 (no. 23490 of Sabin); account of the "Manentine," or "Sea. Cow," at pp. 209, 210, of vol. i. In none of the editions above cited is there any figure of the animal. French, $12^{\circ}, 1744(q . v$.$) , and 1774(q . v$.$) . The accounts of the Manatee in these two$ French editions is entirely different from that of the Spanish, Dutch, and English editions just cited; besides being lwice as long, and containing much new matter, there is an (apparently) original figure.

[114.]

1678. Major, Johann Daniel. De Respiratione Phocrnæ vel Tursionis. <Ephem. Med.-phys. Germ Acad. Nat. Curios., 1677 (1678), pp. 4, 5.

[115.]

1678. Paullinus, Christianus Franciscus. De Singulari Monstro Marino. <Ephem. Med.-phys. Germ. Acad. Nat. Curios., 1677 (1678), pp. 79, 80.

[116.]

1678. "Scholtz, Adam Sigism. Cerebrum Orcae vulgari supposita Spermatis Ceti larva develatum. Lipsiae, 1678. 4०. 11. 12."

Not seen; title from Carus and Engelmann.

1680. Lyser, Polyc. Disputatio physico-philologica de Cetis. Lipsiae, 1680. 4 ㅇ. pp. 20.

Not seen; title at second-hand.

1681. Blasius, G. Gerardi Blasii | Amstelrædamensis, | Medic. Doct. \& Prof. Ordin. | Anatome | Animalium, | Terrestrium variorum, Volatilium, Aquatilium, | Serpentum, Insectorum, Ovorumque, | structuram naturalem | Ex Veterum, Recentiorum, propriisque Observationibus | proponens, | Figuris variis illustrata. | [Vignette.] Amstelodami, | Sumptibus Viduæ Joannis à Someren, | Henrici \& Viduæ Theodori Boom. | - | cIs Ioc L xxxi. 4․ 11. 3, pp. 1-494, pll. i-lx.

Cap. xvi. De Phocena s. Delphino septentrionalium, pp. 286-290, pl. li (animal, skull, lower jaw, scapula, pectoral limb, ear bones, tail, etc. $=8$ figg).

Cap. xxxv. De Tursione, pp. 306, 307.

1681. Grew, N. Musæum Regalis Societatis. | Or a / Catalogue \& Description / Of the Natural and Artificial | Rarities | Belonging to the | Royal Society | And preserved at | Gresham Colledge. | Made | By Nehemjah Grew, M. D. Fellow of the Royal Society, | and of the Colledge of Physitians. | - | Whereunto is Subjoyned the | Comparative Anatomy | of | Stomachs and Guts. | - | By the 
1681. Grew, N.-Continued. same Avthor. | - | London, | Printed-by W. Rawlins, for the Author, 1681. 4. 11. 7, pp. 1-386, 1. 1+1l, 2, pp. 1-42, pll. i-xxxi.

Of Viviperous Fishes, sect.i, chap. i, pp. 81-103. Includes Cetacea, Sirenia, and Finne. pedia as well as true Fishes. Descriptions are given of ear bones and vertebræo of Whales. Narwhal tusks, head and tail of Dolphin, skeleton of "Porpess or Sea-Hog," etc.

[120.]

1681. Major, Johann Thomas. De Anatome Phocænæ, vel Delphini septentrionalis. <Ephem. Med.-phys. Germ. Acad. Nat. Curios., 1672 (1681), pp. 22-32, figs. i, iii-ix.

Fig. i, Tursio integer, vel Phocæna; fig. iii, Os sterni Phocænæ; fig. iv, Scapula sinistri; fig. v, Pinna anterior sinistri, Manum exhibens; figg. vi, vii, Os petrosum sub meatu auditorio; fig. viii, Craninm Tursionis; fig. ix, Maxilla inferioris pars dextra.

[121.]

1681. "Tyson, Edward. Phocæna: Or the Anatomy of the Porpus, dissected at Gresham College: With a Preliminary Discourse concerning Anatomy, and a Natural History of Animals. By Edward Tyson, M. D., London, 1681."

Not seen; title at second hand.

1682. Segnette, - Historia Ceti aut Balænæ ad littora Rupellæ propulsæ. <Zodiacus medico-gallicus, annus secundus, authore Nićolao de Blegny. Genevæ, 1682 , i, pp. 63-67.

Not seen; cited by P. Fisher (Ann. sci. nat., $5^{\bullet}$ sér., xv, 1871, art. no. 3, pp. 8, 9), as giving a description (measurements, external characters, and parasites) of a Whale stranded Feb., 1680, near the island of Re.

[123.]

1683. "AChrelius, L. Cetographia, sive- dissertatio historico-physica de cetis. Aboae, 1683. Met 6 houtgravuren. 80."

Not seen; title from Bosgoed, op. cit., p. 157, no. 2469.

1684. "[OELEN, J. A. VAN]. De seldsaame en noit gehoorde Walvischvangst, voorgevallen bij St. Anna-Land, in 't jaar 1682, den 7 October, mitsgaders eene pertinente beschryvinge van de geheele Groenlandse vaart, verhandeld in prose en versen. Nevens verscheide saaken tot die materie dienende, door P. P. van S., met schoone kopere prentverbeeldinge (van Luyken) versierd; dese 20 druk merkelijk verbeterd en bijna de helft vermeerderd. Tot Leyden in 't jaar 1684. 40. (Zonder naam van uitgever.)"

"Die vermeerdering bestaat o. a. uit het volgende: Ao 1677. Ordre, beraamt bij de Gecomm. van de Groenlandse visserij, over 't bergen der goederen, enz. Contract tusschen de Com. mandeur en zijn rolk na Groenland. Een beschrijving van het scheepsleven en het berijmd 'verhaal' enz.

"De 1e drak verscheen in 1683 onder den titel: Kort en opregt verhaal ran het droevig en avontuurlijk wedervaren van Abr. Jansz. Oelen. Zie voor de beschrijving der walvischvangst op rijm: Fr. Martens, Beschrijv. van Groenland. . . en Zorgdrager's Groenlandsche visscherij."

Not seen; title and comment from Bosgoed, op. cit., p. 243, no. 3523.

1684. Sibbald, Robert. Scotia Illustrata | sive | Prodromus | Historiæ Naturalis | in quo | Regionis natura, Incolarum Ingenia \& Mores, Morbi iisque medendi Methodus, \& | Mediciua Indigena accuratè explicantur: | et | Multiplices Naturæ Partuis in triplice ejus Regno, Vegetabili scilicet, Animali \& Minerali | per hance Borealem Magnae Britaniæ Partem quæ Antiquissimum Scotiæ | Regnum constituit, undiquaque diffusi nunc primum in Lucem eruuntur, \& varii eorum Usus, Medici præsertim \& Mechanici, quos ad Vitæ / cum necessitatem, tum commoditatem præstant, cunctis / perspicuè exponuntur: $|-|$ Cum Figuris Eneis. | Opus viginti Annorum | Serenissimi Domini Regis Caroli. II. Magnæ Britanniæ, \&c.-Monarchæ Jussu editum. | - | Auctore Roberto Sibbaldo M. D. Equite Aurato, Medico \& Geographo | Regio, \& Regii Medicorum Collegii apud Edinbrrgvm Socio. | - | [Vignette.] | - | Edinbvrgi, | Ex officinâ Typographicâ Jacobi Kniblo, Josuæ Solingensis \& Johannis Colmarii, Sumptibus Auctoris. | - | Anno Domini M. DC. LXXXIV. 2०. 11. 2, pp. 1-102, 11. 3.

- Pars Secunda | Specialis. | Tomus Primus | de Plantis Scotiæ | tam indige- 
1684. Sibbald, Robert-Continued.

nis | quam hortensibus $|-|$ Q $æ x$ in Libro Primo et Secundo | tractantvr. $|-|$ [Vignette. $]|-|$... [Imprint as above.] 11. 3, pp. 1-114, 11. 3.

Pars Secunda | Specialis. | Tomus Secundus | de Animalibus Scotiæ | tam feris quam domesticis / et de | Mineralibus Metallis | et | Marinis Scotiæ. | - | De Qvibvs in Libro tertio et quarto agitur. | - | [Vignette, and imprint as above.] 1l. 3, pp. 1-56, 11. 4, pll. i-xxii.

Sectio Quarta. De Piscibus. Caput li (pp. 22, 23, 16 lines). Baloena, the Common Whale; Physeter, the Spouting Whalo; Cetus dentatus Clusii, in cujus capite Sperma Ceti reperitur; Porcus Marinus Harengos persequitur, \& Delphinus esse creditur; Phoccena, the Porpus or Porpoise, Delphini species.

1685. Martinì̀re, P. M. DE LA, en Martens, F. "De Noordsche Weerweld, vertoond in twee nieuwe aenmercklycke Reysen, d' eene van de heer Martinière ... d' andere van F. Martens. Vertaeld en doorgaens met toedoeningen verrijkt door S. de Vries. Amsteldain, A. D. Ooszaen, 1685. 40. Met platen."

Not seen; title from Bosgoed, op cit., p. 252, no. 3604. See 1671. MArtivìre, P. M. DE LA, and 1675. Martens, F., of which the present appears to be a Duteh translation.

1686. Willoughby, Francis. Francisci Willughbeii Armig. | De | Historia Piscium | Libri Quatuor, | Jussu \& Sumptibus Societatis Regiæ | Londinensis editi. | In quibus non tantum De. Piscibus in genere agitur, Sed \& species omnes, tum ab a- | liis traditæ, tum novæ \& nondum editæ bene multæ, naturæ ductum servante | Methodo dispositæ, accurate describuntur. | Earumque effigies, quotquot haberi potuere, vel ad vivum delineatæ, vel ad | optima exemplaria impressa ; Artifici mauu elegantissime in æs incisæ, ad de- | scriptiones illustrandas exhibentur. Cum Appendice Historias \& Observationes | in supplementum Operis collatis complectente. | Totum Opus | Recognovit, Coaptavit, Supplevit, | Librum etiam primum \& secundum integros adjecit | Johannes Raius e Socitate Regia. | [Vignette.] Oxonii, | E Theatro Sheldoniano, Anno Dom. 1686. 2०. 1l. 4, pp. 1-343,1-30 (Appendix), 11. 7, pll. 185+ -

Liber Secundus De Piscibus Cetaceis seu Belluis Marinis, pp. 26-43.-Caput primum. De Cetis vel cetaceis Piscibus in genere, ex scriptis Rondeletii \& Gesneri præcipue, pp. 26, 27. Cap. ii. De Delphino: e Rondeletii, Gesperi, \& aliorum scriptis, pp. 28-31. Cap. iii. Phocæna Rondeletii, Gesn. . . . Phocæna seu Tursio Bellonii \& Scaligeri. Cimbris Marsuin vel Porcus marinus: Angl. A Porpesse, pp. 31-35. C'ap. iv. Balæna Rondeletii, Gesneri \& aliorum. The Whale, pp. 35-38. Cap. v. Balæna vera Rondeletii, Gesn. . . . pp. 38-40. Cap. vi. Orca Rondeletii, \& Bellonii, p. 40. Cap. vii. Physeter Rondeletii, Gesn.... A Whirl-Pool, p. 41. Cap. viii. Cete Clusio Exot., lib. 6. Descriptum Pot-Wallfisch Batavis maris accolis dictum, pp. 41,42. Cap. ix. De Monocerote pisce, qui de genere Cetaceo esse fertur, pp. 42, 43. De Pisce Monocerote, seu Unicornu, App., pp. 12, 13 (ex Tulpio).

The plates have an engraved special title-page, dated 1685-one year earlier than the textand are sometimes cited as a separate work. The following is a transcription of the title:

Francises Willonghby | Icthyographia | ad Amplissimum Virum | D. num Samuelem Pepys, | Præsidem Soc. Reg. Londinensis, | Concilium, | et | Socios ejusdum. | Figuræ Novæ, quæ non pancæ sunt + notantur. | Sumptibus | Societatis Regalis | Londinensis | 1685.

Pl. A. 1. Pisces Cetacei. Fig. 1. Delphinus; Fig. 2. Phocæna (fig. orig.); Fig. 3. Physeter (fig. ex Clnsio). Pl. A. 2. Piscis Monoceros ejusq. cornu a varijs authoribus exhibitum; item embryonis alicujus cornu. 7 figg.-animal, skull, horns; one fig. of horn orig.

[128.]

1687. "Brunsmans, - - Diss. de Ceto Ionae, qua eum verum fuisse Cetum os:enditur. Jen., 1687. 8०."

Not seen; title from Donndorff, Zool. Beytr., i, 1792, p. 776.

1688. Bartholinus, Th. Thomæ Bartholini | de / Unicornu / observationes novæ. I Secunda editione Auctiores \& | emendatiores editæ à Filio | Casparo Bartholino. | [Vignette.] Amstelædami | Apud Henr. Wetstenium, | - | CI, ICC LXXVIII. $12^{\circ}$. 11. 8, pp. 1-381, numerous cuts.

De Unicornu Groenlandico, pp. 108-125 (p. 121, 3 views of the skull of the Narwhal, and one of the detached horn). 
1689. "Barixg, - De Ceto Ionae. Brem., 1689."

Not seen; title from Donndorff, Zool. Beytr., i, 1792, p. 776.

1690. Cleyerus, Andreas. De Ceto minore Ambrophago. <Ephem. Med.-phys. Germ. Acad. Nat. Curios., 1689 (1690), p. 69, fig. 4.

The npper figure represents a fabulous monster nearly in profile, somewhat whale-like in general form, but having two upward-curving, slender, pointed tusks in the end of the upper jaw and two high bosses or humps on the front of the head. The lower figure shows the creature partly on the side; the dorsal fiu, humps, and tusks are not shown, and the flgure has a much more whalo-like aspect.

[132.]

1690. FABER, J. M. Addenda ad A. Cleyeri Observationes de ceto minore Ambrophago. <Ephem. Med.-phys. Germ. Acad. Nal. Curios., 1689 (1690), p. 456.

See above, 1690. Clexkr, A.

1692. "Preifer, - Diss. piscem Ionae deglutitorem fuisse Balaenam. Lub., 1692. 4 ․".

Not seen; title from Donndorf, Zool. Beytr., i, 1792, p. 776.

1693. Axon. An Account of a Book Intituled, Phalcenologia Nova sive Obserrationes de Rarioribus quibusdam Balænis in Scotiæ Littus nuper ejectis, \&c. Aut Roberto Sibbald, Edinburgi in Quarto, 1692. <Philos. Trans. Lond., xvii, no. 205 [1693], pp. 972-976.

Review of the work.

1693. Crayton, J. A Continuation of Mr. John Clayton's Account of Virginia. $<$ Philos. Trans. Lond., xvii, no. 205 [1693], pp. 941-948.

Contains a notice of the discovery of Whale remains near Jamestown, Va.

1694. "D rossander, A. Dissertatio de Balaena. Upsaliae, 1694. 4․ Met eene pliat." [pp. 62.]

Not seen; title from Bosgoed, op. cit., p. 161, no. 2543.

1694. "Pechlin, - De pisce Ionae deglutitore, non fuisse Balaenam. Lub., 1694. 80."

Not seen; title from Donndorff, Zool. Beytr., i, 1792, p. 776.

1696. "Smallegangk, M. Nieuwe Cronyk van Zeeland. Eerste (éńnig) deel. Vervattende de voor dezen uitgegeren cronyken van de Heeren Jacobus Eyndius en Johan Reygersberg, veel vermeerdert omtrent deres landschaps oudheden en herkomsten, wateren en stroomen, eylanden, steden en heerlijkheden. Met vele kopere platen (en kaarten) verciert. Tot Middelburg. By J. Meertens, 1696. fol."

"Walvisvangst, pp. 173-178; van de visschen in onse stroomen en eerst van de zeehonden, zeekatten, bruinvisschen, pp. 178-181."

Not seen; title and references from Bosgoed, op. cit., p. 210, no. 3169.

1697. Lister, M. Of a Venomous Scratch with the Tooth of a Porpos, its Symptoms and Cure. <Philos. Trans. Lond., xix, no. 233 [1697], p. 726.

1697. Molyneux, T. A discourse concerning the Large Horns frequently found under Ground in Ireland, Concluding from them that the great American Deer, call'd a Moose, was formerly common to that Island: With Remarks on some other things Natural to that Country. <Philos. Trans. Lond., xix, no. 227 [1697], pp. 489-512, 3 figs.

Contains remarks upon the nature of ambergris, spermaceti, and on the occurrence of Sperm Whales on the coast of Ireland.

[141.]

1697. Tredwey, R. Part of a Letter of Mr. Robert Tredwey, to Dr. Leonard Plukenet, Dated Jamaica, Feb. 12, $169^{6}{ }^{\prime}$, giving an Account of a great piece of Ambergriese thrown on that Island; with the Opinion of some there about the way of its Production. <Philos. Trans. Lond., xix, no. 232 [1697], pp. 711, 712.

Said to be produced by some unknown sea "Creature," which is believed "to swarm as Bees, on the Sca-Shore, or in the Sea."

[142.] 
1698. AcuÑa, Cristoval D', ACarete, Grillet, and Bechamel. Voyages | and | Discoveries | in | South-America. | The First up the River of Amazons to | Quito in Peru, and back again to Brazil, | perform'd at the Command of the King | of Spain. | By Christopher d'Aevgna. | The' Second up the River of Plata, and | thence by Land to the Mines of Potosi. | By Mons. Acarete [du Biscay]. | The Third from Cayenne into Guiana, in search | of the Lake of Parima, reputed the richest | Piace in the World. | By M. [Jean] Grillet and [Francis] Bechamel. | - | Done into English from the Originals, being the on- | ly Accounts of those Parts hitherto extant. | - | The whole illustrated with Notes and Maps. | - | London, | Printed for S. Buckley at the Dolphin over against | St. Dunstan's Church in Fleetstreet. 1698. 80. pp. i-viii; [Pt. i], pp. 1-190, map; [Pt. ii], 1. 1, pp. 1-79, map; [Pt. iii], 11. 2, pp. 1-68.

Parts ii and iii have each a full title-page, and each part is separately paged.

[Pt. i.] A Relation of the Great River / of Amazons in South-America. | Containing all the Particulars of | Father Christopher d'Acugna's Voy- | age, made at the Command of the / King of Spain. | Taken from the Spanish Original of the I said Chr. A'Ac ugna, Jesuit. [Half-title.]

Chap. xxv. The great Plenty of Fish in this River, and which is the best sort of them, pp. 61, 62. Consists almost exclusively of an account of the "Pege Buey" [Manatus americanus], describing its appearance, how it is taken by the Indians, and extolling its flesh as an article of food. A note at the end refers to the trade in its flesh with the "Antilles or Antego-Islands," to which it is extensively exported. .

The original of this "Relation" (see op. cit., Introd., pp. iv, v) is said to have been published at Madrid in $1641\left(4^{\circ}\right)$ with the title "Nnevo descumbrimiento del gran Rio de las Amazonas," but immediately suppressed by Philip IV., so that copies of it quickly became exceedingly scarce.

[Pt. iii.] A | Journal | of the | Travels | of | John Grillet, | and Francis Bechamel | into | Gviana, | In the Year, 1674. | In | Order to Discover the Great Lake | of Parima and the many Cities | said to be situated on its Banks, and | reputed the Richest in the World. | - | London: | Printed for Samuel Buckley, 1698.

A "kind of Fish, which they catch in the Rivers with a sort of Harping Iron" is allnded to at p. 63 as being the basis of a profitable trade to the Antego Islands. It is evidently the Manatee.

[143.]

1699. "Doonegeest, E. A. van, en C. A. Posjager. Den Rijper Zee-postil, besta ande in xxii predicatiën, toegepast op den Zeevaert. Tot onderwijzinge vermaninge en vertroostiuge in de ware godsaligheyt voor allerlei Zeevarende lieden, dog voornamentlijk voor diegene, welke op den Haring en Walvischvangst uitgaen. Mitsgaders nog en korte beschryvinghe aengaende de opkomst van Holland, waer in 't bezonder ook gehandelt word van't Eyland met zijn dorpen, dog voornamentlijck rakende de eerste oorspronck en ware gelegenheyt der Haring en Walvischvangst. 't Amsterdam, bij Jac. van Nieuweveen, 1699. gr. 80."

"Zie aldaar: bl. 343-360."

Not seen; title and reference from Bosgoed, op. cit., p. 235, no. 3446.

1700. Axox. Description de la piece d'ambregris que la chambre d'Amsterdam a recue des Indes orientales pesant 182 livres; avec un petit traite de son origine \&o de sa vertu par Nicolas Chevalier a Amsterdam chez l'auteur. 1700. in $4^{\circ}$. p. 67. <Philos. Trans. Lond., xxii, no. 263 [1700], pp. 573,574.

Review of the work. See next title.

1700. "Chevalier, Nicol. Description de la piece d'Ambre gris que la chambre d'Amsterdam a reçue des Indes orientales pesant 182 livres. Avec un petit traité de son origine et de sa vertu. (Mit 5 Kpfrtaf. u. Abdruk einer Schaumünze.) in-4. Amsterdam 1700, chez l'auteur."

Not seen; title from Carus and Engelmann.

1702. "Engelbrecht, -. Diss. duae de pisce, Ionae deglutitore. Lips., 1702. $80 . "$

Not seen; title from Donndorff, Znol. Beytr., i, 1792, p. 776. 
1702. Reisel, SAM. "De Unicornu marino duplici.

3, An. 7 et 8. 1699-1700 (1702), pp. 350-352."

Not seen; title from Carus and Engelmann.

<Ephem. Acad. Nat. Cur., Dec.

SOEтEвоOм, H. Oudheden van Zaanland, Stavoren, Vronen en Waterland. Amsterdam, 1702. 2 dln. 120."

"Waarin ook over de visscherij (haring. en walvischvangst der verschillende Zaanland. sche (lorpen) gehandeld wordt."

Not seen; title and comment from Bosgoed, pp. cit., p. 253, no. 3611.

1703. Axon. A | Collection | of | Voyages | Undertaken by the | Dutch East-India Company, | for the Improvement of | Trade and Navigation. | Containing | An Account of sereral Attempts to find out the / North-East Passage, and the Discoveries in | the East-Indies, and the South Seas. | Together | With an Historical Introdnetion, giving an ac- | count of the Rise, Establishment and Pro- | gress of that great Body. | - | Translated into English, and Illustrated with se- | veral Charts. | - | London, | Printed for W. Freeman near Temple Bar, J. Walthoe in the | Temple ... [ [ = 3 lines of names of booksellers ]. 1703. 8. $11.16, \mathrm{pp} .1-336$.

The name of the translator is not given, neither are those of the authors whose works are here translated.

In the history of "Third Voyage of the Dutch to find the Passage to China" (pp. 16-68) occurs, at pp. 21, 22, an acconnt of the "Beasts" of Spitzbergen, among which are included the Whales. About half a page relates to the Greenland Right Whale, giving a quaint description * of its appearance and food.

[150.]

1703-05. DAMPIER, W. A / New Voyage / round the / World. I Describing particularly, | The Isthmus of America, several Coasts | and Islands in the West Indies, the Isles | of Cape Verde, the Passage by Terra del Fue- | go, the South Sea Coasts of Chili, Pern, and | Mexico; the Isle of Guam one of the La- | drones, Mindanao, and other Philippine | and East India Islands near Cambodia, China, | Formosa, Luconia, Celebes, \&c. New Hol- | land, Sumatra, Nicobar Isles; the Cape of | Good Hope, and Santa Hellena. | Their | Soil, Rivers, Harbours, Plants, Fruits, Ani- | mals, and Inhabitants. | Their | Customs, Religion, Government, Trade, \&c. | - | Vol. I. | - | By Captain William Dampier. | - I Illnstrated with Particular Maps and Draughts. | - The Fifth Edition Corrected. | - | London: | Printed for James Knapton, at the Crown in St. / Paul's Church-yard, 1703. 80. 11. 5, pp. i-vi, 1-550, 5 maps, and several small woodeuts in text.

[1705.] Voyages and Descriptions | Vol. II. | In Three Parts, viz. | 1. A Supplement of the Voyage round the World, | describing the Conntries of Tonquin, Achin, | Malacea, \&c. their Products, Inhabitants, I Manners, Trade, Policy, \&.c. | 2. Two Voyages to Campeachy; with a De- | scription of the Coasts, Products, Inhabi- | tants, Logwood-Cutting, Trade, \&c. of | Jucatan, Campeachy, New Spaine, \&c.|3. A Discourse of TradeWinds, Breezes, | Storms, Seasons of the Year, Tides and | Currents of the Torrid Zone thronghout | the World: With an Account of Natal in | Africk, its Products, Negro's, \&c. | - | By Capt. William Dampier. | - | Illustrated with Particular Maps and Draughts. | - | To which is added, | A General Index to both Volumes. | - | The Third Edition. | - | London, | Printed for James Knapton, at the Crown in I St. Paul's Church-rard. MDCCV. $8^{\circ}$, in three separately paged parts, as follows: 11.4 (title, 1 1.; dedication, 1 1.; preface, $1 \frac{1}{2} 11$. ; contents, $\frac{1}{2}$ 1.). Pt. i, pp. 1-184, map; Pt. ii, pp. 1-132, map; Pt. iii, 1. 1, pp. 1-112, 2 maps. Géneral Index, 11. 36; publisher's Catalogue of books, 11. 2.

[1703.] A | Voyage | to | New Holland, \&c. | In the year, 1699. | Wherein are described | The Canary Islands, the Isles of Majo and | St. Jago. The Bay of All Saints, with the / Forts and Town of Bahia in Brazil. Cape / Salvadore. The Winds on the Brazilian / Const. Abrolho-Shoals. A Table of all 
1703-05̨. DAMPIER, W.-Continued.

the | Variations observ'd in this Voyage. Oc- | currenees near the Cape of Good Hope. | The Course to New Holland. Shark's Bay. | The Isles and Coast, \&c. of New Holland. | Their Inhabitants, Manners, Customs, Trade, \&c. | Their Harbours, Soil, Beasts, Birds, Fish, \&c. | Trees, Plants, Fruits, \&c. | Illustrated with several Maps and Draughts; also | divers Birds, Fishes, and Plants, not found in | this part of the World, Curiously Ingraven on | Copper-Plates. | - | Vol. III. | - | By Captain William Dampier. | - | London: | Printed for James Knapton, at the Crown in St. Paul's | Church-yard. 1703. 8०. 11. 12 (title, 1 l.; dedication, 2 ll.; preface, 6 ll.; contents, 3 ll.), pp. 1-162 ; index, $4 \frac{1}{2}$ 11.; publisher's cat. of books, $2 \frac{1}{2}$ 11., 4 topographical pll., 2 pll. of birds, 5 pll: plants, 3 pll. fishes.

Captain Dampier's "Voyages" thus form three rolumes, the second of which also consists of three parts, each separately paged, and with a general index to the first two volumes. In the set I have here collated, vols. ii and iii are bound together. Vol. i belongs to the "fifth edition," vol. ii to the "third," and vol. iii to the first; the date of vols. $i$ and iii is 1703; that of vol. $\mathrm{ii}, 1705$. The date of the first edition of vol. $\mathrm{i}$ is said to be . I have references to a 1702 ed. which correspond exactly with the 1703 ed. here collated.

As is well known, Dampier was an acute natural-history observer as well as a bold navigator and adventurer, and his observations on the Beasts, Birds, and Fishes he met with during his long voyages are among the best and most trustworthy of his time. His work is of importance in the present connection for his vers full account of the Manatee, which he met with at numerous and widely distant points. There are also notices of Whales.

Manatee, or Sea-cow, vol. i, pp: 33-37-description of the animal, its habits, distribution, products, and the manner of its capture by the natives of Blewfield (or Bluefield) River; p. 41, in Darien River; p. 321, its occurrence at Mindenao, in the East Indies; p. 381, do.; pp. 463,469 , its occurrence in New Holland; p. 547, the Manatee of Santa Hellena a Sea-Lyon [i.e., a Seal]. Vol. 2, pt. ii, pp. 73, 109, 128, in Campeachy, and near Vera Cruz.

Whales and Whale-fishery of Bahia, Brazil, vol. iji, pp. 57, 58; Sea-birds feasting on a dead Whale, p. 95; Whales on the coast of New Holland, p. 131; Porpusses, p. 162, pl. ii, fig. 2.

Dampier's references to the "Manatee, or Sea-cow," as occurring in the East Indies and New Holland, relate, of course, to the Dugong. His statement that the Manatees of the West Indies are smaller than those of the American Isthmus and Guiana was seized upon by Buffon as indicating a diversity of species.

[151.]

1703. La Hontan, -, Baron DE. New | Voyages | to North-America. | Containing | $\ldots[=20$ lines $]$. | - | Illustrated with Twenty Three Mapps and Cutts. | - | Written in French | By the Baron Lahontan, Lord Lievtenant | of the French Colony at Placentia in New- | foundland, now in England. | - | Done into English. | - | In Two Volumes. | A great part of which never Printed in the Original. | - | London: Printed for H. Bonwicke in St. Paul's Church-yard; | T. Goodwin, M. Wotton, B. Tooke, in Fleetstreet; and S. Manship | in Cornhill, 1703. 2 vols. sm. $8^{\circ}$. Vol. i, ll. 12. pp. 1-280, 12 maps and cuts.

Vol. i, pp. 243-247, gives a list of the "Fish of the River St. Laurence," and "A Description of the Fish that are not mention'd in the Letters." The Cetaceans enumerated and described are the "Balenot," or "little Whale," the "Soufflenr," and the "White Porpoise." The last is evidently the Beluga catodon, of which he says, "They are a ghastly sort of Animals, and are frequently taken before Quebec" (p. 244).

The original (French) edition, which I have not seen, is said to have been published in 1703 (La Haye, 2 vols, $12^{\circ}$ ). In the second French edition (La Haye, 1705) the matter relating to Cetaceans occurs in vol. ii, pp. 53, 55, 56. In the French editions of 1709 and 1715 (same publisher), it occurs at pp. 51, 53, 54, of the same volume.

[152.]

1704. Leeuwenhoek, A. Van. A Letter from Mr. Antony van Leeuvenhoek, F. R. S., concerning the flesh of Whales, Crystaline humour of the Eye of Whales, Fish, and other Creatures, and of the use of the Eye-lids. <Philos. Trans. Lond., xxiv, no. 293 [1704], pp. 1723-1730, figg. 1-6.

The figures are of the crystalline lens of the eye of a Whale.

1704. Movck, Johs. An | Account | of a most Dangerous | Voyage | Perform'd by the Famous | Capt. John Monck, | In the years 1619, and 1620. | By the special Command of Christian IV. | King of Denmark, Norway, \&c. to Hudson's 
1704. MoncK, JoHN-Continued.

Straits, | in order to discover a Passage on that side, betwixt / Greenland and America to the West Indies. With a / Description of the Old and New Greenland, for the | better Elucidation of the said Treatise. | - | Translated from the High-Dutch Original, printed | at Frankford upon the Maine, 1650. <Churchill's Coll. Voy. and Trav., i, 1704, pp. 541-569.

Unicorns, pp. 550, 551, figg. (skull, 3 views). [Unicorn horns an article of traffic], p. 558. Different kinds of Whales, p. 567. An Account of the Manner of eatching Whales, pp. 567569. A plate to face p. 567 gives a view of Whale-fishing, and another plate (to same p.), giving a view of a Whale lying on the shore, is entitled " $\mathrm{A}$ Whale Female and the Windlass whereby the Whales are brought on shore." One of the plates to p. 543 gives a view of a male Whale.

[154.]

1704. "TAPPE, D. Fünfzehnen jährige curiose Ost-Indianische Reise-Beschreibung, so sich im Jahr Christi 1667 angefangen und im 1682 Jahre geendet hat. Hannover, Gottfr. Freytag, 1704. 40."

"Von Fisschen, Seeläusen, Seekühen, etc., pp. 199-209."

Not seen; title and comment from Bosgoed, op. cit., p. 136, no. 2146.

[155.]

1705. Edge, Thomas. The Ten several Voyages of Captain Thomas Edge and others to Greenland (called by the Dutch Spitsbergen) at the Charge of the worshipful Muscovia Company. <Harris's Coll. Voy. and Trav., i, 1705, pp. 572-574. Of the several sorts of whales and the manner of killing them, p. 574.

1705. "Hartevstein, - De magno pisce, qui Ionam vatim deglntivit. Witteberg, 1705. $4^{\circ} . "$

Not seen; title from Donndorff, Zool. Beytr., i, 1792, p. 776.

1705. [MARTexs, F.] [A Voyage to Spitzbergen, in the Ship call'd the Jonas in the Whate, Peter Peterson of Frieseland, Master, in 1671.] <Harris's Coll. Voy. and Trav., i, 1705, pp. 617-633.

Of the Finned Fishes (includes "The Dolphin," "The Butskopf or Flounder's Head," "The Whitefish," and "The Unicorn"), p. 628. Of the Whale, pp. 629-631. The Finfish, pp. 631, 632. Plate facing p. 629 contains Martens's figures of the Whale and Finfish; also a view entitled "The Whale-fishing and killing of Morses" (two birds, a Walrus, and a small Whalo in the foreground resting on the shore; a Narwhal in the water, and boats attacking Whales in the distance). The text is from Martens. The plate facing p. 617 gives another view of Whale-fishing, also from Martens. The account of the "Voyage to Spitzbergen" is an abridgment of Martens's "Spitzbergische oder Groenlandische Reise-Beschreibung gethan im Jahr 1071," Hamburgh, 1675, q. $v$.

[158.]

1705. Pool, J. The Voyages of Mr. Jonas Pool. <Harris's Coll. Voy. and Trav., i, 1705, pp. $588,589$.

Contains references to many Whales seen.

1706. Camelli, G. J. De Piscibus, Moluscis \& Crustaceis Philippensibus. <Philos.

Trans. Lond., xxiv, no. 302 [1706], pp. 2043-2080 [i. e., 2085-2089].

Includes a description of "Dugong Indorum."

1706. "Tychonius, Tycho Lassen. Monoceros piscis hand monoceros, ad veram formam nuperi e mari Gronlandico hospitis depictus et descriptus, resp. Just. Henr. Weichbart. Havniae, 1706. 4०. pp. 16."

Not seen; title from Carus and Engelmann, ii, p. 1371.

1707. "LARREN, - Monoceros piscis haud monoceros ad veram formam nuperi ex mari Groenlandico hospitis depictus et descripsus. Hafniae, 1707."

Not seen; title from Donndorff, Zool. Beytr., i, 1792, p 757.

1707. Sibbald, R. Part of a Letter from Robert Sibbald, Knight, to Dr. Hans Sloane, R. S. Secr., concerning a Second Volume of his Prodromus Historia Naturalis Scotice; with a Description of the Pediculus Creti, \&c. <Philos. Trans. Lond., $\mathrm{xxv}$, no. 308 [1707], pp. 2314-2317.

1708. Leguat, F. A New | Voyage | To the | East-Indies | by | Francis Leguat | and | His Companions. | Containing their | Adventures in two Desart Islands, | 
1708. Leguat, F.-Continued.

And an Account of the most Remarkable | Things in Maurice Island, Batavia, at the | Cape of Good Hope, the Island of St. He- | lena, and other Places in their Way to and | from the Desart Isles. | - | Adorn'd with Maps and Figures. | - | London: | Printed for R: Bonwicke, W. Freeman, Tim. Goodwin, | J. Walthoe, M. Wotton, S. Manship, F. Nicholson, B. Tooke, | R. Parker, and R. Smith. MDCCVIII. $8^{\circ}$. 1l. 4, pp. i-xv, 1-248, 1l. 12.

Porpoise, p. 7, fig. (pl. fac. p. 7). Whale, pp. 22-24. Lamentin, pp. 67-70, pl. (fac. p. 67).

The remarks about Porpoises and Whales are of interest merely for their quaintness and absurdities. The accont of the Lamantin is one of the earliest descriptions of the African Manatee, and is quoted by Buffon and other early naturalists. The figure of the Lamantin displays a pig-like task in the lower jaw. It is represented as holding its young one in its arms. "The Lamentins, which other Nations call Manati, that is, having Hands, abound in the Sea about this Isle [Manrice], appearing often in numerous Troops ... " (p. 67).

There is an earlier French edition of which this is a translation.

1709. LAwson, J. A New | Voyage | to | Carolina ; Containing the | Exact Description and Natural History | of that | Country: | Together with the Present State thereof | and | A Journal | Of a | Thousand Miles Travel'd thro' several | Nations of Indians. | Giving a particular Account of their Customs, | Manners \&c. | By John Lawson, Gent, Surveyor | -General of North Carolina. | London, I printed in the year 1709. [No publisher.] sm. $4^{\circ}$. 1l. 3, pp. 1-258, map, and $1 \mathrm{pl}$.

The Fish in the salt, and fresh Waters of Carolina, pp. 152-163. Of Whales he says: "Of these Monsters there are four sorts; the first... is the Sperma Cati Whalo..." Others mentioned are "the Bottle-nosed Whale," the "Shovel-nose," and "another sort, ... though not common." He also speaks of the "Grampois" and "Porpoises." The.short but interesting notices of these Cetaceans occur at pp. 153,154.

This is the original edition, issued as a part of Stevens's "Collection of Voyages," of which it forms no. 2. The copy examined (in Harvard College Library) lacks the title-page, bat is other wise complete. The plate, however, is wrongly placed at p. 115 of the preceding memoir, and the map is bound at the end of the volume. The title-page appears to be lacking in many copies of the present edition. That above given is transcribed from Field.

There were later issues of the work, with different title-pages, but otherwise textually identical with the present. See 1714 and 1718. LAwson, JoHN. The following is a transcript of the title-page of Stevens's Oollection of Voyages, in which the work originally appeared:

A new | Collection | of | Voyages | and Travels, | Into several Parts of the World, none | of them ever before Printed in | English. | Containing, | . . [here follow seven titles of works forming the collection, of which the second is], | 2. A new Account of Carolina, by Mr. Lawson. | - | In Two Volumes, Illustrated with sereral Maps and Cuts. | - | London, Printed for J. Knapton, Andrew Bell, D. Midwinter, Will. Tajlor, A. Collins, and J. Baker. 1711.

The dedication, addressed to the Hon. Edmund Poley, is signed John Stevens. The date on the title-page of the first memoir is 1708.

A German translation of Lawson-Hamburg, Frankfurt, and Leipzig, sm. $8^{\circ}$-appeared in $1712, q . v$.

1710. "Martens, Fred. Nauwkeurige beschryvinge van Groenland of Spitsbergen, waerin de Walvischvangst, gelegentheyd van't ys en haer wonderlijke kracht en figuren en de visschen dezer contreyen, dujdelijk wordt aengewezen. Oock hoe de walvisschen gevangen, gekapt en gesueden worden. Alsmede de Walvischvangst op rijm. Amsterdam, G. de Groot, 1710. 4. Met gegrav. platen."

"Eene vroegere vertaling, met de reis van Martiniere door Noorwegen, Lapland, Groenland, Nova-Zembla, enz. verscheen onder den titel: de. Noordsche weereld met anteekeningen van S. de Vries. Te Amsterdam, bij A. Dz. Ooszaen. 1685. 40. Met platen... Nog twee andere vitgaven verschenen te Dordrecht, bij Hendrik Walpot. (znd. jr.) [1750? en 1760 ?]; en nog cene te Amst., bij Abr. Cornelis. 1770. 40."

Not seen; title and comment from Bosgoed, op. cit., p. 242, no. 3511.

$[166$. 
1712. [Lawson, J.] Allerneuste Beschreibung | der Provinz | Carolina / In / West-Indien. | Samt einem | Reise-Journal | von mehr als | Tausend Meilen | unter allerhand | Indianischen Nationen. | Auch einer | Accuraten Land-Carte und andern | Kupfer-Stichen. | Aus dem Englischen [von John Lawson] úbersezet durch | M. Vischer. | - | Hamburg, | Gedruckt und verlegt, durch seel Thomas von Wierings Erben, | bey der Bórse im gúldnen A, B, C. Anno 1712. I Sind auch zu Franckfurt und Leipzig, bey Zacharias Hertelu | zu bekommen. sm. $8^{\circ}$. 11. 7, pp. 1-365, 11. 11/2.

Fische im Saltz- und Süssen-Wasser in Carolina, pp. 232-250. Cetaceen, pp. 232-236.

See original English ed., 1709.

1713. "Mandelslo, J. A. Voyages célèbres et remarquables faits de Perse aux Indes Orientales. Contenant une description nouvelle et très curiense de l'Indostan, de l'Empire du Grand Mogul, des Iles et presqu'lles de l'Orient, des royaume's de Siam, du Japon, du Congo, de la Chine, etc. Traduits de l'original par A. de Wicquefort. Nourelle édition, revue et corrigée. A Leide, chès Pierre van der Aa. 171:3. 2 dln. 1 bd. folio. Met gegraveerde platen en kaarten."

"Baleines qui se trouvent sur les côtes du Japon, p. 464; dans la mer près de la ligne équinoctiale, p. 623; sur les côtes de lîle St. Thomas, p. 6ī5."

Not seen; title and comment from Bosgoed, op. cit., p. 100, no. 1590.

1713. Ray, Johr. Johaunis Raii | Synopsis | Methodica | Piscium. | [Vignette.] | - | Londini: | Prostant apud W. Innys, | sub Insigni- | bus Principis in area Boreali D. Pauli. | $\mathrm{CI}_{\mathrm{O}} \mathrm{I}$ I CCXIII. 8०. pp. 1-166, 11. 6.

Pisces Cetacei seu Bellue marinæ= Cetacea, pp.6-17, 9 spp, to wit: 1. Balcena rulgaris edentula, dorso non pinnato = Balcena mysticetus. 2. Baloena edentula corpore strictiore, dorso pinnato $=$ Physalus antiquorum. 3. Orca Rondel. \& Bellon. $=$ Orca gladiator. 4. Cete Pot Walfish Batavis maris accolis dictnm Clus. Exot. lib. $6=$ Physeter macroccphalus. 5. $\Delta l b u s$ piscis cetacens = Beluge catodon. 6. Afonodon piscis è genere Cetaceo : Narhual Islandis = Monodon monoceros. $\%$. Delphinus antiquorum, The Dolphin $=$ Delphinus delphis. 8 . Phoccena Rondeletii = Phocoena conımunis. Or:

1. Baloena minor utraque maxilli dentata = Orca gladiator. 2. Balcena minor, in inferiore maxilla tantùm dentata, sive pinna ant spina in dorso = Beluga catodon . 3. Baloena major, in inferiore tantùm maxilla dentata macrocephala, bipinnis = Physeter macrocêphalus. 4. Balcena major, in inferiore tantùm maxilla dentata dentibus arcuatus falciformibus, pinnam seu spinam in dorso habens $=$ Physeter tursio.. . Balcena macrocephala tripinnis, ctc. $=$ Physeter tursio. 6. Baloena major laminas corneas in superiore maxilla habens, bipinnis, fistula carens = Balaena mysticetus. $\%$. Balcena major laminas corneas in superiore maxilla habens, fistulâ donata, bipinnis=Baloena mysticetus. 8. Balcena tripinnis, nares habens, cum rostro acuto \& plicis in ventre = Baloenoptera rostrata. 9. Baloena tripinnis, maxillam inferiorem rotundam \& superiore multo latiorem habens $=$ Physalus antiquorum.

Eight valid species fairly defined and classified. See Clavis, p. 17. Martens's "Butz-kopf" is mentioned (p. 10), but not specifically recognized.

[169.]

1714. "Lawson, J. The | History | of | Carolina; | containing the | Exact Description and Natural History | of that Country: ! Together with the Present State thereof. | And | A Journal | of a Thousand Miles, Travel'd thro' several | Nations of Indians. | Giving a particular Account of their Customs, | Manners, \&c. | - | By John Lawson, Gent. Surveyor General | of North-Carolina | - | London: | Printed for W. Taylor at the Ship, and T. Balser at the Black- | Boy, in Pater-Noster-Row, 1714."

"Ilentical in erery respect, excepting the title, with the orig. ed., 1709, q. v. On actual comparison, this seems to be only other copics of the original, furnished with a new title-leaf."

Not seen; title and comment from Coues, Birds Col. Fall., 1878, p. 576. For account of Cetological matter see orig. ed. (1709. LaWsON, J.).

[170.]

1715. ANoN. "Puro e distincto ragguaglio del gran pesce chiamato Balenotto Buffalino, detto anco Capo d'Olio, preso in vicinianza del porto di Pesano 18 Aprili 1715. Venezia. folio. Met houtgrav."

No's seen ; title from Bosgoed, op. cit., p. 171, no. 2696.

1716. Tulpius, N. Nicolai Tulpii | Amstelodamensis exconsulis | Observationes Medicæ. | Editio Quinta. | Cui brevis ipsius Authoris vitæ narratio / est præfixa,

28 G B 


\section{Tulpius, N.-Continued.}

ac textuum auctorum | illustrationibus. | [Vignette.] Labore et coeli favore. I Lugduni Batavorum. |

$$
\text { Apud }\left\{\begin{array}{l}
\text { Joh : da Virie, } \\
\text { Vid \& Fil. C. Boutesteyn, } \\
\text { Andr. Dyckhnysen, } \\
\text { \& J. A. Langerak. । }
\end{array}\right.
$$

$\mathrm{CI}_{D} \mathrm{I}_{\mathrm{D}} \mathrm{CCXVI}$. sm. $8^{\circ}$. 11.10 (includes eng. title-page and illumin. titlepage), pp. 1-392, 1l. 2, pll. i-xviii.

Unicornu marinam, lib. iv, cap. lix, pp. 374-379, tab. xviii.

The text and plates of the body of the work in this edition, even to the pagination, are the same as the editio nova $(1672, q . v$.). There are added 3 prelim. leaves, giving a portrait and biography of the author; also 2 supplem. leaves of "Illustrationes textuum Hippocratis," otc., by Abraham Salomon vander Voort.

[172.]

1718. Josstox, J. Theatrum | universale omnium | Animalium | Piscium, Avium Quadrupedum, | Exanguium, Aquaticorum, Insectorum, | et Anguim, | CCLX. Tabulis ornatum, | Ex Scriptoribus tam antiquis quam recentioribus, | Aristotele, Theophrasto, Dioscoride, Eliano, Oppiano, Plinio, Gesne- | ro, Aldrovando, Wottonio, Turnero, Mouffeto, Agricola, Boetio, | Baccio, Ruveo, Schoufeldio, Freygio, Mathiolo, Tabernomontano, | Bauhino Ximene, Bustamantio, Rondeletio, Bellonio, Cresio, The- / veto, Margravio, Pisone, \& aliis maxima curâ à J. Jonstonio collectum, | Ac plus quam Trecentis Piscibus | Nuperrime ex Indiis Orientalibus allatis, | Ac nunquam antea his terris visis, locupletatum; cum Enumeratione morborum, | quibus Medicamina ex his Animalibus petuntur, ac Notitiâ Animalium, l'ex quibus vicissim Remedia præstantissima possunt capi; cura | Henrici Ruysch M. D. Amstelæd. | VI. Partibus, Duobus Tomis, compreheusum. | Tomus I. | [Seal.] | Amstelædami, | Prostat apud R. \& G. Wetstenios. | - | MDCCXVIII. 2 vols., $2^{\circ}$.

Tomus i. Continet / Collectionem Novam Piscium Ambonensium ac Historiam Naturalem / Piscium, \& A rium. [Pars prima], 1l. 2, pp. 1-40, pll. i-xxi. [Pars secunda]. Historia naturalis Piscium, cura H. Ruysch, pp. 1-160, pll. i-xlviii. Theatri universalis | Animalium | pars secunda. | Sive Historiı Naturalibus | de | Avibus | Libri vi, | . . | Cura Henrici Ruyseh, ... 11. 7, pp. 1-160, pll. i-lxii.

Historiæ naturalis de Piscibus. Liber v. De Cetis, pp. 150-157, pll. xli-xliv, pl.xlv [fig. 1], pl. xlvii.

Caput i. De Cetis in genere, pp. 150, 151; Caput ii. De Cetis in specie. Articulus i, De Balæna, pp. 151, 152, pll. xli, xlii ; Articulus ii, Do Balæna vulgi, \& Physetere, pp. 152, 153; Articulus iii, De Puste \& Orca, pp. 153, 154, pl. xliii; Articulus iv, De Delphino, pp. 154, 155, pl. xliv; Articulus v, Phocæna \& Scolopendra Cetacea, pp. 155, 156; Articulus vi, De Phock, seu Vitulo marino, pp. 156, 157, pl. xli; Articulus vii, De Manati Indorum, p. 157, pl. xliii. Additamentum de cane Aristotelis, pp. 158, 159. Ad Librum v, De Phoca, p. 159. Figuri ]viii [= pl. xlviii]. Appendix Nova de Unicornu Marino, p. 160.

This work is a reprint of the "Historia naturalis do Piscibus et Cetis" of Joh. Jonston (1650, q. v.), and of tho "Historia naturalis de Avibus" of the same author, with the "Collectio Nova Piscium Amboinensium partim ibi ad vivum delineatorum, partim et Museo Henrici Rnysch M. D." prefixed, and an original addendum to Liber $\mathrm{v}$ (De Cetis) of the "Historia naturalis de Piscibus, consisting of p. 160 and pl. xlviii. The text and the figures are otherwise as in Jonston at 1650, except that the latter are colored. Pl. xlviii gives two figures of the Narwhal (figg. 5 and 6 ), three views of the skull (figg. 1, 3, 4), and two (figg. $2 \mathrm{~A}, \mathrm{~B}$, of tho tusk. This edition of the "Theatrum" is often cited under RUYsCH, H., who was author of part of the work, as now constituted, as well as editor.

1718. Lawson, J. The | History | of | Carolina; | containing the | Exact Description and Natural History | of that | Country; | Together with the Present State thereof. | And | A Journal | Of a Thousand Miles, Travel'd thro' several | Nations of Indians, | Giving a particular Account of their Customs, | Manrers, \&c. | - By John Lawson, Gent. Surveyor-General | of North-Carolina. | - | London: | printed for T. Warner, at the Black-Boy in Pater-Noster | Row, 1718. Price Bound Five Shillings. sm. 4. Il. 3, pp. 1-258, map and 1 pl. 
1718. Lawson, J.-Continued.

This edition appears to be merely other copies of the original edition, issued, like the ed. of $1714(q . v$.$) , with a new title-page. The present title-page differs from that of the 1714$ ed. only in the bookseller's imprint. The Cetological matter is, of conrse, the same as in the earlier editions. Field states that "Neither of the first three editions of Lawson's work is often found complete, with the map, and animal plate." The copy of the present edition examined by mo lacks tho map, but has tho plate.

1718. Ruysch, Hexry. See 1718. Jonston, J.

1719. Stukecy, W. An Account of the Impression of an almost Entire Sceleton of a large Animal in a very hard Stoue, lately presented to the Royal Society from Nottinghamshire. <Philos. Trans. Lond., xxx, no. 360 [1719], pp. 963$968,1 \mathrm{pl}$.

Possibly a Phocona. The plate represents the bones of nearly all but the head of the partially preserred animal in situ.

1720. Zorgdrager, C. G. C: G: Zorgdragers | Bloeyende Opkomst der Aloude en Hedendaagsche | Groenlandsche | Vissehery. | Waer in met eene geoffende ervaarenheit de geheele om- | slag deezer Visscherye beschreeven, en wat daar in | dient waargenomen, naaukeurig verhandelt, wordt. | Uitgebreid | Met eene korte Historische Beschryving der Noordere Gewesten, | voornamentlyk Groenlandt, Yslandt, Spitsbergen, Nova | Zembla, Jan Mayen Eilandt, de Straat Davis, en | al 't aanmerklykste in d' Ontdekking deezer / Landen, en in de Visschery voorgevallen. | Met byvoeging van de / Walvischvangst, | In haare hoedanigheden, behandelingen, 't Scheeps- I leeven en gedrag beschouwt. | Door | Abraham Moubach. | Verciert met naaukeurige, correcte en naar't leven geteeken- | de nieuwe Kaarten en kunstige Printverbeeldingen. | [Vignette.] | T' Amsterdam. | By Joannes Oosterwyk, | Boekverkooper op den Dam, 1720. sm. $4^{\circ}$. 11. 18, pp. 1-330, 11. 7, maps 6 , pll. 7 , and frontispiece.

Engr. title-page frontispiece, pl. back; printed title-page (as above given), illuminated, pl. back; half-title, backed by poem entitled "Verklaaring vande tytelprint," signed A. Bógaert; "Aan de Heeren Gecommitteerden der Hollandsche Groenlandscbe Visschery," 2 leaves; "Aan den Lezer," signed A. Monbach, 4 leaves. Korte inhoudt der Hoofutstukken, 1 leaf.

Eerste Deel. Inleiding. Handelende van d' eerste Kust en Land-Ontdekkers in 't algemeen, 9 leaves and 2 maps (no. 1, Nieuwe Kaart van de Noord-Pool; No. 2. Nieuwe Kaart van Oud en Nieuw Groenland als meede van de Straat Davis). I. Hoofdtstuk. Van d' eerste Ontdekkers van Groenlani, en wie die waren, enz., pp. 1-5. II. Hooflt. Ongemeene Vischrykheit der Groenlandsche Zee; en omstandig bericht ran d' Eenhoorns gegeeven, pp. 6-10, pl. facing p. 7 [threo views of the skull]. III. Hoofut. Gesteltheit en gematigheit der Oud. Groenlandsche Lucht, enz., pp. 10-12. IV. Hoofdt. Vruchtelooze togten der Deenen naar Groenlandt, enz., pp. 12-21. V. Hoofut. Groenlandsche Compagnie te Koppenhagen opgerecht, zend Schapen naar de Straat Davis, pp. 21-25. VI. Hoofdt. Onderzoek over Groenlandts strekking naar Tartariö en America, en bericht over Spitsbergens byzonderheden, enz., pp. 24-34. VII. Hoofdt. Yslandts strekking en nitgestrektheit, cerste Ontdekkers, en's Lands gelgentheit, en., pp. 34-47, enz Nieuwe Kaart van Ysland (p. 34), [pl. facing p. 38 eruption of a geyser]. VIII. Hoofdt. Handel en bedryf der Yslanders onderzocht, pp. 47-49. IX. Hoofdt. 't Aloude Landbestier ran Yslandt, invoering van 't Kristendom, enz., pp. 49-53. X. Hoofit. Zeemagt der Yslanders eertyds, en d' aloude Bevolkers naagespenrt, pp. 53-60. XI. Hoofut. Verscheide gevoelens wegens Yslandts bevolking onderzocht, pp. 60-66.

'Tweede Deel. I. Hooflt. Ecrste Ontilckkers van Spitsbergen, en waarom dus genoemt, enz., pp. 67-71, en Nieuwe Kaart van 't Eyland Spitsbergen (p. 67). II. Hooflt. Ongemeene konde to Spirsbergen, en den aart der Verheevelingen-beschreeven, enz., pp. 71-75 [pl. facing p. 74 gives figures of a solar halo and various forms of snow-crystals]. III. Hoofdt. Gesteltheit van 't Ys omtrent Spitsbergen, enz., pp. 75-78. IV. Hoofat. Spitsbergen en Jan Mayen Eilandt, eertyds Vischryke Gewesten, enz., pp. 78-80, en kaart Jan Mayan Eslani, p. 79. V. Hoofut. Veelerly soorten van Walvisschen, waar onder d'Eilandische Walvisch de voornaamste is, enz., pp. 80-87, en pl. p. 81, Walvisch achter over gekant zynde; Gapende Walvisch waar in den Stant der Barden werd aan geweezen. VI. Hoofut. Eilanische Walvisschen waar zich onthouden. 't Walvischaas beschreeven en waar meest gevonden worl, enz., pp. 87-90. VII. Hoofdt. Noordkapers Gewest beschreeren, als medo dat der Vinvisschen, enz., pp. 91-98 [the pl. facing p. 7 gives a figure of the "Vinvisch" describerl at p. 92]. VIII. Hoofdt. Of de Biskayers d' eerste aanleiders tot de Walvischvangst zyn ge- 


\section{Zorgdrager, C. G.-Continued.}

weest, enz., pp. 98-103. IX. Hoofdt. 't Walvisch Gewest van cen ruime nitgestrektheit beschouwt, enz., pp. 103-106. X. Hoofdt. Verscheide gevoelens over den doortogt door de Waigats onderzocht, pp. 106-123, en Nieuwe Kaart vàn Nova Zembla en 't Waygat, enz., p. 106. XI. Hoofdt. Hoedanig de Walvisschen tot in de Tartarische Zee doordringen onder. zocht, enz., pp. 123-134. XII. Hoofdt. Gedachten over de warmte der Zon en haare werkzaamheit, enz., pp. 134-139. XII. Hoofdt. Koerschouding der Zuidys Visschen, en hoe men die moet opspeuren, enz., pp. 140-150. XIV. Hoofdt. Zuidys Visschen van hun gewoon Gewest kundig, en hunne vlucht voor den komst der Groendlandsche Vloot, enz., pp. 150-156.

Deerde Deel. I. Hooflt. Westys Visschen waar voornamentlyk gevonden. Vaart op Spitsbergen begonnen en wanneer, enz., pp. 157-164 [pl. facing p. 102, figg. of "Walrus" and "Zee Rob"; also "Cachelot of Potvisch"]. II. Hoofdt. Walrussen en Robben hoedanig gevangen, enz., pp. 165-172. III. Hoofdt. Eerste opkomst der Walvischvangst, die voordeelig was, en door Compagnieschap omtrent de Bayen van Spitsbergen geoffent wierd, enz., pp. 172-175 [i.e., 185; pp. 184 and 185 are erroneously paged 174-175]. IV. Hoofdt. De Groenlandsche Maatschappy allenks weder gezwakt en om wat reden, enz., pp: 175 [i. e., 185$]-197$. $\nabla$. Hoofdt. Eilandsche Walvisch von voor Spitsbergen verjaagt, en de Zcevisschery ondernomen, enz., pp. 197-203. VI. Hoofdt. Ysvisschery ondernomen, en hoedanig. De wy kende Visschen nagespeurt, pp. 203-208 [pl. facing p. 204 gives a viow of a fleet of vessels engaged in ice-fishingl. VII. Hooflt. Westysvisschery hoe verre zich uitstrekt. Hooge Graden gereeder dan laage om Visch op te doen, enz., pp. 208-211. 'VIII. Hoofdt. Werwaarts de Visch te vinden, wanneer plaatsen en tyden wel worden onderseheiden, enz., pp. 211-215. IX. Hooflt. Visscbery op laage Graden wanneer tydig is; Oud-Groenlands strekking voor wiens Kusten Walvischaas gevonden word, waar zich veel Visch onthoud, enz., 215-221. X. Hoofdt. Orerwintering op Spitsbergen. Verscheide Observatiën orer 't Noorderlicht, pp. 221-23j. XI. Hooflt. Verseheide vreemde ontmoetingen en ongevallen den Groenlands. vaarders bejegent. Loosheit tusschen de West en Zuidys Visschen hoe t' onderscheiden, enz., pp. 235-247 [pl. facing p. 239, ships in the ice]. XII. Hoofdt. Zaaken wegens de Vis. sehery nondig in acht te neemen, enz., pp. 248-260. XIII. Hoofdt. Misbruik in den Traan-en Baarden handel afgeschaft. Voordeelen door de Visschery sedert eenige Jaaren behaalt, enz., pp. 260-283; Byvoegsel [description of Cachelot], p. 234; Groenlandsche Walvischvangst in haar byzonder Sheepsleven en gedrag beschouwt, pp. 287-330.

Toegift voor de Groenlandschvaarders en Matroozen [poem], 1 leaf. Bladwyzer der voornaamste Zaaken, 5 leares. Drukfeilen, 1 page, backed by publisher's list of books.

Zorgdrager's work is by far the most important of the early authorities on the Northern Whalefishery, and must always be one of the chief sources of information for the early histors of the subject. It also gives one of the best figures of the Greenland Right Whale (Baloena mysticetus) published prior to the present century, and also one of the best early figures of the Cachelot. Chap. xiii of pt. iii is statistical, giving the number of Dutch and Hamburg ships annually engaged in the Greenland Whalefishery from the year 1670 to 1719, the number lost each year, the number of Whales killed, the yield of oil and bone, and its value. Also the names of the directors of Whalefishery companies, and of the masters of the ressels engaged in Whalefishing from the Dutch, Hamburg, and Bremen ports. The closing pages of the work give details of the equipment and expenses of ressels engaged in Whaling, etc.

The general character of the work is sufficiently indicated by the abbreviated chapterheadings above given, which are a transcript of the table of contents.

The German version (Leipzig, 1723, $4^{\circ}, q . v$. ) is a translation of the present edition. A second Dutch edition, revised and eniarged by the author, was published at Gravenhage in 1727 (q. v.), which was reissued, with new title-page but otherwise tho same, at Amsterdam in 1728. The only other edition which $I$ have seen is the German edition published at Nürnberg in $1750, q . v$.

1721. Oliver, W. Remarkables in a Journey through Denmark and Holland. <Philos. Trans., Abridged by Jones, 1700-1720, v, pt. 2, 1721, pp. 128-134.

From Philos. Trans. Lond., no. 285, p. 1400. Contains a notice of tho horn of a Sea-Unicorn [Monodon monoceros] brought from Grecnland.

1721. Sibbald, R. Of the Pediculus Ceti. <Philos. Trans., Abridged by Jones, 1700-1720, v, pt. 1, 1721, pp. 25, 26, fig. 32.

From Philos. Trans. Lond., no. 308, p. 2314.

1722. Anon. A Summary Relation of the Discoveries about the North East Passage. $<$ Philos. Trans., Abridged by Lowthorp [1665-1700], iii, 1722, pp. 610-614.

Notice of the reported passage of a Whale through the North-East passage. From Philos. Trans. Lond., no. 118, p. 417. 
1722. Anow. Whales and Whale Fishing about Bermudus. <Philos. Trans., Abridged by Lonthorp [1665-1700], ii, 1722, pp. 842-845.

From Philos. Trans. Lond. [i], no. 1, p. 11[-13]; no.8, p. 132 [133]. See suprd, Axon, at 1665.

1722. [Labat, R. P.] Nouveau | Voyage | anx Isles | de l'Amerique, | contenant | l'Histoire Naturelle de ces Pays, | l'Origine, les Mœurs, la Religion \& lo Gouver- I nement des Habitans anciens \& modernes. I Les Guerres \& les Evenemens singuliers qui y sont | arrivez pendant le long sejour que l'Auteur y a fait. | Le Commerce \& les Manufactures qui y sont établies, | \& les Moyens de les augmenter. / Arec une Deseription exacte \& curieuse / de toutes ces Isles. | Ouvrage enrichi de plus de cent Cartes, Plans, | \& Figures en Taillesdouces. I [Par Jean Pierre Labat.] Tomo Premier [-Seizième]. | [Design] A Paris, Rue S. Jacques, | Chez Pierre-François Giffart, près | la ruë des Mathnrins, à l'Image | Sainte Therese. | - | M. DCC. XXII. | Avec Approbation \& Privilege du Rıy. 6 vols. $12^{\circ}$.

Description d'un poisson appellé Lamentin ou Manati, vol. ii, pp. 200-207, pl. fac. p. 200.Very full original account of external characters and mode of capture, with an original figurean adult clasping its young one to its breast. The figure, slightly altered, is given by Bellin, $1763, q . v$.

[182.]

1722. Lister, M. A venomous scratch with the Tooth of a Porpus. <Philos. Trans., Abridged by Louthorp [1665-1700], ii, 1722, p. 842.

Erom Philos. Trans. Lond. [xix], no. 233, p. 726.

1722. Molneux, G. Several Things in Ireland in common with the West Indies. <Philos. Trans., Abridged by Lowthorp [1665-1700], iii, 1722, pp. 544-546.

From Philos. Trans. Lond. [xix], no. 227, pp. 507[-511]. See supra, this anthor, at 1697.

Relates to that portion only of Dr. Molyneux's discourse which treats of ambergris, spermaceti, and certain plants found in Ireland.

[184.]

1722. Stafforn, R. [Concerning Spermaceti Whales about the Bermudas.] <Philos. Trans., Abridged by Lowthorp [1665-1700], ii,1722, p. 845.

From Philos. Trans. Lond. [iii], no. 40, p. 793 [=792-795]. See suprà, this anthor, at 1668.

1723. ZorgdraGer, C. G. "Alte und newe Grönländische Fischerei und Walltischfang mit einer kurzen histor. Beschreibung von Grönland, Island, Spitsbergen, Nova Zembla u. s. w. ansgefertigt durch A. Moubach. Aus dem Holliindischen übersetzt. Leipzig, 1723. 4०. Met kaarten en platen."

Not seen; title from Boszoed, op. cit., p. 253, no. 3616.

[1724.] Boylston. Ambergris found in Whales. <Philos. Trans. Lond., xxxiii, no. 385 [1724], p. 193.

The writer, Dr. Boylston, of Boston, Mass., states that according to the testimony of whalemen ambergris is found in a cyst near the genital parts of Whales-probably the first annonncement of its real source.

[187.]

1725. Dudley, Paul. An Essay upon the Natural History of Whales, with a particular Account of the Ambergris found in the Sperma Ceti Whale. In a letter to the Publisher, from the Honourable Paul Dudley, Esq.; F. R. S. <Phil. Trans. Lond., xxxiii, no. 387, "for the Months of March and April, 1725" (volume dated 1726), pp. 256-269.

"But here I would have it noted, that the following Account respects only such Whale, as are found on the Coast of Nev England" (p. 256). This short aecount of 14 pp. is the first of importance relating especially to the Whales of the New England cosst, in fact, is almost the only one to the present date. The "divers Sorts or Kinds" nentioned are, 1. The "Right, or Whalebone Whale" (pp. 256,257); 2. The "Scrag Whale"; 3. The Finback Whale"; 4. The "Bunch or humpback Whale" (p. 258); 5. The "Sperma Ceti Whale" (pp. 258, 259); 6. The "Killer... without doubt the Orca that Dr. Frangius (lege Franzius) describes ..." p. 265.

Several of these became later the basis of species of systematic writers. Although described briefly, their characters are so well indicated that it is not difficult to identify the species in the light of present knowledge of the subject. Other portions of the memoir are devoted to an account of "Sperma Ceti Oil" (pp. 259, 260), "of the Ambergris" (pp. 266-269), to the habits of Whales, and to the "Way and Manner of killing Thales."

On the Killer of Dudley, ef. HAMer, Proceed. Am. Assoc. Adv. Sc., viii, 1855. 
1725. "Heerfort, Christoph. Diss. hist.-phys.-crit. de Sirenibus, seu piscibus humani corporis structuram quodammodo imitantibus. Resp. Andr. Bing. Hafniae, 1725. 4०. pp. 20."

Not seen; title from Carus and Engelmann.

1726. "Herrara, A. DE. Historia General de los Hech ${ }^{\text {ts }}$ de los Castellanos en las Islas i Terra Firme del Mar Oceano. Escrita por Antonio de Herrarà, Coronista Mayor de su $\mathrm{m}^{\mathrm{d}}$ de las Indias y sv Coronista de Castilla, En quatro Decadas desde el Año de 1492, hasta el de [1]531. 4 vols., folio, vellum. En Madrid en la Imprenta Real de Nicolas Rodriguez franco Añ de 1726."

Not seen; title from Field (Cat. Libr., 1875, p. 132, no. 964). For the reference to Manati, see ed. of 1728 .

[190.]

1727. Stalpartius, C., Vander Wiez. C. Stalpartii vander Wiel | Medici Hagiensis | Observationum | Rariorum | Medic. Anatomic. | Chirurgicarum | Centuria Prior, | Accedit | De Unicornu | Dissertatio. | Vtraque tertia parte auctior, longeque / emendatior. | Editio novissima. | [Design.] Leidae, | Apud Joannem à Kerkhem, 172\%. sm. $8^{\circ}$. 11.17 (including frontis., eng. title, plain title, etc.), pp. 1-516, 1l. 8, pll. i-ix.

De Unicornu Dissertatio, pp. 463-516, pl. ix. Contains references passim to the Narwhal.

[191.]

1727. ZorgDraGer, C. G. C:[ornelis] G:[ijsbertsz] Zorgdragers | Bloeijende Opkomst der Aloude en Hedendaagsche | Groenlandsche | Visschery. | Waar in met eene geoeffende ervaarenheit de geheele om- | slag deezer Visscherye beschreeven, en wat daar in | dient waargenomen, naaukeurig verhandelt wordt. | Uitgebreid | Met eene Korte Historische Beschryving der Noordere Gewesten, I voornamentlyk Groenlandt, Yslandt, Spitsbergen, Nova | Zembla, Jan Mayen Eilandt, de Straat Davis, en | al 't aanmerklykste in de Ontdekking deezer | Landen, en in de Visschery voorgevallen. | Met byvoeging van de / Walvischvangst, | In haare hoedanighedon, behandelingen, 't Scheeps- | leeven en gedrag beschouwt. | Door | Abraham Moubach. | Tweeden Druk. | Met aanmerkelyke zaaken vermeerdert, | nevens een Korte Beschryving | Van de | Terreneufsche Bakkeljaau-Visschery. | Verciert met naauwkeurige, en naar't leven geteekende | nieuwe Kaarten en kunstige Printverbeeldingen. | [Vignette] In s' Gravenhage. | By P. van Thol en R. C. Alberts, Boekverkopers, 1727. | sm. 4. 11. 20 , pp. 1-392, 11. 7, 6 maps, 7 pll. (and frontispiece?)

The copy examined lacks the frontispicce of the first edition, whieh must, however, havo been lost, as the poem explanatory of it baeks the half-title leaf:

This edition differs from the first (1720) through the addition of some $60 \mathrm{pp}$. of now matter, including nearly $20 \mathrm{pp}$. on the Newfoundland Cod-fishery. To the second part (Tweede Deel) six chapters are added, giving nearly $20 \mathrm{pp}$. of new matter; there are, besides, considerable additions at other points, together with omissions of matter contained in the first edition, so that portions of Part ii are practically rewritten. The account of the Potvisch or Cachelot is transferred from the Appendix to near the middle of Part ii, but the plate illustrating the Walrus, Seal, and Cachelot is omitted (at least is lacking in the copy collated). The only new illustration added is the plate facing p. 21, giving figures of an Eskimo boat. The statistical portion is brought down to 1725 .

The chapters apparently newly added are: II Deel. I. Hoofdt. Strekking der Kusten in en omtrent de Straat-Davis, en welke koes men om de zelve te bevaren, to honden heeft, enz., pp. 71-73. II. Hooflt. Aart en hoedanigheit, kleeding en gedrag der Inboorlingen omtrent de Straat-Davis Knsten, enz., pp. 74-79. III. Hoofdt. Landdieren en 't Gevogelte der StraatDavis Gewesten; hoe verre zich de gewoone Wischplaats uitstrekt, enz., pp. 79, 80. IV. Hoofdt. Verraaderschen aart van eenige Bewooners der Straat-Davis Kusten, en hoe men zieh daar voor to wachten heeft, enz., pp. 81-83. V. Hoofdt. Westkust van de Straat-Davis en den aart ler Bewoonders Beschreeven, pp. 83,84. XVI. Hoofdt. Verscheiden middelen aangewent, uitgevonden en in 't werk gestelt om de lengte van Oost en West daar nit te vinden, doch to vergeess, pp. 153-157.

For further list of contents and comments see the first edition (1820).

This edition was reissued, according to bibliographers, at Amsterdam the following year (1728), with a new title-page but otherwise unchanged, forming the third Dutch edition. [192.] 
1728. Herrara, Antonio DE. Historia general | de las | Indias ocidentales; $|\mathrm{O}|$ de lus Hechos | De los Castellanos en las Islas y Tierra firme | del Mar Oceano, | Escrita | por | Antonio de Herrara | coronista mayor de su Magestad | de las Indias y de Castilla. | En ocho decadas. | Sigue a la ultima decada | la | Descripcion de las Indias | por el mismo Antor. | Tomo Primero[-quarto], | que contiene las flecadas | primera y segunda. I Nueva Impression enriquecida con lindas Figuras | y Retratos. | En Amberes, | Por Juan Bautista Verdussen, Mercador de Libros. M. D. CC. XXVIII. 4 vols. fol. Vol. i, 11. 2 (incl. eng. title-page), pp. 1-496, 1l. 12, pll.

The first edition of this work (given above from Field) appeared in 1726, q. v.

El Manati, rol. i, dec. i, cap. xi, p. 118 (one-third page). A slightly abridged paraphrase of Gomara's account (see 1554. GoMARA, L. F. DE).

1730. Herrara, A. DE. Historia gene / ral de los Hechos / delos Castellanos / enlas Islas i Tierra Fi | rme del Mar Oceano. Es / crita por Antonio de / Herrara Coronista | Mayor de sv Md. de las | Indias y sv Coronis- | tade Castilla | En quatro Decadas des de el Año de | 1492 hasta el de [1]531. Decada primeraAl Rey Nuro. Señor, | Eu Madrid | en la Imprenta | Real | de Nicolas Rodiguez [sic] | franco | Año de 1730. 4 vols. fol.

Los Manati, dec. i, pp. 141, 142.

There is another edition of this date differing apparently only in the title-page, as follows:

1730. Herrara, A. De. Descripcion de | las Indias ocide | ntales de Antonio | de Herrera coro- I nista mayor de | sv Magd. de las Indias, y su Coronista | de Castilla. | Al Rey Nro Señor | En Madrid enla Oficina Real | de Nicolas Rodriguez Franco Año de 1730. Eng. title-page. 4 vols. fol.

Los Manati, dec. i, pp. 141, 142.

1731. La Peyrere, - Relations | de | l'Islande, | et du | Greenland, Par la Peyere, Auteur des Præadamites. < Recueil de Voyages au Nord, Contenant divers Mémoires très utiles au Commerce \& à la Navigation. Tome premier. Nouvelle édition, corrigée \& mise en meilleur ordre. Amsterdam, 1731.

The letter is dated "De la Haye lo 13 Jnin, 1646."

Pp. 93-107 are devoted to a discussion of the question whether the so-called horn of the Narwhal is a tooth or a horn, and whether therefore the Narwhal is a fish. The conclusion reached is that the "horn" is a tooth "de ce poisson, que les Islandois apellent Narhual, \& que ce n'est point une corne" (p. 106). The et ymology of the Icelandic word Narhual is said to be Hual, whale, and Nar, signifying a cadaver, because this whale feeds on cadavers (p. 97). The animal and skull are figured in the plate facing p. 186. with the following legends: Poisson nommé par les Islandois Narwal qui porte la corne, on dent, que l'on dit de Licorne. Teste de Poisson Narwal, avec nn troncon de sa dent, ou de sa corne, long de quatre pieds. The figures are copies from Tulpius, 1672 (q. v.).

1732. "JAxiçon, F. H. De republiek der Vereenigde Nederlanden. • Uit het Fransch. 's Gravenhage, J. van Duren, 1732. 4 dln. $16^{\circ}$."

Kompagnie van 't noorden of van den walvischvangst, ii, pp. 280-291.

Not seen; title and reference from Bosgoed, op. cit., p. 239, no. 3485.

1732. Martens, F. Journal d'un Voyage an Spitzberguen \&c. par Frédéric Martens de Hambourg, tradnit de l'Allemand. <Recueil de Voyages au Nord, ii (nouvelle édition), 1732, 1.1, pp. 1-282.

Du Dauphin, pp. 185-187. Du Butskopf, ou Tète de Plie, pp. 187-189. Du Poisson blanc, pp. 189, 190. De la Licorne, pp. 190, 191. De la Baleine, pp.196-221, pl. fac. p. 196. De la maniére dont on prend les Baleines, pp. 221-238, pl. fac. p. 222. Ce qu'on fait d'une Baleine morte, pp. 239-247. De la maniére dont on tire l'huile ... de la graise, pp. 248-251. Du Poisson à nageoires, autrement Winne-fish, pp. 251-256. Addition qui concerne la Pêche de la Baleine, pp. 267-282.

[198.]

1733. BaJer, Joh. JAc. "De pisce praegrandi Mular. <Acla Acad. Leop. Carol. Nat. Ciw., iii, 1733, pp. 2-6, pl."

Not seen; title from Carus and Engelmann.

1734. Boylston, Dr. Ambergris found in Whales, communicated by Dr. Boylston of Boston in New England. <Philos. Trans., Abridged by Eames and Martyn, 17191733, vii, pt. 3,1734, pp. 423, 424.

From Philos. Trans. Lond., no. 385, p. 193. Ses suprà, BorLston, at 1724. 
1734. Dudley, P. An Essay upon the Natural History of Whales, with a particular Account of the Ambergris fund in the Sperma Ceti Whale. <Philos. Trans., Abridged by Eames and Martyn, 1719-1733, vii, pt. 3, 1734, pp. 424-431.

From 1'hilos. Trans. Lond., no. 387, p. 256. See suprà, DudLex, P., at 1725.

1735. Arkins, J. A / Voyage / to | Guinea, Brazil, and the / West-Indies; | In His Majesty's Ships, the Swallow | and Weymouth. | Describing the several Islands and Settlements, viz- | Madeira, the Canaries, Cape de Verde, Sierraleon, Sesthos, | Cape Apollonia, Cabo Corso, and others on the Guinea Coast; | Barbadoes, Jamaiea, \&c. in the West Indies. I The Colour, Diet, Languages, Habits, Manners, Customs, I and Religions of the respective Natives and Inhabitants. | With Remarks on the Gold, Ivory, and Slave-Trade; I and on Winds, Tides, and Currents of the several Coasts. | - | By John Atkins, | Surgeon in the Royal Navy. $\mid-1 \ldots$ [= quotation, 4 lines.] | [Vignetteship.] London: | Printed for Cæsar Ward and Richard Chandler, at the | Ship, between the Temple-Gates in Fleet-Street; And Sold at their / Shop in Scarborough. M. DCC.XXXV. 80. 1. 1, pp. i-xxv, 1-265.

The Manatea (in tho Sierraleon River), pp. 42, 43. Its external characters and mode of its captare by the Negroes.

1735. EDItor. Editoris Recensio Experimentorum circa Ambram Gryseam à Domino Joh. Browne, R. S. S. \& a Dno. Ambrosio Godofredo Hanckewitz, R. S. S. institutorum, cum D. Neumanni, R. S. S. Experimenti sui vindicatione. <Philos. Trans., Lond., xxxviii, no. 435, 1735, pp. 437-440.

1735. Neumanno, C. De Ambra Grysea. <Philos. Trans, Lond., xxxviii, no. 433, 1735, pp. 344-370; no. 434, pp. 371-402; no. 435, pp. 417-437.

1736. D [Espars]., N., єn F. R. "Chrouyke van Vlaenderen, vervattende haere vindinge, naem, enz., alsook eene generale beschryvinghe van g'heel haer bestreck, steden, casteelen, heerlyckbeden, enz. Beginnende van 't jaer 6211725. Door N. D(espars) en F. R. Met kopere platen. Brugge, Andr. Wijdts, 1736. 3 dln., 4 stukken folio."

"Zie aldaar: Groenland's vaerders, d' eerste in see gesonden door van Brugge. Ao. 1665, iii, bl. 728, 731, 747. De visscherij belooft cen goeden nitslag. De Franschen nemen eenige visschers met hunne schepen, dio sy beswaerlyk doen af kopen, ii, bl. 432.

Not seen; titlo and references from Bosgoed, op. cit., p. 249, no. 3579.

1736. LaNGen, Jo. Jac. "Nachricht von dem Unicornu marino, oder Meereinhorn, welches in Halle 1736 ist zu sehen gewesen. <Hallischen Anzeiger, no. 19, 1736."

Not seen; title from Egede.

1736. Qvellmalz, Sam. Theod. "Observationes de unicornu marino, ex vicinia Bremensi Lipsam delato. <Commerc. litter. Norw., 1736, hebd. xxii, no. 4, pp. 171-273.".

Not seen; title from Egede.

1737. BRICKELL, J. The Natural | History | of | North-Carolina. | With an | Account | of the | Trade, Manners, and Customs of the | Christian and Indian Inhabitants. Il- | lustrated with Copper-Plates, whereon are | curiously Engraved the Map of the Country, | several strange Beasts, Birds, Fishes, Snakes, | Insects, Trees, and Plants, \&c. | - | By John Brickell, M. D. | - | Nostra nos in urbe peregrinamur. Cic. | - | Dublin. | Printed by James Carson, in Coghill's-Court, Dame- | street, opposite to the Castle-Market. For the Author, | 1737. 1 vol. 8०. pp. i-vii, 1-408, woodcuts, map, and 2 folding plates of animals.

Of the Fish of North Carolina, pp. 215-249. The cetological matter occupies pp. 215-226. Pages 215-220, including the first half of the latter, appear to relato in a general and rather vague way to the Right. Whale of the North $\Delta$ tlantic (Balona cisarctica, Cope), but beyond a few particulars respecting their capture near Ocacock Island, there is nothing of much value. The two pages next following are merely a paraphrase of Lawson's account of different "sorts of Whales;" there then follow two paragraphs of original matter, the latter treating of "the Porpoise, or Sea-Hog." The next reference to Cetaceans is at p. 226, which is devoted to an account of "the Dolphin," and is also now matter. 
1737. BRICKELL, J.-Continued.

Field states that Brickell "stole the material" for his work from Lawson, "with scarcely any disguise," and Coues refers to "a 4th ed. [of Lawson], Dublin, 1737, attributed to Brickell." It is true that Brickell stole much of his material from Lawson, but to speak of Brickell's work as a 4th edition of Lawson is quite misleading, since for the first $60 \mathrm{pp}$. of Lawson there is nothing to correspond in Brickell. The part relating to the Indians is not only substantially the same in both, but considerable portions are identical in phrascologs. The "Description of North Carolina" and the "Natural History of North Carolina" giren by Lawson form the basis of tho Natural History portion of Brickell's work, tho latter having incorporated nearly all that the former has said, generally in Lawson's own words, but with the matter more or less transposed and augmented by often merely verbal additions. Brickell has, however, added much that is now, and based ovidently on his own observations, some of Lawson's paragraphs being expanded by Brickell to several times their original length by the addition of wholly now and often important matter.

[208.]

1738. Artedi, P. Petri Artedi | sveci, Medici Iehthyologia | sive | opera omnia | de | Piscibus | scilicet: | Bibliotheca Ichthyologica. | Philosophia Ichthyologica. | Generum Piscium. | Synouymia specierum. | Descriptiones specierum. | Omnia in hoc genera perfectiora, | quam Anthea ulla. | Posthuma | Vindicavit, Recognovit, Cooptavit \& Edidit | Carolus Linnæus, ,| Med. Doct. \& Ac. Imper. N. C. | - | Lugduni Batavorum, | Apud'Conradum Wishoff, 1738. 8०. 11. 10. Pars i, 11. 2, pp. 1-66, 11. 2. Pars ii, 11. 2, pp. 1-92. Pars iii, 11. 4, pp. 1-84, 11. 2. Pars iv, 11. 2, pp. 1-118, 11. 11. Pars v, 1. 1, pp. 1-102 (i. e., 112), 11. 2.

[Pars Prima.] Petri Artedi | Angermannia-Sveci | Bibliotheca | Ichthyologia | seu | Historia litteraria Ichthyologice | in qua | Recensio fit Auctorum, qui de Piscibus | scripsere, librorum titulis, loco \& editionis | tempore, additis judiciis, quid Quivis | Auctor prestiterit, quali metho- | do \& successu scripserit, | disposita secundum | Secula | in quibus quisquis author floruit. | Ichthyologiæ Pars I. | - | Lugduni Batavorum, | Apud Conradum Wishoff, 1738. 11. 2, pp. 1-65, 11. 2.

[Pars Secunda.] Petri Artedi | Sveci | Philosophia | Ichthyologica | in qua quidquid fundamenta artis | absolvit: Characteribus scilicet genericorum, Differentiarum | Specificarum, Varietatum et No- / minum Theoria rationibus de- | monstratur, et Exemplis | comprobatur. | Ichthyologia Pars II. [Vignette.] Lugduni Batavorum | Apud Conradum Wishoff, 1738. 11. 2, pp. 1-92.

Pisces Cetacoi, passim.

[Pars Tertia.] Petri Artedi | Sueci | Genera | Piscium. | In quibus | Systema totum Ichthyologiæ proponitur | cum | Classibus, Ordinibus, | Generum Characteribus, | Specicrum differentiis, | Observationibus plurimis. | redactis | Speciebus 242 ad Genera 5\%. | Ichtbyologiæ Pars III. | - | Lugduni Batavorum, | Apud Conradum Wishoff, 1738. $8^{\circ}$. 11. 4, pp. 1-84, 11. 2.

Ordo v. Plagiuri, pp. 74-81. [Gen.] xlii [lego xlvi]. Physeter (p. 74), cum spp. 2 [= Physeter macrocephalus $]$. xlrii. Delphinus (p. 75), cum spp. $3[=1$. Phocana communis; 2. Delphinus delphis; 3. Orca sp.]. xlviii. Balcena (p. 76), cum spp. 4 [=1. Baloena mysticetus; 2. Phy. salus antiquorum? 3. Balcenoptera rostrata? 4. Physalus antiquorum?] xlix. Monodon (p. 78), curn 1 sp. [= Monodon monoceros]. 1. Catodon (p. 78), cum spp. 2 [=1.? Beluga cato. don; 2. Physeter macrocephalus]. 1i. Thrichcchus [vel Trichechus] (p. 79), cum sp. 1 [= genn. Manatus et Halicore]. lii. Siren (p. 81), cum 1 sp. [= sp. fab.].

[Pars Quatuor.] Petri Artedi | Angermannia-Sveci | Synonymia | Nominum Piscium | fere omnium; | in qua recensio fit | nominum Piscium, omnium facile Au- | thorum, qui umquam de Piscibus scri- / psere: Uti Gracorum, Romanorum, | Barbarorum, nec non omnium in- | sequentium Ichthyologorum, | una cum Nominibus inquili- | nis variarum Nationum. | - Opus sine pari. | Ichthyologix Pars IV. | [Vignette.] Lugduni Batavorum, | Apud Conradum Wishoff, 1738. 11. 2, pp. 1-118, 11. 11.

Ordo v. Plagiuri, pp. 104-108.

[Pars quinque.] Petri Artedi | Sveci | Descriptiones | Specierum Piscium | Quos vivos præsertim dissecuit et | examinavit, inter quos primario | Pisces | Regni Sueciæ | facile omnes | accuratissime describuntur | cum non paucis 
1738. Artedr, P.-Continued.

aliis | exoticis. | Ichthyologis Pars V. | [Vignette.] Lugduni Batavorum, | A pud Conradum Wishoff, 1738. ช०. 1. i, pp. 1-102 (i. e., 112), 11. 2.

Ordo v. Plagiuri, Balæna, G. Pisc. 48, pp. 106-107.

1738. Egede, Haxs. Omstændelig og udf $\phi$ rlig | Relation, | Angaaende | den Gr $\phi n-$ landske Missions | Begyndelse og Fortsættelse, | samt | hvad ellers mere der ved Landets Recognoscering, | dets Beskaffevhed, og Indbyggernes Væesen og | Leve-Maade vedkommende, er befunden; | Af | Hans Egede, | F $\phi$ rst Guds Ords u-værdig Lærere for Bogens Menigheder | udi Nord-Landene derester Kongelig Dansk | Missionair ndi Gronland. | [Vignette.] | Kjübenhaven. 1738. | Trykt hos Joh. Christ. Groth, boende paa Graabrфdre-Torv. 4 ${ }^{\circ}$. 11.10, pp. 1-408.

Contains passing references to Whalefishing by the Greenlanders. There is a German translation, Hamburg, $1740,4^{\circ}$.

[210.]

1738. Hampe, John Henry. A Description of the same Narhual, communicated by John Henry Hampe, M. D. F. R. S. <Phil. Trans., Lond., xl, no. 447, 1738, pp. 149-150.

A further and rather more explicit account of the external characters of the specimen referred to below (see next title).

[211.]

1738. Steigertahl, Dr. Part of a Letter from Dr. Steigertahl, F.R. S., to Sir Hans Sloane, Bart. Pres. R. S., giving an Account of a Narhual or Unicorn. Fish, lately taken in the River Ost, Dutchy of Bremen, dated at Hanover $\frac{\text { May } 1}{A \text { pril } 20}$ 1736. Translated from the French by T. S. M. D., \&c. <Philos. Trans., Lond., xl, no. 447, 1738, pp. 147-149, pl. i, fig. 1.

Monodon monoceros; account of capture and external appearance of a specimen taken January, 1735, in the river Ost, Bremen. P1. i, fig. 1, animal, from "the Figure engrav'd and printed at Hamburg."

[212.]

1739-1804. WAGENAAR, J., and others. "Staat (Tegenwoordige) der Vereenigde Nederlauden (door J. Wagenaar e.a.). Amsterdam, Tirion, 1739-1804. 23 dln. gr. 80. Met platon en kaarten."

"... Walvischvangst, door de West-Indische maatschappij zonder roordeel ondernomen, $\mathbf{i}$, bl. 533. Beginsels der walvischvangst, bl. 588. Wetten omtrent dezelve, bl. 592. Waar zij geschiede, bl. 593. Onderzoek of er de reeders voordeel bij hebben, bl. 599. Kosten op de uitrusting, enz., bl. 501, 506. Walvischbaarden, bl. 597, 599, 608. Walvischspek, hoe dik, bl. 598."

Not seen; title and references from Bosgoed, op. cit., p. 210, no. 3170.

1740. Frisch, Johand Leonhard. De Phocæna in Pomeraniæ lacu quodam inventa. $<$ Miscel. Berolinensia, vi, 1740, p. 124, pl. vi.

Phocoena communis. 1 page of text and fig. of animal.

1740. Herrara, A. DE. The General | History | of the vast | Continent and Islands | of | America, | Commonly call'd, The | West-Indies, | from | The First discovery thereof: | With the best Accounts the People could give of their | Antiquities. | Collected from the Original Relations | sent to the Kings of Spain. | - | By Antonio de Herrara, | Historiographer to His Catholick Majesty. | - | Translated into English by Capt. John Stevens. | - | Vol. I[-VI]. | - | Illustrated with Cuts and Maps. | - | The Second Edition. | - | London, | Printed for Wood and Woodward in Paternoster-Row. | MDCCXL. 6 vols. $8^{\circ}$.

The Manati, vol. i, p. 278. For additional comment, see edd. of 1728.

1740. Kleiv, J. T. Iacobi | Theodori Klein | Historiæ | Piscium | Naturalis | Promovendæ | Missus primus | de | Lapillis eorumqve Numero / in | Craniis Piscium, | cum Praefatione: | de | Piscium auditu. | Accesserunt | I: Anatome 'Tursionum | II. Observata in Capito Raiæ. | - | Virgil. V. Eneid. 239. | Dixit: eumque imis sub fluctibus audiit omnis Nereidum Phorcique Chorus. I Cum Figuris. | [Vignette.] | - | Gedani, Litteris Schreiberianis. 1740. 40. 1. 1, pp. 1-35. 
1740. KLEL, J. T.-Continued.

i. Anatome Phocænæ, auctore Dn. de la Motte; Gedanensi, M. D., pp. 24-28. Additiones [auctore J. T. Klein], pp. 28-32, tab. iv [i. e., v], figg. A, B, cranium; fig. C, penis; fig. $\mathrm{N}$, ductus thorac.; figg. 1-4, 7-9, ossa aud ; fig. 5, vermiculi ; fig.6, lobi et nervi olfact. $[216]$

1741. Egede, H. Det gamle | Grónlano's | Nyo | Perlustration, | Eller | Naturel Historie, | Og | Beskrivelse over det gamle Gronlands Situation, | Luft, Temperament og Beskaffenhed; | De gamle Noorske Coloniers Begyndelse og Undergang der | Samme-Steds, de itzige Indbyggeres Oprindelse, Væesen, | Leve-Maade og Handtæringer, samt Hvad ellers Landet | Yder og giver af sig saasom Dyer, Fiske og Fugle \&c. med | hosf $\phi y e t$ nyt Land-Caart og andre Kaaber-Stykker | over Landets Naturalier og Indbyggernis | Handtringer, | Forfattet af | Hans Egede, | Forhen Missionair udi Grønland. | - | Kjфbenhavn, 1741. | Trykt hos Johan Christoph Groth, hvende paa Ulfelds-platz. 1 vol. $8 m .4^{\circ}$. 6 ll., pp. 1-131, 1. 1, map, and pll. 11.

Cap. vi. Hrad Slags Diur, Fiske og Fugle den Gronlandske, Søe giver af sig etc., pp. 36-55, pll. facing pp. 37 and 42.

Finnefisk, p. 36, fig. pl. facing p. 37. Hralvisk [Baloena mysticetus], pp. 36-40, fig. pl. facing p. 37. Nordkapper, p. 40. Sverdfisk [Orca], p. 40, fig. pl. facing p. 37. Cacheloter, p. 41. Hviid-Fisk, p. 41, fig. pl. facing p. 42. Buts Kopper, pp. 41, 42. Enhierning, pp. 42-44, figg. of animal, three views of skull, and of detached horns. Marsvin, p. 45.

Cap. vii. Om Gronlændernes Handtærenger, Nærings Brug og Redskab, saa rel som Boerkab, pp. 56-62, pll. facing, pp. 57, 59. Page 57 describes how the Greenlanders kill Whales, and the plate facing the same page is a Whaling scene.

"Egede's work is still one of the best existing on Greenland, and claims most of all the title of truthfulness, the author having been no less than 15 years in that country."

The present is the editio princeps, of which there are numerous subsequent ones in rarious languages.

A German translation appeared at Copenhagen in $1742(q . v$.$) ; an English in 1745(q . v$.$) ; a$ Dutch in 1746 (Delft); a French in 1763 (Geneva and Copenhagen); a German in 1763 (q. v.), and in 1769 (Berlin); and probably, also, others, besides various abridgments to be found in collections of voyages.

[217.]

1741. KleIN, J. T. Iaeobi Theodori Klein | Historiæ | Piscium | Naturalis | promovendæ | Missus Secundus | de | Piscibus per Pulmones | spirantibus | ad iustum numerum et ordinem | redigendis. | Accesserunt singularia: | de | I. Dentibus Balænarum et Elephantinis. | II. Lapide Manati et Tiburonis. | - | Horatius: | Delphinum sylvis appingit, fluctibus Aprum, qvi variare cupit rem | prodigialiter unam. | Cum Figuris. I [Vignette.] - | Gedani, Litteris Schreiberianis. 1741. $4^{\circ}$. 11. $3, \mathrm{pp} .1-38,1.1$.

De Piscibus, per Pulmones spirantibus ... [eto.], pp. 1-27, tabb. i-iii. i. De Dentibns Balænarum et Elephantinis, pp. 28-32, tal. iv, figg. 1-4 (teeth of Physeter). ii. De Lapide Manati et Tiburonis, pp. 33-38, tab. iv, figg. 5-7 (ossa petrosa Manati).

Horum Synoptica Tabula [p. 9]:

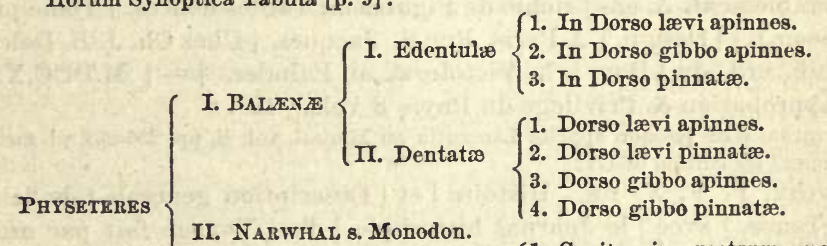

III. Delphaces s. Porcelli

1. Capite in rostrum porcinum, simum, exeunte: Orca:

2. Capite in rostrum porcinum rectum \& lon. gum protenso: Delphinus.

3. Rostro recto, brevi, \& obtuso: Tursio s. Pho. cana.

BALENE EDENTULE [= Iysticete, auct. mod.] In Dorso lavi apinnes. 1. Balæna vera Zorgdrageri, p. 11 [=B. mysticetus]; 2. Balæna albicans; Weisfisch Martensii \& Zorgdr. [=Beluga catodon]; 3. Baliena glacialis = Eisfisch, Zud-Eisfisch, West-Eisfisch, Nordkapper, Zorgdr. $[=B$. mysticetus, part.]. In Dorso gibbo apinnes. 1. Gibbo unico propo caudam [= "Bunch or Hump-back Whale" of Dudles, hence Balcena gibbosa auct. var., nec. Ersleben] 2. Balæna macra [="Scrag Whale" of Dudley]. In Dorso pinnatce. 1. Ore Balænæ vulgaris, $\alpha$, Balæna edentula, corpore strictiore, dorso pinnato Raji; $b$, jubartes $[=?$ Physalus antiquorum]; 2. Ore rostrato [= Hyperoodon bidens]. 
1741. Klein, J. T.-Continued.

BaLexe Dextate. Dorso laevi apinnes. 1. Cete Clnsii [= Physeter macrocephalus]. 2. Cachelot s. Potfish Zorgdrageri [=Physeter macrocephalus]. Dorso laevi pinnatce. 1. Ba. læna major ... Sibbaldi $[=$ ? Physeter macrocephalus $]$; 3. Mnlar Nierembergii $[=$ Physeter macroccphalus]; 3. Linckii $[=?]$. Dorso gibbo apinnis. 1. Dudleji Balæna [="Sperma Ceti Whale" of Dudley, hence Physeter macrocephalus]. Dorso gibbo pinnata. Balæna, Tigridis instar, variegata $[=$ ? sp. fict. $]$.

NARWHaL. Monodon Artedi, etc., p. 18, tab. ii, C, anim. [= Monodon monoceros].

Delphaces s. Porcell. 1. Orca itaqve est, qvie Sibbaldo dicitur Balæna minor in utraqve mandibula dentata, p. 23, tab. i, no. i, cranium; 2. Delphinus, p. 24, tab. i, no. ii, cranium, tab. iii, A, anim. [ = Delphinus delphis]; 3. Tursio sive. Phocæna, p. 26, tab. i, no. iii, cranium, tab. ii, A, B, fœetus, tab. iii, lit. B, anim. ad. [=Phocona communis].

[218.]

1741. Kühn, Johand Michael. "Merkwürdige Lebens- und Reisebeschreibung, dessen Schiffahrten nach Grönland und Spitsbergen. Gotha, 1741. $8^{\circ}$.

"Zie aldaar o. a.: Erste (und zwote) auf einem hamburgischen Schiffe nach Spitsbergen gethane Reise, 1720-22. Adelung geeft in zijn: 'Geschichte der Schiffahrten' van beide reizen ecn uittreksel. bl. 429-438."

Not seen; from Boggoed, op. cit., p. 240, no. 3496. See 1768. Adeluxg, J. C.

1742. EgEde, H. Des alten | Grónlandes | Neue | Perlustration, | Oder | NaturellHistorie | Und | Beschreibung | Der Situation, Beschaffenheit, Lufft und des Temperaments | dieses Landes; | Wie auch | Vom Anfange und Untergange derer alten Nor- | wegischen Colonien daselbst; vom Ursprunge, der Sitten Le- | bensart and den Gebráuchen derer jtzigen Einwohner, und was | Dieses Land an Thieren, Fischen, V\&geln, etc. heget und mittheilet; Deme beygefuget | Eine neue Land Charte und andere in Kupfer gestochene Figu- | ren und Abbildungen der Naturalien und Handthierungen | derer dasigen Einwohner; | Verfasset und beschrieben | von | Hans Egede, | Vormaliger Missionair in Grónland, | - | Aus den Dånischen ins Teutsche ůbersetzt. | - Copenhagen, gedruckt bey Johann Christoph Grothen, 1742. sm. 4. 11. 6, pp. 1-144, pll. 11, map.

This edition appeared almost simultancously with the original Danish, and was issued at Copenhagen by the same publisher. The plates are from the original etchings, not even the page references being changed, they still referring to the Danish edition instead of the present one. In this edition chap. vi occupies pp. 44-66, and the account of how the Greenlanders kill whales occurs at p. 68. For fuller annotation see EGEDL, at 1741.

[220.]

1742. Labat, R. P. Nouveau | Voyage | aux Isles | de l'Amerique, | contenant | l'Histoire Naturelle de ces pays, | l'Origine, les Mœurs, la Religion \& le Gou- I vernement des Habitans auciens \& modernes. | Les Guerres \& les Evenemens singuliers qui y sont | arrivez pendant le séjour que l'Anteur y a fait. | Par le R. P. Labat, de l'Ordre | des Freres Prêcheurs. | Nouvelle Edition augn.ent' 6 considérablement, \& en- | richie de Figures en Tailles-douces. | Tome premier [-huitieme]. | [Design.] A Paris, Rue S. Jacques, | Chez Ch. J. B. Delespine, Imp. Lib. ord. du I Roy, à la Victoire \& au Palmier. | - | M.DCC.XLII. | Avec Approbation \& Privilege du Roy. 8 vols. $12^{\circ}$.

Description d'un poisson appellé Lamantin ou Mauati, vol. ii, pp. 256-263, pl. fac. p. 256. For comment see edition of $172 \dot{2}$.

[221.]

1744. Charlevoix, P. F. X. DE. Histoire / et | Description generale / de la $\mid$ Nonvelle France, | avec | le Journal historique | d'un Voyage fait par ordre du Roi dans | l'Amerique Septentriounale. / Par le P. [Pierre-François Xavier] de Charlevoix, de la Compagnie de Jesus. I Tome premier[-troisième].[Vignette.] A Paris, Chez la Veuve Ganeau, Libraire, rue S. Jacques, près la rue / du Plâtre, aux Armes de Dombes. | - | M. DCC. XLII. | Avec Appro-

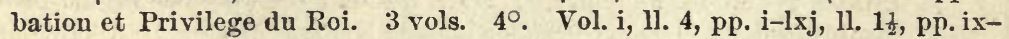
xxvj, 1-644, 9 maps. Vol.ii, ll. 2, pp. i-xvj, 1-582, 1-56, 8 maps, 22 pll. (of plants). Vol. iii, 1l.2, pp. i-xix, $i-x i v, 1-543,10$ maps.

The "Histoire," etc., comprises the first two volumes only, the title changing with the third to the following:

Journal | d'un | Voyage | fait par ordre du Roi | dans | l'Amerique sepentrionnale; | Adressé à Madame la Duchesse | De Lesdiguieres. | Par le P. do Charlevoix, de la Compagnie de Jesus. I [etc. as above.] 
1744. Charlevoix, P. F. X. DF.-Continued.

In the "Initième Iettre" occurz important cetological matter, as follows: De la Pécho du Lonp Marin, de la Vache Marine, du Marsouin, \& des Baleines, pp. 143-149 (Marsouins, pp.147-149; Baleines, p. 149). The account relates mostly to the "Marsouin blanc" [Beluga catodon] and its capture, from which it appears that there were two points, a few miles below Quebec, in the Saint Lawrence River, at which these animals were then taken in consid. erable numbers. A few Whales were still caught at the mouth of the Bay of Saint Lawrence.

Two editions of this work were issued at Paris, by different publishers, in the jear 1744, one in 3 vols., $4^{\circ}$, of which the title and collation are above given; the other in 6 vols., $12^{\circ}$, both with the same titles, differing only in the breaking of the lines and in the publisher's imprint. The collation of the $12^{\circ} \mathrm{ed}$. here follows:

[222.]

1744. Charkevorx, P. F. X. DE. Histoire / et | Description generale | de la | Nouvelle France, | avec | le Journal historique | d'un Voyage fait par ordre du Roi | dans l'Amerique sepentrionnale. | Par le P. [Pierre François Xavier] de Charlevoix, de la Compagnie | de Jesus. | Tome premier[-sixième]. | [Design.] A Paris, | Chez Pierre-François Giffart | rue Saint Jacques, à Sainte Therese. | - | M DCC XLIV. | Avec Approbation \& Privilege du Roi. 6 vols. $12^{\circ}$. Vo!. i, 1l. 3, pp. i-viii, 1-454, 6 maps. Vol.ii, l.1, pp.1-501.3 maps. Vol.iii, 1.1, pp. 1-465, 2 maps. Vol.iv, 1.1, pp.1-388, pll. 22,6 maps. Vol.v, 1.1,pp. ixxviij, 1-456, 7 maps. Vol. vi,1.1, pp. 1-434, 11. 2, 3 maps.

In this edition the title changes with the fifth volume, the title of rols. $v$ and vi of this edition being the same as that of vol. iii of the $4^{\circ}$ ed., save, of course, the publisher's imprint.

Tho cetological matter is the same (as is the text in general) as that of the $4^{\circ}$ ed. (q. v.), and ocenrs in vol. $\nabla$, pp. 217-220.

Of the "Journal d'un Voyage," etc., there are two early English versions, each in 1 vol., $8^{\circ}$ (London, 1761 and 17C3, q. v.). There is a recent English translation of the "Histoire" by Dr. J. G. Shea (8 vols., roy. $8^{\circ}$, New York, 1865), but this does not include the "Voyage," and consequently not the cetological matter.

[228.]

1744. [Despelette, - ]. Cachalot 6́choué près de Baĩonne. < Hist. de l'Acad. roy. des Sci. de Paris, ann. 1741 (1744), pp. 26-28.

This is perhaps editorial, based on a communication from M. Despelette.

1744. [Doorgeest, E. Az. vax.] "Kort Verhael van eenige merkwaerdige geschicdenissen van Holland [door E. Az. van Doorgeest]. Amsterdam, K. de Wit, 1744. $80 . "$

Beschrijving van de haringvisscherij en walvischrangst, pp. 78-96.

Not seen; title and reference from Bosgoed, op. cit., p. 249, no. 3577. Said to be a short extract from "Den Rijper Zee-postil," etc., 1669, Doorgeest and Posjager.

[225.]

1744. Greex, J. Abstract of a Natural History of Greenland, by Hans Egedius, intituled, Det gamle Gronlands Perlustration, eller Naturel-Historie, af Hans Egede, Kiobenhabn, 1741. 4 . Communicated by John Grecn, M. D., Secretary of the Gentlemans Society, at Spalding. <Philos. Trans. Lond., xlii, no. 471, 1744,pp. 607-615.

Chapter vi enumerates the Cetacea, Fish, and Birds common to Greenland.

1744. Oexmelin, A. O. [=Exquemelin, A. O.] Histoire | des | Avanturiers | Flibustiers | Qui se sont signalez dans les Indes. | Contenant | ce qu'ils y ont fait de remarquable, | arec | La Vic, Les Mœurs \& les Coutumes des Boucaniers, | \& des Habitans de S. Domingue \& de la Tort ne; | Une Description exacte de ces lieux; Et un Etat / des Offices tant Ecclésiastiques que Séculieres, | \& ce que les plus grands Princes de l'Europe y | Possèdent. | Le tout eurichi de Cartes Géographiques \& de Figures | en Taille-douce. | Par Alexander-Olivier Oexmelin. | Nouvelle Edition Corrigée | \& Augmentée de l'Histoire des Pirates | Anglois depuis leur Etablissement clans | l'Isle de la Providence jusqu'à présent. | Tome Premier[-Quatrième.] | [Design.] . A Trevoux, | Par la Compagnie. $|-|$ M. DCC. XLIV. 4 vols. 120. Vol. i, 11. 7 (incl. eng. and plain title), pp. 1-394, 1. 1, map and plates.

Histoire des Animaux et des Plantes qui sont sur les Isles de la Tortuö \& de Saint Domingue, vol. i, pp. 315-383. Chap. vi, Des Reptiles de l'Islo de St. Domingue, pp. 359-383, pl. fac. p. 373. Anatomie du Lamentin, pp. 372-376 (nearly 4 pp.), avec tig. du Lamentin. This is an original account (at least written in the first person and evidently from observa- 
1744. Oexmelin, A. O.-Continued.

tion) of the external characters and internal structure of the Manatee, its habits, captnre, etc., with an (apparently) original figure: The figure, like Labat's, represents an old Manateo with a young one in her arms; the figure is more artistic than Labat's, and has the head of the young one directed forward instead of backward.

The first French edition, said to be of "extreme rarity," and a translation from the English, was published at Paris in 1686, 2 vols., $12^{\circ}$. This $I$ have not seen, and therefore cannot say wherein the matter relating to the Manatee differs from that of the present "corrected and enlarged" edition. This is the first edition of the Buccaneers I have seen which con. tains a figure of the Manatee. The matter in this edition is almost entirely different throughout from that of the Spanish, Dutch, and English editions (see anteà, 1678. ExqueMelis, A. O.), and covers many points relating to the Manatee not mentioned in those. This is doubtless explained by the following transcript from the translator's preface of the present edition: "La Relation qu'il a écrite de ce que la nature produit dans les Isles de Saint Domingue \& de la Tortuë se trouve à la fin du premier Tome, on a choisi cet ordre pour ne pas interrompre le fil de l'Histoire des Flibustiers: on l'a même augmentée sur de nouveaux Memoires conte. nant la Relation du naufrage de Monsieur d'Ogeron a Puerto Ricco, l'Histoire du Capitaine Montauban; les Expeditions de Campêche, de la Vera Cruz, de Cartagêne, \& les courses de plusieurs Capitaines Flibusters, dont la valeur est présentement aussi connue en Enrope qu'elle est estimée dans les Indes." The plate illustrating the chapter vi here cited represents (upper half) the "Manière de Pêcher la Tortuë." Below this is the figure of "le Lamantin," and at the bottom of the plate three different forms of harpoon used in capturing Turtles and Lamantines.

The engraved title of this edition is dated 1743. The following is a transcript:

Histoire | des | Avanturiers | des | Boucaniers | et | de la Chambre | des Comptes, | établie | dans les | Indes | 1743.

Respecting the various translations and editions of Oexmelin [ $=$ Exquemelin; also written Esquemeling], see Sabin, Bibl. Amer., vi, pp. 309-318, 328, nos. 23468-23494; also, suprà, 1678. Exqueskin, A. 0.

1744. "RoEDE, - . Diss. de pisce qui Ionam deglutivit, cuiusnam speciei fuerit. Hafn. 1744. 40."

Not seen; title from Donndorff, Zool. Beytr., i, 1792, p. 776.

1744. "Wijbo, J. Canzrus. Dissertatio de balaenarum piscatu. Lugd. Bat., 1774. $4^{\circ} . "$

Not seen; from Bosgoed, op. cit., p. 253, no. 3609.

1745. "EGEDE, H. A | Description | of | Greenland. | Shewing | The Natural History, Situation, Boundaries, | and face of the Country; the Nature of the | Soil; the Rise and Progress of the old Nor- | wegian Colonies; the ancient and modern | Inhabitants; their Genius and Way of Life, | and Produce of the Soil; their Plants, Beasts, | Fishes, \&c. | with | A new Map of Greenland. | And | Severai Copper Plates representing different Animals, | Birds and Fishes, the Greenlanders Way of Hunting | and Fishing; their Habitations, Dress, Sports | and diversions, \&c. $|-|$ By Mr. Hans Egede, | Missionary in that Country for twenty-five Years. | - | Translated from the Danish. | - London: | Printed for C. Hitch in Paternoster Row; S. Austen in I Newgate-Street; and J. Jackson near St. James's Gate. I MDCCXLV. 1 vol. sm. 80. pp. xvi+2 11., 220, with 12 copperpll."

"Chap. vi, pp. 65-99, 'Of the Greenland Sea Animals, and Sea Fowl and Fishes.'"

Not seen; title from Coues, Birds Colorado Valley, 1878, p. 578.

1745. Gumrlla, J. El Orinoeo | Ilustrado, y Defendido, | Historia Natural, | Civil, y Geographica | De este Gran Rio, | y de sus candolosas vertientes: | Govierno, Usos, y Costumbres de los Indios | sus habitadotes, con neuvas, y utiles noticias de Animales, Arboles, 1 Fiutos Aceytes, Refinas, Yervas, y Raices medieinales ; $\boldsymbol{y}$ sobrestodo, se ballaràn convetsiones muy singulares à $\mathbf{N}$. Santa F6, I y casos de mucha edificacion. | Escrita | Por el Padre Joseph Gumilla, de la Comañia de Jesus $\mid \ldots$ [.. tetitles, 6 lines ] Segunda Impression, Revista y Augmentada / por su mismo Autor, y dividida en dos Partes. | Tomo [Seal] Primero | - | En Madrid: Por Manuel Fernandez, Impressor do el Supremo | 
1745. Gumilla, J.-Continned.

Consejo de la Inquisicion, y de la Reverenda Camara Apostolica, I en la Caba Baxa. Año M. DCC. XLV. 2 vols., $4^{\circ}$. 1l. 24, pp. 1-403, 11. 2, map, and pll.

Variedad de Peces, y singulares industrias de los Indios para pescar: Piedras, y buessos medicinales, que se han descubierto en algunos pescados, tom. i, cap. xxi, pp. 314-330.Manati, pp. 319-327. Account of the abnndance of these animals in the Orinoco and its tributary waters, the manner of their capture by the Indians, their habits and external appearance, and the wonderful medicinal properties of their ear bones.

First edition, not seen; there is a later Spanish edition published in 1791 (q. v. $)$; also a French edition $(1758, q . v$.$) , and doubtless others.$

1745. Smith, [W.] A | Natural History | of | Nevis, | And the rest of the English Leeward Charibee Islands | in | America. | With many other Observations on | Nature and Art; | Particularly, An Introduction to | The Art of Decyphering. | In | Eleven Letters from the Revd. Mr. [William] Smith, | sometime Rector of St. John's at Nevis, and | now Rector of St. Mary's in Bedford; to the / Revd Mr. Mason, B. D. Woodwardian | Professor, and Fellow of Trinity-College, in Cambridge. | - | Cambridge: | Printed by J. Bentham, Printer to the University ; . . . [ = names of four booksellers. ] MDCCXLV. 80. 11. 3, pp. 1$318,11.5$.

Natural history, passim. Account of "Millions of Porpusses" seen near the "Leeward Charibbee Islands," pp. 185, 186; two species, one of them "with Noses in the exact form, aud full as big as Quart Glass-bottles, on which account they have justly acquired the name of Bottle-noses." Account of a fight between the "Grampus" and the "Sword-Fish and Thrasher as Allies," pp. 198, 199. Also account of a Baleen Whale, 35 feet long, stranded at Burgh, Lincolnshire, pp. 199-201.

1746. "Anderson, J. Herrn Johann Anderson, | I. V. D. | und weyland ersten Burgermeisters der freyen Kayserlichen | Reichstadt Hamburg, | Nachrichten | von Island, | Grönland und der Strasse Davis, | zum wahren Nutzen der Wissenschaften | und der Handlung. | Mit Kupfern, und einer nach den neuesten und in diesem Worke ange- | gedenen Eutdeckungen, genan eingerichteten Landeharte. | Nebst einem Vorberichte | von den Lebensumständen des Herm Verfassers. | [Vignette.] | Hamburg, | verlegts Georg Christian Grund, Buchdr. 1746. 1 vol. sm. 8 ro, 8 leaves to a sig. Vignette facing title, title, reverse blank, 14 unpaged 11. ('Vorrede' and 'Vorbericht'), pp. 1-328, 3 unpaged 1l. ('Register'); map, and 4 pll., at pp. 43."

"... There are numerons editions; besides the three I here give (see 1750 and 1756), there are these: German, Frankfurt u. Leipzig, 1747; Danish, Copenhagen, 1748; English, London, 1758, folio; and two or three French versions of later dates than 1750.-See Cuv., R. A., iii, 331; Böнм., Bibl., i, 769; AG. \& STrıckL., Bibl., i, 127."

Not seen: title and comment from Coues, Birds Col. Vall., A pp., 1878, p. 579.

Anderson's work, from its early date and the detailed information it gires, is one of imports nce in its relation to Cetology. See later editions, especially the Dutch versions of 1750 and 1756 .

Strange as it may seem, I have been unable to find any edition of Anderson in any of the principal libraries of Cambridge and Boston, the collations here given being all at second hand.

[233.]

1746. Avox." "Lijst (Naauwkeurige) van Nederlandsche schepen die sedert 1661 naar Groenland, en sedert 1719 tot op dezen tegenwoordigen tijd naar do straat Davis zijn uitgevaren. Amsterdam, C. van Tongerloo. 1746. kl. $8^{\circ}$. Een vervolg op deze lijst vindt men bij : Honig."

"In Fr. Muller's Catalogue of bonks on America, wordt onder No. 1781 een Hollandsch MS. vermeld, bevattende aanteekeningen.van de schepen, in de jaren 1753-1773 naar (roenland en de straat Davids, ter walvischrangst vertrokken; en onder No. 1782 eene Lijist in welcke jaaren do meeste en weinigste visschen uit Groenland en de straat Davids zijn aangebragt (1669-1792). 1 vel. folio. No. 6G3: Lijst van do Hollandsche en Hamburger Groenlands- en Straat Davids vaarders Ao 1764 uitgevaaren. Amst., J. Mr. 13rouwer. 1765. 80."

Not seen; title and note from Bosgoed, op. cit., pp. 241, 242, no. 3505. Sec, also, 1867. HoNiG, $J$.

1746. "EGEDE, HANS. Beschrijving van Oud-Groenland, of eigentlijk van de zoogenaamde Straat Davis; behelzende deszelfs uatnurlijke historie, stands gele- 


\section{6. "EgEde, HAxs.-Continued.}

genheid, gedaante, grensscheidingen, veld-gewassen, dieren, vogelen, visschen, enz. Mitsgaders den oorsprong en voortgang der aeloude Noorweegsche volkplantingen in dat gew est; benevens den aart, inborst, woonigen, levenswijze, kleding, enz. der hedendaagsche inboorlingen. Eerst in de Deensche taal beschreven door Mr. Hans Egede, en nu in 't Nederduitsch overgebragt. Met een nieuwe kaart van dat landschap en (10) aardige printverbeeldingen versiert. Te Delft, bij R. Boitet, 1746. $4^{\circ}$."

"Zie aldaar: Van de zec-dicren, zee-vogels en visschen, walvisschen, enz., bl. 54-67 . . . Van de gewono bezigheden als jagen en visschen en de noodigo gereedschappen daartoe, bl. 84-91."

Not seen; titlo anil references from Bosgoed, op. cit., p. 235, no. 3451. For reference to the matter relating to Cetaceans, see the original Danish edition of 1741.

[235.]

1746. Livn€, C. Caroli Linnæi | . . [ [=titles, 2 lines ] Fama | Svecica | Sistens | Animalia Sveciæ Regni:| Qvadrupedia, Aves, Amplibia, | Pisces, Insecta, Vermes, | Distributa | Per | Classes \& Ordines, | Genera \& Species. | Cum | Differentiis Specierum, | Synonymis Auctorum, | Nominibus Incolarum, | Locis Habitationum, | Descriptionibus Insectorum. | - | Stockholmiæ | Sumtu \& literis Laurentii Salvii | 1746. 8०. 14 11., pp. 1-411, pll. i, ii.

Classis iv. Pisces. I. Plagiuri = Cetacea, pp. 98-100, 4 genn., 6 spp., to wit: 1. Catodon fistula in cervice, p. $98=$ Physeter macrocephalus; 2 . Monodon, p. 98 ; 3. Balcena fistula in medio capite, dorso caudam versus acuminato, p. $98 ; 4$. Balana fistula in medio capite, tubero pinniformi in extremo dorso, p. 99; 5. Delphinus corpore subconiformi, dorso lato, rostro subacuto, p. 99; 6. Delphinus rostro sursum repando, dentibus latis serratis, p. 100.

[236.]

1747. Browne, J., and others, or EDITor. An Account of the Experiments relating to Ambergris, made by Mr. John Browne, and Mr. Ambrose Godfrey Hauckwitz, FF. R. S., with Mr. Newman's Vindication of his Experiment, drawn up by C. Mortimer, R. S. Secr. <Philos. Trans., Abridged by Mfartyn, 1732-44, ix, pt. 3, 1747, pp. 366-368.

From Philos. Trans. Lond., no. 435, p. 437. Sce 1735. Ediror.

1747. Hampe, J. H. A Description of the same Narhual [as forms the subject of Dr. Steigertahl's communication]. <Plilos. Trans., Abridged by Martyn, 1732-44, 44, ix, pt. 3, 1747, p. 72.

From Philos. Trans. Lond., no. 447, p. 149. See 1738. HAMPE.

1747. Neuman, C. Of Ambergris . . < Phil. Trans., Abridged by Martyn, 1732-44, ix, pt. 3, 1747, pp. 339-346, 346-358, 358-366.

From Philos. Trans. Lond., no. 443, p. 344 ; no. 434, p. 371 ; no. 435 , p. 417 . See 1738 . NetMANN.

[239.]

1747. [Prívost, A. F.] Sierra-Leona, par Atkins. <Hist. génér. des Voy., du Prérost, iii, 1747, pp. 239-252.

Manatee ou Vache marine, pp. 240-241. External characters and mode of capture, based on Atkins, Voy. en Gliinée, etc., p. 43. (See ATkrNs, under 1735.)

La $\nabla$ ache do mer ou lo Lamantin, ibid., pp. 315-316. A compiled account, based largely on Atkins, op. cit.

Poisson de mer \& de rivieres [de la Côte d'Or], ibid., iv, pp. 2506-262. Le Grampus ou le Souffleur, pp. 259, 260. Le Marsouin, p. 260.

Poisson do mer \& d'eau douce. [de Congo \& d'Angola], ibid., v, 1748, pp. 91-95. L'Ambize Angulo, pp. 92-93. Account of external characters, etc., compiled from Dapper.

[240.]

1747. Scilla, Augustino. De | Corporibus Marinis | Lapidescentibus / quæ defossa reperiuntur, | Auctore Angustino Scilla | addita dissertatione | Fabii Columnæ | de Glossopetris. | [Vignette.] Romæ, Typis Antonii de Rubeis in via Seminarii Romani. | MDCCXLVII. | - | Superiorum permissu. 4. 11. 5, pp. 1-73, 11. 3, pll. $\mathrm{i}-\mathrm{xxviii}+$ frontispiece.

In this first Latin version of Scilla (see 1670. ScILLA) tho description of Squalodont remains occurs at p. 47. The plates are the same as those of the original edition, the Squalodont remains boing represented in fig. 1, pl. xii.

[241.] 
1747. SteigertamL, [J. G.] Account of a Narhual or Unicorn Fish, by Dr. Steigertahl, F. R. S., dated at Hanover Apr. 20, O. S. 1736. Translated from the Frencl by T. S. M. D., \&c. <Philos. Trans., Abridged by Martyn, 1732-44, ix, pt.3, 1747 , pp. 71, 72, pl. v, fig. 42.

From Plilos. Trans. Lond, no. 447, p. 147. See 1738. Stcigertaht.

1748. BAECK, ABR. "De cornu Piscis planes singulari carinae navis impacto. < Acta Acad. Caes. Nat. Cur., viii, 1748, pp. 199-217."

Not seen; perbaps not Cetacean. Titlo from Carus and Engelmann.

1748. Ellis, H. A | Voyage | to / Hudson's-Bay, | by the | Dobbs Galley and California, | In the Years 1746 and 1747, | For Discovering a | North West Passage; | with | An accurate Survey of the Coast, and a short | Natural History of the Country. | Together with | A fair View of the Facts and Arguments from | which the future finding of such a Passage is | rendered probable. I By Henry Ellis, Gent. | Agent for the Proprietors of said Lxpedition. | To which is prefixed, | An Historical Account of the Attempts hitherto made / for the finding a Passage that Way to the East Indies. I Illustrated with proper Cuts, and a new and correct Chart / of Hudson's-Bay, with the Countries adjacent. |-| London: | Printed for H. Whitridge, at the Royal Exchange. | M. DCC. XLVIII. 1 vol. sm. 80 . pp. i-xxviii, 1-335, map, and cuts.

The plate facing p. 132 gives a figure of "The Great Harpoon for Whales, with its Barb, Coil, \& Bouy" used by the Estimo. On the plate facing p. 134 are figures of "A Sea Uni. corn" and " $\Lambda$ Whale." In the text there are merely incidental allusions to these animals. The figure of the Whale was doubtless intended for that of Balcena mysticetus, but the head is very short in proportion to the whole length of the animal.

A Grrman translation of Ellis appeared at Göttingen in 1750, and a French and a Dutch translation at Leiden the same year, each in $8^{\circ}, q . v$.

[244.]

1748. Linné, C. Caroli Linnæi | Archiatr. Reg. Met. et Bot. Profess. Upsal. | Systema | Naturæ | sistens | Regna tria Naturæ. | in | Classes et Ordines | Genera et Species | redacta | Tabulisque ruis illustrata. | [Monogram.] - | Cum privilegio S. R. M. Polonicæ ac Electoris Saxon. | - | Secundum sextam Stockholmiensem emendatam \& auctam | editionem. | - | Lipsiæ, Impensis Godofr. Kiesewetter. | 1748. 11. 3, pp. 1-224, 11. 15, pll. i-vii.

Pisces plagiuri (= Sirenia +Cete), p. 39. Genera Trichecus (1 sp.), Catodon (2 spp.), Monodon (1 sp.), Balcena (3 spp.), Delphinus (3 spp.), Physeter (2 spp.). Reference only to Artedi and Faun. Suec.

Pl. iv, fig. 1, Plagiurus cum cauda horizontali $=$ Delphinus ?

1748-56. "MEYER, J. D. Angenehmer und nuitzlicher Zeitvertreib mit Betrachtung curioser Vorstellung allerhand kriechender, fliegrender und schwemmender, auf dem Land und im Wasser sich befindender und nährender Thiere. Sowohl nach ihrer Gestalt und ausserlichen Beschaffenheit nach der Natur gezeichnet, gemahlet und in Kupfer gestochen vou J. D. Mejer. Nürnberg, 17481756. 3 dln. folio. Met 240 geklemde platen."

Not seen; title from Bosgoed, op. cit., p. 11, no. 126.

[2ی6.]

1749. Condamine, $M$. DE LA. Relation abrégée d'un Voyage fait dans l'intérieur de l'Amerique méridionale, depuis la Côte de la Mer du Sud, jusques aux Côtes du Brésil \& de la Guiane, en descendant la rivière Amazones. < Hist. de l'Acad. roy. des Sci. à Paris, ann. 1745 (1749), pp. 391-492, pl. ix.

Lamentin on Poisson-bœuf, pp. 464, 465.

1749. Gomara, F. L. DE. Francisco Lopez de Gomara, Historia de las Indias. < Historiadores | primitivos | de las Indias occidentales, | que junto, traduxo en parte, | y facò à luz, ilustrados con eruditas No- | tas, | y copiosos Indices, | el ilustrissimo Señor | D. Andres Gonzalez Barcia, | del Consejo, j camara de S. M. | Divididos en tres Tomos. | Tomo 1[-III]. | [Design.] Madrid. Año MDCCXLIX. 3 vols. fol.

Del Pez, que llaman en la Española Manati, vol. ii, cap. xxsi, p. 25. External characters and habits, one balf page.

29 G B

[243.] 
1750. "ANdersox, J. Histoire | Naturelle | do l'Islande, | du Groenland, | du Detroit do Davis, | Et d'autres Pays situes sons le Nord, | Traduite de l'Allemand | De M. Anderson, de l'Académie | Impériale, Bourg-mestre en Chef | de la Ville de Hambourg. | Par M**, de l'Académie Impériale, \& | de la Societé Royale de Londres. | Tome Premier [Second]. | [Device.] | A Paris, | Chez Sebastien Jorry, Imprimeur- | Libraire, Quai des Augustins, près | le Pont S. Michel, anx Cigognes. | - | M. DCC. L. | Avec approbation \& Privilége du Roi. 2 vols. $1^{\circ}$. Vol. 1 , vignette facing title, pp. i-xl, map, pp. 1-314, folding pll. i,ii,opp.p. 84 (birds) and p. 188. Vol.2, 1 p.1. (title), pp.i-iv, 1-391, unnumbered pll. opp.pp. 54 (birds), 78, 108, 168, 220."

"See the orig. ed., 1746; there are said to be later French eds., of 1751 and 1764."

Not seen; from Cones, Birds Col. Vall., App., 1878, p. 580.

1750. "AvDersox, Joll. Besehrijving van IJsland, Groenland en de straat Davis. Verrijkt met (6) platen en een nieure kaart van de ontdekkingen. Benevens een voorberigt, bevattende de levensbijzonderheden van den schrijver. Uit het Hoogduitsch vertaald door J. D. T. Te Amsterdam, bij St. van Esvaldt. 1750. $4^{\circ} . "$

"... Walvisch. Baarden, spek, traan, bl. 78-82. Waarin van andere risschen te onderscheiden, bl. 157. Onderscheidene soorten en nachrichten van dien visch, bl. 158. Walvischdoder, bl. 194.

"Walvischvangst. Hoe de Groenlanders dezelve verrichten, bl. 221. Waarom do Hollanders daarin beter slagen dan do Denen, bl. 129."

Not seen; title and references from Bosgoed, op. cit., p. 231, no. 3418. There is a later Dutch edition ( $\Lambda$ msterdam, $1756, q . v$.), to which are appended Horrebow's observations.

[250.]

1750. "Bring, S. De piseaturis in Oeeano Boreali. Lund., Goth. 1750. 4․"

Title from Bosgoed, op. cit., p. 234, no. 3435.

1750. Ellis, H. Voyage à la Baye de Hudson, en 1744-47, pour la décourerte d'un passage au Norl-Ouëst. Trad. de l'Angl, augmentée, Leide, 17巨̄0. 8०. pll.9. This French translation is said to have been made by C. Sellius.

For account of the Cetological matter, see the original English ed. of 1748.

[252.j

1750. Elis, H. Reize naar de Baai van Hudson, ter ontdeklinge van eenen NoordWester doortogt. Leiden, 1750. $8^{\circ}$. pll. 9, cuts in text.

Dutch translation of the English edition, 1748, q. $v$.

1750. Zorgdrager, C. G. Cornelius Gisbert Zorgdrager's | Beschreibung | des | Grönlåndischen | Wallfischfangs | und | Fischery, | nebst einer grúndlichen Nachricht | von dem | Bakkeljau-und Stocklischfang | bey | Terrenenf, | und einer kurzen Abhandlung / von | Grónland, Island, Spitzbergen, Nova Zembla, | Jan Mayen Eiland, der Strasse Davirls u. a. | Aus dem Hollandischen ůbersezt, und mit accuraten Kupfern und Land-| Charten gezieret. | - 1 Nůrnberg, bey Georg Peter Monath, 17:0. 4․ Frontispiece, 1l.3, pp.1-370, 11. 5 .

Frontispiece title-page, printed title-page, plain back. Vorrede des Verlegers, 2 1l., with the last backed by Erklírung les Kupfer-Blates. Einleitung. Von den ersten Erfindern der neuen Kûsten und Lande insgemein, pp.1-15. Then fullows the Alte und nens Grónlåndischen Fischery, pp. 16-302. Zugabe (account of the Cachelot oder Potfisch), pp. 30:, 303. Gro̊nlåndischen Walltisch-Fang, pp. 301-346. Summarische Nachricht von dem Baklieljauund Stockfisch-Fang bei 'Terreneuf, in den nordlichen 'Theilen von America, aus den Scbrifften des Herrn Deny's gezogen, pp. 346-3c5. Erklärung etlicher fremd-und unbekaunten Wôrter, etc., pp. $36 j-370$. Register, 5 leaves.

This is apparently a translation of the. Dutch edition of 1720 , with more or less abrilgment, especially the omission of the rhymed passnges of the original, and the statistical lists of the Greenland Whale-fishery, with the addition of the Account of the Codfish-fishery of later editions. The copy liandled, although apparently in the original binding, lacks all the maps and plates except tho frontispiece.

[254.]

1751. [Daubenton, L. J. M.] Cachalot. _Encycl., ou Dict. rais. des Sci., des Arts et des Métiers, ii, 1751, pp. 502, 503. 
1751. Klein, J. T. Jacobi Theodori Klein | Sccr. Civ. ged. | Soc. reg. Lond. et Acad. Scient. Bonon. | Membri | Qvadrvpedvm | dispositio | brevisque | Historia Natvralis. | [Vignette.] - | Lipsiae | apvd Ionam Schmidt, bibl.Lvbec. | 1751. 4. 1l. 2, pp. 1-12\%, pll. i-iij +2 unuumb.

Manatrs, pp. 94, 95.

1751. Stri.ter, Georg. Wilhelm. De Bestiis marinis. <Nov. Comm. Acad. sci. imp. Petropolitanae, ii, 1749 (1751), pp. 289-398, pll.

Deseriptio Manati seu Vaceae marinae Hollanilorum, sea-cow Anglornm, Russorum Morskaia Korowa. Oecisal. 12. Inl. 1742 , in insula Berin sita, pp. 294-330. Descriptio partium externarum, pp. 206-209. Descriptio internarum partinm, pp. 309-318. Ossium brevis descriptio, pp. 318-320. Descriptio morum et naturae, pp. 320-330.

[257.]

1751. [Vandenesse, M. De.] Baleine. <Encycl., ou Dict. rais. des Sci., des Arts et des Métiers, ii, 1751, pp. 32-36.

Baleine, pp. 32, 33. Pêche de la baleine, pp. 33-36. Le blane de la baleine, p. 36.

1752. Hill, John. An | History | of | Animals. | Containing Descriptions of the | Birds, Beasts, Fishes, and Iusects, | of the | Several, parts of tho World; | and | Including Acconnts of the several Classes of Animaleules, | visible only l,y the Assistance of Mieroscopes. | In these / The Characters, Qualities, and Forms of the several Creatures are/describerl, the names by which they are commonly known, as well as those by / which Anthors, who have written on the Subject, have called them are explained: | And each is reduced to the Class to which it naturally belongs. | Illnstruted with Figures. | - By John Hill, M. D. | Acad. Reg. Seient. Burdig. \&.c. Soc. | - | London : | Printed for Thomas Osborne, in Gray's-Inn. |- | MDCCLII. 2C. 11. 4, pp. 1-584, 1l. 2, pll. i-xxviii, colored.

Fishes. Class the Fifth. Plagiuri, Cetaceous Fishes, pp. 310-317. Physeter, 2 spp., p. 310; Delphinus, 3 spp., pp. 310, 311; Balcena. 4 spp., pp. 312-314; JIonodon, 1 sp., p. 314, pl. xvi; Catodon, 1 sp., p. 315; Trichechus, p. 317. A short but very good general account of the sulject. The specific names adopted are English, but the species are referred to Linnæan genera. [259.]

1752. Scilla, Augustino. De / Corporibus Marinis / Lapidescentibus / quæ defossa reperiuntur | Anctore Angustino Scilla | addita dissertatione | de Glossopetris | Erlitio altera emendatior. | [Vignette.] Romæ, MDCCLII. | Sumptibus Venantii Monaldina Bibliopolse in via Curfus. $|-|-\mid$ Ex Typographia Linguarum Orientalium | Angeli Rotilii, et Philippi Bacchelli. | In REdipus Maximorum. | Superiorvm pernissv. | $4^{\circ}$. pp.i-viii, 1-84, 1l. 3, pll. i-xxviii +1 $\&$ frontis.

In this edition (see Scichs at 1670 and 1747) the description of the Squalodont remains is at p. 55. The plates are apparently from the original etehings.

[260.]

1753. Axon. "Naamlyst ... van alle de Commandeurs, die sedert 1700 op Groenland en de Straat Davids voor Holland hebben gevaren . . hoeveel vissen en vaten spek ieder heeft aangebragt. Zaandam, 1753. 4 ०."

Not seen; title from Fr. Muller's Cat. A mer. Books, 1877, p. 127, no. 2214. For an apparently later editiou of the same work, see 1770. SANTE, G. VAx.

[261.]

1753. Boxd, J. An account of a machine for killing of Whales, proposed by John Bond, M. D. <Philos. Trans. Lond., xlvii, art. 1xxi, 1753, pp. 429-435.

On account of the difficulty in propelling the harpoon to a sufficient distance, the writer recommends the use of the ancient balista, with certain modifications to suit the exigencies of the occasion.

[262.]

1753. Stwller, G. W. Georg Wilhelm Stellers / ausfihlichehe / Beschreibung | von sonderbaren | Meerthieren, | nit Erläuterungen und nöthigen Kupfern | versehen. | [Vignette.] - | Halle, | iu Verlag, Carl Christiau Kümmel. | 1753. | 80. 11. 9, pp. 1-48.

Beschreibung eines Manati oder Meerknh, welches Thier den 12 ten Julii 1742 auf der Insul Bering, die zwischen America und Asien im Canal gelegen ist, getódtet werden, pI). 48-107.

Detailer account of its exterual aud internal anatomy. This work contains, (1) "Zur Eiñleitung. Anatomie eines Meerkalbes, von Johann Adam Kulmus, in Ac'is Nat. Cur., rol. i, obs. 5," pp. 1-41; (2) "Georg Wilhelm Stellers Abhandlung ron AIcerthieren," pp. 41-218, a translation of De Bestiis marinis. See 1751. Stellen, G. W. 
1753-54. Pontoppidan, E. Erich Pontoppidans, D. | Bischofs inber das Stift Bergen in Norwegen und Mit- | glieds der Ko̊nigl. Dán. Societåt der Wissenschaften | Versuch | einer | natúrlichen | Historie | von Norwegen, | Worinnen die Luft, Grund und Boden, Gewås- | ser, Gewåchse, Metalle, Mineralien, Steinarten, Thiere, | Vogel, Fische und endlich das Naturel, wie auch die / Gewohnheiten und Lebensarten der Einwohner | dieser Konigreichs beschrieben werden. | Erster Theil. | Aus dem Di̊nischen ủbersetzt | von | Johann Adolph Scheiben, | K. D. C. |- | Mit Kupfern. | - | Kopenhagen, | Bey Franz Christian Mumme, | 1753. Zweiter Theil, 1754. 80. Erster Theil, pp. 1-367, mit 16 Tafeln; Zweiter Theil, pp. 1-56, 1-535, mit 14 'Tafeln.

Wallfisch, Zweiter Theil, pp.223-234.

The species designated are: 1. Hvalfisk, pp. 223-232. This relates mainly to the Greenland Whale (Balcena mysticetus), but also euntains some reference to the Sperm Whale; the figure (pl. facing p. 209) is that of Physeter macrocephalus. 2. Tuequal (the Plockfiseh of the Germans), p. 232. 3. Ro̊rqval, p. 232. 4. Troldqual, p. 232. 5. Springhval, pp. 232, 284, pl. facing p. 285. 6. Nebbe-IIval, p. 233, pl. facing p. 209, fig. orig. This last, named also $B a$ loena rostrata, is evidently one of the Beaked Whales, but the others are too briefly mentioned to be identified. \%. Marsvin, p. 257. 8. Narhval, p. 359, pl. facing p. 247.

For further comment see infrà (1755), the Euglish ed.

1753-54. WagevaAR, Jax. Vaderlandsche / Historie, / vervattende de / Geschiedenissen | der Vereenigde Nederlanden, | inzonderheid die van | Holland, | van de vroegste tydenaf: | Uit de geloofwaardigste Schryvers en egte Gedenk- | stukken samengesteld. | Met Konst plaaten en Karten opgehelderd. | . . To A'nsterdam, | By Isaak Tidrion. | 21 vols. 8०. 1749-1759.

Potwalvisch, by Kalwyk, gestrand, ix, 1753, pp. 37, 38. Begensels der Walvischvangst, x, 1754, pp. 67 et seq. Walvisschen voor Scheveningen gestrand, x, p. 158.

[265.]

1754. Axov. "Seeeinhorn. <Berlin. wöchentl. Relat. der Merkw. Sachen a. d. Naturreiche, 1754, p. 719."

Not seen; title from Donndorff, Zool. Beytr., i, 1792, p. 756.

1754. CAtesby, M. The | Natural History | of | Carolina, Florida, and of the Bahama Islands: | Containing the Figures of | Birds, Beasts, Fishes, Serpents, Insects aud Plants: | Particularly the Forest-Trees, Shrubs, and other Plants, not hitherto described, | or very incorrectly figured by Authors. | Together with their Descriptions in English ond French. | To which are added, | Observations on the Air, Soil, and Waters: | With Remarks upon | Agriculture, Grain, Pulse, Roots, \&c. | To the whole is prefixed a new and correct Map of the Countries treated of. | By the Late Mark Catesby, F. R. S. | Revis'd by Mr. [George] Edwards, of the Rojal College of Physicians, London. I - I Vol. I [II]. [French version of the title follows.] London:| Printed for C. Marsh, in Round Court in the Strand; T. Wilcox, over-against the new Church, in the Strand; and B. Stichall in Clare-Court. 1 - I MDCCLIV. 2 vols. fol. pll. col.

This is said to be identical with the original edition of 1731-33. Coues (op. cit.) gives a collation of the $1771 \mathrm{ed}$.

Page xxxii of the "Acconnt of Carolina and the Bahama Islands" contains 2 lines about "Whales" and 10 lines about "The Porpesse," neither of any importance.

[267.]

1754. Daubenton, L. J. M. Dauphin, delphinus. <Encycl., ou Dict. rais. des Sci., des Arts et des Métiers, iv, 1754, p. 645.

1755. AxON.? "Free and impartial remarks on the real importance of the Whalefishery. London, Cooper. 1755. 8०."

Not seen; from Bosgoed, op. cit., p. 251, no. 3600.

1755. Pontoppidan. The | Natural History | of | Norway: | containing | A particular and accurate Account of the Temperature of the Air, the / different Soils, Waters, Vegetables, Metals, Minerals, Stones, Beasts, | Birds, and Fishes; together with the Dispositions, Customs, and | Manner of Living of the Inhabitants: Interspersed with Physiological | Notes from eminent Writers, and Transactions of Academies. | In Two Parts. | Translated from the Danisb 
1755. Pontoppidax-Continued.

Original of the | Right Revd. Erich Pontoppidan, | Bishop of Bergen in Norway, and Member of the Royal Academy I of Sciences of Copenhagen. | Illus- trated with Copper Plates, and a General Map of Norway. I - I [Vignette.] - | London: | Printed for A. Linde, Bookseller to Her Royall Highness the Princess Dowager of Wales, in Catherine-Street in the Strand. I - I MDCCLV. fol. Pt. i, pp. i-xxiv, 1-206; pt. ii, pp. i-viii, 1-292, 11. 6, map, pll.' 18, mostly unnumbered.

Part ii, pp. 118-151, Cetacea, passim. 1. Hral-fisk, or Qual, the Whale, pp. 118-123= Baloena mysticetus, principally, but in the account of this species sereral others are incidentally mentioned; 2. Herring-Whale, pp. 120, 145, doubtless seme kind of Finuer Whale; 3. Tuequal, or Bunch-back'd Whale, p. $123=$ ? Megaptera longimana; 4. Spring-hval, or Springeren, p. $123=$ Bakenoptera rostrata (cf. Fabricius, Faun. Groenl., p. 40); 5. Balcena rostrata, or Nebbe-hval, the Beaked Whale, p. 123=Hyperoodon rostrata; 6. Doglingen, p. $124=$ ? Globiocephalus melas; 7. Marsvin, or Porpesse, which is here called Nice, and also Tumler, the Tumbler, p. $\mathbf{1 3 6}=$ Phoccena communis, at least in part; 8 . Narhval, Unicornu Marinum, the Unicorn Fish, p. 137, pl. marked "no. 4," but apparently no. 22 of the list at the end of the volume=Monodon monoceros; 9. Spek-hugger, or Vahu, pp. 122, 150, figured on pl. "no. 5" (= no. 21 of the list at the end of the volume), described as "in shape much like a Porpesse, and about four feet long," with a sharp snout and "very keen teeth," and "long projecting jaws," and is sail to prey upon the Whales, but the account as a whole cannot be referred to any known species. It is impossible to say whether it be really a Cetacean.

Plates described as " $20,21,22$, Uf Fishes, page 103 " in the directions to the binder on the reverse of p. 291 of pt. ii, embrace, among numerous other figures not Cetacean, 1. The Whale $=$ Physeter macrocephalus, 2. "The Goosebilled Whale," a caricature of probably some species of Hyperoodon, 3. A Whale with two speta huggers, apparently a Delphinoid, attacked by two of the "Spek-huggers" described at p. 150. There is no reference to these figures in the text, and the names of none of them exactly correspond with those of the species there described. 4. The Narwhal-an odd caricature copied from an earlier author. None of the figures are in fact original.

Pontoppidan's account of the Whale tribe is largely derived from preceding authors, the rest being based mainly on accounts received from fisbermen. The author frankly states that he never saw a Whale except once, and then only the back of one as it came to the surface of the water to breathe. It is of interest chiefly as a record of the msths then prevalent respecting these creatures. His notices of them are interspersed among those of the Viviparous Fishes. One specific name still current (Balcena ROstRaTA) for a species of Hyperoodon dates from Pontoppidan.

[270.]

1756. "Axderson, J. Beschryving | van | Ysland, | Groenland | en de Straat Davis. | Bevattende zo wel ene bestipte bepaling van de ligging en | grote van die Eilanden, als een volledige ontvouwing van hunne / inwendige gesteltenis, vuurbrakende Bergen, heete en war- | me Bronnen enz. een omstandig Bericht van de Vruchten | en Kruiden des Lands; van de wilde en tamme Landdie- I ren, Vogelen en Visschen, de Visvangst der Yslanders | en hunne onderscheide behandeling, toebereiding en | drogen der Visschen, voorts het getal der Inwoon- | ders, hunnen, Aart, Levenswyze en Bezigheden, | Woningen, | Kledingen, Handteering, Arbeid, | Veehoedlery, | Koophandel, Maten en Ge- | wichten, Huwelyks Plechtigheden, Opvoe- / ding hunner Kinderen, Godsdienst, Ker- | ken en Kerkenbestuur, Burgerlyke Rege- | ring, Wetten, Strafoeffeningen en wat | wyders tot de Kennis van een Land | vereischt word. |

Door den Heer | Johan Anderson, | Doctor der Beide Rechten, en in Leven eerste Burgermeester | der vrye Keizerlyka Ryksstad Hamburg. | Verrykt met Platen en een nieuwe naauwkeurige Landkaart der | ontdekkinge, waar van in dit Werk gesproken word. | Uit het Hoogduits vertaalt. | Door | J. D. J. | Waar by gevoegt zyn de Verbeteringen | Door den Heer Niels Horrebow, | Opgemaakt in zyn twéejarig verblyf op Ysland. | [Designs.] | Te Amsterdam, | By Jan van Dalen, Boekverkoper op de Colveniersburgwal | by de Staalstraat. 1756. 1 vol. sm. 4\%. Full-page vignette, title, both backed blank, 7 more unpaged 11. ('Voorbericht'), map, pp. 1-285+3 11. ('Bladwyzer'); with 5 pll. at pp. 34 (birds), 149 (birds), 172, 189, 216. To which is appended: Verbeteringen | Wegens de | Beschryving | Van het Groot Eyland | Ysland, | Beschreven | Door den Heer | Johan Anderson. | Opgemaakt in een tweejarig 


\section{6. "Anderison, J.-Continued.}

verblyf | op dat Eyland, | Door den Heer | Niels Horrebow. 5 unpaged 11., pp. 1-158."

Not seen; title from Coves, Birds Col. Vall., 18i8, p. 581. This is the later Dutch edition referred to above at 1750 . It is by the same translator, with the addition of Horrebew's memoir, but is issued by a different publisher. See the references to the cetological matter given from Bosgoed for the ed. of 1750 . See, also, Horisebow, N., at 1769.

[271.]

1756. Brissox, M. J. Regnum animale | in Classes IX distributum, | sive | Synopsis Methodica | sistens generalem Animalium | distributionem in Classes IX, \& duarum primarum | Classium, Quadrupedum scilicet \& Cetaceorum, parti- | cularem divisionem in Ordines, Sectiones, Genera \& / Species, / Cum brevi cujusque Speciei, | descriptione Citationibus Auctorum de is tractantium, | Nominibus eis ab ipsis \& Nationibus impositis, Nominibus- | que vulgaribus./ A D. Brisson, Historiæ Naturalis Musei Realmuriani | Demonstratore. | Cum Figuris æneis. | - | [Vignette.] | Parisi is, | Ad Ripam Augustinorum. | Apud Cl. Joannem-Baptistam Banche, Bibliopolam, ad | Insigne Sta. Genovefue \& Sti. Joannis in Deserto. | M. DCC. LVI. | - | Cum privilegio Regis \& Approbatione. pl. i-vii, 1-382.

[Or],

Le Regne Animal | divisé en IX Classes, | ou | Méthode | contenant la division generale des | Animaux en IX Classes, \& la division particuliere | des deux premieres Classes, sçavoir de celle des | Quaulrupedes \& de celle des Cetacées, en Ordres, | Sectiones, Genres \& Espéces. | Aux quelles on a joint une | courte description de chaque Espéce, avec les Citations | des Auteurs qui en ont traité, les Noms qu'ils leurs ont / donnés, ceux que leurs ont donnés les différentes | Nations, \& les noms vulgaires. | Par M. [Mathurin Jacques] Brisson, Démonstrateur du Cabinet d'Histoire | Naturelle de M. de Reaumur. | Avec Figures en taille donce. [Vignette.] A Paris, | Quay des Augustins. | Chez Cl. Jean-Baptiste Bauche, Libraire, à l'Inage Sainte / Geneviéve \& S. Jean dans le Desert. | M.DCC.LVI. | - | Avec Privilege du Roi \& Approbation. 4 . 11.2, pp. i-vj, 1.1.pp. 1-382, 1.1. Text in both Latin and French.

Genus Odobeni=Sirenia + Walruses, pp. 48-51.-Le Lamantin, Manatus (=genn. Manatus et Halicore), pp. $49-51$.

Classe ii. | Les Cetacées. | [ou] Classis ii. | Cetacea. [half-title, p. 341], pp. 341-382.

The Cetacea are divided into four orders:

Order I. Cetacea edentula, with 1 genus, Baloena, and 7 species, to wit: 1. Baloena vulgaris Groenlandica, p. $347=$ B. mysticetus; ; 2 . Balcena Islandica, p. $350=$ B. biscayensis ; ?. Balana Novoe Anglioe, p. $351=$ "Bunch or Hump-back-wbale" of the English; 4. Balena bipinnis, sex in dorso gibbis, p. $351=$ B. gibbosa, Erxleben or "Serag Whale" of Dudley; Agaphelus gibbo. sus, Cope; 5. Balæna tripinnis, ventri levi, p. š22; 6. Balæna tripinnis, ventre rugese, rostro rotundo, p. $353=$ Physalus antiquorum; 7 . Baliena tripinnis, ventre rugoso, rostro acuto, p. $355=$ Baloenoptera rostrata.

Order II. Cetacea dentata in maxilld inferiore tantùm, with 1 genus, Cetus, and 7 species. 1. Cetus, p. $356=$ Physeter macrocephalus; 2. Cetus albicans, p. $359=$ Beluga catodon; 3. Cetus Novoe Anglice, p. $360=$ "Sperma Ceti Whale" of Dulley, hence Physeter macrocephalus ; 4. Cetus minor, p. $361=$ Physeter macrocephäus, juv.; 5. Cetus tripinnis, dentibus acutis, rectis, p. $362=$ Physeter macrocephalus ; 6. Cetus tripinnis, dentibus acutis, areuatus, falciformis, p. $363=$ Physeter macrocephalus ; $\boldsymbol{\gamma}$. Cetus tripinnis, dentibus in planum desinentibus, p. $364=$ Physeter macrocephalus.

Order III. Cotacea dentata in maxilld superiore tentùm, with 1 genus, Ceratodon, and 1 species: Ceratodon = Monodon monoceros.

Order IV. Cetacea dentata in utráque maxilld, with 1 genus, Delphinus, and 5 species, to wit: 1. Delphinus, p. $369=$ Delphinus delphis; 2. Phocoena. p. $371=$ Phocoena communis; 3. Delphinus pinnâ in dorso unâ Gladii recurvi æmulâ, dentibus acutis, rostro quasi truncato, p. $372=$ Physeter macrocephalus; 4. Orca, p. $373=$ Orca gladiator; 5. Physeter, p. 374 =Physeter macrocephalus.

Total, 4 genera, 20 species. Of the latter no less than 7 are based on different accounts of the Sperm Whale, the author eompiling indiscriminately from Sibbald, Artedi, Klein, etc. [272.]

1756. Lrvné, C. Caroli Linnæi | Archiatr. Reg. Med. et Bot. Profess. Upsal. | Systema | Natura | sistens Regua tria Naturæe | in | Classes et Ordines | Genera 
1756. Linse, C.-Continued.

ct Specics | redacta, | tabulisque æneis illustrata. | Accedunt rocabula Gallica. | Editio multo auctior \& emendatior. | [Vignette.] Lugduni Batavorum, | Apud Theodorum Haak, | MDCCLVI. 8०. 11. 4, pp. 1-227, 11. 9+4, pll. i-viii.

Classis iv. Pisces. Ordo 8. Plagiuri. Genn. Trichecus, Catodon, Monodon, Baicena, Delphinus, Physeter (pp. 39, 40). Trichecus here includes the single species "1. Manatus . . . la Lamantin." Catodon has 2 species; Monodon, 1; Balana, 4; Delphinus, 3; Physeter, $2=$ gern. 6, spp. 13.

1757. Bond, Joux. Bericht wegens een Werktuig om Walvissen te Schieten. <Houtuyn's Citgezogte Verhandl. uit de Nieuwste Werken ran de Societieten der Wetensch. in Europa, etc., i Band, ii Deel, 1757, pp. 1-10.

From: Phil. Trans., 1757, vol. xlrii, pp. 429 et seq. See 1751. Bond, J.

1757. "Debes, L. JAC. Naturliche und Politische Historie der Inseln. Faröe, woriun die Luft, Grund und Boden, Gewässer, Thiere, Vögè, Fische, ete., das Naturel, die Gewohnheiten, Lebensart der Einwohner dieser Inseln und ihre Verfassung beschrieben werden. Aus dem Dänischen übersetzt. Kopenhagen und Leipzig, Pelt, 1757. $8^{\circ}$. Met kopergrav."

Not seen; from Bosgoed, op. cit., p. 50, no. 773. For account of the cetological matter of Debes's work, see English version, at $16 i 6$.

1757. Horrebow, N. The | Natural History | of | Iceland: | containing | A particular and accurate Account of the different Soils, burning Moun- | tains, Minerals, Vegetables, Metals, Stones, Beasts, Birds, and Fishes; I together with the Disposition. Customs, and Manuer of Living of | the Inbabitants. Interspersed with an Account of the Island, by / Mr. Anderson, late Burgo-master of Hamburgh. | 'To which is added, a Meteorological Table, with Remarks. | Trauslated from the Danish Original of $\mathrm{N}[\mathrm{iels}]$. Horrebow. And illustrated with a New General Map of the Islaud. | - I. London: 1 . . [ n names of booksellers, 4 lines]. MDCCLVII. 2०. pr.i-xx, 1-207, map.

Chap. lxv. Concerning the Whale. Chap. Ixvi. Concerning the porpas, pp. 85-87. Brief account of the capture and uses of these animals.

[276.]

1753. Borlase, Williay. The | Natural History | of | Cornwall. | The | Air, Climate, Waters, Rivers, Lakes, Sea, and Tides; / Of the Stones, Semimetals, Metals, Tin, and the Manner of Mining; | The Constitution of the Stannaries; | Iron, Copper, Silver, Lead, and Gold, found in Cornwall. | Vegetabies, Rare Birds, Fishes, Shells, Reptiles, and Quadrupeds: | Of the Inhabitants, | Their Manners, Customs, Plays or Interludes, Exercises, and Festivals; / the Cornish Language, Trade, Tenures, and Arts. | Illustrated with a new Sheet Map of the County, and Twenty-Eight Folio | Copper-Plates from Original Drawings taken on the Spot. | - | By William Borlase, A. M. F. R. S., | Rector of Ludgvan, and Author of the Antiquities of Cornwall. | - 1 . . . . Natale solum dulcedine captos | Ducit. | - | Oxford, | Printed for the Author; by W. Jackson: | Sold by W. Sandby, at the Ship in Flcet-Street London; and the Booksellers of Oxford. | | MDCCLVIII. fol. pp. i-xix, 1-326, 1. 1.

Sect. ii. Sea-fish, and first cetaceous, pp. 263, §64, pl. xxvii, figg. i, 2.

The "blower, or fin-fish (Physeter of authors)," p. 263. "The grampus, or Porcus marinus major of Ray," p. 263. "The porpesse, Porcus marinus seu Plocana vel Tursio," ete., p. 264, pl. xxvii, fig. 2. "The dolphin, the Delphinus of the ancients and moderns," p. 264, pl. xxvii, fig. 1. The figures are from the drawings " of that accurate Ichthyologist, the late Reverend Mr. Jago of Loo."

[277.]

1758. Gumilla, J. Histoire | Naturelle, Civile | Et Gengraphique | de | L'Orenoque. | Et des principales Riviéres qui s'y jettent. | Daus laquelle on traite du Gouvernement, | des usages $\&$ des contumes des Indiens | qui l'habitent, des animanx, des arbres | des fruits, des résines, des herbes \& | des racines médicinales qui naissent dans | le Paĩs. On y a joint le détail de plusieurs | Conversions remarquables \& édifiantes. I Par le Pere Joseph Gumilla, de la | Compagnie de Jesus, Supérieur des Missions de l'Orenoque. | Traduite de l'Espagnol 
1758. Gumilla, J.-Continned.

sur la Seconde | Edition, par M. Eidons ei-devant | Ingenieur des Armées de S. M. C. | Tome Second. | [Ornament.] A Avignon, | Chez la Veuve de F. Girard, Imprimeur. | Et se venr, | A Marseille, | Chez D. Sibié, Imprimeur du Roi, | \& Jean Mossi, Libraire. | - | M. DCC. LVIII. 3 vols. $12{ }^{\circ}$.

Poissons de l'Orenoque. Morens industrieux dont les Indiens se servent ponr les prendre. Vertus Médicinales des Pierres \& des Os qu'on trouve dans quelques uns. Tom. ii, chap. xxí, pp. 36-58.-Manati, pp. 43-55.

For comment, see the Spanish edition of 1745 .

1758-77. "Gmelin, Pr. F., und Christmans, G. F. Onomatologia medica completa, seu Onomatologia historiae naturalis, oder vollstïnd. Lexicon das alle Benennungen der Kunstwörter der Naturgesch. nach ihrem ganzen Unfang erkläret u. den reichen Schatz der ganzen Natur durch deutliche u. richtige Beschreibungen des nützlichen $\mathrm{u}$. sonderbaren von allen Thieren, Pflanzen u. Mineralien sowohl vor Aerzte als andere Liebhaber in sich fasst zu allgemeinem Gebr. von einer Gesellschaft naturforschender Aerzte nach den richtigsten Urkunden zusammengetragen. 7 Bile. A-Z. (1-4 von Ph. F. Gmelin, 5-7 von G.F. Christmann). gr. 80 . Uim ; Frankfortu. Lejpzig, 1758, '61,'66, '73, '75, '77."

Not seen; title at second hand, but source not noted.

Cetaceen, passim.

1759. Scilla, Augustixo. De | Corporibus Marinis | Lapidescentibus | quæ defossa reperiuntur | Auctore Augustino Scilla | addita dissertatione | Fabii CoJunınæ | de Glossopetris | Editio altera emendatior. | [Vignette.] Romæ MDCCLIX. | Sumptibus Venantii Monaldini Bibliopolæ in via Cursus. | - | | Ex Typographia Joannis Zempel | Prope Montem Jordanum. | Svperiorvm permissv. 4०. 11.4, pp. 1-82.11.3, pll. i-xxviii+1 and frontis.

This third Latin edition (see Scilla, at 1670, 1749, and 1752) seems to be textually the same as the first and second, with modifications of title-page and accessories. The matter relating to the Squalodont remains occurs at p. 54; the plates are identical with those of the earlier editions.

1760. Douglass, W. A | Summars, | Historical and Political, | of the | First Planting, Progressive Improvements, | and I'resent State of the British Set- | tlements in North America. | Containing |

I. Some general Account of ancient | and modern Colonies, the grant- 1 ing and settiing of the British | Continent and West India Island | Colonies, with some transient | Remarks concerning the adjoining French and Spanish Settle- I ments, and other Remarks of | various Natures.

II. The Hudson's-Bay Company's | Lodges, Fur and Skin Trarle. I

III. Newfoundland Harbours and | Cod-Fishery.

By William Douglass, M. D. | Vol. I. [-II] | - | Ne quid falsi dicere andeat, ne quid veri non audeat. · Cicero. | - | London, | Printed for R. \& J. Dods!ey, in Pall-mall. | MDCCLX. | 2 vols. $8^{\circ}$.

The title-pages of the two volumes differ only in respect to the matter detailing the con. tents of the volumes. There appears to have been an earlier [1755] edition, from which this seems to be not textually different.

A digression concerning whaling, rol.i, pp.56-61. Ambergris and spermaceti are described; eight different kinds of Whales are briefly described, with some account of the products of each of the habits of Whales, and of whaling.

A digression concerning fisheries, ibia., pp. 294-304. I. Whales, pp. 296-298. This gives an account of the New England Whale.fishery as it existed in 1748, with remarks on the habits of the Whales pursued, and is of especial importance.
[281.] 
1761. Charlevorx, P. [F. X. DE]. Journal | of a | Voyage | to | North-America. | Undertaken by Order of the | French King. | Containing | The Geographical Description and Natural | History of that Country, particularly | Canada. | Together with | An Account of the Customs, Characters, | Religion, Manners and Traditions $\mid$ of the original Inhabitants. I In a Series of Letters to the Duchess of Lesdiguieres. | Translated from the French of P. de Charlevoix. | In two volumes. | Vol. I. | - | London: | Printed for R. and J. Dodsley, in Pall-Mall. | - MDCCLXI. 2 vols. 8०. Vol. i, pp. i-viii, 1-382, 1 nuap. Vol. ii, pp. i-viii, 1-380, 11. 13.

The passage about Porpoises and Whales is in vol. i, pp. 227-230. See, also, Charlevorx, at 1744 and 1763.

1762. Houttuyn, F. Natuurlyke Historie | of | Uitvoerige Beschryving | der | Die. ren, Planten | en | Mineraalen, | Volgens het Samenstel van den Heer | Linnæus. | Met naauwkeurige Afbeeldingen. | - | Eerste Deels, Derde Stuk. | Vervolg der | Zoogende Dieren. | [Vignette.] Te Amsterdam, | By F. Houttuyn. | M D CC LXII. 80. 11. 3, pp. 1-554, 11. 2; pll. xxii-xxviii.

Cetacea, pp. 423-554. 1. Eenhoorn-Visch, pp. 423-441; 2. Mysticetus, Groenlandsche Wal. visch, pp. 442-477 (Historie der Walvisch-Vangst, pp. 457-477); 3. Physalus, Vinvisch, pp. 477-485; 4. Boops, Ossen-Oog, pp. 485-487; 5. Musculus, Breedsmoel, 487-500; 6. Catodon, pp. 503-505; भ. Macrocephalus, Potrisch, pp. 505-530; 8. Microp8, Klein-Oog, pp. 530-536; 9. Tursio, Mastvisch, pp. 536-539; 10. Phoccena, Bruinvisch, pp. 540-543; 11. Delphis, Dolphyn, pp. 543-547; 12. Orca, Botskop, pp. 547-554.

1762. "Jonaeus, W. Dissertatio de piscatura, cujus particula prima, de quibusdam Balaenis in mari Islandico captis vel ad littora ejectis, earumque nsu, praecipue occasione libri, dicti Su Konunglega Skuggsja, sive speculum regale, resp. J. Jonaeus. Hafniae, 1762. 10 bladz."

Not seen; from Bosgoed, op. cit., p. 239, no. 3489.

1762. SpIlMax, H. "Cachelot, gestrand tusschen Zandroort en Wyk op Zee, 1762. Naar J. Augustini door H. Spilman. br. folio."

From Bosgoed, op. cit., p. 176, no. 2777.

1762 (circa). Vinne, V. VAN DER. "Cagelot, lang 61 voeten, den 20 Febr. 1762 tussen Zantvoort eu Wijk-op-Zee aangedreeven. Door $V$. van der Vinne. br. $4^{\circ}$."

From Bosgoed, op. cit., p. 176, no. 2778.

1763. Beclin, S. Déscription | Géographique de la Guyane. | Contenant | les Possessions et les Etablissemens | des François, des Espagnols, des Portugais, | des Hollandois dans ces vastes Pays. I Le Climat les Productions de la Terre et les Animaux | Leurs Habitans, leurs Moeurs, leurs Coutumes. | et le Commerce qu'on y peut faire. | Avec des Remarques pour la Navigation et des | Cartes, Plans, et Figures, | Dressées au Dépost des Cartes et Plans de la Marine | Par Ordre de M le Duc de Choiseul Colonel | Général des Suisses et Grisons, Ministre de la | Guerre et de la Marine. | Par le S. Bellin Ingenieur de la Marine et du | Depost des Plans, Censeur Royal, de l'Academie de / Marine et de la Societé Royale de Londres. | M. DCC. LXIII. 4 $4^{\circ}$. pp. i-xiv (pl. title and engr. title, which is the one here given, and "Avertissement"), 1.1,pp.1-294,1.1, maps, numerous plans, and pll. $\mathrm{i}-\mathrm{x}$.

Le Manati, pp. 65, 66, pl. v (Pêche du Lamentin par les Indiens; Lamenum, Manate, Vache Marine). Description apparently original; figure a copy from Labat (see 1724. LABAT R. R.).

[287.]

1763. Charlevorx, [P.F.X.DE]. Letters | to the | Dutchess of Lesdiguieres; | Giving an Account of a | Voyage to Canada, | and | Travels through that vast Country, | and | Louisiana, to the Gulf of Mexico. | Undertaken | by Order of the present King of France. | By Father Charlevoix. | . . [ [=28 lines of small type in 2 columns, giving description of contents of the work.] Printed for R. Goadby, and Sold by R. Baldwin, in Pater- I Noster-Row, London. 1763. 80. pp. i-xir, 1 1., pp. 1-384. Without maps.

The passage relating to Porpoises and Whales is at pp. 81-88.

See the original edition, 1744; also the oarlier (1761) English edition. 
1763. Egede, H. Herrn Hans Egede, | Missionårs und Bischofes in Grónland, | Beschreibung | und | Natur-Geschichte | von | Gro̊nland, úbersetzet | von | D. Joh[ann]. Ge[org]. Krûnitz. | [Vignette.]- | Mit Kupfern. | - | Berlin, | verlegts August Mylius. | 1763. $8^{\circ}$. pp. i-xii, 1-237, i-xi Tafeln.

Cetacea, pp. 89-106, iv, v Tafeln. 1. Fin-Fisch, p. 89, Taf. iv; 2. Bart-Fisch, p. 90, Taf. ir; 3. Nordcaper, p. 95; 4. Schwerdfisch, p. 96 ; 5. Cachelot, oder Pot-Fisch, p. 97; 6. Weissfisch, p. 98, Taf. v; 7 . Buttskopf, p. $98=$ Hyperoodon, sp.; 8. Seeeinhorn. Einhornfish. Narwal, p. 99, Taf. v, animal and skull; 9. Der Niser oder das Meerschwein, p. 105. Wallfischfang, pp. 124-127.

[289.]

1763. Gronovids, Laur[entius] Theod[orus]. Zoophylacii | Gronoviani | Fasciculus primus | exhibens | Animalia | Quadrupeda, | Amphibia | atque | Pisces, | quae in | Museo suo adservat, rite examinavit, syste- | matice disposuit, descripsit, atque | iconibus illustravit | Laur. Theod. Gronovius, J. U.D. | Civitatis Lugduno-Batavae Senator, Societatis Physico- | medicae Regiae Londinensis, Basilaeensis, | atque Hollandicae Socius. | [Ornament.] Lngduni Batavorum | sumptibus Auctoris. |MDCCLXIII. fol. Fasc. I. 2 11., pp. 1-136; Fasc. II. Insectorum. 1764. pp. 137-236, i-iv, pll. i-xvii+viii ${ }^{\mathrm{a}}$.

Plagiuri, pp. 29, 30.-The onl 5 species described is (no. 139) Balaena dorso impenni, (nearly = Balaena mysticetus), of which there is a detailed account of the external,characters, including measurements.

[290.]

1764. Horrebow, N. Nouvelle | Description | physique-historique, | civile et politique | de l'Islande, | avec | des observations | critiques | sur l'Histoire naturelle | de cette Isle, | Donnée par M. [Johann] Anderson. | Ouvrage traduit de l'Allemand, de M. | [Niels] Horrebows [sic], qui y a été envoyé | par le Roi de Danemarck. | Tome premier [et second]. | - | A Paris, | Chez Charpentier, Libraire, rue du Hurepoix, | à l'entrée du Quai des Augustines. | - | M. DCC. LXIV. | Avec Approbation, \& Privilege du Roi. 2 vols. 120. Vol.i, pp. i-xlij, 1-368; vol.ii, pp. i-v, 1-376.

De la Baleine, i, pp. 305-311. Du Marsouin, pp. 311-313.

This work is a critical commentary upon that portion of Anderson's "Nachrichten von Island, Grönland," etc., relating to Icelaud. The matler relating to Cetacea is not of high importance.

This French version, as the translator himself avows, is more or less abridged, and very freely rendered.- Vol. $i$ is wrongly paged from p. 264 to the end, through an omission in the pagination of 9 numbers (265-272 inclusive).

[291.]

1764. [Krasheninnikof, S. P.] The | History | of | Kamtschatka, | and the | Kurilski Islands, | with the | Countries adjacent; | Illustrated with | Maps and Cuts. | [By Stepan Petrovitch Krasheninnikof.] Published at Petersbourg in the Russiau Language, by Order of her Imperial Majesty / and translated into English | By James Grieve, M. D. | Glocester: | Printed by Raikes | for | T. Jefferys, Geographer to his Majesty, London. | M. DCC. LXIV. 4c. 11.4,pp. i-vii, 1-280, 5 pll. and two maps.

Manati or Sea Cow, pp. 132-136. Whales, pp. 137-142.

Krasheninnikof's work is of special importance from its detailed account of the Sea Cow (Rhytina borealis), its habits, abundance, and products.

Grieve's version is a greatly abridged and condensed translation, but was the first and the only one prior to 1768 , when a French translation direct from the original Russian appeared at Paris $(q . v$.$) , far superior to Grieve's. Of Grieve's abridged English version there uppeared$ a (Yerman translation in 1766 , by J. T. Kohler (Lemgo), a French, by M. E[idous] (Lyon), in 1767 (q.v.), and also, it is said, a Dutch (Amsterdam), in 1770. See especially infra, KizASHENLXNIKOF, at 1768 .

[292.]

1764. Noorde, C. VAN. "Cagelot of potwalvis, gestrand by Egmond op Zee, 1764. Door C. van Noorde. br. folio."

From Bosgoed, op. cit., p. 176, no. 2780.

1765. Avon. Lamantin. <Encycl., ou Dict. des Sci., des Arts et des Métiers, ix, 1765, p. 225. 
1765. [Buffon, G. L. Leclerc, Compte de, et L. J. M. Daubenton]. Histoire | Naturelle, | Générale et Particuliére, | Avec la description | du Cabinet du Roi. | - | Tome Treizième. | - | [Vignette.] A Paris, | de L'Imprimerie Royale. | - | M. DCC. LXV. 40. 11. 3, pp. i-xx, 1-441, 1. 1, pll. i-lix.

Les Phoques, les Morses, et les Lamantins, pp. 330-441, pll. xliv-lix. Le Dugong, pp. 374377 (par Buffon). Le Lamantin, pp. 377-394 (par Buffon). Description d'un embryon de Lamantin de la Guiane, pp. 425-430, pll. lvii-lix (par Daubenton). Description d'une tête de la Lamantin du Sénégal, pp. 431, 432 (par Daubenton). La tête d'un Dugon, pp. 437-440, pl. lvi (par Daubenton).

See later editions at 1792, 1802, and 1826.

1765. Cranz, David. David Cranz | Historie | von | Gronland | enthaltend | Dio. Beschreibung des Landes und | der Einwohner \&c. | inbesondere | die | Geschichte | der dortigen | Mission | der | Evangelischen Brůder | zu | Neu-Herrnhut | und | Lichtenfels. | - | Mit acht Kupfertafeln und einem Register. | - | Barby bey Heinrich Detlef Ebers, und in Leipzig | in Commission bey Weidmanns Erben und Reich.| 1765. 80. 11. 17, pp. 1-1132, 11. 13.

III. Abschnitt. Von den See-Thieren, pp. 140-160. 1. Grónl\&̊ndische Wallisch (=Baloena mysticetus), pp. 141-145; 2. Nord-Caper (=B. biscayensis), p. 145; 3. Finnfisch, p. 145; 4. Jupiter-Fisch, p. 146; 5. Pflok-Fisch, p. 146; 6. Knoten-Fisoh, p. 146; \%. Einhorn-Fisch, oder Narhval, Monoceros, pp. 146-148; 8. Såg-Fisch, Pristis, p. 148 (not a Cetacean); 9. Caschelot oder Pottfisch, pp. 148-150; 10. Weisstisch, p. 150; 11. Butzkopf, p. 151; 12. Meerschwein, p. 151; 13. Delphin, p. 152; 14. Schwerdtfisch (=Orca), p. 152; 15. Eine andre Art Schwerdt-Fische, p. 152. Wallfisch-Fang, pp. 155-160.

Of the 15 species here distinguished 14 are Cetaceans, and nearly all are recognizably described.

1765. "Fermin, Pr. Histoire naturelle de la Hollande équinoxiale; ou description des animaux, plantes, fruits, etc., que se trouvent dans la colonie de Surinam; avec leurs noms différents, tant françois, que latius, hollandais, indiens et négre-anglais. Amsterdam, M. Magerus, 1765. gr. 80."

Not seen; title from Bosgoed, op. cit., p. 56, no. 872.

1766. Livné, C. Caroli a Linné, | . . [ [=titles, 5 lines ] | Systema | Naturæ | Per | Regna tria Naturæ, | Secundum | Classes, Ordines, | Genera, Species, | cum | Characteribus, Differentiis, | Synonymis, Locis. | Tomus I. | - | Editio Duodecima, Reformata | - | Cum Privilecrio S:æ R:æ M:tis Sveciæ \& Electoris Saxon. | - | Holmiæ, | Impensis Direct. Laurentii Salvii, | 1766. 8०. pp. 1-532.

- II. Bruta.> Sirenia. Trichecus Mranatus, pp.49, 50=Manatus et Halicore. Gen. Trichecus inter Elephas et Bradypum sistens spp. 1. T. Rosmarus; 2. T. Manatus.

VII. Cete, pp. 105-108. 1. Monodon Monoceros; 2. Baloena Ifysticetus, p. 105; 3. Baloena Physalus; 4. Baloena Boops; 5. Baloena Musculus, p. 106; 6. Physeter Catodon; 7. Physeter macrocephalus; 8. Physeter microps; Ф. Physeter Tursio, p. 107; 10. Delphinus Pho. coena; 11. Delphinus Delphis; 12. Delphinus Orca, p. 108.

Genn. 4; spp. 12.

In the Vindobonæ reprint (1767), styled "Editio decima tertia, ad Editionem duodecimam reformatam Holmiensem," the pagination and matter relating to these groups is the same as here.

[298.]

1767. "BeckmanN, JoH. Anfangsgründe der Naturhistorie. $8^{\circ}$. Göttingin u. Bremen, 1767."

Not seen; title from Carus and Engelmann. Cited by Doundorff in connection with Cetaceans.

A new and improved edition, $8^{c}$, Breslan, 1813, is also mentioned.

1767. Cranz, David. The | History | of | Greenland: | containing | A Description | of | the Country, | and | Its Inhabitants: | and narticularly, | A Relation of the Mission, carried on for above | these Thirty Years by the Unitas Fratrum, | at | New Herrnhuth and Lichtenfels, in that Country. | By David [Cranz] Crantz. | Translated from the High-Dutch, and illustrated with | Maps and other Copper-plates. | - I In two volumes. | - | Vol. I. | - | London, | Printed for the Brethren's Society for the Furtherance of the | Gospel among the Heathen: | And sold by J. Dodsley, in Pall-Mall; . . . [ = names of seven 


\section{Cranz, David-Continued.}

other booksellers] and at | all the Brethren's Chapels. | MDCCLXVII. 8c. 11. 2, pp. i-lix, 1-405, 2 maps, pll. iii-vii ; vol. ii, 1. 1, pp. 1-498, pl. 2.

Of other singular Sea-Animals, i, pp. 106-122: 1. The Greenland Whale, pp. 10i-109 (avowedly from Martens and Zorgdrager), and pp. 118-121 (the Dutch Whale-fishery-"relation from the mouth of a Missionary"). 2. The North-eaper, p. 110. 3. The Fin-fish, p. 110. 4. The Jupiter-whale, p. 110. 5. The Bunch, or Humpback-whale, p. 111. 6. The Knottedwhale, p. 111. \%. The Unicorn-fish, monoceros, also called narhval, pp. 111, 112. S. The Saw-fish, pristis, p. 112 (not a Cetacean). 9. Cachelot, Catodon, or Pott-fisch, pp. 112-114. 10. The White-fish, p. 114. 11. The Grampus, p. 114. 12. The Porpoise, pp. 114, 115. 13. The Dolphin, cailed also Tumbler, p. 115. 14. The Sword-fish (Orca), p. 115. 15. Another kind of Sword-fish, the ardluit of the Greenlanders (Orca), pp. 115, 116. Whalefishery of the Greenlanders, pp. 121,122.

See above (1765. Craxz, D.) for the first (German) edition. Also the following:

[300.]

1767. Cranz, D. "Historie ván Groenland. Haarlem (or Amsterdam). 1767. 3 vols. 8०. pll. 12, 2 maps."

Dutch translation of the first German edition. The maps are said to be larger and better than in the German edition. A later Dutch edition appeared in 1786, q. v.

Not seen; abridged title from a bookseller's catalogue.

1767. [Krasheninnikof, S. P.] Histoire | de | Kamtschatka, | des Isles Kurilski, | et des contrées voisines, | Publiće à Petersbourg, en Langue Russienne, par | ordre de Sa Majesté Impériale. | [Par Stepan Petrovitch Krasheninnikof.] Ou y a joint deux Cartes, l'une de Kamtschatka, \& / I'autre des Isles Kurilski. | Traduite par M. E***. [Marc Antoine Eiidous.] | Tome premier [et second]. | [Design.] A Lyon, | Chez Benoit Duplain, Libraire rue | Merciere, à l'Aigle. | - M. DCC. LXVII. | Avec Approbation \& Privilege du Roi. 2 vols. $12 \circ$.

Vol. i, 1l. 4, pp. i-xv, 1-327, 1 map; vol. ii, 1l. 4, pp.1-359, 1 map.

Manati on la vache marine, i, pp. 313-325. Baleines, ii, pp. 1-13.

This is merely a retranslation from Grieve, 1764, q.v. See, also, under 1768.

1768. "Adelung, JoH. Chr. Geschichte der Schiffahrten und Versuche welche zur Entdeckung des Nordöstlichen Weges nach Japan und China von verschiedenen Nationen unternommen worden. Zum Behufe der Erdbeschreibung und Naturgeschichte dieser Gegenden entworfen. Halle, bey Joh. J. Gebauer. 1768. 4 $4^{\circ}$ Met 19 gegrav. platen en kaarten."

"Zie aldaar: Geschichte des Spitzbergischen Walltischfanges. bl. 269-438."

Not seen; title from Bosgoed, op. cit., p. 231, no. 3416.

1768. "Евerhardt, JoH. Pet. Versuch eines neuen Entwurfs der Thiergeschichte. Nebst ein. Anh. von einigen seltenen u. noch wenig beschrieb. Thieren. Mit 2 Kpfrtaf. $8^{\circ}$. Halle, 1768."

Not seen; title from Carus and Engelmann.

1768. Krasheninnikof, [S. P.]. Voyage | en Sibérie, | contenant | la Description | du Kamtchatka, | ou l'on tronve | I. Les Mœurs \& les Coutumes des Habitants du Kamtchatka. | II. La Géographie du Kamtchatka, \& des Pays circonvoisins. | III. Les avantages \& les désvantages du Kamtchatka. | IV. La réduction du Kamtchatka par les Russes, les révoltes arrivées en | différents temps, \& l'état actuel des Forts de la Russie dans ce Pays. | Par M. Kracheninnikow, Professeur de l'Académie des Sciences | de Saint Pétersbourg. | Tradnit du Russe. | Tome Seconde. | [Design.] A Paris, | Chez Debure, pere, Libraire, quai des Augustins, à Saint Paul. | - | M. DCC. LXVIII. | Avec Approbation, \& Privilege du Roi. 4०. pp. i-xvi, 1-627, ll. 2, pll. i-xvii, maps i-vi.

"L'Ourrage que l'on publie aujourd'hui, est dn̂ à l'esprit éclairé de M. de * * *, \& à son amour pour le travail: il l'a traduit à Saint Pétersbourg . . ." "-Avis de l'Éditeur, p. x.

Des Vaches marines, pp. 446-454. De la Baleine, pp. 455-462.

A comparison of this work with Grieve's English translation, and the French translation from Grieve, shows at a glance that Grieve's rendering is greatly defectire. All the plates and maps of the original, the editor tells us, are here reproduced, some of them, however, from new designs. The work forms vol. ii of the Voyage en Sibcric of M. l'Abbe Chappe d'Auteroche, published by Debure at Paris in 1768. 
1768. Krasheninnikor, [S. P.]-Continued.

Muller refers to a French edition published in two volumes at Amsterdam in 1770 as having been made directly from the Russian original. Is it other than a reprint of that of l'Abbó Chappe d'Auteroche?

[305.]

1769. [Bancroft, Edward.] An | Essay | on the | Natural History | of | Guiana, | In South America. | Containing | A Description of many Curious Productions | in the Animal and Vegetable Systems | of that Country. | Together with an Account of | The Religion, Manners, and Customs | of several Tribes of its Indian Inhabitants. | Interspersed with | A Variety of Literary and Medical Observations. | In Several Letters | from | A Gentleman [Edward Bancroft] of the Medical Faculty, | During his Residence in that Country. | - |-Ad res pulcherrimas ex tenebris ad lucem erutas alieno | labore dedncimur. | Seneca, De brevitate vitae, cap. xiv. | - | London, | Printed for T. Becket and P. A. De Hondt | in the Strand. MDCCLXIX. $8^{\circ}$. 11. 2, pp. i-iv, 1-402,1.1.

Manatee or Sea-Cow, pp. 186-187. Original account. Of this work there is a German edi. tion of same date (see next title), and also a Dutch translation from the English (Utrecht, $\left.1782,8^{\circ}\right)$.

[306.]

1769. BANcroft, E. Naturgeschichte | von | Guiana | in | Sủd-Amerika. | woriun | von der natúrlichen Beschaffenheit und den vor- | nehmsten Naturproducten des Landes, ingleichen der Re- | ligion, Sitten und Gebråuchen verschiedener Ståmme | der wilden Landes-Einwolıner, Nachricht | ertheilet wird. | - | In vier Briefen. | Von Eduard Bancroft, Esq. | - | Aus dem Englischen. | - | Ad res pulcherrimas ex tenebris ad lucem eruras | alieno labore deducimur. Seneca. | - | Frankfurt und Leipzig, | bey J. Dodsley und Compagnie, 1769. 8०. pp. i-x, 1. 1, pp. 1-248.

Manati oder Meerkuh, pp. 112, 113. See last title.

1769. Fermin, P. Description | générale, historique, | géographique et physique | de la | Colonie de Surinam, | Contenant | Ce qu'il y a de plus Cnrieux \& de plus Remarquable, tou- ! chant sa Situation, ses Rivieres, ses Forteresses; son 1 Gouvernement \& sa Police; avec les mœurs \& les usa- I ges des Habitants Naturels du Païs, \& des Européens | qui y sont établis; ainsi que des Eclaircissements sur l'œ- | conomie générale des Esclares Negres, sur les Planta- | tions \& leurs Produits, les Arbres Fruitiers, les Plan- | tes Médécinales, \& toutes les diverses Especes d'animaux | qu'on y trouve, \&c. | Enrichie de Figures, \& d'une Carte | Topographique du Païs. | Par | Philippe Fermin, | Docteur en Médecine. | Tome Premier [et second]. | [Design.] A Amsterdam, | Chez E. van Harrevelt. | MDCCLXIX. 2 vols. $8^{\circ}$. Map and plates. Vol. i, pp. i-xxiv, 1-252, map; rol. ii, 11. 2, pp. 1-352, pll. 3.

De l'Ichthyologie, ou Description des Poissons, vol. ii, chap. xxii, pp. 248-281. Le Marsonin, pp. $250,251$.

The second volume of this work is largely zoölogical, but the only passage strictly citable in the present connection is that above given. In the chapter "Des Quadrupedes" (vol. ii, chap. xix, pp. 88-140) are two pages (l. c., pp. 122-124) on the "Veau marin," in which the author evidently describes the Common Seal (Phoca vitulina), in which he says: "Tel est le Vearu Marin, qu'on appelle improprement, dans le pays, Zee-Hond ou Zee-Kou." This seems to be a confused reference to the Manatee, or Sea-Cow, and, strangely, the only one in the work. The author also describes "Buffles" (l.c.,pp. $\varepsilon 9,90)$ as inhabitants of the country. These two facts seem to show that the author's zoölogical matter is not wholly trustworthy. Yet Sabin cites Rich as saying: "One of the best books at the time it was written in regard to the colonies," which, doubtless, in other respects, may be true enough.

1769. S., J. A. "Stradavits Reyse ter Walvis-Vangst, rijmsgewijze beschreven door J. A. S. Chirurgijn op het schip Zaandijker Hoop. Antwerpen, P. J. Parys. 1769. 40."

"Curious and rare." Not seen; title at second hand.

1769-92. "PoRte, DE LA. De nieuwe Reisiger: of Beschryving van de onde en nieuwe werelt. Uit het Fransch. Te Dordrecht, bij Abr. Blussé en zn. 1769-1792, 32 dln. gr. $8^{\circ}$."

"De walvisch en do walvischrangst, viii, pp. 213-218 enz."

Not seen; title and reference from Bosgoed, op. cit., p. 246, no. 3545. 
1770. Cranz, David. David Cranz | Historie | von | Grónland | enthaltend | Die Beschreibung des Landes und / der Einwohner etc. | iubesondere / die / Geschichte | der dortigen | Mission | der | Evangelischen Bruder | zu | NeuHerrnhut | und | Lichtenfels. | - | Zwejte Auflage. | - | Mit acht Kupfertafeln und ein Register. | - | Barby bey Heinrich Detlef Ebers, | und in Leipzig | in Commission bey Weidmanns Erben und Reich. | 1770. 3 Theilen. $8^{\circ}$. Th. i, ll. 19, pp. 5-512.

Von den See-Thieren, Th. i, pp. 140-160. For further remarks in relation to cetological matter, see orig. ed., 1765, and the English ed. of 1767.

[311.]

1770. “Javssex, JAC. Merkwïrdige Reise, welcher mit dem Schiffe die Frau Elisa-

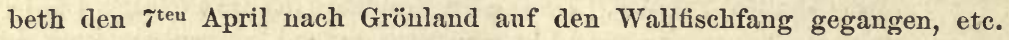
Hamburg, 1770. $4^{\circ}$. Met een plaat."

"Hiervan een kort Verslag in: Lindeman, Arktische Fischerei, bl. 46-48."

Not seen; from Bosgoed, op. cit., p. 239, no. 3487 .

1770. "Janssen, JAC. Verhaal der merkwaardige reize met het schip: de vrouw Maria Elizabeth, den 7 April 1769, van Hamburg naar Groenland ter walvischvangst uitgezeild, tot den 20 Nov. in het ijs bezet geweest, den $21^{\text {sten }}$ dier maand daaruit geraakt en den 13 Dec. deszelfden jaars gelukkig weder to Hamburg aangekomen. Uit het Hoogd. vertaald. Haarlem, 1770. 4०. 24 bladz. Meet eene plaat."

Not seen; from Bosgoed, op. cit., p. 239, no. 3488. Apparently a translation of the work last above cited.

1770. "Pietersz., Fr. Omstandig journaal of reysbeschrijving op het schip 'De vrouw Maria,' gedestineerd ter walvischvangst na Groenland, in den jaare 1769. (Amsterdam), K. van Rijschooten. (1770.) 4\%."

Not seen; title from Bosgoed, op. cit., p. 245, no. 3538.

17\%0. "SANTe, G. VAx. Alphabetische naamlijst van alle de Groenlandsche en StraatDavissche commandeurs, die sedert het jaar 1700 op Groenland en sedert het jaar 1719, op de Straat Davis voor Holland en andere provinciën hebben gevaren. Waarin men met eenen opslag kan zien, hoeveel visschen, vaten spek en quardeelen traan yder commandenr uit Groenland en uit de straat Davis heeft aangebragt en voor wat Directeurs dezelven hebben gevaren. Haarlem, J. Enschede, 1770. Met titelplaat. 4०."

"Dit exempl. is met de pen bijgewerkt tot het jaar 1802."

Not secn; title and comment from Bosgoed, op. cit., p. 247, no. 3550.

There appears to have been a much earlier (anonymous?) edition of the "Naamlijst" ( $4^{\circ}$, Zaandam, 1753, q. v.).

Scoresby observes that this work, "notwithstanding the unpromising title, is in reality an instructive work. It is from it, indced, that the most interesting details of the success of the Dutch fishery during a period of more than a century, included between 1669 and 1779, are derived."-Arctic Regions, ii, p. 155.

[315.]

1771. Forster, J. R. A | Catalogue | of the | Animals | of | North America | Containing, | An Enumeration of the known Qnadrupeds, Birds, | Reptiles, Fish, Insects, Crustaceous and / Testaceous Animals; many of which are New, and | never described before. | To which are added, | Short Directions | for Collecting, Preserving, and Transporting, | all Kinds of | Natural History Curiosities. | By John Reinhold Forster, F. A. S. | - | . . [Motto.] | - | Loudon: | Sold by B. White, at Horace's Head, in Fleet-Street. | - | M. DCC. LXXI. 80. pp. 43. Frontispiece, pl. of Falco sparverius, Linn.

Classis iv. Fish. Section i. Cetaceous. A nominal list of 9 spp., under English names. [316.]

1771. Forster, J. R. See Osbeck, Peter, 1771.

1771. Osbeck, Peter. A | Voyage / to | China and the East Indies, | By Peter Osbeck, | Rector of Hasloef and Woxtorp, | Member of the Academy of Stockholm, and of the | Society of Upsal. | Together with a Voyage to Suratte, | By Olof Toreen, | Chaplain of the Gothic Lion East Indiaman. | And | An Account of the Chinese Husbandry, | By Captain Charles Gustavus Eckeberg. I Translated from the German, | By John Reinhold Forster, F. A. S. | To which 
1771. Osbeck, Petri-Continued.

are added, | A Faunnla and Flora Sinensis. | In two Volumes. | Vol. I [-II]. | London, | Printed for Benjamin White, | at Horace's Head, in Fleet-street. |

M DCC LXXI. $8^{\circ}$.

"SNow-White Dolphins (Delphinus Chinensis) tumbled about the ship; but at a distance they seemed in nothing different from the common species, except in the white colour" (rol. ii, p. 27).

Under the name Delphinus Orca (vol. i, p. 7) is a quotation from Egede in reference to the "Northcaper"!

[318.]

1771. [Pennant, T:] Synopsis | of | Quadrupeds | [By Thomas Pennant.] [Vignette.] Chester | Printed by J. Monk | MDCCLXXI. | M. Griffith Delt. R. Murray Sct. [Engraved title-page.] $8^{\circ}$. pp. i-xxv, 1-382, pl. i-xxxi+xiii bis.

The author's name does not appear on the title-page, but the "Preface" is signed "Thomas Pennant, Downing, March 20, 1771."

Manati, pp. 351-358. A general account of the Sirenians as then known, which were thought to constitute a single species. Pennant's references are here, however, mainly to Steller's SeaCow and the American Manatee. There is also reference to the "Sea Ape" and the "Beluga," the account of which, as here given, is a curious mixture of truth and fiction.

1771. Robertson, J. Description of the blunt-headed Cachalot. <Philos. Trans. Lond., lx, art. xxvii, 1771, pp. 321-324, 1 pl.

The plate represents the animal, the head, and the head in transverse section of "Physeter Catodon Linnaei" = Physeter macrocephalus.

1771. "Trampler, J. C. Umständliche Beschreibung des Grönlïndischen Walfischfanges, ingleichen von den Ursachen und Eigenschaften des Nordlichts. Leipzig, Müller, 1771. $8^{\circ} . "$

Not seen; title from Bosgoed, op. cit., p. 248 , no. 3570.

1773. Bonannio, P. P. Rervm Natvralivm | Historia | nempe | Qvadrvpedvm Insectorvm Piscivm variorumqve marinorvm | Corporvm fossilivm Plantarvm exoticarvm | ac praesertim | Testaceorvm | exsistentivm | in Mvseo Kircheriano | edita iam | A P. Philippo Bonannio | nvnc vero nova methodo distribvta notis illvstrata | in tabvlis reformata novisqve observationibvs locvpletata | a Iohanne Antonio Battarra Ariminiensi | Philosophiae Professore. | Pars Prima [et Segvnda] | [Vignette.] Romae MDCCLXXIII. | In typographio Zempelliano | Aere Venantii Monaldini Bibliopolae. | - | Praesidvm Facrltate. $2 \circ$. pp. i-xl, 1-260, pll. i-xlvii.

Piscis generis Cetacei, quem Capodoglio Itali appellant [=Physeter macrocephalus], i, pp. 157, 158, pl. xxxviii, figg. 34 (anim.), 35 (mand. infer.), 36 (vertebra). Description, with measurements, and an original figure of a Cachalot 48 feet long, taken in the Mediterranean 18 April, 1715.

[322.]

1773. MÜLLER, P. L. S. Des | Ritters Carl von Linné | Kóniglieh Schwedischen, Leibarztes etc. etc. | vollståndiges | Natursystem | nach der | zwôlften lateinischen Ausgabe / und nach Anleitung | des hollåndischen Houttuynischen Werks | mit einer ausfůhrlichen | Erklårung | ausgefertiget | von | Philipp Ludwig Statius Múller | Prof. der Naturgeschichte zu Erlang und Mitglied der Róm. Kais. | Akademie der Naturforscher etc. | Erster Theil. | Von den | såugen- | den Thieren. | - | Mit 32. Kupfern. | - | Nurmberg, | bey Gabriel Nicolaus Raspe, 1773. $8^{\circ}$. 1l. 11, pp. 1-508, 11. 7, pll. i-xxxii.

II. Ordnung. Bruta.> Trichecus IIanatus, pp. 174-176. Tab. xxix, fig. 3.

VII. Ordnung. Wallfischartige oder sångende Seethiere. Cete. 1. Mronodon Monoceros, p. 477; 2. Baloena Mysticetus, p. 481; 3. Balcena Physalus, p. 491; 4. Balcena Boops, p. 492; 5. Balcena Musculus, p. 492; 6. Physeter Katodon, p. 497; 7. Physeter Macroccphalus, p. 498; 8. Physeter Microps, p. 501; 9. Physeter Tursio, p. 503; 10. Delphinus Phoccena, p. 504; 11. Delphinus Delphis, p. 505; 12. Delphinus Orca, p. 506. Auch der Pflockfisch, p. 493; der Knotenfisch, p. 493; der Nordkaper, p. 494; der Såbelfisch (Epée de Mer), p. 507; der Mórder (Killer), p. 507; der Blaser (Souffleur), p. 508.

[323.]

1773. Piscator, Lubrertus. "Brief van Lubertus Piscator over de visscherij, die bij een loterij vergeleken wordt.-Oorzaaken van derzelver afneemen.-Wederlegging.-Middelen ter verbetering op de Walvischvangst."

"Zie: De Koopman of bijdr. ter opbouw van Neêrlands koophandel en zeevaard. Amst.; 1773, iv. No. $5,12,13,25,26 . "$

Not seen; from Bosgoed, op: cit., p. 250, no. 3588. 
1773. Sibbald, Robert. Phalainologia nova; | sive / Observationes / de / rarioribus quibusdam Balænis | In Scotix Littus nuper ejectis: | in quibus, | nuper conspectæ Balænæ per Genera \& | Species, secundum Characteres ab ipsa | Naturâ impressos, distribuuntur; | quædam nunc primum describuntar; errores etiam | circa descriptas deteguntur; \& breves de Dentium, I Spermatis Ceti, \& Ambræ Griseæ ortu, naturâ \& / usu, dissertationes traduntur. | [By Sir Robert Sibbald. Edited by Thomas Pennant.] - -

Mirac'lum ponti narrant ingentia Cete |

Virihus invictis, \& vasta mole moventur.

In littus pauca exiliunt, quæ corporo vasto |

Sunt.- | Oppianus de Pisc. lib. I. | - I

Edinburgi, | Typis Joannis Redi, M DC XCII. | Veneunt apud M. Robertum Edward, verbi divini ministrum, in / vico dicto, The Bishop's Land Closs. | Iterum impressi, Londini, | Apud Benj. White, in Vico Fleet-Street. MDCCLXXIII. 8०. 11. 2, p. 1-105, tabb. 1-3.

Observationes de Balænis quibusdam in Seotiæ Littus nuper ejectis. Præfatio. De Balænis in Genere, pp. 7-14. Sectio prima. De Balænis, quæ Dentes in Ore habent, minoribus. Præfatio de Dentatis in Genere, pp. 15-17. Caput i. De Balænis Minoribns in ntrâque Maxilla Dentatis, quæ Oreæ vocantur, pp. 17-24. Caput ii. De Balænis Minoribus in Inferioro Maxillâ tantum Dentatis, sine Pinná aut Spinâ in Dorso, pp. 24, 25. Caput iii. De Balænis omnium Minimis, incertæ Classis, pp. 25, 26. Sectio secunda. De Balænis Majoribus, in Inferiore Maxillâ tantum Dentatis. Præfatio de hujusmodi Balænis in genere, pp. 27-30. Caput i. De Balæna Macrocephala quæ Binas tantum Pinnas Laterales habet, pp. 30-33. Caput ii. De Balænâ Macrocephala, quæ Tertiam in Dorso Pinnam sive Spinam habet, \& dentes in Maxilla inferiore Arcuatos Falciformis, pp. 33-43. Caput iii. De Balæna Macrocephala Tripinni, quæ in mandibula inferiore dentes habet minus inflexos, \& in planum desinentes, pp. 43-45. Caput iv. De Spermato Ceti, pp. 45-52. Caput r. De oleo quod ex his Belluis paratur, pp. 52-54. Caput vi. De Dentibus harum Balænarum, pp. 54-57. Sectio iii. De Balænis Majoribus Laminas Corneas in Superiore Maxilla habentibus. Præfatio. De hujnsmodi Belluis in genere, pp. 58-64. Caput i. De Balænis hujusmodi Bipinnibus, tam quæ carent fistula, quam qux eam habent, pp. 64-66. Caput ii. De Balænis Tripinnibus, quæ nares habent, in genere, pp. 67-68. Caput iii. De Balænâ hujusmodi Tripinni quæ rostrum acutum habet, \& plicas in Ventre, pp. 68-78. Caput ir. De Balænâ Tripinni quæ maxillam inferiorem rotundam, \& superiore multo latiorem habuit, pp. 78-84. Caput $\mathrm{v}$. De Balæna hujusmodi prægrandi in littus Boênæ nuper ejecta, pp. 84, 85. Caput vi. De laminis corneis, de plicis, \& de oleo hrjusmodi Belluarum, pp. 85-93. Appendix. De iis quæ Balænis communia sunt. Præfatio, pp. 94, 95. Caput i. De Pinguedine Balænarum, p. 96. Caput ii. De Carne harum Belluarum, p. 97. Caput iii. De Balænarum priapo, p. 97. Caput iv. De Ambrâ GriseA, pp. 98-104. Caput ultimum. De tempore quo Balænæ maxime conspiciuntur, pp. 104, 105.

Tab. 1. Balæna Macrocephala. Balæna cum laminis corneis in ore. Vertebræ caudæ, etc.

Tab. 2. Lamina cornea cum pilis. Dens Orcæ. Dens Balænæ Macrocephalæ Oreadensis. Dens Macrocephalæ fulciformis, etc.

Tab. 3. Balæna tripinnis maxilla inferiore rotunda.

Plate i, upper figure, is a very faulty represeniation of Physeter macrocephalus, the blow. hole being at the posterior part of the head and the upper jaw rather small and pointed. Plate $i$, lower figure, is a better representation of a Finner Whale, probably Balcenoptera rostrata. Plate ii, fig. of a blade of baleen of a Finner whale, of a much worn tooth, and a young tooth of Physeter macrocephalus, etc. Plate iii, probably Physalus antiquorim.

The editio princeps of Sibbald's "Phalainologia" (which I haro been unable to see) appeared in $1692\left(4^{\circ}\right.$, Edinburgh). The carly systematists trusted implicitly in Sibball, who unfortunately described different examples of the common Cachalot as different species, resulting in the introduction into systematic zoölogy of several noninal species, which were not effectually weeded out till comparatively lato in the present ceutury. The confusion resulting from Sibbald's work may bo considered as more than balancing the much really new information he contributel to the subject. This is perhaps less his fault than that of later compilers, who knew too little of the subject of which he wrote to have any power of discrimination, or even, in some cases, to understand the author whom they blindly followed. (Cf. Eschricht, "Recent Memoirs on the Cetacea," Ray Soc., 1866, pp. 161-163.)

1774. Axox. The / Journal of a Voyage / undertaken by order of / His present Majesty, | For making Discoveries towards the | North Pole, | by the | Hon. Commodore Phipps, | and | Captain Lutwidge, | in His | Majesty's Sloops | Racehorse and Carcase. | To which is prefixed, I An Account of the several 


\section{ALIEN'S BIBLIOGRAPHY OF CETACEA AND SIRENIA.}

1774. Axon.-Continued.

Voyages undertaken for | the Discovery of a North-east Passage to China | and Japan. | - | London: | Printed for F. Newbery, at the Corner of St. Paul's | Church Yard. | - | MDCCLXXIV. 3ง. 1. 1, pp. i-xxviii, 29-113.

The author's name is not given, but the work was apparently written by an officer of the expedition.

Smearingburgh harbour [Spitzbergen], p. 45. "A View of the Whale-fishery," pl. facing p. 81. There are, howerer, only a few incldental and unimportant allusions to the Whalefishery in the test.

[326.]

17\%4. "Hoogerdurn, Dirk Cornelisse. Singulieren of byzonderen Historiën wegens het verongelukken van het Groenlands Schip, de jufvrouwen Auna Coruelia en Anna, waariop commandeerde D. C. Hoogerduin van de Helder, gedestineerd na Groenland ter Wallevisvangst, met 45 zielen uit Texel gevaeren; in het gepasseerde jaer 17:3 op den 8 April en na een fatigante Rys te hebben gehad, hetzelve schip op de te Huisrys, na alvorens duizende van gevaere te hebbe oudergaen, eindelijk met drie sloepen op den 21 Aug. deszelfs jaers op Egmond gestrand, waervan 29 man op eer wonderbaerlijke w5s het leven hebben behouden en de rest verdronken; vervult mot zeltzame en byna nooit gehoorde gevallen. Amsterdam, W. A. Leeuwendaal. 1774. 40."

Not seen; from Bosgoed, op cit., p. 238, no. 3479.

1774. HÜPSCI, Baron ron. Beschreibung einiger neuentdeckten versteinten Theile grosser Seethiere. <Der Naturforscher, iii, 1774, pp. 178-183.

Ueber Gehörknoclien uud andere Knochen der Seekuh nnd einige Knochen von Walfischen bei Antwerpen entileckt.

[328.]

1774. Oexmelin, A. O. [= Exqubmelin, A. O.] Histoire | des | Adventariers | Flibustiers | qui se sont signalés dans les Indes; | Contenant ce qu'ils y ont fait de remarquable, I avec la vie, les mours \& les coutumes des Bon- | caniers, \& des habitans de S. Domingue \& de / la Tortuë; une description exacte de ces lieux, | \& un état des Offices, tant Ecclésiastiques que | Ś́culiers, \& ce que les grands Princes de | l'Europe y possédent. | Par Alexandre-Olivier Oexmelin. | Nouvelle Edition, | Corrigée \& augmentée de l'Histoire des Pi- | rates Anglois, depuls leur établissement dans | l'Isle de la Providence jusqu'à present. | Tome Premier[-Quatriéme]. | [Design.] A Lyon, | Chez Benoit \& Joseph Duplain, | Pere \& Fils. | - | Arec Privilege du Roi. | M. DCC. LXXIV. 4 vols. $12^{\circ}$. Vol. i, ll. $6, \mathrm{pp} .1-394,1.1$.

Anatomie du Lamentin, i, pp. 372-376.

This ellition is textually the same as that of $1744, q . v$., and appears to be identical with that giren by Sabin as published in $\mathbf{1 7 7 5}$.

[329.]

1774. Phipps, C. J. A | Voyage | towards | the North Pole | undertaken | by His Majesty's Command | 1773 | - | By Constantine John Phipps | - London; Printed by W. Bowyer and J. Nichols, | for J. Nourse, Bookseller to His Majesty, | in the Strand. | MDCCLXXIV. 4․ pp. i-viii, 1-253, 1. 1, pll. i-xiv.

Mammalia, A pp., pp. 183-186.-Balana mysticetus, p. 185; Balaena physalus, p. 184. There is a short account of Smeerenberg, pp. 68, 69. The cetological natter is unimportant.

There is a French translation (Paris, $4^{\circ}, 1775, q$. v.), and a German (Berne, $4^{\circ}, 1777$, q. $x$.).

1774. "WrJBo, J. CANzres. Dissertatio de balaenarum piscatu. Lugd. Bat. 1774. 40."

Not seen; title from Bosgoed, op. cit., p. 253, no. 3609.

1774-75. Olafsex, EgGert. Des | Bice-Lamands Eggert Olafsens | nnd des | Landphysici Biarne Povelsens | Reise durch Island, | veranstaltet | von dẹ Kǒniglichen Socictát der Wissenschaften | in Kopenhagen | nnd beschrieben / von bemeldtem Eggert Olafsen. | - | Aus dem Danischen ubersętzt. | - | Mit 25 Kupfertafeln und einer neuen Charte aber Island | versehen. | - | Erster Theil. | - | Kopenhagen und Leipzig, | bey Heinecke und Faber. | 1774. $4^{\circ}$. Erster Theil, 1l. 8, pp. 1-328, pll. i-xxv, und Charte; zweiter Theil, 17\%5, pp. i-xvi, 1-244, pll. xxvi-1.

Wallfische, Th. i, p. 35, $\$ 90$; Vom Wallfische, Th. i, pp. 287-291, \$\$ 657-663; Wallfische, Th. ii, p. $200, \S 895$. 
1775. Phipps, C. J. Voyage | an Pole Boréul, | fait en 1773, | par ordre du Roi d'Angleterre, | par Constantin-Jean Plipps. | Traduit de l'Anglois. | [Design.] A Paris, I

\section{Chez $\left\{\begin{array}{l}\text { Saillant \& Nron, rue Saint Jean de Beauvais. } \\ \text { Pissot, Quai des Augustins, près la rue Git-le-Cœur. | }\end{array}\right.$}

- | M. DCC. LXXV. | Arec Approbation et Privilége du Roi. 4०. pp. i-xij, 1-25\%, 1. 1, pll. and maps.

Mammifères du Spitsberg, pp.187-190.-Baloena mysticetus, Baloena physalus, p. 100. [333.]

1775. [Stauning, Jorgex.] Kort | Beskrivelse | over | Gr $\phi$ uland. | [Af Jorgen Stauning.] | [Vignette.] - | Biborg, 1775. | Trykt udi det Kongelige privilegerede Bogtrykkerie / ved C. H. Mangor. 80. 11. 7, pp. 1-328, 1. 1.

Fierde Kapitel, Om Soe Dyrene, pp. 121-140, contains an account of the Cetacea. 1. Grenlandske Hralfisk, pp. 124-129 = Balcena mysticetus; 2. Nordkapper, et Slags Hral, p. 129 $=?$ B. biscayensis; 3. Fintisken, p. 129=Physalus antiquorum; 4. Jupiterfisk eller rettero Gurbartas eller Gibbar, p. $130=$ Balaenoptera jubartes et gibbar, Lecépède, etc., hence prob. ably Physalus antiquorum; 5. Flogtisk, p.130=11egaptera longimana; 6. Knudefisk, p. 130 $=$ ? Baloenoptera rostrata; 7. Eenhiorning eller Narhval, Monoceros, p. 131; 8. Snabelfisk, p. 132=? [af Gronlænderne kaldes den Sigukitsok; cf. Fabricins, Faun. Grocnl., p. 52]; 9. Kaschelot eller Potfisk, p. $133=$ Physeter macrocephalus; 10. Hvidfisk, p. $134=$ ? Behiga catcdon; 11. Butskopper, p. 135 =? Orca gladiator; 12. Marsviin, p. $136=$ Phocana communis; 13. Delphin, p. $137=$ Delphinus delphis; 14. Srærdfisk, p. $137=$ Orca gladiator.

[334.]

1775. Valmont de Bomare. Baleine, balcena. <Dict. rais. universel d'Histoire nat., i, 1775, pp. 438-463 ( $8^{\circ}$ él., 1775).

"On ne s'attachera ici, suirant le plan qu'on s'est proposé, qu' à jeter un conp d'œil général sur les especes de baleines les plus curieuse, \& sur celles dont on retire le plus d'utilité. On ne peut rien faire de mieux que de parler d'après le cnrieux Anderson, ainsi que l'ont fait tous ceux qui, depuis lui, ont traite des baleines" (pp. 438-439). The Baleines are termed "faux poisson de mer."

General history, under vernacular names, of the species then known. Baleine de Groënland, pp. 441-446; Licorne de mer, ou Narhwal, pp. 446-448; Cachalot, ou la petite Baleine, pp. 448-452; Pêche des Baleines, pp. 455-456; Ennemis des Baleines, p. 456; Êpée de mer de Groënland, on Poisson Empereur, p. 457; Espadon ou Poisson à scie, p. 458; Marsouin ou Soufflenr, p. 459; Dauphin, p. 460; Autres especes de Baleines, p. 462.

Note.-The Sirenia are treated in the article "Vache marine," tom. ix, p. 178, tho Dugong being the only species recognized, under which is included the African Manatee as well as the American Manatee. "Le dugon est une fausse espece de morse de la mer de l'Afrique \& des Indes Orientales. . ..."

There is an earlier (1764) ed. of Bomare not seen by me.

1776. ANoN. Pêelie de la Baleine. <Suppl. à l'Encycl. ou Dict. rais. des Sci., des Arts et des Métiers, i, 1776, pp. 763, 764.

1776. [Fabricius, O.] <Mülleri Zoologice Danica Prodromus, 1776, pp. viii, ix.

Cetacea, p. viii, Baloena Boops (=Icelandic, Hrafu-Reydur; Greenlandic, Kcporkak); Physeter tursio (= Balcena albicans, Klein; Greenlandic, Pernak).

"Sequentia animalia, quæ impressis jam primis libelli paginis, suppeditabat renerabilis Otho Falbricins," eto., p. viii.

[337.]

1776. MUthler, O. F. Zoologiæ Danicæ | Prodronus, | sen | Animalium | Dania et Norvegia indigenarum | characteres, nomina, | et | synonyma imprimis popnlarinm. | Auctore | Othone Friderico Miiller, | . . [ [=titles, 3 lines ]. - | Impensis Auctoris. | - | Havniæ, | Typis Hallageriis. | CI DCC LXXVI. $8 \circ$. pp. i-xxxii, 1-282.

Cete, pp. 6-8, spp. 44-57=14 spp. 1. Monodon Mronoceros, p. 6; 2. Balana Mystictus, p. 6; 3. B. Physalus, p. 7; 4. B. Musculus, p. 7; 5. B. rostrata, p. 7; 6. B. glacialis, p. 7; 7. B. albicans, p. 7; 8. Physeter Catodon, p. 7; 9. Ph. macrocephalus, p. 7; 10. Ph. microps, p. 7; 11. Delphinus Phocana, p. 7; 12. D. Delphis, p. 7; 13. D. Orca, p. 8; 14.D. Orca [hin]. [338.]

1776. [Pennaxt, Thomas.] British Zoology. | Vol. III. | Class III, Reptiles. | IV, Fish. | - | Warrington: | Printed by William Eyres, | for Benjamin White, at Horace's Head, | Fleet-Street, London. | MDCCLXXVI. 8c. 11.4, pp. 1425, 11. 3, pll. i-xii, xii*-lxxiii. 
1776. [Pennant, Thomas]-Continued.

Div. i. Cetaceous Fish $=$ Cetacea, pp. 47-74, spp. $16-26=11 \mathrm{spp}$. 1. Common Whale, p. $50=$ Baloena mysticetus; 2. Pike-headed Whale, p. 56=? Physalus antiquorum; 3. Fin Fish, p. 57 $=$ ? Physalus antiquorum; 4. Round-lipped Whale, p. $58=$ ? Physalus antiquorum; 5 . Beaked Whale, p. 59, pl. $\nabla$, fig. $1=$ Hyperoodon bidens; 6. Blunt-headed Cachalot, p. 61, pl. vi, animal from Robertson = Physeter macrocephalus; 7 . Round-headed Cachalot, p. 63, pl. vii, fig. 22 , tooth; 8. High-finned Cachalot, p. $63=$ Physeter macrocephalus ; 9. Dolphin, p. $65=$ Delphinus delphis; 10. Porpesse, p. $69=$ Phocana communis; 11. Grampus, p. $72=$ Orca gladiator.

The references to the plates in the text do not correspond with the numeration on the plates.

[339.]

1776. ㄴ. "Artikler hvorefter Commendeurerne og Mandskabet paa Skibene, der udsendes for den Gronlandske Handel og Fiskefangst, skulle rette sig (1776). (Reglementen waarnaar de Kommandeurs zich te gedragen hebben.)"

Not seen; title from Bosgoed, l. c., p. 232, no. 3421.

1777. Erxleben, J. C. P. Io[hannus]. Christ[ianus]. Polyc[arpus]. Erxleben 1 ... [ =titles, 5 lines ] | Systema | Regni Animalis | per | Classes, Ordines, Genera, | Species, Varietates | cvm | Synonymia et Historia Animalivm. | - | Classis I | Mammalia. | [Vignette.] | - | Lipsiæ | Impensis | Weygandianis. | MDCCLXXVII. 80. pp. i-xlviii, 1-636, 11.32, unpaged. Preface dated Goettingae, mense Nouembri, $\mathrm{CI}_{\mathrm{D}} \mathrm{I}_{\mathrm{D}} \mathrm{CCLXXVI}=1776$.

Collation: Dedicatio ad Georgio III, pp.iii-vi; Praefatio, pp. vii-x; Catalogus voluminum eorumque editionem quibus vsus sum, pp. xi-xxviii; Synopses et diagnoses generam, pp. xxix-xiviii; Species, pp. 1-628; Additamenta, pp. 629-631; Nomina Hvngarica mammalivm. pp. 632-636; Index generum, 1 p.+3 ll. unnumbered; Index synonymorvm, $28 \mathrm{ll}$. unpaged; Index synonymorvm Graecorvm, et Index synonymorvm Rvssicorvm, 3 ll. unpaged; Errata, 1 p.

Trichechus (=Sirenia+Walruses), pp. 593-600. 1. T. Rosmarus, pp. 593-596; 2. T. Manatus, pp. 596-599 (=genn. Manatus et Rhytina); 3. T. Dugung, p. 599. Species obscuræ (=Bieluga, Steller, et Sea Ape, Pennant=sp. fict.), pp. 599, 600.

[Cetacea], pp.601-628; genera 48-51=4; spp. 13, to wit: 1. Balcena 1Yysticetus, pp. 601-605; 2. B. Physalus, 605-607; 3. B. Boops, pp. 608, 609; 4. B. Musculus, pp. 609, 610; 5. B. gibbosa, pp. 610,611; Species obscura, p. 611; 6. Physeter Catodon, pp. 611, 612; 7. P. macrocephalus, pp. 612-614; 8. P. microps, pp. 614, 615; 9. P. Tursio, pp. 615, 616; Species obscuræ (= Beluga catodon; Physeter macrocephalus = Spermaceti Whale of Dudley; Anderson's Second species of Cachalot=Physeter macrocephalus), pp. 616, 618; 10. Delphinus Phocaena, pp. $618-621$; 11. D. Delphis, pp. 621-623; 12. D. Orca, pp. 623-626; 13. Monodon Monoceros, pp. 626-628.

Baloena gibbosa, p. 610, sp.n.; not Scrag Whale, Dudley, as usually stated, which is one of the "Species obscuræ" not formally recognized, although some of the synonyms cited under B. gibbosa may cover Dudley's ScragoW hale, which Erxleben cites (or the species based on it) at p. 607, at the end of his account of his Baloena physalus.

The author very justly observes: "Cetorum species pauciores recte cognitae: videtar horum historia denuo fere inchoanda" (p. 601). His treatment of the subject is judicious, being superior, perhaps, to that of any other systematist of the eighteenth century. While still retaining a few species proved later to be merely nominal, he relegated to the list of "Species obscuræ" several which had been current] y recognized by previous compilers. [341.]

1777. "HermanN, JoA. Tabula affinitatum animalium; brevi commentario illustrata. 40. Argentorati, 1777."

Not seen; title from Carus and Engelmann.

1777. Phipps, C. J. Reise | nach dem Nordpol. | Auf Befehl Ihro Konigl. Grossbrittannischen Majeståt. | Unternommen im Jahr 1773. | Von C. J. Phipps, | aus dem Englischen, | Mit | Zusåtzen und Anmerkungen von Herrn Landvogt [Samuel] Engel. | - | Mit Kupfern. | - | [Design.] Bern, | - | bey der typographischen Gesellschaft 1777. | 4․ 11. 3, pp. i-x; 1. 1, pp.1-122; 11. 2, pp. 1-304; 1. 1, maps and pll.

Mammalia [of Spitzbergen], pp. 95-97. 1. Balcena mysticetus; 2. Baloena physalus, p. 97.

1777. Scopoli, J. A. Ioannis Ant. Scopoli | Philos. et Med. Doct. Caesareae Regiaeqve | Maiestatis a consiliis in rebrs metallicis, | chemiae ac botanices Professoris in | regio archigymnasio Ticinensi \&c. | Introdvctio | ad | Historiam | Natvralem | sistens | genera | Lapidvm, Plantarvm, | et |.Animalivm | hac- 
1777. Scopoli, J. A.-Continued.

tenvs detecta, | caracteribvs essentialibvs donata, | in tribvs divisa, | svbinde ad leges natvrae. | [Vignette.] | - | Sur un plan nouveau, toutes connoissances anciennes |\& nouvelles. Adanson. | - | Pragae | Apvd Wolfgangrm Gerle, Bibliopolam. | MDCCLXXVII. 80. 11. 5, pp. 1-506,11. 17.

Tribus xii, Kleinii (Mammalia). Gens i, Cetacea, p. 486, [genera] 428-431, viz: Balena (=Mysticete auct. mod.), Physeter, Monodon, Delphinv8. Gens ii. Quadrvpedia. Divisio i, Aqvatilia.-[Genus] 432. Manatv8, Rondelet, p. 490.

[344.]

1778. Axon. "Echt historisch Verhaal zo uit de mond als pen, vau drie zeelieden, " wegens het verongelukken van het schip, de Wilhelmina van de Helder, alsook de noodlottige en droevige ongelukken van nog negen andere schepen, dewelke alle verongelukt zijn in Groenland, door de bezetting van het Westijs, in den jare 1777. Amsterdam, 1778. 40. 36 bladz."

Bosgoed, from whose work (op. cit., p. 249, no. 3575) the above title is taken, states that a German translation appeared at Bremen in 1779, of which Lindeman gives an abstract in his "Arktische Fischerei," pp. 37-46. See 1778. AxoN.

[345.]

1778. Czexprnski, P. DE. Pauli de Czenpinski, | Nobilis Poloni Varsoviensis. | Dissertatio | inauguralis | Zoologico-Medica, | sistens | totius Regni Animalis | Genera, | in Classes et Ordines Linnæana | Methodo digesta, | Præfixa cuilibet classi terminorum | explicatione. | [Vignette.] - | Viennæ, | typis Joan Thom. nob. de Trattnern, | Sac. Cæs. Reg. Maj. Typog. et Bibl. | - | 1778. 8०. 11.4, pp. 1-122, 1.1.

i. Cete, p. 114. Genera 1. Monodon; 2. Delphinus; 3. Physeter; 4. Balcena.

1778. Ferber, - ["Bereitung des Wallraths."] <Neue Beyträge zur Mineralgeschichte, i, 1778, p. 366.

Not seen; reference from Donndorff, Zool. Beytr., i, 1792, p. 777.

1778. "Jansen, Marten. Kort, doch echt verhael wegens het verongelukken van zyn schip, genaemt: het Witte paard, en nog negen andere schepen, dewelke alle verongelukt zijn in Groenlandt ten jaere 177\%. Waarby nog copia van een brief van commandeur Hidde Dirks Kat, aan zijn huisvrouw, geschreven uit straat Davis. Amsterdam, Nic. Bijl. 1778. 4०. 18 bladz."

"Eene andere uitgave, Leeuwarden, 1778. 4०. 23 bladz."

Not seen; from Bosgoed, op. cit., p. 239, no. 3486.

1778. [RöPER, JÜRGEN.] "Wahrhafte Nachricht von den im Jahre 1777, auf den Walfischfang nach Grönland anfgegangenen und daselbst verunglückten fünf Hamburger Schiffen gezogen aus dem Journal des Küpers Jürgen Röper, auf dem Schiffe genannt Sara Cecilia, Kommandeur Hans Pieters. Altona, 1778."

"Lindeman geeft in zijne 'Arktische Fischerei,' bl. 49, een uittreksel van dit Journaal."

Not seen; title and comment from Bosgoed, op. cit., p. 251, no. 3596.

[349.]

1778-83. Zimmermans, E. A. W. Geographische / Geschichte | des Menschen, | und der | allgemein verbreiteten vierfüssigen Thiere, | nebst einer hieher gehórigen | zoologischen Weltcharte, | von | E[berhard]. A[ugust]. W[ilhelm]. Zimmermann, | Professor am Kollegio Karolino zu Braunschweig. | - | Erster Band. [Vignette.] - | Leipzig, | in der Weygandschen Buchhandlung | 1778. 8. 11. 8, pp. 1-308. Mit ein Chart. Tabvla Mvndi | Geographico Zoologica | sistens | Qvadrvpedes | hucusque notos sedibus suis adscriptos | edidit | E. A. W. Zimmermann. | Aug. Wilh. Knoch delineavit.

Achtzehnter Abschnitt. Der Manate, pp. 253-255.

[Zweiter Band.] Geographische | Geschichte | des Menschen, | und | der vierfússigen Thiere. | - | Zweiter Band. Enthålt ein vollståndiges Verzeichniss aller | bekannten Quadrupeden, | von | E. A. W. Zimmermann, | Professor der Mathematik und Naturlehre am Kollegio Karolino | zu Braunschweig. | [Vignette.] - | Leipzig, | in der Weygandschen Buchhandlung. | $17808^{\circ}$. 1l. 4, pp. 1-432.

XLIU. Geschlecht. Das Walross, Trichechus. Enthält das Wallross (T. Rosmarus), und der Dugong (T. Dugung). XLIV. Geschlecht. Der Manate. Enthält Der Manati von Kamtschatka (MPanati gigas), und der kleinere Manati (Trichechus Manatus, Linn.). 


\section{8-83. Zimmermann, E. A. W.-Continued.}

[Dritter Band.] Geographische | Geschichte | des Menschen, | und der | allgemein verbreiteteu vierfússigen Thiere, $|-|$ mit einer hiezu gehórigen zoologischen Weltcharte, | - | von |E. A. W. Zimmermann, | Professor der Mathematik und Physik in Braunschweig und Mitglied/verschiedener gelehrten Gesellschaften. | - | Dritter Band. | - | Leipzig, |in der Weygandschen Buchhandlung | 1783. 8०. 11. 5, pp. 1-278.

1779. Axon. "Historisch wahre Nachricht von dem Eland und Drangsalen des im Jahre 1777 auf den Walfischfang nach Grönland abgefahrenen, verunglückten Schiffes "Wilhelmina" unter dem Commandeur Jakob Henrich Broertjes, aus dem Holländischen Tagebuch und mündlicher Erzählung der drei Matrosen Harm Henrich Kröger, Harm Henrich Kröger der Sohn, beide von Altenesch im Delmenhorstischen, und Kasten Külke aus Lessum, eine Meile von Bremen,-übersetzt. Bremen, George Ludwig Förster. 1779."

Not seen; title from Lindeman, Arktische Fischerei, 1869, p. 37. A German translation of the Dutch "Echte historisch Verhael," etc., 1778, q. v.

[351.]

1779. Chemsiz, T. H. Von der balaena rostrata oder dem Schnabelfische. < Beschaft. d. Berlinischen Gesellsch. Naturf. Freunde, iv, 1779, pp: 183-189.

Hyperoodon rostrata.

1779. "Graumans, Petr. Bened. Chstr. Brevis introductio in historiam naturalem animalium mammalium in nsum auditorum, cui accedit noinenclatura omnium hujus classis civium, una cum charactere generico, et spécifico, denominatione germanica ac designatione iconum. 80. Rostochii, 1779. pp. 90."

Not seen; title from Carus and Engelmann. Cited by Donndorff, Zool. Beytr., i, 1792. [353.]

1779. "HrJlkes, R. Merkwaardig verhaal van Reinier Hijlkes als matrcos, met het schip: de hopende Visser, commandeur Volkert Jansz. ten jare 1777 na Groenland uitgevaren op de walvisvangst en aldaar met 9 andere schepen verongelukt. Amsterdam. 1779. 4․ 11 bladz."

Not seen; from Bosgoed, op. cit., p. 239, no. 3484.

1780. Clavigero, F.S. Storia antica | del Messico | cavata da' migliori storici Spagnuoli, | e da' manoscritti, e dalle pitture antiche degl' Indiani : | Divisi in dieci Libri, I e corredata di carte geografiche, | e di varie figure: | e | Dissertazioni | Sulla Terra, sngli Animali, e sugli abitatori del Messico. | Opera | dell Abate | D. Francesco Saverio | Clavigero | - | Tomo I [-IV.] | - [ Design.] In Cesena MDCCLXXX. | - | Per Gregorio Biasni all' Insegna di Pallade | Con Licenza de' Superiori. . 4. 4 vols. Vol. i, pp. i-viii, 1-302, map, pll.; vol. ii, pp. 1-276; vol. iii, pp. 1-260; vol. iv, pp. 1-331.

Il Manati o sia Lamentino, vol. i, pp. 100, 101. See Cullen's English transl. under 1787. [355.]

1780. Fabricius, O. Favna / Groenlandica, | systematice sistens | Animalia Groenlandiae occiden- | talis hactenvs indagata, qvoad nomen | specificvm, triviale, vernacvlvmqve; synonyma aveto- | rvm plvrivm, descriptionem, locvm, victvm, genera- | tionvm, mores, vsvm, captvramqve singvli, provt | detegendi occasio fvit, naximaqve parte secvn- | dvm proprias observationes / Othonis Fabricii | Ministri Evangelii, qvondam Groen- | landis ad Coloniam Friderichshaab, posthac Norvagis | Drangedaliæ, nvnc vero Danis hopvnti ivtiae, Mem- | bri Societatis Scientiarvm qvae est Hafniae. | [Vignette.] - | Hafniae et Lipsiae, | Impensis Ioanis Gottlob Rothe, | avlae atqve vnivers. Reg. Bibliopolae. | MDCCLXXX. 80. pp. i-xvi, 1-452, pl. 1.

Cetacea, pp. 29-52, spp. 18-32, to wit: 1. Monodon Monoceros, p. 29; 2. Monodon Spvrivs, p. $31=$ Hyperoodon rostratus; 3. Balaena Mysticetvs, p. 32 ; 4. Balaena Physalvs, p. $35=$ Physalus antiquorum; 5. Balaena Boops, p. $36=$ ? Physalus antiquorum; 6. Balaena mvscvlvs, p. $39=$ B. biscayensis; 7. Balaena rostrata, p. $40=$ Baloenoptera rostrata ; 8. Physcter macrocephalvs, p. 41; 9. Physeter Catodon, p. $44=$ Physeter tursio, L.; 10. Physeter microps, p. 44; 11. Delphinvs Orca, p. $46=$ Orca gladiator; 12. Delphinvs Phocaena, p. $46=$ Phoccena communis; 13. Delphinvs Delphis, p. 48; 14. Delphinvs Tursio, p. $49=$ Orea gladiator; 15. Delphinvs albicans, p. $50=$ Beluga catodon.

Monodon spurius, Balcena rostrata, spp. nn. 15 spp., 12 valid. Synonymy, diagnoses, distribution, etc. 
1780. "Gatterer, ChpH. Wrlh. Jac. Breviarum zoologiae Pars I. Mammalia. 8 maj. Gottingae, 1\%30."

Not seen; title from Carus and Engelmann. Cited by Donndorff, Zool. Beytr., i, 1792. [357.]

1780. Launay, M. DE. Mémoire sur l'origine des Fossiles accidentels des Provinces Belgiques. <Mém. de l'Acad. imp. et roy. des Sci. et Bell.-Lett. de Bruxelles, ii, 1780 , pp. 531-585.

Brief reference (p. 335) to remains of a supposed skeleton of a Crocodile, here identified as that of an Orca, and also to other Cretacean remains.

1780. ManN, L'Abbé. Mémoire sur l'Histoire naturelle de la Mer du Nord, \& sur la Pêche qui s'y fait. <Mém. de l'Acad. imp. et roy.des. Sci. et Bell.-Lett. de Br'uxelles, ii, 1780, pp. 157-220.

Cétacés, p. 197.

"26. Les especes de poissons qui habitent on qui fréquentent la mer du nord, sont les suivantes, savoir:

"Cete-le Cachelot.

"Balcena-la Baleine.

"Physeter-la Sédenette.

"Monoceros-lo Narhwal.

"Ces quatres especes de poissons n'habitent point la mer du nord, mais ils y viennent quelquefois de l'océan septentrional, surtout dans les hyvers rudes. On a eu l'exemple de baleines jettées sur la côte de Flandre" ... (p. 1977).

[359.]

1780. "SÉrionNe, A. DE. Hollands rijkdom, behelzende den oorsprong van den koophandel, en van de magt van dezen staat; de toenemende vermeerdering van deszelfs koophandel en scheepvaart, enz. Uit het Fransch vertaald. Vervolgens overgezien, merkelijk veranderd, vermeerderd en van verscheiden misslagen gezuiverd door El. Luzac. Leyden, Luzac en van Dame, 1780. 4 dln. gr. 8०."

Noordsche visscherij en koophandel, i, pp. 345-350. Walvischvangst, ii, pp. 275-280.

Not seen; title and references from Bosgoed, op. cit., p. 210, no. 3167.

1780. Witry, L' Abbé De. Mémoire sur les fossiles du Tournaisis, et les pétrifactions en général, relativement à leur utilité pour la vie civile. <Mém. de l'Acad. imp. et roy. des Sci. et Bell.-Lett. de. Bruxelles, iii, 1780, pp. 11-44, pl. i-iii.

A reference of four lines to remains of "poissons marins ... qui paroissent avoir appartenu à des animanx cétacés" (p. 21).

[361.]

1780-84. "Borowski, G. H. Gemeinnützige Naturgeschichte des Thierreichs, darinnen die merkwürdigsten und nützlichsten Thiere in systemat. Ordnung beschrieben und alle Geschlechter in Abbildungen nach der Natur vorgestellt werden. Mit den Kupfertaf. 1-228. Berlin und Stralsund, Lange, 1780-84. 5 dln. gr. $80^{\circ}$,

"1. Bd. Säugethiere. Mit 48 Kpfrtaf. 2. Bd. Wallfische, Vögel. Mit $\$ 8$ Kpfrtaf. 8. Vögel. Mit 48 Kpfrtaf. 4. Amphibien. Mit 36 Kpfrtaf. 5. Hische. Mit 42 Kpfrtaf."

Not seen; title from Carus and Engelmann. Cited by Donndorff, Zool. Beytr., i, 1792. [362.]

1780-84. "Gilir, Fulppo Salvadore. Saggio di Storia Americana, o sia Storia Naturale, Civile, e Sacra de Regni, o delle provincie Spanuole di Terra-ferma nell' America Meridionale. 4 vols. 8०. Roma, 1780, '81, '82, '84."

Not seen; title from Carus and Engelmann. Have seen this work referred to as containing (vol. i, p. 84, fig. 1) an account of the Manatee, with a figure.

[363.]

1781. E[RIKsson], J. Um Marsvina rekstr. <Rit dess Islenzka Lardoms-Lista Felags [ii], 1782, pp. 73-96.

I. Kap. Um adferd Medalfarar manna, pp. 73-85; II. Kap. Um adferd Fœreyinga og Sunnmæra, pp. 85-96.

[364.]

1781. Fabricius, Otho. Om Hvalaaset. <Nye Saml. Kong. Danske Videnskabers Selskabs Skrifter, 1781, pp. 557-378 (i. e. 578), figg. 1-4.

1781. Gronovius, Laur [entuus] Theod [orus]. .Zoophylacium / Gronovianum, | exhibens | Animalia | Quadrupeda, Amphibia, | Pisces, Insecta, Vermes, | Mollusca, Testacea, | et Zoophyta, | Quae in Museo suo adservavit, examini | subjecit, systematice disposuit | atque descripsit | Laur. Theod. Gronovius, 
1781. Gronovius, Laur [extius] Theod[orus]-Continued.

J. U.D. | Civitatis Lugduno Batavæ Senator, Societatis physico- | medicæ regire Londinensis, Basilæensis, | atque Hollandicæ Socius. | Additis rarissimorum objectorum iconismis. | - | Lugduni Batavorum, | Apud | Theodorum Haak et Socium | et | Samuelem et Johannem Luchtmans. | MDCCLXXXI. [3 fasc. paged continuously.] fol. 11. 5, pp. 1-380, 11. 10, pp. i-vi, pll. 21.

This is a reissue of the first and second fasc. of the Zoophylacii [pp. 1-236]+fasc. iii, Vermes, etc., 1781, pp. 237-380.

The Cetacean matter is therefore the same as in the editio princeps, q. v., at 1763.

1781. [Pennant, Thomas.] History | of | Quadrupeds. | Vol. I [II] | [Coat of arms.] London. | Printed for B. White, Fleet Street. | MDCCLXXXI. 2 vols. $4^{\circ}$. Vol. i, 1. 1, pp. i-xxiv, 1-284; vol. ii, 1. 1, pp. 285-566, 11. 7.

Sirenia, pp. 536-545, to wit: 1. Whale-tailed Manati, pp. 536-539; 2. Round-tailed Manati, pp. 540-544; 3. Sea Ape, pp. 544, 545. The first is primarily Steller's Sea Cow ; the second includes both the American and African Manatees; the last is a sp. myth.

[367.]

1781. "Westerwout, J. Dibietz. Beknopte beschrijving der XVII Nederlandsche provinciën, waarin den oorsprong en opkomst dezer landen aangetoond wordt. Nijmegen, Is. vau Campen, 1781. gr. $8^{\circ}$."

"... Visscherij; Haringvangst; Walvischvangst, pp. 467-486."

Title and reference from Bosgoed, op. cit., p. 213, no. 3188.

1782. Buffon, [G. L. LEclerc DE.] Histoire | Naturelle, | génórale et particulière. | Par M. le Compte [George Lonis Leclere] de Buffon, Intendant du | Jardin \& du Cabinet du Roi, de l'Acadómie | Françoise, de celle des Sciences, \&c. | - | Supplément, Tome Sixième. | - [ [Arms.] A Paris, / de l'Imprimerie Royale. | - M. DCCLXXXII. 40. pp. i-viij, 1-405, i-xxr, pll. i-xlix.

Les Lamantins, pp. 381-384. Le grand Lamantin de Kamtschatka, 385-395. Le grand Lamantin des Antilles, pp. 396-398. Le grand Lamantin de la mer des Indes, p. 399. Lo petit Lamantin d'Amérique, pp. 400-402. Le petit Lamantin du Sénégal, pp.403-405.

[369.]

1782. Duhamel du Monceau, M. Traité Général | des Pêches, / et / Histoire des Poissons | qu'elles fournissent, | tant pour la subsistance des hommes, | que pour plusieurs autres usages | qui ont rapport aux Arts et an Commerce. | Par M. Du hamel du Monceau, de l'Ácadémie Royale des Sciences; $1 \ldots$. [ = titles, 3 lines]. | - | Suite de la Seconde Partie. | - | Tome Quatrieme. | [Design.] A Paris, | Chez Veuve Desaint, Libraire, rue du Foin Saint-Jacques. | - | M. DCC. LXXXII. | Avec Approbation, et Privilége du Roi. 4 vols. $2^{\circ}$.

Traité général des Péches et Histoire des Poissons, ou des animaux qui vivent dans l'eau. Suite de la seconde Partie. Tome iv. Dixieme Section. Des Poissons Cetacées, \& des Amphibies. pp. 1-73, pll. i-xv.

Introduction, pp. 1, 2. Chap. i. De la Baleine, \& des Poissons qui y ont rapport, pp. 2, 3. Art. i. De la Baleine franche; Cete; Balæna vulgaris, edentula, dorso non pinnato, Raii, pp. 4-9, pl. i, figg. 1, 2. Art. ii. Des différents lienx où l'on trouve des Baleines, pp. 9-11. Art. iii. Détails relatifs aux Navires qu'on destine pour faire la pêche des Baleines au Nord dans les glaces, p. 11, pl. i, fig. 3 , pl. iii, fig. 3. Art. iv. Détail sommaire des utensils nécessaires pour la p6che, pp. 11, 12, pl. ii. Art. v. De la disposition des glaces au Nord, pp. 12, 13. Art. vi. De la nourriture des Baleines, p. 13. Art. vii. De la pêche des Sardes, ou petites Baleines, que je soupçonne être le Nord-Kaper, p. 14. Art. viii. Des endroits où l'on fait les Armements, p. 14. Art. ix. Sur les gages des Equipages, pp. 14, 15. Art. x. Etat des effets, dont ceux qui forment l'équipage doivent se fournir pour faire une campagne de pêche, p. 15. Art. xi. De la Nourriture des Equipages, p. 15. Art. xii. De la pêche des Baleines en général, pp. 16-18. (\$1. Des Harpons. $\S 2$. Des Lances. $\S 3$. Des Crocs. $\S 4$. Des Couteaux.) Art. xiii. De la péche des Baleines, particulierement avec les harpons, pp. 18, 19. Art. xir. De l'Embarquement des Chaloupes, pp. 19, 20. Art. xv. De la maniere de lever le gras, ou de découper les grandes Baleines pour en retirer l'huile, pp. 20, 21. Art. xvi. Méthode pour retirer l'huile des Baleines, p. 22. Art. xvii. Sur la jauge des futailles, p. 23. Art. xriii. Des différentes qualitó \& nature des huiles de Baleine, pp. 23, 24. Art. xix. Exposé sommaire de la pêche des Baleines en différents Parages, \& de la pêche accidentelle de ces poissons, pp. 24-29. (\$1. De la pêche aux côtes de Biscaye, de Galice \& de Saint-Jean-de-Luz. § 2. Lo la Pêche aux Côtes d'Angleterre. $\$ 3$. De la pécho des Baleines par les Groenlandois. $§ 4$. De la péche en Schetland, ou Hithland. §5. De la pêche en Norwege. §6. De la pếche de la Baleine en Russie. $\$ 7$. De la péche par les Hollandois à Spitzberg. $\S 8$. De la pêche des Baleines au Japon. $\S 9$. De la pêche des Baleines à la Corée. $\$ 10$. De la maniere de prendre 


\section{Duhamel DU Moncead, M.-Continued.}

les Baleines à la Floride, dans l'A mérique Septentrionale, par les Saurages du pays. $\$ 11$. Description des Chaloupes qui servent pour prendre des Baleines dans les environs du Canada. §12. Idée générale des pêches qu'on fait à Sinigaglia, jolie petite Ville sitúé au bord de la Mer Adriatique.) Art. xx. Sur les ennemis des Baleines, pp. 29-31. Art. xxi. De l'Ambre gris; A mbra grisea, pp. 31, 32.

Chap. ii. Des Cétaceés. Art. i. Du Cachalot, pp. 33-36. Art. ii. Des Souffleurs, pp. 36-37. Art. iii. Des Marsouins, Tursio; en Breton Meroch; par quelques-uns, Souffleur, pp. 38-42. (\$1. Du grand Marsouin, que plusieurs nomment Souffeur, p. 41. \$2. Du Marsouin à museau arrondi; Tursio ou Phoccena, qu'on regarde comme le rrai Marsouin (figg. 5 \& 6).) Art. iv. Des Dauphins, pp. 42-45.

Chap. iii. Des Amphibies, p. 45. Art. i. Du Loup, Vean Marin, on Phoque; Phoca, pp. 45-51. Art.ii. Description d'un petit Phoque noir, a poil fin \& ondé, pp. 51, 52. Art. iii. D'un petit Phoque, copié sur le dessein qui est dans l'Histoire Naturelle de M. de Buffon, tome xiii, p. 52. Art. iv. Lettre de M. Frameris, sur les Phoques qu'on prend dans les Mers du Nord, pp. 52, 53. Art. v. Description d'un Phoque qui aroit eté péché dans notre Océan Septentrional, \& apporté à Dieppe en 1723, fig. 5, p. 53. Art. vi. Deseription d'un Phoque de la Mediterranée, envoyé de Marseille, pp. 53,54. Art. vii. De quelques Phoques, qu'on a conservé vivans dans plusieurs endroits, pp. 54-56. Art. viii. Du Lamentin, pp. 56, 57. De la péche des Lamentins, pp. 57-59. Art.ix. De la Vache marine, ou Poisson à la grande deut, Morse d'Islande \& du Groenland; Odobenus, ou Rosmarus,pp. 59-61. Art. x. De plusieurs antres Amphibies, \& particuliẻrement du Lion Marin; Leo Marinus, p. 61.

Explication des planches, pp. 62-66. Notice géographique des principaux lieux dont il est fait mention dans cette dixieme Section, pp.67-70. Table Alphabetique, p.71. Table des Chapitres et Articles, pp. 72, 73. Errata, etc., p. 73.

Pl. i. Baleine franche, fig. 1, mâle; fig. 2, femelle; fig. 3, deux chaloupes qui poursuirent une Baleine; figg. 4-6, fanons. Pl. ii. Instruments pour la pêche des Baleines. Pl. iii-viii. Péche des Baleines. Pl. ix, fig. 1, Cachalot d'Anderson; fig. 2, 3, Souffleurs; fig. 4, Souffleur du fleuve Saint-Laurent; fig. 5, Marsouin; fig. 6, Mulard de Rondelet; fig. 7, squélette de la mâchoire inférieure d'un Cachalot. Pl. x. Des Marsouins, 8 figg. Pll. xi, xii. Des Loups Marins, ou Phqques. Pl. xiii. Du Lamentin et du Pêche du même. Pl. xív. De la Vache Marine: fig. 1, Vache Marine avec son petit; fig. 2, squelette d'une tête de Vache Marine; fig. 3, Tuerie de differents Cetacées. Pl.xv, fig. 1, Pescheurs Groenlandois; fig. 2, Lion Marin avec sa Lionne; fig. 3, Cachalot Male.

Dukamel's work was, for its time, a thorongh presentation of the subject, relating, as its title implies, to the subject of the fisheries rather than to the natural history of fishes, although of importance in this relation, especially from the numerous original figures giren. Those of the Cetacea, however, are in part copies from those of earlier writers, some of them more or less modified. His account of the Whalefishery, in relation to the capture and subsequent treatment of the animals, is detailed and very fully illustrated in the plates, and forms a valuable contribution to the history of the subject.

[370.]

1782. Le Grand D'Aussy. "Histoire de la vie privée des Français, depuis l'origine de la nation jusqu'à nos jour. Paris, Imprimerie de Ph. D. Pierres. 1782. 3 dln. gr. $80 . "$

Pêche de la Baleine chez les Basques, ii, pp. 68-77.

Not seen; title and reference from Bosgoed, op. cit., p. 237, no. 3465.

1782. St. Johx [DE Crìveceur], J. Hector. Letters | from an | American Farmer; | describing | certain provincial situations, | manners, and customs, | not generally known; | and conveying | some idea of the late and present | interior circumstances | of the | British Colonies | in | North America. | - | Written for the information of a Friend | in England, | By J. Hector St. John [do Crèvecœur], | A farmer in Pennsylvania. | - | London, | Priuted for Thomas Davies in Russel Street, Covent- | Garden, and Lockyer Davis in Holborn. | M DCC LXXXII. $8^{\circ}$. 11. 8, pp. 1-318, 2 maps.

Letter v. Customary Education and Employment of the Inhabitants of Nantucket, pp. 150-158 (relates mainly to the Whalefishery of this island). Letter vi. Description of the Island of Martha's Vineyard; and of the Whale Fishery, pp. 159-176. Pp. 162-176 relate to the Whalefishery, describing the character, size, and outfit of the vessels employed, the man. ner of capturing Whales, "cutting in," and care of the products, etc. At p. 169 is a list of "the names and principal characteristics of the various species of Whales known to these people" of Nantucket; 11 species being enumerated and briefly described. There are also statistics of the Nantucket Whalefishery for the year 1769. [In the French ed. of 1767 the letter about the Whalefishery is dated "Nantucket, 17 Octobre 1772."] 
1782. St. John [DE Crìvecceur], J. Hector-Continued.

A "New Edition, with an Accurate Index," appeared in 1783, textually the same as the prosent. There are also later editions in English (that of 1793 is given infrà), and in French, the author himself translating and publishing his "Letters" in that language in 1784 ( $q . v$.; see, also, under 1787). Also of. Rich, Bibliotheca Americana Nova, p. 302.

1782-84. "Bock, Friedr. SAM. Versuch einer wirtschaftl. Naturgesch. von Ost- u. West-preussen. 5 Bde. Mit Kpfrn. gr. $8^{\circ}$. Dessau, 1782-84."

Not seen; title from Carus and Engelmann. Cited by Donndorff, Zool. Beytr., i, 1792, p. 782.

[373.]

1783. "Hermans, JoA. Tabula affinitatum animalium, per totum animale regnum in tribus foliis exposita, olim academico specimine edita, nunc uberiore commentario illustrata, cum annotationibus ad historiam naturalem animalium augendam fascientibus. 4c. Argentorati, 1783."

Not seen; title from Carus and Engelmann. Cited by Donndorff and others.

[374.]

1783. [LoNdoN SOcIETY FOR, etc.] [Gun Harpoons.] <Trans. London Soc. for Encour. Arts, Man., and Com., i, 1783, pp. 42, 215.

"Whale-Fishery," p. 42 (announcement of the successful introduction of the gun har. poon). "Gun for throwing Harpoons," p. 215 (prize offered for improvement in its construction). "Harpoon to be thrown by a Gan," p. 215 (prize offered for improvements in its construction). These offers, as also a prize for the captnre of Whales by use of the harpoon gur, were annually renewed by the society for many years. See the society's Trans., 1784 et 8 eq.

[375.]

1783. Schwediawer, F. X. An Account of Ambergrise. . . < < Philos. Trans. Lond., lxxiii, pt. 1, art. xv, 1783, pp. 226-241.

A detailed account of nature, mode of occurrence, and use of ambergris and sperma. ceti.

[376.]

1784. Boddaert, P. P. Boddaert med. doct. $\mid \ldots$. [ $=$ titles, 7 lines $] \mid$ Elenchus Animalium. | Volumen I. | Sistens Quadrupedia huc usque nota, | eorumque varietates. | Ad ductum Naturæ, quantum fieri potuit disposita. | - | . . . [=motto, 6 lines]. | - Roterodami, | Apud C. R. Hake. | MDCCLXXXIV. 8. pp. i-xxxviii, $1-174$.

The Cetacea are not included. The Sirenia are: 1. Rosmarus Indicus, p. $169=$ Indian Walrus, Pennant and Dugon, Buffon; 2. Manati Trichechus, p. 173=The Broad-tailed Manati, Pennant; 3. Manatus Baloenurus, p. $173=$ Whale-tailed Manati, Pennant, there. fore $=$ Rhytina borealis.

[377.]

1784. Chemsitz, T. H. Auszug aus einem Schreiben des Herrn Garnisonprediger Chemnitz zu Coppenhagen, an den Herrn O. C. R. Silberschlag, vom 29sten July, 1783. 5 Taf. Fig. 4 bis 7. <Schriften der Berlinischen Gesellschaft naturforscher Freunde, v, 1784, pp. 463-469.

Account of the capture of a "Nordkaper" "etwa zwischen Nenfundland nnd Issland," from the head of which were obtained examples of the Balanus polythalamius compressus, the same being here described and figured, etc.

1784. Foord, Humphrey. A short Account of the Invention of the Gun Harpoon, which has been introduced into the Greenland Fishery, by means of the Rewards bestowed by the Society; the utility of which will be manifested, by the Facts related in the following Letters. < Trans. London Soc. Encour. Art8, Man., and Com., ii, 1784, pp. 191-222, pl.

Acconnt of "an Harpoon to be fired from a Swivel Gun," invented by Abraham Staghold, in 1771, with a plate giving figures of the harpoon and gun, pp. 191-196. Six letters from Captain Humphrey Foord, giving accounts of the capture of Whales by the Gun Harpoon, and claiming premiums therefor, pp. 197-222. The account gives also the "length of bone" and yield of oil of several of the Whales thus taken.

[379.]

1784. "Leske, Nathax. GtFr. Anfangsgrïnde der Naturgesch. 1 Th. Allgem. Natur- u. Thiergeschichte, mit $12 \mathrm{Kpfr}$. 2 Aufl. gr. 8०. Leipzig, 1784."

Not seeu; title from Carus and Engelmann. Cited by Donndorff. The first edition is said to have appeared in 1779.

1784 (circa). Lichtexberg, Geo. ChPH. Potfisch. <Mag. für Neuste aus der Phys. u. Naturg., ii, (1784?), p. 204.

Not seen; title and reference based on Donndorff, Zool. Beytr., i, 1792, p. 777. 
1784. [ST. John dE CRÈvecceur, J. Hector.] Lettres | d'un | Cultivateur | Americain, | [J. Hector St. John Crèvecœur] Ecrites a W. S. Ecuyer, | Depuis l'Année 1770, jusqu'à 1781. | Traduites de l'Anglois par ***. | Tome Premier L iot Second]. | [Design.] A Paris, | Chez Cachet, Libraire, rue \& hotel Serpente. $1-\mid$ M. DCC. LXXXIV. 2 vols. $8^{\circ}$. Vol. i, pp. i-xxiv, i-iv, 1-422, 1. 1; vol. ii, 1l. 2, pp. i-iv, 1-400, 1. 1. [The copy here collated (Harvard College Library, 15332-22) contains manuscript corrections of numerous typographical errors and additions by the author, with his autograph.]

Septième Lettre. Pêche de la Baleine, vol. ii, pp. 147-157.

This is a much altered and enlarged version, more or less changed throughout, rather than a "translation," as the title-page implies, of the "Letters from an American Farmer" (London, 1782), with a dedication to the Marquis de Lafayette, which is dated "Now Yorck, 24 Septembre 1781," and signed "L'auteur \& Traducteur," with, in manuscript, the word "Cre. vecoeur" added in the copy examined. The matter relating to the Nantucket Whalefishery is substantially the same as that of the English ed. of $1782(q . v$.$) , of which it is, however, by$ no means a strict translation.

[382.]

1784. "SchNeIDER, J. G. Sammlung vermischter Abhandlungen zur Aufklürung der Zoologie und der Handelsgeschichte. Berlin, 1784. 8०."

"Zie aldaar: Kritische Sammlung von alten und neueren Nachrichten zur Naturgeschlohte der Wallfisehe, nebst der Geschichte ihres Fanges und des damit verbunden Handels, bl. 125-303."

Not seen; title and comment from Bosgoed, op. cit., p. 173, no. 2728.

1784-86. Axon. "De Walvischvangst met veele bijzonderheden daartoe betrekkelijk. Amsterdam en Harlingen, bij P. Conradi en V. van der Plaats, 178486. 4 dln. $4^{\circ} . "$

Not seen; title from Bosgoed (op. cit., p. 250, no. 3583), who gives as a new edition of thls work the Nieuwe beschrijving der Walfischvangst, etc., 1791, q. v.

1785. Daubenton, [L. J. M.] Observations sur un grand os qui a été trouvé en terre dans Paris; et sur la conformation des Os de la tête des Cétacées. < Hist. de l'Acad. roy. des Sci. de Paris, ann. 1782 (1785), pp. 211-218, pll. iv-vi.

Pl. iv, tête d'un petit Cachalot; pll. v, vi, tête du Dauphin.

1785. "Gatterer, СhPH. Wilh. Jac. Naturhist. A-B-C-Buch, od. Abbild. u. Beschreib. merkwurd. Thiere. 1785. 3 Aufl. 1799. Mit Kpfr. 80."

Not seen; title from Carus and Engelmann.

1785. Halcrow, Sinclear. [Account of capture of a Whale by use of the Harpoon Gun.] <Trans. London Soc. Encour. Arts, Man., and Com., iii, 1785, pp. 154157.

1785. Monro, A. The | Structure and Physiology | of | Fishes | explained, | and | compared | with those of | Man and other Animals. | - | Illustrated with Figures. | - | By Alexander Monro, M. D. | Fellow of the Royal College of Physicians, | and of the Royal Society, | and | Professor of Physic, Anatomy, and Surgery, in the University | of | Edinburgh. | CE | Edinburgh: | Printed for Charles Elliot, Edinburgh; And G. G. J. and J. Robinson, London. | - M, DCC, LXXXV. 2०. pp. 1-128, pll. i-xliv.

Of the Ear in Cetaceous Fishes, pp. 45, 46, 109-112, pl. xxxv, figg. 19 ("Nose, mouth, ear, and largnx of a Porpess").

[388.]

1785. Pontoppidan, C. Hval-og Robbefangsten | udi | Strat-Davis, ved Spitsbergen, og under | Eilandet Jan Mayen, | samt | dens vigtige Fordele, | i Anledning | af den Kongel. allern. Placat af 13 Octbr. 1784; | tilligemed | nogle oplysende Efterretuinger om Fangsten, Behandilings- | maaden, m. m. | ved | Carl Pontoppidan, | Kongel. Maj. virkelig Justiceraad og medadministrerende Directeur | ved den Kongel. Islandiske, Finmarske, \&c. \&c. Handel. | [Vignette.] | - | Hermed f $\phi$ lger et Kobber. | - | Kiфbenhavu 1785. | Trykt paa Syldendals Forlag, | hos Frid. Wilh. Thiele. 80. 11. 3, pp. 1-124.

1785. "Wrtsen, Nic. Noord en Oost Tartarijen; behelzende eene beschrijving van verscheidene Tartersche en nabuurige gewesten, in de noorder en oostelijke deelen van Aziën en Europa. Zedert naauwkeurig onderzoek vau veele Jaren, 
1785. "Witsen, Nic.-Continued.

en eigen ondervinding ontworpen, beschreven, geteekent en in 't licht gegeven. Tweede druk, nieuwe uitgaaf, verryckt met eene Inleiding (door P. Boddaert) en met eene meenigte (105) afbeeldingen (platen en kaarten) versierd. Te Amsterdam, bij M. Schalekamp, 1785. $2 \mathrm{dln}$. folio.

"Zie aldaar: Grocnlandt; Nova.Zembla; Straet Davids; Waygats, bl. 45, 93, 762, 782, 832, $834,892,897-906,915,919-926,928,940,951$, waar terens van de vischrangst, vooral van de wal. visch- en walrusvangst gesproken wordt. Witsen heeft zich in zijne berigten dikwijls van de mondelinge mededeelingen van walvischvaarders bediend. Verder: Visch in do Kas. pische zee, bl. 614, 690. Visch in Siberië, bl. 787. Vischvangst in 't Samoyeden-landt, bl. 955. Haringvangst in Siberië, bl. 745.

"Vergelijk: Fr. Muller, Essai d'une bibliographie Néerlando-Rnsse, bl. 58, waar eenige belangrijke bijzonderheden en eene naauwkeurige bibliographische beschrijving van dit werk te vinden zijn."

Not seen; title and references from Bosgoed, op. cit., p. 252, no. 3607.

1785-88. "Goeze, Joh. Aug. Ephr. Nützliches Allerley aus der Natur u. dem gemeinen Leben für allerley Leser. 6 Bde. 8०. Leipzig, 1785-88."

"Neue verbess. Ausg. in 3 Bdn. 8. Leipzig, 1788."

Not seen; title from Carus and Engelmann. Cited by Dońndorff.

1785-92. Fischer, F. C. J. Friedrich Christoph Jonathan Fischers / Geschichte | des | teutschen Handels. | - | Der Schiffarth, Fischerei, Erfindungen, Kůnste, Gewerbe, Manufakturen, I der Landwirthschaft, Polizey, Leibeigenschaft, des Zoll- Múnz- | und Bergwesens, des Wechselrechts, der Stadtwirthschaft | und des Luxus. | - | Erster [-Vierter] Theil. | - | Hannover, | in der Helwingschen Hof buchhandlung. | 1785 [-1792]. 4 vols. $8^{\circ}$. Theil i, 1785; Theil ii, 1785; Theil iii, 1791; Theil iv, 1792.

Wallfischfang, Theil iv, pp. 265-272.-Geschichte des Wallfischfangs, der seit der åltesten Zeit von den áussersten Nordischen $\nabla \delta$ lkern getrieben wird. Noch giebt es weder bey der Hansa noch in Holland förmliche Wallfischjager. Nachricht von Wallfischen, die auf die Nicderlindische Kůste gerathen sind. Erst gegen Ende des [sechzehnten] Jahrhunderts fangen die Biseayer und Englinder an, auf den Wallfischfang auszugehen: und die Hollånder werden erst bey der versuchten Nordostlichen Durchfarth mit dem Wallfischfange bekannt.

[392.]

1785. Camper, P. Conjectures relative to the Petrifactions found in St. Peter's Mountain, near Maestricht. <Philos. Trans. Lond., lxxvi, pt. 2, art. xxvi, 1786, pp. 443-456, pll. $x v$, xvi.

Descriptions and figures of various fossil remains, including bones and teeth of Phoccena and Physeter and part of lower jaw of Squalodon.

[393.]

1786. "Cravz, D. Hedendaagsche historie, of tegenwoordige staat van Groenland en Straat Davids, benevens eene uitvoerige beschryving van de walvisch- en robbenvangst. Amsterdam, 1786. 3 vols. $8^{\circ}$. Maps and pll."

"Exactly the same work as the preceding [Dutch ed. of 1767], only the title reprinted." F. Muller, Oat. Am. Books, 1877, no. 836.

[394.]

1786. [Jarman, Nathaniel, William Brown, and other8.] [Letters and Certificates in reference to the capture of Whales with the Gun-Harpoon.] <Trans. London Soc. Encour. Arts, Man., and Com., iv, 1786, pp. 179-182.

1786. Moнr, N. Fors $\phi g$ | til | en Islandsk | Naturhistorie, | med | adskillige oekonomiske samt andre | Anmorkninger, | ved | N[iels]. Mohr. | - 1 - - Siquid novisti rectius istis, | Candidus imperti; si non, his utere mecus. | Horat, Epist. Libr. I. 6. | - | Kiфbenhavn, | trykt hos Christian Friderik Holm, | 1786. $8^{\circ}$. pp. i-xvi, 1-414.

VII. Cete, Hvale, pp. 12-17, spp. 22-32. 1. Monodon monoceros; 2. Balana Mysticetus: 3. B. Physalus; 4. B. Boops; 5. B. Musculus; 6. B. Rostrata, p. 13;. . Physeter Macrocephalus; 8. P. Microps; 9. Delphinus orca; 10. D. Phocana; 11. D. Delphis; 12. D. Albioans, p. 14.

List with brief notes.

1787. Clavigero, F. S. The | History | of | Mexico. | Collected from | Spanish and Mexican Historians, | from | Manuscripts, and Ancient Paintings of the In- 


\section{Clavigero, F. S.-Continued.}

dians. | Illustrated by | Charts, and other Copper Plates. | To which are added, | Critical Dissertations | on the | Land, | the Animals, | and Inhabitants of Mexico. I By Abbe D. Francesco Saverio Clavigero. | Translated from the Original Italian, | By Charles Cullen, Esq. | In Two Volumes. | Vol. I [II]. | London, | Printed for G. G. J. and J. Robinson, No. 25, Pater-noster Row. | MDCCLXXXVII. 2 vols. 4०. Vol. i, 11. 2, pp. iii-xxxii, 1-476, pll. i-xxiv, map. Vol. ii, 1l.2, pp. 1-463.

The Manati or Lamentin, i, pp. 62, 63. The text gives but 10 lines to this animal, to which sro added foot-notes to the amount of 18 lines.

There is a second English $4^{\circ}$ ed., London, 1807, with the same pagination for the body of the work. A later American reprint in 3 vols., $8^{\circ}$, appeared at Philadelphia in 1817, in which the passage about the Manati or Lamentin occurs in vol. i, p. 83. There are German and other translations given by bibliographers, not seen by me.

[397.]

1787. [Hollingsworth, S.] The / Present State | of | Nora Scotia: | with a brief | Account of Canada, | and the | British Islands | on the coast of | North America. | - | The Second Edition, corrected and enlarged. | Illustrated with a map. $|-| \ldots$. [ = quotations, 3 lines]. | Edinburgh : | Printed for William Creech, Edinburgh; | and sold by | T. Cadell, and G. Robinson \& Co. London. 1 - M, DCC, LXXXVII. 80. pp. 1-6, vii-xii, 1-221.

On the importance of giving every possible encouragement to the Canadian Whale-fishery, pp. 153-155. It is predicted that the Whale-fishery from Canadian ports "will soon put an end to that of Nantucket"!

1787. Hunter, Johv. Observations on the Structure and Oeconomy of Whales. <Phil. Trans. Lond., Ixxvii, pp. 371-450, pll. xvi-xxiii. Read June 28, 178\%.

[General Remarks], pp. 371-381; Of the Bones, pp. 381-386; Of the Construction of the Tail, pp. 386, 387; Of the Fat, pp. 387-394; Of the Skin, pp. 394-397; Of the Mode of catching their Food [includes deseriptions of the digestive organs], pp. 397-416; Of the Larynx, pp. 416-418; Of the Lungs, pp. 418-420; The Blow-hole, or Passage for the Air, pp. 420-426; Of the Sense of Touch, p. 426; Of the Sense of Taste, pp. 426, 427; Of the Sense of Smelling, pp. 428-430; Of the Sense of Hearing, pp. 430-437; Of the Organ of Seeing, pp. 437-441; Of the Parts of Generation, pp. 441-446; Explanation of the Plates, pp. 447-450.

The observations relate to the following species: 1. "Delphinus phoccena, or Porpoise"; $2,3$. "Grampus," two species, pll. xvi, xvii, animal; 4. "Delphinus delphis, or Bottle-nose Whale," pl. xviii, animal; 5. Another, but of a different genus, having only two teeth in the lower jaw $=$ Hyperoodon, pl. xix, animal; 6. "Baloena rostrata of Fabricius," pl. xx, animal, pl. xxi, external parts of generation, pl. xxii, one of the plates of whalebone, pl. xxiii, a perpendicular section of several plates of whalebone; 7 . "Baloena mysticetus, or large Whalebone Whale"; 8. "Physeter macrocephalus, or Spermaceti Whale"; 9. "Monodon monoceros, or Narwhale."

These species are treated passim, under the sub-headings above giren.

Hunter's celebrated memoir was for many years the principal sonrce of information respect. ing the anatomy of Cetaceans, and is even still quotable. His observations were repeatedly copied, more or less extensivelr, by many subsequent writers, and his figures were reprodnced in many of the older works, notably by Bonnaterre (1789), who faithfully copied all but one (pl. xix), which he also reproduced with modifications, e.g., the insertion of the two teeth in the lower jaw.

[399.]

1787. Monro, A. Vergleichung | des | Banes und der Physiologie der Fische | mit dem | Bau des Menschen und der úbrigen Thiere | durch Kupfer erlåutert | von | Alexander Monro. | - | Aus das Englischen abersezt | und mit eignen Zusatzen und Anmerkungen von P. Campern vermehrt | durch | Johann Gottlieb Schneider. | - | Leipzig, bey Weidmanns Erben und Reich. 1787. $4^{\circ}$. 1l. 4, pp. 1-192, ll. 2, pll. i-xxxiii.

Von dem Ohre der Wallfischarten, pp. 53, 54, 65-71, pl. xxv.

In this version the text is greatly increased and the plates much changed and reduced in number. For the original ed., see 1785. Monro, A.

[400.]

1787. "Moor, MaARTen. Journael van de reize naer Groenlandt, gedaen door commandeur M. Mooi met het schip Frankendaal, behelzende zijue uitreize van Amsterdam 22 April 1786, bezetting in het ijs, zedert den $10 \mathrm{Junij}$, het voorgevallene met de commandeurs H. C. Jaspers, M. Weatherhead, W. Allen en Volkert Klaassen of Jung Volkert Kundsten, welke twee Engelsche coum. 
1787. "Moor, MaArten-Continued.

beirle hunne schepen verloren hebben; de gelukkige verlossing van den Altoonaasvaarder Gottenburger en van hem M. Mooi, met veel aanmerkelyke byzonderheden. Amsterdam, David Weege, 1787. 4․ $71 \mathrm{blz."}$

Not seen; title from Bosgoed, op. cit., p. 243, no. 3518.

1787. St. John de Creve Coeur, [Hector]. Lettres / d'un Cultivateur | Américain | addressées à Wm. S . . . on, Esq ${ }^{\mathrm{r}}$. | depuis l'Année 1770 jusqu'en 1786.Par M. St. John | De Creve Cœur, | Traduites de l'Anglois, | Keen feelings inspire resistless thoughts. | Tome I[-III]. | [Vignette.] A Paris. | Chez Cuchet Libraire, Rue et Hotel Serpente. | 1787. 3 vols. $8^{\circ}$. Vol. i, front., engr. title, pp. i-xxxij, 1-478, 1. 1, map and 2 pll.; vol. ii, 1. 1, pp. 1-438, 1l. 3, 3 maps; vol. iii, l. 1, pp. 1-592, 1 map and 1 pl.

Septième Lettre. Pêche de la Baleine, pp. 153-163.

Vols. $i$ and ii appear to be the same as the two-volume edition of 1784 , with the addition of maps and of several pages of new matter at the end of each volume. Vol. iii is wholly additional. The matter relating to the Whalefishery is the same as that of the 1784 ed. (q.v.), except that the "lettre" here bears the date "Nantucket, 17 Octobre 1772."

[402.]

1788. "Batsch", Aug. Joh. Geo. Karl. Versuch einer Apleit. zur Kenntniss u. Geschichte der Thiere u. Mineralien, für akad. Vorlesungen entworfen u. mit den nöthigsten Abbildgn versehen. 2 Thle. Mit 7 Kpfrtaf. gr. $8^{\circ}$. Jena 1788, '89."

"1 Thl. Mit d. Kpfrtaf. 1-5, 1788. 2 Thl. Besondere Geschichte der Insecten, Gewürmo a. Mineralien. Mit den Kpfrtaf. 6 u. 7, 1789."

Not seen; titlo from Carus and Engelmann. Cited by Donndorff, Zool. Beytr., i, 1792. [403.]

1788. Blumenbach, J. F. D. Joh. Friedr. Blumenbachs / der Med. Prof. ord. zu Gúttingen | Handbuch | der | Naturgeschichte. | - | Mit Kupfern. | - Multa fiunt eadem sed aliter. | Qvintilian. | - | Dritte sehr verbesserte Ausgabe. | - | Góttingen, | bey Johann Christian Dieterich, | 1788. sm. $8^{\circ}$. pp. i-xvi, 1-715, pll. i-iii.

IX. Palmata, pp. 137-143. Includes Trichecus Manatus, p. 143.

XII. Cetacea, pp. 143-147. 1. Monodon Narwhal, p. 144; 2. Balaena Mysticetus, p. 144; 3. B. Physalus, p. 146; 4. Physeter Macrocephalus, p. 146; 5. Delphinus Phocaena, p. 147; 6. D. Delphis, p. 147; \%. D. Orca, p. 147.

[404.]

1788. Gmelin, J. F. Caroli a Linné, | . . [ = titles, etc., 4 lines $]$ | Systema | Naturae | per | Regna tria Naturae, | secundum | Classes, Ordines, | Genera, Species, | cum | Characteribus, differentiis, synonymis, locis. | Tomus I. | - Editio dccima tertia, aucta, reformata. | - | Cura | Jo[annis]. Frid[erico]. Gmelin, | ... [titles, 4 lines] | - | Lipsiae, 1788. | Impensis Georg. Emanuel. Beer. $8^{\circ}$. 7 11. unpaged, pp. 1-500. Mammalia, pp. 1-232.

Sirenia $[<$ ii Bruta], arranged under the genns Trichechus (pp. 59-61). 1. T. Rosmarus = Walruses, p. 59 ; 2. T. Dugong =Indian Walrus, Pennant, p. 60 ; 3. T. Manatus, a. australis ("Habitat in mari africano et americano"), p. 60; 3a. T. Manatus, B. borealis (= Rhytina gigas), p. 61.

Cete, pp. 222-232; genera 37-40=4; species 15, to wit: 1. Monodon Monoceros, p. 222; 2 . Balaena Mysticetus, p. 223; 3. B. Physalus, p. 224; 4. B. Boops, p. 225; 5. B. gibbosa, p. 225; 6. B. Mrusculus, p. 226; \%. B. rostrata, p. 226; 8. Physeter Catodon, p. 226; 9. P. macrocepha. lus, p. 227; 10. P. microps, p. 228; 11. P. Tursio, p. 229; 12. Delphinus Phocaena, p. 229; 13. D. Delphis, p. $230 ;$ 14. D. Orca, p. 231; 15. D. Leucas, p. 232.

[405.]

1789. "Bechstein, Joh. Matri. Gemeinnïtz. Naturgesch. Deutschlands, nach allen 3 Reichen. 4 Bde. Mit 65 Kpfr. gr. 8 . Leipzig, 1789-95."

"1. Bd. welcher dio nöthigen Vorkenntnisse u. die Geschichte der Säugethiere enthält. Mit 16 Kpfrtaf. 1780."

Not seen; title from Carus and Engelmann. An improved later edition is said to have appeared in 4 vols. 1801-09 (Mammals, 1801).

[406.]

1789. Bonnaterre, - Tableau / Encyclopédique / et Méthodique / des trois Règnes de la Nature, | Dédié et présenté a M. Necker, Ministre d’État, | \& Directeur Général des Finances. | - | Cetologie. | - | Par M. l'Abbé Bonnaterre. | . . . [= motto, 2 lines]. | [Vignette.] | A Paris, | Chez Panckoucke, Libraire, Hotel 


\section{BONNATERrE-Continued.}

de Thou, rue des Poitevins. | - | M. DCC. LXXXIX. | Avec Approbation et Privilége du Roi. | 4 pp. i-xlj, 1-28, pll. 1-12. <Encyclopédie Méthodique, tome 183.

Tome 183 of the Encyclopédie Méthodique also includes:

Tableau | Encyclopédique | et Methodique | des trois Règnes de la Nature. | - | Quadrupèdes et Cétacés. | Par MM. Daubenton et Desinarest. | [It bears the same imprint as tome 182, and the date M. DCCCXXVI (1826)]. $4^{\circ}$. pll. 1-112, pll. suppl. 1-14=126 pll. See 1822. Desmarest, A. G.

"Le Recueil des planches de l'Encyclopédie, destinées à représenter les principales espèces de mammiferes, a été publí, sans texte, il y a environ trente ans." Avertisscment, tome 182, 1820 , p. $\nabla$.

"Avertissement," pp. iii-vi, reviewing the history and difficulties of the subject; "Introduction," pp. vii-xli, defining the "Différences entre les cetacés et les poissons" (pp. vii, viii), and describing in detail the different parts of the various types of Cetaceans (pp. viii-xx), their distribution, migrations, habits, etc. (pp. $x x-x x i i i)$, and the Whale-fishery, as carried on by different nations (pp. xxiii- $\mathrm{xxx}$ ). Then follows "Précis anatomique des Cetacés, Arec l'explication de quelques mots techniques qu'on emploie ordinairement dans les descriptions" (pp. xxxi-xl), with "Table méthodique des Cetacés" (p. xli), giving the characters of the "Classes" and "genres."

Cetologie, pp. 1-28. Genn. 4; spp. 26. Première Classe. Baleines. I'r. Genre. Baleine, Balena. Linn.,p. 1. 1. La Baleine-Franche, B. Mysticetus, p. 1, pl. ii, fig. 1, from Martens= Baloena mysticetus; 2. Le Nord-Caper, B. Glacialis, p. $3=$ B. "biscayensis"; 3. Le Gibbar, $\boldsymbol{B}$. Physalus, p. 4, pl. ii, fig. 2, from Martens=Physalus antiquorum; 4. La Baleine-tampon, $B$. Nodosa, p. $5=$ ? Balcenoptera rostrata; 5. La Baleine a bosses, B. Gibbosa, p. $5=$ Agaphelus gibbosus, Cope; 6. La Jubarte, B. Boops, p. 6, pl. iii, fig. 2, from Sibbald=? Megaptera longimana; \%. Le Rorqual, B. Musculus, p. 7, pl. iii, fig. 1, from Sibbald=? Physalus antiquorum; 8. La Baleine a bec, B. Rostrata, p. 8, pl. iv, from Hunter = Balaenoptera rostrata.

Seconde Classe. Monodons. Ier. Genre. Monodon, Monodon. Linn., p. 9; 9. La Narhwal, M. Monoceros, p. 10, pl. v, fig. 1, animal, flgg. 2, 3, bidentate skull, from Cope $=M$. monoceros ; 10. L'Anarnak, M. Spurius, p. $11=$ ? Hyperoodon bidens.

Troisième Classe. Cachalots. Ier. Genre. Cachalot, Phiseter. Linn., p. 12; 11. Le Grand Cachalot, $P$. Macrocephalus, p. 12, pl. vi, fig. 1, pl. vii, fig. 2, original=Physeter macrocephalus; 12. Le petit Cachalot, $P$. Catodon, p. 14, pl. vi, fig. 4 , tooth $=$ Physeter macrocephalusjuv.; 13. Le Cachalot trumpo, P. Trumpo, p, 14, pl. viii, from Robertson= Physeter macroce, phalus; 14. Le Cachalot cylindrique, P. Cylindricus, p. 16, pl. vii, fig. 1 , from Anderson= Physeter macrocephalus; 15. Le Cachalot Microps, P. Microp8, p. $16=$ Physeter macrocephalus; 16. Le Cachalot Mular, P. Mular, p. 17, pl. viii, fig. 5, tooth=Physeter macrocephalus.

Quatrième Classe. Dauphins. Ier. Genre. Dauphin, Delphinus. Linn.,p.18; 1\%. Le Marsouin, D. Phocaena, p. 18, pl. x, fig. 1, copy of an early figure; 18. Le Dauphin, D. Delphis, p. 20, pl. x, fig. 2, from Klein=Delphinus delphis ; 19. Le Nésarnak, D. Tursio, p. 21, pl. xi, figg. 1, 2, from Hunter=Tursio truncatus ; 20. L'Epaulard, D. Orca, p. 21, pl. xii, fig. 1, from Hunter = Orca gladiator ; 21. L'Epaulard ventru, p. 23, pl. xii, fig. 2, from Hunter $=$ ? Orca sp.; 22. L'Épée de Mer, D. Gladiator, p. 23=Orca gladiator; 23. Le Béluga, D. Albicans, p. $24=$ Beluga catodon; 24. Le Dauphin a deux dents, D. Bidentatus, p. 24, pl. xi, fig. 3, from Hunter, altered $=$ Hyperoodon bidens; 25. Le Butskopf, D. Butskopf, p. $25=H$. bidens (not the Butskopf of the Dutch and Germans, which is an Orea); 26. Le Dauphin fères, D. Feres, p. $27=$ ? Orca gladiator.

Baloena nodosa, Phiscter trumpo, P. cylindricus, P. mular, Delphinus bidentatus, D. butskopf, D. feres, spp. nn.

Systematic names are given to 25 species, 7 of them new. Bonnaterre's memoir, although essentially a compilation, became at once the authority on the subject, and was so recognized till the appearance of Lacépède's work in 1804. With one exception (Physeter macrocephalus) the figures of the animals are all copies from those of previous authors, notably Sibbald, Anderson, and Hunter. The memoir, however, may be taken as the best presentation of the general subject $\mathrm{up}$ to that date, and is especially important for the considerable number of new names introduced.

[407.]

1789" "Groot, J. J. Beknopt en getrouw Verhael, van de reys van Commandeur Jeldert Jansz. Groot, uit Texel na en Groenlandt. Desselfs verblijf op de kust van Ond-Groenlandt, nae het verongelukken van deszelfs onderhebbend schip, voorgevallen in Anno 1777 en 1778. Amsterdam, Wed. van A. van Rijschooten en zn. $4^{\circ}$, (16 pag.)."

Not seen; from Bosgoed, op. cit., p. 237, no. 3467. 
1789. Merck, Henry. Mémoire sur les Cétacés. <Hist. et Mém. de la Soc. des Sci. phys. de Lausanne, ii, 1784-86 (1789), pp. 339-344, pl. vii.

Pl. vii, fig. 1, crane de la baleine ordinaire; fig. 2, dn monodon; fig. 3, dn dauphin; fig. 4, du physeter; figg. 5, 6, de une espèce de baleine inconnue [= Hyperoodon].

[409.]

1789. [Wheatley, Johs, and others.] [Certificates of Capture of Whales by use of the Gun-Harpoon.] <Trans. London Soc. Encour. Arts, Man., and Com., vii, 1789, pp. 175-186.

Gives accounts of the capture of various Whales, with generally a statement of the "length of bone"; one Whale is stated to have had "thirteen feet ten inch bone"; others had "ten feet bone," "eleven feet bone," etc.

[410.]

1790. ANderson, [-], and Coombe [-]. Anderson's | Historical and Chronological Deduction | of the | Origin of Commerce, | from the earliest accounts, | containing | an History | of the | great commercial interests | of the | British Empire, | to which is prefixed, | an introduction, | exhibiting | a view of the ancient and modern state of | Europe; of the importance of our Colonies; | and of the commerce, shipping, manu- | factures, fisheries, \&c., | of | Great Britain and Ireland; | and their influence on the landed interest. | with an | Appendix, | containing | the modern politico-commercial geography of | the several countries of Europe. | Carefully Revised, Corrected, and continued to the year 1789, | By Mr. Coombe. | - I In six volumes. | Vol. I[-VI]. | - | Dublin: | Printed by P. Byrne. | - | M. DCC. XC. 6 vols. $8 \circ$.

The treatment of the Whalefishery is chronological, and therefore runs through the work * and cannot be conveniently cited definitely. The references are generally brief, consisting of summaries, necessarily at second-hand. Vols. i-iii contain the "original part of the historical and chronological work of Mr. Anderson"; vol. iv consists of the "Appendix" (pp. 1-208) and "An Alphabetical and Chronological Index" (pp. 209-577) to And erson's work; rols. v and vi contain tive continuation by Mr. Coombe. The copions and well-arranged indexes greatly facilitate reference to the subjects treated.

[411.]

1790. "Bowkns, JAC. Nauwkeurige beschryving der beroemde zeestad Oostende, van haeren oorsprong af tot het jaar 1787. Brugge, J. de Busscher. 1790. 2 dln. $4^{\circ} . "$

"Zie aldaar: Oesterbank wanneer gemaakt. II, bl. 139. Reglementen raekende de vis. scherijen binnen Oostende. I, bl. 21, 28, 30. II, 143. Acht walvisschen aangespoeld. I, bl. 17. Walvischrangst na Groenland, opgeregt te Brugge. II, bl. 37, 150."

Not seen; title and comment from Bosgoed, op. cit., p. 234, no. 3432.

1790-95. "DonndorfF, JoH. Aug. Natur u. Kunst. Ein gemeinuütz. Lehr- u. Lesebuch. 4 Bde. $8 \circ$. Leipzig, 1790-95."

Not seen; title from Carus and Engelmann.

1791. Anon.? [or Jòng, H. DE, H. Koebel, and M. Salieth.] "Nieuwe Beschrijving der Walvischvangst en der Haringvisscherij. Met XXII fraaije platen en kaarten vercierd. Amsterdam, J. Roos, 1791. 4 dln. 4०."

Not seen; from Bosgoed (op. cit., p. 250, no. 3584), who gives it as a new edition of "De walvischvangst met veele bijzonderheden," etc., 1784-86, $q . v$.

Scoresby gives this work as "door H. de Jong, H. Koebel, en M. Salieth."-Arct. Reg., ii, p. 153, note. There is a French translation by B. de Reste, Paris, 1799, entitled "Histoire des Pêches," etc., $q . v$.

[414.]

1791. Fawkener, W., and LoRds of the Commitee of Council, etc. On the production of Ambergris. A Communication from the Committee of Council appointed for the Consideration of all Matters relating to Trade and Foreign Plantations; with a prefatory Letter from William Fawkener, Esq. to Sir Joseph Banks Bart. P. R. S. <Philos. Trans. Lond., 1xxxi, pt. 1, art. ii, 1791, pp. 43-47.

Mainly a series of questions by the Conncil, with answers by Capt. Joshua Coffin, examined by the Council in reference to the circumstances of his finding ambergris in a Whale.

[415.]

1791. Gumula, J. Historia Natural, | Civil y Geografica | De las Naciones | Situadas en las Riveras | Del Rio Orinoco. | Su Autor | El Padre Joseph Gumilla, | 
1791. Gumilla, J.-Continued.

Misionero que fué de las Misiones del Orinoco, | Meta y Casanare. I N'neva Impresion: | Mucho mas correcta que las anteriores, y adornada con ocho | láminas finas, que manifiestan las costumbres y ritos de | aquellos Americanos. | Corregido por el P. Ignacio Obregón, de los Clérigos Menores: | Tomo I. | Barcelona: | En la Imprenta de Carlos Gibert y Tutó | Año MDCCLXXXXI. 2 vols. sm. $4^{\circ}$. pp. i-xvi, 1-360, map and pll.

Variedad de peces y singulares industrias de los Indios para pescar; piedras y buesos medi. cinales que se han descubierto en algunos pescados. Tom. i, cap. xxi, pp. 277-292.-Manati, pp. 281-289. (See anted, eld. of 1745 and 1758.)

[416.]

1791. [Hullock, TYZaCK, JohN Wineatley, and others.] [Accounts and Certificates of taking Whales with tho Gun-Harpoon.] <Trans. London Soc. Encour. Arts, Mran., and Com., ix, 1791, pp. 158-166.

1791. [Loxdon Society, etc.] [Award of Premium for improved Gun Harpoon.] $<$ Trans. London Soc. Encour. Arts, Man., and Com., ix, 1791, pp. 167, 168, pl. iv. Account of "Mr. Charles Moore's improved Harpoon Gun, with figures of the gun." [418.]

1791. "Meares, J. Voyages | Made in the Years 1788 and 1789, | from China to the $\mathrm{N}$. W. coast of America: | with | an introductory narrative | of | a voyage | Performed in 1786, from Bengal, | in the Ship Nootka. | To which are annexed, | observations on the probable existence | of | a north west passage. | And some account of | the trade between the north west coast of America | and China; and the latter country and | Great Britain. | - | By John Meares, Esq. | - | Vol. I [II]. | - | London: | printed at the Logographic Press; | and sold by | J. Walter, No. 169, Piccadilly, oppesite Old Bond Street. | 1791. 2 vols. sm. 8 vo. pp. i-xii, i-lxxii, 1-363, maps, pll. Vol. II, 2p. ll.,pp. 1-332+32 unpaged 1l. (Appendix), maps."

Not seen; title from Coues, Birds Col. Vall., App., 1878, p. 589. For reference to the cetological matter, see the French version under 1795.

[419:]

1791. OverbeeK, L. "Vinvis, gestrand tusschen Wijk aan Zee en Zandvoort. 1791.

Door L. Overbeek. br. folio."

From Bosgoed, op. cit., p. 176, no. 2781.

1791. Rédacteur. Mémoire [par C. Cuvier] sur l'organe de l'ovie dans les cétacés. p. 99 . < Bull. de la Soc. philom., 1791, p. 99.

Notice.

1791 (circa). Schwedianer, - - ["Ueber den Ursprung des Ambers."] <Samml. zur Phys. und Naturgesch., iii, (1791?), p. 336. Ans d. Phil. Trans., lxxiii, pp. 226 et seqq.

Not seen; title based on a reference in Donndorff, Zool. Beytr., i, 1792, p. 777.

1792. Buffon, [G. L. LeCLerc DE]. Histoire | Naturelle | des | Quadrupedes. | - | Par M. L. Compte de Buffon. | - | Tome septième. | Avec Planches. | - [ [Design.] Berne, | chez La Nouvelle Société Typographique. | - | M. DCC. XCII. 80 . 11. 2 , pp. 5-296.

Les Phoques, les Morses et les Lamantins, pp. 136-203, pll. xv-xvii. Le Dugong, pp. 181185. Le Lamantin, pp. 185-203, pl. xvii.

The text is the same as that of the original edition $(1765, q . v$.$) , with the omission of Dan-$ benton's anatomical observations. The additions made in the "Supplément" (vol. vi, 1782) are not included.

[423.]

1792. Donndorif, J. A. Zoologische | Beyträge | zur | XIII. Ausgabe | des Linnéischen | Natursystems | von | Johann August Donndorff. | - | Erster Band. | Die Säugthiere. | - | Leipzig, | in der Weidmannschen Buchhandlung. | 1792. [Zweyter Band | Die Vögel. | Erster Thiel, 1794. Zweyter Theil, 1795.] $8^{\circ}$. pp. i-xx, 1-840, 11. 30.

Siebente [und letzte] Ordnung. Cete (Säugendle Seethiere), pp. 755-790. 1. Monodon Mo. nocero8, p. 755 ( $\beta$. Spurins? Der Anarnak? p. 760); 2. Balaena Ifysticetus, p. 761 ( $\beta$. Islandica, et $\gamma$. Maior, p. 765); 3. B. Physalus, p. 765; 4. B. Boop8, p. 767 ; 5. B. Gibbosa, p. 769; 6. B. Musculus, p. $770 ;$ \%. B. Rostrata, p. 772; 8. Physeter Catodon; p. 773; 9. P. Macrocephalue, 
1792. DonndorfF, J. A.-Continued.

p. 774; 10. P. Microp8, p. 778; 11. P. Tursio, p. 780; 12. Delphinus Phocaena, p. 781; $13 . D$. Delphis, p. 784; 14. D. Orca, p. 786; 15. D. Leucas, p. 789.

D. leucas, nom. sp. n. $=D$. albicans, Fabric.

Sirenia. All the then known Sirenians are arranged with the Walrus in the genus Trichechus, forming the second species, T. Manatus, pp. 128-131.

For fullness and care in citation of bibliography this work is comparable with Erxleben's Syst. Reg. Anim. No diagnoses are given of the species, but there is noteworthy commentary in foot-notes.

1792. Kerr, Robert. The | Animal Kingdom, | or | Zoological System, | of the Celebrated | Sir Charles Linnæus; | - | Class I. | Mammalia: | containing | a complete Systematic Description, Arrangement, and Nomencla- | ture, of all the known Species and Varieties of the Mammalia, | or Animals which give suck to their Ynung; | being a translation of that part of the | Systema Naturæ, | as lately published, with great improvements, | By Professor Gmelin of Goettingen. | - | Together with | Numerous Additions from more recent zoological writers, | and illustrated with Copperplates: | - | B5 Robert Kerr, F. R. \& A. SS. E. | Member of the Royal College of Surgeons, and of the Royal Physical Society, | and Surgeon to the Orphan Hospital of Edinburgh. $\mid-1$ London: | Printed for J. Murray, No. 32. Fleet-street; | and | R. Faulder, No. 42. New Bond Street. | | 1792. 4०. [Part I, Mammals.] pp. i-xii, 1l. 14, pp.1-400. The | Animal Kingdom, | or | Zoological System, | of the celebrated | Sir Charles Linnæus. | - | Vol. I, Part II. [Or] The | Animal Kingdom. | - | Class II. | Birds. 1. 1, pp. 401-644, pll. 3?

This is a rare work in American libraries. The only copy $I$ have handled (that in the library of the Boston Society of Natural History) is obviously imperfect, lacking pp. 433-468, and apparently several of the plates, and ending abruptly with Corvus brachyurus (p. 376 of Gmelin's edition of the "Systema Naturæ"), with a catch-word for the next page. The plates are nnnumbered, and there is no list of them in the work, nor, apparently, any reference to them in the text, so that the exact number cannot be given from the copy of the work at hand. The figures on the plates, however, have numerals referring to the current number of the species in the text. The work is an important one in respect to nomenclature, since a num. ber of systematic names originated here which have been currently attributed to Shaw and Turton. Cf. Oldfield Thomas, Ann. and Mag. Nat. Hist., 5th ser., vol. iv, 1879, pp. 396-397. Also, J. A. Allen, Hist. North Amer. Pinnipeds, 1880, p. 434.

It is noteworthy that a trinomial system of nomenclature was adopted by Kerr for the designation of varieties, as has recently been done by Schlegel, and still later by most American ornithologists and mammalogists.

[Order] vii. Cete, pp. 355-365, spp. 785-808, pl. facing p. 355, spp. nn. 785, 796, 802, 805 .

1. Monodon Monoceros, p. 355, fig.; 2. Balcena Mysticetus, p. 356; 2a. B. Mysticetus groen

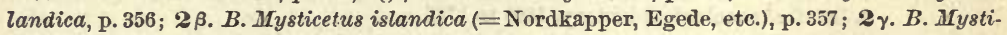
cetus major, p. 357 ; 3. B. Physalis, p. $358 ; 4$. B. Boops, p. 358; 5. B. gibbosa, p. 359; 5 a. B. gibbosa gibbo unico, p. 359 ; 5 ค. B. gibboso gibbis sex, p. 359; 6. B. Musculus, p. 359 ; 7. B. rostrata, p. 360 ; 8. Physeter Catodon (=Beluga catodon), p. 360; 9. P. macrocephalus, p. 360, fig.; 9а. P. macrocephalus niger, p. 369 ; 9 B. P. macrocephalus albicans (=Beluga catodon), p. 361 ;

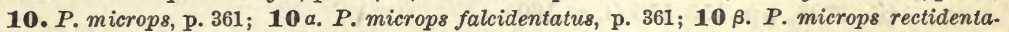
tus, p. 362; 11. P. Tursio, p. 362; 12. Delphinus Phocaena, p. 362, fig.; 12a. D. Phoccena albus, p. 363; 12 в. D. Phocaena fuscus, p. 363 ; 13. Delphinus Delphis, p. 363, fig.; 14. D. Orca, p. $364 ; 14$ a. D. Orca ensidorsatus, p. 364; 15. Delphinus leucas, p. $364=15$ spp. +11 varr.

[425.]

1792. Wheathey, Jonn. An Account of the Whales shot with the Harpoon-Gun, by the undermentioned Harpooners, in the Ship Queen Charlotte, of London, under my command, in Davis's Straights this present year [1791]. <Trans. London Soc. Encour. Arts, Man., and Com., x, 1792, pp. 238-241.

In the same connection is a list of premiums paid for the capture of Whales with the har. poon-gun in the year 1791 (p. 238), and certificates of capture relating to the same (pp. 241245).

[426.]

1793. BeLL, JoHN. Observations on throwing a Gun-Harpoon. <Trans. London Soc. Encour. Arts, Man., and Com., xi, 1793, pp. 185-192, pl.v.

The "Observations".are preceded by a letter from Mr. Bell to the society and followed by "Description of the Plate of Mr. Bell's improved Gun and Harpoon." Fig. 1, the Gun fitted for firing; fig. 2, the form of the Harpoon.

[427.] 
1793. "Doxndonff, Jor. AUG. Handbuch der Thiergeschichte. Nach den besten Quellen u. neusten Beobachtungen zum gemeinnütz. Gebrauche. gr. $8^{\circ}$. Leipzig, 1793."

Not seen; title from Carus and Engelmann.

[428.]

1793. [Lovdon Societr, etc.] [Premium for] Gun for throwing Harpoons, [and for] Taking Whales by the Gun-Harpoon. <Trans. London Soc. Encour. Arts, Man., and Com., xi, 1793, pp. 335, 336.

These offers of premiums were annually renewed by the society for many years. See sub. sequent volumes of the society's Trans.

1793. "Pasteur, J. D. Beknopte natuurlijke historie der zoogende dieren. Leyden, Honkoop en Mortier, 1793. 3 dln. met pl. $8^{\circ} . "$

"Zie aldaar: iii, bl. 305-393: Zoogende waterdieren."

Not seen; title and comment from Bosgoed, op. cit., p. 170, no. 2689.

1793. St. John [DE CRèvecceur], J. Hector. Letters | from an | American Farmer, | describing | certain provincial situatious, | manners, and customs, | and conveying | some idea of the state | of the people of | North America. | - | Written to a friend in England, | By J. Hector St. John, [de Crèvecour]. | A Farmer in Pennsylvania. | - | Philadelphia: | From the Press of Matthew Carey. | March 4,-M. DCC. XCIII. 12०. pp. i-viii, 9-240.

Substantially the same as the ed. prin., 1782, with, however, the omission of the maps and the references to them. The "letters" relating to the Nantucket Whalefishery, etc., are at pp. 118-136. For the character of the matter see ed. of 1782.

[431.]

1793. Sinclair, Johs. The | Statistical Account | of | Scotland. | Drawn up from the Communications | of the | Ministers | of the | Different Parishes. | - | By Sir John Sinclair, Bart. | - | Volume Fifth. | "Ad consilium de republica dandum, caput est nosse rempublicam." | Cicero de Orat. lib. ii. | - | Edinburgh: | printed and sold by William Creech; $\mid \ldots . .[=5$ lines, names of other booksellers]. | - | M,DCC,XCIII. 80. pp. i-vii, 1-591.

A "list of the different kinds of Fish, which are found in the river and frith of Clyde," pp. 535-538. A nominal list, including the following species of Cetaceans (p. 533): Bluntheaded Whale, Physeter microps; Grampus, or Bucker, Delphinus orca; Porpoise, or Pellock, D. phocana.

[432.]

1793-96. "ЕвеRт, Jон. JAC. Naturlehre (u. Naturgesch.) für die Jugend. 3 Bde., 3 Aufl. 80. Leipzig, 1793-96. (1,2 Aufl., 1776-87.)"

Not seen; title from Carus and Engelmann. Cited by Donndorff and others.

1794. Axos. Progress of the Whale Fishery at Nantucket. <Coll. Mass. Hist. Soc. for the year .1794, iii, 1794, p. 161.

A brief chronological history, 1690 to 1785 .

1794. MACY, Z. A short Journal of the first settlement of the island of Nantucket, with some of the most remarkable things that have happened since, to the present time. By Zaccheus Macy. <Coll. Mass. Hist. Soc. for the year 1794, iii, 1794, pp. 155-156 (i. e., 160).

Of the Whale Fishery, pp. 157, 158. A brief but important original account of the origin of the Nantucket Whale-fishery.

[435.]

1794. Pallas, S. P., et J. B. Lamarck. Voyages | du | Professeur Pallas, | dans plusieurs Provinces | de l'Empire de Russie | et | dans l'Asie septentrionale; | Traduits de l'allemand par le C. Gauthier | de la Peyronie. | Nouvelle édition, | Revue et enrichie de Notes par les CC. Lamarck, profes- | seur de Zoologie au Muséum national d'Histoire naturelle; I et Langlès, Sous-Garde des Manuscrits de la Biblio- | thèque nationale, pour les Langues Arabe, Persane, Tatare- | Mantchou, \&c. | Tome Premier[-hnitième]. | - | A Paris, | Chez Marad an, Libraire, rue du Cimetière | André-des-Arcs, no. 9. | - | L'An II de la République [=1794]. 8 vols. $8^{\circ}$.

The title of vol. viii varies from the abore by substitution of the following between "Nouvelle édition" and the number of the volume:

Appendix, | Contenant les descriptions des Animaux et des Végétaux observés | dans les Voyages du Professeur Pallas, et cités ou mentionnés | dans les 
1794. Pallas, S. P., et J. B. Lamarck-Continued.

volumes précédens; | Avec des Notes et Observations par le C. Lamarck, |

Professeur de Zoologie au Muś́um national d'Histoire naturelle.

"Description du Poisson blanc," vol. v, pp. 192-197 (par M. Pallas). "Delphinus leucas [Dauphin blanc], Lo Bélonga de mer ou poisson blanc, pl. lxxix," vol. væi, pp. 25, 26 (par M. Lamarck).

[436.]

1795. Forster, J. R. Faunula Indica / id est / Catalogus animalium / Indiae Orientalis | quae hactenus | Naturae curiosis | innotuerunt; | concinnatus | a | Joanne Latham, | Chirurgo Dartfordiae Cantii, | et | Hugone Davies, | pastore in aber | provinciae Caernarvon, | Secundis curis editus, correctns et auctus | a Joanne Reinholdo Forster, | LL. Med. et phil. D. et LL. AA. M. Med. Philos. et imprimis Hist. Nat. | et Rei Metallicae. Prof. P. O. in Universitate | Litteraria Halensi. | - | Halae ad Salam, | impensis Joannis Jacobi Gebaueri. |

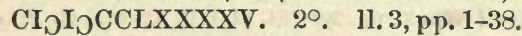

Ordo ix. Cete, p. $5=$ Trichechus Manatus, Trichechus Dugong. Phoca ursina, Delphinus Phocaena, Delphinus Delphis. Merely a nominal list.

1795. Hearne, S. A | Journey | from | Prince of Wales's Fort in Hudson's Bay, | to | the Northern Ocean. | Undertaken | by order of the Hudson's Bay Company, | for the Discovery | of Copper Mines, A Northwest Passage, \&c. I In the Years 1769, 1770, 1771, \& 1772. | - | By Samuel Hearne. | - | London: | printed for A. Strahan and T. Cadell: | And Sold by T. Cadell Jun. and W. Davies, (Successors to / Mr. Cadell,) in the Strand. | 1795. $4^{\circ}$. pp. i-xliv, 1-458, map and pll. i-viii.

Sea Unicorn, pp. 391, 392. Black Whale (three killed in 20 years as far south as Churchill River), pp. 392, 393 . White Whales, pp. 393-395.

There is a later edition, Dublin, 1796, $8^{\circ}$. Also translations in French (Paris, 1709, 2 vols., $8^{\circ}$ ), Dutch (Hague, 1798, 2 vols., $8^{\circ}$ ), and German (Berlin and Hallo, 1797, 8०). (See Sabin, Bibl. Amer, viii, pp. 188, 189, nos. 31181-31186).

[438.]

1795. Meares, J. Voyages | de la Chine | a la côte Nord-Oust | d'Amerique, | faits dans les années 1788 et 1789; I Précédés de la relation d'un autre Voyage exécuté en | 1786 sur le vaisseau le Nootka, parti du Bengale; | D'un Recueil d'Observations sur la Probabilité d'un | Passage Nord-Ouest; | Et d'un Traité abrégé du Commeree entre la Côte Nord-Ouest et la Chine, etc. etc. I Par le Capitaine J[ohn]. Meares, Commandant | le Vaisseau la Felice. | Traduits de l'Anglois | Par J. B. L. J. Billecocq, Citoyen Français. | Avec une Collection de Cartes géographiques, Vues, Marin | Plans et Portraits, gravés en tailledouce. | - | Tome premier[-troisième]. | - | A Paris, | Chez F. Buisson, Libraire, rue Hautefeuille, $n^{\circ} .20 .|-|$ An $3^{\text {e }}$. [1795] de la République. 3 vols. 80. Vol.i,pp. i-xxiv, 1-391. Vol.ii,1l.2,pp.1-386. Vol. iii,1l.2, p1.1-371.

La pêche de la baleine est la branche de commerce la plus avantageuse qu'offre la côte nord-ouest d'Amerique, vol. i, pp. 163-166. Description de la manière dont les naturels de Nootka tuent la baleine, etc., vol. iii, pp. 21-24.

The copy of this work examined (Harvard College Libr.) lacks the collection of maps, views, etc., called for in the title.

[439.]

179j. "SAvary, J. Dictionnaire universel de commerce, d'histoire naturelle et des arts et metiers. Nouvelle édition. Copenhague, C. A. Philibert. 179j. $5 \mathrm{dln}$. folio."

".... Pêche de la Balcine, i, bl 310-316."

Not seen; title from Bosgoed, op. cit., pp. 229, 247, nos. 3394, 3554.

[440.]

1795. WALCOT, S. A | New and complete | Natural History | of |

\begin{tabular}{l|l|l|l} 
Quadrupeds, & Reptiles, & Fossils, & Winds, \\
Beasts, & Insects, & Minerals, & Sun, \\
Birds, & Waters, & Vegetables, & Moon, \\
Fishes, & Earth, & Shells, & Planets, \&c., \&c.
\end{tabular}

Containing | a New History and Deseription | of the several Classes and Species of Auimals which inhabit | The Air, the Earth, and the Water, | in the several parts of the Universe. $\mid$. . [ $[=21$ lines, giving further description of 
1795. WaLcotr, S.-Continued.

contents.] | Forming an | Universal Display of Nature, | Animate and Inanimate. 1... [=3 lines]. | - | By Sylvanus Walcott, Esq., F. R. S. | Assisted by many gentlemen of eminence. | - | Elegantly embellished with a superb group of folio prints: | Representing several Thousand different Objects ... [=2 lines]. | - | London : | Printed for Alex. Hogg, No. 16, in PatérnosterRow, and sold by all the Booksellers of | Bath, Bristol, ... [ [ =8 lines, names of other towns in alphabetical order]. No date. fol. pp. 1-542, pll. i-clix [?]

The plates are not nearly all numbered; the number of the last one is clix. There is no date on the title-page, but at the bottom of the frontispiece page is engraved in small letters: Published Marcb 21, 1795, by Alex. Hogg, No. 16 Paternoster Row.

Book III. A New and Complete History and Description of Fishes in general, pp. 200253, pll. Iviii, lxi, lxii, +3 pll. unnumbered. Chap. I. Natural History of Fishes of the Cetaceous kind, viz.: The Whale and its varieties, the Cachalots, the Dolphin, the Grampus, and the Porpus, pp. 202-206. 1. Greenland Whale, pp. 202-204, pl. lxii, fig. 66. 2. Pike-headed Whale, p. 204. 3. Round-lipped Whale, p. 204. 4. Cachalot, or Spermaceti Whale, pp. 204, 205. 5. Great-headed Cachalot. 6. Round-headed Cachalot, p. 205. \%. Dolphin, 8. Grampus, and 9. Porpus, pp. 205, 206. There is a figure of the Narwhal, but apparently no description. The work is of most interest as a literary curiosity, being a popular compilation, of no scientific value.

[441.]

1796. Abernethy, J. Some particulars in the Anatomy of a Whale. <Philos. Trans, Lond., [lxxxvi], pt. 1, art. ii, 1796, pp. 27-33.

On the structure and function of the lymphatic glands.

1796. "Posselt, K.F. Ueber den Grönl̈̈ndischen Wallfischfang, herausgegeben von A. Niemann. Kiel, 1796. $80 . "$

Not seen; from Bosgoed, op. cit., p. 246, no. 3546.

1796. Stedman, J.G. Narrative, | of a five years' expedition against the | Revolted Negroes of Surinam, | in Guiana, on the Wild Coast of | South America ; | from the year 1772, to 1777: elucidating the History of that Country, and | describing its Productions, Viz. | Quadrupeds, Fishes, Reptiles, Trees, Shrubs, Fruits, \& Roots; | with an account of the Indians of Guiana, \& Negroes of Guinea. | By Capt ${ }^{n}$. J[ohn]. G[abriel]. Stedman. | Illustrated with 80 elegant Engravings, from the drawings made by the Author. | - | Vol. I.[-II]. | - | [Vignette.....$[=$ quotation, 7 lines]. London. Printed for J. Johnson, St. Paul's Church Yard, \& J. Edwards, Pall Mall. 1796. 2 vols. 4\%. Engr. title-page, maps and plates.

Manatee, vol. ii, p. 175, fig. pl. facing p. 176 (general description).

[444.]

1796-1810. BluMENBaCH, J. F. Abbildungen | naturhistorischer Gegenstände / herausgegeben | von | Joh. Fried. Blumenbach. | - | Nro 1-100. | - | Göttingen | bey Heinrich Dieterich. | 1810 | [1796-1810]. $8 \circ$.

Cetaceen. No. 44, Monodon narhwal, text, 2 pp. "Die Abbildung stellt denjenigen Nar. hwal vor, der 1736 in der Mündung der Elbe gestrandet war, und ist aus einem periodischen Blatte jener Zeit, den Hamburgischen Berichten von gelehrten Sachen, genommen."

No. 74. Balcena boops on plate, B. rostrata in text. Original figure of a specimen 52 feet long stranded on the coast of Holland, between Sandfort and Wyk op Zee, in Dec., 1791. Also figure of the head of another example, copied from Sibbald's "Phalainologia."

No. 84. Physeter macrocephalus. "Mier diese Abbildnng ist von dem meisterhaften grossen aber seltnen Blatte genommen, worauf der vortreffliche Künstler J. Saenredam den 60 Fuss langen Pottfisch der im Dec. 1601 am Ufer von Beverwyk gestrandet war, nach dem Leben vorgestellt hat."

No. 94. Balcena mysticetus, "ans Hesel Gerard's descriptio geographica transitus supra terras Americanas in Chiram."

No.95. Delphinus delphis. "Die Abbildung ist von einer trefllichen Zeichnung unsers unvergesslichen G. Forster's genommen."

Eigner Tafel ist mit zwei Seiten von Texte versehen.

1797. Aвernethy, JoH. Einige Eigenheiten in der Zergliederung des Wallfisches. $<$ Reil's Arch. fïr Physiol., ii, 1797, pp. 232-239.

Uebersetzung aus der Plil. Trans. roy. Soc. London for 1796, pt. 1, pp. 27 et seqq. 
1797. "Borkmausen, Mor. Baltir. Deitsche Fauna, oder kurzgefasste Naturgeschichte der Thiere Deutschlands. 1 Thl. S̈̈ugethiere und Vögel. $8^{\circ}$. Frankfurt a. M. 1797."

Not seen; title from Carus and Engelmann.

[447.]

1797. Cuvier, G. Sur les narines des cétacés. <Bull. des Sci. par la Soc. philom. de Paris, i, 1797, pp. 26-29.

1797. [Cuvikr, G.] Mémoire sur l'organe de l'ouie dans les Cétacés. <Bull. des Sci. par la philom. de Paris, i, 1797, p. 99.

Extrait.

1798. Colnetr, James. A | Voyage | to the | South Atlantic | and round | Cape Horn | into the | Pacific Ocean, | for the purpose of extending the | Spermaceti Whale Fisheries, | and other objects of Commerce, by ascertaining | the Ports, Bays, Harbours, and Anchoring Berths, | in certain Islands and Coasts in those Seas, | at which the ships of the British merchants might be refitted. | - Undertaken and performed | By Captain James Colnett, | of the Royal Navy, in the ship Rattler. | - | London: | Printed for the Author, | by W. Bennett, Marsham Street, Westminster. $\mid \ldots \ldots[=3$ lines, names of booksellers]. | - 1798. 4\% pp. i-iv, i-vi, i-xviii, 1-179, maps and plates.

Contains passim references to Whales secn or taken at various points, etc. Also a plate. giving an outline figure of "Physeter, or Spermaceti Whale, Drawn by Scale, from one killed on the coast of Mexico, August, 1793, and hoisted in on Deck," giving the topography of the animal with reference to manner of cutting in, etc. There is also a half-page of descriptive text (engraved on the plate), with also reference to its food, habits, etc. The figure has been many times copied in works relating to Whaling.

[450.]

1798. Cuvier, [G.] Ueber die Nasenlöcher und das Geruchsorgan der Cetaceen; aus einer vom B. Cavier im Nationalinstitut vorgelesenen Abhandlung. Mag. Encjcl. <Voigt's Mag. der Naturkunde, i, St. 3, 1798, pp. 34-40.

Uebersetzung aus Magas. encycl. de Millin, iii, 1797, pp. 293.

1798. Cuvrer, G. Tableau | élémentaire | de l'Histoiro naturelle / des Animaux. |

Par G. Cuvier, | de l'Institut national de France, | .... [titles, 7 lines ]. | - | A Paris, | Baudouin, Imprimeur du Corps législatif et de | l'Iustitut national, place du Carrousel, №. 662. | An 6. [=1798.] 8०. pp. i-xvi, 1-710, pll. i-xir.

Des Mammifères, pp. 83-179: Mammifères Amphibies (pp. 170-173)=Pinnipedia + Sirenia. Sirenia: 1. Trichecus dugong, p. 172; 2. Trichecus manatus, p. 173.

Mammifères Cétacés = Cetacea (pp. 173-179): 1. Delphinus phocoena; 2. D. delphis ; 3. D. orca, p. 175 ; 4. Physeter macrocephalus (= "Le cachalot trumpo, Bonnaterre, Encycl., planches des cétacés, pl. 8, f.1"); 5. P. maximus, sp. n. (="idem., ibid., pl. 7, fig. 2"), p.176; 6. Balaena mysticetus, L., p. 177; \%. B. physalus; S. Monodon, p. 178.

Physeter maximus, sp. n.

1798. [LoNdon Society, etc.] [Premiums offered for "Taking Porpoises" and for "Oil from Porpoises."] < Trans. London Soc. Encour. Arts, Man., and Com., xvi, 1798, pp. $84,85$.

These offers of premiums were annually renewer for a considerable period. See later vols. of these Trans.

[453.]

1798. Truunburg, C. P. Beskrifning | på | Svenske Djur. | - | Första Classen, | om | Mammalia | eller Diggande Djuren, | af | Carl Peter Thunburg, | Riddare af Kongl. Maj : ts Wasa-Orden, | Medicinæ och Botanices Professor | i Upsala. | [Vignette.] | - Upsala, | Tryckt hos J. F. Edman, K. Acad. Boktr. | 1798. 8c. 11. 6, pp. 1-100.

Cete, pp. 96-100. 1. Balana mysticetus, p. 96; 2. B. physalus, p. 97; 3. Physeter macrocephalus, p. $98 ; 4$. Delphinus phocaena ; 5. D. Orca, p. 99.

[454.]

1799. Axox. "Histoire des pêches, des découvertes et des établissemens des hollandois dans les mers du Nord. Onvragre traduit du Hollandois par B. de Reste. Avec des notes, (2S) cartes et figures. Paris, Vve. Nyon, 1799. 3 dln. $80 . "$

"Eene vertaling van het werk: Do Walrischrangst, Amst. 1784 [\%.v.]. Vermeerlerd met anteekeningen en eeue historische verlandeling orer Groenlaud en IJsland, volgens Crantz [8ic], Egede, do la Peyrère, Horrebow e. a."

Not seen; titlo and comment from Bosgoęd, op. cit., p. 244, no. 3528.

$[455$. 
1800. Buffon, [G. L.] Leclerc [Compte de, et C. S. Sonnini]. Histoire Naturelle, | Generale et Particuliere, | Par Leclerc de Buffon; | Nouvelle Edition, accompagnée de Notes, et dans laquelle | les Supplémens sont insérés clans lo premier texte, à la | place qui leur convient. L'on ý a ajouté l'histoire | natnrelle des Quadrupèdes et des Oiseanx déconverts | depuis la mort de Buffon, celle des Reptiles, des Poissons, I des Insectes et des Vers; enfin, l'histoire des Plantes dont | ce grand Naturaliste n'a pas en le tems de s'occnper. | Ouvrage formant un Cours complet d'Histoire Naturelle; | Redige Par C. S. Sonnini, | Membre de Plusieurs Sociétés Savantes. | Tome Trente-Quatrième. | [Monogram.] A Paris, | de L'Imprimerie de F. Dufart. | - | An VIII. [1800.] $8^{\circ}$. 11. 2. pp. 1-324, 1. 1.

Le Dugon, pp. 184-189 (note par Sonnini, p. 184). Le Lamantin, pp. 190-196 (note par Sonnini, p. 191). Le Grand Lamantin du Kamtschatka, pp. 197-211 (note par Sonnini, p. 197). Le Grand Lamantin des Antilles, pp. 212-226 (nôte par Sonnini, p. 212). Le grand Lamantin de la mer des Indes, pp. 32i-330 (note par Sonnini, p. 327). Le Petit Lamantin d'Amérique, pp. 231-239 (note par Sonnini, pp. 238, 239). Le Petit Lamantin du Sénégal, pp. 240-216).

The matter here given is that of the original edition $(1765, q . v$. $)$, followed by that of the "Supplement" (

[456.]

1800. Latreilifi, [P. A.]. Exposition methodique des Quadrupèdes, Specialement mentionnés dans cette édition de l'Histoire Naturelle de Buffon. < Hist. nat. de Buffon, édit. de Sonnini, xxxvi, an VIII (1800), pp. 251-321.

Onzième Ordre. Les Cétacées, pp. 288, 289. Gcnn. : MLanatus, Delphinus, Physeter, Monodon, Balcena.

[457.]

1800. Marum, M. vas. Beschryving van het Bekkeneel van een jongen Walvisch, geplaatst in het Naturalien Cabinet van deeze matschappy. <Natuurk. Verh. van de Holl. Maatsch. der Wetensch., Haarlem, i. Deel, ii. Stuk, pp. 199-202, pl. v.

Description and figure of a skull of a newly-born Baloena mysticetus.

[458.]

1800. NoËL, S. B. J. Tablean historique | de la Pêche | de la Baleine; | Par S. B. J. Noël, | . . . [ [ =titles, 7 lines $]$ | - | A Paris, | Chez Fuchs, Libraire, maison de Cluny, I rue des Mathurins. | - | Thermidor an VIII. [1800.] 8०. pp. 1-108.

Vues générales sur l'antiquité de la pêche de la Baleine, pp. 3-22. Etat présent des péches de la Baleine chez les diverses nations d'Europe et d'A mérique, qui s'en occnpeut, pp. 23-52. Réflexions sur les moyens de ranimer en France cette branche précieuse d'économie maritime, pp. 53-96. Preuves et Tableaux relatifs à la pêche de la Baleine, pp. 97-108.

[459.]

An historical work of well-known value.

1800. Retzius, A. J. Faunae Suecicae / a Carolo à Linné Equ. | inchoatae / Pars prima | sistens | Mammalia, Aves, Amphibia | et Pisces Sueciae | quam | recognovit, emendavit et auxit | Andreas Joannes Retzius | in Academia Lundensi Historiae Naturalis, | Oeconomiae et Chemiae Professor R. O. I - | Cum Tabula aeri incisa. | - | Lipsiae MDCCC. | Apud Siegfried Lebrecht Crusium. $8^{\circ}$. pp. i-x, 1-362, pll. col. (Fringilla flavirostris et $F$. lutensis).

Cete, pp. 48-51. 1. Monodon Monocero\&, p. 48; 2. Balaena Mysticetus; 3. B. Physalus, p. 49; 4. Physeter macrocephalus; 5. Delphinus Phocaena, p. 50; 6. D. Orca, p. 51. [460.]

1800. V., C. Sur les Ossemens fossiles de la Montagne de St. Pierre, près Maëstricht, par Adr. Camper. <Bull. de la Soc. philom. de Paris, ii, no. 42, an 8 de la Repub. (1800), p. 142.

Extrait de cette mémoire, signé "C. $\nabla . "$

1800-01. Shaw, George. General Zoology | or | Systematic Natural History | by | George Shaw, M.D.F.R.S.\&c. | With plates | from the first Authorities and most select specimens | Engraved principally by | Mrr. Heath. | [Vignette.] Vol. I[-II, each in 2 parts. ] Part 1. | Mammalia. | - | London Printed for G. Kearsley, Fleet Street. | $1800[-1801]$. 2 vols. in 4 parts. $8^{\circ}$. The whole work comprises 14 vols., 1800-18:6.

Vol. i, pt. 1, 1800, 1. 1 (engr. title-page). pp. i-xiii, 1. 1, pp. 1-248, pll. i-lxix + lxviii*; pt. 2, 1800, pp. i-riii, 249-552, pll. 1xx-cxxi. Vol. ii, pt. 1, 1801, l. 1 (engr. title-page), pp. i-ri, 1-226, pll. cxxii-clxv; pt. 2, 1801, pp. i-ri, 1.1, pp. 229-560, pll. clxvi-cexxxii + xeiv*. 
1800-01. Shaw, George-Continued.

Trichechus, Walrus [=Sirenia + "Arctic Walras"], vol. i, pt. 1, 1800, pp. 233-248. 1. Trichechus Dugong, p. 239; 2. Trichechus Borealis [= Rhytina borealis mainly], pp. 240-244; 3. Trichechus A ustralis [= Manatus australis], pp. 244, 245, pl. 1xix; 4. Trichechus Mranatus, pp. 245-248 (includes also, as "var.," Trichechus Clusii, from the West Indies; Trichechus Amazonius, from South America; and Trichechus ? Hydropithecus, or Steller's "Sea-Ape."

Order Cete. Whales, or Fish-formed Mammalia, vol. ii, pt. 2, 1801, pp. 471-560, pll. ecxxvcexxxii. 1. MTonodon Monocero8, pp. 473-476, pl. ecxv, animal and skull; 2. MIonodon Spurius, pp. 476, 477, from Fabricius; 3. Balqena Ifysticetus, pp. 478-49ก, pl. ecxvi, animal-plate and most of the text from Martens; 4. Baloena Physalus. pp. 490-491, pl. ccxxvii, lower fig., animal, from Martens; 5. Baloena Boops, pp. 492-494, pl. eexxvii, lower fig.; 6. Baloena Gibbosa, p. 494; 7. Baloena Musculus, p. 495; 8. Balcena Rostrata, p. 496; 9. Physeter Macrocephalus, pp. 497-500, pl. ccxxriii, animal, two figg., from Schreber; 10. Physeter Catodon, p. 501; 11. Physeter Microps, p. 502; 12. Physeter Tursio, p. 503; 13. Delphinus Phoccena, pp. 504-506, pll. cexxix, lower fig., animal, pl. ccxxx, animal laid open to show internal organs, pl. xxxi, skull, skeleton, and fore limb; 14. Delphinus Delphis, pp. 507-512, pl. ccxxix, upper fig., animal; 15. Delphinus Orea, p. 513, pl. cexxxii, lower fig., animal; 16. Delphinus Bidens, p. 514, from Hunter; 17. Delphinus Rostratus, p. 514; 18. Delphinus Leucas, pp. 515, 516, pl. cexxxii, upper fig., animal. Appendix to Whales pp. 517-560, abridged version of Hunter's celebrated memoir on the anatomy of Whales. See 1787. Huxter. J.

Delphinus bidens, p. 514, sp. n.= Bottle-nose Whale of Dale, hence Delphinus bidentatus, Bonnaterre, 1789; Delphinus rostratus, p. 514, sp. n., locality unknown, but "supposed to inhabit the Indian Ocean"; species indeterminable.

The history of the Sirenia and Cetacea is, like most of that part of the work relating to Mammals, purely a compilation.

[451.]

1802. AxON. A Calculation of the State of the Cod and Whale Fisheries, belonging to Massachusetts in 1763: copied from a Paper published in 1764. < Coll. Mass. Hist. Soc., viii, 1802, pp. 202, 203.

A statistical table, less than a page in length. The following is all that relates to Whalefishing: " 180 sail of Whale-fishing ressels, the exportation to Great Britain amounting, iu oil and bone, to $£ 123,36606 "$ (p. 203).

[462.]

1802. Buffon, [G. L.] Leclerc De, [et C.S. Sonvini]. Histoire naturelle, | générale et particulière, I par Leclere de Buffou; | Nouvelle Edition, accompanuée de Notes, et dans laquelle | les Supplémens sont insérés dans le premier texte, à la | place qui leur convient. L'on y a ajouté l'histoire | naturelle des Quadrupèdes et des Oiseaux déconverts | depuis la mort de Buffon, celle des Reptiles, des Poissons, | des Insectes et des Vers; enfin, l'histoire des Plantes, dont | ce grand Naturaliste n'a pas en le tems de s'occuper. / Ouvrage formant un Cours complet d'Histoire Naturelle; rédigé par C. S. Sonnini, | Membre de plusieurs Sociétés savantes. | Tome trente-quatrième. [Les Phoques, les Morses, et less Lamantins.] | [Monogram.] A Paris, | de l'Imprimerie de F. Dufart | - | An X. [=1802]. $8^{\circ}$. 11. 2, pp. 1-316, pll. cexxxii-cexxxv.

A reissue of the An VIrI edition, with only, so far as relates to the body of the work, a change of date on the title-page, luut the "Exposition méthodique" by Latreille (see 1800 . LATIREILLE) is printed in smaller type and occupies 7 loss pages (pp. 251-314), thas giving to the volume a different collation.

[463.]

1802. "Gilibert, J. Emar. Abrégé du système de la Nature de Linné; histoire des Mammirères ou des Quadrupedes et Cétacés; contenuant $1^{\circ}$ la traduction libre du texte de Linné et de Gmelin; '20 l'extrait des observations de Buffon, Brisson, Pallas et autres cé́ebres zoologistes; $3^{\circ}$ l'anatomie comparée des principales espèces; le tout relatif anx Quadrupèdes et aux Cétacés les plus curieux et les plus utiles. Avec portr. et 18 pl. in-8. Lyon, an X (1802), ou 1805, Matheron et Co."

Not seen; title from Carus and Engelmann.

1802. KLEIN, J. T. "Ichthyologia, seu Historiae piscium naturalis quinque missus.

Cui accedit Ichthyologia Kleiniana enodata, sive index rerum ad Historiam piscium naturalem, cum synonymis recentissimorum systematicorum Artedi, Linnaei, Gmelini, Blochii, etc. explicatam. Lipsix, in libraria Gleditschiana.

1802. 4०. Met 53 platen."

Not seen; title from Bosgoed, op. cit., p. 10, no. 113. 
1802. Ozeretskovsky, N. De speciebus systematicnm genus Trichechi constituentibus. <Nov. Act. Acad. Scien. imp. Petropolitance, xrii, 1802, pp. 371-375.

Chiefly about the relationship of the Walrus, Steller's Sea Cow, and the Dugong.

[sє6.

1803. Camper, Pierre. Guvres | de Pierre Camper, | qui ont pour objet | l'histoire] naturelle, | la physiologie | et l'anatomie comparée. | [Trad. par Henri J. Jausen.] | - | Tome premier [-troisième]. | - | A Paris, ! Chez H. J. Jansen, rue des postes. No. 6, I près de l'estrapade. | - | An XI.-1803. 3 vols. $8^{\circ}$. Vol. i, pp. i-civ, 1-392; vol. ii, pp. 1-503; vol. iii, pp. 1-502. Avec une Atlas des planches en-fol.

Conjectures sur les pétrifactions trourées dans la Montagne de S.-Pierre près de Mrstricht, tom. i, pp. 357-377, pll. vi, vii, (Vertèbres ot dents de Cetacés, ete.). Du Dugon du Comte de Buffon, tom. iii, pp. 479-491, pl. vii, firg. 2, 3, animal.

[467.]

1803. "Gruber, J. G. Beschreibung von Grönland und Spitsbergen mit den Wundern der Natur- und Menschen welt um den Nord pol. Zurich und Leipzig, 1803. 4०."

Not seen; title from Bosgoed, op. cit., p. 237, no. 3468.

[468 ]

1803. RoxbUrgi, [W.] An account of a new Species of Delphinus, An Inhabitant of the Ganges. <Asiatic Researches, vii, 1803, pp. 170-174, pl. iii.

Delphinus gangeticus, sp. n., p. 171.

[469.]

1804. Bory DE ST. Vincent, J. B. G. M. Voyage | dans | les quatre principales Iles | des mers d'Afrique, | fait par ordro du Gouvernement, | pendant les années neuf et dix de la | République (1801 et 1802), | Avee l'Histoire de la Traversée du Capitaine Baudin jusqu'au Port-/Louis de l'Ile Maurice. I Par J[ean]. B[aptiste]. G[eorge]. M[arie]. Bory de St-Vincent, / Officier d'Etatmajor; Naturaliste en clief sur la | Corvette le Naturaliste, dans l'Expédition de | Découvertes commandée par le Capitaine Baudin. | Avec la Collection de 58 Planches, grand in-4․, dessinées sur les lieux par l'Auteur, | et gravées en taille-douce | Tome Prenier [Seconde et Troisème] | - | A Paris, | Chez F. Buisson, Imprimeur-Libraire, rue Hantefeuille, no. 20. | An XIII. (1804.) 8. Tom. $1^{\text {re }}$, pp. i-xvi, 1-412; tom. 2e, 11. 2,pp. 1-431; tom. 3e, 11. 2, pp. 1-473.

Cétacés, passim: Delphinus phocaena, de se chasse aux poissons volans et de se mœurs, ete., tom. i, pp. 88, 89; description de danphin [= Delphinus Boryi, Desm. ?], pp. 104-106; Baloena physalus, Linn., pp. 145, 146; " un banc de dauphins... plusieurs milliers," tom. iii, p. 293; dauphins très-gros, pp. 293, 294.

Contains nothing of importance relating to Cetaceans.

[470.]

1804. Fr-P. [=Froriep, L. F. vox]. Tabelle der Unterordnungen, Geschlechten und Gattungen der Walltische. Von Lacepede. <Voigt's Mag. der Naturk., vii, 1804 , pp. $445-450$.

"Aus einem so eben erschienenen Werke von Laccpede, und vom Hrn. Prof. Froriep mitgetheilt."-Siehe op. cit., p. 475.

[471.]

1804. LaCépìde, [Bern. Germ. Étuenne]. Histoire naturelle | des Cétacées, | dediée a Anne-Caroline La Cepède: | par le Citoyen La Cepède | ... [ [ =titles, 11 lines.] | - | A Paris, | Chez Plassan, Imprimeur-Libraire, | Rue de Vaugiard, No 1195. | - | L'an XII de la République [1804]. 4. pp. i-xliv, 1-329, pll. i-xvi. (Pll. vi, vii, xi, xii, xiv, xvi, désignées d'après nature.)

Dédicace, p.v. Table des Articles, pp. vi-viii. A vertissement, et explicatiou de quelques planclies, pp. ix, x. Vue général des Cétacées, pp. xi-xxxiii. Tableau des ordres, genres et espèces do Cétacées, pp. xxxv-xliv.

Les Baleines, pp. 1-113. 1. La Baleine francho (Balana mysticetus), pp. 1-102, pl. i, fig. 1 (d'après Martens). 2. La Baleino Nordeaper (Balcena nordcaper), pp. 103-110, pll. ii, iii, (d'après Bachstrom; fig. = Balaena mysticetus). 3. La Baleine noueuse (Balcena nodosa), pp. 111, 112. 4. La Baleine bossue (Balona giblosa), p. 113.

Les Baleinoptères, pp. 114-141. 5. La Baleinopière gibbar (Balcenoptera gibbar), pp. 114119, pl. i, fiı. 2 (d'après Martens). 6. La Baleinoptère jubarte (Balcenoptera jubartes), pp. 120-125, pl. ir, fig. 1. \%. La Baleinoptère rorqual (Balcenoptera rorqual), pp. 126-133, pl. i, fig. 3, animal, pl. v, fig. 1 ("gravé d'après un dessin de Jacques Quine), pl. vi, tête osseuse, pl. riii, vertèbres cervicales et antres vertèbres et fanons (pll. vi-viii d'après nature). $\mathbf{8}$. La Baleinoptère museau-pointu (Balcenoptera acuto-rostrata), pp. 134-141, pl. viil, figg. 1, 2, animal, fig. 3 , mâchoire supérieure. 
1804. LaCépìde, [Bern. Germ. Étienne]-Continued.

Les Narwals, pp. 112-163. 9. Lo Narwal vulgaire (Narwalus vulgaris), pp. 142-158, pl. iv, fig. 3. 10. Le Narwal microcéphalo (Narualus microcephalus), pp. 159-162, pl. v, fig. 2, animal, d après un dessin par W. Brand), pl. ix, fig. i, téte osseuse. 11. Le Narwal Anderson (Narvalus Anderšonianus), p. 163.

Les Anarnaks, p. 164. 12. L'Anarnak groenlandoise (Anarnak Groenlandicus), p. 164.

Les Cachalots, pp. 165-218. 13. Lo Cachalot macrocéphale.(Catodon macrocephalus), pp. 165-211, pl. x, fig. 1, animal (d'après Bonnaterre), pl. xi, tête osseuse, pl. xii, vertèbres et côte (pll. xi, xii d'après nature). 14. Lo Cachalot trumpo (Catodon trumpo), pp. 212-215, pl. $x$, fig. 2 (d'après Robertson). 15. Le Cachalot svineval (Catodon svineval), pp. 216, 217, pl. ix, fig. 2, tôte osseuse [= Globiocephalus melas]. 16. Le Cachalot blanchatro (Catodon albicans) [=Beluga catodon], p. 218.

Les Physales, pp. 219-226. 17. Le Physale cylindrique (Physalus cylindricus), pp. 219. 2:6, pl. ix, fig. 3 (d'après Anderson).

Les Physétères, pp. 227-243. 18. Lo Physetèro microps (Physeter microps), pp. 227-235. 19. Le Physetère orthorlon (Physeter orthodon), pp. 236-238. 20. Le Physétère mular (I'hy. seter mular), pp. 239-242.

Les Delphinaptères, pp. 243-249. 21. Lo Delphinaptèré béluga (Delphinapterus beluga), [=Beluga catodon], pp. 243-248. 22. Le Delphinaptère sénedette (Delphinapterus senedetta), p. 249.

Les Duuphins, pp. 250-317. 23. Le Dauphin valgai re (Delphinus vulgaris), pp. 250-286, pl. xiii, fig. 1, animal, pl. xiv, fig. 1, tête. 24. Lo Dauphin marsouin (Delphinus phocana), pp. 287-297, pl. xiii, fig. 2, pl. xiv, fig. 2, squelotte (pl. xiv d'après uature). 25. Le Dauphin orque (Delphinus orca), pp. 298-301, pl. xv, fig. 1, pl. xvi, crâne (dianrès nature). 26. Le Dauphin gladiateur (Delphinus gladiator), pp. 302-306, pl. v, fig. 3. 2\%. Lo Dauphin Nesarnack (Delphinus nesarnack), pp. 307,308, pl. xv, fig.2. 28. Lo Duaphin dioclon (Delphinus diodon), pp. 309, 310. 29. Le Dauphin ventru (Delphinus ventricosus), p. 311, pl. xr, fig. 3 (d'après Hanter). 30. Le Dauphin férès (Delphinus feres), pp. 312, 313. 31. Lo Dauphin de Duhamel (Delphi. nus Duhameli), pp. 314, 315. 32. Le Danphin de Péron (Delphinus Peronii), p. 316. 33. Lo Dauphin de Commerson (Delphinus Commersoni), pp. 317, 318.

Les Hypéroodons, pp. 310-324. 34. L'Hypéroodon butskopf (Hyperoodon butskopf), pp. 319-324, pl. $x v$, fig. 3 .

Table alphabetique, pp. 325-329.

The text is an elaborate compilation; the figares of the animals, with the two or three above-noted exceptions, are copies; all the osteological figures, except one, are original. Viewed in the light of to-day, the work is a striking commentary on the poverty of the author's resources, and on the inexact information of the times in all that related to the history of Cetacea. Compared with Bonnaterre's work (1789), the number of species is greatly increased, while the generic nomenclature differs to a very large degree, throu gh the introduction of new genera and the substitution of new names for others. The prominent feature is therefore the classification, which, considering the state of Cetological knowledge at this time, is entitled to praise. Its weakness lies in the recognition of a largo number of species now known to be nominal or fictitious, but which, supported by Lacépède's endorsement, figured prominently for many years in the works of later compilers.

Lacépede's new genera are the following: 1. Baloenoptera, 2. Narwalus (=Monodon), 3. Anarnak (based on Monodon spurius, Fabr.), 4. Catodon (ex Artedi?), 5. Physalus, 6. Delphinapterus, and, \%. Hyperoodon. His new specific designations are: 1. Balcenoptera gibbar (= Baloena physalus, Linn.), '2. Balcenoptera jubartes (= Balaena boops, Linn.), 3. Bala. noptera acuto-rostrata (=Baloena rostrata, Müll.), 4. Narwalus vulgaris, 5. N. microcephalus, 6. $N$. Andersonianus (= Monodon monoceros), \%. Anarnak groenlandicus (= Mono. don spurius, Fabr.), 8. Catodon svincval (= Globiocephalus melas), 9. Physeter orthodon, 10. Delphinapterus beluga (=Beluga catodon), 11. Delphinus vulgaris (=D. delphis), 12. Delphinus nesarnack (=D. tursio, Fabr.), 13. Delphinus diodon (= Hyperodon butzhopf), 14. Delphinus ventricosus (=? Grampus griseus), 15. Delphinus Duhameli, sp. n., 16. Delphinus Peronii (=D. leucorhamphus, PǴron, Ms.), sp.n., 17. Delphinus Commersoni (ex Commersun, Ms.), sp. n.

Besides the Sonnini version of 1804 (q. v.), Lacépède's Hist. nat. de C'tacés was republished in 1805 , in two vols. $12^{\circ}$, in the 90 vol. $12^{\circ}$ ed. of Buffon, forming rols. 89 , 9ง; in Lacépède's $8^{\circ}$ ed. of Buffon published in 1819 (not seen by me), and in later editions of the same. Also in the collected works of Lacépede (ed. Desmarest, 11 rols. $8^{\circ}, 1826-31$ ), and in the later editions of his works published in 1830,1836, 1839, and 1844 (not seen by me). Cf. Carus and Eugel. mann, Bibliotheca hist. nat., i, 1846, p. 332.

[472.]

1804. Sonnini [De Mannoncourt], C. [N.] S. Histoire naturelle, I générale et particulière, | des Cétacées. | Ouvrage fasaint suite à l'Histoire naturelle, générale / et particulière, composée par Leclerc de Buffon, et / mise dans un nouvel ordre par C[HaRLes]. [Nicolas] S[Igisbert]. Sonnini [DE ManNoncourt], 
1804. Sonnini [DE Mannoncourt], C. [N.] S.-Continued.

avec / des Notes et des Additions. | Par C. S. Sonnini, | Membre des plusieurs Sociótes savantes | et littéraires. | [Monogram.] A Paris, | de l'Imprimerie de F. Dufart. | - | An XII [=1804]. So. pp. 1-446, pll. i-v.

Vue générale des Cetacées, pp. 5-30; Tableau des Ordres, Genres et Espèces do Cétacées, pp. 31-42.

Les Baleines, pp. 43-192. 1. La Baleine franche (Balcena mysticetus), pp. 43-179, pl. i. 2. Le Nordcaper (Balcena nordcaper), pp. 180-188. 3. La Baleine noueuse (Balcena nodosa), pp. 189, 190. 4. La Baleine bossue (Balana gibbosa), pp. 191, 192.

Les Baleinoptères, pp. 193-226. 5. Lo Gibbar (Balcenoptera gibbar), pp. 193-199, pl. ii, fig. 1. 6. La Jubarte (Balcenoptera jubartes), np. 200-207. \%. La Baleinoptère rorqnal (Balcenoptera rorqual), pp. 208-217. 8. Le Mnseau-pointu (Balcenoptera acuto-rostrata), pp. 218-226.

Les Narwals, pp. 227-251. 9. LeNarwal vnlgaire (Narwalus vulgaris), pp. 227-245, pl. ii, fig. 2. 10. Le Narwal microcéphalo (Narvalus microcephalus), pp. 246-25 J. 11. Le Narwal Anderson (Narnalus andersonianus), p. 251.

Les Anarnaks, pp. 252, 253. 12. L'Anarnak Groenlands (Anarnak groenlandicus), pp. $252,253$.

Les Cachalots, pp. 254-319. 13. Le Cachalot macrocéphale (Catodon macrocrphalus), pp. 254-311, pl. iii, fig. 1. 14. Lo Cachalot trumpo (Catodon trumpo), pp. 312-316. 15. Le Cachalot svinoval (Catodon svineval), pp. 317,318. 16. Le Cachalut blanchatre (Catodon albicans), p. 319.

Les Physales, pp.320-328. 17. Le Physale cylindrique (Physalus cylindricus), pp. 3:0328, pl. iii, fig. 2 .

Les Physétères, pp. 329-346. 18. Le Physétère microps (Physeter microps), pp. 329-338. 19. Le Physetère orthodon (Physeter orthodon), pp. 339-342. 20. Le Mular (Physeter mular), pp. 3\$3-346.

Les Delphinaptères, pp. 347-355. 21. Le Beluga (Delphinapterus beluga), pp. 347-353. 22. Le Sénedette (Delphinapterus senedette), pp. 354,35..

Les Dauphins, pp. 356-437. 23. Lo Dauphin vulgaire (Delphinus vulgaris), pp. 356-399, pl. iv, fig. 1. 24. Le Marsouin (Delphinus phocaena), pp. 400-412, pl.iv, fig. 2. 25. L'Orque (Delphinus orca), pp. 413-417. 26. Lo Dituphin gladiatenr (Delphinus gladiator), pp. 418-422. 27. Le Nésarnack (Delphinus nesarnack), pp. 423-425, pl. v, fig. 1. 28. Le Diodon (Delphinus diodon), pp. 426,427 , pl. v, fig. 2. 29. Le Dauphin ventru (Delphinus ventricorus), pp. 428, 429. 30. Le Dauphin férès (Delphinus feres), pp. 430-432. 31. Le Dauphin de Duhamel (Delphinus Duhameli), pp. 433,434. 32. Le Dauphin de Péron (Delphinus Peronii), p. 435. 33. Le Dauphin de Commerson (Delphinus Commersonii), pp. 436-437.

Les Hypéroodons, pp. 438-444. 34. Lo Butskopf (Hyperoodon butskopf), pp. 438-444.

Although this work bears the same date (an XII) as Lacépède's Hist. nat. des Cétacées (see 1804. LACìPÈDE), it is merely a slightly abridged version of that work, with here and there slight additions. Although the text is mostly inclosed in marks of qnotation, I fail to find any acknowledgment of the souree. The work is currently attributed, however, to Sonnini. The arrangement of the matter, the number of species treated, their order of succession and nomenclature, are identical in the two works.

[473.]

1804. "Wiedemann, C. R. W. Beschreibung des Schädols vom Lamantin oder Manati. <Wiedemann's Arch. für Zool. und Zoot., iv, 1804, pp. 67-77.".

Not seen; title from Carus and Engelmann.

[474.]

1805. Carlisle, Antrony. The Physiology of the Stapes, one of the Bones of the Organ of Hearing; deduced from a comparative View of its Structure, and Uses, in different Animals. <Philos. Trans. Lond., [xev], pt. 2, art. xi, 1805, pp. 198-210, pl. iv.

The plate gives fignres of the stapeles and columellæ of various animals, including Phoca vitulina, Phoccena communis, and Odobcenus rosmanus.

1805. Holmes, A. American Annals; | or | a Chronological | History of America | from its Discovery in MCCCCXClI to MDCCCVI. I In two Volumes. I By Abiel Holmes, D. D. A. A. S. S. H. S. | Minister of the First Church in Cambridge. | Summ quaque in annuin referre. | Tacit. Annal. | - | Vol. I | Comprising a period of Two Hunclred Years. | - | Cambridge, Printed and Sold by W. Hilliard. | - 1805. 2 vols. 80.

The title of vol. ii differs from the above as follows:

Vol. II. I Comprising a Period of One Hundred and Fonrteen Years.

Whale-fishery in 1730 , vol. ii, p. $125-a$ brief statement embraced in 6 lines. Also brief reforence to Morse-fishing aud Whalo-fishing in tho Gulf of St. Lawrence in 1593, vol. i, p. 133. 
1805. Macpirersox, D. Annals | of | Commeree, | Manufáctures, Fisheries, and Navigation | with | brief notices of the Arts and Sciences connected with them. | Containing the | Commercial Transactions | of the | British Empire and other Countries, | from the earliest accounts to the meeting of the Union Parliament in Jauuary 1801; | and comprehending the most valnable part of the late Mr. Anderson's History of Commeree, viz. from the year 1492 | to the end of the reign of George II, King of Great Britain, \&c. | With a large Appendix, | containing |

Chronological Tables of the Sovereigns of Europe, | Tables of the alterations of money in England and Scotland, I

A Chronological Table of the prices of Corn, \&c. and | A Commercial and Manufactural Gazetteer of the | United Kingdom of Great Britain and Ireland।

With a general chronological Index. | The Antient Part composed from the most authentic Original Historians and Public Records, I printed and in Manuseript, and the Modern Part from Materials of unquestionable | Authenticity (mostly unpublished) extracted from the Records of Parliament, | the Accounts of the Custom-house, the Mint, the Board of Trade, the'| Post-Office, the EastIndia Company, the Bank of England, | \&c. \&c. | By David Maepherson. | - | In Four Volumes. | - | Vol. I [-IV]. | - | Printed for Nichols and Son, . . . [= nearly 4 lines of names of booksellers]. | London; | and for Mundell and Son, Edinburgh. | - | 1805. 4 vols. $4^{\circ}$.

The chronological arrangement of the work precludes reference to special topics, since the same subject may be briefly mentioned in many places. $\Delta$ very detailed and thorough index; however, renders the matter realily accossible, and to this index the present writer would refer the investigator of matters relating to the Whalefishery and kindred topics. The work is one of great research and labor, and is standard authority on the subjects treated.

[477.]

1806. DuméniL, A. M. C. Zoologie analytique, | ou | Méthode naturelle | de | Classification des Animanx, | rendue plus facile | a l'aide de Tableanx synoptiques; | Par A[ndré]. M[arie]. Constant Duméril, | . . . [titles, 6 lines of small type]. Parva sed apta. | - | Paris | Allais, Libraire, quai des Augustins, No.39. | - | M. DCCC. VI. 80. pp. i-xxxii, 1. 1, pp. 1-344.

XIII. Famille, Amphibies [=Pinnipedia + Sircinia]. pp. 26, 27. Genera 3, under French and Latin names, viz: 1. Phoca, 2. Trichecus, 3. Dugong, 4. Manatus.

XIV•. Famille, Cétacés, pp. 28, 29. Gencra 10, under French and Latin names, viz: 1. Balcena, 2. Balenoptera, 3. Narwhahus, 4. Ananarcus, 3. Catodon, 6. Phylasus (sic), 7. Phy. seterus, 8. Delphinapterus, 9. Delphinus, 10. Iyperodon.

1806. TuRTox; W. A general | System of Nature, | through the / Three Graud Kingdoms | of | Animals, Vegetables, and Minerals, | systematically divided | into their several | Classes, Orders, Genera, Species, and Varieties, | with their | Habitations, Manners, Economy, Structure, and Peculiarities. | By Sir Charles Linuè: | Translated Gmolin, Fabricius, Willdenow, \&c. | Together with | Various Modorn Arrangements and Corrections, derived from the | Transactions of the Linnean and other Societies, as well as from the Classical | Works of Shaw, Thornton, Abbot, Donovan, Sowerby, Lathan, Dillwyn | Lewin, Martyn, Andrews, Lambert, \&e. \&c. | with a life of Linuè, | Appropriate Copper-plates, and a Dictionary explanatory of the Terms which | occur in the several Departments of Natural History, | by William Turton, M. D. | Fellow of the Linnean Society, Author of the Medical Glossary, \&c. \&c. | - In Seven Volumes. | - | Animal Kingdom.-Vol. I. | Mammalia. Birds. Amphibia. Fishes. | | | London: | Printed for Lackington, Allen, and Co. | Temple of the Muses, Firesbury-Square. | - 1806. $8^{\circ}$. pp. i-vii, 1-944. ("Printed by Voss aud Morris, Castle-Street, Swansen. 1800," p. 943.)

Order vii. Cete, pp. 127-130. 1. Monodon Mfmoceros, 2. Baloena Mysticetus, p. 127; 3. B. Physalus, 4. B. Boops, 5. B. Gibbosa, 6. B. Musculus, 7. B. Rostrata, 8. Physeter Catodon, 9. P. MLacrocsphalus, p. 128; 10. P. Microps, 11. P. Tursio, 12. Delphinus Phoccena, 13. D. delphis, p. 129; 14. D. Orca, 15. D. Leucas, p. 130. Short, nearly worthless, descriptions, and no references to previous authors. 


\section{Turton, W.-Continued.}

Sirenia: 1. Trichechus Durong (sic), 2.T. Manatus, with var. 1. Australis (= African and American Manatees), var. 2. Borcalis (= Rhytina borealis), var. 3, Sircn (fabulous), pp. 36, 37. The following complete transcript of the aecount of the Trichechus Manatus Sircnus is a sufficient commentary on the character of the work :

"3. Siren. Ears erect, sharp-pointed. Inhabits the north-west coast of A merica, swims around ships with antic gestures. Hcad resembling a dog; eyes large; lips whiskered: body thick, round, tapering downwards; tail divided into 2 unequal lobes; length about 5 feet."

1807. HoMe, E. Observations on the structure of the different Cavities, which constitute the Stomach of the Whale, compared with those of ruminating Animals, with a View to ascertain the Sitnation of the digestive Organ. <Philos. Trans. Lond., [xevii], pt. 1, art. iv, 1807, pp. 97-102, pll. iii, iv.

Investigation based on "a Delphinus Delphis of Linnaeus, or small bottle-nose whale of Mr. Hunter."

1808. Avov. A Short and true Account of Forty-two Persons [Whalers] who perished by shipwreck near Spitzbergen, in the year 1646. <Pinkerton's Coll. Voy. and Trav., i, 1808, p. 535.

1808. Axov. Third Voyage of the Dutch and Zealanders, by the North, along Norway, Moscory, and Tartary, to pass to the kingdoms of Cathay and China, by permission of the Council of the city of Amsterdam, 1596. <Pinlierton's Coll. Voy. and Trav., i, 1808, pp. 90-127.

"Newly translated from the Recueil des Voyages, qui ont servi a l'etablissement et aux progrez de la Compagnie des Indes Orientales. Tom. i, p. 55."

Whales described, pp. 93, 94. Very good description of the Northern Right Whale. [432 ]

1803. Bacstrom, S. Account of a [Whaling] Voyage to Spitzbergen in the Year 1780. By S. Bacstrom, M. D. <Pinkerton's Coll. Voy. and Trac., i, 1808, pp. 614-620.

From Phil. Mag., July, 1799.

1808. Blumenbach, J. F. Manuel | d'Histoire naturelle, | traduit de l'Allemand, | De J. Fr. Blumenbach, Professeur à l'Université | de Gottingue. | Pur Soulange Artaud. | Avec figures. | - | Multa fiunt eadem, sed aliter, | Quintilian. | - | Tome Premier. | [Monogram.] | A Metz, | Chez Collignon, Imprimeur-Libraire. $\mid \ldots$ [ = Names of 3 other publishers. $]$ | | An XI.-1803. 8०. pp. i-xvi, 1-526.

Trichechus manatus, p. 164, Les Cétacées (Cetacea), pp. 165-169. A translation of one of the early editions, but whieh is not stated. The matter relating to the Cetacea is substantially the same as that of the $3 \mathrm{~d}$ ed., $1788, q . v$.

[484.]

1808. LeEms, K. An Account of the Laplanders of Finmark, their language, manners, and religion, by Knud Leems, Professor of the Laplandic, with the notes of Gunner, Bishop of Drontheim, and a Treatise, by Jessen, on the Pagan Religion of the Finns and Laplauders. <Pinkerton's Coll. Voy. and Trav., i, 1808 , pp. 376-490.

Chap. xiii, Of the Fishery, pp. 431-446. Contains a short account of the Whales and Whalefishery of Finmark, pp. 431-433.

The original edition of Leems (not seen by me) was published in Danish and Latin s.t Copenhagen in $1767,4^{\circ}$, with plates.

1808. Pinprs, C. J. A voyage towards the North Pole, undertaken by his Majesty's command, in 1773, by Constantine John Phipps. ¿ Pinkerton's Cor. Voy and Trav., i, 1808, pp. 538-594.

Natural history, pp. 578-585. Balcena Mysticetus, Balcena Physalus, p. 579 (=7 lines of no importance).

1803. Trentuans, D. F. Zoologie. $|-|$ Zu seinen Vorlesungen entworfen | von | D. Friedrich Tiedemann, | Professor der Anatomie und Znologie an der Universität zu | Landshut. | - | Erster Band. | Allgemeine Zoologie, Mensch und Säugthiere. | - | Landshut, in der Weberschen Buchbandlung. | - 1808. 80. pp. i-xvi, 1-610, 1. 1.

XII. Ordnung. Fischartige Säugthiere. Wallfische. Cetacea (Cetacés), pp. 557-585.

Generalities, 557-570; gencra and species, pp. 570-585. 1. Balaena mysticetus, 2. B. islan- 
1808. Tredemans, D. F.-Continued.

dica (Nordkaper); 3. Dor Wallfisch mit einem Höcker, B. nodose, p. 5ï1; 4. B. gibbosa, 5. Balaenoptera gibbar, 6. B. rostrata, p. 572; 7. B. boop8, 8. 13. rorqual, p. 573; 9. Nar walus vulyaris (= Monodon-monoceros), 10. N. microcephalus, 11. N. Andersonianus, p. 5i4; 12. Anarnacus groenlandicus, p. 575; 1:3. Catodon macrocephalus, p. 576 ; 14. C. albicans, 15. C. trumpo, 16. C.svineval, p. 577; 17. Physalus cylindricus, p. 578; 18. Physeter microp8, 19. $P$. orthodon, 20. P. mular, p. 579 ; 21. Delphinapterus beluga, :2. D. senedetta, p. 5s0; 23. Delphinus delphis, 24. D. phocaena, p. 581; 25. D. Orca, 26. Der Delphin mit der hohen Rückenflosse, p. 582; 27. D. tursio, 2S. D. diodon, 22. D. Bonnaterrei, sp. n. (=lo damphin férès, Bonnaterre), p. 583; 30. D. ventricosus, 31. D. Duhamelii, 32. D. Peronii, 33. D. Comersonii, 34. Hyperoodon butzliopf, p. 584.

Delphinus Bonnaterrei, sp. n., p. 583. Genn. 11, spp. 34.

Number of species and nomenclature same as Lacépede's, excepting " $D$. Bonnaterrei."

[187.]

1808. Willovghis, H. The Voyages of Sir Hugh Willoughby, Richard Chancelor, and others, to the Northern parts of Russia and Siberia. <Pinkerton's Coll. Voy. and Trav., i, 1808, pp. 1-80.

From Hackluyt's Voy. and Trav.

[483.]

1809. Abernethy, J. Some Particulars in the Anatomy of a Whale. <Philos. Trans., abridged by Hutton, Shaw and Pearson, 1665-1800, xvii (1791-1796), 1809, pp. 673-677.

From Philos. Trans. Lond., lxxxvi, 1706, pp. 27 et seqq., q. v.

1809. Axon. Of the New American Whale-Fishing about Bermudas. <Philos. Trans., abridged by Hutton, Shaw and Pearson, 165.5-1800, i (1665-1672), 1809 , pp. $6,7$.

From Philos. Trans. Lond., i, no. 1, 1665, p. 11, q. v.

1809. Axos. A further Relation of the Whale-Fishing about the Bermudas, and on the Coast of New-England and New-Netherland. <Philos. Trans., abridged by Hutton, Shaw and Pearson, 1635-1800, i (1665-167\%), 1809, p. 46. [With supplementary note.]

From Philos. Trans. Lond., i, no. 8, 1660, p. 132, q. v.

[491.]

1809. Axon. Description de la Piece d'Ambrerris que la Chambre d'Amsterdam a reçue des Indes Orientales, pesant 182 Livres; avec un petit Traité de son Origine et de sa Vertu, par Nicolas Chevalier, a Amsterdam chez l'Auteur, 1700. 4०. <Philos. Trans., abridyed by Hutton, Shaw and Pearson, 16651800 , iv (1694-1702), 1809, p. 500.

From Philos. Trans. Lond., xxii, no. 263, 1700, p. 573, q.v. See 17C0. Chevalier, N. [492.]

1809. Boyle, [R.] On Ambergris. <Philos. Trans., abridged by Hutton, Shaw and Pearson, 1665-1800, ii (167.2-1683), 1809, pp. 94, 9.5. [Wilh suppl. foot-note.] From Philos. Trans., Lond., vii, no. 97, 1673, pp. 6113-6115, q. v.

[493]

1809. Boylston, - Ambergris found in Whales. <Philos. Trans., abridged by Hutton, Shaw and Pearson, 1655-1800, vii (1724-1734), 1809, p. 57.

From Philos. Trans. Lond., xxxiii, no. 385, 1724, p. 193, q.v.

1809. "Cortesi. Sugli Sceletri d'un Rhinoceronte afric. et d'una Balena. Milan, 1809."

Not seen; titlo from Van Beneden, Oss. foss. des environs d'Anvers, ii, 1880, p. 17.

[495.]

1809. Cuvier, G. Sur l'ostéologie du Lamantiu, sur la place qu') le Lamantin et le Dugong doivent occuper dans la méthode naturelle, et sur les os fossiles de Lamantins et de Phoques. <Ann. du Mus. d'Hist. Nat., xiii, 1808, pp. 273312, pl. xix.

Historique, pp. 273-282; Art. I. Du lamantin d'Amerique, pp. 282-293; Art. ПI. Des espèces nominales du petit lamantin des Antilles et du lamantin des Grandes Indes. pp. 293, 294; Art. III. Du lamantin du Sénégal, pp. 294-290; Art. IV. Du prétendu lamantin du Nioril, do Steller, pp. 296-209; Art. V. Du dugong, pp. 300-302; Art. VI. Ossemens fossiles do lamantins, pp. 303-309; Art. VII. De quelques os de phoques trouvés avec ceux de lamantins, dans lo département de Maine-et-Loiro, et des prétendus os do morso annoncés par quelques uaturalistes, pp. 302-312. PI. xix, Ostéologio des lamantins et du dugong.

This celebrated memoir marks an epoch in tho literary history of the Sirenia. After giving a detailed history of the viows respecting the afinities of theso animals entertained by pro- 


\section{Cuvier, G.-Continued.}

vious writers, including the absurdities of mermaids and mermen, the author closes lis historical résumé by stating that the Sirenia form three distinet genera, the Lamantins (of which he recognizes two species), the Dugong, and Steller's Sea-Cow, and that these three genera constituto a separato family, very different from the seals. with which they had been previ. ously placed, and a littlo nearer to tho Cetacea than the Pachyderms aro to the Carnirores. Buffon's four species of Lamantin he redices to two. Then follows an aecount, with figares, of the osteology of the Brazilian Manateo; a comparison of the skulls of the African and American Manatees, and a résumó of tho distinctivo structural features of Sieller's Sea-Cow, whereby it is generically separated from tho Dugong and Manatees. Curier's results agree closely with tho modern interprotation of the affinities and generic relations of thesu animals. It was left, however, for Desmarest to bestow technical names upon the species here tirst clearly distinguished, Cuvier throighout his memoir omploying only the French vernacular names.

[496.]

1809. Cuvier, G. Sur les Lamantins et les Os fossiles de ces animaux. <Nouv. Bull. des Sci. par la Soc. Philom., no. 24, Sept. 1809, pp. 395, 396.

Extrait d' Ann. du Mus. d'Hist. Nat., xiii, pp. 273-312. Seo last title.

1809. Dudley, P. An Essay on the Natural History of Whales; with a particular Account of the Ambergris found in the Sperma Ceti Whale. <Philos. Trans., abridged by Huttun, Shaw and Pearson, 165j-1800, vii (1724-1734), 1809, pp. 78-84.

From Philos. Trans. Lond., xxxiii, no. 387, 1725, pp. 256-269, q. v.

[1988.]

1809. EDIror. The Editor's Account, with Observations, of Experiments on Ambergris, made by Mr. John Browne, F. R. S., and by Mr. Ambrose Godfrey Hanckewitz, F. R. S. To which are subjoined Dr. Neuman's Vindicatory Remarks. <Philos. Trans., abridged by Hutton, Shaw and Pearson, 16651800, vii (1724-1734), 1809, pp. 668, 639.

From Philos. Trans. Lond., xxxviii, no. 435,1735 , p. 437. See 1735. Neumaxy, C.

[499.]

1809. Edroxpston, A. A / View / of the / Ancient and Present State / of the / Zetland Islands; | including their | Civil, Political, and Natural History; | Antiqnities; | and | An Account of their Agriculture, Fisheries, Commerce, | and the state of Society and Manners. | By | Arthur Edmondston, M. D. | - I In two volumes. | - | Vol. I [-II]. | - | Elinburgh: | Printed by James Ballantyne and Co. / For Longman, Hurst, Rees, and Orme, London; and / John Ballantyne and Co. Ediuburgh. | - 1809. 2 vols. 80. Vol. i, pp. i-xir, 1364, with map; vol. ii, pp. i-vii, 1-345.

The Zetlands not so favorable a point from which to carry on the Whale Fishery as sapposed, vol. i, pp. 290-203. Of Whales and Wrecks. Section I, Of tho Dirision of Whales, vol. ii, pp. 154-174. Fishes [= Pisecs + Cetacea]. vol. ii, pp. 206-316. 1. Balana Mysticetus, 2. Balcena Boops, 3. Balcena ILusculus, 4. Physeter Catodon, 5. Physeter Micrnps, 6. Physeler Tursio, p. 398; g. Delphinus Phocana, p. 399; 8. Delphinus Orax; D. Balcena ros. trata, Pontoppidan [="Delphinus melas, Traill"], p. 310; 10. JIonodon Monoceros, pp. 301, 302. A Mlonodon monoccros "run on shore in W Ceesdale vou in Zctland in September, 1808." Vast multitudes of Ca'ing Whales are noted as appearing regularly on the coast. Tho other notes relating to Cetacea are of littlo importance.

[500.]

1809. Fawkexer, W. On the Production of Ambergris. A Communication from the Committee of Conncil appointed for the Consideration of all Matters relating to Trade and Foreign Plantations; with a prefatory Letter from William Fawkener, Esq., to Sir Joseph Banks, Bart., P. R. S. <Philos. Trans., abridged by Hutton, Shaw and Pearson, 1665-1800, xvii (1791-1796), 1809, pp. 6-8.

From Philos. Trans. Lond., lxxxi, 1791, pp. 43-47, q. v.

[501.]

1809. Hampe, J. H. A Description of the same Narhwal [as mentioned in Dr. Steigertahl's communication ]. . . . < Philos. Trans., abridged by Hutton, Shaw and Pea:son, 1655-1800, viii (1735-1743), 1809, p. 161.

From Philos. Trans. Lond., xl, no. 447, 1738, pp. 149, 150, q.v. 
1809. Huvter, J. Observations on the Structure and Economy of Whales. <Philos. Trans., abridged by Hutton, Shaw and Pearson, 1665-1800, xvi (178j-1790), 1809, pp. 306-351, pl. 5.

From Philos. Trans. Lond., 1xxvii, pt. 2, art. xxxriii, 1787, pp. 371-450, pll. xvi-xxiii, q.v.

1809. Leuwexhozck, [A. VAN]. Concerning the Flesh of Whales, and the Crystalline humour of their Eve. <Philos. Trans., abridged by Hutton, Shaw and Pearson, 1655-1800, v (1703-1712), 1809, pp. 155-157.

From Philos. Trans. Lond., xxiv, no. 293, 1704, pp. 1723-1730, q.v.

1809. Neuman, C. On Ambergris. ... . < Philos. Trans., abridged by Hutton, Shaw and Pearson, 1655-1800, vii, (1724-1734), 1803, pp. 651-663.

From Philos. Trans. Lond., no. 433, 1734, p. 344, etc., $q . v$.

1809. RAY, J. Account of the Dissection of a Porpoive. <Philos. Trans, abridged by Hntton, Shaw and Pearson, 1635-1800, i (1665-1675), 1809, pp. 639-643. [With supplementary note.]

From Philos. Trans. Lond., vi, no. 76, 1671, p. 2274, etc., q.v.

1809. Robertson, J. Description of the Blunt-headerl Cachalot. <Philos. Trans., abridged by Hutton, Shaw and Pearson, 1665-1800, xiii (1770-1776), 1809, pp. 57-59, pl. 1, tig. 6 .

From Philos. Trans. Lond., 1x, 1771, art. xxvii, pp. 321-324, q.v.

1809. SchWEdiaWer, [F. X.] An Account of Ambergris. <Philos. Trans., abridged by Hutton, Shaw and Pearson, 1635-1800, xv (1781-1785), 1809, pp. 389-396.

From Philos. Trans. Lond., lxxiii, art. $\mathrm{x}\ulcorner, 1783$, pp. 226-241, q. $v$.

1809. Sibbald, R. Description of the Pediculus Ceti, \&c. <Philos. Trans., abridged by Hutton, Shaw aud Pearson, 1665-1800, v (1703-1712), 1809, pp. 317, 318.

From Philos. Trans. Lond., xxr, no. 308, 1707, pp. 2314-2317, q.v.

1809. Stafford, R. Of the Tides at Bermudas, also Whales, Spermaceti. . . . $<$ Philos. Trans., abridged by Hutton, Shaw and Pearson, 1635-1800, i (16551672), 1809, pp. 283, 284.

From Philos. Trans. Lond., iii, no. 40, 1668.pp. 792-795, q.v.

1809. Steigrrtair, $D r$. Of a Narhwal or Unicorn Fish [Monodon monoceros], taken in the River Ost, in the Duchy of Bremen. <Philos. Trans., abridged by Hutton, Shaw and Pearson, 1665-1800, viii (1735-1743), 1809, pp. 160, 161, pl. 6, fig. 1.

From Philos. Truns. Lond., xl, no. 447, 1738, pp. 147-149, q. v.

1809. Traill, Thomas Stewart. Description of a new Species of Whale, Delphinus melas. <Nicholson's Journ. Nat. Phil., Chem., and Arts, xxii, Feb., 1809, pp. 81-83, pl. iii.

Ninety-two Whales of this species were driven ashore in Scapay Bay, in Pomona, one of the Orkneys, in December, 1806, at which time the drawing was taken by James Watson, esq. Account of the external characters and habits of the now well-known "Blackfish."

[512.]

1809. Tyson, E. Phocæna; or, The Anatomy of a Porpus, dissected at Gresham College; with a preliminary Discourse concerning Anatoms, and a Natural History of Animals. <Philos. Trans., abridged by Hutton, Shaw and Pearson, 1655-1800, ii (1672-1683), 1809, pp. 500, 501.

From Philos. Collections, no. 2, p. 37. Sec 1681. Trsos, E.

1810. Albers, J. A. Undersögelse over Eenliörningens (Monodon Narwal) Hierte. $<$ Kongel. Danske Videnskab.-Sels. Skrivter for aar 1808, $3^{\mathrm{e}}$ Rek., v, 1810, pp. 179183.

1810. LEdRU, A.-P., et [C. N. S.] Sonvini. Voyage | anx Iles | de Ténériffe, | la Trinité, Saint-Thomas, | Sainte-Croix et Porto-Ricco, | exécuté par ordre du Gouvernement Français, | Depuis le 30 Septembre 1796 jusqu'au 7 Juin 1798, sous la | Direction du Capitaine Baudin, pour faire des Recherches / et des Collections relatives à l'Histoire Naturelle; | Contenant | Des Observations sur le Climat, le Sol, la Population, / l'Agriculture, les Productions de ces Iles, le Caractère, les | Mœurs et le Commerce de leurs Habitants, | Par André-Pierre Ledru, | 
1810. Ledru, A.-P., et [C. N. S.] Sonvrni-Continned.

L'un des Naturalistes de l'Expedition, Membre de la Société des Arts | du Mans, de l'Académie Celtique de Paris, du Musée de Tours, | Ex-Professeur de Législation près l'Ecole Centrale de la Sartho. | Ouvrage accompagné de Notes et d'Additions, | Par M. [C. S.] Sonnini. | Avee une très-belle Carte gravée par J. B. Tardieu, d'après Lopez. | Tome Promier [et Sccond]. | A Paris, | Chez Arthus Bertrand, Libraire, rue Hantefeuille, $n^{\circ} .23 .|-| 1810.2$ vols., $8^{\circ}$. Vol. i, l, 1. pp. i-xlvij, 1-315, 1. 1; vol. ii, 1. 1, pp. 1-324, 1. 1. Map.

Dauphin (Delphinus delphis Linu.), p. 2 (par Ledru), pp. 24-27 (par Sunnini). Marsouin (Delphinus phoccena L.), p. 214 (par Ledru), pp. 221-224 (p2r Sonnini). Combat entre une Baleino (Le Gibbar, Balaena physalus L.) et Scie (Squalus pristis L.), pp. 217, 218 (par Ledru), Le Gibbar, pp. 220, 221 (par Sunnini). Le Lamantin (Manatus australis Gm.), p. 258 (par. Ledru), pp. 294, 295 (par Sonnini).

[515.]

1810. Péron, [François], et [Charles Alexander] Le Lesuer. Notice sur l'habitation des Animaux Marius. <Ann. du Mus. d'Hist. nat., xv, 1810, pp. 287-292.

Balcena mysticetus, p. 288.

1810. ViвorG, E. [Supplementary note to J. A. Alber's "Undersögelse over Eenhiörningens (Monodon Narwal) Hierte."] <Kongel. Danske Videnskab.-Selsk. Skrivter, for aar 1808, v, 1810, pp. 183, 184.

1811. Axox. A Description of the Ferve Islands, containing an Account of their Situation, Climate, and Productions; together with the Manners and Customs of the Inhabitants, their Trade, \&c. By the Rev. G. Landt. <Quar. Rei., iv, 1811, pp. 333-342.

Contains a fow lines (pp. 338, 339) respecting the dread of the Feroese fishermen of Whales, and their method of driving them away by the use of unpleasant oders, as castoreum and oil of juniper!

[518.]

1811. ANon. ? [ReNaudot, Abbé, translator.] An Account of the Travels of two Mohammedans through India and Chiva in the Ninth Century. Translated from the Arabic by the Abbé Renaudot. <Pinkerton's Coll. Foy. and Trav., vii, 1811, pp. 179-230.

Of Ambergris, pp. 222, 223. Ambergris is cast upon the coast of the Indian Ocean, and is also found floating on the surface of the sca. "When a certain fish of the Whale kind, called Tol, sees these floating lumps, he swallows the same, and is killed thereby." Then men seize the dead whale and tow it ashore and take out the A mbergris.

[519.]

1811. Fleming, Joins. Deseription of a Small-headed Narwal, cast ashore in Zetland. <Mem. Wern. Soc. Nat. Hist., i, 1811, pp. 131-148, 1 pl.

A short diagnosis, with synonymy of Mronodon vulgaris and M. microcephalus. The plato gives two figures of $\boldsymbol{M}$. microcephalus.

1811. G. Recherches d'anatomie comparée sur les dents, par 1. C. Cuvier. <Bull. de la Soc. Plitom. de Paris, iii, 1811, No. 62, pp. 155*-169* (i. e., 265-269).

Dans le dugong et le narval, p. 105.

[521.]

1811. Herausgeber. E. Home über einige Eigenthümlichkeiten des Gehörorgans des Wallfisches (Balaena mysticetus). (Aus den Philosoph. Tr., 1811, p. i.) <Deutsches Archiv f. d. Physiol., iii, 1817, pp. 137-139.

Auszug.

[522.]

1811. Illiger, C. Caroli Illigeri D. | Acad. Reg. Scient. Berolinens. et Bavaricae sod. | Museo Zoologico Berolin. Praefecti, | Professoris extraod. | Prodromus | Systematis | Mammalium et Avium | additis | Terminis zoographicus utriusque Classis, | eorumque | versione Germanica. | - | . . . [= Motto, 3 lines. ]

| - | Berolini | Sumptibus C. Salfeld | 1811. 80. pp. i-xviii, 1-302.

Sirenia, pp. 140, 141. Genera, 1. Manatus, 2. Halicore, 3. Rytina. 2 et 3 genn. nn.

Cete, pp. 141-144. 1. Balaena [Linn. et auct. var.]; 2. Ccratodon (ex Briss.=Monodon, Linn., Diodon, Storr, Narwalus, Lacép.); 3. Ancyclodon [gen. n.=Anarnacus, Lacép.]; 4. Physeter [Linn. et auct. var.]; 5. Delphinus [Linn. et auct. var.] ; 6. Oranodon [gen. n. $=H y$ peroodon, Lacép.]. Cum charac. gener.

[523.]

1811. Kempfer, E. The History of Japan. By Engelbert Kenpfer, M. D. Physician to the Dutch Embassy to the Emperor's Court; and translated from his orig- 
1811. KжMPFER, E.-Continued.

inal Manuscript, in the German Language, never bcfore printed. By J. G. Scheuchzer, F. R. S. And a Member of the College of Physicians, London. <Pinkerton's Coll. Voy. and Trav., vii, 1811, pp. 652-821.

Chap. VIII. Of Fish and Shells, pp. 705-712. At pp. 706, 707 is a short account of "several sorts of whales," to wit: 1. Sebio, "the largest fish of the Whale kind,-probably Balcenre mysticetus, 2. Awo sangi or kokadsura, a small gray or ash-colored whale, probably Rhachianectes glaucus, 3. Nagass, "twenty to thirty fathoms long," 4. Sotoo-kadsura, 5. Moko, "three or four fathoms in length," 6. Ivasikura, "that is, sardin's-eater,"-doubtless a Balcenoptera. The Satsifiko, also mentioned, may be an Orca, but as described is certainly a myth.

The original work, of which merely an extended abstract is here given, was published in 1727 (London, fol.). The Appendix, containing the observations on Ambergris, is omitted. For notice of the original work, see Addenda, 1727. KEMPFER.

[524.]

1811. Marsden, W. The | History of Sumatra, | containing an account of $\mid$ the.Government, Laws, Customs, and Manners | of | the Native Inhabitants, | with | a description of the Natural Productions, | and a relation of the | Ancient Political State of that Island. | - | By | William Marsden, F. R. S. | - | The third edition, with corrections, additions, and plates. | - | London: | Printed for the Author, | by J. M'Creery, Black-Horse-Court, | And sold by | Longman, Hurst, Rees, Orme, and Brown, Paternoster-Row. | - 1811. 4. pp. i-viii, 1-479, 11. 4.

Düyōng or Sea Cow, p. 122. Grampus Whale (Delphinus sp.), p. 122.

[525.]

1811. NeIll, Patrick. Some account of a Fin-Whale stranded near Alloa. <Mem. Wern. Soc. Nat. Hist., i, 1811, pp. 201-214.

Identified as Balcenoptera acuto-rostrata.

1811. Parkinson, J.' Organic Remains of a Former World. | - | An | Examination of the Mineralized Remains | of the | Vegetables and Animals | of the | Antedeluvian World; | generally termed | Extraneons Fossils. | - | By James Parkinson. | In three volumes. | [Vignette.] The third Volume; $\mid$ containing | the Fossil Starfish, Echini, Shells, Insects, Amphibia, Mammalia, \&c. 1 - | Lordon: | Printed by Whittingham and Rowland, | Goswell Street; | and published by Sherwood, Neely, and Jones, Paternoster-Row; $\mid \ldots . .[=3$ lines, names of other publishers. $\mid$ - | 1811. 40. pp. i-xvi, 1-479, pll. i-xxii.

Vol. i, The Vegetable Kingdom, 1820; vol. ii, The Fossil Zoophytes, 1808.

"Cete, or Ceti," and "Amphibia" [=Pinnipedia + Sirenia], vcl. iii, pp. 309, 310, pl. xx, ffg.

1 (supposed Cetacean tooth).

[527.]

1811. Scoresir, W., jr. Account of the Balæna mysticetus, or Great Northern or Greenland Whale. <Mem. Wern. Soc. Nat. Hist., i, 1811, pp. 578-586, 1 pl.

Description, measurements, and habits.

[528.]

1811. Zrmmermann, E. A. W. Die | Erde und ihre Bewohner | nach | den neuesten Entdeklkungen | - | Ein Lesebuch für Geographie, Volkerkunde | Produktenlehre und den Handel | von | E[berhard]. A[ugnst]. W[ilhelm]. Zimmermann. | - Dritter Theil. | Die westliche aretische Welt. | - | Mit einem Titelkupfer und einer Karte. | - | Leipzig bei Gerhard Fleischer dem Júugern. | 1811. $8^{\circ}$. pp. i-viii, 1-327.

Die grossen Fischereien der arctischen Erde.-1) Der Wallfischfang, pp. 239-261. 1. Der gemeine Wallfisch (Balaena Iyysticetus), p. 241-245. 2. Der Finnfisch (Balaena Physalus L.), p. 245. 3. Der Nordkaper, Das Breitmaul (Balaena Musculus), pp. 245, 246; [4.] Der Cachelot oder Pottfisch (Physeter macrocephalus), pp. 246, 247. 15.] Der Narwal (Monodon Mfonocoros), p. 248. [Wallfischfang], pp. 249-261. (The Seal-fishery is treated, pp. 261266.)

[529.]

1812. C., F. [= Cuvier, Frépréric]. Description des Cétacés Échonés dans la baye de Paimpol; par M. G. Cuvier. <Nouv. Bull. de la Soc. Philom. de Paris, iii, $5^{\mathrm{c}}$ anuée, no. 56 , mai 1812 , pp. $69-91$.

Extrit. 
1812. C., F. [= Cuvier, Frédéric]. Notice sur une espèce de Dauphin observée dans la mer glaciale; par M. Fréminville, lieutenant de raisseau. <Nouv. Bull. de Sci. par la Soc. Philom. de Paris, iii, 5e année, no. 56, mai 1812, p. 71.

Extrait.

1812. Cuvier, [G.]. Rapport fait à la classe des Sciences mathématiques et physiques, sur divers Cétacés pris sur les côtes de France, principalement sur ceux qui sont échoués près de Paimpol, le 7 janvier 1812. <Ann. du Mus. d'Hist. nat., xix, 1812, pp. 1-16, pl. i.

Remarques générals sur les espèces de la famille des Dauphins, qui sont divisé do la manièro suivante: Io. Les Delphinaptères (Lacép.); II‥ Les Marsouins; III‥ Les Dauphins proprement dits; IV 0 . Les Hyperoodons.

Delphinus griseus, Delphinus globiceps, Delphinus dubius, spp. nn., p. 14.

Pl. i, Delphinus griseus, D. globiceps (2 figg.), D. Aries?

1812. Home, Everard. An Account of some Peculiarities in the Structure of the Organ of Hearing in the Balæna Mysticetus of Linnaus. <Philos. Trans. Lond., [cii], pt. 1, art. iii, 1812, pp. 83-89, pll. i, ii.

Description of the membrana tympani, with figures of the external and internal parts of the organ of hearing.

1812. La Hontan, Baron de. Travels in America, etc. <Pinkerton's Coll. Voy. and Trav., xiii, 1812, pp. 254-273.

Reprinted from the second English ed., London, 1735, 2 vols., $8^{\circ}$.

The Cetacean matter is at pp. 356, 357. See 1703. La Hontan.

1813. Home, Everard. On the Tusks of the Narwhale. <Philos. Trans. Lond., [ciii], pt. 1 , art. xviii, 1813, pp. $126-130$, pl. vii.

Figures are given of the young skull of a male Narwihal, a female skall, millk tusks, lower jaw, and section of a full-grown tusk.

1813. Scoresby, William, $j r$. Account of the Balæna Mysticetus, or Great Northern or Greenland Whale. (Illustrated by an Engraving.) <Annals of Philos., i, 1813, pp. 51-55, pl. 1.

Reprinted from the Mem. Wern. Soc., vol. i, p. 578 et seqq., q. v.

1814. Blumenbach, J. F. Handbuch | der | Naturgeschichte | von | Joh. Fried. Blumenbach. | - | Multa fiunt eadem sed aliter. | Quintilian. | - | Neunto Ausgabe. |- Göttingen, 1814. | Bei Heinrich Dieterich. 8०. pp. i-xiv, 1-754, 11. 20 , pll. i, ii.

IX. Cetacea, pp. 134-137. 4 genera, 6 species. The eighth order, Palmata, includes Trichechus, of which the Manatees form the second "species" (Trichechus Manatus, p. 134), the habitat being given as the rivers and sea coasts of the warmer parts of the carth.

[537.]

1814. Lewis, M., and W. Clarke. History | of | The Expedition | under the command of | Captains Lewis and Clark, | to | the sources of the Missouri, | thence | across the Rocky Mountains | and down the | River Columbia to the Pacific Ocean. | Performed during the years 1804-5-6. | By order of the | Goverument of the United States. | Prepared for the press | by Paul Allen, Esquire. I In two Volumes. | Vol. I [II]. | Philadelphia: | Published by Bradford and Inskeep; and | Abm. H. Inskeep, Newsork. | J. Maxwell, Printer. | 1814. 2 vols. 8०. Vol. i, pp. i-xxviii, 1-470, maps; vol. ii, pp. i-ix, 1-522, maps.

"This is the editio princeps of the anthentic narrative." Coues (Bull. U. S. Geol. and Geog. Surv. Terr., 2d ser., no. 6, Feb. 8, 1876, pp, 417-444) gives a detailed account of the different editions and versions of this important work, with a commentary on its zoölogical matter.

At pp. 105-111 are passing references to a stranded Whale met with near the month of the Columbia River, the skeleton of which (p. 111) was found to measure 105 feet in length. At p. 196, same volume, is a shert account of "the whale" and "the porpoise." I omit reference to the numerous subsequent editions.

[533.]

1814. Rafinesque, C. S. Précis | des déconvertes et travaux | somiologiques | de Mr. C. S. Rafinesque Schualtz. | entre 1 $\times 00$ et 1814 | Ou choix raisonné de ses principales Déconvertes | en Zoologie et en Botaniqne, pour servir | d'introduction à ses ouvrages | futurs | - | De Linné le génie il a choisi pour 
1814. Rafinesque, C. S.-Continued.

guide. | - | Palerme | Royale Typographie militaire. | 1814. | Anx dépens de l'Auteur. $16^{\circ}$ (4० by sig.). pp. $1-56$.

"IIr. G. Eprodon (Cétacé). Plusieurs dents à la machoire supérieure, aucune à l'ìnfé. rieure; aucune nageoire dorsale, évents róunis sur la tête.

“5. Epiodon urganantus. Corps oblong, attenué postérieurement: museau arrondi, ma. choire supérieure un peu plus longue, dents égales obtuses.-Obs. Ce Cétacé fut pris vers 1790 sur les côtes de la Sicile, j'en ai eu le dessin. Dans ma Mastologie Sicilieune je fixerai et décrirai plusieurs autres Cétacés des mers de la Sicile, figurés par Mrongiture, je les ai nommé Delphinus dalippus, Physeter urganantus, Oxypterus mongitori N. G. a deux nageoires dorsales, \&c." p. 13.

The above is a full transcript of that portion of this rare work relating to Cetaceans.

1815. Axov. Notes on Nantucket, August 1st, 180\%. <Coll. Mass. Hist. Soc., 2d ser., iii, 1815, pp. 19-38.

Hunting of Seals, Whale Fishery, pp. 29, 30. Number of vessels employed in Sealing and Whaling, and where cruising.

[540.]

1815. Axon. Size of the Whale. <Ann. of Philos., vi, 1815, pp. 74, 75.

A propos of a statement by $W$. Scoresby (op. cit., i, 1813, 51-55) on the size of the Whale is here cited Capt. Clarke's measurement of a Whale's skeleton near the Columbia River, " 105 feet in length." (See 1814. Lewis, M., and W. Clarke.)

[541.]

1815. Blatvirlle, H. DE. Note sur l'existence des nerfs olfactifs dans le dauphin, et, par analogie, dans les autres cétacés. <Bull. des Sci., par la Soc. Philom., 1815, pp. 193-195.

1815. Hubbard, William. The General History of New England, from the first discovery thereof, till the year 1680. <Coll.,Mass. Hist. Soc., 2d ser., vols. v, vi, 1815, pp. 1-676.

Whales killed on the south side of Long Island, near Southhold, vi, pp. 668, 669, 673.

1815. Illiger, [C.]. Ueberblick der Süugthiere nach ihrer Vertheilung über die Welttheile. <Abhandl. d. Kön. Akad. d. Wissens. in Berlin, 1804-1811 (1815), pp. 39-159.

Cete und Sirenia passim. Die Ordnung Natantia enthält 2 Familien (Sirenia und Cete), 9 Gattungen und 47 Arten (p. 52). Sirenia, 7 Arten; Cete, 40 Arten (p. 53).

Of the " 40 " spp. of Cete enumerated in his several tables of distribution a considerable proportion are nominal, they including such names as Mronodon microcephalus and M. andersonianus, Ancylodon anarnak, Physeter orthodon, cylindricus, trumpo, etc., Delphinus senedetta, ventricosus, feres, etc.; in addition to a Delphinus bidens we have Hyperodon retusus. There is also a "Mranatus? Simia," a Manatus fluvialis, and M. Sphaerurus, in addition to M. australis. There is also a Rytina cetacea as well as a Rytina borealis. The lists are, so far at least as the Cete and Sirenia are concerned, worthless conglomerations, which, as in the case of other groups treated in the same connection, appear to contain some names coined for the occasion, without descriptions or textual references. The paper may be safely ignored so far as Cetology is concerned.

[544.]

1815. Scoresisy, Williak, $j r$. Description of the Woaps: and Observations on the Size of the Whale. <Annals of Philos., vi, 1815, pp. 313, 314.

In reply to previous remarks in the Annals (l.c., p. 74) on the size of the Whale.

[545.]

1815-18. "LAing, JoHN. Voyage to Spitsbergen; containing a full description of that country, of the zoology of the North, and of the Shetland isles, with an account of the Whale-fishery. London, 1815-1818. 8०."

Not seen; from Bosgoed, op. cit., p. 240, no. 3497.

1816. Blatnville, H. DE. Prodrome d'nne nouvelle distribution systematique du règne animal. <Bull. de la Soc. Philom. de Paris, 1816, pp. 105-124.

Mammifères, p. 109 . Sous-Classe Iro. Monodelphes, III Io degré ou Ordre, les Edentés? $\{$ Normanx $\ldots . . . \ldots \ldots \ldots$ E....... Etés

Anurmaux, pour nager.. Cétac's?

[547.]

1816. G[eradin], S. Baleine. <Dict. des Sci. Nat., iii, 1816, pp. 417-468.

[Considérations générales], pp.417-432. 1. La Baleine franche (Balcena mysticetus, Linn.), pp. 433-438. 2. La Baleine nord-caper (Baloena mysticetus, Linn., var. B. édit. de Gmelin), pp. 438, 439. 3. La Baleine noueuse (Baloena nodosa, Lacép.), pp. 439, 440. 4. La Baleine bossue (Balcena gibbosa, Lacép.), p. 440. 5. La Baleinoptère gibbar (Balonoptera gibbar, 


\section{G[ERADIN], S.-Continued.}

Lacép.), pp. 441, 442. 6. La Baleinoptère jubarte (Baloenoptera jubartes, Lacép.), pp. 442-444. 7. La Baleinoptère rorqual (Balcenoptera rorgual, Lacép.), pp. 444, 445. S. La Baleinoptèrı musean-pointu (Balcenoptera acuto-rostrata, Lacép.), pp. 446,447. [Sur les organs du sens, des mœurs et de Pêche des Baleines, etc.], pp. 447-468.

We find here again the curions myth about the Indians of Florida capturing Whales by getting astride them and plugging their blowholes with conical pieces of wood, etc., here borrowed from Duhamel. See 1590. Acosta, J. DE, and 1002. De BRY.

[548.]

1816. Pitkin, T. A | Statistical View / of the / Commerce / of the / United States of America: | its connection with | Agriculture and Manufactories: | And an Account of the | Public Debt, Revenues, and Expenditures | of the | United States. | With a brief Review of the Trade, Agriculture, and | Manufactories of the Colonies, previous to | their Independence. | Accompanied with Table illustrative of the | Principles and Objects of the Work. | - | By Timothy Pitkin, | a Member of the House of Representatives of the United States, | from the State of Connecticut. | - | Hartford: | Printed by Charles Hosmer. |-|1816. 80. pp. i-xii, 1-407, i-xx.

The Whale Fishery, pp. 42-47. Table no. viii. State of the Whale Fishery in Massachusetts, from 1771 to 1775 , inclusive, p. 78 . Table no. ix. State of the Whale Fishery, from 1787 to 1789 , both inclusive, p. 79. Table no. x. Whale Oil-gallons, p. 80. Table no. $x$-continued. Spermaceti Oil-gallons, p. 81.

A succinct history of the American Whalefishery, with statistica tables of its products.

[549.]

1816-17. Virex, - et [A. G.] Desmarest. [Des Baleines, des Baleinoptères, des Cachalots et des Dauphins.] <Nouv. Dict. d' Hist. Nat., iii, 1816, pp. 164-201; iv, 1816, pp. 525-534; ix, 1817, pp. 146-180.

This is a joint production by Virey and Desmarest, written mainly, however, by Virey, nnder the words "Baleine," "Balcinoptera," and under the same words with various specific modifications, signed respectively "Virey" and "Desm." In the list of anthors facing the title-page of the several rolumes of the Nouv. Dict., etc., the articles on "Les Quadrupèdes, les Cétacés et les Animaux fossiles," are said to be written by Desmarest, and Virey is stated to have written "Les articles généraux de l'Hist. nat., particulièrement de l'Homme, des Animanx, de leur structure, de leur physiologie et de leurs facultés." In the following collation each author's share in the work is indicated.

Baleine, Baloena, generalities of the subject, and acconnt of the species, pp.16t-194, signed. Virey. 1. Baloena mysticetus, Linn., pp. 168-183, pl. exl, fig. 1, juv., fig. 2, ad. from Scoresby; 2. Baloena glacialis, Bonn., pp. 183-185; 3. Balcena gibbosa, Linn. et Bonn., pp.185-186; de la Pèche de la Baleine, pp. 186-194. Thus far by Virey. Then follows a nominal list of six species under French names, by Desmarest.

Baleinoptère, Balcenoptera, pp. 194-201, mostly by Virey, with the interpolation of paragraphs by Desmarest. 1. Baloenoptera gibbar. Lacép., pp. 195-196, by Virey; 2. Balcenop tera jubartes, Lacép., B. boops, Gmel., pp. 196-198, by Virey ; 3. Balcenoptera rorqual, Lacép.; B. musculus, Gmel., p. 198, partly by Desmarest and partly by Virey; 4. Balaenoptera acuto. rostrata, Lacép., Balaena rostrata, Gmel., p. 200, partly by Desmarest and partly by Virey. Cachalot, Physeter, t. iv, 1816, pp. 525-531, signed, "Virey et Desm." General history of the group, pp. 525-532; 1. Physeter macrocephalus, Shaw, pp. 532, 533; 2. Physeter trumpo, Bonu., pp. 533; 3. Physeter catodon, Linn. et Bonn., pp. 533, 534.

Dauphin, Delphinus, t. ix, 1817, pp. 146-180, purtly by Virey and partly by Desmarest. External characters and general liistory (the first paragraph signed "Desm.," then about four pages signed "Virey," anil abuut another page signed "B. V."), pp. 146-151; [1 Sous-genre, Delphinoryhnchus, Blainv.]. 1. Delphinus Geoffrensis, Blainv., pp. 151, 152; 2. *Delphinus coronatus [Fréminville], pp. 152, 153; 3. *Delphinus Shavensis, Blaiuv. (D. rostratus, Shaw), pp. 153, 154; 4. Delphinus Pernettensis, Blainv., p. 154; [2。 Sous-genre, Del. phinus, Blain r.]. 5. *Delphinus delphis, p1. 154-158; 6. D. chinensis, Osbeck, p. 158; \%. *D. dubius, Cuv., p. 158 ; 8. ${ }^{*} D$. tursio, Bonn., p. 158 ; 9. D. tursio, Fabr., p. 159 ; 10. ${ }^{*} D$. rostratus, Cuv., p. $160 ; 11 .{ }^{*} D$. orea, p. $161 ; 12$. D. feres, Bonn., p. $162 ; 13$. D. canadensis, Blainv., p. 163; 14. D. Bertini, Duhamel, p. 163 ; [3 Sous-genre, Oxypterus, Rafines.]. 15. O. Mongitori, Rafines., p. 163; [ $^{\circ}$ Sous-genre, Phoccena, Cuv.]. 16. *Delphinus phocoena, Linn., p. 163 ; 17. D. Peronii, Lacép., p. 165 ; 18. D. Commersonii, Lacép., p. 106; 19. * D. gladiator, Lacép., p, 160; 20. D. grampus, Hunter, p. 168; 21. *D. griseus, Cuv., p. 169; $22 . D$. ventricosus, Blainv., p. 169 ; 23. ${ }^{*} D$. globiceps, Cuv., p. 170 ; 24. Dauphin de Risso, Cuv., $D$. aries? p. 172; [5e Sous-genre, Delphinopterus, Lacép.]. 25. D. leucas, Gmel., p. 173; [0 Sous-genre, Heterodon, Blainv.]. 26. Anarnacus groenlandicus, Lacép., p. 175; 2\%. D. Chemnitzianus (Baloena rostrata, Chemu.), p. 175; 2S. D. edentulus, Schreb., p. 175; 29. D.biden. 


\section{6-17. Virey, - et [A. G.] Desmarest-Continued.}

tatus, Hunter, p. 176; 30. Hyperodon Butskopf, Lacép., p. 176; 31. D. Sowerbensis, Blainv., p. 177; 32. Epiodon urganantus, Rafines., p. 177; 33. * D. densirostris, sp. n., p. 178 (based ou a fragment of upper jaw); Dauphins fossiles, p. 179; French names of Dolphins, pp. 179, 180.

Species 1-25 are described by Virey, with the interpolation of a short paragraph by Desmarest in the account of no. 19, p. 167; species 26 to 33 , as well as the remaining pages of the article, are by Desmarest.

Delphinus densirostris, Desm., sp. n., p. 178. The 14 specles marked with an asterisk, the authors state (p. 151, note), are those whose validity is considered to be well established. In concluding, they state (p.178): "Pour rectifer convenablement la synonymie de ces espèces, de nouveaux reneignemens nous sout absolument indispensables"; and for this purpose invite travelers and naturalists to give special attention to their descriptions, and direct attention to points to be observed.

In these articles the compilers have brought the subject thoroughly up to date; they not only include the species described since the time of Lacépede, but reject a few admitted by that author. Although strictly a compilation, it well represents the state of the subject at this date.

[550.]

1816-29. Cuvrer, F. Dictionnaire | des | Sciences naturelles. $|-|$ Planches. | $2^{\mathrm{e}}$ Partie: Règue organisé. | Zoologie. | - | Mammifères. | Par | M. Fréderic Cuvier, | Membre de l'Académie des sciences, chargé en chef de la Ménagerie royale. | - | Paris, | F. G. Levrault, libraire-éditeur, rue de la Harpe, $\mathrm{n}^{0} .81$, Même maison, rue des Juifs, $n^{0}$. 33, à Strasbourğ. | 1816-1829. 80. pp. 1-13, pll. col., i-c.

Cétacés (=Sirenia + Cete), pl. xevi, fig. 1, Lamantin; pl. xevii, fig. 1, Dugong des Indes, fig. 2, Delphinorhynque (=Platanista); pl. xcviii, fig. 1, Dauphin vulgaire, fig. 2, Heterorlon à deux dents; pl. xcix, fig. 1, Narwal vulgaire, fig. 2, Cachalot macrocéphale; pl. c, fig. 1, Baleine francho (altered from Martens?) fig. 2, Baleinoptère Rorqual.

The plates themselves are not numbered, but in the "table des planches" (p. 4-13) these are numbered consecutively from 1-100, with a list of the names engraved on the plates and reference to the volume and page of the Dictionnaire where the species are describe. [551.]

1817. Cuvier, G. Le | Règne animal | distribué | d'après son organisation, | pour servir de base a l'histoire naturelle des ani- | maux et d'introduction a l'anatomie comparée. | Par M. le Cher. Cuvier, | ... . [titles, 5 lines]. | Avee Figures, desinées d'après nature. | Tome I, | contenant | l'introduction, les Mammifères et les Oiseaux. | Chez Deterville, Libraire, rue Hautefeuille, $\mathbf{n}^{0} .8$. | - | De l'imprimerie de A. Belin, | 181\%. $8^{\circ}$. pp. i-xxxvii, 1-540.

This is the editio princeps of the celebrated Rène animal.

Huitième Ordre des Mammifères. Les Cétacés, pp. 271-287.

Les Cétacés herbivores=Sirenia ; genera 1. Manatus, p. 273, 2. Halicore, p. 274, 3. Ry. tina, p. 275; species not formally designated.

Les Cétacés ordinaires = Cetacea : Les Dauphins (Delphinus, L.), pp. 277-280. Les Dan. phins proprement dits (Delphinus, Cuv.), pp. 277,278. 1. Delphinus delphis, L., p. 278; 2. D. rostratus, Shaw, p. 278; 3. D. tursio, Bonn., p. 278. Les Marsouins (Phocana, Cuv., gen. n.), p. 279 ; 4. Le Marsouin commun (D. Phoccena, L.), p. 279; 5. L'Epaulard (D. orca et $D$. gladiator, Lacep.), p. 279. Les Delphinaptères (Lacep.); 6. Le Beluga ou Epaulard blanc (D. leucas, Gm., D. albicans, Fabr.), p. 280; Les Hyperoodons (Lacep.), p. 280 ; [7. D. edentulus, Schreb.], p. 280. Les Narwals (IFonodon, L.), pp. 280-282; 8. Monodon monoceros, Lin., p. 281. Les Cachalots (Physeter, L.), pp. 282-284; [9. Cachalot macrocéphale de Shaw et de Bonn. non le macrocéphale de Linné], p. 283. Les Physétères (Lacep.), p. 284 [no species formally recognized]. Les Baleines (Balcena, L.), pp. 284-286; 10. La Baleine franche ( $B$. mysticetus, L.), pp. 285, 286; 11. Le Nord-Caper (R.glacialis, Klein), p. 286. Les Balénoptères à ventre lisse, pp. 287, 288; 12. Le Gibbar (Baloena physalus, L.), p. 287. Les Balénoptères à ventre plissé, p. 287; 13. La Jubarte des Basques (Bal. boops, L.), p. 287.

Phocana, gen. n., p. 279.

The treatment of the Cetacea here presented is strongly in contrast with that of Bonnaterre, Lacépède, and their followers, and even with tliat of still earlier systematists. While Cuvier rejects many of the fictitious species of the early authors, recognizing but a single species of Narwhal, and sagaciously hinting at the existence of only a single species of Cachalot, he runs to the opposite extreme among the Fin-Whales, rejecting species as too vaguely known that have since proved well-founded. We bave here the foreshadowing of the wholesome conservatism later displayed by the author in his treatment of the Sirenians and Cetaceans in his Ossemens fossiles. 
181\%. Desmarest, A. Dugong. <Nouv. Dict. d'Hist. Nat., ix, 1817, pp. 603-604.

Résumé of its affinities as variously maintained by previous authors, with the recognition of the single species "Trichecus dugong, Gmel.

[553.]

1817. Desmarest, A. G. Lamantin. <Nouv. Dict. d'Hist. Nat., xvii, 1817, pp. 258264.

Generalities, pp. 258-261; Species, 262, 263; Lamantins fossiles, pp. 263-264. Spp. 2, Man. atus americanus et $\mathbf{M}$. senegalensis, Desm.

[554.]

1817. Desmarest, A. G. Mammalogie. <Nouv. Dict. d'Hist. Nat., xviii, 1817, pp. 483-542.

History, including synopsis of classifications, pp. 483-526; external characters, pp. 526-542.

1817. Edrop. Narrative of a Voyage to Hudson's Bay, in His Majesty's Ship Rosamond, containing some Account of the North-eastern Coast of America, and of the Tribes inhabiting that remote Region. By Lient. Chappell. <Quart. Rev., xviii, 1818, pp. 199-223. Map.

Review of the work. Contains a paragraph (p. 212) on Whales struck with tho harpoon on the coast of Spitzbergen and afterward killed in Davis Strait.

[556.]

181\%. G[erardin], S. Cachalot. <Dict. des Sci. Nat., vi, 1817, pp. 38-83.

[Considérations générales], pp. 38-44. Première famille, Les Narwals, Narwali, pp. 44-49. 1. Le Narwal vulgaire (Monodon monoceros, Linn.), pp. 45-48. 2. Le Narwal mierocéphale (Narivalus microcephalus, Lacép.), 1) 48. 3. Le Narwal andersonien (N. andersonianus), p. 49. Deuxième fanille. Les $\Delta$ naruaks, Anarnaci, pp. 49, 50. 4. L'Anarnak groenlandois (Anarnak groenlandicus, Lacép.), p. 49. Troisième fumille. Les Cachalots proprement dits, Catodontes, pp. 50-59. 5. Le Cachalot macrocéphale (Physeter macrocephalus, Gm.), pp. 5056. 6. Le Cachalot trumpo (Catodon macrocephalus, Gm.), pp. 56-58. \%. Le Cachalot svineval (Physeter catodon, Grm.), p. 58. 8. Le Cachalot blanchatre (Catodon macrocephalus, Var. B., Gm.), p. 58. Quatrième famille. Les Physales, Physali, pp. 59-61. 9. Le Phrssalo cylindrique (Physalus cylindricus, Lacép.), pp. 59-61. Cinquième famille. Les Physétères, Physeteres, pp. 61-65. 10. Le Physétère mycrope ( $P$. mycrops, Gm.), pp. 61, 62. 11. Le Physétère orthodon (B. mycrops, Var. B., Gm.), pp. 63, 64. 1:. Le Physétère mular (P. tursio, Gm.), pp. 64, 65. Síxième famille. Les Delphinaptères, Delphinapteri, pp. 65-67. 13. Le Delphinaptère béluga (Delphinapterus leucas, Gm.), pp. 65-67. 14. Le Delphinaptère sené. dette (Delphinapterus senedetta, Lacép.), p. 67. Septième famille. Les Dauphins, Delphini, pp. 67-81. 15. Le Dauphin vulgaire (Delphinus delphis, Gm.), pp. 68-71. 16. Le Dauphin marsouin (D. phocaena, Gm.), pp. 71-74. 17. Le Dauphin orque (D. orca, Gm., Var. A.), pp. 74, 75. 18. Le Dauphin gladiateur (D. orca, Gm., Var. B.), pp. 75-77. 19. Le Dauphin nésernack (D. nesarnack, Lacép.), p. 77. 20. Le Dauphin diodon (D. diodon, Lacép.), p. 78. 21. Le Dauphin ventru (D. ventricosus, Lacép.), p. 78. 22. Le Dauphin férès, $D$. feres. Lacép.), p. 79. 23. Le Dauphin de Duhamel (D. Duhamelii, Lacép.), p. 79. 24. Le Dauphin de Péron (D. Peronii, Lacép.), p. 80. 25. Le Dauphin de Commerson (D. Commersoni, Lacép.), p. 81. Huitième et dernière famillo des cachalots. Les Hypéroodons, Hyperoodon. te8, pp. 81-82. 26. L'Hypéroodon butskopf (D. orca, Gm., Var. C.), pp. 81-83.

A compilation, mainly from Lacépède, whose nomenclature is followed. The species are the same as those recognized by Lacépède.

[557.

1817. [Millar, or Miller, James.] Cetology. <Encycl. Brit., 5th ed., v, 1817, pp. $327-360$, pll. cxl, cxli.

Chap. i. Of the Classification and Natural History of Cetaceous Fishes, pp. 328-341. Chap. ii. Of the Anatomy and Physiology of Cetaceous Fishes, pp. 341-353. Chap. iii. Of the Whale Fishery, pp. 353-359.

The genera recognized are, i, Balcena, ii, IFonodon, iii, Physeter, ir, Delphinus. The species are the following: 1. Balaena Ifysticetus, pp. 329, 330, pl. cxl, fig. 1. 2. Balana Glacialis, pp. 330, 331. 3. Baloena Physalus, p. 331. 4. Balona Nodosa, p. 331. 5. Balana Gibbosa, p. 332. 6. Balcena Boop8. p. 332. \%. Balcena Musculus, p. 333. S. Balana Bostrata [sic], p. 333. 9. Monodon Monoceros, p. 334, pl. cxl, fig. 2. 10. Monodon Spurius, p. 335̂. 11. Physeter Macrocephalus, pp. 334, 335, pl. exl, fig. 3. 12. Physeter Catodon, p. 336 . 13. Physeter Trumpo, p. 336. 14. Physeter Cylindricus, p. 337. 15. Physeter Ificrops, p. 337. 16. Phy. seter Mular, p. 337. 1\%. Delphinus Phoccena, p. 338. 18. Delphinus Delphis, pp. 338, 339. 19. Delphinus Tursio, p. 339. 20. Delphinus Orca, p. 339, pl. cxl, fig.4. 21. Delphinus Gladiator, p.310. 22. Delphinus Leucas, p.340. 23. Delphinus Bidentatus, p.340. 24.Del. vhinus Butskopf, pp. 340, 341. 25. Delphinus Feres, p. 341.

Pl. cxli gives views in profile of two skulls of Whales, and views of baleen from side, above, ete. The 4 figures of Whales given in pl. exl are copios of well-known figures. 
1817. [Mrllar, or Mrller, James]-Continued.

This article appeared originally in the 4 th ed. of the Encycl. Brit. (1810), according to the preface of the present (5th) ed., and is by the editor, Dr. James Millar. It is as fair a presentation of the subject as could be expected from a writer merely qualified to glean from respectable sources.

[558.]

1818. Blaivville, [H.] DE. Mammifères, Mammalia. <Nouv. Dict. d'Hist. Nat., xix, 1818, pp. 1-152.

1818. Desmarest, A. E. Mammifêres fossiles. <Nouv. Dict. d'Hist. Nat., xix, 1818, pp. 152-156.

1818. Dissmarest, A. E. Narwhal, Narwhalus. <Nouv. Dict. d'Hist. Nat., xxii, 1818, pp. 224-228.

Species: 1. Narwhalus vulgaris, Lacép., p. 224 ; 2. N. microcephalus, Lacép., p. 227; 3. $N$. andersoni, Lacóp., p. 228.

[561.]

1818. Egede, Haxs. A | Description of Greenland. | By Hans Egede, | who was a Missionary in that country | for | twenty-fivo years. | - | A Now Ellition. $|-|$ With an | Historical Introduction | and | a Life of the Author. | Illustrated | with a map of Greenlind, and numerous engravings on wood. | Second Edition. | [Vignette.] London: | Printed for T. and J. Allman, | Frances Street, Hanover Square; | W. H. Reid, Charing Cross; and Baldwin, Cradock and Joy, | Paternoster Row. | 1818. 8०. pp. i-cxviii, 1-225, map and woodcuts.

Chap. vi. Of the Greenland Sea Animals, and Sea Fowls and Fishes, pp. 66-99. Cetaceans are treated pp. 66-82.

For the editio princeps, see 1741.

1818. Fabricius, Otho. Zoologiske Bidrag. <Kongel. Danske Videnskab.-Sels7. Skrivter, vi, Deel 1 (for 1809-1810), 1818, pp. 57-138.

2det Bidrag. Om Stub-Hvalen, Baloena Boops, Linn., pp. 63-83.

1818. Fabricius, Отто. Nöjogtig Beskrivelse over Grönlændernes Landdyr-, Fugleog Fiskefangst med dertil hörende Redskaber. <Kongel. Danske Videnskab.Selsk. Skrivter, vi, Deel 2 (for 1811-1812), 1818, pp. 231-272.

III. Fiskefangst og dertil hörende Redskaber, pp. 253-272. Hralfangst, pp. 253-256.

1318. Fremliville, [C. P. de la Porx De.] Sur une nouvelle espèce de Dauphin. $<$ Bull. des Sci. par la Soc. philom. de Paris, 1818, pp. 67, 68.

Delphinus globiceps?

1818. Herausgebers. Ueber den Bau des Beluga (Delphinus albicans Linn. Delphinapterus beluga Lacépède). Von Barclay. (Aus Thomson's Annals of Philosophy. Vol. ix, p. 233 ff.) <Deutsches Archiv f. Physiol., iv, 1818, pp. 296-298. Anszug.

[566.]

1818. Home, E. A description of the teeth of the Delphinus Gangeticus. <Philos. Trans. Lond., [cviii], pt. 2, art. xxi, 1818, pp. 417-419, pl. 20.

Figures of the upper and under jaws and of isolated teeth.

[567.]

1818. "KAT, H. D. Dagboek eener reize ter walvisch en-robbenvangst, gedaan iu 1777 en 1778. Haarlem, Wed. P. Loosjes, 1818. 80. Met eene Kaart eu portret."

Not seen; from Bosgoed, op. cit., p. 240, no. 3493.

1818. LACÊPÈde, [B. G. ÊT.]. Note sur des Cétacées des mers voisines du Japon. <Mem. du Mus. d'Hist. nat., iv, 1818, pp. 467-475.

Balcena japonica, Baloena lunulata, Baloenoptera punctulata, Balcenoptera nigra, Balcenoptera coerulescens (p. 473), Balcenoptera maculata, Physeterus sulcatus (p. 474), Delphinus niger (475), spp. nn.

"Les dessins coloriés d'après lesquels j'ai décrit ces huit espèces de cétacées japonois, ont été communiquéés au Musénm rosal d'Histoire naturelle, par M. Abel de Rémusat, membro de l'A cadémie des Inscriptions et Belles-Lettres. Ils présentent pour les caractères distinctifs, une grande netteté, et tòus ces signes de l'wuthentieité et de l'exactitude que les zoologistes sont maintenant si aecoutumés à reconnoître; et voici les traits partieuliers do ces hnit espèces" (p. 469).

This highly reprehensible pieee of work has receired just condemnation at the hands of most writers who have had occasion to treat of the Cetacea of the Japan seas, and the spe- 


\section{LaCÉPÈde, [B. G. ET.]-Continued.}

cies, when not wholly ignored, go to swell the list of those which are indeterminable. Allow ing that the drawings were reasonably correct, which is far from probable, the characters drawn from them are so vague and general that the diagnoses are valueless as a scientific basis. There is, furthermore, no assurance that the drawings were eren attempts at facsimile representations of natural objects. With the nine species described six years later by Chamisso from Japanese wooden models, and those described by Rafinesque, Lesson, and others, from observation of animals swimming in the sea, they form altogether a fine rubbish pile, but one which need give little trouble, since the species are quite unworthy of any attemp at recognition, only showing to how great a depth of folly tho vanity of authorship may sometimes lead.

[569.]

1818. O'Reilly, B. Greenland, | the | Adjacent Seas, | and | the North-west Passage | to | the Pacific Ocean, | illustrated in a voyage to Davis's Strait, | during the Summer of 1817. | - | With charts and numerous plates, | from drawings of the author taken on the spot. | - | By | Bernard O'Reilly, Esq. | - | London: | printed for Baldwin, Cradock, and Joy, | 47, Paternoster-Row. | - | 1818. 1 v. $4^{\circ}$. pp. $\mathrm{i}-\mathrm{riii}, 1-293$, pll. $\mathrm{i}-\mathrm{x}$ viii +3 charts.

Chap. v, Arctic Zoology, pp. 96-148. MIonodon MIonoceros, pp. 104-107. "Baloena Mysticetus (the common Whale)," pp. 107-130, pl. x, fig. 3, transverse section of body at lumbar region, fig. 4, section of tail, fig. 5, animal, figg. orig. "Baloena Mysticetus (the finner)," pp. 130, 131. Delphinus Orca, pp. 132-134. Delphinus Leucas, pp. 134, 135, pl.x, fig. 1. There are incidental allusions to other speeies at pp. 131. 132.

Although the author was not without opportunity of observing the northern Cetacea, and especially the Baloena mysticetus, he contributes nothing of importance to the subject, but on the other hand, displays gross ignorance respecting many points touched upon. The nande Balcena mysticetus is first employed in its correct sense (p. 107), but later, doubtless by inadvertence, is used to designate "the finner Whale." From one who describes the "Sword Grampus" as having the dorsal fin long and bony, growing longer with age, etc., and. who states that the Balcena mysticetus "received its specific name from the Scriptural record of the adrenture of Jonas," little can be expected in the way of new information.

[570.]

1818. SAABYE, Hans Egede. Greenland: | being | Extracts from a Journal | kept in that Country | in the Years 3770 to 1758. | By Hans Egede Saabye, | Formerly ordained Minister in the Districts of Clanshavn and Christianshaab; | now Minister of Udbye, in the Bishopric of Fühnen; and | Grandson of the celebrated Hans Egede. | (Now first published.) | - | To which is prefixed | An Introduction; containing some | Accounts of the Manners of the Greenlanders, | and of the | Mission in Greenland; | with various interesting information respecting | the Geography, \&c., of that Country; | And illustrated by a | Chart of Greenland, | By G. Fries. | - | Translated from the German. | - | London: | Printed for Boosey and Sons, | 4 Broad Street, Royal Exchange, |- | 1818. $8^{\circ}$. pp. i-viii, 1-293.

There is a short account of the Whalefishery, as carried on by the Greenlanilers, at pp. 29, 30. Reference to trade in "unicorn horns," p. 161. Chapter xiii. The Whale found, pp. 19n195, recounts the behavior of the Greenlanders on finding a Whale, and their manner of pro. cedure in saving its products.

For the $c d$. prin. see 1741. Besides the German edition of this work, of which the present is a translation, a Dutch version appeared in 1818. See Bosgoed, op. cit., p. 247, no. 3552. [571.]

1819. Axon. Skeleton of a Whale found in Clackmannanshire. <Blackwood's Edin. Mag., v, 1819, p. 737 .

Account of the exhumation of the skeleton, with measurements of some of the principal bones.

1819. AxsPaCH, L. A. A | History | of the | Island of Newfoundland: | containing a | Description of the Island, | The Banks, the Fisheries, | and | Trade of Newfoundland, | and the | Coast of Labrador. | Illustrated with Two Maps. | - |. By the | Rev. Lewis Amadeus Anspach, | Late a Magistrate of that Island and Missionary for the District | of Conception Bay. | - | London: | Printed for the Author, | And Sold by T. and J. Allman, Princes-Street, Hanover- | Square; and J. M. Richardson, 23, Cornhill, opposite / the Royal Exchange. | - 1819. $8^{\circ}$. pp. i-xxviii, 1-512.

Contains, pp. 396-399, a short notice of the Whale-fishery formerly carried on along the eastern coast of North America. 
1819. Aríault, $M$. Sur les coquilles et des ossements fossiles, découverts et observés dans les environs d'Anvers. <Ann. générales des Sci. phys., ii, 1819, pp. 124128.

Trois vertèbres énormes; "elles furent évidemment celles de quelque cétacée de la plus grande taille" (p. 127).

1819. BALD, RoBErT. Notice respecting the discovery of the Skeleton of a Whale on the Estate of Airthrey, near Stirling, the property of Sir Robert Abercromby, Baronet. <Edinb. Philos. Journ., i, no. 2, art. xxxii, 1819, pp. 393-396.

Particulars of the finding and exhumation of a skeleton "which is evidently that of a Whale," which "appears to have been about 72 feet in length."

[575.]

1819. Cortesi, Giuseppe. Saggi Geologici / degli Stati di Parma e Piacenza | Dedicati | a Sua Maestà | la Principessa Imperiale | Maria Luigia | Arciduchessa d' Austria | Duchessa | di Parma Piacenza Guastalla ecc. ecc. | dal guidice | Gituseppe Cortesi | Professore Onorario | di Geologia | Piacenza | Dai Torchj del Majno | MDCCCXIX. 4º. 11. 4, pp. i-x, 1-165, pll. i-vii.

Articolo IV. Degli Scheletri di Balene e di altri Cetacei, pp. 45-67, pll. ii-iv.

Description (p. 48) and figure (pl. ii, fig. 1, skull) of a fossil Dolphin, which later was named Delphinus Cortesii by Desmoulin, and a fossil Whale (p. 61, pl. v, fig. 1, skeleton), afterwards named Baloena Cortesii by Desmoulins.

[576.]

1819. Desmarest, A. G. Rytine, Rytina, Ill. <Nouv. Dict. d'Hist. nat., xxix, 1819, pp. 573-576.

1819. "Hellwig, JoH. Chr. Ludw. Tabellarische Uebersicht der Ordnungen, Familien u. Gattnngen der Säugethiere, nach Illigers prodromus system. Mammalium, mit Auffïhrung aller Arten, welche der Verf. nach den Schreberschen Säugthieren u. nach den Werken Anderer zu seinen Gattungen zog, in $65 \mathrm{Ta}-$ bellen. gr. $8^{\circ}$. Helmstïidt, 1819."

Not seen: title from Carus and Engelmann.

1819. Humboldt, Alexander von. Vojage / aux Régions Équinoxiales | du Nouveau Continent, | fait en 1799, 1800, 1801, 1802, 1803 et 1804, | par Al. de Humboldt et A. Bonpland; | rédigé | Par Alexandre de Humboldt. | Arec deux Atlas, | qui renferment, l'un les vues des Cordilieres et les monumens des peuples indigènes | de l'Amérique, 'ot l'autre des cartes géographiques et physiques. | - Tome [premier,] second [et troisième]. | - | A Paris, | Chez N. Maze, Libraire, rue Git-le-Coeur, No. 4. | - | [1814,] 1819 [1825]. Vol. ii, 3 1l., pp. 1-722. 3 vols. 4 . Vol. i, 1814; vol. ii, 1819; vol. iii, 1825.

Souffleurs, ii, pp. 201, 202. Manati ou Lamantin, ii, pp. 226-228, 606.

1819. "Matthiesen. Ein Steindruck [Balaenoptera rostrata]. Hamburg, 1819."

Not seen; reference from Reichonbach, Walthiere, p. 22, note.

1819. Pseudon. Jourual | of a | Voyage of Discovery, | to the | Arctic Regions, | performed between the 4th of April and the 18th of | November, 1818, | in His Majesty's Ship Alexander, | W [illia]m Edw[ard]. Parry, Esq., Lieut. and Commander. | - | By an officer of the Alexander. | - | London: | Printed for Richard Phillips; by G. Sidney, Northumberland-street, Strand. I [No date. "March 15, 1819" in MS.] 8०. pp. i-viii, 1-104, map, and pll. i-iii. The siguature mark is "Voyages and Travels, No. 1, Vol. I."

Appendix, No. viii. A brief Sketch of the Quadrupeds, Birds, and Fishes, seen by those employed on the late Expedition to Davis' Straits and Baffin's B.y, pp. 99-104.

"Fishes" (i.e., Cetacea and Pinnipedia!), p. 104. Baloena mysticetus, Balona Physalus, Phoca, Monodon Monoceros. Brief remarks on each. At pp. 42-44 is given a rather detailed account of the "female fish" (Baloena mysticetus) taken by a Hull whaler, giving account of external characters, baleen, measurements, etc.

[581.]

1819. Ross, J. A | Voyage of Discovery, | made under the orders of the Admiralty, | in | His Majesty's ships | Isabella and Alexander, | for the purpose of | exploring Baffin's Bay, | and inquiring into the probability of a | North-west Passage. | - By John Ross, K. S. Captain Royal Navy. | - | London: | - | 
1819. Ross, J.-Continued.

John Murray, Albemarle-street. | - | 1819. 1 vol. 40. 11. 2, pp. i-xl, 1-252,

1 1., pp. i-cxliv, maps, plates.

Appendix ii. Zoological Memoranda. Mammalia, pp. xli-xlvii.

Baloena Mysticetus, pp. xlvi, xlvii. Description of a specimen 46 feet long. No other Cetacean mentioned.

[582.]

1819. Ross, J. A | Voyage of Discovery, | made under the orders of the Admiralty, | in | His Majesty's Ships | Isabella and Alexander, | for the purpose of | Exploring Baffin's Bay, | and enquiring into the probability | of a | North-West Passage. | - | By John Ross, K. S. Captain Royal Navy. | - | Second edition. | In two volumes. | Vol. I[-II]. | - | London: | Printed by Strahan and Spottiswoode, Printers-Street; | for Longman, Hurst, Rees, Orme, and Brown, | Paternoster Row. | 1819. | 2 vols. 80. Vol. i, pp. i-lxix, 1-265, 1 double map; vol. ii, pp. i-ii, 1-258, 1 double plate.

Appendix no. iv. Zoological Memoranda, vol. ii, pp. 14j-179. Mammalia, pp. 145-153. See the $4^{\circ}$ ed. (last title).

[583.]

1819. Scoresir, William, $j r$. Remarks on the Size of the Greenland Whale, or $B a$ lana Mysticetus, designed to show that this animal is found of as great dimensions in the present day as at any former period since the establishment of the whale-fishery. <Edinb. Philos. Journ., i, 1819, pp. 83-88.

1820. Axon. Grússẹ des gr5nlåndischen Wals, Balcena mysticetus L. <Isis von Oken, vi, $1820, \mathrm{pp} .506,50 \%$.

Auszug aus Edinb. Phis. Journ., i, 1819, pp. 83-88.

1820. Camper, Pierre. Observations Anatomiques | sur | la structure intérieure et le squelette | de plusieurs espèces | de Cétacés. | Par Pierre Camper, | . . . [=titles, 4 lines. $]$ | Publiées par son fils, Adrien-Gilles Camper, | . . [ = titles, 3 lines]. | Avec des Notes par M. G. Cuvier, | . . [ [=titles, 1 line ]. | On y a ajouté un Atlas composé de 53 Planches, dont 3 sont en conleur. | Ouvrage qui peut faire suite anx Annales et Mémoires du Muséum | d'Histoire naturelle, et aux Recherches sur les Ossemens | fossiles des Quadrupèdes, par M. Cuvier. | - | Paris, | Chẹz Gabriel Dufour, Libraire, | Rue de Vaugirard, No. 34. | - | 1820. 4०. 11. 2, pp. 1-218.

The Atlas has the following title:

Recueil de Planches | pour servir | aux observations anatomiques | sur | la structure intérieure et le squelette | de plusieurs espèces | de Cétacés, | Par MM. Camper, Père et Fils. | cinquaute-trois planches, dont trois eu couleur. | - I A Paris, | Chez Gabriel Dufour, Libraire, | Rue de Vaugirard, No. 34. $\mid$ - 1820. 20. 1l. 2, pll. i-liii. [1. 2, Table.]

Discours preliminaire, pp. 1-8. Observations anatomiques, etc. Première Partie. Chapitre premier. Vues générales sur la nature des Cétacés, pp. 9-18. Chapitre II. Sur la Classification des Cétacés, pp. 18-25. Chapitre III. Sur les Cétacés du premier ordre, ou Cétacés a fanons, pp. 26-41. Chapitre IV. Sur la Forme exterieure et la Structure des parties interieures de la Baleine franche, pp. 41-52. Chapitre V. Sur la Structure de l'appareil digestif, circulatoire et sexuel, ainsi que sur quelques Particularités du squelette, pp. 52-58. Chapitre VI. Sur l'Ostéologie du crâne des Baleines, pp. 58-73. Chapitre VII. Sur l'ostéologie d'un Baleinoptère Gibbar, Physalus de Linné, pp. 74-77. Chapitre VIII. Sur l'Ostéologie du crâne d'un Cétacé que nous croyons être lo Baleinoptère Museau pointu, on Balcena rostrata de Linne, pp. 78-86. Note génerale sur la première partie, pp. 86, 87.

Seconde Partie. Chapitre Ier. Sur la Classification du second ordre, ou du genre du Cachalot, pp. 88-94. Chapitre II. Sur l'Ostéologie du crâne des Cachalots, pp. 94-110.

Troisième Partie. Sur les Cétacés du troisième ordre, ayant les mâchoires supérieures et inférieures armées de dents. Chapitre Ier. Sur les Dauphins en général, pp. 111-114. Chapitre II. Sur la première famille des Dauphins, ou les Narwals, pp. 114-118. Chapitre III. Sur l'Ostéologie du crâne du Narwal monodon, pp.118-121. Chapitre IV. Sur le crâne du Narwal edenté, du Musée royal de France, pp. 121-124. Chapitre V. Sur les Dauphins armés de dents dans les mâchoires supérienres et inférieures, pp. 124-126. Chapitre VI. Sur l'Oudre, pp. 126-130. Chapitre VII. Observations anatomiques sur le Dauphin vulgaire, pp. 131-141. Chapitre VIII. Description anatomique dn Dauphin Marsouin, Delphinus Phocæna, pinna in 
1820. Camper, Pierre-Continued.

dorso una, rostro brevi obtuso de Brisson, pp. 142-157. Chæpitre IX. Sur la Strncture du Crâne des diverses familles de Cétacés, considérée dans ses rapports avec celle du crâne de l'Homme, pp. 157-163.

Explication des Planches, pp. 164-216. Table des chapitres contenus dans cet ouvrage, pp. pp. $217,218$.

Sujets figurées: Embryon d'une baleine franche, pll. i-iii; crane d'une jenne baleine franche, pll. iv-vi; profile du crâne d'une autre baleine, dans laquelle on a conservé les fanons, pl. vii; de l'organe de l'ouïe des baleines, pll. viii, ix; máchoires inférieures l'une baleine, pl. x; le crâne d'un Baleinoptère Gibbar (Physalus ç̣e Linné), pll. xi, xii; crâne du baleinoptèro museau pointu (Balcena rostrata de Linné), pll. xiii-xvi ; crâne d'un cachalot conservé dans je chøur de l'église de Schevelinge, proche la Haye, pll. xvii, xx-xxii; cráne d'un cachalot macrocéphale, pll.xviii, xix; ostéologie del'oreilledu cachalot, pll. xxiii-xxvi; les máchoires inférieures d'un cachalot, pl. xxvii; vertèbres cervicales d'un cachalot et l'atlas d'une baleine, pl. xxviii; erâne du narwal, pll. xxix-xxxi; erâne d'un narwal édenté, pll. xxxii-xxxiv; crâne d'un dauphin vulgaire, $x \times x \nabla-x l$; rertèbres cervicales dos plusieurs espèces de dauphins, pl. xli; vertèbres cervicales d'un marsouin, et d'uno vertèbre cervicale d'nn grand cétacé du Masée britannique, avec quelques vertèbres lombaires, sacrées, etc. d'un dauphin vulgaire, pl. xlii; myologie de l'extrémité pectorale du dauphin vulgaire, pl. xliii; les épaules de diffé. rentes espèces de cétaçs, ainsi que les os du bras du dauphin yulgairo, pl. xliv; le danphin marsouin, en profil et ouvert, pll. xlv-xlvii; la structure des narines, de l'cil et de larynx, du dauphin marsouin, pl. xlviii ; crâne du marsouin, pl. xlix; tête d'un marsouin, pl. 1; cerveau d'un marsouin nouveau-né, pl. li; profil d'un fœetus mâle du marsouin; les parties sexuelles d'un fotus femelle; osselets pelvienne; portion supérieure dn tube alimentaire; l'omoplate, tous du même espèce, pl. lii ; analogie du crâne des cétacés avec celui de l'homme, etc., pl. liii.

[586.]

1320. Donovan, E. The | Natural History | of | British Quadrupeds; | ecnsisting of coloured figured, | accompanied with | Scientific and general descriptions, | of all the species that are known to inhabit | the British Isles: | including | as well those found in a wild as in the domesticated state; | and also such as are | clearly authenticated to have been originally indigenous, but are now | extirpated, or become extremely rare; the whole arranged in systematic order, after the manner of Liunæus. | - | By E. Donovan, F. L. S. W. S. | Author of the Natural Histories of British Birds, Fishes, Insects, Shells, \&c. | - I In three volumes, | Vol. I [II, III]. | - | London: | Printed for th $\ominus$ Author: and for F. C. and J. Rivington, 62, St. Paul's Church-yard, and 3, Waterloo-Place, Pall-Mall. $|-|$ 1820. $88^{\circ}$ pll. i-lxxii, with several unpaged folios of text to each.

1. Balcena rostrata, pl. xxiv, and 1 p. of text. 2. Balcena physalus, pl. $x \times x v$, and $3 \mathrm{pp}$. of text. 4. Delphinus orea, pl. 1vii, and 3 pp. of text. 5. Delphinus ? bidens, pl. 1xvii, and 3 pp. text.

[587.]

1820. Goldfuss, G. A. Handbuch | der | Zoologie. | Von | Georg Angust Goldfuss, | ... [ = titles, 11 lines, and monogram.] | Zweite Abtheilung. | - | Nürnberg, | bei Johann Leonhard Schrag. | 1820. <Handbuch | der Naturgeschichte, | Zum Gebrauch | bei Vorlesungen. | Von | Dr. G[otthilf]. H[einrich von]. Schubert. | - | Dritter Theil. | Zweite Abtheilung. | - | Nưrnlłerg, | bei Johann Leonhard Schrag. | 1820. | 8०. pp. i-xxiv, 1-510.

Systematische Uebersicht der Gattungen, pp. v-xxiv (Cetoe and Sirenia, p. xix,-list of genera and subgenera).

Erste Ordnung, Cete, Walle, pp.360-336. 1. Balaena mysticetus, 2. Balaenoptera rostrata, 3. B. boops, 4. Physeter (Physalus) gibbosus, 5. Physeter (Catodon) macrocephalus, 6. Phy. seter (Physeter) Microps, 7. Ancylodon groenlandicus, 8. Ceratodon monoceros, 9. Delphinus (Hyperoodon) bidens, 10. D. (Delphinapterus) Leucas; 11. D. (Delphinus) Delphis, 12. D. (Phocaena) Phocaena, 13. D. (Phocaena) Orca; $=6$ genera, 7 subgenn., 13 spp.

Zweite Ordnung. Sirenia, Sirenen, pp. 336-339, 1. Rytina Stelleri, 2. Manatus australis, 3. Halioone (lege Halicore) indica.

1820. Hove, E. On the milk tusks, and organ of hearing of the Dugong. <Philos.

Trans. Lond., [cx], pt. 2, art. ix, 1820, pp. 144-155, pll. xii-xiv.

The plates give profile and basilar riews of the skull, section of the task, milk dentition, lower jaw, incisors, and section of molars. 
1820. Hомe, E. Particulars respecting the anatomy of the Dugong, intended as a Supplement to Sir T. S. Raffles' Account of that animal. <Philos. Trans. Lond., [cx], pt. 2 , art. $\mathrm{xx}, 1820$, pp. $315-323$, pll. $\mathrm{xv}-\mathrm{xxxi}$.

The observations were made on a young female, and the viseera of a male, eight feet long. Pl. xxv, animal; pll. xxvi, xxvii, stomach, tongue, and cæeum; pl. xxviii, heart; pl. xxix, part of trachea and portion of lungs; pl. xxx, sexual organs; pl. xxxi, sternum and pelvic bones.

[590.]

1820. "Köhlfr, Fr. Gotrl. Reise ins Eismeer und nach den Küsten vom Grönlaud und Spitsbergen im Jahre 1801, und Beschreilung der Wallfischfang. Leipzig, 1820. $80 . "$

Not seen; from Bosgoed, op. cit., p. 240, no. 3494.

1820. "Köhler, Fr. Gotrl. Reis naar de IJszee en naar de kusten van Groenland en Spitsbergen, in het jaar 1804. Benevens eene beschrijving van de walvischvangst. Naar het Hoogduitsch. Te Amsterdam, bij J. C. van Kesteren 1820. gr. 8०."

Not seen; from Bosgoed, op. cit., p. 240, no. 3495. Apparently a translation of the last, although the date of the voyage is in the one case 1801, and in the other 1804.

1820. Raffles, T. S. Some account of the Dugong. <Philos. Trans. Lond., [cx], pt. 2, art. xiii, 1820, pp. 174-182.

External charaeters, anatomy, and habits.

1820. Ranzani, Camillo. Elementi | della / Storia naturale / dei Mammiferi | dell' abate | Camillo Ranzani | Professore di Mineralogia, e di zoologia | nella pontificia Universita | di Bologna. | - | Volume Primo [Secondo e Terzo, mut. mut.]. | - | Bologna. | - | Per le Stampe di Annesio Nobili | 18:0. 80. pp. 1-736, 1. 1, pll. i-xiii (the three volumes are continuously paged).

Ordine ottavo de Cetacei, pp. 668-708.

Famiglia prima. De Cetacei erbivori, pp. 670-677. 1. Manatus americanus, p. 673; 2. Halicore Dugong, p. 674; 3. Rytina Stelleri, p. 676.

Famiglia seconda. De Cetaeei carnivori, pp. 677-708. 1. Delphinus Geoffrensis, p. 682; 2. Delphinus coronatıs, p. 682; 3. Delphinus Delphis, p. 683; 4. Delphinus Tursio, p. 685; 5. Delphinus Mongitori, p. 686; (6. Delphinus Phocaena, p. 687; \%. Delphinus Beluga, p. 688; 8. Delphinus Urganantus, p. 689; 9. Delphinus Diodon, p. 690; 10. Ceratodon vulgaris, p. 691; 11. Physeter macrocephalus, p. 695; 12. Balaena Mysticetus, p. 701 (pl. xiii, fig. 1); 13. Balaena Fisalis, p. 705; 14. Balaena Boops, p. 706.

[594.]

1820. Sconesby, W., jr. An | Account | of the | Arctic Regions, | with a / History and Description | of the | Northern Whale-Fishery. | By W[illiam]. Scoresby Jun. F. R. S. E. | Illustrated by Twenty-four Engravings. | In Two Volumes. | - | Vol. I [-II]. | - | Edinburgh: | Printed for Archibald Constable and Co. Edinburgh: | and Hurst, Robinson \& Co. Cheapside, London. | - | 1820. 2 vols. $8^{\circ}$. Vol. i, pp. i- \x, 1-551+1-82 and frontisp.; vol. ii, pp. i-viii, 1574 , pll. i-xxii (including maps) $+\times$ xii. $^{*}$

A Sketch of the Zoology of the A retic Regions, i, pp. 446-551. Sect. I. A Deseription of Animals, of the Cetaceous Kind, frequenting the Greenland Sea, pp. 449-501. 1. Balaena Ifysticetus, pp. 449-478, pl. xii, figg. 1, 2, xii [bis]; 2. Baloenoptera Gibbar, La Cepède; B. Physalis of Linué, pp. 478-482. 3. Balcena Rorqual (La Cepède) Balcena Musculus of Linné, or Broad-nosed Whale, pp. 482, 483. 4. Baloenoptera Jubartes (La Cepède)-Baloena Boops of Linné, or Finner of the Whalo-fishers, pp. 484, 485. 5. Baloenoptera Acuto-rostrata (La Cep̀de) - Balcena rostrata of Linné, or Beaked Wh.1le, pp. 485, 486, pl. xiii, fig. 1. 6. Monodon Monoceroz (Linné) - Narwal, or Unicorn of the Whalers, pp. 486-495, pl. xii, fig. 3, pl. xv, figg. 1,2. \%. Delphinus Deductor (Traill)-Ca'ing or Leading Whale, pp. 496-500, pl. xxii, fig. 1. 8. Delphinapterus Beluga (La Cepède) - Delphinus leucas of Linné; Beluga of Pennant, or White Whale of the fishers, pp. 500, 501, pl. xiv.

Pl. xvi, Medus:e, \&e., (i.e., "Whale's Food"). Pll. xvii, xix-xxii, Instruments and Apparatus used in the Whalefishery.

Account of the Northern Whale-Fisheries, \&c., ii, pp. 1-537. Chap. i. Chronologieal History of the Northern Whale-Fisheries, pp. 1-95. Chap.ii. Comparative View of the Origin, Progress, and Present State of the Whale-Fisheries of the different European Nations, pp. 96-171. Chap. iii. Situation of the Early Whale-Fishery,-Manner in which it was conducted,-and the Alterations which have subsequently taken place, pp. 172-186. Chap. iv. Account of the Modern Whale-Fishery, as conducted at Spitzbergen,pp. 187-381. Chap. 


\section{SCORESBY, W., jr.-Continued.}

v. Account of the Davis' Straits Whale-Fishery, and a comparison with that of Greenland, with Statements of Expences and Profits of a Fishing Ship, pp. 382-396. Chap. vi. Methols of Extracting Oil and Preparing Whalebone, with a Description of these Articles, and remarks on the uses to which the several products of the Whale-Fishery are applied, pp. 397-437. Chap. vii. Narrative of Proceedings on board of the Ship Esk, during a Whale-Fishing Voyage to the coast of Spitzbergen, in the year 1816, pp. 438-438. Appendix, pp. 489-558.-I. Abstract of the Acts of Parliament at present in force for the Regulation of the Whale-fishery of Grecnland and Davis' Straits, pp. 491-505. II. Some Remarks on the most advantageous Dimensions of a Whale-Ship, [and] Further No. tices respecting the Fortifications of a Greenland Ship, pp. 506-509. III. Schedule of the Principal Fishing Apparatus necessary for a Ship, of 300 tons burden or upwards, intended to be employed in the Groenland Trade, pp. 509-511. IV. . . Manner of Mustering the Crew of Whale-Ships... pp.512-518. V. Account of a Trial respecting the right of the Ship Experiment, to a Whale struck by one of the Crew of the Neptune; Galo v. Wilkinson, pp. 518521. VI. Signals used in the Whale-fishery, pp. 521-525. VII. Account of Some Experiments for determining the Relations between the Weight and Measure, in certain quantities of Whale-Oil, pp. 525-528. VHI. Some account of the Whale Fishery conducted in the Southern Seas, pp. 529-537. IX. On the Anomaly in the Variation of the Maguetic Needle, ss observed on Ship-board, pp. 537-554. X. Explanation of the Plates, pp. 554-558.

Scoresby's Arctic Regions is well known as one of the most important contributions to the history of the Greenland Whale (Balcena mysticetus) and the Northern Whale-fishery extant, and as the source whence many later writers on the subject have largely derived their materials. His figures of the Greenland Whale are the best published prior to 1874, and those of the Narwhal are also excellent. Those of the other species were copied from previous writers, and his brief notices of the other Cetaceans he describes were mostly giren at second hand, and indicate that he knew little about them from personal observation. His four species of Balcenoptera are all to be referred to Physalus antiquorum, anct. (=Balaenoptera musculus). His nomenclature is that of Lacépède. Failing to recognize the Nordkaper (Baloena biscayensis of recent European cetologists) as a distinct species, he has confounded its history, in his historical summary of the Norther $\mathbf{n}$ Whale-fishery, witl that of Balcena mysticetus. Not meeting with the former, for now obvious reasons, in any of his Whaling expeditions, he was very naturally led to disbelieve in its existence as a species distinct from the Greenland Whale.

1821. Blumenbach, J. F. Handbuch | der | Naturgeschichte | von | Joh. Fried. Blumenbach. | - | Multa fiunt eadem sed aliter. | Quintilian. | - | Zehnte Ausgabe. | - Gôttingen, | in der Dieterichschen Buchhandlung. | 1821. sm. 8. pp. i-xiv, 1-814, pll. i, ii.

VIII. Palmata, pp. 131-136. Trichechus Manatus, p. 136.

Cetacea, pp.137-140. 1. Monodon Narwhal, p.137; 2. Balana Mysticetus, p. 137; 3. B. Rostrata, p. 138 ; 4. Physeter Macrocephalus, p. 139; 5. Delphinus Phocaena, p. 139; 6. D. Delphis, p. $140 ;$ \%. D. Orca, p. 140.

B. Rostrata replaces B. Physalus of the early editions, and the text is greatly changed.

1821. Bowdich, T. E. An Analysis | of the | Natural Classifications | of | Mammalia, | for the use of | Students and travellers. | By 'T. Edward Bowdich, Esq. | Conductor of the Mission to Ashantee, Member of the Wettervian Suciety of Natural History. | - | Paris, | Printed by J. Smith. | - 1821. 80. pp. i-iv, 5-115, pl. i-xv (osteology).

"The first part [pp. 5-89] of the text is a translation of almost all but the specific descrip. tions of the Mrammiferes of Curier's Règne Animal, ... interwoven with additions from his Comparative Aratomy, Fossil Remains, the works of Frederic Curier, Dumeril, ete.... The second part contaius a general outline of tho system of Illiger...." (p. iv).

Order VIII. Cetacea, pp. 84-89, 105, pl. xii, skulls of Balcena boops and Physeter macroce. phalus ; pl. xiii, fig. 3, skull of Dugong ; pl. xiv, fig. 6, skull of American Manatee, fig. 7, do. of African Manatee.

1821. Delavorpik̀re, - Faits | relatifs | a la | Pêche de la Baleine, | Par Mr. Delavoipière, Capitaine français du Navire-Baleinier La Cérés, du Havre. | - 1 Au Havre, | Chez Stanislas Faure, Imprimeur dn Roi. |-|1821. 8०. pp. 1-30.

Différence qui existe entre les Baleines, et le mojen de les reconnaitre, p. 3. De la Baleino proprement dite, pp. 3, 4. De la Baleine ì bosse, p.4. De la Baleine à ailoron, p. 5. Du Cachalot, p. 6. Parages et saison où se trouvent plus communément les poissons dont on extrait l'huile, pp. 6-8. Armement des piroques, pp. 8-10. De la poursuite, p. 11. De l'a.taque, pp. 


\section{Delavoipik̀re-Continued.}

12-15. De l'amarrage, p. 15. Observation à l'egard du Cacholot, p. 16. De l'amarrage à bord, pp. 16-19. Manière de découper la Baleine, p. 19. Disposition des caillornes et courans des garans, pp. 20-22. Manière de faire l'Huile,-Extraction du Sperme et des Fanons, pp. 22-26. Attaque de la Baleine dans les baies, pp. 26-28. Remarques sur la pêche, pp. 28-30.

[598.]

1821. EDitors. Analysis of a Journal of a Voyage for the Discovery, \&c. of a North-West Passage from the Atlantic to the Pacific, in the years 1819-20. By Captain W. E. Parry, R. N., F. R. S. Lond.1821, 4to., p. 479, with 20 Plates and Charts; and of A Journal of a Voyage of Discovery to the Arctic Regions. By Alexander Fisher, Surgeon, R. N. 8vo. pp. 320. <Edinb. Philos. Journ., $\nabla$, no. 9, art. xxviii, 1821 , pp. 177-196.

A review of the works containing incidental references to Arctic Cetacea, ineluding a description of musical sounds made by the Beluga (p. 181). See 1821. Fisher, A.

[599.]

1821. Edrors. Clay-slate Axe found in a Whale. <Edinb. Philos. Journ., iv, no. 7, 1821 , p. 216, pl. 3, fig. 11.

Apparently the head of an Esquimaux lance, cut out of the blubber of a Whale in Davis's Strait.

[600.]

1821. Fisher, A. A | Journal | of a | Voyage of Discovery | to the | Arctic Regions, | in | His Majesty's ships | Hecla and Griper, | in the years $1819 \& 1820 . \mid-$ | By | Alexander Fisher, Surgeon R. N. | - | Fourth edition, corrected. | London: | Printed for | Longman, Hnrst, Rees, Orme, and Brown, PaternosterRow. 1821. 8०. pp. i-xi, 1-320, chart, map, and cuts.

Notices of Cetacea passim, to wit: Balcena Physalus, p. 23; Balcena Mysticetus, p. 31; Beluga or White Whale, pp. 72-74; Monodon Monoceros, pp. 74, 83-87 (cut, p. 84, external characters, and anatomical observations).

The "Journal", though rarely cited in zoölogical literature, is worthy of attention, con. taining many intelligent obserrations in natural history, and especially in reference to birds and Mammals. In regard to the latter, particularly important is the account of the Walrus (pp. 38-43, with a cut), which gives weight and detailed measurements of a specimen taken; also those of the Polar Bear (pp. 44-46, cut and measurements), and the Musk-Ox (pp. 249-253, 259, cut, measurements, external characters, and habits).

[601.]

1821. Hone, E. An acconnt of the skeletons of the dugong, two-horned rhinoceros, and tapir of Sumatra, sent to England by Sir Thomas Stamford Rafles, Governor of Bencoolen. <Philos. Trans. Lond., [cxi], pt. 2, art. xviii, pp. 268-275, pll. $\mathrm{xx}-\mathrm{xxiv}$.

Dugong, pp. 208-269; Pl. xx, skeleton of a female.

1821. Jameson, William. Narrative of a Voyage to Davis' Straits in 1820 . <Edinb. Philos. Journ., v, 1821, pp. 309-318.

A passing reference to Delphinus leucas (p. 312) and a short description of Monodon monoceros (p. 317).

[603.]

1821. Montagu, George. Description of a Species of Delphinus which appears to be new. <Mem. Wern. Soc. Nat. Hist., iii, 1821, pp. 75-82, 1 pl.

Description of Delphinus truncatus. Figures are given of the head and teeth.

[604.]

1821. Neill, Patrick, and [John] Barclay. Account of a Belugia, or White Whale, killed in the Frith of Forth. <Mem. Wern. Soc. Nat. Hist., iii, 1821, pp. 371394,2 pll.

Description, measurements, and anatomy. [Also separate.]

[605.]

1821. Raffles, T. S. Descriptive Catalogne of a Zoological Collection, made on account of the Honourable East India Company, in the Island of Sumatra and its Vicinity, under the Direction of Sir Thomas Stamford Raffles, LieutenantGovernor of Fort Marlborough; with additional Notices illustrative of the Natural History of those Countries. <Trans. Linn. Soc. Lond.; xiii, pt. 1, art. xvii, 1821, pp. 239-274.

On page 272 are five lines on "Halicora Dugong."

[606.]

1821. Raffles, Thomas Stamford. Some Account of the Dugong. <Philos. Mag., 1vii, 1821, pp. 341-346.

Exterual characters and anatomy. 
1821. Raffles, Thomas [Stamford]. Einige Nachrichten ůber den Dugong. <Froriep's Notizen aus dem Gebiete der Natur-und Heilkunde, i, no. 8, Sept. 1821, pp. 113-11\%.

Aus den Phil. Trans. Roy. Soc. Lond. for 1820, pt. ii, pp. 174-182.

1821. Rossily, - and Rossel, [E. P. E.]. Analysis of Mr. Scoresby's Account of the Aretic Regions, being a Translation of the Official Report of MM. Rossily and Rossel, to Baron Portal, Minister of the French Marine. <Edinb. Philos. Journ., iv, no. 8, art. viii, 1821, pp. 285-294.

Includes remarks on the Whale-fishery of the Aretic Seas.

1822. C., F. [Cuvirr, F.] Lamantin. <Dict. des Sci. nat., xxv, 1822, pp. 169-173.

Lo Lamantin d'Amériquo (Mfanatus americanus), pp. 171, 172. Le Lamantin du Sénégal (M. senegalensis), p. 172. Lamantin (foss.), pp. 172, 173.

[610.]

1822. Demarest, A. G. Mammalogie | ou | description des espèces de Mammèifres.Premiere Partie, | contenant les ordres des Bimanes, des Quadrumanes et des Carnassiers. | Par M. A. G. Desmarest, | Professeur de Zoologie à l'École royale d'Economie rurale et vétérinaire d'Alfort; . . . [ = additional titles, 3 lines ]. | - | A Paris, | Chez $\mathbf{M}^{\text {me }}$ Veuve Agasse, Imprimeur-Libraire, rue des Poitevins, $n^{\circ} 6 .|-|$ 1820. | 4० ${ }^{\circ}$ pp. i-viij, 1-276. | - | Seconde Partie, | contenant les ordres des Rongeurs, des Édentés, des Pachydermes, des Ruminans | et des Cétacés. | . . A Paris, | . . | - | 1822. 40. pp. i-viij, 277-556=Encyclopédie methodique, tome 182. $4^{6}$. 1820. (See 1789. Bonvaterre.)

Huitièmo Ordre. Cétacés, Cetae, pp. 506-530. Première Famille, Cétacés herbivores. Sirenia, pp. 506-511. 1. Manutus americanus, p. 507; 2. Manatus Senegalensis, p. 508, 3. Halicore indicus, p. 509 ; 4. Stellerus borealis, p. 510.

Seconde Famille, Cétacés ordinaires, Cete, pp. 511-530. Ire Division, Cétacés a petite têto. 1. Delphinus [Delphinorhynchus] Geoffroyi $[=D$. Geoffrensis, Blainv.], p. 512. 2. D. [Delphinorhynchus] coronatus, p. 512 . 3. D. [Delphinorhynchus] gangeticus, p. 513. 4. D. [Delphinorhynchus] Pernettyi $[=D$. Pernettiensis, Blainv.], p. 513. 5. D. [Delphinus] Boryi ("espèce nouvelle"), p. 513 . 6. D. $[D$.$] delphis, p. 514$. \%. D. $[D$.$] sinensis, p. 514$. 8. D. $[D$. dubius $[=$ Dauphin douteux, Cuv.], p. 514. 9. D. $[D$.$] tursio, p. 514. 10. D. [D$.$] nesarnac,$ p. 515. 11. D. $[D$.$] niger (Lacép.), p. 515. 12. D. [D$.$] rostratus, p. 515. 13. D. [D.] orca,$ p. 515. 14. $D .[D$.$] feres, p. 516. 15. D$. $[D$. $]$ canadensis $[=$ Dauphin blanc du Canada, Duhamel=Bcluga catodon $]$, p. 516 . 16. D. [D.] Bertini [=Dauphin de Bertin, Duhamel], p. 516. 1\%. D. [Oxypterus] Mongitori, p. 516. 18. D. [Phocana] phoceena, p. 516. 19. D. [Ph.] Peronii, p. 517. 20. D. [Ph.] Commersonii, p. 517. 21. D. [Ph.] gladiator, p. 517. 22. D. $[P h$.$] grampus, p. 517. 23. D. [P h$.$] griseus, p. 518$. 24. D. [Ph.] ventricosus, p. 518. 25. D. [Ph.] globiceps, p. 519. 26. D. [Ph.] Rissoanus [= Dauphin de Risso, Cuv.], p. 520. 27. D. [Delphinapterus] leucas [=Beluga catodon], p. 520. 28. D. [Heterodon] anamacus, p. 521. 29. D. [H.] Chemnitzianus (=Balana rostrata, Chenınitz) = Hyperoodon butzkopf, auct. recent.), p. 520. 30. D. $[H$. $]$ Hunteri $[=D$. bidentatus, Hunter], p. 521. 31. D. $[H$.$] edentulus, p. 521. 32. D. [H.] hyperoodon [=D$. butskopf, Bonnaterre], p. 521. 33. D. $[H$.$] Sowerbyi [=D$. Sowerbensis], p. 521. 34. D. $[H$.$] epiodon [=$ Epiodon urganantus, Raf.], p. 521. 35. Monodon monoceros, p. 523. 36. M. microcephalus, p. 523. 37. Mr. andersonianus, p. 523. 38. Physeter [Catodon] macrocephahus, p. 524. 39. P. [C.] trumpo, p. 524. 40. $P$. [C.] catodon $[$ Bonnat. $=$ Catodon svineval, Lacép.], p. 525. 41. P. [Physalus] cylindricus, p. 525. 42. $P$. $[$ Physeter $]$ microps, p. 525. 43. $P$. $[P$.$] orthodon, p. 526. 44. P .[P$. mular, p. 526. 45. P. $[P$. $]$ sulcatus (Lacép.), p. 526. 46. Baloena $[$ Baloena] mysticetus, p. 527. 47. B. $[B$. $]$ glacialis, p. 527. 48. B. $[B$.$] nodosa, p. 527. 49. B. [B$.$] gibbosa, p. 528. 50$. B. [B.] japonica (Lacép.), p. 528. 51. B. [B.] lunulata (Lacép.), p. 528. 52. B. [Balcenoptera] gibbar, p. 528. 53. B. [Balcenop.] boops, p. 528. 54. B. [Balonop.] musculus, p. 529. 55. B. [Balcenop.] rostrata, p. 529. 56. B. [Balcenop.] punctata (Lacép.), p. 529. 5\%. B. [Balcenop.] nigra (Lacép.), p. 529. 58. B. [Baloenop.] coerulescens (Lacép.), p. 529. 59. B. [Balánop.] maculata (Lacép.), p. 530.

Delphinus Boryi (p. 513), D. dubius (p. 514), D. Bertini (p. 516), D. canadensis (p. 516), D. Rissoanus (p. 519), spp. nn., D. Hunteri (p. 520), D. hyperoodon (p. 521), D. epiodon, nomm. nn.

"Le tableau de l'ordre des cétacés que nous allons tracer, est particnlièrement destiné à faire connoîtro les progrès de l'histoiro naturelle de ces animaux, depuis l'époque où Bonnaterre (1789) a pu'slié sa description des planches de Cétologie. Nous ne ferons qu'indiquer très-sommairement les espèces dont il a rapportó les caractères, en renvoyant ì son texte et en indiquant ses figures. En un mot, lo travail de Bonnaterre ne doit pas étre considéré comme un double emploi du nôtre; mais celui-ci doit l'être, au contraire, comme son complément" (p. 506, noto 1). 


\section{Demarest, A. G.-Continued.}

The plan here unfolded the author carried out in detail, every specles added since the date of Bonnaterre's work being apparently included, regardless of its merits. Althongh many new specific names were introduced, only one species (Delphinus boryi) was given as "espece nourelle." Few of those described by Bonnaterre are here redescribed, or only briefly so, the author adding: "Descrip. Voyez la Cétologie de Bonnaterre, loc. cit.," to which work refer. ence is always duly made.

[611.]

1822. Desmoulins, A. Cachalot. <Dict. class. d'Hist. nat., ii, 1822, pp. 615-619.

Cachalot, Physeter: generalities, pp. 615-617; species, pp. 617-619. 1. Physeter [Catodon Lacép.] macrocephalus, Shaw, p. 617; 2. Catodon macrocephalus, var. B. Bonn. (=Physeter gibbosus, Schreb., pl. 338), p. 618; 3. Ph. catodon, L., p. 618; 4. Ph. australianus, Quoy, p. 318; 5. Ph. [Physeter] microps, Schreb., pl. 339, p. 618; 6. Ph. Tursio ou mular, p. 619; \%. Ph. sulcatus, Lacép., p. 619.-The Cachalot's are divided into two groups or genera, as abovo.Catodon, spp. 1, 2, and Physeter, spp. 3-7. The article is an indiscriminato compilation. [612.]

1822. Edrtons. Extracts from Dr. Hibbert's Description of the Shetland Islands. <Edinb. Philos. Journ., vi, no. 11, art. vii, 1822, pp. 240-255.

Account of the pursuit and eapture of a drove of Whales [Globiocephains melas], pp. 240243.

[613.]

1822. Home, Everard. Ueber die Eigenthímlichkeiten, wodurch sich de Manati der Westindischen Meere von dem Dugong der Ostindischen unterscheidet. < Froriep's Notizen, ii, Jun. 1822, pp. 260, 261.

Aus den Phil. Trans. Roy. Soc. Lond.

[614.]

1822. Manby, G. W. Journal | of a | Voyage to Greenland, | in the year 1821. | - | With graphic illustrations. | By George William Manby, Esq. | - | London: | Printed for G. and W. B. Whittaker, | 13, Ave-Maria Lane. | 1822. $4^{\circ}$. pp. vii, 143, maps, pll., and woodec.

Remarks upon the Failure which has for some years attended the Whale-Fishery; with Considerations for removing the Obstacles which have occasioned the same. Appendix, pp. 123-143, numerous cuts of gun-harpoons and other harpoons, etc. Acconnt of the common Greenland Whalo (Balcena Mysticetus) and "of the early state of the fishing," pp. 20-37, with cuts. Also allusions to whaling and to the habits of various Cetacenns passim. Plate facing p. 60, "A boat going on the tail of a Whalo"; plate facing p. 61 , " $A$ Whale upsetting a boat"; plate facing p. 81, "Lancing the Whale."

A German translation was published at Leipzig in 1823, and a Dutch version ot Amsterdam in 1825 .

1822. Mourt, -. Mourt's Relation. <Coll. Mass. Hist. Soc., 2d ser., ix, 1822, pp. $26,73$.

Cape Cod "a place of good fishing; for we saw daily great whales of the best kind for oil and bone come close aboard our ship, and in fair weather swim and play about us; ..." p. 36. This relates to the first visit of the Puritans to Massachusetts Bay in 1620. [616.]
[6.

1822. President and Council of New England. A brief Relation of the discovery and plantation of New England: . . < Coll. Muss. Hist. Soc., 2d ser., ix, 1822, pp. 1-25.

Originally published in London, 1622.

"Ambergris, [and] great numbers of whales along the coast," p. 20.

1822. [Riccio, AvTovio, et autres]. Les Pêcheurs / étrangers, | domicilies et stationnés | à Marseille, | a MM. les Députés des Départemens. 80. 1. 1, pp. 16.

Le brochure est signée par Antonio Riccio, Joseph Vila et cinque autres, Billard, Arocat. Marseille, le 6 A oût 1822.

[618.]

1822. RUdolPH, D. K. A. Einige anatomische Bemerkungen über Balaena rostrata. <Abliandl. d. phys. Kl.d. K.-P. Akad. d. Wissensch. zu Berlin, 1820-1821 (1822), pp. $27-40$, pll. i--v.

Pl. i, Skelet, pll. ii-iv, Schädel, pl. v, Kehlkopf, Rippe, Schwanzwirbelbein, n. s. w. [619.]

1822. Whatton, W. R. [Note respecting the capture of a female Monodon monoceros in the North Seas in 1821.] <Trans. Linn. Soc. Lond., xiii, pt. 2, 1822, p. 620.

1823. Baer, K. E. von. De | Fossilibus Mammalium Reliquiis | in / Prussia | adjacentibusque regionibus | repertis. | - | Dissertatio, | quam | ad Professoris ordinarii munus | in Academia Albertina | rite capessendum | scripsit | Carolus Ernestus a Baer | ... [ = titles, 4 lines $]$. $|-|$ Cum icowe. $|-|$ Regiomonti 1823. | In Libraria Academica. sm. 4०. 1. 1, pp. 1-38, 1. 1, pl.

§. Cetorum reliquiae fossiles, pp. 34, 35 . 
1823. Cuvier, G. Recherches | sur les | Ossemens fossiles, | où l'on rétablit | les caractères de plusieurs animaux | dont les révolutions du Globe détruit les espèces; | Par M. le Bon. G. Cuvier, | . . . [=titles, 5 lines. $]$ | Nouvelle Édition, | entièrement refondue, et considérablement augmentée. | - | Triomphante des eaux, du trépas et du temps, I La terre a cru revoir ses premiers habitants. | Delille. | - | Tomecinquième, Ire.partie, | contenant les rougeurs, les étentés, et les mammifères marins. | Paris, | Chez G. Dufour et E. d'Ocagne, Libraires, | Quai Voltaire, No. 13. | Et a Amsterdam, chez les mêmes. | 1823. 4. 11. 2, pp. 1-405, pll. i-xxvii.

Chapitre II. Des Lamantins et des genres qui appartiennent a la mêmo famille, pp. 235271, pll. xix, xx. Première Section. Des Espèces vivantes et de leur Ostéologie, pp. 235-265, Article première. Du lamantin d'Amerique et de son ostéologie, pp. 242-253. Article II. Des espèces nominales du petit lamantin des Antilles et du lamantin des Grandes-Indes, p. 254. Article III. Du lamantin du Sénégal, pp. 251-256. Article IV. Du prétendu lamantin du nord de Steller, pp. 256-259. Article V. Du dugong, pp. 259-265.

Section II. Ossemens fossiles de Lamantins pp., 266-271.

Pl. xix, Lamantins et Dugong. Pl. xx, Ostéologie du Dugong. Lamantin d'Amérique, pl. xix, fig. 1, squelette; figg. 2, 3, crâne; figg. 8-10, l'os de l'oreille; fig. 11, une de ces dents; figg. 14-16, avant-bras; figg. 17, 18, humérus. Lamantin du Sénégal, pl. xix, figg. 4, 5, crâno. Dugong, pl. xix, figg. 6, 7, crâne; pl. xx, fig. 1, squelette; figg. 2-4, crâno; figg. 5, 6, humérus; figg. 9-11, avant-bras; figg. 12-14, l'os de l'oreille; fig. 15, attas. Lamantin fossile, pl. xix, fig. 12, vertèbre; figg. 22, 23, partie supérieure du crâne; figg. 19-21, avant-bras. Pl. xix contenant aussie (figg. 24-28) os fossiles des phoques.

[Chapitre II is a reprint of the sameauthor's memoir entitled "Sur l'Ostéologie du Lamantin," etc., published originally in tome xiii (1809) of the Annales du Mus'um d' Histoire naturelle, (pp. 273-312) with the omission of Artiele vii, and the addition of new matter (the additions occurring at pp. 244-248, 261-265, 270, 271, with alterations at p. 266, of the Ossemens fossiles.) Pl. $\mathrm{xx}$ is also added, but pl. $\mathrm{xix}$ is the same as pl. xix of the Annales, $\tau_{\text {. c.] }}$

Chapitre III. Des Ossemens de Dauphins, pp. 273-318. Première section. Des Dauphins vivans, pp. 273-308. Article premier. Détermination des espèces de dauphins. \$1. Les dauphins à bec, pp. 275-280. §2. Les dauphins à tête obtuse, pp. 280-287. §3. Les dauphins sans dorsale on delphinaptères de M. de Lacépède, pp. 387-389. Article II. Ostéologio comparative des différentes espèces. §1. Tête de dauphins, pp. 290-302 [remarques générales, pp. 290-295; Delphinus delphis ou le dauphin vulgaire, p. 295, pl. xxi, figg. 9, 10, crâne; Le Delphinaptère à museau blanc ou dauphin de Péron, p. 295, pl. xxi, figg. 5, 6, crâne. Le frontatus, p. 296, pl. xxi, figg. 7, 8, crâne, pl. xxiii, figg. 6-8, conpes transversales du museau. Le tursio, p. 296, pl. xxi, figg. 3, 4, crâne. Le marsouin, p. 296, pl. xxi, figg. 1, 2, crâne. Le griseus, p. 297, pl. xxiii, figg. 1, 2, crâne. Le grampus ou épaulard, p. 297, pl. xxii, figg. 3, 4, crâne. Le globicep8, p. 297, pl. xxi, figg. 11-13, crâne. Le beluga (D. leucas), p. 297, pl. xxii, figg. 5, 6, crâne. Le dauphin du Gange, pp. 298-300, pl. xxii, figg. 8-10, crâne. Principales dimensions des diverses têtes de dauphins, p. 302.] \$2. Du reste du squelette des dauphins, pp. 303-308. [Le Dauphin vulgaire, pp. $303-305$, pl. xxiii, fig. 23, atlas, fig. 25 , quatrièmo cervicale, fig. 26, huitième cervicale, fig. 27 , deuxième lombaire, fig. 28, neuvième lombaire, fig. 29, quatrième caudale, fig. 18, omoplate, fig. 22, humérus. Le tursio, p. 305, pl. xxiii, fig. 17, omoplate. Le globiceps, p. 305, pl. xxiii, fig. 16, omoplate. Le griseus, p. 306, pl. xxiii, fig. 15, omoplate. Le marsouin, p. 306, pl. xxiii, fig. 13, omoplate; le dauphin du Gange, p. 307, pl. xxiii, fig. 19, omoplate. Le leucorhamphus, p. 307 , pl. xxiii, fig. 20, omoplate. Principales dimensions de quelque squelette de dauphins, p. 308.] Section II. Des Dauphins fossiles. Article premier. D'un dauphin voisin de l'épaulard et du globiceps, dont le squelette a été déterré en Lombardie, pp. 309-312, pl. xxiii, fig. 1, squelette, fig. 2 , tête en dessous, fig. 3, sternum, fig. 15, os styloïdien. Article II. D'un danphin à longue symphyse de la máchoire inférieure, déterié dans une falunière du département des Landes, pp. 312-315, pl. xxiii, figg. 4, 5, mâchoire; figg. 9-11, un fragment du même. Article III. D'un dauphin fort voisin de l'espèce conmune, trouré également dans les falunières du département des Landes, p. 316. Article IV. D'un dauphin dont une portion de mâchoire supérieure a été trourée dans calcaire grossier du département de l'Orne, pp. 317, 318, pl. xxiii, fig. 38.

Chapitre IV. Des Ossemens de Narwals, d'Hyperoodou et de Cachalots, pp. 319-357. Première Section. Des Espèces vivantes, pp. 310-348. Artiele premier. Des Narwals. \$1. Description de l'animal, pp. 319-322. §2. Ostéologie, pp. 322, 323, pl, xxii, fig. 7, crâne. Article II. De l'Hyperoodon. §1. Caractères extérienrs, pp. 324-326. §2. Ostéologie, pp. 326-328, pl. xxir, figg. 19-21, crâne, fig. 23, omoplate. Article III. Des Cachalots, pp. 328-348. §1. Réca. pitulation des caractères indiqués pour leurs espèces; incertitude de ces caractères [historique et critique], pp. 328-342. \$2. Ostéologie des Cachalots. $1^{\circ}$. De la Tête, pl. 342-346, pl. xxir, figg. $1-5$, crâne. $2^{\circ}$. Du reste du squelette, pp. $246-348$, pl. xxiv, fig. 13, atlas, fig. 12, les six autres vertebres cervicales, fig. 15, la deuxième dorsale, fig. 16, la neuvième dorsale, fig. 17, la 


\section{Cuvier, G.-Continued.}

troisième lombaire, fig. 18, quatrième lombaire, fig. 11, omoplate; fig. 14, humérus et arant-bras, figg. 6-10, mâchoire inférieure, exemplaires différens. Section II. Des Ossemens fossiles de Narwals et de Cétacés voisins des Hyperoodons et des Cachalots, pp. 349-357. Article premier. Fragmens fossiles de Narval, pp. 349, 350. Article II. Sur une tête pétrifiée de Cétacé d'un genre inconnu, voisin des cachalots et des hyperoodons, trouvée sur la cóte de Provence, pp. 350-352, pl. Xxvii, fig. 3, crâne. [Cette espèce est nommé Ziphius cavirostris.] Article III. Sur des têtes du genre caractérisé dans l'article précédent, complétement pétrifiées, déterrées en creusant les bassins d'Anvers, pp. 352-356, pl. xxvii, figg. 4-6, crâne. [Cette espèce est nommée Ziphius planirostris.] Article IV. D'un morceau qui indique nne espèce voisine des précédentes, mais à museau plus allongé, pp. 356-357, pl. xxvii, figg. 9, 10, partie du rostre. [Cette espèce est nommée Ziphius longirostris.]

Chapitre V. Des Ossemens de Baleines, pp. 359-396. Première Section. Des Espèces vivantes, pp. 359-388. Article premier. Détermination des espèces, pp. 360-370 [historique et critique]. Article II. Ostéologie. §1. De la tête, pp. 370-377, pl. xxvi, figg. 1-4, crâne de rorqual du Cap; fig. 5, crâne de rorqual de la Méditerranée; fig. 6, crâne de rorqual de la mer du Nord; pl. xxv, figg. 1-4, crâne d'une baleine proprement dite d'après un jeune individu du Cap; figg. 5-8, d'après un adulte de la même espèce; figg. 9-11, d'après un adulte du Groënland; pl. xxvii, figg. 10-15, os de l'oreille d'après l'espèce du Cap. §2. Du reste du squelette. 10. Dans les baleines proprement dites, pp. 378-381, pl. xxvi, fig. 13, vertèbres cervicales, fig. 14, quartrième dorsale, fig. 15, onzième dorsale, fig. 16, première lombaire, fig. 17, une des premières caudales, fig. 11, sternum, fig. 7, omoplate, fig. 23, humérus, avant-bras et manus-toutes les figures d'uprès la grande baleine du Cap; fig. 18, vertèbres cervicales d'après une autre espèce, fig. 8, omoplate, d'après de baleine franche. 20. Dans les rorquals, pp. 381-385, pl. xxvi, fig. 19, atlas, fig. 21 , quatrième cervicale, fig. 9 , omoplate, fig. 22 , humérus et os de nageoire, tontes les figures d'après le rorqual du Cap; [quelques observations sur l'os du bassin et sur l'os hyoüde des cótacés], pp. 385-388, pl. xxri, fig. 24, os du bassin d'après le rorqual, fig, 25, os du bassin d'après la grande baleine, pl. $x \times \mathrm{v}$, fig. 12, os hyoüde d'après les dauphins, fig. 14, os hyoïle d'après la grande baleine du Cap, fig. 15, os hyoïde d'après le cachalot d'Audierne(?). Section II. Des Baleines fossiles, pp. 389-396. Article premier. D'une baleine du sons-genre des rorquals, dont il a été déterré deux squelettes en Lombardie, pp. 390-292, pl. xxvii, fig. 1, squelette, copiée de M. Cortesi. Article II. D'un fragment considérable de tête de Baleine déterré dans le sein de la ville de Paris, pp. 393-396, pl. xxvii, fig. 16.

Résumé de cette septième partie,pp. 397-399. Addition importante à cette septième partie [relative au Delphinus frontatus, nommé à p. 278], p. 400.

Delphinus frontatus, pp. 278, 296,400, D. griseus, p. 284, note 1, p. 297, spp.nn.; Ziphius cavirostris, p. 352, Z. planirostris, p. 356, Z. longirostris, p. 357 , gen. et spp. nn.

Cuvier, in his classic memoir on the recent and fossil Cetacea, thoroughly sifted the literature of the subject, critically separating, for the first time, the few grains of wheat from the vast amount of chaff that had already accumulated, placing the subject on a solid basis, besides adding, in both his plates and text, a large amount of new and well-considered information respecting the osteology of the species. In his historical résume, no less than in the technical portions of the work, is seen the hand of the master. Unfortunately, however, for the nomenclature of the subject, the species are largely treated under simply vernacular names, but they may be easily identified with their proper systematic cognomens. A single new genus (Ziphius) with three new species, and two or three new species referred to Delphinus, are for the first time defineu, while the untenability of various nominal species is clearly shown. In some instances, however, he appears to have overstepped the bounds of judicious criticism, but not to the extent claimed bv Dr. J. E. Gray, who says that Cuvier, in examining previous authorities, approached "the work with a predisposition to reduce the number of species, which his predecessors had described, to the smallest number .... To make this reduction: first, he believes that tho Hump-backed Whale, of Dudley, is only a whale that has lost its fin, not recognizing that the Cape Rorqual, which he afterwards de. scribed from the fine skeleton now shown in the inner court of the Paris Musenm, is one of this kind; secondly, that the Black-fish [Physeter Tursio, Gray], and the Sperm Whale are the same species; an error which must have arisen from his not having observed that Sibbald had figured the former, for he accuses Sibbald of twice describing the Sperm Whale; and when he came to Schreiber's [8ic] copy of Sibbald's figure, he thinks the figure represents a Dolphin which had lost its upper teeth, overlooking the peculiar form and posterior position of the dorsal fin, and the shape of the head, which is unlike that of any known Dolphin. This mistake is important, as it vitiates the greater part of Cuvier's critioism on the writings of Sibbald, Artedi, and others, on these animals."-(Cat. Mam. Brit. Mus., pt. i,.Cetacea, 1850, 3. Cf. also Gras, l. c., p. 54.)

Gray's criticism, however, lacks the support of the best modern Cetologists, who discard Gray's Physeter Tursio, based on Sibbald as above, and still known only from Sibbald's figure and description, and the grotesque figure of Bayer's Mular. He for the first time reduced the Cachalots to a single species, - a conclusion amply sustained by later inrestigators. 
1823. Desmoulins, ANtorve. Cétacés. <Dict. class. d'Hist. nat., iii (Cad-Chè), 18:23, pp. 411-417.

General account of the order, according to the classification of G. Cuvier (Règne Animal, tome i). Contains a correction of the article Baleine (op. cit., t. ii, p. 165), and adds the following, previously described (Mém. du Muséum, t. iv) by Lacépèdo from Japanese paintings: 14. Balanoptera punctata; 15. Bal. nigra; 16. Bal. ccerulescens; 17. Bal. macu* lata, p. 417.

[623.]

1823. "Евеrt, Frz. Das Thierreich. Eine belehrende Darstell. der bekannten lebenden Geschöpfe der Erde. 4 Thle. Mit 8 Kptrtaf. 8०. Wien, 1823."

Not seen; title from Carus and Engelmann.

1823. Editors. [Vertebra of a Whale found near Dingwell.] <Edinb. Philos. Journ., ix, no. 17, art. xxii, 1823, p. 185.

Notice (10 lincs) in a report of the Proceedings of the Royal Society of Edinburgh for March $27,1823$.

[625.]

1823. Fleming, Johv. Gleanings of Natural History, gathered on the Coast of Scotland during a voyage in 1821. <Edinb. Philos. Journ., viii, no. 16, art. x, 1823, pp. 294-303.

Mentions seeing Baloenoptera rostrata, p. 303.

1823. Home, Everand. Lectures | on | Comparative Anatomy; | in which are explained | the Preparations | in | the Hunterian Collection. | - | Illustrated by Engravings. | - | To which is subjoined, | Synopsis Systematis Regni Animalis, | nunc primum ex ovi modificationibus propositi. | - | By Sir Everard Home, Bart. | V.P. R. S. F.S. A. F. L. S. | . . [ =titles, 8lines ]. | - | In Four Volumes. | Vol. III [-IV]. | London: | Printed for Longman, Hurst, Rees, Orme, and Brown, | Paternoster-Row. | 1823. 4. Vol. iii, text, 1. 1, pp. ixvii, 1. 1, pp. 1-586; vol. iv, plates, pp. i-viii, 1. 1, pll. i-clxxi, each with an explanatory leaf.

The whole work consists of 6 vols., 3 of text and 3 of plates, published as follows: vol.i, ii, 1814; vols. iii, iv, 1823; vols. v, vi, 1828.

Cetacea and Sirenia, passim, in lectures Fifth, Sixth, Seventh, Ninth, and Tenth. The following is a list of the plates relating to these groups:

Pl. xvii, jaws of Delphinus gangeticus ; pll. xxi-xxiii, skull and teeth of Dugong; pll. xxiv, xxv, tongue, stomach, and cæcum of Dugong; pl. xxvi, stomach of Manatee; pl. xxvii, cæcum of Manatee; pl. l, heart of Dugong; pl. li, portion of trachea and section of lungs of Dugong; pl. lii, Dugong (animal); pl. liii, sternum and pelvis; pl. liv, skeleton of Dugong; pl. lv, Manatee (animal); pl. Ivi, skeleton of Manatee; pl. c, ear bone of Balcena mysticetus, external view; pl. ci, do., internal view; pl. exvi, uterus and penis of Dugong.

The plates here noted all first appeared in the Phil. Trans. Roy. Soc. London. See Home, E., at 1818,1820 , and 1821 .

[627.]

1823. Jonkaire, M. DE la. Notice géologique sur les environs d'Anvers. <Mém. de la Soc. d'Hist. Nat. de Paris, i, 1823, pp. 110-126.

Ossemens de Cétacés, p. 117.

1823. "MANBY, G. W. Journal | of a | Voyage to Greenland, | in the year 1821. | With graphic illustrations. | - | By George William Manby, Esq. | - | The Second Edition. | London: | Printed for G. and W. B. Whittaker, | A ve-Maria Lane. |-| MDCCCXXIII. I vol. 8vo. pp. xi, 225, maps, pll., and woodcc."

A reprint in $8^{\circ}$ of the $4^{\circ}$ edition of 1822 . Not seen; title from Coues, Bds. Col. Vall., p. 606. For notice of cetological matter see suprà, $4^{\circ}$ ed., 1822.

[629.]

1823. Sconesby, William, jr. Journal | of a Voyage to the | Northern Whale-fishery ; | including | researches and discoveries on the Eastern Coast | of | Greenland, | made in the Sunmer of 1822, in the ship | Baffin of Liverpool. | By | William Scoresby, Junior, | F. R. S. E., M. W. S. \&c. \&c. | commander. | - | Edinburgh: | Printed for Archibald Constable and Co. Edinburgh: | and Hurst, Robinson and Co. Cheapside, London. $|-|$ 1823. $8^{\circ}$. pp. i-xliii, pp. 1-472, pl. i-viii.

List of Animals met with on the Eastern Coast of Greenland, with Notes and Memoranda. I, Mammalia, pp.416-420. Cetacea, 1. Balbena Mysticetus, 2. B. gibbar, 3. Monodon MFono. ceros, p. 420. 


\section{SCORESBY, WilliaM, $j$. - Continued.}

Whalefishery and Whales, passim, in text, to wit: A Whale captured, p. 41; Narwhals, pp. 75,76 ; capture of Whales, pp. 123-130, 134-136; Narwhal taken,-description of the animal, including measurements, p. 132 ; further account of the Narwhal, including its anatom, pp. 136-142, figg. at pp. 140,141, illustrative of structure of blow-hole; anatomy of the Whale, pp. 148-158, figg. showing structure of blow-holes at pp. 152, 153; Whales taken, pp. 285-290.

[630.]

1824. Axov. Udtog af en Dagbog, holdet paa en Rejse i Grönland i Sommeren 1823. $<$ Örsted, Tidsskrift for Naturvidenskaberne, 1824, no. 9, pp. 271-289, no. 10, pp. 1-:35.

References passim to various Cetaceans, e. g., no. 10, pp. 2, 4, 20, 26, 29, etc.

1824. Anov. A Voyage to Cochin China. By Joln White, Lieutenant in the United States Navy. <Edinb. Rev., xli, 1825, pp. 123-142.

An extended review of the work (8ee 1824. WHITE, J.), containing, at pp. 136-142, some account of the Southern Whale Fishery.

1824. Chamisso, Adelbertus DE. Cetaceorum maris Kamtschatici imagines, ab Aleutis e ligno fictas, adumbravit recensuitque Adelbertus de Chamisso, Dr. <Nor. Act. Phys.-med. Acad. Caes. Leop.-Carol. Nat. Curios., xii, 1, 1824, pp. 249-260, pll. xvi-xx; xii, 2, p. 873 (corrigenda).

1. Balaena Kuliomoch, pp. 249-256, pl. xvi, fig. 1 (i.e., pl. xvii, fig. 3). 2. Balaena Abugulich, pp. 256, 257, pl. xvi, fig. 2 (i.e., pl. xvii, fig. 1). 3. Balaena Mangidach, p. 257, pl. xvii, fig. 3 (i. e., pl. xvi, fig. 1). 4. Balaena Agamachtschich, pp. 257, 258, pl. xviii, fig. 4. 5. Balaena Aliomoch vel Aliama, p. 256, pl. xviii, fig. 5. 6. Balaena Tschickagluk, p. 257, pl. xix, fig. 6. 7. Physeter Agidagich vel Agdagjach, pp. 257, “260" (i.e., 258), pl. xix, fig. 7. 8. Ancylodon? Alugninich, pp. "261, 262," pl. xx, fig. 8. 9. Delpinus [sic] Aguluch, p. 260, pl. xx, fig. 9.

A more barbarous piece of work was doubtless never perpetrated in nataral history than the burdening of Cetology by Chamisso with nine "species" of Cetaceans based on wooden images made by the Aleuts. In the light of present knowledge of the Cetacea of the Japan seas most of them may be determined generically, mainly, however, on the basis of exclusion. The delineations and descriptions are of interest as showing the proficiency of sav. ages in carving natural objects in wood, but as diagnoses of actual species they are not entitled to recognition, and the barbarous names by which they are specifically designated may well drop from the system as indeterminable synonyms. A page of errata in the second part of the volume shows that the references in the text to the first three figures are erroneous, while, to further complicate the citation of the paper, pp. 256 and 257 and p. 260 are duplicated, while there are no pp. 258 and 259.

Balaena Kuliomoch (fig. iii, not fig. $i$, as given in tho text) relates quite evidently to some species of Balaena. Balaena Abugulich (fig. i, not fig. ii, as given in the text), Balaena Mangidach (fig. ii, not fig. iii, as given in the text), and Baloena Agamachtschich (fig. iv), all apparently relate to Fin-Whales. The size of the pectoral fin in Balcena Aliomoch (fig. v) seems to indicate that it is a species of Megaptera. Baloena Tschilkagluck (fig. vi) is nnrecognizable even generically ; it may, however, relate to Rhachianectes. Physeter Agidagich (fig. vii) has a general resemblance only to Physeter. The Ancylodon? Alugninich (fig. viii) is unrecognizable. Delp[h]inus Aguluch (fig. ix) is apparently some species of Orca.

[633.]

1824. Cuvier, G. Sur la détermination des diverses espèces de Baleines vivantes. <Ann. des Sci. nat., ii, 1824, pp. 27-41.

Extrait de Recherches sur les Ossemens Fossiles, 5, pp. 360-370.

1824. Desm[ARE]ST, [A. G.] Revue et representation d'images sculptées en bois par les habitans des lles Aléoutes, représentant diverses espèces de Cótacés des mers du Kamtschatka; par A. de Chamisso; av. 5 pl. litogr. (Nov. Acta Acad. Caes. Leop. Carol. Nat. Cur., to. xii, $1^{\text {re }}$ partie). <Férussac's Bull. des Sci. nat., iii, 1824, pp. 70-75.

Résumé.

1824. Desmoulins, A. Dauphin. <Dict. class. d'Hist. nat., v, Cra-D, 1824, pp. 348-361.

Dauphin, Delphinus: generalities, pp. 348-353; species, pp. 353-361. 1. Delphinus Delphis, L., p. 363 ; 2. D. Tursio, Fabr., p. 354 ; 3. D. frontatus, Cuv., p. 354 ; 4. D. Bredanensis, Cuv., p. 355; 5. D. coronatus, Frém., p. 355; 6. D. gangeticus, Lebeck, p. 355 ; \%. D. dubius, Cuv., p. 356; 8. D. Boryi, Desm., p. 356, pl. cxli, fig. 1 (original); פ. D. Phoccena, L., p. $55 i$ (i. e., 357); 10. D. Orca, Fabr., p. 557 (i.e., 357); 11. D. griseus, Cuv., p. 557 (i. e., 357); 12. D. globiceps, Cuv., p. 358 ; 13. D. Leucas, Pall., p. $358 ; 14$. D. Peronii, Lacép. $(=D$. leucorhamphus, Péron), p. 359; 15. Dauphin Rhinocéros, Quoy et Gaim., p. 359; 16. Dauplin 
1021. Desmoulins, A.-Continued.

crucigère, Quoy et Gaim., p. 359; 17. Dauphin albigère, Quoy et Gaim., p. 360; 18. Dauphin de Cortési, Cuv. (foss.), p. 360; 19. Dauphin à longue symphise, Cuv. (foss.), p. 360; 20. [not named], foss., p. 361; 21. [not named], foss., p. 361 .

The genus Delphinus is divided into three sections, to wit, "† Dauphins à bec," including spp. 1-8; "†† Dauphins à tête obtuse," spp. 8-12; " $+\dagger+$ Danphins sans dorsale, Delphinaptères de Lacépède," spp. 13, 14. Numbers 15-17 (I-III in the original) are entered incertac cedis, between spp. 14 and 15 of the original article; and then follow "Dauphins fossiles," spp. 18-21 (15-18 in the original).

[636.]

1824. Deswoulrss, A. Dugong, Trichechus Dugong, Gmel. < Dict. class. d'Hist.nat., v, Cra-D, 1824, pp. 640, 641, pl. cxli, fig. 2.

[637.]

1824. D. [? Desmoulins, A.] De l'existence du nerf olfactif ou ethmoïdal dans les Baleines; par A. Desmoulins. (Dict. class. d'Hist. nat., t. 2, art. Baleine.) < Férussac's Bull. des Sci. nat., ii, 1824, pp. 362, 363.

1824. Edrons. Habits of the Whale. <Edinb. Philos. Journ., xi, no. 21, 1824, pp. $220,221$.

Note on the occurrence of a Whale in the St. Lawrence River, near Montreal.

[639.]

1824. Edrtons. Notice in regard to a Fossil Whale discóvered in Dunmore Park. $<$ Edinb. Phil. Journ., xi, no. 21, 1824, p. 220.

Its position similar to that of Airthrie; estimated length, "70 or $7 \bar{\jmath}$ feet." (See infrà, 1824 . KEDDOCH.)

[640.]

1824. Erchwald, E. Observationes nonnullæ circa fabricam Delphini Phocænae aetatis nondum provectae. <Mém. de l'Acad. imp. des Sci. de St.-Pétersbourg, ve sér., ix, 1824, pp. 431-452.

$[641$.

1824. FABER, [FriEdrich]. Udtog af en Skrivelse fra Regiments-qvarteermester og Auditeur Faber til Prof. Reinhardt, dateret Horsens d. 28 Juli 1824. < Örsted, Tidsskrift for Naturvidenskaberne, iv, no. 10, 1824, pp. 110-118.

A slight reference to Balcena Boops at p. 110.

[642.]

1824. Harlan, Rrchard. On a species of Lamantin resembling the Manatus Senegalensis (Cuvier) inhabiting the Coast of East Florida. <Journ. Acad. Nat. Sci. Phila., iii, 18:24, pp. 390, 394, pl. xiii, figg. 1-3.

Manatus latirostris, sp. n., based on "two skulls, two ribs, and a strip of skin, seren feet six inches in length, half an inch thick." Skulls described in detail, with figures (pl. xiii, figg. 1-3), and compared with skulls of $M$. americanus (pl. xiii, fig. 5) and $M I$. senegalensis (pl. xiii, fig. 4). No ellaracters are found in the skall to separate M. latirostris from $\mathbf{M r}$. senegalensis, but the name latirostris is proposed for adoption in case further investigation should reveal external differences sufficient to separate the Florida Manatee from the African!

[643.]

1824. Herausgeber. Rudolphi; anatomische Bemerkungen úber Balaena rostrafa. < Isis von Oken, xiv, 1824, pp. 620, 621.

Auszug aus Abhandl. d. phys. Classe d. k. p. Acad. d. Wissen. zu. Berlin, 1820-1821 (1822), pp. $27-40$.

[644.]

1824. Herausgeber. Über die Strecken, welche die Walfische durchschwimmen. <Froriep's Notizen aus dem Gebiete der Nat:r- und Heilkunde, viii, no. 8, Sept., 1824, pp. 121, 122.

Abstract aus Hr. Baron rom Zach's Correspondence astronomique, géographique, hydro. graphique et statistique, ix, no. 1, 1823, p. 95.

[645.]

1824. Kendocr, - - Further particulars in regard to the Fossil Whale of Dunmore. <Edinb. Philos. Journ., xi, no. 22, 1824, pp. 415-417.

A letter supplementing an editorial communication in the preceding number, giving a de. tailed account of the situation of the skeleton.

[646.]

1824. KNox, [RoberT]. Anatomische Beobachtungen über die Milchgefïss im Seehund und Wal, aus Briefen von Dr. Knox an Dr. Duncan. <Froriep's Notizen aus dem Gebiete der Natur- und Heilkunde, viii, no. 4, August, 1824, pp. 49-53.

Uebersetzet aus Edinburgh Med. and Surg. Journ., July, 18:4, p. 23.

[647.] 
18:4. Raive, Thomas. Notice in regard to Macquarie Island. <Edinb. Philos. Journ., xi, no. 21 , art. iii, 1824 , pp. $46-50$.

Reference (p. 49) to "the.black or proper whale," and to the "fish called by whalers the Killer," which "is said to kill its prey by goring it in the belly with its dorsal fin, which is sharp, and sometimes from 8 to 10 feet long, shaped like a scythe."

[648.]

1824. Sabine, E. A | Supplement | to | the Appendix of Captain Parry's Voyage for the | Discovery of a North-West Passage, | in the years 1819-20. | Containing | an account of the subjects | of | Natural History. | - | London; | John Murray, Albemarle-street. | - MDCCCXXIV: 4º. 11. 5, pp. clxxxiii-ccex, pll. 6.

Mammalia, by Edward Sabine, pp. clxxxiii-cxcii.

Monodon monocero8, p. cxcii (short description of a specimen killed).

1824. SCHLEep, [B. C.] Einige zoologische Bemerkungen. <Isis von Oken, $\mathrm{xv}, 1824$, pp. 891-899.

Delphinus phocaena, p. 892. Die Schwanzflosse horizontal und nicht vertical war (!) wie Block und Bechstein gesagt haben.

$[650$.

1825. Blainville, H. DE. Note sur un cétacé ́choú́ au Havre, et sur un ver trouvé dans sa graisse. <Nouv. Bull. des Sci. de la Soc. philom. de Paris, 1825, pp. 139-141.

Caractères externes, etc., d'un cétacé sans nom scientifique.

[651.]

1825. Blainville, H. DE. UUber ein bei Havre gestrandetes fischartiges Sängethier und einen in dem Speck desselben gefunden Wurm. <Froriep's Notizen, etc., xii, No. 256, Dec. 1825, pp. 212-214.

[652.]

18:25. Blumenbach, J. F. Handbuch | der | Naturgeschichte | von | Joh. Fried. Blumenbach. | [Vignette.] Eilfte rechtmåsige Ausgabe. | - Góttingen, 1825. I In der Dieterich'schen Buchhandlung. 8'. pp. i-xii, 1-668, pll. i, ii.

Trichechus manatus, p. 112. Cetacea, pp. 113-115. Genn. 4, spp. 7. Text substantially the same as in the 10th ed., 1821, $q . v$.

1653.]

18:5. Cuvier, F. Des | Dents des Mammifères, | considérées | comme caractères zoologiques. | Par M. F. Cuvier. | - | Le Cabinet d'anatomie formé par M. G. Cuvier, | au Jardin du Roi, pouvait senl donner l'idée et | fournir les matériaux de cet ouvrage. | [Monogram.] | F. G. Levranlt, Editeur, à Strasbourg, | et rue de la Harpe, No. 81, à Paris. | Le Normant, rue de Seine, No. 8, a Paris. | 1825. $8^{\circ}$. pp. i-lv, 1-258, 1. 1, pll. i-ciii + iii bis, xi bis, xxii bis, xxxiv bis, lxxxvi bis, xci bis, xciii bis $=\mathrm{cx}$.

Cétacés herbivorc8. pp. 236-239. Pl. xcvi, Manatus americanus ; pl. xcvii, Halicore dugong.

C'tacés piscivores, pp. 240-246, pll. xcviii-ciii. Pl. xcriii, Delphinus sp.; pl. xcix, D. gangeticus; pl. c, "Marsouins"; pl. ci, Grampus sp.; pl. cii, Monodon monoceros; pl. ciii, Physeter macrocephalus.

The descriptions are brief; there are no textual references to the plates, nor is there any exact indication of what species are figured. The work is of little importance in reference to Cetaceans.

[654.]

18:25. Cuvier, G. Recherches | sur les | Ossemens fossiles, | où l'on rétablit | les caractères de plusieurs animaux / dont les révolutions du Globe ont détruit les espèces; | Par M. le Bon. G. Cuvier, | . . . [=titles, 5 lines ]. | Troisième Edition. | - | Triomphante des eaux, du trépas et du temps, | La terre a cru revoir ses premiers habitants. | Delille. | - | Tome Premier [-Cinquième]. | [Seal.] Paris, | Chez G. Dufour et E. D'Ocagne, Libraires, Quai Voltaire, No. 13. | Et a Aunsterdam, chez les même. | 1825. 4? 11. 2, pp. 1-405, pll. i-xxvii.

This is apparently a reissue of the "Nonvelle Edition," $1823, q . v$., from the same plates, with a new title-page, altered as above.

[655.]

1825. Desm[ARE]st, A. G. Sur une nouvelle espèce de Lamantin, qui ressemble au Manatus senegalensis de M. Cuvier, et habite les côtes de la Floride orientale; par M. R. Harlan. (Journ. of the Acad. Nat. Sc. of Philadelph., vol. iii, no. 13, mai 1824.) <Férussac's Bull. des Sci. nat., iv, 1825, pp. 106-108.

Résumé. 
1325. Editors. Remains of a Fossil Whale brought from the Apennines, by Lord Glenorchy. <Edinb. Philos. Journ., xiii, no. 26, 1825, p. 385.

1825. F. Lamantine. <Edinb. Journ. Sci., ii, 1825, p. 186.

A brief abstraet of Harlan's paper (Journ. Acad. Nat. Sci., Philadelphia, iii, pp. 390 et seqq.) on Manatus latirostris. (See 1824. Harrax, R.)

1825. Harlan, Richard. Fanna Americana: | being | a Description | of the / Mammiferous Animals | inhabiting North America. | - | By Richard Harlan, M. D. $\mid \ldots[=$ titles, 6 lines $] .|-| \ldots[=$ motto, 3 lines $] .|-|$ Philadelphia: | published by Anthony Finley. | J. Harding, Printer. | 1825. 8॰. pp. $\mathrm{i}-\mathrm{x}, 11-320$.

"Order Ceta" (pp. 274-301) includes: "1. Family Cetacea Herbivora, Sirenia" (pp. 274-281), and, "2. Family Ceta, or Whales proper" (pp. 281-301).

Sirenia: 1. Manatus latirostris, p. 277; 2. Fossil Manatus, p. 278; 3. Stellerus borealis, p. 279.

Cetacea: 1. Delphinus [Delphynorhynchus] coronatus, p. $282 ;$ 2. Delphinus [Delphinus] ${ }^{\circ}$ delphis, p. 284; 3. Delphinus [Delphinus] canadensis [=Bcluga catodon], p. 285; 4. Delphinus [Phoccena] phocoena, p. 286; 5. Delphinus [Phoccena] gladiator, p. 286; 6. Delphinus

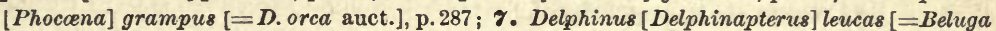
catodon], p. 288; 8. Delphinus [Heterodon] anarnachus, p. 289; 9. Mtonodon monocero8, p. 290; 10. Afonodon microcephalus, p. 291; 11. Physeter [Catodon] macrocephalus, 294; 12. Phy. seter [Catodon] trumpo, p. 294; 13. Baloena [Balcena] mysticetus, p. 292; 14. Baloena [Baloena] glacialis, p. 297; 15. Balaena [Balcena] nodosa, p. 298; 16. Baloena [Baloenoptera] gibbar, p. 299; 17. Baloena [Baloenoptera] boops, p. 300; 18. Baloena [Baloenoptera] rostrata, p. 301.

The matter relating to the Cotacea is wholly compiled. . There is no "internal evidence" that specimens were examined in any case, but the general subject is intelligently handled.

[659.]

1825. Harlan, Richand. Notice of the Pleisiosaurus and other Fossil Reliquiæ, from the State of New Jersey. <Journ. Acad. Nat. Sci. Phila., iv, pp. 232-236, pl. xiv, fig. 1.

First notice of the Cetacean remains, here erroneously referred to a Saurian, which became later the basis of Priscodelphinus harlani, Leidy. Cf. Leidy, Proc. Acad. Nat. Sci., Phila., 1851, p. 320.

[660.]

1825. Latreille, [P. A.] Familles | naturelles | du Règne Animal, | exposées succinctement et dans un ordre analytique, | avec l'indication de leurs geures. | Par M. [Pierre André] Latreille, | Membre de l'Institut (Académio royale des Sciences), de la Légion-d'Honneur, etc., etc. $|-| \ldots[=$ motto, 5 lines $] .1-1$ Paris | J.-B. Baillière, Libraire, | Rue de l'École de Médecine, No 14. | Baudouin frères, Rue de Vaugirard, No $36 .|-|$ 1825. 80. 1l. 3, pp. 1-570.

Onzième Ordre, Cétacés. Cetacea, pp. 64, 65. Première Famille, Herbivores, Herbivora (=Sirenia). Seconde Famille, Souffleurs, Hydraula (=Cetacea). Genera enumerated under French names-Herbivora, 3 genn.; Hydraula, 2 primary unnamed divisions, each with two unnamed subdivisions; genn. 10.

[661.]

1825. Lyngbye, Chr. Von dem Fange der Meerschweine auf den Ferroe-Inseln, nebst einem Beitrag zur Naturgeschichte derselben. <Froriep's Notizen, etc., xii, no. 245, Okt. 1825, pp. 33-41.

Chiefly about the Grindelwalen, of which two species are distinguished, differing in size. Measurements of these are given at p.40, as well as also of "Baloena rostrata." There is a detailed account of their external characters, etc.

[662.]

1825. Richardson, J. Appendix / to / Captain Parry's, Journal | of a / Second Voyage | for | the discovery of a Northwest Passage from | the Atlantic to the Pacific, | performed in | his Majesty's Ships Fury and Hecla, | in | the years 1821-22-23. | - | Published by anthority of the Lords Commissioners of the Admiralty. | - London: | John Murray, | Publisher to the Admiralty and Board of Longitude. | - MDCCCXXV. 4․ 11. 2, pp. 1-432. >Zoological Appendix.-No. I. Account of the Quadrupeds and Birds, by John Richardson, M. D., M. W. S. pp. 287-399.

Mammalia, pp. 288-341. Balcena mysticetus, p. 336. ILonodon monocero8, p. 336. Delphinapterus beluga, p. 337. 
1825. "Rosenthal, F. C., et F. Honnschuir. De Balæuopteris quibusdam ventro sulcato distinctis; epist. gratul. ad J. F. Blumenbachium, 4 maj. Gryphiswald., Koch, 1825."

Not seen; titlo from Carus and Engelmann.

1825. "Sconesby, W. Tagebuch einer Peise auf den Wallfischfang, übers. von Kries, 1825. pp. 178."

Not seen. See the original English edition of 1823.

[665.]

1825. ThaArup, F. Statistisk Udsigt/ over / den danske Stat / i Begyndelsen af Aaret 1825. I - | Som Haandbog for Forretningsmœnd og Bejiledning for | Statistikens Dyrkere. | - Af | Fr[ederick ]. Thaarup. | Statsraad. | - | . . [=quotation, 9 lines]. | - | Kjobenhavn. | Forlagt af Fr. Brummer. | Trykt hos C. Grabe. | 1825. 80. pp. i-xxiv, 1-739, og tab. i-xxxviii.

Marsvinet, Delphinus phocaena, pp. 200-202. Hvalfisk-Fangst, pp. 380, 381, 660.

[666.]

1825. Trompson, J. L. Bottle-nose Whales. <Edinb. Philos. Journ., xiii, no. 26, 1825, p. 389.

Short description of two specimens, male and female, stranded in East Lothinn, Scotland; the female contained two foetuses.

[667.]

1826. Axon. Whale killed in the River St. Laurence, 600 miles from the Sea. <Edinb. New Philos. Journ., [i], 1826, pp. 193-195.

Account of a species of "Finner," 42 feet 8 inches in length, captured near Montreal; "Extract of a letter from Montreal, dated September 13, 1823."

[668.]

1826. BAER, [K. E. vox]. Ueber den Braunfisch (Delphinus phocaena) .... (Als Vorlïufer einer vollståndigen anatomischen Monographie dieses Thiers.) <Isis von Oken, xix, 1826, pp. 807-811.

[669.]

1826. BaEr, [K. E. voN]. Die Nase der Cetaceen erlåntert durch Untersuchung der Nase des Braunfisches (Delphinus phocaena). <Isis von Oken, xix, 1826, 811847 , pll. v, vi.

[670.]

1823. BAER, [K. E. voN]. Nachtrågliche Bemerkung ůber die Riechnerven des Braunfisches. <Isis von Oken, xix, 1826, p. 944.

[671.]

1820. BAKKer, G. Eenige woorden over de waarde der ondervinding, ter geleide van waarnemingen over Wormen, bijzonder in het hart en de luchtvaten van Bruinvischen [Delphinus phocaena]. <Bijd. tot de natuurk. Wetensch., i, 1, 1826, pp. 449-475.

[672.]

1825. "Blocquel, Sim. Ichthyologie de la jeunesse, ou beautés de l'histoire naturelle des Poissons, Cétacés et Crustacés. Avec 60 fig. in-16. Lille et Paris, 1826."

Not seen; title from Carns and Engelmann.

1826. Buffon, [G. L. Leclerc] De, et [G.] Cuvier. OEuvres / complètes | de Buffon | mises en ordre et précédées d'une notice historique | par M. A. Richard, | Professeur agrégé a la Faculté de Médecine de Paris; I Suivies de deux Volumes | sur les progrès des Sciences physiques et naturelles | depuis la mort de Buffon, | par | M. le Baron Cuvier, | Secrétaire perpétuel de l'Académie royale des Sciences. | [Medallion.] A Paris | Chez Baudouin Frères, Editeurs, | Rue de Vaugirard, No 17, | et chez N. Delangle, Editeur, | Rue du Battoir, No 19. | - M. DCCC. XXVI. 8०. 1l. 3, pp. 1-350.

Les Phoqnes, les Morses, et les Lamantins, pp. 188-334. Le Dugong, pp. 294-297. Le Lamantin. pp. 297-313. Sur les Lamantins, pp. 313-316. Le Grand Lamantin du Kamtsehatka, Stellurus borealis, Cuv., pp. 316-320. Le Grand Lamantin des Antilles, Manatus Americanus Desm., pp. 326-329. Le Grand Lamantin de la Mer des Indes [= Dugong], p. 329. Le Petit Lamantin d'Amérique, pp. 330-332. Lo Petit Lamańtin du Sénégal, Manatus Senegalensis Desm., pp. 332-334.

In this edition we have the text of the original edition $(1765, q . v$.$) , with the omission of the$ references to authorities, followed by the text of the Supplement $(1782, q . v$.$) , with here also$ omission of reference to authorities. There are a few brief notes by the editor, signed "A. R."

[674.]

1826. Desm[are]st, [A. G.]. Note sur un Cétacé échoué a Havre, et sur un Ver trouvé dans la graisse; par M. H. de Blainville. (Bull. de la Soc. philom., sept. 1825.) <Férussac's Bull. des Sci. nat., vii, 1826, pp. 370-373. 
1826. Drummond, H. H. Notice regarding Fossil Bones of a Whale discovered in the

District of Montieth. <Mem. Wern. Soc. Nat. Hist., v, pt. ii, 1826, pp. 440, 441.

Brief description of the remains, which are not specifically determined.

[676.]

1826. Edrons. Whale-Fishery at Van Dieman's Land. <Edinb. New Philos. Journ., •

[i], 1826, p. 393.

Initiation of the enterprise at Van Dieman's Land, May, 1824.

1826. Lesson, R. P. Indication de quelques Cétacés nouveanx ubservés dans le voyage autour du monde de la corvette la Coquille. <Férussac's Bull. des Sci. nat. et de géol., vii, 1826, pp. 373,374 .

Delphinus bivittatus, D. superciliosus, D. leucocephalus, D. lunatus, D. minimus, D. malaya nus, p. 373; D. maculatus, Delphinapterus Peronii, p. 298.

The "indications" are very brief, and, in some cases, so general as to be valueless. See next title for further comment respecting these species.

1826. Lesson, R. P., and P. Garnot. Voyage / autour du Monde, | Exécuté par Ordre du Roi, | Sur la Corvette de Sa Majesté, La Coquille, pendant | les années 1822, 18:23, 1824 et 1825, | sous le Ministère et conformément aux instructions de S. E. M. le Marquis / de Clermont-Tonnerre, Ministre de la Marine; | Et publié sous les auspices | de son Excellence Mgr le Cte de Chabrol, | Ministre de la Marine et des Colonies, | Par M. L[onis]. I[sidore]. Duperrey, | Capitain de Frégate, Chevalier de Saint-Louis et Membre de la Légion d'Honneur, | Commandant de l'Expedition. | - | Zoologie, | Par MM. [René Primevère] Lesson et [Prosper] Garnot. | - | Tome Premier. =1re Partie. $\mid$ [Seal.] Paris. ! Arthus Bertrand, Libraire-Editeur, | Rue Hautefeuille, $\mathbf{N}^{\circ}$ 23. $|-| 1826 . \quad 4^{\circ}$. Tome Premier, $1^{\text {re }}$ Partie, ll. 2, pp. i-iv, 1-360. Tome Premier $=2^{\mathrm{e}}$ Partie, 1828, 1l. 2, pp. 361-743. Tome Second $=1^{\text {re }}$ Partie, 1830, 11. 2, pp. 1-471. Tome Second $=2^{\circ}$ Partie, 1830, ll. 2, pp. i-xii, 1-319, 1-155.

Atlas $2^{\circ}$, 1826. Engraved title-page, 1l. 4, pll., mammifères, 1-9; Oiseaux, 10-50 +21 bis, $31^{\text {bis }}, 35^{\text {bis }}$; Reptiles, 1-7; Poissons, 1-38; Mollusques, 1-16 ; Crustacés, 1-5; Insectes, 1-21+14 $4^{\text {bis }}$; Zoophytes, 1-16.

Chap. IV. Observations générales sur quelques Cétacés, par R. P. Lesson, pp. 177-186. 1. Delphinus bivittatus, sp. n., p. 178, pl. ix, fig. 3; described and figured from specimens seen swimming in the sea! 2. Delphinapterus Peronii, p. 179, pl. ix, fig. $1=$ Delphinus peronii Lacép. = Delphinus leucorhamphus, Péron; description and figure of a specimen taken. 3. Delphinus superciliosus, sp. n., p. 181, pl. ix, fig. 2. 3. Physeter macrocephalus, p. 182. 4. Delphinus lunatus, sp. n., p. 183, pl. ix, fig. 4 ; described and figured from specimens seen swimming in the sea! 5. Delphinus maculatus, sp. n., p. 183, not figured; described from specimens seen swimming in the sea! 6. Delphinus leucocephalus, sp.n., p. 184, described from examples seen in the sea! 7. Delphimus malayanus, sp. n., p. 184, pl. ix, fig. 5; described and figured from a specimen captured. 8. Delphinus minimus, sp.n., p. 185; described from animals seen in the sea.

[679.]

1826. Mackenzie, G. S. Notice respecting the Vertebra of a Whale, found in a Bed of bluish clay, near Dingwall [Scotland]. <Trans. Roy. Soc. Edinb., x, pt. 1, art. v, 1826, pp. 105, 106.

A short communication concerning the position in which the bone was found and the material inclosing it.

[680.]

1826. O. [= OKen, Lonenz]. Schlussworte an den Herausgeber der Işis [zu von Baer's "Die Nase der Cetaceen" u.s. w.] <Isis von Oken, xix, 1826, pp. 840-842.

Cf. 1826. BAER, K. E. voN.

[681.]

1826. Pander, Chr., und E. D'Alton. Die Skelete / der Robben und Lamantine, | abgebildet und verglichen | von | Dr. Chr[istian Heinrich]. Pander und Dr. E[duard] d'Alton. | - | - Bonu, | in Commission bel Eduard Weber, 1826. obl. $2^{\circ}$. 1l. 2, pp. 1-10, pll. i-vii. <Vergleichende Osteologie, von Pander und d'Alton, 1821-1831.

Die Lamantine, pp. 8-10, pl. v, (das Skelet des Dugong, Halicore indica). Auch pl. vi, das Skelet eines jungen Narwals (Monodon monoceros). Pl. vii, Schädeln vom Delphinus (Delphinus Phocaena, D. delphis, D. leucas).

1826. Prévost, Constant. Mammifères fossiles. <Dict. class. d'Hist. nat., x, MaclMn, 1826, pp. 127-129. 
1826. Risso, A. Histoire naturelle | des principales productions | de | l'Europe méridionale | et particulièrement de celles des environs | de Nice et des Alpes maritimes; | par A. Risso, | . . . [ = titles, 7 lines ]. | Servandis et instruendis viatoribus. | Tome Troisième. | - | A Paris, | Chez F.-G. Levrault, Libraire, | Rue de la Harpe, N. 81 ; | et mênı Maison, Rue des Juifs, N. 33, a Strasbourg, | 1826. $8^{\circ}$. ll. 2 , pp. i-xvi, 1-480, figg. 1-50, en 16 pll., sans numeros.

Enumeration des Mammifères, Oiseaux et Reptiles.des Alpes maritimes, suivie de l'histoire naturelle des Poissons de la Méditerranée qui frequentent leurs côtes et qui vivent dans le golfe de Nice = tom. III. Mammifères, pp. 1-25.-Ordre cinquième, Cétacée, pp. 21-25.-Delphinus delphis, D. tursio, p. 21; D. Bayeri, p. 22; D. globiceps (fig. 1), D. Risso (Cuv.), (fig. 2), p. $23 ; D$. Desmaresti, p. 25, fig. 3.

Delphinus Desmaresti, sp.n.

[684.]

1826. Ross, J. C. Journal | of a | Third Voyage for the discovery of a / North-west Passage | from the Atlantic to the Pacific; | performed in the years 1824-25, | in His Majesty's Ships | Hecla and Fury, | under the orders of | Captain William Edward Parry, R. N., F. R. S., | and commander of the expedition. | - | Illustrated by plates and charts. $|-|$ Published by authority of the Lords Commissioners | of the Admiralty. | - | London: | - John Murray, | publisher to the Admiralty, and Board of Longitude. I - MDCCCXXVI. 1 vol. 4\%. pp. i-xxviii, 1-186, 1 l., 1-151, maps, pll., and woodcc. >Appendix. Zoology. By Lieut. James Clark Ross.

Mammalia, pp. 92-95. Balcena mysticetus, p. 94. Monodon monoceros, p. 94.

[685.]

1826. SaINT-Hilaire, Is. G. Lamantin, Manatus. <Dict. class. d'Hist. nat.; ix, IoMacis, 1826, pp. 177-181.

General history of the group, pp. 177-180; species, 180, 181. 1. Manatus americanus, Desm. p. 180; 2. M. Sencgalensis, Desm., p. 180; Lamantins fossiles, pp. 180, 181.

M. latirostris, Harlan, is considered as not well distinguished.

[686.]

1826. Saint-Hilaire, Is. G. Mammalogie, Mammalogia. < Dict. class. d'Hist. nat., x, Macl-Mn, 1826, pp. 63-73.

Historique.

[687.]

1826 (circa ?). SLuYTER, D. "Vinvisch, in 1826 gestrand, naar H. Schlegel door $D$. Sluyter. br. folio."

From Bosgoed, op. cit., p. 176, no. 2782.

[688.]

1826. Vrolik, W. Waarneming van Wormen, in de Long-aders en Slagader, de takken der Luchtpijp en de Longzelfstandigheid van eenen Bruinvisch, (Delphinus phocaena). <Bijd. tot de natuurk. Wetensch., i, 1, 1826, pp. 77-84.

[689.]

18:27. Alderson, J. An Account of a Whale of the Spermaceti Tribe, cast on shore on the Yorkshire Coast, on the 28th of April, 1825. <Trans. Camb. Philos. Soc., ii, pt. 2 , art. xv, 1827 , pp. 253-266, pll. xii-xiv.

External measurements and description of internal parts of a male specimen. Two views of the animal (pl. xii), skull (pl. xiii), side vlew of skull, eje, etc. (pll. xiv).

[690]

1827. Avon.? "Iets over de Walvisch-vangst in de Zuidzee en den Indischen Oceaan. <Nederl. Hermes. Tijdschr. v. kooph. en zeev., 1827, no. 2, bl. 44-60."

Not seen; title from Bosgoed, op. cit., p. 250, no. 3589.

1827. Axan.? "De Groenlandsche en Straat Davidsche Walvischvangst. <Nederl. Hermes. Tijdschr. v. kooph. en zeev., 1827, no. 4, bl. 39-55."

Not seen; title from Bosgoed, op. cit., p. 250, no. 3589.

[692.]

1827. BoITard, [P.]. Manuel | d'Histoire | naturelle, | comprenant | les trois règnes de la nature; | ou | généra complet des animaux, des végétaux | et des minéraux; | par M. [Pierre] Boitard. | - | Première Partio [et seconde partie]. | - | Paris, | Roret, Libraire, Rue Hautefeuille, | au coin de celle du Battoir, | 1827. $12 \circ$.

Les Cétacés (i, pp. 45-49)=Sirenia + Cete. Briefly mentioned under (mostly) French generic names; species enumerated passim, under the Latin names then current.

[693.] 
1827. Desm[arest, A. G.]. Rytine; Rytina, Ill. <Dict. des Sci. nat., xlvi, 1827, pp. 476, 477.

1827. Edirors. Professor Harlan on the Mammalia of North America. <Edinb. Journ. Sci., vi, 1827 , p. 328.

Brief notice of Harlan's Fauna Americana, 1825, $q . v$.

[695.]

1827. Edmonstone, Lawrexce. On the Origin of the Power of suspending Respiration, possessed by Aquatic Mammalia and Birds. <Philos. Mag., 2d ser., ii, 1827, pp. 126-130.

Relates mostly to Seals, but contains a paragraph of 7 lines about Whales.

1827. Faber, [Friederich]. Ueber das Blasen der Wale. <Isis von Oken, 1827, 858-860.

Gegen Baer, Isis von Oken, 1826, Heft 8.

[697.]

1827. GraY, J. E. Description of the Skulls of two apparently undescribed Species of Dolphins, which are in the British Museum. <Phil. Mag. or Ann. of Chem., Math., Astr., Nat. Hist., and Gen. Sci., ii, 1827, pp. 375, 376.

Delphinus (Delphinapterus ?) Kingii, p. 375; Delphinus intermedius, p. 376.

1827. Lesson, R.-P. Manuel | de | Mammalogie, | ou | Histoire naturelle | des Mammifères, | Par Rén6-Primeverre Lesson, | . . [ [ = titles, 11 lines in small type]. Multa paucis. | - | Paris, | Roret, Libraire, rue Hautefeuille, | au Coin de celle du Battoir | 1827. 12०. pp. $\mathrm{i}-\mathrm{xv}, 1-442$.

VIIII Ordre. Les Cétacées ou Bipèdes, Cetce, pp. 401-432. 1re Tribu. Les Herbivores, pp. 401, 402. Genre CCXVIIL-CCXX ${ }^{\circ}[=3$ genn.]. Espèces 1049e-1053e [=5 spp.]. 20 Tribu. Les Souffleurs (Hydraula) ou Cétacées ordinaires piscivores, pp. 404-432. Genres CCXXIe$\operatorname{CCXXXLe~[=12~genn.].~Espèces~1054~} 1124^{\circ}$ [=70 spp.]. Heterodon dalei, sp. n.

Sirenia: 1. Manatus americanus, Cov.; 2. Mr. senegalensis, Cuv.; 3. M. latirostris, Harlan; 4. Halicore dugong, F. Cuv.; 5. Stellerus borealis, Desın.

Cetacea: Delphinorhyncus, Blainv., 4 spp.; Delphinus, L., 18 spp.; Oxypterus, Rafinesque, 2 spp.; Phocoena, Cuvier, 11 spp.; Delphinapterus, Lacép., 3 spp.; Heterodon, Blainv., 7 spp.; Monodon, L., 3 spp.; Catodon, Lacép., 4 spp.; Physalus, Lacép., 1 sp.; Physeter, Lacép., 4 spp. ; Balcena, L., 6 spp.; Balcenoptera, Lacép., 8 spp. Cétacées décrits par M. de Chamisso, d'après des images sculptées en bois par les habitans des îles Aléoutiennes, pp. 429-432, 9 spp., not technically named.

"Monsieur, L'excellent Traité de Mammalogie que vons avez rédigé pour l'Encyclopédie, et où vous avez coordonné avec autant d'habileté que de savoir les connaissances zoologiques modernes, a été mon principal guide. En suivant toutes les divisions de l'ourrage fondamental et justement célèbre du règne animal, vous $\mathrm{y}$ avez rattaché arec soin tons les travaux modernes nationaux et étrangers. . . ."-Dédication, à M. A. G. Desmarest, pp. vii, viii.

Like the rest of the "Manuel," the part devoted to the Cetacea is an indiscriminate compilation, nseful mainly as giving a list of the species described up to this date.

[699.]

1827. [Lesson, R. P.] Atlas | de / Mammalogie, | ou | Histoire naturelle | des Mammifères; | composé de 80 planches | Représentant la plupart des Animaux déscrits dans | lo Manuel de Mammalogie et dans celui d'Histoire naturelle. | [By Réne Primevèro Lesson.] - | Paris, | Roret, Libraire, rue Hautefeuille, | au Coin de Celle du Battoir, | 1827. 120. pp.1-16, pll. 1-80. Deux éd.: d'une avee figures noires, de l'autre avec tigures coloriées.

Cetacea, pll. 1xxvi-1xxx. Pl. lxxvi, fig. 1, le Marsonin (Phocaena communis) ; fig. 2, le Danphin (Delphinus delphis); fig. 3, lo Dauphin à 2 Dents (Heterodon hunteri). Pl. lxxvii, fig. 1, le Gibbar (Baloenoptera gibbar); fig. 2, la Jubarte (B. jubartes); fig. 3, le Narval (Monodon monoceros). Pl. 1xxviii, fig. 1, le Trum po (Catodon trumpo); fig. 2, le Microps (Physeter microps); l'Epaulard (Phocana grampus). Pl. 1xxix, la Baleine franche (Balcena mysticetus). Pl. 1xxx, fig. 1, le Rorqual (Balcenoptera rorqual); fig. 2, la Baleine à bec (Baloena acuto rostrata); fig. 3, le Grand Cachalot (Catodon macrocephalus).

None of the figures are new, being simply reduced copies from Sibbald, Martens, Hunter, etc.

[700.]

1827. "Linder, P. J. VAN DER. Notice sur un squelette de Balénoptère. Lue à la Soc. des Scienc. médic. et natur. de Bruxelles et publiée séparément. Brurelles, 1827. $80 . "$

Not seen; title from Carus and Engelmann, Bibl. Hist. nat., ii, p. 1312. 
1827. Pander, Chr. [H.], und E. D'Alton. Die | Skelete der Cetaceen, | abgebilded und beschrieben | von | Dr. Chr. [H.] Pander und Dr. E. d'Alton. | - | Bonn, | In Commission bei Eduard Weber. | 1827. obl. 2०. 11. 2, pp. 1-10, pll. i-vi. <Vergleichende Osteologie, von Pander und d'Alton, 1821-1831.

Einleitung, pp. 1-3. Vergleichende Beschreibung des Skeletes der Walfisshartigen, pp. 3-9. Erklärung der Kupfertafeln, p. 10.

Pl. 1, Skelet des Braunfisches (Delphinus phocaena). Pl. ii, pl. iii, figg. $a$-d, Skelet des schnabelkiefrigen Walfisches (Balaena rostrata). Pl. iii, figg. $e, f$, Hand nnd Brustbein vom Jupiterfisch (Balaena boops). Pl. iv, figg. $a-d$, Schädel vom grönländischen Wale (Balaena mysticetus); figg.e. $f$., die fünf Hals- und drei Rückenwirbel, Shulterblatt, Ober, - und Vorderarm vom Jupiterfisch. Pl. v, figg. a. b., Schädel des Narwales; figg. $c, c, c$, Schädel des Butzwales (Hyperoodon edentulus); figg. $d$, $e$, Shulterblatt und Ober- und Vorderarm vom Pottfisch (Physeter macrocephalus).

[702.]

1827. "Rosenthal, Fr. Chr., u. F. Hornschuch. Einige naturhistorische Bemerkgn. über dis Walle, nebst 1 (lithogr.) Abbild. Dem Hru. Landrath n. ersten Biirgermeister Dr. S. J. Meyer zur Feier seines 50jühr. Amts-Jubiläums gewidmed. gr. fol. Greifswald, 1827 (Koch)."

Not seen; title from Carus and Engelmann.

1827. Saint-Hilaine, Is. G. Narval, Monodon. <Dict. class. d'Hist. nat., xi, Mo-Nso, 1827 , pp. 439-443.

History, affinities, and critical remarks on the nominal species of earlier authors, all the species previously described being referred to one, the Monodon monoceros.

1827. Tredemanx, F. Hirn des Delphins mit dem des Menschen vergleichen. <Tiedemann u. Trcviranus, Zeitschr. für Physiologie, ii, H. 2, 1827, pp. 251263, pl. xii.

[705.]

1827. Tiedeman, F. The Brain of the Common Dolphin compared with that of Man. <Edinb. New Philos. Journ., [iii], 1827, pp. 296-298.

Abstract from Zeitschr. für Physiologie, ii, p. 251, q. v.

1828. BAER, [K. E. vor]. Noch ein Wort ůber das Blasen der Cetaceen. <Isis von Oken, 1828, pp. 927-931.

Gegen Faber, Isis, 1827, Bd. xx, p. 858.

1828. [BRookes, J.] "A prodromus of a Synopsis Animalium, comprising a catalogue raisonné of the zoological collection of Joshua Brooks. $8^{\circ}$. London, 1828."

Not seen; title from Carus and Engelmann.

As cited by J. E. Gray (Cat. Cetacea Brit. M(us.) appears to contain matter of some importance in relation to Cetacea.

1828. "Dubar, J. Ostéographie de la Baleine echouée à l'Est du port d'Ostend, le 4 Nov. 1827; précédée d'une notice sur la découverte et la dissection de ce cétacé. Bruxelles, Laurent frères, 1818. 80. Met 13 platen."

Not seen; title from Bosgoed, op. cit., p. 161, no. 2544.

1828. Edrtors. Fossil Rib of a Whale, discovered in Diluvium near Kemp Town, Brighton. <Edinb. New Philos. Journ., [v], 1828, pp. 198, 199.

1828. Godman, J. D. American | Natural History. | - | Vol. III. | Part I.-Mastology. | - | By John D. Godman, M. D. | . . [ [=titles, 4 lines $]$ | - | Philadelphia: | Carey, Lea \& Carey-Chestnut street. | - | 1828. [Vols. I, II, 1826.] 80. 11 . (engraved title-page), pp. 1-264.

Order VIII. Cete, pp. 39-145.-Family I, Sirenia, pp. 39-55. 1. Manatus Americanus, p. 43 , pl. facing p. 43, fig. 3 ; 2. Stellurus Borealis, p. 49.

Family II. Cetoe, pp. 55-145.-1. Delphinus Delphis, p. 59, pl. facing p. 59; 2. D.Gladiator, p. 67; Fabulous History of the Dolphin, pp. 72-80; 3. Monodon Monoceros, p. 81; pl. facing p. 43, figg. 1, 2, from Scoresby; 4. Physeter Macrocephalus, p. 94; 5. Baloena Mysticetus, p. 98, pl. facing p. 08, from Scoresby; 6. Balona Physalis, p. 134; 7. Balana Musculus, p. 141; 8. Balana Boops, p. 142 ; 9. Baloena Rostrata, p. 144.

The Whale Fishery, pp. 145-237, pl. facing p. 160, Instruments used in the Capture of the Whale, from Scoresby.

A compilation, mainly from Scoreshy, without acknowledgment and generally without citation of authorities. The account of the Right Whale, of the Narwhal, and of "The Whale Fishery," is from Scoresby's "Arctic Regions." The latter is a transcript from Scoresby, 


\section{ALLEN'S BIBLIOGRAPHY OF CETACEA AND SIRENIA.}

1828. Godmax, J. D.-Continued.

vol. ii, pp. 207-310, with the omission of a few paragraphs and additions from other parts of Scoresby's work, the reprint including most of the sub-headings and the foot-notes, withont stating the source from which the matter was appropriated.

[711.]

1828. Gray, J. E. Part I.] [Price 7s. | Spicelegia Zoologica; | or | Original figures and short Systematic Descriptions | of | New and Unfigured Animals. | By John Edward Gray, F. G. S. M. R. S. L. / Honorary Member of the Philosophical Society of Colchester, Corresponding Member of the Maclurean Lyceum, \&c., \&c. 1 - | London: Published by Treuittel, Würtz and Co., Soho Square; and W. Wood, Strand. | [1828.] 4. pp.1-8,pll.i-vi. [The title occupies the upper fourth of the first page. The date ("British Museum, I July 1, 1828") occurs at the bottom of p. 8.]

Mammalia, pp. 1, 2. Family Delphinidce. Subgenus Delphinus, p.1. 1. Delphinus longirostris, p. 1; 2. Delphinus Capensis, p. 2, pl. ii, fig. 1, animal. Subgenus Grampus, p. 2; 3. Dclphinus (Grampus) acutus, p. 2; 4. Delphinus (Grampus) Heavisidii, p. 2, pl. ii, fig. 6, animal; 5. Delphinus (Grampus) obscurus, p. 2, pL ii, fig. 2, animal (young), fig. 3, animal (adult), figg. 4, 5, skulls. Subgenus Beluga, p. 2. Subgenus Phocona, p. 2.

Delphinus longirostris, p. 1; D. Capensis, D. (Grampus) acutus, D. (Grampus) Heavisidii, D. (Grampus) obscurus, p. 2, spp. nn.

To the subgenns Delphinus are referred, besides $D$. longirostris and $D$. capensis, 'D. Delphis, leucorhamphus, dubius, frontatus, and Tursio (D. truncatus, Montagu in Wern. Trans., iii, $t$. 3)," p. 2. To the subgenus Grampus are referred, besides the new species here describerl under this section, "D. griseus, Cuv., D. Grampus, Linn., D. globiceps (which is the D. melas of Traill, the D. deductor of Scoresby)," p. 2. The subgenus Beluga "is formed by the D. leucas, Pall.," p.2. The subgenus Phoccena, "comprehending the D. Phocana of Linne," p. 2. These subgenera, like the species, are followed by the letter "n." (=nobis).

This work, announced to appear in parts, was not continued beyond Part $I$.

1828. Hagelstam, - O On the Regions of Perpetual Snow in Norway and Sweden. <Edinb. New Philos. Journ., [v.], 1828, pp. 305-308.

Contains a reference to the abundance of Whales on the coast of Nordland.

1828. Harwood, J. Communication on the Structure aud Economy of the Greenland Whale, made at the Royal Institution of Great Britain. <Quart. Journ. of Science, xxvi, 1828, pp. 10-24. ("To be continued.")

A popular general account of Balaeng mysticetus, based largely on the anthor's own observations. At the close of the paper are the words "To be continued," but the remainder appears not to have been published.

[714.]

1828. "Linden, P. L. VAN DER. Notice sur un squelette de Baleinoptère exposé à Bruxelles en Juin et Juillet 1828; in-8०. Bruxelles, 1828."

Not seen; title from Van Beneden. $C f$. 1827. LINDEN, P. J. van DER. Can this be the same work?

1828. L[Urotr]., S. G. Recherches anatomiques sur quelques organes des Cétacés; par W. Rapp. (Naturwissenschaftl. Abhandl.; Tom. I, '2 cah., 1827, pag. 259.) <Férussac's Bull. des Sci. nat., xiv, 1827, pp.253,254.

Résumé.

1828. RÉDacteurs. Sur le phénomène du soufflage chez les Cétaces; par M. Faber. (Isis, 18:7, Tom. xx, nº. 10, pag. 858.) <Férussac's Bull. des Sci. nat., xiv, 1828, pp. $252,253$.

Résumé.

1829. "Bernaert, Mathieu Benoit Felix. Notice sur la Baleine échouée prìs d'Ostende le 5 novembre 1827, et sur les fêtes données par M. Kessels, à l'oceasion de la prise de possession au nom de S. M. le roi des Pays-Bas du sque. lette de ce cétacé, in-8. Paris. 1829, imp. de la Normant, 1829. (64 pag.)"

Not seen; title from Carus and Engelmann.

1829. Brandt, J. F., und J. 'T. C. Ratzeburg. Medizinische Zoologie | oder | getreue | Darstellung und Beschreibung | der | Thiere, | die | in der Arzneimittellehre in betracht kommen, | in systematiseher folge herausgegeben | von | J. F. Brandt and J. T. C. Ratzeburg, | Doctoren der Medizin und Chirurgie, berechtigten Ärzten zu Berlin, Docenten an der Friedrich-Wilhelms- I 


\section{Brandt, J. F., und J. T. C. RatzeburG-Continued.}

Universität daselbst, Mitgliedern und Ehrenmitgliedern mehrerer GelehrtenGesellschaften, etc. | = Erster Band. | Mit 24 Kupfertafeln unter XXIII Nummern. | = | Berlin | bei den Verfassern und in Commission bei A. Hirschwald. $|=|$ Gedruckt in der Druckerei der Königlichen Acarlemie der Wissenschaften und bei Trowitzsch und Sohn. | 1829. | Der Titel des ersten Bandes wird ausgeschnitten und dieser dafiir eingeklebt. | $4^{\circ}$. pp. i-iv, 1-19ß, pll. i- $x x i i i+v^{a}$ and one unnumbered $=25$.

Cetacea, pp. 90-134, pll. xii-xvi. Physeter macrocephalus, pp. 91-94, pl. xii, fig. i, fem. (nach Bonnat.), fig. 2, mas (nach Jonston), pl. xiii, Schädel (nach Cuvier). Physeter Trumpo, pp. 94-99, pl. xiv, fig. 1 (nach Robertson). Physeter polycyphus, p. 99, pl. xiv, fig. 1 (aus Freycinets Voy.). Die Cachalot-Anatomie, pp. 99-104. Die Verbreitung der Pottwalle, pp. 104-106. Die Lo. bensart der Pottwalle, pp. 106-108. Sperma ceti nnd Amber, pp. 108-111. Balaena Mysticctus, pp. 111-116, pl. xiv, fig. 4, fem. et juv. (nach Scoresby), pl. xvi, fig. 3, Schädel (fig. orig.). $B a-$ lacna Boop8, pp. 116-118. Balaena rostrata, pp. 119-122, pl. xv, fig. 3, fem. (nach dem Steindruck von Matthiessen), fig. 4, mas (nach Rosenthal), pl. xvi, fig. 1, Skelet, figg. 2-4, Schädel (figg. orig.). Balaena longimana, pp. 122-124, pl. xvi, figg. 5-8 .(Schnauzentheils des Schädel, Kopfe und Barten-figg. orig.). Die Verbreitung der Walle, pp. 125-127. Die Lebensart der Walle, pp. 127-132. Der Nutzen der Walle, pp. 132, 133. Das Fischbein, pp. 133, 134. Erklärung der Kupfertafeln, pp. 134, 135.

Zweifelhaftere Arten: Physeter cylindricus, p. 95, pl. xii, fig. 3 (nach Anderson). Physeter catodon, p. 95. Physeter orthodon, p. 98. Physeter —— pl. xiv, fig. 3 (aus Colnett's Voy.).

Other species incidentally noticed in foot-notes are; Balaena glacialis, Balaena nodosa, Balaena gibbosa, Balaena japonica, Balaena lunulata, p. 114, Balaena punctata, Balaena nigra, Balaena physalus, Balaena musculus, p. 117.

The synonymy and bibliography of the species formally treated are given in great fullness, as are the external characters and anatomy, so far as then known; also their geographical distribution, habits, and products. Many of the figures are original, and those copied have the originals explicitly indicated. Especially noteworthy is the figure of the skull of Baloen a mysticetus, from the specimen in the Berlin Museum. Notwithstanding the large number of nominal species of Cachalots admitted, this treatise is one of much importance. As already said, the bibliographical references are very full.

[719.]

1829. C[Uvier]., F. Zoologie= Mammalogie. <Dict. des Sci. nat., lix, 1829, pp. 357-519.

XI Ordre. Les Cétacés, pp. 514-519. Iro Famille. Les Cétacés herbivores. Genres: 1. Manatus, 2. Halicon [sic=Halicore], 3. Rytina. II Famille. Cétacés piscivores. Genres: 1. Delphinus, 2. Delphinorhynchus, 3. Phocoena, 4. Delphinopterus [sic], 5. Hyperoodon. III Famille. Les Narvals. Genre: Monodon. IV Famille. Les Cachalots. Genre: Physeter. V. Famille. Les Baleines. Genre: 1. Balcena, 2. Balenopterus [sic].

Famm. 5; genn. 13.

1829. Cuvier, [G.]. Le | Règne Animal | distribué d'après son organisation, | pour servir de base | a l'histoire naturelle des Animaux | et d'introduction a l'anatomie comparée. | Par M. le baron Cuvier, | . . [ [=titles, 5 lines ] | avec figures dessinées d'après nature. | Nouvelle Édition, revue et augmentée. | Tome I. | - | Paris, | Chez Déterville, Libraire, | rue Hautefeuille, No. 8; | et chez Crochard, Libraire, | cloitre Saint-Benoit, No.16. | - | 1829. $8^{\circ}$. pp. i-xxxviii, 1-584.

Neuvième ordre des Mammifères. Les Cétacés, pp. 281-298.

Les Cétacés herbivores = Sirenia, pp. 283-285. The same as in the first edition (see 1817. Cuvier, G.) save the addition of a few words to the account of the Dugong.

Les Cétacés ordinaires = Cetacea, pp. 285-298.- "Il n'est point de famille de mammifères plus difficile à observer, et dont les des criptions soient plus incomplètes et la synonymie plus vacillante que celle des cétacés. J'ai cherché à ne donner que des espèces authentiques" (p. 287, note 1). Much new matter is now added, and the number of species is considerably increased; the fabulons or very uncertain basis of others is pointed out. The species recognized may be indicated as follows: 1. Delphinus delphis L., 2. D. tursio Bonnaterre, p. 287; 3. D. dubius Cuv., sp. n., 4. D. frontalis Duss., 5. D. frontatus Cuv., 6. D. plumbcus Duss. ( $?=$ D. malaianus Less. et Garn.), \%. D. velox Duss., 8. D. longirostris Duss., 9. D. microp. terus Cuv., p. 288; 10. D. rostratus Cuv., 11. D. gangeticus Roxb., p. 289; 12. D. phocona L. (12-17 form the genus Phocona Cuv.), 13. D. capensis Dnss.; 14. D. orca, 15. D. gladiator, p. 289; 16. D. aries Kisso, 17. D. globiceps, p. 290; 18. D. leucas Gm. (18-20 are given as Delphinaptères); 19. D. leucorhamphus Péron, 20. D. phocanoides Duss., p. 291 


\section{Cuvier, [G.]-Continued.}

21. Hyperoodon (D. edentulus Schreb.), p. 292 ; 22. Monodon monoceros L., p. 292; 23.Physeter (cachalot macrocéphale de Shaw et Bonnaterre, n'est pos de Linné), p. 294; 24, 25. Les Physétères de Lacép., deux espèces, microps et tursio ou mular), p. 295; 26. Baloena mysticetus, p. 296; 27. B. physalus L., 28. B. boops L., 29. B. musculus L., p. 298.

In foot-notes are mentioned the following species, which are consilered as indications of what may exist, but which are not sufficiently known to be introduced into the work: 1 . $D$. albigena Quoy et Gaym., 2. D. superciliosus Less. et Garn., 3. D. cruciger Quoy et Gaym., 4. D. bivittatus Less. et Garn., 5. D. lunatus Less. et Garn., p. 288, noto 2. D. griseus is referred to $D$. aries Risso., p. 290, note 1.

Other species are criticised and rejected, as notably "le danphin ì deux dorsales" of Rafinesque and the D. rhinoceros Qnoy et Gaym., "ce qui pent faire craindre quelque illusion d'optique," p. 291, note 3.

Compare G. Cuvier (Recherches sur les ossemens fossiles) at 1823, where the Cuvierian spocies here mentioned were first named.

[721.]

1829. Desnoyers, J. Observations sur un ensemble de dépóts marins plus récens que les terrains tertiaires du bassin de la Seine, et constituant une Formation géologique distincte; précédées d'un Aperçu de la non simultanéité des bassins tertiaires. <Ann. des Sci. nat., xvi, 1829, pp. 171-214, 402.

Mammifères marins (Lamantin, Dauphin, Dugong, Rorqual, Baleine et Cachalot), pp. 446-448.

1829. Editors. An enormous Whale. <Loudon's Mag. Nat. Hist., i, 1829, p. 283.

Brief notice of the "Ostend Whale," the skeleton of which was prepared by $\mathbf{M}$. Kessels of Gheut, exhibited there and in London. From New Monthly Mag., no. xcii, p. 357. See 1832. DewhURST.

1829. Harlan, Richard. Description of a new species of Grampus, (Delphinus, Cuv.) inhabiting the coast of New England. <Journ. Acad. Nat. Sci. Phila., vi, pt. i, 1829 , pl. 51-53, pp. i, fig. 3.

D. intermedius, sp. n. (= Globiocephalus melas); Salem Harbor, Mass.

1829. Harwood, [JoHN]. Hands of the Whale. <Loudon's Mag. Nat. Hist., ii, 1829, p. 487.

Popular account-ten lines.

1829. Holl, Friedrich. Handbuch | der | Petrefactenkunde, | von Friedrich Holl | Mitglied der Academia Truentina zu Ascoli. | - | Mit / einer Einleitung | über die | Vorwelt der organischen Wesen | auf der Erde, | von | Dr. Ludwig Choulant | Professor an der chirurg. medicin. Akademie | zu Dresden $\mid-1$ Erstes [-viertes] Bändchen | - | - Dresden, | P. G. Hilscher'sche Buchhandlung. | - 1829. <Allgemeine | Taschenbibliothek | der | Naturwissenschaften. | - | Neunter Theil. | - | Handbuch der Petrefactenkunde. | Erstes Bändchen. | Dresden, | P. G. Hilscher'sche Buchhandlung. | - | 1829. sm. $8^{\circ}$. pp. i-viii, 1-115.

The four "Bändehen" are paged consecutively (pp. 1-489) with interpolated title-pages for vol. ii-iv. Bändehen iii and iv are dated 1830. The title-pages of vol. ii-iv differ from that of the first by the omission of the second [Einleitung] portion of the title.

Manatus fossilis, p. 69; Delphinus Delphis, D. Bordae, D. platyrhynchus Cuv., D. stenorhynchus Cuv., p. 70; Ziphius cavirostris Cnv., Z. longirostris Cuv., D. planirostris Cuv., Monodon monoceros, p. 71; Physeter, p. 71; Balaena, p. 72.

1829. Hunter, Percival. A Male Spermaceti Whale, Physèter Catodon (katō, below, odous, a tooth; teeth in lower jaw only) Lin. <Loudon's Mag. Nat. Hist., ii, 1829, pp. $197,198$.

Brief account of a specimen taken near Whitstable, south coast of England, Feb. 15, 1829.

1829. KNox, [RoBert]. Notice regarding the Osteology and Dentition of the Dugong. <Edinb. Journ. of Sci., i, n. s., no. 1, 1829, pp. 157, 158.

1829. Lesson, R. P. Rytine ou Stellère, Rytina. <Dict. class. d'Hist. nat., xv, Rua-S, 1829, pp. 25-28.

1829. MaYer, [F. J. C.] Ueber die Geruchsnerven des Delphins. <Froriep's Notizen, xxiv, no. 516, Mai 1829, p. 150. 
1829. Morren, Cirarles F. A. Over de Balaenoptera rostrata van Fabricius en beoordeeling der Werken, welke over een Dier dezer sort, den 4den November 18:27, ten oosten van de haven van Ostende gestrand, uitgegeven zijn. <Bijd. tot de Natuurk. Wetenschap., iv, 1829, pp. 52-84, fig. 2 (p. 60, tongheen).

[731.j

1829. Rédacteurs. Mémoire sur un Cétacé échoué le 27 novembre 1828 , sur la côte dépendante de la commune de Saint-Cyprien (Pyrénées-orientales); par MM. Farines et Carcassonne. In- $8^{\circ}$, de 27 pages, Perpignan; 1829, Tastu, Avec une planche représentant la tête de l'animal au trait. <Férussac's Bull. des Sci. nat., xix. 1829, pp. $349,350$.

Résumé.

1829. Rédacteuns. Notice sur un Cachalot (Physeter macrocephalus L.), trouvé sur la côte du York-shire, lé 28 avril 1825, avec fig.; par James Alderson. (Transact. of the Cambridge Philosoph. Society; ii, 1827, p. 253.) <Férussac's Bull. des Sci. nat., xvii, 18:29, pp. 282, 283 .

Résumé.

1829. RédaCteurs. Description d'une nouvelle espèce de Dauphin [Delphinus intermedius ]; par M. R. Harlan. (Journ. of the Acad. of Nat. Sci. of Philadelphia; Tom. vi, cah. 2, p. 51, 1827.) Avec 1 fig. <Férussac's Bull. des Sci. nat., xviii, 1829, pp. $2 \varepsilon 1,282$.

Résumó.

1829. Rédacteurs. Sur deux têtes osseuses de Dauphin appartenant à des espèces jrobablement non décrites; par J. E. Gray. (Philos. Magaz. and Annals of Philos.; nov. 1827, p. 375.) <Férussac's Bull. des Sci.nat., xviii, 1829, p. 282. Résumé.-Delphinus Kingii, Gray, et D. intermedius, Gray (non Harlan).

1829. Smitr, A. Additions a la zoologie du Sud de l'Afrique. <Férussac's Bull. des sci. nat., xviii, 1829, pp. 272-278.

Traduc. du Zoological Journal, no. 16, Jan.-May, 1829, pp. 433 et seqq.

Phocaena Homeii, p. 276.

1829. Sters, C. G. D. Handbuch | der | Naturgeschichte | für | die gebildeten Stånde, Gymnasien | und Schulen, | besonders in Hinsicht auf Geographie | ausgearbeitet | von | D. Christian Gottfried Daniel Stein, | ... [titles, 4 lines]. | Erster [Zweiter] Band. | - | Dritte verbesserte und vermehrte Auflage. | Mit; 135 Abbildungen anf 15 Kupfertafeln. | - | Leipzig, 1829. | T. C. Hinrichscbe Buchhandlung. $8^{\circ}$. Erster B., pp. i-viii, 1-38\%, 1. 1; zweiter B., ll. 2, pp. i-xxxii, 1. 1, pp. 1-274, pll. i-xv.

Achte Ordnung, ... Palmata, pp. 78-83. Trichecus (pp. 82, 83) includes the Sirenians.

Neunte Ordnung, ... Cetacea, pp. 83-87, pl. iv, figg. 28-32. Genn. 4; spp. 10.

[737.]

1829. Thompson, Tuomas. Physèter catòdon. <Loudon's Mag. Nat. IIist., ii, 1829, p. 477, fig. 114.

Original figure of a specimen cast on the Holderness coast in 1825; its skeleton is reported to be in the possession of Sir Cliffurd Constable, and was lat $\mathrm{r}$ described by Beale (Nat. Hist. Sperm Whale, 1839, q. v.).

[738.]

1829. Woods, Hexry. Capture of a Cachalot on the Sonth Coast. <Loudon's Mag. Nat. Hist., ii, 1829, 198-202.

Particulars of its capturo, dimensions, and external characters, mainly from the observa. tions of Mr. Johu Gould of the Zoological Society. The skeleton was presented to the muserm of the Zoological Soeiety by Messrs. Enderby and Sturge, "but goverumcnt having put in a claim to the 'royal fish,' the whole proceeds of it are under arrest, and the bones now lie whitening on the shore" (p. 200).

1829. Yarrell, William. Notes on the internal appearance of several Animals examined after death, in the collection of the Zoological Society. <Zoolog. Journ., ir, Jan., 1829, pp. 314-322.

Note on the anatomy of Phoccena.communis at pp. 318, 319.

1829-30. Fiscuer, J. B. Synopsis | Mammalium. | - | Auctore | Joanue Baptista Fischer, | Med. et Chir. Doctore. | - | Stuttgardtiae | Sumtibus, J. G. Cottae | MDCCCXXIX. 8०. pp. i-xlii, 1-528. 
1829-30. Fischer, J. B.-Continued.

Addenda, Emendanda et Index | ad | Synopsis | Mamalium. | - Anctore | Jnanne Baptista Fischer, | Med. et Chir. Doctore. | - | Stuttgardtiae, | Sumtibus J. G. Cottae. | MDCCCXXX. 1. 1 (bastard title), pp. 329-456, 657-752. Tabb. i-vii, inter pp. 666, 667. Pp. "329" et seqq. ad p. "456" Addend., etc., lege 529-656.

P. ii, motto; p. iii, Dedicatio; pp. v-x, Praefatio; pp. xi-xxii, Catalogus voluminum earum. que editionum, quae in hoc opere citantur; pp. xxiii-xlii, Conspectus Ordinum et Generum; pp. 1-527; Addenda et Emendata, pp. "329" (i.e., 529)-666; tab. i-vii, Conspectus distribu. tionis Mammalium geographicæ; pp. 667-745, Index; pp. 747-752, Corrigenda.

Cete. A.'Artubns anticis apparentibas brachiiformibas posticis compedibus, pp. 501-504. =Sirenia. 1. Manatus australis, p. 501; 2. M. senegalensis, p. 502; 3. Halicore Dugung, p. 503; 4. Rytina Stelleri, p. 504. Species dubiae: M. latirostris Harl., M.? Hydropithecus Shaw, p. 502.

Cete. B. Pinnis Pectoralibus. Artnbas, etc., pp. 504-527, “455" (i. e., 655)-657.=Cetacea. 1. Delphinus Geoffroyi Desm., p. 504; 2. D. coronatus Fremin., p. 505; 3. D. Bredanensis Cuv., p. 505 ; 4. D. macrogenius, sp. n., p. 505 ; 5. D. Gangeticus Lebeck, p. $506 ;$ 6. D. longirostris Gray, p. "455" (i. e., 655); 7. D. velox Dussum., p. " 455 " (i. e., 655); 8. D. Boryi Desm., p. 506; 9. D. Delphis Linn., p. 506; 10. D. cruciger Q. et G., p. 507; 11. D. maçulatus L. et (X.., p. 507; 12. D. dubius Cuv., p. 508; 13. D. frontális Dussam, p. " 455 " (i.e., 655); 14. D. Tursio Fabr., p. $508 ; 15$. D. niger La Cép., p. 508; 16. D. Malayanus L. et G., p. 508; 1\%. D. plumbeus Dussum., p. "455" (i.e., 655); 18. D. lunatus L. et G., p. 509; 19. D. minimus L. et G., p. $509 ; 20$. D. Rhinoceros Q. et G., p. 509; 21. D. Phoccena Linn., p. 509; 22. D. Dussumieri (=D. capensis Dussum.), p. "456" (i. e., 656); 23. D. Homei (= Phocana Homei A. Snith), p. "456" (i.e., 656); 24. D. leucoccphalus L. et G., p. $510 ; 25$. D. bivittatus L. et G., p. 510 ; 26. D. superciliosus L. et G., p. 510 ; 27. D. acutus (= Grampus acutus Gray), p. "456" (i. e., 656); 2S. D. Heavisidii (Grampus Heavisidii Grav), p. "456" (i.e., 656); 29. D. obscurus (=Grampus obscurus Gray), p. "456" (i. e., 656);; 30. D. Orca Linn., p. 511 ; 31. D. griseus Cuv., p. 512 ; 32.'D. Harlani $(=D$. intermedius Harlan), p. "456" (i. e., 656); 33. D. globiceps Cuv., p. 512 ; 34. D. Cortesii (fossil), p. 512; 35. D. leucas Pallas, p. 513; 36. D. Peronii La Cép., p. $513 ; 3 \%$. D. phocanoïdes Dussum.; p. 657 ; 38. D. Dalei p. $514 ; 39$. D. capensis Gray, p. 657; 40. D. Hyperoodon Desm., p. 515 ; 41. D. 9 spurius (= MFonodon spurius Fabr.), p. 515 ; 42. Monodon monoceros Linn., p. 516; 43. Physeter macrocephalus Shaw; ? \& Trumpo, ? $\gamma$ Catodon, p. 518, 44. Ph. polycy. phus Q. et G., p. 518; 45. Ph. cylindricus Bonnat., p. 519; 46. Ph. Tursio Linn., ? $\beta$ Mficrops, p. 519 ? $\gamma$ Orthodon, p. 520; 4\%. Ph. sulcatus La Cép., p. 520; 48. Balaena Mysticetus Linn., p. 521 ? $\beta$ Glacialis, p. 522; 49. B. australis Desmoul., p. 522; 50. B. Japonica La Cép., p. 522; 51. B. lunulata La Cép., p. 522; 5:2. B. Physalus Linn., p. 523; 53. B. borealis (=B; rostrata Rudol.), ? a Boops Linn., p. 524 ? \& Musculus Linn., ? y Rostrata "Mull.," p. 525. 54. B. Antiquorum (= Rorqual de la Mediterranće, Cuv.), p. 525; 55. B. Lalandii (=Rorqual du Cap de Bonne Espérance Cav.), p. 525; 56. B. Quoyi (=B. rostrata australis Desmoul.), p. 526 ; 57. B. punctulata Desm., p. 526; 58. B. nigra Desm., p. 526; 59. B. caerulescens, Desm., p. 526; 60. B. maculata Desm., p. 526; 61. B. Cuvicri Desmoul. (fossil), p. 527; 62. B. Cortessii Desmonl. (fossil), p. 527.

Species dubiae: 1. Delphinus canadensis Desm., p. 505; 2. D. Pernettyi Desm., p. 507; 3. D. albigena Q. et G., p. 507; 4. D. Mongitori Desm., p. 509; 5. D. intermedius Gray, p. 511; 6. D. Rissoanus Desm., p. 512 ; \%. D. Feres Bonnat., p. 513 ; 8. D. Kingii Gray, p. 514 ; 9. $D$. Epiodon Desm., p. 515 ; 10. Balaena nodosa Bonnat., p. 525; 11. B. gibbosa Erxl., p. 525. Delphinus macrogenius, p. 505; D. Dussumieri, p. "456" (i.e., 650); D. Cortesii, p. 512; D. Harlani, p. "456" (i. e., 656); D: Dalei, p. 514; Balaena borealis, p. 524; B. Quoyi, p. 526, nomm. spp. nn.

62 spp. veræ; 11 spp. dubiæ; 7 spp. nn.

1829-32. Fischer, G. Prodromus Petromatognosiae animalium systematicae, continens bibliographiam animalium fossilium. <Nouv. Mém. de la Soc. imp. des Nat. de Moscou, i, 1829, pp. 301-374; ii, 1832, pp. 95-277, 447-458.

In Pars II, Monographia Animalium fossilinm, mammals occupy ii, pp. 100-129.

1830. “Breschet, Gilbert. Organ auditif du Marsonin. Avec. 1 pl. in-4․ Paris 1838. (11 pag.)"

Not seen.

1830. Cheek, H. H. On the natural history of the dugong (Halicore indicus Desm.), the mermaid of early writers; and particularly on the differences which occur in its dental characters. <Edinb. Journ. Nat. and Geol. Sci., i [1829], 1830, p. 161-172.

[744.] 
1830. Companyo, L. Mémoire descriptif | et | Ostéographie . de | la Baleine, | échouéo | sur les côtes de la mer, près de Saint Cyprien, I Département des Pyrénées-orientales, | Le 27 Novembre 1828, I Par L. Companyo, Docteur en Médecine, I Membre du Comité central de Vaccine, Membre correspondant de la Société + linnéenne de Paris. .| Avec figures dessinées d'après nature. | [Vignette.] A Perpignan, / Chez J. Alzine, Imprimeur du Roi. | 1830. $4^{\circ}$. pp. 1-71, pll. i-v.

A vant.Propos, pp. 3-8. Première Partie. Chap. Ior. Considérations générales sur les C6tacées, pp. 9-14. Chap. II. Notice historique, pp. 15-18. Chap. III. Deseription, pp. 19-22. Chap. IV. Détermination, pp. 23-31. Seconde Partie. Ostéographie. Chap. Ier. Généralités, pp. 32-34. Chap. II. De la tête, pp. 34-46. Chap. III. Du tronc, pp. 47-58. Conclusions, pp. 59-68. Explication des planches, pp. 09-71. "Pl. i. Profil de la tête. Pl. ii. Ensemble de la tête. Pl. iii. Base dn crâne, mâchoire 'infórieure. Pl. iv. Os hyoïlo, axis, atlas, sturnum, côtes. P1. v. Omoplates, os pelvien, nagcoires pectorales.

"Nous pensons done que la Baleinoptère que nous avons obserrée est nn jeune individu de la Baleinoptère Rorqual" (=Baloena musculus, Linn.), p. 23.

[745.]

1830. G., A. Natural History of the Neighborhood of Cromer [Norfolk, Engl.]. <Loudon's Mag. Nat. Hist., iii, pp. 155-158.

At p. 157 is a notice of the capture of two Baloen Whales, with a statement of their measnrements.

[746.]

1830. Jonkaire, A. de la. "Considérations sur la Pêche de la Baleine. Paris, 1830. $80 . "$

Not seen. Seo Foreign Quart. Rev., vii, 1831, pp. 355-370, for an extended review of this "respectable pamphlet."

[747.]

1830. KAUP, J. Versuch einer natúrlichen Eintheilung der Sáugethiere. < Isis von Oken, 1830, pp, 799-802.

Sirenien, p. 801.

[748.]

1830. KNox, [R.], and [D.] BREwSTER. Notice regarding the nature of a peculiar Structure observed in the Second Stomach of certain Cetacea, generally considered as simply glandular, but seemingly analogous to the Electric Organs of the Torpedo and Gymnotus ... To which is annexed the Microscopical Examination of the Structure by Dr Brevster. <Edinb. Journ. of. Sci., iii, n. s., no. 6, 1830, pp. 325-338.

Based principally on the Porpoise.

1830. KuHN, [J.] Description de l'appareil mammaire du Marsonin (Delphinus Phocena). <Férussac's Bull. des Sci. nat., xxii, 1831, pp. 322, 323.

[750.]

1830. Quoy, J. R. C., et P. Gaimard. Voyage | de déconvertes | de / l'Astrolabe | exécuté par ordre dn Roi, pendant les Années 1826-1827-1828-1829, | sous le Commandement | de M. J. Dumont D’Urville | - | Zoologie | par | MM. [Jeant René Constant] Quoy et [Paul] Gaimard. | - | Tome Premier. | - I Paris | J. Tastu, Editeur-Imprimenr, | No 36, Rue de Vaugirard. | 1830. $8^{\circ}$. pp. i-l, 1-268. Arec nn Atlas de 200 Planches an moins.

Cétacées, pp.149-152, pl. xxviii, Delphinus Novoe-Zealandice (sp. n.) et D. obscurus.

1830. RAPP, W. Beitrïge zur Anatomie und Physiologie der Wallfische. <Mcckel's Archiv f. Anat. u Phys., 1830, pp. 358-368.

Hauptsächlich über Delphinus phoccena.

[752.]

1830. Rousseau, Emmanuel. Sur l'Existence de moustaches chez les fot us de Dauphins et de Marsonins. <Ann. de8. Sci. nat., xxi, 1830, pp. 351, 352.

"Tels sont les Danphins et les Marsouins, qui alors portent au-dessus de la lèrre snpé. rieure une ligne de poils raides, prolongée sur les côtés, et $y$ formant une petite paire de moustache."

[753.]

1830. WAGLER, Jor. Natürliches System | der | Amphibien, | mit | vorangehender Classification | der | Sängthiere nnd Vögel. | Ein | Beitrag zur vergleichenden Zoologie. | Von | Dr. Joh. Wagler, | Professor der Zoologie nnd Mitglied der Königlichen Akademie der | Wissenschaften in Miinchen. | - [ [Motto. | | - | Mit Kupfern und einer Verwandtschaftstafel. | - | München, Stutt- 
1830. WAGLER, JoH.-Continued.

gart und Tübingen. | In der J. G. Cotta'schen Buchhandlung. | 1830. $8^{\circ}$. pp. i-vi, 1-354.

Mammalia. Ordo XVI. Ceti, Walle, pp. 32-35, 53, 54. Familia I. Hedraeoglossi. A. $O$. naribus anticis in rostri apice. Gonus 1. Manatus Rondel., p. 32 ; genus 2 . Halicore Illig., p. 33; genus 3. Rytina Illig., p. 33. B. C. naribus superiis in rostri basi. Genns 4. Balaena Linn., p. 33; genus 6. Physeter Linn., p. 33; genus 7. Cetus (species: Delphinus globiceps Cuv.), p. 33; genus 8. Delphis (=Beluga), p. 34; genus 9. Tursio [=Delphinapterus Less.] (species: Delphinus Peronii Cuv.), p. 34; genus 10. Nodus [= Heterodon Less.] (species: Delphinus edentulus Schreb.), p. 34; genus 11. Ceratodon Briss. [=Monodon Linn.], p. 34; genus 12. Orca (species: Delphinus bidentatus Hunt.), p. 34; genus 13. Phocaena, Cur., p. 34; genus 14. Delphinus Linn., p. 35; genus 15. Platanista [=Susu Less.], (species: Dclphinus gangeticus), p. 35. Hedraeoglossi, fam. n. (= Sirenia et Cetoe), p. 32.

Cetus (p. 33), Delphis, Tursio, Nodus, Orca (p. 34), Platanista (p. 34), genn. nn.

Critical remarks respecting various genera and species of authors are giren in foot-notes.

[754.]

1830. Watson, J. F. Annals | of | Philadelphia, | being a collection of | Memoirs, Anecdotes, \& Incidents | of the | City and its Inhabitants | from | The days of the Pilgrim Founders. I Intended to preserve the recollections of Olden Time, and / to exhibit society in its changes of manners and / castoms, and the city in its local changes | and improvements. | To which is added / An Appendix, | containing | Olden Time Researches and Reminiscences of | New York City. | - "Oh! dear is a tale of the olden time!" $\mid-1$ "Where peep'd the hut, the palace towers; I Where skimm'd the bark, the war-ship lowers: I Joy gaily carols, where was silence rude; / And cultur'd thousands throng the solitude." | - | By John F. Watson, | Member of the Historical Society of Pennsylvania. | - | Philadelphia, | E. L. Carey \& A. Hart; | New York, | G. \& C. \& H. Carvill. | 1830. | 80. pp. i-xii, 1-740+1-78 pll.

Whales and Whalery, pp. 667-668. On the early Whalefishery of the Delaware, with records of the stranding or capture of Whales in the river down to 1809.

[755.]

1831. Avor. Considérations sur la Pêche de la Baleine. Par A. de la Jonkaire. <For. Quar. Rev., vii, 1831, pp. 355-370.

An extended account, in part statistical, of the "progress and present state of the Whale Fishery," apropos of the appearance of the brochnre, the title of which forms the caption of the paper.

[756.]

1831. C., F. D. Notice sur l'ostéologie et la dentition du Dugong; par le Dr. Knox. (Edinb. Journ. of Sci., i, 1829.) <Férussac's Bull. des Sci. nat., xxv, 1831, p. 350. Résumé.

1831. Craigie, David. Observations on the History and Progress of Comparative Anatomy. . . . Section III. Early Zootomical Authors to Eustachius, 15011576. <Edinb. New Philos. Journ., [xi], 1831, pp. 42-56.

Contains an extended critical résumé of Belon's account of the anatomy of the Dolphin as given in that author's "L'Histoire Naturelle des Estranges Poissons Marins, avec la vraio Peincture et Description du Daulphin et de plusieurs antres de son espece. Paris 1551," $q . v$.

[758.]

1831. Cuvier, G. The / Animal Kingdom / arranged in conformity with its or ganization, | by the Baron Cuvier, | Perpetual Secretary to the Royal Academy of Sciences, etc. etc. etc. | - | The Crustacea, Arachnides and Insecta, | by P. A. Latreille, | member of the Royal Academy of Sciences, etc. etc. etc. | - | Translated from the French, | with Notes and Additions, | by H. M'Murtrie, M. D. \&c. \&c. I - I In four volumes, with plates. | Volume I. [Mammals and Birds.] / New York: | G. \& C. \& H. Carvill. | MDCCCXXXI. 8०. pp. i-xxxii, 1-448, 1. 1, pll. i-iv.

Order ix. Cetacea (=Sirenia + Cete), pp. 202-214.

This is a scholarly translation of the "nonvelle edition" (1829), q. $v$. Says the translator: "An immaculate book is perhaps rather to be wished for than expected, and that errors should have crept into the Regne A nimal is not at all surprising. These I have endeavoured to correct, not by erasure or altering the text (those cases always excepted where the mistake was evidently and purely typographical), but by note, either on the page itself or in the appendix. Thus, whatever has been added, nothing has been taken away, and the text of my author remains as I found it" (pp. $\nabla, v i)$. 
1831. Godman, JoHr D. American | Natural History. | - | Vol. III. | Part I.-Mastology. | - | By John D. Godman, M. D. | . . [ [=titles, 4 lines ]. | Second Edition. | Philadelphia: | Stoddart and Atherton, 60, N. Front Street. | 1831. 8. pp. 1-264, 9 plates, cuts.

Order viii. Cete; Cetaceous Animals, pp. 37-237. For analysis and comment see the ed. prin., 1828, with which this is textually identical.

[760.]

1831. Graves, R. J. An account of a Peculiarity not hitherto described in the Ankle, or Hock-joint of the Horse; with Remarks on the Structure of the Vertebro in the Species of Whale, entitled Delphinus Diodon. <Trans. Roy. Irish Acad., xvi, pt. 2, 1831, pp. 85-91.

On the separation of the vertebral epiphyses in maceration, and the degree of union useful as an index of the age of the animal among Cetaceans, pp. 88-91.

Reprinted in Edinb. Journ. Sci., new ser., iv, 1831, pp. 47-52, and in Edinb. New Philos. Journ., [x], 1831, pp. 59-64.

[761.]

1831. Johnston, George. Some account of a Whale stranded near Berwick-nponTweed. <Trans. Nat. Hist. Soc. of Northumberland, Durham and Nercastle upon Tyne, Vol. I, 1831, pp. 6-8, pl. I.

A ocount of the external characters and figure of a specimen apparently referable to $M e$ gaptera longimana; believed by the author to be the Balaena Boops of Tnrton's "British Fauna."

[762.]

1831. KNox, [RoBERT]. Notiz ûber die Natur einer eigenthulmlichen Structur, welche im zweiten Magen gewisser Cetaceen beobachtet worden ist und die man iu der Regel als bloss drůsiger Beschaffenheit betrachtet hat, die aber offenbar den electrischen Organen des Torpedo und Gymnotus analog ist; mitgetheilt in einem Briefe von Dr. Knox. Demselben ist beigefugt die mikroscopische Untersuchang der Structur von Dr. Brewster. <Froriep's Notizen, xxix, no. 629, Jan. 1831, pp. 193-196.

Aus Brevoster's Edinburgh Journ. Sci., new ser., no. 6, July, 1830. See 1830. Kvox, R. [763.]

1831. KNox, R. Observations to determine the Dentition of the Dugong; to which are added Observations illustrating the Anatomical Structure and Natural History of certain of the Cetacea. <Trans. Roy. Soc. Edinb., xi, pt. 2, art. xxiii, 1831, pp. 389-417, pl. xv.

[Preliminary remarks on the osteology and dentition of the Dugong], pp. 389-397. The zoölogical arrangement of the Dugong, pp. 398-400. True Cetacea, pp. 400, 401. Skeleton or the Narwhal, pp. 401-404. Delphinus phocoena, pp. 404, 405. Other specimens of the genus Delphinus, pp. 405, 406. Of the size of the Foetus of the Cetacea at the time of birth, pp. 406413. Digestive Organs, pp. 413-416. The plate represents the cranium of adult and young Narwhal, the atlas dentata and third cervical vertebra of the Narwhal, the tooth and gastric carities.

[764.]

1831. Lavz, H. O. Naturgeschichte | der | Sångethiere, | nach Cuvier's Systeme bearbeitet | von Dr. Harald Othmar Lenz, | Lehrer an der Erziehungsanstalt zu Schnepfenthal. | - | (Preis: 1 Thlr. oder 1 fl. 48 fr. Rhnl.) | - Gotha, | Beckersche Buchhandlung. | 1831. $8^{\circ}$. pp. 1-324.

Neunte Ordnung der Såugethiere: Fischsångethiere.-Cetacea, pp. 294-306.

Sirenia: 3 genera, 4 species. Cetacea, 4 genera, 24 species, to wit: Delphinus, 14 spp.; Monodon, 1 sp.; Physeter, 3 spp.; Balcena, 6 spp. The notices of the species are very short; the references relate only to fig ures. The technical names are marked for accent and their etymology is given. Evidently prepared for use as a concise hand-book of Mammalogy. [765.]

1831. Less[oN]., [R. P.]. Quelques détails sur un cétacé échoué près Berwich [sic], sur la Tweed; par Georges Johnston. (Trans. of the nat. hist. society of Northumberland; part I, tom. I, pag. 6, avec une planche.) <Férussac's Bull. des Sci. nat., xxvii, 1831, pp. 184-186.

Résumé.

[766.]

1831. M'Murtrie, H. See 1831, Cuvier, G.

1831. Mavtel, Mr., of Lewes. Large [Baleen] Whale recently found in the Chanuel near Brighton [England]. <Loudon's Mag. Nat. Hist., iv, 1831, pp. 163, 164. 
1831. M[ANTEL ?], G. Some Account of a Grampus (Delphìnus Orca) recently captured in Lynn Harbour [England]. <Loudon's Mag. Nat. Hist., iv, 1831, pp. 338-341, fig. 56.

Description and figure of the specimen.

1831? Pallas, P. [S.]. Zoographia | Rosso-Asiatica, | sistens | omnium animalium | in extenso Imperio Rossico | et | adjacentibus maribus observatorum | recensionem, domicilia, mores et descriptiones, I anatomen atque icones plurimorum. | Auctore | Petro [Simones] Pallas, | Eq. Aur. Academico Petropolitano. $|-|$ Volumen Primum. $|-|-\mid$ Petropoli $\mid$ in officina Caes. Academiae Scientiarum impress. MDCCCXI. | Edit. MDCCCXXXI. 3 vols. $4^{\circ}$, with folio atlas. Vol. i, 11. 2, pp. i-xxii, 1-568, 11. 2.

Imperii Rossici Animalia Lactantia, i, pp. 1-296. Ordo VII. Cetacea (= Sirenia + Cetacea), pp. 271-296, joll. "xxx-xxii," spp. 142-151. 1. Manatus borealis, p. 272, pl. xxx; 2. Delphinus Leucas, p. 273, pll. xxxi (auditus organum), xxxii; 3. Delphinus Delphis, p. 284; 4. Delphinus Phocaena, p. 284; 5. Delphinus Orca, p. 285; 6. Physeter macrocephalus, p. 287; 7. Balaena Physalus, p. 289; 8. Balaena Boops? p. 291; 9. Balaena Musculus, p. 293; 10. Ceratodon Monodon, p. 295.

At p. 286 three species of Physeter are mentioned under Alept names, and at p. 288 six species of Balaena. These are cited by Chamisso (Nov. Act. Acad. Caes. Leop.-Carol. Nat. Curio8., xii, 1, 1824, pp. 249-260), who refers to volume and page of Pallas's work, showing that this portion of the work, at least, was accessible to Chamisso as early as 1824, although not commonly recognized as "published" till 1831. On this point see Cones, Birds Col. Valley, 1878, p. 615 .

[769.]

1831. "Saxdifort, G. Bijdragen tot de ontledkundige Kennis der Walvisschen. <Nieuve Verhandl. der eerste Klasse van het Nederl. Inst., 3 D., 1831, pp. 223270, pll. 5."

This important memoir I have been nnable to see. Title from Carus and Engelmann. [770.]

1831. Surth, A. Beyträge zur Naturgeschichte von Súd Africa. <Isis ron Oken, 1831, pp. 1359-1362.

Uebersetzung aus der Zoological Journal, iv, no. xvi, 1829, pp. 433 et seqq.

Phocaena homeii, p. 1362.

1831. SNelling, W.J. The | Polar Regions | of the | Western Continent Explored; | embracing a / Geographical Account | of | Iceland, Greeuland, the Islands of the Frozen Sea, | and the | Northern Parts of the American Continent, | including I a particular description of the Countries, the Seas, In- I habitants, and Animals of those Parts of the World; | also, a minute account of the Whale Fisheries, | and the dangers attending them; | with remarkable adventures of some of the Whale Fishers, | descriptions of Mount Hecla, and the other volcanoes of Iceland; | [Vignette.] Together with the | Adventures, Discoveries, Dangers, and Trials | of | Parry, Franklin, Lyon, and other Navigators, | in those Regions: | - | By W[illiam]. J. Snelling, | author of Tales of the Northwest. | - | Illustrated by a map and engravings. | | | Boston: | Printed for W. W. Reed. | - | 1831. 80. 11.2 (title-pages), pp. i-xii, 1-501.

Chap. iii. Early History of the Whale Fishery.-Of the Manner in which a Whale Ship is manned.-The Crow's Nest. - Whale Boats.-Implements used in the Whale Fishery. - Whale Killing.-Danger of Striking, pp. 77-82. Chap. iv. Further Account of Whale Killing.Length of Time required to kill a Whale.-Character of the Whaleman.-Anecdotes of the Greenland Fishery, pp. 82-88.

Appendix, pp. 485-501,-being an account of the Mammals, with numerous cnts, forming 8 pll. (not all zoölogical), entitled "Illustrations for Polar Region," with references to the descriptions of the species in the text. The Narwal, pp. 494, 495. There is a cut of a "Spermaceti Whale."

"The object of this work . . is . . . to give the reader a condensed account of what is known of the northern regions of the new world, from the latest and best anthorities. To this end the compiler has availed himself of the writings of Henderson, Crantz, Parry, Franklin, Richardson, Kotzebue, and others, and, in many instances, has used their own words."Author's preface.

[772.]

1831. Spix, Joh[anN] Bapt[ist] von, und Carl Friedr. Phil. von Martius. Reise | in | Brasilien | auf Befehl Sr. Majestät | Maximilian Joseph I. | Königs von Baiern | in den Jahren 1817 bis 1820 / gemacht / von / weiland Dr. Joh. Bapt. von Spix, | ... [= titles, 3 lines ] | und | Dr. Carl Friedr. Phil. von 
1831. SpIX, Joh[ANN] BAPt[IST] von, et al.-Continued.

Martius, | . . [ = titles, 4 lines. ] [ [Erster-] Dritter und letzter Theil, | bearbeitet und herausgegeben vou | Dr. C.F.P. von Martius. | Mit sieben Blättern Charten und zwei Tafeln Abbildungen. | - | München, [1823-]1831, | bei dem Verfasser. Leipzig, in Comm. bei Friedr. Fleischer. 3 vols. $4^{\circ}$. mut. mut. Vol. iii, pp. i-lvi, 883-1388.

Vol. i, 1823; vol. ii, 1828; vol. iii, 1831.

Delphin vom Amazonas (Delphinus amazonas, sp. n.), pp. 1118-1120, 1133. Lamantin oder Manati (Manatus americanus), pp. 1121, 1122.

[774.]

1832. Bronv, H. G. Delphinus (Palåontologie). <Ersch und Gruber's Allgem. Encyklop. der Wissensch. und Künste, Erste Sect., xxiii, 1832, pp. 420-422.

4 spp.

1832. Cuvier, F., et Dr. Dumezille. Histoire naturelle | des | Mammifères, | Par M. F. Cuvier, | Membre de l'Institut (Académie royale des Sciences), etc. | et | Le Docteur Dumezille. | - | Tome premier [et second]. | - | Paris, | Rue et place Saint-André-des-Arts, $N^{\circ} 30 .|-|$ 1832. 120. Vol. i,pp.1-108; vol. ii; 1.1,pp. 1-100.

Dixième ordre. Les Cétacés, vol. ii, pp. 48-56.

1832. Dewhurst, Hexry William. Observations on the Zoology and Comparative Anatomy of the Skeleton of the Balænoptera Rórqual, or Broad-nosed Whale, now exhibiting at the Pavilion, King's Mews, Charing Cross. <Loudon's Mag. Nat. Hist., v, 1832, pp. 214-233.

Generai History of the Whale Tribe, pp. 214-219; History of the Balænóptera Rorqual, pp. 219-233. This is the "Ostend Whale," found floating dead Nov. 4, 1827, between the coasts of England and Belgium, prepared under the direction of $\mathbf{M}$. Kessels and exhibited at Ghent, London, and elsewhere, and which was the subject, in part or wholly, of several earlier memoirs.

[777.]

1832. "MAREC, - Dissertation sur la pêche de la baleine, faisant snite à celle sur la pêche de la morue, pour servir à la discussion du projet de loi présenté, sur l'une et l'autre pêches à la chambre des Députés. Paris, Giraudet. 1832. 4." Not seen; title from Bosgoed, op. cit., p. 242, no. 3509.

1832. Meyer, Hermany von. Palaeologica | zur | Geschichte der Erde | und | ihrer Geschöpfe. | Von | Hermann von Meyer, | ... [=titles, 4 lines $] .|-|-\mid$ Frankfurt am Main. / Verlag von Siegmund Schmerber.|1832. 8०. pp. ixii, 1-560.

Cetaceen, pp. 98-100. Manatus (Lamantin) fossilis, Cuv., p. 98; Delphinus Oortesii, $D$. macrogenius, D. - D. longirostris, p. 99; Monodon fossilis. (?) Cuv., p. 99; Ziphius cavi. rostris, Cuv., p. 99; Z. planirostris, Cuv., Z. longirostris, Cuv., p. 100; Balcena Cuvieri, Desmoul., B. Cortesii, Desmoul., p. 100.

[779.]

1832. RAFINESQUE, C. S. Remarks on the Monthly Jonrnal of Geology and Natural Science of G. W. Featherstonaugh, for May, 1832, (but only published in July.) <Atlantic Journ., i, no. 3, autumn of 1832, pp. 110-114.

"As to the bone called Nephrosteon, I acknowledge that it may be the Epiphysis of a Whale, as Dr. H[arlan]. did tell me in 1831, after my pamphlet was published. But it is, perhaps a new Whale, since he could not find it in Cuvier's (ossemens fossiles). Nephrosteon is howerer a very good name, and may become specific" (p. 112). Cf. Harlan, Trans. Geol. Soc. Penn., i, pt. i, 1834, p. 75.

[780.]

1832. Rosenthal, Friedrich Christian. Über die Barten des Schnabel-Walfisches (Balaena rostrata). <Abhandl. der Kön. Akad. der Wissensch. zu Berlin, 1829 (1832), pp. 127-132, pll. i-v.

[781.]

1832. RudolphI, [D. K. A.]. Ưber Balaena longimana. <Abhandl. d. phys. Kl. d. Kön. Akad. d. Wissensch. zu Berlin, 1829 (1832), pp. 133-144, pll. i-v.

Osteologische. P1. i, Skelet; pll. ii, iii, Schädel; pl. ir, linker Beckenknochen in nat. Grösse; pl. v, der Walfisch selbst.

[782.]

1832. ScHÜBLER, [G. ?]. [Ueber Fossilen aus der Molasse von Baltringen.] «Jahrb. für Mineral., Geogn., Geol. und Petrefakt., iii, 1832, pp. 79,80.

Bruchstücke eines Unterkicfers einor Balaena, p. 79. 
1832. Thacher, J. History | of the / Town of Plymouth[, Mass.]; | from its first settlement in 1620, to / the year 1832. | - By James Thacher, M. D., A. A. S., \&c. | - "Ask thy fathers, and they will show thee; thy elders, and they will tell thee." | - | Boston: | Marsh, Capen \& Lyon. | 1832. 6०. pp: i-xi, 12-382, map, and frontispiece.

Whales at Plymonth, p. 20. Whale Fishery, pp. 343, 344.

1832. Thon, D. Delphinus Linné (Mammalia), Delphin. <Ersch und Gruber's Allgem. Encyklop. der Tissensch. und Künste, Erste Sect., xxiii, pp. 413-420.

Twenty-eight species are given, divided among 6 subgenera, as follows: Delphinorhynchus Lacép., 4 spp.; Delphinus Blainv., 10 spp.; Oxypterus Raf., 2 spp.; Phoccena Cuv., 7 spp.; Delphinapterus Laçp., 2 spp.; Hyperoodon, 2 spp.

[785.]

1833. BRANdT, J. F. Über den Zahnbau der Stellerschen Seekuh (Rytina Stelleri) nebst Bemerkungen zur Charakteristik der in zwei Unterfamilien zu zerfällenden Familie der pflanzenfressenden Cetaceen. <Mém. de l'Acad.imp. des Sci. de St.-Pétersbourg, vie sér., ii, 1833, pp.103-118, pl.

Halicoreae, Rytinea, tribb. nn.

[786.]

1833. [Breschet, Gilbert, et Vauselle. Observations anatomiques sur la tête d'une baleine.] <Nouv. Bull. des Sci., publié par la Soc. philom de Paris, Ann. $1833,4^{\text {e }}$ sér., ii, 1833 , p. 82.

[787.]

1833. D'Orbigny, A. Notice sur un nouveau genre de Cótacé, des rivières du centre de l'Amérique méridionale. <Nouv. Ann. du Mus. d'Hist. nat., iii, 1834, pp. 28-36, pl. iii.

Inia boliviensis, gen. et sp. n., p. 31. Pl. iii, fig. 1, vu de profil ; fig. 2, tête osseuse; fig. 3, dents.

[788.]

1833. Dufrénoy, - [Note sur la découverte récente faite par M. Harlan, dans l'Amérique, de plusieurs nouvelles espèces de Sauriens fossiles.] <Bull. Soc. géol. de France, iv, 1833-34, pp. 123, 124.

Basilosaurus (=Zeuglodon, Owen), p. 124.

1833. Editors. Antediluvian Ambergris. <Edinb. New Philo8. Journ., xv, 1833, p. 398.

Said to occur in the clay ironstone of the coal-formation near Bathgate, Burntisland. [790.]

1833. "Fisscher, J. F. van Overmeer. Bijdrage tot de kennis van het Japansche Rijk. Met platen. Amsterdam, J. Muller, 1833. 4०."

"Zie aldaar: De walvisch en andere visschen. bl. 217-18."

Not seen; title from Bosgoed, op. cit., p. 163, no. 2572.

[791.]

1833. Lecomte, Jules. Pratique / de la Pêche / de la Baleine / dans / les Mers du Sud. | - | Par Jules Lecomte. | Redacteur en chef du Navigateur. | [Vignette.] Paris. | Lecomte et Pougin, Editenrs, | Quai des Augustins, 49. | - Bachelier, Libraire éditeur, même quai. | - 1833. 8०. pp. i-xvi, 1-280.

Coup d'œil historique sur la péche de la Baleine, depuis les premiers essais jusqu'à nos jours, pp. ix-xvi. De la Coque du Navire, pp.1-14. Observations sur le gréement, pp. 15-18. Du matériel, pp. 19-28. Suite du matériel, pp. 29-35. Des vivres et secours médicaux, pp. 36-43. Du personnel, pp. 44-47. Travaux du mer, pp. 48-58. Suite des travaux de mer, pp. 59-66. Anatomie de la Baleine (de la franche), pp 67-85. Des autres espèces de Baleines, pp. 86-102 (du Cachalot, pp. 86-94; de la Baleine à aileron = La Baleinoptère gibbar de Lacépède, pp. 95-97; de la Baleine à bosse, p. 97; le Soufleur, p. 98; du Requin, du Dauphin gladia teur et de l'Espadon, pp. 99-102). Lieux de pêche, pp. 103-125. Suite des Parages de pêche, 126-136. Introduction à la pêche, pp. 137-140. De la pêche, pp.141-171. De la manœuvre des piroques, pp. 172-179. De l'amarrage de la Baleine, pp. 180-196. Des autres travaux, pp. 197-219. De l'emploi ultérieur de l'huile de Baleine, pp. 220-223. Lois et ordonnances sur la péche de la Baleine, pp. 224-278.

[792.]

1833. Leslie, [John], [Robert] Jameson, and Hugh Murray. Harper's Stereotype Edition. | - | Narrative | of | Discovery and Adventure | in the | Polar Seas and Regions: | with illustrations of their | Climate, Geology, and Natural History: | and an account of | the Whale-Fishery. | - | By Professor [John] Leslie, Professor [Robert] Jameson, I and Hugh Murray, Esq. F. R. S. E

| - | New-York: | Printed by J. \& J. Harper, 82 Cliff St. | . . . [=six lines, 


\section{Leshie, [JoHn], [Robert] JaMeson, and Hugh Murray-Continued.}

names of booksellers]. | - 1833. 12०. Prelim. title-page, with vignetto "Perils, attending the Whale-Fishery," pp. $i-v i i, 9-373$, map, and cuts. = The Family Library, no. xiv.

Chap. ii. Animal and Vegetable Life in the Polar Regions, pp. 53-82.-Cetacea, pp. 55-61,a popular compiled general account of "the Whale" (Baloena mysticetus), Finner Whales, the Cachalot and "Narwal," with a cut (facing p. 57) entitled "Whale with its Cub, Narwal, etc.," the principal figures from Scoresby.

Chap. ix. The Northern Whalefishery, pp. 297-351; cuts of harpoons, lance, etc., p. 315. Based largely on Scoresby's account of the Northern Whalefishery.

There are later reprints from the same stereotype plates, the title-page only modified. The work appeared originally at Edinburgh $\left(8^{\circ}\right.$, Oliver and Boyd), as vol. i of the Edinburgh Cabinet Library (not seen by me), probably in 1832 or 1833, of which the Harper edition is a literal reprint. A fifth Edinburgh edition appeared in 1845, and a German translation in 1834. See BOSGOED, op. cit., p. 241, no. 3501.

[793.]

1833. Lesson, [R. P.]. Allgemeine Bemerkungen úber einige Wale. <Isis von Oken, 1833, pp. $42,43$.

Uebersetzung aus "Voyage antour du monde exécuté par ordre du Roi sur la Corvette La Coquille pendant les années 1822-1825, Zoologie par Lesson, cap.4, p. 177."

1833. MeYen, F. J. F. Beiträge zur Zoologie, gesammelt auf einer Reise um die Erde. Zweite Abhandlung. Sängethiere. <Nova Acta Phys.-med. Acad. Cas. Leop.-Carol. Nat. Curios., xvi, p. ii, 1833, pp. 549-610, pll. xl-xlvi.

Delphinus coeruleo-albus, sp. n., pp. 609, 610, pl. xliii, fig. 2. Gegend des Rio de la Plata.

1833. Parkinson, James. Organic Remains of a Former World. | - | An Examination of the | Mineralized Remains of the Vegetables and Animals | of the | Antediluvian World; | generally termed extraneous fossiles. | - | By James Parkinson. I In three Volumes. | [Vignette.] Encrinus. Stone Lilly. | The third Volume; | containing | the fossil Starfish, Echini, Shells, Insects, Amphibia, Mammalia, \&c. | Second Edition. | - | London: | M. A. Natali, 24, Tavistock-Street, Covent-Garden. | - | M. DCCC. XXXIII. | T. Combe, Junior, Gallowtree-gate, Leicester. $4 \circ$. Frontispiece, 1.1,pp. ix-xii, 1l.2,pp. 1-467, 11. 2+11. 8, pll. i-xxii.

A few remarks about Cetaceans and Sirenians occur at pp. 321, 322, and a tooth presumed to be Cetacean is figured in pl. $x x$, fig. 1 .

[796:]

1833. Roussel de Vauzìme. [Présentation d'un modele en plâtre d'un fotus de Baleine extraite en sa présence du sein do sa mère, aux environs de l'lle Tristan d'Acunha.] <L'Institut, 1' ${ }^{\text {re }}$ ann., no. 13, 10 aout 1833, p. 106.

Avec remarques historiques.

1833. Saint-Hilaire, Bourjot. Considérations sur le nerf facial, dans ses rapports avec les évents, et sur son influence dans l'acte de la respiration chez lo marsouin. <L'Institut, $1^{\text {re }}$ ann., no. 32, 21 déc. 1833, p. 266.

Résumé.

1833. Sampson, William. Notice of a Cetaceous Animal supposed to be new to the American coast. <Am. Jour. Sci. and Arts, xxv, 1833, pp. 301-303, fig.

"Phoccena globiceps"=Globiocephalus melas. Short description and figure of the animal,

with synonymy and general remarks.
1833. SERRES, MarCEL DE. Mémoiro sur la question de savoir si des animaux terres-

with synonymy and general remarks.
1833. SERRES, MarCEL DE. Mémoiro sur la question de savoir si des animaux terrestres ont cessé d'exister depuis l'apparition de l'homme, et si l'homme a été contemporain des espèces perdues, ou du moins qui ne paraissent plus avoir de représentans sur la terre. <Bibl. univ. des Sci. et Arts, liii, 1833, pp. 277-314.

II. Des êtres réels et actuellement existans, répresentés ou sculptés sur les monumens antiques, et dont on peut reconnaître les espèces, pp. 295-314.-Mamnifères marins on C6́tacés, p. 303 (Trichcchus manatus. Lo lamantin d'Afrique. Delphinus delphis, Balcena mysticetus).

[800.]

1833. "Siewald, H. voN. De cranii formatione in Delphino Phocaena. Cum 2 tab. Dorpati, $1833.80 . "$

Not seen; title from Carus and Engelmann. 
1833-34. T.-C. [=Thédore Cocteau.] Baleine. <Dict. pittoresque d'Hist. nat. et des Phénom. de la Nature, i, livrr. xlvi, xlvii [1834 ?], pp. 365-373.

[Obserrationes générales], pp. 365-368, 370-373. [Espèces] : 1. Balcena mysticetus, p. 368, pl. xxxix, fig. 1; 2. B. Physalus, p. 368; 3. B. Boops, 4. B. Musculus, 5. B. rostrata, 6. B. nodvera, p. 369.

1833-34. P. G. [=Paul Gentrl.] Cachalot, Physeter. <Dict. pittorcsque d'Hist. nat. et des Phénom. de la Nature, i, livr. Ixx [1834?], pp. 557-559.

[Observations génúrales], pp. 557-559. [Espèces]: 1. Le Grand Cachalot, Physeter macrocephalus, p. 559, pl. lxiii, fig. 1; 2. Cachalot trumpo, Catodon macrocephalus, p. 559; 3. Cachalot australasien, p. 559; 4. Physeter microp8, p. 559; 5. Physeter tursio ou mular, p. 559; 6. Cachalot sillonué, p. 559.

1834. ANon. Animal and Vegetable Physiology considered with reference to Natural Theology. By Peter Mark Roget, M. D. <Edinb. Rev., lx, 1835, pp. 142-179.

A review of the work, giving, at p. 171, an extract from it describing the "Filter of the Whale," or the "curious contrivance" of the Whale-bone Whales by which they are enabled to capture their food.

[804.]

1834. [Bennetr, E. T. On the structure and use of the Monotrematic glands, and particularly on those glands in the Cetacea.] <Proc. Zool. Soc. Lond., 1834, pp. 26,27 .

A brief résumé of the views of Geoffroy Saint-Hilaire on this subject.

1834. Breschet, G., et Roussel DE VAUzł̀m. Recherches anatomiques et physiologiques sur les appareils tégumentaires des animaux. <Ann. des Sci. nat., $2^{\mathrm{e}}$ sér., Zool., ii, 1834, pp. 167-238, 321-370, 2 pll.

Cétacés passim.

[806.]

1834. Brongiart, Alex., et F, Cuvier. Rapport fait à l'Académie des sciences sur un Mémoire de M. Christol ayant pour objet de ramener au genre Dugong les débris fossiles que M. G. Cuvier avait rapprochés des Hippopotames. <Ann. des Sci. nat., $2^{\bullet}$ sér., i, Zool., 1834, pp. 282-290.

Sur l' Hippopotame moyen de G. Cuvier. See 1834. Christol, J. DE.

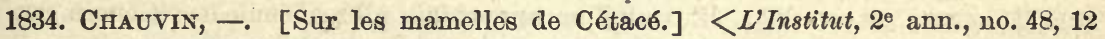
avril 1834, p. 118.

1834. [Christol, J. DE.] Extrait d'un Mémoire intitul6: Comparaison de la population contemporaine des mammifères de deux bassins tertiaires du département de l'Hérault, presenté à l'Académie des Sciences de Paris, le 24 février 1834, par M. J. de Christol. <L'Institut, $2^{\mathrm{e}}$ ann., no. 42, 1 mars 1834, pp. $75,76$.

[809.]

1834. Christol, Jules de. Ḿ́moire sur le Moyen Hippopotame fossile de Cuvier, replacé au genre des Dugongs. <Ann. des Sci. nat., $2^{\text {e }}$ sér., ii, Zool., 1834, pp. 257-277, pl. xiii.

Halicore Cuvierii, gen. et sp. n., p. 274=Hippopotamus medius, Cuvier. Pl. xxiii, mâchoire inférieure ot molaires de Moyen Hippopotame fossile de Nantes (Hippopotamus medius, Cuv., Halicore Cuvierii, Christol); mâchoire inférienre et molaires de Dugong fossile de Montpellier (Halicore Cuvierii, Christol); tête et mâchoire inférieure de Dugong vivant, et d'Hippopotame, etc.

[810.]

1834. Dewhunst, H. W. The | Natural History | of the | Order Cetacea, | and the $\mid$ oceanic inhabitants | of the | Arctic Regions. | - | By William Henry Dewhurst, Esq., | ... [ = titles, etc., 10 lines $].|-| \ldots[=$ mottoes, 7 lines $]$. | - | Illustrated with numerous lithographic | and wood engravings. | - | London: | Published by the Author, | 16, William Street, | Waterloo Bridge Road. | - | MDCCCXXXIV. 80. 11. 2, pp. i-xx, 1-331.

Natural History of the order Cetacea, pp. 1-204. Order I. Edentatæ, or Toothless Cetacea. General history and character of Whales, pp. 10-15. 1. Baloena mysticetus, ${ }^{*}$ pp. 15-85. 2. Balcena islandica vel nordcaper, pp. 86-91. 3. Balanoptera gibbar, pp. 92-97. 4. Balcenoptera acuto-rostrata, pp. 97-101. 5. Baloenoptera jubartes, pp. 101-107. 6. Baloenoptera rorqual, pp. 107-129.

* The specific names are in all cases capitalized, both in the text and on the plates. 
1834. Dewhurst, H. W.-Continued.

Order II. Predentate Cetacen, or those with teeth only in the anterior part of the upper jaw, pp. 130, 131. \%. Monodon monoceros, pp.131-142. 8. Monodon microcephalus, pp. 142144. 9. Arnanacus groënlandicus, pp. $145,146$.

Order III. Subdentate Cetacea, or those having teeth only in the lower jaw, p. 147. 10. Physeter macrocephalus, pp. 148-157. 11. Physeter cetadon [sic], p. 158. 12. Physeter trumpo, pp. 159-160. 13. Physeter cylindricus, p. 161. 14. Physeter microps, pp. 162-164. 15. Physeter mular, p. 164 16. Physeter bidens sowerbyi, pp. 165-167. 17. Physeter gib. bosa, p. 168.

Order IV. Ambidentate Cotacea, or those having teeth in both jaws, p. 169. 18. Dclphinus phoceana [sic] communis, pp. 170-174. 19. Delphimus didelphis [sic], pp. 174-178. 20. Delphinus orca communis, pp. 178-181. 21. Delphinus gladiator, pp. 181, 182. 22. Delphinus bidentatus, p. 182. 23. Delphinus feres, p. 183. 24. Delphinus tursio, p. 184. 25. Hyperöodon butskopf, vel Delphinus deductor, pp. 185-190. 26. Delphinapterus beluga, pp. 190-193.

Con luding observations on the Cetacea, pp. 194-204.

The book closes with a fitting and diagnostic "Appendix" devoted to "Testimonials, Certificates, Letters, etc., etc.," which, as the saying is, "should be seen to be appreciated."

Besides nnmerous wood-cuts, there are plates of the following species, none of them original, and most of them are even poor copies-almost too poor to render the originals from which they were taken recognizable in them: Balcena mysticetus, Balcena islandica, Baloenoptera gibbar, pl. to faco p. 15. Balcenoptera acuto-rostratus, pl. to face p. 97. Baloenoptera jubartes and Baloenoptera rorqual, $\mathrm{pl}$. to faco p. 107. Skeleton of Balcenoptera rorqual, pl. to face p. 115. Monodon monoceros (two figures), pl, to face p. 131. Physeter macrocephalus and Physeter microp8, pl. to face p. 148. Physeter cylindricus, pl. to face p. 161. Physeter bidens sowerbyi, pl. to face p. 165. Physeter gibbosa, pl. to face p. 169. Delphinus didelphis [sic] and Delphinus phoceana [8ic], pl. to face p. 170. Skull and Skeleton of Porpoise (too wretched for criticism), pl. to face p. 174. Delphinus orca communis, pl. to face p. 178. Delphinus gladiator and Delphinus tursio, pl. to face p. 184. Delphinus deductor and Delphinus bidens, pl. to face p. 185. Delphinapterus beluga, pl. to face p. 190 .

From the standpoint of systematic zoology, the present work merits little consideration; it contains, however, a modicum of information based on the author's own observations, which in some degree redeems it from being mercly an indiscriminate compilation, which is, however, its general character.

[811]

1834. Duméril, [AUguste]. Extrait d'un rapport fait à l'Académie des Sciences par M. Duméril sur un mémoire ayant pour titre: Considérations sur le nerf fascial et sur son influence dans l'acte de la respiration chez le Marsouin; par Bourjot Saint-Hilaire. <Ann. des Sci. nat., $2^{\mathrm{e}}$ sér., ii, Zool., 1834, pp. 255257.

1834. DumériL, [A. M. C.]. Rapport fait à l'Académie des Sciences par M. Duméril, sur un Ḿ́moire intitulé: Description d'un organe vasculaire découvert dans les cétacés, suivie de quelques considérations sur la respiration chez ces animaux et chez les Amphibies, par M. G. Breschet. <Ann. des Sci. nat., 2e sér., ii, Zool., 1834, pp. 376-380.

Voici les conclusions du mémoire de M. Breschet par les rédacteurs, loc. cit., p. 379. [813.]

1834. [Duméril, A. M. C.]. Rapport verbal sur une lettre de M. le Piez, D. M. à Sainte-Germain-en-Laye, relative à l'anatomie du marsouin; lu à la séance de l'Acadómie royale des sciences du lundi 8 fóvrier 1835. <Ann. des Sci. nat., $2^{\circ}$ sér., ii, Zool., 1834, pp. 380-382.

1834. Duméril, [A.M.C.], F. Cuvier et [J. B.] Dumas. [Rapport sur les organes génitaux externes du Delphinus globiceps, d'après les pièces adressées par M. Le Maout.] <L'Institut, $2^{\mathrm{e}}$ ann., no. 48, 12 avril 1834, p. 117.

[815.]

1834. Edwards, H. MrLne. Elémens | de Zoologie, | ou | Leçons | sur l'anatomie, la physiologie, | la classification | et les mours des Animaux, | par | H. Milne Edwards, | Docteur en Médecine, | Professeur d'Histoire naturelle au Collége royal de Henri IV I et à l'Ecole centrale des Arts et Manufactures. | - | Paris. | Chez Crochard, Libraire, | Place de l'École de Médecine, N. 13. | - | 1834. 80. pp. i-viii, 1-1066,1.1. Numerous cuts in the text.

Ordre des Cétacés, pp. 468-486. Famille des Cétacés herbivores, pp. 471, 472. Famille des Cétacés ordinaires ou Souffleurs, pp. 471-486. Divisée en 1. Tribu des Delphiniens; 2. Tribu des Cétacés à grosse tête.

A brief review of the genera and species, mostly under French names.

[816.] 
1831. Felt, J. B. History | of | Ipswich, Essex, and Hamilton. | - | By Joseph B. Felt. | - | Magno usui est memoria rerum gestarum. | Sallust. | - | Cambridge: | Printed by Charles Folsom. | 1834. 80. pp. i-xvi, 1-304.

Whaletishery engaged in at Ipswich, 1707, on a small scale, p. 109.

1834. "GeOFfroY-SAINT-HIlaire, EtienNe. Philosophie anatomique: fragmens sur la structure et les usages des glands mammaires des Cétacées. Avec $2 \mathrm{pl}$. in $8 \circ .88$ pp. Paris, 1834, Deville-Cavellin."

Not seen; title from Carus and Engelmann.

1834. Harlan, Richard. Notice of Fossil Bones found in the Tertiary Formation of the State of Louisiana. <Trans. Am. Phil. Soc., 2d ser., iv, 1834, pp. 397-403, pl. xx, figg. 1,2 .

First account of the Cetacean (then supposed to be Saurian) genus Basilosaurus. Basilosaurus gen. n.; p. 403. Pl. xx, vertebra, fragnent of jaw, etc.

1834. Harlan, Richard. Critical notices of various organic remains hitherto discovered in North America. <Trans. Geol. Soc. Pennsylvania, i, pt. i, Ang., 1834, pp. 46-112.

"Order Cetacea," pp. 73-75. Genus Manatus, p. 73. "Cetacea proper," pp. 74, 75. Remains of Spermaceti Wbale from an estuary at mouth of Mississippi River=Megistosaurus, Godman, Ms. Neophrosteon, Raffinesque, affirmed to have been founded on an epiphysis of a Whale vertebra, p. 75.

[820.]

1834. Harlan, R. Critical Notices of various Organic Remains hitherto discovered in North America. <Edinb. New Philos. Journ., xvii, 1834, pp. 342-362, xviii, pp. 28-40.

Order Cetacea. xvii, pp. 361, 362. Genus Basilosaurus, xviii, pp. 29-31.

From advance sheets of the Trans. Geol. Soc. Penn., i, pt. 1, 1834, q.v.

[821.]

1834. KNox, RoBert. Observations on the Anatomy of the Rorqual (a Whalebone Whale of the largest magnitude), drawn up from the dissection of a specimen found dead off North Berwick. <Edinb. New Philos. Journ., xvi, 1834, pp. $181,182$.

Abstract of a paper having this title read before the Royal Society of Edinburgh, March $18,1833$.

1834. LE MAỐT, [E.] [Détails relatifs aux vingt-neuf Dauphins (Delphinus globiceps) échoués sur les côtes de Bretagne.] <L'Institut, $2^{\circ}$ ann., no. 43, 8 mars 1844, pp. 77, 78.

Voyez anssi op. cit., pp. 95, 102,117.

1834. Le MaOôt, [E.] [Surles Dauphins (D. globiceps) échoués sur les sillons de Talbert. ] <L'Institut, $2^{\mathrm{e}}$ ann., no. 46, 29 mars 1844, p. 102.

Sur la vérification des observations.

1834. Milne-Edwards, H. See 1834. Edwards, H. Milne.

1834. "D'Orbigry, A. Notice sur un nouveau genre de Cétace, des rivières du centre de l'Amérique Méridionale. Avec une planche." Paris, 1834. Jules Didot l'ain6. 4०. pp. 9."

Not seen; title at second hand.

1834. D'Orbigry, A. Nouveau genre de Cétacé. <L'Institut, 2 ann., no. 62, 19 juillet 1834, p. 240.

Inia Boliviensis, D'Orb.

1834. RÉDACTEURS. [Observations sur l'anatomie du Rorqual par M. Robert Knox.] $<L^{\prime}$ Institut, $2^{\circ}$ ann., no. 61,12 juillet 1834, p. 224 .

Résumó.

1834: RédaCteurs. [Rapport sur le dissection d'un jeune Rorqual (Baloena rostrata), accompagné de quelques observations sur l'anatomie d'un fotus de. Mysticetus, par le Dr. Knox.] < <'Institut, $2^{\mathrm{e}}$ ann., no. 74, 11 octr. 1834, p. 336.

Résumé.

1834. Roussel de VAuzìme. Note sur les Polypes qu'on trouve sur les fanons des Baleines. <Ann. des Sci. nat., 2 sér., Zool., i, 1834, 331-333, pl. ix. 
1834. R[o]Ussel de VAuzìme. Ueber die an den Barten der Walfische vorkommenden Polypen. <Froriep's Notizen, xliii, no. 925, Dec. 1834, pp. 5-7, figg. $3 \mathrm{~A}-7 \mathrm{~A}$.

1834. Roussel, de Vauzìme. Anatomie d'un fotus de Baleine. <L'Instilut, $2^{\mathrm{e}}$ ann., no. 69,6 sept. 1834, pp. $289,290$.

1834. Rousser DE VAuzk̀me. Recherches anatomiques sur un fœtus de Balaine. <Ann. des Sci. nat., 2e sér., ii, Zool., 1834, pp. 125-127.

Extrait du Journ. de l'Institut.

1834. Saivt-Hilaire, Geoffrox. Lecture des anciens en ce qui toucho la naissance et la première éducation des Cétacés. <L'Institut, $2^{\circ}$ ann., no. 40,15 févr. 1834, p. 54.

Résumé.

1834. Saint-Hilaire, Geoffroy. Anatomie des glandes mammaires d'un marsouin,

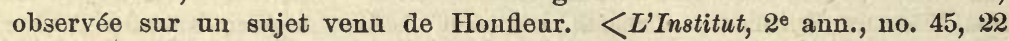
mars 1844 , pp. $95,96$.

Avec discussion au sujet par MM. de Blainville, M, de Serres et G. St.-Hilaire.

1834. Saint-Hilairie, Geoffroy. Traité physiologique où l'on considère l'emploi des diverses parties des glandes mammaires des Cétacés. <L'Institut, $2^{\mathrm{e}}$ ann., no. 46, 29 mars 1844, pp. 102, 103.

1834. SaINt-Hilaire, Geoffroy. Mémoire sur les glandes mammellaires pour établir que les Cétacés n'allaitent point comme a l'ordinaire leurs petits, et qüils pourraient s'en tenir à les nourrir de mucus hydraté <Ann. des Sci. nat., $2^{\circ}$ sér., i, Zool., 1834, pp. 174-188.

1834. Saint-Hrlaire, Geoffrox. Extrait de deux f́crits sur la lactation des Cétacés. <Ann. des Sci. nat., 2e sér., Zool., 1834, pp. 188-192.

1834. Serres, [M. De] , et BourJot SaInt-Hilaire. Considérations sur le nerf facial et sur son influence clans l'acte de la respiration chez le Marsouin. <L'Institut, $2^{2}$ ann., no. 76, 25 oct. 1834, pp. 347, 348.

1834. Shepard, Charles U. Geological observations upon Alabama, Georgia and Florida. <Amer. Journ. Sci. and Arts, xxv, 1834, pp. 162-173.

Mention of fragments of teeth and bones of Manatus americanus from Suannee Spring in Florida, p. 164.

1834. Traill, [T.S.]. On some of the Cetacea. <Edinb. New Phil. Journ., xvii, 1834, pp. $177-180$.

On the questions, "1. Have the Cetacea mammoe? 2. If they have, do they secrete milk? 3. Have they a nipple? And, 4. Do the young derive their nourishment from the teats?" in reference to the positions taken by von Baër and-Geoffroy St.-Hilaire. Dr. Traill answers these questions affirmatively, adducing proofs. He also gives measurements of his "Delphi nus Deductor" from the manuscript notes of Mr. James Watson, corrects a misprint in the measurements given by him in his original description of the species, and affirms that the Delphinus globiceps of "the French savans" is only his "D. Deductor." There is also a correction of the measurements of Baloena Rostrata given by Scoresby (Arct. Reg.) from Watson's notes.

1834. [Williams, J. R.] The Whale Fishery. <North Amer. Rev., xxxviii, 1834, pp. 84-115.

Devoted mainly (pp. 94-115) to a general history of the Ameriean Whale Fishery.

[841.]

1835. BAER, K. E. v. Über das Gefäss-system des Braunfisches. <Nova Acta Phys.med. Acad. Caes. Leop.-Carol. Nat. Curios., xvii, p. i, 1835, pp.394-408, pl.xxix.

[842.]

1835. "Beale, Thomas. A few Observations on the Natural History of the Sperm Whale, with an account of the rise and progress of the Fishery and of the modes of pursuing, killing and cutting that animal. London, $1835.80 . "$

Not seen.

1835. Christol, Jules DE. Comparaison de la population contemporaine des Mam. mifères de deux bassins tertiaires du departement de l'Hérault. <Ann. des Sci. nat., $2^{\mathrm{e}}$ sér., iv, Zool., 1835, pp. 193-238.

Mammifères marins, pp. 216-220. Lamantin, p. 216. 
1835. Dumb́rin, [A. M. C.]. [Sur une lettre par M. Lepiez dans laquelle il donnait les détails anatomiques d'une Marsouin femelle.] <L'Institut, $3^{\text {e }}$ ann., no. 92, 11 févr. 1835, pp. 46, 47.

[845.]

1835. Duvernoy, [G. L.]. Tableaux des ordres, des familles et des genres de Mammifères, adoptés pour le cours de zoologie de la Faculté des Sciences. <Mém. de la Soc. du Mus. d'Hist. nat. de Strasbourg, ii, 1835, Mém. K K, 10 pp., avec 5 feuilles grosses.

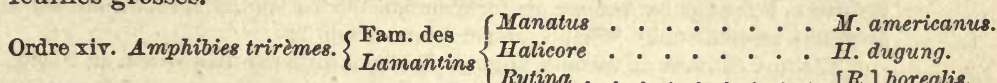

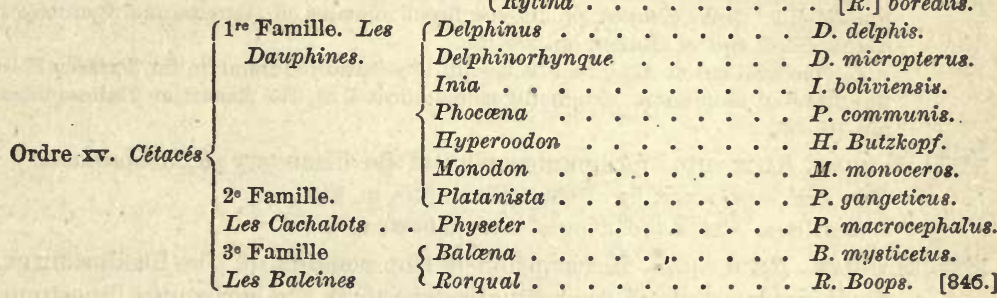

1835. Duvernoy, G. L. Plusienrs notes sur quelques ossemens fossiles de l'Alsace et du Jura. <Mém. de la Soc. du Mus. d'Hist. nat. de Strasbourg, ii, 1835, Mém. E E, pp. 12, arec 1 pl.

I. Sur un Cétacé fossile, voisin des Dugongs et des Lamantins, trouvé a Rœedersdorf, dans le Département du Haut-Rhin, pp. 1-9, figg. 1, 2.

[847.]

1835. Duvernoy, [G. L.]. [Sur le squelette d'un Cétacé fossile déconvert dans une carrière de Rœdersdorf, village du département du Haut-Rhin.] <L'Institut, $3^{\text {e }}$ ann., no. 126,7 oct. 1835 , pp. 326,327 .

Its affinities, not fully determined by the anthor, appear to be Sirenian.

[848.]

1835. Edtors. Descriptive Catalogue of the Preparations in the Anatomical Department of the Musenm of the Royal College of Surgeons in Ireland. $<$ Edinb. New Philos. Journ., xviii, 1835, pp. 369-372.

Extracts from Dr. Honston's " Descriptive Catalogue of the Preparations in the Anatomical Department of the Royal College of Surgeons of Ircland," here taken from the Dublin Journ. of Med. and Chem. Science, vi, no. xviii, p. 435, respecting the respiration of diving animals, as exemplified in the Cetacea, Seals, the Otter, eto

[849.]

1835. Gerv. [=Paul Gervais.] Dugong, Halicore. <Dict. pittor. d'Hist. nat. et des Phénom. de la Nature, ii, 1836, livr. clv, pp. 595-596.

Halicore indicus.

1835. Gerv. [=Paul Gervais.] Dauphin, Delphinus. <Dict. pittor. d'Hist. nat. et des Phénom. de la Nature, ii, 1835, livrr. 1x, lxi, pp. 477-483.

[Observations génerales], pp. 477-479. [Espèces]: 1. Delphinus (Delphinorhynchus) Geoffroyi, p. $479 ; 2 . D$. (D.) coronatus, p. $479 ; 3 . D$. (D.) gangeticus, p. $479 ;$ 4. $D$. (D.) pernettensis, p. 479; 5. Delphinus Boryi, p. 479; 6. D. delphis, p. 480, pl. exxxv, fig. 9; 7. D. sinensis, p. 480 ; 8. D. dubius, p. 480 ; 9. D. tursio, p. 480 ; 10. D. Bayeri, p. 480 ; 11. D. orca, p. 480 ; 12. D. (Oxypterus) mongitori, p. 481 ; 13. D. (O.) rhinoceros, p. $481 ; 14$. D. (Platanista) rostratus Shaw (D. gangeticus, Lebeck), p. 481; 15. D. (Inia) bolivensis, p. 481; 16. D. (Phocoena) phoccena, p. $481 ;$ 1\%. D. (Ph.) grampus, p. $482 ; 18 . D$. (Ph.) rissoanus, p. $482 ; 19 . D$. (Delphinapterus) leucas, p. 482 , (voy. aussi, tome i, p. 425); 20. D. (D.) senedetta, p. 482; 21. D. (D.) Peronii, p. 482; 22. D. (Heterodon) ananarcus, p. 482; 23. D. (H.) Hunteri, p. 482; 24. D. (H.) edentulus, p. 482; 25. D. (H.) butskopf, p. 483; 26. D. (H.) sowerbensis, p. 483.

[851.]

1835. Harlan, R[IChard]. Medical | and | Physical Researches: | or | original memoirs | in | medicine, surgery, physiology, geology, zoology, and | comparative anatomy. | Illustrated with plates, containing 160 figures. | - | By R. Harlan, M. D., F. L. S. Lond., | . . [ = titles, 12lines. $]|-| \ldots[=$ quotation, 6 lines.] | - | Philadelphia: | Printed by Lydia R. Bailey, | No. 26 North Fifth Street. | 1835. $8 \circ$. pp. i-xxxix, 9-653, 1. 1; pll. (unnumbered).

1. Description of a new Species of Manatns, or Sea Cow [Manatus latirostris], inhabiting the coast of East Florida, pp. 68-71, pl. -, fig. 1, skull in profile; fig. 2, lower jaw; fig. 3, an- 
1835. HARLAN, R[ICHARD]-Continued.

terior portion of skull from above; fig. 4, do. of Manatus senegalensis; fig. 5, do. of $M$. americanus, anct.

2. Description of the Delphinus intermedius-a new Species of Grampus, inhabiting the Coast of New England, pp. 72, 73, fig. of animal.

3. Observations on a large Skeleton recently disinterred from the mouth of the Mississippi River, pp. 76, 77. Identified as Physeter macrocephalus.

4. Revised Catalogue of the Mammiferous Animals of North America, pp. 78-83. Order Cetacea: First family, Sirenia, or Herbivorous Whales, spp. 2 (Manatus latirostris, Stellurus borealis); second family, Whales proper, genn. 4, spp. 14 .

5. Critical Notices of various Organic Remains hitherto discovered in North America, pp. 253-313. Order Cetacea, pp. 278-280 (fossil remains of Manatee and Spermaceti Whale). Genus Basilosaurus, Harlan, pp. 282-283.

6. Observations on the Fossil Bones [of Basilosaurus] found in the Tertiary Formation in the State of Louisiana. Originally communicated to the American Philosophical Society, pp. 337-343,

[852.]

1835. HARLAN, RichaRd. [Announcement of the discovery of Basilosaurus.] <Bull. Soc. géol. de France, iv $(1833,1834), 1835$, p. 124.

Ten lines, - abstract of a verbal commanication.

1835. Harlan, Richard. Description of the remains of the Basilosaurus, a large fossil marine animal, recently discovered in the horizontal limestone of Alabama. LTrans. Geol. Soc. Penn., i, 1835, pp. 348-357, pll. xxii-xxiv.

Cetacea "proper," pp. 74, 75. "The 'New Fossil Genus' of Rafinesque, named 'Nephrosteon, ( id. Atlantic Journal), and the bone on which the genus is constructed ... . has no other foundation than one of these epiphyses from the remains of a recent spermaceti whale," p. 75. Basilosaurus, pp. 77-80, pll. xxil-xxiv. Plesiosaurus (=Priscoidelphinus, Leidy), p. 77.

[854.]

1835. Hrinasgeber. Knox, besonderer Bau im 2ten Magen gewisser Wale.... $<$ Isis von Oken, 1835, pp. 302,303.

Auszug aüs dem Edinburgh Tourn. Sci., iii, 1830, pp. 325-388.

1835. Herausgeber. Alderson, ůber einen mãnnlichen Walrath-Wal, der Ende April 1825 an die Kúste von Yorkshire geworfen wurde. <Isis von Oken, 1835, pp. 1006-1008.

Anszug aus Trans. Cambridge Phil. Soc., i, 1822; pp. 253-266, pll. xii-xiv.

1835. Herausgeber. Harlan: uiber einige neue Arten fossiler Saurier (Bull géol., 1833, iv, 124). <Neues Jahrb. für Mineral., 1835, p. 737.

Basilosaurus.

1835. Herausgeber. Knox, ûber die Knochen und das Zahen des Dugongs. < Isis von Oken, 1835, p. 290.

Auszng ans dem Edinburgh Journ. Sci., i, 1829, pp. 157, 158.

1835. Herausgrber. Einige Beobachtungen úber die Naturgeschichte des Pottfisches, ec. Vom Chirurgen T. Beale. <Froriep's Notizen, xliv, No. 961, Mai 1835, pp. 230-232.

Uebersetzung ans "The Literary Gazette."

1835. KaUP, J. J. Das | Thierreich | in seinen Hanptformen | systematisch beschrieben | von | Dr. J. J. Kaup, | Mitglied der K. K. Leopoldinischen Akademie in Bonn, der naturforschenden Gesellschaften in Moskau, Zúriçh, Manuheim etc. $|-|$ [Mit in den Text eingedruckten | Abbildungen | von | L. Becker und Ch. Schûler, | unter Mitwirkung | von | Wilhelm Pfnor. | - | Drei Bånde.] Erster Band. | Naturgeschichte der Menschen und der Säugethicre. | Mit 180 in den Text eingedruckten Abbildungen. | - | Darmstadt, 1835. | Verlag von Johann Philipp Diehl. 80. 11. 2, pp. 1-xxxv, 1-452, 1. 1.

Vierter Stamm. Dritte Ordnnng. Delphine. Cetacea (incl.), pp. 372-376. 1. Monodon Monoceros, p. 373, fig.; 2. Delphinapterus lencas, p. 375; 3. Phocaena vulgaris, p. 375; 4. Ph. Orca, p. 375; 5. Delphinus Delphis, p. 576.

Fünfter Stamm. Zweite Ordnung. Pflanzenfressende Walthiere. Cetacea herbivora, Sirenia, pp. 426-430. 1. Halicore Dugong, p. 428, fig.; 2. Manatus americanus, p. 429; 3. Rytina Stelleri, p. 430.

Fünfter Stamm. Dritte Ordnung. Wale. Hydraula, pp. 431-445. 1. Physeter macrocephalus, p. 433, fig.; 2. Balaena Mysticetus, pp. 434-445, fig.; 3. B. Physalus, p. 445.

Phoccena vulgaris, nom. sp. n., p. 373. 
1835. Kvox, [R.]. Account of the Dissection of a Young Rorqual, or Short Whalebone Whale, (the Balæna Rostrata of Fabricius); with a few Observations on the Anatomy of the Fœtal Mysticetus. <Edinb. New Philos. Journ., xviii, 1835, pp. 197-199.

A bstract of a paper read at the meeting of the Royal Soc. Edinb., April 21, 1834.

[861.]

1835. Krox, Robert. Section eines jungen Nordkapers (Balaena rostrata, Fabr.), nebst anatomischen Beobachtungen rúcksichtlich eines F8̂tus der B. Mysticetus. <Froriep's Notizen, xliii, No. 935, Feb. 1835, pp. 164-165.

Ans $L$ 'Institut, no. 74, 11. Oct. 1834.

[862.]

1835. KÜster, H. C. Beytrågo zur Naturgeschichto der Insel Sardinien. < Isis von Oken, 1835 , pp. 75-85.

Cetacea, p. 85 (Delphinus phocaena).

1835. KƯster, H. C. Beobachtungen ůber das Wasseransspritzen der Cetaceen. <Isis von Oken, 1835 , pp. 85-87.

1835. Lenz, H. O. Gemeinnútzige | Naturgeschichte, | von | Dr. Harald Othmor Lenz, | Lehrer an der Erziehungsanstalt zu Schnepfenthal. | - | Erster Band: Såugethiere. | Mit Acht Tafeln Abbildungen. | - | Grotha, | Beckersche Buchhandlung. | 1835. $8^{\circ}$. pp. i-vi, 1-450, pll. i-viii.

Neunte Ordnung der Sångethiere. Fischsångethiere, Cetacea, pp. 426-440, pl. vii, figg. 59-62. Erste Familie . . Herbivora (=Sirenia) : 1. Manatus australis, p. 427; 2. M. senegalensis, p. 427; 3. Halicore cetacea, p. 428; 4. Rhytina Stelleri, p. 428.

Zweite Familie . . Hydraula (=Cetacea): 1. Delphinus Delphis, p. 428, fig. 59; 2. D. Tursio, p. 429 ; 3. D. Phoccena, p. 429; 4. D. Orca, p. 429; 5. Monodon monoceros, p. 430 , fig. 60 ; 6. Physeter macrocephalus, p. 432, fig. 61; \%. Balcena Mysticetus, p. 433, fig. 62; 8 . B. Physalus, p. $440 ;$ 9. B. rostrata, p. 440.

[865.]

1835. Lepiez. See suprâ, 1835. Duméres, in L'Institut, 1835 , no. 92, pp. 46, 47.

1835. MACY, O. The / History of Nantucket; / being a compendious Account of the first | Settlement of the Island by the English, | together with the | Rise and Progress | of the | Whale Fishery; | and other historical facts relative to said | Island and its Inhabitants. | In Two Parts. |- - By Obed Macy. | - | ... [ [ = quotation, 3 lines. ] | Boston: | Hilliard, Gray, anḍ Co / $|-| 1835.8^{\circ}$. pp. i-xi, 1-300, map and cut.

Whales and the Whale Fishers are noticed passim in Part I, as follows: pp. 27-33, 36-38, 50-55, 68-72, 110-117, 119-134, 137-145, 149-151, 154-172, 208-216. Adventures of two whalemen (Part II), pp. 219-221. Description of the outfit and cruise of a Sperm Whale ship, pp. 221228. The Right Whale, p. 229. Description of a sixty-barrel Sperin Whale, pp. 229-232, pl. (Physeter or Spermaceti Whale, copied from Colnett's "Voy. to South Atlantic and Pacific Ocean" (18 , q.v.). Prugress of the Whale Fishery at Nantucket, pp. 232-234 ("from the Historical Society's Collection"). Produce of the Whale Fishery carried on at Nantucket, between the years 1804 and 1834, inclusive, p. 235 (statistical table). Accounts of the loss of varions whaling ships, pp. 236-253. Proposal from the French government to the people of Nantucket to remove to Dunkirk, pp. 253-259.

[866.]

1835. Mulder, ClaAs. Over de tanden van den Narwal of Eenhoorn (Monodon Monoceros L.). <Van der Hoeven en de Vriese's Tijdsch. voor Natuurl. Gesch. en Phys., ii, 1835 , pp. $65-100$, pl. ii.

The number, development, and functions of the teeth, treated historically and eritically. "Bij het ontleden van mijne meergemelmelde voorwerpen, heb ik weerzijds in de bovenkaak eenen tand outdekt, zoodat daardoor de analogie van Narwal met Dolfijnen verstekt, de overgang geleidelijker wordt" (pp. 107, 108).

The plate gives figures of the tusks and back teeth of a foetal and an adult specimen, and of the tusk, with sections of the latter.

[867.]

1835. Piez. [= Leptez.] Ueber ein Meerschweinweibchen (Delphinus phocaena). <Froriep's Notizen, xliii, No. 940, pp. 243, 244.

Anatomische Bemerkungen. Aus l' Institut, $3^{e}$ ann., 1835, pp. 46, 47. (See 1835. DürÉriL.)

[868.]

1835. REID, JoHN. Einige Beobachtungen rúcksichtlich der Structur der Gekro̊sdrůsen bei Balaenoptera rostrata. <Froriep's Notizen, xliii, No. 938, Feb. 1835, pp. 209-211.

Aus Edinb. Med. and Surg. Journ., No. cxxi, Jan. 1, 1836. 
1835. Ross, J. C. Appendix | to the | Narrative | of a | Second Voyage in search | of a | North-west Passage, | and of a | Residence in the Arctic regious | during the years 1829, 1830, 1831, 1832, 1833. | By | Sir John Ross, C. B., K. S. A., K. C. S., \&c. \&c. | Captain in the Royal Navy. | Including the reports of | Commander, now Captain, James Clark Ross, R. N., F. R. S., F. L. S., \&c. I and | the discovery of the northern magnetic pole. | - | London: | A. W. Webster, 156, Regent street. | - | 1835. 4to. pp. i-xii, 1-120, i-ciii, pll.

Zoology, by James Clark Ross, pp. vii-c.

Delphinapterus Beluga, p. xxii; Monodon Monoceros, p. xxii; Balcena Mysticetus, pp. xxiii, xxiv. There are valuable notes regarding the last two.

1835. Sharpey, [W.]. Observations on the Anatomy of the Bloodvessels of the Porpoise. <Rep. Brit. Ass. Adv. Sci., 4th meeting, Edinburgh, 1834 (1835), pp. 682,683 .

1835. Swainson, W. The / Cabinet Cyclopædia. | Conducted by the / Rev. Dionysius Lardner, LL. D. F. R. S. L. \& E. | M. R. I. A. F. R. A. S. F. L. S. F. Z. S. Hon. F. C.P. C. \&c. \&c. | assisted by Eminent Literary and Scientific Men. | - | Natural History. | - | A Treatise | on | the Geography and Classification | of | Animals. | By | William Swainson, Esq. A. C. G. | Honorary Member of the Cambridge Philosophical Society, I and of several Foreign Academies.

| - | London: | Printed for Longman, Rees, Orme, Brown, Green, \& Longman, | Paternoster-Row; | and John Taylor, | Upper Gower Street. | 1835. 8. pp. i-vii, 1-367, 1. 1.

Part II. On the Rise and Progress of Systematic Zoölogy (pp. 122-223), treats of the prin. cipal systems of classification, with critical remarks thereon from the quinarian.standpoint.

[872.]

1835. Thacher, James. History | of $\mid$ the Town of Plymouth, [Mass.] | from its first Settlement in $1620, \mid$ to the present time: | with a concise / History of the Aborigines | of New England, | and their Wars with the English, \&c. | By James Thacher, M.D. A.A.S. | "Ask thy fathers and they will show thee; thy elders and they will tell | thee." | Second Edition, enlarged and corrected. | - | Boston: | Marsh, Copen \& Lyon. | 1835. 80. pp. i-iv, 1-16+13401, map.

Whales in Plymonth Bay, p. 21. Whale Fishery, pp. 317, 318.

For first ed. see 1832.

1835. Trlesius, [G. W.]. Die Wallfische. <Isis.von Oken, 1835, pp. 709-752, 801-828.

Octe herbivora, pp. 709-719.

[Aechten Cetaceen], pp. 719-752, 801-828. Spec. 1. Der weisse Delphin aus Canada, p. 721; Sp. 2. D. coronatus Fréminville, p. 721; Sp. 3. D. bredanensis Cuv., p. 721 ; Sp. 4. D. macrogenius [Cuv.], eine fossile Species, p. 721; Sp. 5. D. gangeticus Lebeck, p. 721; Sp. 6. D. boryi, p. 722; Sp. 7. Delphinus delphis Linn., p. 722; Sp. 8. D. cruciger, p. 722; Sp. 9. D. maculatus Lesson et Garnot, p. 722; Sp. 10. D. dubius Cuv., p. 722; Sp. 11. D. Tursio Fabricii, p. 722 ; Sp. 12. D. niger Lacép., p. 723; Sp. 13. D. malayanus Lesson et Garnot, p. 723; Sp. 14. $D$. lunatus Less. et Garn., p. 724 ; Sp. 15. D. minimus Less. et Garn., p. 724 ; * D. Bertini Desm, p. 724; *D. Mongitori Desm., p. 724; Sp. 16. D. monocero8, Rhinoceros Quoy et Gaimard, p. 724 ; Sp. 17. D. Phocaena Linn., p. 724 ; Sp. 18. D. leucocephalus Less. et Garn., p. 724 ; Sp. 19. D. bivittatus Less. et Garn., p. 724; Sp. 20. D. superciliosus Less. et Garn., p. 725; Sp. 21. D. orca Fabric., p. 725 ; *D. intermedius Gray, p. 726 ; Sp. 22. D. griseus Cuv., p. 726 ; *D. rissoanus, p. 726; Sp. 23. D. globicep8 Cuv., p. 726; Sp. 24. D. cortesii, p. 726; *D. ferc8, p. 726; Sp. 25. D. leucas Pallas, p. 728; Sp. 26. D. Peronii Lacép., p. 730; *D. Kingii Gray, p. 730; Sp. 27. D. dalei, p. 730; Sp. 28. D. hyperoodon Desm., p. 731; Sp. 29. D.? spurius, p. 731; *D. Epiodon Desmar., p. 731; Monodon monoceros Linn., p. 731; Monodon microcephalus Lacép., p. 734; Monodon Andersonianus Lacép., p. 734.

Thiere, deren Kopf sehr gross und voluminoss ist und daher mit dem K8rper in keinem Verhåltnisse steht. A. Physcteres, Blaser. 1) Cachalot Lacép. Cetac. Catodon, p. 735 ; 2) Ziphius cavirostris, p. 735; 3) Oatodon macrocephalus, pp. 736-739; 4) Der Trumpo der Ber. muden Brown, p. 739; 5) Catodon polycyphus, p. 739; 6) Catodon suineval, p. 739; 7) Physalus cylindricus Lacép., p. 740; 8) Physeter microp8 Lacép., p. 740; Die zweyte Art der Caschelote [Physeter microp8], pp. 740-743; Die dritte Species der Caschelote [Ph. tursio Linn.], p. 743; Die vierte Species der Caschelote, p. 744. A mbra grisea, Ambergries der Kaufleute, pp. 745747. Vom Walrath oder Sperma ceti der Kanfleute und A potheker, pp. 747-751.

Von den eigentlichen Walfschen mit Barten, pp. 801-820. Der gemeine gro̊nlåndische 
1835. Tilesius, [G. W.]-Continned.

Walfisch, Balacna mysticetus Linn., pp. 801-807; Dio zweito Species, der Finufisch (Balacna physalus Linn.), pp. 807-810; 3. Spec., Balaena Boops, pp. 810-813; 4. Spcc., Der Nordkaper, Balaena musculus, pp. $814-816$; 5. Spec., Schnabelfisch, Balaena rostrata, pp. 816-819; 9) Physeter orthodon Lacép., p. 819; 10) Physeter mular Lacép., p. 820; 11) Physeter suleatus Lacép, p. 820.

Balaenae. Eigentliche Walfische mit Barten in den Kieferbeinen. . . . W . Walfische ohne Rúckenflossen und ohne Buckel. 12) Balaena mysticetus Linn., p. 820 ; 13) Balaena glacialis Klein, p. 821. B. Walfische, die einen oder meherer Buckel auf dem Rúcken haben. 14) Balaena nodosa Bonnaterre, p. 821; 15) Balaena gibbosa Bonnaterre, p. 821 ; 17) Balaena lunu. lata, p. 821. Die Gattung Balaenoptera des Lacépède fủhrt eine Rúckenflosse. A. Keine Falten (?) weder unter dem Banche noch unter Kehle. 18) Balaenoptera gibbar Lacép., p. 822. B. Walfische mit Falten, die unter dem Bauche und der Kchle der Långe nach fortlaufen. 19) Balaenoptera jubarte Lesson, p. 822 ; 20) Balaenoptera acuto-rostrata Lacép., p. 822 ; 21) Balaenoptera musculus Pallas, p. 822 ; 22) Balaenoptera punctata Lacép., p. 823 ; 23) Balac. noptera nigra Lacép., p. 823; 24) Balaenoptera coerulescens Lacép., p. 823; 25) Balaenoptera maculata Lacép., p. 823.

Pallas russische Walfische oder Cetaceen [6 spp.], pp. 824-826 [and the following:] B. Die Blaser, Physeteres. Springer, pp. 826-827 ; C. Ancylodon Illiger. Lesson Man. de Mammal., pag. 432 , p. 827 ; D. Delphin, p. 828.

Of the many bad pieces of cetological composition there are few more worthless, viewed from the stand-point of to-day, than this pretentious compilation of some fifty closely printed pages of Oken's I8is ; even Lacépède's and Chamisso's baseless species, described respectively from Japanese drawings and Aleut carvings in wood, to say nothing of many other purely nominal species, being here formally introduced. The literal transeription of the sub-headings and specific names above given renders further comment needless.

[874.]

1835-36. Cuvier, F. Cetacea. <Todd's Cyclopcedia of Anatomy and Physiology, vol.i, 1835-36, pp. 562-594, figg. 246-279.

At the end of the paragraph giving the "Bibliography" occurs the following: "(The preceding article has been derived from the work last named in the Bibliography, with the addition of the extracts from Mr. Hunter's papers and the other passages between brackets.)" The work "last namod" here referred to is "Cuvier, Fr. Histoire naturelle des Cétacés, 8ro. Paris, 1836." Tho bracketed passages not from Hunter, giving the classification and charac. ters of the group (pp. 562-564), and some other passages, are presumably by the editor, Dr. Robert B. Todd.

Tribe I. Phytophaga: Manatus (2 spp.), Halicore (2 spp.), Rytina (1 sp.).

Tribe II. Zoophaga: Family Delphinidoe, with genn. Delphinorhynchus, Delphinus, Inia, Phocona, Ionodon, Hyperoodon, Platanista. Family Catodontida, with genn. Catodon, Phy. seter. Family Balcenidce, with genn.'Balcenoptera, Balona.

The Zoophaga are divided into two groups, A and B, gronp A consisting of the Delphi. nidce, and group $\mathrm{B}$ of the Catodontidoe and Balcenidce.

183j-39. JäGER, G. F. Ueber die | Fossilen Säugethiere | welcbe | in | Würtemberg | aufgefunden worden sind | von | Med. Dr. Georg Fried. Jïger, | . . . [=titles, 8 lines.] | [Erste Abtheilung.] | - | Stuttgart, | Bei Carl Erhard. | 1835.

[Oder] Úber die | Fossilen S̈̈ngethiere, | welche $\mid$ in | Würtemberg | in verschiedenen Formationen | aufgefunden worden sind, | nebst | geognostischen Bemerkungeu iiber diese Formationen | ron | Med. Dr. Georg Fried. Jäger | . . . [=titles, 11 lines.] | [Zweite Abtheilung.] | - | Stuttgart, | Bei Carl Erbard. | 1839. $2^{\circ}$. Abth. I, 11. 3, pp. 1-70, 1. 1, pll. i-ix. Abth. II, 11. 2, pp. 71-212, 1. 1 , pll. $x-\mathrm{xx}$.

[N. B.-In "Bermerkung für den Buchbinder," affixed to the wrapper of Abth. II, the anthor directs the second of the above-given titles (which is that of $\Delta$ bth. II) to be used in binding as that of the completed work.]

Dedication to George Cuvier, 1. 3; Vorrede, 1. 4; Vorwort zu der Zweiten Abtheilung, 1. 5, erste Seite; Inhalts-Anzeige, 1. 5, zweite Seite; Einleitung, pp. 1, 2; I. Die Ueberreste von Säugethieren aus der Molasse Oberschwabens, pp. 3-10, 71. II. Die Ueberreste ron Sängethieren aus den Bohnerzgruben der schwäbischen Alb, pp. 11-59, 71-79. III. Die Ueberreste von Säugethieren aus dem Süsswasserkalk bei Steinheim, pp. 59-70. IV. Die Ueberreste von Säugethieren in der Höhlo bei Erpfingen, pp. 80-94. V. Ueberreste von Säugethieren aus der Schellershöhle bei Wittlingen, pp. 91-98. VI. Ueberreste ron Säugethieren aus dem weicheren Kalktuffe der schwäbischen Alb und aus der in ihm gebildeten Hōhle bei Seehurg, pp. 98-105. VII. Die Ueberreste von Säugethieren der Diluvial-und älteren Allurial-Formiation, pp. 105-182. VIII. Ueberreste von Säugethieren im Torf, pp. 183-197. VII (i.e., IX)i。 
1835-39. JÄGER, G. F.-Continued.

Ueberreste von Säugethiere aus alten Grabhügeln und Gräbern, p. 197. VIII (i.e., X). Dio Ueberreste von Säugethiere in dem neueren Alluvialboden, pp. 197-200. Resultate, pp. 200212. Erklärung der Tafeln und Druckfehler, 11.

Cetaceen, pp. 4-7. Flgg. : pl. i, figg. 4-28, spp. incog., aus der Molasse; pl. ix, figg. 1-6, Cetaceum (sp. incog.), aus der Molasse.

The remains of Cetaceans here described and figured are not definitely referred to either species or genus, though some are thought to be referable to Ziphius, others to Physeter, Delphinus, etc.

[876.]

1835-44. "Beale, Tromas. The Natural History of the Sperm Whale and a Sketch of a South-Sea Whaling Voyage. London, J. van Voorst, 1835-44. 80."

Not seen; title at second hand.

1836. Baer, Carolo Erx. A. Delphini Phocaenae anatomes sectio prima. <Bull. sci. de l'Acad. imp. des Sci. de St.-Pétersbourg, i, 1836, pp. 26-28.

Extrait en langue français du mémoire de cet titre publié dans les Mém. de l'Acad. imp. de St.-Pétersb.

[878.]

1836. BAER, [C. E.] DE. Sur lo prétendu passage de l'eau par les évents des Cétacés. <Bull. sci. de l'Acad. imp. des Sci. de St.-Pétersbourg, i, 1836, pp. 37-40.

Historique et critique. "Voila, Messieurs, l'histoire d'une idée que je crois fausse, et que s'est conservée dans la zoologie par l'autorité des anciens, par la rareté de la connaissance de la langue allemande parmi les antres peuples qui cultivent les seiences, par l'empressenient des Allemands à apprendre tontes les langues et à consulter la littérature de toute l'Europe, et par les mésentendus d'un traducteur." (p. 40.)

[879.]

1836. BAEr, [K. E.] voN. Ueber das Gefässsystem des Braunfisches (Delphin. Phocaena). <Froriep's Notizen, 1, No. 1081, Sept. 1836, pp. 37-39, fig. 33.

[880.]

1836. Bexeden, [P.J.] vas. Observations sur les caractères spécifiques des grands cétacés, tirés de la conformation de l'oreillo osseuse. <Ann. des Sci. nat., $2^{\mathrm{e}}$ sér., Zool., vi, 1836, pp. 158, 159.

[881.]

1836. BENEDEN, [P. J.] van. Os de l'oreille considéré commé ayant une valeur caractéristique dans les Cétacés. <L'Institut, 4 sér., no. 177, 28 sept. 1836, p. 318.

[882.]

1836. Bennetr, Frederick Debell. Notes on the Anatomy of the Spermaceti Whale (Physeter macrocephalus, Lac.). <Proc. Zool. Soc. Lond., 1836, pp. 127-129.

Dentition, structure of the eye, etc.

1836. "Bodel NiJenhuis, J. T. Over de walvischaardige dieren, op de kusten ván Nederland van de vroegste tijden of gestrand of gevangen."

"Zie: Algem. konst en letterbode. 1836, i, bl. 153, 163, 331."

Not seen; title from Bosgoed, op. cit., p. 158, no. 2500.

1836. "Bruns, V. Disquisitiones de nervis Cetaceorum cerebralibus. Tübingen, 1836. $80 . "$

Not seen; title from Carus and Engelmann.

1836. Cauchy, [F. P.]. [Rapport sur un os fossile trouvé a Tuyvenberg.] <Bull. de l'Acad. roy. des Sci., etc., de Bruxelles, iii, 1836, pp. $42,43$.

Remarques supplémentaires au rapport par M. le professeur Fohmann. (Voyez 1836. FoHMANN.)

[886.]

1836. Cuvier, F. De l'Histoire | naturelle | des Cétaceés, | ou | Recueil et examen des Faits / dont se compose l'Histoire naturelle do ces Animanx; Par M. F. Cuvier, | de l'Académie des Sciences, de la société de Londres etc. | Paris. | Libraire encyclopédique de Roret, | Rue Hautefeuille, No 10bis. | - | 1836. $8^{\circ}$. 11. 2, pp. i-lii, 1-416, pll. i-xxii.

Discours préliminaire. Considérations générales sur l'histoire naturelle des Jétacés, pp. i-lii.

Des Cétacés herbivores [Sirenia] en général, pp. 1-6.-Les Lamantins-Manatus, p. 6; 1. Manatus americanus, pp. 7-21; 2. Manatus Senegalensis, pp.21-25; 3. Manatus latirostris, pp. 25-26; Mesures comparatives des têtes des trois espèces de Lamantins, p. 27; Les Dugongs-Halicore, pp. 27, 28; 4. Halicore Indicus, pp. 29-38, 375, 376, pll. iv, v, vi; Rytina, pp. $38-40$; 5. Rytina borealis, pp. 41-71, 376 (une traduction du mémoire de Steller, sans aucun retranchement), pp. $376,377$. 


\section{Cuvier, F.-Continued.}

Des Dauphins en génóral, pp. 73-113,377; Les Delphinorhynques-Delphinorhyncus, pp. 113, 378; 1. D. micropterus [Blainv.], pp.114-117, pl.ix, fig. 1; 2. D. Coronatus [Fréminr.], pp.117-120; 3. D. Frontatus, pp. 120-122; Les Dauphins proprement dits-Delphinus, pp. 122, 123, pl. x, fig. 1, skull; 4. D. delphis [Linn.], pp.123-142; 5. D. tursio [Bonn.], pp. 142-147; 6. D. Capensis [Gray], pp. 147-148; \%. D. superciliosus [Less. et Garnot], pp. 148, 149; 8. D. novae Zelandice [Quoy et Gaim.], pp. 149, 150; 9. D. malayanus [Less, et Garnot], pp. 150, 151; 10. D. plumbeus [Dussnm.], pp. 151-153; 11. D. dubius [G. Cuv.], pp. 153, 151; :. D. velox [Dussum.], pp. 154, 155; 13. D. fronatus [F. Cuv.], pp. 155, 156, pl. x, fig. 1; 14. D. rostatus (sic), [G. Cuv.], pp. 156-158, pl. x, fig. 2; 15. D. cephalorhyncus [sp. n. =D. heavisidii, Gray, 1828], pp. 158, 159; 16. D. Desmaresti [Risso], pp. ]59-161; 1\%. D. hastatus [sp. n. =D. heavisidii, Gray, 1828], pp. 161, 162; 18. D. obscurus [Gray], pp. 162-164; 19. D. Peronii [Lacép.], pp. 164-166, pl. xv, fig. 2; Les Inias - Inia, pp. 166,167; 20. J. Boliviensis [D'Orb.], pp. 167-170, pl. $\mathrm{x}$ bis; Les Marsonins-Phocoena, pp. 170, 171; 21. P. communis [Linn.], pp. 171-177; 22. P. orca [Wagl.], pp. 177-182; 23. P. griseus [Less.], pp. 182-186; 24. P. compressi caudata [Less.], pp. 186-190; 25. P. globiceps [G. Cuv.], pp. 190-196,379; 26. P. rissonnus (sic), [G. Cuv.], pp. 196-199, pl. xiii, fig. 6; 2\%. P. leucas [Pallas], pp. 199-211; Des Dauphins dont l'existence comme espèce est douteuse (=29 spp.), pp. 212-230, 381 - voyez sous, p. 379; Les Narvals-Monodon, p. 230; 2S. M. monoceros [Linn.], pp. 230-240, 380, pl. xvii, figg. 2, 3; Les Hypéroodons-Hyperoodons, pp. 240, 241; 29. H. Butzkopf [Bonnat.], pp. 241-251, pl. ix, figg. 1-3, pl. xvii, fig. 1; Les Platanistes-Platanista, pp. 251, 252; $30 . P$. gangeticus [Lebeck], pp. 252-257, pl. viii, fig. 2, pl. xviii, figg. 1-3; Des Cachalots en général -Physeter, pp. 259-286; 31. P. macrocephalus [Linn.], pp. 286-302, 381-386, pl. xix, figg. 1-3; Des Baleines en général-Baloena, p. 303 ; Les Rorquals-Rorqualıs [gen. n.], pp. 303-321; 32. R. Boops [Albers], pp. 321-334, 386, 387; 33. R. musculus [Linn.], pp. 334-347 (contenent une traduction d'une mémoire de M. Companyo); 34. $R$. antarcticus [sp. n. = Baloena lalandi, Fisch.], pp. 347-354; Les Baleines-Balcena, pp. 354-361; 35. B. antarctica [s;. n. = B. ustralis, Desmoul.], pp. 361-36t; 36. B. mysticetus [Linn.], pp. 364-375.

Additions et corrections, pp. 375-391. Le Dugong, pp. 375, 376; Le Stellère, pp. 376, 377; Anatomie des Dauphins, pp. 377, 378; Le Delphinorhynque douteux, p. 378; 37. Delphinus ceruleo-albus [Meyen], pp. 378, 379; 38. Le Dauphin de Bory [D. Boryi], p. 379 [voyez p. 217]; Le Marsouin globiceps [Ph. globiceps], pp. 379, 3๖0; Du Narval, p. 380; Hyperoodon dans la Méditerranée, p. 381; Dauphins douteux, p. 381; Cachalots, pp. 381-386; Ambre gris, p. 386; Le Rorqual jubarte, pp. 386, 337; Rorquals et Baleines douteuses, pp. 388-391 (relatires d des quelques baleines de Pallas dans sa Zoog. Rosso-Asiat.); Baleine dons lo Fleure SaintLaurent, p. 391; Baleine du Cap, p. 391.

Table chronologique des ouvrages ou se trourent les notions diverses qui servent au jourd'hui de fondement à l'histoire naturelle des Cétacés, pp. 392-405, titles 1-165+12 interpol., et $1-10=187$; Table alphabútique des auteurs, avec les numéros de renvoi à la table chronologique des ouvrages, pp. 407-409.

Table des matières, pp. 411-413; Errata, pp. 415, 416.

Espèces douteuses. 1. Dclphinus senedetta, Lacép. ex Rondelet, p. 212; 2. D. sinensis, Desm. ex Osbeck, p. 213; 3. D. Pernettyi, Desm., pp. 213, 214; 4. D. canadensis, Desm. exDuhamel, pp. 214,215 ; 5. D. Bertini, Desm. ex Duhamel, p. 215 ; 6. D. spurius vcl anarnacus, O. Fabr., pp. 215, 216; \%. D. ventricosus, Bonnat. ex Hunter, pp. 216, 217; 8. D. Commersonii, Lacép. ex Commerson, p. 217 ; 9. D. Boryi, Desm. ex Bory, pp. 217, 218 [rojez p. 379 ou ce danphin est admetté êtré une espèces distincte]; 10. D. Sowerbyi, Desm. ex Blainv., p. 218; 11. D. épiodon, Rafinesque, pp. 218, 219; 12. D. feres, Bonn., pp. 219-221; 13. D. niger, Lacép., p. 221 ; 14. D. longirostris, Gray, 15. D. acutus, Gray, 16. D. intermedius, Gray, 17. D. kingii, Gray, p. 122; 18. D. troncalus (sic), Montaigu, pp. 222, 223; 19. Lo Globiceps de Risso, p. 223; 20. D. Bayeri, Less. ex Risso, pp. 224, 225; 21. O[xypterus]. mangitori, Rafinesque, p. 225; 22. D. cruciger, Quoy, 23. D. bivitatus, Quoy, pp. 225-227; 24. D. albigenus, Quoy et Gaim., p. 227; 25. D. rhinoceros, Quoy et Gaim., pp. 227, 228 ; 26. D. lunatus, Less., p. 228 ; 27. D. maculatus, Less., p. 228, 229; :S. D. leucocephalus, Less., p. 229; 29. D. minimus, Less., pp. 229-230.

Espèces nouveaux: 1. Delphinus cephalorhyncus, p. 158; 2: D. hastatus, p. 161 (tout deux $=D$. heavisidi, Gray, 1828) ; 3. Rorqualus antarcticus, p. $347=$ Balona lalandi, Fisch., 1829; 4. Balcena antarctica, p. $361=$ B. australis, Desmoul., 1822.

Genre nouveau, Rorqualus, p. $303=$ Balanopterido, auct. mod.

Espèces admette, 38; espèces doutouses, 28.

The work, as the title indicates, is a critical digest and compendinm of the literature of the Cetacea as then existing. Nearly everything of value relating to the various species is noted, and often special papers are given nearly in full. The large number of species considered as of doubtful existence indicates a judicious conservatism on the part of the author rarely exhibited by his predecessors.

[887.] 
1836. Cuvier, G. Recherches | sur les | Ossemens fossiles, | où l'on rétablit les caractères | de plusieurs animaux dont les révolutions du Globe | ont détruit les espèces; I par | Georges Cuvier. | Quatrième Edition, | Approvée et adoptée par le Conseil royal de l'Instruction publique. | Triomphante des eaux, du trépas et du temps, | La terre a cru revoir ses premiers habitans. | Delille. | Tome Huitième, Deuxième Partie. | [Seal.] Paris. | Edmond d'Ocagne, Editeur, | 12, Rue des Petits-Augustins. | ... [ =names of 4 other publishers.] | 1836. $8^{\circ}$. 1l. 3, pp. 1-332. Atlas, $4^{\circ}$, pll. 220-228.

The title of the wrapper has, after "Quatrième Edition," in addition to the above:

Revue, et completée | Au moyen de notes additionelles et d'un supplément | laissés par l'Auteur. |

"Les additions qui se trouvaient à la fin de chacun des volumes des précédentes éditions, sont classées par ordre de matières; et, lorsque lo sujet s'y prête, les faits noureaux recueillis par M: Georges Cuvier sont joints an texte, mais en note seulement, afin de conserver au texte son intégrité. Le plus grand nombre de ces faits cependant est destiné à trourer place dans le. Supplément dont M. Cuvier avait préparé tous les matériaux, et que M. Laurillard ajoutera aux Recherches sur les os fossiles."-Extrait de l'A vis de l'éditeur, which also states that the plates were retouched for this edition. The prospectus states, "M. Frédéric Cuvier, de l'Institat, s'est chargé de suivre la réimpression de l'ourrage de son frère."

Tome Huitième, Deuxième Partie, contains chapters II and III of the Nourelle édition (1823), q.v. The additions consist of (1) note 1 to p. 86 (7 lines), respeeting Delphinus frontatus, signed "Fréd. Cur."; (2) note to p. 121 (5 lines), explaining the substitution of the word rostratus for frontatus, also signed "Fréd. Cuv."; (3) this note is followed by the " $\Delta d$ dition a l'bistoire des dauphins vivans," appearing at the end of the volume in the earlier editions, with verbal changes in the first paragraph; (4) note (3 lines, signed "F. Cuv.") referring to the note at p. 121; (5) note (1 line, signed "Laur.") supplementiug the text; (6) note (14 lines, no signature), entitled "Sur le Rorqual de la mer Adriatique au cabinet de Bologne."

The references in the text to the plates are changed to correspond with their reissue with consecutive numbering.

This Quatrième édition of the Ossemens fossiles contains (Tome premier, 1834, pp. i-xxiv) "Obserrations préliminaires, par M. Frédéric Cuvier;" and "Eloge de M. Le Baron Cuvier, par C.-L. Laurillard" (loc. cit., pp. 1-78). The Atlas is accompanied by a detailed explanatory table of the plates, an important desideratum which the other editions lack.

[888.]

1836. Cuvier, Georges. Le | Règne animal | distribué | d'après son organisation, | pour servir de base à l'Histoire naturelle des Animanx, | et d'introduction à l'Anatomie comparée, | par | Georges Cuvier. | - | Édition | accompaguée de planches gravées, | représentant | les types de tous les genres, | les caractères distinctifs des divers groupes et les modifications de structure | sur lesquelles repose cette classification; | par | une réunion de disciples de Cuvier, | MM. Audouin, Blauchard, Deshayes, Alcide D'Orbigny, Dozère, Dugès, Duvernoy, Laurillard, | Milne Edwards, Roulin et Valenciennes. | - | Paris | Fortin, Masson et Cie, Libraires, | Successeurs de Crochard, I Place de l'École-deMédecine, N. 1. | - Imprimé chez Paul Renouard, | Rue Garancière, n. 5. [1836 ct 8cq.] 20 vols. 4०.

Les Mammifères. | - | Avec un Atlas, | par MM. | Milne Edwards, Laurillard, et Roulin. I Texte, 1. 1, pp. i-xxxvi, 1-350; Atlas, pll. i-c, coloriées.

Les Cétacés herbivores, pjp. 320-331, pl. xcvi. Les Cétacés ordinaires, pp. 331-346, pll. xevii-c.

Pl. xevi, fig. 1. Trichechus manatus, Linn., fig. orig.; fig. 2. Halicore Dugong (animal, d'après MM. Hombron et Jacquinot; squelette et crâne, d'après Cuvier, Oss. fos.). Pl. xcvii, fig. 1. Delphinns Delphis (fig. orig.); fig. 2. D. Globiceps (d'après une planche de Risso, Hist. nat. de l'Europe mérid., t. iii); fig. 3. D. Phocana (fig. orig.). Pll. xeriii-xeix, Appareil soufflant du Marsouin. Pl. c, fig. 1. Baloena mysticetus, Linn. (d'après Scoresby, Arct. Reg., t. ii, pl. xii).

The text appears to be unehanged from that of the edition of 1829.

1836. Dumortier, B. C. Mémoire sur le delphinorhyaque microptère échoué à Ostende. Lu à la séance dn 5 novembre 1836. LNouveaux mém. de l'Acad. roy. des Sci. et Belles-lettres de Bruxelles, xii, 1839, pp. 13, pll. 3.

Sur les caractères extérieurs et anatomiques du Delphinorhynchus micropterus. Pl. i. vu de côte; pl. ii, son squelette; pl. iii, appareil hyoïde, oreille osseuse, système urinaire, le cœur, et la queue. 
1836. Edrtorial. The Black Whale. <Edinb. Phil. Journ., xx, 1836, pp. 208, 209.

On the diminution in numbers of Balcena mysticetus. A brief general statement of the matter, with an extract of 16 lines accredited to "Ross's Voyage."

[891.]

1836. Fommann, [V.], et [F.P.] Cauchy. [Rapport sur deux fragmens d'un os fossilo trouvés à Tuyvenberg.] <L'Institut, $4^{\mathrm{e}}$ ann., no, 150, 23 mars 1836, p. 95.

Fragment de rertèbre d'un Cétacé.

1836. Formavn, [V.]. Rapport sur un os fossile trouvé à Tuyrenberg.] <Bull. de l'Acad. roy. des Sci., etc., de Bruxelles, iii, 1835, pp. 40-42.

Un fragment d'une vertèbro d'un Cótacé du genre Balana.

1836. Gerv. [=Paul Gervars.] Lamantin, Manatus. <Dict. pittor. d'Hist. nat. ct des Phénom. àe la Nature, iv, 18:36, livr. cclxxxii, pp. 331-333.

1. Manatus americanus, p. 331, pl. cclxxxviii, fig. 3 ; 2. Mr. sencgatensis, p. 332; 3. Mr. latirostris, p. 332 .

[834.]

1836. Gerv. [= Paul Gervars.] Mammalogie on Mastologie. <Diet. pittor. d'Hist. nat. el des Phénom. de la Natnre, iv, 1836, livr. ccexvii-cccxx, pp. 614-610.

Cétacés, passim. Mammifères do France, pp. 639,640. Cétacés, 1. Delphinorhynchus sa'onicus, Less.; 2. Delphinus micropterus; 3. D. dclphis; 4. D. tursio; 5. D. deductor ou globiceps; 6. D.edentulus, Schreb.; F. Physeter macrocephalus; 8. Baloena musculus; D. B. rostrata.

[895.]

1836. Herausgeber. Harlan; kritische Bemerkungen über einige bisher in NordAmerika gefundene organische Überbleibsel (nach dem Aushängebogen der Transactions of the geological Society of Philadelphia, vol. i, in James. Edinb. $n$. phil. Journ., 1834, xvii, 342-362; F. f.). <Neues Jahrb. für Mineral., 1836, pp. 99-109.

Manatus und eigentliche Cetaceen, p. 104; Basilosaurus, p. 106.

1836. JACOB, A. On the structure of the Mammary Glands in the Cetacea; with Observations on the mechanism of the Mouth and Soft Palate, as applied by the Young Animal in Sucking. <Fifth Report British Assoc. Adv. Sci. (Dublin meeting, 18:35). Notices of Com., 1836, pp. 86, 87.

[897.]

1836. Lemaốt, [E.]. Sur la nageoire dorsale du delphinus globiceps (Cuvier). <Cornple rendu de l'Acad. des Sci., ii, 1833, p. 65.

1836. Mulder, ClaAs. Een word over het werk van Geoffroij Saint-Hilaire, den titel voerende: Fragmens sur la structure et les usages des glands mammellaires des Cétacés. Paris, 1834. $8^{\circ}$. avec 2 pl. in $4^{\circ}$. <Van der Hoeven en de Vriese's Tijdssch. voor Naturl. Gesch. en Phys., iii, 1836, ii, pp. 41--.

1836. Rapr, WrLm. Bemerkungen úber die Gehörwerkzeuge der Cetaceen. <Froriep's Notizen, xlix, No. 1064, Juli 1836, pp. 116-121.

Auszug.

1836. Ravis, F. P. Oservations anatomiques sur les les Fanons, sur leur mode d'insertion entre eux et avec la membrane palatine. <Ann. des Sci. nat., $2^{\mathrm{c}}$ sér., Zool., v, 1836, pp. 266-278, pl. xi.

Sur les fanons de "Balcenoptera acuto-rostrata, Lacépèlle."

1836. Rédacteurs. Histoire naturelle des Cétacés, par M. Frélérie Cavier. <Ann. des Sci. nat., $2^{\mathrm{e}}$ sér., Zool., v, 1836, p. 379.

Notice.

1836. REDACTEurs. [M. K. E. von Baer. Sur l'anatomie du marsonin.] <L'Institut, $4^{e}$ anu., no. 177, 7 décem. 1836, pp. 401, 410.

Résumé.

1836. Robert, [C.]. [Note sur quelques particularités observées dans le squelette d'uu Lamantin du Sévégal.] <L'Institut, 4 ann., no. 153, 13 avril 1836, p. 114.

[901.]

1836. RoBert, [C.]. Lettre de M. Robert sur les spirules, sur le lamentin du Sénégal et sur l'existence, dans certe même région de l'Afrique, de hyène tachetće. <Ann. des Sci. nat., $2^{\mathrm{e}}$ sér., Zool., v, 1836, pp. 226, 227; Comp. rend. de l'Acad. des Sci., ii, 1836, pp. 362-364.

Donné quelques particularités dans le squelette d'nn Lamantin du Sénégal. 
1836. Salacioux, A. Noveaux Élémens | d'Histoire Naturelle | contenant | La Zoologie, la Botanique, | la Minéralogie et la Géologie, | par A. Salacroux | Docteur en Médecine de la Faculté de Paris, | Professeur d'Histoire naturelle au Collége de Saint-Louis, | Membre de la Société des Sciences naturelles de France. | Avec 44 planches gravées sur acier et représentant | près de 400 sujets. | - | Paris | Germer Baillière, Libraire-Editeur, | Rue de l'École de Médecine, No. 13 (bis). | . . [ [=names of 5 other booksellers. ] 1836. sm. 8०. pp. i-vii, 1-970, pll. i-xliv.

X' Ordre.-Cétacés, pp. 188-203, pl. xi. Ire Famille. Cétacés herbirores, pp. 190, 191. II Famille. Cétacés souffleurs, pp. 191-203. Divisée en Iro Tribu, Delphinoïdes avec genres Delphinus, Phocaena, Monodon; II Tribu, Macrocéphales, arec genres Physeter, Baloena. Les espèces ne sont pas spécialement indiquées.

[905.]

1836. Vanbeneden. [= Beneden, P. J. van.] Caractères spécifiques des grauds cetacés, tirés de la conformation de l'oreille osseuse. <Compl. rend. de l'Acad. des Sci., iii, 1836, pp. 400, 401.

[906.]

1837. BeLL, Thomas. A | History | of | British Quadrupeds, | including the Cetacea. | By | Thomas Bell, F. R. S. F. L. S. V.P.Z.S. | . . [ =titles, 3 lines. ] | [Vignette. ] | Illustrated by nearly 200 woodcuts. | London: | John Van Voorst, 1, Paternoster Row. | M. DCCC.XXXVII. 8०. pp. i-xviii, 1-526.

Cetacea, pp. 452-526. General Structure, pp. 452-462. Spp. 1. Delphinus delphis, p. 463; 2. D. tursio, p. 469 ; 3. Phocoena communis, p. 473; 4. P. orca, p. 477; 5. P. melas, p. 483; 6. Beluga leucas, p. 489; 7. Hyperoodon butzkopf, p. 492; 8. Diodon sowerbaei, p. 497; 9. IFonodon monoceros, p. 500; 10. Physeter macrocephalus, p. 506; 11. P. tursio, p. 512; 12. Baloena mysticetus, p. 514 ; 13. Balcenoptera bnops, p. 520.

Except Physeter tursio, all the species are represented in wood-cuts, and include the skulls of seven species, as well as the animal. The text forms a carefully prepared account of the species as then known.

Sirenia,-notice at p. 525 of stranding of epecimens of the Manatee ("Manatus borealis") on the British coast, from Stewart and Fleming.

[907.]

1837. Bennetr, F. De Bell. On the Natural History of the Spermaceti Whale (Physeter macrocephalus). <Proc. Zool. Soc. Lond., 1837, pp. 39-42.

General account of habits.

183 ( circa). Bonaparte, C. L. Synopsis / Vertebratorum Systematis | A Charolo L. Bonaparte Muxiniana Principe S. L. S. etc. etc. | Societati Linnaeanae exhibiti / die septima Nor. 1837 [title occupying upper third of page 1]. $8 \circ$. pp. 1-30. [Apparently a separate publication.]

In the "Index Familiarum et Subfamiliarnm," p. 7, is the following:
9. Manatidae. •
Ordo 4. Cete. (Natantia.)
10. Delphinidae.
11. Physeteridae.
12. Balaenidae.
18. Manatina.
19. Delphinina.
21. Physeterina.
20. Monodontina.
22. Balaenina.

[909.]

1837. "Breschet, [G.], et Roussel de Vauzìme. Nouvelle recherches sur la structure de la peau. Paris, 1837."

Tiré des Ann. des Sci. nat., 2e sér., Zool., ii, 1834, pp. 16ī-238, 321-370? Voyez 1834. Breschet et Roussel DE VAUZÈMe.

Cétacés, passim. Not seen; title at second hand.

1837. Burveister, H. Handbuch | der | Naturgeschichte. | Zum Gebranch bei Vorlesungen | entworfen | von | Hermann Burmeister | ... [titles, 6 lines.] | - | Berlin, 1837. I Verlag von Theod. Chr. Friedr. Enslin. 80 , in zwei Abtheilungen, 1. 1 (general title-page), pp. i-xxri, 1-8.58.

Cetacea, pp. 791-793. Divided into 3 families - Balaenodea, Delphinodea, Sireniformia. Genera briefly characterized, with an enumeration of the species.

"Hyperoodon verus (Butskopf), atl. Ozean," nom. sp. n., p. 792.

1837. G., Z. Narval, Monodon. <Dict. pittor. d'Hist. nat. et des Phénom. de la Nature, v, 1837, livr. cecxeiv, pp. 591, 592.

Narvalus vulgaris Lacép., Ionodon monoceros, Lin. 
1837. Gerv. [= Paul Gervars.] Mammifòres fossiles. <Dict.pittor. d'Hist. nat. et des Phénom. de la Nature, v, 1837, livi. ccexxi, pp. 1-5.

Cétacés, passim.

1837. "GraAil, W. A. Narrative of an Expedition | to the | East Coast of Greenland, | sent by orler of the King of Denınark, | in search of | the lost colonies, | under the commind of | Capt" ${ }^{\mathrm{I}}$ W. A. Graah, of the Danish Royal Navy, | Knight of Dannebrog, \&c. | - | Translated from the Danish, | by | the late G. Gordon Macdongall, F. R. S. N. A., | for the | Royal Geographical Society of London. I With the / original Danish chart completed by the Expedition. | - | London: | John W. Parker, West Strand. | - | M.DCCC.XXXVII. 1 vol. 8vo. pp. xvi, 199, map."

Not scen; titlo from Cones, Birds Col. Vall., App., 1878, p. 624. The Appendix is said to contain zoölogical matter.

1837. Herausgeber. G. Fr. Jüger: über dis fossilen S̈̈ngethiere, welche in Württemberg anfgefunden worden sind. Erste Abtheilung. Stuttgart, 1835, 70 pp. und 9 lithogr. Tafeln in Fol. <Neues Jahrb. für Mineral., Geogn., Geol. und Petrefakt., 1837, pp. 7:31-740.

Auszug.

1837. Herausgeber. [Bemerkungen über die Anatomie des Pottfisches (Physeter macrocephallus).] <Froriep's Neue Notizen aus dem Gebiete der Natur-und Heilkunde, iv, No. 18, Dec. 1837, pp. 273-275.

Abstract von Bemerkungen des Hrn. Debell Bennett's in Proc. Zool. Soc. Lond., 1836, pp. 127-129.

[916.]

1837. Jardne, W. The | Natural History | of the | Ordinary Cetacea | or | Whales. |

[By Sir William Jardine, Bart., F. R. S., etc.] Illustrated by thirty-two colonred plates, | numerous wood-cuts, with memoir | and portrait of Lacepede. |

Edinburg: | W. H. Lizars, 3, St. James' Square; | S. Highley, 32, Fleet Street, London; and W. Curry, jun. and Co. Dublin. | 1837. [Or,] The | Naturalist's Library | conducted by | Sir William Jardine, Bart. | F. R. S. E., F. L. S., \&c. \&c. | Mammalia. | Vol. VI. | On the | Ordinary Cetacea | or | Whales. | "Ah! pour les peindre, il faudroit le pincean de Buffon." | Lacépède. I . . . [=imprint as above.] sm. $8^{\circ}$. pp. $\mathrm{i}-\mathrm{xvi}, 17-264$, pll. $\mathrm{i}-\mathrm{xxix}+\mathrm{iv}$, frontispiece (portrait of Lacépède), and engraved title-page (figures of Narwal) $=32$ pll. Figg. in text.

Title-pages, four in number, pp. i-viii; Advertisement, pp. ix-xii; Contents, pp. xiii-xv; Memoir of M. le Comto de Lacépède, pp. 17-32; Introduction, pp. 33-42; Comparative Anatomy of the Cetacea, pp. 43-75; the Greenland Whale (Balaena JIysticetus, Linn.), pp. 76-93, pl. ii; the Northern Whale Fishery, pp. 93-98 (pl. iii, whale's fool); Proceedings and dangers in capturing the Whale (pp. 99-121, pll. iv, iv*); Whalo of the Southern Seas (Balcena A ustralis, Desmoul.), pp. 122-124; Rorqualus Borealis, Cuv., pp. 125-141, pl. v, animal, pl. vi, skeleton; the Lesser Rorqual (Rorqualus Rostratus), pp. 142-146, pl. vii; Rorqual of the Sonthern Seas (Rorqualus A ustralis, Cuv.), pp.146-150; Fossile Rorquals, etc., pp. 150-153; the Spermaceti Whale (Physeter Catodon, Linn.), pp. 154-169, pl. viii (from Robertson), pl. ix (from Beale); [South Sea Fishery], pp. 169-180, pl. x, Dying Struggles of the Spermaceti Whale (from Beale); the Heterodons,p. 181; the Narwhal, or Sea Unicorn (Narwhalus), pp. 182-190, pl. xi (from F. Cuvier), and Vignette, p. iii; Diodons, or Two-teethed Whales, pp. 191-193-Diodon Desmaresti (p. 191), Diodon Sowerbi (p. 192), pl. xii; Hyperoodon Honfloriensis, pp. 194-197, pl. xiii; Aodons - A. Dalei, Less., pp. 198-200, pl. xiv (from F. Cuvier); Xiphius -X. Planirostris (fossil), p. 201; Third Subdivision, pp. 202, 203; the Btluga, or White Whale (Beluga), pp. 204-209, pl. xv; Delphinapterus Peronii, pp. 210, 211, pl. xvi, from Quoy and Gaim.; the Deductor, or Ca'ing Whale (Globiocephalus Deductor or Mfelas), pp. 212-219, pl. xvii, from Scoresby; the Globiocephalus Rissii, p. 219, pl. xviii, from F. Cuvier; Fossile Globiceps, pp. 220, 221; the Comnon Porpoise (Phoccena Communiø), pp. 222-227, pl. xix, fig. 1, from F. Cuvier; the Porpoise of the Cape of Good Hope (Phocaena Capensis Dussm.), p. 227, pl. xix, fig. 2, from F. Curier; the Grampus (Phocaena Grampus), pp. 228-232, pl. xx; the P[hoccena]. Grisens, pp. 233, 234, pl. xxi, from D'Orbigny; the Striped Porpoise (P[hocoena]. Bivittatus), pp. 234, 235, pl. xxii, fig. 2; Genus Delphinus, pp. 236-238; the Common Dolphin (Delphinus Delphis, Linn.), pp. 238-243, pl. xxiil, from Cuvier; Pernetty's Dolphin (Delphinus Pernettii, Desm.), pp. 244-246, pl. xxiv; Lead-coloured Dolphin (Delphinus Plumbeus, Dussm.), p. 246, pl. xxr, fig. 1; the Bridled Dolphin (Delphinus Froenatus, Dnssm.), p. 247, pl.xxv, fig. 2; Delphinus Supercilio. 
1837. JARDINE, W.-Continued.

sus, Less., pp. 248, 249, pl. xxvi, from Less. and Garn.; the Fuenas of the Chilians, p. 250, pl. xxii, fig. 2; Delphinus Youngii (Fossile), p. 251; Delphinorhynchus of Breda (Delphinorhynchus Bredanensis, Less.), p. 252, pl. xxrii, from Cuvier; the Soosoo of the Ganges (Soosoo Gange. ticus, Less.), pp. 254-256, pl. xxviii; the Soosoo of M. De Borda (Soosoo Bordaii, Fossile, Cuv.), p. 257; I[nia]. Boliviensis, D'Orbign,, Fr. Cuvier, pp. 259-261, pl. xxix; the Rhinoceros Whale (Oxyptcrus Rhinoceros, Less.), pp. 262-263, cut, from Quoy and Gaimard.

$\Delta$ popular general account of the Cetacea.

About 32 species are described and figured, arranged in 17 genera. The figures are copied from those of previous authors, sometimes more or less altered in position, and embellished with "appropriate scenerg." In many cases the original sources are indicated. The technical names above giren in parentheses are those adopted in the table of contents; these generally correspond with the first name given in the body of the work in the lists of s.rnon. yms of the species, and the authority abore alded to the name is thence derived.

[917.]

1837. McCulloch, J. R. A | Dictionary, | practical, theoretical, and historical, | of | Commerce | and | Commercial Navigation: | Illustrated with Maps and Plans. | By J[ohn]. R[amsey]. McCulloch, Esq. | A New Edition. | Corrected and improved: | With an enlarged Supplement, | containing many new Articles, and bringing down the information / contained in the work to / December, 1836. $|-| \ldots[=4$ lines, quotation. $]$ | $-\mid$ London: | Printed for | Longman, Rees, Orme, Brown, Green, and Longmau. I MDCCCXXXVII. Large 8०. pp. i-xvi, 1-1269, +1-118.

Whalebone, p. 1238. Whale (Common) [Balaena mysticetus], p. 1238. Whale-Fishery, pp. 1238-1245. Whale Fishery (Southern), Suppl., p. 116. Whale Fishery (Northern), Suppl., p. 117.

[918.]

1837. Pusch, Geong Gotrumer. Polens Paläontologie | oder | Abbildung und Beschreibung | der | vorzüglichsten und der noch unbeschriebenen Petrefakten aus den / Gebirgsformationen in Polen, Volhynien und den Karpathen | nebst | einigen allgemeinen Beiträgen zur Petrefaktenkunde und einem Versuch zur | Vervollständigung der Geschichte des europiiischen Auer-Ochsen. | Von | Georg Gottlieb Pusch, | Münzmeister zu Warschan, ehemaligen königl. polnischen Bergrath und Professor, Mitglied einiger gelehrten Gesellschaften | zu Moskau, St. Petersburg, Paris, Dresden, Breslau, Bonn und Altenburg. | - | Mit Abbildungen auf 16 lithographirten Tafeln. |-|-| Stuttgart. | E. Schweizerbart's Verlagshandlung. | 1837. $4^{c}$. pp. i-xiii, 1-218.

Fossile Ueberreste von Wirbelthieren, pp. 167, 168. Rückenwirbel eines Meer-Säugthiers (pp. 167, 168, pl. xv, fig. 4) aus Jurakalk. Wahrscheinlich ein Cetaceen-Wirbel.

1837. RAPP, W. Die Cataceen | zoologisch-anatomisch dargestelt / von | Wilhelm Rapp, Professor der Anatomie in Túbingen. | - Mit Abbildungen. $\mid-1$ Stuttgart und Tübiugen, | Verlag der J. G. Cotta'schen Buchhandlung. | 1837. 8 . 1. 1, pp. i-vi, 1-182, 1. 1, pll. i-viii.

Geschichtliches, pp. 3-20. I. Zoologischer Theil, pp. 21-58.

A. Pflanzenfressende Cetaceen (Sirenia, Ill.). 1. Manatus americanus Desmar., p. 25 (Ir. senegalensis et latirostris, spp. dub.); 2. Halicore indica Desmar., p. 26; 3. Stellurus borcalis Desmar., p. 27.

B. Aechte Cetaceen. 1. Delphinus delphis Linn., p. 29; 2. D. longirostris Dussumier, p. 30; 3. D. velox Dussumier, p. 30 ; 4. D. Tursio Bonnat., p. 31 ; 5. D. capcnsis Gray, p. 31; 6. D. plumbeus Dussumier, p. 32; \%. D. superciliosus Lesson et Garnot, p. 32 ; 8. D. frenatus Dussumier, p. 32; 9. D. coeruleo-albus Mejen, p. 33; 10. D. rostratus Cur., p. 33; 11.D. dubius Gray, p. 33; 12. D. Boryi Desmar., p. 34; 13. D. lunatus Lesson et Garnot, p. 34; 14. D. Novae Zeelandiae Quoy et Gaimard, p. $34 ; 15$. D. (Phocaena) globiceps Cuv., p. 34; 16. D. (Ph.) Rissoanus Cuv., p. 36 ; 17. D. (Ph.) griseus G. Cnv., p. 36 ; 18. D. (Ph.) Pho. caena Linn., p. 36; 19. D. (Ph.) hastatus Fr. Cuvier, p. 37: 20. D. (Ph.) cruciger Quoy et Gaimard, p. 38; 21. D. (Ph.) bivittatus Lesson et Garnot, p. 39; 22. D. (Ph.) compressicauda Lesson, p. 39; 23. D. (Ph.) obscurus Gray, p. 39; 24. D. (Ph.) gladiator (=D. orca Fabr. non Linn.), p. 39; 25. D. (Delphinorhynchus) Geoffroyi Desmar., p. 40; 26. D. (D.) coronatus Fréminville, p. 40; 27. D. (D.) micropterus Cuv., p.40; 28. D. (Platanista) gangeticus Lebeck, p. 41; 29. D. (Inia) Boliviensis d'Orbigny, p. 42; 30. D. (Delphinapterus) leucas Pallas, p. 42; 31. D. (D.) leucorhamphus Péron, p. 43; 32. D. (D.) phocaenoides Dussumier, p. 43; 33. D. (Heterodon) Datei Lesson, p. 41; 31. D. (II.) Desmaresti Risso, p. 45; 35. Monodon 
1837. RAPP, W.-Continued.

monoceros Linn., p. 40; 36. Physeter macrocephalus Shaw, p. 49; 37. Balaenoptera borealis Lesson, p. 52; 3S. B. longimana, p. 55; 39. Balaena mysticetus Linn., p. 55; 40. Balaena antarctica Less., p. $58,=$ spp. 40.

II. Anatomischer Theil, pp. 59-179. Von den Knochen, pp. 61-78. Von den Muskeln, pp. 79-91. Ange, pp. 92-97. Gebörorgan, pp. 98-104. Nasenhöhle, pp. 105-i09. Allgemeine Bedeckungen, pp. 110-114. Nervensystem, pp. 115-123. Verdauungswerkzeuge. pp. 124-145. Athmungswerkzouge, pp. 146-152. Haruwerkzeuge, pp. 153-155. Gefässsystem, pp. 156-168. Werkzenge der Fortpflanzung, pp. 169-176.

Erklärung der Abbildnngen, pp. 181, 182. Erste Tafel, Eines 13 Par. Zoll langen Fötus des Dugong (Halicore Indica). Zweite Tafel, Delphinus Capensis, Gray. Dritte Tafel, Del phinus hastatus F. Cur. Fig. A, ron der Scite; flg. B, von unten. Vierte Tafel, Skelet eines erwachsenen, männlichen Delphinus delphis aus dem mittelländischen Meere. Fünfte Tafel, Skelet eines Delphinus Phocaena aus der Nordsee. Sechste Tafel, Der Magen der Delphine in den rerschicdenen Lebensperioden; drei Figuren. Siebente Tafel, Niere ron Delphinus delphis und eines fast reifen Fötus des Dugong. Achte Tafel, Herz des DugongFötus. Alle Figuren sind nach der Natur.

The historical introduction traces briefly the history of the subject from the time of Aristotle to date, with copions references to the literatnre in foot-notes.

Theil I gives a carefully prepared synopsis of the species, with brief diagnoses, the principal synonymy, and references to the more important works relating to the species. Theil II is devoted to a general acconnt of the anatomy of the Sirenians and Cetaceans, largely from original investigation. The eight plates are based on material studied by the author.

[920.]

1837. RATHKe, [M. H.]. Bemerkungen ůber ein angeblich bei Tannenberg gefundenes Schulterblatt eines Wallfisches. <Preuss. Provinz.-Blätter, xviii, 1837, 562-565.

1837. Ravin, [F. P.]. Anatomische Beobachtungen ůber die Barten, úber deren Einfúgungsweise in Bezng auf einander und auf die Gaumenhaut. <Froriep's Neue Notizen, i, No. 3, Jan. 1837, pp. 33-40, figg. 16-25.

Aus Ann. des Sci. Nat., 2॰ sér., v, 1836, pp. 266-278, 1 pl.

1837. RÉdacteur. [Notes sur l'anatomie de la Baleine au sperma-ceti (Physeter macrocephalus, auct.), principalement sur sa dentition et sa structure ainsi que l'aspect que présentent ses parties molles, par M. Debell Bennett.] <L'Institut, $5^{\text {e }}$ ann., no. 221 , novembre 1837, p. 359.

Résumé.

1837. Richardon, J. Report on Nortlı American Zoology. <Rep. 6th Meeting Brit. A8s. Adv. Sci. for 1836, v, 1837, pp. 121-224.

Ord. Cetacea, pp. 161, 162. Nominal list of 19 species of Sirenia and Cetacea.

1837. "Suckow, G. A. Osteologische Beschreibung des Walles [Balaena mysticetus]. Mannheim, C. Lamina, 1837. $4^{\circ}$. 5 pll."

Not seen; title at sccond hand.

1837. Vanbenedex, [P. J.]. [= Beneden, P. J. van]. On the Specific Characters of the larger Cetacea, as deduced from the Conformation of the Bones of the Ear. <Edinb. New Philos. Journ., xxii, 1837, p. 198.

From Compte Rendu, iii, 1833, pp. 400, 401.

183\%. VRoLIK, W. Ontleedkundige aanmerkingen over den Noordschen Vinvisch (Balaenoptera rostrata), in de maand September desjaars 1835 te Wijk aan Zee gestrand. < Tander Hoeven en de Vriese's Tijdssch. voor Natuurk. Gesch. en Phys., iv, 1837-38, pp. 1-24.

On various points in its anatomy.

1838. Axon. Notices of some of the specimens of natural history, which were collected during the voyage of the Morrison to Lewchew and Japan. <Chinese Repository, vi, 1838, pp. 406-417.

Globioccphalus Rissii, pp. 411-413. Description of external characters with a page of anatomical observations. 
183\%. BAsr, K. E. voN. Untersuchungen über die ehemalige Verbreitung und die gïnzliche Vertilgung der von Steller beobachteten nordischen Seekuh (Rytina, Ill.). <Bull. de l'Acad. imp. des Sci. de St.-Pétersbourg, iii, 1838, pp. 355-359.

Extrait en langue français du mémoire de cet titre, imprimé dans les $\mathbf{M}$ rém. de la même acad.

1838. Bexneti, F. Debell. Ueber Physeter macrocephalus, besonders sein Gebiss. < Isis von Olecn, 1838, pp. 217, 218.

Auszug aus Proc. Zool. Soc. Lond., iv, 1836, pp. 127-129.

1838. Blaivvirle, M. H. DE. Sur les Cachalots. <Ann. franç. et étrang. d'Anat. et de Phys., ii, 1838, pp. 335-337, pl. x.

Physeter brevicep8, sp. n. (p. 337), pl. x, crâne.

1838. Breschet, G. Aperçu descriptif de l'organe auditif du Marsouin (Delphinus phoccena L.). <Ann. des Sci. nat., $2^{\mathrm{e}}$ sér., Zool., x, 1838, pp. 221-229, pl. $\mathbf{}$.

$1^{\circ}$ Conduit auditif externe. $2^{\circ}$ Os tympanal. $3^{\circ}$ Cavite du tympan. $4^{\circ}$ Oreille interne ou labyrinthe.

[932.]

1838. Brown, Heinrich Georg. Lethaea Geognostica, | oder | Abbildungen und Beschreibungen | der | für die Gebirgs-Formationen bezeichnendsten | Versteinerungen, | mit | lithographirten 47 Quart., 1 Folio-Tafel und 2 Tabellen, | von | Heinrich Georg Bronn, | . . [ [=titles, 7 lines. ] | - | Zweite Auflage. | Zweiter Band, I das Kreide- und Molassen-Gebirge enthaltend. | - | Stuttgart. | E. Schweizerbart's Verlagshandlung. | 1838. 8०. 1l. 2, pp. 545-1346, 11. 2 .

Cetacea, pp. 1175-1177, pll. xliii, fig. 6. Ziphius planirostris, p. 1176, pl. xliii, fig. 6.

[933.]

1838. Gluge, [Théophile]. Sur la terminaison des nerfs.-10 Sur leur terminaison dans la peau de la baleine. <Bull. de l'Acad. roy. des Sci. et Belles-lett. de Bruxelles, v, 1838, pp. 20-25.

1838. Humboldt, Alexander von, und A. F. A. Wiegmans. Ueber den Manati des Orinoko. <Wiegmann's Arch. für Naturgesch., 1838, Bd. i, 4. Jahrg., pp. 1-10, pll. i, ii.

Aus dessen französischen Manuscripten übersetzt mit Bemerknngen vom Dr. A. F. A. Wiegmann. Sehe HuмвоLDт, A. v., Voyog. aux ríg. équinox., vi, p. 235, pll.

Detailed account of its external characters, with measurements, of the mouth parts, and some account of its digestive tract, food, and habits. Pl. i gives views of the animal in profile and from below; pl. ii, of the mouth, of the head from above and in profile, and an ideal longitudinal section of the body.

[935.]

1838. Kaup, J. J. [Ueber Zähnen von Halytherium und Pugmeodon aus Flonheim.] <Neues Jahrb. für Mineral., 1838, p. 319, pl. ii, D. figg. 1, 2, C. figg. 1, 2.

Halytherium dubium; Pugmeodon Sehinzii.

1838. KAUP, J. J. [Ueber Zähnen von Halitherium.] <Neues Jahrb. für Mineral., 1838, p. 536.

1838. "KNox, F. J. Catalogue of Anatomical Preparations illustrative of the Whale, by F. J. Knox, Conservator of the Museum in Old Surgeons' Hall. $8^{\circ}$. Edinburgh, 1838."

Not seen; title and commentary here following from Gray (Cat. Mam. Brit. Mus., pt. i, Cetacea, 1850).

"In 1828 Mr. F. J. Knox, the Conservator of the Musenm of the Old Surgeons' Hall in Edinburgh, published a catalogue of the Anatomical preparations of the Whale, in which he gives many interesting details on the anatomy of the Balcena maximus and B. minimus, which had been stranded near Edinburgh, of the foetus of B. mysticetus from Greenland, and of Delphinus Tursio (D. leucopleurus), D. Delphis and Phocana communis, Soosoo gangeticus, and Halicore Indicus; but the paper has been very generally neglected or overlooked," (loc. cit., p. 3).

"Mr. Knox (Cat. Prep. Whale) gives the best acconnt of the development, position and distinction between the baleen of the Whales of the North Sea which has come under my observation" ... (loc. cit., $p$. 7).

"But the pamphlet in which these observations were published, being a more guide to the 
1838. "Kvox, F. J."-Continued.

exhibition, has been overlooked, and I could only procure a copy last year after great trouble, and from the family of the author" (loc. eit., p. 21).

Dr. Gray makes frequent quotations from this paper, which seems to be one of consider able importance.

[938.]

1838. Meyer, IIerm. v. [Halianassa.] <Neues Jahrb. für Mineral., 1838, p. 667. Halianassa, gen. n., zwischen Halicore und Manatus.

1838. OKen, [L.]. Allgemeine | Natnrgeschichte | für | alle Stånde, | von | Professor Oken. | - | Siebenten Bandes zweyte Abtheilung, | oder | Thierreich, vierten Bandes zweyte Abtheilung. | Süugthiere 1. | - | Stuttgart, | Hoffmann'sche Verlags-Buchhandlung. | 1838. $8^{\circ}$. pp. i-viii, 689-1432.

Zweyte Stuffe. Obere Haarthiere. Vierte Ordnung. Hufthiere. [ Dio Walfische, Schweine und Rinder.] 10. Zunft. Die Wale oder Walfische, pp. 993-1115.

Historische Bemerkungen, pp. 995-1012.

A. Die fleischfressenden Wale (=Cetacea), pp. 1012-1091. a. Die Grossköpfe. I. Genus. Die Bartenwale. 1. Baloena mysticetus, pp. 1014-1036; 1 b. Nordeaper (B. glacialis, musculus), pp. $1036-1039$; 1 c. B. australis, p. 1039 ; 2. B. physalus, boops, musculus, rostrata, pp. 1039-1047.

II. Genns. Die Pottfische ... Physeter, pp. 1047, 1048. 1. Ph.'macrocephalus, pp. 1049-1058. 16. Ph. polycyphus, p. 1058.

C. Die Dünnköpfe, p. 1059. III. Genns ... Monodon, p. 1059. 1. M. monocero8, pp. 10591067. IV. Genus . . Delphinus, pp. 1067-1070. a. Die Spitzköpfe. 1. D. Delphis, p. 1070; 2. D. tursio, orca L., pp. 1070-1072; 3. D. gangeticus, p. 1072. b. Stumpf köpfe; 4. D. phocana, pp. 1072-1074; 5. D. aries, gladiator, orca, Fabr., pp. 1074-1078; 6. D. melas, globiceps, pp. 1078-1085; [\%.] D. leucas, albicans (Beluga), pp. 1085-1088; [8.] D. rostratus sive edentulus (Hyperoodon), pp. 1088-1091.

B. Die pflanzenfressenden Wale (=Sirenia), pp. 1091-1115. V. Genus . . Mranatus. 1. M. borealis (Rytina), pp. 1091-1098; 2. Manatus atlanticus, Trichechus manatus, pp. 1098-1106; 3. Die ostindische oder der Dujong (Halicore), pp. 1106-1115; 4. Dinotherium giganteum, p. 1115.

Genn. Cetac., 4; spp. 11.

The references to writers of the 15 th to the 18 th centuries are especially full, as well as to the still earlier classic authors. Only the more important species are treated at length. Several species are in some cases obviously confounded under the same specific designation.

[940.]

1838. Owen, [R.]. [On the Anatomy of the Dugong.] <Proc. Zool. Soc. Lond. 1838, pp. 28-45.

Digestive Organs, pp. 29-34; Cireulating System, pp. 34-36; Respiratory System, pp. 36-39; Uropoietic System, p. 39; Generative System, pp. 30, 40; Ossens System, pp. 40, 41; Dentition, pp. 41-43; Measurements of cranium, p. 44: external measurements and measurements of intestines, p. 45.

[941.]

1838. Serres, Marcel de. Note sur les animaux des terrains marins supérieurs découverts dans le sol immergé des environs de Montpellier. <Ann. des Sci.nat., $2^{\mathrm{e}}$ sér., Zool., ix, 1838, pp. 281-292.

Mammifères marins, pp. 285, 286. 10 Lamantins (Manatus Cnv.), $2^{\circ}$ Danphin à longue symphyse, Cuvier, $2^{\circ}$ bis. Dauphin très voisin du Dauphin ordinaire (Delphinus Delphis), p. 285; $3^{\circ}$ Dugeng (Halicore medius), $4^{\circ}$ Baleine (Baloena), $5^{\circ}$ Cachalots (Physeter), $6^{\circ}$ Rorqual, p. 286.

[942.]

1838. Thompson, Wicliam. Upon the Identity of Hunter's Delphinus bidentatus, Banssard's Hyperoodon Honfloriensis, and Dale's Bottle Head Whale. <Charlesworth's Mag. Nat. Hist., ii, 1838, pp. 221-223.

All referred to Hyperoodon honfloriensis ( $=$ H. bidens); brief account of the external characters and osteology of a specimen stranded at Hull, England.

[943.]

1838. TraIlx, [T. S.]. Ueber einige Dinge bey den Cetaceen. <Isis von Oken, 1838, pp. 46, 47 .

Anszug aus Uebersetznng aus Edinburgh New Phil. Journ., vol. xvii, 183, p. 177.

1838. Traill, [T. S.]. Ueber den Bau and die Verrichtung der Milchdrâsen der Wale. < Isis von Olen, 1838, pp. 47, 48.

Anszug ans dem Edinburgh New Phil. Journ., xvii, p. 263. 
1838. Vrolik, W. Note sur l'anatomie d'une Baleinoptère à bec (Balıenoptera rostrata) échonée au mois de septembre de l'année 1835 sur les côtes de la Hollande, près du village de Wijk aan Zeo. <Ann. des Sci. nat., $2^{e}$ sér., Zool., ix, 1838, pp. 65-77.

Description des viscères de l'animal du sese féminin.

[946.]

1838. Vrolik, [W.]. Ueber die Anatomie einer Balacnoptera rostrata, die im Septbr. 1835 an der Hollåndischen Kúste strandete. <Froriep's Neuc Notizen, vii, No. 152, Sept. 1838, pp. 304-313, 325-327.

1838. Waterhouse, G. R. Catalogue / of | the Mammalia / preserved in / the Museum | of | the Zoological Society | of London. | G. R. Waterhouse, | curator. | - | second edition. | - | London: | Printed by Richard and John E. Taylor, | Red Lion Court, Fleet Street, | 1838. $8^{\circ}$. pp. 1-68.

Order IV, Cetacea, 4 spp., including Halicore Dugong.

[948.j

1838. Waterhouse, [G. R.]. On a new Species of the genus Delphinus. <Proc. Zool. Soc. Lond., 1838, pp. 23, 24 .

Delphinus fitzroyi; external characters; measnrements by Charles Darwin. "Habitat, Coast of Patagonia, lat. $42^{\circ} 30^{\prime}$ (A pril)".

[949.]

1838. Wiegmann, A. F. A. [Ueber den amerikanischen Manati.] <iegmann's Arch. für Naturgesch., 1838, Bd. i, 4. Jahrg., pp. 10-18.

Supplement to a paper entitled "Ueber den Manati des Orinoko," by A. von Humboldt (see 1838. HUMвоLDT, A. vox), translated from French MSS. of A. von Humboldt. The trans lation is annotated by the translator. The supplement is devoted to a discussion of the number of species of Manati inhabiting the coasts and islands of $\Delta$ merica, maintaining "dass der Manati Südamerika's von denen der westindischen Gewässer specifisch verschieden ist." A paragraph is also devoted to the etymology of the word Manati.

[950.]

1838. "Zimmermann, W. T. A. W. De zee, hare bewoners en wouderen. Uit het Hoogd. Amst., 18.38. 2 dln. $8^{\circ}$.

"Zie aldaar: De walvischo en do walvischvangst. 3e stuk. bl. 120-164."

Not seen; title and reference from Bosgoed, op. cit., p. 253, no. 3614 .

1838-39. Kr $\phi$ Yer, Hexrik. Nogle Bemærkninger med Hensyn til Balænoptera rostrata. <Kroyer's Tidsskrift, ii, 1838-39, pp. 617-538, fig. in text, p. 6:7.

Synonymy, external characters (with detailed measurements), and osteology.

1339. A., M. S. Recherches sur la structure et la formation des dents des Squaloïdes. <Rev. zool., 1839, pp. 369-370.

Analyse d'un mémoire de cet titre par M. Owen, presenté à l'Acad. roy. des Sci. de Paris, séance du 16 décembre 1839.

[953.]

1839. Anov. The Natural History of the Sperm Whale, \&c. \&c. To which is added, a Sketch of a South-Sea Whaling Voyage. By Thomas Beale, Surgeon. $<$ Quart. Rev., lxiii, 1839, pp. 318-341, cuts.

review of the work, with copious extracts.

[954.]

1839. Avon. Histoire | naturelle / des Animaux | les plus remarquables de la classe des Mammitères | (Quadrupèdes et Cétacés); par | un Naturaliste du Muséum; | Ornée de soixante figures d'Animanx, | Dessinées et gravées par C. Franc, peintre d'histoire naturelle. | [Vignette.] Paris, | à la Libraire de Piété, d’Éducation, Sciences, | Arts; et Magasin d'Objets Pieux | de J. Samson, rue de Sévres, 17. 1839. 12०. 11. 2, pp. i-viii, 1-232, pl. i-xii.

Mammifères édentés. §ii. Cétacés, pp. 126-139, pl. vi, fig. 6, Dauphin, pl. vỉ, Cachalot.

[955.]

1839. Bonaparte, C. L. Prodromus systematis Mastozoologiæ Caroli luciani Bonaparte Muxiniani Principis. $8^{\circ}$. pp. 1-13.

The copy examined, although apparently complete, has neither title-page, imprint, nor date.

Ordo 4. Cete, pp. 4, 5,=Familia 9, Manatidce. Subfamilia 18, Manatina. Familia 10, Delphinidoe. Subfamilia 19, Delphinina. Subfamilia 20, Monodontina. Familia 11, Physeteridoc. Subfamilia 21, Physcterina. Familia 12, Balcenidoe. Subfamilia 22, Balcenina. Cum characteribus.

[956.] 
1839. Bruno, Giovanxi Domenico. Illustraziono di un nuovo Cetaceo fossile. <Mem. della Reale Accad. delle Scienze di Torino, ser. 2, i, 1839, pp. 143-160, pll. i, ii.

Part of skull, numerous vertebrw, ribs, etc., of a Sirenian. Chierotherium, gen. n., p. 160.

1839. Desm., E. [=? Desmarest, E.]. Stellère, Stellurus. <Dict. pittor. d'Hist.nat. et des Phénom. de la Nature, ix, 1839, livr. delxii, p. 173.

Stellurus [=Rhytina $]$ borealis.

1839. Dumortier, B. C. Mémoiro sur le Dalphinorhynque microptère échoué à Ostende. <Nouv. Mém. de l'Acad. roy. des Sci. et Belles-lett. de Bruxelles, xii, 1839. $17 \mathrm{pp} .3 \mathrm{pll}$.

Caractères externes et ostéologiques, et sur les organes internes. Pl. i, Delphinorhynque microptère, vu de côte. Pl. ii, Son squelette. Pl. iii, Appareil hyoïde, oreille osseuse, systèmo urinaire, le cour, la queue, vae en dessus.

[959.]

1839. Editors. The Natural History of the Sperm Whale. By Thomas Beale.... London, Van Voorst, 1839. <Charlesworth's Mag. Nat. Hist., iii, 1839, pp. 249-252.

Review of the work.

[960.]

1839. Harlan, [R.]. Notice sur le Basilosaure et sur le Batrachiosaure. <Ann. des Sci. nat., '2e sér., Zool., xii, 1839, p. 221.

Basilosaurus, "un noveau genre do Sauriens." Voyez 1839. Owes, R. Sur le genre Basilo saurus, Harlan.

[961.]

1839. Harlan, Richard. [Sur le Basilosaurus.] <Bull. Soc. géol. de France, $x, 1839$, p. 89.

In an abstract of a letter to M. Verneuil. Doubts Basilosaurus being a true Saurian. [962.]

1839. HarlaN, [Richard]. [Sur les affinités du Basilosaurus, etc.] <Bull. Soc. géol. de France, $\mathrm{x}, 1839$, p. 91.

[963.]

1839. Herausgeber. R. Harlan: über die Entdeckung des Basilosaurus und des Batrachiosaurus (Lond. Edinb. Phil. Mag., 1839, xix, 302). <Neues Jahrb. für Mineral., Geogn., Geol. und Petrefakt., 1839, pp. 622, 623.

Anszug.

1839. Herausgeber. R. Owen: Beobachtungen über die Zähne des Zeuglodon, Harlan's Basilosaurus ([Lond. Edinb. Phil. Mag., 1839], S. 302-307). <Neues Jahrb. jür Mineral., Geogn.; Geol. und Pelrefakt., 1839, pp. 623-626.

Auszug.

1839. Leibleis, V. Grundzüge | einer | methodischen Uebersicht | des | Thierreiches | nach seinen Classen, Ordnungen, Familie'n und | Gattungeu, nebst Aufzählung ihrer Haupt- | Repräsentanten. | - | Ein Leitfaden beim zoologischen Studium. | Von | V. Leiblein, | ... [=titles, 5 lines. ] | - Erstes Bändchen. | Der Mensch und die Säugethiere. | - | Würzburg. | In Cornmission der Stahel'schen Buchhandlung. | - 1839. <Berichte | vom | zoologischen Museum | der königlichen | Julius-Maximilians Universität | zu Würzburg, | enthaltend | eine methodische Uebersicht der Thiere | dieser Sammlung. | Vom | Conservator dieses Attribut's | Prof. Dr. V. Leiblein. | - | Erster Bericht. | Eine kurze Geschichte des zoologischen Museum's, nebst | Aufriss der Anordnung im Allgemeinen, und die | Aufzählung der Süngethiere umfassend. | - | Würzburg. | Druck der Carl Wilhelm Becker'schen Universitäts-Buchdruckerei. | - | 1839. 8०. ll. 4, pp. 1-182.

II. Wassersäugethiere. IX. Ordnung. Cetacea. Fischzitzthiere.

A. Pflanzenfressende, Herbivora. 1. Fam. Halicorea, Sirener. 2. Fam. Rytinea, Borkenwalle.

B. Fleischfressende, Carnivora. 3. Fam. Dell]phinoidea. Delphine. 4. Fam. Balaenodea, Bartenwalle.

Sirenia:-1. Manatus americanus, 2. M. Senegalensis, 3. Halicore Dugong, p. 165; 4. Rytina Stelleri, p. 167. (Between Halicore and Rhytina is interpolated the extinct genus Dinotherium.)

Cetacea:-1. Delphinus Delphis, 2. D. Phocaena, 3. D. cruciger, 4. D. albigena, 5. D. gangeticus, p. 168; 6. Oxypterus Mongitori, 7. 0. Rhinoccros, 8. Delphinapterus leucorham. 
1839. Leiblein, V.-Continued.

phus, 9. Epiodon Urganantus (Raf.), 10. Ancylodon groenlandicus (= Monodon spurius, Fabr.), 11. Monodon Monoceros, p. 109; 12. Physeter macrocephalus, 13. P. polycyphus, 14. P. Trumpo, 15. P. cylindricus, 16. Ifular (Klein) Tursio, 17. M. microps, p. 170; 18. Balaena Mysticetus, 19. Balaenoptera Physalus, 20. B. longimana, 21. B. rostrata, p. 171.

[966.]

1839. Meyer, Herm. v. [Pugneodon Sehinzii Kanp gehört zu Halianassa Studeri Meyer.] <Neues Jahrb. für Mineral., 1839, p. 77.

[957.]

1839. Meyer, Hermann v. Die fossilen Saügethiere, Reptilien und Vögel aus den Molasse-Gebilden der Schweitz. <Neues Jahrb. für Mineral., 1839, pp. 1-9.

Cetaceen, p. 4: Halianassa Studeri, H. v. Meyer, und ein ungestimmt Genus.

[968.]

1839. Mrtcheld, T. L. Three Expeditions | into the interior of | Eastern Australia; | with descriptions of the recently explored region of | Australia Felix, and of the present Colony of New South Wales: / Major T[homas]. L[ivingston]. Mitchell, F. G. S. \& M. R. G. S. | Surveyor-General. | [Vignette.] Second Edition, carefully revised. | - | In two volumes. | Vol. I [-II]. | London: | T. \& W. Boone, New Bond Street. I MDCCC XXX IX. 2 vols. $8^{\circ}$. pll. and maps.

Whale Fishery, ii, p. 241; A Whale-chase, pp. 242. 243.

[669.]

1839. Owen, R. Recherchès sur la structure et la formation des dents des Squaloïdes, et application des faits observés à une nouvelle théorie du développement des dents. <Ann. des Sci. nat., 2e sér., Zool., xii, 1839, pp. 209-220, pl. ix. [970.]

1839. Owen, R. Observations sur les dents dı Zeuglodon (Basilosaurus du Dr. Harlan). <Ann. des Sci. nat., $2^{\mathrm{e}}$ sér., Zool., xii, 1839, pp. 222-229.

Zeuglodon, gen. $\mathbf{n} .=$ Basilosaurus, Harlan.

[971.]

1839. Owen, [R.]. Ueber die Zåhne des Zeuglodon, Harlans Basilosaurus. <Isis von Oken, 1839, pp. 602-604.

Uebersetzung aus dem London and Edinburgh Phil. Mag. and Journ. Sci., xiv, April, 1839, p. 302.

1839. Owen, Richard. Ueber die Zahne des Zeuglodon, Basilosaurus des Dr. Harlan. < Froriep's Neue Notizen, x, no. 210, Mai 1839, pp. 177-182.

Aus London and Edinb. Phil. Mag., xiv, April, 1839, p. 302.

1839. Owen, Richard. Observations on the teeth of the Zeuglodon, Basilosaurus of

Dr. Harlan. <Charlesworth's Mag. Nat. Hist., iii, 1839, pp. 209-213.

From Proc. Geol. Soc. Lond., iii, 1838-42 (1839), pp. 24-28.

Shows the genus Basilosaurus to be Mammalian and not Saurian, and "proposes to substitute for the name of Basilosaurus that of Zeuglodon" (p. 213).

[974.]

1839. Richardson, William. On the Fossil Remains of Cetacea. <Charlesworth's Mag. Nat. Hist., iii, 1839, pp. 98, 99.

Account of Cetacean vertebræ from the brick earth of Herne Bay, Kent, England.

1839. Thompson, B. F. History of Long Island; | containing | An Acconnt | of the | Discovery and Settlement; | with other | important and interesting matters | to the | Present Time. | By Benjamin F. Thompson, | Counsellor at Law. | . . . [=quotation, 5 lines.] | New York: | Published by E. French, 146 Nassau Street. $1839.8^{\circ}$. pp. i-x, 11-536, 2 pll.

Whaling business of Southampton (Sag Harbor), pp. 221-224. A brief, partly statistical, account.

[976.]

1840. BAER, K. E. voN. Untersuchung über die ehemalige Verbreitung und die gänzliche Vertilgung der von Steller beobachteten nordischen Seekuh (Rytina Ill.).

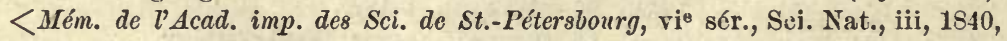
53-80.

[977.]

1840. Bennett, F. Debell. Narrative | of a | Whaling Voyage | round the Globe, | from the year 1833 to 1836. | Comprising sketches of | Polynesia, California, the Indian Archipelago, | etc. | With an Account of | Southern Whales, the Sperm Whale Fishery, | and | the Natural History of the Climates visited. | By | Frederick Debell Bennett, Esq. F. R. G. S. | Fellow of the Royal College of Surgeons, London. I In two Volumes. | Vol. I [-II]. | London: | Richard 
1840. Bennett, F. Debell-Continued.

Bentley, New Burlington Street, | Publisher in Ordinary to Her Majesty. | - | 1840. 2 vols. $8^{\circ}$. Vol. i, pp. $\mathrm{i}-\mathrm{xv}, 1-402$; vol. ii, pp. $\mathrm{i}-\mathrm{vii}, 1-395$. Map, woodcuts, and a fronticepiece plate to each volume.

Vol. i contains a Zoölogical Appendix, nearly $100 \mathrm{pp}$. of which are devoted to Cetaceans, to wit:

Chap. I. General Remarks on Whales, pp. 145-152. Chap. II. Whales of the Southern Oceans (general aud anatomical description of the Cachalot, or Sperm Whale ["Catodon ma. crocephalus, Lacep."]. its diseases, deformities, and parasites), pp. 153-170, fig. Chap. III. Natural history and habits of the Cacbalot; Geographical distribution of the species; Natural indications of its places of resort, pp. 171-183. Chap. IV. Historical notice of Sperm Whale Fishery; commereial details; equipment of ressels, etc., pp. 184-201. Chap. V. Pursuit and capture of the Sperm Whale, pp. 202-212. Chap. VI. Dangers of the Sperm Whale Fishery, pp. 213-222. Chap. VII. Commercial products of the Sperm Whale Fishery, pp. 223-228. Chap. VIII. Southern Whales (concluded), pp. 229-241.-Batcena A ustralis, Desm., pp. 2229231. Baloenoptera sp. (Humpback of southern whalers), pp. 231, 232. Phocana sp. (Black Fish of South Sea whalers), pp. 233-235, fig. Delphinus Peronii Lacép., pp. 235-237, fig. Delphinus delphis, pp. 237, 238. The Grampas, p. 238. Fin-backs, Cow-fish, and Killers, pp. 239-240.

There are also in vol. i various references to Sperm Whales' and other Cetaceans, relating mainly to their capture.

[978.]

1840. Christor, J. DE. Recherches sur divers ossemens fossiles attribués par Cuvier à deux espèces d'Hippopotames et rapportés au Métaxytherium, nouveau genre de Cétacés de la famille des Dugongs. <Rev. zool., 1840, p. 283.

Resumé par d'auteur d'un mémoire de ce titre.

1840. Christor, J. DE. Recherches sur divers ossements fossiles attribués par Cuvier à denx Phoques, au Lamantin, et ì denx espèces d'Hippopotames, ct rapportés au Metaxytherium, noveau genre de Cétacé de la famille des Dugongs. $<L^{\prime}$ Institut, 8 e ann., no. 552, 24 sept. 1840 , pp. 322, 323.

Résumé.

1840. Conrad, T. A. On the Geognostic position of the Zenglodon, or Basilosaurus of Harlan. <Am. Journ. Sci. and Arts, xxxviii, 1840, pp. 381, 382.

[981.]

1840. [Dana, Richard H., Jr.] Two Years | Before the Mast. | A / personal narrative of | Life at Sea. $|-| \ldots[=$ poetry, 6 lines. $]|-|$ New York: | Harper \& Brothers-82 Cliff Street. $|-| 1840$. 12. pp. 1-482.

Breathing of "shoals of sluggish whales and grampuses," near Falkland Islands, described, p. 36. Whales off San Pedro, Lower California, pp. 169, 170.

There are numerous later editions. In that of 1876 , the passages abore cited occur at pp. 30 and $156,157$.

[982.]

1840. Denny, Henry. Sketch of the Natural History of Leeds and its vicinity for Twenty Miles. <Ann. and Mag. Nat. Hist., v, July, 1840, pp. 382-396.

Occurrence of Delphinus Phocana and Delphinus Orca, recorded, p. 386.

1840. Editors. '[Notice of an extinct Dolphin, Delphinus karsteni, Von Olbers.] <Ann. and Mag. Nat. Hist., v, May, 1840, p. 151.

Based on a skull from near Bünde, Westpbalia.

1840. Erchwald, Ed. Notice sur l'opuscule qui a ponr titre: Le Monde primitif de la Rnssie. <Bull. de la Soc. imp. des Nat. de Moscou, 1840, pp. 473-487.

Delphinus priscus, pp. 474, 481-483.

1840. Eichwald, Eduard. Die / Urwelt Russlands, / durch Abbildungen erlæutert | von | Eduard Eichwald, | der. Phil., Med. und Chir. Dr, Akademiker und gelehrten Secretarien / der St. Petersburgischen Med. Chir. Akademie u. s. w. | Erstes Heft. | - | Aus deu Schriften der kaiserlichen St. Petersburgischen mineralogischen Gesellschaft besonders abgedruckt. | - Mit 4 lithographischen Tafeln. | - | Aus dem russichen nebersetzt. | - I St. Petersburg. | Gedruckt in der Druckerei des Journal de Saint-Pétersbourg. |-|1840. 4\%. 1l. 2, pp. 1-106, pll. i-iv.

II. Beschreibnng einiger Knochen des Ziphius priscus, pp. 25-53, pll. i, ii (Wirbelbeine, zwei Bruchstücke des Unterkiefers, ein Bruchstïck der ersteu Rippe, und Fingerknochen).

Ziphius priscus, sp. n.

[986.] 
1840. Eschricht, [D. F.]. [Over Delphinernes og Sxlluundes Karsystemer.] <Förhandlingar vid det af Skandinaviska Naturforskare och Läkare hallna Möte $i$ Göthberg år 1839 (1840), pp. 135, 136.

[987.]

1840. Gosse, P. H. The / Canadian Naturalist. | A Series of conversations / on the | Natural History of Lower Canada. | By | P[hilip]. H[enry]. Gosse. | Cor. Mem. of the Nat. Hist. Soc. of Montreal, and of the / Lit. and Hist. Soc. of Quebec. |[Vignette.] "Every kingdom, overy province, should have its own monographer." | Gilbert White. | Illustrated by forty-four Engravings. | London: John Van Voorst, 1, Paternoster Row. / M. DCCC. XL. 8०. pp. ixii, 1-3\%2.

Observations on the habits. of Delplinus canadensis ( $=B$ cluga catodon) and D. delphis at pp. 171-174.

[988.]

1840. Grateloup, [J. P. S. DE]. Description / d'un fragment de machoire fossile, | D'un genre nouvean de reptile (Saurien), de taille gigantesque, I voisin de l'Iguanodon, trouvé dans le Grès marins, à Léognan, I près Bordeaux (Gironde); | Par le docteur Grateloup. $8^{\circ}$. pp. 1-8, 1 pl. [Bordeaux, le 1 mai 1840. Imprimerie d'H. Gazay, rue Gouvion 15.]

Squalodon, gen. n., p. 8. This is the original place of description of the genus Squalodon, here regarded as Saurian, but later identified as Cetacean, and the basis of the Squalodon grateloupi, auct.

[989.]

1840. Grateloup, [J. P. S. DE]. Considérations générales sur la Géologie et lia Zoologie fussile de la commune de Léognan, près Bordeaux. Discours prononcé à l'occasion de la fête linnéenne célébrée le 25 juin 1840. <Act. Soc. linn. de Bordeaux, xi, 1840, pp. 335-346.

Squalodon, gen. n., p. 346. Also refers to the occurrence of remains "des Dauphins et autres Cétacés."

[990.]

1840. Harlan, [Ricinad]. [On the Discovery of the Basilosaurus and the Batrachiosaurus.] <Proc. Geol. Soc. Lond., i, 1840, pp. 23, 24.

Abstract.

[991.]

1840. Herausgeber. E. Eichwald: die Urwelt Russlands durch Abbildungen erlïutert, Heft I, 73 SS, $8^{\circ}$ mit 4 lithogr. Tafeln, auf Kosten der mineralog. Gesellsch. in Petersb. 1840. <Neues Jahrb. fiir Mineral., Geogn., Geol. und Petrefakt., 1840, pp. 731, 732 .

Notiz.

[992.]

1840. Herausgeber. G. D. Bruno: Beleuchtung eines neuen fossilen Cetaceum. (Mem. d. Accad. di Turino, Class. Mat. Fis. B, 1 [20 Seiten] tab. 1, 2.) $<$ Neucs Jahrb. für Mrineral., 1840, pp. 496-501.

Auszug.

1840. Herausgeber. Harlan: über einige fossile Wirbelthiere Nord Amerika, (Bullet. géol., 1839, x, 89, 90). <Neıcs Jahrb. für Mincral., 1840, pp. 741, 742.

Enthält Bemerkungen über Basilosaurus, p. 741.

[994.]

1840. Jounson, [H.]. Ueber den flaschennasigen Walfisch (Hyperoodon). <Froriep's

Neue Notizen aus dem Gebiete der Natur-und Heilkunde, xv, No. 4, Jnli 1840, p. 58.

External measurement, etc., of a specimen taken near Liverpool.

1840. Johnson, Hexry. Bottle-nosed Whale. <Ann. and Mag. Nat. Hist., v, Julys 1840, pp. 361, 35:. Communicated, with a note, by Wm. Thompson.

Description of a specimen of Hyperoadon butzkopf taken near Liverpool, Feb., 1840. [936.]

1840. KaUP, J. J. Notizen über die fossilen sogenannten Gras-fressenden Wale. $<$ Neves Jahrb. für Mineral., etc., 1840, pp. 673-676.

Gegen Christol (Ann. des Sci. nat., 1834, ii, 257) über den Caviersc'2en Hippopotamus medius und H. dubius. Synonymie von Halitherium Cuvieri Kanp und Halicore Cuvieri Christol, p. 675.

Pontotherium, gen. n. = Cheirotherium Christol, ein schon vergebenen Name. Manatus fos. silis Cuvier $=$ Pugmeodon Schinzii Kaup.

[997.] 
1840. Keyserling, A. Graf, und J. H. Blasius. Die / Wirbelthiere / Europa's. I Vou | A. Graf Keyserling und Professor J. H. Blasius. | - Erstes Buch: | Die unterscheidenden Charactere. | - | Braunschweig, | Druck und Verlag von Friedrich Vieweg und Sohn. | - | 1840. 8०. 11. 4, pp. i-xeviii, 1-248.

Systematisches Verzeichniss der Europäischen Säugethiere, pp. i-xxiv. Cetacea, pp. xxiixxiv, spp. $158-175=18 \mathrm{spp}$.

Erstes Buch. Die unterscheidenden Charactere, pp. 1-248. Sängethiere, pp. 3-75. Cetacea, pp. 72-75. Genn. 57-65, spp. 158-175. 1. Delphinorhynchus coronatus; 2. D. microp. terus; 3. D. Delphis; 4. D. rostratus; 5. D. Tursio; 6. Phocaena communis;.$P$. . Orca; 8. Ph. Melas; 9. Ph. Rissoana; 10. Ph. grisca; 11. Delphinapterus Leucas; 12. Heterodon diodon; 13. H. Desmarestii; 14. Ceratodon Monodon; 15. Physeter macroce. phalus; 16. Balaenoptera longimana; 1\%. B. Boops; 18. Balaena Mysticetus.

[998.]

1840. [Lanmax, James H.]. The American Whale Fishery. <Hunt's Merchants' Mag., iii, 1840, pp. 361-394, cuts.

An outline history of the Whale flshery as conducted in the United States, recounting its origin and progress, with an account of modes of captnre (giving cuts of the implements used), and the preparation of the products.

[999.]

1840. MEYer, Herm. v. [Ueber Halianassa-Reste.] <Neues Jahrb. für Mineral., etc., 1840, p. 587 (6 Zeilen).

1840. MeYer, HerM. v. [Ueber Cheirotherium Bruno and Squalodon Grateloup.] $<$ Ncues Jahrb. fuir Mineral., etc., 1840, pp. 587, 588.

Cheirotherium subaponninum ist Haliunassa (=Halitherium). Squalodon ist nicht ein Saurier-Genus, wie Grateloup glanbt, aber ein fleischfressenden Zetazeen.

[1001.]

1840. Nordmann, Alexander von. Voyage | dans la | Russie Méridionale | et la Crimée, I par la Hongrie, la Valachie et la Moldavie. I Exécuté en 1837, sous la direction | De M. Anatole de Demidoff, I par MM. de Sainson, le Play, Huot, Léveillè, Raffet, Rousseau, de Nordmann et du Ponceau ; | Dédí́ à S. M. Nicolas Ier, Empereur de toutes les Russies. | Tome premier [-quatrième]. | [Arms.] Paris, | Ernest Bourdin et Ce, Editeurs, | 51, Rue de Seine Saint-Germain. | - | 1840 [-1842]. 4 vols. 4\%. Vols. i, iii, 1840; vols. ii, iv, 1842. Avec Atlas in fol.

Observations sur la Faune Pontique, [par A. von Nordmann], = vol. iii, 1840.-Catalogue raisonné des Mammifères de la Faune Pontique, ibid., pp. 9-65.-Cetacea: 1. Delphinus Phoccena, p. 64. 2. Delphinus tursio, p. 65. 3. Delphinus delphis, p. 65.

[1002.]

1840. OWEN, Richard. Observations on the Teeth of the Zeuglodon, Basilosaurus of Dr. Harlan. <Proc. Geol. Soc. Lond., i, 1840, pp. 24-28.

Abstract.

[1003.]

1840. Schusz, H. Europäischen Fanna | oder | Verzeichniss der Wirbelthiere | Europa's | von | Dr. Heinrich Schinz | ... [=titles, 8 lines. ] | - Erster Band. | Säugethiere und Vögel. | - | Stuttgardt. | C. Schweizerbarts Verlagshaudlung. | 1840. $8^{\circ}$. pp. i-xxiv, 1-448.

Achte Ordung ... Cetasea (sic), pp. 90-96. 1. Delphinus Delphin (sic), p. 91; 2. Del. phinus Tursio, p. 91 ; 3. Delphinus phocaena, p. 91; 4. Delphinus griseus Cuv., p. 2 ; 5. Delplïnus Rissoanus, p. 92; 6. Delphinus globiceps, p. 92; 7. Delphinus Feres Bonnat., p. 93; 8. Delphinus Dalei, p. 93; 9. Delphinus Epiodon (=Epiodon Urganantus, Rafin.), p. 93; 10. Delphinus leucas, p. 94; 11. Monodon Monoceros, p. 94; 12. Physeter Tursio, p. 94; 13. Physeter macrocephalus, p. 95; 14. Balaena physalus, p. 95; 15. Balaena Boops, p. 96; 16. Balaena musculus, p. 96.

[1004.]

1840. Serres, Marcel de. [Note sur la découverte d'un squelette entier de Metaxytherium. ] <L'Institut, $8^{\mathrm{e}}$ anu., no. 360, 19 nov. 1840, p. 392.

[1005.]

1840. Swretixg, R. H. Dimensions and Description of a supposed new species of Balanoptera, stranded at Charmouth Beach, February 5, 1840. <Charlesworth's Mag. Nat. Hist., iv, 1840, pp. 341-343.

Baloenoptera tenuirostris, sp. n. Account of its external characters and brief notice of its skeleton.

[1006.]

1840. Sweetring, R. H. Notes relating to a female Rorqual Whale (Balanoptera boops of authors). <Proc. Zoöl. Soc. Lond., 1840, pp. 11,12. Ann. and Mag. Nat. Hist., vi, Dec., 1840, pp. 301, 302.

Brief account of external characters and osteology. Conmunicated by W. Tarrell.

[1007.] 36 G B 
1840. Sweeting, R. H. On a Species of Balænoptera stranded on Charmouth Beach. <Ann. and Mag. Nat. Hist., vi, Sept., 1841, p. 72.

Correcting errors in former communications (see Charles. Mag. Nat. Hist., iv, 1840, pp. 341-343) on the same specimen, and stating his conviction "that it is nothing more nor less" than the Rorqual, Balcenoptera boops.

[1008.]

1840. Thompson, William. Note on the Occurrence at various times of the Bottlenosed Whale (Hyperoodon Butzkopf, Lacep.) on the coast of Ireland; and on its nearly simultaneous appearance on different parts of the British coast in the autumn of 1839 . <Ann. and Mag. Nat. Hist., iv, Feb., 1840, pp. 375-381.

Account of the capture of seven individuals at different times and places, with notice of habits, dimensions, etc.

[1009.]

1840. Thompson, William. Additions to the Fauna of Ireland. <Ann. and Mag. Nat. Hist., v, March and June, 1840, pp. 6-14, 245-257.

Notice of the occasional stranding of herds of Delphinus melas, Traill, p. 6.

1840. Vrourk, W. Anatomische Bemerkungen úber den nordischen Finnfisch ( $\mathrm{Ba}$ lanoptera rostrata), welcher im Sept. 1835 . zu Wyk aan Zee gestrandet ist. $<$ lsis von Oken, 1840, pp. 370-372.

Auszug aus Tijdschrift for natuurlijke Geschiedeniss, uitgegeven door van der Hoeven en de Briese, iv, 1837.

[1011.]

1840. WrLde, - Wie das Junge der Cetaceen, wåhrend es an den Zitzen hángt, athmen kónne? <Froriep's Neue Notizen, xv, No. 316, Juli 1840, pp. 121, 122. Beantworten der Frage.

[1012.]

1840. Yarrell, W. See 1840. Sweeting, R. H., title no. 1007.

1840-45. OWEN, RICHARD. Odontographpy ; | or, a | Treatise / on the / Comparative Anatomy of the Teeth; | theirphysiological Relations, Mode of Development, | and | Microscopic Structure, in the | Vertebrated Animals. | By Richard Owen, F.R. S. | . . [ [ =titles, 2 lines.] | Volume I. | - | Texte. | [Volume II $\mid-1$ Atlas | containing one hundred and sixty-eight Plates.] | - | London: | Hippolyte Bailliere, Publisher, | Foreign Bookseller to the Royal College of Surgeons. | 219, Regent Street. | Paris: J. B. Baillière Libraire de l'Acadénie de Médecine. | Leipzig: T. O. Weigel, | 1840-1845. Roy. 80. pp. i-xx, 1. 1, pp. i-lxxiv, 1-655. Atlas, Roy. 80. pp. 1-37, pll. 1-150, + 1bis, 2bis, 62bis, 62ter, 63bis, 63ter, 64bis, 64ter, 65bis, 65ter, 70bis, 73bis, 75bis, $87 \mathrm{bis}, 89 \mathrm{bis}, 113 \mathrm{bis}$, $119 \mathrm{bis}, 122 \mathrm{bis}=168$.

Teeth of Cetacea, pp. 345-372, pll. Ixxxvii, lxxxvii A., lxxxviii, lxxxix, lxxxix A., xci-xcvii (includes Sirenia). Pl. lxxxvii, Narwhal, sknll, two examples, male and female, from below, after Home. Pl. Ixxxvii A., Baloenoptera boops ("Balcena" on plate), fig. 1, alveolar groove of foetal specimen, figg. 2-6, teeth, nat. size, from Eschricht; fig. 7, Platanista, lower jaw, and two detached teeth, the latter nat. size. PI. Ixxxviii, fig. Hyperoodon, beak from below, fig. orig.; fig. 2, Delphinus delphis, part of lower jaw, fig. orig. Pl. 1xxxix, Cachalot (Physeter macrocephahus), lower jaw and teeth, figg. orig. Pl. lxxxix, ibid., mag. sections of tooth, fig. orig. Pl. xci, Zeuglodon cetoides, mag. sectinns of tooth, figg. orig.

Sirenians, pp. 364-372, pll. scii-xcrii; Halicore, pp. 364-371; Manatus, p. 371; Halitherium, p. 372. Pl. xcii, Dugong ("Halicore indicus"), lower jaw, flg. orig. Pl. xciii, ibid., fig. 1, upper jaw ; fig. 2, part of lower jaw ; figg. 3-6, teeth; figg. from Home. P1. xciv, ibid., transverse section of molar, fig. orig. Pl. xcr, ibid., section of task, fig. orig. Pl. xcvi, figg. 1-3, Manatus americanus, teeth. PI. xcvii, Halitherium brocchii, fragment of upper jaw, part of lowor jaw, and detached teeth.

[1013.] 
Article VIII.-Descriptions of a New Species and a New Subspecies of the Genus Lepus. By J. A. Allen.

The American Museum has recently received from Mr. E. C. Thurber a specimen of a Hare, allied to but very distinct from Lepus troubridgei, collected at San Fernando, Los Angeles County, California. It may be characterized as follows :

\section{Lepus cinerascens, sp. nov.}

Type, No. $\frac{2888}{280}$, + ad., San Fernando, Los Angeles Co., Cal., March 22, 1890 ; collected by E. C. Thurber. On the label is written, by the collector, "Contained four fœtuses."

Length (head and body), $294 \mathrm{~mm}$.; tail, 24 ; nose to ear, 72 ; nose to eye, 28 (collector's measurements from the specimen in the flesh); height of ear from notch, $5^{8}$; length of hind foot (to end of nails), 63 (last two measurements from the skin).

Skull : basilar length, $48 \mathrm{~mm}$; ; total length, 62 ; greatest breadth, 29 ; breadth at postorbital construction, Io; length of nasals, 25 ; width of nasals at front border, 7 ; greatest width of nasals posteriorly, 12 ; length of lower jaw, 42 ; height of lower jaw at condyle, 27 ; length of upper molar series at alveolar border, 6 ; width of palatal shelf opposite first true molar, 9.5 ; least length of palatal shelf, $5 \cdot 5$.

Post-orbital processes very slender, not touching the brain case posteriorly.

General color above (in the spring or breeding pelage), gray mixed with blackish brown, the sides clear gray, the dorsal region pale buffy gray; lower surface grayish white, the hairs at base light plumbeous ; breast band brownish gray; nape pale brownish rusty; anterior surface of fore limbs dull yellowish brown; upper surface of hind feet white, of fore feet soiled white; sides of both fore and hind feet grayish brown; soles yellowish brown; tail dark gray above, white below with the terminal third gray; ears very thinly haired, nearly naked (the skin showing through over most of the surface, both externally and internally). brownish gray, without black at the tip or any black or white edging (probably with a narrow white fringe along the basal half of the anterior border in full winter pelage); feet scantily furred; eye enclosed by a whitish area, which broadens into a distinct spot behind the posterior canthus, and also in front of the eye.

This is a small, semidesert form, representing in the arid interior of Southern California the much larger, darker L. trowbridgei of the coast region of Central California, from which it differs in its coarse instead of soft, fine pelage, in the pale buffy gray instead of dull chestnut brown of the upper surface, and its much smaller size, $L$. cinerascens being but little more than half the bulk and weight of $L$. trowbridgei.

[October, 1890.$]$ 


\section{Lepus sylvaticus floridanus, subsp. nov.}

Type, No. $\frac{1890}{115 \frac{5}{5}}$; 9 ad., Sebastian River, Brevard Co., Fla., March 18, 1889; collected by Frank M. Chapman.

Length of head and body, $455 \mathrm{~mm}$. ; tail to end of hairs, 65 (collector's measurements from the fresh specimen); length of hind foot (to end of nails), S4; height of ear from notch, 57 (last two measurements from the skin).

Skull: basilar length, $57 \mathrm{~mm}$; total length, 72 ; greatest breadth, 44; breadth at postorbital construction, $2 \mathrm{I}$; length of nasals, 29 ; width of nasals in front, 9.5 ; greatest width of nasals posteriorly, 16 ; length of lower jaw, 58 ; height of lower jaw at condyle, 37 ; length of molar series at alveolar border, 24 ; breadth of palatal shelf opposite first true molar, ro.5.

Above mixed buffy gray and black, the black prevailing, especially posteriorly, instead of yellowish brown slightly varied with black as in ordinary L. sylvaticus; nape and the usual brown areas of the fore and hind limbs much darker rufous than in northern examples; below the white areas are grayer, and the color of the sides encroaches further upon the ventral surface; breast band broader and darker ; ears darker, more scantily haired, and more broadly edged and tipped with black; light area in front of and surrounding the eye grayish white instead of creamy white. The feet are also much less heavily furred.

A young specimen, less than one-fourth grown, shows the same dark colors as the adult, thus differing strikingly from young of the northern form of corresponding age.

The skull indicates the size to be about one-tenth less than in average northern specimens.

Specimens from Gainesville, central Florida, are darker than specimens from North .Carolina and Louisana, but are nearer the northern $L$. sylvaticus than the South Florida form above characterized. 
Article XI. - Notes on Collections of Mammals made in Central and Southern Mexico, by Dr. Audley C. Buller, with Descriptions of New Species of the Genera Vespertilio, Sciurus, and Lepus. By J. A. ALLEN.

Extracted from Bull. Am. Mus. Nat. Hist, Vol. III, No. 1. Author's edition issued December $10,1890$. 

Article XI.-Notes on Collections of Mammals made in Central and Southern Mexico, by Dr. Audley C. Buller, with Descriptions of Nere Species of the Genera Vespertilio, Sciurus, and Lepus. By J. A. Allen.

Since the publication, in October, 1889 , of my report on the first collection of mammals made by Dr. Buller in Mexico, the American Museum has received from him two additional collections, containing many species not included in his first shipment, among them several apparently new to science. To make the list complete to date, all of the species thus far received from Dr. Buller are mentioned in the present paper, those contained in the former paper being here briefly entered, with a reference to the fuller record already published.

Dr. Buller's collection of mammals numbers 238 specimens, representing 46 species and subspecies, of which seven proved new to science. Several others were new to the fauna of Mexico, and the habitats of others are extended much beyond their previously known limits. Finally, it is safe to say, Dr. Buller's collection of Mammals is one of the most extensive and important ever received from Mexico from any single collector.

In the preparation of this paper I have been greatly indebted to Dr. C. Hart Merriam, Chief of the Division of Economic Ornithology and Mammalogy of the United States Department of Agriculture, for the loan of material, and especially for the opportunity of comparing some of the obscure species of Vespertilio and Hesperomys with the types of species recently described by him from Arizona, and also with De Saussure's types of all the latter's Mexican species of "Hesperomys," fortunately just at present in Dr. Merriam's possession, De Saussure's types having been generously loaned him by the authorities of the Musée d'Histoire Naturelle de Ville de Genève for examination. I am also indebted to Mr. F. W. True, Curator of the Department of Mammals in the United States National Museum, for the opportunity of examining other authentic specimens of De Saussure's species (some of them labeled by De Saussure himself), and also the type of Dr. Coues's Hesperomys melanophrys, as well as a good series of Merida specimens of Lepus.

[December, 1890.]

[175] 
1. Ateles vellerosus Gray.-Female, skin and skull, and male, skull, Chimalăpa, 'T'ehuantepec, March 17 and 26, I89o.

2. Felis onca Linn.-Skull of a female from the coast range, below Colima, Jan. $15,1890$.

3. Felis tigrina Erxl.-An imperfect hunter's skin, without data.

4. Felis pardalis Linn.-An imperfect hunter's skin, male, Colima, Jan. 15, 1890.

5. Felis yaguarundi Desm.-Two imperfect flat skins, without data.

6. Putorius brasilianus frenatus (Stew.).-One specimen, Tepic. (See this Bulletin, II, p. 165.)

\%. Urocyon virginianus (Schreber).-One specimen (without skull), male, Santó Domingo, Tehuantepec, April 25, 189o. It is much smaller than United States specimens, and more strongly colored throughout. It doubtless represents a form well worthy of subspecific recognition.

8. Procyon lotor heruandezi (Wagler).-One specimen, a female but little more than half grown, Tehuantepec City, Feb. 28, 1890 . It agrees well with Arizona specimens in color, which differ much in this respect, as well as in size, from specimens from Eastern North America, and especially from Florida specimens.

9. Vesperugo fuscus (Beauv.).-Two specimens, males, Sierra de Colima, Jalisco, Dec. 7, I89o. (See also this Bulletin, II, p. 165.)

1899

10. Antrozous pallidus ( Le Conte).-Eleven specimens, one male and ten females, Sta. Cruz del Valle, Guadalajara, Jalisco, Sept. 7 and 8, 1889. Not appreciably different from specimens from Fort Verde, Arizona, collected by Dr. Mearns.

Not previously reported from south of the northern boundary of Mexico.

11. Plecotus (Corinorhinus) townsendi (Cooper).-One specimen, male, San Pedro, Guadalăjara, September $27, \mathbf{1} 889$.

Not previously recorded from Mexico. 
12. Atalapha cinerea (Beauv.).-One specimen, male, Hidalgo San Marcos, Tonila, Jalisco, Dec. 5, 1889. Apparently not different from California examples. (See also this Bulletin, II, p. 165.$)$

13. Yespertilio lucifugus Le Conte.-One specimen, male, Sierra de Colima, Jalisco, December 6, r889.

14. Vespertilio nitidus $H$. Allen.-Two specimens, males, Sierra de Colima, Jalisco, Dec. 6, I889. These specimens appear to be not typical, either in size or color, and their reference to this species is provisional.

\section{Vespertilio velifer, sp. nov.}

Size of $V$. albescens, with nearly the coloration of $V$. nitidus, and the ears of $V$. subulatus.

Above basal two-thirds of the fur blackish, passing into dark broccoli brown at the surface; below much paler, the surface pale buffy gray. Pelage full and soft, extending on the membranes about as in $V$. lucifugus. Ears of medium size, similar in general form to those of $V$. subulatus, but rather narrower and more attenuate at the tip, the upper posterior third distinctly hollowed, the lower third abruptly much expanded ; tragus long, rather narrow, fully or rather more than half the length of the ear, the front border nearly straight, the posterior border slightly rounded as far as a little beyond the middle, then sloping gradually to the rather narrow but rounded tip, with a distinct notch opposite the anterior base.

Wings from the base of the toes; calcaneun strongly developed; feet large ; thumb short, stout, with a rather thick claw ; tip of last caudal vertebra free.

Length of head and body (measurements from dry skin), $44 \mathrm{~mm}$.; tail, 33 ; ear from base of inner margin, I4; tragus, 9 ; forearm, 42 ; thumb, 8 ; third finger (metacarpal, 38 ; Ist phal., I3 ; 2d phal., I2 ; 3d phal., 10), 73 ; tibia, I 7 foot, II.

Skull broad, rather short; basilar length 14 ; total length, 16 ; greatest width, I0.5; lower jaw (front border to condyle), 13. First upper premolar about twice the size of the second, both placed on the inner border of the tooth row.

Type, 2696, of ad., Sta. Cruz del Valle, Guadalajara, Jalisco, Sept. 7, 1889, Dr. A. C. Buller.

Three specimens, one male and two females, and six additional skulls, Sta. Crǔ̌ del Valle, Guadalajara, Jalisco, Sept. 7 and 8 , r889.

These specimens agree very closely in size and coloration, and in all other characters, and represent an apparently new species, 
quite different from any heretofore described. Its large size readily distinguishes it from any other known Mexican or North American species of the genus, except $V$. albescens Geoffroy, which it appears to equal in size, while differing from it almost as widely as possible in coloration, and also greatly in the size and form of the ear, and in the very differently shaped tragus. Fortunately a Maximilian specimen of $V$. leucogaster Wied, a species currently synonymized with $V$. albescens (see Dobson, Cat. Chirop., pp. 326,327 ), in the American Museum, enables me to make a direct comparison of $V$. albescens with the present species.

16. Vespertilio melanorhinus Merriam.-Seven specimens, four males and three females, Sierra Nevada de Colima, altitude 7500 feet, Jalisco, Dec. 6 and 7, 1889. "Taken while drinking at a water-trough."

The series varies in color above from golden brown to dull yellowish brown, irrespectively of sex, the brightest specimens, and also the darkest, including both males and females.

The series has been compared with the type of $V$.melanorhinus, to which the specimens seem distinctly referable.

17. Saccopteryx plicata (Peters). - This rare species, originally described from a Costa Rican specimen, and only once before reported from Mexico ( $c f$. Alston, Biol. Centr.-Am., p. 29), is represented by two skins (males), and eleven specimens in alcohol, collected at Tehuantepec, Feb. 12, 1890. Of the thirteen specimens nine are males and four are females. In the latter the wing sac is rudimentary.

18. Nyctinomus brasiliensis $I$. Geoffr. -Nine skins and skulls and eight additional skulls, about equally divided between males and females, all from Sta. Cruž del Valle, Guadalajara, Oct. 5, r889, except two, taken at San Pedro, Guadalajara, Oct. I6, I889. There appears to be no sexual variation in size.

The length of the forearm varies from 39 to $43 \mathrm{~mm}$., averaging 41.3. Traces of a gular pouch are distinctly seen in four of the five males, but there is no indication of it in any of the four females.

19. Pteronotus davyi Gray.-One specimen, male, Plains of Colima, Jan. 15, 1890. 


\section{Macrotus bulleri $H$. Allen.}

Macrotus californicus J. A. Allen, Bull. Am. Mus. Nat. Hist., II, No. 3, p. I66 (Oct. 21, 1889).

Macrotus bulleri H. Allen, Proc. Am. Phil. Soc., XXVIII, p. 73 (April I4, I890).

Five specimens (skins), three males and two females, and an additional skull, San Pedro, Guadalajara, Sept. 27, r889. These are additional to the eleven specimens already recorded from Bolaños (1. c.), and provisionally referred to $M$. californicus.

The series from Bolaños, Northern Jalisco, were taken in July; the series from Guadallajara, Central Jalisco, were collected in September. There is no appreciable difference in coloration in the two series. Above the color is nearly uniform dark plumbeous, with the basal half of the fur pure white; below the color is much lighter and more grayish. The length of the forearm varies from 42 to $48 \mathrm{~mm}$., averaging 45 .

On sending the Bolaños specimens to Dr. H. Allen, the wellknown specialist in Chiroptera, some time after the publication of my paper on Dr. Buller's first collection of Mexican mammals, Dr. Allen found them to be specifically different from $M$. californicus, and later described them as above cited.

\section{Macrotus mexicanus De Saussure.}

Macrotus mexicanus De Saussure, Rev. et Mag. de Zool., $2^{\mathrm{e}}$ Sér., XII, 1860, p. 486.

? Macrotus bocourtianus Dobson, Ann. \& Mag. Nat. Hist., 4th Ser., XVIII, 1876, p. 436 ; Cat. Chirop., 1878, p. 467.

Eight skins with skulls, eight additional skulls, and six specimens in alcohol, Tehuantepec City, Jan. 27, I890.

This series of fourteen specimens differs strikingly in respect to coloration from the series of thirteen specimens from Bolaños and Guadalajara, State of Jalisco, but not appreciably in any other external feature. In both forms the basal half or two-thirds of the fur of the dorsal surface is pure white passing gradually into the darker color of the terminal portion, with the extreme tips of the hairs grayish. In bulleri the terminal third or more of the fur is dark plumbeous, varying from dark clove brown to plumbeous black; in mexicanus it is dark brown, varying from pale cinnamon to dusky chestnut. The same tints prevail respec- 
tively below in the two forms, where, however, the basal white zone is more restricted, the dark subterminal portion is less deeply colored, and the gray tips of the hairs are longer. In bulleri the ears and wing-membranes are blackish; in mexicanus they are brown. The difference in the general coloration of the two forms is thus very striking, with no tendency to intergradations, so far as the material in hand is concerned.

A comparison of the skulls shows well-marked cranial differences between the two forms, the skull in $M$. mexicanus being much the larger, with the rostral portion much broader, and quite different in general contour.

The type of De Saussure's $M$. mexicanus came from Yautepec, in the tierra caliente south of the City of Mexico, and hence from a region physiographically very different from that inhabited by $M$. bulleri. His description appears to agree perfectly with the Tehuantepec specimens above referred to $M$. mexicanus.

$M$. mexicanus, $M$. bulleri, and $M$. waterhousii ( $M$. californicus is not at hand for comparison), differ very markedly from each other in coloration, but only slightly in size or other external features. The ears appear rather larger in both $M$. waterhousii and $M$. bulleri than in $M$. mexicanus. $M$. waterhousii seems also to be slightly the largest of the three forms, and $M$. bulleri the smallest, the length of the forearm varying as follows : $M$. bulleri, 42 to $48 \mathrm{~mm}$., averaging $45 ; M$. mexicanus, 48 to 53 , averaging 5 I $M$. waterhousii, $5^{\mathrm{I}}$ to 53 , averaging 52 . In coloration $M$. buller $i$ is much the darkest and $M$. mexicanus the lightest and most rufescent, especially below. $M$. waterhousii is intermediate, being darker and less rufescent than $M$. mexicanus, but not nearly so dark above as $M$. bulleri, though of about the same tint below. $M$. waterhousii, however, differs from both the others in having the posterior third of the dorsal surface lighter and of a decided yellowish brown, in contrast with the sooty grayish brown of the rest of the dorsal surface, while in the others the whole dorsal region is concolor.

The length of the free portion of the tail varies in all; while generally only the last caudal vertebra is wholly free, not unfrequently half or more of the autepenultimate is also free. This is notably the case in both $M$. waterhousii and $M$. mexicanus. It 
hence seems not improbable that $M$. boucourtianus, from Vera $\mathrm{Paz}$, based mainly on this last feature, may be referable to $M$. mexicanus.

22. Sturnira lilium (E. Geoffr.).-One specimen, Sierra Nevada de Colima, Jalisco, Dec. 6, I889.

This is apparently the first record for this species from any point north of Honduras and Costa Rica.

\section{Artibeus carpolegus Gosse (?).}

Artibeus jamaicensis De Saussure, Rev. et Mag. de Zool., I86o, p. 438. Artibeus perspicillatus Alston, Biol. Centr.-Am., Mam., 1879, p. 47 (Mexican and Central American references).

Two specimens, male adult in alcohol, and female adult, skin, Santo Domingo, Tehuantepec, May, 1890 . (For remarks on these specimens see this Bulletin, antea, pp. I70-I 72 .)

\section{Sciurus aureogaster $\mathrm{Cuv}$.}

Sciurus aureogaster F. Cuvier, Hist. des Mam., III, liv. lix, I829; Allen, N. Am. Roden., 1877, p. 700 ; Bull. U. S. Geol. Surv., IV, 1878, p. 882 (in part).

Sciurus variegatus Alston, P. Z. S., 1878, 660 (in part-the "aureogaster type" only) ; Biol. Centr.-Am., Mam., I880, p. I27 (in part, not the figure, pl. xi).

Two skins with skulls and one additional skull, Sarabia, Tehuantepec, Mexico, April I9, I89o.

These are very red examples of this form, the whole ventral surface being not only deep orange red, but the same color extends high up on the sides of the body and across the shoulders, so as to occupy the whole thoracic region from the nape to beyond the scapulæ, and including also both fore and hind limbs, except the feet, which are dark gray more or less mixed with dark red. The rest of the dorsal surface is varied with dark rufous, black, and white, the hairs being tipped with white, then ringed narrowly with black, and then broadly banded with deep chestnut red.

In Mr. Sennett's six specimens from near Tampico, to which I have previously referred (Bull. Am. Mus., II, p. I66), the hairs of the dorsal surface are much more broadly tipped with white, and the red of the ventral surface, while extending far up over the shoulders and covering the fore limbs, scarcely reaches the median dorsal line. It is worthy of note that Mr. Sennett's 
specimens were taken in May, and that among them is a suckling, apparently only a few days old, which has the same pattern of coloration and about the same tints as the adults. These specimens of course represent the summer or breeding pelage.

\section{Sciurus leucops (Gray).}

Sciurus aureogaster Geoffroy, Voyage de la Venus, Zool., I855, p. I56, pll. $\mathrm{x}$, xi (not $S$. aureogaster F. Cuvier, 1829).

Macroxus leucops Gray, Ann. and Mag. Nat. Hist., 3d Ser., XX, I867, p. 427. Sciurus leucops Allen, N. Am. Roden., 1877, p. 753.

Sciurus variegatus Alston, P. Z. S., 1878, p. 660; Biol. Centr.-Am., Mam., 1880, p. 127, pl. xi (the "leucops type" only).

Six skins and skulls, Tehuantepec City, State of Oaxaca, Feb. 3 to March 9, I890.

These specimens appear to typically represent the Macroxus leucops of Gray, described from "Oaxaca." The material now before me, taken in connection with that previously examined, leads me to resume the position I took in 1877 (N. Am. Roden., pp. 750-756) regarding the status of the forms then recognized as $S$. aureogaster and S. leucops, from which I have since wavered, in deference to Mr. Alston's conclusions. $†$ The pattern of coloration in the two forms is very different, in leucops there being always a well-defined nuchal patch of rufous, and generally another rufous area on the rump, the latter, however, sometimes absent. While the color of the ventral surface may vary from pure white, through buff and pale yellow to golden and even orange rufous, it does not extend up the sides of the body at the shoulders, nor encroach upon the outer surface of the limbs, as in aureogaster, the line separating the colors of the dorsal and ventral surfaces being a straight line at the usual point in other mammals having the two surfaces differently colored. The skull, while of nearly the same size in the two forms, is much heavier and stronger in aureogaster, with the first premolar much larger and the dentition much heavier.

The six specimens from Tehuantepec City vary considerably in color above, and greatly in the color of the ventral surface. All have a large fluffy conspicuous white patch behind the ear (possibly disappearing later in the season). 'The nuchal patch is 
strongly developed (about two inches long and nearly as broad), varying in color, however, from rather pale rufous mixed with gray to deep clear ferrugineous. The rump patch is less strongly colored, less clearly defined, and in two specimens is quite obsolete. The ventral surface in two specimens is grayish white; in a third faintly washed with buff ; in a fourth deep yellowish buff; in a fifth orange rufous, and in the sixth deep orange rufous.

\section{Sciurus cervicalis, sp. nov.}

Sciurus aureogaster leucops Allen, Bull. Am. Mus. Nat. Hist., II, Art. XVI, Oct. 21, 1889, p. I66 (excluding synonyms).

Eight specimens, as follows : Sierra Nevada de Colima, Jalisco, Dec. I-I I, r889, six specimens; Hacienda San Marcos, Volcán de Fuego, Tonila, Jalisco, Dec. 30, 1889, one specimen ; Plains of Colima, Jan. ro, 1890 , one specimen. These with four previously received and reported upon (1. c.) form a series of $\mathrm{r} 2$ specimens, collected during the months of December, January, April, and May. The series is remarkably uniform as regards coloration, in this respect May and December specimens being indistinguishable, while the range of individual variation is astonishingly narrow, and is covered by the remarks on the four specimens in my former paper on Mexican Mammals (1. c.).

In comparing the first four examples with a series of Tampico specimens of S. aureogaster I said, "it seems hardly possible that the two forms should be considered as conspecific, the style of coloration being so radically different.... In view, however, of former experience in respect to the variability of Mexican Squirrels, especially in color, it seems probable that Mr. Alston's view that the S.leucops is only a form of S. aureogaster Cuv., occupying a distinct habitat of its own, is correct."

I then reluctantly identified this form with $S$.leucops, under the name $S$. aureogaster leucops, noting, however, that it differed from any leucops specimens I had previously examined. I have since (thanks to Mr. Buller's excellent work) received specimens of true leucops from near the type locality, and also additional specimens of aureogaster. This new material shows that not only are leucops and aureogaster very distinct forms, each with its own habitat, but that the specimens from Jalisco then referred to leucops repre- 
sent still another form very different from either. This may be characterized under the name above given, as follows :

Top of head black, generally varied more or less with gray, through the gray tipping of some of the hairs; general color above dark gray, the hairs plumbeous at base, subterminally broadly ringed with black and narrowly tipped with white; a broad nuchal patch, extending generally from the hinder portion of the crown to the shoulders, and more or less on to the sides of the neck, yellowish rufous varied with black, the hairs here being tipped with rusty instead of white ; a very broad area of the same color as the nuchal patch covers the lower back and rump, extending from a point opposite the hips to the base of the tail, and across from one hip to the other. (These patches vary somewhat in size and in the tone of the rufous, which varies from yellowish rusty to brownish rusty. In one specimen these patches are quite pale, and in another nearly obsolete, but in the other ten are conspicuously developed.) Below pure white, in summer pelage (May specimens) the hairs being pure white to the base, in winter specimens with the basal portion ashy. The tail, both above and below, is black, washed heavily with white, the hairs of the upper surface being generally wholly black from near the tip to the base, with a long white tip, those of the lower surface white at the extreme base, then narrowly ringed with black, followed by a narrow band of white, and this with a broad band of black and a long white tip. Feet varying from nearly pure white to grayish white; ears gray varying to blackish, generally more or less tinged with rusty, with a white woolly patch at the posterior inner base, well developed in winter specimens.

Measurements. - Head and body, $250 \mathrm{~mm}$. ; tail, 330 ; total length, 550-600 $\mathrm{mm}$. (collector's measurements). Hind foot, $60-63$; height of ear from crown, I 8-20 (from skin).

Type, No. I991, Hacienda San Marcos, Tonila, Jalisco, ô ad., May I4, I889.

Summer and winter specimens appear to differ only in the pelage in winter being longer and softer than in summer, the fluffy white post-auricular patches better developed, and in the white of the ventral surface being somewhat grayish, from the basal portion of the pelage being ashy.

While both $S$. leucops and $S$. cervicalis have generally distinct rufous nuchal and rump patches, they are very different in the two forms, not only in color but in the position occupied by the rufous portion of the hairs composing these patches. In S. cervicalis the rusty tint is restricted to the tips of the hairs, and simply replaces the gray tipping of the hairs on the rest of the dorsal surface ; in $S$. leucops the tips of the hairs of the rump patch are gray, the rufous occupying the subterminal instead of the terminal color zone of the hairs, while in the nuchal patch the rufous occupies all but the extreme base of the hairs. In other words the subterminal color zone in cervicalis is black; in leucops rufous. 
Furthermore, in cervicalis the only rufous tint present is the tipping of the hairs of the nuchal and rump patches, while in leucops it more or less deeply suffuses the whole sub-apical portion of the dorsal pelage.

S. cervicalis ranges from the Plains of Colima (to which, according to Dr. Buller, it migrates in winter) up to the summits of the neighboring Sierras, some of the specimens being labeled as taken at an altitude of $\mathrm{r} 2,000$ feet, while $S$. leucops and $S$. aureogaster both come only from the tierras calientes of eastern and southeastern Mexico. These two occur together, however, in the neighborhood of Tehuantepec, as shown not only by the present collection, but by material which passed through my hands in 1876 . Then, as now, I considered them distinct species.

Probably $S$. cervicalis has, like the next species, a rather restricted distribution, the specimens received from Dr. Buller being all from the mountains of Colima, except one taken in January, on the plains at the base of the Sierra.

\section{Sciurus nayaritensis Allen.}

Sciurus alstoni Allen, Bull. Am. Mus. Nat. Hist., II, No. 3, Art. XVI, Oct. 21, 1889, p. I67 (not $S$. alstoni Anderson, I878).

Sciurus nayaritensis AlleN, Bull. Am. Mus. Nat. Hist., II, No. 4, Feb. I8go. p. vii.

No specimens have been received since those already described (1. c.). Attention, however, should be called to the change of name, published Feb., 1890 , in "Additions and Corrections" to Volume II of this Bulletin, that originally given proving to be preoccupied.

28. Spermophilus grammurus macrourus (Bennett).Three specimens, male and female adult, and a young (half-grown) female, Zapotlan, Jalisco, Dec. I3, I7, and 23, I889. (See also this Bulletin, II, p. I70.) These scarcely differ from the four April specimens previously recorded, although taken at the opposite season of the year. They bear out all that was claimed for this subspecies in my former paper.

29. Spermophilus spilosoma Bennett. - Two specimens, Zacatecas. (See this Bulletin, II, p. I72.) 
30. Spermophilus annulatus $A u d$. \&'Bach.-In addition to the single specimen recorded in my former paper (this Bulletin, II, p. I72), Dr. Buller has sent eight others, two males and six females, and three additional skulls, collected at the Hacienda Nogueras, Colima, Nov. I $3^{-15}, 1889$.

Dr. Buller adds to his former notes as follows: "Local name, Tesmo. Said not to occur above Ranch 'El Trapiche,' on road between Colima and Tonila. Below Colima ranges to the base of coast range, to where sand commences. Lives in holes in sides of dykes. Also in stone walls and walls of barns, in the vicinity of habitations. Food, maize, and seeds of Pasta Christi."

The extremes of the series vary somewhat in depth of color, the light tipping of the hairs of the dorsal surface varying from buff to yellowish rufous, with corresponding differences in the intensity of color of the sides of the neck, limbs, and ventral surface.

\section{Tamias bulleri Allen.}

Tamias asiaticus bulleri Allen, Bull. Am. Mus. Nat. Hist., II, No. 3, Art. $\mathrm{XVI}$, Oct. 2I, I889, p. I73.

Tamias bulleri Allen, ibid., III, No. I, Art. IV, June, I89o, p. 92.

Eight specimens, Sierra de Valparaiso, Zacatecas (see this Bulletin as cited above). The later collections contain no additional specimens.

32. Mus rattus Linn.-Two adult males, Zapotlan, Jalisco, Dec. I7 and 21 , I889. (See also this Bulletin, II, p. I79.)

33. Mus alexandrinus $E$. Geoffr.-One adult male, Zapotlan, Jalisco, Dec. 20, I889.

34. Mus musculus Linn. - Four specimens, Tehuantepec City, Feb. 12 and May 12, 1889. 1590

35. Neotoma ferruginea Tomes. - Four specimens : three females, Tehuantepec City, Feb. 27 and 28 ; one male, Santo Domingo, Tehuantepec, April 25, I89o.

\section{Sigmodon hispidus berlanderi (Baird).}

Hesperomys (Deilemys) toltecus DE SAussure, Rev. et Mag. de Zool., $2^{\mathrm{e}}$ Ser., XII, 1860, p. 98.

Four specimens, Colima Plains, Jan. 5-I I, 1890; one specimen, Santo Domingo, Tehuantepec, May I, 1890. 
These specimens seem to be indistinguishable from De Saussure's types of his Hesperomys toltecus, from the "Cordilière de la province de Véra Cruz," which, through the kindness of Dr. C. Hart Merriam, I have had an opportunity to examine.

37. Sigmodon fulviventer Allen.-One specimen, Zacatecas. (See this Bulletin, II, p. I80.)

38. Hesperomys leucopus sonoriensis (Le Conte).-See this Bulletin, II, p. I80.

39. Hesperomys aztecus De Saussure. - Two specimens, Jalisco. (See this Bulletin, II, p. I79.)

A comparison of these two specimens (shown by the skulls to be not fully mature) with two of De Saussure's three original specimens of this species, shows their former reference to $H$. aztecus to have been correctly made. They are a little smaller than De Saussure's specimens, but agree with them almost exactly in color and in all external details.

\section{Hesperomys melanophrys Coues.}

Hesperomys mexicanus Allen, Bull. Am. Mus. Nat. Hist., II, p. 179 (not $H$. mexicanus De Saussure).

The single specimen, from Zacatecas, formerly reported (1. c.), has since been compared with De Saussure's type of $H$. mexicanus and found to be very different. On the other hand, it agrees well with the type of Coues's $H$. melanophrys, to which species it is now referred. $H$. mexicanus and $H$. melanophrys prove on comparison to be very different species.

41. Hesperomys (Nyctomys) sumichrasti De Sauss.-Five specimens, three adult males, one adult female, and one immature female, Santo Domingo, Tehuantepec, April 24 to May I, 1890. The young specimen differs from the adults in being yellowish ashy above instead of golden cinnamon.

These specimens have been compared with De Saussure's types (see above, p. I75), with which they strictly agree.

42. Oryzomys conesi (Alston).-One specimen, adult male, Hacienda San Marcos, Tonila, Jalisco, Dec. 30, I889. 
43. Lepus sylvaticus aztecus, subsp. nov.

Smaller than L. sylvaticus of the Eastern States, with much longer ears (in this respect resembling $L$. arizonce), and lighter in coloration.

Length (measurements from skins) of head and body, $300 \mathrm{~mm}$. ; tail to end of hairs, 37 ; length of hind foot, 82 ; height of ear from notch, 64 .

Top of head and middle of back buffy cinnamon varied with black, the hairs light plumbeous at base, subterminally ringed with pale buffy cinnamon and tipped with black ; sides gray, the hairs ashy at base, broadly ringed with white and tipped with black; sides of neck brownish, nearly like the middle of the back ; large nape spot and outer surface of limbs bright yellowish rufous; upper surface of fore feet yellowish white, of hind feet pure white, which extends upward in a narrow band along the inner anterior edge of the leg to the inner side of the thigh; lower surface pure white, nearly to the base of the hairs; breast band yellowish white, the hairs brownish beneath the surface; a well defined supra- and subocular grayish white stripe, meeting in front and behind the eye, giving the effect of a broad grayish white band through the eye, from near the nose to the base of the ear ; cheeks gray, with a small spot of rusty brown below the eye ; upper surface of the tail light cinnamon rufous, the same color extending forward on to the rump, the hairs plumbeous (in some specimens dusky plumbeous) at the base broadly tipped with light rufous. Ears very large, scantily haired, dark brownish gray, darkening to blackish towards the tip and along the anterior border externally; anterior border towards the base fringed externally with white.

Cranial Characters. - Skull, basilar length, $56 \mathrm{~mm}$.; total length, 72 ; breadth at middle of zygomatic arch, 35 ; at base of occiput, 23, at postorbital constriction, 12 ; nasals, length, 33, breadth at anterior border, Io, at posterior border, I7; length of malar bone, 31 ; length of upper molar series along the crowns, I2, at alveolar border, I4; lower jaw, length from front to angle, 53, height at condyle, 36 .

The posterior end of the postorbital process is in contact with the brain-case, but not fused with it. In general features the skull is similar to that of L. sylvaticus, differing from it merely in being rather smaller than average northern skulls.

Type, $\frac{3116}{2438}$, of ad., Tehuantepec City, Feb. 19, 1890 .

Three adult males, skins and skulls, and one additional skull, as follows : Salina Cruz, Feb. 17, Sta. Maria Petapa, April 29, Santo Domingo, April 30, I89o, Isthmus of Tehuantepec; Tehuantepec City, Feb. I9, I89o.

This form differs from L. sylvaticus in having the middle of the dorsal surface much paler, the sides grayer, and the upper surface of tail and rump cinnamon rufous instead of dusky gray, and in the very much larger size of the ears. In respect to the size of the ears it closely resembles $L$. arizonce, but differs from it in much larger size, and greatly in coloration, through the almost entire absence in the latter of any rufous in the coloration of the upper surface. 


\section{Lepus insolitus, sp. nov.}

Similar in general appearance externally to Lepus sylvaticus, but much paler in color, much larger, and with much larger ears, but especially different in the structure of the malar bone, which is exceptional in its character. Also generally similar in size and color to $L$. verce-crucis Thomas, recently described from Vera Cruz, but apparently different.

Length (of skin), $440 \mathrm{~mm}$. ; tail to end of hairs, 40 ; hind foot to end of claws, 92 ; height of ear from notch, 74 , above crown, 78 .

Above sandy buff mixed with black, more grayish on the sides, black prevailing over most of the dorsal region, hairs at base dark plumbeous, ringed with black, then with sandy buff, and tipped with black; nape patch and fore limbs externally from shoulder to carpus deep rufous ; upper surface of fore feet brownish yellow; hind limbs posteriorly and externally yellowish brown; upper surface of hind feet white, continuous with a whitish band running up the front inner edge of the leg; light area surrounding the eye buffy gray; upper surface of tail and contiguous portion of rump pale rusty brown, the hairs plumbeous at extreme base and slightly black tipped; ears sparsely haired, externally rusty brownish gray, blackish along the edge towards and at the tip ; internally ears naked to near the tip, where they are sparsely covered with yellowish brown hairs for the terminal fifth ; ventral surface pure white, the hairs wholly clear white to the base; a faint wash of yellowish along the sides bordering the white ventral area; breast pale yellowish brown, plumbeous beneath the surface. Feet not heavily furred.

Skull, basilar length, $66 \mathrm{~mm}$. ; total length, 83 ; greatest width (opposite anterior end of orbital foramen), 39 ; interorbital breadth, 2I ; intertemporal breadth, 20.5 ; nasals, length, 34 , width anteriorly, 12 , posteriorly, 18.5 ; length of malar bone, 36 ; length of palatine foramen, 21 ; least length of palatal bridge, 8 , width, II.5 ; length of upper molar series at crown surface, 22.5 ; length of lower jaw, 58 ; height at condyle, 40.

Type, $\frac{2655}{213}$, s ad., Plains of Colima, Jan. 15, 1890.

A second specimen ( $q$ ad., near City of Colima, Jan. 7, I890), agrees essentially in size, but is in thin, very worn pelage, and is less black above, doubtless owing to the wearing away of the long black tips of the hairs.

While in a general way strongly resembling externally both $L$. sylvaticus and $L$. verce-crucis, it differs from the former in much larger size, disproportionately larger ears, the less amount of rufous and greater prevalence of black above; and from the latter in the whiteness of the ventral surface, and in other minor details of coloration. It differs from all of the species of Lepus known to me in the peculiar structure of the malar bone, which is formed on the general pattern of that of Lepus aquaticus, with, however, its peculiarities greatly exaggerated. Externally for its anterior 
half both the upper and lower borders are greatly produced, especially the lower, which is somewhat everted or deflected upward and incurved, the two produced borders thus forming between them a deep groove on the external surface of the anterior half of the malar bone, the groove being deepest anteriorly and there partly covered by the incurved lower edge of the malar. The square process occupying the anterior fourth of the malar in the L. sylraticus group is in effect extended backward, gradually narrowing till it becomes obsolete posterior to the middle of the malar bone. The form of this bone is thus very different in the two species when viewed either from below or from the side. The postorbital processes touch the brain-case at tip but are not fused with it, as in the L. aquaticus group.

In accordance with the great development of the external ear, the auditory bullæ are correspondingly enlarged.

The only species with which this needs comparison is apparently the Lepus verce-crucis, from the opposite coast of Mexico.

45. Tatusia novemcincta (Linn.).-Male, Volcan de Fuego, Tonila, Jalisco, Dec. 27, I889.

\section{Didelphys (Micoureus) murina Linn.-Six specimens,} four males and two females, Santo Domingo de Guzman, Tehuantepec, April 25 to May 2, 1890.

These specimens are doubtfully referred to this species, which they resemble in size. None of them, however, have the general color above "bright rufous," or "deep dull rufous," as described respectively by Alston and Thomas. Some are clear ashy, others ashy brown, with a very faint fulvous or exceedingly slight rufescent tinge.

Additional Notes on Mexican Leporidre--Since the above was put in type I have had opportunity, through the kindness of Mr. F. W. True, Curator of the Department of Mammals in the United States National Museum, of reëxamining specimens of Lepus from Merida, Yucatan, and Mirador, Mexico, referred by me in 1877 (N. Am. Roden., pp. 365 and $36 \mathrm{I}$ ) respectively to Lepus aquaticus and L. palustris. 


\section{Lepus sylvaticus aztecus Allen.}

Five adult and two young specimens of Lepus, belonging to the U. S. National Museum, from Merida, Yucatan, collected by Dr. A. Schott in February and. March, 1865 , were formerly referred by me (N. Am. Roden., pp. $365-367$ ) to Lepus aquaticus. Three of these specimens are now before me, and while externally much resembling $L$. aquaticus, a skull, now for the first time removed from one of the skins for examination, shows that they are not $L$. aquaticus but referable to my $L$. sylvaticus aztecus, described on page 188 of the present paper, with which these specimens are found to agree in both external and cranial characters. The skins were badly prepared and somewhat overstuffed, and without recourse to the skull might readily be mistaken for $L$. aquaticus, the coloration being nearly the same, and the feet very scantily furred for a member of the L. sylvaticus group. Other specimens collected at Mirador, by Dr. Schott, and forming part of the same collection, were referred by me to $L$. sylvaticus, as were specimens from 'Tehuantepec, collected by Mr. F. Sumichrast (1. c., pp. 330 and 336). The latter series included a number of skulls, which served for the ready identification of the Tehuantepec series. Although these specimens are not now accessible for reëxamination, I have little doubt of their being referable tō the form here recognized as L. sylvaticus aztecus. A part of the Orizaba specimens are referable to the following species:

\section{Lepus veræ-crucis Thomas.}

Lepus vera-crucis Tномаs, P. Z. S., I89o, p. 74, pl. vii.

Lepus aquaticus Allen, N. Am. Roden., 1877, p. 364 (in part, Orizaba specimens only).-Alston, Biol. Centr.-Am., Mam., p. I80 (Dec. 1880), in part, or so far as based on the preceding.

A reëxamination of the Orizaba specimens referred by me in I 877 (1. c.) to L. aquaticus shows, on removal of the skull from the skin, that they belong to the L. sylvaticus type instead of to L. aquaticus. I have little doubt that they are identical with what Mr. Oldfield Thomas has recently described as Lepus vera-crucis, based on specimens from Las Vigas, Jalapa, a locality not far from Orizaba. In general size and in external characters it closely resembles my $L$. insolitus, described above, but the skull 
is very much broader, and the form of the malar bone very different. Both species somewhat resemble L. aquaticus externally, but are readily separable from it and from each other by the cranial characters.

\section{Lepus truei, sp. nov.}

? Lepus palustris Tomes, P. Z. S., I861, p. 281 (Dueñas, Guatemala).

Lepus palustris Allen, N. Am. Roden., I887, p. 360 (in part, the Mirador specimen only).-Alston, Biol. Centr.-Am., Mam., p. I79 (Dec. I880), so far only as based on the above.

In 1877 a single specimen of Lepus from Mirador was referred by me (1. c.) to Lepus palustris. This was the only specimen thus referred, or then known to me, from any point outside of South Carolina and Georgia. Florida has since been added to its known range, but it has not yet been found at any point in the Gulf States west of Florida, where considerable collecting has since been done. Hence the single record from so remote a point as Mirador, Mexico, has of late seemed open to serious question. I am hence much gratified to be able to revise the record by a reëxamination of the Mirador specimen. It is in poor condition, but is still available for study. The skull having just now been removed by my request, it proves to represent a very distinct type of the genus, so far as cranial characters are concerned. Externally it so much resembles L. palustris, that on seeing it again after a long interval the question arose as to whether its alleged Mirador origin might not have resulted from a transposition of labels. As soon, however, as the skull became available it was evident that the resemblance of the Mirador specimen to $L$. palustris was wholly superficial, and limited to external characters. It differs, however, somewhat from L. palustris in coloration, as stated in my former reference to it, as follows: "By far the most highly-colored specimens is one from Mirador (near Vera Cruz), Mexico, in which the black is considerably more prevalent than in average specimens from the Atlantic States. The grayish area below is also more restricted and more suffused with brownish." Mr. Alston quotes this (1. c.), and adds : "The same remarks apply to an example contained in Mr. Salvin's Guatemalan collections in the British Museum," the specimen here referred to being the one mentioned by Tomes (l. c.), from 
Dueñas. These two specimens are apparently all thus far referred to L. palustris from Mexico or Central America, or from any point outside of the lowlands of the coast region of South Carolina and Georgia, and the peninsula of Florida.

In now describing this new form, it gives me pleasure to name it in honor of the Curator of Mammals at the U. S. National Museum, to whose kind offices I have been many times indebted.

Similar to L. palustris in all external characters, except that it is rather darker in color, and much more varied with black above, which is almost the prevailing tint over much of the dorsal region. Feet quite as scantily furred as in $L$. palustris. The skin is unfilled, and hence satisfactory measurements cannot be taken. (The feet have been partially denuded by insects.) It is evidently smaller than average full grown specimens of $L$. palustris. Length of hind foot, $75 \mathrm{~mm}$. ; of fore foot, 40 ; height of ear from crown, 54 ; from notch, 46.

Cranial Characters. - The skull is imperfect, lacking most of the occipital portions. It shows the animal to have been fully adult. In dorsal outline it much resembles skulls of $L$. sylvaticus aztecus, except that the cranial portion is more depressed posteriorly ; the frontal and parietal bones much pitted, as in $L$. palustris and L. aquaticus. The postorbital processes are slender, and barely touch the cranium posteriorly, thus enclosing a large broadly oval foramen. The zygoma is broad and short, flattened below anteriorly and not much expanded, with the sinus on the lateral face anteriorly about as in L. sylvaticus. The zygomatic and mastoid portions are vertically much expanded, the zygoma being thus much shorter and relatively much broader than in any of the allied forms; with a length of $28 \mathrm{~mm}$. the vertical breadth is 4.5 , against 30 and 4 respectively in L. sylvaticus aztecus, and 34 and 3.5 in L.palustris of corresponding general size. The teeth are broad, the middle upper molars having a transverse breadth at the crown surface of $4 \mathrm{~mm}$. against a total length of the upper molar series of $\mathbf{1 2}$. The palatal region is very broad (distance between inner base of middle molars $\mathbf{1 2 . 5}$, with a very short palatal bridge $(6 \mathrm{~mm}$.) ; there is a slender spiny process on the anterior border, with, however, no trace of any on the posterior border. The palatal walls are widely separated, forming a broad U-shaped arch instead of the narrower and more sharply V-shaped arch of L.palustris and other allied forms. The basisphenoid stands at about the usual angle with the axis of the skull, and the basioccipital lies in the same plane, instead of forming, as in allied species, an obtuse angle with the basisphenoid. The nasal bones are much flattened and much less than half as much arched in front as in any allied form. The posterior half of the brain-case is very abruptly depressed, in conformity to the depressed plane of the basioccipital below. The middle portion of the skull is very broad in comparison with the width of the brain-case, or with the total length of the skull.

The following are the principal measurements : Basilar length, $57 \mathrm{~mm}$. ; total length (?) ; greatest breadth (at zygomatic arch), 35 ; least interorbital breadth, 
25 ; palatal breadth at middle of palatal bridge, II ; length of nasals, 27 ; width of nasals posteriorly, 14 ; width at anterior border, 10; length of zygoma, 28 ; length of upper molar series at alveolar border, 14 ; length of lower jaw (?); height at coronoid process, 32 .

Type, $\frac{6357}{25953}$, U. S. Nat. Mus., Mirador, Mexico; C. Sartorius.

It hence appears that thus far no authentic specimens of either L. palustris or L. aquaticus are known from Mexico, the habitat of the former being, so far as now known, Florida and the coast region of Georgia and the Carolinas, and of the latter, the Gulf coast of the United States, from western Alabama to Texas, and thence northward in the cane-brake region to southern Illinois. Their introduction into the list of Mexican mammals, so far as the present writer is concerned, is due to the fact that the skulls of the Mexican specimens referred to these species were not removed from the skins for examination, the determinations being based on external characters, which proved very misleading. 



\section{SMITHSONIAN INSTITUTION.}

\section{UNITED STATES NATIONAL MUSEUM.}

\section{DESCRIPTIONS OF TWO SUPPOSED NEW SPECIES}

OF MICE FROM COSTA RICA AND MEXICO, WITH REMARKS ON HESPEROMYS MELANOPHRYS OF COUES.

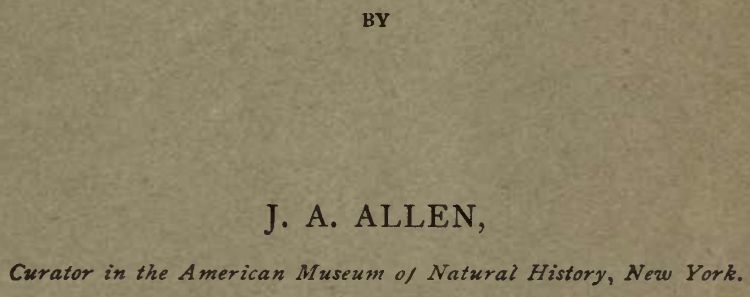

J. A. ALLEN,

Curator in the American Museum of Natural History, New York.

From the Proceedings of the United States National Museum, Vol. X1V, pages 193-195 [No. 850.$]$

WASHINGTON:

GOVERNMENT PRINTING OFFICE.

1891. 

DESCRIPTIONS OF TWO SUPPOSED NEW SPECIES OF MICE FROM COSTA RICA AND MEXICO, WITH REMARKS ON HESPEROMYS MELANOPHRYS OF COUES.

\author{
$\mathrm{BY}$ \\ J. A. Allen, \\ Curator in the American Museum of Natural History, New York.
}

Having recently had in hand a small collection of mammals from Costa Rica for identification, I found it desirable to examine in that connection as much material as possible from Central America and Mexico bearing upon the Costa Rican Muridæ. In response to $\mathrm{my}$ solicitation, Mr. Frederick W. True, curator of mammals in the U.S. National Museum, kindly secured for me the use of the specimens in the collection under his charge. They not only were of great assist. ance in the work in hand, but proved to iuclude two forms apparently new to science.

\title{
Oryzomys talamancæ, sp. nov.
}

Pelage short, thick, soft, velvety. Abore, russet-brown medially, mixed with blackish brown, passing gradually into clear yellow-brown on the sides; beneath, grayish white, the hairs being white or faintly yellowish white at the tips and gray beneath the surface, the basal gray portion showing through the surface, giving the effect of grayish white with a faint yellowish east. Cheeks, sides of the neck, and flanks deep yellowish brown or golden cinnamon. Sides of the muzzle, dull soiled grayish white. Upper surface of fore and hind feet, dull pale yellowish gray, very scantily haired, and the toes nearly naked, except at the base of the claws. Soles entirely naked, tubercles 6. Ears large, blackish, naked. Tail about as long as head and body, naked, blackish above, dark brown below, hence indistinctly bicolored.

Length (approximate from skins), head and body, 114.3 millimetres (4.50 inches); tail, 114.3 millimetres (4.50 iuches); hind foot (with claws), 30.8 millimetres (1.15 inch $\cdot \mathrm{s}$ ); ear, from crown, 13.7 millimetres (.54 inch); muzzle to eye, 17.8 millimetres (.70 inch).

Sliull in general form very similar to that of Cryzomys palustris, but much smaller. Basal length, 28.5 millimetres, 1.12 inches); total length, 31.2 millimetres ( 1.23 inches); palatal length, 16 millimoters (.63 inch); greatest breadth, 15.8 millimetres $(.63$ inch) ; least interorbital breadth,

Proc. N. M. $91 \longrightarrow 13$ 
5.3 millimetres (.21 inch.); nasals, 12.7 millimetres (.50 inch); upper molar series, 5.1 millimetres (.20 inch). (Lower jaw lacking.)

Type $\frac{122222}{2} \frac{22}{74}$, U. S. National Museum, ô ad. Talamanea, Prof. W. M. Gabb.

This species is based on two specimens, skins, in the Gabb collection, belonging to the U. S. National Museum. One still retains the skull; from the other (the type) the skull has been removed, but, unfortunately, lacks the lower jaw. The two skins differ somewhat in coloration, and apparently represent different seasons of the year, one being in rather fuller and darker pelage than the other.

On the back of the labels I find written in pencil, "Near or $=H$. laticeps Lund," a species based on specimens from Lagoa, Santa Brazil. To say nothing of the wide separation of the habitats of the two, the present species is very much smaller than $H$. laticeps, and the resemblance in coloration is by no means close. Mr. Oldfield Thomas's Hesperomys (Oryzomys) laticeps rar. nitidus, from central Peru (see P. Z. S., 1884, p. 452 , pl. xlii, fig. 1 ), is also much larger than the present species, and evidently very different in coloration, as he speaks of its "dark, rich, rufous color."

\section{Hesperomys melanophrys Coues.}

Hesperomys (Vesperimus) melanophrys Coues, Proc. Acad. Nat. Sci., Phila., 1874, p. 181 ; Mon. N. Am. Roden., 1877, p. 10\% (in part only).

Dr. Coues in describing his Hesperomys (Vesperimus) melanophrys considered it as doubtfully distinct from $H$. mexicanus of De Saussure. An actual comparison of the types of the two species, which, through the kindness of Dr. C. Hart Merriam, I recently had the opportunity of making, in company with himself and Mr. F. W. True, at the U. S. National Museum, has shown that they are not at all closely related. I have since then been able to study more critically the specimenssix in all-referred by Dr. Coues to this species in his final notice of H. melanophrys. His original description of it (Proc. Acad. Nat. Sci. Phila., 1874, p. 181) refers only to the single type specimen from which it was described; his later notice (Mon. N. Am. Roden., p. 102) refers in part to other specimens, only the first three of which (given in Table xxIx, 1. c.), his diagnosis, and the main body of the article relate to $H$. melanophrys. In a note to the article as originally prepared he provisionally referred three other specimens to $H$. melanophrys, though recognizing that they presented many points of difference, respecting which he says:

Since writing the preceding, we have examined three other specimens from Tehuantepec, which, if the same, as the types of melanophrys, lessen the chances that the latter is different from mexicanus [De Saus.]. But they differ in many respects from the specimens just enumerated [the three originally referred to melanophrys], being so very much smaller that we can not satisfy ourselves of their identity. The tail only exceeds the body in one specimen, and here only a little; in the others, it is about as long, relatively, as De Saussure gives for mexicanus. That these specimens are not immature is shown by the fact that one of them is a nursing female. In color, 
they are almost precisely like the foregoing, but do not show the black ring round the eye, nor the dusky spot at the base of the metatarsus. One of them is pure white below ; another is grayish (it looks as if soiled); while the third has the faintest possible fulvous tinge all along the under parts." He says further: "Much more material than that now in our possession will be required to determine the limits of variation of this large, gray, leucopus-like mouse of Mexico, and fix the species upon secure basis.

In his three specimens originally referred to $H$. melanophrys (as shown by his tables of measurements), the length of head and body averages 4.02 inches and the tail 4.83 , as against 3.20 and 3.10 respectively in the other three specimens mentioned in the above quotation. This difference, with the differences in coloration pointed out by Dr. Coues himself, clearly shows that the latter have no close relationship to $H$. melanophrys, but are strictly of the leucopus type.

H. melanophrys is a large, long-tailed, big-eared species, somewhat recalling the general aspect of $H$. californicus, from which, however, it differs greatly in coloration, and especially in cranial character, the skull being much heavier and much broader in proportion to its length, with the rostral portion greatly thickened, in comparison with the same part in $H$. californicus. There are also well-marked differences in dentition and in the form of the palatal region; the auditory bullæ are smaller and more spherical, and the condylar portion of the lower jaw is much broader, heavier, and less depressed.

\section{Hesperomys (Vesperimus) affinis, sp. nov.}

Hesperomys (Tesperimus) melanophrys Coues, Mon. N. Am. Roden., 1877, p. 102 (in part only).

Similar to typical $H$. leucopus in size, proportions, and cranial char. acters, but with a close general resemblance in coloration to $H$. melanophrys Coues.

Above brownish fulvous varied with blackish, darker along the median line, more fulrous along the sides. Below white, with a very slight tinge of yellow. Feet dnll white; ears brownish, narrowly edged with white; tail brown, indistinctly lighter below, scantily haired.

Measurements (approximate from skins): head and body, 81.3 to 88.9; tail, 76 to 83; hind foot (including claws), 19.8; ear from crown, 4.5 to 4.8 millimeters. Skull: total length, 26.4 ; basal length, 25.9 millimeters; greatest width, 13.5 ; length of nasals, 11.4; lower jaw (from tip of incisors to condyle), 16; height (angle to condyle), 6.4 millimeters.

Type, No. $\frac{7382}{86 \frac{5}{5}}$, U. S. National Museum, $q$ ad., Barrio, Tehuantepec, Mexico, October 30, 1868, Prof. F. Sumichrast. (This specimen presents a soiled grayish appearance below, evidently accidental.)

Two other specimens ( $\delta$ ad., No. $\frac{93}{86} \frac{89}{70}$, U. S. National Museum; $q ?$ juv., No. $\frac{938}{86} \frac{3}{6}$, U. S. National Museum, same locality and collector, October, 1868), are similar above, but one almost wholly lacks the faint 
yellowish tinge below plainly seen in the others, which, howerer, I suspect may be due to soiling.

In the type the teeth are much worn, indicating full maturity.

This form is evidently a member of the leucopus group of Vespermice, having the same pattern of coloration as regards the extension of the dark color of the dorsal surface upon the limbs. The relative length of the tail to the length of the head and body is about the same as in leucopus proper, the tail being longer than in the sonoriensis group, although the color is not much different from occasional specimens of what is usually known as sonoriensis. It has, however, a longer hind foot, and the facial portion of the skull is longer and narrower than in average specimens of either leucopus or sonoriensis.

The specimens here under notice were provisionally referred by Dr. Coues to his $H$. melanophrys, in his supplementary note to his account of that species in "Monographs of North American Rodentia," p. 305, as fully explained above. 
Article XII. - Description of a Nerw Species of Big-eared Bat, of the Genus Histiotus, from Southern California. By J. A. Allen.

Article XIII-Further Notes on Maximilian Types of South American Birds.-By J. A. Allen.

Extracted from Bull. Am. Mus. Nat. Hist, Vol. III, No. 2. Author's edition issued February $20,1891$. 

ARTICLE XII.-Description of a New Species of Big-eared Bat, of the Genus Histiotus, from Southern California. By J. A. Allen.

The finding of a Big-eared Bat, of the South American genus Histiotus Gerv., in Southern California, is a most unlooked for occurrence, exceeding possibly in interest the recent discovery in the same region of a species of Molossus, allied to $M$. perotis of Brazil, by Dr. Merriam.*.

The specimen on which the present description is based was "caught on a fence," at Piru, in the western part of Ventura County, California, in March, I 890 , by Mr. Thomas Shooter. I am indebted to the kind offices of Mr. E. C. Thurber, of Alhambra, California, for the specimen, through whom it was secured for the American Museum of Natural History.

On attempting to remove the skull from the skin, the specimen proved to be mummified, having been simply eviscerated and allowed to dry. By careful treatment it yielded not only a good skin, but the greater part of the skeleton and skull. Unfortunately the sex of the specimen could not be determined, owing to mutilation in the process of evisceration. The skull and dentition show it to have been a rather young though doubtless full-grown individual.

\section{Histiotus maculatus, sp. nov.}

Ears joined at the base, foliaceous, very large, twice as long as the head, about one-half as broad as long, well fringed with whitish hairs along the inner border, but elsewhere naked; expanse from tip to tip, $76.2 \mathrm{~mm}$. (3.00 in.). The ears are convex on the inner border, broadly rounded at the tip; outer border convex on the basal half, slightly hollowed toward the tip. The inner border near the base forms an obtuse angle; the outer border is continued as a low fold to a point below the angle of the mouth. The tragus expands abruptly on the outer border at the end of the basal fourth, at which point it also has an abrupt lateral deflection, the inner border forming an obtuse angle about opposite the beginning of the basal third. The upper three-fourths of the tragus is straight on the inner border, convex on the outer, and very obtusely rounded at the top. Nostrils prominent, at the end of a narrow, low, naked disk, divided by a slight groove, and narrowing posteriorly to a point. Rest of the face well

* Description of a New Species of Molossus from California (Molossus californicus). By Dr. C. Hart Merriam. North American Fauna, No. 4, Oct. 8, 1890, p. 31.

[February, 1891.$]$

[195] 
haired, blackish, apparently (judging from the dry skin) without warts or tubercles. Thumbs with a small basal pad. Toes thinly haired. Wing membranes from the base of the toes, pale brown, everywhere wholly without fur. About half of the last caudal vertebra free.

Pelage long, full, and soft. Whole dorsal surface deep black, the fur uniform from the surface to the base, except on the rump, and a large patch on each shoulder, where the apical half of the fur is pure white, the basal portion being black. The white rump patch has a length of about three-fourths of an inch, by a width of half an inch. The shoulder patches are symmetrical in form and position, being directed obliquely backward and inward, about half an inch wide by nearly an inch in length. The black of the dorsal surface extends downward on the sides of the neck in front of the shoulders, forming a broad lunate patch on each side. Posterior base of the ears, the whole throat and sides of fore neck to the ears, pure white, the fur dusky at the base. Rest of the lower surface with long white tips to the hairs, which over the breast are so long as to wholly conceal the dusky underfur.

Measurements. - Length of head and body, $62 \mathrm{~mm}$. (2.45 in.); tail, $49.5 \mathrm{~mm}$. (1.95 in.) ; length of ear, $38.1 \mathrm{~mm}$. (I.50 in.), width across the middle, $27.9 \mathrm{~mm}$. (I. Io in.); height of tragus, $12.7 \mathrm{~mm}$. (.50 in.), breadth at middle, $5.6 \mathrm{~mm}$. (.22 in.) ; humerus, $29.7 \mathrm{~mm}$. (I.I7 in.); forearm, $50.8 \mathrm{~mm}$. (2.00 in.); thumb, $6.9 \mathrm{~mm}$. (.27 in.); third finger: metacarpal, $49.3 \mathrm{~mm}$. (I.94 in.), Ist phal., I $5.75 \mathrm{~mm}$. (.62 in.), $2 \mathrm{~d}$ phal., $27.9 \mathrm{~mm}$. (r.ro in.) $=95.5 \mathrm{~mm}$. (3.76 in.); fourth finger: metacarpal, $46.2 \mathrm{~mm}$. (I.82 in.), Ist phal., $14 \mathrm{~mm}$. (.55 in.), $2 \mathrm{~d}$ phal., I6 mm. (.63 in.) $=76.2 \mathrm{~mm}$. (3.00 in.); fifth finger: metacarpal, $45.7 \mathrm{~mm}$. (1.80 in.), Ist phal., Ir.4 mm. (.45 in.), $2 \mathrm{~d}$ phal., ro. $2 \mathrm{~mm}$. (.40 in.) $=67.3 \mathrm{~mm}$. (2.65 in.); femur, $43.7 \mathrm{~mm}$. (r.72 in.); tibia, $22.9 \mathrm{~mm}$. (.90 in.); hind foot, $7.6 \mathrm{~mm}$. (.30 in.).

Skull and Dentition.-Basilar length, I6.5 mm. (.65 in.); total length, I9 mm. (.75 in.) ; zygomatic width, $10.9 \mathrm{~mm}$. (.43 in.); height, $7.6 \mathrm{~mm} .(.30 \mathrm{in}$.$) ;$ length of lower jaw, $12.7 \mathrm{~mm}$. (.50 in.); height at condyle, $33 \mathrm{~mm}$. (.13 in.); height at coronoid process, $3.8 \mathrm{~mm}$. (.. 5 in.) ; length of upper tooth row, 6.86 $\mathrm{mm}$. (.27 in.) ; length of lower tooth row, $7.6 \mathrm{~mm}$. (.30 in.). Dental formula : incisors, $\frac{2-2}{6}$; canines, $\frac{1}{1}-\frac{1}{1}$; premolars, $\frac{1}{2}-\frac{1}{2} ;$ molars, $\frac{8}{3}-\frac{8}{8}=\frac{14}{18}=32$.

The skull is thin and papery, being evidently that of a young animal. The facial portion is narrow and pointed ; the brain case is quadrate, flattened above, but rises abruptly at the frontal border, the forehead being suddenly depressed.

The lower border of the zygomatic arch is curved upward; the upper border is greatly expanded vertically, the upper border of the malar forming a high angular process at the middle of arch ; the zygomatic process of the squamosal is short, and, with the malar, passes forward in a line nearly parallel with the axis of the skull, with only a very slight outward cuvature. The tympanic bullæ are enormously expanded, having an antero-posterior length of $5.84 \mathrm{~mm}$. (.23 in.) and a transverse breadth of $3.3 \mathrm{~mm}$. (. I3 $_{3} \mathrm{in}$.), their length fully equaling onethird of the length of the skull. In other respects the ventral aspect of the skull 
presents nothing peculiar. The lower jaw is narrow, the coronoid process small, rising but little above the condyle; the angle is well developed.

The dentition is weak, the incisors and canines being very small, relatively to the molar series. The outer upper incisor is about one-half the size of the inner; both have a small outer cusp at the base. The upper canine is about equal in size to the anterior half of the upper premolar. The molars present nothing distinctive. The lower incisors are slightly double-notched (trifid); the lower canines are very small; the first premolar is about half the size of the second.

The present species appears to bear a general resemblance to Histiotus velatus and $H$. macrotus of Brazil and Chili, as regards general size and the form and size of the ears. It is, however, larger than either, with the ears relatively as large as in $H$. macrotus, and differs from both in the form of the tragus, which instead of being narrowed apically and subacutely pointed, is broad towards the tip and obtusely rounded. In $H$. macrotus, according to Dr. Peters, * the outer upper incisor is minute as compared with the inner, while in the present species the upper incisors are comparatively subequal. There is also a striking difference in coloration, the present species being particolored, black and white, the others yellowish brown above and whitish gray below.

The coloration of the present species is striking and almost unique among bats. The white patches are possibly in part due to albinism, but this does not seem at all probable. The spots are symmetrical in form and position, and the white is confined to the surface, the under fur being blackish, like the under fur on the rest of the body, whereas in white spots due to albinism the white extends to the base of the fur.

Explorations recently made in Southern California present in striking relief the ignorance of its mammalian fauna which prevailed to within a recent date, and warrant the supposition that further novelties still await discovery. Just three years ago Dr. Merriam described from San Bernardino County a new fox (Vulpes macrotis) $\nmid$ with remarkably large ears, and very unlike anything previously known from North America. The species was based on a single specimen, but subsequently others were

* Monatsb. Akad. Wissen. Berlin, 1875, p. 788, pl., fig. 2.

+ Proc. Biol. Soc. Washington, Vol. IV, I886-88, pp. 5-7. Extras issued Feb. I8, I888. 
obtained, and its known range extended eastward into Arizona. The wonder now is that so conspicuous an animal should have so long escaped observation.

It is of course not remarkable that among the comparatively inconspicuous burrowing mammals many new forms should come to light, including some with very strongly pronounced characters ; or that some form of $N y$ ctinomus, known for many years as Californian on the basis of a single record, should prove common, as has now been recently found. This, although a tropical genus, is well represented near our southern border and thence southward. The case, however, is quite different with the Promops section of the genus Molossus, where $M$. perotis finds a geographical representative in Merriam's $M$. californicus of Southern California. This immense bat, one of the largest known from America, is now represented by numerous specimens (I have myself examined nine), and proves to have no very close relation to $M$. perotis; though of equal size, it differs widely in coloration, and more or less in various points of structure, as shown by direct comparison with Wied's type of $M$. perotis, preserved in this Museum.

The present species adds another to the many surprises this general region has recently supplied to the mammalogist, finding as it does its nearest allies at far remote points on the opposite side of the equator. 


\section{Article XIII.-Further Notes on Maximilian Types of South American Birds. By J. A. Allen.}

Since the publication of my paper "On the Maximilian types of South American Birds in the American Museum of Natural History," in December, I889, the types of Maximilian's Anthus pacilopterus have come to light, and it has been found that the type of Maximilian's Myiothera ardesiaca was wrongly referred to Hypocnemis myiotherina (Spix), from which it proves to be even generically distinct, and also not referable to any of the commonly recognized genera.

\section{Rhopocichla, gen. nov.}

Bill much compressed and attenuated; width and depth at nostrils equal; wings rounded, shorter than the graduated tail ; tarsi long and slender, smooth, the scutes obsolete.

Type, Myiothera ardesiaca Wied.

This genus is allied to Pyriglena, but has the bill much more compressed, the tail relatively longer, as also the tarsi, which are not obviously scaled. The plumage is not black, and there is no concealed white at the base of the interscapulars.

\section{Rhopocichla ardesiaca ( Wied $^{\mathrm{l}}$ ).}

"Myiothera ardesiaca Lrchr., MS. Mus. Berl."

Myiothera ardesiaca WIED, Beitr. Naturg. Bras., III, 2, I83I, p. I055.

Myrmeciza ardesiaca WIED (MS., on label and in his MS. Catalogue).

Formicivora ardesiaca MênÉTR., Mém. Acad. St. Pétersb., sér. vi (Sci. Nat.), I, 1835, p. 507 (ex Wied).

Myrmonax ardesiaca BURM., Thiere Bras., III, I856, p. 65 (in part).

Myrmonax myiotherinus CAB., Orn. Not. in Wiegm. Arch., 1847, i, p. 2 ro (in part).

Formicarius (Myrmoborus) myiotherinus GRAY, Hand-1. Bds., I, 1869, p. 300, No. 4443 (in part).

Formicarius myiotherinus GreBEL, Thes. Orn., I, I875, p. I79 (in part).

Hypocnemis myiotherina TACz., Orn. Pér., II, 1884, p. 65 (in part).-RIDGw. (MS. label). - Allen, Bull. Am. Mus. Nat. Hist., II, No. 3, Dec. I889, pp. 255, 275.

Adult Male (No. 6827, Am. Mus. Nat. Hist.).-Above nearly uniform dark plumbeous, wings and tail (especially the latter) darker; below deep ash gray, a little lighter on the middle of the abdomen; whole throat including fore neck deep black, strictly limited laterally to the space between the mandibular rami ;

* Bull. Am. Mus. Nat. Hist., Vol. II, No, 3, pp. 209-276. 
cheeks, sides of face, including eye-region and ear-coverts, ash gray, like the lower parts ; lesser, median, and greater wing-coverts black, broadly edged with pure white; outer web of first primary edged with white; rest of remiges edged with gray, and the rectrices with deep plumbeous, like the color of the back; axillaries and inner surface of wings gray, like the flanks. Bill dusky horncolor ; feet lighter. "Iris carmine red" (Wied).

Length, 6.45 in. ; wing, 2.95 ; tail, 3.12 ; culmen, .70; tarsus, I.I7 ; hind toe with claw, $.67 ;$ middle toe with claw, .78 .

Adult Female.- "Above pale grayish brown, shoulders, and upper back grayer; lower back and larger wing-coverts more washed with yellowish brown, the latter edged with a lighter tint of the same ; lower parts pale reddish yellow, darkest on the breast ; under wing-coverts reddish yellow" (Wied, 1. c.).

Only the male, of the two birds described by Wied, is now in the collection of the American Museum.

This species has a curious history, and apparently has not been seen by any of the writers who have referred to it, it being thus far known only from Wied's description. While generally synonymized with what is now known as Hypocnemis myiotherina (Spix), it has no close relationship with it, the resemblance in color being by no means exact. While both are gray birds, with a black throat, the black in the present species is confined within the mandibular rami, while in the other it extends over the cheeks and the whole sides of the face to and including the region surrounding the eyes. While $H$. myiotherina has of course a short tail, the present species is one of the longest tailed forms of the subfamily. As early as 1847 Cabanis (1. c.) started the error of synonymizing the two species; Burmeister (1.c.), in 1856 , strangely confounded the two birds in his description as well as in his text, the result being a hypothetical composite species.

Mr. Sclater, in $185^{8}$ (P. Z. S., 1858, p. 288), placed Wied's Myiothera ardesiaca in his "list of species not recognized," but on p. 25 I (1. c.), under Hypocnemis myiotherina, he says: "I do not believe Myiothera ardesiaca of Prince Max. of Neuwied to be the same as this species; but I have never seen specimens of it. It is referred here by Cabanis and Burmeister." In his late Catalogue of the Formicariida (Cat. Bds. Brit. Mus., Vol. XV, r8go), it is apparently not mentioned.

In the absence of proper material for comparison Mr. Ridgway and myself naturally followed previous authors in referring it to Hypocnemis myiotherina. 


\section{Geobates poecilopterus ( Wied).}

Anthus pecilopterus WIED, Beitr. Naturg. Bras., III, i, I830, p. 633. Anthus, sp. incog. Allen, Bull. Am. Mus. Nat. Hist., II, No. 3, I889, p. 215. Geobates pacilopterus ScL., P. Z. S., I866, p. 205, pl. xxi ; Cat. Bds. Brit. Mus., XV, I89o, p. 4.-Allen, Bull. Am. Mus. Nat. Hist., II, No. 4, I89o, p. viii.

Since my former note on this species, to the purport that the types were not in this Museum, the two original Maximilian specimens have come to light, and are fortunately in an excellent state of preservation, with, furthermore, the original Maximilian labels still attached to them. As before said, they are not entered in the Wied MS. Catalogue, and had been misplaced in the collection before it came under my charge.

The two birds agree respectively with Wied's "Beschreibung des männlichen Vogels," and with that designated as "Weibchen, welches noch jung schien," the latter being distinguished by having the feathers of the upper parts edged with pale reddish ("hell röthliche"). The birds are labeled with a small paper tag as follows : "No. 393, Fem. 393 Mas. J.," although in the "Beiträge" the sexes are reversed. A larger label (on ordinary writing paper, about $13 / 4$ by $2 \mathrm{I} / 3$ inches in size, and apparently the original field label), covering both specimens, is inscribed, on one side "Ist mein Anthus pacilopterus," the first two words being in German script. On the reverse, also in German script, is the following: "Ein junge Vogel aus dem ich nicht zu machen weiss. Selbs der genus ist schwer zu bestimmen. Am besten möchte er zu Myiothera stimmen. Aber im ausgefiederten zustand könnte es auch ein Anthus sein."

Wied's specimens agree perfectly with Mr. Sclater's figure and description (1. c.), leaving no question of the correctness of the identification of Wied's species by von Pelzeln.

\section{Chætura cinereiventris $\mathrm{Scl}$.}

? Cypselus acutus WIED, Beitr. Naturg. Bras., III, i, I830, p. 35 I.

Chatura cinereiventris Allen, Bull. Am. Mus. Nat. Hist., II, No. 3, Dec., I889, p. 26 r.

Since my former reference to this species (1. c.) Wied's specimen has been found and proves to be an example of Chatura cinereiventris Scl., with which species Wied's Cypselus acutus has 
been generally heretofore synonymized. The specimen (No. $586_{4}$ bis, "Mas.") is still in good preservation, and agrees well with his description. He seems to have had only the single male specimen, taken in the vicinity of Bahia. 

ArticLE XV.-On a Collection of Mammals from Southern Texas and Northeastern Mexico. By J. A. Allen.

Extracted from Bull, Am. Mus.' Nat. Hist., Vol. III, No. 2. Author's edition issued April 29, 1891. 
5.

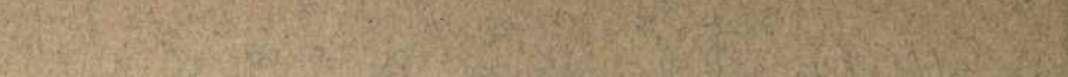
E. (x) 25

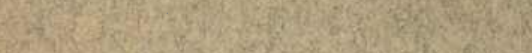

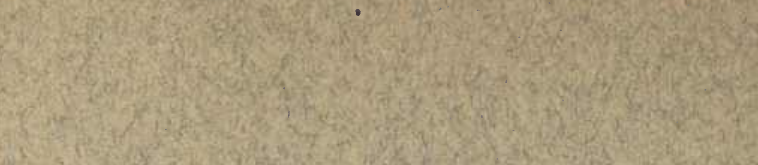

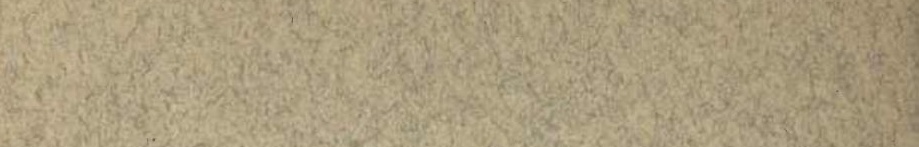

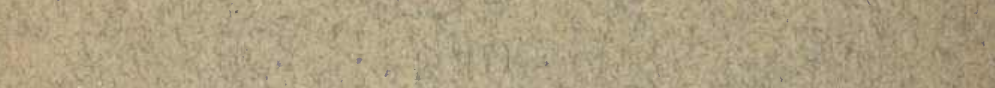

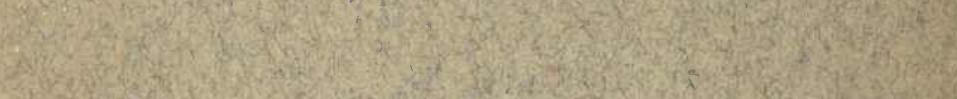
Whas

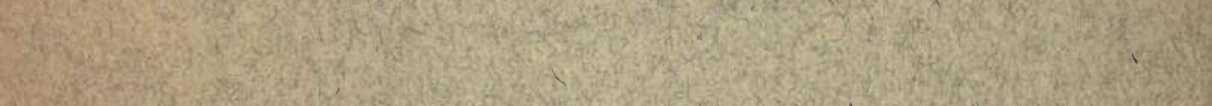

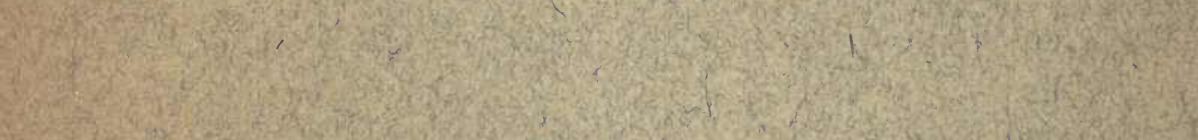

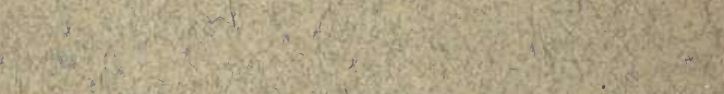

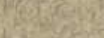

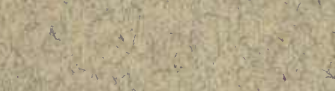
If Q cons

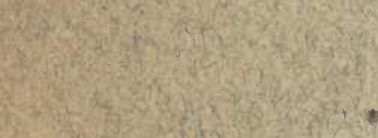
in D.
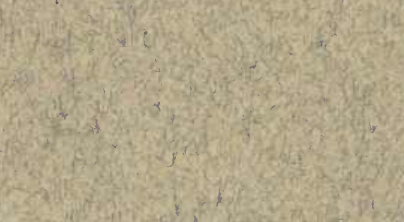

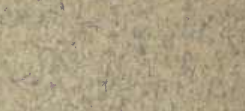

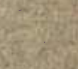

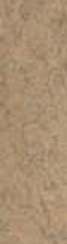

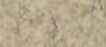

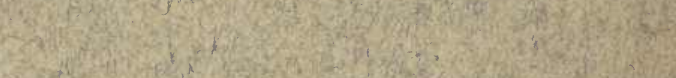

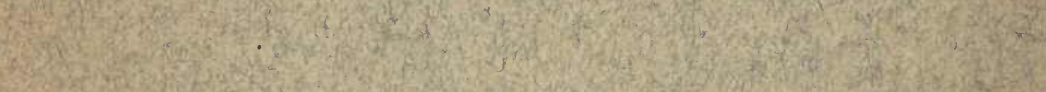

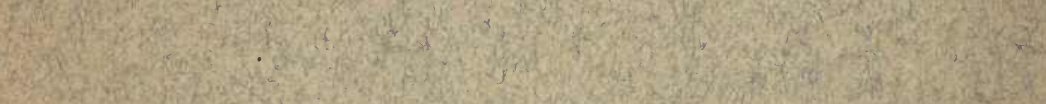

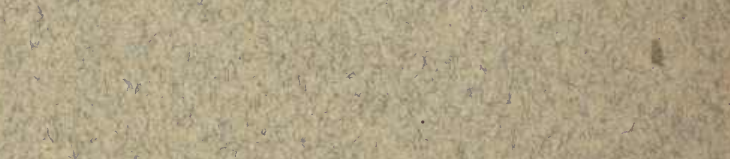
W.

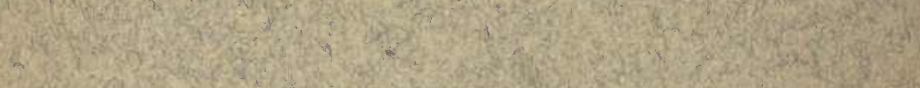
astity

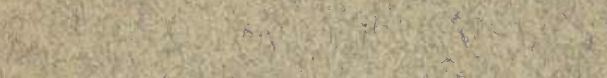
35.

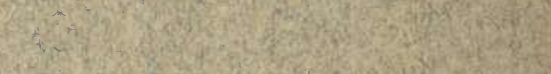

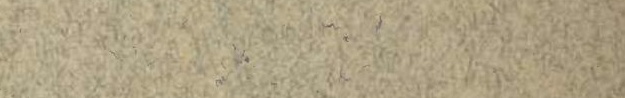

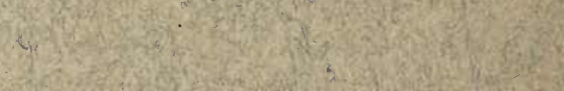
0902

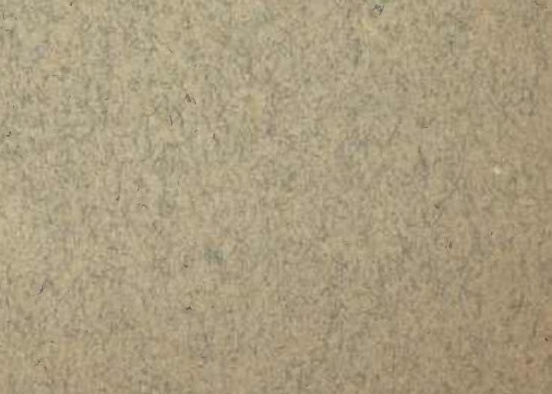


ARTICLE XV.-On a Collection of Mammals from Southern Texas and Northeastern Mexico. By J. A. Allen.

The series of mammals forming the basis of the present paper has been presented to the American Museum of Natural History by Mr. George B. Sennett, the well-known ornithologist, together with many specimens from Pennsylvania and Minnesota. The portion of the collection here especially considered was mainly gathered by Mr. Sennett and his collectors in Southern Texas and in the State of Tamaulipas, including, however, a few specimens from the States of Nuevo Leon and San Luis Potosi. The Texan specimens are principally from Presidio, Bee, Nueces, and Cameron Counties. They number about 90 specimens, representing $3 \mathrm{I}$ species. Two are apparently new to science, and much light is thrown upon the geographical range of many others.

1. Lynx rufus maculatus (Horsf. \& Vig.).-A single specimen, skin and skull, $q$ ad., from near. Brownsville, Texas, March I2, I888, J. M. Priour. The specimen. is already in the red summer coat.

2. Canis latrans Say.-One specimen, skin and skull, Aransas Co., Texas, Oct. 20, I888, J. M. Priour.

3. Putorius brasiliensis frenata (Licht.).-A young male, Corpus Christi, Texas, May 15, 1882, George B. Sennett. This specimen has the distinctive features of coloration of frenatus, which does not appear to have been before recorded from the coast of Texas north of the mouth of the Rio Grande.*

\section{Spilogale indianola?}

? Spilogale indianola Merriam, N. Am. Fauna, No. 4, Oct., I89o, p. Io.

Mr. Priour collected a single specimen of Spilogale during his trip through Tamaulipas, but the exact locality and date seem not to have been recorded. It differs from all other examples of the genus I have seen in its very dark colors, the light markings being very much restricted and of a deep creamy white. The skull unfortunately is imperfect, consisting of only the facial portion.

* As this paper goes to press a specimen has also been received from Brownsville, through Mr. C. K. Worthen, collected Jan. 3, r8gr. 
It indicates a full-grown but not old individual, apparently a male, so far as can be determined from the skin. The specimen may be described as follows :

Size large; pelage coarse. Length of head and body (approximate from the skin), $330 \mathrm{~mm}$. : tail vertebræ, I35; tail to end of hairs, I46; hind foot; 44. Color black or brownish black, with the usual white areas and markings very much restricted, as follows: The light spot on the forehead is pale creamy white, about the size of an ordinary pea; the lunate spot in front of each ear pale creamy white, very small, less than half an inch in extreme length, very narrow, and widely separated from the light area on the side of the neck; the two inner dorsal white stripes begin at the usual point, but are mere lines of creamy white, in places irregularly obsolete; the outer dorsal stripe begins behind the ear as a broad, clavate, deep cream-colored patch, narrowing posteriorly ; the flank stripe, like all of the body markings, is deep cream color, and while of the usual pattern is very narrow, being only about one-half as wide as the black stripe above it, instead of much wider, as in $S$. putorius and allied forms. The thigh patches are little more than small tufts of creamy white hairs, and a mixture of such hairs with black at the base of the tail represents the usual rump patch. The white in the tip of the tail forms a broad terminal pencil, which extends forward on the lower surface of the tail for about an inch.

The buffy tint of the light markings may be merely individual, since a similar phase occurs in allied forms.

According to Mr. Alston* the genus Spilogale ranges southward to Yucatan and Guatemala, whence specimens are represented in the collections of M. Boucard and the British Museum, but I find no descriptions of these specimens. Dr. Merriam, in his recent revision of the genus, $\nmid$ has described a species based on two skulls from Indianola, Matagorda Bay, Texas, as S. indianola, the skins, and therefore the external characters, being unknown. Unfortunately the skull of the Tamaulipas specimen is too imperfect to furnish any basis for comparison with the Indianola specimens. For the present it may be best to provisionally refer this specimen to $S$. indianola Merriam, since he suggests that it is "probably a Mexican tropical species extending north along the Gulf coast of 'Texas."

5. Dicotyles tajacu (Linn.).-Several specimens from various localities in Texas and Tamaulipas.

* Biol. Centr.-Am., Mam., p. 83.

+ North Amer. Fauna, No. 4, Oct., r8go, pp. I-16, pl. i. 
6. Vesperugo georgianus ( $F$. Cuv.).-Two specimens, Bee Co., 'Texas, April, r887, J. M. Priour.

7. Vesperugo hesperus (H. Allen).-One specimen, skin and skull, sex?, Presidio Co., Texas, Sept., 1887, Wm. Lloyd. One specimen, skin and skull, sex ?, Monterey, Mexico, May 30, 1889, J. M. Priour.

This species, originally described from Southern California (Posa Creek and Fort Yuma), has since been recorded by Dr. Merriam* from the little Colorado River, Arizona. The present specimens show that it ranges eastward to Western Texas, and southward to Monterey, Nuevo Leon.

8. Antrozous pallidus (Le Conte).-Two specimens, skins, without labels, but probably from Presidio Co., Texas, or Nuevo Leon.

\section{Scalops argentatus texanus, subsp. nov.}

Much smaller than either S. argentatus or S. aquaticus, and bronzy chestnut brown instead of silvery plumbeous, or brownish plumbeous. Above uniform pale chestnut brown, with a decided bronzy lustre; below darker, irregularly varied with lighter areas, - rather strong chestnut with patches of rufescent ash.

Measurements (approximate from skin): head and body, $100 \mathrm{~mm}$. (3.94 in.) ; tail, $24(.95)$; hind foot, I6.5 (.65); fore foot, length, I8.8 (.74), breadth, I5.2 (.6o).

Type $\frac{3488}{2740}$, sex?, Presidio Co., Texas, Sept., I887, Wm. Lloyd.

This is apparently a small southern form of $S$. argentatus, from which it differs markedly in its smaller size (nearly one-third smaller), and its strong bronzy chestnut coloration. 'The single specimen is an adult, with the teeth much worn. The skull when removed from the skin was found to be imperfect, the part posterior to the middle of the orbits having been cut away. The dentition in both jaws is intact, and the portion of the skull remaining presents nothing peculiar except small size.

Since $S$. aquaticus is represented by a similar small form in Florida (of which I have seen a number of specimens), and Scapanus townsendii by a corresponding form in Southern California (though neither of them have as yet been characterized), it seems reasonable to consider the present specimen as a fair representative of the Texan form of $S$. argentatus. 
10. Sciurus aureogaster $F$. Cuv.-Six specimens, as follows : $\hat{s}$ and $q$ ad., Tampico, Mex., June, $1888, \mathrm{Wm}$. B. Richardson ; $q$ ad., Tampico, May 2 I, I 888, J. M. Priour ; $\hat{o}$ ad., and $q$ juv., Valles, San Luis Potosi, May, $\mathbf{1 8 8 8 , W m . ~ B . ~ R i c h a r d s o n ~ ; ~} q$ ad., Rio Corono, 'Tamaulipas, April 7, r888, J. M. Priour. (These are the specimens previously mentioned in this Bulletin-II, p. 166 , and III, p. I8r.)

11. Sciurus deppei Peters.-Four specimens, as follows : 2 1 ad., Victoria, Tamaulipas (alt. $5000 \mathrm{ft}$.), April 16 and May I, I888, J. M. Priour ; of ad., Valles, San Luis Potosi, May, I888, Wm. B. Richardson; also one specimen without label.

These specimens vary in the color of the upper surface from olive-gray to rusty brown, and in the color of the lower surface from pale buff to ochraceous buff.

12. Sciurus arizonensis Coues.-One specimen, skin and skull, $q$ ad., San Pedro Mines, Nuevo Leon, Mex., May 7, 1889, J. M. Priour. Also one specimen, skin and skull, $\hat{o}$ juv., labeled as from Brazoria Co., Texas, May 22, 1887, J. M. Priour; if this locality is not erroneous, it carries the range of the species far to the eastward of its previous known range, it not having been previously reported in the United States from east of Arizona. Mr. Priour's note-book shows that a squirrel was taken on this date at this locality (about fifteen miles above the mouth of the Brazos River, in Bee County). The skin, in all features of coloration, resembles a common phase of the Southern Gray Squirrel (Sciurus carolinensis), the species that would be naturally expected to occur in Bee County, but the skull lacks all trace of the small premolar almost invariably present in this species.

13. Sciurus hypopyrrhus $W$ irgler? - In addition to the specimens of Sciurus above recorded are four skins without skulls, all received, Mr. Sennett informs me, from Mr. Wm. B. Richardson, but only one of them has a label, inscribed, in Mr. Sennett's hand-writing, " Tampico, Mexico, Richardson, I888." 'They are all intense glossy black throughout, of large size, with very long heavy tails, and high pointed ears. They resernble a melanism of $S$. hypopyrrhus, but this species has not been reported from north of the southern border of Mexico. In three of the speci- 
mens the pelage at the extreme base, on the dorsal area, is tinged with rufous, in one strongly so.

14. Spermophilus grammurus $(S a y)$.-One specimen, Presidio Co., Texas, Sept., 1887, Wm. Lloyd. This specimen represents the ordinary phase of true grammurus.

15. Spermophilus mexicanus (Licht.).-One specimen, of ad., Pecos City, Texas, June, r887, Wn. Lloyd. One specimen, Corpus Christi, Texas, G. B. Sennett ; two specimens, $\hat{o}$ ad. and juv., Xecotencatl, Tamaulipas, May, I888, J. M. Priour.

16. Spermophilus tridecemlineatus (Mitchell).-Two specimens, Bee Co., Texas, April $30, \mathbf{1} 887$, J. M. Priour. In coloration they are not distinguishable from Minnesota examples.

1\%. Mus musculus Linn.-Two specimens, adult and young, Victoria, Tamaulipas, April, 1888, J. M. Priour.

18. Ochetodon mexicanus (De Saussure).-Two specimens, $\hat{o}$ and $q$ adult; skins and skulls, Bee County, Texas, January, r 887, J. M. Priour. Also two specimens, of and of young, skins only, Santa Teresa, Tamaulipas (about fifty miles southwest of Matamoras), March 23, 1888, J. M. Priour.

The two young specimens from Santa Teresa are less than half grown, but in general coloration above exactly resemble the adults from Bee County, Texas. Below they are like a young house mouse. The Bee County specimens, in midwinter pelage, are superficially nearly pure white below, with the fur plumbeous for the basal half. Above they are mouse gray strongly suffused with yellowish brown, passing into pale orange brown on the sides. A conspicuous feature in all of the specimens is the color of the inner surface of the ears, which is strong yellowish brown, or brownish orange.

This species has been recorded from Duval Co., Texas, by Mr. Thomas, * and also from as far north as Grand Coteau, La., by Dr. Coues. $\dagger$

19. Neotoma floridana mexicana (Baird).-One specimen, $q$ ad., Presidio Co., Texas, Oct. 15, 1887, William Lloyd. "Head and body, 11.75 in. ; tail, 5.00." 
20. Neotoma micropus Baird.*-Three specimens, San Fernando de Presas, Tamaulipas, March 30, I888, J. M. Priour.

21. Sigmodon hispidus berlandieri Baird.-Three specimens : $\hat{o}$ ad., Corpus Christi, Texas, May 23, I887, J. M. Priour; $q$ juv., Corpus Christi, Texas, Jan. 12,1887 ; $q$ ad., San Fernando de Presas, Tamaulipas, March 26, 1888.

22. Oryzomys palustris (Harlan).-One specimen, $\hat{\delta}$ ad., Wharton Co., Texas, May 27, I887, J. M. Priour.

This specimen is provisionally referred to O.palustris, though paler and grayer than any example in a large series from Florida and Louisiana. It is much nearer this, however, than to $O$.couesi from further south.

23. Vesperimus leucopus texanus (Woodhouse). $\uparrow-O n e$ specimen, Bee Co., Texas, $q$ ad., April 2r, 1887, J. M. Priour.

24. Vesperimus leucopus sonoriensis (Le Conte).-Four specimens, Presidio Co., Texas, $\hat{s}$ and $q$ ad., and two immature specimens in the blue pelage, Oct., $1887, \mathrm{Wm}$. Lloyd.

A single specimen from Tampico, Mexico, April, I888, W. B. Richardson, is also provisionally referred here. It lacks the skull, and nothing is left of the tail but the unfilled curled-up skin.

\section{Geomys personatus True.}

Geomys personatus TRUE, Proc. U. S. Nat. Mus., I888, p. 159.

In I888 Mr. F. W. True described a new species of Geomys, based on two specimens from Padre Island, Texas. Mr. Sennett's collection contains four specimens, from the same locality, collected in February, 1887 , by Mr. Priour. They include two very old breeding females and a half-grown young one, and a very young one taken apparently when not more than a week or ten days old. The two adults agree fairly well with Mr. True's description, but are apparently rather paler and more of an ashy ecru tint above than his description seems to imply. The halfgrown example appears to agree exactly with his description. In all the specimens the lower parts are white, as described by $\mathrm{Mr}$.

* The status of this form will be discussed at length in a later paper in the present volume of this Bulletin.

+ See Mearns, Bull. Am. Mus. Nat. Hist., II, No. 4, Feb., 18go, p. 285. 
True, this feature forming their most striking external difference from $G$. busarius, although the blackish frontal region is also in a measure distinctive.

There are also two specimens, about two-thirds grown, from Corpus Christi, that seem referable to this species.

The skull of Geomys personatus differs from the skull of $G$. busarius and $G$. tuza in being much heavier, with heavier dentition; while of the same length it is broader, the rostral portion being especially thickened.

26. Perognathus flavus Baird.-One specimen, skin, without skull, Presidio Co., Texas. Provisionally referred to this species.

\section{Perognathus paradoxus spilotus Merriam.}

Perognathus paradoxus spilotus Merriam, N. Am. Fauna, No. I, Oct., I889, p. 25.

Two specimens, $q$ ad., skin with skull, and skin of a young specimen about two-thirds grown, Bee Co., Texas, A pril, I887, J. M. Priour. Also $q$ ad., skin and skull, Padre Island, Nueces Co., Texas, Feb. 24, 1887, J. M. Priour.

These specimens were at first presumed to be P. hispidus Baird, but on comparing them with the type of that species, kindly loaned me for this purpose by the authorities of the U. S. National Museum, they prove to have no near relationship with that species. They are therefore provisionally referred to Dr. Merriam's $P$. paradoxus spilotus, based on specimens from Gainesville, Texas, though presumably different, Bee County and Gainesville being separated by nearly the whole length of the State of Texas, and are, furthermore, in very different faunal districts. The type being in Dr. Merriam's private collection, his absence in the field renders its examination for the present impracticable. Judging from his descriptions, measurements and figures of $P$. paradoxus and $P$. paradoxus spilotus, these specimens belong to the same group. While they seem to scarcely differ from the latter in coloration, they are much smaller, though two of them are fully adult (the female had evidently suckled young), as shown by the skulls. No. $\frac{34}{2} \frac{8}{3} \frac{0}{5}$ measures as follows :

Measurements (approximate from skin): head and body $91.5 \mathrm{~mm}$. ; tail vertebræ, 78.7 ; hind foot, 23 ; ear from crown, 8. 
Skull : total length, 29.2; basal length (condyle to incisors), 22.9; greatest mastoid breadth, 14 ; least intermastoid breadth, 7.6. These measurements in paradoxus and spilotus are respectively as follows: 32,$31 ; 26.6,25.2 ; 15.7$, I $4.5 ; 9,8.6$.

The Bee County specimens are thus more than one-tenth smaller than even $P$.p. spilotus; the fore limbs are not fulvous to the wrists (except partly so in the young specimen), while the lower surface of the tail is strong fulvous, like the flanks, instead of white or yellowish-white, as in paradoxus and spilotus.

\section{Dipodops compactus (True).}

Dipodomys compactus True, Proc. U. S. Nat. Mus., 1888, p. r6o. (Padre Island, Texas.)

Three specimens, Padre Island, Nueces Co., Texas, skins with skulls, Feb. 19-22, $1887, \mathrm{~J}$. M. Priour. One of the specimens is very pale ashy gray above, apparently albinistic.

\section{Dipodops sennetti, sp. nov.}

Pattern of coloration as usual in the group. Above strong yellowish ochraceous-buff, very much mixed with blackish, the dark tint almost prevailing over the middle of the dorsal region from the crown to the base of the tail, lessening insensibly on the sides and passing into nearly unmixed strong buffy yellow on the flanks. Upper tail stripe dusky brown; the lower similar but paler, both extending the whole length of the tail. Lateral tail stripes white, continued considerably beyond the vertebræ. Tail slightly crested and penicillate.

Measurements (approximate from skin): Total length, $210 \mathrm{~mm}$. (7.20 in); head and body, I0O (3.94); tail vertebræ, I10 (4.33), pencil, $20(.79)$; hind foot, 35 (I.46); ear, from crown, 9 (.28), from anterior base, $13(.5 \mathrm{I})$.

Skull, total length, $38.8 \mathrm{~mm}$. ; greatest width, 23.7 ; nasals, 13.6, as against, respectively, $4 \mathrm{I}, 25.5$, and $\mathrm{I} 5$ in $D$. ordii, and $26,21.3$, and 14 in $D$. compactus.

Type No. $\frac{34}{87} \frac{78}{3}$, f ad., near Brownsville, Cameron Co., Texas, March 9, 1888, J. M. Priour.

This form is nearest to $D$. ordii, which it much resembles in coloration, but is rather darker and less golden, the cheeks more mixed with blackish and the dusky eye ring broader, and the tail very differently colored. Compared with one of Dr. Merriam's El Paso specimens (No. $\frac{18142}{25040}$, U. S. Nat. Mus., kindly loaned me by the Department of Agriculture), forming one of the series of specimens from which Dr. Merriam recently redescribed* the 
species, the following differences are to be noted. Besides the general difference in coloration already noticed, the tail in $D$. sennetti is broadly and continuously blackish both above and below, with the white lateral stripes sharply defined; in $D$. ordii the basal half of both the upper and lower surfaces of the tail is so much mixed with whitish as to produce a general grayish effect; the ears in $D$. sennetti are broadly edged with blackish on the outer anterior border, of which marking there is barely a trace in D. ordii. But these differences may be seasonal, the El Paso specimen having been taken in December and the Cameron County example in March. There is apparently but little difference in general size or proportions, except in the size of the ears, which are much the larger in D. sennetti. A comparison of the skulls, however, shows surprising differences. In $D$. ordii the skull is more triangular, the rostral portion being narrow, pointed and rather short, while the mastoid portion is greatly swollen. Just the reverse of this occurs in $D$. sennetti, the rostral portion being both elongated and broadened, while the mastoids are much less inflated and widely separated by an interparietal area three times as broad as in D. ordii and of an entirely different shape. The interparietal in $D$. ordii is subtriangular, and nearly three times broader at its anterior than at its posterior edge; while in $D$. senuetti the interparietal is slightly hour-glass shaped-quadrate, slightly hollowed on the lateral margins-with the anterior and posterior width about equal. The expanded orbital bridge of the maxillary is broader and much more developed in $D$. sennetti than in $D$. ordii. The lower jaw is also very different in the two species, in $D$. sennetti the condylar portion being much more depressed and the condyle itself longer and very different in form from the same part in $D$. ordii, while the angle is much broader and its plane less oblique to the vertical plane of the ramus.

$D$. sennetti differs from $D$. compactus in being about one-third larger (judging from the skulls), and in its very much darker coloration. In other words, $D$. compactus. is a small, pale form, probably restricted to Padre Island.

30. Tatusia novemcincta (Linn.).-One specimen, Tampico, Mex., June 1, 1885, J. M. Priour. 
31. Didelphys virginana ealifornica (Bennett).-Three specimens, Corpus Christi and Brownsville, Texas, G. B. Sennett.

In general color specimens of the Opossum from the Lower Rio Grande are nearly black, the surface of the pelage being deep brownish black or black, the under pelage yellowish white.

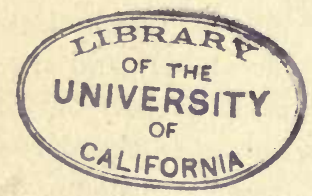






List of Mammals and Birds collected in Northeastern Sonora and Northwestern Chihuahua, Mexico, on the Lumholtz Archaslogical Expedition, $1890-92$.

$$
\text { By J. A. Alleen. }
$$

AUTHOR'S EDITION, extracted from BULLETIN OF THE

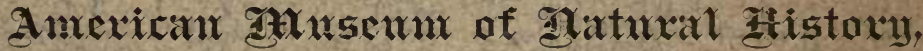

VOL. V, ARTiCle III, pp. $27-42$.

New York, March 16, 1893 . 

Article III.-LIST OF MAMMALS AND BIRDS COLLECTED IN NORTHEASTERN SONORA AND NORTHWESTERN CHIHUAHUA, MEXICO, ON THE LUMHOLTZ ARCHÆOLOGICAL EXPEDITION, $1890-92$.

\section{By J. A. Allen.}

The expedition of Dr. Carl Lumholtz, under the auspices of the American Museum of Natural History, was primarily undertaken for research in the line of archæology. During the first two years of its work, however, some attention was given to general natural history, collections being made in zoölogy and botany. While only about fifty-five mammals were collected, they possess considerable interest. About one thousand birds were obtained, representing one hundred and sixty-two species. Unfortunately, however, most of the ornithological work appears to have been done during fall and winter, and thus the results are less satisfactory than would have been the case had collecting been more actively carried on during summer. The bulk of the collection consists of North American species, but the record of localities given below often affords definite information of much interest respecting their winter distribution.

The expedition set out from Bisbee, in southeastern Arizona, early in September, 1890 , proceeding south ward about two hundred and twenty-five miles to Bacadehuachy and Nacory, on the Rio Yaqui, passing the following places in the order named: San Pedro ( 32 miles south of Bisbee), Los Trincheras, Santa Barbara, Fronteras, Cachuta (102 miles south of Bisbee), Los Trinitas (1 29 miles south of Bisbee), Los Pinitos, Los Cuevas (alt. I 750-2300 feet), Oputo, Granados, Bacadehuachy (the last three on the Rio Yaqui). Thence turning eastward toward and across the Sierra Madre the following were passed: Nacory (alt. 3400 feet), Heurachi (alt. 4000 feet), Napolera, El Puerto (alt. $6300 \mathrm{feet}$ ), Bavispee River (on its extreme upper course), Rancheria de los Apaches (alt. 6620 feet), Chuhuachupa, Tachico (alt. 2000 feet), to San Diego (alt. 4000 feet) on the eastern 
slope. San Diego was for some time (Feb. I6 to May 6) the base of operations, from which trips were made to Guanopa, Rio Chico and Tatuara (Feb. I5-March 1).

The specimens of birds and mammals were collected principally by Mr. F. Robinette, of Washington, D. C. A few were collected by Mr. A. D. Meeds, of Minneapolis, Minn. Unfortunately no notes accompany the specimens, beyond the locality and date of collecting, and many of the localities are not on published maps.

\section{MAMMALS.}

I. Lepus alleni Mearns.-Two specimens, Oputo, Oct. 27.

2. Lepus arizonæ Allen.-One specimen, San Diego, northern Chihuahua, Nov. 5 .

3. Thomomys umbrinus (? Rich.).-Seven specimens, Juarez, northern Sonora. Referred provisionally to this species, and doubtless the same as T. umbrinus of Baird, based in part on Sonoran specimens.

4. Perodipus sp.?-One specimen, imperfect, and without label.

5. Mus musculus Linn.-Three specimens, Juarez, northern Sonora.

6. Neotoma mexicana Baird.-One specimen, Cachuta, northern Sonora, Oct. 3 .

7. Sigmodon hispidus arizonæ Mearns.-One specimen, Granados, Nov. 16.

8. Onychomys sp.?-One specimen (in poor condition), Jaurez, northern Sonora.

9. Cynomys arizonensis Mearns.-Three skins, San Diego, Chihuahua, Nov. 14, 1891, A. D. Meeds.

I0. Sciurus aberti Woodh.-One skin, in the gray phase, and an additional skull and skeleton. Without labels, but probably taken in December, on the upper Bavispee River. 


\section{Sciurus apache, sp. nov.}

Upper premolars $\frac{1}{1}$. Size large ; tail long, full and bushy, the vertebræ alone nearly equal to head and body. Above pale yellowish gray, varied with black, darkest on the head; dorsal pelage at base pale plumbeous, the coarser hairs pale buff, with a broad subterminal ring of black and a whitish tip ; below uniform pale orange yellow, as are also the limbs and feet; tail above black, broadly fringed with yellowish white, below with a broad central band of dull ferrugineous orange, bordered on either side with a broad band of black, and a broad fringe of yellowish white, the basal half of the hairs being dull orange, the next fourth black, and the apical fourth yellowish white. A pale yellow eye-ring. Ears moderate, rounded, yellowish, mixed with gray, both externally and within.

Measurements.-(Approximate, from skin.) Head and body, $320 \mathrm{~mm}$.; tail vertebræ, 265; tail to end of hairs, 360 ; hind foot, 72 ; ear, from crown, 20.

Skull.-Rostral portion short and broad, the nasals but little narrowed posteriorly. Total length, 64 ; basilar length, 58 ; greatest breadth, 36 ; least interorbital breadth, 22; length of nasals, 20 ; width of nasals at posterior border, 12.

Type, No. $\frac{53}{4 \frac{3}{3} 0 \frac{0}{2}}$, Northern Chihuahua, Lumholtz Expedition.

This species is based on two skins and skull taken in Northern Chihuahua by the Lumholtz Expedition, probably in November or December, the specimens being evidently in late fall or winter pelage. They were unfortunately without labels when received.

The skull presents a general resemblance in size and form to skulls of other species of the subgenus Parasciurus, or the group with the premolars $\frac{1}{1}$. It appears to most resemble the skull of S. arizonensis Coues, but has the rostral portion shorter and broader than in average specimens of this species. The skull differs in a similar way from that of $S$. nayaritensis Allen.

In coloration $S$. apache, as the above description shows, presents no suggestion of close affinity with either S. arizonensis or $S$. nayaritensis, but strongly recalls that of pale examples $S$. niger ludovicianus; and it is undoubtedly related to the S.niger group. At first it seemed probable that the specimens above described would prove referable to Sciurus limitis Baird, based on a specimen from "Devil's River, or the San Pedro of the Rio Grande, Texas," but reference to Baird's description of $S$. limitis shows the latter to be very different from the form here described as S. apache. 
Note on Sciurus arizonensis Coues. - A large series of skulls of this species, recently presented to the American Museum of Natural History by Dr. Edgar A. Mearns, by whom they were collected at various localities in Arizona, shows that this species belongs to the Parasciurus group, the upper premolars being $\frac{1}{1}$ instead of $\frac{2}{1}$, as formerly supposed. When treating of this species in $1877,{ }^{1}$ no skulls were available for examination, and from its general resemblance in coloration to Sciurus carolinensis it was referred, erroneously as it now appears, to the same section of the genus. Parasciurus thus proves to have a nearly transcontinental range, instead of being an exclusively 'Eastern' genus, as recently assumed by the present writer. ${ }^{2}$ It also has a wide range in Mexico, occurring in the Sierra Madre region southward into the States of Zacatecas and Vera Cruz, where it is represented respectively by $S$. nayaritensis Allen and $S$. niger melanonotus Thomas.

I2. Cariacus virginianus (subsp.?).-Several imperfect flat skins, including two with skulls and feet, and two separate skulls of does. The skins include one that is pure white (albino). Bavispee River, October, 1890 .

A full-grown male has antlers of the usual style of C.virginianus, but another specimen shows that old bucks sometimes develop antlers of large size, with very numerous tines, the left antler in this specimen having eight points and the right one six points; they are, however, unsymmetrical in the two antlers and represent an abnormal development. This head strongly suggests the remarkable growth of points seen in some specimens of $C . v$. leucurus. The length of the left antler measured along the convexity of the beam is sixteen and one-half inches; the length of the principal tine is six inches.

In coloration these specimens closely resemble $C$. v. leucurus, but are rather lighter, with a whiter tail. They apparently represent a much larger form than Baird and some other authors have recognized under the name Cariacus mexicanus.

I3. Mephitis estor Merriam.-Two specimens, San Diego, northern Chihuahua, Oct. 28.

1 Monographs of N. Am. Rodentia, pp. 738-74I.

2 This Bulletin, IV, p. 218. 
These specimens agree with Dr. Merriam's description of his $M$. estor from San Francisco Mountain, Arizona, to which species they are here provisionally referred.

I4. Procyon lotor hernandezii (Wagler).-Represented by a single skin without label.

I5. Urocyon virginianus scottii Mearns.-Several skins, separate skulls, and a skeleton.

I6. Canis latrans Say. - Two skins with skulls, from northwestern Chihuahua, in winter coat. These compared with specimens in summer pelage from Arizona (Mearns Coll.) show that the seasonal change in the coloration and texture of the pelage is very great. In winter specimens the coat is long, fine and soft, above yellowish gray varied with black; in summer examples it is thin, coarse and harsh, above yellowish brown, with very little mixture of black.

Specimens in winter coat from Montana are very different in coloration from those from northern Mexico taken at the same season, the southern specimens being much more yellowish throughout, with the posterior surface of the ears; occiput, and the outer surface of the limbs golden brown, much brighter and more golden than in the northern specimens. Doubtless a proper amount of material for comparison would demonstrate the desirability of recognizing several subspecies among the Coyotes, which range from Central America northward to beyond the northern boundary of the United States.

\section{I7. Lynx rufus maculatus (Horsf. \&o Vig.).}

Felis maculata HoRsf. \& VIG. Zool. Journ. IV, 1829, p. 381, pl. xiii. (Mexico.) Lynx rufus var. maculatus BAIRD, Mam. N. Am. 1857, p. 93.

? Lynx baileyi Merriam, N. Am. Fauna, No. 3, I890, p. 79 . (Southern Arizona.)

Two specimens, in winter pelage, without labels, but probably from Camp 2 I, on the Bavispee River, I 5 miles from Chuchuichupa, December, 1891 . One is adult, the other about half grown. The adult specimen agrees very well with the description of Felis maculata Horsfield \& Vigors, to which these specimens are provisionally referred. Whether or not it is the same as Lynx baileyi 
Merriam, from Arizona, is not easy to determine, since Dr. Merriam's comparisons are exclusively with specimens of $L$. rufus from Connecticut.

A series of $\mathrm{I}_{5}$ specimens from Arizona (Mearns Collection) presents a wide range of variation in color, summer specimens being more tawny than winter specimens, with the black spots of the lower parts more vividly contrasted with the purer white ground color. There is also much individual variation, especially in respect to the distinctness of the face and head markings.

Two specimens from Florida (Tarpon Springs) are, as compared with northern rufus, very dark in general coloration, especially over the hinder portion of the dorsal surface, and the head markings are stronger. These represent a fairly recognizable Florida form, provisionally termed "Lynx rufus var. floridanus Rafinesque" by Baird in 1857 (1. c., p. 9 , in text). A single specimen from Brownsville, Texas, is strikingly similar in general coloration. Two specimens from the formerly so-called 'Neutral Strip,' Indian Territory, are much more like the northern $L$. rufus. Two winter specimens from Montana have, in comparison with all of the other specimens, a much longer, thicker, softer pelage, as would be expected from the season and locality, but they are also grayer and less strongly spotted.

Doubtless the Lynxes of the widely distributed $L$. rufus group will be found separable into a number of more or less well-marked geographical forms, when sufficient material for comparison is brought together.

\section{BIRDS. ${ }^{1}$}

I. Mergus americanus. - Two specimens (labels lost).

2. Anas strepera.-San Diego, Feb. 2.

3. Anas americana.-Cachuta, Oct. 2.

4. Anas carolinensis.-Nacory, Nov. 30; San Diego, Feb. 2.

5. Anas discors.-Cachuta, Oct. 2.

1 As nearly all of the species here mentioned occur in the American Ornithologists' Union ' Check-List of North American Birds,' authorities for the scientific names are omitted, except where the species is extralimital to the A. O. U. Check-List. 
6. Anas cyanopterus.-San Diego, Nov. ro.

7. Dafila acuta.-Cachuta, Oct. 3.

8. Spatula clypeata.-San Diego, March I4.

9. Erismatura rubida.-Pachico, June 22.

I0. Plegadis guarauna.-Cachuta, Oct. 5 .

II. Ardea herodias.-San Diego, Feb. r9.

12. Ardea candidissima.-Three specimens (labels lost).

13. Fulica americana.-Pachico, June 22; Cachuta, Sept. 28-30.

I4. Recurvirostra americana.-Oputo, Oct. 22.

I5. Himantopus mexicanus.-Cachuta, Oct. ro.

I6. Gallinago delicata.-Pachico, Jan. 25; Chuhuichupa, Jan. 2-r4; San Diego, Oct. 23.

I7. Tringa bairdii.-- One specimen (without label).

18. Tringa minutilla.-San Pedro, Sept. I5; San Diego, April $\mathbf{~}$.

I9. Ereunetes occidentalis.-Cachuta, Oct. 2.

20. Totanus melanoleucus.-One specimen (without label).

2I. Totanus solitarius.-San Diego, April I3.

22. Totanus solitarius cinnamomeus.-Cachuta, Oct. 8.

23. Agialitis vocifera. - Bisbee and Greenbush Ranch, Sept. 6-1o; Pachico, June 22.

24. Cyrtonyx montezumæ. - Los Pinitos, Los Vengos, Nacory, and Huerachi, Oct. I2-Dec. 6.

25. Callipepla gambeli.-Santa Barbara, Sept. 2 I.

26. Callipepla elegans (Less.).-Nacory, Nov. 27.

[March, 1893.] 
27. Callipepla squamata.-San Pedro and Bisbee, Aug. I5Sept. 26; San Diego, Feb. 16.

28. Zenaidura macroura.-Near Bisbee, August; Huerachi, Dec. 6.

29. Melopelia leucoptera.-Bisbee, July.

30. Scardafella inca.-Granados, Nov. 12-15.

31. Cathartes aura.-Fronteras, Sept. 23.

32. Circus hudsonius. - Rancheria de los Apaches, Jan. Io.

33. Accipiter velox.-Granados, Nov. I I; Pachico, June 22.

34. Buteo borealis calurus.-Chuhuichupa, Jan. I4.

35. Buteo swainsoni.-Fronteras, Sept. 23.

36. Urubitinga anthracina.-San Diego, March $3 \mathbf{r}$.

37. Asturina plagiata.-Fronteras, September; Oputo, Oct. 26.

38. Falco columbarius.-San Diego, Oct. 23.

39. Falco sparverius deserticolus.-Pachico, June 28 and Jan. 25; Granados, Sept. 27 and Nov. I I; Nacory, Nov. 29; Bavispee River, Dec. 3 .

40. Asio wilsonianus.-San Diego, March I4.

4I. Bubo virginianus subarcticus.-San Diego, Feb. I923.

42. Speotyto cunicularia hypogæa.-San Pedro, Sept. 15.

43. Rhynchopsitta pachyrhyncha (Swains.). - Three specimens, Pachico, June 20.

44. Geococcyx californianus.-Near Bisbee, August.

45. Euptilotis neoxenus (Gould).-One specimen, sexed'as a male, but if so it is immature, taken at El Pinita, Dec. $16,1890$.

46. Ceryle alcyon.-San Diego, Feb. 24; Chuhuichupa, Jan. 14. 
47. Campephilus imperialis (Gould).-Seven specimens, taken as follows: Chuhuichupa, Jan. 25-29, I892; Bavispee River, Dec. 24, 1890; Rancheria de los Apaches, Jan. Io, I891. Dr. Lumholtz informs me that the species is common at the localities last named.

48. Dryobates villosus hyloscopus. -El Puerto, Dec. 7; Rancheria de los Apaches, Jan. I4-25.

49. Dryobates arizonæ.-Rancheria de los Apaches, Jan. 14 and 15 .

50. Dryobates scalaris.-Oputo and Bacadehuachy, Sept. 25-Nov. 29; San Diego, Feb. 24.

5I. Sphyrapicus varius nuchalis.-El Pinita and Los Cuevos, Oct. I 2-15; El Puerto, Dec. I6; Bavispee River, Dec. 30; Rancheria de los Apaches, Jan. 15. One of the El Puerto specimens (No. $56,498, \hat{\delta}$ ), shows an excessive tendency to erythrism, the usual red throat patch extending posteriorly over the whole breast, where the feathers are merely black at the base and red apically, the usual broad black breast patch being concealed by the broad red tips of the feathers. The posterior half of the superciliary and subocular white stripes is also strongly washed with red-a feature occasionally developed in specimens from other localities. The El Puerto specimen thus has very much the appearance of a small $S$. ruber.

52. Sphyrapicus thyroideus. - Female, Bavispee River, Dec. I2; male, Rancheria de los Apaches, Jan. 15. This last example (No. 56,494 , $\hat{3}$ ad.) also shows an abnormal development of red on the breast, the usual red gular stripe broadening posteriorly and continuing over the breast, where it occupies the middle third of the pectoral area. The feathers of the whole top of the head are also broadly tipped with bright red. It thus at first sight, through the red crown and extension of the red throat spot over the breast, has the appearance of being a very different species from $S$. thyroideus. In the absence of other specimens, however, it seems best to treat it as merely an abnormal example of $S$. thyroideus. 
53. Melanerpes formicivorus bairdi.-Cachuta and El Pinita, Oct. 9-14; Pachica, June 22; San Diego, Oct. 30.

54. Melanerpes uropygialis. - Fronteras, Sept. 20-27; Bacadehuachy, Nov. 20.

55. Colaptes cafer.-Los Trincheras, Sept. 20; El Pinita, Oct. 12; Rancheria de los Apaches, Jan. Io; San Diego, Nov. 5.

56. Phalænoptilus nuttalli nitidus.-San Diego, Nov. I 2.

57. Chordeiles acutipennis texensis.-San IDiego, April $2 \mathrm{I}-24$.

58. Aëronautes melanoleucus.-Granados, Nov. I6.

59. Trochilus alexandri.-Bisbee, Arizona, July and A ugust.

60. Calypte costæ. - El Pinita, Oct. I4.

6I. Selasphorus alleni.-Bisbee, August and September; Santa Barbara, Sept. 2 r.

62. Tyrannus vociferans.-Leoncita and Fronteras, Sept. $21-27$.

63. Tyrannus verticalis.-San Diego, April i $3^{-2 x}$.

64. Myiarchus cinerascens.-San Diego, April 21-23.

65. Myiarchus inquietus (Salv. \& Godm.).-Oputa, Sept. 9; Bacadehuachy, Dec. 20.

The two specimens above recorded seem unquestionably referable to Mr. Salvin's recently described Myiarchus inquietus, ${ }^{1}$ from the State of Guerrero, Mexico, although from localities so much further north. We have, however, a specimen from Zapotlan, Jalisco (collected by Dr. A. C. Butler), a much more southern but still an intermediate point. Doubtless it will prove to range throughout the mountainous parts of Mexico, as Myiarchus cinerascens nutting $i$ has recently been found to do.

66. Sayornis phœbe.-San Diego, Feb. 24. 
67. Sayornis saya.-San Pedro, Sept. 9; San Diego, April 5.

68. Sayornis nigricans.-San Diego, May 15 and Nov. 5; Granados, September and November.

69. Contopus richardsoni.-San Diego.

70. Empidonax difficilis.-Los Cuevos, Oct. 15.

71. Empidonax wrightii.-Oputo, Nov. 9-25; San Diego, April 3-22.

72. Empidonax hammondi.-Los Cuervos, Oct. 15.

73. Pyrocephalus rubineus mexicanus.-San Pedro, Sept. 15; Granados and Nacory, November; San Diego, March ro and April 15; Pachico, June 22.

74. Otocoris alpestris adusta.-San Diego, Feb. I6 and Nov. 5 .

75. Cyanocitta stelleri macrolopha.-El Pinita, Oct. I2; also four specimens without labels.

76. Aphelocoma woodhousei.-Bisbee, July 44.

77. Aphelocoma sieberi arizonæ.-Cachuta, Oct. 9; Bavispee River, Dec. 16; San Diego, April 8.

78. Corvus corax sinuatus.-Chuhuichupa, Jan. I4.

79. Corvus cryptoleucus.-San Pedro, Sept. r6.

80. Molothrus ater obscurus.-Bisbee, July 30.

8I. Xanthocephalus xanthocephalus.-Pachico, June 22; San Pedro, Sept. 12.

82. Agelaius phœniceus sonoriensis.-Nacory, Nov. 26; San Diego, March I3; Pachico, June 22.

83. Sturnella magna mexicana.-San Diego, Oct. 20 and Feb. 26; San Pedro and Cachuta, Sept. 15-30; Nacory, Nov. 24.

84. Icterus parisorum.-Bisbee, July $2 \mathrm{I}$.

85. Icterus cucullatus nelsoni.-Bisbee, July i 7. 
86. Scolecophagus cyanocephalus.-San Pedro and Cachuta, Sept. 15-30.

87. Carpodacus mexicanus frontalis.-Oputo, Oct. 25-27; Granados and Nacory, November.

88. Spinus psaltria.-Los Cuevos, Oct. 15.

89. Spinus pinus.-San Diego, March and April; Rio Chico, Feb. 9.

90. Calcărius ornatus.-San Diego, Feb. 18-24.

91. Rhynchophanes mccowni.-San Diego, Feb. 16.

92. Poocætes gramineus confinis.-San Diego, Feb. 16I 8.

93. Ammodramus sandwichensis alaudinus.-San Diego, Feb. 18.

94. Ammodramus bairdi.-Nuevencha Plain, Feb. 15.

95. Chondestes grammacus strigatus.-Bisbee, Aug. I214; Nacory, Nov. 27.

96. Zonotrichia leucophrys intermedia.-Fronteras, Sept. 27; Oputo, Oct. 30; Granados, Nov. 15; San Diego, Oct. 30 and April 3-ז 3 .

97. Spizella socialis arizonæ. - Puerto de los Pinitos, Bacadehuachy, and Nacory, Nov. 13-24; San Diego, April and October.

98. Spizella pallida.-Oputo, Oct. 27; San Diego, Feb. 18 and April i 3.

99. Spizella breweri.-Granados, Nov. 15.

I00. Junco hyemalis shufeldti.-Chuhuichupa, Jan. II.

Ior. Junco annectens.-Rancheria de los Apaches, Jan. IO-I 7 . 
I02. Junco caniceps. - Napolera, Dec. I2; Bavispee River, Dec. 22; Rancheria de los Apaches, Jan. Io; Chuhuichupa, Jan. $1 \mathrm{I}$.

I03. Junco cinereus palliatus.-Chuhuichupa, Jan. I9.

I04. Junco cinereus dorsalis.-San Diego, Nov. II.

105. Amphispiza bilineata.-Bisbee, July 9-Sept. 9; Oputo, Oct. 30 .

I06. Aimophila superciliosa (Swain.).-Bavispee River, Dec. 21-26; Pachico, Jan. 27.

I07. Aimophila mcleodi (Brewster),-Puerto de los Pinitos, Oct. I 4.

108. Peucæa ruficeps boủcardi.-Bisbee, July ro; Bavispee River, Dec. 26.

I09. Peucæa notosticta (Scl. \& Salv.).-Bavispee River, Dec. 26; Guanopa, Feb. 2.

II0. Peucæa carpalis.-Granados, Nov. 16.

III. Peucæa cassini:-Cochise Co., Arizona, Aug. 24-Sept. 4.

II2. Melospiza fasciata montana.-Bavispee River, Dec. I 2-26.

II3. Melospiza fasciata mexicana.-Bavispee River, Dec. $21-26$.

II4. Melospiza lincolni.-Fronteras, Sept. 27; Nacory, Nov. 27; Napolera, Dec. 9-то; Bavispee River, Dec. 26.

II5. Pipilo maculatus megalonyx.-Los Pinitos, Oct. 9I 3 .

II6. Pipilo chlorurus.-Fronteras, Sept. 26, 27; Bacadelhuachy, Nov. 2 I.

II7. Pipilo fuscus mesoleucus.-Granados, Nov. I2; Nacory, Nov. 24; San Diego, Oct. 27; Neuvencha Plain, Feb. I4.

II8. Cardinalis cardinalis superbus.-Oputo, Oct. 27. 
II9. Pyrrhuloxia sinuata beckhami.-Granados, Nov. 14.

120. Calamospiza melanocorys.-Oputo, Oct. 27-30.

121. Piranga rubra cooperi. - Fronteras, Aug. 25; San Diego, April 2 I-May 6.

122. Piranga hepatica.-El Pinita, Oct. I2-I4.

123. Tachycineta bicolor.-San Diego, Feb. 24-26.

124. Tachycineta thalassina.-Bisbee, July 7; San Pedro, Aug. I2; San Diego, Feb. 26.

125. Phainopepla nitens.-Oputo, Sept. I5-27; Nacory, Nov. 26.

126. Lanius ludovicianus excubitoroides. - Cachuta, Sept. 2; San Pedro, Sept. 15; San Diego, Feb. I6.

127. Vireo solitarius cassini.-Cachuta, Sept. 2.

I28. Vireo solitarius plumbeus.-San Diego, April 28; Pachico, June 22.

I29. Vireo huttoni stephensi.-Bacadehuachy, Nov. 20.

I30. Helminthophila luciæ.-Bisbee, July zo.

I3I. Dendroica æstiva sonorana.-Bisbee, Aug. 13; San Diego, March 3, April I and I3.

132. Dendroica auduboni.-Los Cuevas, Sept. 3; Oputo, Sept. 15-27; San Diego, March 13 and April I5.

133. Dendroica nigrescens.-San Diego, April 2 I.

I34. Geothlypis trichas melanops (Baird).-San Diego, May 6.

I35. Icteria virens longicauda.-San Diego, May 6; Lansito, Aug. 9.

I36. Sylvania pusilla pileolata.-San Diego, April i $5^{-2 \text { I. }}$

I37. Setophaga picta.-Guanopa, Feb. 2; Huerachi, Dec. 6. 
I38. Basileuterus rufifrons (Swain.).-Napolera, Dec. 8.

I39. Cinclus mexicanus.-Chuhuichupa, Jan. 22.

I40. Mimus polyglottos.-Oputo, Sept. 23; northern Chihuahua (without labels), mostly young birds in spotted plumage.

I4I. Harporhynchus curvirostris.-Oputo, Sept. 23 and Nov. 9; Nacory, Nov. 24.

I42. Campylorhynchus brunneicapillus.-Oputo, Sept. 2 I.

I43. Salpinctes obsoletus.-Fronteras, Sept. 27; Bavispee River, Dec. I 2.

I44. Catherpes mexicanus.-Pachica, Feb. 3.

I45. Thryothorus bewickii bairdi.-Chihuahua, Jan. I5 and March ro; San Diego, April 3.

I46. Troglodytes aëdon aztecus.-Bavispee River, Dec. 22; San Diego, April 15; El Puerto, Dec. 16.

I47. Certhia familiaris mexicana.-Napolera, Dec. I2; Chuchuichupa, Jan. 22.

148. Sitta pygmæa.-Bavispee River, Jan. 15; Totuaco, Feb. 29.

I49. Sitta carolinensis aculeata.-El Pinita, Sept. ro; Napolera, Nov. I7; Bavispee River, Dec. 22-30.

I50. Parus wollweberi.-Puerto de los Pinitos, Sept. I4; Napolera, Dec. I 2.

I5I. Parus meridionalis.-Chihuahua, Jan. 14 , r5; Tatuaca, Feb. I3-29.

I52. Psaltriparus lloydi.-Bavispee River, Dec. 28.

I53. Auriparus flaviceps. - Granados, Nov. I3; Bacadehuachy, Nov. 20.

I54. Regulus calendula.-Los Cuevas, Sept. I5; Bacadehuachy, Nov. Ix; Nacory, Nov. 24; Napolera, Dec. Io; Guanopa, Feb. 3; Tatuaca, Feb. 29. 
I55. Polioptila plumbea.-Oputo, Sept. 10-23.

I56. Polioptila cærulea obscura.-Oputo, Sept. 10; Bacadehuachy, Nov. 20.

157. Turdus aonalaschkæ.-Bacadehuachy, Nov. II.

I58. Turdus aonalaschkæ auduboni.-Rio Chico, Feb. 8; Bavispee River, Jan. $\mathbf{x}$.

I59. Merula migratoria propinqua.-San Diego, March I5.

I60. Sialia sialis.-Bavispee River, Dec. 30; Red Bank, Feb. 27 .

I6r. Sialia mexicana.-Nacory, Nov. 24.

I62. Sialia arctica.-Nacory, Nov. 24; Pachico, Jan. 5.

The foregoing list of birds shows that the following Mexican species occur, probably as resident birds, within about 150 miles of the southern border of the United States.

Callipepla elegans.

Rhynchopsitta pachyrhyncha.

Euptilotis neoxenus.

Campephilus imperialis.

Myiarchus inquietus.
Aimophila supercilosa.

Aimophila meleodi.

Peucæa notosticta.

Geothlypis trichas melanops.

Basileuterus rufifrons. 


On a Collection of Mammals from the Island of Trinidad, with Descriptions of New Species. .

By J. A. Alteen and Frank M. Chapman.

AUTHOR'S EDITION, extracted from BUILITIN OF THE

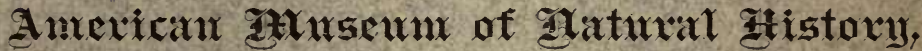

VOL. V, ARTICLE XIII, pp. 203-234.

New York, September 21,1893 





\section{Article XIII.-ON A COLLECTION OF MAMMALS FROM THE ISLAND OF TRINIDAD, WITH DE- SCRIPTIONS OF NEW SPECIES.}

\section{By J. A. Allen and Frank M. Chapman.}

This paper is based on a collection of about 200 specimens made by the junior author during the months of March and April, r893. With few exceptions the species herein recorded were secured in the south central part of the island, at a point twelve miles north of the southern coast and seven miles southeast of Princestown. Here, at the border of the forest which reaches to the coast, is situated a Government rest-house. Collecting was confined to within a radius of a mile of this resthouse. Points where small streams entered the forest proved the best collecting grounds. Here in close proximity were water, the dense low growth of bordering balisiers (Heliconia), and the forest itself. All the species secured near the rest-house doubtless might be taken in a short time within a radius of one hundred feet in a locality of this nature. The indigenous species secured here are doubtless all forest inhabiting.

The collection of small Rodents is of special interest as containing the results of perhaps one of the first attempts at systematic trapping of small mammals with the most approved traps. The collector, however, was handicapped by entire ignorance of the habits or even of the kinds of mammals which might be found, and also by the fact that birds were the first object of his efforts. Furthermore, at least one-third of the animals trapped were destroyed by predatory mammals or ants.

We believe, therefore, that, prolific as the field has proven, further collecting in the same region would add many species among the smaller Rodents.

A future paper in this Bulletin will give a report on the birds collected, and more fully describe the localities visited and the faunal affinities of the island.

Very little has been hitherto written especially upon the mammals of Trinidad, and very few specimens known to have 
been collected on the island appear to be extant in museums. Ledru $^{1}$ gave a list of ten species as early as 1810. De Verteuil, in his "Trinidad," devotes a number of pages to the mammals (pp. $85-89$ and $361-365$ ), and gives also a vague nominal list of the species (pp. 360, 36r). The list, however, is so indefinite that it is impossible to determine the number of species it is intended to include, while the nomenclature adopted is too erroneous to merit serious consideration. His remarks on the habits and distribution of many of the larger species are of interest.

The first serious attempt to give a scientific catalogue of the mammalian fauna of the island is Mr. Oldfield Thomas's 'A Preliminary List of the Mammals of Trinidad," published early in the present year. "The present list," says Mr. Thomas, "is only written to form a basis on which a complete scientific list of the mammals inhabiting Trinidad may be founded, and to show members of the Society how extraordinary little is definitely known of the mammals of the Island." He accordingly urges upon the attention of the members of the Trinidad Field Naturalists' Club the importance of collecting specimens for transmission to the British Museum for scientific determination. Mr. Thomas's list includes $5^{2}$ species, of which 27 , or more than one-half, are Bats, and 8 only are Rodents, one of these being mentioned only generically. Mr. Thomas believes that this large number of Bats represents less than half of the species actually occurring on the island, and calls special attention to the Rodentia as likely to afford species "which are as yet absolutely unknown." Mr. Thomas's foresight in respect to these groups is well vindicated by the present collection, which adds one species to the list of Bats, and raises the number of known Trinidad Rodents from 7 to 19. The number of known indigenous Muridæ is raised from one to eight, six of which it has been considered advisable to describe as new. It is not probable that any of them are strictly confined to the island, but doubtless occur on adjoining portions

\footnotetext{
1 Voyage aux Iles de Ténériffe, la Trinité, etc., I, I8Io, p. 256.

2 Trinidad: Its Geography, Natural Resources, Administration, Present Condition, and Prospects. By L. A. A. de Verteuil, M. D. P., etc. One vol., 8 vo., 1858 . We are able to cite only the second edition, published in $188_{4}$, which, so far as the natural history matter is concerned, appears to be textually the same as the first.

3 Journ. Trinidad Field Naturalists' Club, 1, No. 7, April, 1893, pp. I58-168.
} 
of the mainland. Some of them are obviously related more or less closely to species described from western and southern Brazil, though it is hardly probable that any of them will prove strictly identical. While a large number of species of Muridæ have been recorded from Ecuador, Peru, Chili, southern Brazil and the more southern parts of the continent, the literature of the subject contains very few references to specimens from northeastern South America, so that Mr. Thomas's pertinent remarks on our ignorance of the Muridæ inhabiting Trinidad will apply with equal force to a large area of the adjoining portions of the mainland.

I. Mycetes, sp.-A Howling Monkey was not uncommon in the forests about two miles from the rest-house. At this distance their howling or, better, roaring chorus, in the early morning could frequently be heard. No specimens were secured, but it is probable, as Mr. Thomas remarks, that the species is $M$. seniculus.

2. Saccopteryx bilineata (Temm.).-Two specimens, male and female adult.

3. Saccopteryx leptura (Schreber).-Five specimens, two males and three females.

In both of these species the females are larger than the males, as shown by the following measurements :

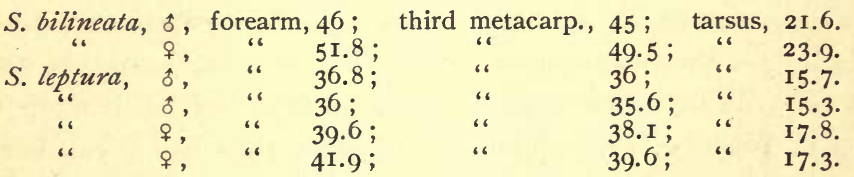

All of the specimens show the two faint whitish dorsal stripes, but in addition to its smaller size $S$. leptura is paler colored throughout, including all of the membranes, and the wing membrane is attached at the ankle joint instead of slightly above it, as in S. bilineata.

In the gloomy depths of the forest $S$. leptura was frequently seen coursing for insects during the day. 
4. Noctilio leporinus (Linn.).-Two specimens, male and female adult. Both have a distinct fulvous line down the middle of the back.

The cave on Monos Island in the first Boca from which so many of these remarkable bats have been secured, seems now to be deserted by them. The specimens above mentioned were taken from a large cave-like fissure in the Huevos Boca to which the collector was piloted by Mr. Morrison. Their stomachs contained the partially digested remains of fish; confirmation, if confirmation be needed, of the now well-known fish-eating habits of this species. At a recent meeting of the Trinidad Field Naturalists' Club ( $c f$. Journal, Vol. I, p. 204), the president of the Club, H. Caracciolo, Esq., described the manner in which these bats captured their prey, "by throwing it up with their interfemoral membrane. Simultaneously they bend their heads towards their tails to seize the fish as it is thrown from the water." In support of this observation Dr. A. Woodlock said (l. c.), "that early one morning, at Monos, he distinctly saw the bats in this act." Is it not possible that the much lengthened, curved, acute toe-nails of this species are of assistance to it in catching or hooking fish?

5. Molossus rufus Geoffr.-The 25 specimens representing this species show a wide variation in coloration. The specimens representing the extreme color phases were preserved as skins, the others in alcohol. The general coloration varies from deep rich chestnut to blackish seal brown. The ventral surface is a little lighter than the dorsal. Measurements of six adult females and four adult males indicate only a slight sexual difference in size, as follows: Six females, forearm 49.8 (48.3-50.8) mm.; third metacarpal, 49.8 (48.3-50.8); tibia, I8.6 (I8.3-18.8); free portion of tail, $25.6(2 \mathrm{x} .6-27.7)$. Four males, forearm, $5 \mathrm{I}(50.8$ $5^{\mathrm{I} .3)}$; third metacarpal, 50.3 (49.3-50.8); tibia, 20.3 ( $\left.9.8-20.6\right)$; free portion of tail, $27.9(26.9-28.3)$ :

This was by far the most common species of bat observed, and was the only one regularly seen at evening coursing for insects about the rest-house clearing. A colony of about thirty bats of this species, with evidently a few of $M$. obscurus, occupied the 
attic of a neighboring house. Their retreat was invaded and nineteen specimens secured. A short stick was the only weapon necessary to effect a capture, for while their abode was large and light, and access to the outer air was easy, not one took wing but all endeavored to escape by running. Some ran up the rafters to hide beneath the peak of the house; others ran across the floor, going so rapidly that it was difficult to strike them. When at rest they seemed to prefer sticking to a vertical surface rather than hanging after the usual manner of bats. Of the nineteen specimens taken seventeen were females and two males. Sixteen of the females contained a single fœtus each.

6. Molossus obscurus Geoffr.-This species is reprsented by a single specimen preserved in spirits. It is an adult female, and contained a single half-grown fœtus. The specimen measures as follows : forearm, $38 \mathrm{~mm}$. ; third metacarpal, $3^{8}$; tibia, I3.2; free portion of tail, I7.8.

A comparison of the measurements of this fully adult female with those given above of $M$. rufus would seem to indicate that these two forms are specifically distinct.

This specimen was found with the colony of $M$. rufus first mentioned. There were evidently other individuals in the same colony, but their smaller size enabled them to secrete themselves in holes from which it was not possible to dislodge them.

\section{Chœronycteris intermedia, sp. nov.}

Similar in size and general proportions to Charonycteris minor, but with the calcaneum one-half shorter, tibia longer, thumb shorter. Also different in coloration.

Above snuff-brown, the fur slightly paler basally, not " light grayish brown," as in $C$. mexicana and $C$. minor. Below slightly paler than above, about the color of the basal portion of the hairs above. Ears, feet and membranes blackish, naked, except that the fur extends on both surfaces of the wing membranes as far as the elbows, and also along the basal third of the forearm bones on both surfaces. Calcaneum conspicuously shorter, instead of " conspicuously longer," than the foot. Thumb shorter, tibia longer, than in $C$. minor.

Type, No. $\frac{6072}{478}$, $\&$ ad., Princestown, Trinidad, March 28, I893, coll. of Frank M. Chapman.

The present species is based on three specimens, a skin and skull, and two examples in alcohol. 
The genus Charonycteris is now for the first time recorded from Trinidad. The present species, while agreeing with $C$. minor from Surinam in size, appears to differ from it decidedly in coloration, particularly of the underfur, and in the shortness of the thumb, in the greater length of the tibia, and in the calcaneum being much shorter, instead of much longer than the hind foot.

While agreeing in the relative length of the calcaneum with C. mexicana, it is widely dissimilar in size, as well as in other features, it being very much smaller in all parts, as shown by the following comparative measurements :

\begin{tabular}{|c|c|c|c|c|c|c|c|}
\hline & 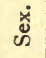 & Forearm. & $\begin{array}{c}\text { Third } \\
\text { Metacarp. }\end{array}$ & Tibia. & Foot. & Calc'um. & Thumb. \\
\hline termedia ${ }^{1}$ & q & \begin{tabular}{|c|c|}
$\mathrm{mm}$. & in. \\
34.5 & $\mathrm{r} .36$
\end{tabular} & \begin{tabular}{|c|c|}
$\mathrm{mm}$. & in. \\
34.5 & $\mathrm{r} .36$
\end{tabular} & \begin{tabular}{|l|l|}
$\mathrm{mm}$. & in \\
$\mathrm{I} 2.2$ & .48 \\
\end{tabular} & \begin{tabular}{|c|c|}
$\mathrm{mm}$. & in. \\
8.6 & .34 \\
\end{tabular} & \begin{tabular}{|c|c|}
$\mathrm{mm}$. & in. \\
6.6 & .26 \\
\end{tabular} & $\begin{aligned} & \mathrm{mm} . \text { in. } \\
& 5.6 .22\end{aligned}$ \\
\hline 6105 “ & i & $\begin{array}{ll}33.5 & 1.32\end{array}$ & \begin{tabular}{l|l}
33.5 & 1.32
\end{tabular} & 12.7 .50 & 8.1 .32 & 6.1 .24 & 5.1 .20 \\
\hline $6 \mathrm{ro}^{\prime \prime} "$ & $\hat{\delta}$ & $\ldots \ldots$ & \begin{tabular}{|l|l}
35.5 & $\mathrm{r} .40$
\end{tabular} & 13.5 .53 & 9.1 .36 & 6.1 .24 & 5.8 .23 \\
\hline C. minor ${ }^{3} .$. & & $\begin{array}{lll}34.3 & 1.35\end{array}$ & 34.31 .35 & I1.4. 45 & $8.1 \cdot 32$ & II. 2.44 & 7.1 .28 \\
\hline C. mexicana ${ }^{3}$. & & $\begin{array}{lll}43.2 & \text { I. } 70\end{array}$ & 40.61 .60 & 15.7 .62 & 10.6 .42 & 6.6 .26 & $8.9 \cdot 35$ \\
\hline
\end{tabular}

In dental and cranial characters $C$. intermedia appears to agree with $C$. mexicana and $C$. minor. The position of the lower premolars as shown in Dobson's plate (Cat. Chirop., Pl. xxvii, Fig. 6, $6 a$ ) does not agree, however, with his description given in the text (1. c., p. 5 ro).

8. Artibeus, sp. nov. ?-A large Artibeus, not referable to either $A$. planirostris or $A$. perspicillatus, is represented by a single skin, the skull unfortunately having been stolen by the resthouse cat. It differs in coloration and in the distribution of the fur on the wing-membranes, from any of the currently recognized species of Artibeus. The forearm measures $63 \mathrm{~mm}$.; the third metacarpel, 6r, and the tibia, 25.4. Color above and below light brown, much lighter on the head and anterior half of the body, the hairs nowhere tipped with gray. A broad white stripe above and a faint whitish line below each eye.

9. Lutra insularis $F$. Cuv.-An adult female (No. $\frac{6042}{4765}$, fully mature but not aged) gives the following measurements:

\footnotetext{
1 Measurements from skin.

2 Measurements from alcoholics.

${ }^{3}$ Measurements from Dobson, Cat. Chirop., pp. 510, 5 Ir.
} 
Total length, I060 mm.; head and body, 6ro; tail vertebræ, 450 ; hind foot, 103 ; ear from crown, 20 . Skull : basal length, ${ }^{1}$ 98 ; interorbital breadth, $\mathbf{1 9 . 5}$; Pm.4, 9. These cranial measurements somewhat exceed those given by Mr. Thomas (1. c.) for two specimens of $L$. felina. In the absence of proper material for comparison we provisionally adopt the name above given.

The Otter is apparently a rare animal in Trinidad. Hunters were either ignorant of its presence or said that they had met with it on very few occasions.

I0. Sciurus æstuans hoffmanni Peters.-A series of ten specimens prove to be much nearer subspecies hoffmanni from Costa Rica, both in size and coloration, than to the true astuans of Brazil, although clearly intermediate between the two, as respects both size and coloration.

The measurements of this series are as follows : Total length, 37 I $(348-390) \mathrm{mm}$.; head and body, 197 (182-208); tail vertebræ, 174 (145-208) ; hind foot, $47\left(43^{-52}\right)$; ear, r9. The skulls of six specimens average $50 \mathrm{~mm}$. in total length and 28.7 in greatest zygomatic breadth, as against respectively 53 and $3 \mathrm{r}$ in three skulls of hoffmanni from Costa Rica. The coloration is much nearer that of hoffmanni than it is to Santarem and Chapada examples of astuans.

This species is very common. It lives in the forests, particularly in those which are bordered by cacao groves, to the fruit of which they do much damage. Its voice bears an unmistakable resemblance to that of Sciurus hudsonius, but its vocabulary is more limited, and it is far less noisy than that species.

\section{Nectomys palmipes, sp. nov.}

Similar in general external and cranial features to $N$. apicalis Peters, but much smaller and darker, with a relatively much shorter tail.

Adult.-Pelage soft, full, glossy. General color above pale yellowish brown ; the middle of the dorsal region, from the nose to the tail, strongly blackish; the sides grayish buffy brown, sparingly varied with black-tipped hairs; the top of the head, from the muzzle to behind the eyes, blackish varied with gray. Below, whitish with a wash of pale buff, strongest over the middle of the

1 These measurements are in conformity with those given by Mr. Oldfield Thomas, P. Z. S., r889, p. 200.

[September, 1893.] 
ventral region, the fur grayish plumbeous beneath the surface. The line of demarcation between the coloration of the dorsal and ventral surfaces very indistinct. Ears oval, evenly rounded above, flesh colored at base, dusky apically, sparsely haired. Limbs externally grayish brown, the feet scaly, so thinly haired as to be nearly naked. Palms and soles scaly, the latter 5-tuberculate. Tail a little shorter than head and body, blackish, nearly unicolor, heavily furred for the basal half-inch or more, the rest scantily clothed with short bristly hairs, which form a very slight pencil at the tip.

Measurements, average of six adults (four males and two females) taken before skinning: Total length, $402(380-433) \mathrm{mm}$; head and body, 206 (I89-223) ; tail, I96 (I75-2I0); hind foot, 46.5 (44-48); ear from crown, I8.6 (I6-20). The females are considerably smaller than the males.

Young.-Above uniform mouse-gray, varying to mouse-brown, over the whole dorsal region; sides with a wash of buff, very slight in the quarter-grown specimens, becoming stronger as the animal increases in age; ventral surface clear gray, in older specimens whitish gray.

Skull similar to that of $N$. apicalis, ${ }^{1}$ especially in regard to the size and form of the interparietal, in which it differs notably from $N$. squamipes. An adult male skull measures as follows: Total length, ${ }^{2} 47$; basal length, 38 ; greatest zygomatic breadth, 24 ; mastoid breadth, I6.3 ; least interorbital breadth, 3.6 ; length of nasals, 18.3 ; length of interparietal, 4.3 ; width of same, 8.9 ; distance from incisors to first molar, II.9 ;'length of crown surface of upper molar series, 6.9 ; length of lower jaw (point of incisors to posterior border of condyle), 26.9; height at condyle, I3.5.

Type, No. $\frac{5928}{4658}$. 5 ad., Princestown, Trinidad, April Io, 1893, coll. Frank M. Chapman.

This species is based on a series of 12 specimens, 7 of which are adult and five in various stages of immaturity, the youngest about one-fourth grown.

The adults vary somewhat in coloration, chiefly in the intensity of the yellowish brown above, the amount of black over the middle of the dorsal region, and in the degree of buffy suffusion below, which varies from a slight tinge to a strong wash. The skulls of course vary in size and proportions with age, but in the

\footnotetext{
${ }^{1}$ As figured by Peters, Abhandl. Akad. Wissensch. zu Berlin, 1860, p. 148, pl. ii.

2 In this paper "total length," unless otherwise stated, is the distance from the most projecting part of the skull in front-anterior border of nasals or premaxillaries, as the case may be-to the most projecting part of the skull behind-occipital plane or occipital condyles, as the case may be ; "basal length" is the distance from the inner base of the incisors to the posterior border of occipital condyles. The length of the lower jaw is taken from the tip of the incisors to the posterior edge of the condyle, unless stated otherwise. In all instances measurements are taken with callipers in a straight line between the extreme points mentioned.
} 
fully adult there is little variation. The nasals end in an acute $V$-shaped point, which projects beyond the fronto-maxillary suture. The interparietal is convex posteriorly, nearly straight or slightly convex on its anterior border, with the transverse about twice the antero-posterior extent, or rather less.

In cranial characters this species is much more nearly related to $N$. apicalis Peters, from Guayaquil, than to $N$. squamipes (Brants); the very largest skulls about equal the dimensions given by Dr. Peters for that of $N$. apicalis. It also resembles $N$. apicalis in its 5 -tuberculate soles, but differs from it in its darker coloration, smaller size, and relatively much shorter tail, which is considerably shorter than the head and body, instead of considerably longer as in $N$. apicalis. The tip of the tail is not white, as was the case in the type of $N$. apicalis.

$N$. palmipes differs from $N$. squamipes in having the soles 5 -tuberculate instead of 6-tuberculate, and in the very different form of the interparietal, which in $N$. squamipes is very much narrower antero-posteriorly, and transversely much more extended.

Mr. Thomas gives "Holochilus squamipes Bts." from Trinidad (presumably $=$ Nectomys squamipes Peters), but that species is unrepresented in the present collection.

All the specimens secured were taken in the low, dense growth near a small stream.

\section{Tylomys couesi, ${ }^{1}$ sp. nov.}

Of the size and general coloration of $T$. nudicaudatus, but with the tail uniform dusky, somewhat hairy and slightly tufted, instead of particolored and naked as in $T$. nudicaudatus and T.panamensis.

Above nearly uniform cinnamon brown, everywhere punctated with black, through the presence of longer black-tipped hairs overtopping the general pelage. Below white, with a slight tinge of yellow, the white extending to the base of the fur. Line of demarcation between the color of the dorsal and and ventral surfaces well defined. Edges of the feet and toes soiled whitish. Whiskers very long, black, the longest measuring $70 \mathrm{~mm}$. Ears large, naked, dusky. Tail rather longer than head and body, black from base to tip, nearly naked basally, but scantily clothed with short blackish hairs, increasing in

1 Named for Dr. Elliott Coues, in recognition of his important contributions to North American mammalogy. 
length and abundance toward the tip, where they conceal the annulations, and form a well-defined pencil at the tip. Hind feet short and broad, with naked soles.

Measurements (from the fresh specimen): Total length, $460 \mathrm{~mm}$. ; head and body, 208 ; tail to end of vertebræ, 252 ; pencil at tip, II ; hind foot, 35 ; ear from crown, 24.

Type and only specimen, No. $\frac{5956}{468}$, o ad., Princestown, Trinidad, April 6, I893, coll. Frank M. Chapman.

This specimen is in apparently rather worn pelage. The coat is very short but thick and soft, and the underfur very woolly, particularly on the ventral surface. Probably in fresh pelage the color would be brighter and more yellowish rufous.

The skull is that of a true Tylomys, and presents the following measurements : Total length, $44.5 \mathrm{~mm}$. ; basal length, $3^{8}$; greatest zygomatic breadth, 23.4; greatest mastoid breadth, 14.7; least interorbital breadth, 6.4; length of nasals, 16.5; distance from incisors to first molar, 12.7 ; length of upper molar series, 6.6 ; distance from posterior border of palatal floor to end of pteygoid hamuli, 8.9; length of lower jaw (tip of incisors to posterior border of condyle), 27 ; height of condyle, r 2 ; length of lower molar series, 6.7.

This species has a close general resemblance in coloration to the $T$. nudicaudatus Peters of Guatemala and Costa Rica, but it has a hairy, relatively much longer, and very differently colored tail.

The single specimen was taken in the forest, at the entrance to a hole which penetrated beneath the roots of a tree.

\section{I3. Oryzomys speciosus, sp. nov.}

Pelage short (about $9 \mathrm{~mm}$. long on the back), thick, soft, cottony below. Color above yellowish rufous, darker reddish brown over the middle of the back, where there are intermixed a few longer black-tipped hairs; paler and more yellowish along the sides. Below, pure white to the base of the fur. Ears of medium size, rather narrow, evenly rounded on their posterior upper border, dusky brown, well clothed with very short brownish hairs, which have a slight reddish cast. Fore limbs yellowish like the sides of the body, as far as the base of the toes, the toes lighter, buffy white; palms yellowish flesh-color. Hind limbs yellowish, like the flanks, as far as the base of the toes; toes very scantily haired, yellowish gray; soles dusky, 6-tuberculate. Tail considerably 
longer than head and body, the basal half inch heavily furred and colored, below as well as above, like the rump, forming a basal, furred, yellowish brown ring ; rest of the tail uniform pale brown, annulations very narrow and indistinct, the scales minute, practically naked except near and at the tip, where it is thinly clothed with short dusky hairs, forming a minute, scarcely appreciable pencil. Under a lens the whole tail is found to be haired, but so scantily as not to appreciably obscure the annulations. Whiskers scanty, black.

Measurements, from the fresh specimen: Total length, $26 \mathrm{I} \mathrm{mm}$; head and body, I24; tail vertebræ, I37 ; hind foot, 24 ; ear from crown, I4.

$S k u l l$, in general features, much like that of $O$. palustris; it is, however, heavier and larger, with a heavier raised supraorbital ridge; the interparietal is also several times larger, relatively as well as absolutely; the anterior palatine foramen is shorter and much broader. Total length, 30.5 ; basal length, 25 ; greatest zygomatic breadth, 17.3; greatest mastoid breadth, 12.2; least interorbital breadth, 5.6 ; length of nasals, II ; length (antero-posterior axis) of interparietal, 5 ; breadth (transverse axis) of interparietal, 9.4 ; length of anterior palatine foramen, 5.6 ; greatest breadth of same, 2.8 ; distance between incisors and first molar, 7 ; length of crown surface of upper molar series, 4.5 ; length of lower jaw (point of incisor teeth to posterior border of condyle), 18.8 ; height at condyle, 8 ; length of crown surface of lower molar series; 4.8.

Type and only specimen, No. $\frac{5942}{4672}$, + ad., Princestown, Trinidad, April 26, 1893, cỏll. Frank M. Chapman.

This species in size, proportions and coloration, strongly suggests Hesperomys concolor Wagner, from the Rio Curicuriari, in northeastern Brazil, with which it may prove to be identical.

\section{Oryzomys trinitatis, sp. nov.}

Pelage full, soft and rather long (I3 mm. on the middle of the back). Color above bright yellowish rufous, darker, approaching chestnut, and finely varied with black-tipped hairs over the middle of the dorsal region, lighter and more strongly yellowish on the sides; nose blackish and head rather darker than back; below grayish white, the tips of the hairs being soiled whitish and the basal portion gray, showing more or less through the surface. Line of demarcation between the coloration of the dorsal and ventral surface not sharply defined. Ears rather large and quite broad, dusky, and thinly coated with very short blackish hairs. External surface of fore and hind limbs dusky yellowish brown, becoming lighter grayish brown on the toes, which are thinly haired; palms and soles naked, the former brownish flesh color, the latter more dusky and 6-tuberculate. Hind feet rather broad in proportion to their length. Tail very much longer than head and body, furred all around for the basal half inch, the fur yellowish ashy below and colored like the rump above; remainder of the tail pale dusky brown, unicolor, non-penicillate and practically naked throughout, 
though clothed with very short dusky hairs, generally not readily seen without a lens.

Measurements, from fresh specimens: Total length, $27 \mathrm{I} \mathrm{mm.;} \mathrm{head} \mathrm{and}$ body, I23 ; tail, I48; hind foot, 25 ; ear above crown, I6.

Skull similar to that of the preceding species, except that the nasals and the facial portion of the skull are much longer and the interparietal much smaller. In old skulls the supraorbital ridge is continued backward to the posterior border of the parietals. Total length, 32.5 ; basal length, 27.2 ; greatest zygomatic breadth, I7.8; greatest mastoid breadth, I2 ; least interorbital breadth, 6.I ; length of nasals, II.4; antero-posterior breadth of interparietal, 3.5 ; transverse breadth of same, 9.3 ; length of anterior palatine foramen, 6.4 ; greatest width of same, 2 ; distance between incisors and first molar, 8.4 ; length of crown surface of upper molar series, 4.5 ; length of lower jaw, 20.3; height at condyle, 8.6 .

Type, No. $\frac{5943}{4673}$, ô ad., Princestown, Trinidad, April 25, 1893, coll. Frank M. Chapman.

This species is based on three specimens, a very old male and an old female, and a young adult male. The very old specimens are closely similar in all features; the younger specimen, although practically adult as regards size, is less rufous and more yellowish above and rather more whitish below, with the throat pure white to the base of the fur.

This species differs from the preceding in the character of the pelage, in coloration, especially of the lower parts, in being larger and with a relatively longer and less hairy tail, and in various cranial differences, particularly in the much shorter interparietal. What its nearest relative may be among the continental species it is impossible to decide in the absence of proper material for comparison.

\section{I5. Oryzomys velutinus, sp. nov.}

Pelage thick, short (about $7 \mathrm{~mm}$. long on the back), velvety below. General color above dark cinnamon-brown, darkest and much mixed with blackish on the middle of the back, lighter and more reddish on the sides, brighter reddish on the hinder part of the crown and posteriorly over the shoulders; anterior part of the head dusky grayish brown with only a faint tinge of reddish, and a narrow, indistinct blackish eye-ring; beneath grayish white at the surface, dusky plumbeous basally. Ears large, broadly oval, naked on both surfaces, dusky with a faint reddish cast. External surface of the limbs like the adjoining portions of the body; feet thinly haired above, yellowish gray, this color extending on the hind feet to slightly above the ankles; palms and soles naked, 
the former flesh-colored, the latter dusky brown, 6-tuberculate. Tail considerably shorter than head and body, naked, very distinctly and clearly annulated in comparison with the two preceding species.

Measurements, from fresh specimens: Total length, $252 \mathrm{~mm}$.; head and body, I35; tail, 118 ; hind foot, 28 ; ear from crown, 18.

Young.-Pelage very short, soft and velvety, almost plush-like on the ventral surface. Above blackish plumbeous, paler on the sides, whitish gray below. Later the back becomes nearly black, and the sides acquire a mousebrown wash.

The skull is of the typical Oryzomys style, with, however, the facial portion somewhat lengthened, and the anterior palatine foramen rather short and broad, and the supraorbital ridge, even in old individuals, rather feebly developed. Total length $33 \mathrm{~mm}$.; basal length, 27; greatest zygomatic breadth, I7; greatest mastoid breadth, 12.2; least interorbital breadth, 5; length of nasals, 12.7; antero-posterior breadth of interparietal, 3.8 ; transverse breadth of same, I0.2 ; distance between incisors and first molar, 7 ; length of crown surface of upper molar series, 4.5 ; length of lower jaw, 20.3 ; height at coronoid process, 8.6.

Type, No. $\frac{5949}{4679}$, ô ad., Princestown, Trinidad, April 16, 1893, coll. Frank M. Chapman.

This species is based on a series of ten specimens, three of which are fully adult, two nearly adult, and five in the blackish plumbeous pelage of the young, varying in age from sucklings to half or two-thirds grown.

The peculiar blackish plumbeous pelage of the young recalls the corresponding 'blue' stage in the genera Sitomys, Neotoma and Nectomys, but which is not found in the typical species of Oryzomys, as the genus is represented in the United States. In this species there is a slight deviation toward Sitomys in the relatively slightly narrowed and lengthened facial portion of the skull. The auditory bullæ, however, are unusually small, even for an Oryzomys, in which genus they are always much smaller than in Sitomys.

This species was not found associated with the other species of Oryzomys, but was met with in the forests, where it seemed to - live beneath the roots of trees or stumps.

\section{I6. Oryzomys brevicauda, sp. nov.}

Adult.-Pelage full, soft, and long ( $9.5 \mathrm{~mm}$. long on middle of back). General color above yellowish brown, darker and strongly varied with black-tipped 
hairs over the middle of the dorsal region, lighter, more buffy yellow on the sides; below gray, with a slight buffy wash, the basal portion of the fur dusky plumbeous. Line of demarcation between the coloration of dorsal and ventral surfaces indistinct, often passing gradually the one into the other. Ears of medium size (smaller than in either of the preceding species of this genus), low, broad and very evenly rounded above, dusky, practically naked (pulverulent) on both surfaces (under a lens the surface is shown to be covered with very minute short whitish-tipped hairs). Feet above light grayish brown, with a faint yellowish or buffy tinge, scantily haired; palms and soles naked, the former brownish flesh-color, the latter a little darker brown, 6-tuberculate. Tail about one-fourth shorter than head and body, naked (clothed scantily with hairs so minute as to be nearly invisible without a lens), indistinctly bicolor, pale brown above, lighter, almost isabella color below for the basal two-thirds, the line of demarcation between the two colors indistinct.

Young.-A very young example (probably a nursling) is uniform dusky brown above faintly washed with yellowish gray, more distinct on the head, and particularly on the sides of the head. Below similar but much paler. Inside of ears well clothed with very short yellowish dusky hairs. Nearly fullgrown examples are variously intermediate between this and the fully adult phase.

Measurements (average of ro adult males, taken in the flesh): Total length, 265 (250-280) mm. ; head and body, I 54 (I4I-I6I); tail, III (IOI-I20); hind foot, 28 (27-30); ear from crown, 15.3 (13-18). A similar number of females average smaller, as follows : Total length, 235 (220-253); head and body, I42 (132-I50); tail, 93 (86-105); hind foot, 26.6 (25-29).

The skull is that of a typical Oryzomys (taking O.palustris as the type of the genus), except as regards a few minor details, principally the form of the interparietal, which is very narrow antero-posteriorly and very broad transversely, as it is in most of the species of Oryzomys here described. An average adult male skull measures as follows: Total length, $32.5 \mathrm{~mm}$.; basal length, 28.7 ; greatest zygomatic breadth, 17.3 ; greatest mastoid breadth, 12.5 ; least interorbital breadth, 5.8 ; length of nasals, 13.5 ; antero-posterior breadth of interparietal, 2.5 ; transverse breadth of same, ro.2 ; distance from incisors to first molar, 8.9 ; length of anterior palatine foramen, 6.9 ; length of crown surface of upper molar series, 4.5 ; length of lower jaw, 22.9; height of same at condyle, 7.6.

Type, No. $\frac{5981}{4} \frac{81}{8}$, of ad., Princestown, Trinidad, April 12, 1893, coll. Frank M. Chapman.

This species is represented by a series of $3^{8}$ specimens, nearly all adults, but including one nursling, and a few others slightly immature. Among the practically adult specimens the general 
color above varies from strong clear yellowish brown to a darker shade, approaching yellowish chestnut. Below the color varies from pale buffy gray to quite strong buff over the middle of the ventral surface, fading to lighter on the throat and towards the anal region. 'This variation is, however, mainly due apparently to age, the younger adults being more buffy below and yellower above. The young, as already described, are dusky brown, with a faint wash of pale yellowish brown.

This species is very distinct from either of the preceding, both in external and cranial characters. Its heavy, comparatively coarse pelage gives it almost an Arvicoline appearance, which its relatively smaller ears and shorter tail tend to heighten. In cranial characters it most nearly approaches $O$. palustris of any of the species here described, particularly in the form of the lower jaw, which has the coronoid process longer and more decurved, and the posterior border of the mandible more deeply hollowed than is the case in any of the others. It differs from $O$. palustris in the form of the interparietal, through its great transverse breadth as compared with its antero-posterior extent; in this respect essentially agreeing .with the preceding species, as it does also in the comparatively slight development of the supraorbital ridges.

This was apparently the most abundant Rodent near the resthouse. With $O$. speciosus and $O$. trinitatis it was found in the dense, low growth which bordered small streams.

I7. Abrothrix caliginosus (Tomes).-A series of I I specimens of a short-tailed, Arvicola-like, rich chestnut-colored mouse is provisionally referred to this species. They agree with a single specimen from Costa Rica provisionally identified with this species, ${ }^{1}$ and with 'T'omes's description of caliginosus. As, however, the type locality of caliginosus is Ecuador, it seems probable that a comparison of specimens from the two localities will show that the Trinidad animal may be separable.

The coloration above is dark rusty chestnut finely punctated with black, much paler and more yellowish below; ears, tail, and feet black. A series of six adults, measured before skinning,

\footnotetext{
1 See this Bulletin, III, r8gr, p. 2 ro.
} 
give the following dimensions: Total length, 192 (I88-196) mm. ; head and body, I23 (121-125); tail, $69(65-70)$; hind foot, $24.6(23-27)$; ear from crown, $13(12-15)$. The dental and external characters agree with Waterhouse's diagnosis of his subgenus Abrothrix.

This species, with Loncheres, was the only one of the Muridæ or Octodontidæ which seemed to be diurnal in its habits. Their appearance in life suggests that of an Arvicola.

I8. Mus rattus Linn.-A single specimen was captured at a neighboring cacao estate, and was the only one observed.

19. Mus alexandrinus Geoffr.-Common in the vicinity of houses, and on two occasions captured at a small uninhabited palmetto thatch in a forest.

20. Mus musculus Linn. - Common at Port-of-Spain, and probably occurs throughout the island. The presence of cats and dogs at the rest-house doubtless prevented the occurrence there of either of the three species of Mus.

2I. Heteromys anomalus (Thompson).-This species was originally described by Thompson in $1815,{ }^{1}$ from a single specimen from the island of Trinidad. Few examples appear to have as yet fallen into the hands of naturalists, and even the people of Trinidad are almost unaware of its existence. According to $\mathrm{Mr}$. Oldfield Thomas (Journ. Trinidad Field Nat. Club, I, r892, p. 165), the type and one other specimen, the latter received in $\mathrm{r} 89 \mathrm{I}$, are in the collection of the British Museum. It is therefore gratifying to report that the present collection contains a series of 30 specimens, including five in alcohol. Both sexes and all ages are represented, from the suckling young to aged adults. From this material the species may be redescribed as follows :

Adult.-Above grayish dusky brown faintly washed with chestnut; below pure white to the base of the hairs. The dark color of the upper surface is sharply defined against the white of the lower surface, without any trace of the fulvous lateral line seen in most of the northern species. Outer surface of the fore and hind limbs like that of the adjoining portions of the body; inner surface white, except that the dusky color of the outer surface completely

1 Trans. Linn. Soc. London, XI, 1815, p. 161, pl. x. 
encloses the middle portion of the fore arm and a short space on the leg at and just above the ankle. Upper surface of all the feet white. Palms flesh-color, soles blackish, both entirely naked. Ears large, for a member of this genus, flesh-colored at the base, passing into blackish apically, which is the color of most of the exposed portion. Tail considerably longer than the body, sharply bicolor, dusky above and whitish below, naked and nearly tuftless at the end, the very short hairs scarcely at all concealing the annulations.

The pelage of the dorsal surface consists largely of grooved spines, almost wholly so over the greater part of the back, mixed sparingly with fine bristly hairs ; on the sides of the body the spines are weaker and fewer, here, as below and on the head, the pelage consisting of rather coarse stiff hairs more or less profusely mixed with softer hairs. The whole pelage above, spines as well as hairs, is whitish basally, passing into blackish and tipped generally with very pale bay or chestnut. The flanks and limbs, however, are rather paler and grayer than the middle region of the back.

Measurements.-The average and extreme measurements of ten fully adults, taken in the flesh, are as follows : Total length, $280(265-292) \mathrm{mm}$. ; head and body, I30 (I20-I42); tail, I5O (I35-I60); hind foot, 33 (3I-35); ear from crown, I4.5 (I4-I6).

An average adult skull measures as follows : Greatest length, 36 ; basal length, 28 ; greatest zygomatic breadth, 26 ; least interorbital breadth, 13.5 ; distance between incisors and first molar, 9.5; crown surface of upper molar series, 4.5 ; lower jaw, length, 20 ; height at condyle, 12.5.

Young.-Nursing to half or two-thirds grown young are dusky plumbeous with a slight sooty tinge, but otherwise marked as in the adult. At a more advanced stage the general color becomes a little lighter or grayer, with a faint tinge of brown. The hair on the middle of the back becomes coarser and stiffer, but well-developed spines do not appear much before the animal attains adult size.

The only other species of this genus available for comparison with the present is Heretomys alleni, of ' which the Museum has now a large series, collected in the vicinity of Brownsville, Texas. This proves so distinct from $H$. anomalus that no comparison between the two is necessary, except that it seems desirable to improve the present opportunity to elucidate further the characters of $H$. alleni. ${ }^{1}$ The youngest specimen (about half-grown) of $H$. alleni indicates that the young, even during the suckling stage, are not greatly different in general coloration from the adults, being perhaps a little paler and more uniform gray, and 
not blackish plumbeous as in $H$. anomalus. A series of adults of $H$.alleni, measured in the flesh, give the following dimensions : Total length, $25^{\circ}\left(23^{8-260}\right) \mathrm{mm}$.; head and body, I 22 (I I 2-135); tail, I 28 (Ir5-136); hind foot, $29(28-30)$; ear from crown (measured from the dried skin), ı.

In general, $H$. alleni differs from $H$. anomalus in its much smaller size, in the very much smaller ears, in the tail being hairy and slightly tufted, and radically in coloration, $H$. anomalus being very much darker at all ages, and entirely lacking the fulvous lateral line seen in $H$. alleni. In fact, as recently pointed out by Mr. Oldfield Thomas (Ann. and Mag. Nat. Hist., 6th Ser., XI, I 893, p. 329), these two species belong to very different sections of the genus, ${ }^{1}$ in respect especially to the character of the hind feet, $H$. anomalus belonging to the section having the soles naked and 6-tuberculate, and $H$. alleni to the section with the soles hairy and 5 -tuberculate.

This species made its home beneath the roots of forest trees. The pouches are used to carry food. One specimen had no less than fifty-three seeds the size of peas in its pouches, while the pouches of most of the specimens captured contained a few kernels of the corn used as bait which they had stored away before springing the trap.

\section{Loncheres guianæ Thomas.}

Loncheres guiance Thомаs, Ann. and Mag. Nat Hist. 6th Ser. II, I888, p. 326 (Demerara); Journ. Trinidad Field Nat. Club, I, No. 7, I892, p. I66 (Trinidad).

This species is represented by five specimens, all females, and all taken in the mangroves at the mouth of the Caroni River. Four are adult, the other is a half-grown young one. One of the specimens was collected by Mr. Chapman, April 29, 1893, and the others, taken June ro and II, were collected and presented to the Museum by Messrs. F. W. Urich and R. R. Mole, of Portof-Spain. Three of the adults are skins, with the skulls; the other two specimens are skins preserved in alcohol. The June adults all contained fœtuses, two of which are preserved in alcohol.

${ }^{1}$ Mr. Thomas, however, appears not to have had full-grown specimens of H. alleni. 
These specimens are provisionally referred to this species, with the description of which they appear sufficiently to agree as regards the general external characters. There are, however, some discrepancies in respect to measurements. The dimensions of an adult female (No. $\frac{60}{4} \frac{00}{2} \frac{0}{7}$ ), measured in the flesh, are as follows : 'Total length, $456 \mathrm{~mm}$. ; head and body, 231 ; tail, 225 ; hind foot, 43 ; ear from crown, 15.

Three skins measure as follows :

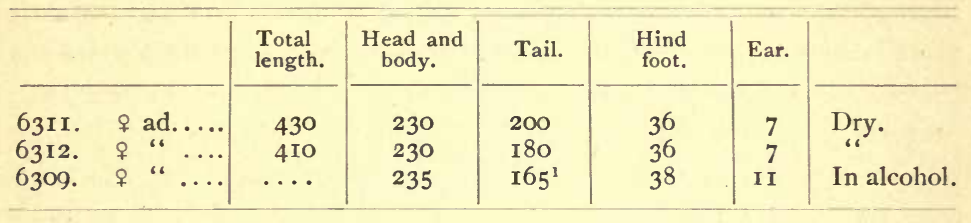

Mr. Thomas's measurements of the type, from Demerara, taken from the skin, are as follows: "Head and body, I90 millim.; tail, 167 ; [hence, total length, 357 ;] hind foot, 36.2 ; ear (contracted), 5.5."

Hence Mr. Thomas's type, though said to be adult, is a much smaller animal than either of our Trinidad specimens, if we restrict our comparisons to the skins. The measurements of the skulls of the Demerara and Trinidad specimens would seem to indicate that this discrepancy is more apparent than real, as shown by the following:

\begin{tabular}{|c|c|c|c|c|c|c|}
\hline No. & $\begin{array}{l}\text { Basal } \\
\text { length. }\end{array}$ & $\begin{array}{l}\text { Greatest } \\
\text { breadth. }\end{array}$ & $\begin{array}{l}\text { Length of } \\
\text { Nasals. }\end{array}$ & $\begin{array}{l}\text { Least } \\
\text { interorb. } \\
\text { breadth. }\end{array}$ & $\begin{array}{l}\text { Dias- } \\
\text { tema. }\end{array}$ & $\begin{array}{l}\text { Length of } \\
\text { Upper molar } \\
\text { series. }\end{array}$ \\
\hline $\begin{array}{l}\frac{6000}{4727} \\
472\end{array}$ & 50 & 26 & I7 & I3 & II. 7 & II. 2 \\
\hline$\frac{6312}{4945} \ldots \ldots$ & 40 & 23 & I6 & II. 5 & IO & 10.5 \\
\hline$\frac{6311}{4944} \ldots \ldots \ldots$ & 43 & 25 & I 7.5 & I3 & II. 5 & II \\
\hline Demerara.... & 47 & 26 & 15.5 & I3 & II. 8 & II.2 \\
\hline
\end{tabular}

As noted above, Mr. Thomas has already recorded (1. c.) this species from Trinidad, this being its second known occurrence. Mr. Urich writes concerning the specimens collected by himself and Mr. Mole: "They seem to be particularly plentiful on the Caroni now, especially between the hours of five and seven in 
the afternoon. The stomachs of all killed contained the fruit of the mangroves, of which there is an abundance at present."

\section{Loncheres castaneus, sp. nov.}

Similar in size and proportions to L. guiane, but differing from it in coloration and cranial characters.

External characters. - Thickly spinous except on the ventral surface and limbs, the spines strongly developed over nearly the whole dorsal aspect. General color above orange-tawny, more intense on the front part of the head and at the base of the tail, gradually paler on the sides, everywhere heavily lined with black; ventral surface isabella color, finely lined with dusky, the line of demarcation between the dorsal and ventral surfaces fairly well defined. Upper and under surface of the limbs respectively similar in color to the adjoining portions of the body; upper surface of hind feet paler, yellowish gray, becoming nearly clear gray on the toes. Palms and soles naked, blackish. Ears small, rounded, blackish, nearly naked. Tail (in the young) similar to that of L. guiana, finely annulated, well-clothed for a short distance at the base, the remainder nearly naked, the very short, dusky yellowish hairs only partly concealing the annulations.

The dorsal pelage consists of spines mixed with hairs, the spines coarse and heavy over the median dorsal area, gradually becoming thinner and weaker on the sides of the body, passing into grooved bristly hairs on the ventral surface. The spines of the back are plumbeous at base passing into black on the apical half, without orange-rufous tipping on the anterior half or third of the dorsal region, but posteriorly subapically ringed with this color and minutely tipped with black, the orange-rufous subapical ring becoming broader and conspicuous posteriorly. On the sides of the body the spines are nearly uniform plumbeous gray to the tip. The intervening hairs are coarse and bristly, blackish basally and very broadly tipped with orange-rufous, this color usually occupying one fourth to one-third the length of the hair, but with the extreme tip often black.

Measurements. - Head and body (adult female), $245 \mathrm{~mm}$.; tail, - ; ${ }^{1}$ hind foot, 40 ; ear from crown, 16. (Measurements from the fresh specimen.) A very young specimen, in alcohol, measures as follows: Total length, 235; head and body, IIO; tail, I 25 ; hind foot, 29 ; ear from crown, II.

Skull.-The skull, in size and proportions, is almost indistinguishable from that of I. guiance, but differs in details, as will be presently noticed. Basal length, 43; greatest breadth, 25.5; least interorbital breadth, 13 ; length of nasals, I5.5; diastema, II.5 ; length of upper molar series, II.2.

Type, No. $\frac{6001}{4728}, \quad$ ad., Princestown, Trinidad, April 20, 1893, coll. Frank M. Chapman. 
This species is based on three specimens, an adult female and two young males one-fourth to one-half grown. The adult specimen and the larger of the two young ones are unfortunately tailless, the entire tail having been lost apparently in early life, as happens often with the Trinidad species of Echimys, as noted below. The young specimen with a perfect tail shows that this member is relatively of about the same length as in L. guiana.

This species differs from L. guiane, apparently its nearest ally, in the general coloration being much brighter and stronger, the dorsal surface being orange-rufous heavily lined with black instead of pale yellow or yellowish gray rather sparingly lined with black, while the ventral surface is many shades darker. The cranial differences consist in the slightly narrower and shorter anterior palatine foramen; in the slenderer, narrower and posteriorly more extended nasals ; in the palatal emargination being bluntly oval instead of sharply V-shaped; in the greater breadth of the basi-occipital ; and in the greater slenderness of the ascending maxillary branch of the zygoma.

It is probable that the baits used in trapping were not attractive to this species. The two young specimens were trapped, but the only adult secured was caught by dogs near the banks of a small stream. It was called by the natives, Agouti Rat.

\section{Echimys trinitatis, sp. nov.}

Similar in size and proportions, and apparently in color, to E. cayennensis but in cranial characters and in the distribution of the spines more nearly resembling $E$. semispinosus Tomes.

Adult.-General color above rusty brown, nearly uniform except over a rather broad median dorsal area, where the rusty brown is profusely mixed with black, in some specimens the black prevailing; whole ventral surface pure white to the base of the hairs, except that occasional specimens show traces of a prepectoral dusky color. Ears narrow, rounded at top, slightly hollowed on the posterior border, nearly naked, flesh-colored, broadly margined with dusky. Tail a little shorter than the head and body, well furred for about an inch at the base, the rest practically naked, the annulations scarcely at all concealed by the very short, much scattered whitish hairs, and there is no tendency to a terminal pencil, as in E. cayennensis. Palms and soles naked, the latter uniform blackish, the former usually mottled flesh-color and dusky, sometimes one color prevailing and sometimes the other. Upper surface of fore feet grayish brown, becoming lighter on the toes : upper surface of hind feet dusky brown on the 
inner half, gray or grayish white, varying in different specimens, to pure white on the outer half.

The spines are restricted (in a series of Io adults) to an oval area on the middle of the back, between the shoulders and the hips, extending laterally on to the sides of the body. The spines are grayish white or whitish at base, passing gradually through gray and dusky gray to black, the exposed portion being black, except on the lateral portions of the spiny area, where the spines are often whitish nearly to the tip.

Measurements (average of five specimens measured in the flesh).-Total length, $446 \mathrm{~mm}$. ; head and body, 244 ; tail, 202 ; hind foot, 50 ; ear from crown, 23. The males average somewhat larger than the females, as shown by the subjoined table.

Young.-One-third grown young (in the 2-molar stage) are blackish above, nearly pure black over the central portion of the dorsal area, paler, brownish black on the sides, where the dusky tint has a purplish or faint vinaceous tinge ; below white, with or without a dusky prepectoral collar, traces of which are sometimes present in the adult. The whole pelage is spineless and soft. When about half-grown (in the 3-molar stage) the sides become faintly tinged with pale rusty brown, and a few weak spines begin to appear in the middle of the back. At a more advanced stage the general coloration above is still dusky brown, with a blackish spiny area over the middle of the back (between the hips and shoulders), with rusty-tipped hairs more or less generally intermixed over the whole upper surface of the body.

Skull.-An average adult skull measures as follows: basal length, $48 \mathrm{~mm}$. ; greatest breadth, 29; least interorbital breadth, 13.3 ; length of nasals, 24 ; diastema (distance between incisors and first molar), I4 ; upper molar series, Io. The nasal bones extend considerably beyond the fronto-maxillary suture, and are squarely truncate or slightly rounded on the posterior border. A series of young skulls shows the development of the molar series from two to four teeth.

Type, No. $\frac{5913}{46 \frac{3}{3}}$, of ad., Princestown, Trinidad, April 26, 1893, coll. Frank M. Chapman.

This species is based on a series of 2 I specimens- $\mathbf{2}$ adults, five young in the spineless, soft, hairy coat, and four in intermediate stages between the spineless young and the fully adult. 'Two of these are preserved in alcohol, the rest as skins with the skulls separate. All were taken at Princestown during March and April.

Echimys trinitatis differs from $E$. cayennensis, its nearest geographical congener, in various external characters, notably in the restriction of the spiny area to the central portion of the back, in the less hairy condition of the tail and the entire absence of a hairy pencil at the tip, and also somewhat in coloration, especially in the absence of a pale rufous patch behind the ears. In cranial 
characters it differs at many points, but it may be sufficient to mention the much greater posterior extension of the nasals, which extend much beyond the fronto-maxillary suture instead of terminating considerably in front of it, as in E. cayannensis, in which the axis of this suture is oblique instead of transverse. In other words, the nasals and the direction of the fronto-maxillary suture are about as in E. brevicauda, as figured by Günther (P. Z. S., r876, p. 749). In this respect it also much resembles $E$. semispinosus Tomes, from Ecuador, from which species, however, it differs in its very much larger and very differently shaped ears and much longer tail. It appears to resemble this latter species, however, in the restriction of the spines to the central portion of the dorsal area, in the naked and tuftless tail, and in general features of coloration.

The adults present very little variation in coloration or in external characters beyond that already noted, except that three of the adults were entirely tailless, the loss of the tail having evidently occurred in early life, leaving only a broad cicatrix where the tail joined the body. The young specimens are also quite uniform in general coloration, except that in three there is a broad dusky prepectoral collar, varying in width in different individuals, and represented in others by a broken collar, the two halves failing to meet on the median line.

The principal variations in external measurements in ten adult specimens are shown by the following table:

External Measurements.

\begin{tabular}{|c|c|c|c|c|c|c|}
\hline Cat. No. & Sex. & $\begin{array}{c}\text { Total } \\
\text { length. }\end{array}$ & $\begin{array}{l}\text { Head and } \\
\text { body. }\end{array}$ & Tail. & Hind foot. & Ear. \\
\hline $6112^{1} \ldots \ldots \ldots$ & q & 442 & 242 & 200 & 47 & 22 \\
\hline$\frac{5908}{4638} . \ldots \ldots \ldots$ & $\hat{\jmath}$ & .. & 265 &.$^{2}$ & 50 & 25 \\
\hline$\frac{5909}{4639} \ldots \ldots \ldots \ldots$ & ㅇ & . & 268 &.$^{2}$ & 50 & .. \\
\hline$\frac{5910}{4640} \ldots \ldots \ldots \ldots$ & $\hat{o}$ & $\cdots$ & 260 &.$^{2}$ & 55 & 26 \\
\hline$\frac{59}{46411} \ldots \ldots \ldots \ldots$ & . & . & .. & $2 \mathrm{IO}^{3}$ & 53 & .. \\
\hline$\frac{5912}{4642} \ldots$ & $q$ & 404 & $23 \mathrm{I}$ & 173 & 45 & 21 \\
\hline$\frac{5913}{4643} . \ldots \ldots \ldots$ & $\hat{o}$ & $49 I$ & $26 \mathrm{I}$ & 230 & 53 & $2 \mathrm{I}$ \\
\hline$\frac{5914}{4644} \ldots \ldots \ldots \ldots$ & $q$ & 442 & 242 & 200 & 47 & 22 \\
\hline$\frac{5915}{4645} \ldots \ldots \ldots \ldots$ & 운 & 345 & I 55 & Igo & 50 & .. \\
\hline$\frac{5916}{4646} \ldots \ldots \ldots \ldots$ & $f$ & 450 & 245 & 205 & 53 & $2 \mathrm{I}$ \\
\hline
\end{tabular}

1 Alcoholic. 2 Tail wanting.

${ }^{3}$ Body destroyed by some predatory bird or mammal.

[September, 1893.] 
The skulls of course vary greatly according to age, in proportion of parts as well as in size. There is also considerable individual variation, especially in respect to the posterior extension of the nasals. These in some examples pass but little beyond the fronto-maxillary suture, while in others they extend much further. There are also minor variations in other parts, as shown by the following table of measurements of eight adult skulls :

Cranial Measurements.

\begin{tabular}{|c|c|c|c|c|c|c|c|c|}
\hline & $\begin{array}{l}4638 \\
5908\end{array}$ & $\begin{array}{l}4640 \\
5910\end{array}$ & $\frac{4643}{5913}$ & $\begin{array}{l}4646 \\
5916\end{array}$ & $\begin{array}{l}\frac{4639}{5909} \\
\end{array}$ & $\begin{array}{l}4842 \\
5912\end{array}$ & $\begin{array}{l}4644 \\
5914\end{array}$ & $\begin{array}{l}4645 \\
5915\end{array}$ \\
\hline Total length & $62^{8}$ & $\begin{array}{c}\hat{0} \\
60.5\end{array}$ & 6I & $62^{\hat{\beta}}$ & $6 I^{f}$ & $56^{9}$ & $5^{9}$ & 우 $10-1010$ \\
\hline Basal length. . & $47 \cdot 5$ & 46 & 47 & 48 & 46 & 43 & $\ldots$ & $\ldots$ \\
\hline Greatest breadth... & 27 . & $27 \cdot 5$ & 2 & & 27 & 26 & 27 & 27 \\
\hline Interorb. cons & 12.5 & 12.5 & 13 & 12.5 & 13 & I2 & 12.5 & 12.5 \\
\hline Length of nasals. . & 22.5 & 22.5 & $2 I$ & 21.5 & 22 & 19 & 20 & 20 \\
\hline Diastema......... & I3 & I3 & $\mathrm{I} 2.5$ & $13 \cdot 5$ & I3 & II. 5 & 12.5 & 12 \\
\hline $\left.\begin{array}{c}\text { Length of upper } \\
\text { molar series... } \\
\text { (crown surface) }\end{array}\right\}$ & 8.5 & 8.5 & 8.5 & 8.5 & 8.5 & 8.5 & 8.5 & 8.5 \\
\hline $\left.\begin{array}{r}\text { Length of lower } \\
\text { molar series... }\end{array}\right\}$ & 9 & 9 & 9 & 9 & 9 & 9 & 9 & 9 \\
\hline Length of lower jaw & 34 & 34 & 33 & $35 \cdot 5$ & 35 & $3 I$ & $33 \cdot 3$ & $32 \cdot 3$ \\
\hline $\left.\begin{array}{c}\text { Height of do. } \\
\text { at condyle..... }\end{array}\right\}$ & 12.5 & I2 & II 5 & I3 & I2. 5 & II & I2 & 12.5 \\
\hline
\end{tabular}

The tendency in these animals to lose the tails renders an examination of the posterior portion of the vertebral column of the tailless examples a matter of interest. Fortunately this portion of the skeleton of two of the tailless specimens was preserved, and shows that the amputation occurs at the second vertebra behind the posterior border of the pelvis, or just behind the fifth caudal. The first four caudals are normal in size and proportions, and appear to be in a healthy condition; the fifth caudal is abnormal, the posterior third or half having apparently been lost by absorption. A further interesting fact was noted in skinning the specimens in which the tail was still intact, namely, its easy separation at the fifth caudal vertebra, in several specimens the tail breaking at this point in the process of skinning.

The genus Echimys is now for the first time positively shown to be an inhabitant of the Island of Trinidad. It is true that "Echimys, sp." is entered in Mr. Thomas's list, but it is given 
solely on the authority of Verteuil, who mentions two species, namely, "Echymys chrysuros" and "Echymys rufus (?)." What these are it is impossible to determine, as the names given are not pertinent to any Trinidad animal, and there is no other clue as to what he intended to indicate. Verteuil doubtless knew of the existence of two spiny rats in Trinidad, one of which was probably a Loncheres and the other possibly the present species.

This species is known by the native name of Pilori, and by some is considered excellent eating. There are popularly supposed to be two species, one with and the other without a tail. It lives in the forest, making its home in holes in the banks of streams or beneath the roots of trees. Three females contained respectively two, four, and six large embryos.

\section{Synetheres prehensilis (Linn.).-Represented by an} adult skull.

The presence of this arboreal species is made known by the nauseating odor it gives forth. This is especially noticeable in the early morning when the air is humid and before the daily trade-winds begin to blow. In walking through the forests at this time it was not unusual to encounter odoriferous strata of air proceeding from individuals of this species. So dense, however, was the parasitic vegetation on the trees in which they conceal themselves, that they were practically invisible from below.

26. Dasyprocta aguti (Linn.).--Represented by three adult skins and four adult skulls.

The Agouti is a very common animal in the forests near the rest-house. It is diurnal, but is more frequently met with late in the afternoon and early in the morning. It is much hunted for food, the usual method of capture being from a scaffold which the hunter erects near some favorite feeding-place. Here at a height of eight or ten feet, and distant only a few yards from the spot at which the game is expected to appear, the almost worthless guns of the negroes prove effective. 'The Agouti is an exceedingly shy animal. In approaching its feeding-ground it advances with the utmost caution, pausing frequently to listen. In eating it sits erect, holding its food between its front feet. 
27. Cœlogenys paca (Linn.).--Represented by a single adult male, skin and skull.

The Lape is yearly becoming more rare in Trinidad, and will soon be confined to the less accessible parts of the forests. The fact that hunters in unearthing a Lape, which has been driven into a hole by dogs, frequently encounter the unwelcome Maperire (Crotalus), has given rise to the belief among some of the negroes that the hunted Lape flees to the snake's hole for protection. His passage simply arouses the reptile, which is then en garde for the hunters and dogs.

28. Cariacus (Coassus) nemorivagus (F. Cuv.).-Represented by a skull of an adult male, presented by Mr. R. S. Rowbottom, said to be the skull of one of the largest deer ever killed in the vicinity of Princestown. This skull measures as follows : Basal length (ant. border of premax. to post. border of occip. condyles), 21 $3 \mathrm{~mm}$.; greatest zygomatic breadth, roo; greatest mastoid breadth, 66 ; length of nasals, 62 ; anterior border of premaxillæ to front edge of first premolar, 68; length of molar series, 67 ; length of antler from frontal bone, ro9.5; same from anterior base of the burr, 102.5; length of lower jaw (incisive border to posterior border of angle), $\mathbf{I}_{72}$; height at coronoid process, 83 ; height at condyle, 55.5 ; length of lower molar series, $73 \cdot 5$.

On the right side of this skull is the alveolus of a small upper canine (diameter $3.3 \mathrm{~mm}$.) ; but there is no trace of a corresponding alveolus on the left side.

We provisionally follow Mr. Thomas in adopting the above name for the Trinidad deer, in the absense of the necessary material for deciding its relations to the several allied continental species.

These Deer are among the worst enemies to young cacao trees, of which they destroy thousands. Nevertheless, they are protected by a recently enacted law. In view of their abundance and the injury which they cause to agriculture it would seem inadvisable to protect deer until they are so lessened in numbers as not to prove the enemy of cacao growers. 
29. Dicotyles.-Two species of this genus have long been recognized as inhabiting the island. One of the species was common near the rest-house, but no specimens were secured.

30. Cyclothurus didactylus (Linn.). - One adult female, Princestown, March r8. Measurements: Total length, $490 \mathrm{~mm}$.; head and body, 216 ; tail, 274 ; hind foot, 40.

This small Ant-eater, according to popular report, is evidently not uncommon in the forests, where its food is said to consist of the white-ants or termites. Its vernacular name of "Poor-meone," meaning poor me alone, expresses exactly the sentiment of the indescribably sweet, sad call which, heard only at night, is generally ascribed to this species. This call was frequently heard in the forests near the rest-house during moonlight nights, but the caller was identified only by the negroes' descriptions. We are now informed by Mr. Albert B. Carr, of Trinidad, at present in New York, that the call so generally supposed to be uttered by the ant-eater is in reality the note of a goatsucker, and that he has shot the bird in the act of calling.

The only specimen secured of this ant-eater was purchased alive from some negroes. It was kept alive for several days. During the day it slept holding on to a branch with the aid of its strong fore-claws and prehensile tail. It moved only when disturbed, and as soon as it was permitted relapsed into its former stupor. Just after sunset it raised its head, and, like a sleepy person, rubbed its eyes, using either the front or hind-foot for this purpose. This effort seemed to weary it, for it again rolled itself into a ball and slept. A few minutes later it rearoused itself, and after rubbing its eyes as before, raised itself on its hind-legs and felt about in the air, uttering a low, whining snuffle and evidently seeing nothing. As darkness increased it seemed to become thoroughly awakened, and climbed slowly up and down its perch, feeling vainly for some way by which to leave it. It released its hold with its tail only when standing on all four feet, and at the first step this member was coiled around a branch as a safeguard in case of a misstep. The tail is so muscular that its grasp could be released with difficulty, while it was almost impossible to dislodge the hold of the long, curved nails of the fore-feet. 
31. Tatusia novemcincta (Linn.).-Signs of this animal were seen in the forests, and part of one was brought by a hunter to the rest-house kitchen. Its flesh proved excellent eating.

32. Didelphis marsupialis (Linn.).-This species is represented by three specimens, two males and a female, taken at Princestown. They measure as follows :

\begin{tabular}{|c|c|c|c|c|}
\hline & Total length. & Head and body. & Tail. & Hind foot. \\
\hline 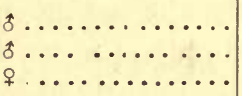 & $\begin{array}{l}920 \\
810 \\
740\end{array}$ & $\begin{array}{l}455 \\
385 \\
350\end{array}$ & $\begin{array}{l}465 \\
425 \\
390\end{array}$ & $\begin{array}{l}66 \\
55 \\
55\end{array}$ \\
\hline
\end{tabular}

A common inhabitant of the forests. The pouch of a female contained seven young, each measuring about $50 \mathrm{~mm}$. in length. Two living examples of this species were seen near the Grand Etang in the island of Granada. They were in the possession of two negro boys who had just captured them, and from whom one, an adult female, was purchased.

33. Didelphis (Philander) philander Linn.-A single, apparently full-grown male (No. $\frac{604 \frac{3}{4}}{76}$ ), taken March 9, is provisionally referred to this species. It differs from it, however, in its much smaller size, in the tail being hairy for only an inch and a half at the base (instead of for "from two to three inches"), and uniform grayish brown from base to tip, instead of white for its apical half, as in Brazilian examples. Measurements of the freshly-killed animal are as follows: Total length, $495 \mathrm{~mm}$; head and body, 2ro; tail, 284; hind foot, 34 . The Trinidad animal heretofore referred to this species may prove separable from the $D$. philander of the mainland-a point further material must decide.

34. Didelphis (Micoureus) murina Linn.-Although this species has not been previously recorded from Trinidad, it appears to be at least locally common on the island, it being represented in the present collection by a series of 20 specimens, taken at Princestown. 
Sixteen adult males, measured before skinning, range in size as follows: Total length, 36r (340-395) mm.; head and body, I 7 I ( $\left.155^{-1} 89\right)$; tail, I90 (I 75-218) ; hind foot, 24.4 (20-28); ear, $25(22-29)$. Four females measure as follows: Total length, $324(3 \circ 2-365)$; head and body, 148 ( $132-168)$; tail, г76 ( $163^{-}$ 197); hind foot, $22(20-24)$; ear, 22 (20-23.)

In coloration the variation is chiefly in the brightness of the rufous of the upper parts, which varies from dull grayish brown to quite strong rufous brown, and in the depth of the yellowish white tint below, which varies from buff to ochraceous buff. The younger (at least the smaller) specimens of the series are duller and darker colored above than the larger, older examples.

This little Opossum was so abundant as to prove a positive source of annoyance. Traps baited with meat were sure to be preoccupied by it, while many trapped specimens of other species were partially eaten by probably this species.

\section{List of LAND MAmmals knOWN From Trinidad.}

For convenience of reference we here add a list of the land manmals thus far recorded from the Island of Trinidad. It consists of Mr. Thomas's 'Preliminary List,' with the additions made in the present paper. The fourteen species here added are distinguished by an asterisk prefixed to the current number.

\section{Order PRIMATES.}

Family CEBID $Æ$.

I. Mycetes, sp. Probably M. seniculus (Linn.). Red Howler.

2. Cebus, sp. Sapajou. Capuchin Monkey.

\section{Order CHIROPTERA. \\ Family VESPERTILIONIDÆ.}

3. Vespertilio nigricans Wied.

4. Thyroptera tricolor Spix. 


\section{Family EMBALLONURIDÆ.}

5. Furipterus horrens (F. Cuv.).

6. Saccopteryx bilineata (Temm.).

7. Saccopteryx leptura (Schreber).

8. Saccopteryx canina (Wied).

9. Rhynchonycteris naso (Wied).

Iо. Noctilio leporinus (Linn.). Fish-eating Bat.

I I. Molossus rufus Geoff.

I2. Molossus obscurus Geoff.

\section{Family PHYLLOSTOMATID $A$.}

13. Chilonycteris rubiginosa Wagn.

14. Pteronotus davyi Gray.

15. Mormops megalophylla Peters.

16. Lonchorina aurita Tomes.

I7. Mycronycteris megalotis (Gray).

I8. Phyllostoma hastatum (Pall.).

19. Hemiderma brevicaudum (Wied).

20. Glossophaga soricina (Pall.).

21. Anoura geoffroyii Gray.

*22. Charonycteris intermedia All. \& Chapm.

23. Artibeus perspicillatus (Linn.).

24. Artibeus planirostris (Spix).

25. Artibeus hartii Thos.

26. Artibeus quadrivittatus Peters.

27. Vampyrops caraccioli Thos.

28. Chiroderma villosum Peters.

29. Sturnira lilium (Geoffr.).

30. Desmodus rufus Wied. Blood-sucking Bat.

\section{Order CARNIVORA.}

\section{Family FELID Æ.}

31. Felis, sp. Ocelot. Tiger-cat. 


\section{Family MUSTELID E.}

32. Galictis barbara (Linn.). Wood-dog.

33. Lutra insularis F. Cuv. Otter.

\section{Family PROCYONID Æ.}

34. Procyon cancrivorus (Cuv.). Mangrove-dog.

35. Cercoleptes caudivolvus (Pall.). Kinkajou.

\section{Order RODENTIA.}

\section{Family SCIURIDÆ.}

36. Sciurus astuans hoffmanni Peters. Squirrel.

\section{Family MURID瓜.}

37. Holochilus squamipes (Brants).

*38. Nectomys palmipes All. \& Chapm.

*39. Tylomys couesii All. \& Chapm.

*40. Oryzomys speciosus All. \& Chapm.

*4r. Oryzomys trinitatis All. \& Chapm.

* 42. Oryzomys velutinus All. \& Chapm.

*43. Oryzomys brevicaudus All. \& Chapm.

*44. Abrothrix caliginosus (Tomes).

*45. Mus rattus Linn. Black Rat.

*46. Mus alexandrinus Geoffr. Roof Rat.

*47. Mus musculus Linn. House Mouse.

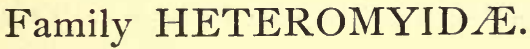

48. Heteromys anomalus (Thompson). Pouched Rat.

\section{Family OCTODONTID $Æ$.}

49. Loncheres guiance Thos. Spiny Rat.

*50. Loncheres castaneus All. \& Chapm. Agouti Rat.

${ }_{5}{ }_{5}$ I. Echimys trinitatis All. \& Chapm. Pilori. 
Family HISTRICID E.

52. Synetheres prehensilis (Linn.). Porcupine.

Family DASYPROCTID E.

53. Dasyprocta aguti (Linn.). Agouti.

54. Calogenys paca (Linn.). Lape.

\section{Order UNGULATA.}

Family CERVID瓜.

55. Cariacus (Coassus) nemorivagus (F. Cuv.). Deer. Biche.

Family DICOTYLID $Æ$.

56. Dicotyles tajacu (Linn.). Collared Peccary. Quenk.

57. Dicotyles labiatus Cuv. White-lipped Peccary. Quenk.

\section{Order EDENTATA.}

Family BRADYPODID E.

58. Cholopus didactylus (Linn.). Two-toed Sloth.

\section{Family MYRMECOPHAGID $Æ$.}

59. Myrmecophaga jubata Linn. Great Ant-eater.

6o. Tamandua tetradactyla (Linn.). Tamandua.

6r. Cyclothurus didactylus (Linn.). Little Ant-eater. Poor-meone.

Family DASYPODID $A$.

62. Tatusia novemcincta (Linn.). Armadillo. Tatou.

\section{Order MARSUPIALIA.}

Family DIDELPHIID $\approx$.

63. Didelphis marsupialis Linn. Manicou.

64. Didelphis (Philander) philander Linn. Manicou gros yeux.

*65. Didelphis (Micoureus) murina Linn. Manicou gros yeux. 

Further Notes on Costa Rica Mammals, with Description of a New Species of Oryzomys.

$$
\text { By J. A. AlLen. }
$$

AUTHOR'S EDITION, extracted from BULLETIN OF THE

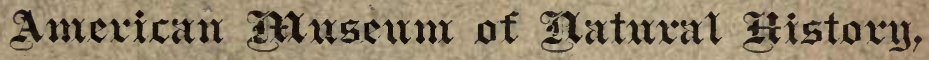

VOL. V, ARTICle XV, pp. 237-240.

New York, September 22, 1893 . 



\section{Article XV.-FUR'THER NOTES ON COSTA RICA MAMMALS, WITH DESCRIPTION OF A NEW SPECIES OF ORYZOMYS.}

\section{By J. A. Allen.}

In a former volume of this Bulletin (Vol. III, pp. $203^{-218} 8$, April, 1891) will be found a paper entitled 'Notes on a Collection of Mammals from Costa Rica,' based on collections received from the Museo Nacional de Costa Rica, through the kindness of Don Anastasio Alfaro, Director of the Museum, and Mr. George K. Cherrie, the Acting-Curator of Mammals, Birds and Reptiles. Another small collection has been since received from the same source, which adds eight species to the 38 given in the previous list, and contains additional specimens of other species of special interest. The present collection numbers about 50 skins, each with the skull separate, representing $\mathrm{I} 7$ species. I also take this occasion to record an additional species of Costa Rican Bat recently presented to the Museum by Mr. José C. Zélédon, making in all 9 species additional to those of the previous list. These are distinguished by an asterisk prefixed to the current number.

I. Atalapha frantzii Peters.-One adult male, San Sebastian, (San José), Oct. 8, I89I, George K. Cherrie.

*2. Rhogeëssa parvula H. Allen.-Three specimens, Pacific coast of Costa Rica, J. C. Zélédon.

*3. Saccopteryx bilineata ( Temm.).-Two specimens, male and female adult, Jimenez, August, I89I, A. Alfaro.

*4. Diclidurus albus Wied.-One specimen, La Palma (San José), August, I890, George K. Cherrie.

*5. Nyctinomus brasiliensis I. Geoffr.-One specimen, male, San José, June 22, I891, George K. Cherrie. 
6. Hemiderma ${ }^{1}$ brevicaudum (Wied).-Five specimens, two males and three females, San Sebastian, San José, August, 1891 .

*7. Artibeus cinereus (Gerv.).-Two adult females and an additional adult skull, San Sebastian, San José, August, I89r.

8. Artibeus carpolegus Gosse--One adult male and five specimens more or less immature, as shown by the skulls. The adult male was taken at San José, June 21 , I89I, the immature examples at Limon, May 27, I891, all collected by Mr. Cherrie.

The single adult male has faint whitish head-stripes; in the immature examples there is no trace of head-stripes; and the coloration of the pelage everywhere is darker-slaty black instead of browish black-and the measurements are all much smaller. As regards external characters, the young might be readily mistaken for a distinct species; the skulls, however, show them to be simply immature examples of $A$. carpolegus.

*9. Vampyrops lineatus Geoffr. - One specimen, adult female, Jimenez, Sept. 9, I891, A. Alfaro.

*Io. Blarina micrura (Tomes).-One specimen, San Isidro, San José, Sept. 25, 189r, Geo. K. Cherrie.

II. Sigmodon hispidus toltecus (De Sauss.).-One specimen, adult male, San José, November, I890, Geo. K. Cherrie.

12. Abrothrix teguina (Alston).-Two males and a female, La Carpintero, Sept. 2, I891, Geo. K. Cherrie.

\section{Sitomys cherriei Allen.}

Hesperomys (Vesperimus) cherrii Allen, Bull. Am. Mus. Nat. Hist. III, p. 21 I, April I7, I89r.

This species is represented by a series of 15 specimens, including immature examples as well as adult. There is little, however, to add to the description of the species already given (1. c.). They are all from La Carpintero, the original locality, taken July 15-26, 189 I, by Mr. Cherrie. 


\section{I4. Sitomys nudipes Allen.}

Hesperomys (Vesperimus) nudipes AlleN, Bull. Am. Mus. Nat. Hist. III, p. 213, April 17, 1891.

Two specimens, Santa Clara, A. Alfaro. Both are immature and differ from the type (see this Bulletin, 1.c.) in being much darker, especially above, as would be expected in the young. Above the pelage is black with a faint tinge of sooty brown, passing into grayish black on the sides, and then into the purer gray of the ventral surface, which is tinged more or less with yellowish rusty over the pectoral region. The ears and tail are naked, and the abruptly whitish feet are thinly haired.

An adult skin and skull, from near San José, collected and presented to the Museum by Mr. George K. Cherrie since the publication of the original description, agrees with the type.

This is an aberrant Sitomys, but the species seems to belong here rather than elsewhere.

\section{*I5. Oryzomys costaricensis, sp. nov.}

Size very small ; ears small ; tail one and a half times the length of the head and body. Pelage full, long ( $7 \mathrm{~mm}$. on middle of back), soft, but rather coarse for so small a mouse.

Above yellowish brown, varying to yellowish chestnut, with a heavy admixture of black hairs ; sides paler, ochraceous buff with little or no black, passing gradually into the clear, rather strong buff of the ventral surface, which is separated from the color of the upper parts by a quite distinct but narrow fulvous lateral line. Ears small (height above crown, in dried skin, about $7 \mathrm{~mm}$.), oval, well haired on both surfaces, dusky brown externally, darkest on the anterior third, more yellowish on the inner surface. Upper surface of fore and hind feet buffy white, scantily haired, especially the hind feet, where the short light-colored hairs scarcely conceal the scaly annulations; palms and soles naked, flesh-colored, the latter 6-tuberculate. Tail very long, naked, unicolor, pale brown.

Total length, I96 mm. ; head and body, 79 ; tail, II7 ; hind foot, 23 (average of three specimens, from measurements made before skinning); ear from crown, 7 (from skins).

The skull is that of a nearly typical species of Oryzomys in all of its essential features, except that the supraorbital ridge is so feebly developed as to be quite lacking, even in a skull with well-worn teeth. An adult skull measures as follows: Total length, $2 \mathrm{I} \mathrm{mm}$.; basal length, 17.8; greatest zygomatic breadth, II.4 ; greatest breadth of brain case, IO.I ; least interorbital breadth, 
4.3 ; length of nasals, 8 ; interparietal, length, 2 ; interparietal, breadth, 8.4 ; incisors to first premolar, 2.5 ; length of upper molar series, 3 ; length of lower jaw, II. 7 ; height of same at condyle, 4.3 .

Type, $\subsetneq$ ad., El General, altitude 2I50 feet, Feb., I89I, coll. H. Pittier.

This species is based on four specimens, all nearly or quite adult (in one the teeth are well-worn), three of them taken on El General at an altitude of $215^{\circ}$ feet, and one in the Cerro de Buena Vista, "altitude 10,342 feet," in February, 1891, by $\mathrm{H}$. Pettier. Another specimen, labeled "La Carpintera, + , July 26, I 89I, Geo. K. Cherrie," I also refer to the same species. This would seem to give the species quite a range in altitude, if the elevation recorded on the labels is correctly indicated. These are all skins, four of which are accompanied by their separate skulls.

Oryzomys costaricensis needs comparison with no other species described from north of the Isthmus of Panama. It is well characterized by its very small size (head and body three inches or less) and its exceedingly long tail (nearly five inches). In size, coloration and general external appearance it is strongly suggestive of a very long-tailed species of Reithrodontomys, but the resemblance is entirely superficial. Its nearest representative appears to be Oryzomys lonsicaudatus (Benn.), of Chili and Peru, from which, however, it is obviously distinguished by its small ears and different coloration. The absence of the usual supraorbital 'bead' may be easily due to the very small size and consequent delicate structure of the species.

*I6. Oryzomys couesi Alston.-One specimen, female, Bahia de Salinas (on the Pacific coast), July, r89o, A. Alfaro. Skin and skull, from an alcoholic specimen, with the following measurements inscribed on the label: "Length, 9.15 in. [ 232 mm.]; tail, 5.35 [I35.6]; hind foot, I.I7 [29.7]." This specimen is provisionally referred to $O$. couesi Alston, as recently redefined by Thomas (Ann. and Mag., 6th Ser., XI, 1893, p. 403).

I7. Lepus gabbi Allen.-One specimen, San José.

18. Didelphis (Micoureus) murina Linn.-One specimen, a half-grown male, Jimenez, August, r89r, A. Alfaro. 

(he

$-1,100$ .

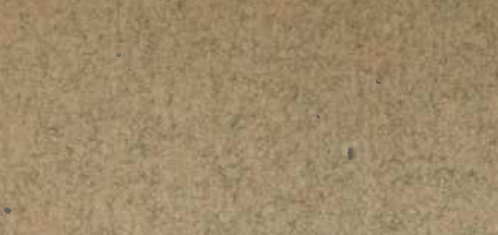

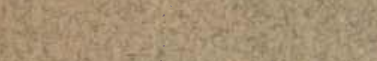

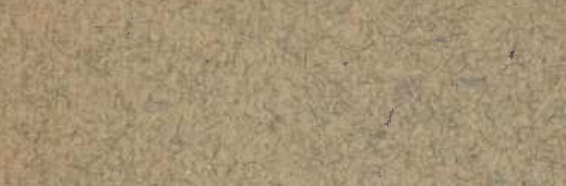

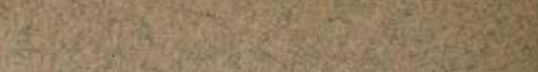
W $x_{0}$ tion:

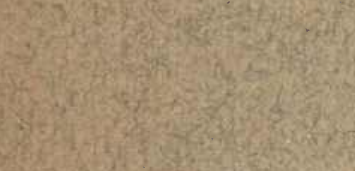
Q. $x$ t.

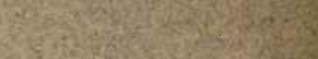
sis

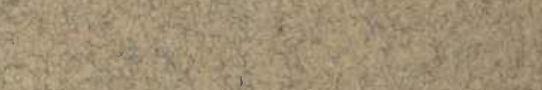
4. atesents

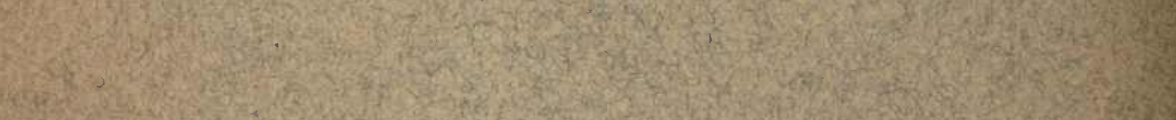

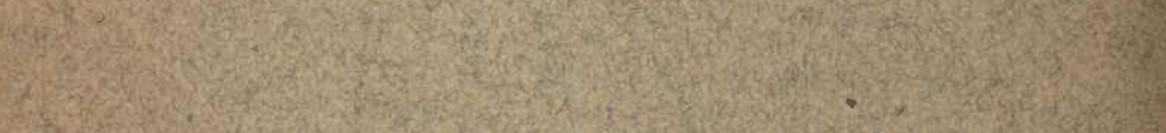

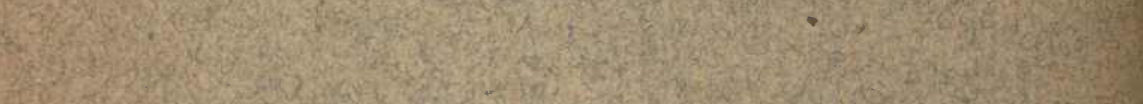

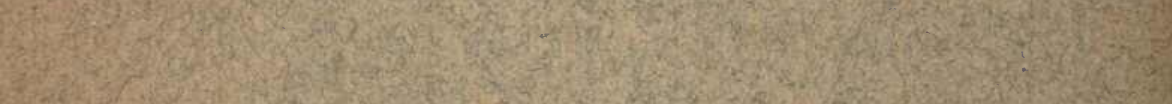
W.

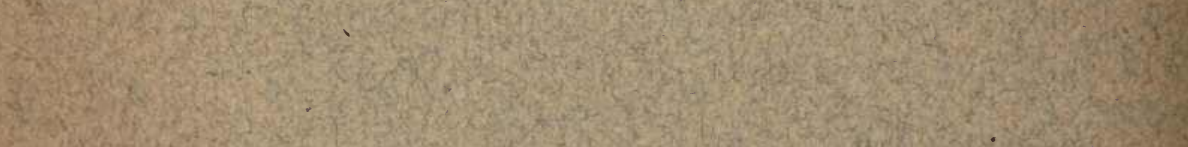

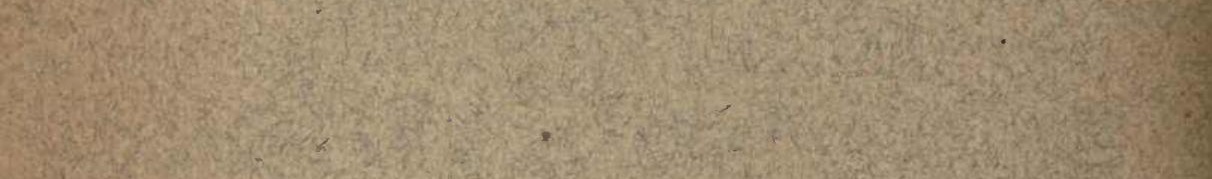

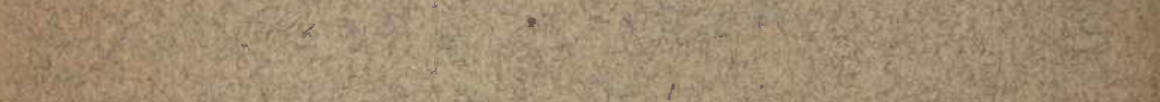

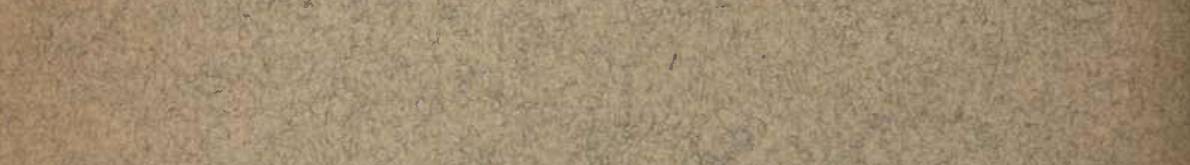
W.

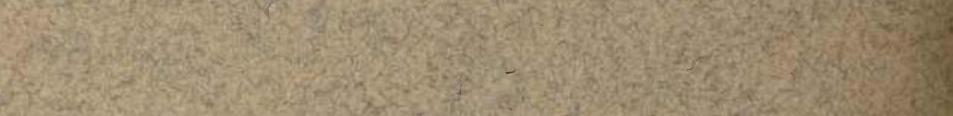

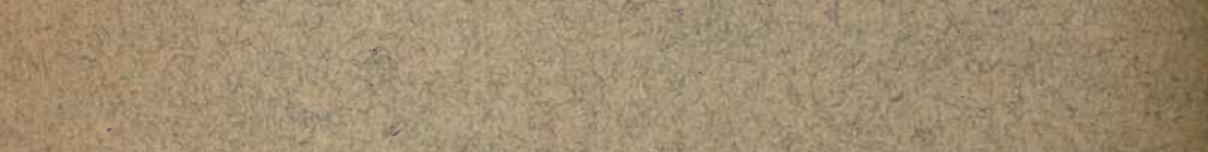

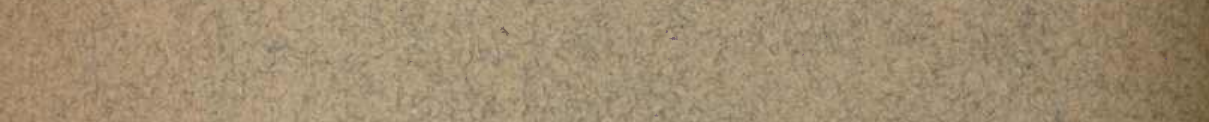

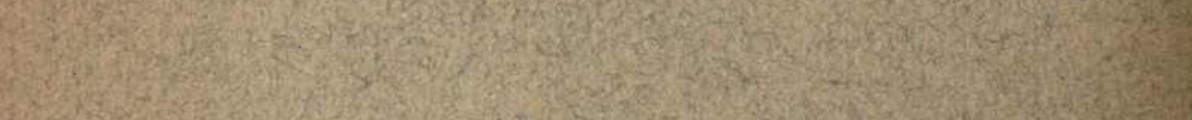

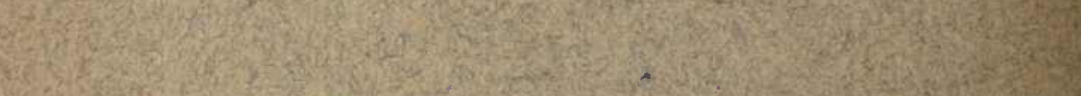

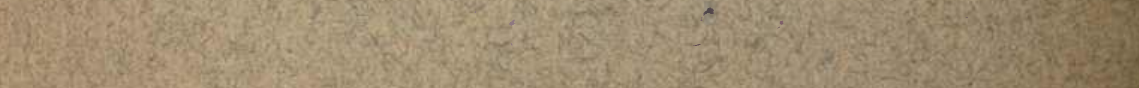


Description of a New Mouse from Lake County, California.

Description of a New Species of Geomys from Costa Rica.

$$
\text { BY J. A. ALLEN. }
$$

AUTHOR'S EDITION. extracted FrOM BULLETIN OF THE

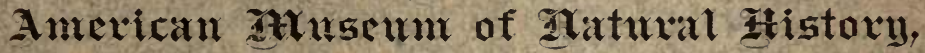

VOL. V, ARTICLES XIX and XX, pp. $335^{-3} 38$.

New York, December $16,1893$. 



\title{
Article XIX.-DESCRIPTION OF A NEW MOUSE FROM LAKE COUNTY, CALIFORNIA.
}

\author{
By J. A. Allen.
}

\section{Sitomys robustus, sp. nov.}

Similar in proportions and coloration to Sitomys americanus gambelii, but nearly twice the bulk of that form; hence about equaling $S$. gilberti in. size, but differing from the latter in much smaller ears and much shorter tail, and also in coloration.

Above uniform dull yellowish brown, much varied with blackish, the pelage being plumbeous at base, subterminally broadly ringed with fulvous and tipped with blackish ; middle of back darkest, gradually becoming more fulvous on the sides, without, however, forming a distinct fulvous lateral line nor a distinct dorsal band of dusky ; beneath white, as also the upper surface of both fore and hind feet. Ears moderate, in size, form, color and hairiness about as in $S$. $a$. gambelii. Feet large; soles sparsely haired posterior to the last tubercle. Tail a little shorter than head and body, sharply bicolor, dusky brown above and white below, fairly well clothed with short hairs and non-penicillate-about as in $S$. americanus.

Measurements. - Two specimens, both males, and measured in the flesh by the collector, give the following dimensions: Total length, I74-175 mm.; head and body, 94-I02 ; tail, ${ }^{1}$ 73-80; hind foot, 2 I-22 ; ear, I9-2I.

Skull.-Of the size and general proportions of Sitomys gilberti, or of small specimens of $S$. californicus, except that the auditory bullæ are markedly smaller, being scarcely larger than in average specimens of $S$. a. gambelii, notwithstanding the much larger size of the skull. In other respects there appear to be no tangible cranial differences. Total length of the type (the other skull is imperfect), $26 \mathrm{~mm}$; ; basal length (posterior base of incisors to posterior border of occipital condyle), 22 ; greatest width of brain-case, 12.5 ; least interorbital breadth, 4.5 ; length of nasals, Io ; length of lower jaw, 13.5 ; length of lower jaw to tip of incisors, 16 ; height at coronoid process, 6 .

Type, No. 282, Mus. Leland Stanford University, Lakeport, Lake Co., Cal., March 20, I893; collector, S. Parrish.

This species is based on two adult males, in the museum of the Leland Stanford University, collected by Mr. S. Parrish at Lake-

1 It is barely possible that the extreme tip of the tail in both specimens was mutilated in life, but it seems by no means probable. 
port, Lake Co., California, March 20, 1893 , kindly placed at my disposal for study by Prof. Charles H. Gilbert, of Stanford University. These specimens were at first regarded as greatly overstuffed examples of $S$. a. gambelii, till an examination of their skulls showed the fact to be otherwise. S. robustus requires no comparison with other species beyond that already made, its short tail, relatively small ears, robust body, large feet, and small auditory bullæ, at once serving to distinguish it. It would seem, however, to much resemble $S$. boylii in size and coloration, but the latter is described as having a much longer tail-much longer than head and body instead of much shorter, as in the present species. 


\title{
Article XX.-DESCRIPTION OF A NEW SPECIES OF
}

\author{
GEOMYS FROM COSTA RICA.
}

\author{
By J. A. Allen.
}

A specimen of Geomys, collected at Santa Clara, Costa Rica, by $\mathrm{Mr}$. George $\mathrm{K}$. Cherrie, has recently been received from that gentleman for identification, which on examination appears to be undescribed. It belongs to the G. hispidus section of the group, but differs from it markedly in size, coloration and in the character of the pelage. It may be described as follows :

\section{Geomys cherriei, ${ }^{1}$ sp. nov.}

Above everywhere blackish chocolate brown, except a large patch of pure white on the crown, subtriangular in shape, $30 \mathrm{~mm}$. in length and 6 to $17 \mathrm{~mm}$. in breadth, broadest behind ; inner surface of fore and hind limbs, throat and breast, dusky grayish; rest of lower surface pale grayish buff. Tail (except extreme basal portion), and upper surface of both fore and hind feet naked, apparently reddish in life.

Mcasurements (approximate from dried skin): Total length, $275 \mathrm{~mm}$.; head and body, I95; tail, 80 (naked portion, 65); hind foot, 40; middle claw of same, 5 ; fore foot, 34 ; middle claw of same (arc of curve), I 5 .

Skull, total length, 6o ; basal length (posterior border of occipital condyle to posterior base of incisors), 47 ; zygomatic breadth, 34 ; occipital breadth, 30 ; length of nasals, 20 ; lower jaw (posterior border of condyle to posterior surface of incisor), 38 ; height at coronoid process, 17 .

Type, No. 664, Museo Nacional de Costa Rica, Santa Clara, Costa Rica, October, 1892 ; George K. Cherrie.

The specimen described above is evidently about full grown, but the sutures of the skull indicate a rather young animal. The

1 Named for Mr. George K. Cherrie, Acting-Curator of Birds and Mammals, Museo Nacional de Costa Kica, the discoverer of the species, and to whose kindness I am greatly indebted for mammalogical material from Costa Rica.

[December, 1893.$]$ 
skull is of the heavy, short, broad type of G. hispidus, ${ }^{3}$ with the malar greatly expanded. The coloration of the animal, however, is much darker, especially below; the pelage is rather soft and not hispid, and the tail is relatively much longer than in hispidus. The white patch on the crown is possibly albinism, but if normal is a striking feature.

In addition to the differences in external characters and in size, $G$. cherriei differs from $G$. hispidus in several important cranial details, notably in respect to the shape and size of interparietal bone, which in $G$. hispidus is broad and short (much broader than long), and gently convex in front, while in G. cherriei it is narrow, subtriangular, and nearly twice as long as broad.

Possibly this species may need comparison with Geomys heterodus Peters, from Irazú, Costa Rica ; but Alston says (Biol. Cent. Am., Mam., p. I60) that Peters's type "proves identical with Mexican specimens."

${ }^{1}$ I am indebted to Dr. C. Hart Merriam, Chief of Division of Ornithology and Mammalogy, U.S. Department of Agriculture, for a specimen of $G$. hispidus for comparison in the present connection. Dr. Merriam writes me that this specimen "may be regarded as a duplicate type [of G. hispidus], since it was collected at a point probably not more than six miles from the exact spot where the original type was obtained."

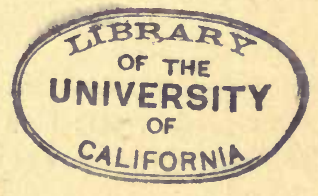





UNIVERSITY OF CALIFORNIA LIBRARY,
BHIS BOOK IS DERELEY

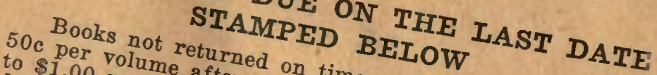
to $\$ 1.00$ volume after on tim BLW

demand per volumer the thire are subject expiration of be renewed the sixth overdue, in a fine of
loan period if application. B. loan period. application is mooks not in
made before

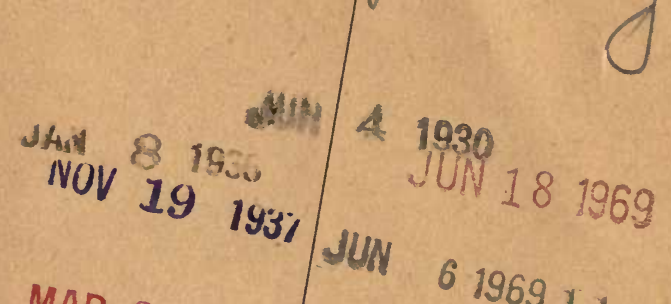

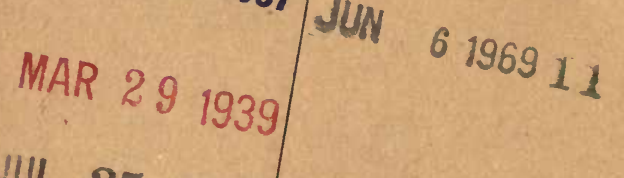

JAN \& 1944

JUL 25

MAY -91949

MÁAY

Nov 31949

Nov $300 \begin{array}{ccc}3 & 0 & 1953 \\ 1950 & 0\end{array}$ 


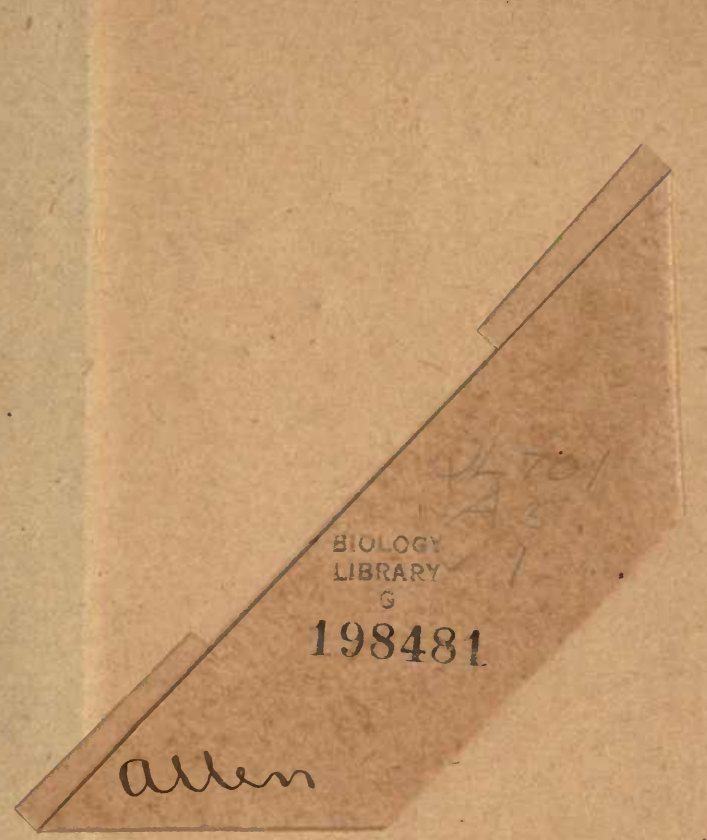


